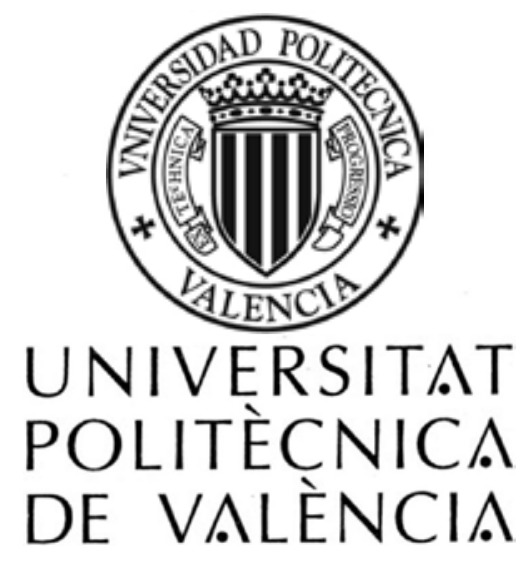

DEPARTAMENTO DE PINTURA

Programa de Doctorado Artes Visuales: Producción, Gestión, Restauración

\title{
BASES PARA UN ANÁLISIS TEÓRICO FORMAL DEL ACTO DIBUJO
}

TESIS DOCTORAL

Presentada por:

Aureliano Sánchez Tejeda

Dirigida por:

Dr. José Manuel Guillén Ramón

Valencia, mayo 2012 



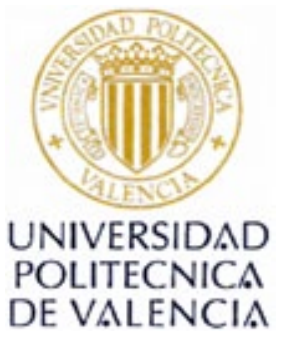



DEPARTAMENTO

DE PINTURA 



\section{BASES PARA UN ANÁLISIS TEÓRICO FORMAL DEL ACTO DIBUJO}

\section{SINOPSIS}

Esta tesis es un intento por contribuir al análisis de la condición del territorio del dibujo en el concierto artístico de las tres últimas décadas.

El problema central en el que se origina esta investigación es la ruptura del vínculo sistémico que unió al dibujo y las artes por más de 500 años, hasta el momento de la modernidad formalista y Greengberiana, la Abstracción Pospictórica y la Tardomodernidad estética; frente a las prácticas y estrategias del arte posmoderno, la Cita, la Apropiación, la Alegoría, la Estrategia Sígnico-Sintáctica y demás.

Trabajamos bajo la hipótesis de que la supuesta autonomía del dibujo era más una ruptura general de la condición posmoderna hacia los paradigmas modernos del arte. Pero sostenemos en este trabajo que esa ruptura, no implica necesariamente la pérdida de sentido del dibujo como un campo definido del arte ni como promotor central de los procesos gestálticos de representación de las formas, la imagen y el proyecto artístico. Todo esto es analizado en el primer capítulo como parte del planteamiento del problema.

Como segundo capítulo y parte de la estrategia de análisis, desarrollamos una visión del dibujo y su carácter Proyectual Prefigurativo. Esto porque planteamos como necesaria la mención explícita del sentido teórico que explicara la trama del vínculo histórico y formal entre el dibujo y las demás artes.

Revisamos desde la condición histórica y teórica que reviste la categoría de proyecto dentro de las artes, para terminar con el estudio del dibujo como práctica estratégica y metodológica. Se analizó la visión lineal del método, frente a las flexibilizaciones estratégicas sustentadas en una visión de la complejidad constructivista, así como la teoría del pensamiento proyectual en el nacimiento de la modernidad y su paso a la posmodernidad.

Siempre pensamos en el curso de esta investigación que un análisis de la condición teorizante en torno al dibujo, tendría que surgir desde el pensamiento y la interioridad del propio campo como una teoría mayormente endógena, ese era incluso parte del planteamiento hipotético. Así, en el tercer capítulo desarrollamos un primer segmento dedicado a la formulación de los modelos como categoría teórica y estratégica en el territorio artístico; los modelos como ficción, como paradigmas, como fundamento técnico; el modelo histórico, el modelo relacional, el modelo estratégico, el modelo perceptivo, el modelo autorreferencial y otros. La segunda parte de ese capítulo se basa en una división modelística del dibujo con base en sus sistemas formales de representación a lo largo de la historia, pensamos que ese trazo de las formas en los sistemas del dibujo es el material sobre el que tendría que basarse un análisis crítico de la disciplina, y es así como sustantivamos una posible interioridad analítica.

En el capítulo final desarrollamos una visión teórica de lo que llamamos el "acto dibujo" es nuestra particular reflexión sobre el proceso y la fenomenología que implica el acto de dibujar. Explicamos el acto dibujo como un acto gestáltico de representación, de apertura formal y generador de imágenes de primera generación. Este segmento se basa en un par 
categórico de análisis; la vivencia y el pensamiento experiencial, ambos como tramos ineludibles dentro del acto del dibujo.

Exponemos el acto dibujo desplegado en una mecánica que se desarrolla sobre una triada sustantiva: El espacio como locación, el tiempo como flujo de las vivencias y la materialidad que sustantiva el acto y la obra. Sobre esta tercia retomamos el postulado del tiempo muerto, la huella psíquica y el materialismo elemental.

Es una tesis que va de lo ya dado como historia y teoría, a lo formulado como nuestra respuesta y parte de una apuesta teórica.

AURELIANO SÁNCHEZ TEJEDA 


\section{BASES FOR A THEORETICAL FORMAL ANALYSIS OF THE ACT OF DRAWING}

\section{SYNOPSIS}

This thesis intends to contribute to the analysis of the conditions in the field of drawing in the artistic concert of the last three decades.

The main problem where this research begins is the rupture of the systemic bond that linked drawing to the arts for over 500 years, to the moment of formalist and Greenbergian modernity, Post-pictoric Abstraction, and late modernity aesthetics, in the face of the practices and strategies of Post-modern art, the Cite, the Appropriation, the Allegory, the Signic-syntactic Strategy, and others.

We work under the hypothesis that the supposed autonomy of drawing was more of a general rupture of the post-modern condition with the paradigms of modern art. Yet, in this work, we hold that that rupture does not necessarily imply the loss of the sense of drawing as a defined field of art, or as the main promoter of Gestaltic processes of shape representation, of image, and the project of art.

This is all analyzed in the first chapter, as a part of the problem statement. In the second chapter, as part of the analytical strategy, we develop a vision of drawing and its Prefigurative Projective character. This, because we propose that it's necessary to explicitly mention the theoretical sense that will explain the historic and formal link between drawing and the other arts.

We review from the historic and theoretic condition that envelopes the category of project in the arts, to end with the analysis of drawing as a strategic and methodological practice. We have analyzed the lineal vision of method in the face of the relaxing of strategies sustained on a vision of constructivist complexity, as well as the theory of projective thinking in the birth of modernity, and its turn to post-modernity.

In the course of this research, it was always thought that an analysis of the theoretical condition of drawing must come from within its own field, as an endogenous theory; this was, in fact, part of the hypothetical proposal. Thus, in the third chapter, we develop a first section dedicated to the formulation of models as a theoretical and strategic category in the artistic field: models as fiction, as paradigms, as technical foundations, the historic model, the relational model, the strategic model, the perceptive model, the self-referenced model, among others. The second part of this chapter is developed on a model-based division of drawing, constructed on its formal systems of representation throughout history. We believe that that division of drawing systems is the material on which a critical analysis of the discipline should be made. This is how we substantivate a possible analytical interiority.

In the final chapter, we review a theoretical vision of the "act of drawing". It's our particular review of the process and the phenomenology that the act of drawing implies.

We explain the act of drawing as a Gestaltic act of representation, of formal opening and generator of first generation images. This segment is based on a categorical pair of analysis: the experience, and experiential thought, both as inescapable stretches in the act of drawing. 
We present the act of drawing displayed on a mechanism that is developed on a substantive triad: space as location, time as a flowing of experiences, and the materiality that substantivates the act and work. On these three we return to the postulate of dead time, the psychic imprint and elemental materialism.

It's a thesis that goes from the given in history and theory, to the formulated as our answer, and parts from a theoretical proposal.

AURELIANO SÁNCHEZ TEJEDA 


\section{BASES PER A UNA ANÀLISI TEÒRICA FORMAL DE L'ACTE DIBUIX}

\section{SINOPSI}

Aquesta tesi és un intent per contribuir a l'anàlisi de la condició del territori del dibuix en el concert artístic de les tres últimes dècades.

El problema central en què s'origina aquesta investigació és la ruptura del vincle sistèmic que va unir el dibuix i les arts més de 500 anys, fins al moment de la modernitat formalista i greengberiana, l'abstracció postpictòrica i la tardomodernitat estètica; enfront de les pràctiques i les estratègies de l'art postmodern, la cita, l'apropiació, l'a/•legoria, l'estratègia sígnico-sintàctica i altres.

Treballem sota la hipòtesi que la suposada autonomia del dibuix era més una ruptura general de la condició postmoderna cap als paradigmes moderns de l'art. Però sostenim en aquest treball que aqueixa ruptura no implica necessàriament la pèrdua de sentit del dibuix com un camp definit de l'art ni com a promotor central dels processos gestàltics de representació de les formes i la imatge i el projecte artístic. Tot això és analitzat en el primer capítol com a part del plantejament del problema.

Com a segon capítol i part de l'estratègia d'anàlisi, desenvolupem una visió del dibuix i el seu caràcter projectual prefiguratiu. Això perquè plantegem com a necessari l'esment explícit del sentit teòric que explicara la trama del vincle històric i formal entre el dibuix i les altres arts.

Revisem des de la condició històrica i teòrica que revesteix la categoria de projecte dins de les arts, per acabar amb l'anàlisi del dibuix com a pràctica estratègica i metodològica. S'ha analitzat la visió lineal del mètode, enfront de les flexibilitzacions estratègiques sustentades en una visió de la complexitat constructivista, com també la teoria del pensament projectual en el naixement de la modernitat i el pas a la postmodernitat.

Sempre pensem en el curs d'aquesta investigació que una anàlisi de la condició teoritzadora entorn del dibuix hauria de sorgir des del pensament i la interioritat del mateix camp com una teoria majorment endògena, aqueix era fins i tot part del plantejament hipotètic. Així, en el tercer capítol desenvolupem un primer segment dedicat a la formulació dels models com a categoria teòrica i estratègica en el territori artístic; els models com a ficció, com a paradigmes, com a fonament tècnic; el model històric, el model relacional, el model estratègic, el model perceptiu, el model autoreferencial i uns altres. La segona part d'aquest tercer capítol es basa en una divisió modelística del dibuix amb base en els seus sistemes formals de representació al llarg de la història; pensem que aquest traç de les formes en els sistemes del dibuix és el material sobre el qual s'hauria de basar una anàlisi crítica de la disciplina, i és així com substantivem una possible interioritat analítica.

En el capítol final desenvolupem una visió teòrica del que anomenem l'acte dibuix: és la nostra reflexió particular sobre el procés i la fenomenologia que implica l'acte de dibuixar. Expliquem l'acte dibuix com un acte gestàltic de representació, d'obertura formal i generador d'imatges de primera generació. Aquest segment es basa en un parell categòric d'anàlisi; la vivència i el pensament experiencial, tots dos com a trams ineludibles dins de l'acte del dibuix. 
Exposem l'acte dibuix desplegat en una mecànica que es desenvolupa sobre una tríada substantiva: I'espai com a locació, el temps com a flux de les vivències i la materialitat que substantiva l'acte i l'obra. Sobre aquest tres termes reprenem el postulat del temps mort, l'empremta psíquica i el materialisme elemental.

És una tesi que va del que ja s'ha donat com a història i teoria, a allò que s'ha formulat com la nostra resposta i part d'una aposta teòrica.

\section{AURELIANO SÁNCHEZ TEJEDA}






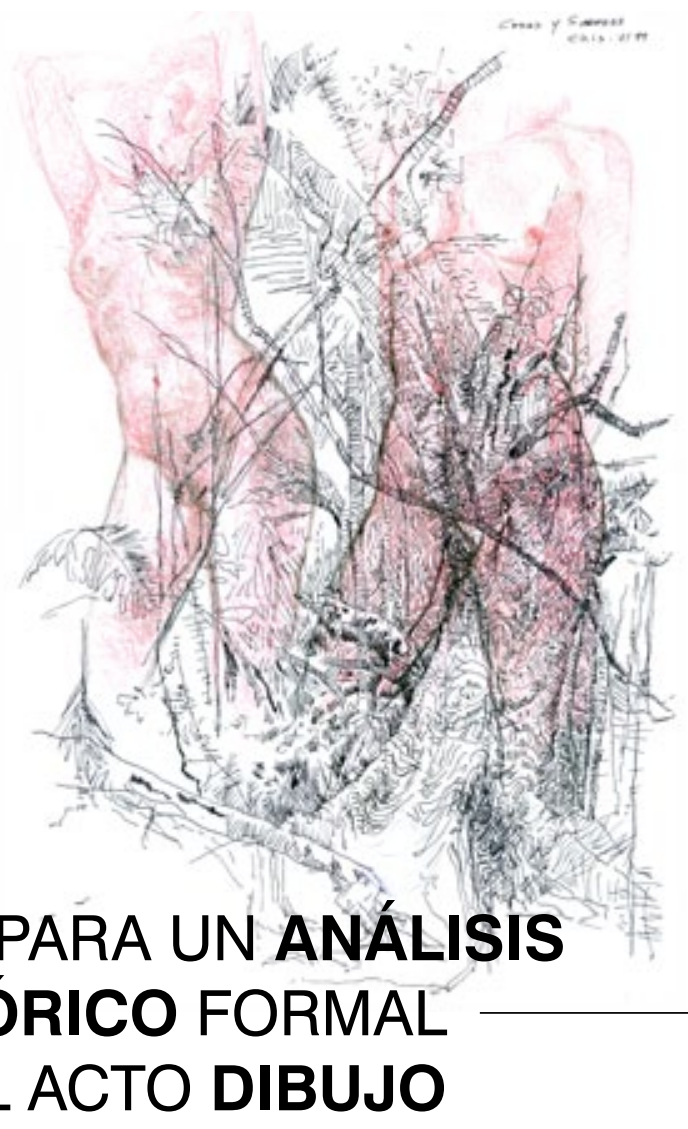

\title{
BASES PARA UN ANÁLI
TEÓRICO FORMAL DEL ACTO DIBUJO
}

\author{
TESIS DOCTORAL \\ Presentada por: \\ Aureliano Sánchez Tejeda
}

Dirigida por:

Dr. José Manuel Guillén Ramón 



\section{ÍNDICE}

INTRODUCCIÓN 19

\section{CAPÍTULO I}

PLANTEAMIENTO DEL PROBLEMA 29

I-1 Panorama histórico 29

I-2 Consideraciones epistémicas 35

I-3 Modernidad, posmodernidad. Citacionismo y apropiación 50

I-4 Campos disciplinares, identidad y diferencia 72

I-5 El dibujo en el fin del arte, en el fin de la estética 89

I-6 La estrategia del arte, modernidad y posmodernidad 92

I-7 La crisis de la representación 97

\section{CAPÍTULO II}

EL PENSAMIENTO PROYECTUAL PREFIGURATIVO EN LAS ARTES Y EL DIBUJO 109

II-1 El proyecto artístico y su condición teórica e histórica 109

II-2 La interioridad del proyecto artístico y del dibujo 117

II-3 Relaciones sistémicas del pensamiento proyectual 129

II-4 El pensamiento proyectual en el dibujo 137

II-5 Metodología proyectual y estrategia en el dibujo 158

II-6 Proceso y proyecto en el dibujo 181

\section{CAPÍTULO III}

\section{LOS MODELOS DEL DIBUJO 213}

III-1 El modelo es la ficción que calza con la realidad 218

III-2 Los modelos paradigmáticos de análisis 229

III-2-1 El modelo histórico 232

III-2-2 Pensamiento autorreferencial 236

III-2-3 El modelo relacional 243

III-2-4 El modelo perceptivo 245

III-2-5 El modelo técnico 247

III-2-6 El modelo simbólico 249

III-2-7 La estrategia como modelo 251

III-3 Formalización e interioridad del dibujo 254

III-4 Los modelos y la otredad 255

III-5 El modelo interior del dibujo 262

III-6 Los modelos formales del dibujo en la historia 265

III-6-1 El modelo Renacentista 267

III-6-2 El dibujo en el Manierismo y el Barroco 289

III-6-3 Del Naturalismo al Romanticismo en el dibujo 312 
III-6-4 El dibujo de la forma 331

III-6-5 La acción de dibujar 345

III-6-6 El dibujo de la modernidad a la posmodernidad 364

\section{CAPÍTULO IV}

\section{EL ACTO DIBUJO 401}

IV-1 Extensiones del concepto de representación 403

IV-2 Vivencia y experiencia en el acto dibujo 425

IV-3 El acto dibujo como un acto de representación 430

IV-4 El acto dibujo como un acto de apertura y abducción 439

IV-5 Espacio y locación; tiempo y vivencia en el acto dibujo 449

IV-6 La mecánica del acto dibujo 461

\section{CONCLUSIONES 483}

\section{PROLEGÓMENOS 513}

Cuentos del bosque sombrío punta de plata 523

Cuentos del bosque sombrío grabado 537

Cuentos del bosque sombrío temple 548

Tótem y tabú 561

Los testamentos de Cornelius Castoriadis 586

Lo que nunca termina (masa visual, sincronía espacial y temporal) 603

\section{BIBLIOGRAFÍA 665}

Fichas bibliográficas de páginas web consultadas 676 


\section{INTRODUCCIÓN}

\section{Estimados lectores:}

Gracias por acercarse a este trabajo. Es una satisfacción; o mejor un honor para mi, haber llegado hasta este punto; ver las divagaciones vividas al trazar mis dibujos convertidas en atribulados pensamientos, expresados en letra y dados para la lectura.

Cuando era joven y pasaba mis días de estudiante en la academia, mis compañeros y yo veíamos con admiración el dibujo español, significaba un paradigma a penetrar.

De una manera u otra, quizá por casualidad siempre, he resultado cercano al campo del dibujo, llevo realizados muchos trazos y atentados en contra de ese oficio. Mis ideas sobre la vida, el contexto y el arte, de alguna manera estuvieron influidos por aquellos dibujos de la españolidad, y algunos otros.

Varios de mis profesores fueron españoles emigrados, personajes de una alta estatura humana y artística.

Se que eso no me vuelve dibujante por extensión y mucho menos presta calidad a mi trabajo; los riesgos y errores son responsabilidad mía. Pero es un privilegio presentarme ante ustedes, aunque sea sólo por un corto espacio, y con tan magras credenciales, para rozar la orilla de vuestra tradición.

Esta introducción está redactada en primera persona del singular, como debe ser según creo, para dar la cara, el cuerpo del trabajo fue escrito en primera persona del plural porque mucho de lo dicho es palabra de otros, sólo una parte nos corresponde.

Encontrarán reflexiones que seguramente han leído antes y mejor desarrolladas, identificarán como conocedores aquello que he tomado de la historia.

El tema tratado es un territorio difícil, los capítulos con los que he intentado dilucidar el problema pueden ser leídos sin un orden lineal estricto. Pienso que aún así conservan una liga teórica sustantiva.

No miento al decirles que muchas de las ideas iniciales de este estudio se originaron entre la hierba, caminando bosques, recorriendo caminos en el verano, lo que tienen en sus manos puede ser más una insolación que un libro.

Me presento ante ustedes con una memoria ya tocada por el tiempo y un tanto deteriorada, esto no es un decir, es una simple realidad, un motivo más para solicitar su comprensión. La masa de conocimientos, textos y autores que se requieren para sustentar este tipo de trabajos empieza a resultarme una tarea muy compleja.

Es importante mencionar que el orden de los capítulos y los bloques en que están agrupados, varía un poco del que inicialmente proyecté. Esto es debido a que, como en toda investigación, el curso del trabajo mostró su propia lógica y una mejor coherencia estructural para el análisis. 
Pero también digo con honestidad que todos los tópicos del proyecto original están contenidos en el escrito final; ninguno fue eliminado ni se introdujeron elementos nuevos para facilitar el trabajo. Cuento con que ustedes sabrán notarlo.

Algunos segmentos (pocos en realidad), de esta investigación fueron trabajados dentro de mi proyecto para el examen de Suficiencia Investigadora, corresponden a El Dibujo como Disciplina Proyectual, pero su sentido teórico ha sido expandido en relación al nuevo tema de investigación, de manera que, ni su extensión ni su contenido corresponden al trabajo anterior. El sentido del Pensamiento Proyectual en este trabajo es más rico y mucho más complejo.

Por alguna razón que desconozco, en varias ocasiones se me sugirió realizar esta tesis partiendo de mi producción en el terreno del dibujo y la pintura. Pero hace algún tiempo descubrí que para dar consistencia a mi obra era necesario estudiar sólidamente la historia del arte y su teoría en el trecho de la modernidad formal y vanguardista que arranca en el siglo XIX y se prolonga en el proyecto estético de la tardomodernidad del XX.

Era urgente para la claridad de mi producción realizar ese estudio, de ahí que este trabajo tenga una esencia centralmente teórica e histórica.

Por otra parte, la investigación artística implica colocar el arte como aparato mediador entre la realidad problematizada y la inteligencia cognoscente, pienso que aún no arribo a ese terreno. Aunque como lo dije líneas arriba, los planteamientos problemáticos centrales de esta investigación emanan del proceso de realización de mis dibujos. Ésta es una tesis teórica, pero, paradójicamente el problema central y los cuerpos capitulares se originaron dentro de la producción de mis proyectos y series expositivas.

Más allá del pensar para hacer y el pensar al hacer el dibujo, tengo la certeza de que es posible la investigación del contexto y del aparato formal del propio campo, basados en el ejercicio artístico, relacionarnos con el mundo a partir del territorio del dibujo y trasladar el acto cognitivo al seno del acontecimiento dibujístico.

Como se menciona en el texto, La Investigación en Bellas Artes de Ricardo Marín, José Luis Tolosa y Juan Fernando de la Iglesia, ésta sería una tesis que trata asuntos de la historia y teoría del arte, pero marcada por el enfoque metodológico de la propia experiencia como productor del dibujo.

Y así fue; mi paso por el trabajo como dibujante se constituyó en el filtro y la brújula que marcaron la postura epistémica de este estudio, creo que tal vez ése sea el elemento que genera algunos rasgos de conocimiento nuevo como debe ser en éste tipo de tesis.

"El investigador en arte conoce desde su propia experiencia como actúan los materiales y las técnicas, tiene una idea de cómo se piensa en el cuadro, como se responde ante lo que ahí sucede. Distingue las zonas en las que se ha decidido el mérito de la obra, las resueltas solo con oficio y las que se completan con aburrimiento. Su propia experiencia y conocimientos enfrentándose a los mismos problemas que cualquier otro artista son sus armas decisivas."1

1 Marín Vidael Ricardo, De Laiglesia Juan Fernando, Tolosa Marín José Luis. LA INVESTIGACIÓN EN BELLAS ARTES, Tres aproximaciones a un debate. España: Grupo Editorial Universitario; 1998. 
La pregunta clave es entonces ¿cómo ha trabajado el dibujante? En ese sentido existe una tipicidad generalizante del campo artístico que hermana en cierto nivel el pensamiento experiencial.

Como dice el texto citado, la investigación, sea en sentido artístico o teórico, es conocimiento nuevo que hace avanzar socialmente la disciplina.

Al hacer hincapié en conceptos como los de una epistemología del dibujante y la fenomenología del acto dibujo intenté centrarme en la experiencia empírica y en el análisis de hecho dibujístico, participando desde esta perspectiva en el debate crítico y como orientación para resolver el problema planteado.

Desde este punto de vista es que el origen de las preocupaciones que animan esta investigación se encuentra en mis proyectos como dibujante; y de ahí que buscara tomar la historia y la teoría de las prácticas de los artistas del dibujo como una característica importante en la tesis.

El cuerpo anexo de esta investigación contiene una relatoría en imágenes de los proyectos que se relacionan directamente con esta investigación, ustedes juzgarán por su cuenta el sentido de estas afirmaciones.

Uno de esos proyectos de producción de 1995 a 1998 me llevó a considerar las estructuras no-lineales y la teoría del caos como parte significativa dentro del proceso del arte. Finalmente advertí la esencia matemática de ese campo, pero en el proyecto pude derivar estructuras formales de representación que dieron un carácter propio a esas obras. En ese proceso resultó esencial el estudio del pensamiento constructivista para encontrar la claridad epistemológica que permitió una mediana solución a ese problema.

Pero lo más importante es que desde esa serie de trabajos se sembró la idea de un Dibujo y Pintura Contextual, sospeché la relación que traba el contexto como origen del proceso del dibujo; no en el sentido sencillo como lo estudiamos en la escuela, sino como el origen de las formas de representación y los nexos epistémicos de relación entre el dibujante y el mundo. Esa serie de trabajos se centró en el bosque como motivo temático, la consistencia de las imágenes que obtuve me llevó a pensar si en realidad constituían una posibilidad estructural para la forma en el dibujo, o si sólo eran efectivas en lo particular para ese tema y motivo. Inicié el trabajo de Los testamentos de Castoriadis de 1998 a 2002, con el motivo central de llevar a la figura humana las estructuras formales que se originaron en el proyecto anterior. Como resultado de ese tramo de la producción concluí en las obras, y como extensión crítica, que sí era posible un proyecto de producción centrado en la representación formal y la estética, lo cual es un principio toral dentro de esta investigación.

En las exposiciones que realicé posteriormente probé la relación del tema como eje de subjetivación y discurso significante, todo en relación a la complejidad trabajada hasta entonces.

Estos proyectos generaron en su interior una suma extensa de términos, conceptos y categorías referidas a la interioridad estructural de mis imágenes y del dibujo en general; también con respecto al método y la estrategia.

No quise convertir todos ellos en el núcleo o parte de esta tesis, de hecho ni siquiera los expongo. Es así porque asumo que tal vez no alcancé mis metas, y que la calidad de la obra no justifica una buena conclusión necesariamente. Pero entiendo su valor como generadores de una convicción y sospecha, la que mira en el dibujo un campo de 
disciplina de la forma eidética y la representación, cuya vigencia no se puede cancelar mediante ninguna declaración.

Para saber que tanto todo eso era mi propio pensar, que tanto se había desarrollado como parte de una teoría actual del dibujo y el arte, y que tanto esa disyuntiva había sido resuelta, es que me di a la tarea de esta investigación; ella mostró lo positivo de la sospecha, pero como siempre, igual extendió el problema, aunque concluyó que en lo central el planteamiento de origen era acertado.

Al centro de esta investigación se encuentra una formulación que relaciona tres factores temáticos:

La independencia del dibujo en el arte de las cuatro últimas décadas, es una disociación del vínculo sistémico que unió al dibujo con las artes de la imagen. Es más un resultado de la ruptura paradigmática entre el arte de la Modernidad y la Tardomodernidad frente a la producción artística Posmoderna.

Esta contradicción se concreta en la siguiente triada categórica.

- La quiebra de la representación, el fin de la estética y el arte como eje del proyecto artístico posmoderno.

- El Pensamiento Proyectual Prefigurativo del Dibujo.

- El Acto Dibujo.

Dediqué el primer capítulo de la investigación al planteamiento del problema, ya que en este caso no bastaba con una simple mención.

Desarrollé el carácter del problema como un conflicto de la postura epistemológica del dibujante.

Expliqué el carácter categórico del concepto de Artes Plásticas como paradigma dramático de la forma y la materialidad en el arte del siglo XIX; desarrollé el inicio del nuevo paradigma del Lenguaje de la Visión que terminaría por concretarse en la categoría de la Artes Visuales y en la auto-referencialidad crítica del medio propuesta por Greenberg. Como siguiente corte, se expuso el inicio de las tensiones introducidas por la postura de la crítica posmoderna.

Dentro de ese primer capítulo se desarrollaron los conceptos de cita, apropiación y alegoría que son el eje de la mecánica constructiva posmoderna y que orientan ese proyecto hacia una postura epistémica de combinatoria semiológica.

Como parte de esa tensión paradigmática se desarrolló el planteamiento de la estrategia que flexibiliza metodológicamente el proyecto artístico, lo que opone una vez más la modernidad frente a la posmodernidad; aunque expuse como, dentro del pensamiento proyectual del dibujo, ambos términos, estrategia y método se reconocen como indispensables y que por otra parte ya desde la producción del Informalismo y el Expresionismo Abstracto había venido dándose un proceso de flexibilización metodológica.

Uno de los ejes más fuertes del pensamiento posmoderno que se liga con la visión posestructuralista y deconstructiva, y que más impacto ideológico tiene, es la formulación del 
Campo Expandido, desde el artículo de Rosalind Krauss se toma por la crítica posmoderna como una verdad sin cuestionamiento y como el carácter general del arte actual.

Al investigar ese asunto encontré mayor coincidencia con la postura de Hall Foster quien cuestiona radicalmente tal disolución de los campos disciplinares y su expansión.

La postura de Danto, Brian Wallis y otros, sobre el fin del arte, el fin de la pintura y el fin de la estética es un planteamiento que va quedando rebasado para la práctica actual del arte, pero me detuve en esos aspectos porque se enlazan con la base de la postura posmoderna que sostiene la renuncia a los procesos de representación y su concreción formal; ese es el territorio en el que hoy se desenvuelve el ejercicio de nuestro trabajo como dibujantes, ése es el contexto de presión que pesa sobre la orientación de nuestros proyectos.

El planteamiento del problema concluye con la exposición de la Crisis de la Representación como uno de los ejes del proyecto posmoderno artístico; expongo las consecuencias que esa tesis acarrea para la práctica del dibujo que es centralmente un área de reflexión de la forma y la imagen.

El segundo capítulo se centra en la categoría del Pensamiento Proyectual Prefigurativo del Dibujo. Ésta era una idea que ya animaba desde el inicio de la investigación; pero en el curso del trabajo encontramos que el sentido de lo proyectual como función, se extiende hasta el terreno del proyecto histórico y teórico del arte y el artista. Particularmente el texto de Santiago Vera Cañizares resultó importante en este punto.

Tomé como propia la visión del proyecto artístico que se divide en la modernidad y permanece hasta nuestros días, en el sentido del proyecto crítico existencial o el proyecto positivo ascendente. Disyunción en la que se debate el artista y el dibujante.

Esta relación del proyecto con la historia se traba en la triada.

\section{El Contexto - El Dibujante - La Obra Proceso}

Finalmente, luego de la extensión histórica, analizamos el proyecto del dibujo como una figura de la interioridad del campo y su particularidad formal y procesual.

Así expuse la postura clásica del proyecto artístico en la que el dibujo desarrolló el eje de planeación, para posteriormente analizar la flexibilización que lo convirtió en el centro estratégico y no solo formal del proyecto.

El sentido proyectual del dibujo le lleva a establecer relaciones sistémicas desde la perspectiva del lenguaje, como desde la interioridad del proceso y las partes de la disciplina. En ese punto introduje el entendimiento del tema como el espacio de cruce fenoménico entre el contexto, el dibujante y la obra en proceso. Pero igual en este capítulo desarrollamos el sentido clásico del dibujo y la planeación proyectual como función histórica y metodológica de las artes.

En ese espacio y en lo sucesivo, el análisis se auxilia frecuentemente en la exposición de imágenes y obras capitales de la historia del arte y el dibujo. Esta particularidad me parece relevante porque así el centro y la base reflexiva se remiten a la interioridad de las construcciones del dibujo, postura consecuente con el carácter central e inicial de esta investigación. Desde este punto de vista, frecuentemente se retoman argumentos y análisis típicos de la historia y teoría del dibujo y las artes, pero en múltiples ocasiones el análisis se basa en categorías formales constructivas que son una precisión de esta investigación. 
Ya el trabajo de Gómez Molina menciona el término "Los dibujos del dibujo" en alusión a las diversas funciones que el dibujo cumple a lo largo de la historia del arte y dentro del pensamiento proyectual; pero no realiza una puntualización de las diversas funciones metodológicas y el tipo de dibujo que requieren y que se fue perfilando en la historia del arte. Esta seriación es una particularidad que fuimos desarrollando en el cuerpo de nuestro análisis. Reconocemos la importancia del trabajo de Gómez Molina y el apoyo que presta a esta investigación, pero pensamos habernos extendido un tanto más allá de ese pensamiento.

La flexibilización metodológica del proyecto hacia la estrategia fue desarrollada tomando en cuenta el pensamiento complejo de Edgar Morin, no se buscó una plena coincidencia de categorías epistémicas, pero en buena medida el trabajo creativo consiste en una desnaturalización del conocimiento para buscarle órdenes alternos de constitución.

Se recurrió a la teoría del Pensamiento Complejo y la Lógica Abductiva no como una arbitrariedad, sino porque en ellas se encuentra un elemento que aclara el sentido desnaturalizador y creativo de la representación como revolución del pensamiento y la gestalt de las formas.

Aquí es donde se introduce la Prefiguración, Configuración y Presentación como conceptos que aportamos al pensamiento proyectual; son términos que encontramos dentro de la literatura general del dibujo y el proyecto artístico, pero de manera casual y excesivamente imprecisos, en esta investigación se les lleva más allá de una mención general y se les intenta sustantivar como categorías proyectuales.

Ya en el aspecto fenoménico adjuntamos los conceptos de vivencia y pensamiento experiencial, que sumados a la triada anterior desarrollan la completud de la acción de dibujar, según nuestro punto de vista.

Mencionamos el Apunte, el Boceto, el Estudio, el Proyecto y la Obra terminal como la secuencia metodológica del dibujo que se inicia en el arte del Renacimiento y se completa en la visión del Barroco; y que es la misma que desde el Naturalismo y el Romanticismo inicia su proceso de flexibilización formal y estratégica; aunque igual se señala como esta función metodológica permea hasta las producciones neoconceptuales contemporáneas.

Resultó una experiencia satisfactoria el poder relacionar la categoría de Proceso dentro del proyecto artístico, tal como la estudié en la asignatura Obra Gráfica y Proceso del programa doctoral; darle cuerpo en conceptos sustantivos de una mecánica de la acción de dibujar.

Pero centralmente se intentó explicar el proceso del dibujo como una secuencia que sustantiva el acto de la representación, en una dirección eidética y de creación de sistemas formales, desprendiéndolo de su rancio sentido practicista y tecnológico.

El capítulo III de la investigación desarrolla la categoría de Modelo en el dibujo. En ese espacio se posiciona esta categoría desde la visión clásica en donde el modelo es la otredad que sirve como referente del dibujo y fuente de la representación. Paso por la visión de la modernidad que crea la visión del modelo como esencia de la dinámica recursiva del lenguaje.

También se aborda la postura del modelo como parte de la presión contextual que la cultura naturalizada ejerce sobre el ideario del dibujante. Este constituye el núcleo de negación existencial que es el centro del proyecto romántico crítico. 
Planteo el modelo como esencia actitudinal del dibujante que intenta la reconstrucción y extensión del pensamiento modelístico del que parte.

Pero centralmente coloco la categoría de modelo en el terreno del dibujo como la esencia particular de un pensamiento hecho formas y sistemas de representación. Pensamiento de la interioridad disciplinar, cuyo devenir en la historia constituye el trazo del pensamiento de la representación llevada al interior del dibujo.

Por lo anterior este capítulo se orienta en dos apartados básicos: Uno que trata sobre las posturas epistémicas del dibujante ante el concepto de modelo como eje metodológico del acto y la práctica de dibujar.

La segunda parte de este capítulo III desarrolla la secuencia de Los Modelos Formales del Dibujo en la Historia; en muchas ocasiones en relación íntima con los sistemas de la pintura y las demás artes, y no porque se haya perdido el centro del análisis, sino porque ése es el carácter típico de tales estados del sistema. Una parte de esos contenidos se pueden leer ya en la historia del arte occidental, pero en general la orientación tiende a desarrollar el cúmulo de operaciones técnicas, conceptuales y estratégicas que son la sustancia de la interioridad de la acción de dibujar.

También señalo como importante la segmentación paradigmática que realizo como secuencia de este proceso histórico; ya que está basada en la fluctuación general de las características formales de representación, éstas se pueden observar al interior del sistema del dibujo.

- El Modelo Renacentista

- El Modelo Manierista y Barroco

- El Modelo Naturalista Romántico

- El Modelo de la Forma

- El Modelo de la Acción del Dibujo

- El Modelo de la Modernidad y la Posmodernidad

Existe una base constitutiva de este capítulo; es la que plantea que el modelo del dibujo es una forma típica del pensamiento, así el problema central a desarrollar lo constituyó la profundización en esa tipicidad. Y fue en este punto en donde la investigación mostró la pertinencia de esa ruta. Hall Foster en su ensayo "Asunto: Post" dentro del texto de Brian Wallis "Arte después de la modernidad"; Deleuze en su texto Pintura el concepto de diagrama y Alain Bois en su "Painting as Model" y el clásico de Michael Fried "Arte y Objetualidad" todos ellos participan de la afirmación que sostiene una forma típica del pensamiento en la interioridad del acto artístico; no solo realizan ensayos críticos sobre la pertinencia de esa posibilidad, elaboran sendos análisis parados en la historia, en el dato y en el hecho, de modo que fueron una base inmejorable para fundar la positividad y corrección de la hipótesis inicial de esta investigación.

Tomando como base el estudio de Hubert Damish, incluido en Painting as Model, trabajé una serie de posibilidades y extensiones modelísticas de la estrategia interior del dibujo.

- El Modelo Histórico

- El Modelo Autorreferencial

- El Modelo Relacional

- El Modelo Perceptivo 
- El Modelo Técnico

- El Modelo Simbólico

- El Modelo de la Estrategia

- Los Modelos y la Otredad

La riqueza de aquellos textos trabaja sobre la vertiente del pensamiento pictórico y su distancia con respecto a la filosofía y la crítica, de modo que así se probaba la pertinencia epistémica de mi tesis; la de la interioridad del modelo teórico formal del dibujo; pero quedaba aún por elaborar la sustancia y el contenido de tal teoría, y ésa fue la orientación del último capítulo de este trabajo.

Mucha de la literatura revisada en esta investigación en relación con el tema del dibujo, se dirige en el sentido analítico del panorama de la disciplina dentro del concierto del arte en la modernidad y la posmodernidad, son análisis un tanto teóricos sobre el arte en general, más que del dibujo, o bien críticas referidas a uno u otro autor; pocos textos en realidad (destacan los que corresponden a la literatura española de los tres últimos decenios) intentan siquiera internarse dentro de la tipicidad fenoménica del dibujo.

Por lo anterior considero que reviste una cierta importancia el haber iniciado la reflexión en ese sentido, pero reconozco que lo escrito en ese segmento no constituye una prueba de tal tesis sino una muestra de su pertinencia.

La reflexión del acto dibujo se inicia con las extensiones de la categoría de la representación. En el planteamiento del problema se dejó claro porqué la concepción posmoderna de la representación significa un problema para el ejercicio del dibujo. A manera de un desarrollo consecuente, explicito el fondo formalizante y eidético de la representación, rebasando el sentido mimético, y con ello su relación en la interioridad del acto de dibujar.

La mecánica reflexiva del acto dibujo como extensión de la representación se efectúa sobre la base de una lógica triádica; la que relaciona el dibujante, la obra y el contexto; ya lo mencioné anteriormente; pero con esta base triádica se supera la lógica binaria como tipicidad analítica del pensamiento moderno, éste no era un objetivo inicial pero se gestó como consecuencia al realizar el análisis retroactivo de mis proyectos de dibujo.

Coloqué al centro de la postura actitudinal del dibujar, la vivencia y la experiencia como par fenoménico categorial; en esta dupla se concreta mi visión que considera el dibujo como una disciplina eminentemente reflexiva, pero la cual no puede carecer del plano vivencial y fáctico.

Esta visión que mantiene el vivir y el reflexionar como esencia del dibujar es la que me llevó a desarrollar el cuerpo conceptual del último capítulo desde una perspectiva psíquica y subjetiva a la vez que conceptual y formal, pero nunca como parte de una lógica dialéctica de oposición de contrarios.

Finalmente concebí el acto dibujo como un suceso fenoménico, de ahí que centrara el análisis en la ubicación del dibujante como sujeto emplazado en una puntualización espacial y en una particularidad temporal.

Concebí una primeridad vivencial del dibujante inmerso en el contexto.

Una segundidad proyectual prefigurante. 
Una terceridad de configuración experiencial.

Y el momento del acto expositivo como cierre temporal del proceso.

Si bien expliqué que la dinámica secuencial de estas etapas no es la de una linealidad metodológica sino la de una sincronía compleja y rizomática.

Sobre este capítulo del trabajo no quiero extenderme más en esta introducción, queda a su consideración el aporte que ello representa, si es que hay tal.

Concluyo el cuerpo de mi tesis con un anexo que contiene algunas series de mis proyectos de dibujo, los realicé tiempo atrás y en ellos se originó la inquietud de este estudio.

No las ofrezco como prueba ni fundamento lógico de la investigación, sólo es una manera de compartir con ustedes la fuente de mis reflexiones.

Esta investigación se realizó fundamentalmente a partir de fuentes bibliográficas; otro tanto partiendo de la observación directa de las obras, cuando esto fue posible, y muy poco basada en sitios electrónicos de red, de ahí que aparezcan mínimamente en las fuentes de consulta; no es por ningún prurito metodológico en particular, pero el debate central de esta tesis se vierte muy poco en ese medio, cuando menos de manera directa.

Pienso sinceramente que las preocupaciones que animan estas páginas pertenecen a un pensamiento generacional, no soy tanto yo sino los otros, los de mi tiempo, mis compañeros de viaje mis cómplices y amigos, pero claro que ellos no tienen que asumir mis fallas.

Finalmente recuerdo las clases y las asignaturas que nos fueron impartidas dentro de este programa doctoral. Expreso mi agradecimiento sincero a toda la planta docente que participó en esos cursos.

¿Como olvidar particularmente las cátedras de Pintura y Contexto, la de, El Proyecto en la Escultura Contemporánea y la de Obra Gráfica y proceso?

Quizá imaginen ustedes la felicidad que me invadió al ver en esas clases y sus contenidos temáticos una gran parte de las preocupaciones que me ocupaban. Por otra parte el proceso mismo de esta investigación resolvió muchas de las incógnitas que me asaltaban, espero haber aclarado en alguna medida el problema planteado.

Deseo que esta investigación finalmente alcance una suficiencia intelectual, ustedes podrán decirlo.

Quedo tranquilo; ahora sé algunas cosas más; y dispongo de mucho tiempo para dibujar.

Gracias.

AURELIANO SÁNCHEZ TEJEDA 



\title{
CAPÍTULO I
}

\section{PLANTEAMIENTO DEL PROBLEMA}

\section{I-1 PANORAMA HISTÓRICO}

\begin{abstract}
"El auténtico dibujo no está en el dibujo final, sino en la estrategia que dibuja la malla que articula los estratos de dibujos que componen el proyecto. Una acción que permite mantener la individualidad de cada uno de ellos, como un sistema contradictorio de posibles reconstrucciones, y como la clave de una reflexión diferenciada sobre la identidad de lo representado."

- Juan José Gómez Molina.
\end{abstract}

En las dos últimas décadas del siglo XX se desató un ímpetu divulgador del dibujo como disciplina artística, sin que tuviera que relacionarse necesariamente con cualquier otro campo del arte plástico y visual. En este camino de supuesta autonomía, el dibujo perdió en gran medida la esencia estructural que lo mantenía como eje fundamental en la construcción del proyecto artístico y generador de las estructuras de representación en las artes y aún fuera de ellas. Éste es el problema que enunciamos y a su estudio e investigación dedicaremos en gran parte nuestra tesis.

Mediante la historia y la teoría del dibujo estudiamos los cuerpos formales que constituyen la sustancia de sus sistemas de representación. Así como las estrategias y procesos que representan al dibujante como actor frente a la historia de la disciplina. Actualmente está aún por realizarse el agrupamiento de estos sistemas, que se expresan en los cuerpos teóricos aportados por los propios artistas y movimientos de las artes a lo largo de la historia y por los análisis de la teoría y la crítica que se orientan hacia el entendimiento interno del dibujo. Llamamos a estos segmentos teóricos, Los Modelos del Dibujo, hasta hoy se encuentran dispersos en gran cantidad de escritos y tratados, generalmente este material se revisa como parte de la historia de la pintura y las demás artes. Es necesario formular un análisis en el que se proponga un modelo de estudio con base en los contenidos específicos de la teoría e historia del dibujo.

Revisar la interioridad teórica del dibujo implica el estudio de la postura epistémica del dibujante a lo largo de esta ruta histórica.

Enunciar la independencia del campo del dibujo, o bien de su particularidad disciplinar, sólo es posible si contamos con una claridad sobre las posturas teóricas en que se basa. La centralidad del dibujo como columna de las Artes Plásticas y Visuales se debió a su capacidad como constructor del pensamiento eidético y consecuentemente del proyecto artístico.

Desde el Renacimiento Europeo y hasta la modernidad que se da en los inicios del siglo $\mathrm{XX}$, se construyen los lazos de unicidad entre el dibujo y las Artes Plásticas, sus paradigmas y categorías serán modificados por la revolución neoplasticista en los primeros 
decenios del 1900. En ese punto se inicia la construcción de la Gramática de las Artes, el paradigma de la forma plástica como expresión dramática se derrumba. La construcción del taxos formal de la alfabetidad visual abre una fisura de escisión, pero aún ahí la relación del dibujo con las artes se mantiene en términos generales como disciplina eidética estructurante y prefiguradora del proyecto artístico.

Al enunciar un cuerpo general para la forma de las Artes Visuales se abre el camino para que el dibujo derive hacia una nueva postura. Podemos decir que corresponde a la propuesta neoplasticista el papel del último movimiento artístico en el que se intenta la construcción de un sistema taxonómico integral.

Será dentro del Informalismo europeo y el Expresionismo Abstracto Americano, en donde se generen los primeros desplazamientos radicales de la disciplina del dibujo como función en el proceso artístico. Después de las tres primeras décadas del siglo XX comienzan a aparecer dibujos que no operan como planeadores de obras posteriores, el rigor constructivo de las artes se modifica, la relación clásica del dibujo como representación de la naturaleza externa al sujeto comienza a ser abandonada por los artistas, se consolidan los modelos interiores del proceso pictórico iniciados en el romanticismo y el pintoresquismo del siglo XVIII, que serán rastreados hasta la revolución abstraccionista de principios del $X X$ y, después de ellos, la forma de la forma, con esto, el dibujo inicia su proceso temprano que lo lleva al campo expandido. Aún dentro de la revolución informalista y expresionista abstracta el proyecto artístico se basa en una propuesta de construcción formal; los modelos de representación, aún aquellos de la interioridad individual, se plasman en obras de innovación formal y procesual. Clement Greenberg en sus compilaciones sobre la pintura moderna y Michael Fried en su texto Arte y Objetualidad dejan claramente establecida la vocación formal y estética del proyecto moderno abstraccionista.

Así el dibujo al ser liberado de su función prefigurativa se convierte en una acción ejecutante, pero no por ello carente de sentidos conceptuales teorizantes profundos; y diríamos (como más adelante en nuestro capítulo IV lo veremos) que mejor aún se interioriza en el cuerpo de la pintura y las demás artes.

Las propuestas conceptuales de los años 60 y 70 son la puerta de ingreso a la posmodernidad, que en el campo que nos ocupa marca el abandono de las categorías artísticas anteriores. El arte posmoderno y sus estrategias, derrumban de una vez por todas la necesidad de formular campos disciplinares particulares con cuerpos formales propios. Son el cierre circular del proceso iniciado por Duchamp y el Dadá. Esta etapa se corresponde claramente con la enunciación de la llamada independencia del dibujo.

Con las dos últimas décadas del siglo XX arribamos a una producción numerosa de obras del dibujo, pero la construcción de un pensamiento profundo, expresado en material teórico sobre el tema no ha corrido la misma suerte.

El trabajo de los pensadores españoles, como Gómez Molina, Lino Cabezas, Juan Bordes y otros, constituye un esfuerzo loable en este terreno, en él se expresa el intento por sentar las bases de un material histórico en el que se construya una posibilidad teórica.

Un factor que consideramos sustancial en este panorama contemporáneo del dibujo, es el que se deriva del avance de las estrategias citacionistas y apropiacionistas en el 
arte actual. No es de nuestro interés construir una tesis de oposición al respecto, lo que deseamos puntualizar es el hecho de que estas estrategias de construcción del sentido significante, se basan en el uso de sistemas formales e imágenes de la tradición y la historia artística, usan en la construcción del discurso, imágenes de segunda y tercera generación, para desmontar su sentido significante inicial e introducirles una nueva posibilidad semántica, no interesa en ese caso la posibilidad de ejercer el dibujo como un acto de representación, que al enfrentar el contexto en una acción primera pueda transformar la vivencia y la experiencia en fuente de procesos de representación.

Así pues en este trabajo intentamos una posibilidad teórica en la que se estudie tanto la historia del pensamiento dibujístico como la construcción de las bases de un análisis particular al interior del campo disciplinar del dibujo hoy día. Pensamos que esta tarea puede ser abordada bajo la consideración del Dibujo como un Acto, un suceso que implica la conciencia epistémica del dibujante, el análisis del artista en una particularidad histórica espacial y temporal y el devenir fenoménico del proceso.

La realización de esta investigación parte de un hecho específico, aunque no del todo claro. La ubicuidad de la disciplina del dibujo en el terreno de las artes actuales.

El estado de cualquier disciplina del conocimiento humano es la expresión de la intencionalidad de quienes la ejercen. Hablamos de prácticas humanas, de las que habrán de derivar sus posibles definiciones, terrenos del hacer que posibilitan la crítica y el análisis ulterior.

Señalemos el hecho de que nuestra investigación se funda en la noción de estado de un problema. Con esto nos referimos a un proceso fenoménico en continuo devenir, las afirmaciones terminales no nos interesan, dado que no hablamos de formulaciones estables. No perseguimos a lo largo de la historia y en las últimas décadas, la enunciación de análisis que propongan especificidades en el terreno de la definición del dibujo.

Al mencionar el proceso del dibujo como la expresión de un estado, nos referimos al devenir de un fenómeno. En él se manifiestan circunstancias que atañen al sujeto autor, a su relación con el contexto en que se generan y al conjunto de situaciones que surgen en el proceso de su hacer. Tanto sujeto dibujante, modelo contexto y devenir dibujístico se imbrican en un conjunto complejo de situaciones, estas se suscitan en una particularidad espacial y temporal, en la que el punto de vista del dibujante constituye la voluntad rectora que asume las decisiones desde el origen y a lo largo del proceso hasta su cierre específico en cada obra o conjunto seriado del proyecto, si bien señalamos la presión que el contexto y la ecología cultural ejercen sobre su ideario, determinando en parte el carácter histórico de su pensamiento proyectual.

Dentro de todo esto, las circunstancias del dibujo como disciplina artística muestran signos de variación importantes en las tres últimas décadas del ejercicio artístico. Claro que esto no es privativo del momento actual. La historia del dibujo y la de cualquier campo del hacer humano viven procesos igual de complejos y relativos. Pero en este caso las variaciones en ese devenir contienen particularidades que pensamos guardan giros que llevan la práctica del dibujar en direcciones hasta ese momento no contempladas.

No nos inclinamos por aquellos análisis que buscan definir tanto al dibujo como sus partes, ya que ese trabajo nos llevaría al establecimiento de formulaciones que tienen más una consistencia conceptual taxonómica de corte positivista, y con ello una distancia que 
los separa del tiempo del hacer y la vivencia del suceso. Es por ello que nuestra investigación reviste en parte un giro fenomenológico, porque toma como centro de origen la consideración de la primeridad vivencial en el acto de dibujar, y no las definiciones abstractas y conceptuales que orbitan en el ámbito teórico o de la historia general del arte. Y no es que no recurramos a la historia y la teoría del dibujo, o de las artes en general; pero el orden de esas consideraciones será determinado en función del centro gravitacional de la acción dibujística. Tiempo, espacio y sujeto serán considerados en una particularidad histórica y contextual; un aquí y ahora que confiere especificidad al proceso del dibujo, llevándolo de la generalidad histórico cultural, a la actualidad temporal, que dicho sea de paso es el momento en el que el dibujante actualiza el dibujo y su historia.

Intentamos así una reflexión surgida de la interioridad del ejercicio del hacer el dibujo; análisis endógeno de su proceso sistémico. Buscamos con ello escapar al círculo de análisis exógenos, basados más en la crítica del arte, o en modelos analíticos de disciplinas que toman el dibujo como su objeto de estudio, que por otra parte no han puesto suficiente énfasis en el suceso del dibujo como en el de las artes en general.

Intentar un análisis desde la interioridad de la praxis del dibujo no conlleva el desconocimiento de la historia ni la teoría como disciplinas estudiosas del arte, por el contrario, queda claro que no es posible ninguna práctica humana que no esté preñada de la anterioridad de su propia historia y ejercicio reflexivo; incluso en el momento del dibujar se filtran partes de saberes y disciplinas anexas que interesan al dibujante, de cara y en compromiso con su tiempo.

Lo particular de nuestra postura es un asunto de episteme. La ubicuidad para pensar y analizar el dibujo será aquella de quien lo realiza. Así guardaremos distancia de la postura de la crítica y la historia como disciplinas con particularidades metodológicas, pero que en común estudian los fenómenos del arte a posteriori. Aclarando que no es ésta una tesis que formule juicios contrarios a esas disciplinas o que les confiera una carencia de sentido.

Pensamos el dibujo como una construcción humana que comprende afectos y preceptos, como lo plantea Gilles Deleuze, agregamos que también formula conceptos y leyes, estas constituyen un pensamiento nuclear, sistema en el que el dibujante opera y del que se sirve para construcciones objetuales y mentales posteriores. Así se integra un centro de gravedad que se resiste a ser entendido, pero que es origen de su propio pensamiento, la dirección reflexiva del dibujante se origina en el interior de su práctica, en el pensar el mundo en tanto dibuja, o bien el pensamiento retroactivo que se pliega sobre la sustancia de su propio campo, el plano experiencial que sigue a la vivencia del dibujo es el establecimiento de las razones y las constantes que llevan al dibujante a resumir y establecer formulaciones, la obra dibujo como lo veremos es el campo de batalla, que no el laboratorio donde el dibujante establece sistemas en contra del caos.

Es por lo anterior que entendemos que las formulaciones que la crítica y la historia como disciplinas en sí, puedan hacer en el terreno del dibujo, en muchos casos reportan conciencia y conocimiento profundo del campo disciplinar; pero en muchísimos otros sus conceptos y formulaciones del dibujo no lograrán penetrar la interioridad de la obra objeto, el dibujo concreto y fáctico que se constituye en filtro o bloque de resistencia para el pensamiento no coincidente con su tendencia sistémica interior.

Pero las consideraciones teóricas de la interioridad del dibujo, no son sino la manera con la que intentamos responder a las circunstancias contextuales en las que actualmente se hunde la práctica del dibujo. 
Los análisis y opiniones en el terreno que nos interesa, encuentran fundamento en los derroteros del arte actual y sus rupturas paradigmáticas. No resulta difícil comprender que si el dibujo mantenía un vínculo sistémico constante con el corpus de las Artes Visuales, éste se ha fragmentado, cuando menos parcialmente en la medida que el concepto integrador de las artes se desdibuja en la posmodernidad.

De manera demasiado rápida se asume que las fluctuaciones en el terreno de las artes visuales son por extensión aplicables a los otrora campos disciplinares.

Pensar el tiempo en la historia de la filosofía, o del conocimiento humano nos obliga a establecer parámetros mucho más amplios que los que competen a nuestra propia vida, el tiempo de la historia es mucho muy dilatado, sus procesos pueden prolongarse por siglos o más. Sucede algo similar en la historia del dibujo. La construcción del modelo sistémico del dibujo en occidente es un proceso que se inicia lo menos 500 años atrás. La centralidad de este campo como constructor del pensamiento en imágenes, sus preceptos epistémicos que determinan la conciencia metodológica y demás particularidades conceptuales, no son producto de una historia reciente. De manera que mucho de aquello que se vio afectado con la revolución posmoderna no es una condición joven en el campo disciplinar del dibujo.

Si bien una acción libre y autónoma del artista en el proceso de crear, puede tener repercusiones de peso en el sistema del dibujo, cabe preguntarse sobre el origen y condición de aquello que trastocamos, es esta una responsabilidad que compete al artista maduro, el que realiza la obra y traza la línea de cara no solo a su impulso, sino frente a la historia.

En el devenir del arte occidental, cuando menos desde el renacimiento temprano se formula la importancia del dibujo como columna vertebral de las Artes Plásticas. Aunque ésta es sustancia de un capítulo dentro de este trabajo, necesitamos realizar una panorámica que nos ubique en el asunto.

Los procesos de formalización de la realidad externa, mediante el trabajo del dibujante, acompañan al hombre en la creación del lenguaje. El dibujo y la escritura contemplan un origen común. La Forma Dibujo es la representación de un suceso particular, posibilita el surgimiento del pictograma, que es la representación dibujada de un modelo asumiendo una acción, más adelante el ideograma consistió en una forma dibujada que estandarizaba a los modelos separándolos de sucesos específicos.

La formalización que el dibujo realiza de la realidad se mantiene viva en los sistemas de escritura pictográficos, su camino se distancia de la historia de la escritura con la aparición del alfabeto, esto es, un sistema de signos cuantitativamente cerrado y en el que el signo no alude a ningún referente externo, sino a un valor abstracto, inexistente fuera de la mente sígnica, pero con el enorme potencial de combinatoria que le permite un máximo de economía de signos, con los cuales se expande sin embargo al infinito la posibilidad discursiva.

Ya podemos desde esta perspectiva vislumbrar en cierta medida el carácter de la revolución neoplasticista y bauhasiana en su intento por establecer la gramática integrada de las artes. Como se comprende ésta es una particularidad que marca nuestro análisis. Coincidimos en que las tres primeras décadas del siglo XX significaron un cambio radical para las artes, pero no solo vemos en este periodo el inicio de la desintegración objetual del arte como sistema de representación. Consideramos que el intento de las artes integracionistas de principios del XX seguía sus propios motivos, si bien pudo abrir la puerta para revoluciones diversas. 
Tiempo atrás la teoría renacentista se inicia en el primer tercio del siglo XV con los tratados de Piero Della Francesca y León Batista Alberti. En ellos se asume un rigor analítico, matemático y procedimental que los diferencia de los manuales escritos por un maestro de taller, como el libro de Cenino Cennini o el de Benvenuto Cellini, si bien éste ultimo corresponde a fechas de un periodo renacentista ya avanzado.

El paso del manual como compendio de la experiencia del maestro acopiada en el taller se complementa con el ejercicio de unas artes ahora basadas en la razón mesurable de la forma y la estructura plástica, tomando como fuente de conocimiento mismo al modelo natural, para llegar al establecimiento de la razón proporcional, que no es sino el resumen de un cúmulo de observaciones y experiencias, resumidas y expresadas en una métrica mesurable. En toda la tratadística renacentista el dibujo es desarrollado ya como uno de los cuerpos básicos de la pintura.

Precisamente éste es un factor sustancial dentro de nuestra investigación. El análisis de la causalidad y los fenómenos que confieren al dibujo un papel central dentro de la estructura sistémica de las Artes Plásticas y Visuales. En el capítulo siguiente habremos de centrarnos en este punto, pero ahora es importante señalar que muchos de los cambios y giros del arte en el siglo XX se determinan en función de las rupturas y variabilidades de esta relación.

Líneas adelante retornaremos al asunto de los momentos disyuntivos del arte moderno y contemporáneo, pero; lo importante a señalar es la necesidad de fundar el análisis de lo acontecido en el dibujo y las artes actuales sobre la lógica de ese modelo analítico interior del campo.

De frente a lo anterior pareciera ser que hundimos demasiado lejos las fuentes de nuestra investigación, pero no es así, habremos de ocuparnos del devenir del dibujo retribuyéndole un carácter que se basa en el desarrollo de un modelo teórico formal, el cual, pese a sus variaciones opera como estructura sistémica con características básicas que no se diluyen frente a sus fluctuaciones.

En este estudio tiene importancia relevante el giro dado a las artes con las primeras revoluciones de la vanguardia anicónica del siglo XX. El siguiente corte se sucede muy rápidamente con la propuesta informalista y del Expresionismo Abstracto.

Desde ahí y hasta las aportaciones del Pop Art en 1964 se habla del periodo de la estética formalista, paradigma del arte moderno en el siglo XX.

La tardomodernidad de los años sesenta es el corte inmediato anterior a lo que ha sido denominado como el fin del arte, inicio de la era del Pos Arte o Arte Posmoderno.

Nuevamente, no es asunto de este estudio el análisis y surgimiento de las artes del fin de milenio. Tampoco deseamos que se tomen nuestras consideraciones como una crítica negativa a los procesos de transformación artística aludidos, reconocemos su trascendencia en el concierto de las artes y la cultura globales; pero no intentaremos desde la periferia un análisis que resultaría desde ahora carente de dirección.

Cabe aquí un primer señalamiento esencial, coincidimos con lo expuesto por Rosalind Krauss, Arthur Danto, Donald Kuspit, Juan Martín Prada y en general con la postura de la crítica posmoderna que señala la postura de establecer cortes paradigmáticos significativos en el proceso del arte moderno, y que desembocan en la revolución del arte en la posmodernidad. 
Ese es en parte el contexto artístico e histórico en el que se mueve esta investigación. Pero los alcances que hemos visualizado como necesarios dentro de la historia del dibujo alcanzan periodos más amplios.

Dedicaremos un capítulo de este trabajo para realizar un panorama del devenir de las teorías y la historia del dibujo en occidente. Lo haremos bajo una premisa teórica, la que considera que existe una línea conductora en el derrotero de este proceso, ésta es la condición del Dibujo como Disciplina Proyectual dentro de las artes.

En esa investigación revisaremos la historia del dibujo, intentando establecer espacios de territorio y temporalidad, en los que se estabilizan los acuerdos sobre una concepción del dibujo en particular y su formalización como sistemas de representación.

De ahí la coincidencia con las formulaciones posmodernas que señalan aquellos momentos como giros paradigmáticos en el arte. Pero si bien coincidimos en lo observado, no lo estamos tanto en las causas y concluimos nombrar ese proceso y esos movimientos de manera un tanto diferente. Esto es así en función de que no realizamos un análisis básicamente filosófico, o bien en el campo de la crítica del arte.

De manera general se menciona la irrupción del Pos Arte en el terreno de la filosofía, con los procesos de cita, apropiación, alegoría y el ascenso de la estrategia semiótica significante, que presenta los fragmentos de realidad, dejando de lado las intensiones para lograr estructuras de representación formal, ubicando con ello el fenómeno artístico más allá del campo estético.

La historia que estudiamos es aquella que comprende el proceso del dibujo, con ello marcamos metodológicamente nuestro análisis. Los tiempos revisados resultan sincrónicos a los de los demás procesos del arte, muchos de los sujetos implicados son incluso los mismos; pero lo que hace la diferencia es la sustancia, el corpus teórico y la relación sistémica funcional del dibujo con las artes.

Aclaremos; nuestro análisis no soslaya la importancia de los factores contextuales del marco cultural o incluso de campos artísticos cercanos al propio dibujo. Considera con claridad que en muchos momentos históricos el ser del dibujo estuvo indisolublemente ligado al corpus de la pintura, la escultura y el grabado, incluso al de disciplinas científicas como la botánica o la arqueología. Pero en ese proceso contamos con construcciones teóricas, formales y metodológicas que dotan al dibujo de una especificidad en la que se aclara su sentido fenoménico y filosófico como vinculo relacionante con la realidad contextual.

En su momento en este capítulo, líneas más adelante, puntualizaremos sobre aquellos cortes en la historia del arte que muestran con claridad giros determinantes, lo haremos mencionando nuestras coincidencias y aquellas consideraciones en las que nos basamos para extender y particularizar nuestro análisis.

\section{I-2 CONSIDERACIONES EPISTÉMICAS}

Con su muerte el maestro Juan Acha, deja sin terminar una última investigación.

Se trata de un trabajo en el que intentó analizar la práctica del dibujo a través de la historia humana.

El libro es publicado postmortem y, aunque no contiene conclusiones acabadas pone 
de manifiesto cuestiones peculiares que suceden en torno a la historia del dibujo al final del siglo $X X{ }^{2}$

En estas reflexiones el maestro Acha analiza el papel que el dibujo ha tenido a lo largo de la historia, desde regiones que se ubican fuera del terreno artístico, hasta llegar a la estética, introduciéndose finalmente en el campo de las Artes Visuales.

Aún sin concluir, la investigación arroja puntos de esclarecimiento sobre el problema. El maestro Acha toca el dibujo como una manera de artizar la imagen.

A lo largo de varias décadas del siglo XX se sintió la carencia de textos que analizaran específicamente el dibujo. Para fin de milenio se desata un ímpetu divulgador del asunto.

Al término de la década de 1980 se escuchaba recurrentemente la enunciación del dibujo como una disciplina para sí, cuyas obras contienen valores propios, sin que necesariamente tengan que relacionarse con cualquier otro campo del arte visual para encontrar su fundamento.

La llamada independencia del dibujo irrumpe en el terreno del arte de manera un tanto tardía, consideramos que esa situación está relacionada más bien con los factores de desintegración de los campos disciplinares en el terreno del arte dentro de la posmodernidad, en su momento nos detendremos para revisar este punto.

Pero al respecto ya desde años atrás coincidimos con Gómez Molina cuando refiriéndose al dibujo afirma que:

"Hemos perdido todas aquellas funciones que el dibujo asumía, al considerarse el mismo el auténtico encargado de dar testimonio de la realidad de la representación la reivindicación de su libertad se efectuaba también desde la pérdida de su utilidad en los procesos vinculados con la descripción objetiva de las cosas, tradicionalmente relacionada con los procesos de formalización necesarios en la producción industrial. Dos pérdidas sustanciales que dejan al dibujo sin dos de sus pilares de justificación histórica.

La recuperación de un valor del dibujo aparentemente tan importante como el de ser obra final, producto estético con autonomía propia, en igualdad con la pintura y la escultura, lo diluye definitivamente entre el resto de sus producciones, haciéndole perder su valor privilegiado de concepto fundamental en el entendimiento de la obra de arte."3

En la aceptación de una autonomía artística se ha opacado el sentido fundamental de la disciplina. Ahora se mira académicamente al dibujo como una práctica que formaliza la representación, las más de las veces parado en una supuesta mimesis; pero se deja de lado el potencial que tiene como proceso para problematizar y dar forma estructural a la idea que anima todo proyecto artístico; a la vez que se asume de manera simple la correspondencia entre el concepto de representación como mimesis de la realidad en la imagen, o bien como la manera en que los sectores dominantes o de rectoría cultural se autoproyectan, justificando su discurso y con ello su posición en el corpus social.

El dibujo tal vez ganó su autonomía. Pero para esto pagó con la pérdida de su sentido.

He aquí una falsa correspondencia, que genera en parte el problema que nos ocupa.

2 Acha Juan. Teoría del dibujo. Su sociología, su estética. México: Ed. Coyoacán; 1999.

3 Gómez Juan José, et al. Las lecciones del dibujo. Madrid España: Ed. Cátedra; 1999. P. 26. 
La ruptura de los campos disciplinares del arte en la posmodernidad, que por otra parte nunca terminaron de ser establecidos más allá de las formulaciones de Clement Greenberg; es un asunto cuyo fondo teórico nos remite al análisis formal y a la interioridad del lenguaje en el arte, mientras que el tratamiento que se le sigue por la crítica lo ubica en la esfera de la pragmática social del lenguaje, la sociología y el arte como manifestación crítica contextual.

Si actualmente se piensa en la posibilidad de un dibujo con especificidad artística no siempre ha sido así.

Lo particular del dibujo como campo artístico radica en la tipicidad sistémica de su estructura y sus componentes, éstos no son otros que los conceptos que sustantivan formalmente el pensamiento eidético, las leyes creadas para expandir su combinatoria y las categorías representacionales y filosóficas en que se basan. Cabe aclarar que esta no es una formulación invariable, dado que estas estructuras y posturas epistémicas no han sido constantes a lo largo de la historia del arte. El estudio de los sistemas del dibujo y su base fenoménica habrá de mostrarnos la riqueza de este devenir, sus giros y sus constantes. Pero su particularidad primigenia, tal vez sea la de ser una disciplina cuya matriz epistemológica lo define como práctica inherente a los procesos de representación mediante la imagen. No aludimos a una relación estructural determinista, el carácter de estos códigos de representación formal fluctúa de manera, si no sincrónica, si en relación con el contexto cultural y artístico en la historia. Guardamos diferencia con la postura moderna que basaba la diferencia posible de los campos artísticos en una noción formalista, que buscaba establecer sistemas lingüísticos taxonómicos propios para cada una de las artes.

El dibujante como todo artista trabaja involucrado con su modelo, que en otro tiempo fue la naturaleza, o bien el contexto en sentido amplio; objeto, sujeto, cosa o fenómeno, interioridad psíquica y también herencia cultural. El dibujante traza sus líneas y construcciones en razón de lograr una estructura estable que organice la forma de la imagen como consecución de un concepto, pero también traza de cara a la historia y la filosofía, el artista maduro sabe de la ubicuidad histórica de las obras que persigue.

Como lo menciona Juan Acha, los órdenes del dibujo son lo temático, lo estético y lo sistémico, al igual que en toda obra artística.

El trabajo de Acha en cuanto al dibujo demanda la consideración del cuerpo teórico y formal de la disciplina, aunque en su texto no se profundice más que respecto a la línea y la mancha distendida como categorías formales del dibujo.

Solo posicionándonos en la interioridad del dibujo se observarán sus cercanías y distancias con respecto a los sistemas de otros campos del arte. Estos procesos de construcción son el resultado de un desarrollo lento, que se proyecta en el tiempo más allá de un solo autor. Implica por tanto el estudio y análisis de las actividades concretas que se suceden en la práctica del dibujante. Van desde el posicionamiento del artista frente al modelo, el proyecto como aspiración, la conciencia de los sistemas utilizados en la formalización del proceso, hasta las prácticas técnicas y manuales; de manera esencial la consideración actitudinal del dibujante y la conciencia de la corporalidad implicada en el acto.

Tal vez esto inscriba el pensamiento del maestro Acha dentro de un terreno formalista, y lo haga coincidente con el pensamiento de Teodoro Adorno, al considerar la obra como la representación formalizada de un segmento de la realidad. 
No renunciamos a la coincidencia con esa postura, pensamos que la riqueza del dibujo radica centralmente en la esencia de su ser disciplinar, el cual concreta una postura estética, filosófica y artística en formas dadas a la experiencia estética, o bien el usufructo de las imágenes resultantes.

Líneas arriba señalamos la importancia de fijar posturas epistémicas.

El ser del dibujo sería inexistente como entidad independiente del pensamiento y práctica del dibujante, sólo es posible ese ser, en función de una práctica construida para establecer un vínculo orgánico con la realidad contextual. Pocas veces el proyecto del dibujo ha sido el de revolucionar la interioridad de la forma misma y sus sistemas, nos referimos a una postura plástico purista o autocrítica en el sentido que expone Clement Greenberg, lenguaje que no habla sino del lenguaje, forma de la forma. Pensamiento que por otra parte no es banal, pues nos dice de la cualidad humana racional implicada en ese acto de plegar el lenguaje para retrotraerlo y potenciarlo refiriéndose a sí mismo.

En otro sentido la praxis del dibujo siempre, o casi siempre, ha asumido la existencia de un otro, un algo o alguien, sujeto, cosa o fenómeno que al afectarnos y entrar en relación con él nos impele a trazarlo, ya adelante nos hundiremos en el pensar esta circunstancia.

Pero es en este filo de posturas en el que se comparte el origen del problema.

La práctica de las artes dentro del periodo posmoderno no prioriza ninguna definición como generatriz del trabajo artístico, circunstancia que la diferencia del proyecto de las vanguardias y el arte plástico del XIX y el lenguaje visual del XX; el artista sigue los impulsos que sus reflexiones, y a veces la intuición le señalan como posibilidades. Con ello se detiene poco a contemplar las consecuencias de sus obras, por más que cuente con una visión política del entorno y haga de su práctica un ejercicio mediante el cual desmonta los sistemas de representación del estatus. No es censurable la dirección en la que ha corrido el ejercicio del arte de tiempo acá, pero de esa manera también concluimos que ese derrotero no cancela ninguna posibilidad en el terreno del dibujo.

¿En qué medida la obra de Dennis Oppenheim, o el Spiral Jetty de Robert Smithson guardan distancia o contienen segmentos disciplinares del dibujo?

Éste es el tipo de pregunta que nos interesa, pero en su análisis no buscamos un ejercicio hermenéutico, ni una crítica hacia el autor. Nos mueve el interés de adentrarnos en el pensamiento que mantiene, prolonga o diversifica la idea dibujística. Y tenemos ese interés como dibujantes, seres que aspiran a ver el mundo mediante la práctica de esa disciplina; y en esa medida aprender de lo hecho por los otros.

A veces parecerá que retornamos demasiado atrás en la historia para nuestro análisis, ello no se debe a meras preferencias arbitrarias, es así porque muchos de los conceptos, formulaciones y sistemas que constituyen la disciplina del dibujo tienen su origen en esos puntos temporales, y aunque nos parezca distante, esa forma de pensamiento opera como vehículo de organización de la obra y estructura del proyecto artístico.

En éste trabajo habremos de intentar el acercamiento al origen y carácter de la razón metodológica y estructural que el dibujo guarda dentro de la región artística de la plástica y el arte visual. Esta circunstancia no es resultado de temporalidades recientes, como podría parecernos; tiene su origen en la aventura del arte plástico renacentista. En esa tempora- 
lidad se gesta la base de un modelo artístico de representación que como habremos de demostrar se continúa, cambia y se complementa hasta el arribo del informalismo y el expresionismo abstracto. He aquí una disidencia de nuestro pensar que se suma a las anteriores, el giro cualitativo en el modelo del sistema proyectual del dibujo no se corresponde sincrónicamente con los cambios radicales de la totalidad artística. Como habremos de ver la secuencia del modelo sistémico se proyecta hacia momentos cercanos en la actualidad.

Un espíritu científico experimental, una cualidad mesurable para la razón métrica de las formas invade el arte del Renacimiento, ésta es la cualidad básica que separa sus textos de las cartelas prerenacentistas o del Medioevo como la de Vilar de Honnecourt.

Dentro de toda la literatura artística del siglo XV y especialmente en la cultura italiana, se menciona al dibujo como disciplina que determina el ejercicio de la pintura, la escultura, el grabado, la orfebrería y la arquitectura.

Desde los tratados renacentistas tempranos de Cenino, León Batista Alberti y Piero de la Francesca, hasta los textos clásicos del Barroco con Battista Aguchi, Palomino y demás, se mantiene un carácter central para el dibujo como disciplina de construcción del proyecto artístico.

Generalmente en estos tratados se integra al dibujo dentro del cuerpo de la pintura, junto con la geometría y el color, pero de cualquier modo siempre guardó una relación cercana y estructural con éstas. Además de que esta circunstancia teórica nos muestra una definición de la pintura y el dibujo diferente a la que opera hoy día.

El dibujo es disciplina que permite el ordenamiento del pensamiento de una manera eidética, ahí se origina el término dibujo-diseño que será común en el ambiente artístico florentino y que centrará su interés en el valor de la línea como elemento constructivo del dibujo. El contorno como circunscripción de los cuerpos en unión con la capacidad de organización de los elementos del proyecto.

La pintura barroca mantiene en el centro el enfrentamiento de la función del dibujo como expresión de un ideal racional frente a la exigencia de una actitud más liberal, representada por la postura colorista aristotélica sensorial. Estas dos vertientes muestran los extremos del fenómeno que determina el nexo del dibujo con la pintura la escultura y la arquitectura. Pero nunca esta distancia significó un alejamiento radical, ya que obligó a la interiorización de la ejecución del dibujo en el momento de construir la forma pictórica.

Entre el dibujo y las artes plásticas ha existido siempre una relación simbiótica intensa, éste no es el punto a dilucidar, más bien lo es el carácter de ese vínculo, así como los giros teóricos y metodológicos que ha revestido a lo largo de la historia. Esta relación de interioridad sistémica será la que se vea trastocada en el arte de las tres o cuatro últimas décadas en el trabajo de los artistas posmodernos.

Coincidiendo con un planteamiento complejo, no podemos considerar la historia del dibujo y su relación con las artes como un tejido terso en el que la relación metodológica se incline decididamente por una causalidad directa, o bien esta se haya roto generando una supuesta independencia. 
Así como sucede con todo sistema complejo, la relación artes-dibujo se manifiesta en el sentido de una variabilidad con distintos grados de intensidad, el problema consistirá en ubicar históricamente los estados fenoménicos de esta relación, así como en anotar sus características epistémicas.

El devenir de la Artes Plásticas y después el de las Artes Visuales es el corrimiento de un sistema, cuyo proceso no puede suceder sino pensando en un estado histórico específico, situación que le dé particularidad espacial y temporal; lo que no es otra cosa que la conciencia del dibujante como parte del Modelo Histórico Estratégico. Mirando todo ello con el dibujo como centro gravitacional. Dicha particularidad constituirá el apoyo de un nuevo desplazamiento que a su vez sirve de apoyo a otras relativizaciones que complementan el sistema, o bien lo niegan o cancelan parcialmente.

Señalamos como cualidad importante el que toda variación emergente del sistema dibujo no puede suscitarse sino desde el interior del sistema mismo, y de su relación con los campos disciplinares y de lenguaje adyacentes. Así el dibujo manierista solo es posible como expresión ampliada y en cierto sentido negación del dibujo renacentista.

Esta postura que interioriza el cambio y evolución de los campos artísticos hacia su propio seno suele ser cuestionada tangencialmente, en el sentido de que la deriva de una disciplina se puede originar desde campos afines o adyacentes, o como presión del contexto cultural sobre la intencionalidad del artista. Ya el propio Thomas Kuhn en su libro sobre la estructura de las revoluciones científicas, (que además es un texto paradigmático dentro de la filosofía de la ciencia) aclara lo contrario, el hecho de cualquier cambio sistémico o estructural se gesta en la interioridad del propio sistema en cuestión; por su parte Hal Foster en un ensayo magistral incluido en el texto de Brian Walis, "Arte después de la modernidad" analiza esta situación bajo supuestos lógicos y nos conduce a la conclusión igualmente de que la deriva estructural de un campo disciplinar se configura en su interioridad, este asunto será revisado con más detenimiento en un momento posterior dentro de nuestro trabajo.

Aquí advertimos ya el carácter relativizante de esta investigación, en ella intentamos analizar los momentos de estabilización temporal en las concepciones y funciones del dibujo, a estos momentos habremos de llamarlos Modelos del Dibujo, son también modelos del pensamiento.

Igualmente nos interesa el carácter fluctuante y diacrónico del fenómeno. Importan aquí, aquellas peculiaridades, paradojas o desviaciones de los modelos o estados de la disciplina del dibujo.

El pensamiento lógico racional y proyectual del arte renacentista se prolonga cuando menos hasta la primera mitad del siglo XIX, por eso los sistemas compositivos fueron herramientas básicas del dibujo y la pintura; mediante su aplicación se buscaba la estabilidad estructural de la obra artística, incluso esta postura habría de mantenerse hasta la formulación neoplasticista.

La flexibilización del dibujo en el movimiento romántico aunada a la estética de lo pintoresco y lo sublime en la escuela inglesa, abre la puerta a una postura casi gestual, así se inicia un proceso que culminará en giros radicales en el dibujo y la pintura de las vanguardias de la posguerra en el siglo XX. El paradigma del dibujo como arte del pensamiento 
platónico se desintegra, ya que la razón métrica y la forma racional de los modelos dejan de ser la base del dibujo, pero las formas y las obras construidas en ese momento de la modernidad aún se caracterizan por su carácter plástico y su objetivo estético formal. La crítica posmoderna propone la ruptura informalista y expresionista abstracta como una expresión centralmente filosófica, cuyas estrategias y posturas actitudinales llevan a la pintura a la definición del proyecto moderno, pero al revisar la historia del dibujo encontramos que ya para fines del 1700 y en lo subsiguiente existen tratados de dibujo que formulan explícitamente el inicio de la sustitución de la forma del referente objetual por la forma aleatoria como base de la estructura de representación, nuevamente aparece una discrepancia. Los tratados de Alexander Cozens destacan en este sentido; dentro del capítulo que se refiere a los modelos del dibujo habremos de dedicarle un espacio suficiente.

Los artistas que integraron el Informalismo y el Expresionismo Abstracto buscaron de manera expresa el rompimiento de la estabilidad al interior de la pintura y el dibujo. Negaron el valor de la armonía como objetivo central de la composición. Por otra parte pusieron un énfasis mayor en el propio proceso que genera la obra, más que en el objeto artístico. Buscaron también el absoluto filosófico de la pintura al investigar individualmente la forma absoluta, sostenemos que en todo este viaje el dibujo jugó un papel fundamental, aunque los análisis comúnmente aceptados que se ocupan de la pintura de 1940 a 1965 no atiendan esencialmente en esa dirección.

Así resulta evidente que el transcurso de los modelos del dibujo reviste una variabilidad considerable.

La historia del pensamiento proyectual en el dibujo quizá es un devenir oscilante, de lo lineal proyectual a lo estratégico aleatorio.

Fundamentar esta idea y establecer los nexos históricos y formales que explican este proceso será en parte nuestra materia de trabajo.

Reconociendo la dificultad del asunto intentaremos en un primer momento plantear al dibujo como conjunto universo, una entidad compuesta, cuyas partes guardan una relación sistémica. Las relaciones sistémicas que nos interesan son aquellas que establecen vínculos de afectación cualitativa, las que generan en el todo propiedades que las partes por si solas no tienen.

Por eso es que el dibujo en ocasiones, es incluido como una de las partes de otras disciplinas, en otros momentos guarda un margen de distancia.

Un primer ángulo del problema consiste en delimitar el área conceptual del dibujo según el contexto histórico particular, aunque de hecho no intentaremos aquí, establecer o respaldar ninguna definición.

Nos fundaremos en aquellas consideraciones en las que los propios actores y creadores del fenómeno manifiestan su entender sobre la definición de lo que es dibujo, pero también tomaremos en cuenta el trabajo de una serie de pensadores que de dos décadas hacia acá señalan la necesidad de teorizar los fenómenos del arte desde la interioridad de su proceso y el pensamiento.

Trabajaremos sobre la base de que cualquier definición aludida en el análisis mantiene un 
carácter histórico referencial, el del contexto y las necesidades que la originan.

En la medida que alejamos una formulación del entorno en que surge, pierde su capacidad de construir sistemas útiles al análisis, estaríamos creando variables e interpretaciones a conveniencia.

Cabe aclarar que nos interesan las definiciones del dibujo como un pensamiento que delimita ámbitos de competencia, y no como un enunciado taxonómico de propiedades excluyentes. Esta visión ha generado la búsqueda de las definiciones de las artes basándose en sus cuerpos táxico lingüísticos. Creemos que la postura constructivista de Watzlawik, y Froester así como la complejidad de Moran ofrecen una visión epistémica que permite el análisis que aquí nos interesa.

Entonces, trataremos el corpus del sistema, su integración y reunión estabilizada, configurando una entidad que manifiesta características que se agregan a las de las partes por separado. Pero todo ello bajo la construcción artística de lo que hemos llamado el Pensamiento Proyectual del Dibujo.

Un primer giro del problema se decide así por una situación de estudio sobre las relaciones epistémicas y metodológicas en el interior de la disciplina del dibujo.

En segunda instancia compete analizar el estado del sistema a través de la historia del arte, buscando establecer cortes relativos, que sean entendidos como estados parciales de estabilización temporal en la concepción del dibujo, momentos en los que son más las características de semejanza que nos permiten hablar de lo que en nuestra segunda formulación llamamos los Modelos del Dibujo. Estos cortes temporales muestran también una relación diferenciada en relación con las demás artes en cuestión, consideradas estas a su vez como sistemas, que por supuesto son constituidos por un corpus más o menos estabilizado.

Intentamos un ejercicio reflexivo que nos permita encontrar puentes de relación y diferencia entre los dibujos de Leonardo, Miguel Ángel, Lomazzo, Zuccari, Carracci, Rubens etc. Pero pensemos también en dibujos tan distantes de aquel tiempo, como los de Dubuffet, o los de Antonio Saura, intuimos en ellos una distancia teórica y conceptual. Precisamente ése es el interés de este trabajo, el de aclararnos las diferencias generadas en ese devenir. Entendemos esta investigación como el análisis de una fluctuación de modelos teóricos estabilizados en un marco de temporalidad, estos definen el papel metodológico del dibujo, como disciplina proyectual, de prefiguración, representación y configuración de la imagen.

La epistemología como elemento de la filosofía se encarga de analizar la consistencia del conocimiento alcanzado y los procesos que lo originan. Estudia la estrategia que relaciona el fenómeno investigado con el sujeto que habrá de conocerlo. La epistemología extrae sus juicios lógicos en función de la correspondencia entre el sistema metodológico empleado y la postura que el conocedor asume frente a la realidad estudiada.

Una definición epistémica viene a ser entonces la reflexión en cuanto al sistema cognitivo mismo y su coherencia interna, siempre en relación al momento vivencial particular y a la actitud asumida por el autor, esto caracteriza consecuentemente la postura del sujeto en una esfera filosófica determinada. 
En la definición filosófica determinista la episteme condiciona el rango científico del sistema y sus resultados en conjunto, es curioso que el momento histórico del determinismo filosófico se corresponda con el ascenso de una estética naturalista en la pintura flamenca, tomemos por caso el trabajo de Van Ruisdael corriendo hacia una estética de lo sensible y subjetivo.

Hoy en día sin embargo se reconoce una raíz epistémica en las disciplinas artísticas, pese a que éstas no intentan alcanzar un conocimiento preciso y cierto.

En el caso del dibujo en concreto, al integrarse en un acto común el autor, el contexto, el cuerpo teórico formal de la disciplina y la obra en proceso de gestación, se formula por parte de los artistas; un constructo normativo que define los límites de pertinencia del sistema formal que se está usando, más allá de los cuales su rendimiento conformador de imágenes se desintegra.

Debido a estas causales nos interesa sobremanera el plano vivencial y experiencial del autor en el proceso de hacer la obra, como una parte sustantiva en la construcción del modelo dibujístico.

Surge aquí la necesidad de entender el método más allá de una postura rigidizante y lineal, es necesario comenzar a verlo como una serie de punteos que determinan una intencionalidad programática, pero que se flexibilizan en su aplicación práctica estratégica, creando así una extensión del conocimiento y anexiones al modelo teórico.

La enunciación de una posible independencia del discurso dibujístico, o bien de su autonomía epistémica, nos enfrenta al estudio de su definición teórica anterior. Exige de necesidad el esclarecimiento de lo que toca a su integración como parte del taxos de la teoría y forma plástica clásica y sus vínculos sistémicos con los demás campos disciplinares del arte. Nos demanda en la medida de lo posible el trazo de un organigrama imaginario de las disciplinas plásticas, en el que el dibujo siempre fue colocado como columna vertebral.

Resumiendo la formulación anterior; la definición del dibujante frente a la realidad y sus modelos, así como la metodología que ha utilizado para apropiárselos o representarlos no siempre ha sido la misma.

Como sabemos las construcciones teórico-formales creadas, deben en gran medida su consistencia, a las maneras metodológicas y a los instrumentos utilizados para capturar la información básica del proceso especulativo.

La dimensión constructiva del sistema formal del dibujo, en este caso, se encuentra fijada porque su propia teoría eidética y formal, determina una direccionalidad lineal, que opera en un sentido específico y no otro; a esto nos referimos al señalar la función del dibujo como campo de la representación y el proyecto.

En la función clásica del dibujo que opera hasta los movimientos integracionistas del siglo XX, la obra no antecede al proyecto, pero en los casos del arte posmoderno y en los conceptualismos como el de llya y Emilia Kabakov el proyecto es la fuente y parte continua del proceso como obra. Aún en este caso, el proyecto se origina de una región externa a la obra, y aunque la sola idea del proyecto contiene los elementos necesarios para ser una obra, esta se ajusta a una causalidad temporal imposible de invertir en su orden. Es así porque generalmente estas intervenciones neoconceptuales son determinadas en ra- 
zón del espacio geográfico, temporal e histórico social, constituido en contexto primario de la obra. Estamos hablando del vínculo que por siglos unió al dibujo como práctica de representación que formaliza en sus obras y procesos el vínculo del artista con el contexto aludido y en el que se halla inmerso.

Es esta una parte de nuestro planteamiento problemático, la operación del vínculo que se establece entre el dibujante y sus modelos o contexto y que se constituye en la base de la representación, aunque esta última categoría tenga que ser revisada y puesta en análisis.

De ahí en adelante la obra habrá de irse construyendo, conformándose de manera gradual, en la mente del autor primero, y después en lo concreto de la materia que la dota de presencia fáctica, o bien en la intervención inmaterial en un contexto dado.

Por una parte la inclusión de la categoría proyectual en el presente estudio obedece con precisión a la intencionalidad manifiesta en el espíritu del autor, para crear un sistema metodológico que le permitiera la planeación de la obra final, fijando cada una de sus etapas y dentro de estas, un grado de certeza cada vez mayor que le permitiera concebir la obra y realizarla en razón del proyecto.

Se requería poder visualizar la obra antes de enfrentar su construcción definitiva reduciendo el margen de incertidumbre.

Para hoy, es probable que este objetivo resulte en buena medida equivocado, pero a la luz del pensamiento renacentista constituyó toda una revolución.

Actualmente la categoría de proyecto tiene también un carácter flexible, se entiende como pauta estratégica, como centro de intención, pero que puede ser variado, cambiado y adaptado según el desarrollo y la construcción de la obra lo sugiera.

Pero en segunda instancia entendemos el pensamiento proyectual no sólo en su acepción procesual, es también para nosotros la posibilidad de concebir la obra en la región mental, determinar su completud y fundamento antes de la secuencia de acciones prácticas. El pensamiento proyectual es la posibilidad de pensar nuestra actividad y sus obras frente a su pertinencia histórica y como lenguaje, y ésta ha sido una de las facultades primordiales del dibujo.

El presente análisis tratará por tanto de la secuencia estratégica constituida a lo largo de siglos como sistema metodológico, ésta define la función del dibujo dentro de las artes plásticas y de cómo en si misma esta ruta estratégica es la expresión del autor y su postura epistémica. Esta habrá de conectarlo al Sujeto Modelo como parte de la realidad contextual, mediante la aplicación de una estructuración teórica de la forma que significa a su vez un modelo de pensamiento. Habremos de detenernos un tanto en esta circunstancia, la de la extensión de la categoría de modelo en el terreno del dibujo.

El fenómeno que estudiaremos inicia sus particularidades paradigmáticas con el pensamiento racional renacentista, dentro de la revolución general que animó la mentalidad humana en la Europa del 1400.

La aceleración de los procesos industriales y su gran crecimiento, trajo consigo una modernidad tecnológica que ordenó las cadenas productivas más allá del ámbito gremial, aceleró el proceso de especialización y división de los campos del conocimiento humano.

La expresión del fenómeno anterior al seno de la plástica se encuentra en la concreción 
de las disciplinas preicónicas, como es el caso de la geometría y la composición, o bien la perspectiva piramidal como degradación de las dimensiones reales de los cuerpos.

El común denominador de estos sistemas teóricos, es su existencia y postulación antes de las imágenes mismas. Cobran así su sentido como partes o eslabones de una cadena constructiva de la obra plástica y del proceso de la representación.

El dibujo en la Europa del mil cuatrocientos, mil quinientos, mil seiscientos y parte del mil setecientos, tiene en su teoría y método una buena parte de esta razón que antecede a la obra misma, aunque por otra parte sincrónicamente siempre estuvo integrado dentro de la acción ejecutante de la pintura.

Y ésta es una dinámica y función compleja que destacamos como cualidad de nuestra reflexión; el dibujo se desarrolló tanto como ejercicio proyectual en el momento de la concepción de la obra como en el tiempo de realización fáctica de la misma; además de ser un aparato para abordar la primeridad vivencial del artista y transformarla en experiencia formalizada sistemática.

Los tratados renacentistas de la plástica en 1430 ya mencionan con claridad los cuerpos formales integrantes de la pintura: la geometría, el colorido y el dibujo.

Por más de 150 años se discute entre artistas en cuanto a la supremacía de la escultura o la pintura, pero en lo tocante al dibujo siempre se está de acuerdo en su centro conceptual prefigurador y en su base como expresión del pensamiento abstracto, de ahí su carácter eminentemente platónico.

Tal como Leonardo, Miguel Ángel, Paolo Lomazzo y Batista Aguchi lo dijeran, era necesario saber dibujar para poder considerarse un artista cabalmente capaz.

Desde el tratado de la pintura de León Batista Alberti (1435) hasta los elementos de la pintura redactados por John Ruskin (1857) se dedica enorme importancia al papel del dibujo en la plástica.

El Renacimiento marca el inicio del ascenso del artista como centro irradiador de ideas, no solo como artesano. De manera paralela la pintura asciende poco a poco en un proceso de valoración hacia el centro de las artes plásticas.

Una episteme racionalista anima la mentalidad renacentista. Con el tiempo ésta desemboca poco a poco en la construcción de una cadena metodológica para organizar la postura del artista frente a la realidad en la que se inscribe, así como las maneras para representarla en la imagen.

Asomarnos a cualquier tratado pictórico del cuatrochento significa descubrir la complicada rigurosidad del pensamiento artístico de esa época y sus delicadas elaboraciones conceptuales.

En este complejo metodológico juegan un papel básico el plano experiencial y el de la observación como fuente de conocimiento. Dedicaremos a su análisis un espacio en el momento adecuado.

En la historia del arte occidental Leonardo da Vinci cabalgando entre dos siglos designa la pintura como un proceso mental. Lo mismo encontraremos en el ideario de Federico Zuccari en 1607 refiriéndose al dibujo, y así a lo largo de la historia hasta nuestros días.

Si el dibujo contiene un carácter ordenador del pensamiento y un potencial prefigurador, 
esto es lo que determina su función relacionante con las demás artes. Esta es una relación simbiótica entre la pintura, la escultura, el grabado y el dibujo y más tarde las Artes Visuales. Relación sumamente compleja y saturada de fluctuaciones teórico-formales.

El dibujo así concebido es una herramienta de representación y proyección, nos sirve para concebir el mundo en imágenes fortaleciendo nuestro pensamiento eidético.

Esta función epistémico metodológica comienza a ser atacada en el Romanticismo, sin llegar a una ruptura total.

De manera cada vez más frecuente ya no se dibujan bocetos de modelos concretos sino de la sensación subjetiva que el conjunto contextual produce en la mente del artista. 0 bien de aquellas distorsiones en la dinámica de la imagen que trastocan la sintaxis de la obra. El campo de lo histórico y mitológico representativo, cede terreno al de los valores plástico-dramáticos, variación que se origina desde el Barroco en su vertiente naturalista, como en Claude Lorrain.

Por esta segunda vía el dibujo varía en su condición proyectual y gana en la autonomía que alimenta su estructura conceptual. Si bien ya estaba aceptado el papel ordenador del dibujo en el plano del pensamiento desde la experiencia renacentista, pasarían cuatro siglos lo menos para poner el centro de atención específico en el acontecer del artista y ubicarlo como el territorio donde se concreta la intención pictórica y dibujística.

Los movimientos vanguardistas del siglo XX y dentro de ellos la obra de Van Doesburg, Mondrian, Kandinsky, Klee y muchos otros, construyeron un desplazamiento epistémico en cuanto a la síntesis del taxos formal de las artes visuales.

Los cambios sufridos por las artes plásticas en ese entonces fueron de $180^{\circ}$. Pero en el caso del dibujo esto habría de suceder de manera mucho más pausada. En su intencionalidad de fondo, encontramos una postura epistémica, en donde la forma estructurada por el autor, es producto de su intención racional y su sistema perceptual.

Dentro de este sistema se define claramente una secuencia metodológica: percepción, reflexión, proyecto, construcción.

Pero aquí interesa realmente señalar que si bien esta postura de los integracionismos fue radicalmente renovadora, varió muy poco la relación sistémica del dibujo con las artes de la imagen y el vínculo del artista con el contexto natural como referente de representación.

Esto se evidencia al analizar como el dibujo, en todo este viaje reforzó su condición proyectual, apuntalada ahora por categorías como las de observación, visualidad, gestalt, sintaxis de la imagen, pensamiento eidético y gramática de las artes.

En el siglo XIX el positivismo propugnó la utilización del método experimental como sinónimo del método científico, en estos modelos de pensamiento no solo se mantuvo sino que se reforzó una episteme proyectual prefigurativa para el dibujo.

La simbiosis pintura dibujo y su modelo proyectual, mostró por fin signos de variación radical a partir de la tercera década del siglo XX. Comienzan a aparecer dibujos que no sirven para planear obras posteriores; el rigor constructivista de la pintura se debilita y su ejercicio integra métodos de otras artes. 
Como ya dijimos líneas arriba, no existe un punto fijo para el origen de un concepto o postura, de manera que la relativización de la episteme dibujística que lo integra con las artes, se había iniciado ya en el siglo anterior. El rompimiento de la base fija como soporte compositivo y la ordenación de la materia de la obra con base en la búsqueda de una forma subjetiva y significativa, en oposición a la materialidad subordinada a la forma objetual, son postulados del dibujo romántico, con ellos se desplaza la concepción del dibujo del plano racional neoclásico hacia el camino subjetivo dramático de la forma, el trabajo de autores como Turner, Delacroix Gericault, Daumier y otros, muestran esta línea de ascendencia.

Poco a poco el dibujo al ser liberado de su función prefigurativa proyectual se convierte en un acto en sí mismo.

Todo aquello que sucede antes o después del dibujar disminuirá en relevancia, lo importante es aquello que acontece en el momento de dibujar.

Si por definición el concepto de composición implica un modelo estructural para medir la obra ¿cómo calificar obras que carecieron de un modelo compositivo inicial?

Actualmente la problemática atravesada por el dibujo y quienes lo trabajan, es parte de una sintomatología, que nos muestra como los paradigmas del arte visual actualmente carecen de respuestas para preguntas cada vez más numerosas.

El pensamiento racional renacentista proyectó su pináculo en la visión determinista enciclopédica del siglo XVIII, que en las artes; y dentro de éstas el dibujo, se expresa en el alto refinamiento de los sistemas plásticos al final de la teoría barroca de las artes.

Con los cambios del pensamiento científico, artístico y filosófico del siglo XIX se inicia una nueva revolución del conocimiento humano, la del relativismo antideterminista. La ciencia en varias de sus ramas causó un impacto fundamental en la mente de los artistas, éstos no pudieron sustraerse a los elementos metodológicos que las ciencias les ofertaron, no quisieron hacerlo y se dejaron seducir por estas posibilidades. Ese siglo fue un tiempo de revoluciones epistémicas (como muchos otros) en él, la ciencia marcó el proceder de los artistas, pero éstos en su agudo análisis del fenómeno y la realidad contextual, retribuyeron a la ciencia con un pensamiento que la colocó frente a disyuntivas que, entrando el nuevo siglo cambiarían la visión cierta y segura del racionalismo positivista y científico.

Los proyectos de la modernidad integracionista se expresan en las intenciones de crear un nuevo modelo social constructivo con las vanguardias de inicios del siglo XX.

Con la nueva construcción del taxos formal para las Artes Visuales se desplazó al dibujo de la función proyectual, abriendo un espacio de escisión. A mediano plazo esto posibilitó un salto de órbita, en donde el dibujo ya no operaría sobre su anterior función dentro de las artes, pero se habría de producir una manera de relación diferente y no menos sustantiva entre el dibujo y las prácticas artísticas de la modernidad expresionista abstracta e informalista.

Cuando el dibujo no pone el centro de su atención en el pensar para planear una imagen o proyecto, su peso específico se desplaza hacia la acción, de esta manera los aspectos de la ejecución se constituyen en un punto de gravedad importante. 
Así como el proyectar implica intelectualmente al autor, el trazar lo involucra, en el plano corporal y psíquico de la realización. Lo acontecido antes ó después de la ejecución del trazo pasa a un segundo plano aunque no desaparezca.

En una primera mitad del 1800 la ciencia dotó de rigor sistemático los procesos artísticos, mostró a los pintores y dibujantes una naturaleza que representaba una fuente de reflexiones y estructuras para la forma artística. Pero el arte y sus autores a su vez, mostraron a la ciencia que las aplicaciones deterministas del pensamiento, serían incapaces de explicar regiones y fenómenos de la realidad, la sociedad y el espíritu humano que se resistían a ser entendidos con precisión. Ahí se inscriben las lecciones del Romanticismo, el Naturalismo y el Realismo del XIX.

Más temprano que tarde, el arte de fines del XIX mostró la mentira de una ciencia de proyectos triunfalistas y precisos.

Pensamos que el carácter del método en la búsqueda del conocimiento, hoy cuando menos, reviste un carácter interdisciplinar, las fronteras que delimitan espacios de acción para la reflexión se desdibujan y se vuelven nuevamente permeables, incluso sería deseable una aceptación de cercanías buscadas, para establecer una solidaridad entre quienes se dedican a construir de alguna manera el conocimiento.

En esta investigación se considera un apartado en el que ubicamos el dibujo y su función proyectual como un centro complejo de gravedad que atrae recurrentemente el proceso estratégico de los artistas.

Esto nos orilla a la reflexión sobre la estructuración secuenciada de los planos de la representación, configuración y prefiguración en el dibujo. La misma categoría de proyecto será puesta en perspectiva desde un punto de vista flexible, que permita la ubicación de los distintos procederes del dibujo en la construcción del proyecto significante.

Haciendo un resumen, señalaremos que, en la presente investigación se consideran las distintas definiciones y posturas del dibujo como relativas al contexto que las genera, no intentaremos un ejercicio de unificación, veremos a través de ellas el ideario colectivo que las origina, sabiendo que su enunciación arranca de tiempo atrás y se relaciona con un cuerpo paradigmático cultural, que existiendo fuera del dibujo lo afecta.

De manera importante consideramos la obra dibujo como un sistema, el dibujo en tanto obra condensa una multiplicidad de momentos y pensares que atañen tanto a las intenciones de significación del autor como a las del ideario social.

Considerando la obra como un sistema, pasamos de una condición objetual determinista a una visión en la que el todo del dibujo se convierte en un proceso integrado por partes, que se pueden definir por sí mismas y por las características que asumen dentro de una nueva entidad.

Por lo tanto es fundamental tomar el dibujo como materia de análisis a manera de un proceso cuyo devenir muestra tendencias; en ocasiones más acusadas hacia una función proyectual y otras como un acto por parte del autor, sin la intención de construcciones posteriores.

Si consideramos el carácter del dibujo como pensamiento proyectual, y además ubicamos esta esencia dentro de una serie de fluctuaciones históricas, se hace necesario un ejerci- 
cio de flexibilización que se desplace de lo estrictamente metodológico a una postura que entienda la necesidad de lo estratégico como ejercicio de adecuación del método.

Reviste entonces importancia central el análisis y precisión de los momentos epistémicos y metodológicos que integran la práctica del dibujar. La prefiguración, la representación y la configuración bajo una estrategia proyectual.

El fenómeno que nos ocupamos en analizar implica a varios actores, hablar de dibujo es hablar de quien lo hace, de lo que éste piensa en el proceso del hacer, de los cambios que el objeto creado provoca en el creador, del ideario que permea todo los momentos y factores del proceso. Por ello hablaremos del dibujar, del dibujo, de los dibujos y del dibujante. La noción de modelo a la que intentaremos arribar será la del dibujo, o los distintos modelos del dibujo como expresión de los modelos del pensamiento artístico.

Consideramos también la necesidad de revisar el cambio de los modos paradigmáticos en el arte del siglo XX y su relación con el campo del dibujo. Señalamos la coincidencia con esos cortes históricos que otros autores analizan como el fenómeno del arte moderno y su paso a la posmodernidad, aunque mencionamos que nos mueven diferencias teóricas para el establecimiento de dichos cortes, y que dentro de este proceso no se han contemplado con amplitud sus repercusiones en el dibujo.

Ya desde aquí mencionamos que la llamada autonomía del dibujo no lo es tanto, entendemos esta situación más como una liberación de la función proyectual que el dibujo asumía dentro de las artes. La estrategia en las producciones del arte posmoderno apropiacionista se basa en una interrelación sígnica contenida en las imágenes tomadas como apropiación, el sentido de la obra es la reconstrucción, o deconstrucción de lo que cada imagen contenía como sentido significante, por eso es que el sentido de la búsqueda de nuevas formalizaciones de primera generación pasa a un segundo término en este proceder significante.

Así, esa autonomía es una consecuencia y no tanto una voluntad propositiva. Este es el punto en el que se ubica la hipótesis general de nuestra investigación.

¿La postulación de la autonomía del Dibujo dentro de las Artes Plásticas y Visuales, es consecuencia derivada de la ruptura paradigmática de los proyectos artísticos de la modernidad del siglo XX, frente a la emergencia de las estrategias de flexibilización y expansión de los campos disciplinares en las artes de las tres últimas décadas?

De ser así esta posibilidad no excluye la consideración del dibujo como un acto de representación, en el que se posibilita la apertura de los sistemas formales de representación vigentes dentro del campo del arte visual.

Hemos dicho que el análisis que intentamos se basará en una perspectiva epistémica endógena, tomaremos como centro de cruce los factores sistémicos y las causalidades del dibujo, para establecer seguidamente la relación con los demás elementos analíticos de la historia general del arte y el discurso de la crítica, sobre todo referidas a la disciplina que nos ocupa.

Nos basamos en la consideración anterior porque pensamos que el dibujo como praxis artística implica un cúmulo de factores en su interioridad que van desde la postura epis- 
témica del dibujante hasta las particularidades técnicas como vía de concreción de la búsqueda conceptual. Y porque entendemos los procesos de representación más allá de la directa formalización mimética del modelo que dibujamos. Mencionamos también la recurrente consideración del dibujo como columna vertebral de la Artes Pláticas, éste es un lugar común en la reflexión de la crítica, líneas adentro profundizaremos en ello, intentando aclarar con fundamento esta afirmación. Basados en lo anterior quedaremos en posición de exponer como en el proyecto de las Artes Visuales queda íntegra la capacidad proyectual del dibujo, pero su carácter central como base de los procesos de representación empieza a ser compartido con otras estrategias metodológicas.

La irrupción de la ola posmoderna en el arte, acarrea como consecuencia la liberación del Dibujo de su papel sistémico metodológico, lo pone en perspectiva de una aparente libertad para ser en sí mismo. Pero en las manifestaciones del más radical conceptualismo artístico se observan con claridad las funciones básicas del dibujo como prefigurador del proyecto artístico, si bien en una doble vía sincrónica el trabajo de los llamados artistas posmodernos llevan los factores sistémicos de la disciplina hacia una expansión interdisciplinar en la que se pueden rastrear sus componentes sustantivos, pero de manera trastocada por la esencia de unas artes que corresponden a nuevos terrenos de acontecimiento fáctico, el soporte del dibujo puede ser la superficie nevada en un bosque, como en Anillos anuales de Denis Oppenheim, o el firmamento del cielo neoyorquino en los dibujo de nube de Vik Muniz.

Con lo anterior quedamos en posición de continuar hacia un terreno más específico del problema, veamos de qué manera se suscita la historia enunciada.

\section{I-3 MODERNIDAD, POSMODERNIDAD. CITACIONISMO Y APROPIACIÓN}

Antes de dar paso a la reflexión sobre el tema de este punto, es necesario plantear varias precisiones.

La primera consiste en exponer que la modernidad entendida como el pensamiento artístico maduro de la cuarta década del siglo XX, tiene como antecedente la plástica que irrumpe con la revolución de los primeros abstraccionismos. Tomaremos como categoría definitoria el término Neoplasticismo, que como sabemos fue un movimiento de vanguardia que acontece sincrónicamente al Integracionismo. Van Doesburg, Mondrian, Klee, Kupka y una serie de artistas mucho más amplia formaron parte de esta corriente.

¿Por qué iniciar con una alusión a estos autores y a su pensamiento?

Porque consideramos que es necesario hacer una disección de aquello que en el arte se entiende como modernidad específicamente dentro del siglo XX, aunque no es nuestro centro de análisis el dilucidar este asunto, si es necesario plantear los cortes históricos dentro de este paradigma.

Dentro de la propuesta neoplasticista y en su tiempo, se encuentra el punto de giro que diferencia la modernidad de las primeras vanguardias de aquella que caracteriza los movimientos posteriores a la segunda guerra mundial, que son la irrupción plena de lo que la crítica posmoderna entiende como la modernidad desarrollada en la estética de Clement Greenberg. 
El término Neoplasticismo fue propuesto por los propios artistas que conformaron ese movimiento.

Lo que nos interesa destacar es el hecho de que la categoría de la Plástica permanece dentro del sistema teórico de este movimiento y sus autores. La Plástica en su definición clásica se entiende como la materia susceptible de ser moldeada, modificada por una serie de acciones encaminadas a darle forma. La Forma es el intento del artista por dotar a la materia de un sentido constructivo que la arranque del caos original.

Desde la concepción de la estética Pintoresca y Sublime del siglo XVIII, se suma a la concepción original de la plástica el sentido espiritual y dramático. Con el pensamiento naturalista se agrega la intención de dotar de sentido dramático a la forma organizada. Como habremos de ver en el siguiente capítulo la modernidad, filosófica y culturalmente se inicia con el proyecto racional, determinista y enciclopédico de la ilustración. Pero ya en ese momento la iniciativa del movimiento romántico agrega a la modernidad una intención subjetiva y espiritual que entra en conflicto con el proyecto ascendente y evolucionista. El siglo XIX es el tiempo de maduración de la postura plástico dramática, sobre todo en el Romanticismo y el Naturalismo. La poética de estos movimientos es la expresión de la materia conformada en un sentido dramático. Coincidente con ello en 1843 aparece la primera edición del libro Los Pintores Modernos de John Ruskin, en este texto se defiende por el autor la importancia de los pintores modernos por sobre los maestros de la escuela anterior, no es casual que Ruskin fuera el crítico que por excelencia apoyó la revolución pictórica de William Turner. Desde las primeras líneas del texto se posiciona la visión de Ruskin haciendo una traducción del paisaje hacia términos absolutamente formalistas y anicónicos, veamos la cita en cuestión.

"Cuando yo dejaba, hace algún tiempo, muy de mañana una ciudad de Suiza, apercibí entre las nubes, detrás de las casas, una montaña que no conocía, más admirable que todas aquellas a las cuales podría compararla... Se hubiese dicho que limitaba, de un lado, con un precipicio de una profundidad inconcebible, mientras que del otro se extendía, durante leguas, en un campo de hielo brillante, claro, puro y azul, arrojando resplandores de plata bajo el sol matinal. Experimenté al principio una impresión de sublimidad, que ninguna otra, motivada por un objeto natural, podría sobrepasar; un instante después vi que mi Alpe desconocido no era más que el techo vidrioso de una fábrica de la ciudad, dominando las casa vecinas, y a la cual el humo azulado de la madera, saliendo de las chimeneas intermedias, daba un conjunto vago y etéreo." ${ }^{4}$

Con esta postura se llega al inicio del siglo XX. Retomando el hilo de nuestra reflexión, es en este punto en el que la concepción Neoplasticista irrumpe, el propio concepto con el que los artistas denominan a su movimiento contiene el carácter plástico, pero ya los propios artistas se encargaron de llevar esa postura hasta el límite. El mismo Mondrian reflexiona ampliamente sobre la necesidad de sentar las bases de una pintura que se despoje del ropaje del sentimiento dramático, para él, los sentimientos penetrando la naturaleza nublan la verdadera visión de una plástica nueva.

El Neoplasticismo, el Integracionismo, y en general las primeras vanguardias anteriores a la segunda guerra mundial logran el giro que postula el lenguaje visual y la gramática de

4 Ruskin John. Los pintores modernos. Argentina: Ed. Labor; 1953. P. 7. 
las artes como superación del paradigma plástico. Por eso decimos que la modernidad última, la del Informalismo, el Expresionismo Abstracto, la de Greenberg y su pensamiento son el corolario de un proceso en el que las artes de la imagen se colocan en perspectiva para la ruptura posmoderna.

Con estas relaciones históricas y formales intentamos trazar la ruta del ascenso de la modernidad.

Ya hemos dicho que nuestro arco temporal de análisis es un tanto más dilatado de lo que comúnmente se utiliza, por eso es que las relaciones a las que aludimos abarcan este trazo histórico.

Parecería que el dibujo desaparece de nuestro pensamiento en este análisis, pero no es así, creemos necesario establecer una puntualización mínima del desarrollo de la modernidad como asunto de las artes, en particular de la pintura y el dibujo. Por ahora solo diremos que dentro de este proceso el dibujo y su relación con las Artes Plásticas y más tarde la visualidad, se mantiene en términos de su función prefiguradora y proyectual, pero en lo referente a sus procesos de formalización y sus rutas metodológicas vive a través del pensamiento de los artistas un variedad riquísima de aportaciones a los sistemas de representación, al revisar los modelos del dibujo a lo largo de la historia habremos de profundizar en ello.

El proyecto de la llamada modernidad en el arte del siglo XX que comprende de 1940 a 1964 (aunque la crítica posmoderna lo extiende hasta 1978, Krauss, Kuspit, Danto) opera sobra la base de una concepción de la estrategia totalmente diferente a la del arte plástico anterior. Todo el tramo de la modernidad del XX ha sido considerado como un proyecto de esencia estética y formalista. Esto quiere decir que la búsqueda de sus absolutos se concretaba en la consecución de una forma o sistema, en el que se compendiaban las aspiraciones estéticas y filosóficas del artista.

Hasta los cambios introducidos por Kandinsky, Paul Klee, Mondrian etc. La pintura no se había desprendido del todo de la narrativa histórica como centro temático, tiempo, figura, composición y forma parecían una unidad imposible de separar. El modernismo hace de este punto su centralidad. Se pone en la tarea de construir un sistema de representación en el que la imagen no alude a un referente externo a la pintura misma.

Pero en este punto recordemos que tanto la estrategia de Kandinsky como la de Mondrian guardaron similitudes interesantes. Ambos llegan a la abstracción total mediante un proceso secuenciado que diluye poco a poco la similitud del referente inicial con la forma de la pintura y los dibujos finales. La serie de las acuarelas que Kandinsky realiza sobre los pianos de cola y la de Mondrian sobre sus árboles frutales son claras en ese proceso. Ejemplifican también como los cambios creados en el campo de la disciplina surgen de su propia interioridad. Fig. 1

Generalmente se define el proceso de Kandinsky para llegar a la abstracción con un carácter subjetivo y espiritual, en tanto que el trabajo de Mondrian es cualificado como una vía purista y racional que desemboca en el Neoplasticismo. En parte así es, pero esto no contradice las consideraciones que arriba apuntábamos.

No es el arte en general el que se vuelve el tema de la pintura. Desde 1900 y hasta 1945 la revolución abstraccionista se dirigió en el sentido de un lenguaje general de la visualidad, pero con el Informalismo y el Expresionismo Abstracto dentro del dibujo y la pintura se inicia una ruta diferente. Nuevamente se piensa en términos de lenguajes diversos de 

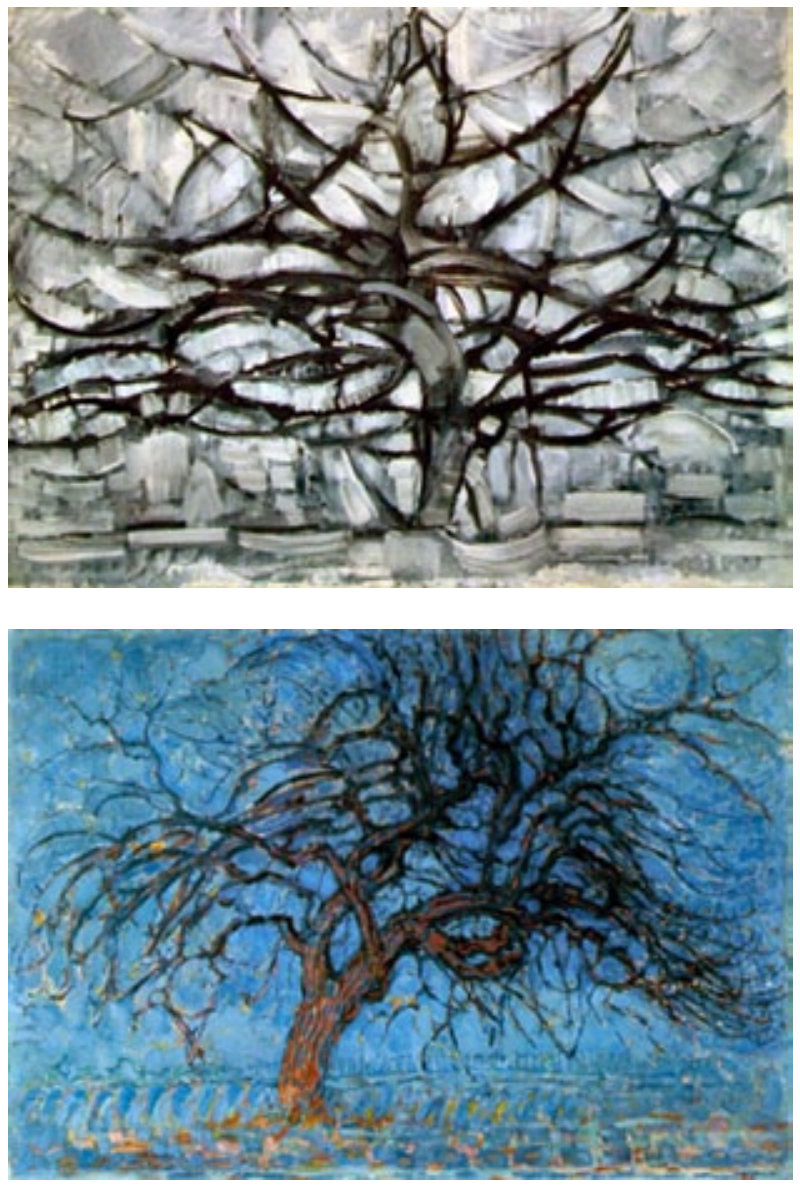

Fig. 1 las artes y de campos definidos para cada disciplina.

En la modernidad el lenguaje de la pintura y el dibujo se constituye en la razón de ser del propio proceso de representación. Se da como resultado de un cambio en el que la pintura y las artes miran hacia su interioridad, con el inconsciente del artista como guía estratégica. Danto lo señala como el camino del arte alejándose de la naturaleza contextual (que por otra parte hasta ese entonces fue el origen del proceso de representación) dirigiéndose hacia la pureza tautológica de su ontología, ya fuera como proceso artístico o como formalización representacional.

Los primeros abstraccionismos puristas y neoplásticos del XX formularon el lenguaje y la gramática de la visualidad, esto fue claramente un ejercicio de plegamiento retroactivo del lenguaje, pero la etapa de la modernidad siguiente no hace hincapié en una tesis gestáltica de la vi-

sualidad. La concepción de la visualidad de Greenberg se desplazó hacia el entendimiento genérico de las particularidades de la pintura como entidad ontológica. Tal concepción se originó al observar el centro de interés de los nuevos artistas orientado hacia la explotación del lenguaje de los territorios de cada arte, con la cualidad de abandonar el relato histórico dentro de la obra, constituyendo la interioridad del campo y su estructura el nuevo relato de la pintura.

El artepurismo neoplasticista, se prolonga en la visión modernista del 1944 generando como consecuencia el establecimiento de los campos disciplinares del arte plástico visual y la formulación del lenguaje de las artes; que no el de las leyes del lenguaje visual.

Todo esto constituye el núcleo teórico del trabajo crítico de Greenberg, será desarrollado por el autor a lo largo de tres décadas, aunque su trabajo se prolonga hasta los años 70' del siglo XX. "Vanguardia y Kitsch", "Towards a Newer Laocoon", "La crisis de la pintura de caballete" y "La pintura moderna" fueron artículos publicados y que sentaron las bases del pensamiento y la estética de la modernidad.

Al originar la obra y su proceso en fuentes que no partían de un modelo natural se logró 
una estructuración interna radicalmente distinta.

Estos procesos de producción integraron definitivamente lo aleatorio e impredecible como generador de los procesos de formalización, esto fue posible ya que al no partir de un modelo externo, no se contaba con estructuras de ese modelo que fueran las causales de las formas construidas, por lo tanto las partes y formas usadas no contenían una relación estructural que no fuera la que se iba presentando en el suceso configurante.

Con todo esto la pintura moderna se organiza partiendo de las categorías de Orden vs. Lo Aleatorio y accidental.

Dado que los grafismos y construcciones resultantes no son producto de una mímesis o estructura de los modelos naturales se les puede entender como la expresión indexal de la acción corporal del artista, describiéndola como el universo de la ejecución en el que la gestualidad cobró relevancia.

La huella indéxica en estos casos, mostraba tanto las acciones del trazo como el estado mental y emocional del artista.

Georges Mathieu entendió esta forma de pintura dividida en dos vertientes, una cósmica en la que el espacio genera estructuras y composiciones no relacionales con el plano soporte, y otra sígnica, en la que domina la creación de formas sígnicas. Entendió esto como una pintura lírica bajo tres categorías, la ligereza de ejecución, la ausencia de premeditación de las formas y los gestos y la necesidad de un segundo estado de concentración. Lo político de la postura de los artistas del Expresionismo Abstracto consistió en mantener su proceso al margen del proyecto histórico social, en tanto que el movimiento Informalista en Europa siempre se situó como una reflexión filosófica del arte en relación con su pasado y presente histórico.

Pero para la mayoría de estos artistas el acto de pintar es una experiencia vital en sí misma, un modo de vida.

Pollock decía estar dentro de la pintura en el momento de realizarla, él y muchos otros afirmaban esto, no sólo por estar físicamente dentro y sobre la superficie de la pintura, sino por entender la pintura como un campo abstracto, no literal sino experiencial, del que Pollock decía que era una arena en la que se suscitaba el evento. De ahí que Harold Rosenberg observara como la diferencia entre la vida y el arte se había disuelto, ya que el pintar era un fragmento de la vida del artista en sentido estricto.

Las producciones del Informalismo y el Expresionismo Abstracto decantan el viaje del dibujo y la pintura como sistema indexal, esta postura se prolonga y refina hasta el trabajo de artistas como Morris Louis, Kennet Nolan o Frank Stella en la Abstracción Pospictórica y en los conceptualismos italianos de Niele Toroni y Piero Manzoni.

En los procesos de semiosis el índex se puede entender como la huella directa y física que es producto de la acción, en ella leemos el carácter sígnico indicial. Así esta pintura y dentro de ella el dibujo nos revelan de modo nítido el proceso y las acciones del autor en el acto, nos enfrentan también a la personalidad matérica de los componentes empleados y al sentido cualitativo que el dibujante les confiere; podemos leer en ellas también la marca de la herramienta en su ejercicio de apertura que la separa de la tradición. La huella nos revela finalmente el estado psíquico del ejecutante y el sentido emocional que busca despertar en el espectador. 
Hasta antes de esos años (1940) la pintura pasaba por una etapa de prefiguración, un estado de planeación, bocetaje que no era sino una existencia mental previa a la obra terminal; posterior a ese momento, el peso fenoménico del hacer la pintura se preocupó por reducir el momento prefigurativo y centrarse en el de la configuración sin un proyecto previo, cuando menos en el sentido gráfico y compositivo, aunque en este caso el proyecto previo se desplazaría al terreno de la estrategia técnica ejecutante en tiempo real, sincronía de pensamiento y acción retroactiva.

Una de las aportaciones de los artistas que operaron dentro de las vanguardias del XIX y del XX, y que posteriormente Greenberg tomaría como base de su análisis, consistió en la sustitución temática, en el despojo de los historicismos narrativos dentro del cuerpo de la obra, en la que ahora las ideas y conceptos de la pintura serían ubicados como eje temático, lanzándose claramente al entendimiento de la pintura y el dibujo como formas de lenguaje. Con esto queda listo el camino para plantear la forma como el contenido mismo del arte, superando así la vieja contradicción hasta ese entonces insalvable.

El pintor moderno para Greenberg, analiza y explora los fundamentos de la disciplina en la que opera, lo hace para consolidarla en su definición ontológica, esto realizado con los recursos de la propia disciplina, logrando un resultado de depuración del lenguaje. En este supuesto se funda el pensamiento de la vanguardia moderna que se orienta hacia la consecución del absoluto de las artes.

El absoluto como base del proyecto del arte corrió hacia el establecimiento de los caracteres propios del campo en cuestión, como ya lo hemos mencionado, para Greenberg, en el caso de la pintura esos parámetros irreductibles consistían en: La superficie plana, la forma del soporte pictórico, las propiedades del pigmento, la pincelada, el color en su forma primaria y la textura homogénea.

Dentro de este universo de conceptos podemos decir que significan una reducción y generalización inteligente del carácter de la pintura para ese momento, coincidiríamos con ello, pero señalamos el hecho de que se norman por un pensamiento técnico y formal, en ellos no aparece la importancia del acto de ejecución, que por otro lado ya era práctica sustancial en el hacer de esos artistas, tampoco parece que se observe la importancia del dibujo como disciplina que soporta y da potencia tanto a los resultados de las obras como a su dinámica estructural de configuración.

Para el pensamiento de los artistas modernos, desde el Informalismo y el Expresionismo Abstracto el tema icónico e histórico requería de una habilidad mimética y configurante, por eso su búsqueda se centró en la superación de ese problema. Para ellos, al buscar la pureza del campo pictórico se debía explorar en la consecución de los medios expresándose como tales. Frente a ese proyecto el material mostraba una resistencia a la conformación de la idea y el ser físico de la pintura, de ahí que el dibujo mantuviera su carácter eidético configurante aunque lo dibujado careciera de asociación mimética.

Esta situación aunque complicada para el análisis nos resulta esencial.

Si la configuración de la obra se alejó de los referentes icónicos y objetuales, y si se buscó la pureza de la expresión de los medios, entonces la función del dibujo cambió radicalmente, mímesis y representación asumieron un nuevo giro, el dibujo se subsumió 
en el proceso y la acción pictórica, adquiriendo con ello una dimensión exponencialmente dilatada, aunque paradójicamente, y al contrario de la pureza del campo buscada, lo que se dio fue desde nuestro punto de vista una integración entre la pintura y el dibujo, una fusión transdisciplinar, como suele haber pocas en la historia del arte. Fusión que alcanzó en gran medida al dibujo, la escultura y la gráfica. Por otra parte el ejercicio de la representación se desligó de una función mimética que buscaba hacer presente la realidad, para convertirse en un acto cuyos móviles, estrategias y resultados formales constituyeron el cierre circular de un nuevo entendimiento de la representación, el binomio mímesisrepresentación adquirió un nuevo carácter epistémico y formal.

Todo esto no puede ser un trabajo sencillo y general, dado que es un plegamiento del lenguaje, un ejercicio de retroacción; la forma de la forma, y esto sólo es posible en función de las consideraciones conceptuales que constituyen el corpus de cada campo artístico. Así la reflexión inaugurada en la modernidad es la de la pintura pensando su forma de ser pintura, la del dibujo retrotrayéndose en la reflexión de la formas de su lenguaje y la del dibujo integrando su huella indéxica consustancialmente en el proceso y resultados formales de la pintura y las demás artes.

Muchas de estas circunstancias se prolongan hasta el final del periodo de la modernidad y su relevo dentro de la Abstracción Pospictórica. En alguna medida es así, pero algunas situaciones requieren ser puntualizadas.

Aunque en un momento posterior regresaremos a ello, precisemos que la ruta de la abstracción en las tres primeras décadas del XX se encamina a la formulación de un lenguaje de las artes visuales, como ya lo mencionamos, se advierte que la construcción de categorías y un taxos lingüístico no obedece a las anteriores divisiones compartimentales de las Artes Plásticas y se mira claramente que éste es un trabajo que generaliza el total de los campos artísticos, de ahí que más tarde se hable de Artes Visuales como aquellas que comparten similitudes antes no reveladas. Pero en general el pliegue del lenguaje del arte para remitirse a sí mismo, se proyecta como un nuevo paradigma de la modernidad. Así lo advirtió Danto al recordar las palabras de Clement Greenberg en su ensayo sobre Pintura Modernista de 1960.

"La esencia del modernismo descansa en mi opinión, en el uso de los métodos característicos de una disciplina para la autocrítica, no para subvertirla sino para establecerla más firmemente en su área específica"5

Pero si bien los integracionismos y la modernidad que les siguió fueron movimientos de formalización anicónica, la esencia teórica y estructural de ambos guardó distancias radicales; el Integracionismo finalmente se originaba en una reducción formal representativa de la naturaleza y los modelos referenciales, mientras que la modernidad de 1940 rompió ese vínculo milenario, además de que sus artistas no buscaron el establecimiento de un sistema paradigmático y categorial de leyes y conceptos explícitos para las artes y sus campos. Esta fue una de las causas que originaron la dispersión de una teoría integral.

El pintor y dibujante moderno no tomó imágenes ni fragmentos de la realidad y la historia del arte para reintegrarlas en su obra. El pasado se filtraba en su conciencia como

5 Danto Arthur C. Después del fin del Arte. España: Ed. Paidós; 1999. 
experiencia que tenía que ser asimilada para trascenderla. La búsqueda de la forma artística nueva es un paradigma de la modernidad. Una de sus secuelas inmediatas fue la comprensión de que si el lenguaje hablaba del propio lenguaje entonces era posible el establecimiento de una Pintura-Pintura, una pintura pura, que por extensión colocó a los demás campos del arte en la ruta de una autonomía, aunque esta posibilidad fuera mucho más difícil de ser lograda que visualizada. Vemos de esta manera con claridad la contradicción existente entre el proyecto de la modernidad tardía frente al impulso integracionista de inicios del XX.

A este terreno habremos de retornar para pensar con claridad la mecánica y posibilidad de la existencia del dibujo como un campo disciplinar en sí mismo.

Lentamente los pintores construyeron un nuevo capítulo en el devenir del arte, esto dio forma al proceso que llevó la pintura y con ella al dibujo hacia puntos cada vez más distantes de la imagen mimética representativa, en términos del pensamiento posmoderno.

Desde Turner hasta los pintores cubistas la pintura se interesó en el potencial de las formas como constructoras de realidades varias para la imagen, se hizo conciencia y claridad en el hecho de que la naturaleza y la realidad podían ser interpretadas con formas que no les eran similares y miméticas, pero que de manera extraña seguían permitiendo su asociación visual. Éste es el punto entendido por Greenberg como premodernidad. Fig. 2

No se trató sólo de la capacidad del artista y su potencial creativo, las posibilidades que se abrieron al arte fueron consecuencia de una cadena formada por eslabonamientos
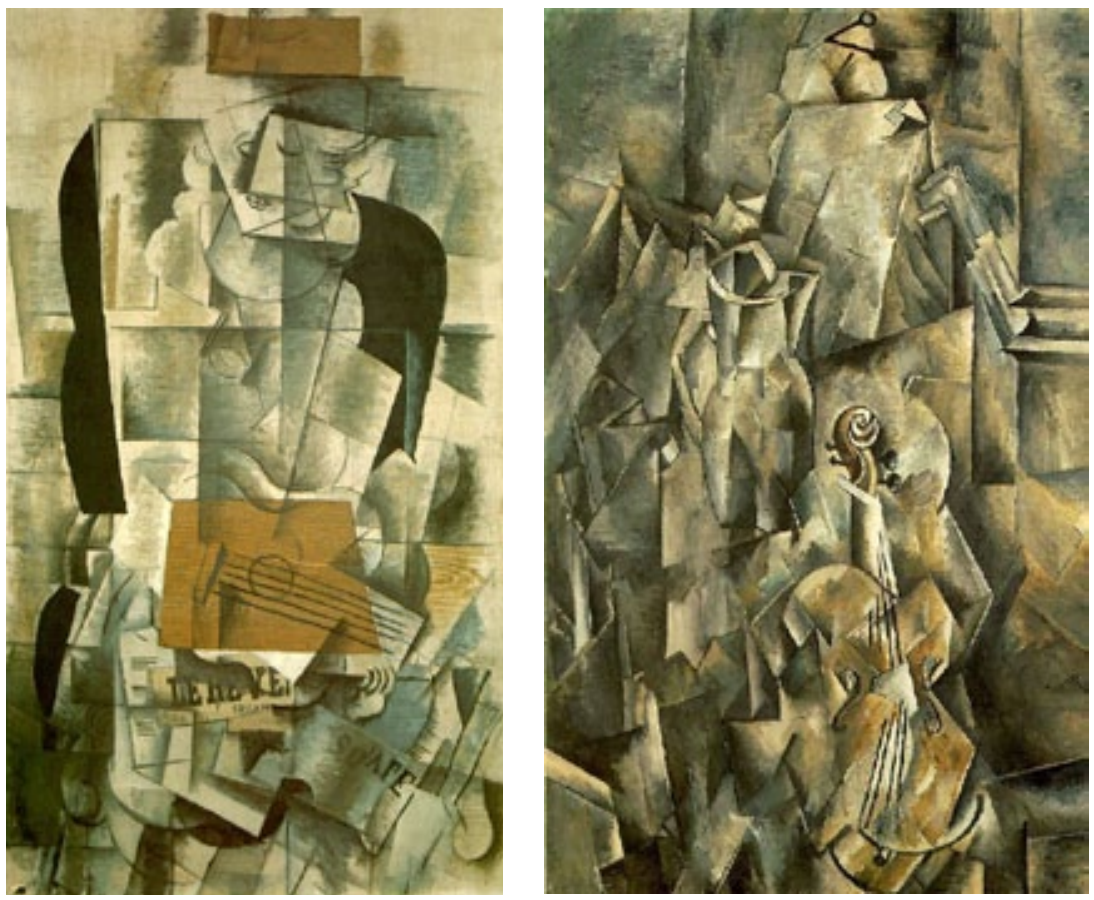

Fig. 2 Georges Braque. 
secuenciados, la pintura vanguardista del XIX sólo pudo ser pensada y concretada en ese momento.

La diferencia básica señalada por Greenberg descansa en el abandono de la primacía que une el referente con su igual en la forma de la imagen. Para él, despojar la pintura de sus rastros miméticos es en buena medida el carácter de la modernidad pictórica.

Ya sea por la influencia de la imagen fotográfica y su sombra en la pintura y el dibujo del siglo XIX, o por las razones que fueren, el resultado de este proceso significó una ruptura fundamental. No hablamos sólo de trastocar los órdenes de las estructuras del dibujo y la pintura, nos referimos a esa nueva visión requerida para relacionarse con esas obras. El ojo humano a lo largo de treinta mil años de historia fue conformado culturalmente en una línea de lectura. Con la aventura de Cézanne y luego el Cubismo el ojo y el cerebro humano hubieron de modificar su propia gestalt.

Fue aquel un cambio radical en la manera que la pintura y el dibujo representan el mundo, esto trajo como consecuencia un tipo de conciencia diferente.

Decimos entonces que los cambios aludidos recaen en el terreno epistémico definido por el artista. Éste deja de pensar en la naturaleza como el modelo ideal, en su lugar, se permite a si mismo pensar en estructuras subyacentes, que en lo profundo de los modelos determinan su apariencia externa; por otra parte cada vez era más consistente la idea de que las artes constituían un campo de pensamiento con sus propias formalizaciones, no las de los modelos objetuales. Estas razones fueron las que impulsaron la búsqueda de órdenes formales de representación en las artes como signo de la vanguardia y origen de los Ismos. Dentro de esta situación el dibujo desempeñó una labor esencial, pero cabe señalar que esto lo hicieron los artistas sin trastocar radicalmente las funciones sistémicas que unían al dibujo con las demás artes.

Tomemos como ejemplo los dibujos de Cézanne, en ellos se advierte su intención estructural, son análisis constructivos que intentan la adaptación del modelo natural hacia formalizaciones, basadas como él mismo lo dijera, en el cono, el cilindro y la esfera. En sus dibujos como en sus pinturas en proceso y aquellas terminadas, se logró una construcción modulada de la superficie, tanto del cuadro como de la forma acabada de la imagen. Eso lo sabemos y ha sido revisado suficientemente. Pero en ese proceso, se mantuvo íntegra la relación sistémica proyectual del dibujo con la pintura. Queremos decir que el dibujo siguió operando como función proyectual de la obra terminal, pero también como tiempo reflexivo de la construcción mental de estructuras alternas en la plástica, formas y procesos nuevos de representación.

La lección cubista como sabemos es base fundamental en el proceso de cambio del arte, ya arriba señalamos el calibre de esta revolución, en ese viaje el dibujo enriqueció potencialmente el logro de ese objetivo. Como gestor de estructuras de representación mantuvo su relación sistémica, pero ésta misma no fue objeto de cambios radicales tampoco en ese momento.

Estas veredas reflexivas no podían ser recorridas anteriormente, y fue así porque simplemente no estaban trazadas en la mente del artista. Hasta ese punto pudo ser replanteada la relación que guardaban los artistas con la realidad y la naturaleza como fuente de representación. Una vez que el camino quedó claro a los ojos del artista le fue concedido un plano de conciencia alterna. 
Por eso nuestro interés profundo no radica en la búsqueda de características formales semejantes, se ubica en la intención de analizar los órdenes de intención que subyacen en el ejercicio del trabajo de realización artística y como éste se diferencia en el trayecto de la premodernidad, la modernidad y la posmodernidad.

El pensamiento moderno dentro de las artes se basa claramente en la universalidad temática, en los asuntos que competen filosóficamente a todo el género humano, y en la ejecución heroica de la pintura y el dibujo, en el proceso que reviste un alto grado de dificultad y sacrificio para concretar la pintura y dibujo absolutos, no como definición filosófica solamente sino como concreción del pensamiento formal innovador, y subrayamos esto último:

Para nuestro entender, la modernidad en el terreno del arte, específicamente del dibujo, define su frontera hasta el momento en el que se conserva la intención expresa de una representación, pero más allá de la mímesis, proceso que intenta una consecución de estructuras formales eidéticas de primera generación. Por esto es que ubicamos como planteamiento problemático nuestra consideración de que, si bien la pintura y el dibujo rompieron la relación milenaria que unía mímesis y representación, esto sólo dio paso a una extensión de la categoría de representación, dado que el dibujo de ese momento logró cristalizar procesos y acciones de representación así como repertorios icónicos formales nuevos.

Para finales de los años setentas se gestaba sin embargo una nueva condición del arte y del dibujo; la mayor parte de los artistas del Expresionismo Abstracto, del Informalismo y de la abstracción pospictórica declinaban o comenzaron a morir.

Por otra parte el contexto social y cultural de los ochentas vivía el fracaso de los proyectos triunfalistas de la modernidad. Las condiciones culturales en el sentido más amplio fomentaron una nueva ruptura de paradigmas, lo moderno comenzó a ser cuestionado.

En palabras de Donald Kuspit, uno de los factores que conllevan al descrédito de las prácticas disciplinares modernas es el arribo de la vulgaridad temática y de las imágenes penetrando el campo del arte y la pintura. Los temas de la vida comercial, que no es lo mismo que la vida cotidiana, irrumpen haciendo del arte un terreno en el que se prolonga el sentido de una sociedad relajada.

"El arte ha sido sutilmente envenenado por la apropiación social, es decir, por el hincapié que se hace en su valor comercial y su tratamiento como entretenimiento de alto nivel, lo cual lo convierte en una especie de capital social. Cooptado por lo vulgar, pierde lo que tiene de vulgar. También lo ha socavado la creencia de que para ser artista todo lo que uno tiene que hacer es tener un -concepto- lo cual sugiere que el concepto de artista, lo mismo que el de arte, ha dejado de tener un significado claro. Por eso es por lo que tantas personas se tienen a si mismas como artistas, pues todo el mundo, al fin y al cabo, tiene un concepto favorito, especialmente de alguna persona, algún lugar y alguna cosa que conoce."6

El pensamiento posmoderno asume la centralidad de un sujeto expectante y receptor de la propuesta artística, como lo menciona Juan Martín Prada en su texto La Apropiación Posmoderna ${ }^{7}$ Este sujeto es condición unitaria y terminal, es el que cierra el círculo de sig-

6 Kuspit Donald. El fin del arte. Madrid: Ed. Acal; 2006. P. 15.

7 Prada Juan Martín. La apropiación posmoderna. Colección Arte. España: Ed. Fundamentos; 2001. 
nificación de la obra al mirarla y pensarla desde su propia subjetividad. En la reflexión de este espectador opera la estabilidad que relaciona signo, significado y connotación. De ahí que la estrategia posmoderna del arte busque la fractura de este vínculo partiendo de la estrategia citacionista y apropiacionista. Cabe aquí una cita de Allan Kaprow.

"Durante la reciente era del análisis en la que la actividad humana era vista como una pantalla de humo que había que disipar, las explicaciones y las interpretaciones funcionaban. Pero hoy en día las mismas artes modernas se han convertido en comentarios y quizá predicen la era postartística. Comentan sus respectivos pasados; por ejemplo, el medio de la televisión comenta el cine; un sonido en directo producido a la vez que su versión grabada comenta lo que es real; un artista comenta los últimos movimientos de otro; algunos artistas comentan el estado de su salud o del mundo; otros comentan el hecho de no comentar (mientras que los críticos comentan todos los comentarios tal como yo estoy comentando aquí)". ${ }^{8}$

La modernidad se basaba en la solidez de la razón total como el fundamento de las prácticas de la vida. Esto requirió de una serie de regiones de lo artístico en las que este objetivo se concreta. Dentro de ellas la figura del autor como sujeto sustancial, el contenedor que llevaría implícita la voluntad rectora, el principio de autonomía inherente al sujeto que reflexiona el proceso y asume la ruta estratégica y de configuración.

La posmodernidad imaginó una situación en la que el autor de la obra no fuera sino una parte incluida como función del discurso, en clara oposición a la postura moderna del gran artista, el monstruo sagrado.

Nosotros pensamos en un autor dibujante que se constituye en un espacio vivo, región psíquica y pensante, afectada por la subjetividad interna, bajo este carácter lo definimos como un espacio de cruce en el que las funciones formales y de representación, tanto como el ideario cultural e individual se recombinan de manera compleja y un tanto aleatoria hasta lograr la consistencia de un pensamiento que se explicita en el logro del objeto dibujo. Así el sujeto cambia su condición de ser, hacia la de un espacio contextual específico, en el que el tiempo de la historia y el del dibujar se manifiestan en la acción de representar el mundo y configurar la obra.

Cabe aquí una cita de Juan Martín Prada coincidente con lo que mencionamos.

"La dualidad entre sujeto y objeto que permea la objetividad de tanto pensamiento occidental es sólo un impedimento para un verdadero acercamiento al yo... Puesto que el arte existe en el contexto y como contexto, puede configurarse como herramienta una crítica no sólo en la actividad autorreflexiva sino también en la liberación de las restricciones de la moda, gusto y de los dictados de las estructuras sociales dominantes"9

Queda claro entonces que el autor como espacio de cruce es en parte una manifestación interiorizada del contexto que ejerce presión en él, pero es también el espacio en el que la voluntad de ruptura emerge, esto bajo la búsqueda de manifestaciones formales significantes alternas.

8 Allan Kaprow. Ensayos sobre el desdibujamiento entre el arte y la vida. Berkeley: Universidad de California Press; 1993. P. 108.

9 Prada Juan Martín. La apropiación posmoderna. Colección Arte. España: Ed. Fundamentos; 2001. P. 128. 
Llamamos a considerar esto como un asunto sumamente relevante, dado que el sujeto se constituye en espacio de cruce y cuestionamiento del contexto, pero también en alguien interesado en la concreción formalizada de dicha actitud.

Cuando las artes, y dentro de ellas el dibujo y la pintura se internan en la acción misma del suceso al hacer la obra, y cuando el acontecimiento en sí, cobra relevancia, frente a la prioridad del objeto acabado, se inicia un camino donde se pondera al artista como un ejecutante. El acto de la representación deja de ser algo negado al espectador y se convierte en parte estratégica del proyecto. La propuesta del fluxus y el situacionismo se desprenden de esta línea de origen.

Al considerar los actos mediante los cuales se generan la pintura y el dibujo, en igualdad de importancia y capacidad discursiva se da paso a una nueva postura epistémica por parte del artista. En este proceso se cobra conciencia poco a poco de que no sólo la acción reviste importancia fundamental; todas y cada una de las partes del discurso constitutivo de la producción artística serán sometidas a una revisión radical. Sin embargo pensamos que esta revolución no surge sino de la interioridad de la propia dinámica de los movimientos artísticos de la modernidad.

En los accionismos que se suceden con la irrupción posmoderna se encuentra la huella de la experiencia del informalismo y el expresionismo abstracto. No creemos que sea solamente una nueva lectura que podamos hacer de esos movimientos, ni una posibilidad hermenéutica. La potencia de esos pilares estratégicos descansa sobre la base del pensamiento de los propios artistas, es a ellos fundamentalmente a quienes debemos ese capital metodológico, independientemente de las comprensiones teóricas que de ello podamos desprender.

Bajo esta postura epistémica, quizá la posmodernidad no sea tanto una ruptura con la visión moderna, sino el siguiente estado de estabilización de un sistema de pensamiento artístico que como siempre contiene dentro de si una capacidad reconfigurante. El incremento de las inconsistencias entrópicas del arte en la modernidad termina por llevar a sus producciones y artistas junto con sus críticos y pensadores a un estado de inestabilidad en el que irrumpe una diáspora estructural de los campos del arte, pero como todo proceso estocástico, y como todo sistema complejo; dicho momento de crisis no es permanente, dentro de él se manifiestan las tendencias a una nueva estabilización del proceso; si bien ésta no debe ser entendida como una superación o mejoría del estado de cosas, como en algún momento lo entendió el pensamiento integracionista de la modernidad del XX.

Pensamos en cambio en una modernidad re-formada, cuyo arte no es sino el nuevo estado de integración del pensamiento de sus autores. Es necesario recordar que el pensamiento de los artistas no es sólo una serie de afirmaciones excluyentes, como se nos ha querido hacer ver; es más bien una adición de negaciones, afirmaciones, correcciones, traslaciones, aperturas y cierres que resultan ser el móvil epistémico del fenómeno. Situación que no dudamos es más loable que la ausencia deseada de todo sistema, sea porque jamás la ausencia de propuestas estructurales ha sido causalidad instituyente de nada, y si por otra parte, la formulación de representaciones formales sienta las bases de un proceso que nos posiciona con respecto a sus partes, objetivos, esencias y pertinencia. 
De ahí que la práctica artística posmoderna, basada en la recuperación historicista o estilística de fragmentos de los códigos artísticos, para refuncionalizarlos en una práctica crítica, si bien es una postura epistémica sólo alcanza para fundamentar una ruptura crítica, mas no una reestructuración de los sistemas.

Ya con la aseveración de Pollock, en el sentido de que él no representa la naturaleza, sino que, él, en su accionar es la naturaleza, y con el trabajo de Newman que no alude sino a criterios formales que no guardan referentes objetuales, se sientan las bases para un arte que rompe con el vínculo tradicional que ligaba a la naturaleza como origen del proceso del arte.

"Arte y Objetualidad" es el texto de Michael Fried ${ }^{10}$ en el que realiza un análisis de las estrategias del arte en la modernidad. En el ensayo del mismo nombre señala como la obra moderna es observada como una visión instantánea en una experiencia inmediata. El Minimalismo para Fried introdujo una dimensión dilatada en la expectación de la obra, debido a su condición objetual y literal, esta característica es lo que el autor entiende como teatralidad; en ella el autor toma en cuenta al espectador y la relación duradera que tomará en relación a la obra, precisamente esa relación obra-espectador se sucederá dentro de un tiempo dilatado y no instantáneo.

Douglas Crimp señala estar de acuerdo con dicha condición fenoménica que trasciende la mera opticalidad de la teoría moderna del arte. Esta característica teatral de tiempo extendido se continúa en las prácticas artísticas y estrategias de la posmodernidad en los años de 1970, con obras que emplean medios diversos de varios campos del arte, integrados en una unidad que rebasa el territorio de pureza autocrítica moderna; y en donde además el trabajo resultante no manifiesta la huella autógrafa factural de la subjetividad del artista.

Lo anterior es desarrollado por Crimp en la presentación que escribió para la exposición "Pictures" en el Artist Space de Nueva York en 1977, dos años después lo completaría como un ensayo que fue publicado.

Crimp decidió utilizar el término imágenes por la ambigüedad del concepto, para aludir a una serie de obras realizadas con diferentes mezclas de medios, refiriéndose tanto a la condición objetual como al proceso mental generador del proyecto y la obra.

En el capítulo donde trataremos los Modelos del Dibujo habremos de regresar a estas fuentes reflexivas, ahora nos interesan en su dimensión teórica general para plantear la disyuntiva vivida por el arte y el dibujo en ese corte histórico.

Varios de los trabajos de esta exposición utilizaban el video como medio de realización, esto comportaba de por sí una condición temporal típica, además de que los videos se cerraban en una repetición circular constante.

Específicamente en esa exposición no se presentaron obras pictóricas o netamente dibujísticas, aún con ello, Crimp menciona la inclusión de lo teatral dentro de la imagen pictórica al transformarla en una obra cuya duración y presencia es enteramente psicológica. El espectador es tomado en cuenta como el agente que completa el sentido significante de la obra al leerla desde su propia carga cultural, psicológica y subjetiva.

10 Fried Michael. Arte y objetualidad, ensayos y reseñas. Madrid: Machado Libros; 2004. P. 364. 
En esa exposición Cindy Sherman presentó fotografías que se podían relacionar como cortes estáticos de filmes clásicos del cine, pero las fotografías no eran estrictamente Films Still, sino emulaciones caracterizadas por ella misma bajo tipificaciones del género femenino. Estas fotos no se relacionan con la duración teatral de la experiencia frente a la obra, sino como fragmentos que se entienden extraídos de una temporalidad fílmica que se asume como relato incumplido, fragmento que no rebasa su condición parcial.

Robert Longo presentó un montaje de dos fotogramas de la película "The American So/dier" de Rainer Werner Fassbinder. Colocó la imagen de una escultura de un león, tomada de un recorte de periódico y superpuso a un lado de ella, un fragmento de figura tomada de otro fotograma de la misma película, en la que se aprecia la figura de un hombre al momento de recibir el impacto de las balas.

Mediante el aislamiento de estas figuras de su contexto narrativo se les vacía de su sentido original (la lectura y significación que guardaban originalmente dentro de su medio) se les dirige hacia la estrategia de la cita, acción con la que se desmonta el sentido original, como lo hemos dicho, pero se les construye un sentido alterno de significación, el que el montaje construido propone.

La cita, la apropiación y el montaje dan como resultado lo que Crimp llamó "estratos de representación" con esto, la ruptura con la modernidad no se refirió sólo al abandono de la pureza de los campos y los medios, sino también al abandono de la categoría de autoría y originalidad.

El montaje como estrategia artística comprende las condiciones de la alegoría, la apropiación y el vaciado de las imágenes de su sentido original, la fragmentación y conjunción dialéctica de los fragmentos, y con esto la separación del significante de su significado.11

Un caso clásico dentro de esta estrategia es el de Robert Rauschenberg con su obra "Dibujo de De Kooning borrado" (1953). Por ese tiempo Rauschenberg trabajaba sobre la idea del blanco y encontró la manera de llevar esta idea al terreno del dibujo. Se entrevistó con De Kooning y le explicó su proyecto de borrar dibujos ya realizados. De Kooning aceptó y le cedió un dibujo que iba a extrañar y que según él sería difícil de borrar. Era un trabajo realizado con grafito, carbón, crayón y óleo.

El trabajo de borrar el dibujo fue tardado y meticuloso, casi un mes. Rauschenberg dejó en el reverso algunos apuntes de De Kooning que constatan la autoría. El frente del dibujo borrado mantiene algunos indicios de la obra original, éstos operan como huella e índice del proceso creativo. El dibujo borrado fue montado en un marco dorado con una placa metálica en la parte inferior con el título "Erased De Kooning Drawing. Robert Rauschenberg. 1953” El texto escrito opera como generador del sentido de lo que se ve, y de lo que no se ve, nos pone frente a una autoría paradójica, quien realiza el dibujo original es De Kooning, pero el autor de la nueva maquinación y el borrado es Rauschenberg. Los vestigios del dibujo y la placa prueban la originalidad, pero ésta es desmantelada por la apropiación de Rauschenberg. Se partió del estatus de la obra inicial, lo que era incuestionable dentro de los sistemas de legitimación artísticos, los espacios expositivos y la crítica de arte. Fig. 3

11 Buchloh Benjamín H. D. Formalismo e Historicidad. Madrid: Ed. Akal; 2004. Pág. 91. 


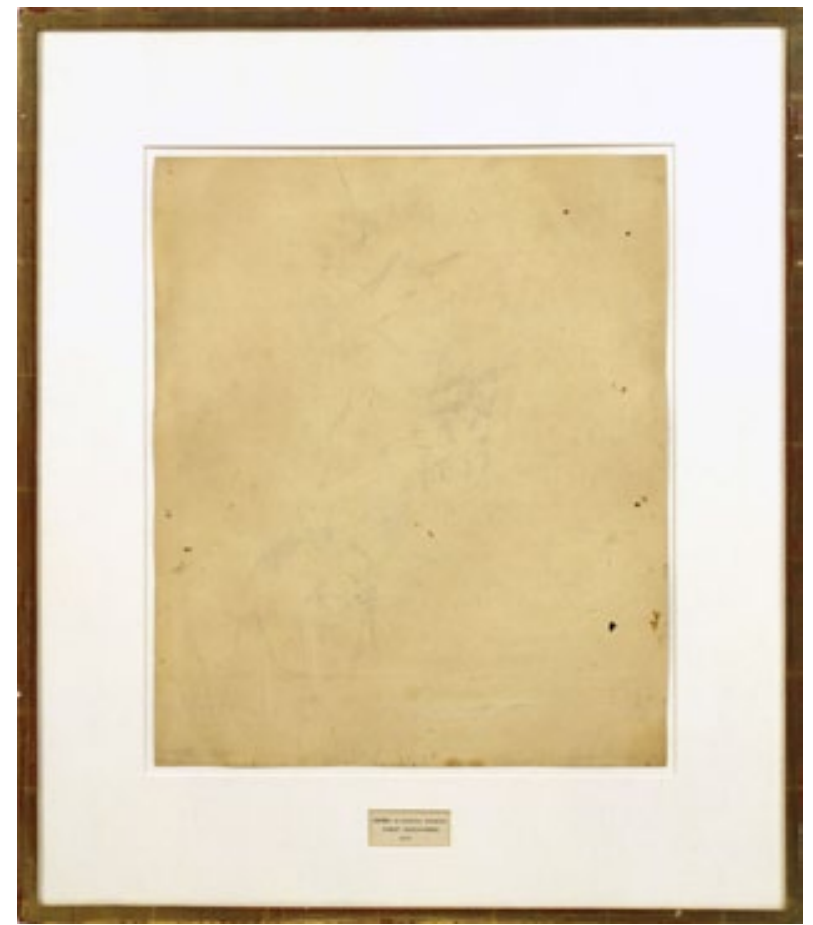

Fig. 3 Erased De Kooning Drawing. Robert Rauschenberg.
Buchloh menciona este caso como un ejemplo claro de la alegoría característica de la posmodernidad.

El enmarcado del dibujo desplaza la atención del índice autoral y gestual hacia otro índice; el de las convenciones de presentación y exposición como modelos de legitimación del espacio expositivo institucional.

Pero para Buchloh, esta obra y otras del POP, no logran una crítica verdadera sobre los sistemas de distribución y exposición como espacio de legitimación. Esto es así según Buchloh debido al carácter disciplinar del trabajo y a la individualidad que priva en todo el proceso.

Douglas Crimp en su ensayo "Sobre las ruinas del museo" en 1980 señala la crisis del museo como espacio expositivo historicista del arte y la cultura humana. En ese artículo escoge principalmente obras de Rauschenberg, en las que reproduce mecánicamente mediante la serigrafía, obras centrales de la historia del arte. En ese trabajo Crimp señala como importante el hecho de usar citas y extractos, así como la acumulación y repetición de imágenes ya existentes dentro del campo de la historia del arte. Para Crimp, la reproducción de obras pasadas, dentro de obras actuales, para construir un nuevo discurso expositivo es una evidencia del declive del arte moderno y el final de la originalidad como paradigma normativo del proceso artístico.

Al apropiarse de imágenes ya colocadas dentro de la historia del arte se sucede el acto de sustitución de la autoría; tal es el caso de las fotografías de Sherrie Levine realizadas a partir de la obra de Walker Evans y After Atget. Estos fotógrafos en sus respectivos lugares, Estados Unidos y París tomaron fotografías documentales en la calle y de la vida cotidiana, Evans dentro de la gran depresión económica estadounidense y Atget en los inicios del S. XX. Las fotos de Levine simplemente hacen una nueva toma de las fotografías originales, llevándolas con esto a perder su valor mercantil y recuperar su sentido como reproducciones. Para esto la fotografía resultó ser un recurso ideal dada su originalidad en el negativo y de ahí su igualdad supuesta en cada una de las copias producidas; aunque esto, dentro de los análisis del campo fotográfico sea también algo muy cuestionable.

Pero en la postura de Levine, como en la del posmodernismo, vemos algunas contradicciones, por un lado dice tener una empatía estética con las fotografías apropiadas y en las que advierte un compromiso social, esto frente a su propia carencia de compromiso 
y distanciamiento de la finalidad de dicha estética; y en el reconocimiento de un ideal expuesto en la obra de Evans nuevamente ante la oposición de no tener ideales.

Básicamente éste es el fenómeno comprendido como cita y apropiación, plagio reconocido de imágenes de primera generación, que no son creadas por el artista actual, sino que son reutilizadas para provocar un dislocamiento temporal e histórico del discurso inmanente en ellas. El planteamiento central descansa en una intención estratégica, que busca la crítica a la representación entendida como sistema de legitimación de la cultura estabilizada. Tomemos una cita de Arthur Danto quien también precisa el sentido de la cita y la apropiación como signo posmoderno.

"El mundo del arte de los setenta estaba lleno de artistas cuyos objetivos no tenían nada que ver con mover los límites o ampliar la historia del arte, y sí con poner éste al servicio de metas personales o políticas. Los artistas tenían en sus manos toda la herencia de la historia del arte, incluida la historia de la vanguardia, que puso a disposición de ellos todas las maravillosas posibilidades que ella misma había elaborado y que el modernismo hizo todo lo posible por reprimir. En mi opinión, la principal contribución artística de la década fue la aparición de la imagen -apropiada-, o sea, el -apropiarse- de imágenes con significado e identidad establecidos y otorgarles nueva significación e identidad. Cuando una imagen pudo ser objeto de apropiación se admitió inmediatamente que no podría haber una unidad estilística perceptible entre esas imágenes de las que se apropia el arte."12

Pero el centro de la estrategia apropiacionista y citacionista no era la simple transgresión estilística, se trataba de desmitificar, derrumbar el mito de clase con que se rodea a las imágenes y obras artísticas, denunciar la apropiación que el sistema dominante hace de la práctica e imágenes de los grupos sociales periféricos. Por ello Buchloh considera esta apropiación una devaluación semiótica de la cultura y sus obras como lenguaje primero, las imágenes del estatus devalúan aquellas de los grupos sociales particulares; así el artista posmoderno al realizar nuevas apropiaciones alegóricas estaría devaluando en segunda instancia las imágenes, pero ahora desde su origen dentro de una cultura dominante.

La posmodernidad convierte la superficie de la pintura y la obra en un vasto campo para citar un extenso repertorio de imágenes que guardan disparidad histórica, pero que construyen un sentido discursivo. Douglas Crimp y Leo Steinberg observaron ese fenómeno basados en el trabajo de Robert Rauschenberg de 1965. Crimp ve incluso en esa estrategia citacionista una apropiación de las imágenes que la historia nos pone a disposición, mediante la cual se logra la alteración del conocimiento exigido por el sistema cultural moderno, basado en un discurso ordenado.

La cita y la apropiación rompen con la necesidad del recurso de originalidad y autenticidad.

Algo importante que puntualizamos como característica sustantiva de esta estrategia, es el hecho de que, entre cada uno de los elementos que constituyen la interioridad de este tipo de obras, se establecen constantemente relaciones de interacción y transferencia de los significados; éste es el nuevo sentido de la pintura y el arte antiguo, sobre todo en nuestro mundo permeado por la cultura de la imagen masiva. El espacio natural e histó-

12 Danto Arthur C. Después del fin del arte. Barcelona: Ed. Paidós Transiciones; 1999. P. 37 
rico de los fragmentos primarios, se relaciona con el espacio social y cultural del ser humano en un tiempo de no linealidad. De este modo la categoría de construcción espacial que permanece hasta la modernidad, como generación del espacio virtual formalizado de la obra, es trascendida por el entendimiento espacial como un deslizamiento de la representación hacia una ubicuidad social y política más que formal o estética.

"En la medida en que en el auténtico montaje contemporáneo las distintas fuentes y autores citados como textos se dejan intactos y son, por tanto, plenamente reconocibles, el espectador se encuentra con un texto descentralizado que se completa a través de su lectura y de la comparación del sentido original con las posteriores capas semánticas que ha adquirido el texto-imagen."13

De ahí que la disposición de los fragmentos y elementos dentro de la obra apropiacionista posmoderna no obedezcan estrictamente a un sentido compositivo, sino a una estrategia de significación icónica semiológica, que produce una reflexión espacio temporal referida a la historia y su crisis. Texto en el que no se busca el origen y la fuente sino la estructura del sentido significante, por eso debajo de cada imagen siempre habrá otra imagen, pero en esa estructura se hace necesaria la comprensión de la imagen primera, ya que ésta opera como el núcleo inicial contrastivo para el desmontaje.

El espacio en la posmodernidad significa más que una forma, la crisis existencial y cultural. La utilización de partes y citas del arte en un sentido temporal arbitrario, comporta una concepción no lineal de la historia, de ahí que se nos presente como una ruptura, en donde el devenir temporal puede ser considerado indistintamente hacia el pasado o el futuro, incluyendo contenidos significativos de un presente.

El empleo de reproducciones fragmentadas de obras de arte del pasado, ligadas a imágenes de actualidad social y política, reunidas todas ellas en un tratamiento que semejaba formas pictóricas compositivas, implicaba un arte que pretendía sustituir la linealidad de la comprensión histórica del arte y la cultura, para en su lugar proponer la discontinuidad, la ruptura, el límite y el umbral.

El trabajo de Rauschenberg pone en perspectiva el ingreso de la práctica del arte al espacio de la desterritorialización, basado en el uso del fragmento y la reproducción como vestigios distantes del referente que en otro momento operó como modelo inicial del proceso.

Una aplicación de esta estrategia, es la que consiste también en vaciar de significado discursivo las imágenes apropiadas, para llegar a una postura en la que aquella es despojada de su tema y trama inicial, es el caso de aquellas imágenes que son tomadas de fragmentos de fotografías o fotogramas y que son ampliadas hasta generar una dispersión del grano de definición que se funde en lo tonal, de esta manera es imposible establecer o reconstituir cualquier lectura basada en su sentido temático o conceptual original. Ésta no es sin embargo una liberación del lenguaje visual respecto del referente objetual, ni tampoco una forma más pura de expresión de la subjetividad del artista. No podemos llamar a estas imágenes como abstractas, al menos dentro del criterio de la modernidad final. Dentro del informalismo y el expresionismo abstracto se intentó la consecución de un absoluto formal, pero en estas obras posmodernas el resultado es un vacío, acaso ése sea su significado.

13 Buchloh Benjamín H. D. Formalismo e Historicidad. Madrid: Ed. Akal; 2004. Pág. 103. 
El desmantelamiento del sentido de la imagen apropiada establece una diferencia radical con respecto al sentido simbólico en la obra moderna. El símbolo comprendía la esencia de toda la obra moderna, pues estaba expresado en todas y cada una de las partes como elementos que constituían su unidad, así la obra era un todo simbólico, mientras que la alegoría comprendía un añadido al conjunto integrado.

La integridad simbólica de la obra de arte suponía la conjunción de forma y contenido, por eso la alegoría como agregado disociaba esa unidad. Pero en la estrategia posmoderna la alegoría no puede ser excluida como un anexo ya que opera como otro contenido, éste no es sólo una adición sino la transformación del contenido simbólico original quedando cubierto este por el velo alegórico. La alegoría se convierte en un texto que se lee mediante otro texto.

Craig Owens analiza la alegoría traspasando la categoría de estilo ya que "implica tanto la metáfora como la metonimia". ${ }^{14}$ Ello quiere decir que la concreción formal de una obra presenta un contenido estabilizado, pero puede tener un contenido diferente. Esto sucede en el arte contemporáneo y desde la modernidad en los autores que usan lo visual y lo verbal, en donde frecuentemente se trata las palabras escritas con un carácter visual, mientras que las imágenes se ofrecen como un texto que debe ser descifrado, ya adelante revisaremos éste particular en autores como Sol LeWitt. Esta conjunción entre lo visual y la lectura es una dinámica más que posibilita la alegoría. Así la alegoría puede generar que una obra atraviese no sólo los géneros y estilos sino también los medios disciplinares suscitándose lo que se denominó como híbrido.

Hasta el fin de la modernidad y dentro de la abstracción pospictórica, el dibujo se consideró una disciplina de representación eidética, con él, la pintura se construyó como una ventana de acceso al mundo, o bien como un campo cósmico y subjetivo para arribar al ensueño poético que expandiera el espíritu, o como una forma reflexiva teórica que pensó los límites de la indexalidad del Dibujo y la Pintura. Con la construcción estratégica de la obra posmoderna se construyen imágenes y objetos que son en sí presencias fragmentadas del mundo concreto, incluso escenas completas de un momento trivial, pero son presentaciones de ese mundo cotidiano, acontecimientos simultáneos en los que la representación eidética desaparece.

Resumiendo, los artistas apropiacionistas toman imágenes que provienen de un espacio específico de la historia del arte, espacio que es el que se busca subvertir, se las vacía según esto de su sentido original para construirles otro que opera como sustituto. Pero el significado original se mantiene, ya que es lo que permite la lectura del texto por parte del espectador-lector. Basado en el sentido original el espectador puede detectar los textos sobrepuestos, reflexionando las dinámicas de relación, en parte por un proceso sintáctico que liga los signos que operan en el juego. Una vez armada la lectura de los textos apropiados se puede apreciar la alegoría, como segundo contenido o sentido. Al mantener en parte las formas y significados de las imágenes iniciales junto con la nueva construcción, la mecánica significante opera sobre la base del sentido inicial, por eso se dice que las prácticas apropiacionistas caen en una complicidad o fracaso deconstructivo.

14 Wallis Brian. Arte después de la modernidad. Nuevos planteamientos en torno a la representación. Madrid: Ediciones Akal; 2001. P. 208. 
Así, al mantener vigentes los significados semánticos culturales inmanentes en dichos fragmentos de obras, el carácter crítico de estos trabajos dista todavía de una radicalidad cuestionadora. La fase Terminal y profunda de la estrategia citacionista y apropiacionista descansará sobre la base del descentramiento del sentido histórico de las imágenes o fragmentos incluidos en la nueva obra construida. Así, no toda práctica apropiacionista es una actividad crítica de fondo.

El propio Juan Martín Prada señala oportunamente que no todas las prácticas y autores apropiacionistas posmodernos mantienen un carácter crítico radical, en el sentido de la descentralización de los principios organizativos de la institución y de la historia. Menciona acertadamente que la estrategia de yuxtaposición de fragmentos de obras de la historia del arte no necesariamente resulta en una práctica crítica y paródica.

La revolución del collage descansó en el acierto, que no era cosa simple, no de introducir fragmentos objetuales que sustituían la imagen pintada, evitando el problema de formalizar materias complejas en la imagen, más bien nos colocó en la posibilidad de ubicar fragmentos de realidad en un marco formalizado que no era el de las circunstancias comunes de donde esos fragmentos emergían, así el collage promovió un sentido reflexivo epistémico.

Sobre la ruptura anterior la posmodernidad profundiza en la inclusión de los objetos cotidianos o fragmentos de materiales de la vida común dentro del cuerpo físico de la obra de arte, la renuncia de la obra objetual propuesta por el arte conceptual agudiza la tendencia a la desaparición del concepto clásico de obra de arte y de campos definidos para su quehacer. En muchas ocasiones excluye al dibujo del cuerpo final de la obra y lo remite de manera arcaica a la función elemental de proyectar las partes del proceso. Aunque en otros casos como el de Piero Manzoni y Sol LeWitt fuera el eje determinante de la estrategia.

No es nuestra intención repetir en estas páginas el inicio de la las rupturas del siglo XIX, desde Turner, la primera exposición impresionista hasta la revolución del Cubismo y el collage, o el inicio del arte objeto, el ensamblado. Pero lo que sí nos interesa dentro de esa aventura que conduce a la posmodernidad artística, es la ruta que este proceso genera. Señalamos un tanto como ya otros lo han hecho, el carácter reduccionista que la práctica artística sufrió hasta constreñirse casi a un sucedáneo de pensamiento filosófico. Al prescindir del carácter estético y suprimir la búsqueda de una representación formalizada, el arte podía ser conseguido mediante la presentación de cualquier objeto, siempre y cuando mediara una estrategia que le diera consistencia en un proceso de significación crítica, así se trasladó la generación del arte, del terreno de la experiencia sensible hacia su sustitución por un pensamiento filosófico o conceptual.

Nuevamente; no es que el arte hasta antes de esta situación estuviera ausente o distante de un pensamiento filosófico; seamos firmes, cuando menos desde el Renacimiento temprano, que marca el inicio del arte occidental como centro de gravedad, la filosofía acompañó íntimamente al campo de las artes. Hace falta recordar la necesidad de una lectura detenida y pausada de los tratados esenciales de este periodo, y no sólo estos, también la tratadística manierista, barroca y en general hasta el siglo XVIII guardan una relación profunda no solamente con el pensamiento filosófico, sino que esta relación se da en términos epistemológicos y cognitivos. 
Arte y filosofía estuvieron siempre ligados de manera orgánica, hoy nos parece que las artes visuales en la modernidad y los tiempos actuales se acercan sustantivamente a la filosofía, pero desde antes era así; aunque éste no es nuestro asunto de estudio, diremos que la relación entre la filosofía y el arte tiene que ser revisada por la historia como un proceso que se inscribe dentro del devenir de la división del conocimiento en compartimientos especializados, suceso que se origina en el Renacimiento y que para el siglo XIX vive sus más claras diferencias en el pensamiento positivista taxonómico.

De manera que la fusión entre la filosofía y el arte posmoderno no es sino una forma actual que asume una relación añeja. Si alguna diferencia existe en este planteamiento, se da en los términos que se alejan de los procesos de formalización artística. Es decir, la vía de concreción del pensamiento filosófico inmanente en el arte ya no pasa por la búsqueda de un sistema de representación formalizado de la realidad contextual, en su lugar se aplica una estrategia de sustitución del modelo a representar por el acto de presentación del propio sujeto y modelo dentro de la propuesta artística, a cuyo momento de realización asiste el público en tiempo real. Creemos que de esta manera nos internamos en el análisis que busca dentro del fenómeno artístico las diferencias epistémicas para señalar la cualidad de las posturas reflexivas, pero no su exclusión.

Este es el centro problemático que nos ocupa.

Recordando a Deleuze, diremos que el pensamiento filosófico busca la formulación de prospectos y conceptos teóricos, éstos se plasman en la construcción de modelos teóricos que no son en si la realidad, pero tampoco la suplantan. Estos modelos se dan en el plano de la razón intelectual, en tanto que el arte apunta hacia la concreción de preceptos y afectos formalizados, nosotros agregamos que estos afectos apuntan hacia la construcción de entidades fácticas, que son alternas de la realidad contextual, guardan diferencias de esencia con respecto a los cuerpos formalizados de la filosofía y la ciencia; al ser clausurados en la completud de la obra artística y con la asistencia del espectador, se concretan en una realidad por si mismos; además de señalar que la lógica interna y sistémica que los rige es también de cualidades diferenciadas.

Por eso establecemos una distancia con la idea de quienes señalan como característica del fin del arte e inicio de la posmodernidad, la peculiaridad que ésta última hace para servirse del arte del pasado en la construcción de un nuevo discurso; marcamos aquí una discrepancia, a lo largo de la práctica artística, siempre los artistas se han apoyado en el pensamiento y las obras de sus antecesores y aún sus contemporáneos. La diferencia estriba en el vínculo mediante el cual se da esa relación causal.

La cita y la apropiación, el plagio y el uso de imágenes de otros discursos, constituyen una estrategia basal del proceder posmoderno, sean sus fines los de la crítica o la denuncia, situación que no es discutible.

Pero en la práctica artística que antecede a la posmodernidad también se establece como sabemos un vínculo con los sistemas artísticos de representación y su pensamiento inmanente, por ahora sólo diremos que la calidad de ese vínculo no anteponía la intención franca y primaria de disidencia o negación del sistema de representación utilizado, por el contrario se le asumía las más de las veces como lecciones de excelencia, que constituían el inicio del ejercicio artístico. La distinción fundamental que permitía, pese a lo anterior, el cambio positivo en el devenir de las artes y el dibujo en su caso, era fundamentalmente epistemológica. 
La práctica del dibujo no era un ejercicio auto referencial, siempre estaba remitida hacia una causalidad originada en la realidad contextual que rodeaba al artista, fuera esta natural o cultural, de manera que las formalizaciones concretadas en la obra eran ejercicios de representación cuyo centro causal era el de un modelo a investigar con el campo artístico de que se tratara. En tanto el arte posmoderno, en palabras del propio Danto, se poblaba cada vez más de una pléyade de artistas que había desdeñado, u olvidado dibujar.

Una vez más es necesaria otra precisión, las manifestaciones interdisciplinares, o híbridas del arte posmoderno, significan una postura importante en el devenir del arte, por diversas razones, En segunda instancia, y es necesario remarcarlo; no todos los artistas conceptuales, ni todos los posmodernos, prescinden del dibujo, ni lo han olvidado, muchos de ellos incluso lo integran como parte sustantiva de su estrategia. En este punto resulta interesante señalar la importancia que las escuelas de arte guardan como conformadoras del pensamiento y actitud del futuro artista. Podríamos señalar un mapa de la práctica artística en función del dibujo, y en relación con las regiones en que los artistas actuales se han formado; la "Art Students' League" escuela de artes de Nueva York fue el centro formativo de varios de los artistas capitales del Expresionismo Abstracto, no deja de seducirnos la familiaridad que se observa entre las formulaciones pedagógicas de esa escuela y el derrotero seguido por sus egresados. Por su parte los centros y universidades de la costa californiana en los Estados Unidos de Norte América son el punto de origen de lo que se conoce como la iniciativa posmoderna. Al revisar la obra de los conceptualistas rusos y brasileiros actuales, es evidente la huella del rigor formativo en el terreno disciplinar del dibujo.

El arte del siglo XX, y en especial el de la posmodernidad es en cierta medida una práctica tautológica de causalidad circular retroactiva, la forma de la forma, la pintura como eje de la pintura etc. Significan una práctica auto referencial, por más que la posmodernidad la refiera a la crítica y denuncia de los significados de dominación de los distintos discursos de la historia del arte.

Aunque en lo general se asume de la manera anterior la postura posmoderna frente a la estética y el arte, vale la pena marcar una distancia, que se genera entre el entender de la crítica y el pensamiento de los artistas; es una cita de la propia Sherrie Levine incluida en el texto de Juan Martín Prada y en la que se ratifica su filiación estética. La que resulta interesante al marcar esa distancia.

"Nunca pensé que no estuviera haciendo arte, y nunca pensé en el arte que estaba haciendo como una no mercancía... Nunca pensé que lo que estaba haciendo estuviera en una estricta oposición a lo demás que se estaba haciendo. Estaba cansándome de que nadie mirara la obra. Incluso cuando hago fotografías, quiero que se experimenten como hermosas, como objetos sensuales." ${ }^{15}$

Dejamos hasta este punto la reflexión.

En otro sentido para el historiador posmoderno reviste importancia el fijar los momentos de giro en la historia del arte en los que encuentran sucesos esenciales que permi-

15 Prada Juan Martín. La Apropiación Posmoderna. España: Ed. Akal; 2001. P. 87. 
ten la construcción de su análisis, demos paso a una cita del propio Danto para aclarar esa postura.

"Moderno, después de todo, implica una diferencia entre el ahora y el antes: el término no se podría usar si las cosas continuaran siendo firmemente y en gran medida las mismas. Esto implica una estructura histórica y en este sentido es más sólida que una expresión como -lo más reciente-. Contemporáneo, en el sentido más obvio, significa lo que acontece ahora: el arte contemporáneo sería el arte producido por nuestros contemporáneos. Es evidente que podría no haber pasado la prueba del tiempo. Aunque debería ser significativo para nosotros que el arte moderno haya pasado esa prueba cuando podría no haberla pasado: sería -nuestro arte- en un sentido íntimo y particular. Así como la historia del arte ha evolucionado internamente, el arte contemporáneo ha pasado a significar el concebido con una determinada estructura de producción no vista antes, creo, en toda la historia del arte. Entonces, así como-moderno- ha llegado a denotar un estilo y un periodo, y no simplemente un arte reciente, -contemporáneoha llegado a designar algo más que el arte del presente. En mi opinión no designa un periodo sino lo que pasa después de terminado un relato legitimador del arte y menos aún un estilo artístico que un modo de utilizar estilos. Por supuesto hay arte contemporáneo de estilos no vistos antes, pero no quiero profundizar en el asunto en esta etapa de mi exposición. Sólo deseo alertar al lector de mi esfuerzo para trazar una distinción clara entre -moderno- y contemporáneo"16

Ya en esta cita advertimos la necesidad de sentar el análisis de los momentos de ruptura del proceso artístico en bases que se ubiquen sobre categorías estructurales; parece ser que se atiende a la urgencia de recurrir nuevamente a los procesos de interioridad artística.

Pero pese a ello el pensamiento posmoderno-inmanente en la propia cita continúa recurriendo a conceptos como el de estilo; no sólo en lo referente a la mezcla citacionista y apropiacionista del arte posmoderno. Se menciona la significación que el arte nos puede ofrecer recurriendo a la capacidad que muestre para generar discurso basándose en la consecución de estructuras; que no pueden ser otras que las de variaciones en los sistemas de representación.

En otro sentido se atiende con demasiado peso al factor temporal como eje de construcción del análisis, modernidad, posmodernidad, contemporaneidad, arte actual. Queremos remarcar que desde nuestro punto de vista la temporalidad del arte sirve para referirnos a una ubicación histórica y al ritmo de transformación de los procesos; pero en todo caso la teorización del arte de un tiempo se debe al análisis de los sucesos y complejos en la interioridad del hecho artístico y la relación que ellos establecen con su contexto. La riqueza de un pensamiento de esta naturaleza pondría al descubierto la intencionalidad relacionante del pensamiento del artista y nos conduciría posiblemente a un panorama constelar de las conexiones causales del fenómeno. Bajo criterios de este orden se posibilita una lectura y análisis de los momentos de ruptura paradigmática en la historia del arte, lo que Danto advierte como los relatos legitimadores del arte. Este giro peculiar, genera en nuestro pensamiento la necesidad de formular un trazo inicial de la historia de los sistemas del dibujo, basado en sus características sustantivas y diferenciadas como sistemas de representación, llamamos a estos segmentos los Modelos del Dibujo y ya desde ahora advertimos que su devenir no se corresponde de manera totalmente sincrónica con los

16 Danto Arthur C. Después del fin del arte. Barcelona: Ed. Paidós Transiciones; 1999. P. 32 
cortes que la historia moderna y posmoderna propone para la agrupación del fenómeno artístico; de ahí que parte de nuestro estudio se ocupe en un capítulo particular de este asunto. Sin el panorama analítico del curso e historia del dibujo, y el pensamiento que sus artistas han exteriorizado de manera expresa, cualquier análisis u opinión que vertiéramos sería un discurso carente de rigor teórico, propuesto desde una reflexión exógena al propio campo que deseamos analizar, y nos desviaríamos tal vez por el camino de un estudio general del arte sin poderlo retornar al interior del proceso del dibujo.

Dicho sea de paso; para intentar ese trazo inicial que dé cuerpo a la historia de los modelos del dibujo requerimos también el establecimiento de la categoría analítica central que ordenará el estudio. Por eso propusimos como un capítulo más de la investigación un segmento dedicado a plantear el carácter proyectual prefigurativo del dibujo a lo largo de la historia.

Un matiz delicado se advierte en este momento del estudio; vemos como la crítica posmoderna en el análisis que efectúa utiliza las categorías de análisis y los cortes históricos de modo muy flexible. Cuando Rosalind Krauss analiza la originalidad de la vanguardia, recurre de manera sumamente elástica a los segmentos de la historia del arte para encontrar en ellos los argumentos que fundamentan su artículo; lo mismo cita a William Gilpin para fundamentar un suceso típico del arte del siglo XX, que analiza a Rodín como centro de una ruptura escultórica.

En la distancia dada entre un acontecimiento artístico y otro están contenidos una suma de procesos culturales incontables, de manera que si existe una posible relación entre el problema planteado y los argumentos a que se recurre, ésta se diluye hasta el punto de repercutir de una manera suave en la formulación planteada.

Intentamos decir con lo anterior que, para cualquier análisis del dibujo como fenómeno artístico se requiere necesariamente un marco teórico e histórico que de estructura y solidez a nuestro análisis. Hace algunos años, en 1994 nuestro trabajo como productores de arte nos llevó a sospechar la posibilidad de un dibujo y pintura con causes diferenciados de representación formal en el panorama general del arte, pero en ese mismo momento nos dimos cuenta que una propuesta de ese tipo no podía ser lanzada sin un conocimiento esencial del arte de nuestro tiempo, del de su historia en la medida de lo posible y del pensamiento explicitado por los dibujantes en ese arco temporal. En gran medida ése es el origen e intención de este trabajo. Y pensamos con ello marcar una diferencia metodológica como pensadores; esto es, no utilizar sólo los segmentos de la historia que sentimos coincidentes con nuestro pensar, sino hacer un recorrido más amplio que nos muestre distintas situaciones históricas y pensamientos que bien pueden no ser coincidentes con nuestro ideario e hipótesis inicial.

\section{I-4 CAMPOS DISCIPLINARES, IDENTIDAD Y DIFERENCIA}

En 1978 Rosalind Krauss publica su artículo “La escultura en el campo expandido" en este análisis se aboca a establecer como un fenómeno posmoderno la extensión del campo disciplinar de la escultura. Este proceso es el resultado de la exploración que hacen los artistas de los factores espaciales y los soportes, así como las construcciones objetuales de la periferia del campo escultórico. En este artículo propone categorías de análisis y agrupamiento como las de "construcción localizada", "lugares señalados" o "emplazamientos señalizados" y "estructuras axiomáticas". 
Con ello entra de lleno en la nueva manera en que la crítica aborda no sólo el problema de la escultura, sino el de todos los territorios del arte.

Frente a la diversidad de obras que irrumpieron desde los años sesenta, y que para los setenta habían invadido el espacio expositivo, se hizo necesario el ejercicio de apertura reflexiva correspondiente. La cantidad de materiales que constituían estas obras, montones de fibras, trozos de madera simplemente aserrados, maquinarias que se autodestruían, cantidades de tierra movilizadas de un lugar a otro, oquedades que remitían el espacio escultórico hacia el subsuelo etcétera.

Inicialmente la crítica de arte desarrolló la estrategia de relacionar estas producciones con la genealogía de manifestaciones culturales de muchísimo tiempo atrás. Stonehenge, las líneas de Nazca, los túmulos funerarios prehispánicos. Rosalind señala que tales producciones culturales, no eran cosas que pudieran ser definidas como esculturas, por lo tanto la dirección de ese análisis era una manera de seguir manteniendo el criterio historicista para analizar el fenómeno del arte.

Según la misma Rosalind, es con dos de los trabajos de Rodín que se inicia el desplazamiento del objeto escultórico hacia una condición de negatividad del propio campo, entrando en la etapa moderna caracterizada por la ausencia de hábitat para el antiguo monumento, quedando entonces como una mera señal, funcionalmente desubicado y como práctica autorreferencial. Estos trabajos fueron el Monumento a Balzac y Las Puertas del Infierno.

La experimentación del periodo moderno condujo a la escultura a tensar el límite crítico planteado por la negatividad de lo escultórico. El objeto escultórico devino en pura negatividad, el filón experimental se agotó hasta trascender el límite de su propia propuesta. Según la misma Krauss se estaba frente a algo cuyo contenido positivo era cada vez más difícil de definir, cuyas señales se inclinaban rápida y totalmente hacia esas partes que no constituían el campo de la escultura, lo que la escultura no era cobraba sentido para su propia definición, así la negatividad del campo marcaba la contraparte positiva del modelo purista moderno. Sin ser una broma, se entendió a la escultura simplemente como aquello que estaba en las plazas, los espacios, la arquitectura y el paisaje sin ser nada de todo eso.

Citaremos aquí una parte del artículo de Rosalind Krauss para no dar pie a equívocos.

"Ahora bien, aunque la propia escultura se convirtió en una especie de ausencia ontológica, en una combinación de exclusiones, en una suma de negaciones, eso no significa que los propios términos a partir de los cuales se construía -el no-paisaje y la no-arquitecturano tuvieran cierto interés. Ello se debe a que dichos términos expresan una oposición estricta ente lo construido y lo no construido, lo cultural y lo natural, una oposición entre la cual parecía estar suspendida la producción artística escultórica... Si bien dichos términos son la expresión de una oposición lógica planteada como un par de negaciones, una sencilla inversión permite transformarlos en la misma oposición polar pero expresada positivamente. Así, la no-arquitectura no es más, de acuerdo con la lógica de cierto tipo de expansión, que otra manera de expresar el término paisaje, y el no-paisaje es, sencillamente, arquitectura. La expansión a la cual me refiero se denomina "grupo de Klein" cuando se emplea matemáticamente, aunque se conoce también con otros nombres, entre ellos el de "grupo de Piaget" que utilizan los estructuralistas que se ocupan de trazar un mapa de operaciones en el seno de las ciencias humanas. Mediante esta expansión 
lógica, una serie binaria se transforma en un esquema cuaternario que refleja la oposición original y al mismo tiempo la despliega. Se convierte en un campo lógicamente expandido con el siguiente aspecto:

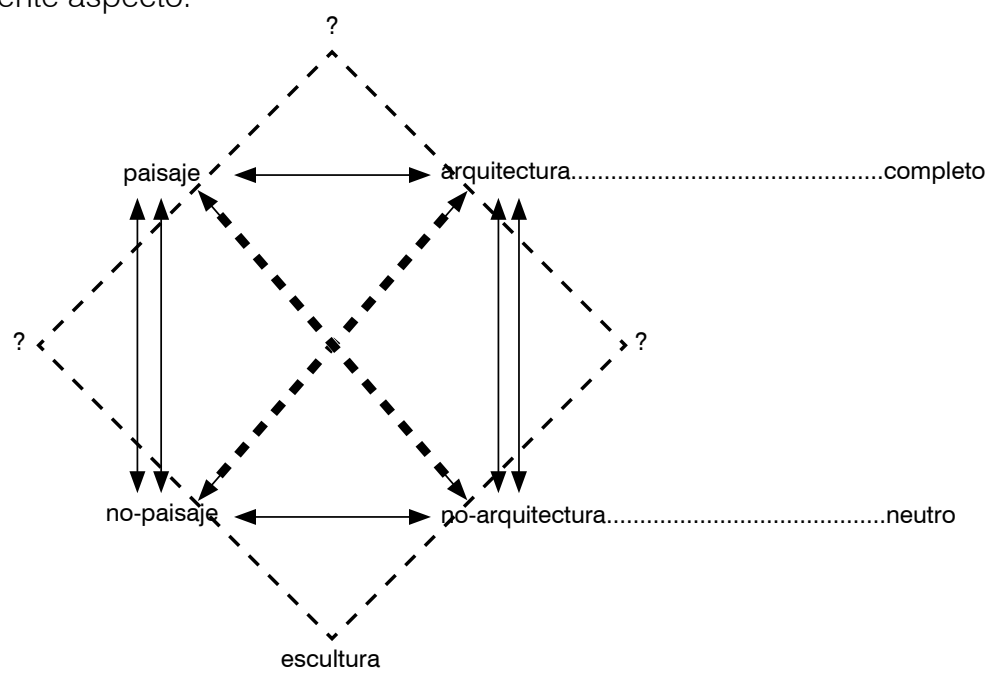

El campo expandido se genera de este modo problematizando el conjunto de oposiciones entre las que se encuentra suspendida la categoría de escultura. Cuando esto ocurre, cuando uno es capaz de concebir el propio camino hacia esa expansión, se puede prever -lógicamente- otras tres categorías, todas ellas condiciones del campo en si y ninguna asimilable a la escultura. Porque como puede verse, la escultura ya no es el privilegiado término medio entre dos términos ajenos. La escultura no es más que un término en la periferia de un campo en el que hay otras posibilidades estructuradas de diferentes maneras. Y hemos logrado "el permiso" para pensar en esas otras formas. Nuestro diagrama se completa por tanto de este modo"17

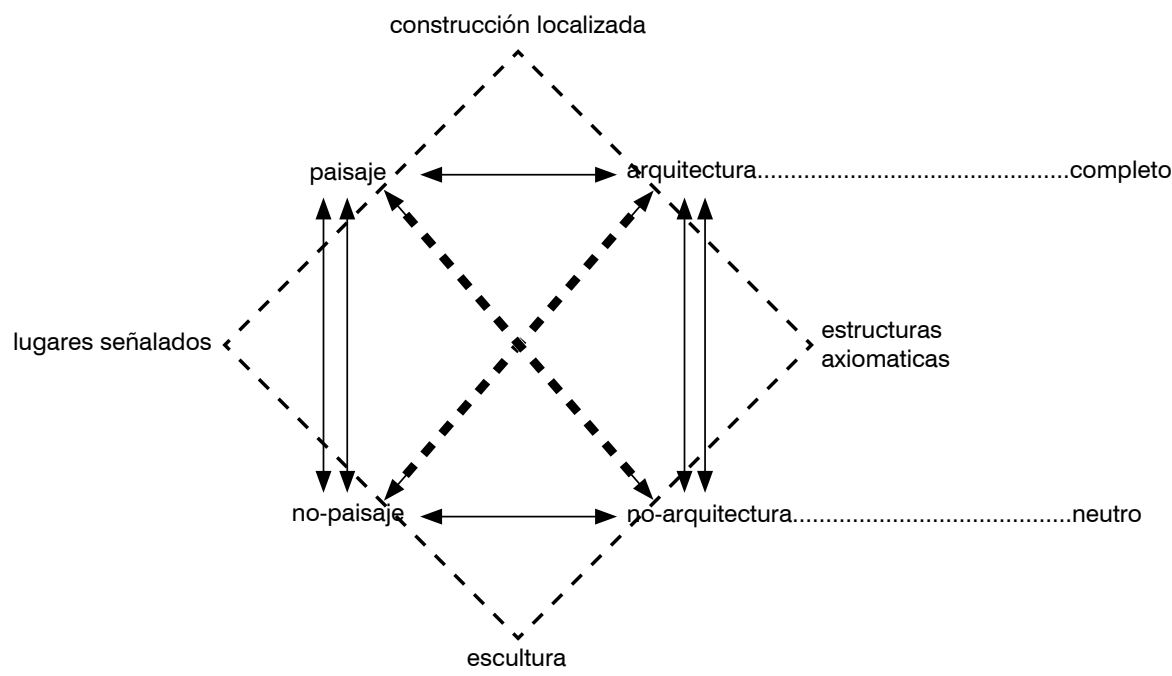

17 Krauss Rosalind. La originalidad de la vanguardia y otros mitos modernos. Madrid: Ed. Alianza Forma; 1996. P.296-297. 
La operación del campo expandido como característica de la posmodernidad se desarrolla por una parte en relación dependiente de la estrategia de cada artista. En otro sentido se basa en la diversidad de medios pensados y utilizados. Para la visión posmoderna, la práctica del arte no se define en relación a un campo específico, purista y central, sino en relación a las operaciones lógicas que impactan un grupo de términos culturales, y para las que se puede utilizar cualquier medio.

Ésta es la operación mental en la que se funda la propuesta posmoderna de expansión de los campos disciplinares del arte.

La reflexión de este problema y el devenir de su expansión ha introducido importantes cuestionamientos para la historia del arte y sus modelos de estudio, y ha obligado a una reconfiguración de los discursos del arte y su integración en territorios de ejercicio diferenciados; pero hasta ahora no ha logrado el establecimiento definitivo de regiones que remplacen las construcciones históricas que trasciende.

La expansión de los campos disciplinares se asienta originalmente sobre una polémica en contra de los valores políticos y culturales que apuntan a una visión tradicional, que se ha estancado en formas institucionalizadas; formas que pierden toda capacidad de apertura en la comprensión del público.

Pero la propia expansión pierde rápidamente su potencial crítico y se encamina a ser ella misma una práctica remitida a la interioridad del sector académico institucionalizado.

Se hace necesario comprender estas extensiones no como un territorio de estudio sino como una serie de intervenciones estratégicas dentro de las disciplinas existentes. No son así una búsqueda de un nuevo discurso capital, son la alteración de los límites de definición de las figuras territoriales de las áreas existentes, donde las configuraciones conceptuales y discursivas serán movilizadas para responder a casos históricos y contemporáneos específicos.

De este modo los campos disciplinares expandidos siempre dependen y en algún modo retribuyen a los territorios de donde emergen, pero esto remarca su lógica fundacional de no ser historicistas, no ser construcciones de la foto, la pintura, el dibujo etcétera.

Pero si bien, la dilatación de los horizontes clásicos de la modernidad resultó en un ejercicio saludable de reflexión y cuestionamiento hacia las posturas esteticistas anquilosadas y a la repetición infinita de las mismas obras, sometidas a variaciones mínimas que poco aportaron al patrimonio de la historia. También es cierto que se generó un clima de excesiva reflexión simple, un desdeño desmedido de las prácticas artísticas y su dificultad como proceso de habilidades manuales, reflexivas y procedimentales a las que se les tenía que dedicar tiempo y paciencia para detentarlas como formas del poder artístico. Hasta la modernidad, el ser artista era condición ganada con heroísmo y esfuerzo, hoy el ser artista se logra al tener un concepto que organice la reunión de partes integradas de la realidad cotidiana.

La inclusión de fragmentos de papel y madera en los collages cubistas significó una enorme revolución en el pensamiento artístico, fundió la esencia representacional de la pintura con la posibilidad de presentación del referente aludido. Pero no concedió la sustitución simple de la dimensión artística y estética; que al fin y al cabo sigue siendo una manera de aprehender el mundo y aprender de él. 
Cuando la posmodernidad centra sus ataques en el logro de los cánones los mira como un pensamiento dictatorial, entiende en ellos la visión de una norma a seguir por el dictado de alguna oscura voluntad que se ha de beneficiar de su seguimiento. Pero se olvida totalmente que el establecimiento de las formas, procederes y estrategias como formulación propuesta, es la conclusión y consecución del absoluto intuido por el proceso creativo de artistas encarnados; sujetos que no son una definición sino seres que libran batallas a lo largo de su vida para ser escuchados. Ya el propio Deleuze en varios de sus trabajos, y específicamente en el libro titulado "Pintura: el concepto de Diagrama"18 insiste en que debemos aprender a escuchar a los artistas y su lenguaje, y que tenemos que aprender a medir el manejo y las repercusiones de los materiales y las técnicas a través de los cuales se crea la obra de arte. Generalmente aquello que hemos dado en llamar teoría, tiende a eliminar esta red compleja de relaciones del acto de producir el arte, en su lugar se les mira como pensamientos menores del artista que no logran el estatus de organizaciones conceptuales firmes.

Pareciera que en el terreno del dibujo el oficio vuelve a estar muy solicitado; aunque pensamos que en realidad en este campo, la valoración crítica nunca dejó de lado el grado de dificultad que esta disciplina encara. Señalamos lo anterior como una crítica al pensamiento posmoderno y a su cuestionamiento. Dentro del proyecto de la modernidad se sucedieron aportaciones plurales, variadas e importantes en el desarrollo del dibujo como terreno de la representación, y en el periodo que se sobrepone tanto a la modernidad como a la posmodernidad y que es conocido como la abstracción pospictórica. La visión de Hans Hartung, Dubuffet, Saura, Still, Manzoni, Toroni, Stella, Ryman y tantos otros abrió una senda que no se basaba sólo en variaciones simples y estéticas de las categorías formales, su revolución se orientó a formas del pensamiento y posturas epistémicas ricas y variadas. Puede ser que en el territorio de la escultura y otras disciplinas la ruptura y expansión de los campos disciplinares reportara posibilidades de amplitud filosófica y artística, pero en el terreno del dibujo pensamos que más bien se suscitó una contracción del proceso de avance iniciado hasta ese punto.

Éste es en parte el planteamiento del problema que nos interesa ubicar. En el momento de tratar a cerca de los modelos del dibujo como formalizaciones del pensamiento a lo largo de la historia habremos de detenernos un tanto en esta reflexión, ahí desglosaremos lo que desde nuestro punto de vista puede ser una síntesis de las tendencias asociadas y estratégicas dentro del dibujo en su desplazamiento desde la modernidad hacia la posmodernidad. Adelantándonos a ese punto diremos desde aquí que por una parte la valoración de una falsa mímesis dibujística sigue vigente en todo su esplendor, mientras que por otra parte coexiste una práctica sumamente prístina del dibujo como diagrama mínimo de asociación referencial, en la que no media un ejercicio representacional complejo sino una asociación sígnica elemental.

Ya desde las páginas del tratado de la pintura de Leonardo se asumió a la pintura como cosa mental, y al dibujo como el arte de pensar la forma de los seres, la naturaleza y los modelos. La revolución del arte conceptual vino a recordarnos la importancia del concepto como base del proyecto artístico, pensamiento que en su sola existencia mental nos humaniza y que convirtió al público tanto en lector reflexivo como en espectador estético,

18 Deleuze Gilles. Pintura: el concepto de diagrama. Buenos Aires: Ed. Cactus; 2007. P. 290. 
pero aún dentro del propio arte concepto fueron pocos los artistas que asumieron esta ruta radical, las más de las veces se llevó la idea concepto a un plano de realización fáctica, en donde nuevamente el objeto cobró su peso específico.

Por su parte el dibujo dentro del campo expandido, si bien prescindió del soporte del papel y la tela para atacar literalmente la tierra, el cielo, la nieve etcétera; se mantuvo en su propio orden como disciplina platónica reflexiva, y se magnificó extensamente en cuanto a su presencia y realización fáctica.

El esquema del campo expandido difícilmente sería aplicable al campo del dibujo, dada la carencia de variables que completaran la operación conectiva y de negatividad.

No pensamos que los "Anillos anuales" de Denis Oppenheim (por ejemplo) guarden una distancia con el dibujo concebido como función estratégica de las artes plásticas y visuales; no son paisaje ni arquitectura, pero si que siguen siendo trazos, dibujo de la idea.

Nuevamente insistimos; aunque ya desde la modernidad se crea la asociación entre el artista y el crítico, y aún el galerista como pilar de construcción de los movimientos de vanguardia, el motor que mueve las ruedas del arte sigue siendo el de las variaciones y propuestas generadas por el artista, es él en todo caso, el sujeto que descentra las prácticas y construcciones del arte, aunque dentro de su ideario e intención pese el imaginario colectivo del Gran Otro.

En esta visión, el logro de los absolutos artísticos representa el arribo a la claridad cognitiva de la que el artista nos quiere hacer partícipe, no con la finalidad de formularlos como un credo ante el que tenemos que hacer acto de fe sin cuestionamiento, sino como una invitación a ver y sentir el mundo, la historia y la realidad con miradas nuevas. Por el contrario con ello nos abren la perspectiva para considerar posibilidades varias frente a cualquier panorama que nos sugiriere lo contrario.

Pero se tiende a dar importancia mayor a lo que se escapa del canon y la norma, como si lo trivial fuese garantía de escapar a la gravedad que nos atrae hacia las prácticas repetitivas, pensando que lo trivial es inmune a erigirse en una nueva norma.

La posmodernidad desplaza la categoría de arte por la de imagen, parece no tomarse en cuenta que ya los procesos integracionistas del Neoplasticismo y la Bauhaus derrumbaron la categoría taxonómica de Artes Plásticas en dirección hacia la construcción de lenguaje de la visualidad y la forma como resultado gestáltico plasmado en imágenes, es en ese parteaguas donde se origina el concepto de artes visuales, que sin embargo contenía un proyecto instituyente formal y estético.

Para la posmodernidad, la representación se mira como proceso político de justificación social del estatus.

En su lugar se toma la percepción de lo contextual y la historia como su sustituto. Otro olvido, quizá aparente, en esta postura se une de modo fácil la percepción con la visualidad, como sustituto o transgresión de la representación; se olvida que todo el trabajo de la gestalt, movimiento profundo y significativo, se encaminó a develar como el acto perceptual no es desinteresado, sino que lleva ligado el hecho de una construcción cultural, vale recordar que nuestros sentidos no son meros aparatos de captura de estímulos, se unen a la vez con una interpretación y construcción histórica y cultural, que mira de manera interesada la realidad que nos rodea. 
Por eso no es sorprendente que se abogue por borrar las fronteras de los campos disciplinares, que se decida tomar partido por las mezclas y el mestizaje por sobre la separación de territorios artísticos que mejor habría que considerar como formas del pensamiento.

Simón Marchán Fiz aporta elementos que aclaran el problema que venimos exponiendo, demos paso a una cita de su discurso.

"Con el fin de soslayar la inmanencia de las obras artísticas, estas disciplinas parecen proporcionar los nuevos criterios para el análisis de cualquier manifestación visual, reproduciendo a menudo, aunque sin apenas percatarse de ello, el carácter circular de las ciencias humanas en crisis, esa actitud frecuente que alimenta la ilusión de que el remitir a criterios ajenos palia las diferencias e insatisfacciones de los propios.

Me refiero a la categoría de lo interdisciplinar. Entre las actuales remisiones interdisciplinares a veces no puede por menos de provocarme ciertas perplejidades la tranquilidad con que se ignoran las aportaciones de los denostados campos disciplinares. Que el inclusivismo metodológico sea refrescante tanto para la Historia del arte como para la de las imágenes visuales no me cabe la menor duda, pero, tal vez, es excesivo que sea al precio de un sincretismo sin pertinencias. Y, desde luego, más que de lo interdisciplinar, me inclinaría a hablar de lo transversal."19

No dejamos de pensar cuan a menudo se recurre de manera fácil a la categoría de interdisciplina para justificar una inmediata legitimación de prácticas y estrategias artísticas que sin embargo adolecen de solidez epistemológica, pero que participan fácilmente del concierto y la moda en turno.

Intentaremos abordar tópicos que corresponden a la problemática de la modernidad y posmodernidad en el arte, buscando aquellos que pensamos constituyen causalidades que determinan afectaciones al campo del dibujo, buscaremos también establecer esa relación y aportar elementos a su reflexión.

Resulta paradójico que para hablar del dibujo en este momento tengamos que referirnos a circunstancias que rodean el fenómeno artístico y que no son estrictamente tópicos del dibujo. Pero estas condiciones si bien constituyen formaciones artísticas generales, y en este sentido al estar fuera del campo de acción y producción directa del dibujo vienen a ser una serie de circunstancias del no dibujo, sin embargo constituyen una parte importante del campo de presión que marca, obliga y determina, el límite de existencia de esta disciplina y su conformación expandida, ya que este ideario y circunstancias pesan en la intencionalidad del dibujante.

La modernidad primaria en sentido histórico social, la que arranca con la revolución industrial y la ilustración del siglo XVIII, lleva en su interior ya una contradicción dialéctica irresoluble, la del pensamiento ilustrado y determinista que intenta llegar a la organización del conocimiento total, estableciendo la división de todas las disciplinas, de todos los campos del conocimiento, abarcando en esta intención a la filosofía, la ciencia y también el arte; frente al proyecto del pensamiento liberador y negativo encabezado por los románticos, quienes

19 Brea José Luis. Estudios Visuales, la epistemología de la visualidad en la era de la globalización. Madrid: Ed. Akal; 2005. P. 88. 
se asumen como la primera crítica feroz al proyecto triunfalista y moderno ascendente. Pero al fin y al cabo y a pesar de todas las críticas, el proyecto positivo de la modernidad se prolonga en el arte hasta la ruptura posmoderna, que se gesta desde mediados de la década de los años sesentas del siglo XX.

Éste es el periodo entendido como la modernidad artística tardía, cuyo signo distintivo consistió en la formulación autocrítica de las disciplinas para establecer sus propios procesos de auto revisión. El acto de retroacción causal circular dejaba en manos de las propias disciplinas la posibilidad de cuestionar su raíz epistémica. La modernidad artística, en términos de la crítica posmoderna equivale a la búsqueda de la pureza del campo artístico, donde el concepto arte sólo es significativo en término de las artes particulares. La estrategia central de esta postura entiende el proceso artístico como la producción de una obra que opera como sustituto del referente primario. Al establecer áreas de competencia se coloca al artista en la posibilidad de convertirse en el propio crítico del sistema que hereda, así como de la manipulación y variación que de este hace. Así la pintura, la escultura, el dibujo y demás campos son inconfundibles, cada uno tiene un código o naturaleza, y en la revelación y desarrollo de dicho código se sustenta el devenir del arte.

La expansión disciplinar posmoderna no opera sobre la base de los territorios conceptuales propios de las artes, ni en función de los medios de concreción utilizados, la estrategia del artista se desplaza hacia términos culturales que requieren de una comprensión estructural.

La expansión del campo disciplinar de las artes y el dibujo operó sobre la base de una recombinación estructural expansiva de los términos que la definición moderna del campo incluye, de la expansión que niega los términos y definiciones iniciales se generan otros conceptos a su vez, de manera que el ejercicio de expansión no puede ser entendido como la eliminación del campo sino como su reconversión estructural, de ahí que este fenómeno cuadre con una visión estructuralista más que como un ejercicio de deconstrucción.

Nunca en la modernidad ni en la posmodernidad, y diríamos que en toda la historia del arte y del dibujo, las rupturas de cualquier tipo o las variaciones al sistema disciplinar o el todo cultural se han suscitado de manera externa al propio sistema o contexto.

Hace tiempo, cuando exteriorizamos esta reflexión, causó una reacción francamente adversa. Afirmamos que la ruptura del campo del dibujo debe su acontecer a una práctica productiva suscitada en la interioridad del propio campo del dibujo. Señalamos también que las disciplinas de la crítica, la Teoría del Arte, y la Historia del Arte constituían campos exógenos a la reflexión acontecida en el acto de dibujar, claro que incluíamos estas áreas como parte de un contexto que ejerce presión sobre la autonomía del dibujante, que en ese sentido no es total. Pero marcamos con claridad que los contenidos y procederes de estas áreas se determinan en función de su propia razón epistémica y por tanto no serían consideradas como definitorias del deber ser del dibujo y sus estrategias de representación y construcción de sentido. Tiempo debía transcurrir para que las aguas se aclararan.

A ello contribuyó el sentido reflexivo del pensamiento deconstructivo, éste siempre criticó la denuncia y reorganización de las estructuras culturales de poder desde afuera de ellas mismas. La única manera de minar este pensamiento consistía en habitarlo, actuando dentro de ese propio marco contextual para llegar así al plano profundo de su razón estructural. 
Igualmente la práctica del dibujo como ejercicio conciente se tenía que desarrollar analizando los conceptos, las estrategias, las técnicas, los sistemas procedimentales etc. Mismos que constituyen las fronteras que limitan el ejercicio del campo y su apertura. Por eso es que la relación advertida en el pensamiento deconstructivo, en el sentido de la imposibilidad de dividir el texto de su contexto cobra relevancia.

Las razones anteriores determinan un pensamiento homeopático con la interioridad del campo dibujo, aunque esto no quiera decir que se renuncie a una práctica crítica y reconstituyente del mismo.

Vale la pena repasar el pensamiento de Hal Foster quien puntualiza el problema con claridad suficiente, aunque la cita es extensa vale la pena recobrarla.

"Mi pregunta, en definitiva, es simple: ¿entienden los críticos el arte posmoderno de la forma que parece exigir su naturaleza textual? -Tan pronto como se intenta demostrarescribe Derrida, -que no hay significados trascendentales o privilegiados y que el dominio o juego de la significación ya no tiene límites, se debe rechazar incluso el concepto y la palabra "signo" - Pero esto es precisamente lo que no se puede hacer, éste es el dilema epistemológico al que se enfrenta el posestructuralismo y la posmodernidad. Sin lugar a dudas esta catástrofe también tiene una dimensión teórica.

Ahora bien, el arte posmoderno a menudo se califica como deconstructivo, que es lo mismo que decir que implica una contradicción; debe usar, al menos como herramienta metodológica, los mismos conceptos que pone en cuestión. Quizá sea excesivo afirmar que esta complicidad sea una conspiración, pero las formas, convenciones, tradiciones, etc., sólo pueden deconstruirse desde dentro. En consecuencia, la deconstrucción se convierte en una reinscripción, pues no hay -afuera- (excepto en el sentido positivista de -al margen de los medios- una transgresión que confirma el límite). Es decir; no hay manera de no estar en un campo de términos culturales, pues es muy posible que sean estos términos los que nos conforman.

Es por esto que la teoría y la crítica como ejercicio reflexivo revisten un problema que se antoja de difícil solución. Se piensa de manera recurrente que el arte está limitado por sus prácticas procedimentales y por los espacios en que se aloja, pero es quizá la teoría la que deba encontrar un nuevo emplazamiento. Las prácticas teóricas tienen que asumir la problematicidad de su territorio, que es en parte la relación con el arte como esencia de su análisis, y de esta manera repensar las formas que permitirían la materialización de su pensamiento. En otros términos estar un tanto dispuestas a despojarse de su carácter de evaluadoras, emisoras de juicios y explicadoras de asuntos artísticos que muchas veces no requieren de traducciones lógicas lineales.

Así pues, si el arte posmoderno es referencial, lo cierto es que sólo hace referencia a la problematización de la actividad de la referencia. Por ejemplo, puede robar tipos e imágenes para desarrollar una -apropiación de cariz crítico -tanto respecto a una cultura en la que las imágenes son mercancías, como a una práctica estética que permanece apegada a un arte de originalidad. ¿Es posible llevar a buen puerto una crítica desde el interior de las mismas formas que se critican? Una vez más, la respuesta es afirmativa: ¿de qué otro modo podría hacerse? No obstante, esta crítica no puede pretender remplazar estas formas; a lo sumo puede señalar su índole mitológica y acentuar la 
necesidad de pensar y representar de otra manera. Hay, sin embargo, otra pregunta menos obvia: los medios dados ¿no están mediados? Es decir un medio como la pintura ¿se presenta estático y neutral, o está de hecho re-formado, re-presentado en y por las mismas formas que media?"20

Este doble carácter de interioridad y exterioridad de la expansión representativa, que puede llegar a prolongarse hasta el límite, donde las nuevas construcciones sígnicas no se asemejen ya a sus originales, puede no ser sólo un resultado del ejercicio deconstructivo posmoderno, y he aquí un punto interesante.

El arte posmoderno opera sobre una base deconstructiva, esto quiere decir que desmantela los discursos y las construcciones sígnicas, para intentar atribuirles órdenes constructivos de sentido que no eran los originales, de ahí que Foster advierta ya que, la cita posmoderna y la apropiación implican la concurrencia de las partes del sistema mismo, aunque con combinatorias y mezclas alternas. El trabajo continuo en la historia del dibujo generalmente no se orienta de esta manera, por el contrario, en lo general se entiende las construcciones formales del dibujo como sistemas reflexivos que permiten la organización y el pensamiento del proyecto artístico, es en el momento operativo de estos sistemas cuando el dibujante y los artistas detectan disfunciones o falta de correspondencia de los factores estructurales y los procederes del dibujo con respecto a las necesidades implicadas en el proyecto. Pero hablamos de la falta de coherencia que se manifiesta en las ligas que sostienen la integración de los códigos del dibujo con respecto a si mismos, con respecto a su posibilidad proyectual y como expresión en si de un pensamiento variable.

No obstante que la posmodernidad se presenta como una ruptura con respecto a su pasado inmediato moderno, junto con su concepción estética, no logra borrar del todo el concepto de campo, éste permanece, incluso como figura teórica para analizar su auto dispersión. Esto reporta una necesidad de considerar recurrentemente a la representación, dentro de la posmodernidad incluso como proceso que se ocupa de figuras teóricas, códigos y convenios estabilizados que permean las figuras retóricas y conformantes del arte. La intención del artista posmoderno al deconstruír la codificación estética clásica de las artes y dispersar su sintaxis constructiva, deja a la crítica en el papel de ser una extensión mas del texto artístico y su sentido significante.

Sin embargo, una característica fundamental del pensamiento deconstructivo, que resulta ser, esa sí epistemológica; es la que nos propone sustituir el carácter evolutivo y evolucionista del devenir de las artes, específicamente dentro del siglo XX, para en su lugar pensar sus movimientos, vanguardias y obras como un conjunto constelar, que se suscita en una suma de sincronías con relaciones de interdependencia e influencias infinitas, en las que descubrir o denunciar una causalidad determinista es imposible y a estas alturas irrelevante.

Retornando a la estrategia deconstructiva, pensamos que, el desarmar un sistema y mezclarlo con partes de sistemas distantes, no considera en sí, si no la reutilización de las partes en cuestión, cualquier mezcla determinada de componentes teóricos o formales no puede generar de manera espontánea sistemas de representación alternos, cuando

20 Wallis Brian. Arte después de la modernidad, nuevos planteamientos en torno a la representación. Madrid: Ed. Akal; 2001. P.197. 
menos en el sentido del lenguaje expuesto por Foster y Derrida. Esto no implica el que no sean prácticas artísticas relevantes con una alta dinámica crítica; pero guardan distancia con las acciones de reconstrucción al interior del campo artístico; que operan sobre la consistencia de sus sistemas estructurantes de representación, si bien su intención es la de mantenerlas en continua tensión, desplazándolas al límite del campo, que es donde se manifiestan las inconsistencias del sistema, pero al mismo tiempo se manifiestan de por sí, las posibilidades alternas que una lógica lineal inicial del artista no podría contemplar; como en la estrategia posmoderna. Es así porque en este caso la manifestación de la posibilidad alterna está indicada en muy bajo porcentaje por la voluntad rectora y lineal del artista. Debe su causalidad en gran medida a la construcción de un tiempo, un espacio y a la concepción particular del dibujante que se integran en el acontecimiento fenomenológico llamado dibujo. Y al que en adelante llamaremos "El Acto Dibujo"

Claro que el establecimiento de territorios definidos para la producción artística estuvo basado en la enunciación de denominadores comunes que permitieran el ejercicio de agrupamiento. Al mismo tiempo la variación en los denominadores comunes permitía con claridad la demarcación de un periodo o movimiento nuevo.

Bajo la premisa anterior, tenemos que asumir como lógica primera, la existencia previa del concepto que define la práctica del campo artístico, para extenderla o aplicarla posteriormente a los productos u obras sujetos al análisis, actuamos de esta manera por extensión. Pero en el sentido pragmático, esto es, en el terreno de la derivación fáctica del hacer el arte no sucede de esa manera; nos referimos a la actitud de intencionalidad del artista, quien muchas veces deja de lado la primacía de la definición al reconocer las posibilidades alternas de conformación, de esta manera el resultado es inverso, lo que se extiende, o tiene que ampliarse, es la categoría de definición misma del campo artístico. Si las cualidades formales y prácticas estratégicas usadas son más o menos consonantes con la definición del campo, éste se mantiene en ciertos límites, pero si por lo contrario, y esto es lo que ha sucedido, dichas prácticas y procederes se internan en terrenos varios del arte, el resultado es la casi imposibilidad de definir el producto resultante en términos de una región conceptual y formal estable.

Agregaremos el señalamiento de que las limitaciones del modelo extensionista dejan de lado la riqueza compleja y múltiple con la que el arte se manifiesta como suceso pragmático.

El pensamiento causal del artista y las prácticas que lo concretan son de una riqueza y direccionalidad múltiple, en la que no puede ser desechada ninguna posibilidad relacionante, por menor que pudiera parecernos.

La expansión de los campos disciplinares artísticos, fue consecuencia paradójica de las prácticas artísticas de la modernidad, las tensiones constructivas ejecutadas al interior de los campos clásicos de las artes, sumadas a la presión contextual ejercida por la crítica y el ámbito contextual de la cultura, terminaron por mostrar al artista posibilidades para configurar obras que alargaron los alcances de los campos clásicos de las artes.

Resulta importante señalar este doble carácter, la afectación a la morfología de los anteriores campos disciplinares es resultante tanto de procesos de causalidad interna como de las presiones exógenas que pesan y determinan el criterio de autonomía del artista. La pintura y las artes, dentro de ellas el dibujo son definiciones generadas por el sujeto artista, la independencia que llegan a lograr en el suceso activo de ejecución es relativo, 
esto quiere decir que podemos hablar de una ontología del pintor y el dibujante, pero en términos de la praxis hemos de referirnos a campos disciplinares de definición teórica. Por tanto el ser de la pintura, el dibujo y las artes es el de su condición teórica y pragmática como campo de ejercicio de la práctica del sujeto artista.

En el fenómeno del posible fin de la pintura y la expansión de su campo disciplinar son los contornos de sus definiciones teóricas, sus prácticas procedimentales y estrategias de construcción del sentido significante las que van perdiendo claridad. La definición del límite de la pintura implicaba por tanto su contraste con los campos adyacentes de las artes, su precisión disciplinar la contrastaba del contexto constituido por el resto de las prácticas artísticas; esto es lo que se entiende como fondo de polución.

Con la profusa hibridación en la posmodernidad el criterio de pureza en el ser de las artes pierde razón de ser, en consecuencia la definición de impureza también sufre una condición de cierto sinsentido.

Si hasta el arte de los años cincuenta y principios de los sesentas del siglo XX, se podía hablar de agregados de impureza dentro de algún campo artístico, basados en la concepción ontológica particular del lenguaje, en el arte subsiguiente tal condición pierde sentido, pues al desmantelarse los límites críticos de los medios y las disciplinas la posibilidad de transgresión desaparece, no se puede transgredir el límite fronterizo de definición, puesto que en el acto anterior de transgresión ha desaparecido.

Así la impureza concebida como condición de desviación en el proyecto moderno, cede ante una nueva condición dentro de un arte que ha desaparecido como integridad territorial, y como espacio ordenado dentro de una visión taxonómica del repertorio de las artes. El arte y sus obras, el propio artista ya no es impuro por contraste ante nada, puesto que los límites han desaparecido cediendo a la presión de la causalidad interna del proyecto artístico y a la externa del contexto. El nuevo sentido de la impureza disciplinar se asienta en una debilidad, lo vuelve casi inexistente, característica del nuevo territorio de la producción posmoderna.

La desterritorialización de los campos artísticos plantea la perspectiva de hibridación, mezcla o mestizaje de los propios campos. En una visión simple del asunto, la hibridación de los lenguajes sería entendida como la mezcla de sus repertorios formales y sus procederes técnicos; pero sucede que es ante todo un suceso de índole ontogénica, el ser conceptual que define cada uno de los campos no es susceptible de hibridación, en la nueva condición de existencia, el campo anterior desaparece para ceder su existencia a un algo que está por definir. Por eso se considera el arte como una idea gestada al amparo de una postura esencialista, y no se puede regir más que por la búsqueda de productos y prácticas que lo continúan. Cuando es así se suscita un movimiento de expansión, que niega la realidad de sus límites anteriores, fijados por la tensión crítica a la que nos hemos referido. Por eso en el híbrido nada queda del arte anterior, cuando menos nada que nos remita a la posibilidad de una construcción fuerte, es decir basada en la idea de la contradicción dialéctica pureza-impureza; en la que se encuentran implícitos los límites tensados de cada uno de los medios puestos en juego.

Cabe distinguir entre una práctica de montaje discursivo y una mezcla híbrida, en la primera las partes se sobreponen en una idea de transparencia, en ella queda a la vista el ser disciplinar alterno, el resultado es la reunión altamente estetizada del trabajo final, podemos distinguir en él la incidencia de cada campo participante y sus recursos proce- 
dimentales. En la segunda, la condición definitoria de cada campo se diluye, el carácter de lo resultante no es propiamente la reunión de las parcialidades que lo originan, aparece en el producto obra, una serie de cualidades emergentes que no se observaban en ninguno de los conjuntos anteriores, se está de esta manera frente a un algo alterno, ante el que es inconveniente hablar desde nociones de transgresión de límites, reflexión que es pertinente frente al panorama moderno que genera su propio límite de impureza y que opera como frontera de transgresión.

Con la claridad diferenciadora entre un arte de definición de campos y uno que transgrede la noción de territorios diferenciados, aparece una nueva pregunta; aquella que nos remite al espacio de acontecer en el que ese fenómeno tiene lugar, ya que tanto la praxis moderna y posmoderna siguen siendo praxis al fin, si bien guardan diferencias estratégicas radicales. De aquí comprenderemos el uso de conceptos como el de campo, que reporta una esencia de lugar, a la vez que alude a la comprensión de una extensión conceptual que define los lenguajes en cuestión. Campo y territorio se vuelven conceptos esenciales dentro de la fenomenología de las prácticas artísticas. El campo remite al aquí, al ahora que es condición fenoménica insustituible en el análisis. El aquí y el ahora son la condición espacial y temporal que particularizan el suceso y lo arrancan de las definiciones generalizadoras, lo enriquecen porque significan la particularidad y la presencia de factores y circunstancias específicas que no pueden ser consideradas en el proyecto inicial. El aquí y el ahora equivalen a la riqueza positiva del movimiento estocástico y aleatorio del proceso artístico. El campo es la región del acontecer en la que se manifiesta el aumento entrópico de los procesos, situación que sin embargo contiene una positividad irrenunciable, para cualquiera que sea la estrategia que se aplique.

Las creaciones híbridas posmodernas al transgredir la definición de campos no se ubican entonces en ninguna territorialidad definida, su zona de existencia opera en el ínter espacio de las fronteras de cada campo, casi es una condición lineal, un entre zonas que se prolonga como capa de espesor indefinible pero que no se mezcla con ningún campo adyacente.

Este espacio de morfología indefinible opera como zona de contacto entre los campos cuyas fronteras lo generan, no es un espacio vacío es el lugar del híbrido posmoderno, zona de inter-limitación, con características de espacialidad negativa, de ahí que el campo expandido de las artes, y del dibujo se advierta con la irrupción dentro del dibujo de condiciones, morfologías y sucesos que le son atípicos al campo propio.

De este modo se puede identificar este espacio como la zona de contacto que se afirma negativamente en la interacción de los diferentes lenguajes y medios dentro de la práctica posmoderna del montaje.

Recordemos que al operar dentro de la región teórica de estos asuntos nos hemos referido a figuras de abstracción, pero en el plano fáctico del mismo problema tenemos que entender lo anterior desde la óptica epistémica del productor. Con esto queremos decir que desde la perspectiva epistémica lo que en la definición aparecía como una forma espacial, ahora se nos presenta como un decurso de acciones proyectadas en una temporalidad. El campo expandido, es consideración territorial del problema, el decurso de acciones configuradoras del artista define un trayecto, ruta enriquecida grandemente, porque de inmediato aparecen categorías que amplían el análisis, a la vez que nos abren luces para el entendimiento de problemas en la práctica posmoderna de expansión de los campos o bien de las prácticas de representación artística. Nos referimos a la noción de "actitud", 
"acción", "acto", "proceso", "configuración", "aptitud”, "identidad” y otras que en su momento habremos de reflexionar. Pero sobre todo al pasar de una noción de territorio a la de trayecto concebimos el asunto desde una perspectiva temporal de praxis humana, acontecimiento dentro del cual la causalidad e intencionalidad del autor es determinante, sin por ello dejar de reconocer los problemas que el análisis del territorio disciplinar reporta.

Al llevar la desterritorialización del arte hacia su entendimiento como un decurso continuo e impredecible, se le reconoce su capacidad para encontrar y establecer relaciones, más que instaurar o fundar órdenes de cualquier tipo. Se han abandonado las direcciones fundacionales únicas de la modernidad para ganar en movilidad y complejidad. Esta situación ha generado una red de relaciones interdisciplinares que cada vez se complejiza de manera creciente.

En este trayecto donde el arte ha cambiado su fijeza por el dinamismo de una relación, la categoría del ser se ha conmutado por la del hacer. El qué, se origina en el cómo, y no viceversa, tal como era en la modernidad.

Así la modernidad y sus autores se esforzaron por lograr el trazo de las líneas de frontera definidas de los campos artísticos, el arribo del pensamiento posmoderno, y con él sus creaciones artísticas desechan este paradigma y se internan en las prácticas de distensión y expansión.

Ciertamente la disolución del límite de definición es generada por la hibridación de las prácticas artísticas, que operan como presión interna en la fenomenología de la producción, a esto se suma la presión de la exterioridad ejercida por la crítica.

Cuando en la modernidad, se ejercía la voluntad de artista como vocación estable para la construcción del campo de la pintura, ésta actuaba como contrapresión a los factores ejercidos por la exterioridad crítica, de ese modo se establecía un equilibrio que mantenía más o menos estable la delimitación del campo pictórico con respecto al contexto general de la crítica y los taxos de las demás artes.

La profusa hibridación de los medios artísticos perdió la capacidad de definición del límite del campo pictórico como integridad de lenguaje.

La posibilidad de establecer conceptos, categorías y prácticas particularizadas para cada uno de los campos del arte implicaba consecuentemente una concepción de identidad, la modernidad en el arte, y aún más allá, asumió la identidad como el establecimiento de las diferencias ontológicas que separaban el ser de la pintura.

En el concepto de la ilimitación poscrítica y posmoderna, al diluirse los contornos de contraste se abre la puerta a un nuevo modo para entender la identidad, esta será vista más como una manera de compartir características sustantivas similares; lo que poseo como definición y aparece en la estructura del otro es aquello que me permite identificarme como un tanto igual, identificarme con la otredad.

Pero en el armado de la obra posmoderna se recurre incluso a la reunión y mezcla de partes desarticuladas de sistemas artísticos y extra artísticos de representación que no guardan similitudes entre sí. De manera que el fenómeno de la identidad se prolonga fuera de los límites de los campos artísticos para extenderse al discurso de la filosofía. No consideramos lo anterior un error, lo que señalamos es su importancia como origen de un problema que desplaza el ejercicio del dibujo fuera de su capacidad de construcción del proyecto artístico y como práctica de abducción dentro de la representación.

Ningún campo del arte en ningún periodo de la historia ha existido como práctica aislada, 
siempre se ha aplicado como parte de una suma pragmática compleja en el contexto de la cultura y su historia.

Dentro de la modernidad quedaba claro que el ejercicio de la práctica artística buscaba ante todo la consecución de una obra estética, una formalización que integraba la visión de la realidad representada, con ello quedaba definida claramente toda acción no artística, pero en el arte más allá de la modernidad, se integran prácticas, acciones, objetos y construcciones varias que desdibujan la identidad de lo artístico. El fondo, el marco de lo anteriormente no artístico operaba como el límite de definición del arte y sus campos disciplinares, lo no artístico era par indisociable de lo artístico; en esta situación se expresa claramente la relación de una lógica binaria que sostiene dialécticamente el proceso, situación paradigmática de la modernidad. La ruptura de esta relación binaria es uno de los ejes posmodernos de estrategia.

La teoría posmoderna de la visualidad considera la ruptura binaria del fondo de polución de lo no artístico frente a lo específicamente artístico como comportamiento fundamental y de carácter positivo y deseable en el decurso de la cultura visual, para ellos la pérdida de negatividad del fenómeno artístico está implicada en las estrategias transgresoras que llevan el arte a lo ilimitado, abriéndolo a una positividad indiscutible; en la que se supera cualquier necesidad de comparación o niveles que pudiera limitar y circunscribir el fenómeno con presiones o tensiones críticas. Cabe mencionar en este punto una cita de Pedro A. Cruz Sánchez, que nos parece aclara el punto.

"No es difícil inferir, al respecto de todo esto, que, en el tránsito de la modernidad a la posmodernidad, aquello que ha perdido el arte es lo que nunca ha poseído ni ha querido poseer: su -no ser-. Y, cuando esto sucede -es decir cuando lo artístico deja de ser el resultado de una ontología contrastiva- termina por convertirse en una tarea harto comprometida hablar de arte. Debido a ello -lo artístico- es decir ese conjunto de códigos singularizados en la integridad territorial de su tensión crítica, constituye, en la actualidad una aporía. Y si así sucede no es debido a la desintegración primera e interna de su ser, si no, más bien, a la ausencia de ese horizonte de contaminación, compuesto por su no ser, por aquello que se establece como diferencia." ${ }^{11}$

Lo anterior es de sumo interés para retomarse en consideraciones que ya competen de manera más cercana al campo del dibujo.

Desde el terreno de la antropología, resulta capital el reflexionar sobre la identidad como reconocimiento del yo frente a la otredad, pero esa no es la ruta que nos ocupa, ni en la que nos mostramos capaces del análisis.

Pensemos en la identidad refiriéndola al ejercicio de la disciplina del dibujo. Ésta reviste una doble posibilidad. La identidad de la propia disciplina del dibujo como campo que se contrasta respecto de las demás artes; por otra parte la identidad como la relación del dibujante con las entidades a las que se avoca a dibujar, el dibujar casi siempre implica la asistencia frente a un otro, sea de manera concreta o en la existencia psíquica y subjetiva. En ambos rumbos del asunto la reflexión se muestra como un filón profundo para el análisis, de entrada digamos que si bien la postura posmoderna que contempla como virtud el rompimiento o elongación de los límites que contrastan los campos de las artes,

21 Brea José Luis. Estudios visuales. La epistemología de la visualidad en la era de la globalización. Colección estudios visuales. Madrid: Ed. Akal; 2005. P. 97. 
llevándolas hacia una deseable expansión no resulta de principio negativa; en el terreno del dibujo y su relación con las artes en la premodernidad del siglo XIX, la modernidad del XX y la posmodernidad de las últimas tres décadas, no mantiene características del todo coincidentes con esa elaboración teórica.

Veamos; la relación que unió al dibujo con la pintura y las artes a lo largo de todo el siglo XIX y en gran parte del siglo XX, lo menos hasta el último cuarto, fue de carácter sistémico, con ello queremos decir que era una relación en la que de manera orgánica se establecían retribuciones de un campo hacia el otro.

El dibujo por mucho tiempo fue considerado como disciplina de carácter platónico, con ello se quería señalar su esencia conceptual y prefiguradora del proyecto artístico y la imagen, así como su capacidad para pensar y configurar la forma. Pensamiento que tendía a la representación formalizada y racional de los modelos contextuales, de ahí la postura filosófica del dibujo manierista que formuló la existencia del dibujo interno como la región mental de la disciplina y el dibujo externo como la concreción fáctica de la forma racional en la imagen. La pintura por su parte, desde el surgimiento de las academias romana y francesa, es señalada como disciplina de corte aristotélico, apuntando con ello su objetivo de aprehensión sensible del mundo, basada en los fundamentos del color, según esto más cercanos a la percepción visual del mundo.

Pero desde el origen de esa polémica, que por otra parte nunca quedó del todo aclarada, el dibujo y el color eran considerados como dos cuerpos constitutivos de la pintura. Igualmente para el desarrollo del campo de la escultura se reconocía el dibujo como conocimiento indispensable para la realización de la obra. Basado lo anterior como ya hemos dicho en el carácter eidético del dibujo, y en su capacidad para enfrentar la realidad primera y los modelos como fuente de representación.

En un capítulo, más adelante de nuestro trabajo intentaremos profundizar en el carácter proyectual del dibujo. Por el momento sólo diremos que es precisamente esta relación de interdependencia sistémica la que se mantiene fuertemente aún dentro de la evolución del proyecto de los campos disciplinares del arte en la modernidad, e incluso en gran parte del trabajo artístico posmoderno y conceptual.

Remitiendo el asunto de la identidad al problema de expansión de los campos artísticos en la posmodernidad, señalaremos que la demarcación del campo del dibujo, poco estuvo en relación a la delimitación de un cuerpo definido de conceptos y categorías que se diferenciaran de las del resto de las artes y en especial de la pintura.

Más aún, los conceptos que operan al interior del dibujo, como lo serían el de tono, valor, contraste, relieve, modelado etc. Sufren adaptaciones cuando se aplican de manera constructiva en el ejercicio de las distintas disciplinas plásticas y visuales, de ahí que incluso en la modernidad los pensadores y críticos enfrentaran serias dificultades para delimitar los susodichos campos disciplinares con una serie de conceptos independientes.

Suceden fenómenos particulares dentro del proceso artístico del siglo XX. Diremos que en muchas de las prácticas conceptuales de Kabakov, Spírito, Muntadas y otros, así como en el trabajo posmoderno de Levine se mantiene vigente el carácter proyectual del dibujo como disciplina de prefiguración del proyecto artístico; a diferencia de autores clásicos del periodo moderno, como Dubuffet, Hartung, Ives Klein o Pollock, estos últimos llevaron el ejercicio de la pintura a reducciones del factor cromático, acercaron la pintura a la región 
tonal, caligráfica y atmosférica, sustituyeron en algunos casos casi en su totalidad la pincelada por el dripping y el esgrafiado; de esta manera diluyeron mucho más la distancia disciplinar entre el dibujo la pintura y el grabado, que en cualquier otro momento posterior. De manera que la generalidad del fenómeno disciplinar entre la modernidad y la posmodernidad, si bien es analizable bajo posturas teóricas y filosóficas, cuando menos en el terreno del dibujo y su relación con las artes reviste puntualizaciones de carácter especial, ese es en buena parte el problema que planteamos, la autonomía del dibujo no existe más que como intento reflexivo posible, pero en su lugar sufrió un proceso doble, en el que por una parte se mantiene íntegro su carácter eidético proyectual y por la otra se transfunde con disciplinas con las que ya históricamente estaba sistémicamente relacionado. Ésta es nuestra formulación hipotética, es nuestra ubicación problemática central, sobre ella construimos la vigencia del dibujo como disciplina de representación formal, y habremos de demostrarla partiendo del análisis histórico del dibujo y los artistas que lo ejercen ocupando el tramo de tránsito de la modernidad a la posmodernidad en el siglo XX.

La inclusión de estrategias tan variadas como el uso de imágenes de segunda y tercera generación, los objetos encontrados, la suma de textos escritos en la imagen, sonidos, el uso del cuerpo del artista y el de sus modelos en acciones performáticas como manifestación artística, los cuestionamientos a la temporalidad y espacialidad de la obra planteados en las instalaciones e intervenciones efímeras, la extracción del arte de los lugares tradicionales que lo acogían y legitimaban, todo este conjunto de situaciones evidencian el ansia del artista por reinscribir el arte en la realidad vital.

Todo lo anterior manifiesta la constante preocupación del artista por vivir de manera sincrónica dentro de su tiempo histórico e incidir en ese contexto, hoy día de la manera señalada, tenemos que asumir esta postura como una actitud consecuente sin dudarlo; pero no nos equivoquemos al tomar todo esto como argumento que justifica la desintegración del terreno del arte, y de una disciplina como el dibujo.

Aún con todo lo mencionado, el dibujo se mantiene como disciplina que reflexiona la obra y su proyecto.

Parece que históricamente no se ha atinado a formularlo; pero aquí aventuramos una postura: el dibujo puede ser considerado como la disciplina de la definición de la forma y su comportamiento dentro de las categorías de la representación en las artes de la imagen; a parte de su función proyectual artística e histórica, función estratégica ya naturalizada en el pensamiento artístico y de la que sin embargo nos ocuparemos en el siguiente capítulo para precisarla.

Hoy sabemos que una sola definición no mantiene la extensión necesaria para contener la pluralidad de variaciones históricas de una disciplina, y menos aún si entendemos el arte como el territorio de las posibilidades más que de las afirmaciones excluyentes, por eso decimos que además el dibujo es una disciplina fenoménica de representación, en la que se introduce la subjetivación y los afectos que el dibujante concluye de su vivir el mundo, sin menoscabo de la actividad reflexiva, originaria de los territorios conceptuales del campo dibujo, y que también es la disciplina que nos permite la operación del pensamiento en imágenes.

La postura que mira el dibujo como definición de la forma, se funda en una visión elemental que entiende la forma como la identidad somática y corpórea de los sujetos, pero más que nada en el pensamiento racional, en el que la forma es una posibilidad de construir el 
mundo mediante el intelecto, basándose en un análisis racional; y también en la postura moderna, en donde la estrategia se centra en un procedimiento tautológico reflexivo que piensa la forma de la forma.

Pero finalmente el dibujo continúa siendo una manera de conocer el mundo, de acercarse a él para entenderlo y llevarlo al interior de un algo llamado obra, que por su ser definido, no puede entenderse como la realidad primaria de que parte. Y es también desde siempre pensamiento que analiza la esencia del mundo y la concreta en imágenes.

Es este un momento de saturación que desborda los límites ontológicos del campo, pese a eso los afectos y los preceptos se interiorizan en los conceptos para adquirir sentido significante, sin perder la resonancia subjetiva que marca nuestra psique.

¿Y que es todo esto, sino la esencia de un proceso de representación, sin importar la no linealidad de la ruta estratégica aplicada?

\section{I-5 EL DIBUJO EN EL FIN DEL ARTE, EN EL FIN DE LA ESTÉTICA}

"En 1981 había evidencias, si uno estaba dispuesto a verlas, de que la pintura ya no tenía hacia donde avanzar, de que las pinturas completamente negras de Reinhardt, las completamente blancas de Robert Ryman o las sombrías rayas de Daniel Buren señalaban etapas terminales de agotamiento interno. Si bien uno se podía contentar, si quería ser pintor, con repetir esas soluciones o con hacer variaciones marginales, quedaba la pregunta de porqué uno quería hacerlo. Había un número alentador de variables con las cuales experimentar-dimensión, matiz, textura de la superficie, borde, hasta forma- pero esto se debía hacer sin la esperanza de una ruptura histórica"22

Quizá una particularidad del pensamiento teórico y crítico posmoderno es que descansa en demasía sobre las similitudes estilísticas de las imágenes a que recurre, y con ello a la estabilización social de esas imágenes dentro del corpus cultural establecido. Pero más que ver el estilo como categoría definitoria tenemos que señalar que bajo la similitud formal de las obras, en su origen se deben a fenómenos de reflexión formal diferenciados, y tenemos que pensarlas de acuerdo a esa causalidad que las personaliza, para poder acercarnos a su sentido significante, y por tanto a su sentido expresivo.

Recordando la tesis del propio Arthur C. Danto, quien formula el fin del arte, nos parece interesante la consideración de la historia del arte como la historia de los discursos legitimadores de los distintos sistemas culturales. Podemos considerar las grandes divisiones de la historia clásica y moderna del arte como un secuencia de agrupamientos formales, estilísticos, teóricos e históricos en los que se lee el pensamiento mediante el cual los sistemas sociales se auto representan. Como el mismo Danto lo señala, en el ordenamiento terso de estos relatos se excluyen prácticas, autores y procesos que no son ajustables al orden propuesto por estos discursos. Ya incluso en el arte contemporáneo del siglo $\mathrm{XX}$ aparecen francas divergencias que requieren de un modelo distinto para entender el fenómeno artístico.

Un proceso que se observa en muchas de las producciones del arte de la modernidad, y que se continúa en el arte posmoderno llegando a ser su carácter definitorio, es la amplia

22 Danto Arthur C. Después del fin del Arte. España: Ed. Paidós, Transiciones; 1999. P. 164-165. 
disociación de los movimientos integrados sobre un ideario común, siendo esta una diferencia clara con la vanguardia en un sentido clásico, ya que la última operó sobre bases programáticas y formales establecidas las más de las veces en manifiestos que hicieron públicos. La reducción excesiva del programa artístico se convierte ahora en un estado patológico que hace imposible la integración del pensamiento y las obras posmodernas. Pareciera ser que es imposible cognitiva y perceptualmente lograr un pensamiento ordenado en la mente de los artistas para generar una forma orgánica en consecuencia.

Se vive un frenesí por lo efímero de las producciones, estas cada vez más se vuelven imposibles de conservar para sus propietarios y en el mercado del arte. Pero se asume lo efímero como algo más dinámico que las producciones permanentes de la modernidad. De la misma manera se piensa en lo "Actual" como aquello que comporta un valor superior frente a lo histórico. Nos excita sobremanera las características anormales que podamos introducir en el fenómeno. Pero lo efímero se constituye en su propia debacle, pues demanda un ritmo de crecimiento y producción desenfrenada, y el agotamiento rápido del manantial de lo sorprendente, resultando imposible mantenerse al día y totalmente informado de lo que acontece en el panorama en el que nos inscribimos, por más que uno lo intente.

Vivimos la inestabilidad continua, artística y socialmente, parece imposible; y lo es, lograr valores duraderos y convenios de integración que nos lleven a significados sostenidos en los que veamos un propósito profundo. El exceso de pluralidad que en un principio nos pareció saludable, la multiplicidad de lo que el lenguaje nos puede decir del mundo, que pensamos era una claridad democrática, nos llevó por el contrario a un estado de relatividad que vuelve imposible la institución social del imaginario colectivo.

El peso de lo anterior comprime el terreno del arte con claridad que se advierte sin dificultad. La ausencia de formas de integración artística actualmente se debe a varias razones, la primera y más simple es que de principio el artista posmoderno se preocupa muy poco por la búsqueda de esa forma orgánica, se mueve cómodamente dentro de la estrategia que retoma de las producciones e imágenes del pasado para servirse de ellas. En segunda instancia, la desintegración y pluralización infinita de los discursos del arte es vista como una cualidad positiva, esto es, se busca su afirmación como anteproyecto de integración cultural, más que intentar trascenderla y superarla.

Además de lo anterior, la práctica recurrente de pluralización y mezcla de los sistemas de representación que forman la historia del arte, generan un fenómeno de combinatoria exponencial de las formas y las imágenes, en el cual cada parte de un sistema integrado al corpus de la obra y del fenómeno en general se convierte en una variable que se multiplica junto con los demás factores en uso. El resultado de esta progresión geométrica basada en la mezcla directa, es el aumento de la entropía dentro del sistema artístico. La consideración de este proceso nos lleva a entender el comportamiento del panorama artístico como un estado de cosas que aumenta continuamente el grado y número de sus contradicciones internas; de ahí que se haga imposible cualquier ejercicio de integración que no sea la reunión indiferenciada de producciones que muestran una debilidad para establecer denominadores comunes.

Señalamos de este modo el carácter entrópico del arte posmoderno como una característica que lo diferencia de la modernidad, quien llevó al interior de la obra y el proceso artístico el factor de azar y aleatoriedad, pero con la intención clara de alcanzar una forma estética que lo estabilizara en la propuesta de un sistema de representación. Con esto 
rebasamos la idea directa de comprender la diferencia entre los periodos del arte como una división estilística y cronológica.

El modelo de la historia del arte moderno establece así lindes que marcan el territorio de lo que ha de ser llamado artístico, estos lindes como sabemos son la frontera transgredida por la práctica posmoderna.

Es cierto que hoy disponemos de un inmenso archivo de imágenes y sistemas de representación del cual podemos servirnos como artistas, lo que no nos es accesible es el espíritu inmanente en esas construcciones, ya que de manera exprofesa, incluso repudiamos la postura epistémica que conformaba aquella mirada determinando la práctica de los artistas.

Una más de las distancias entre modernidad y posmodernidad se sucede en la pretensión clara posmoderna de renunciar a la dimensión estética que busca la formalización del concepto en el corpus de la obra, como se muestra en la cita inicial de este punto.

El arte de la modernidad continuó proponiéndose la integración de la forma con el asunto tratado en la obra, tema y contenido se tenían que fusionar en una entidad resultante del proceso de artización de la realidad, que sería revelado en la materialización sensible. El arte posmoderno considera la forma como algo dado ya, tanto en las imágenes de la historia del arte de que se sirve como en la mismidad de los objetos y porciones de la realidad concreta que incluye en sus obras. Para éste, la forma es un andamiaje estructural de tránsito, desde el que proclama su crítica y cuestionamiento, más que el objetivo a concretar y revolucionar.

Todo arte comporta una dimensión política del asunto y tema tratado, y es esta visión y opinión la que el artista presenta al espectador. En el proyecto estético hasta la modernidad, la forma como concreción de la representación era en sí la postura y opinión propuesta, junto con el discurso histórico evidenciado. Para la posmodernidad el plano político no atravesará la dimensión formal y estética, se manifiesta en la exposición y presentación directa de los fragmentos discursivos del arte del pasado, que se aúnan a la integración de acciones performáticas y objetos cotidianos, o a la captura de fragmentos en imágenes del contexto, que pocas veces pasan por procesos de alteración formal. Muchas veces, son imágenes y porciones de discurso ofertadas por los medios masivos de comunicación que en estricto no pertenecían a la región artística de la modernidad.

En el arte más allá de la estética se tiende a vivir el asunto y la postura política como algo exhibido directamente, porque no se somete a un proceso de representación; es decir, se hace un esfuerzo mínimo para conferirle una reconstrucción formal.

La forma que el asunto y los sujetos presentan en la vida real y cotidiana es considerada como su forma verdadera, aquella que lo muestra como realmente es. De este modo el asunto es forma por sí mismo en la postura posmoderna, lo cual significa que cualquier proceso que nos lo re-presente en una forma alterada es tomado como un acto de falsificación.

El arte posmoderno trata ante todo de presentar la vida cotidiana como se sucede frente a nosotros, sin pasar por un proceso de transmutación, pero organizado para su presentación por medio de un proceso estratégico metodológico que estructura el sentido significante; para esta postura la vida es más interesante que el arte mismo, éste sólo será importante cuando la obra pueda ser confundida con la vida misma, claro que en este caso el arte desaparece como esencia diferenciada. Por esa falta de distancia entre la obra pos- 
moderna y la realidad cotidiana cobra relevancia el espacio expositivo, pues es en él donde se enmarca la lectura artística de lo incluido en su espacio, de no ser por el espacio expositivo, la diferenciación sería insalvable y todo se diluiría en un continuo indiferenciado.

Pero lo anterior se sucede más en el pensamiento de la crítica que en el de los propios artistas. Adelante nos referiremos a la crisis de la representación en la era posmoderna, en ese momento trataremos el pensamiento de artistas importantes que, siendo emblema de la posmodernidad sin embargo mantienen clara la distancia entre la realidad presentada crudamente como acto postartístico y la creación de un espacio fenoménico típicamente artístico. Por ahora sólo nos referimos a la voluntad de renuncia al plano estético como construcción de la obra y de su proyecto expositivo.

En el sentido anterior al prescindir de la formalización como vía estética, también se renunció al plano de la experiencia estética por parte del espectador, esta será cambiada por la generación de un estado de shock propiciado por las obras que, desde Duchamp crean una disconformidad en el público y el espectador.

La intención que esta estrategia buscó desnaturalizar, es la de una correspondencia directa entre los sistemas sociales de representación que formulaban un concepto prefijado de identidad del territorio artístico, máxime cuando la sociedad global diluye las diferencias entre las culturas periféricas y las metrópolis, al integrar las formas culturales arcaicas dentro de la estética de la vanguardia.

Se atacó el sentido de individuo como definición estatuida en abstracto dentro del discurso humanista propio de la modernidad, porque se aludía a un valor moral y no un sujeto específico y encarnado en el tiempo y espacio social particularizado. Pero con esta ruta se llegaría demasiado temprano a la desintegración del imaginario colectivo y de la institución imaginaria de la sociedad. La noción de lo social como convenio en el que se pondera al todo grupal por encima del uno, desaparece cada vez más, haciendo imposibles los acuerdos que convoquen al grupo humano bajo un ideario común. El imaginario colectivo, como visión que los propios hombres tienen de si, sucumbe ante un imaginario entendido ahora como el inmenso reservorio de imágenes y prácticas que la historia nos pone a disposición.

La relación de lo anterior con el campo de las artes se observa en la profusa aparición de discursos particulares del artista, que dificultan hasta el imposible la formulación de códigos y razonamientos sistémicos, en los que se dibuje el ser y función social del arte, en su lugar preferimos declarar muerta esa práctica milenaria llamada arte.

\section{I-6 LA ESTRATEGIA DEL ARTE, MODERNIDAD Y POSMODERNIDAD}

Con el pensamiento posmoderno se asume la tesis de que toda imagen es un sustituto o copia de la realidad que pasará a ser tomado como la existencia misma del entorno que la genera.

El presente es una vivencia original, aunque generalmente se viva en confrontación con la experiencia, esta última como suma de la conciencia cultural y lo aprendido como formación en una disciplina.

La linealidad histórica que domina nuestro pensamiento es heredada del modelo ordenador del siglo XIX. La posmodernidad es el momento de ruptura que busca la fractura de 
dicha linealidad. Es terreno de desplazamientos que denuncian la intencionalidad política subyacente en los discursos estabilizados del conocimiento.

Según Juan Martín Prada, no es posible pensar en un análisis de la recepción estética del producto artístico sin pensar en una crítica inmanente a los sistemas de representación de la imagen.

Es por eso que las prácticas museísticas posmodernas buscan la reorganización posible de las colecciones que históricamente integran su acervo. No resulta difícil relativizar el contenido significante de las obras y series. Sobre todo si nos atenemos al ejercicio hermenéutico que contempla la posibilidad de significados varios en una misma estructura de lenguaje. Pero el problema se agudiza en cuanto se trata de refuncionalizar el discurso de las colecciones que ya cercanas en el tiempo dictan el ser de lo que se ha llamado el Arte Moderno, y que problematizan la definición de los propios museos que se dedicaron específicamente a contener el arte que es sustancia de ese tiempo y periodo histórico. Pensamos que el problema estriba en una indefinición analítica. El arte, y dentro de él el dibujo, rozan una gran variedad de campos del saber y el trabajo humano, sea porque se apropian de parcialidades varias, que le sirven como posibilidades que aclaran su postura epistémica, o bien porque sean regiones tecnológicas que se le proponen como ofertas de construcción técnica. Aclaremos que el arte, y dentro de él los dibujantes nunca se han preocupado específicamente por guardar una distancia con respecto al ejercicio reflexivo del lenguaje, la filosofía, o las ciencias naturales. De ahí que la función filosófica del dibujo en el Renacimiento clásico sea la de un pensamiento platónico que se esfuerza en fundar su proceder, la construcción de su teoría y sentido a manera de una vía reflexiva que organice un orden racional y métrico para representar el mundo.

Así podríamos hablar de un sinfín de circunstancias tangenciales al dibujo que son lecturas de cómo esta disciplina se encuentra en relación con el contexto del que surge. Pero trayendo al centro del análisis la afirmación compleja de un sistema, al que se le confieren posibilidades de integración múltiples, recordemos que la tendencia organizacional del sistema, en este caso el del arte y el dibujo se debe al centro de atracción gravitacional, que es el que marca la tendencia organizativa del proceso. Y gústenos o no, también hemos de puntualizar que esta tendencia organizacional del dibujo no es la de un sistema natural, o un sistema sociológico, sino la de un proceso de representación artístico. Esto es que, su sentido y vocación son los de la intencionalidad de un sujeto dibujante, cuyo principio de autonomía, en términos de un pensamiento constructivista, determina la toma de decisiones fundamentales; no consideramos necesaria la aclaración simple que nos recuerda como las decisiones asumidas se encuentran en el panorama contextual que opera como presión psíquica e intelectual en el artista. Decimos claramente que la direccionalidad del proceso establece una línea de tiempo y proceder cuyas características no se pueden subvertir arbitrariamente.

Para decirlo directamente, el discurso contenido en los productos artísticos es el de la visión del mundo mediada por el territorio y velo del dibujo, búsqueda del artista por lograr un contenido que estabilice sus intenciones significantes, aunque con ello lleve dentro la desestabilización parcial de los sistemas estables en el orden de las formas y estrategias del arte. Concordando con Edgar Morin ${ }^{23}$ planteamos que todo exceso de relativización termina por destruir la cohesión del sistema, que de cualquier manera necesita de una estabilidad temporal por corta o relativa que esta tenga que ser.

23 Morin Edgar. Introducción al Pensamiento Complejo. Barcelona: Ed. Gedisa; 2001. 
En este punto se origina uno de los problemas del pensamiento posmoderno, que lo diferencia de la modernidad en el arte. La búsqueda por relativizar los discursos totales termina por desintegrar los acuerdos de codificación fundacionales, generando un sentimiento de aislamiento y la imposibilidad de construir un discurso teórico sólido, como si lo hizo el proyecto moderno y específicamente en el terreno del arte, la pintura y el dibujo.

Todo análisis de los procesos de representación implicados en el ámbito cultural, se roza con los mecanismos que establecen los acuerdos culturales como una forma de poder, que opera en el plano ideológico de las sociedades. Esta relación integra uno de los intereses principales en la investigación de la historia del arte de la posmodernidad.

La estrategia posmoderna del arte se basa en gran medida en la subversión de los mecanismos de representación, para deconstruir las bases de una imagen cultural y retrotraerlas hacia su reconvención, como manera de cuestionar el estatus implicado en las formas estables de la representación y su potencial político activo.

La dirección que determina esta intención es la de una denuncia en lo referente a los beneficios que reporta una imagen estable concebida en la representación formalizada. Se pretende cuestionar la falsa correspondencia entre representación de la imagen y verdad naturalizada. Lo potencialmente interesante de esta postura es que su fundamento crítico no está sólo en la consideración temática de sus contenidos, sino en la forma misma de la construcción representativa. La estrategia deconstructiva radica en el acto de romper el orden constitutivo del discurso en el arte, para reagrupar sus componentes estructurales, formales y temáticos, asociándolos con otros repertorios que pueden ser sincrónicos o no, dentro de la temporalidad histórica del arte, pero que al ser organizados en una malla sintáctica relacionante, muestran un sentido significante que cuestiona el orden mismo de los sistemas e imágenes utilizados.

Para el artista posmoderno es perfectamente válido el servirse de la historia del arte y sus imágenes, en todos los terrenos disciplinares, para organizar un nuevo sentido. El sustento clave en este accionar es el desplazamiento que se da en la actitud del autor, hacia una postura en la que se sirve de imágenes de generación anterior para reciclarlas en la obra. Consideramos este un punto medular que requiere detenernos en la extensión de su análisis más allá de lo que ya tratamos como montaje y desmontaje de las imágenes históricas apropiadas.

Llamemos imagen de primera generación a toda aquella que surge de un enfrentamiento primario del autor con su modelo, sea éste una porción de lo que se ha dado en llamar realidad externa, o bien de una condición reflexiva que determina la búsqueda de órdenes formalizados nuevos. La imagen de segunda generación es aquella que surge del uso de cualquier tipo de obra visual o sus fragmentos, sea esta artística o del dominio de los medios masivos de comunicación, cuya característica básica es la de ser una construcción en la que el autor no enfrenta las condiciones de formalización primaria del modelo, sino que ahora estas características inmanentes acompañan a la imagen reciclada, incluso esta conciencia es parte de la intencionalidad discursiva del artista. Foto de la foto, foto de la pintura, foto de la escultura, foto de otro algo que no presencié de manera directa, etc. Para el artista posmoderno el concepto de estrategia resulta fundamental, pero tenemos que ubicarlo como el centro ordenador que busca construir el discurso de la obra estableciendo vínculos de relación y cuestionamiento al asociar la carga sígnica ya determinada culturalmente en las imágenes que está utilizando, para lograr un nuevo juego de sentido. Diríamos que es ésta una estrategia discursiva que opera y se funda básicamente en la 
desestabilización del plano semántico en la obra, mediante una organización sintáctica atípica. En el arte posmoderno, estrategia y desestabilización del discurso son una característica sustantiva, veamos una cita de Donald Kuspit.

"La interacción entre lenguaje y objeto en un juego de referencias es la norma del postarte. Es una aventura semiótica que emplea medios cotidianos para generar una fricción conceptual. La meta es crear una aporía, no simplemente una ambigüedad; una dilema irresoluble, no simplemente un significado incierto."24

En este orden de pensamientos la estrategia dentro del proyecto de la modernidad tiene su lugar en el momento de la planeación de la obra, pero sobre todo en el proceso de configuración y construcción fáctica del dibujo y la pintura. El cúmulo de situaciones acontecidas en el hacer el dibujo y la pintura fueron advertidas claramente por el artista informalista y expresionista. Se cobró conciencia del carácter orgánico y vivo de ese momento, la estrategia en ese sentido se entendió como la manifestación viva y consciente que unía la intencionalidad inicial del proyecto con la necesidad de modificaciones emergentes sugerida por el proceso mismo de configuración del dibujo, la pintura y sus partes.

Esta concepción que mencionamos de la estrategia se encuentra en íntima relación con la esencia de los procesos de representación que operan en la disciplina del dibujo. Ambos asuntos, estrategia y representación ocuparán nuestras reflexiones en capítulos posteriores.

Tenemos así una característica diferenciadora. Mientras que para el arte moderno, el motor sustantivo de la acción es la creación de sistemas de representación, y dentro de ello la estrategia guarda su sentido básico en los momentos de prefiguración y configuración, en la posmodernidad se busca la desestabilización de esta meta.

La estrategia opera también como categoría fundamental en el arte posmoderno, diríamos incluso que estamos de acuerdo con quienes señalan que la estrategia del armado de la obra posmoderna entra en conflicto con el proceso de representación de la modernidad. Hemos explicado de que manera la categoría de la estrategia también opera dentro del trabajo de representación en el arte de la modernidad, la diferencia estriba en que dentro del proceso constructivo posmoderno la estrategia se define con un carácter dirigido prioritariamente a la relación sintáctica entre imágenes de segunda generación, estas conllevan ya una carga sígnica y formalización previa, de la recombinación sintáctica, de ello y su descontextualización depende el acierto crítico de esos proyectos.

Por eso es que la estrategia guarda distancias importantes dentro del arte en la modernidad y la posmodernidad. Esta distancia en la función de la estrategia es una diferencia fundamental epistemológica y origina diversas consecuencias. Estrategia y postura epistémica se relacionan de manera muy cercana determinando causalidades y definiciones radicales que diferencian al arte, al artista y a la práctica productora de imágenes diferenciada en la modernidad y la posmodernidad. El tema de la expansión de los campos disciplinares de las artes es una de la expresiones de esta condición.

No consideramos aún así el que la diferencia de posturas sea una contradicción excluyente que aniquile la posibilidad de existencia de cualquiera de las partes. Tal vez ésta sea la visión de la crítica posmoderna, la toma de partido por la estrategia que ve en la cita y la

24 Kuspit Donald. El fin del arte. Madrid: Ed. Akal; 1999. P. 73. 
apropiación la posibilidad que sustituye a la representación, y en este sentido se mantiene ese pensamiento prisionero de una lógica dialéctica y binaria.

Nosotros pensamos en una disyunción, una bifurcación de rutas, el hecho de que se decida recorrer una de las ramas que se separan no implica la inexistencia de la otra, esa sigue estando ahí, y no podemos afirmar de ninguna manera que es una posibilidad cancelada a la que haya que enterrar en la historia del arte o de la que tengamos que ocuparnos en franca contradicción.

La lógica causal y fáctica del acto dibujo puede darse sobre bases estratégicas y teóricas varias, sean estas deconstructivas, constructivistas, tectónicas, formalistas, proyectuales, o cualquier otras; la diferencia sustantiva radica en trasladar la estrategia a la interioridad del acontecimiento y del proyecto del dibujo, y no considerarla ni ubicarla como motivo causal del trabajo artístico y sustituto de la construcción formal; no es una cuestión de matiz, nos parece esencial la distinción porque en ella se comienza a trazar el organigrama de la práctica del dibujo.

Con el postulado anterior quedamos en posibilidades de aportar nuevas luces a la hipótesis inicial de esta investigación. La estrategia posmoderna, centrada en la cita la apropiación y el desconocimiento del plano estético y formal como objetivos del trabajo artístico, trajo como consecuencia el trazo de nuevos alcances para los campos disciplinares que anteriormente fueran el centro del proyecto moderno.

En el proyecto de la modernidad formalista que alcanza hasta mediados de los años sesenta, se mantiene vigente la relación sistémico funcional del dibujo que como pensamiento eidético se interpenetró con las demás artes, la función proyectual y estratégica-racional del dibujo operaría sólidamente aún en el trabajo y proceso de los artistas conceptuales más rigurosos de nuestros días. Ilya Kabakov, Iran Do Spírito, Muntadas, Vik Muniz etc.

Con la voluntad expresa de no basar la construcción de la obra en la búsqueda de sistemas formales de representación y con el rompimiento de las fronteras de los campos disciplinares del arte se dan las dos condiciones que precipitan un salto de órbita en la función sistémica del dibujo, éste no ganó autonomía artística, ni se le llegó a definir como un arte en sí mismo; lo que resulta a todas luces contradictorio en el momento en que los propios campos son una aspiración cancelada de la modernidad.

Pensamos más bien en una situación del estar, región de indefinición en la que los dibujantes se encuentran de repente como consecuencia de una práctica posmoderna en la que los rigores de la educación del dibujo ya no son necesarios, o cuando menos una base indispensable.

La ubicuidad en esta región un tanto imprecisa, sin embargo representó una potencia expansiva para el ejercicio del dibujo, como habremos de reseñarlo más tarde.

El asunto temático tiene un potencial discursivo en tanto se le integre dentro de una estrategia expresiva, y para la posmodernidad esto es esencial y suficiente, al margen de la búsqueda de imágenes de primera generación.

Por eso consideramos la estrategia posmoderna en el arte como una construcción de la obra que descansa sobre el contenido semántico social y culturalmente inmanente en los 
fragmentos llevados a la interioridad de la obra, ya ahí se les interconecta en una reconstrucción sintáctica que organiza lecturas dirigidas del discurso.

Pero aún dentro de este orden de pensamiento se descarta la dimensión pragmática como aquella que considera la afectación y reconstitución del signo dentro de su deriva contextual; por eso es que, en el ejercicio del arte posmoderno, no importando que tanto la acción y el suceso artístico se den en un tiempo real y con la concurrencia de espectadores muchas veces en grupos masivos, está cerrada de inicio la posibilidad de un acto de retroacción causal, en la que el público diverso pueda ejercer una modificación en el sistema de representación, ya que no se espera de todo esto un logro de códigos sígnicos formalizados.

Dicho sea de paso, la creatividad en el plano de las artes se asume como la formulación de desviaciones, aportaciones y extensiones al sistema, sea este el arte mismo o los constructos formalizados que lo concretan; ésta es la comprensión abductiva del problema, coincidimos con ella, y desde esta postura explicamos un tanto en estos tiempos la crisis creciente de representación en el terreno del arte.

\section{I-7 LA CRISIS DE LA REPRESENTACIÓN}

Los sistemas de reproducción mecánicos y fotográficos, serán utilizados en la práctica apropiacionista posmoderna como un recurso fuerte en el cuestionamiento del viejo arte moderno, que descansa sobre el fenómeno aurático y de originalidad. Frente a este objetivo, el empleo de los sistemas de reproducción dentro de la práctica posmoderna se orienta hacia la deconstrucción y crítica radical de la representación.

Sherrie Levine, en su serie de trabajos, After Walter Evans, procede realizando fotografías de otras fotografías, las presenta además con el lema: Una imagen no es sustituto de nada. De esta manera hace explícita su crítica a los sistemas de representación. Al presentar sus fotografías de fotografías como propias, cuestionaba también la búsqueda de originalidad y, por supuesto no dependía ya del contenido semántico que la imagen primera pudiera comunicarnos, el mensaje era solamente el plagio y la apropiación de algo que en origen no le correspondía.

El auge de los medios masivos de comunicación, de las instituciones y empresas de distribución de imágenes, coloca al arte en un lugar limitado dentro del panorama de las representaciones visuales. En parte esto es el resultado de la ampliación representacional que generaron dichos medios y tecnologías, y también por la tendencia de las imágenes a inscribirse en el universo de espectáculos típicos de estas sociedades. Sólo puntualizamos un aspecto, la política de la representación se entiende como el uso social de los sistemas de imagen en función de intereses grupales, es decir que sustancialmente es una función social establecida dentro de las prácticas de poder y organización del estado y la economía, en tanto que la representación remitida a la interioridad artística es primariamente una función epistémica del lenguaje, y aunque ambas se sucedan dentro de una relación sincrónica en el contexto de la sociedad, no obedecen a las mismas causas y determinaciones; sus grados de relación, dependencia y afectación no corren en un solo sentido ni de manera lineal determinista, la cultura y el arte, como parte de una superestructura cultural no siempre se derivan directamente de los factores estructurales de una formación social. En este sentido la cultura de las imágenes y la representación no es una construcción social de lo visual y artístico, como un reflejo, sino una artización 
y construcción visual de lo social, es decir instauradora de una visión del mundo y la realidad contextual.

Cuando el artista propone una imagen, un proyecto o una serie de trabajos no parte del vacío representacional, ni en su mente ni en la del espectador, no está inventando en esos espacios mentales una nueva representación ni una subjetividad no vista. Sabe y tiene en cuenta la suma de subjetividades y construcciones imaginarias previas que operan en la reflexión artística y del espectador, los modos de ver y de relacionarse con las obras e imágenes, las construcciones del lenguaje de que se dispone para traducir, sentir e incorporar la nueva experiencia en su entender del mundo.

Los sistemas formalizados de la representación y sus modos de producción así como sus estrategias, funcionan asociados al aparato psíquico de subjetivación, tanto del artista que los genera como del espectador. Guardan un grado de independencia del contexto del que surgen, porque las más de las veces operan como crítica y separación abductiva de este. Desarrollan dinámicas particulares propias, su uso recurrente los vuelve del dominio generalizado y así parece que se agotan, máxime cuando aparecen nuevos modelos, pero los anteriores no se extinguen, quedan operando como parcialidades fluctuantes en una u otra medida.

Los clichés se filtran insistentemente al dominio de nuestro pensamiento y aceptación, así aunque por vocación nos inclinamos por un arte de imágenes crítico, seguimos valorando como formas supremas y de dominio pictórico las pinceladas rápidas, los trazos vigorosos aunque carezcan de sentido más allá de su capacidad de sorpresa, la línea que muestra nerviosismo en contra del trazo seguro que grafica la estructura del modelo, los contrastes crudos y directos de color, cuando es mucho más difícil construir cromáticamente basados en una estructura de alturas tonales. En fin que si revisáramos el repertorio de lo ofrecido por las obras contemporáneas encontraríamos una reducción y empobrecimiento de los procesos y estructuras formales disciplinares, en gran modo esta es la crisis de la representación y no sólo la inutilidad que su sentido tiene, como intentan hacernos creer.

Veamos la opinión que Deleuze y Guattari manifiestan al respecto.

"El arte abstracto únicamente trata de afinar la sensación, de desmaterializarla, trazando un plano de composición arquitectónica en el que se volvería un mero ser espiritual, una materia resplandeciente pensante y pensada, y ya no una sensación de mar o de árbol, sino una sensación del concepto de mar o del concepto de árbol. El arte conceptual se propone una desmaterialización opuesta, por generalización, instaurando un plano de composición suficientemente neutralizado... para que todo adquiera un valor de sensación reproducible al infinito: las cosas, las imágenes o los clichés, las proposiciones, una cosa, su fotografía a la misma escala y en el mismo lugar, su definición sacada del diccionario.

No es nada seguro sin embargo, en este último caso que se alcance así la sensación o el concepto, porque el plano de composición propende a volverse informativo, y porque la sensación depende de la mera opinión de un espectador al que pertenece la decisión eventual de materializar o no, es decir de decidir si aquello es o no arte. Tanto esfuerzo para volver a encontrarse en el infinito con las percepciones y las afecciones comunes, y reducir el concepto a una doxa del cuerpo social o de la gran metrópoli americana... 
Bien es verdad que estos puntos culminantes comportan dos peligros extremos: o bien retrotraernos a la opinión de la cual pretendíamos escapar, o bien precipitarnos en el caos que pretendíamos afrontar."25

El texto de Juan Martín Prada, "La apropiación posmoderna" se publica en el año 2001. En este trabajo se redondea la postura de la crítica y la teoría posmoderna en cuanto a la crisis de la representación en el terreno de las artes, para ser sustituida por las estrategias de cita y apropiación, y por la inclusión de segmentos físicos y objetuales del contexto al interior de la obra de arte. La representación retrocedería al influjo de la pequeña variación introducida por la reproducción de la imagen y su repetición.

Dentro de este panorama el dibujo sería despojado de una de sus funciones sustantivas, la de ser generador del pensamiento en imágenes y base de los procesos de representación; sólo le quedaría repetir al infinito las prácticas académicas de formalización (que por otra parte fueran tan repudiadas en la modernidad, y todavía hoy) y continuar sirviendo como soporte proyectual dentro de la planeación del trabajo artístico. Ése es precisamente un segmento del problema que intentamos plantear y que nos ocupa en este capítulo. El dibujo frente al campo expandido y la crisis de la representación queda fluctuando en un panorama de flexibilización extrema, pero es limitado en la extensión de varias de sus posibilidades epistémicas, las que históricamente construyeron la riqueza de su pensamiento, sus sistemas formales y estrategias. Demos paso a este asunto.

Consideramos que la modernidad en términos de la propia crítica posmoderna alcanza hasta la producción pictórica del informalismo y el expresionismo abstracto, nosotros agregamos su extensión hasta la experiencia de la abstracción pospictórica. Aún en el proyecto de estos movimientos y sus autores la concreción de la intencionalidad creativa se cristaliza en la consecución de un orden formal que ejemplifica la consecución del absoluto artístico. Incluso las primeras lecturas que podemos hacer del Pop muestran claramente una esencia de corte analítico del lenguaje de la obra visual y su forma. Mucho del trabajo de Warhol, Linchstenstein, Hockney, Rauschenberg, Oldenburg etc. muestran una vocación para profundizar la disección del lenguaje en las artes.

Hacemos hincapié que ninguna de las producciones del Expresionismo Abstracto y el Informalismo guarda una relación mimética con la realidad perceptual que contemplamos comúnmente. Hartung, Dubuffet, Saura, Still, Newman y un larguísimo etcétera son prueba de ello.

Tenemos que precisar esta situación, la correspondencia demasiado directa que la crítica posmoderna realiza al asociar la categoría de representación con la consecución de imágenes u obras en las que el resultado es similar al de la visión humana, mímesis como sinónimo de símil o copia. Las palabras de Danto lo muestran claramente.

"El modernismo marca un punto en el arte, antes del cual los pintores se dedicaban a la representación del mundo, pintando personas, paisajes y eventos históricos tal como se les presentaban o hubieran presentado al ojo. Con el modernismo, las condiciones de la representación se vuelven centrales, de aquí que el arte, en cierto sentido,

25 Guilles Deleuze, Félix Guattari. ¿Qué es la filosofía? Barcelona: Ed. Anagrama; 2005. P. 200-201. 
se vuelve su propio tema. Éste fue precisamente el sentido en el que Clement Greenberg definió el asunto en su famoso ensayo de 1960, Pintura Modernista". ${ }^{26}$

Sólo diremos que nos parece sorprendente e ingenua la consideración de todos los movimientos artísticos previos a la modernidad, como productos de esencia mimética. Parece no distinguirse, y pensamos que es grave, la importancia y diferencia entre el dibujo naturalista y el romántico, la claridad con que el Naturalismo antecede a los expresionismos, o el trabajo de Corot, quien nada tiene de mimético, Gauguin, Lautrec, el Cubismo, el Orfismo y un largo etcétera son colocados de golpe en un cajón con una etiqueta única. Simplemente desastroso, por eso decimos que éste es en parte el problema que vive el dibujo como disciplina, y por eso pensamos que se hace necesario el trazo inicial de un organigrama histórico de los sistemas de representación formal del dibujo, sin el cual la reflexión sobre el asunto correría dispersa y en un sinsentido. Ya en un capítulo subsiguiente profundizaremos en el tema.

En otro sentido se concibe a la representación como una configuración que sustituye otra realidad, un operativo en el que el espectador vive su presencia frente a la imagen como en esa región primera del mundo.

Es claro que por algún tiempo el ideal mimético fue una búsqueda dentro de proyecto de Dibujo, ya adelante habremos de exponerlo, también estamos de acuerdo en que mucha de la producción de la pintura y el dibujo logró en determinados momentos o con muchas obras, la asistencia de un espectador que se siente llevado al ámbito y temporalidad del momento representado en la imagen, retratos de Ingres, paisajes de Corot, naturalezas muertas de Franz Halls, nuevamente etc.

Pero en lo que no estamos de acuerdo, y es lo que queremos precisar, es el hecho de que la categoría de representación se agote en esta definición.

Nos interesa romper con la visión que relaciona directamente la mímesis con la representación, para analizar esta última como una práctica en la que el ser humano construye sus maneras de formalizar el mundo, pero como una circunstancia de vivir y transcurrir en el.

La dimensión implicada en la representación se hunde en regiones que claramente corresponden al terreno filosófico, antropológico, etnológico y lingüista entre otros.

Al realizar este estudio rozamos con estos territorios, son apasionantes, pero tenemos que dirigir nuestro pensamiento en la dirección que comprende a la representación como la práctica estructural que determina el acto de dibujar, de este proceso y sus partes es de lo que deseamos ocuparnos, y ya desde aquí se observa como la concepción de una representación mimética es limitante para esos fines.

El segundo factor de correspondencia directa, que limitaría el análisis es el que contempla la representación como una extensión del ejercicio de poder, específicamente político. Tampoco es así de manera única.

No nos anima un sentido crítico destructivo, no es que no consideremos a la práctica de la representación en parte como una extensión y abuso de poder ideológico, ni que no nos interese la relación que los procesos de representación tienen con campos alternos del saber humano, ni es que nos resistamos a una práctica interdisciplinar. Lo que sucede es que no estamos dispuestos a operar nuestro análisis sobre la base de una mezcla tan

26 Danto Arthur C. Después del fin del Arte. España: Ed. Paidós, Transiciones; 1999. P. 29. 
ecléctica de territorios del saber, práctica que por otra parte consideramos esencial en la estrategia reflexiva y crítica posmoderna. Dicho sea de paso, pensamos que en cierta medida es aquí en donde se genera la problemática del dibujo y su posible teoría.

No decimos nada nuevo aunque nuestras palabras puedan sonar graves, la renuncia a los campos reflexivos ortodoxos es parte de la condición posmoderna, la interdisciplina ha sido asumida como el ejercicio que flexibiliza las fronteras que definen los campos del saber y la práctica humana.

Pero esto ha traído como consecuencia en el terreno del arte, y específicamente del dibujo, una imposibilidad para lograr construcciones teóricas de fondo, como lo hemos expuesto anteriormente.

Convendríamos en señalar una posible crítica basada en la correspondencia directa que asocia representación y mímesis, también en el señalamiento que intenta la denuncia y deconstrucción de los mecanismos de poder ideológico que operan dentro de los sistemas de representación en la sociedad. Cabe aquí una cita de Juan Martín Prada.

"No es, por tanto, un análisis de los contenidos de la imagen, de lo narrado, sino de sus presupuestos de verdad, de los discursos institucionales e históricos que la acompañan, enuncian o transmiten.

La teoría posmoderna exige, pues, la crítica a la concepción tradicional de la representación como sustitución o como imitación (Vorstellung, representación, en el sentido de una actividad simbólica y Darstellung, presentación, pero en el sentido de una presentación teatral), es decir, la polarización de este concepto en torno a los conceptos de ausencia-presencia. De hecho, la concepción idealista de la presencia del significado previo a todo acto de enunciación es el origen que justifica toda la serie de operaciones valorativas que conforman la tradición: realidad/apariencia; presencia/ausencia."27

La creación de imágenes se entiende como una práctica de creación de sustitutos, así la representación deriva directamente en una falsa sustitución de lo real. Pero esta relación se acepta de modo general y muy rápido, no todas las formas artísticas operan sobre la base de una falsa realidad que se sobrepone a la realidad primera, física y vivencial. Como habremos de ver adelante, en muchas ocasiones la creación de la obra es un recurso mediúmnico en el que se prolonga la experiencia primera de la vivencia original, en las imágenes creadas bajo ese entender la vida es posible, tan plena de vivencia y subjetividad como en la realidad contextual no artística. Mucho del proyecto de la modernidad descansa sobre la base de este orden fenoménico. Por otra parte bajo una concepción diversa de la representación, se sabe que las obras y las imágenes no suplantan la realidad social no artística, se les tiene como entidades que conforman una realidad alterna, la del arte, creadas para referirse al contexto histórico, natural o social del que surgen, son opiniones o incidencias que pretenden expandir nuestro entender de ese contexto inicial; tal objetivo se logra mediante la creación de códigos y sistemas formales que nos obligan a entender el mundo, pero no de la manera en que habitualmente lo percibimos, así el binomio mímesis-representación no es tan universal.

Podemos mencionar que la crítica cabe al establecimiento de estos postulados para ha-

27 Prada Juan Martí Prada Juan Martín. La Apropiación Posmoderna. España: Ed. Akal; 2001. P. 30. 
cerse pasar como la perspectiva esencial determinada para el devenir y ser del arte. Sin considerar lo anterior un equívoco nos interesa marcar una disyunción fundamental, en la que insistiremos recurrentemente.

Los procesos de representación no son sólo el establecimiento de relaciones de poder en las que grupos sociales dominantes se proponen a sí mismos como justificados socialmente. Esta es una postura que da prioridad al análisis sociológico del problema, se hace necesaria entonces una investigación cuya especificidad y método corran en este sentido. Esto tendría contenidos relevantes, pero nuestra perspectiva es la que se ocupa de los procesos de representación como un terreno de configuración formal de alternativas varias y nuevas para la historia del pensamiento en imágenes, en las que el artista genera construcciones alternas para los códigos que integran el repertorio sistémico de las estructuras formales de las artes.

Se asume demasiado rápido en la postura posmoderna, el hecho de que el espectador está dispuesto a aceptar la realidad de la representación contenida en la obra como un sustituto de la realidad contextual en la que transcurre su existencia. No pensamos que el hecho sea tan directo. Creemos en un espectador y en un artista con suficiente sentido reflexivo, que le permite establecer la distancia entre la realidad de la imagen artística y la realidad percibida. Y de reflexionar sobre la relación que une a ambas.

Nos interesa una consideración del espectador, y de un artista intencionado que sabe que la obra de arte es la sugerencia y posibilidad de otra realidad, una ficción que le invita a la reflexión y el cuestionamiento del plano de la realidad que le rodea.

También es un hecho histórico conocido, la reacción y resistencia que los públicos manifiestan frente a las novedades y alteridades de los códigos formales de significación propuestos por el artista en sus rupturas. Tal situación es entendible en el sentido de que toda propuesta artística nueva necesita formar la mirada de su propio público, hasta fijar en el ideario colectivo su manera de formalizar el mundo y el arte. Pero en los tiempos que ahora corren también sucede que el espectador está cansado de tanta ruptura, que se sucede además a una velocidad extrema, con lo cual pierden su vigor crítico y no alcanzan un objetivo más amplio. El artista piensa que de esta manera escapa a las convenciones, pero lo cierto es que convierte su trabajo en un espectáculo, y no tanto en un aspecto teatral, sino corriente, dentro del cual él mismo se incluye.

El arte por el arte, la forma de la forma, el lenguaje del arte, la pintura-pintura, el dibujo en sí mismo, se originan en el tramo de la modernidad, y remiten su esencia y objetivo a la retroacción de causalidad circular, que pliega sus logros hacia la interioridad del lenguaje mismo en el que se originan, pero adquieren su salto de órbita en la práctica posmoderna, dentro de la cual no interesa ya el plano formalizado y estetizante del trabajo artístico. Se convierte en una mirada de diseñador repasando la enciclopedia de las artes y sus estilos, en la que el carácter de innovación eidética se pierde sustituido por el cliché habitual.

Ya lo mencionamos, pero cabe resumirlo, la apropiación descontextualizadora y la restauración recontextualizadora, la alegoría como desmantelamiento de las capas de significación es el método básico del arte posmoderno, con el objetivo de una crítica a la representación. El arte más allá de la modernidad, el postarte, está minado por la banalidad, intenta ser crítico de la representación y la realidad cotidiana; pero se constituye así mismo como una cotidianeidad, dado que no busca ninguna trascendencia. Es un arte en el que la distancia entre imaginación creadora (recordamos a Gastón Bachelard, La poética de la ensoñación) y la realidad banal que utiliza como material básico se ha desdibujado, con- 
fundiendo la reproducción mecánica del material social, o su presentación objetual en la obra, como un triunfo de la imaginación.

Dentro de la postura posmoderna la representación no es valorada como búsqueda de lo original, ni se piensa que tal cosa exista, ni siquiera en el sentido de formas variadas, que se basen en la experiencia configurativa de la obra por el artista, momento en el que una forma alterna pudiera ser original dentro de nuestra existencia y evidenciarse a nuestro intelecto como tal. Al renunciar a la originalidad se renuncia por extensión a un segmento básico de la creatividad. Es casi una pérdida de fe, puesto que en arte no se puede decir nunca que alguna ruta esté cancelada, cuando se prima la copia no original por sobre lo originalmente creado, lo mecánico asumido conscientemente, por encima de las construcciones de lo inconsciente, mostramos un miedo y falta de entereza para emprender procesos creativos que sabemos comprenden un compromiso largo y profundo con el arte y la humanidad.

Así decimos que tampoco se puede formular la imagen representativa como el reflejo de la realidad, por más que la obra de arte sea determinada en cierta medida por el pensamiento cultural que ejerce presión sobre la intencionalidad del artista. Las presiones que comprimen las acciones del artista no traen como consecuencia resultados directos y deterministas en las construcciones formalizadas que constituyen la obra.

Se olvida que en gran medida el contexto de valores culturales que rodean al creador, sobre todo desde el establecimiento de los paradigmas románticos, es una incitación a la ruptura y al comportamiento inestable, referido especialmente a la búsqueda de construcciones alternas en la interioridad de la obra y sus sistemas formales.

De lo anterior se profundiza en una diferencia que establece la otredad de la obra de arte con respecto a la realidad primera y contextual, incluye de manera inseparable otra alteridad inevitable, la del artista que vibra como entidad de intención discursiva.

Bajo este panorama las formas y sistemas del dibujo son al mismo tiempo las formas de su lenguaje estable, las de la visión cultural naturalizada y las de las concreciones logradas por el artista.

Se presentan estas en una sincronía temporal, que no implica la coincidencia plena de los sujetos que las viven cada uno desde su ubicuidad contextual y subjetiva.

Se dice que muchos artistas han intentado cerrar la brecha entre la realidad interior y la exterior, entre abstracción y representación, nosotros diríamos que todo artista trabaja sobre esa línea de comportamiento, aportando diversas maneras fácticas de proponerlo, con formalizaciones diversas. Lo importante es aclararnos que la interiorización reflexiva de la vivencia es el momento primero del ejercicio de representación, la experiencia asociativa que formaliza la representación es el ejercicio de la segundidad, aunque en el plano fenoménico ambas se susciten casi de manera sincrónica.

Decimos nosotros entonces que los sistemas formales, los signos, el texto imagen del dibujo no es sino el ejercicio fenoménico de la representación; pero no entendida como el logro estable de un repertorio sígnico y formal; la representación, es y ha sido, desde siempre un ejercicio de deriva y complementación de los sistemas de la forma artística y las propias obras, lo que en sí constituye una continua abducción que expande, varía y alterna el propio sistema de representación como proyecto histórico, que a su vez también nos representa en ejercicio contextual. 
Lindamos el borde de un problema grave, que constituye uno más de los núcleos conflictivos que deseamos trazar en este capítulo.

La postura posmoderna constituye un problema para el dibujo como práctica de representación porque formula el sinsentido de dicha praxis. Por otra parte la estrategia deconstructiva reviste un problema teórico cuya lógica resulta inconsistente.

Para que exista una ruptura epistemológica sólida, y no sólo una variación estilística -que por otra parte no sería sino un variante estética formalizada- el pensamiento posmoderno tiene que basarse en la autorreflexión del sistema de conocimiento que utiliza, y enfrentarlo a su consistencia como herramienta pertinente en función de su objeto de estudio. Este sería un trabajo epistemológico consciente, y no puede traer como consecuencia sino la creación de órdenes formalizados alternos, o con desviaciones abductivas, que cualesquiera que sea su grado, se reconocen como características emergentes dentro del campo artístico aplicado, derivas que poco a poco logran en su continuidad, frecuencia e intensidad el surgimiento de una concepción nueva y alterna del campo en cuestión como visión representada del mundo; campo que sin embargo se sigue llamando dibujo. De ahí que el mero objetivo crítico, o de criticar en términos sociales no sea suficiente para constituirse en matriz de procesos que no sean los de la recurrencia o mezcla de los sistemas anteriores o sus partes desmanteladas.

La categoría de estrategia cumple un papel fundamental en la definición posmoderna del arte. Se ocupa del plano sintáctico asociativo buscando la deconstrucción de los sistemas de representación y con ello intenta una crítica que denuncia las relaciones de poder inmanentes en las maneras de representar el mundo. Pero también en la modernidad, la estrategia en el dibujo se ubica en el plano fenoménico de la acción dibujística.

La estrategia en sus consideraciones alternas resulta un elemento sustantivo en la comprensión de la distancia que diferencia el pensamiento posmoderno con la modernidad.

Las vanguardias que se suscitan a principios del siglo XX y se prolongan hasta la posguerra operan mediante la mecánica de desarmar los elementos constitutivos de la forma visual, y hacen de cada uno el centro de cada movimiento; pero con ello se ubican a sí mismos como un ejercicio de descentralización, cambian su punto de apoyo, de la totalidad formal hacia una de sus regiones, hasta aquí queda claro su carácter formalizante y estético.

Pero no sólo eso, el pensamiento de la vanguardia se plantea de manera explícita la disolución de los convencionalismos del lenguaje, acompañados de un cambio actitudinal, que esencialmente se da tanto al interior de la práctica epistémica del artista, como de este frente al proyecto total de sociedad.

El Constructivismo Soviético, el Futurismo Italiano, el Surrealismo, la Bauhaus etc. buscaron el rompimiento de los principios operativos heredados de la tradición, que se correspondían con la injusticia humana de los regímenes que los generaron.

Para ellos el arte nuevo no era posible sin el advenimiento de una nueva sociedad, así su proyecto corrió de la mano del proyecto instituyente y político de una nueva sociedad.

El pensamiento de la vanguardia quería evidenciar y poner al descubierto los valores culturales reaccionarios implícitos en los modos tradicionales de ver, exigió su denuncia como encubridoras de las contradicciones sociales. Para la vanguardia, forma, función y contenido debían de integrarse en una unidad de lenguaje nuevo, que no podía ser otra que la de una sociedad moderna más justa. 
Con ello se generó una brecha difícil de salvar. Muchos de los artistas de la modernidad y sus movimientos incluso llegaron poco a poco a la concreción de un arte formalizado auto referencial.

Pareciera ser que el conflicto no tuviera solución, la autonomía de la obra de arte parecía no corresponderse con la búsqueda de una práctica con contenidos temáticos de denuncia. El conflicto se mantuvo, y continúa incluso hoy dentro del pensamiento contemporáneo. Y sucede de esa manera porque se sigue pensando en tres órdenes categóricos diferenciados; tema, contenido y forma, cuya relación con el todo social es la de una retribución utilitaria, cuando menos en el terreno político de la denuncia.

Nosotros pensamos que el asunto se debe reflexionar desde una postura epistémica distinta. En primer lugar, las categorías de reflexión son entidades que sólo se diferencian en la interioridad mental, es este un ejercicio de abstracción, la separación de un suceso fenoménico en sus partes para poder acceder a su análisis y entendimiento. Pero en el mundo real el acontecer se suscita de manera integrada, queremos decir con lo anterior que debemos asumir un modelo reflexivo en el que las partes se contemplen sistémicamente relacionadas, haciendo imposible su disociación. Creemos que el pensamiento mismo, que se concreta en formas y formulaciones nuevas, no puede ser sino un acto de liberación que expande el pensamiento social hacia nuevos lindes históricos, en gran medida este fue el espíritu del Suprematismo y el Constructivismo, incluso la Bauhaus. Para ellos el problema no era tal, la forma abstracta y el lenguaje auto referencial eran la expresión de una nueva sociedad que se correspondía con un nuevo modo de ver el mundo. Incluso el Informalismo Europeo y el Expresionismo Abstracto fueron actitudes que encontraron su centro estratégico en formas del pensamiento hasta ese momento no consideradas como válidas en la construcción del arte.

El carácter doble del arte, como hecho autónomo y como manifestación social al mismo tiempo se debe lograr sin desbordar el terreno de su autonomía. La denuncia ideológica no requiere de una representación explícita del conflicto social, el fracaso del Realismo Socialista en la Unión Soviética fue testimonio histórico de ello.

La revolución de las vanguardias operó más en la postulación de códigos de expansión del pensamiento, que en el uso de los sistemas de la tradición, por más nobles que fueran sus fines.

La idea de utilidad política y social se asoció fuertemente al concepto de retribución practicista del arte, pero la expansión de las herramientas del pensamiento y el lenguaje constituyen en sí un acto de liberación humana.

El supuesto problema de la obra orgánica y el intelectual orgánico planteado por Adorno y Gramci significaba más un problema político y sociológico que de teoría del arte.

La integración del artista como militante social no es desdeñable, pero es un acto de libertad política al que no se puede obligar a nadie, de ninguna manera la riqueza del proceso y la obra artística dependen únicamente de esta puesta al servicio de la sociedad de manera directa. La riqueza del pensamiento contenido en la vanguardia se cristaliza tanto en la explicitación de su pensamiento mediante los manifiestos y su programa político, como en el discurso reflexivo en torno al fenómeno artístico y las obras que logran. El compromiso del arte es el de constituirse en una fuerza estética productiva, en una radicalidad formal y procesual que contiene la marcha del pensamiento. Todo esto es patrimonio del total de la sociedad y nos podemos servir de ello sin restricciones. 
Aquí el pensamiento de Adorno es claro y nítido; para él el arte más efectivo políticamente es el que se mantiene en toda su autonomía, la forma en su pureza representa la libertad que puede mover el pensamiento humano no sólo en dirección al placer, sino a todas las regiones de la psique y su gradiente sentimental.

De ahí que la mayoría de las exposiciones de vanguardia, cubistas, orfistas, fovies fueran proscritas y rechazadas por el pensamiento conservador como formas aberrantes de la cultura en decadencia.

Basándonos en lo anterior consideramos como parte del planteamiento del problema, el que la sola denuncia y disconformidad posmoderna no sean suficientes como acto de construcción fundacional, si bien se marca su carácter descentrador de discursos culturales.

Pero el pensamiento posmoderno considera a la vanguardia como una manera asimilada del fenómeno artístico. La postura posmoderna frente a este asunto se manifiesta claramente en el ensayo clásico de Rosalind Krauss La originalidad de la Vanguardia, tomemos una cita de ese ensayo, que aunque larga deja ver claramente su pensamiento.

"Tanto la vanguardia como el arte moderno dependen de esta represión.

¿Qué ocurriría si no se reprimiese el concepto de copia? ¿Cómo sería una obra que actuara al margen del discurso de las reproducciones sin originales...? Una posibilidad es que se pareciera a cierto tipo de juego con las nociones de reproducción fotográfica, un juego que se inaugura en los lienzos serigráficos de Robert Rauschenberg y que ha florecido recientemente en la obra de un grupo de artistas más jóvenes cuya producción ha sido identificada por la crítica anglosajona bajo el término pictures. Me centraré en el ejemplo de Sherrie Levine, ya que parece cuestionar con especial radicalidad el concepto de origen y la noción de originalidad.

Levine trabaja con fotos pirateadas. En la serie de fotografías realizadas a partir de Edward Weston de su hijo Neil, por ejemplo, se limita a fotografiar de nuevo las obras de Weston, transgrediendo sus derechos de reproducción... El robo de Levine, que tiene lugar, por así decirlo, frente a la superficie de la imagen de Weston, abre dicha imagen a toda la serie precedente de modelos que a su vez ha robado, de las que ella misma es una reproducción...

En la medida que la obra de Levine reconstruye explícitamente la noción moderna de origen, su esfuerzo no puede contemplarse como una extensión de la modernidad. Es, al igual que el discurso de la copia, posmoderno, y por tanto tampoco puede considerarse vanguardista... Al deconstruír las nociones hermanas de origen y originalidad, la posmodernidad provoca un cisma con el dominio conceptual de la vanguardia, a la que contempla más allá del abismo que marca una división histórica. El periodo histórico que la vanguardia compartió con la modernidad ha terminado."28

Así la noción de reproducción sustituye a la de representación, que será llevada al extremo por el uso del concepto de repetición, pensando que en esta práctica se encuentra inmanente la noción de diferencia, aún en el traslado de una imagen misma hacia otra ubicación dentro de una nueva obra, por mínima que pudiera resultar la distancia que las diferencia.

28 Krauss Rosalind E. La originalidad de la Vanguardia y otros mitos modernos. Madrid: Ed. Alianza Forma; 2006. P. 181-182. 
Vemos el pensamiento de Donald Kuspit como el de un autor que formula juicios críticos y no se deja llevar rápidamente por el ímpetu de la gran ola posmoderna. Cerraremos este punto con una cita de este autor, ella resume la visión posmoderna frente a la crisis de la representación en el arte.

“...el empuje y el coraje creativos parecen haberse perdido en la posmodernidad, razón por la que gran parte de ella -incluso sus performances- es un postarte de apropiación. Es más fácil apropiarse de algo de otro artista -que no es lo mismo que ser influido por él- que hacer algo a partir y por obra de uno mismo. Es decir, es más fácil recuperar el pasado -lo cual no necesariamente significa comprenderlo- que hacer algo con presencia propia. (Las influencias se integran en el arte de uno. Miguel Ángel, por ejemplo integró a Giotto y a Masaccio en su propio arte figurativo, como indican sus dibujos a partir de las figuras de éstos. Análogamente, Pollock integró el automatismo y a Picasso en sus abstracciones dinámicas, como indican sus llamados dibujos psicoanalíticos. Por el contrario a las apropiaciones se las hace pasar como un arte propio aun cuando, en el mejor de los casos, no son más que inteligentes manipulaciones del arte de otros artistas." 29

29 Kuspit Donald. El fin del arte. Madrid: Ed. Akal; 1999. P.116s. 



\section{EL PENSAMIENTO PROYECTUAL PREFIGURATIVO EN LAS ARTES Y EL DIBUJO}

\section{II-1 EL PROYECTO ARTÍSTICO Y SU CONDICIÓN TEÓRICA E HISTÓRICA}

"La naturaleza fundamental del proyecto artístico, situado dentro del panorama histórico e incidiendo sobre él, será de índole programática.

El proyecto, que significa etimológicamente "plano", "designio", "empresa" (del latín projicere: "lanzar para adelante"), ocupará un lugar protagonista en los recorridos evolutivos de la Historia del Arte, especialmente desde el siglo XVIII (aunque se puede identificar desde el Humanismo y el Renacimiento), desde donde comenzará a funcionar como evocación del programa general; globalizador, total, insertado en el contexto de la sociedad en su conjunto. Será el ámbito de elaboración de los discursos y de las manifestaciones creativas. Declaración de intenciones. Primer laboratorio ideológico, conceptual y artístico. Proyección previa de deseos. Paisaje para la utopía. Voluntad de transformación social y cultural. Propósito de lucha. Campo de batalla y espacio, mental y físico, donde explosionar las estructuras antiguas. Plano previo de la concreción artística. Escenario de la liberación del Arte: el programa de la utopía moderna." ${ }^{30}$

Hasta aquí hemos dedicado nuestro esfuerzo a la revisión de la problemática actual que atraviesa el dibujo como campo artístico dentro de la situación del arte contemporáneo. Hemos señalado como en las construcciones formales creadas a través del tiempo, y en los procesos realizados en la producción del dibujo se muestra la postura epistémica del autor en cuanto a sus reflexiones sobre la pertinencia del método que utiliza y las interrogantes que le mueven a estudiar sus modelos, o el contexto en el sentido teórico e histórico más amplio. También nos adentramos en la situación que la disciplina atravesó dentro del panorama artístico en el paso del periodo moderno hacia la posmodernidad en el siglo XX. Ahí señalamos el abandono del objetivo primario de las disciplinas artísticas, en lo referente a crear y revolucionar los sistemas formales que cristalizan su visión del mundo a través del dibujo. Con lo anterior marcamos el fin del periodo del arte, que estaba basado en los objetivos de consecución del plano estético formal como logro terminal del proceso artístico. En ese panorama ubicamos el dibujo enmarcado dentro de la crisis de los sistemas de representación formalizada, situación que lo dejó al margen de uno de sus objetivos históricos centrales en tanto disciplina generadora de un pensamiento eidético.

Al prescindir el arte contemporáneo de fines del siglo XX de la intención de formalizar la realidad mediante el proceso del dibujo, coloca a esta disciplina en una paradójica situación de libertad para desarrollarse como campo artístico por sí mismo. Señalamos como lo anterior en realidad es una ruptura del vínculo sistémico y funcional que unió al dibujo con las demás disciplinas del territorio de las artes plásticas y visuales.

El arribo de las estrategias de significación citacionistas y apropiacionistas dejó de lado la función central del dibujo como columna del pensamiento artístico.

30 Vera Santiago. Proyecto Artístico y Territorio. Granada: Ed. Universidad de Granada; 2004. P. 27. 
Nos detuvimos pausadamente en el análisis de la ruptura de los campos disciplinares clásicos como expresión típica del arte en la posmodernidad. Pero así mismo, señalamos analíticamente la dificultad e imposibilidad de prescindir del concepto de campo como figura central en el análisis de los fenómenos del arte, aún en el proyecto de la posmodernidad. Con lo anterior intentamos fundamentar la vigencia de un análisis endógeno del territorio del dibujo, sus prácticas procedimentales, su raíz epistémica y la postura del dibujante. Marcamos como, dentro del periodo previo a la posmodernidad y aún en el clímax de este tramo del suceder artístico, muchas de las prácticas del dibujo así como sus partes formales que comprenden fragmentos y mezclas de sistemas de representación, continúan sosteniendo el ejercicio del suceso dibujístico, dejando íntegra la función del dibujo como disciplina de gestión y generatriz del proyecto de la obra de arte.

Al mencionar las estrategias de significación de la posmodernidad basadas en la cita y la apropiación, intentamos aclarar este proceso como una sustitución del ejercicio de la representación por una estrategia de combinatoria sígnico sintáctica, derivada de los contenidos culturales estabilizados, que yacen inmanentes en las imágenes de segunda y tercera generación utilizados en esta estrategia.

Frente al problema central de análisis, señalado como la ruptura del vínculo sistémico que unió históricamente al dibujo como campo del pensamiento eidético para dejarlo en una situación de autonomía, formulamos la hipótesis de que esta situación no implicaba necesariamente la carencia de sentido del dibujo como ejercicio de una búsqueda de ampliación y renovación de los sistemas formales de representación.

Para el desarrollo de las tesis anteriores marcamos como necesidad el estudio de la categoría teórico formal que subyace en la interioridad de campo del dibujo, misma que le permitió a lo largo del tiempo y la práctica artística, ubicarse como gestor del pensamiento en imágenes y constructor del proyecto artístico. Llamamos a esta categoría El carácter Proyectual Prefigurativo del Dibujo. Junto a lo anterior planteamos la idea de intentar la construcción de un análisis del Acto Dibujo. Con la finalidad de extender la comprensión del fenómeno hacia una serie de regiones que pudieran ampliar el espacio reflexivo de la disciplina, más allá de las posturas formalistas e instrumentalistas o bien pragmáticas.

Habremos de dedicar este capítulo a la formulación del dibujo como disciplina proyectual. Esperamos en este espacio desarrollar un análisis que tienda un puente de entendimiento para unir la visión del pensamiento proyectual como postura histórica irrenunciable y la interioridad del campo dibujo. Colocándonos de esta manera en posición de entender aquella región que se transmite como línea de ascendencia histórica, misma que hasta nuestros días se manifiesta en el ejercicio de la disciplina del dibujo, tanto como un arte que no retribuye a otros campos, como en el caso de continuar siendo parte sustantiva del proceso de gestión y desarrollo del proyecto artístico.

El término proyecto encara hoy día una contradicción dentro del territorio del pensamiento metodológico, máxime si referimos esta categoría al territorio del arte.

Contradicción que por nuestra parte no consideramos insalvable.

La oposición contenida en el proyecto es derivada de su entendimiento como figura que antecede a la creación de la obra de arte, en cuya organización ya se hayan definidas las partes y procedimientos que integran la obra posterior, por tanto el proyecto sería una 
formulación rigidizante del método, ya que sería condición insalvable el seguimiento de la estructura planeada para conseguir con certeza la obra concebida.

Resulta claro que el terreno del arte y dentro de él el dibujo, es una región en la que se apuesta a la renovación y extensión del conocimiento y sus estructuras internas, de ahí que la definición determinista del proyecto genere fuertes reacciones de rechazo en el pensamiento artístico. Sin embargo y pese a lo anterior, podemos afirmar que no existe movimiento u obra de arte que no contenga un ejercicio de reflexión proyectual, frente a esto nos rendimos ante las evidencias abrumadoras.

El proyecto dentro del arte nos lleva a considerar las propuestas originales contenidas en él y su consecuente variación o desviación, cuando son llevadas al terreno del acontecer de la producción de la obra.

De lo anterior podemos ubicar nuestra paradoja en términos de un ejercicio rigidizante del proyecto artístico, frente a una flexibilización que requiere de conciencia metodológica continua en el desarrollo del hacer el dibujo.

No nos referimos a una práctica instrumentalista, sino al hecho de que la reflexión proyectual tiene la vocación irrenunciable del pensamiento que corre delante del acontecer fáctico de la obra.

Ya desde aquí señalamos el entendimiento del carácter proyectual como una estructura reflexiva que contiene la intencionalidad primigenia de la obra. Pensamiento que da dirección al accionar del sujeto. El proyecto no es la ruta única de la ejecución, sino la reflexión inicial y continua que mantiene presente la intención significante y la búsqueda conceptual originaria, si bien nos aclara concientemente todo aquello que aparece como agregado a la búsqueda deseada, y las desviaciones surgidas en la ruta planteada. Y no porque sea deseable evitarles, pensemos mejor en una manera consciente que integra el curso de los acontecimientos con aquella estructura deseada.

Al concebir el proyecto como un ejercicio continuo de conciencia reflexiva de inmediato nos separamos de una visión lineal y determinista del concepto. Precisamente esta será una característica inicial en nuestro análisis. La valoración constante del proyecto nos lleva al terreno de la metodología, el logos del método, que es la formulación epistémica de pertinencia del sistema utilizado en la búsqueda de la obra y el conocimiento.

En el terreno del arte y el dibujo tendemos a pensar el proyecto como una situación personal y un tanto arbitraria. No es así, el proyecto artístico comprende dos planos culturales iniciales. El del pensamiento general implícito en el imaginario colectivo, del cual el artista no puede escapar totalmente, bajo cuya presión trabaja. Pensamiento cultural histórico que se explicita tanto en las prácticas efectuadas como en las estrategias ponderadas, en los sistemas representacionales y en las decisiones de formalización de la obra. La porción histórica general del proyecto expresa la dirección global que la sociedad busca como ideario para si misma y los valores del deber ser del arte. Todo esto se funde con aquella parte individual que el artista se marca como programa en su viaje artístico. Por eso el proyecto tiene necesariamente una naturaleza dinámica en la que se logra la integración de las aspiraciones personales en lucha e integración con la institución imaginaria colectiva de la sociedad. 
El proyecto artístico en su dimensión histórica deja ver claramente las posturas y concepciones generales de la sociedad, o del núcleo cultural y artístico en una ubicuidad espacial y temporal.

Tenemos entonces que una visión metodológica de esta naturaleza se roza de manera cercana con el terreno de las aspiraciones ideológicas y las prácticas políticas, ya sea como visión ascendente en el logro de la construcción del corpus social, en el cual el arte cobra un término relevante; o bien como ejercicio crítico constante de desestabilización de las certezas que rigidizan el pensamiento de una sociedad.

Es en este sentido que se aclara el papel del proyecto dentro del pensamiento vanguardista del arte.

El análisis del proyecto nos refiere a los núcleos de intención de las obras y la dimensión en la que se desea inscribirlas dentro del conjunto complejo del escenario artístico, de los movimientos culturales y filosóficos de una época y de cómo el artista desea impactar esa particularidad contextual.

La dimensión personal del proyecto se adentra en el territorio de la interioridad del sujeto específico. En un primer momento crea escenarios de conflicto entre la ambición personal de definición de una identidad particular, frente a ese pensamiento marcado por una globalidad totalizadora que uniforma el ser.

Si una característica típica de la modernidad y la posmodernidad es la fragmentación del individuo y la sociedad, el pensamiento proyectual coloca al dibujante de cara a esta situación crítica, no le permite evadirla, frente a ella lo obliga a tomar posición, a crear un plan de manifestación de la obra en el que concrete su opinión frente esa crisis. Cualquiera que sea la postura del artista y en este caso el dibujante, la sola ruta de su proyecto explicita claramente su elección frente a la historia de su disciplina, sea en el terreno de sus prácticas o en el de las maneras representacionales que utiliza, como en la cadena de construcción y planeación del propio proyecto. En este punto el campo del dibujo se muestra en ventaja para develar los recursos que sostienen tanto la concepción del proyecto y la obra, como su dimensión teórica y el origen histórico de esas formas y sistemas puestos en juego.

Cuando mencionamos el pensamiento proyectual como la integración de todo el material histórico social y su expresión en los sistemas e imágenes que nos representan, junto a la posibilidad irrenunciable del artista para unir, criticar y trascender todo ello, estamos siendo consecuentes con lo analizado en el capítulo anterior, en él señalamos las demarcaciones de los campos artísticos como expresión de un pensamiento construido en secuencias históricas que no se deben totalmente a la labor de un solo artista, pero igual aclaramos la relevancia del dibujo como puesta en práctica de una actividad dirigida a la expansión y modificación de esas concepciones y sistemas formales. La cualidad histórica del proyecto y la representación formal que nos marca aún hoy día, se origina dentro de la dimensión pre renacentista, y alcanza su madurez con la plenitud de ese mismo periodo.

La diferencia que lo separa del pensamiento que le antecede se basa en la característica que mira en la razón reflexiva y en los procesos secuenciados de observación de la naturaleza, el origen del proyecto, situación que nos posibilita conocer el mundo circundante. Pero ya desde el humanismo medieval tardío se pone especial interés en el pensamiento empírico, con ello la naturaleza se revela ante la mirada del artista como fuente para 
comprender las razones estructurales que ordenan el universo. Esto orienta el arte hacia la postura reflexiva y los intentos de organización de sus conceptos intrínsecos. Nace en este punto la necesidad del trazo programático de la ruta a seguir. Poco a poco se irán suscitando los procesos diferenciadores del pensamiento proyectual, que en el dibujo integran los modelos de pensamiento formalizados de representación.

Por una parte se mira en la naturaleza el origen de la estructura organizada y estable por excelencia, en otro sentido, la visión objetiva del mundo se plasma en las estructuras métricas que permiten la repetición de los procesos cognitivos como explicación del mundo.

No decimos nada nuevo al mencionar el ascenso del artista en el Renacimiento desde el lugar artesanal que ocupaba, hacia el sitial de sacerdote del arte. Reunirá en sí, no solo la maestría sobre la herramienta y la materia, busca y se interna en espacios intelectuales múltiples, su mundo conceptual y filosófico se expande hacia el terreno de lo multidisciplinar. El proyecto del arte en ese punto rebasa la mera planeación instrumental y objetual de la obra, para convertirse en reflexión del logos metodológico en el sentido más amplio y profundo.

Tenemos entonces que el pensamiento proyectual prefigurador moderno arranca en la consolidación de la visión renacentista, ahí se inicia el cuestionamiento existencial del ser humano, la fe es sustituida por la búsqueda de la razón, y aunque el ser humano se coloca en situación sustantiva, en la realidad se le sabe parte de la naturaleza y no centro de ella, pero se llega a entender su capacidad para acceder al conocimiento del todo de la realidad mediante el empleo de la razón y el método.

El proyecto de conocer el mundo mediante el pensamiento racional es la base de la nueva humanidad.

Una dualidad nace en el interior del proyecto moderno; la percepción interiorizada producto de reflexionar el mundo, tiene un carácter en buena parte subjetivo. Se tiene en el otro extremo una realidad objetiva y material, que se organiza por sí al margen de la conciencia cognoscente.

Si bien la realidad objetiva tenía sus causes organizativos y estructurales sin embargo representaba el territorio a ser conquistado con la herramienta del proyecto instrumental y el pensamiento racional.

Esta visión alcanzará su pináculo en el proyecto ilustrado y en la postura determinista de la ilustración; pero se prolonga en la visión de la función, que será entendida en el arte como la aplicación de la creatividad en la consecución de objetivos previos, tendientes a la solución de problemas específicos.

Esta consideración general en extremo, se manifiesta claramente en el pensamiento dibujístico de ese periodo histórico. Como habremos de ver, la tratadística especializada en el dibujo y la pintura se orienta profundamente hacia la observación de los modelos naturales como fuente de los procesos de representación en el sentido formal y conceptual; se insiste también en la reunión de los mejores atributos estructurales que los modelos naturales tienen, para reunirlos en una unidad métrico formal abstracta, que no aparece sino ocasionalmente en la naturaleza, pero que representa la aspiración a la perfección por medio de la vía racional. 
En específico, los artistas renacentistas consolidan y van afinando dos regiones en el cuerpo disciplinar del dibujo, una metodológica y la otra formal.

La cadena metodológica organiza el proceso del pensamiento proyectual al establecer la diversidad funcional del dibujo. El apunte, el boceto, el estudio y el proyecto dibujado son secuencias epistémicas que guardan relaciones diferenciadas con los modelos y las intenciones subyacentes en la construcción de la obra. En un punto posterior trataremos este aspecto.

En otro sentido la observación de la naturaleza y la visión racional se concretan particularmente en conceptos y categorías de construcción formal de la imagen por medio del dibujo, el claroscuro, el regatino, el achurado, los pasajes, el relieve, la grisalla, estos son parte de un conjunto formalizante que opera desde la interioridad del campo del dibujo y que terminan por lograr las características de representación que tipifican esa visión metodológica propuesta.

El pensamiento de Federico Zuccari y del movimiento Manierista acepta como central la división del dibujo en dos territorios; El Dibujo Interno y el Dibujo Externo.

Aunque no es posible establecer una relación total, es claro que esta concepción expresa la visión dual filosófica del mundo renacentista. El orden del dibujo como reflexión ideal y platónica en consonancia y aplicación sobre la realidad fáctica, natural y matérica del dibujo y su configuración.

Una diferencia que marca el proyecto en la región del arte es el hecho de que pese a guardar relación histórica con su espacio cultural, siempre manifiesta particularidades específicas. En el caso del dibujo, la propuesta renacentista se afina y prolonga hasta el advenimiento de los naturalismos y el romanticismo del siglo XVIII.

Nos referimos a el hecho de que la cadena metodológica expresada en las diferentes funciones que el dibujo desempeña se mantienen constantes en lo general; pero la relación que une al dibujante con sus modelos, así como los planos y categorías de representación que grafican esa postura comienzan a cambiar significativamente.

Con base en lo anterior, que por otra parte es una característica general del proyecto artístico, podemos mencionar que en la región del arte, después del inicio del romanticismo y el pintoresquismo, el pensamiento proyectual se orienta en dos direcciones divergentes; una con vocación estable y ascendente que aspira a la construcción integrada del arte, la cultura y la sociedad.

Aquí el arte se considera como posibilidad de transformación de la realidad, aporta construcciones nuevas de estrategias en el arte, su destino final es participar en la revolución general de la sociedad. Esta visión del proyecto plantea sistemas objetivos y modelos de construcción racionales. Con esta concepción se avanza en el terreno de la elaboración teórica del arte, se intenta de manera expresa la enunciación de una teoría particular del fenómeno.

El proyecto artístico de manera positiva anima el Clasicismo, El Impresionismo, el Futurismo, De Stijl, Bauhaus etcétera.

Esta visión se conserva hasta los últimos proyectos de la modernidad que a inicios del siglo XX caracterizan a la vanguardia. Pero ya la modernidad que antecede al postarte expresa la voluntad de ruptura con esa posición, el Informalismo y el Expresionismo Abstracto se desenvuelven sobre posturas muy diferentes. 
La otra es una visión crítica, cuestionadora de la estabilidad social y su proyecto artístico cultural, esta habrá de expresarse en términos de una desconfianza en el espíritu ascendente y evolucionista. Muchas veces el pensamiento de este proyecto crítico se orienta hacia la revolución interior de las estructuras y formas del propio arte, el arte por el arte, la forma de la forma, son la expresión del inicio de un pensamiento de vanguardia crítica. También en este caso esa postura habrá de manifestarse en la construcción de sistemas y formas diferenciadas que llevan el proyecto artístico de una situación crítica y filosófica hacia una concreción artística con propuestas de representación alternas.

El Romanticismo, Dadá, el Surrealismo, los distintos expresionismos y la oleada de artistas posmodernos son muestra de esta visión.

Esta postura del proyecto con bases filosóficas críticas era una reacción a la excesiva razón instrumental del racionalismo, llevó a los artistas hacia la región y territorio del arte como el espacio de realidades subjetivas que no se originan en el terreno de la visualidad, espacios reflexivos que ocuparán una buena parte del pensamiento del artista y su proyecto. Esta visión del proyecto pone al centro del fenómeno el carácter vivencial de la práctica artística y la postura del pintor y dibujante.

De esta manera, al estudiar el proyecto artístico en su dimensión histórica se nos revela tanto la perspectiva utópica y constructiva que la misma sociedad y el artista desean para si, como los esfuerzos desplegados en su consecución. En el otro sentido el proyecto se orienta hacia las regiones profundas del individuo, buscando en ese proceso territorios de expansión y nuevo hábitat, dirigidos hacia un proceso de libertad en el sentido más amplio y subjetivo. Así el pensamiento proyectual de la modernidad nace con una división del ser humano, acaso irreconciliable: la diversidad y el deber ser social del arte, frente a los impulsos de la interioridad individual como principio de autodeterminación y autonomía.

Dentro de la concepción del proyecto como concreción histórica señalamos las líneas de construcción por un lado y las de crítica por otro. Dentro de ese espíritu crítico la visión del proyecto artístico se expresa en la posmodernidad llevando al extremo esa visión. Al renunciar al territorio del arte, y al de las construcciones formales de representación se llega al límite crítico, el que niega la propia existencia del proyecto con una intención, cualesquiera que esta pudiera ser. Pero si observamos detenidamente, veremos que el ejercicio y la práctica de los dibujantes mantienen activos, aún dentro de la propuesta posmoderna, muchos de los procesos y funciones históricas del dibujo como ya habremos de exponer.

Una condición fenoménica del pensamiento proyectual del dibujo, y podemos decir que de todo el arte, es la que consiste en dejar de ser una ruta de aplicaciones de procedimientos para convertirse en un proceso continuo de reconocimiento epistémico.

Este reconocimiento será coincidente con las dos vías históricas del proyecto.

La afirmación histórica, filosófica y cultural mediante el proyecto del arte implica el reconocimiento constante del pensamiento global de esa sociedad, así como la conciencia de los sistemas artísticos formales que constituyen su estructura de representación. El tema de la obra en este caso es la región circunstancial en que se cruzan esas reflexiones en el proceso de hacer la obra, desde los momentos de su prefiguración hasta los de configuración y clausura. En el pensamiento del proyecto crítico, el proceso, la forma, el lenguaje, la interioridad subjetiva etcétera, pueden ser el asunto mismo de la obra, también en este 
caso el proyecto artístico y su puesta en operación significa el continuo análisis del yo actuante, en relación más o menos graduada con el yo de la totalidad humana.

De esta manera concebimos el proyecto no como una ruta lineal para la concreción del objeto artístico, sino como la operación continua que convierte el tema en el territorio de cruce de las vivencias, las experiencias y las intenciones iniciales de significación. Merced a lo anterior se muestra claramente la condición del pensamiento proyectual como un proceso, un continuo de afectaciones y relaciones causales que requieren del constante pensamiento del dibujante en este caso, y de las correspondientes tomas de decisión ante las circunstancias aleatorias que se presentan.

Por eso el pensamiento proyectual del dibujo es desde siempre un diálogo con la historia, con el dibujo mismo y sus maneras de representar el mundo, un diálogo que se prolonga en el hacer el dibujo, no solo en el pensarlo. Un diálogo con el otro, con todo aquello que constituye el modelo a ser dibujado, la aceptación de las otras presencias ontológicas. Un diálogo con la sustancia y la materia del dibujo, o bien con su insustancialidad y su condición efímera y cambiante, un diálogo con nosotros mismos. Diálogos que nos hablan claramente de quienes somos, de nuestra ubicuidad contextual, de la medida y dimensión de nuestras capacidades y nuestro no poder.

Incluimos aquí una cita que expresa lo que hemos expuesto.

"Merced a esta naturaleza antropológica, existencial y metodológica, el proyecto va a consolidarse como el lugar donde realizar todo el complejo tejido del hacer y del pensar artístico. Ciertamente el proyecto tendrá una efectividad multiactuante que está referida a las reflexiones, a los espacios sobre los que incide (espacio como lugar mental y territorio físico) y a las técnicas utilizadas. La actuación reflexiva del proyecto establece los mecanismos de pensamiento y diálogo del artista sobre el tema (lugar seleccionado para lo artístico, físico o mental)." ${ }^{31}$

Al ser el proyecto del dibujo un proceso, implica una condición dinámica y temporal. Esta condición es el desplazamiento del sujeto, del dibujante, quien en ese proceso opera sobre la base de flexibilizaciones mentales de la propia realidad física y de la conceptual. Suma y convierte en ese proceso la vivencia que lo inscribe como parte de lo que ha de representar, lo integra en el proceso, despojándolo de aquellas visiones en las que se le consideró el espíritu rector externo a los modelos dibujados. El proyecto construye continuamente el plano experiencial del artista, entendido como la acumulación contrastada de los acontecimientos procesuales, técnicos y de formalización de la obra, pero también construye al dibujante en el sentido de retroacción constructivista, al ser modificado él mismo por el proceso que inició sobre causes determinados.

Vega Cañizares menciona como el proceso del proyecto se convierte en un lugar artístico totalizador, que dinamiza la relación de tres factores:

\section{El Tema - El Artista - La Obra}

Por nuestra parte pensamos en una triada de entidades ontológicas diferente, en la que el

31 Vera Santiago. Proyecto Artístico y Territorio. Granada: Ed. Universidad de Granada; 2004. P. 21. 
tema es considerado como función relacionante, más que como entidad constitutiva.

\section{El Contexto - El Dibujante - La Obra Proceso}

Aquí el proyecto puede operar como vía de exploración y fusión específica, acercando la razón abstracta y experiencial, con las pulsiones profundas y espirituales del individuo. Ya sea que lo anime una intención crítica o positiva, en todo caso el proceso del arte en este sentido es un acto de construcción cultural, en el que lo propio se funde con los otros.

Aún más, en esta condición, el pensamiento proyectual del arte y el dibujo, opera en el espacio y territorio de la planeación y configuración del proyecto, momento en el que los diálogos del acto dibujo se diversifican y adquieren profundidad de construcción, tanto de la idea inicial como de los sistemas representacionales usados y del propio sujeto actuante y el espectador.

Este tipo de reflexiones constituyen el material que habremos de tratar en el capítulo final de nuestro trabajo.

Con la crítica a los sistemas de representación modernos, al trabajar por el derrumbe de los campos tradicionales del arte y su expansión hacia procesos y procederes de difícil encuadre metodológico; la visión del pensamiento proyectual del dibujo vive un proceso alterno de reconstrucción. En este acontecer, la ruta de trabajo de los propios artistas, y dentro de ella, la función y la manera en que utilizan el corpus del proyecto del dibujo, es la línea de conducción del análisis, sobre de esta base hemos de discurrir para reflexionar sobre las aperturas de nuestro proyecto.

De esta manera el proyecto del dibujo y su posible autonomía tal vez se diversifiquen en direcciones múltiples, o aún contradictorias, pero de cualquier manera continuaran siendo prácticas en las que se integran los episodios vitales del artista en lo individual junto con la dimensión social colectiva e histórica.

\section{II-2 LA INTERIORIDAD DEL PROYECTO ARTÍSTICO Y DEL DIBUJO}

Sobre este aspecto es necesario hacer una primera distinción. No vamos a referirnos al pensamiento proyectual como aquel que trata a cerca de la manera de una particular forma de producción de objetos. Nos interesa referir el proyecto hacia la interioridad de la actividad artística misma.

Buscamos con ello sumergirnos en el proceso de interacción entre el concepto como norte de intención y la materialidad que constituye la obra proyectada.

Entendemos la materialidad del proyecto en una ampliación del término que irá desde lo concreto y físico, hasta el orden de los pensamientos que animan y orientan las acciones del dibujante artista. Esto es, el conjunto de circunstancias exteriores en las que se desarrolla el trabajo productivo del dibujo y en las que por otra parte se halla inmerso.

Comprendemos como parte del proyecto y su pensamiento, tanto la postura epistémica del dibujante como los factores de orden conceptual, los procedimientos y las estrategias de relación significante, pero también el conjunto de acciones que gestionan e inscriben la obra en su espacio social expositivo de destino.

No debemos confundir o sobreponer la categoría del Proyecto a la del Método. 
El pensamiento proyectual del dibujo es el ejercicio y puesta en activo del pensamiento que reúne método, metodología y estrategia.

Ya más adelante en otros incisos puntualizaremos en ese sentido. Por ahora diremos que coincidimos con quienes piensan la metodología como un ejercicio epistemológico, esto es la reflexión de pertinencia del método en función del problema inicial y la postura que dentro de todo ello tiene el dibujante. El método por su parte es la claridad de la ruta y secuencia de técnicas que se orientan a resolver el problema, la estrategia se entiende como las trayectorias a seguir, las modificaciones circunstanciales frente a la toma de decisiones del dibujante ante lo no previsto en el esquema inicial.

Básicamente con lo anterior determinamos la postura filosófica del dibujante al asumir una decisión metodológica. Marcamos con la estrategia el carácter de la ruta seleccionada para el proyecto y su grado de flexibilidad. Con el método puntualizamos específicamente el programa inicial que contiene las premisas que desencadenan el proceso.

Tanto la estrategia como el método y la metodología, parten y se basan en los contenidos, las normas y leyes que constituyen el cerco del campo disciplinar del dibujo, (ya hemos analizado como de cualquier manera, aún dentro de la intención de prolongación o ruptura de los límites del campo dibujo, estos siguen operando como categoría de contraste y definición). Pero también se basan en la información que sobre el problema que se quiere resolver tiene el dibujante, el marco teórico, contextual e histórico que el dibujante maneja, tanto de la interioridad del dibujo como en el sentido amplio de relaciones temáticas implicadas en el proyecto.

El método como límite rigidizante se opone a la visión metodológica que busca la ampliación y extensión del conocimiento, pero la historia muestra como todo proyecto posibilita la apertura del sistema en el que se basa. Para esto es necesario ver el método como algo más que un trazo programático que hay que seguir a toda instancia.

Poco a poco se avanza en la consideración del proyecto como una entidad sustantiva del proceso artístico, si bien todavía se considera el término en su acepción rigidizante, esto es, una organización previa en la que se persigue un fin específico para lo que se vale de técnicas particulares. Esta acepción es claramente reduccionista, y lo es porque se basa en el supuesto de la certeza inicial de las consideraciones conceptuales, las que ya desde ahí se asumen como ciertas, dejando el problema a las etapas subsiguientes para el logro de lo considerado. Etapas que por otra parte no podrán ser alteradas salvo la desviación del objetivo buscado. Con esto se dejan de lado los sucesos aleatorios y entrópicos del proceso, que son los que promueven la consideración heurística generadora de nuevas concepciones.

Un lugar recurrente dentro del pensamiento común es el de asumir que la determinación de límites encara una reducción de la libertad artística, cuando sucede en realidad lo contrario. La limitación es la expresión de aquellos problemas surgidos en el seno del propio pensamiento proyectual, o bien de las fronteras que decidimos trazar para circunscribir el viaje para no llegar a la dispersión absurda, también lo son las limitaciones al proyecto, están dadas por las circunstancias externas a las que no podemos imponer una conformación conveniente a nuestros fines, sino que tenemos que aceptarlas como parte de la realidad contextual que nos determina y con ello a nuestro proyecto. La limitación sea del tipo que sea contiene una paradoja, ya que opera como obstáculo determinado 
pero también como motor para la búsqueda y construcción de las variaciones abductivas, o sea los desplazamientos transversales que enriquecen el sistema metodológico y de representación sobre el que operamos.

La actitud que desdeña el establecimiento consciente de los límites teóricos, formales y operativos estratégicos, en realidad es una visión infantil del arte, por decir lo menos.

El artista y dibujante experimentado saben que al aumentar el rigor de los límites que marcan el territorio de su proyecto se activan exponencialmente las propuestas estratégicas que lo transforman en un proceso creativo.

Tradicionalmente el método es una herramienta de trabajo, pero una primera extensión nos lleva a considerar que hoy el método es también un ejercicio del pensamiento en el sentido extenso de la expresión. En él se considera la pertinencia o no, para la inclusión de los diversos factores, formas y estrategias en la integración de la obra.

Los métodos instrumentales típicos de la dinámica de taller expresan su potencial en la consecución altamente lograda del objeto proyectado, resumen también el cúmulo de experiencias integradas en la capacidad del artista. Pero se limitan como extensión hacia casos de naturaleza variable o divergente. Este es un carácter alterno del método como extensión del pensar; el hecho de que se concrete en formulaciones reflexivas que son extendidas y aplicables con mayor amplitud hacia diversas regiones del arte o casos que no guarden similitudes.

El método representa tanto la cualidad de diálogo con la materia como con el razonamiento abstracto.

La idea de método como diálogo con la materia nos trae a la mente el carácter clásico de las artes. Pero los inicios del arte moderno, ya en el siglo XIX nos enfrentan a pensar el proyecto como una ponderación del propio proceso de pensamiento de manera tan valiosa como la cualidad plástico conformante dada a la materia. Llegamos a los tiempos en los que incluso el proyecto es entendido como el proceso en su totalidad, no importando la consecución objetual de ninguna obra.

Así el proyecto puede generar formas concretas, productos, objetos, espacios o formas sociales, puede buscar la proyección de formas sociales, relaciones entre sujetos y el entorno etcétera.

El pensamiento proyectual es una función creativa dentro del arte, un algo orientado hacia la consecución de otro algo. Pero en si mismo es también una forma del pensamiento y una obra que nos significa a nosotros mismos en el proceso de su construcción.

El artista entiende las obras como el devenir del proyecto, en ese lapso ejercita el cuestionamiento continuo del rumbo inicial y lo adapta, si así lo considera necesario.

La obra, cualquiera que sea su sustancia, es asumida como el territorio del actuar artístico. La imagen de la obra puede representar un algo exterior y contextual, pero en si misma es la maquinación reflexiva puesta en operación.

El proyecto es el impulso que anima la identificación del autor frente a sus realidades interiores y el conjunto cultural imaginario, sumado a la potencia de los sentimientos de su realidad vivencial.

Por eso el proyecto es un espacio físico y reflexivo, conceptual y metafórico de autoconocimiento individual que entra en crisis o se suma a la corriente del pensamiento cultural naturalizado.

En él se encuentran los trazos que nos integran con lo universal del arte y lo particular de nuestras vivencias y pulsiones. Nos invade en ese punto la posibilidad de intuir el carácter 
resultante y configurado de la obra. Mediante el proyecto sentimos el potencial expresivo, crítico o conmovedor de aquello en lo que estamos trabajando.

Si hemos convertido el pensamiento del proyecto en un territorio reflexivo y del hacer, comprenderemos porque para el artista la producción de su proyecto es un decurso, un moverse en el trayecto temporal mientras recorre el territorio existencial y fáctico en el que ha entrado.

Al transitar por el espacio y el tiempo del proyecto, el artista vive la experiencia que lo lleva a encontrarse con sus propias aspiraciones, que no son otras que las del marco intencionado del proyecto. En este proceso la experiencia puede reafirmar las premisas iniciales, y puede facilitar las respuestas y organizaciones formales que cuadran con lo esperado. Pero igual nos enfrenta a la negatividad, entendida como la presencia de situaciones conflictivas que no podían ser previstas en el plan inicial, pero que son las que verdaderamente amplían el horizonte de nuestro proyecto y lo convierten en proceso de autoconstrucción cuando integramos esas experiencias a nuestro repertorio formal dibujístico, o bien cuando el carácter entrópico de la obra al hacerse nos lleva a modificar nuestra ruta proyectual ante la evidencia y pertinencia de aquello que se nos revela como posibilidad que consigue la extensión temática. Por ello el tema de la obra viene a ser el asunto de que esta trata, y no solo la relatoría del acontecimiento en una puntualización espacial.

Cuando la evolución del proyecto nos lleva a reconocer en su negatividad aquellas partes y concepciones incluidas en la intención inicial del proyecto, pero que obstruyen su realización o que generan resultados no previstos, surge la evidencia que nos lleva a cambiar la actitud inicial. Bien puede ser esta una idea equivocada o poco precisa, o una estrategia poco rentable etc. Pero lo importante en todo caso es el cambio de actitud que asumimos. Cuando verdaderamente nos apropiamos de estas circunstancias se da en nosotros y no en los otros un cambio de actitud. En ese momento las cosas, las ideas, los procesos rompen sus amarras cotidianas y se convierten en promotores que suscitan las abducciones constructivas del proyecto inicial, nos llevan más allá de la función del método hacia la reflexión epistémica y metodológica.

La experiencia en este caso se remite al trazo de la ruta de exploración vivencial del propio proyecto, con ello a la posibilidad de reconstruir en otro tiempo y otros casos el ejercicio de flexibilización creado. El trazo del mapa experiencial del proyecto lo vuelve además transmisible, socializable, ofreciendo con ello la posibilidad de servir al otro.

Así se desarrolla una metodología de formulación y apropiación del propio modelo propuesto y el itinerario de su decurso, todo ello trasluciéndose y reconociéndose en la sustancia ontológica de la obra, la cual desde su presencia nos revela la integración del pensamiento y la ruta que la hacen posible.

La conciencia experiencial y teórica que nos deja el proyecto consigna claramente las partes iniciales del viaje, su evolución mental y fáctico-matérica, los momentos de giro flexible en la ruta inicial, las partes del sistema de representación utilizado y que corresponden a reservorios típicos de la representación estable, nos marca entonces claramente las desviaciones emergentes y las adiciones a estos sistemas de formalización así como su grado de modificación. Pero quizá sobre todo nos dibuja al dibujante artista en el curso de las acciones y decisiones tomadas, nos enseña el carácter positivo o desafiante de esas 
decisiones, así manifiesta la actitud en el sentido más amplio como postura del artista. Con todo lo anterior el proyecto se convierte en una maquinaria de causalidad retroactiva y rizomática que expande el potencial de diversidad en todos los puntos por los que se le aborde. Expansión y desplazamiento del territorio explorado por el proyecto como de la integridad del dibujante, tanto en los contenidos y significados que ya existían en el espacio del proyecto, y de las repercusiones no sospechadas. Todo esto, causa de nuevas relativizaciones, suelo móvil por excelencia pero que no carece de conciencia sobre su emplazamiento inicial y su decurso relativizante.

Decimos por esto que el pensamiento proyectual del dibujo y en lo general el del arte se basa en dos núcleos de causalidad, que contienen su sustancia mental, simbólica, histórica, formal y representacional, tanto particular como colectiva.

El primero es el de la aplicación de las resonancias culturales naturalizadas que se refieren a los sistemas conceptuales, estratégicos, representacionales que operan en ese presente inicial del proyecto, sea de manera expresa o de modo latente.

El segundo núcleo de determinación del proyecto se integra por las dimensiones nuevas que emergen en todos esos sentidos mencionados. La integración de estas dos partes que impulsan el proyecto integran una nueva realidad que va más lejos del mero carácter visual de la obra, se instaura una región especial en la que acontecen los diálogos profundos y diversos que generan las propuestas y los pensamientos que iluminan, modificando la geografía del espacio del proyecto y sus entidades ontogénicas.

Por lo anterior el pensamiento proyectual es una traslación cognitiva. En ella se puede identificar las redes de lo artístico y del dibujo, en su relación con los factores que sin ser parte específica de ellos se introducen al espacio del proyecto y lo nutren como pensamiento y posibilidad que el paisaje en el que se actúa ofrece.

La ampliación del espacio en el que acontece el proyecto artístico va mas lejos de la anterior concepción del taller del artista, se convierte en un campo en el que se exploran las identificaciones del hecho cognitivo y en el que acontecen los diálogos renovadores que anuncian las posibles soluciones, los procesos de síntesis que fragmentan y renuevan la cultura contemporánea.

Cuando el dibujante transcurre en el espacio del proyecto es conciente de su situación dinámica. En este viaje le resulta clara la implicación de su persona y existencia en el suceso, no se considerará ya un espectador o voluntad al margen.

Esta integración es ganada por los sucesos y encuentros novedosos que nos confrontan con nosotros mismos.

No existe proceso creativo carente de base proyectual, su naturaleza es de índole subjetiva, determinada por la intención, la búsqueda intuida y las más de las veces incierta.

Por eso en la activación del proyecto se demanda una actitud atenta hacia el interior y el exterior, la que nos permite escuchar sin prejuicios para advertir los síntomas de lo fortuito, ganando con ello la posibilidad de reintegrar los fragmentos de un pensamiento y realidad dispersos.

Así el propio espacio y taller se integran a la región temática del proyecto, naturalizando la propuesta como acto creativo, que en si mismo expone la búsqueda planteada. 
Por eso hemos dicho que lo verdaderamente importante no es la conclusión de la obra ni tanto sus aciertos, nos inclinamos a valorar el viaje como expresión vivencial del proceso que abre las posibilidades a la experiencia, y toma los equívocos y circunstancias fortuitas como el verdadero sentido del viaje y base de las extensiones del conocimiento.

"El viaje, por si solo, organiza las potencialidades hermenéuticas; instaura las vías de identificación simpática; armoniza los trazados restantes, aún no habiendo sido explorados, por haber seleccionado otras ramas del circuito hermético. El viaje nos permite focalizar la naturaleza esencial del campo donde nos reconocemos; su estructura rizomática, interconectada y multisemántica." ${ }^{2}$

Nos encontramos frente a la consideración del proyecto que se orienta a favorecer la atención a las necesidades de trascendencia de la realidad inmediata y aparente, dirigiéndose a la generación de estados experienciales de conciencia superior.

Aquí señalamos dos características actitudinales de importancia fundamental. La primera es la que se refiere a la actitud del dibujante a resistirse a las primeras soluciones que en apariencia plantean salidas a los problemas de resolución del proyecto que realiza o bien a la aplicación de las conductas o fórmulas con las que de manera habitual responde frente a problemas similares de configuración. Es esta una actitud de resistencia a la conclusión o cierre prematuro de cada una de las etapas del proyecto. Vale decir en este sentido que en tanto más sea capaz el dibujante de mantener abiertos los estados configurativos y de cuestionamiento reflexivo de la construcción de la obra, más abierto y cercano estará a la obtención de alternativas nuevas y variadas de conformación representacional, y dicho sea de paso más se alejará de las soluciones que mecánica y repetitivamente utiliza.

Sabemos que se genera un estado de tensión en tanto no se alcanzan las soluciones deseadas al problema planteado, pero es importante que el dibujante se mantenga en ese estado, sin precipitar respuestas o formalizaciones. Es esencial mantener abierto el estado de tensión y manejarse en él, ya que de su meditación y observación constante surgirán de manera decantada las posibilidades de extensión del conocimiento. Sólo así se está en camino de aportar algo nuevo como reestructuración o abducción del conocimiento naturalizado preexistente. Por eso consideramos importantes las estrategias de seriación, ya que en un solo dibujo difícilmente hayamos lo buscado, mediante la seriación y la intensidad reflexiva ejecutante nos acercamos gradualmente a los saltos de cualidad y de formulaciones formales emergentes.

Si bien el proyecto nos postula inicialmente frente al problemay sus rutas de esclarecimiento, el verdadero conflicto se revela en la medida que el proyecto se desarrolla, el primer tramo del trabajo consistirá entonces en la ubicación del nuevo núcleo problemático, es en ese punto en el que se dificulta su emplazamiento. Separar lo que es la esencia del factor que atrae inicialmente la integridad del proyecto, es de importancia capital frente a las posibilidades de derivación hacia los causes generados aleatoriamente en el trabajo, ya en otro momento señalamos la emergencia múltiple de vías que sin embargo nos alejarían del centro del proyecto. En ese momento es en el que más pesan los deseos de adaptarse a las normas preexistentes y a los cursos que el contexto y la crítica señalan como deseables y positivos. Aquí la interioridad del proyecto en el ámbito existencial del

32 Vera Santiago. Proyecto Artístico y Territorio. Granada: Ed. Universidad de Granada; 2004. P. 94. 
dibujante lo coloca en el enfrentamiento de sus miedos a no ser aceptado, a desviarse de la corriente general para hacer el ridículo, la inseguridad que uno mismo siente sobre la relevancia de lo hecho y lo pensado, aunque en el cuerpo de la obra se manifieste como un recurso nítido de organización representacional en el que sentimos claramente los nexos de relación temática y contextual.

Al respecto Luigui Pareyson considera el arte como un proceso formativo, que en si mismo expresa su forma de hacer, proyecta sus reglas estructurales en el momento de realizar la obra, de ahí que se pueda entender la obra, en este caso el dibujo como un logro, más que un objeto resultante. Ese logro será el del encuentro que define afortunadamente la posibilidad estructurante de una obra, que encadenada con las subsiguientes muestran el camino de una tendencia que corre hacia causes alternos de representación.

Pareyson citado por Esteve de Quesada nos dice que:

"La producción artística consistirá en un intentar, un proceder a través de propuestas y esbozos, pacientes interrogaciones de la materia. Pero esta aventura creadora tiene un punto de referencia y un término de comparación. El artista procede a través de intentos, pero sus intentos están guiados por la obra tal como habrá de ser, que bajo forma de llamada y exigencia intrínseca a la formación orientan el proceso productivo: el intentar, por lo tanto, dispone de un criterio, indefinible pero sumamente sólido: el presentimiento de la solución... la intuición de la forma." ${ }^{33}$

Esta cita al resumir nuestra reflexión nos pone en posición de comprender la diferencia entre una concepción lineal del método y una formulación metodológica en la que se expresa la reflexión consciente del artista que opta por una estructura con alto grado de indeterminación, para irla configurando en su proceso generador, en el acto de dibujar, así como en la explicitación de la suma experiencial mediante el discurso expositivo.

Esta cualidad de apertura constante en el desarrollo del proyecto, es importante sobre todo aplicada en el orden de las estrategias procedimentales y la reflexión procesual del proyecto, ya que de ahí se desprenderá la posibilidad de encontrar maneras y modos alternos de respuesta variada a los problemas propios del campo de trabajo.

De esta manera ampliamos el territorio de análisis desde los problemas relativos a la elaboración y gestación de la obra como a los factores de interioridad y exterioridad que determinan la normatividad del proyecto en una particularidad espacial y temporal específica.

El pensamiento proyectual del dibujo corre hacia una extensión metodológica, cuando el dibujante dentro del tiempo del hacer realiza una confrontación. Esto es, se plantea su propia posición dentro del sistema que ha desencadenado. Se cuestiona también sobre la manera y efectividad de la ruta seleccionada y las adecuaciones que en su curso ha ido implementando. Pero también piensa en ese mismo momento sobre la relación que sus procedimientos y pensamientos mantienen con los que históricamente otros autores han utilizado, así como los resultados a los que eso los condujo.

33 Esteve de Quesada Albert. Creación y Proyecto. Colección Formas Plásticas. Valencia: Institució Alfons El Magnánimo; 2001. P. 66. 
En este punto se aclara el sentido de la capacidad imaginativa, que se expresa en la búsqueda de maneras, formas y estrategias alternas que resuelvan el problema planteado pero con una distancia que las particularice de aquellas ya naturalizadas.

Por eso es que el pensamiento proyectual del dibujo tiene un carácter social, porque por más que se base en el territorio del conocimiento histórico, significa una ampliación del mismo, que a partir de ese momento se transforma en una extensión del conocimiento puesta a disposición del conjunto social.

Una cita de Esteve de Quesada redondea la idea anterior.

\begin{abstract}
"De igual modo se podría concluir que todo proyecto podrá desarrollarse en la medida que contemple el contexto cultural y social donde se debe llevar a término. Lo cual implica tener en consideración, de entre aquellos factores que afectan al mismo, cuanto mayor número posible de estos. Es preciso no olvidar aquí que todo proyecto tendrá una configuración que lo singularice de los demás en función de estos factores, pero también siempre habrá unos aspectos comunes a otros proyectos anteriores, e incluso ciertos arquetipos o caracteres tipológicos que pueden servir perfectamente como esquema inicial. No obstante, estos caracteres iniciales hay que considerarlos solamente eso, un esquema inicial a partir del cual desarrollar la complejidad del proyecto." ${ }^{34}$
\end{abstract}

Consideramos el pensamiento proyectual tanto como conciencia epistémica como un modelo de formalización que concluye en una visión que representa la realidad y con ello a nosotros mismos. Pero igual lo vemos como el ejercicio de un modelo simbólico de significación. En él se introducen la concepciones e imágenes del reservorio amplio de nuestra cultura y la historia en un ejercicio alterno de refuncionalización o deconstrucción sígnica.

Pensamos que en el trabajo del dibujante se parte de una intencionalidad inicial, algunas veces precisa, otras vaga e indeterminada. Como veremos en la siguiente parte del capítulo, esto no se considera un aspecto rigidizante, ni contradictorio con la esencia compleja y flexible del proyecto. Es así porque el proyecto en su arranque contiene el norte conceptual y las estrategias iniciales, pero no puede ni quiere anticipar los resultados en una obra de carácter cerrado. Aunque en el territorio del arte no existen los caminos únicos y preestablecidos, no se da ningún paso carente de intencionalidad. Al optar tanto más por lo específico, o bien por lo indefinido, se ha tomado una dirección que marca la esencia del proyecto.

Los modelos evolucionistas del conocimiento entran en conflicto con esta visión. Nos inclinamos por una concepción compleja que considera estos sucesos como desplazamientos, extensiones del conocimiento en el sentido general del pensamiento naturalizado, pero también dentro de las estructuras sistémicas del campo dibujo, que es la región donde se originan.

Generalmente se entiende la obra como el resultado de la aplicación del proyecto, o en otros casos como el campo de cruce temporal y espacial de la realización proyectual. Pero

34 Esteve de Quesada Albert. Creación y Proyecto. Colección Formas Plásticas. Valencia: Institució Alfons El Magnánimo; 2001. P. 42. 
destacamos aquí el hecho de que el tipo de obra que intentamos, esa figura preexistente en nuestro ideario determina de manera inversa el carácter del proyecto que habrá de gestarse. Dentro de lo anterior miramos el susurro de los campos disciplinares, que si bien se pueden interpenetrar siguen siendo entidades y regiones ontológicas dentro del territorio artístico.

Así el proyecto es entidad de cruces cognitivos, encuentros entre regiones que se podían pensar distantes. Vale la pena recordar que dentro de una caracterización actual del conocimiento y la metodología se han descartado los procesos de superación negativa del conocimiento, en su lugar se recurre a figuras de superposición y yuxtaposición de ideas. Sobre todo en el terreno del arte, que es geografía de constante movilidad. De ahí que nos preguntemos, ¿Por qué postular entonces la quiebra de los sistemas formales de representación? En todo caso, para ser consecuente con la tesis arriba mencionada la posibilidad de un ejercicio de representación dentro del dibujo debería de ser considerada como una posibilidad de cruce y paralaje que coexista con cualquier otra orientación.

Con la extensión del espacio del proyecto logramos la explosión amplificada que extiende las formulaciones técnicas disciplinares, pero no solo en el sentido artístico que conforma la materia sino en su visión que envuelve y revoluciona las disciplinas del conocimiento. El proyecto es la voluntad que se dirige a transformar las relaciones de jerarquía promoviendo la participación activa de sus componentes en la exploración de los territorios que son tierra de nadie. De esta manera se identifica un lugar de difícil definición pero en el que miramos claramente los conjuntos temáticos, programáticos y estratégicos del campo en el que nos desenvolvemos. Con esto nos queda clara la visión de los límites y su extensión interdisciplinar.

Sin embargo queremos mencionar una peculiaridad importante, esta se refiere al hecho de que mayormente las reflexiones del dibujante en el plano proyectual están referidas al sentido de formalizar y dar cause al sentido significante deseado, esto es, al asunto de expresar aquello que se quiere opinar. Pero también en este plano el ejercicio proyectual atiende, o debería, al diseño de las estrategias para despejar aquellos puntos oscuros que constituyen el conocimiento a alcanzar. Básicamente en este segundo terreno es en el que se desarrolla la estrategia en su potencial más creativo, y no solo en el de las acciones procedimentales de formalización técnica; aunque ambos en conjunto, claro está, operan de manera complementaria como activadores de las aperturas de representación formalizada y metodológica.

Varios autores plantean que el artista no es conciente de la dinámica señalada. Mencionan que la reflexiones que ellos aportan se dan a posteriori, y que solo conjuntándolas con todo el material elaborado a lo largo del proyecto se puede recomponer su gestación y devenir. Concordamos con la visión que señala la integridad del proyecto vista en el conjunto de sus momentos y sus partes. También hemos visto en la historia el ejercicio reflexivo posterior que muchos dibujantes desarrollaron como ejercicio retroactivo de conciencia sobre su trabajo. Pero como artistas que intentamos ser, tenemos que matizar la cuestión y señalar también nuestro desacuerdo.

Ya desde el inicio la sola intencionalidad proyectual del dibujante implica la existencia de un pensamiento abstracto, esto es un ejercicio metodológico que piensa el proyecto en 
su integridad y sus partes deviniendo en un tiempo planeado. Es este un pensamiento que se sucede desde el origen mismo del proyecto del dibujo, su existencia particular es la de ser contenido en el plano mental. En segunda instancia el proyecto al ser operado en su momento de realización fáctica también implica un ejercicio del pensamiento y del juicio autónomo del dibujante, este acto de reflexión es continuo y retroactivo, puesto que en él los efectos de las intenciones proyectuales se convierten a su vez en causa y origen de nuevas causalidades, el pensamiento y juicio volitivo del acto dibujo es continuo y retroactivo, aunque se pueda guiar en mucho por la intuición, implica inmediatamente un a posteriori que valora el resultante de manera inmediata, decidiendo su pertinencia como refuerzo de la ruta inicial, o bien como derivación aleatoria de posibilidad abductiva. Finalmente al término del acto se realiza igualmente un pensar que determina el estado de cierre particular de cada obra.

El pensamiento proyectual inicial contiene y determina las premisas e intenciones que marcan el rumbo original del proyecto, así como las vías de concreción buscadas.

Con el ejercicio de reflexión fáctica retroactiva, el proyecto acontece en el tiempo de su acto y realización como ejercicio continuo de contrastación y flexibilización.

La reflexión a posteriori del proyecto significa su entendimiento como estado comparado con la figura inicial y el carácter y contenido del resultado obtenido.

Todo esto genera la conciencia del dibujante, quien decide los estados de cierre temporal del proyecto, o bien determina su encadenamiento con secuencias que prolongan el proyecto y lo lanzan hacia nuevas etapas.

No en todos los casos el devenir del proyecto coloca al dibujante en el terreno del no saber con claridad el motivo y consecuencia de las acciones que ejecuta.

En muchos casos el dibujante opera con fundamento causal y conciencia de las acciones y procesos que abre. Regula por su cuenta tanto las decisiones estratégicas para enfrentar el rumbo del proyecto como las acciones y procesos de configuración del dibujo. Puede suceder que el resultado del proyecto se asemeje en alto grado a la idea inicial pensada, o bien que al final del trabajo lo obtenido parezca ser tan distante de aquello que constituyó su punto de origen.

Como trataremos en el capítulo que habla de los modelos teóricos y formales del dibujo en la historia, este campo de análisis no puede ser reducido a una sola causalidad, ni tampoco a una contradicción dialéctica simple. El espectro de situaciones y autores dentro de lo que adelantadamente hemos llamado El Acto Dibujo es mucho más variado y complejo de lo que el análisis común nos dice.

En ocasiones las maneras de formalizar y trazar son previstas en el sentido deductivo e inductivo directo. Pero muchas veces también elaboramos trazos y estrategias en el sentido contrario a lo que la deducción nos indica, lo hacemos a manera de reactivo, para generar disonancias dentro del sistema que opera con sentido conformador y regular. Otras veces desarrollamos una dinámica ritual de trabajo en la que nos vemos absortos, el proceso cobra tal ritmo que solo alcanzamos a intuir los trazos que con urgencia realizamos. No creemos que todo esto signifique un plano inconsciente del dibujar; pensamos mejor que es un ejercicio del estar dibujando en el que nos podemos situar en planos diversos de conciencia, incluso desplazarnos transversalmente de uno a otro sin que esto signifique alguna contradicción, siempre y cuando el devenir de la obra que se hace, muestre como 
reactivo fáctico la efectividad de nuestro pensamiento y estrategia como vía de concreción de un algo estructurado con lógica interna sólida.

Ante las reflexiones anteriores, que revisten un carácter metodológico referido a la interioridad del dibujante, cabe recordar el sentido histórico del pensamiento proyectual. Queremos señalar con ello que el material reflexivo que ocupa la mente del dibujante en su actuar, es una línea que recorre en sentido de profundidad el espectro de todo aquello que atañe al contexto en el que se desenvuelve, es decir lo que no es él, el dibujante. Hasta que esa línea ahonda en lo profundo de su interioridad subjetiva. El pensamiento del hacer el proyecto del dibujo permea la región social en su sentido histórico y la conecta con la visión subjetiva existencial del dibujante.

Así los planos de conciencia en el pensamiento proyectual del dibujo atañen a la exterioridad en el sentido más amplio, tanto como a la interioridad en su visión más profunda; pero pocas veces, creemos, en situación de una inconsciencia del punto en el que nos ubicamos y de las acciones desencadenadas.

Nuevamente una cita de Esteve de Quesada al respecto.

"El proceso artístico no siempre avanza de un problema a su solución, o de una necesidad a un procedimiento técnico... Es más acertado caracterizar los estadios sucesivos de la producción como un desplazamiento constante del núcleo central, que como un progreso de un estadio al siguiente. La primera idea de la obra puede ser concebida conscientemente y con reflexión, mientras que la última mano puede mostrar elementos inconscientes, una inspiración feliz conexión insospechada, una solución inesperada."35

La estructura del proyecto del dibujo se puede ubicar en dos extremos diferenciados, que pese a todo nunca encontramos aplicados completamente en un sentido u otro.

Muchas veces el dibujante opera con un amplio margen de certeza en la elaboración de su proyecto. Tiene clara la demarcación conceptual y temática que abordará, define también los límites procedimentales y las estrategias a utilizar. En este sentido el proyecto se manifiesta con transparencia y permite la especulación previa sobre el devenir y los alcances del trabajo, mucho del arte conceptual y posmoderno que utiliza el campo del dibujo opera sobre esta base, se llega al extremo de plantear que la concepción ideada del proyecto contiene ya la completud sin ser necesaria su realización objetual.

En un sentido opuesto muchos artistas y dibujantes conciben el pensamiento proyectual como el caminar en una región oscura, impredecible, en la que es imposible determinar el número y cualidad de las situaciones que pueden presentarse, incluso se desarrollan estrategias que desde el inicio carecen de un norte formal y estructurante específico. La apertura total del proyecto desde los primeros momentos del proceso formó parte de la postura sustantiva de los artistas que desde el Informalismo y el Expresionismo Abstracto profundizaron en esa dirección.

Ya mencionamos que ambos extremos del carácter metodológico proyectual nunca se encuentran en estado puro, en cualquier caso que revisemos encontraremos una fusión típica que guarda distancia particular con este gradiente metodológico.

35 Esteve de Quesada Albert. Creación y Proyecto. Colección Formas Plásticas. Valencia: Institució Alfons El Magnánimo; 2001. P. 46. 
Valga recordar en este punto la relación del carácter proyectual con su dimensión histórica. El inicio del pensamiento proyectual tiene su sustento en el pensamiento racional, desde esta perspectiva asumió una tendencia hacia lo lineal determinista. Las primeras fracturas de la modernidad llevan la concepción del proyecto hacia una postura crítica, que con el tiempo se define como una visión abierta que asimila lo aleatorio como pilar metodológico. Con el advenimiento de la posmodernidad el pensamiento proyectual se abre a una diáspora epistemológica que lo coloca en la imposibilidad de un emplazamiento. Apuntamos por nuestra cuenta que en esta suerte de construcción el pensamiento proyectual posmoderno apuesta más hacia la estrategia como emergencia crítica que no busca lo nuevo ni la comprensión heurística del dibujo ni de los modelos de que se ocupa. Aunque suene distante, esta deriva se origina en el hecho de que pocas veces en el dibujo actual se opera sobre la base de un enfrentamiento del dibujante con los modelos ontológicos como fuente de representación y se parte de la estrategia de segundidad propuesta en la cita, la apropiación y el plagio de imágenes ya insertas en el circuito iconográfico del arte y la cultura global.

Pero en definitiva el pensamiento proyectual implica una causalidad retroactiva, es tanto una especulación sobre la realidad contextual externa en sentido amplio, como un viaje a la región profunda de la psique del dibujante, que no puede concluir sino a modo de interrogante a nosotros mismos.

La obra terminal del dibujo no será la conclusión directa de las premisas iniciales, será en todo caso su superación, la expansión de los límites que sin embargo determinaron la demarcación original del problema. Muchas veces en la historia se han escuchado las voces detractoras de lo nuevo y la originalidad, pero en este punto de la reflexión podemos ver con meridiana claridad como el pensamiento proyectual contiene en su dinámica interna la construcción y la deriva de los supuestos conceptuales y formales de representación que involucra.

La dimensión temporal del pensamiento proyectual del dibujo contiene cursos curiosos y contradictorios. En el proyecto se reconoce una primeridad mental, esto es, una temporalidad prefiguradora inicial, en la que el proyecto solo existe en la región racional del dibujante. Esta se separa claramente de un segundo segmento temporal en el que el proyecto inicia su ciclo fáctico configurador, su devenir pragmático, tanto como empresa o bien en su consistencia objetual.

Pero el pensamiento y juicio del dibujante se mueve en un continuo ejercicio de futuro y pasado que se alternan y se mezclan. El dibujante opera sobre un continuo análisis a posteriori de la acciones que planea, de su resultado y afectación en la obra y de su pertinencia como postura de impacto en el contexto artístico y cultural, todo esto aunque la obra en sí no esté concluida. El pensamiento proyectual del dibujante analiza en una doble dirección temporal los factores iniciales del proyecto, pero también analiza continuamente el proceso de gestación, aunque en él muchas veces la intuición corra por delante de la reflexión racional y experiencial, y analiza también el todo de lo que va logrando como posibilidad de una obra, cuyo cierre clausure la solución a la intencionalidad problemática propuesta.

El carácter proyectual del dibujo permite (incluso cuando opera como función dentro de otros territorios del arte) la reflexión no solo de las rutas procedimentales que concretan la 
obra, también posibilita el análisis de la articulación y relación de las partes que integran el todo proyectual.

Este proceso es un continuo entrar y a la vez tomar distancia del acto dibujo, ganando con ello la posibilidad de reflexionar sobre el propio modo metodológico de proceder, es este un ejercicio epistémico en su sentido fundamental.

Finalmente la interioridad del pensamiento proyectual del dibujo se funda en la historia y el bagaje de los modelos de representación del dibujo, junto a ello, la claridad en los supuestos y objetivos contenidos en el problema que el proyecto implica. Estas dos regiones serán activadas dependiendo del bagaje cultural, formal, actitudinal y aptitudes del dibujante.

\section{II-3 RELACIONES SISTÉMICAS DEL PENSAMIENTO PROYECTUAL}

Para este momento la literatura dedicada al estudio del proyecto artístico es abundante; este trabajo se nutre un tanto de ella, ahí hemos encontrado una sistematización a muchas de las ideas y preocupaciones que de manera dispersa orbitaban nuestro pensamiento. Descubrimos que el fondo y alcance del tema iba mucho más lejos de lo que sospechábamos. Quizá una de las alegrías más emotivas en este proceso fue la de descubrir que en muchas de las disertaciones estudiadas se mencionaban situaciones que como dibujantes vivimos, producto de nuestra práctica en el hacer la imagen, descubrir como se alude con claridad a situaciones y sentimientos que creímos guardados en el interior de nuestras vivencias.

En el momento de redactar estas líneas nos vemos en la necesidad de someter a una cierta organización nuestras ideas, con la finalidad obligada de hacerlas comprensibles, reconocemos así el criterio de rigor teórico. Pero sentimos también que en muchos de los textos revisados, se recurre a una organización del análisis basada en una estructura taxonómica, que en orden deductivo va centrando la conclusión buscada.

Una inquietud interna, una razón reflexiva nos impele a plantear la organización de los campos del proyecto más como una determinación de zonas de un sistema complejo que como partes de un método lineal.

No pensamos por supuesto que los esfuerzos en el sentido de un análisis organizado y puntual de las partes del proyecto sean territorios estériles o equivocados, de ninguna manera, nos basamos en ellos, pero deseamos discurrir hacia una ruta de flexibilización que esperamos sea entendida como una pequeña extensión a lo ya estudiado, y no como un pensamiento que intente cancelar ninguna alternativa.

Basados en lo anterior es que no hemos querido adentrarnos en el estudio de las partes del proyecto artístico (para ello contamos con los estudios mencionados) decidimos enmarcar este segmento del trabajo en términos de una formulación de relaciones sistémicas que operan en la interioridad del pensamiento proyectual del dibujo.

Aquí hacemos algunas precisiones que nos parecen modestamente significativas.

En primer lugar nos referimos no a las partes del proyecto artístico, sino a las relaciones sistémicas del pensamiento proyectual del dibujo. Es así porque intentamos la consideración del proyecto no como una formulación metodológica que se expresa a posteriori y finalmente en un orden racional y graficado con una secuencia específica, aún sin caer en la linealidad del método rigidizante. Queremos hacer un ejercicio de extensión para llevar la reflexión hacia el terreno de una forma del pensamiento, por eso 
es que desde antes nos hemos referido al territorio del proyecto, como una formulación del pensamiento proyectual del dibujo.

Aquí se encuentra una de las primeras bases que dan cause a una parte de la hipótesis inicial de este trabajo, el carácter proyectual prefigurativo del dibujo es la función sustantiva que le ha conferido a lo largo de la historia su capacidad formadora del proyecto artístico, esta cualidad aunada a su esencia como generador del pensamiento eidético son los pilares estructurales que lo definen como un campo disciplinar y del pensamiento, más allá de la posibilidad, que no está negada, de contemplar y analizar los sistemas de representación formal que nos son legados por la historia de los artistas.

Aunque hemos tenido determinaciones de presión desde un contexto teórico y artístico extenso, la ruta de crecimiento de nuestras ideas ha sido de carácter interior hacia el campo del dibujo, aunque el resultado de la investigación nos señale continuamente la familiaridad y similitud de nuestros resultados y formulaciones.

Después de haber discurrido en el terreno de la historia del proyecto y de haber poco a poco realizado una traslación hacia las consideraciones de su interioridad, intentaremos ahora referirnos a los vínculos que de manera más específica operan como funciones relacionantes y unidades temáticas y ontológicas en el cauce del pensamiento proyectual del dibujo, esperando de esta manera adentrarnos en la primera etapa del discurso que despeja las partes de la hipótesis planteada.

El "Tema" suele ser entendido como la figura de identidad, tema y proyecto se miran como la relación entre generación del argumento lógico conceptual y método de la propuesta artística.

Ya no podemos mirar el tema desde la visión historicista que le confería la cualidad de ser el suceso dramático que se proyectaba en el devenir temporal como circunstancia de las vicisitudes de un acontecimiento, que por otra parte estaba firmemente arraigado en la pintura de género. El tema se consolida como el concepto que habrá de ser graficado por la intencionalidad del dibujante; pero que al mismo tiempo es el motivo de la investigación y tratado del proyecto. El tema así, es un generador de reflexiones. Será entendido como un lugar de existencia mental, relativo al entendimiento y a las capacidades para ampliarlo mediante la aplicación de la inteligencia y la estrategia.

En este punto mencionamos una particularidad importante. La reflexión sobre el campo temático no se manifiesta en el pensamiento del dibujante como la intención de explicitar directamente el discurso expresivo. El tema se origina como producto del conflicto artístico que el dibujante detecta en la interioridad del campo dibujo, esta sería la visión autocrítica de la que hablaba Greenberg, o bien como intención de incidencia crítica y opinión sobre asuntos del contexto en el sentido amplio, a manera de proyecto crítico social. El tema y su base conceptual se fundan en la sospecha e incomodidad que el dibujante tiene con respecto a las posibilidades del dibujo y su proceso para discurrir sobre causes alternos al pensamiento estabilizado. Muchas veces la intuición como estrategia impulsa la reflexión e intenciones del dibujante en la organización temática del proyecto, reflexiones poco claras que esperan ser despejadas en el curso de realización del dibujo, y que encontrarán su posibilidad en la concreción formalizada de la imagen.

La sospecha opera también como generatriz determinante del campo temático, el pensar 
que una posibilidad alterna puede sustituir al sistema o sus partes se convierte en el impulso del proyecto del dibujo.

Pensamos en el tema como una demarcación problemática, no como la claridad que habrá de ser realizada mediante el proyecto.

En su posibilidad problemática, como sospecha o como intuición primordial el tema opera como impulsor del proyecto, debe a este carácter problemático su capacidad de generar aperturas formales, epistémicas y de todo tipo.

En este orden de ideas el tema asume dos posibilidades, la de mostrar ante todo el carácter del acontecimiento contextual sobre el que se quiere discurrir y opinar, o bien, el de centrarse en la interioridad del propio campo del arte y hacer de su estructura lingüística el asunto discursivo.

Por esta vía el tema sería el contenido central de la obra y el proyecto, motivo de las acciones y pensamientos desarrollados en el decurso del trabajo.

Se dice que la idea del proyecto sería el encuentro de la conciencia con el tema.

Nos detenemos un tanto en este punto y anotamos por nuestra parte la consideración de que el concepto temático, como momento inicial del proyecto, tiene una vocación de tiempo presente que en lo inmediato se convierte en pretérito, es así dado que esa idea primigenia comienza a generar sus posibles cauces de realización estratégica y formal, ese sería entonces el tiempo presente del hacer la obra. Pero desde ese instante, toda consideración reflexiva sobre lo avanzado en la significación temática implica un distanciar la mirada y el pensar para volver atrás, reflexionar sobre la pertinencia de lo ya hecho. Por eso la consideración del tema dentro del proyecto dibujístico reviste un estado continuo de introspección que se relaciona con la exterioridad del ser dibujante.

A todas estas consideraciones les atribuiríamos un sentido organizativo diferente, sin que ello desconozca la importancia del pensamiento formulado.

Entendemos el tema como una unidad problemática central del pensamiento proyectual del dibujo. Pero no como el asunto determinante, ni como unidad ontogénica inicial.

Decimos que el proyecto artístico se basa en la interacción de tres entidades ontológicas de afectación originaria:

\section{El Contexto}

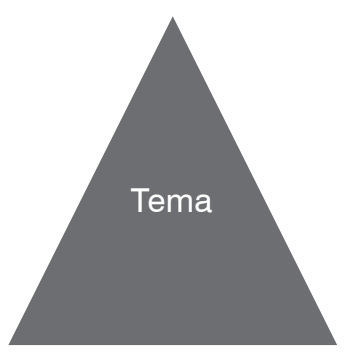


En esta triada el tema no es el inicio del proceso sino el área resultante de la demarcación de los tres factores iniciales, función relacionante, área de cruce de las interacciones y determinaciones de estos tres campos.

Por otra parte, el tema se puede conducir de nuestra parte como una doble manifestación, esto es, ser a la vez un relato en el sentido dramático, histórico y contextual, o bien ubicarse en la región de la interioridad de la forma y el lenguaje del propio campo disciplinar en el que nos desenvolvemos.

Bajo el esquema triangular propuesto, el tema podría ser incluso la relación problemática, compleja y rizomática que se traba entre los tres componentes ontológicos que determinan el campo temático del dibujo.

De lo anterior podemos concluir que el tema como centro y función problematizante de relaciones nos lleva a considerar una doble intencionalidad histórica del proyecto.

La de un proyecto que entiende su razón de ser en función del querer decir del dibujante. La naturaleza de esta intención se orienta hacia el sentido de la crítica, la opinión y la incidencia volitiva dentro del marco cultural y político en el que se inscribe nuestro artista. En segunda instancia el proyecto puede asumir una intencionalidad que metamorfosea la crítica y la opinión, sustantivándola en sistemas y propuestas de formalización que trastoquen y revolucionen los sistemas de representación del campo dibujo. Esto es, una crítica que trasciende el terreno temático, para manifestar una meta-postura política en términos de una evolución, abducción o revolución de los modos del lenguaje, los modos de ver y con ello las maneras de la representación.

Pero la relación triádica compleja que hemos enunciado lleva la región temática del proyecto hacia una visión holística totalizante, la que comprende la relación gnoseológica entre sujeto, realidad contexto y modo metodológico del conocimiento.

Esta relación triple es la que sucede como acontecimiento fenoménico en el proceso de representación, y lo coloca así más allá de la formulación mimética del concepto, la que se soportaba en una lógica binaria que relaciona al sujeto con la realidad en la acción de representarla; esta es una primera extensión reflexiva que realizamos de esta categoría.

De esta manera el tema se expande como problema, se enlaza con la intencionalidad originaria del proyecto; manifestará históricamente un carácter crítico o positivo, como ya lo mencionamos en el punto anterior. Razón, subjetividad, lógica formal, psíque y postura existencial conformarán la visión temática del proyecto.

Con la crisis de los sistemas de representación, o cuando menos con la renuncia de los artistas para buscar cauces formalizados de representación alterna, se generan consecuencias fundamentales hacia las relaciones sistémicas del pensamiento proyectual del dibujo y su fenomenología.

Con la renuncia posmoderna a la representación, tanto la realidad externa, sus sujetos y fenómenos, como la realidad reflexiva interna son dejadas de lado en el proceso de formalización primaria del proyecto. Queremos decir con esto que no se constituyen como 
modelos y fuentes de conocimiento, aunque sean la base de la intención significante. El proyecto de la modernidad en el inicio del siglo XX llevó el territorio del pensamiento proyectual hacia la interioridad mental y subjetiva del artista, de ese modo la naturaleza externa dejaba de ser la fuente de origen de la experiencia artística y el proceso estético formal. La posmodernidad lleva un tanto más allá las cosas al prescindir incluso de la realidad interior como origen de un proyecto estético.

La "actitud" puede ser considerada como un principio incipiente de postura epistémica, en tanto que posiciona al dibujante frente a la región temática, frente a las presencias ontológicas y ante los procesos que motivan su trabajo. Lo define, aunque no del todo conscientemente ante la elección de la estrategia y el método con el que inicia sus operaciones.

Una actitud poco problematizante, aunque pueda darse con un fondo crítico se opera dentro de la estrategia posmoderna del dibujo. Esto es así porque se dispone con prontitud al armado de la estrategia significante, los contenidos implícitos en las imágenes recicladas se asumen como ya dados, con ello su formalización es parte de la cultura estable a la que se alude. En el proyecto del dibujo posmoderno (como veremos más adelante) la problematización se centra en las estrategias de relación sintáctica entre las imágenes, o bien en los procesos de montaje y realización del dibujo, que las más de las veces se orientan hacia flexibilización de los campos o hacia extensiones del soporte del dibujo.

Pero en otros casos y aún ahora, la postura actitudinal se prolonga hasta arribar a una conciencia epistémica, con ello se logra la formulación buscada de una claridad metodológica frente al contexto y las realidades en las que se inscribe y origina la obra. Se está claro en la construcción de los procesos secuenciados del proyecto, y se busca su consecuencia en cauces de representación formalizada que funden vestigios de prácticas formalizantes de primera generación. Esta es la base del núcleo problematizante del proyecto; la relación que se establece entre el tema vuelto problema y su posibilidad de conceptualizarlo en una forma y sistema que soluciona la estructuración buscada.

En este punto es importante que el dibujante despierte una actitud imaginativa, en el sentido de la capacidad para relacionar formas e imágenes entre sí, tanto en términos de una historia de la forma como en el sentido emotivo. Con esta claridad se alumbran los posibles cambios y desviaciones a los sistemas utilizados, se inicia así con la actitud el camino de la abducción formal.

Al vincular la forma histórica y los conceptos aprendidos con posibilidades alternas se da paso a la imaginación, se entra en el mundo donde el proyecto solo existe como posibilidad imaginada hasta ese momento, pero así construimos la realidad partiendo de la imaginación. De igual manera que una apertura a nuevas formas nos abre un mundo imaginario más rico.

Pero hasta este punto la actitud del dibujante reconoce que la imaginación dota al proyecto de una completud mental, existe con forma y visión total en nuestro intelecto, pero igual sabe que esa completud para que lo sea ha de acontecer en el plano fáctico del proyecto, en el que comulga con la materia y se expande con las aperturas generadas en el acto de dibujar.

Diríamos que el concepto idea se integra con el concepto de la forma fáctica constituida. 
En este orden de acontecimientos el proyecto demanda del dibujante una actitud creativa y abierta, esto para considerar sin temor los conflictos contenidos tanto en el inicio del proyecto como los que se originan en su decurso; creativa para no resolver esas situaciones con las respuestas que habitualmente damos y que forman parte de nuestro reservorio de construcciones dibujísticas que organizan nuestras imágenes. La forma nueva o un tanto alterna y la estrategia enriquecida son así la respuesta que ofrecemos al problema de la representación formalizada, se concreta en ella el ejercicio de la creatividad.

La inteligencia nos advierte que la forma que emerge nueva, constituye una modificación a nuestra mirada, implica un cambio en el pensamiento y la gestalt y en sí es el ejercicio más libre de la crítica, porque no solo señala su desacuerdo político explícito, sino que también transforma las estructuras profundas del pensamiento legalizado y estable.

Las ampliaciones estratégicas constituyen el desarrollo metodológico cognitivo que es la base de la extensión de la conciencia epistémica.

En este proceso se comprenden e interpretan los hechos y las ideas y se constituyen en una base de deducción e intuición de conocimiento significativo.

Esteve de Quesada resume en seis puntos el tema de la creatividad:

1- Su relación con el método

2- Sus semejanzas y diferencias con los conceptos de inteligencia e imaginación.

3- Las diferentes definiciones del hecho creativo, así como aquello que contribuye a un desarrollo del pensamiento creativo.

4- El ámbito social, esto es, el contexto cultural que incide en la investigación sobre la creatividad.

5- La aplicación generalista o a ámbitos concretos de los métodos creativos.

La consideración de estas variables constituye ya una claridad metodológica. Nosotros agregamos como parte sustantiva de la postura epistémica, el hecho de que el proyecto del dibujo posiciona al dibujante fuertemente con los modelos que trabaja, sean estos formas del pensamiento o entidades ontológicas y fenómenos fuente de representación. Lo colocan también frente a la decisión de la ruta procedimental con la que construirá la materialidad de la obra y el carácter del acto dibujo que emprende.

Así el primer nivel de existencia del proyecto se da en la región del pensar, es un campo abstracto y virtual en el que se organizan las coherencias de las partes y el todo.

El primer campo abstracto del proyecto contiene la motivación original. Las circunstancias que lo detonan. Estas se originan en un contexto, sea desde la exterioridad del dibujante o desde la interiorización del mundo social, del arte y el lenguaje; de aquí se plantean los objetivos como problematización temática y dentro de ellos aparece casi de manera paralela la especulación o hipótesis a manera de vía de solución. Parte de la solución proyectual incluye las dinámicas y acciones de construcción procesual de la obra.

El segundo plano de existencia es el acontecer fáctico del proyecto. Este es el acontecimiento procesual que genera las aperturas recursivas al pensamiento inicial. Aquí la estrategia 
deja de ser entidad mental y se convierte en el centro temporal del acontecimiento del dibujo, que junto con el devenir de la obra haciéndose plantean conflictos y aperturas al autor. Si el primer momento del proyecto contiene las decisiones de planeación abstractas, el devenir fáctico es el tiempo de las decisiones emergentes e intuidas. El tiempo del acto dibujo es el tiempo del pensamiento con causalidad recursiva circular, ahí causa y efecto subvierten su linealidad reflexiva y se retrotraen en un ejercicio de apertura metodológica. En ese momento se piensa en presente y pasado simultáneamente.

Este párrafo y su contenido describen una aplicación particular de la postura constructivista, aquella que entiende el conocimiento como un acto de construcción en el que el conocimiento no es algo dado, sino un producto que se alcanza en el hecho de su suceder, suceso en el que se construye tanto el conocimiento en sí como el sujeto que lo elabora.

En tercera instancia el proyecto se sustantiva en una entidad ontológica alterna, la obra, que en su interioridad contiene su propia historia, memoria y estructura del proceso conceptual y fáctico al que se debe.

Ya desde su existencia mental el proyecto es una entidad de relaciones orgánicas. En primer lugar se demarca el problema como centro temático, en segunda instancia se establecen las bases conceptuales que se refieren al campo del dibujo y que operan como campo sustantivo y área de operación del proceso. Se idean los medios técnicos y objetuales que materializan el proyecto y la construcción de la obra, se establecen las unidades temáticas que se derivan del núcleo central del problema y las relaciones entre modelos, contexto, autor y obra en configuración.

Un lugar primordial dentro de esta condición sistémica lo ocupa el diseño de las estrategias de configuración en sentido amplio. Estas se refieren desde las que relacionan al dibujante con el contexto como modelo, o bien asumido como espacio de impacto, hasta las acciones y actitudes corporales en el momento de los trazos específicos de configuración.

Con base en todo lo anterior podemos considerar el pensamiento proyectual del dibujo como un viaje de causalidad recursiva. Este se inicia con la motivación original del proyecto y se emplaza como entidad abstracta, en su decurso se transforma en acto de configuración complejo que se cierra temporalmente y se emplaza en lo concreto de la obra presentada. Si bien el viaje se inicia con la visualización del problema inicial, a lo largo de su acontecer el proyecto es un proceso continuo de solución y toma de decisiones frente a los causes emergentes y aleatorios que no podían ser considerados al inicio del trayecto.

Por eso al abordar el problema inicial se descubren una serie de subdivisiones y conflictos que necesariamente se tienen que resolver para lograr la resolución del proyecto. De ahí que el acto del dibujar arroje claridades que despejan los márgenes de incertidumbre del pensamiento que define el campo disciplinar.

La claridad con que los problemas centrales son resueltos y el acierto de las formas y sistemas en que esas respuestas se concretan generan en el dibujante una tendencia normativa, tendemos a reiterar una respuesta que resultó asertiva en un caso, hacia circunstancias similares. Aunque por otra parte hay quienes deciden un modelo de relaciones proyectuales que busca la particularidad en cada caso, evitando las construcciones similares como respuesta y tendencia. 
Las relaciones que introduce el dibujante como forma conectiva entre el contexto, y la obra pueden sustentarse en un principio estocástico, cuando buscan la generación de condiciones no previstas en el tiempo de la configuración. O bien se pueden sustentar en una búsqueda holística como intento de integración en un pensamiento genérico, buscando establecer con cada caso una tendencia como centro de atracción proyectual. Así es común que un proyecto solo sea un corte parcial que se relaciona de manera serial con los proyectos subsiguientes como parte de un sentido generalizante.

Pero el acto de proyectar siempre será una acción de transformación, ya sea en sentido convergente o divergente. En ese acto las consideraciones iniciales se irán transformando, manteniendo su vocación divergente hacia derroteros alternos, o bien, encausadas hacia la ruta del concepto y problema inicial.

Así lo más importante del pensamiento proyectual consiste en la partida desde un inicio conceptual intencionado, pero considerando los causes surgidos en el proceso de configuración, ya que cuando el proyecto se construye llega a ser el mismo el que sugiere las ideas, cuando el proyecto entra en contacto con el acontecer fáctico, la obra cambia y en un sentido inefable se independiza. Pero, recordemos que esto no se sucede por generación espontánea, se basa en el componente reflexivo previo o que se conforma en el avance del trabajo. La idea inicial debe convertirse en idea estratégica de la acción que reflexiona sobre los acontecimientos que se precipitan en cascada.

Tomemos las palabras de Esteve de Quesada para ubicar las regiones relacionantes que operan en el cause del acto dibujo, aunque referidas al campo del diseño describen en parte pero con claridad lo acontecido en el proceso del dibujar.

"Morfológico: aquellas que operan sobre la apariencia formal y sus aspectos Geométricos... las deformaciones topológicas, los procesos de abstracción, las analogías con la naturaleza, o de tipo maquinista, incluso todo tipo de analogía formal que permite las transferencias creativas de un campo a otro.

Sintáctico: aquellas que operan sobre la distinta relación o conexión de los elementos que configuran un proyecto.

Contextuales: Aquí incluiría todas aquellas operaciones que alteran el tamaño, la ubicación o la función de un objeto, imagen o construcción cualquiera"36

Nuestra visión que amplía el entendimiento del contexto como un campo de circunscripción del proyecto, de la obra y la intencionalidad del dibujante. El contexto significa el universo de inmersión fenoménica del proyecto en sentido amplio. El problema, la obra y el artista se hunden en él más que posicionarse frente a él.

Por otra parte el contexto opera como campo de presión sobre las inclinaciones del dibujante, marca su credo ideológico, sus aspiraciones y su pulsión psíquico afirmativa, aún dentro del carácter disidente que el proyecto pueda tener.

Casi siempre el contexto cultural y artístico marca la tendencia a seguir, como afirmación o disidencia.

El repertorio formal que constituye la estructura del campo dibujo es un manifestación

36 Esteve de Quesada Albert. Creación y Proyecto. Colección Formas Plásticas. Valencia: Institució Alfons El Magnánimo; 2001. P. 125. 
del contexto de alguna manera, este marca el poder y el no poder del dibujante, tanto en el sentido configurante como en la estrategia desarrollada en la acción. Hoy día tanto las formas como los procederes y las actitudes mantienen un sello contextual, muchas veces como una moda o corriente hegemónica.

Si bien el contexto es el marco cultural de las formas y estructuras del campo dibujo también es el espacio de la vivencia del dibujante, aún en la soledad posible de la configuración no estamos tan solos ni somos tanto nosotros mismos.

Pero con todo eso, el contexto es la fuente que prima el origen del tema problematizado.

A manera de recuento decimos que para nosotros las relaciones sistémicas dentro del pensamiento proyectual del dibujo son aquellos nexos complejos de causalidad que se establecen entre estas tres unidades ontológicas: El Dibujante, El Contexto y La Obra. El área resultante de esta triada está constituida por el tema problematizado, este consistirá entonces el espacio de cruce de las relaciones múltiples y no lineales suscitadas en el acto del dibujar y representar el mundo.

\section{II-4 EL PENSAMIENTO PROYECTUAL EN EL DIBUJO}

El pensamiento proyectual es la expresión de los diálogos interiores del artista consigo mismo y con el contexto en el que le tocó en suerte desenvolverse.

Es un diálogo porque se soporta en la lógica que admite la existencia de un otro u otros, sujetos o contexto independiente del propio dibujante, entidad a la que hay que escuchar y de la que hay que aceptar su determinación. El diálogo supone el flujo de un material comunicativo que migra del dibujante hacia sus interlocutores y viceversa, esta es la base de la intersubjetividad del lenguaje expuesta por Barthes.

Este pensar es el inicio del dibujo. Es también la relación vivencial y experiencial del dibujante con el lugar, el paisaje y los modelos que lo motivan. Desde este punto, el proyecto en sus secuencias puede constituirse como obra que guarda un lugar en la geografía de la evolución artística y del autor.

El proyecto del dibujo se concreta en una obra; objeto o idea que se caracteriza por su movilidad, expandiendo la reflexión en relaciones de intercomunicación que rebasan los lindes del propio campo disciplinar.

El proyecto posee desde su constitución el carácter de obra, aún sin la concreción del producto final proyectado. El proyecto del dibujo revela los causes y órdenes del pensamiento, los diálogos que se busca establecer y el acontecimiento artístico específico, para la mirada atenta se revela como la completud del pensar dibujando.

Demos paso a una región más interna que nos introduzca desde las reflexiones generales hacia los entreactos del dibujo puesto en acción.

"PROYECTO s. m. (Del Lat. Proiectus) Intención de hacer algo o plan que se idea para poderlo realizar. 2. Conjunto de planos y documentos de una obra o edificio, instalación, máquina, etc. , que se han de construir o fabricar. 3. Redacción o disposición provisional de un escrito, un tratado, un reglamento, etc." ${ }^{37}$ 
Esta es la definición etimológica del término proyecto, en ella encontramos los componentes sustantivos que fundan nuestro análisis y nos permiten llevar este concepto a planteamientos categóricos en el terreno de las artes y particularmente del dibujo.

Actualmente nos aqueja un ánimo de indefinición, parece que rehuimos toda postura que nos ate en un punto determinado.

En la definición de líneas arriba, se advierte con claridad que al enunciar el proyecto este tiene una vocación a futuro, se menciona la intención como una voluntad que imagina secuencias de la acción, estas terminarán con la concreción de la obra, lo cual finiquitará la condición de proyecto.

La correspondencia entre plan y proyecto encuentra aquí su fundamento, el proyecto como hemos revisado es la ruta construida mentalmente para lograr una obra, aunque el proyecto en si mismo constituya una posibilidad terminal. Luego entonces su cualidad temporal es la de un pensamiento o trazo que antecede y va formando al producto posterior. Proyectamos para organizar nuestra secuencia de acciones y conseguir el fin propuesto, el plan se establece para seguirlo, es la garantía de conseguir lo deseado. Nos preocupa poder garantizar la predictibilidad de las empresas que iniciamos.

Cuando se considera el proyecto como un conjunto de esquemas, ya sean gráficos o no, que contienen la elaboración estructurada de la obra deseada, se sobreentiende la distancia entre el objeto planeado y su consecución fáctica final.

La última cualidad de la definición inicial resulta por demás interesante, disposición provisional de. El carácter del proyecto implica una cualidad provisional y perfectible, se le pueden agregar o modificar las partes y cualidades, puede incluso ser desechado si no demuestra su efectividad. Se puede ajustar en su estructura y la relación de los elementos para hacerlo más efectivo. Esto no suena ya tan limitado en términos de una rigidez metodológica.

Por nuestra parte agregaremos una cualidad más al concepto de proyecto; este determina un proceder, o sea una manera típica de reflexionar y conducirse en los actos.

Las estrategias y procederes son también parte de la concepción de un proyecto, habremos de considerar la ampliación del término más allá de la visión instrumentalista y practicista que comprende las partes de la obra en planeación.

Una primera ampliación de la categoría proyectual correrá hacia la esfera de la proyección de las dinámicas reflexivas implicadas íntimamente con aquellas elaboraciones de las partes de la obra. Sumado a lo anterior el proyecto en nuestra visión refrendará la construcción de una temporalidad consecuente con la acción propuesta, tanto desde el punto de vista de la agenda procedimental como en la profunda concepción de esta categoría.

En la práctica, el dibujo actuaba, y aún hoy lo hace, como guía previa e imagen que representa el objeto a lograr.

Cuando proyectamos con una intención de construir lo planeado estamos asumiendo una actitud que tiende a la estabilización metodológica. 
El proyecto como solución al tema problematizado, contiene la suma de las partes de la obra y sus momentos de construcción, no sólo eso, incluye también los datos del pensamiento que lo genera, el proyecto mismo, antes de su realización, nos enseña el ejercicio mental de su autor.

El artista y el dibujante cuando se aplican a la proyección de una obra, se enfrentan con aquellas zonas poco claras dentro de sus capacidades, al proyectar quedan expuestas las partes de la idea que requieren algún análisis particular, y nos coloca en posición de estudiarlas para su solución.

Las páginas anteriores corrieron sobre la suerte general y teórica del pensamiento proyectual, es el momento de establecer relaciones y ejemplos particulares con el campo disciplinar que nos ocupa.

Iniciamos con un ejemplo de pintura del siglo XIX, El salvamento de la Medusa de 1810, cuadro que es tomado como el manifiesto del Romanticismo en la pintura. Partimos de esta obra y esta temporalidad porque el Romanticismo es el primer movimiento de vanguardia típicamente crítico históricamente; pero en el sentido metodológico mantiene fuertemente la función estratégica del dibujo en la construcción del proyecto artístico; aunque el dibujo romántico haya logrado características formales de representación propias y nuevas dentro del sistema del dibujo.

Es esta una tela de $490 \mathrm{~cm}$. de alto por $716 \mathrm{~cm}$. De ancho. Como se sabe esta pintura trata el tema del rescate de los náufragos de la fragata llamada Medusa. Es una obra plena de tensiones psicológicas y espirituales. Lo interesante es que estas inquietudes del pintor, se concretan en estructuras formales que las exponen de manera plástica. Fig. 4

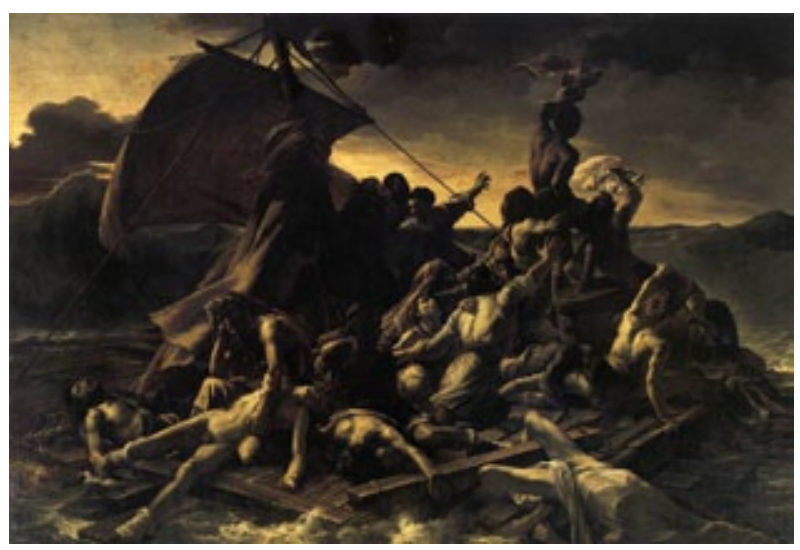

Fig. 4 Teodoro Gericault "El salvamento de la Medusa"

No es nuestra intención hacer poética sobre esta obra, ni tampoco efectuar una descripción. Las figuras humanas que integran el cuadro asumen una gama muy variada de actitudes frente a la angustia de la situación, las cuatro figuras de la zona inferior del cuadro yacen casi en estado moribundo, dos más en la zona intermedia les siguen en actitud desinteresada y en un abandono mental, parecen haber decidido dejar de luchar. El área intermedia del cuadro está dominada por dos diagonales, la que corre del lado inferior derecho hacia el superior izquierdo, esta línea de fuerza, conjunta un grupo de figuras empeñadas en apoyar a una sola que se eleva hacia la parte mas encumbrada de la composición, en el primer tercio derecho del plano compositivo.

La diagonal contrapuesta resume el movimiento gestual del conjunto, genera una masa dinámica que es coherente con el sentido temático del cuadro. Los cuerpos constituyen 
una ola de voluntad que no sucumbe ante el embate del mar bastante agitado.

La esperanza permanece en un punto lejano que casi está perdido en el horizonte un tanto luminoso y promisorio, el barco que habrá de rescatarlos es una pequeña mancha en la línea que divide mar y cielo.

Existen muchos dibujos que muestran como esta obra fue un asunto que interesó a Gericault por mucho tiempo, varios cartones de muy pequeña dimensión en los que analizó el movimiento compositivo de esta obra, en el primero de ellos que incluimos, Fig. 5

El desarrollo de la escena guarda pesos y grados compositivos similares para todas las figuras del conjunto, la espacialidad tiene una lectura demasiado similar en sentido vertical. Incluso el desarrollo de la acción discurre de derecha a izquierda, lo contrario al planteamiento definitivo, lo miramos y es un cuadro distinto, parece que no satisfizo al pintor y se lanzó a otro intento.

El segundo boceto, contiene ya una disposición fundamental muy similar a la de la dinámica

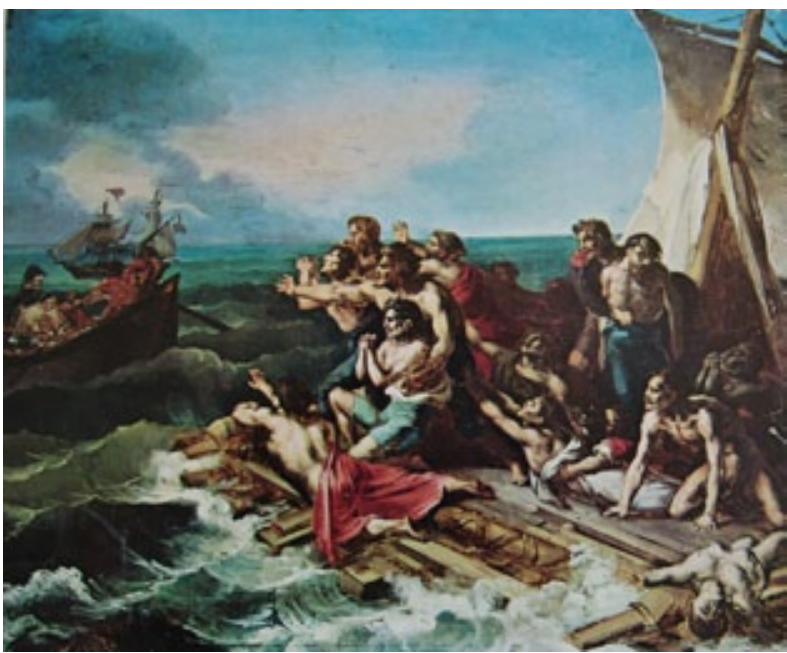

Fig. 5 Gericault "El salvamento de la Medusa" $1^{\circ}$ boceto

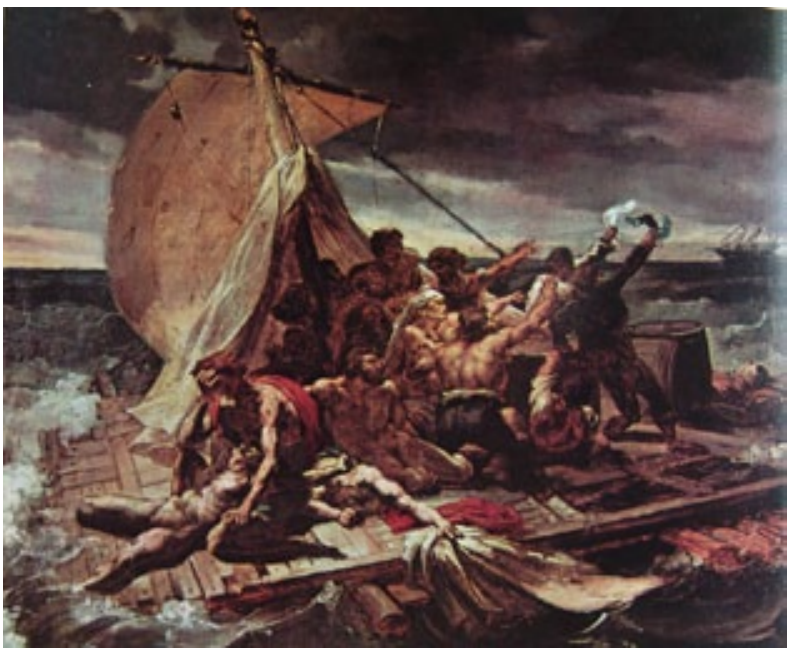

Fig. 6 Gericault "El salvamento de la Medusa" $2^{\circ}$ boceto definitiva. Fig. 6

Para la tercera versión que incluimos aquí, se afinaron todas las variables compositivas que aparecerán en el cuadro de dimensiones finales, los náufragos desarrollan un movimiento de impulso pero aparece una figura que matiza un tanto la diagonal con un movimiento escalonado que la eleva por lo alto de todo el grupo. El tamaño del velero que protagoniza el rescate a lo largo de cada boceto va reduciendo su tamaño y peso dentro de la composición, en la obra final es un mero punto que irónicamente se recorta en el horizonte acentuando el conflicto dramático y la tensión psicológica que anima la narración. Fig. 7 


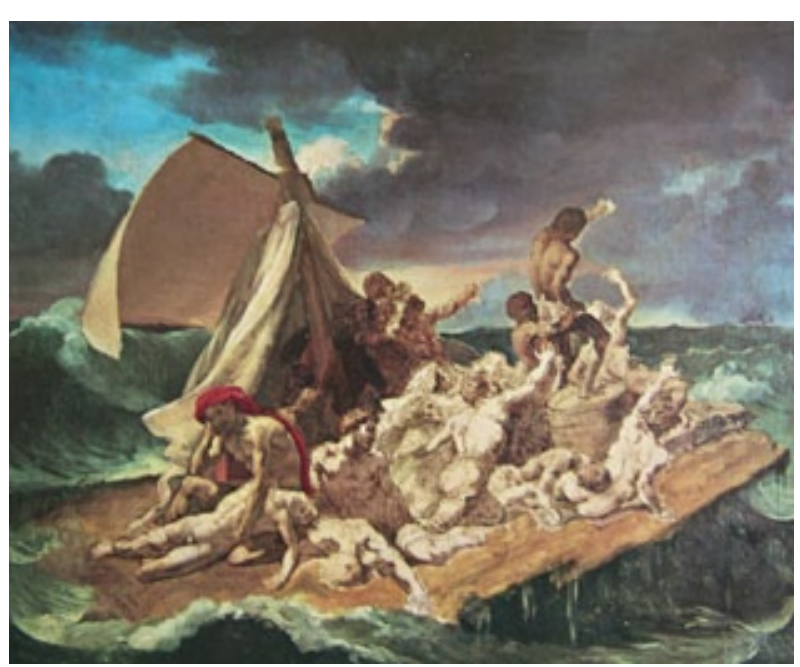

Fig. 7 Gericault "El salvamento de la Medusa" $3^{\circ}$ boceto

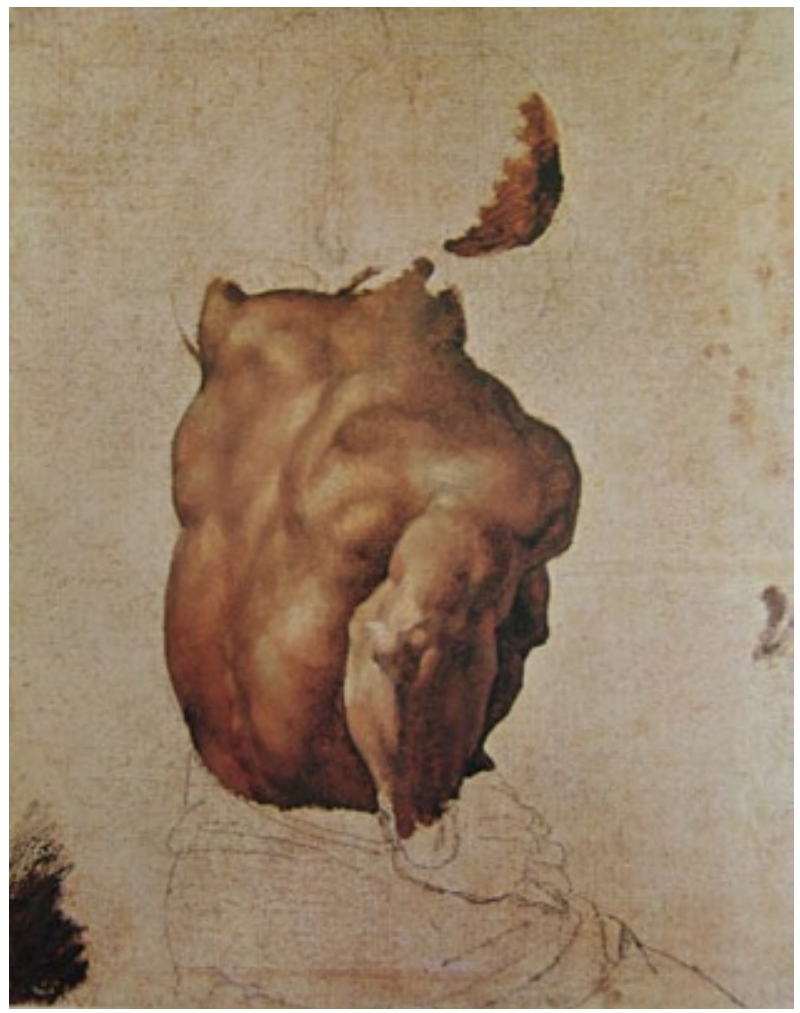

Fig. 8 Gericault, El salvamento de la Medusa Estudio
Muchas de las concepciones formales en la pintura de aquellos años guardan íntima relación con los avances científicos de esa época, pero desde el punto de vista ontológico, el pintor representará en muchas ocasiones la batalla del hombre frente a la furia natural que le sobrepasa en fuerza elemental más no en voluntad espiritual.

No obstante que este movimiento propugnó la flexibilización del dibujo para lograr la libertad cromática, en el Salvamento de la Medusa tenemos cátedras magistrales de dibujo, seleccionamos para este análisis el estudio del torso del marinero que encumbra la pirámide humana pidiendo auxilio, aquí no caben más palabras, por si misma la imagen explica la intencionalidad de Gericault, si acaso, agregaríamos que esta tela parece que no solo analiza la anatomía de la espalda y el brazo del personaje, parece buscar la adecuación del ritmo contrastado en los ejes de la figura para aumentar la tensión dentro de la situación temática, ésta claro, es una conjetura. Fig. 8

Incluimos una suma de dibujos sobre esta obra, algunos son claramente bocetos, intentan estructura las masas y zonas generales del cuadro para obtener una composición que grafique la tensión espiritual temática; otros son apuntes ligeros que solo rondan en acercamientos primarios al tema; pero 
en su conjunto ejemplifican la intensidad y recurrencia con que el autor analizó el proyecto de esta pintura y la función que el dibujo aportó al proceso. Fig. 9
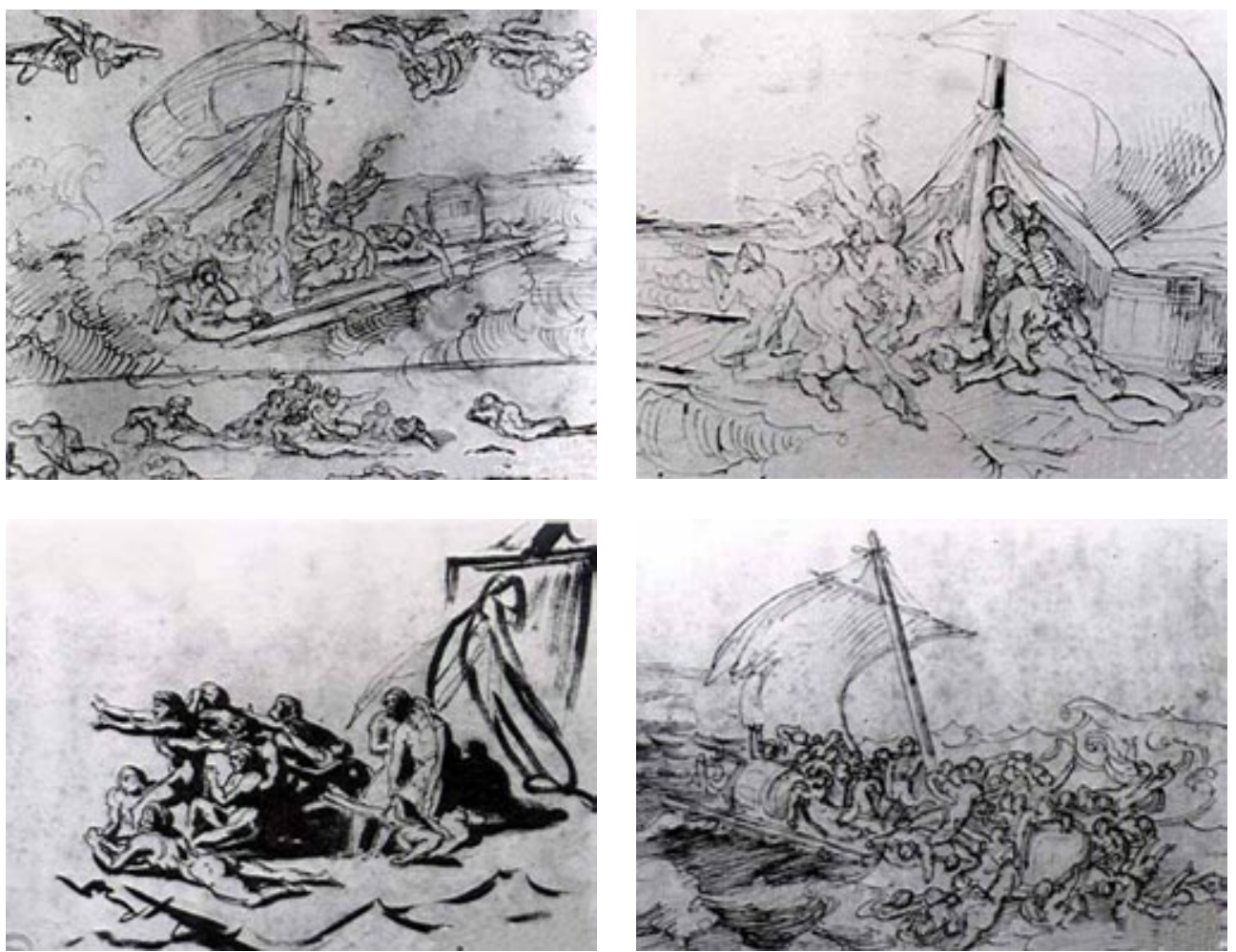

Fig. 9 Gericault, El salvamento de la Medusa, bocetos.

En el ejemplo seleccionado se muestran claramente las disertaciones de los puntos anteriores. El tema se define dentro del marco filosófico del romanticismo, los viajes de exploración, la dificultad que estos implicaban en el siglo XVIII y XIX y las situaciones que el hombre afrontaba en ese contexto, pero la problematización del tema se observa en la evolución de los bocetos, en ellos se define la ruta que traduce el tema histórico en una estructura formal que tensa los sistemas plásticos de la pintura y el dibujo en ese momento y que establece una relación causal magistral entre el tema y una consecuencia formalizada que exterioriza la tensión subjetiva.

De por si la noticia de ese naufragio fue un asunto que conmovió a Europa, al decir esto queremos señalar la relación contextual que lleva al pintor a realizar esa selección temática.

Los ajustes de proporción son realizados para todas la áreas del plano pictórico, no solo en las figuras y objetos. Estas adaptaciones proporcionales terminan en una solución altamente contrastada que opera como estructura sintáctica en la imagen. La lectura visual se ve reforzada por el afinamiento y corrección continua de las líneas de fuerza dinámicas, estas ordenan los cuerpos pero también el conjunto de masas plásticas, mar, cielo y vacío cobran presencia gravitacional. 
El ritmo se une a la dinámica a partir de los ejes diagonales compositivos, estos están dedicados a organizar la tensión de las masas, pero el ritmo se decide por una secuencia de movimiento que proyecta la masa corpórea en una dirección ascendente, todo esto coincidente con las estructuras del dibujo romántico que rompe con la base fija de asentamiento posicional para las figuras humanas.

La unidad corporal se diluye en la construcción de una masa unitaria, que sin embargo mantiene la definición de cada sujeto, esto es logrado en parte por la definición lineal que circunscribe cada figura, pero más que nada por la organización tonal compositiva, esta permite que pese a la definición de área de cada figura estas se unan en zonas de proyección dinámica en consonancia con la sintaxis planteada.

Con este ejemplo mostramos como la obra final, y el proyecto son una suma compleja de partes, ambos distan mucho de ser una entidad unívoca, las relaciones de esas partes revisten una importancia fundamental para nuestro análisis.

Diremos que el proyecto es una suma de pensamientos y procederes, que estos señalan un carácter de proceso, un algo que deviene en un tiempo de realización. La obra condensa el pensamiento que la genera, puede mostrarnos la lectura de la técnica que la concreta, nos habla de su aparecer poco a poco y del ideario del pintor, y de cómo el dibujo lo guía en la construcción de las soluciones adecuadas al querer decir.

Pero indefectiblemente, la obra terminada nos enfrenta al cierre parcial del proceso, a la clausura momentánea del pensar, esto se demuestra en aquellas decisiones que el dibujante toma en el curso de la configuración, y que marcan el carácter cualitativo de la obra, si bien pueden suscitarse los arrepentimientos o rectificaciones como estratos del devenir, finalmente la obra se estabiliza en un punto temporal, en aquellas decisiones y elecciones formales que configuran la presencia de la obra como imagen final que cristaliza un concepto y promueve una experiencia estética.

Con la intención de abrir la obra se ha querido ver en la acción de su exposición y en la lectura del público nuevas maneras de inacabarla, dejándola abierta a una permanente construcción.

En esta inquietud tienen su origen los palimpsestos, son estos la seducción de nunca terminar, construir la obra y quizá construirnos de manera permanente.

Por su parte la obra representa una etapa terminal del proceso, la finitud, la cancelación de la acción en una etapa, cuando menos en lo que a ese tramo se refiere.

Contiene, eso si, en su cuerpo expuesto y en su críptico contenido, las claves de aquello que la generó y los procesos y tiempos de configuración. Para quien quiere leer en ella, la obra se revela plena de discurso.

Hemos dicho que un proyecto artístico reviste una importancia fundamental, aunque pueda nunca ser realizado, o aunque tarde en concretarse largo tiempo. La envoltura del parlamento alemán concebida por Christo y Jean Claude en 1970 hubo de esperar casi tres décadas para consumarse.

El Palacio de los Proyectos de llya Kabakov como el espacio de todo aquello que mejora al ser humano es simplemente utópico y no por ello menos valioso. 

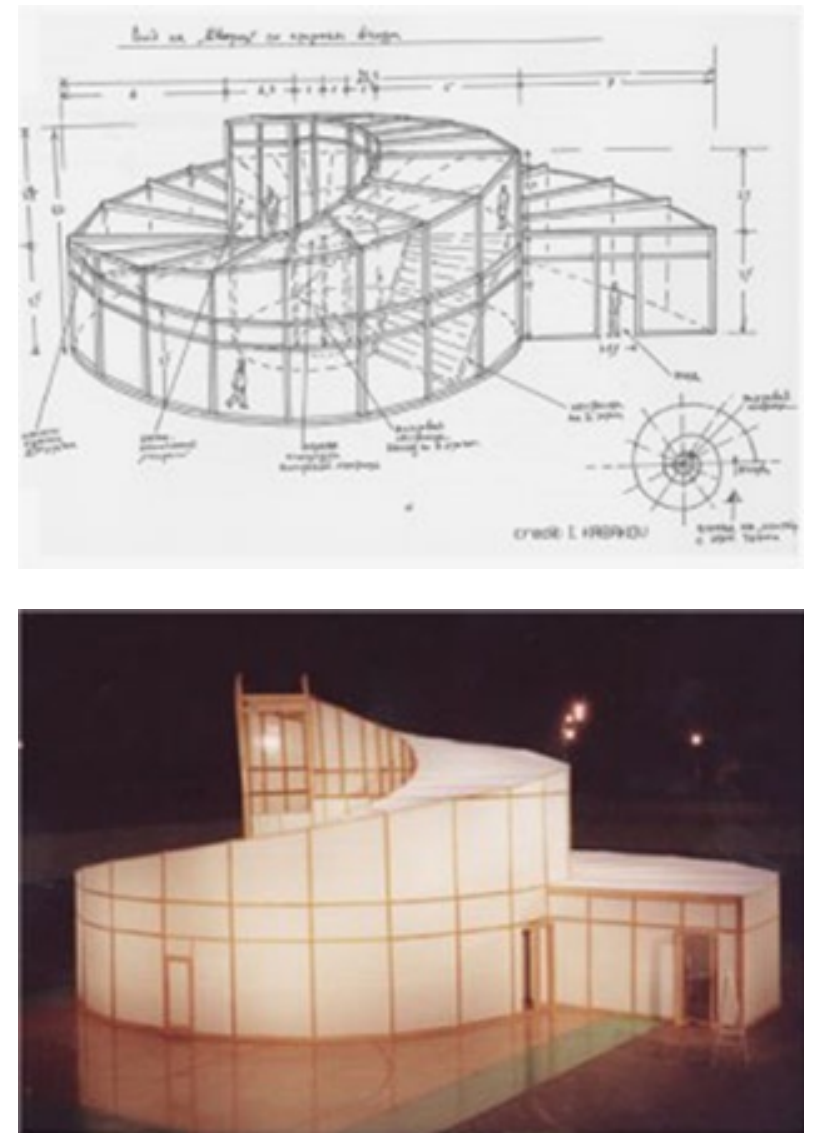

Fig. 10 El Palacio de los Proyectos
En estos dos últimos casos la función del dibujo sustantivó la existencia del proyecto convirtiéndose en la obra primaria.

Tenemos entonces que desde una postura sencilla y metodológica lineal el proyecto del dibujo es la prefiguración de la obra que se desea. Esto implica un carácter procesual y secuenciado en el que se ordenan ciertas partes de la obra y del método que las genera y estructura. Aquí la obra es el objetivo a lograr y su tiempo es el de la conclusión del proceso. Esto se corresponde con una postura determinista del conocimiento.

La obra y su proyecto son cuerpos integrados por una cantidad de elementos que los convierten en un sistema de relaciones. Al interior de estos sistemas se suscitan situaciones de causalidad, estas corren en los más diversos sentidos, llegando incluso al punto en el que los efectos de una acción sobre la conformación de la materia plástica, se convierten también en causas de reconstrucción del proyecto.

Tanto la obra resultante como el proyecto que la genera se norman por un elemento que actúa a manera de conductor y guía del fenómeno, este será el concepto que el artista trata de esclarecer o representar en el dibujo y al que hemos llamado el Tema Problema. Resulta importante considerar que si el dibujo contiene el concepto central de alguna obra, y si logra encontrarle causes coherentes de formalización, entonces este dibujo contiene valores propios y no necesariamente desligados del proceso que le da origen. Entendemos los collages, pinturas y dibujos de Christo Javacheff como obras que por si mismas alcanzan una realización, si bien forman parte del complejo constructo de un proyecto mayor que los genera.

Por eso hasta en las más flexibles posturas una obra está terminada cuando contiene o representa a juicio de su autor el concepto que la origina, o que despeja un tanto el problema planteado.

Existen dibujos y pinturas en las cuales el artista busca e investiga la manera de construir la estructura que su instinto intuye, pero esas imágenes, en tanto no consigan ese logro 
serán pruebas inacabadas, estudios de una búsqueda del objetivo terminal.

De ahí que en arte interese tanto como la obra; el proceso que la genera. Este proceso no es sino la vivencia y la lucha del dibujante en un viaje, las más de las veces lleno de experiencias que resultan mucho más constructivas que el logro directo del proyecto, la creatividad radica en la ubicación de los problemas y en la construcción de sus soluciones.

Lo anterior tiene relación con la educación tradicional, en ella se nos enseña a evitar los problemas y a buscar las soluciones sencillas para los conflictos que se presentan.

Pero en el campo de las artes partimos de la base de desaprender lo aprendido. Cuando menos, nos lleva tiempo descubrir y convencernos de que los proyectos artísticos descansan sobre la base de desestabilizar el conocimiento, encontrar soluciones nuevas para viejos problemas, aprender a problematizar los temas, o encontrar variaciones en la estructura de los sistemas de representación, etc.

Las posturas creativas dentro del campo de la abducción se dividen en tres grados. Primero, tenemos aquellas situaciones en las que el autor intenta resolver un caso atípico, y lo hace mediante la aplicación de una estructura o ley establecida. Segundo, el caso en cuestión implica una revisión de los conjuntos de normas de que se dispone, y se estudian para seleccionar aquella que más conviene. Tercero, el caso plantea características insolubles que ninguna de las teorías o normas estabilizadas resuelve satisfactoriamente, se hace necesaria la adecuación de alguna de ellas, o la creación de alguna norma que satisfaga los casos del nuevo tipo. ${ }^{38}$

Ya advertimos de inmediato la relación que esta formulación tiene con el campo del arte y la definición de proyecto como plan y como estrategia de consecución, al respecto una cita deja claro el problema.

"Las abducciones del tipo $3^{\circ}$, subtipo $3^{\circ}$, las más inventivas, son escasas en el domino de la creatividad científica... Sin embargo en la creatividad artística, tanto este subtipo como los otros del tercer tipo abductivo, es decir, las abducciones cuya ley o sistema de mediación se ofrece como nuevo, son las más habituales. La novedad del sistema viene asociada aquí a su singularidad, a lo irrepetible de la creación, y al carácter implícito del sistema; parece ser en efecto, que en este tipo de creación el resultado -la obra en sí- es consecuencia de un sistema implícito incluso provisional (sin que por ello la creatividad esté entonces condenada al misterio eterno: La propia fijeza de la obra abre la posibilidad de leer el sistema de mediación bajo ese caso suyo, la obra). Y de ahí tal vez la veneración que las obras artísticas despiertan, registros únicos de una verdad que con ellas se ha inventado"39

La producción artística entraña desde donde la queramos ver, procesos de complejización del conocimiento y de la metodología que aplicamos en la consecución de la obra. Por ahora basta con señalar que los proyectos en arte integran una intencionalidad de organización, pero no se niegan a la inclusión de las emergencias cualitativas, dentro de la conformación de la obra. En su momento retomaremos los planos de la abducción como parte de la estrategia para flexibilizar el proyecto dentro de su linealidad.

38 Herrero Ángel. Semiótica y Creatividad. La lógica abductiva. Madrid: Ed. Palas Atenea;1988. P. 18.

39 Herrero Ángel. Semiótica y Creatividad. La lógica abductiva. Madrid: Ed. Palas Atenea;1988. P. 18-19. 
El proyecto consiste en una especie de ruta estratégica para conseguir la obra con una guía conceptual o índice de predictibilidad. En el ejemplo del cuadro de Gericault mostramos como aún en el pensamiento romántico permanecen procederes y funciones del dibujo heredados de la tradición artística.

Las etapas de planeación y modificación a la idea inicial, definen el carácter y motivo de la categoría de proyecto dentro de las artes, y la función primordial que dentro de ello guarda el dibujo.

Pero tomando como base el pensamiento abductivo tenemos que los proyectos, y sobre todo en arte incluyen soluciones y adaptaciones emergentes a las estructuras de representación, con la finalidad de dar solución a los casos presentados.

Tanto el proyecto y la obra terminal son sistemas integrados por elementos, y estos guardan relaciones de complementariedad entre si y con respecto al todo teórico del dibujo. Detengámonos un tanto en esta consideración para aclarar su contenido.

La idea básica de que el sistema es un grupo de elementos que conforman una unidad global y que manifiestan relaciones entre si, quedó anotada líneas arriba.

Pensar la obra como un todo constituido de partes, así como la noción de partes interrelacionadas, es un inicio importante, pero se carece todavía de un elemento unificador, algo que confiera tipicidad al sistema que se integra, tomemos una cita de Edgar Morin:

"De hecho, la mayor parte de las definiciones de la noción de sistema, desde el siglo XVII hasta los sistemas de la General Sistems Theory reconocen esos dos rasgos esenciales, poniendo el acento bien sea en el rasgo de la totalidad o globalidad, bien sea en el rasgo relacional... Un sistema es un conjunto de partes (Leibniz, 1666), todo conjunto de componentes definible (Maturana, 1972). Las definiciones más interesantes unen el carácter global y el rasgo relacional: Un sistema es un conjunto de unidades en interrelación mutua (Von Bertalanffy, 1956), es la unidad resultante de las partes en mutua interacción (Akoff, 1960), es un todo que funciona como todo en virtud de las partes que lo constituyen (Rapoport, 1969). Otras definiciones nos indican que un sistema no está necesariamente ni principalmente compuesto de partes, algunos de entre ellos pueden ser considerados como conjunto de estados (Mesarovic, 1962) incluso conjunto de eventos... En fin la definición de Ferdinand de Saussure (que era sistemista más que estructuralista) está particularmente bien articulada, y hace surgir, sobre todo, uniendo al de totalidad y al de interrelación el concepto de organización: el sistema es una totalidad organizada, hecha de elementos solidarios que no pueden ser definidos más que los unos en función de su lugar en esa totalidad (Saussure, 1931) En efecto, no basta con asociar interrelación y totalidad, es preciso unir totalidad a interrelación mediante la idea de organización"40

Por eso, basándonos en este pensamiento, afirmamos que la obra de arte no puede ser la mera reunión de elementos en un espacio particular, hace falta dotar esa confluencia de partes de un sentido conceptual relacionante, este es proporcionado por el área temática

40 Morin Edgar. El método. La naturaleza de la naturaleza. Colección Teorema. Madrid: Ed. Cátedra; 2001. P. 123-124. 
llevada a un conflicto de configuración formal, si en los sistemas vivos las ligas de relación entre las partes son dadas por la tendencia natural a la asociación, en la obra de arte este es un fenómeno que no acontece de por sí, requiere de la voluntad y accionar del autor como espíritu rector que inicia e impulsa la organización del sistema, sobre todo cuando este se haya en la fase proyectual, puesto que en los momentos de configuración, los propios elementos de la obra haciéndose sugieren pautas al dibujante, incluso desde la misma negativa de sumarse a la organización.

Dentro de las artes el elemento organizacional integrador, está constituido en buena medida por la relación que el tema concepto establece con el sistema de representación que se utiliza, dentro de este, la composición opera basada en una razón matricial que marca las secuencias y disposiciones de la partes para definirles una posición y función dentro de la obra, de ahí que en un sentido estable, toda composición tenga carácter distributivo y posicional y se encargue de graduar la proporción de peso, grado y número de las partes, así como la estructura sintáctica general (como en el ejemplo del Salvamento de la Medusa de Gericault)

Ligado a lo anterior se entiende el proyecto como el plan para conseguir un objetivo directamente, pero; todavía estamos acogiéndonos a una visión determinista del método.

¿De donde emerge entonces la cualidad flexible del proyecto?, ¿En que momento se suscita la conversión de un plan en una estrategia de puntos programáticos, o en una reflexión metodológica?, ¿Cuáles son las causalidades que motivan al dibujante a derivar en procedimientos aleatorios que lindan con lo inefable como territorio de lo no planeado?, ¿Más aún, debido a que razones se generan los desplazamientos abductivos en la metodología de los artistas?

Menuda tarea la de responder a estas interrogantes. Claro que no intentamos su solución final ni su completud; pero si creemos estar en disposición de aportar elementos que inicien una brecha de esclarecimiento a la cuestión.

La obra y el proyecto son sistemas integrados por elementos, estos apuntan hacia una integración del todo, además mantienen o son dotados de una cualidad organizacional.

Es importantísimo plantear aquí, que los sistemas del dibujo no son conjuntos fijos en un espacio indeterminado, siempre corresponden a una temporalidad y espacialidad puntual, esto es, son reales en una concreción teórico histórica, incluso física.

Digamos que los sistemas dibujísticos tienen un devenir continuo. Tienen un pasado que les antecede, un presente circunstancial y temporal relativamente estabilizado, y tendrán un futuro como vocación inevitable cuyas circunstancias y carácter se vuelven sumamente impredecibles, así el proyecto del dibujo tiene voluntad de conseguir emplazamientos pero genera y trabaja sobre la base de desplazamientos continuos.

Esta es la nueva base analítica de la historia del arte. Si se trata de producir obra artística, será sobre este suelo móvil en el que se asentarán temporalmente las obras y temporal será su respuesta a los enigmas que satisface.

Cuando nos ubicamos en el terreno de la artes nos plantamos en un campo de desorden 
e intentos de organización continuos. Por más que el artista de hoy renuncie a la vocación estética y formalista de la modernidad, al proponer su obra realiza un acto de emplazamiento cultural, este quedará fijo en tanto otra obra nos coloque en un estado emergente del dibujo.

Arte es terreno de lo aleatorio, porque no tenemos certeza sobre la consistencia del proyecto inicial en tanto no lo bajemos a su aplicación fáctica. Ya hemos mencionado que el proyecto se origina en la vivencia y la intencionalidad del dibujante, pero su existencia primera se da en la región mental, esta contrasta con su segundo estado de existencia fáctica. Por tanto en el proyecto del dibujo tenemos que adecuarnos al trato continuo con lo estocástico, aunque tengamos la intención de fijar referentes metodológicos que permitan una acción que ponga límites a los procesos entrópicos que devendrían en simple acumulación de sinsentidos.

Los límites del proyecto no son otros de los que se trazan en el ordenamiento conceptual o poético al que aspira. Orden consistente en la aplicación continua de la ley compositiva, no es buscar su variabilidad, sino su aplicación. Orden es todo aquello que puede ser organizado en cualquiera de los paradigmas de representación disponibles en el ideario humano, encuadrable dentro de una ley o estructura; mientras que organización es la tendencia a establecer vínculos sistémicos de estructuración, aunque estos contradigan las guías metódicas iniciales.

La tendencia entrópica dentro de las artes comporta todo aquello irregular, desde la materialidad misma del objeto hasta lo sutil de su giro poético. Así como el proyecto del dibujo nunca ha pretendido limitar la potencialidad creativa, tampoco jamás en arte será posible un exceso de relatividad compleja.

El proyecto artístico requiere de un norte conceptual, no programático, pero si estratégico que le permita conducirse como proyecto abierto y creativo.

El arte como forma de poder, genera obras que en ocasiones desafían desde el pasado de siglos la tendencia a fenecer en aras de la inestabilidad, suelen ser incluso objetos que se emplazan, resisten todo intento de guardarlos en el olvido y la inutilidad.

Existe en lo profundo de la psique humana el impulso irrefrenable de trascender. Se basa según creemos entre otras cosas en el deseo de estabilizar el arte y la institución social humana, nos desviaríamos intentando calar este problema, pero es claro que esta situación se explica dentro de la historicidad positiva del pensamiento proyectual.

Bástenos decir que esto genera un par dialéctico de contrarios. El deseo de trascender mediante la permanencia de la obra y su discurso, enfrentado esto a la resistencia del arte como sistema, a permanecer estable en cualquiera de sus partes y momentos.

Aquí se encuentra el inicio de la respuesta a nuestras preguntas formuladas.

La obra y el proyecto al estar formados por partes que se integran mediante principios de organización, guardan en cierta medida sus características particulares, entre ellas el principio de autonomía, su facultad de determinarse por si mismas sin recurrir al sistema, sobre todo cuando se trata de entidades ontológicas vivas. Estas muestran una resistencia mayor que aquellos elementos del sistema que son incluidos por un espíritu rector externo, o sea el autor, mismo que constituye la voluntad estabilizadora. 
Lo anterior es señalado por Francisco Varela en su trabajo El círculo creativo. Esbozo histórico natural de la reflexividad. ${ }^{41}$

Desde el origen de la teoría renacentista del dibujo y la pintura, ya había sido advertida la tendencia de los elementos de una obra a generar rutas de organización diferentes a las del proyecto inicial, pero precisamente para negarlas es que se generó una pauta de pensamiento epistémico, tendiente a reducir el margen de variación en la construcción de la obra, cabe recordar que el artista del 1400 reunía en su persona las disciplinas de la arquitectura, la pintura, la escultura y el dibujo. No se podía proceder en campos tan demandantes de una manera arbitraria, como a veces de manera simplista suponemos.

Tomemos en nuestras manos el Tratado de Pintura de León Battista Alberti, si lo estudiamos con calma no podremos menos que admitir el rigor procedimental en la esfera de la planeación.

Sabemos que el periodo barroco, cuando menos en las artes plásticas, se alza sobre los cimientos de la flexibilidad manierista, ya en su tiempo se decía de sus excesos formales. Pero revisemos el libro de Antonio Palomino de Castro y Velasco titulado El Museo Pictórico y escala óptica. ${ }^{42}$ Tenemos frente a nosotros tres tomos que en total suman 1222 páginas en la edición que revisamos. El contenido está dividido en tres partes, dentro de la primera se dedican cien páginas al estudio de las degradaciones geométricas que los cuerpos, planos y líneas reales, sufren en su aplicación sobre superficies para pintar. Este capítulo enmarcado en el contexto de todo el tratado no deja lugar a dudas, la práctica de la pintura en el barroco constituía una disciplina de procedimientos proyectuales rigurosos, aunque también es justo decirlo, Palomino dedica suficiente espacio a la formulación de juicios que enmarcan el libre criterio del pintor, y el impacto que este genera en el carácter de la pintura.

Retornando a nuestro tema de análisis, estos tratados muestran claramente una concepción de la pintura en la que el dibujo guardaba un carácter proyectual por excelencia, todavía en el barroco las libertades estilísticas quedaron ubicadas en la manera. Esta no fue suficiente para romper el cerco metodológico de la voluntad determinista que impelía a realizar el cuadro planeado.

Agregamos en este momento unas imágenes que muestran claramente este argumento. Consisten en impresiones radiográficas de pinturas renacentistas, las hemos tomado del libro "Underdrawings in Renaissance Paintings"43 este es un texto editado por la nacional Gallery Company London. En esta publicación se muestran los trabajos de investigación correspondientes a los estratos constitutivos de las pinturas renacentistas patrimonio de esta galería. Lo que nos interesa señalar es la consistencia y continuidad metodológica existente entre los dibujos que subyacen en las capas primarias de las pinturas y su evolución siguiente, pero esto con un margen de variación mínima en donde la pintura terminal se corresponde ampliamente con el plan trazado por el dibujo originalmente. Por si mismas estas radiografías demuestran el rigor metodológico del procedimiento pictórico

41 Watzlawik Paul, et al. La realidad inventada. $3^{a}$ ed. Barcelona: Ed. Gedisa; 1994.

42 Palomino de Castro, Velasco Antonio. El museo pictórico y escala óptica. Madrid: M. Aguilar Editor; 1947.

43 Bomford David. Underdrawings in Renaissance Paintings. London: Nacional Gallery Company; 2002. 

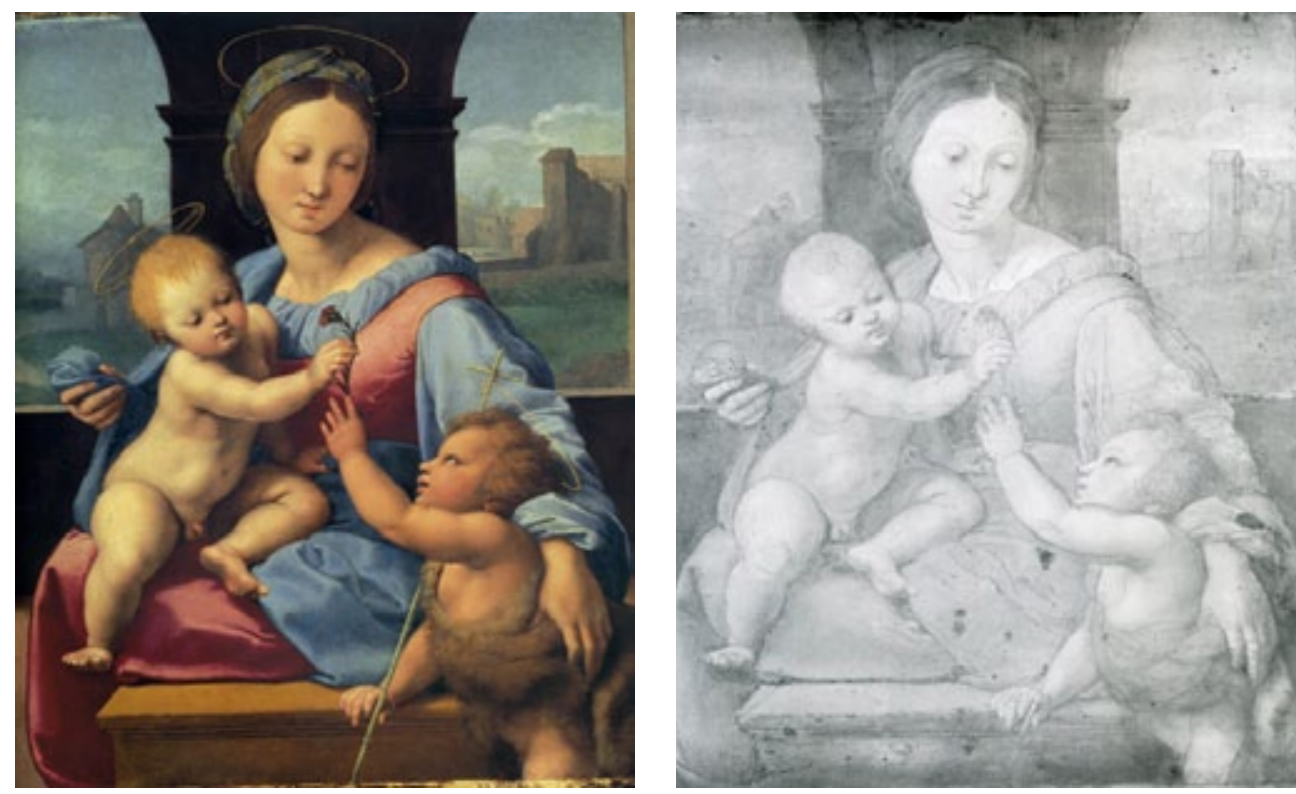

dentro del que el dibujo constituye un recurso sistémico de planeación proyectual. Figura. 11

Un elemento importantísimo en el esclarecimiento de la episteme proyectual de la pintura, a lo largo de la historia moderna de las artes; que arranca en el renacimiento y se prolonga hasta el primer cuarto del siglo $X X$, es el papel que la Geometría juega en la construcción de la obra.

Más adelante en su momento nos detendremos en cada uno de los modelos artísticos del dibujo a lo largo de esta historia. Pero ahora recordaremos que en pocas palabras la geometría no es sino la métrica del espacio, basada en procedimientos matemáticos. La geometría vuelve el espacio mesurable, cuantificable, comprensible en su degradación perspectiva; pero sobre todo, la geometría junto con el dibujo, acer-

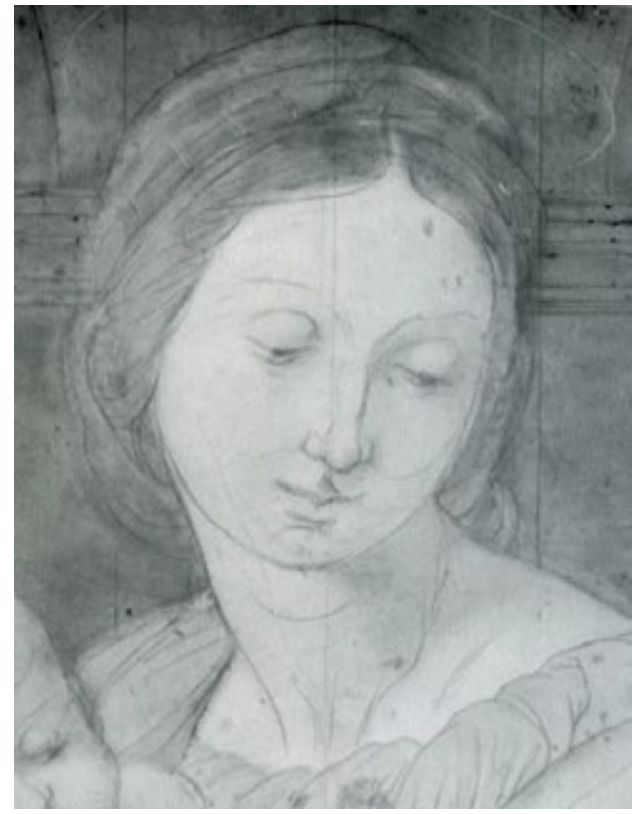

Fig. 11 Rafael. "La Virgen El Niño y San Juan Bautista niño" caron la pintura a ese ideal de representar el mundo externo tal como en apariencia se desplegaba frente a los ojos.

El tratado de perspectiva de Piero Della Francesca es rico en la parte que concierne a la degradación o escorzo geométrico de las dimensiones reales de los cuerpos. La importancia de la geometría y el dibujo y en las clases de diseño de la Bauhaus en Alemania, o en los Vkhtemas de la naciente Unión Soviética que formaron parte del proyecto 
Constructivista, demuestra tanto el proceder proyectual de ambas disciplinas, como su permanencia en el ideario de representación del artista.

Geometría, Composición y Dibujo constituyen sistemas encargados de dotar a la imagen de un orden, basado en la razón métrica estructural.

Son campos de trabajo prefiguradores y configuradores del proyecto, su tendencia es la de la estabilización de la obra, sin embargo aquí sucede un proceso de retroacción interesante, la aplicación de los tres campos de trabajo anteriores suponen un ejercicio de activación del verbo, nunca existen en infinitivo, nos indican la acción del autor, pero además la ubican en el sentido de construir variantes para la imagen, sobre la base de cuerpos teóricos estables. A esto se agrega que las variables obtenidas mediante la activación de estas disciplinas son más valoradas en tanto reportan un mayor número de elementos de novedad al sistema, de ahí que el principio de búsqueda impulse al dibujante en éste caso a desplazar el conocimiento y la norma en busca de la evolución del sistema.

Y lo anterior es así porque la relación entre el lenguaje visual y el sentido significante no es directa y lineal; se encuentra mediada por la subjetividad del sujeto que dibuja y sus espectadores, incluso el objetivo es establecer relaciones expandidas entre las formas visuales y su lectura interiorizada.

El fenómeno del lenguaje mediado por la subjetividad y la cultura contribuye en gran medida a explicarnos la dimensión poética y las resonancias subjetivas que relativizan las lecturas sígnicas de la imagen y le agregan significados polisémicos.

Por otra parte, aunque la modernidad del Informalismo y el Expresionismo abstracto significaron un corte con el pensamiento plástico clásico del XIX, y después de ellos la posmodernidad se alejará de las propuestas formalistas y de representación, lo curioso y paradójico es que utilizan y reciclan estructuras conceptuales y formales que la tradición e historia del dibujo nos legaron como patrimonio. De ese modo los sistemas formales no pueden ser trascendidos sino desde su interioridad, como ya lo analizamos, recordando a Barthes el campo del dibujo opera como límite de tensión aún con la intención de rebasarlo.

Causa y efecto se compenetran, la geometría, el dibujo y la composición son causa del orden de la imagen y la imagen que deviene es causa de la aplicación de variantes al sistema que la origina. Todo esto suscitado por la autonomía creativa del autor, en la que se expresa todo el complejo de una ecología intelectual señalada por Rafael Porlán. ${ }^{44}$

Los procesos de variación en la construcción de la imagen no se deben exclusivamente a la autonomía de la voluntad configuradora. También las partes que integran el sistema proyectual y formal, que se activa en el acto prefigurante y de representación, manifiestan una tendencia a la degradación entrópica. Es decir que, las estructuras artísticas integradas por un número variable de elementos generan relaciones (de configuración y representación artística en este caso) que tienden a complejizar la estabilidad de la obra proyectada.

La desorganización parece ser una tendencia de los sistemas. Ésta se incrementa según

44 Porlán Rafael. Constructivismo y escuela. Hacia un modelo de aprendizaje y escuela basado en la investigación. Sevilla: Ed. Díada; 1993. P. 43. 
se suman elementos al corpus de la obra, se amplían exponencialmente en razón de las funciones compositivas implicadas en el proyecto.

Actualmente el dibujante no ejerce su práctica desde la soledad individual, no es tan él solamente, cuando traza una línea sobre el tejido de la tela, o sobre la arena como lo hiciera Beuys, pesan sobre sus hombros siglos de historia y teoría de la forma.

Es por eso que en los últimos cien años lo menos, el artista se ha preocupado por generar procesos epistémicos de trabajo que le permitan manifestarse con ojos nuevos y un pensamiento fresco.

Cuando el dibujante inicia un proyecto ha de tomar un sinnúmero de decisiones, incluso antes del primer trazo. El repertorio de técnicas y modelos teóricos de que dispone es amplísimo. En la primera elección intelectual para iniciar en una ubicuidad teórica e histórica y no otra, se incluye ya el elemento de complejidad.

Una condición universal de los sistemas es que estos aumentan su tendencia a la declinación en la medida que se incrementa el número de elementos que los integran, a este fenómeno suele llamársele Grados de Libertad.

Esta es una formulación de la teoría general de los sistemas, pero aplica totalmente en el terreno del dibujo.

"La mayoría de los sistemas dinámicos deterministas tienen movimientos tan complejos, con sus trayectorias entrecruzándose de forma tan errática y turbulenta, que resulta imposible toda predicción detallada para tiempos grandes... esa estocasticidad o aleatoriedad aparece en sistemas con un número grande de grados de libertad... Tratase del número de coordenadas o momentos en la composición de un sistema"45

De ahí que en el terreno del dibujo se siga la norma general de las formas y composiciones sintéticas, al hacer una reducción de las formas y elementos de la imagen se tiende a la eliminación de lo redundante y se obtiene el máximo de expresividad, de fuerza plástica y claridad visual.

Para crear un marco referencial, diremos que el espacio analítico del que emergen los comportamientos irregulares de los elementos que integran el sistema, es el de la teoría de los sistemas dinámicos.

Estos sistemas constan de dos partes: la noción de estado y una regla que describe la evolución del sistema en el tiempo.

Entendiendo la formulación anterior dentro del campo proyectual de las artes, se comprende que el aumento de los elementos en la obra, y las normas que regulan su estructuración aumentan el grado de complejidad para organizar el sistema. El desorden y lo complicado de la composición, aumentan en relación exponencial directa con la cantidad de factores incluidos en el proyecto.

Hemos escuchado el término prueba de estado, estados del proyecto, avances de la obra etc. Todas estas palabras aluden al hecho de que la obra y el proyecto viven momentos.

45 Radaña Antonio. Movimiento Caótico. Investigación y ciencia, Scientific Américan 1986; (114):12. 
Cada una de estas etapas del devenir del proceso se define como un Estado del Sistema, porque representa una particular construcción de existencia de la obra final.

Un estado del sistema representa para nosotros, la conjugación específica de los elementos e intenciones configurantes y de representación en un momento dado. Es un tiempo en el que aparentemente el proyecto parece ser definitivo, detiene su proceso y aparenta estar concluido.

Desde dos o tres siglos antes ya los conocedores se interesaban por las carpetas de dibujos, en ellas los coleccionistas agrupaban los bocetos y proyectos que los artistas realizaban como parte del proceso creativo, en la estampa, las pruebas que consignan estados intermedios de la obra final fueron también notadas como elementos que contenían un valor.

Pero en definitiva hasta hace muy poco, se considera la obra y sus estados en igualdad de importancia, partes que permiten comprender lo global del proceso y ahondar en lo profundo de la intencionalidad significante del autor.

Los límites del concepto proyecto se encuentran precisamente en su interior.

Es una categoría que en el dibujo, reconoció una vocación estabilizadora de la obra que a futuro se deseaba.

Sin el ejercicio proyectual sería imposible abordar obras de una envergadura monumental, cuando el dibujante plasma en una superficie los trazos que aclaran una idea, la vuelve inteligible, es posible entonces que otros comprendan su intención y retomen la tarea de finiquitar la empresa. Recordemos que muchas de las obras desde el Renacimiento; son producto de una tecnología anterior a la revolución industrial. Las catedrales no son empresas de un solo hombre, ni en su concepción ni en su proceso de edificación ni en el fin de su construcción.

Pensemos frente a los excesos de relativismo, que el pensamiento proyectual permite la socialización de la creatividad y el entendimiento que faculta la interdisciplina en última instancia.

El pensamiento proyectual se fue construyendo como estrategia, para reducir el margen de variación en los objetivos buscados, pero al estar integrado por un número amplio de partes y al ser estas dispuestas por un criterio relativo del autor, se presenta siempre una tendencia a la complejidad de la estructura de representación y formalización que da cuerpo al proyecto.

Aún con todo esto, el proyecto como postura epistémica conserva sus facultades de aclaración del pensamiento artístico, es a no dudarlo una estrategia que se retoma en lo más contemporáneo del dibujo y las demás artes plásticas y visuales.

Con el estudio de las limitaciones del proyecto hemos introducido las bases para la comprensión de la elasticidad del concepto.

En el proyecto se hace manifiesta la voluntad de configurar una idea o representación que de cause a la problematización del tema. Para ello conjuntamos una serie de elementos que creemos necesarios, recurrimos también a sistemas estabilizados de composición o modelos de pensamiento del dibujo, cuya forma y método nos acercan a nuestro objetivo. Resulta que al incluir elementos y sistemas estructurales de la forma, aunados al criterio del autor se genera una dinámica de cauces que empujan a la deriva el proyecto inicial. 
Será decisión del autor (si es que se sabe consciente de la disyunción) el modelar los márgenes de flexibilidad y variación, o bien incluirlos en el carácter estructural y final de la obra. Aquí radica la intencionalidad metodológica, que implica la activación de estructuras formales y sistemas estabilizados, no se persigue de entrada su rompimiento sino su aplicación en la solución de los conflictos que la obra plantea. Solo cuando el sistema y estructura formal resultan insuficientes para la organización del caso en una imagen, es necesario agregar condiciones o variables emergentes al modelo, con miras a resolver el caso que no cuadra con el sistema.

Nuevamente el exceso de flexibilidad emergente por el hecho mismo de flexibilizar carece de sentido, la variabilidad se funda en la posibilidad de construir organizaciones formales, se busca dotar al dibujo obra de una completud con base en el concepto que la anima. Éste, más tarde podrá integrarse en sistemas generales.

Esto queda expresado con claridad en la propia cita que hacemos de Porlán:

"Cuando una comunidad de científicos abandona la estructura teórica por la que se rige normalmente por otra incompatible con la anterior, se produce lo que Kuhn denomina una revolución o cambio paradigmático.

Pero no siempre la ciencia, alguna ciencia en concreto, se encuentra inmersa en procesos de cambio radicales. Más bien sucede lo contrario. Kuhn (1977) describe los periodos de ciencia normal como aquellos durante los cuales los científicos, guiados por un único paradigma incuestionado en sus aspectos básicos, resuelven los problemas teóricos o experimentales de su área mejorando la articulación y la coherencia interna del mismo. (El subrayado es nuestro) Sin embargo en un periodo dado, no todos los problemas son susceptibles de solución dentro del paradigma dominante; cuando esto ocurre, se considera que existen anomalías. Si éstas se acumulan y progresivamente van afectando a los aspectos fundamentales del paradigma, surge un periodo de crisis que incide profundamente en el trabajo de los científicos. Su actividad normal se ve alterada por discusiones filosóficas y epistemológicas que remueven los principios más profundos. Si en este proceso se gesta progresivamente un paradigma rival e incompatible con el anterior o, dicho de otra manera, si entre la comunidad de científicos cobra fuerza un punto de vista global, alternativo al anteriormente existente, las condiciones para una revolución paradigmática están dadas."46

Tomamos recurrentemente citas de autores constructivistas y del pensamiento complejo por la razón de que estas fuentes de estudio resuelven en cierta medida las incógnitas metodológicas que oscurecían el análisis del proceso artístico; de tiempo atrás nuestra investigación ahondó en la posible relación del territorio de la complejidad y el pensamiento constructivista y el análisis del proceso dibujístico; aunque intentamos claramente no forzar cauces conceptuales entre ambos territorios.

La intencionalidad es cualidad esencial del proyecto, en ella radica la voluntad originaria de todo el proceso. Existe como determinación del artista al iniciar el pensamiento de la obra. Nos detenemos en la intencionalidad, con el fin de clarificar algunos criterios que rodean el terreno de la voluntad o necesidad de cambio, la sustitución de paradigmas y sistemas estructurales de la forma artística.

46 Porlán Rafael. Constructivismo y escuela. Hacia un modelo de aprendizaje y escuela basado en la investigación. Sevilla: Ed. Díada; 1993. P. 38. 
No estamos de acuerdo con la idea de que todo conocimiento viene a sustituir a los sistemas anteriores, una visión de este tipo no se puede comparar a una revolución del pensamiento, pues resulta altamente destructiva en tanto que desecha el patrimonio intelectual que le antecede. Tampoco sucede que para que el conocimiento avance es necesario un estado de malestar crítico. En el terreno del arte no siempre los cambios se han dado en función de la inoperancia de los sistemas vigentes, debemos las más de las veces a la casualidad y la observación aguda, la evolución de los sistemas.

Las formulaciones artísticas nuevas surgen del interior de los estados que les anteceden, no podría ser de otra manera, llevan en su ser alterno, una parte de los cuerpos y variables de las posturas anteriores, no existe un cambio repentino al ciento por ciento de los paradigmas.

También se dice y se asume que es difícil, si no imposible escapar de la órbita gravitacional de los paradigmas artísticos que marcan un estado actual.

Creemos que con la aplicación de principios reflexivos y con la claridad proyectual y de investigación, podemos manejarnos adecuadamente en el clima de inmovilidad o dificultad conceptual que hoy entrañan las artes, y especialmente el dibujo dentro de su aparente estado de indefinición. Cualquier reflexión en sentido inverso implica una carga de ideologización, y no de pensamiento sustentado en el análisis.

Basamos esta opinión en el pensamiento de Bunge (1985)

"La marcha del conocimiento es continua en algunos aspectos y discontinua en otros. Todo cambio epistémico, por drástico que sea, es parcial antes que total (solo los charlatanes rechazan la totalidad del sistema de conocimientos existentes). Y los cambios epistémicos son desiguales: en cada periodo algunas ramas de la investigación avanzan más rápidamente que otras, con lo cual dan inspiración y a veces incluso dirección a las menos desarrolladas. Más aún la frontera no avanza rellenando todos los huecos: quedan incontables bolsones de problemas no resueltos, algunos de los cuales serán planteados más adelante, en tanto que otros serán olvidados para siempre"47

Con las ideas anteriores intentamos centrarnos en un núcleo denso para el análisis. El de la intencionalidad que subyace en el ideario del dibujante en el momento de realizar un proyecto. Asumimos de manera directa y fácil el hecho de que el artista se encuentra imbuido de una voluntad renovadora, ante todo le preocupa cambiar la estructura de su arte. Pensamos que aquí radica una equivocación, no es el ánimo renovador de por sí, el que interesa al artista genuino, es ante todo el deseo de aclararse puntos oscuros no resueltos, que ha detectado dentro de la estructura de los sistemas que viene aplicando. ¿O porqué no, como un ejercicio de poetizar el contexto?

Se dibuja también para resolver simplemente aquellos asuntos implicados en la construcción de los proyectos, para capturar aquello que de la realidad transcurre frente a nosotros y no volverá, dibujamos para hacer un resumen que despoje a la realidad visible de lo aparente y la exponga en su sustancialidad, esa fue la lección de Cézanne y de Mondrian. También se dibuja para tomar del contexto la información necesaria que tipifica nuestros modelos cualesquiera que sea su carácter.

47 Porlán Rafael. Constructivismo y escuela. Hacia un modelo de aprendizaje y escuela basado en la investigación. Sevilla: Ed. Díada; 1993. P. 39 
Reduciríamos este núcleo de intencionalidad en cinco factores (sin que estemos intentando un grupo de definiciones excluyentes y cerradas):

- Primero, aquellos motivos que tienen que ver con el análisis de los modelos y la captura de la información básica razonada por el dibujante.

- Segundo, La necesidad de combinar y reunir tanto lo visto vivido como lo ideado, contenido en la intención de la imagen mental primaria de la obra.

- Tercero la búsqueda de soluciones combinatorias de las estructuras usadas, aplicadas a la solución de la obra como un problema específico planteado.

- Un cuarto motivo de causalidad generativa en la intención del artista, es aquel que corresponde a la incidencia del contexto ideológico cultural en su mente e ideario. Los criterios de valoración impuestos por el medio social, desde fuera de la lógica de representación y configuración del proyecto y la obra, marcan fuertemente la intencionalidad del autor, a veces al grado de desviarlo por el camino de proyectar una obra en función de lo que el gran otro demanda.

- Un quinto móvil de causalidad, es aquel que se origina desde el interior profundo del dibujante y que le impele a dibujar lo inefable, sin importar los vínculos de funcionalidad que su proyecto pudiera contener.

Cerraremos diciendo que el proyecto es voluntad de representación, de reconstrucción del contexto, Ánimo de construir sueños para hacerlos visibles a los demás. Mediante nuestros proyectos ofrecemos explicación y solución a los conflictos planteados, adecuamos el pensamiento global a lo especial de una situación. Con la intención inmanente en el proyecto, construimos el pensamiento artístico y nos construimos a nosotros mismos.

Concibiendo el proyecto como una manera de construcción pasamos del terreno de la intencionalidad al de la función, ¿para que sirve un proyecto? o ¿por que proyectamos? Y aquí retomamos algunas de las características que adjetivan al concepto.

Es una manera de planear la acción, tiene carácter dinámico y permite una lectura desglosada de las partes que lo integran.

Cuando consideramos el proyecto como una función metodológica lo estamos acercando al terreno de la consecución del conocimiento. Dentro de este marco, el proyecto en muchas ocasiones se toca con la metodología experimental, el experimento y su realización en el espacio del laboratorio buscan la observación de un fenómeno, tratan de llegar a su comprensión mediante la repetición controlada del proceso. Así resulta clara la cercanía histórica entre el dibujo y el laboratorio de anatomía o botánica. Dentro de la arqueología los sistemas del dibujo han sido adaptados para lograr el registro y análisis de los bienes objetuales generados por el hombre a lo largo de su historia.

No debemos correr demasiado rápido en una negativa de este planteamiento; la visión experimental refina sus técnicas de planeación de pruebas, el diseño de un nuevo experimento constituye una muestra innegable de creatividad. 
Llevando más a fondo el análisis, encontraremos situaciones relevantes en la similitud de la función metodológica del proyecto dibujístico con el plano de la experimentación.

Solamente mediante la aplicación sistemática de la observación, logramos detectar aquel comportamiento de las variables que integran nuestro experimento. Cuando enfrentamos el papel y la tela, cuando dibujamos día a día tratando de comprender la estructura de lo dibujado y del dibujo, comenzamos a notar la aparición recurrente de ciertas características dentro del fenómeno, aparecen en circunstancias similares y de manera continua, llamemos a estas características Síntomas, pueden ser caracteres formales, tipos de líneas haciendo funciones diversas, manchas que disocian el contorno y generan cualidades atmosféricas, o pueden ser procedimientos e incluso modos de pensamiento que comenzamos a notar en el suceder de nuestro proyecto. En fin, los síntomas dentro del proyecto son recurrentes y revisten un carácter muy variado. La manera y las condiciones en que se presentan determinan un comportamiento que poco a poco rebela una tipicidad, los síntomas marcan una tendencia de comportamiento, tienden hacia un punto o zona de atracción.

El proyecto se convierte en una función proyectual, algo que muestra el movimiento y relaciones sistémicas y constructivas de las partes que lo integran, decimos entonces que el concepto se vuelve elástico y amplia sus límites que lo definían en un inicio, y que los síntomas se convierten en tendencias.

Dentro de la producción artística la individualidad de un caso tiene relevancia en tanto es el intento de solución a un problema determinado y nuevo, en ese sentido el caso es emergente y sus cualidades son únicas y valiosas. Pero para los procesos de tendencia constructiva de la teoría artística y sus estructuras formales, el valor singular de un caso radica en mostrarnos el carácter que comparte con otros sucesos del mismo tipo, evidenciar con su capacidad estructural la condición organizacional dentro del proyecto (recordemos la noción de la obra y el proyecto como sistemas), o sea; dotar al sistema formal de algunas de sus características particulares, así es como vamos del caso, a una fenomenología que finalmente se define como tendencia.

El síntoma es la emergencia de una nueva cualidad en el sistema o sus partes, quiere decir que no son cualidades de origen primero, devienen como resultado de características anteriores, se manifiestan producto de una síntesis, sus cualidades son nuevas y en ese sentido primarias, pero aclaremos, son situaciones que se desprenden de un sistema de causalidad anterior.

Cuando concebimos el proyecto como una función generativa de construcciones le conferimos caracteres de causalidad.

En ella involucramos la subjetividad y el pensamiento objetivo del artista, que se manifiesta en descripción y representación.

La representación es el hacer visible a los demás lo presenciado por el artista pero transmutado en una síntesis de formas que significan una realidad alterna de existencia gestáltica, basada en las modificaciones que su imaginario le confiere. El dibujo nace desde el acto de unir la vivencia con la conformación de los datos perceptuales recopilados en el contexto, a esto se agrega el impulso que nace en lo profundo del gesto interior, en la tensión previa a la acción de trazar.

Lo anterior puede darse en un sentido directo y lineal, cuando nos aplicamos a la organización del concepto y la materia, para darle una configuración según la idea prefigurada. 
Hablamos de una causalidad circular o retroactiva cuando el proyecto genera como consecuencia organizaciones que se convierten en causas de nuevas construcciones. Existe una causalidad que no solo se convierte en parte del origen de un nuevo constructo, sino que al ser considerada por la inteligencia que la genera, se le advierte como causa de una modificación epistémica, entonces el autor de la propuesta, termina siendo modificado por el proceso y el producto que generó. ${ }^{48}$

En el dibujo del siglo XX las estrategias proyectuales de flexibilización buscaron ponerle diques al pensamiento lineal, después de la experiencia surrealista, el Informalismo y el Expresionismo Abstracto cargarán fuertemente de incertidumbre los procesos proyectuales del dibujo.

Cuando se busca poner diques al pensamiento racional conciente, para disponerse a crear la obra, se ataca de frente el curso lineal del proyecto en un sentido clásico, desde ese momento el proyecto no sólo persigue un objeto dibujo sino que creará una dinámica, tanto o más importante que la imagen.

Si el proyecto como intención hasta inicios del siglo pasado significaba una voluntad constructiva e instituyente, después de la tercera década de ese siglo correrá en un sentido inverso. En ese punto hacen crisis los síntomas acumulados desde tiempo atrás, y se avanza en una senda que desplaza el proyecto del campo de las construcciones formalizantes de representación hacia terrenos de la acción y la estrategia.

\section{II-5 METODOLOGÍA PROYECTUAL Y ESTRATEGIA EN EL DIBUJO}

El mejor truco de muchos artistas en el siglo XX fue convencer a la crítica y el público de carecer de estrategia y proyecto en su obra, y hasta de la intención de buscarlos.

Concordando con Morin, decimos que el exceso de complejización y flexibilización de un sistema termina por desintegrarlo, generando una simple reunión de elementos. ${ }^{49}$ Así se advierte en el texto Abstract Expressionism: Creators and Critics An anthology, ${ }^{50}$ en este libro se reseñan las reuniones y discusiones que el grupo de los expresionistas abstractos tuvieron en su momento, es impresionante escuchar a muchos de los grandes pintores del siglo pasado manifestando su diferencia con los demás, sin preocuparse por construir vínculos de acercamiento, en su momento cuando tratemos de los modelos del dibujo como formas del pensamiento volveremos a esta circunstancia con especial interés. Por ahora son ejemplo de una actitud que se hace método, el buscar lo no referencial, querer desprenderse de todo antecedente que defina al artista en relación a un pasado, que por razones indescifrables parece estorbarles. Esta es la base del modelo estratégico observado por Damish y que adelante expondremos.

Para aclarar las diferencias y cercanías del proyecto, con las de una postura estratégica, es necesario adentrarnos en el espacio de la reflexión metodológica. Antes de entrar a estos aspectos creemos importante referir algunas situaciones propuestas por artistas y

48 Morin Edgar. Introducción al pensamiento complejo. Barcelona: Ed. Gedisa; 2001. P. 123.

49 Morin Edgar. Introducción al pensamiento complejo. Barcelona: Ed. Gedisa; 2001. P. 131.

50 Abrams Harry N. Abstract Expressionism. Creators and Critics. An Anthology. Nueva York: Clifford Ross Ed. 1990. 
movimientos que enmarcan la cuestión. Adelante veremos como con estos casos, el análisis aterriza coincidentemente en la esfera del arte y el dibujo, que es la que puntualmente interesa en este estudio.

André Bretón consigna en sus Manifiestos del Surrealismo como introdujo técnicas del psicoanálisis a fin de lograr abrir un camino que lo llevara al inconsciente profundo y abrevar ahí como fuente de la obra de arte.

La postura surrealista enfrentó serios problemas metodológicos para lograr internarse en la pintura y las artes plásticas. Fue el dibujo como disciplina el que logró cauces estratégicos para penetrar la propuesta surrealista. El dibujo automático y demás procedimientos surrealistas, muestran un plano de la función metodológica que lleva el proyecto hacia una ruta de puntos flexibles, ya que al sustentarse en la región del inconsciente, no puede corresponderse con procesos programáticos lineales.

Por su parte la postura de los profesores que integraron la Bauhaus nos enseña un camino diferente, las prácticas iniciáticas que rodeaban las clases, y que se efectuaban previas al ejercicio artístico en sí, se mencionan poco en los textos, pero no son más que el deseo de encontrar sendas alternas a la concepción de una obra y a la construcción espiritual del artista.

A estas alturas y distancias históricas es innegable que el contexto científico, filosófico y cultural de principios del siglo XX, impactó profundamente el ideario de aquellas generaciones de artistas. Cuando todo en derredor mostraba la relativización del saber, el arte no tenía porque ser territorio marginal.

Como rasgo sustancial por el momento, diremos que en varios de estos movimientos como es el caso del Surrealismo o bien el Informalismo, la imagen terminal, producto del proyecto, no guarda semejanza visual con elementos identificables en el contexto inmediato. Los trazos de los cadáveres exquisitos si bien representan sujetos somáticos, no son producto de un enfrentar al modelo de modo presencial en el espacio físico, y eso es lo interesante. Los pintores dibujantes informalistas, llegaron incluso a la imagen anicónica, la que existe en una corporeidad concreta sin hacer alusión a un referente objetual.

Corresponde a los artistas de las cuatro primeras décadas del siglo XX el haber logrado un giro metodológico radical, que ya se anunciaba de tiempo atrás, y que se seguiría profundizando con el correr del siglo.

La revolución informalista y abstracto expresionista, descansa sobre la base de formalizar lo informe, o bien por el contrario, restar caracteres a la forma de la obra.

Los análisis de Greenberg dejarán asentada claramente esta postura, la particularidad de los territorios artísticos descansa sobre la base se sus formas puras, lo cual define el carácter abstracto de esas artes en términos de Greenberg, y de esa manera su no referencialidad a los modelos icónicos de la exterioridad contextual y natural.

En estas prácticas artísticas se reconoce la forma de la materia misma que integra la plástica, la forma de lo informe y la forma tautológica de los lenguajes, en estos casos, la estrategia estriba en dar importancia al proceso; mediante el cual el autor explota en un vuelco gestual, que dispone la materia como testigo de la forma del sentimiento.

Con respecto al proceso neoplasticista y bauhasiano, inmersos por otra parte en un contexto diferente, se puede decir que es el gran constructor de la alfabetidad visual. 
La reducción de la taxonomía de los elementos visuales, y sus leyes de combinación a un número definido de elementos, cierra el alfabeto de la forma; pero amplía su capacidad de aludir a todo fenómeno del contexto, incluso se logra la formulación de la forma misma como tema del discurso.

El proyecto de la alfabetidad visual y su gramática también es metodológicamente autorreferencial y recursivo, al igual que el del Informalismo y el Expresionismo Abstracto, su diferencia consiste en que aquel se concreta en estructuras generalizantes de la forma y el lenguaje, mientras que estos últimos dispersan la ruta metodológica hacia la postura epistémica de cada artista y su huella autógrafa.

La postura de ver formas en lo informe, o cuando menos en situaciones no referidas a la construcción humana, tiene una larga historia. Leonardo, Botticelli o Cozens definen ya esta situación en tiempos artísticos muy dispares.

Es el momento de realizar puntualizaciones.

Hasta los textos de Alexander Cozens, la postura con que se apreciaba el fenómeno del azar construyendo forma plástica, era básicamente despreciado o cuando menos dejado de lado y se le restaba importancia.

Con el trabajo de Cozens no solo se hace mención del asunto, se le dedica un análisis y se le integra en un método formulado para dibujar, Paisajes por Invención le llamó. Tal postura se enmarca dentro de lo que se llamó la Estética de lo Pintoresco, regresaremos a ello más adelante.

Un caso interesante dentro de la teoría del dibujo lo constituye Kimon Nicolaides. En 1941 tres años después de su muerte se publican sus estudios bajo el título: La manera natural de dibujar. ${ }^{51}$ Su idea central consiste en el planteamiento de que se puede aprender a dibujar haciendo una correcta observación de la naturaleza. El autor expone que la naturaleza tiene leyes que la estructuran y la presentan a nuestra percepción. El arte y el dibujo por su parte tienen reglas formuladas por el hombre que facilitan la expresión artística basada en la naturaleza.

Podemos extraer tres asuntos básicos de la forma del dibujo desarrollados en el texto. En ellos se trasluce la postura del autor para el análisis que nos ocupa.

En primer lugar se considera el dibujo de contorno, como estrategia para sentir y conectarse con el modelo, sea este del género que sea. En segunda instancia reviste importancia el entendimiento masivo de la imagen, poner el interés en su calidad táctil, tocar el modelo con todos los sentidos. Con ello Nicolaides introduce valores que desembocarán en una concepción tectónica del dibujo.

Como tercer asunto relevante en el texto, se expone la necesidad de establecer una comunicación profunda entre la intencionalidad latente en el impulso original mostrado por el modelo, con la dinámica de trabajo y concentración del dibujante.

El texto de Nicolaides se encuentra a medio camino entre el proyecto y la estrategia. Es una formulación analítica en la que nada es tajantemente opuesto. Este caso es una

51 Nicolaides Kimon. The Natural way to Draw. Boston: Houghton Mifflin Company; 1969. 
muestra de lo relativo del proceso de cambio de las artes y el dibujo.

La concepción que anima dentro de este trabajo sigue siendo la de las posturas neoplasticistas y espirituales como las de Klee, Kandinsky Doesburg etc. La naturaleza tiene que ser estudiada y penetrada por la reflexión artística, desde esa base se tiene que exteriorizar el impulso creativo del dibujante. El propio libro se estructura en una serie de ejercicios organizados rigurosamente en sus objetivos, tiempos, procedimientos y técnicas, mantiene en esa medida una postura moderna lineal evidente; el método es una garantía de lograr resultados, pero sólo en la dirección que la concepción del método contiene; además es planteado en una dimensión normativa y como recurso metodológico para aprender a dibujar, de ahí su distancia como reflexión potencial de aplicación en el ejercicio de la producción del proyecto del dibujo en un sentido amplio.

Tal vez por eso los informalistas y expresionistas abstractos no hacen mayor referencia a este autor.

Pero pese a la rigurosidad de los procedimientos del método de Nicolaides, contiene elementos de flexibilización importantes; estos giran en torno a la propuesta de considerar los modelos con una intencionalidad vital, incluso los modelos inanimados. Menciona también el gesto como la tensión que genera la acción de la vida y da unidad al suceso. ${ }^{52}$

La postura de Kimon Nicolaides es la manifestación de la actitud vuelta estrategia, en sus notas se contiene el antiguo pensamiento y se agregan elementos que hacen variar la postura inicial. Para él el dibujo no será solo asunto de desarrollo de habilidades manuales y constructivas, es manifestación de los impulsos internos del artista en su intento por compenetrarse con los modelos que lo rodean.

Hasta aquí hemos aludido sin mayor rigor a una serie de momentos en la historia del dibujo. Estos significan emplazamientos estabilizados en el pensamiento artístico, nos servirán ahora como marco referencial al que remitiremos continuamente el análisis en su fase teórica, es necesario mantener en nuestra mente siempre presente que estamos refiriéndonos a situaciones que implican la región del arte y el dibujo.

Revisemos ahora la cuestión desde el punto de vista teórico y metodológico.

La noción del programa y el método como una ruta estable, que puede abrir otros caminos alternos al conocimiento, frente a la de metodología y estrategia que pondera las partes poco claras del proceso cognitivo, pero que termina por abrir el camino basándose en la inclusión de los elementos emergentes en el proceso, es aceptada ya con recurrencia, dedicamos la primera parte de este capítulo a establecer esas condiciones de flexibilidad.

Pero corremos el riesgo de caer en una oposición entre un racionalismo que busca la objetividad del proyecto, o un empirismo de corte positivista, que confía en el abordaje del proceso esperando que del mismo y su observación se susciten las propuestas procedimentales.

En primer lugar es necesario desechar las posturas de contraste total. No existen procesos totalmente rígidos en el sentido metódico ni completamente flexibles como estrategias intencionales.

52 Nicolaides Kimon. The Natural way to Draw. Boston: Houghton Mifflin Company; 1969. P. 13. 
"la mayoría de las veces en los conceptos que manejamos aparece de manera resistente el modelo que tratábamos de superar. El propio texto de Bruce Nauman es un buen ejemplo de ello, nos habla de aquello que modifica la relación que mantiene con su actividad, lo hace con la voluntad de ampliar las expectativas del posible espectador, pero sobre todo con el deseo de redefinirse él mismo en su trabajo, y lo hace utilizando conceptos que son profundamente básicos en el discurso de aquello que entendemos como dibujo; no podía ser de otra manera: la cultura, sea cual sea, no es otra cosa que un sistema de referencias, como decía Baxandall, siempre tenemos que recurrir a usar modelos preexistentes. Picasso partió de ciertos problemas de Cézanne, pero desde entonces solo podemos entenderlo a través de la interpretación que éste hizo de él."53

El proyecto como parte de una metodología estabilizada tiene sus raíces en el pensamiento determinista del siglo XVII, en él se consideraba la naturaleza como sinónimo de estabilidad, si sus procesos eran afectados por alguna circunstancia, la naturaleza tenía la facultad de regenerarse por si misma y recuperaba su estabilidad. Por tanto se pensó factible desarrollar sistemas metodológicos estables que se pudieran acercar a esa razón inmanente de la estructura natural, para incluso poderla dominar. Este ideario se vio alentado por el arribo de la Revolución Industrial del siglo XVIII que dotó al ser humano de un potencial de transformación del entorno hasta entonces no imaginado. Ya las consideraciones históricas que hacíamos sobre el pensamiento proyectual nos hablaban de ello.

El impulso de buscar la teoría y su estructura como sinónimo de estabilidad y emulación del orden natural se proyectó a la actividad del dibujo. Pero las teorías programáticas no son un grupo de enunciados lógicos sólidos, son cuerpos complejos, cuya estructura contiene e integra subsistemas y formulaciones que prueban la efectividad del método, y garantizan temporalmente su permanencia, en tanto tienen la capacidad de resolver casos o estructurar procesos de producción con buen término. De ahí que los métodos mantengan una característica de resistencia al cambio.

Las artes y dentro de ellas el dibujo revisten una característica importante: No son objetivas, debido a que el autor se encuentra fuertemente involucrado en el fenómeno que produce. Aquí se establece una distancia con el trabajo científico y su carácter objetivo, que diseña el método manteniendo su punto de vista al margen, para no afectar el desarrollo de las pruebas o procesos reflexivos.

Para el dibujante la cualidad de lo que acontece en su imaginario en el momento de la producción reviste un interés mayúsculo.

Cuando afirmamos líneas arriba que el dibujante traza con el peso de la historia en su mente nos referíamos a esta situación. Al prefigurar un dibujo lo hacemos desde el conocimiento de los sistemas actuales, nos planteamos la pertinencia de usarlos repetidamente, aunque sentimos la incomodidad de aquellas situaciones que los métodos en cuestión no resuelven, hay anomalías que se han acumulado a lo largo del uso del sistema y nos sentimos obligados a encontrarles solución.

Nos seduce también la posibilidad de aludir metafóricamente a ese nuevo pensamiento, dentro del dibujo como objeto o práctica realizada en exposición hacia los demás.

53 Gómez Juan José, et al. Las lecciones del dibujo. Madrid España: Ed. Cátedra; 1999. P. 43. 
Como artistas tenemos de manera irrenunciable siempre un punto de vista específico en lo referente al sistema mismo del dibujo, y lo incluimos en el interior del proceso generativo de la obra, esta postura puede ser más o menos tangible o introyectada en la imagen presentada.

Este punto de vista se funda en gran medida sobre el conjunto de creencias y concepciones del mundo que construyen la ideología, esto es, no necesariamente ideas verdaderas o demostradas desde una formulación cognitiva rigurosa.

Muchas veces el artista suple la carencia de rigor procedimental en su campo, con material especulativo y metodológico que extrae del contexto en el que se haya inmerso, esto no significa que el conocimiento en cuestión sea pertinente al problema que desarrolle en sus dibujos.

Todas estas son situaciones que se presentan en el pensar del dibujante y en el contexto que enmarca su práctica. No están realmente sujetas a discusión, pero mediante el peso que ejercen en la autonomía volitiva del artista suscitan el fenómeno de flexibilización estratégica, al incluir en el proceso la sistematización de la experiencia cotidiana del artista.

Para aproximarnos al entendimiento de la multiplicidad enunciada es necesario recurrir a la noción de complejidad. Hasta donde sabemos la teoría de la complejidad es formulada sobre todo por el matemático ruso Kolmogorov. ${ }^{54}$ En ella la regularidad de un fenómeno se determina de acuerdo a la cantidad de información y elementos que integran un sistema, ya que en tanto más pequeño y cerrado el sistema es menor la complejidad del mismo, en razón de la información menor que será manejada. Así se comprende porqué el artista al enfrentar comúnmente situaciones que involucran números elevados de variables, recurre con frecuencia a la ruptura y flexibilización del programa o proyecto.

Con esto llegamos a un punto interesante del análisis: La evidencia del comportamiento proyectual y programático y estratégico flexible en los procesos artísticos. Puede ser observada en el devenir secuenciado de los conceptos y estructuras usados por el artista.

Se observa también dentro de las conductas procedimentales de ejecución aplicadas, en la toma de decisiones a lo largo de la configuración y en la postura epistémica del dibujante ante el problema y el método.

A todo esto es a lo que nos referimos como dimensión fenoménica del acto dibujo.

La historia de estos factores contiene el relato de su afectación, en función del empuje de los demás elementos y decisiones configurantes.

Todo esto enmarcado en un arco temporal específico, sea el de la creación de un cuadro, o el proceso creativo del autor, dividido en los periodos que formula como proyectos a lo largo de su vida.

Por eso los cuadernos de notas y las libretas de apuntes, estudios y proyectos, o cualquier material que captura pasos intermedios del trabajo constituyen una posibilidad de clarificación de las acciones estratégicas del artista.

La película de Clouzot que captura a Picasso mientras pinta se funda en esta convicción, parte del principio que entre el inicio de una obra y el cuadro final existen varios cuadros, tal era el pensamiento de Picasso.

54 Radaña Antonio. Movimiento Caótico. Investigación y ciencia, Scientific Américan 1986; (114): 23. 
Nuevamente, Obra, Proceso, Autor y Tema Problema, son los personajes del programa y la estrategia dentro del proyecto del dibujo.

Vera Cañizares nos dice:

"El tema es también el proceso. El proceso es la misma obra. La obra, en realidad, es la colocación en movimiento de los elementos ya existentes, el artista apenas hace de promotor. Tema y poética igualmente se unifican. Este funcionamiento globalizador, que incluye todos los elementos existentes, y donde su propia ubicación es la obra (ubicación como caracterización intrínseca del tema), es lo que consideramos como una instauración del nuevo lugar expositivo"55

La Obra; condensa, estabiliza, muestra lo alcanzado. Al dibujante la obra lo reta desde su resistencia, desde sus oscuridades no resueltas. En su constitución se integran los estratos que la vienen configurando, es potencial discursivo para el espectador en virtud de sus múltiples sentidos significantes. Para el dibujante la obra es la existencia de un otro ontológico con el que se establecen diálogos del silencio.

El Proceso; es el devenir y reajustarse de las partes, la aplicación del saber histórico, las intensiones, las soluciones, las respuestas lanzadas.

El proceso es el tiempo y el espacio del suceso, la aplicación pragmática del tema problematizado, suceso en el que el dibujante se hunde en el acto de dibujar y en el que será transformado.

El proceso se inicia desde el primer momento, el de la vivencia, vivencia del dibujante hundido en el contexto, vivencia como primera instancia fenoménica, ubicación puntual en un aquí y ahora, vivir que sin embargo ya es interesado en determinada circunstancia, vivir el mundo mediado por la condición de dibujante, visión de la vida pasada por la transparencia del medio del dibujo.

El Autor, el dibujante; es la voluntad de acción, el que prefigura y representa lo vivido, el que inicia la suma y el comparativo experiencial, es la intención de significación. Es el sujeto de las vivencias primeras en las que se inicia la conformación del tema, es el pensamiento de suma experiencial mediante la que se sintetizan las tendencias de construcción formalizada y las que modifican el sistema conceptual y operativo del campo dibujo. Es el productor y conductor del rito del dibujo inducido por lo artístico, tanto en el nivel de reconocimiento y autorreferencia, en el que se actúa con sentido crítico y autocrítico, como en el de la dilatación y contextualización cultural e histórica en la que se inscribe el accionar individual. Marco de comprensión de la intimidad dentro del pasado disciplinar que lo antecede como en la proyección futura de las estructuras representacionales formalizadas que propone. Concretando con lo anterior una dimensión ritual en el que el propio dibujo renace continuamente.

El Tema problematizado es el territorio, campo de circunscripción y pertinencia del proyecto, en el se establecen los límites del alcance de lo pensado y configurado, límites más allá de los que el proyecto se relativiza y se desfigura.

55 Vera Santiago. Proyecto Artístico y Territorio. Granada: Ed. Universidad de Granada; 2004. P. 132. 
Las categorías anteriores tienen un peso importante en el análisis del proyecto y la estrategia. Son las entidades cuyas relaciones se ponen en juego en la acción. Una cita al respecto.

"El proyecto creativo, como promotor previo y protagonista de las evoluciones artísticas, tiene la facultad de convertirse en instaurador metodológico y programático del lugar discursivo y simbólico para el Arte, merced al establecimiento de relaciones íntimas e intensas con el tema, fomentadas como una estructura rizomática, donde todos y cada uno de sus componentes (elementos vivos dentro del circuito rizomático artístico) establecen vías de comunicación con todos los demás, creando a modo de un sistema de vasos comunicantes; no eximiendo la posibilidad de actuaciones independientes o aisladas. Estas relaciones íntimas, biocenóticas, acogen aspectos multisemánticos (metáforas, símbolos, arquetipos) alcanzando contenidos, tanto denotados (con significado estable dentro del sistema cultural donde están insertados), como connotados (con significados variables según contextos o grupos o grupos culturales)"56

La acción implica el devenir en el tiempo de los tres sujetos descritos anteriormente, la acción es el desarrollo del proceso y se debe a la voluntad de activación del autor, el dibujante.

Parece simple decirlo, pero el proceso no se inicia sin una voluntad inicial, esa es una cualidad positiva del proyecto, la voluntad de emprender de parte del dibujante.

El inicio de la acción supone un norte intencional por parte del dibujante, mismo que se concreta en un cuerpo llamado proyecto.

Dentro del proyecto están contenidas las vivencias del autor, pero con ello no basta, todo ser humano lleva en su memoria el repertorio de una vida hecha de vivencias.

La segunda parte de un proyecto, es la traducción de ese mundo vivencial en una región temática que lo lleva a pensar conceptual y dibujísticamente una obra.

Lo que le sigue es la formalización imaginada de ese tema. Aquí se busca la relación del tema y lo que de él opina el artista en valores y elementos plásticos y visuales, nace en su mente una concepción eidética del tema.

El proyecto del dibujo también centra su interés por los aspectos formales múltiples, que lo identifican ontológicamente y lo disponen a la interdisciplinariedad. Esos aspectos formales nos interesan como participantes de la sustantivación temática y como organización conceptual del problema. Hacemos hincapié en ir delante de la visión purista formal o instrumentista del asunto, para introducirnos en la consideración semántica profunda de esos factores formales.

Esa visión en imágenes y procederes impone ya una estructura de formas y estrategias a la futura obra. En este punto y de manera sincrónica el autor piensa ya a la par en los tiempos y etapas de la realización de la obra, esto es en la acción. De manera que el proyectar implica un proceso intelectual, agrupado en momentos que contienen su propia complejidad y distan de ser tan simples como se les suponía.

Ambos, el tema y su conceptualización y el pensamiento de las estrategias y acciones integran la prefiguración proyectual.

56 Vera Santiago. Proyecto Artístico y Territorio. Granada: Ed. Universidad de Granada; 2004. P. 113. 
Agregaremos que las etapas de un proyecto obligan una línea de temporalidad a la que no es fácil imponerle un orden arbitrario.

Cuando nos referimos anteriormente a los procesos de causalidad lineal, circular, recursiva y compleja, hacíamos referencia a la posibilidad de que un factor pudiera ser causa y efecto a la vez y que en ello terminara creando al sujeto creador.

La temporalidad del proyecto y la estrategia, el accionar de sus partes, generan por si mismas una línea del tiempo que no podemos hacer retroceder, esta avanza a la par que el trabajo del autor, podrá detenerse, variar del rumbo inicial, ramificarse en múltiples variantes, pero nunca regresará, ni el objeto construido, ni la experiencia del dibujante vivida en la acción de dibujar pueden deshacerse.

Por eso es que, decir acción en el análisis, tanto del proyecto como de la estrategia, es decir toma de decisiones. Podemos no realizar el proyecto operativamente, o podemos iniciarlo sin una precisión de sus partes, pero aún ahí hemos tomado decisiones, apostamos y con ello introducimos el riesgo y la incertidumbre en el proyecto, lo convidamos un tanto de las características de la estrategia.

El proyecto requiere mantenerse en la dirección de crear la obra que contenga el concepto planteado como espíritu central. No implica respetar un programa hasta el absurdo, nadie puede considerarlo así, significa la voluntad de concretar la obra bajo la estructura de representación deseada, sin liberar el proceso al azar.

Estrategia significa una decisión y desviación disyuntiva, considera de antemano distintas posibles consecuencias de la acción inicial, las visualiza antes de que se presenten en el terreno concreto de la acción. Las imagina como escenarios y opta por alguna de ellas como aplicación a la obra. Esto no es otra cosa que lanzar hipótesis, se decide por una de ellas y si el resultado es el imaginado inicialmente (que no es lo mismo que el deseo configurante), se continúa en una dinámica de refuerzo de lo logrado, así se torna un tanto estable el accionar, la situación parece ser más compleja de lo pensado.

Cada agregado de elementos o cualidades emergentes en el proceso del hacer, significa la inclusión de elementos estocásticos en el proyecto y un aumento en los grados de libertad del acto de dibujar, al hacerlo se han tomado decisiones de flexibilización lo que nos aleja de las hipótesis formuladas, estas son las perturbaciones recursivas integradas en el proceso de la acción estratégica.

Una mirada simple vería en la estrategia el opuesto a una actitud proyectual, pensaría en ella como el terreno generativo del azar; pero no es así, vale la pena recurrir a Morin nuevamente:

"La estrategia lucha contra el azar y busca a la información. Un ejército envía exploradores, espías, para informarse, es decir, para eliminar la incertidumbre al máximo... Aquí interviene la noción de ecología de la acción. En el momento en que un individuo emprende una acción cualesquiera que fuere, esta comienza a escapar a sus intenciones. Esa acción entra en un universo de interacciones y es finalmente el ambiente el que toma posesión, en un sentido que puede volverse contrario a la intención inicial. A menudo la acción se volverá como un boomerang sobre nuestras cabezas. Esto nos obliga a seguir la acción, a tratar de corregirla..."57

57 Morin Edgar. Introducción al pensamiento complejo. Barcelona: Ed. Gedisa; 2001. P.114. 
La acción al sucederse es sumamente azarosa y aleatoria. Por eso reiteramos que se requiere de un estado consiente y atento, que de cuenta de los momentos disyuntivos de la acción, que agregue las cualidades alternas que se presentan, en fin, la reflexión general sobre el proceso activado y su devenir.

Proyecto y estrategia parecen ser vías de divergencia pero no es así totalmente.

El proyecto como postura de planeación constituye un freno al exceso de la acción estratégica, le recuerda las intencionalidades conceptuales iniciales y se las plantea como el centro de gravedad organizativo de la obra sistema.

El proyecto al ser algo más que puntos programáticos contiene paradójicamente una estructura más compleja. Arranca desde el momento mismo de la transformación de la vivencia en un tema posible para la obra, y concluye en la redondez del logro conceptual.

En la vanguardia que sucede en inicio del siglo XX con los movimientos funcionalistas, neoplasticistas e integracionistas se establece la concepción del proyecto del dibujo ya nítidamente como Función metodológica. Es así porque se orienta el pensamiento hacia la consecución de objetivos premeditados que potencian la penetración del proyecto hacia las esferas de lo político cultural, lo individual, como en la interioridad de la forma en el campo del dibujo. El proyecto del dibujo muestra entonces claramente la fuerza programática funcional y evidencia las estrategias de representación como vía no solo formal sino como agente de cambio y proyección cultural.

El dibujo dentro de estas vanguardias da fe clara de la intensidad y ruta teórica, de las ideas proyectuales y su integración dentro de la estrategia general del arte.

Pero en este mismo momento el proyecto vive una etapa más de su división paradójica, es así porque también se formula como vía de expresión del yo subjetivo, el parteaguas del proyecto romántico histórico cobra fuerza nuevamente. Muchas veces la fusión de la subjetividad individual con el todo social humano se expresa en términos de una contradicción insalvable, aunque dentro de otros movimientos alcance la identidad satisfactoria entre lo colectivo y lo individual.

El pensamiento proyectual del dibujo se manifestó como una vía para posicionar al yo frente al mundo y la realidad contextual externa, así sus límites quedaron trazados por la circunscripción natural o social que operó como campo de presión represiva hacia la autodeterminación de la interioridad del sujeto; en su momento el Surrealismo propuso la liberación no solo de la sociedad, sino dentro de ella, la libertad completa, que sólo era posible con la expansión plena de la interioridad individual.

Aquí se inició el proceso que veinte años más tarde se aclara dentro del Informalismo y el Expresionismo Abstracto, que por otra parte entendemos como la modernidad esteticista, formalista y Greengberiana; el ideal artístico se expreso en la intención de construcción utópica de nuevos universos mentales para ser ocupados como forma vital de existencia. Se exploraron las vías tribales, orientalizantes etcétera en las que la naturaleza no era ya considerada como sujeto de estudio y exploración sino como el campo mismo del acontecer del ser del dibujante, origen y crisol de lo sublime e inefable. 
Y no es que caigamos en pensamientos vagos e imprecisos, todo esto se expresó en la interiorización del dibujo hacia la práctica de la pintura, la escultura y la gráfica con el resultado de un impulso revitalizador para esas artes que encontraron nuevas rutas de configuración, en esos momentos el dibujo comenzó a presionar y orientar a las artes hacia una ponderación de la acción por sobre un pensamiento que hasta entonces había puesto su centro de atención en lo concreto de la obra como objeto y texto estético.

Generalmente el dibujo dentro de la vanguardias neoplasticistas e integracionistas operó como función metodológica proyectual, dentro de las vanguardias cuyo proyecto era de carácter crítico el dibujo se dirigió hacia la estrategia y la acción como tiempo y espacio de la flexibilidad de ruptura con el proyecto moderno.

Por un lado el dibujo como función proyectual dentro de las vanguardias normativas propuso un sistema de formas como modelo de expansión social y del sujeto como protagonista. En su contraparte el dibujo habría de operar ponderando las anomalías particulares de cada sujeto, anomalías en el sentido de atomizaciones de la función metodológica que el dibujo aportó a los campos disciplinares hasta la modernidad del XIX.

El pensamiento proyectual se propuso como vía de transformación y construcción humana y social, pero también como posibilidad de infinitud estratégica en el proceder del arte partiendo de la individualidad de cada uno de los artistas modernos.

Tanto en el pensamiento positivo y normativo del arte, como en el de expresión nihilista en tanto negación sistemática de la norma, se manifiesta una postura epistémica, sólo salvable quizá en el terreno del arte como espacio de la posibilidad. Queremos decir que la contradicción en si no es importante, ambos polos de la formulación lo son porque se constituyen en rutas de construcción de estrategias y pensamiento que se plasman en lo específico del pensamiento del dibujo.

Así, método y estrategia no son opuestos dialécticos, son términos que definen posturas y procederes proyectuales, que la más de las veces se interpenetran en proporciones múltiples.

Cuando ubicamos el proyecto no sólo en el plano conceptual y teórico, cuando descendemos a su aplicación temporal específica nos resulta fácil entenderlo como el tiempo de la vivencia del dibujante, tiempo de la confrontación de lo pensado con las vicisitudes de la configuración, éste es el tiempo de la investigación y el viaje nutriente. Aquí vivir y dibujar se identifican una vez más.

La estrategia por su parte también impone una conciencia atenta al transcurrir del proceso, esto es porque no cuenta con la confianza de un programa firme que le garantice el resultado con certeza. En todo momento debe dar cuenta de lo sucedido y actuar reforzando lo emergente, o negándolo para retornar a la idea inicial. La inclusión de la estrategia dentro del proyecto artístico obliga al reconocimiento de la necesidad de construir vínculos de relación y solidaridad que propicien la integración de la obra y más allá. De no ser así el exceso de complejidad y la inclusión de un número excesivo de elementos en el proceso, complicaría tanto el proyecto que llegaría a desintegrarlo.

La estrategia nos atrae por su actualidad, su modernismo y su contemporaneidad, pero no existe en estado puro, siempre parte de un inicio proyectual. El artista de los siglos anterio- 
res tampoco confiaba ciegamente en los proyectos. Cuando las circunstancias le mostraban soluciones mejores o problemas no contemplados, modificaba el planteamiento inicial sin por eso demeritar el logro de la obra. Los ejemplos comentados nos muestran como el proyecto en arte no está ceñido a una postura rigidizante. Dentro del arte de los últimos cincuenta años el proyecto se concreta a veces en su sola concepción y eso basta.

Nuevamente nos anima una visión para el análisis que se ubica en la complejización de las posturas y no en su negación excluyente. Entonces el asunto consiste en realizar el estudio de cada caso para advertir la medida de la conclusión, el grado de la apuesta por una u otra postura.

El proyecto del dibujo, como territorio y tiempo del acontecimiento dibujístico es proceso de evolución constante, bien basado en el trazo metodológico inicial o bien, con las flexibilizaciones estratégicas contempladas. Promueve continuidades en lo simbólico, lo metafórico, suscita amplificaciones en todas las rutas conceptuales y formales que se presentan como caminos a ser investigados bajo un afán de apropiación extensión y enriquecimiento.

Esto influye decisivamente en la misma metodología del dibujo, en sus técnicas, en sus soportes y formatos, en la relación del dibujo con prácticas y conceptos de campos alternos del arte.

Todo ello surgido en la decisión individual, pero que corre hacia el marco colectivo del dibujo, su lenguaje y sus dimensiones culturales e históricas.

Incluimos una cita de Santiago Vera que se refiere claramente al asunto.

"Las propuestas en permanente movimiento, estarán siempre atentas a los nuevos estados de la conciencia que favorecen los posicionamientos mentales, motivados por las actitudes ante lo creativo y que se relacionan con la propia presencia humana.

En esta permanente actuación, constituyéndose metodológicamente en un taller ilimitado, el proyecto desenvuelve un diálogo entre el suceso previsto y las sugestiones que van apareciendo por su propio direccionamiento para lo artístico; diálogo que hará surgir repercusiones sorprendentes e inesperadas, acentuando la dimensión fabuladora, desconocida y utópica, del hecho creativo.

Asistimos, de esta manera, a una naturalización de la obra que aparece como proceso abierto, interdisciplinar y multiformal... superando delimitaciones técnicas o fronteras académicas...

Así, el artista se sitúa más allá de los límites o fronteras de los distintos lugares de conocimiento; con una disposición, para las situaciones, no funcionalista; lo que le compromete con ámbitos insospechados y fuera de catalogación. Es un infiltrado con capacidad para recontextualizar la realidad como una nueva realidad artística, no por sus aspectos icónicos, ni de uso, sino por las manifestaciones que fueron seleccionadas en el deambular creativo." ${ }^{58}$

La obra, el autor y el proceso son las partes que se interconectan en la realización del proyecto, esta realización nos introduce al terreno de la acción, la acción acontece en un curso temporal que nombraremos el acto dibujo.

58 Vera Santiago. Proyecto Artístico y Territorio. Granada: Ed. Universidad de Granada; 2004. P. 104. 
Acto que se basa en la necesidad de trascendencia de la realidad inmediata y que se dirige a la generación de estados experienciales que buscan esclarecer y comprender las relaciones posibles del tema problematizado, vías de formalización basadas muchas veces en lo inefable pero que nos remiten a estados de conciencia superior holística.

Cuando el autor realiza los procesos de configuración de la obra, está bajando el proyecto del plano reflexivo al de la ejecución.

Al decir ejecución anunciamos la introducción de una nueva categoría en el análisis, de momento, solo esa puntualización.

Las acciones de la ejecución del proyecto llevan aparejada una postura intencional, no existe ejecución carente de sentido significante. Junto a esta postura hipotética inicial, la ejecución como forma específica de la acción artística enfrenta el continuo fluir de situaciones que demandan decisiones estratégicas, es nuestra responsabilidad hacer que la idea corra delante del pincel, aunque también podemos dejar que el dibujo fluya de nuestro interior sencillamente porque de tanto pensarlo y hacerlo lo llevamos dentro, la acción ejecutante es como un tubo de tinta reventado, no deja de fluir hasta que el manantial se agota, así no podemos en determinados momentos detenernos a reflexionar, debemos apostar y hacer que las decisiones generen consecuencias integrables al proyecto.

Nuevamente no tomamos partido por una u otra situación, señalamos solamente lo que ya se adivina, se puede enfrentar la acción ejecutante desde una perspectiva estratégica racional o desde una vertiente emotiva subjetiva, entre ambas cabe un sinfín de posibilidades.

Veamos que nos dice la historia al respecto.

"El tratado de teoría perspectiva de Piero Della Francesca (1472/1475) es una obra fundamental y de excepcional importancia en la historia de la pintura y de la ciencia perspectiva. Es el primer tratado cuyo contenido es rigurosa y estrictamente científico, sin ninguna concesión a exigencias literarias, con exposición orgánica y coherente, sin errores conceptuales notables y con finalidad explícitamente didáctica."59

Charles Baudelaire en 1845 exaltaba la imaginación y creatividad por sobre la idea de conseguir una imitación fútil de la realidad. En la celebración del salón de la academia ese año conoce a Delacroix, quien lo atraerá como un típico romántico. A Baudelaire se le considera el más claro exponente de la crítica romántica y de la del siglo XIX. Contamos con la definición que en 1846 daba del Romanticismo.

"Decir romántico es decir arte moderno, es decir intimidad, espiritualidad, color, aspiración de lo infinito, expresado todo ello por los medios artísticos."60

El enfrentamiento entre los pintores neoclásicos y románticos es la expresión de dos actitudes ante el proyecto de la pintura.

59 Freixa Mireia, Garriga Joaquim, Yarza Joaquín, editores. Fuentes y Documentos para la historia del Arte. Renacimiento en Europa. Barcelona: Ed. Gustavo Gili; 1983. (IV). P. 99.

60 Freixa Mireia, Garriga Joaquim, Yarza Joaquín, editores. Fuentes y Documentos para la historia del Arte. Ilustración y Romanticismo. Barcelona: Ed. Gustavo Gili; 1983. (VII). P. 335. 
La contradicción interna de la pintura que separa el color de la forma y el dibujo tiene sus raíces en el periodo manierista, se sostiene sobre la base de un enfrentamiento entre el pensamiento platónico y aristotélico. El idealismo platónico prioriza la idea como rectora de las acciones mentales y prácticas subsiguientes, la visión aristotélica construye su discurso sobre la experiencia sensible y el acontecer como centro del arte.

El dibujo como acto implica las secuencias de ejecución a no dudarlo; si estas se basarán en el trazo de una intencionalidad manifiesta, o sobre el acontecer del suceso y la interacción del dibujante es un problema de postura epistémica, pero no necesariamente de términos excluyentes.

El Constructivismo en la Rusia posterior a la revolución de 1917 es un movimiento, con una voluntad colectiva de institución social; frente a un arte individual de elite, opusieron el arte unido a la vida del pueblo. Intentaban terminar con la creación de la obra única y en su lugar propugnaron por una producción en serie del objeto visual. En esa medida se ubicaron como artistas, pero también como creadores de una nueva sociedad. No querían halagar el gusto del público, sino ser conformadores del pensamiento consciente del ser humano.

Otra de sus tesis centrales era la de unir los avances tecnológicos con el discurso y lenguaje contemporáneo del arte, El pueblo merecía un arte de avanzada.

Como resultado de la aplicación de estos planteamientos en la realización de proyectos artísticos, la obra escultórica, gráfica, pictórica y de dibujo se geometrizó fuertemente, se acercó nuevamente a una concepción moderna del diseño, al interior de los sistemas constructivos de la obra, abrió nuevos campos y transformó radicalmente la función social del arte. Dejó lista también la situación para el arribo de la Bauhaus.

A todo esto es a lo que llamamos líneas arriba los proyectos positivos de institución social.

Por ahora señalemos solo las confluencias de la postura Bauhaus con las escuelas del constructivismo, los Vkhtemas. Estos eran los talleres de avanzada del estado, en ellos se formarían los artistas que unirían el arte con la industria.

Como se sabe la Bauhaus también fue un proyecto de institución de la colectividad, sus autores llevaron más a fondo la postura de unir el arte con la tecnología, hicieron un desglose de las partes del diseño, el dibujo, la pintura y la arquitectura, las organizaron para su enseñanza bajo un nuevo proyecto conceptual y pedagógico, animados por una filosofía de renovación y mejoramiento de la sociedad.

En general los movimientos del Modernismo del siglo XX, desde Viena hasta Alemania, incluso México, con el programa de estudios formulado por Diego Rivera en su paso como director de la Academia de San Carlos, manifestaron ser un proyecto de revolución artística dentro de una reconstrucción de toda la sociedad, tuvieron a no dudarlo un ánimo ascendente.

La cantidad de autores y movimientos que representan giros de actitud en la definición del proyecto artístico es larga y muy variada, no es necesario abundar en ello. Con los casos comentados queda clara la tesis sostenida; la actitud es parte característica del proyecto artístico, no puede ser ni la hemos colocado como antitética de la noción planificadora. Reflexionemos ahora después de los ejemplos. 
La actitud contiene los elementos que nos hablan de la postura del ser frente a los procesos en los que se inscribe, o que él mismo ha desencadenado, como es el caso de los proyectos artísticos, en la actitud está contenida la intención, pero no solo la de los objetivos y las metas a lograr, también lo está la de la manera en que se decide abordar el proceso. Esto es muy importante en el análisis del proyecto y la planificación de la estrategia; porque dependiendo de la postura epistémica será el curso del suceder de los acontecimientos y en consecuencia los resultados no lo serán tan solo del plan trazado, sino también del carácter cognitivo contenido en dicho plan.

La actitud determina las distancias y decisiones que el autor asume con respecto al marco histórico y el marco teórico en que se basará su proyecto. También concreta una postura referente al proceso del hacer fácticamente la obra. En el plano más abstracto la actitud determina el punto de vista desde el que se analiza un sistema, y también la posición que el artista ocupa dentro de él; por lo tanto la definición del mismo que realicemos y las consideraciones que de él tengamos son dependientes de la actitud, esta condicionará el margen de verdad del proyecto y la pertinencia de la estrategia: la actitud corresponde al terreno de la epistemología porque se encarga de dar coherencia al sistema propio, desde el cual la inteligencia rectora accede al conocimiento y a la puesta en marcha del proyecto.

Una revisión de los modelos artísticos del dibujo puede ser considerada en buena medida un análisis de las actitudes epistémicas de un autor un movimiento o toda una época del arte.

La actitud está mal entendida si se le considera territorio de lo individual, claro que puede darse en el círculo de cercanía que rodea al dibujante, o desde la aplicación de su autonomía ontológica, pero el ideario del artista no es producto solitario ni se da por generación espontánea, ese ideario y la actitud se determinan por los procesos ideológicos de la época, por el ideario colectivo o por lo que Slavoj Zizek llama el gran otro, ${ }^{61}$ ese abstracto psíquico colectivo y social contra el que nos revelamos pero del cual nos interesa el reconocimiento, y del que no queremos desprendernos del todo.

Uno no es tan uno mismo aunque lo suponga, el artista es más un ser de identidades incluyentes, aunque se preocupa por la identidad como aquel sello que lo vuelve diferente. La actitud es una postura que se ubica en la esfera de lo colectivo histórico hacia lo personal volitivo.

Traigamos a colación una cita más de Rafael Porlán, dentro del análisis que realiza de la experiencia empírica como parte de un sistema de obtención de conocimiento.

"Más bien, los constructos personales se organizan de manera idiosincrásica en una
red de esquemas cognitivos de diferente tipo, que mantienen cierto grado de relación
entre sí y que se constituyen en auténticas construcciones singulares, creativas y com-
plejas de información... En su organización interna aparecen conceptos prototípicos
sobre el mundo físico, extrapolados de la experiencia cotidiana individual, y estereoti-
pos sociales e ideológicos asimilados e interiorizados en el transcurso de la experien-
cia educativa y social del individuo... Los esquemas abarcan tanto el plano profundo
experiencial de la persona (plano implícito) como el lingüístico, verbal y simbólico de
la misma (plano explícito), así como las relaciones entre ambos. Dichos esquemas
configuran, en definitiva, la memoria semántica y experiencial."62

61 Zizek Slavoj. El Sublime objeto de la Ideología. México. Siglo XXI Editores; 2001.

62 Porlán Rafael. Constructivismo y escuela. Hacia un modelo de aprendizaje y escuela basado en la investigación. Sevilla: Ed. Díada; 1993. P. 72. 
Por lo anterior, la actitud busca de una u otra manera inscribir el pensar del autor dentro de una forma de pensamiento universal.

El proyecto artístico introduce la historia lejana y actual como referente, apoyo, sustento y argumento irrefutable dentro del proyecto en cuestión. Por lo tanto es necesario conocer a fondo o mínimamente, las partes y el funcionamiento organizacional del campo en el que se opera.

Podemos concluir que la actitud lleva al artista a reconocer la necesidad de contextualizar su práctica, el conjunto de circunstancias que rodean la acción que decidió emprender. La actitud motiva la interpenetración del artista con el contexto o la porción de la realidad que le sirve de modelo, porque la actitud no es otra cosa que la ubicación puntual del sujeto ante aquello que desea conocer, es la gradación de las relaciones de acercamiento entre el artista y esa realidad, así como las maneras proyectuales que ha definido para el proceso.

La estrategia actitudinal es parte del proyecto de construcción, de la obra, del público, de la teoría del arte y del artista ejecutante.

Para concretar, la actitud artística es un constructo personal, asentado en varios planos, el empírico experiencial que contiene las vivencias circunstanciales de cada autor, en él se basa la riqueza y tradición utilitaria de los manuales artísticos, porque contienen la adaptación específica en tiempo y técnica del saber general, son extensiones del conocimiento, complementos imprescindibles de la teoría total.

El otro plano de asentamiento de la actitud es el de las estructuras formales de representación, del área del dibujo y los sistemas y estrategias de significación.

La experiencia como actitud cognitiva comprende grandes expectativas de parte del autor, cuando la experiencia deviene, puede generar resultados coincidentes o no con las expectativas estratégicas de inicio, su aceptación constituye un conflicto para el artista, quien generalmente asume las consecuencias de su práctica experiencial como pruebas de verdad, pero no es así.

Los resultados de la experiencia tienen que ser confrontados con el universo extenso del panorama contextual vigente e histórico del dibujo, de no hacerlo sencillamente se asume una actitud ingenua o solipsista.

Un plano más es el que se refiere a la actitud como postura que se asume con el tema y su conceptualización, en esta práctica se contiene la postura epistémica del dibujante ante sus posibles modelos, su manera de mirarlos, pensarlos, interrogarlos conocerlos, dialogar con ellos. Pero también aquí se expresa la postura del dibujante ante el sistema del campo disciplinar del dibujo y ante la dimensión del acontecimiento dibujístico, en el proyecto como actitud podemos mirar la distancia o la inclusión del artista como voluntad al margen o como testigo involucrado en el proceso.

Aquella actitud que mira la creatividad como una manera de saber más, está equivocada, trabajar con la finalidad acumulativa de conocimiento nos lleva hacia una teoría de la información, en lugar del manejo creativo de ella. De todas maneras al trabajar los proyectos con una actitud coherente hacia el problema y su formalización y siendo analíticos en el proceso, nuestro conocimiento se expande, pero en un sentido significativo, conectivo y complejo, sabiendo que somos parte de una ecología intelectual a la que reportamos nuestra experiencia. 
Dentro de este círculo de cepos complejos, la experiencia como materia central de la actitud tiene un valor mayúsculo, mediante ella recobramos el asombro ante el contexto que se despliega a nuestro derredor, con ella la materia de exploración está asegurada.

Es mentira que en el ensueño de todo dibujante no haya grandes objetivos, solo las actitudes Zen en su estado profundo alcanzan el dibujar como el fluir simple del ser en consonancia con el universo.

Por eso decimos que todo proyecto de alguna manera es un plan para llegar a algún lado, es el trazo de un derrotero que el artista se ha formulado.

En el camino habrá de improvisar giros estratégicos para sortear las vicisitudes del proceso.

Es el proceso el que nos coloca frente a entidades densas, cuya masa gravitacional nos atrae y las convierte en presencias frente a las que tenemos que definirnos; nuevamente la actitud como postura epistémica.

Esas entidades de atracción se hayan dispersas como ya lo dijimos en el imaginario del artista, en su memoria semántica y experiencial en términos de Porlán.

Agregamos nosotros que la definición disyuntiva del dibujante se concreta frente a la Obra como presencia ontológica, producto de su voluntad y de la cual lo quiera o no, es responsable. Habrá de posicionarse frente a la teoría como marco referencial. De ahí seleccionará el material conceptual para aplicarlo en la construcción del proyecto y su discurso. También se asumirá dentro y frente a él contexto en el que se inscribe su proyecto.

Estas son tres causalidades a las que no puede escapar y por lo tanto frente a las cuales tiene que asumir una actitud y tomar una decisión.

El arte; especialmente el dibujo es una forma de poder, es esta una tesis de altísima gravedad. No solo poder ideológico, ni político, hablamos del dibujante como el que puede hacer la forma, al que no se le resiste la materia en su plasticidad, el mago que lleva en su capacidad el poder generar ensueños, alguien que tiene el poder de construir obras con nuestros sentimientos y llevarlos a recorrer el amplio espectro del gradiente dramático humano.

Cuando se renuncia al proyecto como un plan y se confía todo a la actitud relativizante y al azar, que sin duda se presentará como cuando arrojamos los dados; se está renunciando en gran medida a una forma de poder, en ese momento dejamos un tanto nuestro papel de configuradores.

Frecuentemente la actitud ha sido relegada al simple papel de elegir una disposición de ánimo, o una de las partes del fenómeno descontextualizado.

Recordemos; la actitud se refiere a la reflexión de pertinencia de las relaciones que el autor traza con respecto al contexto, los sistemas teóricos de significación propios, de su campo y anexos, la historia de la disciplina que ejercita, la toma de posición frente a sus modelos y la postura que asume frente a los otros, sus colegas o sus públicos.

El proyecto es un plan que da curso a la actitud, ésta en su forma más profunda implica el ejercicio atento del proceso para tomar decisiones, la actitud por si sola no puede ser sustituta del proyecto, es uno de los elementos naturalmente constituyentes del proceso cognitivo, pero no la única. Con la afirmación anterior renunciamos a los últimos vestigios 
románticos que sobrevaloran la actitud como sustituto de claridad epistémica en aras del ejercicio del principio de autonomía.

“...y en definitiva ha de procurar saber la proporción de todas las cosas naturales y artificiales [...]. Además de lo cual el pintor ha de usar también estas líneas proporcionadas con cierto método y regla, que no es otra que la utilizada por la misma naturaleza al realizar sus composiciones; para ello, en primer lugar, presupone la materia, que es algo sin forma, sin belleza y sin término, y luego en la materia introduce la forma, que es algo bello y con término. Lo mismo hace el pintor: toma una tabla, cuya cara posee solo una superficie o un plano sin belleza y cuyas partes no tienen fines ni términos, y le da belleza y término delineando y dibujando en ella un hombre, un caballo, una columna, y formando y puliendo todos sus contornos; y en definitiva imitando con las líneas la naturaleza de la cosa que está pintando, tanto en la anchura como en la longitud, corpulencia y grosor."63

Como lo señala Lomazo desde el pensamiento manierista barroco, el pintor es la voluntad de conformación basada en preceptos de orden.

Martin Heidegger menciona también la necesidad del reconocimiento de la obra como una cosa, esta es un ente, tiene presencia ontológica y como tal está constituida por sustancia y estructura. ${ }^{64}$

La escuela Pitagórica desde el año 500 a. c. señalaba a los números como entidades autónomas que se resisten al entendimiento, la teoría del tetraktis tiene ahí su asiento. ${ }^{65}$ Para el pensamiento griego del periodo clásico parece que la materia sí podía existir en estado informe, y parece que este pensamiento se encontraba bastante difundido y aceptado en la Europa barroca del 1600 porque se muestra en la cita de Lomazo.

Ligada a lo anterior tenemos la raíz etimológica de plástica, como materia dúctil, susceptible de ser moldeada.

El vacío es una noción central en la filosofía Chan, en su interior se considera la certeza de que al centro del origen se encuentra el vacío, este engendra el uno que no tiene forma. ${ }^{66}$

La postura actual de Herman Parret es la más compartida en el terreno de la semiótica y la estética. Parret nos dice que la materia no existe en ningún lugar careciendo de forma, toda la materia existe ligada a la expresión de la Physis organizada.

Estas son posturas encontradas, en realidad no interesa directamente en este análisis el esclarecimiento último de esta cuestión. Tenemos eso sí, una ruta reflexiva que se toca tangencialmente con estos problemas.

Formularemos un axioma bastante sencillo:

63 Freixa Mireia, Garriga Joaquim, Yarza Joaquín, editores. Fuentes y Documentos para la historia del Arte. Renacimiento en Europa. Barcelona: Ed. Gustavo Gili; 1983. (IV). P. 313.

64 Heidegger Martin. Arte y Poesía. México: Ed. Fondo de Cultura Económica; 1997. (Breviarios 229).

65 Chávez Pedro. Historia de las doctrinas filosóficas. México: Wesley Longman Addison; 1998. P. 32.

66 Cheng Francoise. Vacío y plenitud. Madrid: Ed. Siruela;1993. P. 45. 
La obra de arte es un ente que debe su existencia primigenia a la manifestación de una voluntad de producirla.

El devenir de la producción de la obra introduce elementos de deriva aleatoria en su curso, parece que el objeto producido se independiza de la voluntad del artista.

Aunque en este proceso se pueda dar una dinámica recursiva de causa y efecto, sigue existiendo una línea temporal, en donde la acción de la voluntad sobre la materia y la estrategia, son las acciones que deciden el curso del proceso. La obra en sus estados parciales solo indica e incita, es el artista el que decide.

Generalmente los análisis de este asunto se han orientado sobre todo a la consistencia matérica de la obra, en este aspecto se ligan directamente con una concepción plástica del fenómeno.

Pero ya las posturas visualistas expandieron el asunto hasta el terreno de interpenetración de las artes, ampliando la categoría taxonómica a todo el arte de cualidades visuales.

De manera que el artista no sólo construye obras plásticas sino también visuales. Tenemos aquí una primera extensión del fenómeno proyectual.

Agregaremos que la construcción de una obra se da no sólo en su materialidad. El dibujante decide y proyecta también sobre el carácter de la poética de su obra, traza una sintaxis narrativa para su discurso, también selecciona y adecua dentro de los sistemas de estructuración formales aquel que se corresponde con su estrategia. El núcleo de la obra sobre el que el artista toma decisiones de confrontación es mucho más amplio, rico y complejo, que el de la materialidad únicamente.

Sin ánimos de contradicción diremos en todo caso que, la plasticidad conformante dota a la materia, de un sentido significante, plástico dramático; usando para ello la aplicación de los sistemas abstractos de la región artística en cuestión, ésta es la definición de lo que se entendió como Forma Significativa.

Dicho sea de paso hoy el término materia de la obra, comprende mucho más que una definición orientada en un sentido físico, la materia del dibujo es la de los sueños, los cuestionamientos a su entorno, al lenguaje, las tensiones y angustias del dibujante, sólo por ampliar un poco.

La enseñanza de la pintura Flamenca, en Alemania Inglaterra y Holanda daría frutos en la Estética de lo Pintoresco y lo Sublime, Cozens, Turner, Ruskin, Van Ruisdael, Constable, Joshua Reynolds, William Gilpin integran una corriente de pensamiento ligada al Romanticismo que se concreta en la dramatización del discurso plástico, se basaba en los valores matéricos desde su selección y percepción en la naturaleza hasta su modulación en la superficie de la pintura.

Con lo anterior el dibujo asumió un giro estratégico en su papel como organizador del discurso y la forma dentro de las artes, se le exigieron actitudes sumamente flexibles, su función pero sobre todo su condición formal cambiaron sustantivamente.

Cozens, Delacroix, y John Ruskin no comparten una causa artística y filosófica pese a casi haber sido sincrónicos en la historia (Cozens les antecede un tanto) 

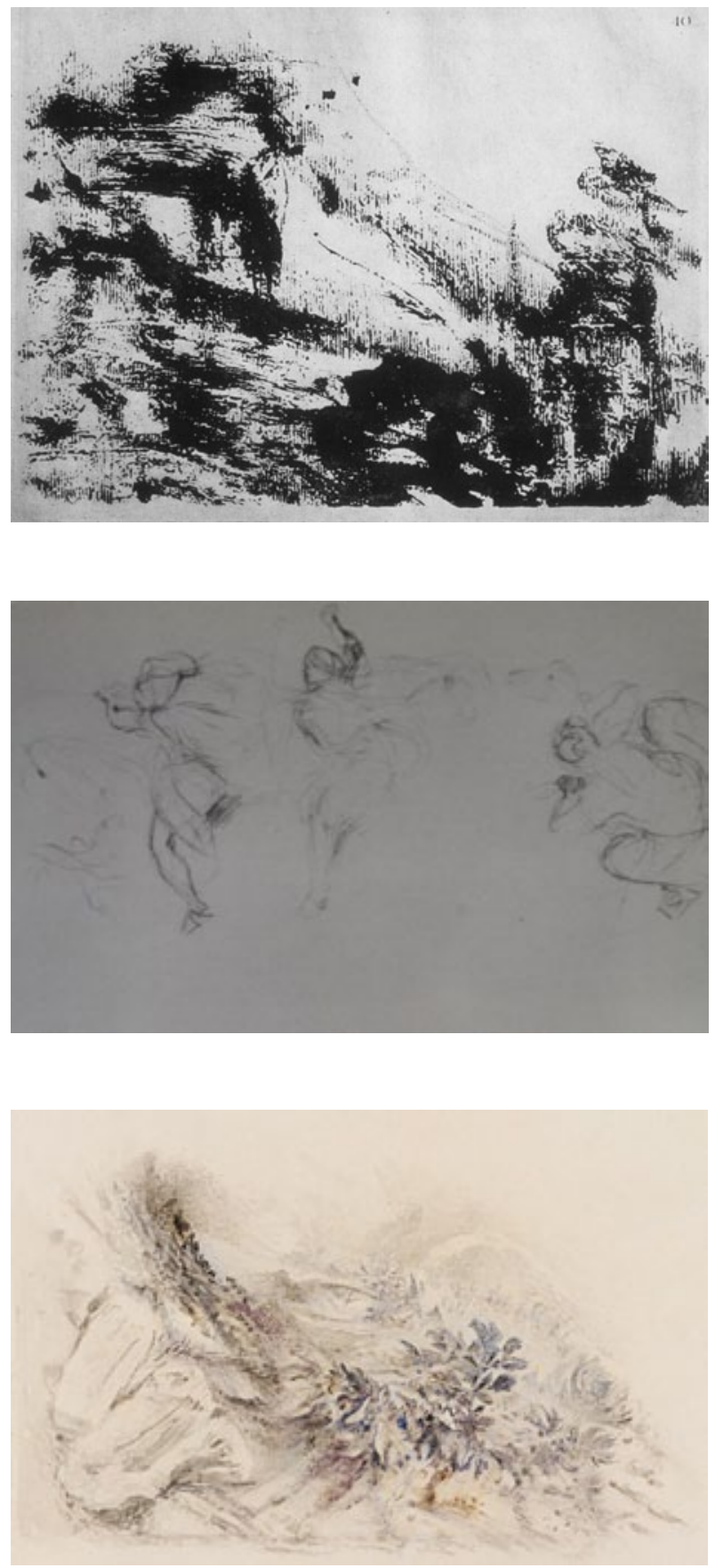

Fig. 12 Cozens, Delacroix, Ruskin. Apuntes
Pero en términos de un análisis de las formas de sus dibujos salta a la vista la cercanía que los emparenta; Para ello nos remitimos a sus cuadernos de dibujo. Fig. 12

En los tres casos la forma discurre por intenciones que rebasan lo mimético para profundizar en una postura que ya evidencia la gestualidad.

La valoración de la materialidad sugerente de la naturaleza junto a los temas de la vida diaria (lección del paisaje Holandés) y la ruina como signo subjetivo temporal, son la base central de la estética pintoresca, la materia se considera como continente de los sentimientos, la obra manejada con este sentido proyectual es la puerta de acceso al espíritu.

El Realismo, el Naturalismo del XIX, y el Romanticismo, basaron gran parte de su discurso en la expresión espiritual contenida en la materialidad plástica de la obra, en su cuerpo físico y en su dinámica agitada como vía del sentimiento.

Cuando Van Doesburg, Kandinsky, Franz Marc, Itten y tantos otros formularon su planteamiento de una gramática visual, introdujeron al arte sistemas de pensamiento que lo acercaron mucho más de lo que ya lo estaba al terreno de un lenguaje alfabético finito.

Detengámonos un tanto en el punto.

El dibujo dentro del arte es considerado una forma de expresión, así, en lo general. Me- 
diante el dibujo damos a entender multiplicidad de contenidos referenciales y descriptivos, o podemos generar sensaciones que agitan la región sentimental.

La respuesta a los mecanismos que operan al dibujar para transmitir un comunicado, surge en alguna medida del fenómeno de construcción de un código.

El estudio de la evolución de la escritura arroja elementos esclarecedores en este análisis. ${ }^{67}$

Hasta hoy, el dibujo no ha perdido su potencial de graficar un plan o transmitir un comunicado. A través de milenios el dibujo ha sido un sistema de narración y consignación de sucesos, de la historia o de la reflexión humana, un graficador de información visual. Esto conecta su práctica con la del origen de la escritura. El dibujo es una forma del pensamiento, concedámoslo, pero se hace necesario adentrarnos en el sistema de esa manera de pensar.

Los pictogramas, ideogramas y silabarios son antecedentes de los sistemas alfabéticos modernos, por ahora sólo decimos que estos son las estructuras más acabadas dentro de la evolución de la escritura. Lo son porque consisten en cadenas cerradas de números de elementos que no aluden directamente a ningún referente, sino sólo al carácter abstracto de ellos mismos. Así la letra "A" no hace referencia a ningún objeto, ser o situación del contexto, existe como abstracción inventada en el intelecto humano. A las cadenas alfabéticas se les complementa con sistemas sintácticos y gramaticales que determinan la combinatoria reglamentada de las letras.

La novedad consiste en que, mediante un número cerrado de elementos relativamente pequeño, que no alude a nada sino a si mismo, podemos construir discursos que con claridad hablan de todo lo que nos interesa del contexto, se puede incluso mediante ellos elaborar la poesía como expresión metafórica inefable del lenguaje.

Aquí notamos ya la conexión directa con la postura neoplasticista, bauhasiana y demás, de los movimientos modernistas. Cuando Kandinsky publica su Gramática de la creación ${ }^{68}$ cerraba una revolución que distanciaba el arte de la plasticidad del siglo XIX y lo colocaba de lleno en la revolución visualista del XX.

Todo el proyecto de organización de los artistas modernos de 1900 a 1930 en general, es la expresión conformante de sentido para un arte nuevo proyectado a la sociedad. Se intentó ir aún más allá al considerar e intentar un proyecto integracionista de todas las artes. La posible construcción de un sistema sinestésico de equivalencias lingüísticas de la pintura a la música fue una de sus grandes ambiciones, estas se basaron incluso en argumentos de la ciencia neurofisiológica.

Con claridad meridiana vemos en sus textos que son verdaderos manifiestos, en ese sentido, posiciones de renovación y superación de los viejos problemas con formulaciones proyectuales, estratégicas y programáticas.

El pensamiento plástico dramático buscó tomar del contexto aquellos valores matéricos

67 Morhouse A. C. La Historia del Alfabeto. México: Ed. Fondo de Cultura Económico; 1982. (Breviarios 160).

68 Kandinsky Vasili. La Gramática de la creación. El futuro de la Pintura. España: Ed. Paidós; 1987.

(Estética 10). 
para graduar el discurso sentimental en la obra, ahí entran las opiniones de Baudelaire sobre la pintura romántica.

Contrario a esto los movimientos integracionistas y neoplásticos pretendieron despojar el arte de su sentido dramático mirando a través de la naturaleza para llegar a la esencia estable del espíritu, las palabras de Mondrian lo denotan claramente.

"No debemos mirar más allá de la naturaleza sino, mejor, a través de ella: debemos ver más profundamente, nuestra visión debe ser abstracta, universal. Entonces lo exterior se convierte para nosotros en lo que efectivamente es: el espejo de la verdad. Para llegar a ello es menester que nos liberemos del apego a lo exterior, pues solo entonces sobrepasamos lo trágico y podemos contemplar conscientemente, en todas las cosas, el reposo."69

Las vanguardias formularon la disección de la obra de arte, la desarmaron en sus partes para estudiarla.

Con la introducción del Informalismo se inician las vanguardias de la posguerra, comienza entonces un proceso de desplazamiento del interés por el objeto hacia el proceso que lo genera.

El terreno de la vanguardia que apostó por la visualidad, se centró en el proyecto como necesidad de organizar la forma de la imagen bajo las leyes de la Gestalt y el lenguaje visual, se propugnó incluso un rigor compositivo y proyectual duramente basado en la geometría, frecuentemente se mencionaban los conceptos de composición, construcción contraconstrucción, las retículas o sistemas compositivos basados en redes de polígonos geométricos fueron una innovación dentro de la composición. Esta vía se prolongará en el arte geométrico, en la escultura urbana y en el minimalismo.

Dentro de esta postura el dibujo se vio duramente disminuido, los recursos de planeación y diseño de la obra retornaron a la utilización de la geometría, las maquetas y modelos a escala.

Los informalistas y expresionistas abstractos plantearon una postura diametralmente opuesta, intentaron colocarse al margen de cualquier proceso que tuviera que ver con la planeación rigurosa de la obra. En ellos el azar y lo aleatorio y la huella autógrafa cobraron capital importancia, paradójicamente las obras correspondientes adquirieron un potencial sígnico matérico enorme.

Aquí el proceso se remitía a las etapas en que la obra se concretaba como objeto. Se puso especial interés en bloquear la filtración de ideas antes del hacer la obra prácticamente; para ellos el hacer arrancaba en el momento del vacío reflexivo proyectual, cuando se iniciaba la descarga matérica en el campo pictórico.

Jean Dubuffet decía que el material y la herramienta tenían una voz propia que debía dejarse escuchar. Para él la construcción de la obra era una lucha tenaz entre el pensamiento las acciones configurantes y el material que discurría por su propio sendero y cuyas voces era necesario escuchar y no someter.

69 Mondrian Piet. Realidad natural y realidad abstracta. Madrid: Ed. Debate; 1989. (Serie Arte). P. 24. 
En esta situación el dibujo se fundió en alto grado nuevamente con la pintura, aunque podemos encontrar dibujos en el sentido particular de la acepción, en las obras y autores más representativos las diferencias tienden a integrarse. Ya expondremos en su momento, como aún en una situación tan extrema existen dibujos de varios autores en los que hay una evidencia de estudios de las formas y comportamientos del material. No es que estos dibujos planearan un cuadro en especial, pero sí que constituían ensayos para compenetrarse del supuesto proceso aleatorio que sobrevendría en el momento de elaborar una obra final. El dibujo aquí de una u otra manera mantiene una función gobernadora del proceso en alto grado.

Tenemos entonces la postura que considera la materialidad de la obra y su organización como un objetivo del proyecto plástico, en ella el dibujo tiene una función primordial. Las posturas neoplasticista y elementarista, junto con otras, desembocaron en el planteamiento visualista, pero seguían utilizando una dinámica de configuración basada en el trabajo mediante proyectos que antecedían a la obra. Todos ellos como ejemplo del panorama artístico del siglo XX en su primera mitad, aplicaron sin lugar a dudas una postura que consideró necesaria la sistematización previa de la materia y la forma visual dentro de una dinámica proyectual.

El Informalismo y el Expresionismo Abstracto, aunque en menor grado, fueron movimientos que implicaron una utilización del dibujo integrado al cuerpo pictórico, pero en ellos el dibujo aparece frecuentemente a manera de ensayo de situaciones propias de la ejecución final. Incluso dentro de este movimiento las definiciones de cada autor serán muy variadas, lo cual coincide con el hecho de que realmente nunca formaron un grupo compacto.

Las posturas que encontramos son tan diversas como la de Hartung, quien en ocasiones dibujaba con los ojos cerrados, o el caso de David Smith, para él, dibujo y línea no deberían de imponer su propio curso, el dibujante tenía que dictar el concepto y hacer que la forma lo expresara, para él este era el trazo más estricto. ${ }^{70}$ Jackson Pollock se encuentra a medio camino entre el controlar el flujo matérico que cae sobre la tela o permitir su propio carácter, ya que en sus acciones pictóricas no tocaba propiamente la superficie de la tela con la mano ni con herramienta alguna, pero él mismo decía que con suficiente práctica se podía llegar a comprender esta situación y manejarla apropiadamente.

Ambas posturas proyectuales, (la de conformar la materia y la de dar curso a su devenir) tienen su parte de razón, y no son incompatibles en su totalidad.

El concepto de regularidad conformante tiene una larga tradición, la composición se entendía como estabilización de las formas y los elementos, la regularidad y la búsqueda de variantes dentro del sistema, siempre sin llegar a derrumbarlo.

Cuando el artista intenta dar forma a la materia bajo el proyecto, finalmente acepta que la obra terminal guarda una distancia con respecto a la idea inicial y que no existen proyectos exactos al cien por ciento. En aquellas situaciones en las que el dibujante decide dar curso al fluir del proceso y la materia, observa que tanto materia como las partes del proceso manifiestan maneras o tendencias recurrentes en su suceder y al autoconformarse,

70 Abrams Harry N. Abstract Expressionism. Creators and Critics. An Anthology. Nueva York: Clifford Ross Ed. 1990. 
en ese momento está detectando patrones regulares de tendencia o atractores compositivos, de manera que lo proyectual como pensamiento comienza a permear la acción.

De lo anterior se desprende el que la formulación de estructurar la materia y la forma como parte de un proyecto está más ubicada en el terreno de la actitud que en el de las definiciones exactas. Es finalmente el autor el que decide el cause mas estructurante dentro de su proyecto o la integración mayoritaria de elementos aleatorios en el dibujo, él decide si lo fortuito en la estructuración es un caso o la constante.

\section{II-6 PROCESO Y PROYECTO EN EL DIBUJO}

"Hay algunos que emplean el oro sin miramiento alguno, creyendo que la abundancia de él da majestad a la pintura; nada de esto apruebo; antes bien si se me ofreciera pintar la Dido de Virgilio que tenía el carcaj de oro, el cabello sujetado con cintas de lo mismo, los ceñidores y guarniciones del vestido de oro, los frenos de los caballos que tiraban de su carro de oro igualmente, en fin en todo resplandecía el oro, lo que haría sería imitar este metal con los colores, y no poner nada del verdadero, pues entonces heriría en la vista de los que la mirasen la reverberación de tanto oro."71

No poner las cosas, figurar que las cosas están, no presentar los objetos, re-presentar los objetos. No es posible repetir un suceso en el tiempo tal y como sucedió en detalle, pero es posible representarlo en el dibujo.

Aclarar el proceso mostrando las huellas que el autor deja en el dibujo a lo largo del proceso. Esta es la distancia que separó al dibujo, como ficción del pensamiento occidental racional; de aquella concepción en la que tenía una presencia totémica, mágica, y en la que las representaciones eran creaciones nuevas y cíclicas del universo.

"Dibujar es fundamentalmente re-presentar, volver a hacer presente, visible, aquello de lo que habla el dibujo...; solo podemos hacer una abstracción si somos capaces de generalizar una experiencia y sacar conclusiones de muchas de sus representaciones para realizar una que de idea de aquellos rasgos que son comunes a todas ellas... la acción más desordenada deja siempre huella de su propia acción, nos retrotrae al momento mismo en que la realizamos; cada uno de sus trazos hace evidente la velocidad, las dudas y la ansiedad con que fueron ejecutados, nos los re-presentan nuevamente. Visualizan el tiempo mismo de la acción que lo realiza. La acción de dibujar nos representa a nosotros mismos en la acción de representar, clarifica los itinerarios de nuestra conciencia, haciéndose evidente ante nosotros mismos." ${ }^{2}$

Nuevamente el asunto de la representación nos enfrenta al dibujo como una manera de organizar y graficar conceptos. El dibujo debe ser trabajado hasta que contiene y muestra la idea que lo anima, no más, no menos. Antes de eso estaría incompleto y después sería redundante.

Los dibujos plasman el ideario representado, en ellos se muestran los sistemas que organizan la representación y el relato propuesto.

71 Battista Alberti León. Tratado de pintura. México: Universidad Autónoma Metropolitana; 1998. (Colección Ensayos). P. 113.

72 Gómez Juan José, et al. Las lecciones del dibujo. Madrid España: Ed. Cátedra; 1999. P. 49. 
En las academias, cuando se aprendía a dibujar, una parte inicial del proceso se basaba en el trabajo sobre las carpetas de grabados o dibujos de otros autores ya reconocidos, se recurría también continuamente a las esculturas griegas que toda academia atesoraba. En las etapas terminales de la educación el estudiante accedía al estudio de los modelos vivos o del natural. Tanto los modelos que dibujaba, como los sistemas de construcción que se le enseñaban constituían sistemas de representación, porque eran la expresión formalizada de alguna práctica que en su origen enfrentó reiteradamente al artista con el modelo natural, hasta que generó ese proceso de reducción y estabilización formal. Por eso cuando el estudiante enfrentaba finalmente los modelos del contexto, llevaba implícito un sistema de representación formal previo al acto de dibujar, los dibujos resultantes se parecían más al canon aprendido que al modelo trabajado, se estaba dibujando un modelo de representación y no el modelo natural.

Hoy día la amplitud de los esquemas de representación es enorme, las maneras en que se filtran a nuestro pensamiento en imágenes son múltiples y bastísimas. Las representaciones del dibujante actual son en mucho representaciones basadas en representaciones anteriores, lo que hemos llamado imágenes de segunda y tercera generación.

Aquí hacemos una intervención pertinente. Los procesos originales de representación, o sea aquellos en que se reconoce una primera edad, no fueron acaecidos en ciclos temporales para nada cortos, ni son privativos de un individuo.

Hablamos de procesos evolutivos largos y complejos de construcción del lenguaje y sus códigos. Primero; todo sistema de representación es un producto social, no fue creado ni formulado por un solo individuo, significa el esfuerzo de una o varias comunidades a través del tiempo.

Esos sistemas de representación eran sucedáneos del mundo fenoménico, su construcción implica una relación vital y experiencial, por tanto la fuerza de impacto en el intelecto de sus usufructuarios es mayúscula, en su expresión y uso les va algo más que una imagen simple.

Estas representaciones mantienen el carácter de evocación, son tomadas por el espectador no como mentiras, son aceptadas como realidades que tienen la calidad vital del mundo contextual en el que habitamos, la pintura China clásica sería el extremo de esta postura, para el pintor en el lejano oriente la pintura no era un objeto formal, constituía un lugar en el que la vida era posible, en el se tenía que respirar y escuchar como en cualquier paisaje, la tinta debía de tener tono semejante a la vida, aliento vital, y la línea debía contener el nervio y hueso de las cosas.

El determinismo, aunado a la sobrevaloración de la ciencia como manera de comprender el mundo, generó el exceso de racionalismo en el pensamiento artístico. Los sistemas de representación del dibujo se tiñeron aún más de un racionalismo escéptico. El primer cuarto del siglo XX asistió a una penetración del arte por la filosofía y sistemas científicos. La gramática de las artes, la sintaxis de la imagen y los fundamentos del diseño, expresan una postura enmarcada por las formas de representación ligadas a las ciencias.

En los últimos ochenta años lo menos, el dibujar se ha convertido cada vez más en una disposición agrupada de elementos, intentando generar relaciones significantes entre 
ellos para plantear lecturas diversas del discurso, esta es una estrategia de representación que trae como consecuencia la inclusión de maneras del dibujo que pertenecen a campos diferenciados del artístico, con ello se valida su uso en tanto sirven en la construcción del sentido, por eso actualmente la representación en el dibujo y sus estructuras de formalización son tan amplias como campos del dibujo existen.

A este fenómeno como tipicidad de la posmodernidad ya nos hemos referido al analizar la estrategia de cita, plagio y apropiación.

Se entiende ahora la distinción entre la representación basada en la construcción de estructuras formales estrictamente dibujísticas y la representación como un estiramiento del concepto que abarca nexos con estructuras sígnicas y sintácticas varias, en donde el referente dibujado contiene una carga simbólica que rebota hacia los elementos que integran la imagen. En esa medida se construye un proceso de multiplicación dentro del cual el dibujo tiene que contemplar la necesidad de incluir y si es posible integrar en una estructura representacional todos esos factores.

Hoy día dibujar es una práctica compleja, porque al desaparecer las estructuras únicas y estables de representación, se tiene que saber hacer el total de las prácticas involucradas en toda la historia del dibujo, de ahí que ahora veamos cada vez menos portentos del dibujo, y cada vez más estrategas del dibujo.

El artista de hoy muestra una urgencia por querer decir, le angustia el ser escuchado, esto lo lleva a disponer objetos y partes de una imagen, confiando en que su necesidad de decir sea comprendida; no toda disposición de partes es una representación ni un discurso, hace falta un centro conceptual formalizante para que la estructura se ordene y tenga clara la tendencia de estabilización, ese vínculo conceptual no puede ser generado al azar o por el objeto mismo, solo la voluntad de representación puede generar el norte de la estructura y sus grados de dependencia y organización, las funciones atribuidas a las formas y las leyes de interacción.

Resulta que lo que el dibujante supone ser su repertorio de estructuras representacionales, es en realidad un conjunto ecléctico formado por fragmentos dispersos y disociados de sistemas de representación, partes que ya no operan con la lógica y capacidad constructiva, porque están escindidas del sistema que las articulaba.

La representación es una parte fundamental dentro del proceso de búsqueda de la coherencia conceptual del dibujo, concreta su expresión mediante sistemas de formas y maneras operativas de las mismas:

"Y puesto que aquí encaja muy a propósito un precepto de Miguel Ángel, voy a referirlo sencillamente... Y en este precepto me parece que consiste todo el secreto de la pintura, puesto que la mayor gracia y apostura que una figura puede poseer está en que demuestre moverse, lo que los pintores llaman furia de la figura. Y para representar este movimiento no hay forma más adecuada que la de la llama del fuego, la cual según Aristóteles y todos los filósofos es el elemento más activo de todos y cuya forma es la más apta de todas para el movimiento porque tiene el cono y la cúspide aguda, pare- 
ciendo querer perforar con ella el aire y ascender a su esfera, de modo que cuando la figura tenga esa figura resultará bellísima... Y aún esta puede observar dos maneras: una colocando el cono de la pirámide, que es la parte más aguda, hacia arriba, y la base, que es lo más amplio de la pirámide, colocado en la zona inferior, como el fuego; y entonces en la figura hay que exhibir por abajo amplitud y anchura, como en las piernas o ropajes, y por arriba hay que sutilizarla a guisa de pirámide, mostrando un flanco y haciendo escorzar el otro, haciendo que el cuerpo se tuerza y un flanco se oculte y el otro resalte y quede al descubierto. La figura que se pinta puede estar también a guisa de una pirámide que tenga la base y zona más amplia orientada hacia arriba, y el cono hacia abajo: y así la figura aparecerá ancha en la parte superior, o enseñando ambos hombros, o extendiendo los brazos, o mostrando una pierna y ocultando la otra, o de otro modo similar, según el avisado pintor juzgue que le quedará mejor."73

La anterior es una cita bastante extensa, pero hemos querido incluirla porque nos muestra claramente lo que sería un sistema de representación, con un repertorio de formas que se basan en la observación y generalización de principios que tocan esferas externas al dibujo, pero que retornan a su interior en un código establecido. Formula también las leyes que rigen su actuación y aclara que el juicio del pintor es en última instancia el que decide.

La representación es así un acto muy elaborado de evocaciones vividas y trasladadas a estructuras formales, estas se pueden descifrar porque se encuentran en cierta medida dentro del reservorio de imágenes y signos que constituyen la memoria social preexistente. La existencia actual de un conjunto de imágenes patrimoniales de toda la historia humana, paradójicamente ha traído la disociación de un vínculo fundamental en la secuencia de representación, el dibujante ya no requiere de plantarse frente a la cosa modelo para traducirla a formas y estructuras; estas ya están dadas.

Para ir redondeando diremos que la representación es un proceso de abstracción, la separación de una cosa en sus partes para mejorar su análisis. Esta abstracción tiene como objetivo la construcción de estructuras que en el dibujo consisten en sistemas para rearmar la realidad y presentarla en el dibujo objeto.

En un plano primario la representación se puede dar como un acto que incluye las partes del modelo o modelos representados en el dibujo, para que la mirada del espectador establezca la lectura asociada de los elementos de la sintaxis planteada, en alguna medida los modelos o sus partes no son afectadas en su forma somática, son dispuestas o mimetizadas en lo posible por los trazos del dibujo, la representación se consuma en la presentación sumativa de los elementos ligados por una intencionalidad sígnico semántica.

En otro sentido la representación es una estrategia de elaboración de sistemas de formas abstractas, que se entiende, no son la cosa representada sino su icono, sustituto o sucedáneo.

Si la representación es un acto; éste se subdivide en momentos que revelan la naturaleza de su mecánica. Es una cadena procedimental que refleja la postura epistémica del dibujante.

73 Freixa Mireia, Garriga Joaquim, Yarza Joaquín, editores. Fuentes y Documentos para la historia del Arte. Renacimiento en Europa. Barcelona: Ed. Gustavo Gili; 1983. (IV). P. 314-315. 
En el momento de exponer nuestras reflexiones sobre el acto dibujo en el último capítulo de este trabajo nos dedicaremos a realizar una serie de extensiones más a fondo sobre la categoría de representación, como paso necesario para acceder a la dinámica de lo que el acto dibujo significa.

Lo primero que acontece es el enfrentamiento con el modelo o el contexto, la vivencia, el modelo penetra en la mente y psique del dibujante de manera perceptual y cultural hereditaria, en nuestra intencionalidad consciente se disparan y asocian imágenes psíquico formales que son el impulso temático o el centro del conflicto dramático de nuestra representación. El enfrentamiento experiencial del dibujante con el modelo y el contexto no es una vivencia fugaz, generalmente el dibujante busca la prolongación de esa experiencia en la que establece vínculos muy complejos con el modelo, lo busca una y otra vez, acude al paisaje un sinnúmero de ocasiones hasta que logra un estado de comprensión o de compenetración con él. Como dibujantes recurrimos al modelo hasta que lo hemos penetrado, hasta que creemos haber comprendido su sentido existencial y filosófico; pero sobre todo cuando pasamos del ámbito temático a la problematización del modelo, y lo resolvemos en estructuras de formalización que dan cause al sentido significante que elaboramos.

En ese ir y venir del dibujante hacia el modelo se genera un pensar, pensar el modelo intentando comprenderlo. Pensar el modelo antes de intentar nada, sentirlo, dejar que se acerque y nos envuelva con su ser.

La representación continúa, cuando poco a poco imaginamos la conversión de nuestra experiencia con el modelo, hacia posibilidades de concreción mental, en ese acto lo reconstruimos en nuestro ideario, vuelve a ser pero en nuestro pensarlo, en ese plano de existencia el modelo no es el mismo, ahora tiene aquello que decidimos anexarle, lo que quisimos reducirle, el carácter que le modificamos, lo hacemos aparecer y vivir en un espacio que no es el de su procedencia, este espacio puede ser totalmente carente de referencias de cualquier tipo, o puede ser puntual y específico en extremo para generar dislocaciones en la lectura.

En la representación rearmamos el mundo, pero lo hacemos construyendo estructuras formales y estratégicas de representación.

La inclusión de imágenes simples en la mente constituye un rudimento de representación. Está basado en el material perceptual pero no profundiza en la afectación de lo percibido como información ni lo trasciende con la creación de formas gestálticas estructurales. La abducción como acción creativa se introduce en el acto de representación y ésta puede darse en variaciones de nivel que llegarán incluso a la modificación de los sistemas de representación. Por eso es que la estrategia de colocación simple de elementos en el dibujo reviste en el mejor de los casos una añoranza de corte elementarista.

Cuando pensamos al modelo para representarlo, aparece en nuestra mente con el carácter formal que decidimos, y que en parte no es nuestro sino del ideario colectivo. Simultáneamente ya lo estamos trazando, el dibujante suele trazar mientras piensa, al trazar comienza a presentar lo representado, el momento de la configuración alcanza el plano fáctico.

El paso del plano experiencial y la vivencia en el contexto y frente a los modelos es precedido por el sentido profundo de la representación. Este acto implica no solo hacer presen- 
te de nueva cuenta lo visto vivido ahora en la imagen; sino la elaboración de conceptos y estructuras de formalización que se desprenden de la postura epistémica asumida por el dibujante. Estas estructuras formales se superponen a la visión y concepción del modelo y del contexto tal y como lo percibimos, son por eso una nueva realidad, una ficción que se transparenta sobre la realidad perceptual primera, la imagen de representación es una alteridad ya del contexto y el modelo que la origina, es la construcción de una realidad inventada porque es posible vivirla y sentirla, aún y cuando se sabe no es la realidad contextual primaria. La representación es la estrategia de invención formal que puede conducirnos a una visión de formas sumamente diferenciada de la cosa modelo o contexto inicial, o bien a una imagen más o menos asociada con estos.

Concebimos la representación como una estrategia de construcción de sistemas de la forma en el dibujo y de las acciones y estrategias que soportadas en la actitud generan relaciones de identidad y conocimiento del contexto.

El sentido significante de la representación no se agota solo en la inclusión de los valores subjetivos y espirituales del artista, no es solo el querer decir, es ante todo la construcción de modelos formales que constituirán formas del pensamiento eidético y que en adelante nos permitirán pensar el mundo de nuevas maneras. La representación no es el querer decir, sino la estructura formal con que, y como se dice.

Podemos considerar el dibujo objeto, como la representación, o pensar en ella como un proceso cognitivo que se sucede en la mente del dibujante; o que bien se prolonga en el hacer la obra, ese es el gran momento, la Obra final es el término del proyecto, ¿porqué negarlo? Podemos reconocer la importancia del proceso pero nada como el término de la batalla, y más, si el resultado nos favorece y fue el planeado, pero ¿cuantas veces presentamos lo fortuito, el cuadro que nos encontramos como si fuera el que planeamos?

Nos deleita asumir el arte como forma de poder, el poder que da la seguridad.

El artista parte de la confianza, confianza basada en el saber que sabe lo que sabe, poder consciente de saber que podemos hacer lo que otros no pueden, potencial que lleva dentro y la capacidad que ha cultivado, ¿para que? Precisamente para ese momento, el de la ejecución configurante.

Pero antes del acto final están los entreactos.

Uno de ellos es el de la prefiguración, momento que se encuentra posicionado entre la ejecución configurante de la obra terminal.

El pensamiento proyectual del dibujo y dentro de él la prefiguración, no corresponden solamente al campo de imaginar las imágenes que integran el desarrollo temático del cuadro, tiene que ver también con la planeación de las calidades y cualidades matéricas deseadas. El dibujo no solamente agrupa figuras y toma información de los modelos, también regula la cualidad matérica de la obra final, desarrolla el tacto matérico y visual de manera que permite una concepción bastante certera de la obra y sus cualidades sinestésicas aún en el plano de la imaginación.

Quizá estemos tratando una de las funciones más aceptadas del dibujo, la de constituirse en herramienta de prefiguración de obras posteriores, pero de cualquier modo es impor- 
tante ubicar esta función dentro del plano general del proyecto y el suceso del dibujo.

En los movimientos integracionistas fue condición fundamental la postura proyectual en las artes, los artistas como Kandinsky realizaron escenografías, otros como Doesburg proyectaron arquitectura. El anhelo de integrar las artes llevó al dibujo a acercarse con disciplinas que implican un rigor proyectual muy alto, esto originó que la vena prefigurativa del dibujo se reactivara.

La prefiguración en el dibujo se complementa con disciplinas preicónicas como la geometría y la composición.

Después de las propuestas románticas de flexibilizar el dibujo o las búsquedas de Cozens y Turner, o las litografías de Daumier, el dibujo se cargaría fuertemente de un carácter rectilíneo y geometrizante dentro del Neoplasticismo y el Integracionismo, los útiles del dibujo geométrico cobraron relevancia.

Con la exposición del proyecto para el vitral Gran Pastoral de van Doesburg se muestra la secuencia rigurosa y ordenada del proceso proyectual típico de estos movimientos. Fig. 13

Primero realizó un estudio basado en los sembradores de Millety de van Gogh, con algunos apuntes de posibles simplificaciones. Se aprecia en el segundo dibujo la síntesis basada en líneas verticales y horizontales con contrastes básicos de diagonales. El tercer dibujo ya es una reducción de la figura a los módulos que corresponden con la estructura de los cortes y soporte del cristal y las líneas del emplomado.

Frente a unas imágenes tan claras es poco lo que se puede agregar. Se muestra nítidamente la secuencia del pensamiento y el nacimiento de la obra en su prefiguración.

Antes de los cambios que se avecinaban con el Informalismo, el dibujo en el Neoplasticismo y el Elementarismo, en la Secesión de Viena y la Bauhaus tuvo un carácter proyectual prefigurativo referido a las artes que intentaron aglutinar, el proyecto se realizó para exteriores, interiores, muros, ventanales, techos, unidades habitacionales
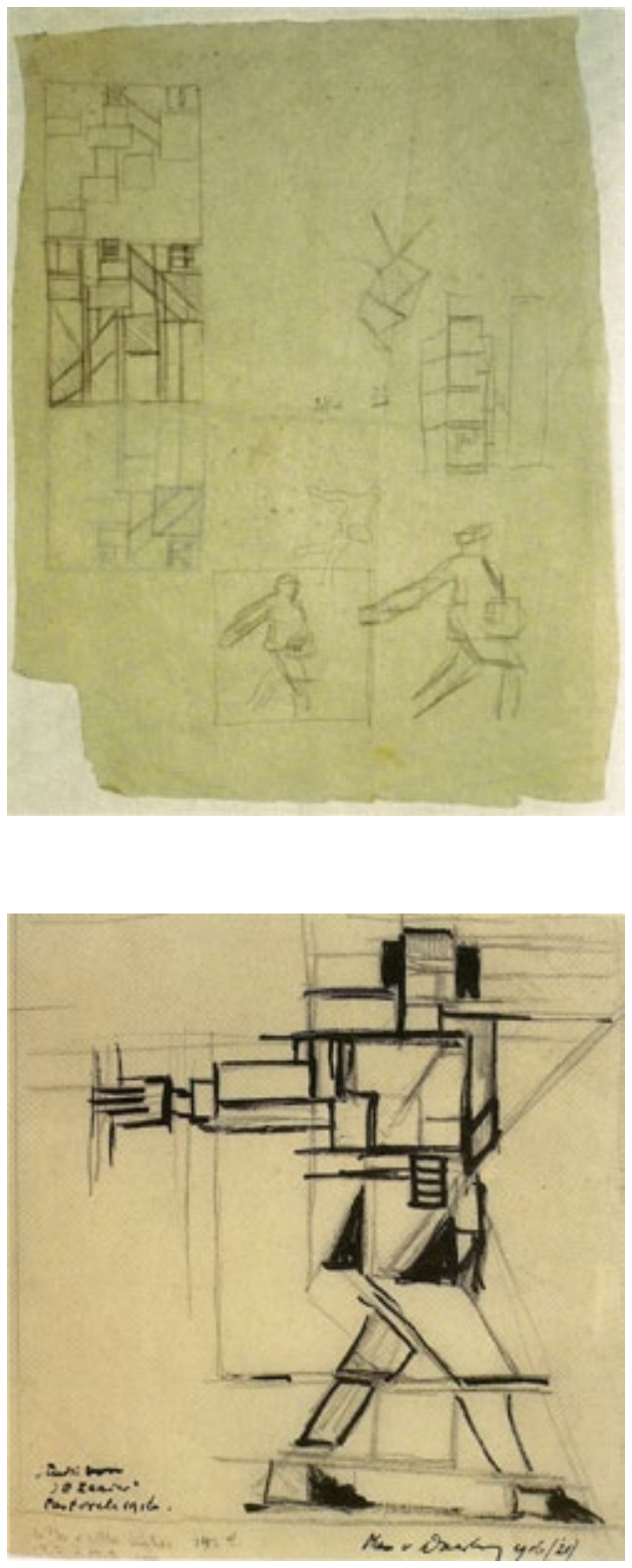

Fig. 13 Doesburg, Bocetos "Gran pastoral" 

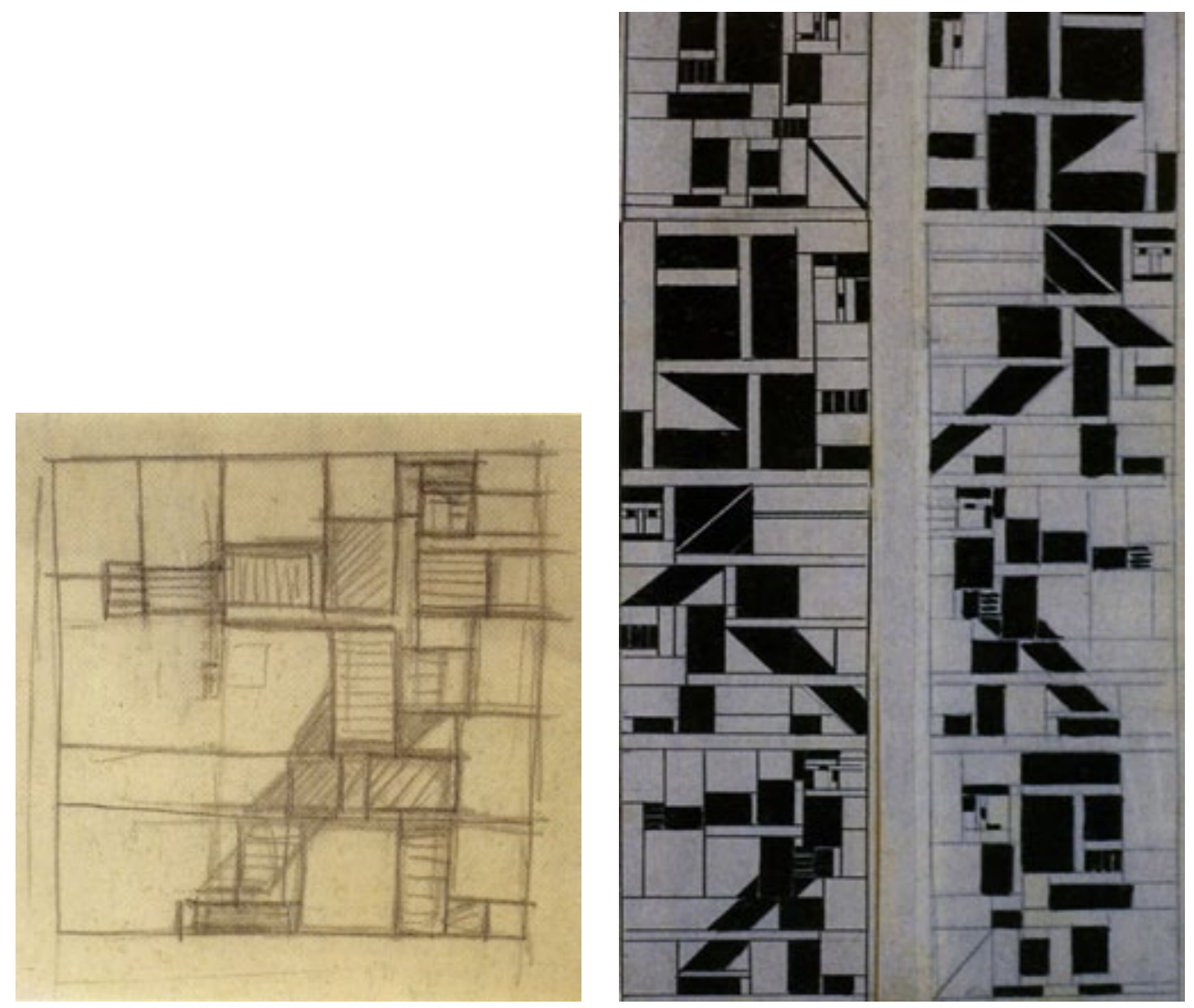

Fig. 13 Doesburg, Bocetos "Gran pastoral" (cont.)

etc. Los proyectos fueron dibujados aplicando las estructuras de representación formuladas por ellos mismos manteniendo una coherencia integral. Estos sistemas prefigurativos tienen un carácter ambivalente; por una parte se basan en estructuras elementales y sumamente reducidas en su cantidad de partes, pero eso determina que la búsqueda de combinaciones se abra sorprendentemente.

Dos décadas después, con el desplazamiento de paradigmas que se vivió, la función prefiguradora del dibujo se vio disminuida, pero el segmento configurante de la acción dibujística se convirtió en el gran operador de la acción pictórica y aún escultórica.

En los aspectos fundamentales de una definición epistémica el dibujo se integró al cuerpo de la pintura.

Ya que estamos analizando las etapas del pensamiento dibujístico y dentro de ellas la prefiguración, es interesante el caso de Jean Dubuffet. Reviste importancia porque experimentó con imágenes realizadas por gente demente y presidiarios, utilizó este material para generar una estrategia de trabajo como es sabido, lo que le interesaba era la manera en que esas mentes distintas veían y dibujaban la realidad, para Dubuffet el arte debía de ser una experiencia violenta como lo fue el arte elemental primitivo, basándose en 
maneras de ver alternas, compartió el pensamiento que prefigura el carácter sígnico y formal del dibujo. Trató de penetrar la mente de esos estados alterados, para vislumbrar maneras genuinas de ver el mundo y trazar la imagen, deseaba incluso una pintura sin color, compuesta de un barro o cieno primordial en el que se hundieran las incisiones del dibujo, honestamente deseaba volver a ver el mundo con una mirada nueva.

En el Informalismo y Expresionismo Abstracto subsistió la práctica de realizar algunos trabajos que me permitiré llamar experimentos de prefiguración. Son lienzos o papeles que no corresponden a ningún cuadro que a futuro se fuera a realizar, pero en ellos se advierte un estudio y análisis del comportamiento de los materiales al ser aplicados aleatoriamente en el soporte. Estos trabajos constituyen partes de un experimento porque metodológicamente fijaban las variables del proceso, las sometían a una activación práctica y realizaban un seguimiento de sus comportamientos, obteniendo así una posibilidad de anticiparse a las situaciones que se desencadenarían en la realización de la obra definitiva. Ya mencionábamos en el inciso anterior que estos trabajos constituyen una extensión del campo de representación de los pintores, les permitieron prefigurar resultados en un sentido muy general. Pero estos estudios son testigos incómodos que señalan la existencia menor de una necesidad proyectual representativa. Fig. 14

El cuadro de gran formato significaba el hacer definitivo, el proceso y la experiencia vivencial, la lucha contra la obra, o el estado mental de arrobo en el que desaparece el objeto y el lienzo es la esfera de la existencia.

Se usó el concepto de all-over para definir una Pintura que transcurre en toda la superficie.

Es por excelencia un sistema de composición no relacional. Ya que no toma en cuenta el perímetro del soporte, sus relaciones de estructuración entre los elementos, no
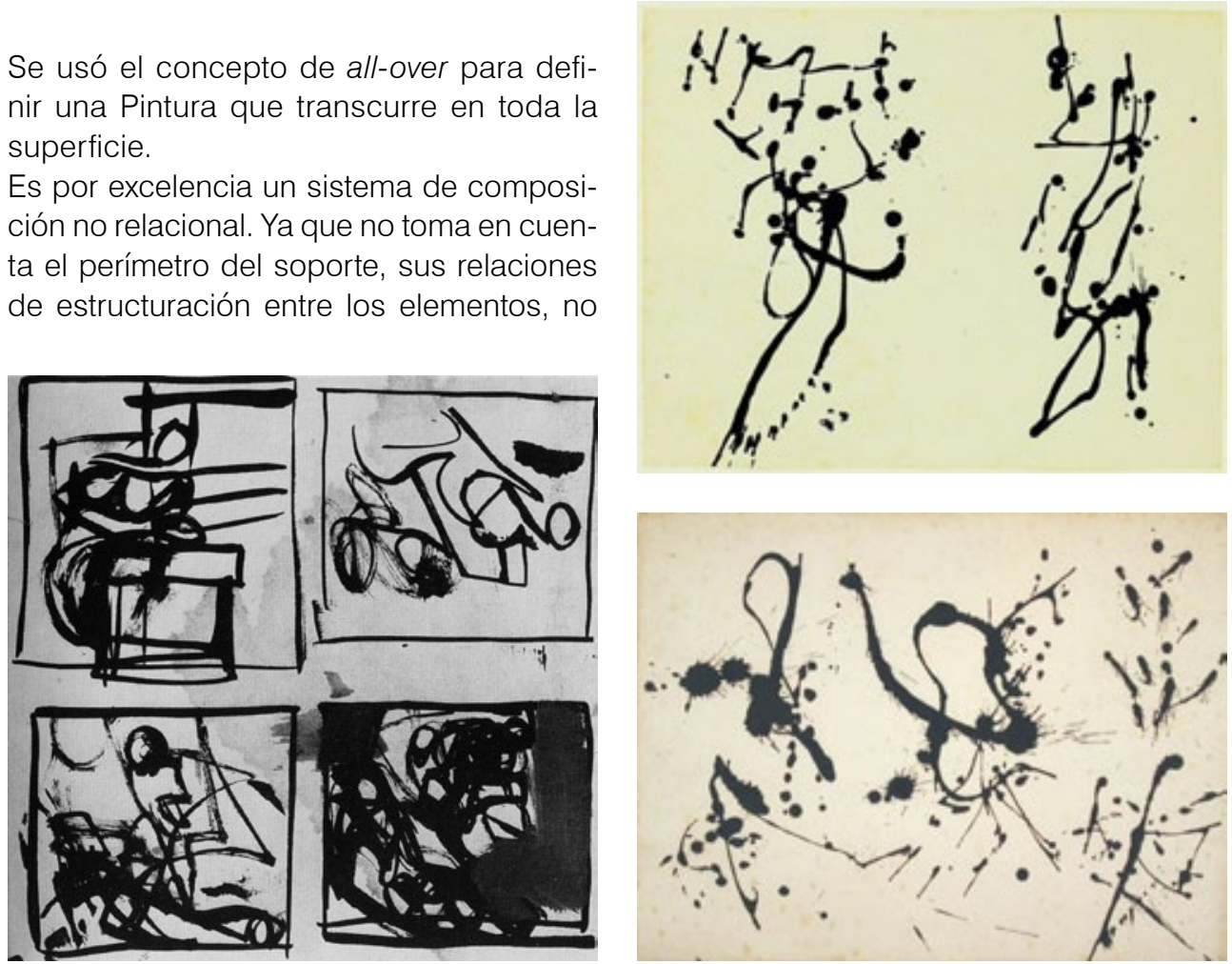

Fig. 14 Kline, Pollock. Estudios 
dependerán del carácter geométrico y poligonal del plano.

Es una Pintura que fluye con intencionalidad orgánica o cósmica sobre toda la superficie, se contrapone a los sistemas de composición relacional, que tienen una esencia distributiva y posicional.

El all-over será una noción espacial más que una definición. El expresionismo abstracto lo utiliza en la pintura y el dibujo. Convierte así el soporte en un campo subjetivo, metafísico y filosófico.
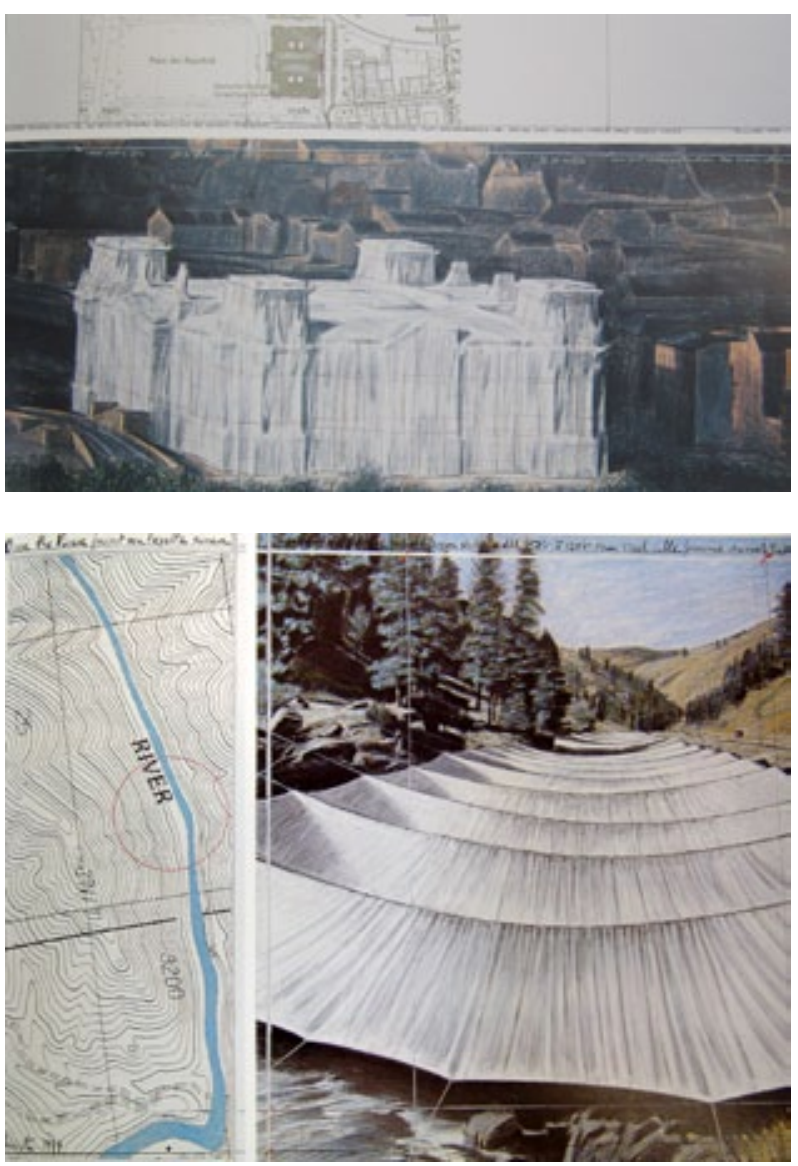

Fig. 15 Christo Javacheff. Proyectos

Pasado el furor del abstraccionismo, los artistas con más calma retomarán las prácticas prefigurativas del dibujo, los bellos proyectos de Christo Javacheff son una lección de organización conceptual mediante el dibujo, expandido hacia el collage y la fotografía, particularmente la obra de Christo es un ejemplo de organización del pensamiento artístico, en él podemos apreciar cada una de la partes de su historia personal y de cada proyecto. Fig. 15

La descripción de la cosa corresponde a la configuración, ésta se complementa con la descripción de la obra que se busca, esa es la prefiguración, el acomodo de las partes, no del modelo sino ya de la obra, esto requiere la conciencia sencilla pero precisa de saber el momento en que se haya el dibujante. La descripción de la cosa modelo puede contener las características morfológicas del modelo, o puede ser un resumen violento de ellas pero se debe a la necesidad de representar el modelo y el contexto, al prefigurar nos sabemos en el plano de la mentira del dibujo que tiene presencia paralela al modelo. Aquí la línea de separación es débil y quizá sea una membrana sumamente permeable que necesita de toda la entereza reflexiva del autor.

Coincidiendo con Gómez Molina decimos que el dibujo mantiene el papel de ser un modelo formal de representación y también el de ser el elemento más activo en la prefiguración de la idea.74

74 Gómez Juan José, et al. Las lecciones del dibujo. Madrid España: Ed. Cátedra; 1999. P. 26. 
La prefiguración de los dibujos actuales parte ya en muy pocos casos de la relación directa con el modelo somático, natural o contextual. Es frecuente que el artista se auxilie o recurra para sus proyectos a fuentes de imágenes de segunda línea, estas provienen de campos diferentes y son la representación de una experiencia previa, resumen ya un modo de ver y están construidas con una estructura de representación alterna.

Es válido utilizarlas aunque vuelvan el dibujar algo muy difícil y complicado, porque el fin de dibujar es crear sentido, hacer discurso coherente, esa es la razón que subyace en el dibujar, especialmente en la prefiguración.

Tendemos a creer que el sentido se construye al configurar la obra, pero una postura fenoménica nos muestra que eso también se da a la hora de prefigurar un proyecto.

Claro que la realización última de la obra construye el sentido al que asiste el espectador pero este se funda en una claridad anterior, que será el timón del viaje de la acción del hacer la obra.

En términos fenoménicos proyectuales la especificidad de la obra del dibujo inicia con su prefiguración, existencia del dibujo en estado mental, gestación porque atraviesa muchos estratos hasta convencer al propio autor de que vale la pena realizarla.

Esa realización estará integrada por una cantidad enorme de partes, dibujos necesarios para hacer un dibujo, prefiguraciones que desnudan el proceso interno que subyace en la obra terminal en su aparente y engañosa unidad.

La acción prefigurante obliga a tener conciencia de las partes y a la necesidad de crear vínculos de solidaridad para que estas puedan retribuir a un todo.

Los dibujos contenidos en la prefiguración de un dibujo elaboran un todo sistémico, en él; se generan características que las partes no poseen, pero esas partes variadas mantienen su presencia dentro del dibujo y ofrecen a una mirada atenta, lecturas multiplicadas dentro de la gran lectura general.

La valoración de la estrategia como postura de flexibilidad metodológica domina las artes hoy día. El proceso es considerado tan importante como el objeto dibujo que produce. La apertura es una condición cualitativa en este terreno, abrir expectativas en cada etapa de la creación y buscar su integración con otras prácticas artísticas, ya que históricamente el dibujo mantiene vínculos fenoménicos y formales con ellas.

Dentro de la valoración del proceso se implica directamente la acción configurante, dibujar es tanto o más importante que los dibujos.

En el proceso de la configuración el dibujo prefigurado se enfrenta a la materialidad que le ha de dar cuerpo presente, el autor en el momento de la ejecución conforma y tiende puentes entre ambos. Aquí el proyecto inicial va siendo penetrado por las aplicaciones circunstanciales que se presentan.

Si la fenomenología del dibujo es el centro del análisis, en ella la configuración resulta de particular interés.

El dibujo no parte de una base matricial que permita su multireproducción, pero también tiene un proceso, y también entraña una serie de estados, aunque su secuencia no sea serial como en la estampa. El ritmo-tiempo del dibujo puede ser mucho mas sincopado y entrañar discontinuidades y saltos mucho más violentos. 
El resultado final, el dibujo que vemos, generalmente es producto de una serie de intervenciones o ataques a la superficie del formato. Contiene ciclos de labor entre cada estrato constructivo. Una fenomenología del dibujo auxiliada por el análisis de la forma nos revelaría los estados anímicos y psíquicos del dibujante, y al igual que la radiografía de una pintura, mostraría las capas depositadas y las negaciones y arrepentimientos; la obra dibujo dice mucho más de lo que el dibujante quiso decir, es multivocívoca. Estas voces le son agregadas en el proceso de configuración mediante las acciones y decisiones del dibujante.

También es cierto que el dibujo está caracterizado por la rapidez de su ejecución, demanda del artista maestría en el dibujar. Podemos ver dibujos muy construidos, corregidos y pulidos, pero a veces en ellos no se puede ocultar el pavor del dibujante al trazo definitivo en el vacío del papel. Siglos van y siglos vienen, el dibujo siempre estará ahí como el arte de la configuración, su tiempo puede ser tan veloz como la capacidad del dibujante lo permita, y el concepto lo requiera. El dibujo desnuda charlatanes en su ejecución.

El dibujo acabado es un cardiograma de los sentimientos del autor, una tomografía de sus pensamientos y un mapa de su transcurrir en el campo del soporte, todo junto es la muestra de su proyecto y estrategia configurante.

Cuando contemplamos un dibujo terminado, estamos mirando muchos dibujos que pudieron ser, dibujos sepultados bajo el último ciclo. Si pensamos de manera concreta y simple, casi infantil, daremos cuenta de que ese cubrir el dibujo no es total, siempre hay una porción de vacío, lagunas entre islas dibujadas, que denotan la presencia de los otros, en realidad hay dibujos sobrepuestos, dibujos yuxtapuestos, dibujos que tapan, dibujos que transparentan, dibujos que se funden con otros; estaríamos frente a un territorio de huellas e índex abierto a la interpretación.

Probablemente el proceso del dibujo tenga más semejanzas que diferencias con el de otras artes, en todo caso son felices encuentros y constructivas mezclas disciplinares.

No estamos derivando a una poética del discurso, mencionamos lo anterior porque dentro de esos dibujos contenidos en el dibujo, están integradas las decisiones configurantes, las que están determinadas por una intención conceptual, sensible o poética. En cierto sentido configurar un dibujo comporta darle forma y disposición a la poética.

Esas capas representan los estados del sistema analizados en el punto anterior. Cuando lo decimos solo estamos poniendo una señal, completamos la idea.

Los estados señalados en las capas y momentos configurantes del dibujo, grafican decisiones del dibujante, estas pueden ser; lineales y de refuerzo al plan original del proyecto, en cuyo caso el accionar continuado buscaría el reiterar lo dicho, un pleonasmo, o bien dar una cualidad superlativa a lo ya trazado. Ese estado del dibujo intermedio puede mostrar también un giro radical en la selección constructiva, la búsqueda de alternativas variadas al proyecto inicial, o puede ser una disyunción en una zona de varias posibilidades. Lo fundamental en este momento es señalar que es ahí, en ese tiempo-ritmo en donde se han generado los pensamientos que alumbran, ahí el dibujante abre su ideario a rutas que nunca pudo imaginar, ahí el azar le abre el entendimiento a nuevas formas, ahí la configuración de la obra configura al dibujante.

Las etapas intermedias y no terminadas del dibujo constituyen estados valiosos en su no finitud, en si mismos están concluidos porque contienen y han alumbrado un nuevo pensamiento. 
No es que el dibujo tenga que detenerse en cada estado de abducción, esta sería una decisión que toca al autor. Lo que nos interesa marcar en el análisis es la existencia de tipos variados de dibujo en relación a la función que generan en el proceso de dibujar.

La configuración activa y pone en juego todas las prácticas del dibujo que son patrimonio de nuestra historia artística.

Cualquier configuración se basa en sistemas compuestos por un grupo de partes, esta sería la estructura de los sistemas usados en una configuración específica, pero la configuración como acción, incorpora los procederes, no solo las partes.

Dentro de la configuración se incluyen también las acciones corporales que disponen y organizan la materia en el espacio y soporte del dibujo.

Ya que llegamos naturalmente al punto que introduce el cuerpo del dibujante dentro de la acción configurante, diremos que la corporalidad del artista siempre incluye su conciencia y su sentir, su estado de ánimo y la manera en que percibe su estar haciendo la obra. Cuando aludimos al artista nos referimos a su integridad, su pensar su sensibilidad su accionar su intencionalidad y su pertenencia contextual.

La relación metodológica de el estar haciendo la obra, llega a ser tan importante y profunda, que se constituye el centro del acto configurante.

La configuración abarcando el momento en que la imagen va avanzando en la superficie de un formato y se va revelando poco a poco según la idea del pintor y dibujante, es también un acto asombroso.

Asistir al progreso de los frescos de Miguel Ángel en la capilla Sixtina debió de ser algo inimaginable.

La impresión de José Clemente Orozco cuando fueron retirados los andamios, y pudo él mismo contemplar su Hombre en llamas en la cúpula del Hospicio Cabañas fue algo similar seguramente.

El tiempo en presente de la configuración, es el tiempo de las asociaciones discursivas que establecen el sentido de la obra. También en ese momento se libran las batallas de las que tanto se habló en el Informalismo y el expresionismo Abstracto. Decir batalla supone la presencia de un enemigo, una voluntad no sujeta a nuestro deseo. ¿Pero que tal si no es una batalla? ¿Qué pasaría si en ese momento se libra un diálogo?

Al configurar, no solo la materia se presenta en el espacio de la obra, con ella interactúan las estrategias y estructuras mentales y teóricas del autor, también la corporalidad demandada para disponer las partes de la imagen. Las decisiones de que y como disponer, son tomadas bajo la razón de las ideas iniciales del proyecto y en función de las situaciones que el devenir de la obra muestra al dibujante.

Dibujamos desde la historia y la teoría, utilizamos las estructuras formales y los códigos de significación aprendidos por todas las rutas posibles. Pero en el acto de trazar estamos solos, en lo que respecta a las apuestas asumidas con las acciones de configuración.

El proceso de dibujar nos coloca como actores centrales, vivimos una dimensión de oposición dialéctica, por una parte el tiempo se diluye y se logra alcanzar estados suspendidos de arrobo y ensoñación, nos compenetramos con la obra y nos hacemos uno con 
ella y nuestros modelos. En otro sentido siempre está presente una conciencia exterior al dibujo, esta introduce elementos de valoración correspondientes al ideario del contexto. Cuando configuramos el dibujo dibujamos nosotros pero lo hacemos también para los otros, de ahí que quepa el pensar que no es pertinente imponer nuestro discurso, valdría la pena intentar un diálogo con un carácter de identidad. Pese a todo nada diluye la contradicción central, esta es la generatriz del sentido y la creatividad compleja.

Ya el siglo XIX había puesto la mirada en la actitud como componente central en la acción de dibujar, nuevamente mencionamos el temperamento ponderado por Delacroix y Baudelaire como comportamiento del artista hecho forma. También la estética de lo sublime y lo pintoresco marcaron un giro en la valoración del temperamento y la selección de los motivos a dibujar. Pero será hasta el primer cuarto del XX que se inicie el análisis metodológico de la actitud y como se puede concretar en algo más que el temperamento del artista.

Nicolaides en sus notas apunta que es más importante dibujar que hacer dibujos, el dibujo en el papel es un vehículo para comprender la intencionalidad del artista y una constancia que resulta del estar dibujando. En el acto de dibujar acontece lo verdaderamente significativo para el dibujante, en la acción de dibujar el autor se compenetra de la dinámica intencional de su modelo, imagina incluso lo que haría después basado en la actitud presente.

Para Nicolaides la figura humana sigue siendo una suma de partes integrada en una dinámica estructural, pero plantea que se debe dibujarla directamente del natural sin previas experiencias de esquematización. En su lugar propone el dibujo de gesto, aquel que se realiza con furia y condensa la intención elemental del modelo y su acción. ${ }^{75}$ Esto era lo que los pintores chinos llamaban el hueso de las cosas. Hacer estos dibujos no es nada fácil, de hecho las líneas que los componen pueden discurrir con facilidad, pero es un dibujo que demanda un estado de concentración profunda del autor, en este punto el saber lo que se tiene que trazar no garantiza el poder configurarlo. Según Nicolaides el gesto es el elemento unificador de la configuración, es el que unifica las partes. ${ }^{76}$

La primera vanguardia que explota el gesto como potencial configurante es el Informalismo, ya que este movimiento intentó explícitamente separarse de la construcción de la obra aplicando sistemas proyectuales, así desplazó el proyecto del terreno de la configuración al de la actitud. Los objetivos de belleza, equilibrio y composición figuraron en su ideario solo como antagonistas.

Estos artistas se refieren explícitamente al gesto, para Mathiew el gesto es el signo que no es legible, debe ser según él, veloz en su trazo, debe ser producto de un estado de conciencia que nos lleve a no planear la obra.

La obra de Hartung es plena en ese sentido, aunque en él no encontramos referencias de un discurso con su opinión sobre la gestualidad es uno de los autores que más la practican y cuyos resultados son de una belleza enorme. Fig. 16

75 Gómez Juan José, et al. Las lecciones del dibujo. Madrid España: Ed. Cátedra; 1999. P. 26.

76 Nicolaides Kimon. The Natural way to Draw. Boston: Houghton Mifflin Company; 1969. P. 28. 


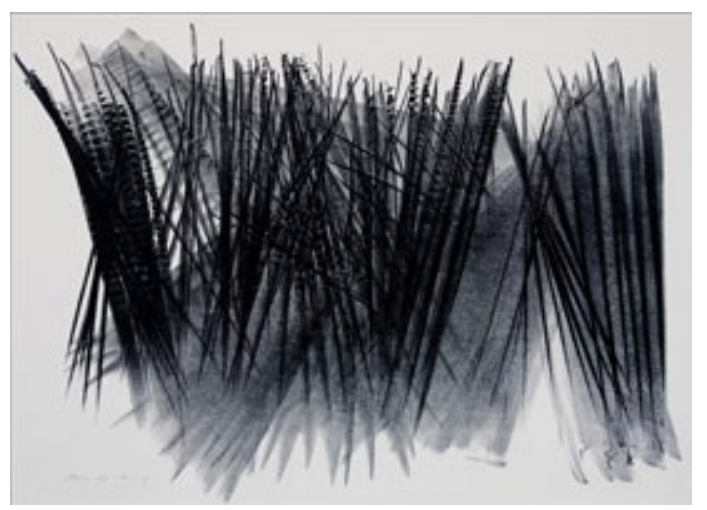

En obras tan condensadas como las de Hartung, sin embargo se advierte con plena claridad lo que es el proceso de configuración; sus obras son diáfanas en el sentido que permiten un entendimiento del accionar que las construye, dejando al intelecto lo complejo de la lectura conceptual y sus intencionalidades inmanentes.

Dubuffet como artista matérico es de los que desarrolla una gestualidad más complicada, el tema, el dibujo, la psique, la materia, la reducción cro-
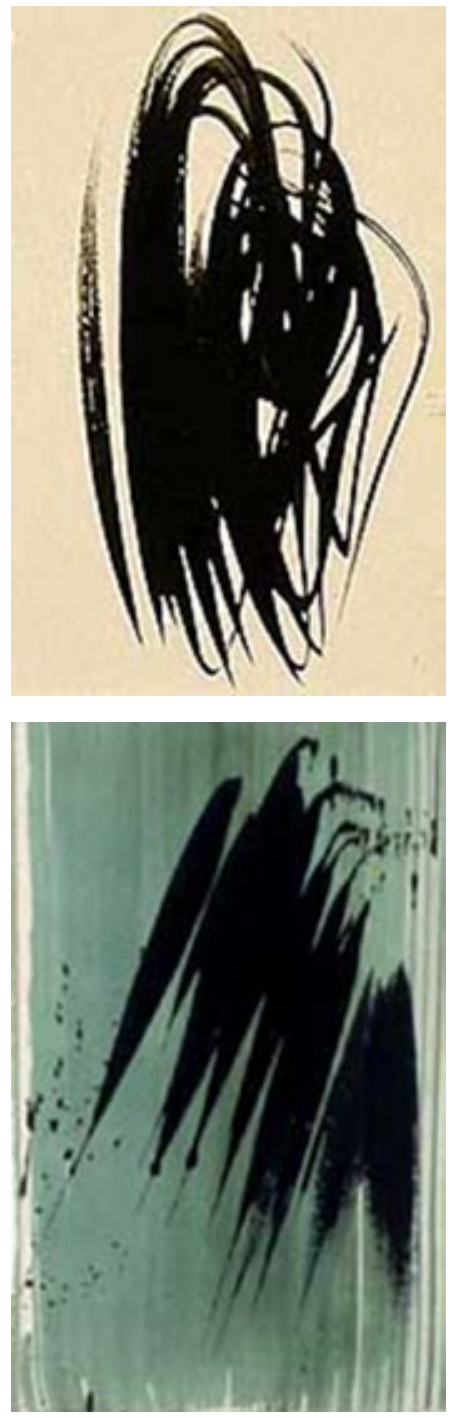
mática, demuestran una gestualidad al margen de pensamientos y rutas de estructuración tradicionales, pero indudablemente desnudan un pensamiento complicadísimo en términos de la estrategia de configuración. Pero aparte de sus pinturas sus dibujos exponen con claridad esa esencia elemental. Fig.17

Generalizando, se puede decir que en el informalismo la gestualidad asumió el papel de estrategia de configuración, que descartó los sistemas de representación del modernismo de principios del siglo XX, pero se basó en un pensamiento formal que en muchas ocasiones tuvo que ver con etapas del pensamiento humano elementales.

En el informalismo el proceso de dibujar fue el centro de gravedad, por eso la ejecución cobró también mucha importancia, no sólo como una manera de dejar rastros gráficos indexales, sino como algo en lo que el dibujante se envuelve personalmente.

Los ciclos de configuración de la obra informalista no están dados en función de corregir la obra, obedecen a depósitos de intenciones, ciclos de actitudes, ataques que se le hacen a la obra o a la entidad que ésta representa o contiene, es por eso que sí existe un proceso de configuración, y muy rico en este arte. Particularmente en este movimiento el dibujo cobró una importancia mayúscula. El Expresionismo Abstracto agregó decididamente la categoría de acción y acontecimiento al proceso de configuración del dibujo. Aquí es donde el formato de la obra deja de ser el plano de la composición, y se constituye campo de la lucha entre el cuadro y el autor. En la configuración de la obra de este expresionismo se enuncia el suceder de un diálogo, el autor abre el ciclo con

Fig. 16 Hans Hartung 

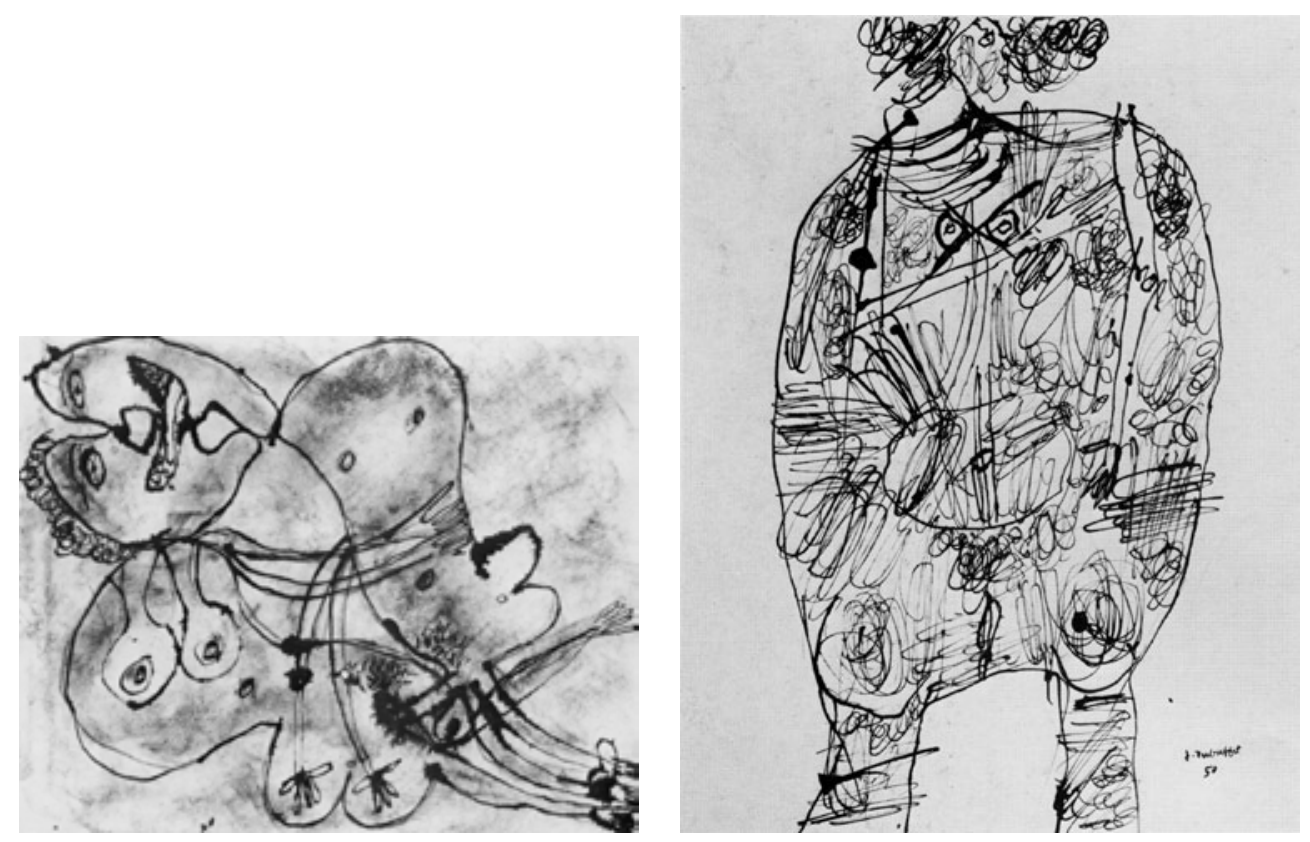

Fig. 17 Dubuffet. Dibujos

las primeras intervenciones no planeadas, la obra muestra los resultados de su accionar y le formula interrogantes, el autor apuesta con la acción y así se prolonga el ciclo hasta que la obra es concluida.

Las referencias al dibujo dentro del Expresionismo Abstracto son importantes, se le considera según David Smith como una entidad de resistencia enorme a la configuración, con una tendencia a marcar su propia estructura.

"El Dibujo es el más directo, el más cercano a lo verdadero mismo, la más natural liberación del hombre"77

Dentro de la facilidad de opinión de los expresionistas, se reconoce que aunque el dibujo sea un boceto, incluso así, es una acción. El mismo Smith dice que el dibujante se debe resistir a la rebelión de la línea, que debe someterla al cause buscado, con esto se inclina por una apuesta de cause proyectual.

Un punto arriesgado pero que no deseamos dejar pasar, consiste en formular como dentro del informalismo y el expresionismo Abstracto la pintura vivió un fenómeno en el cual el dibujo contribuyó fuertemente a su proceso de configuración.

Aunque en muchos casos (Hartung, Pollock, Mathiew etc.) existía una carga cromática, ésta no dependía de estrategias colorísticas de transparencia o modulación clásicas, el fenómeno de la paleta como ordenador cromático se dirigió a la elección de los colores, el color se modeló y esfumó en su campo, la teoría del color field no alcanza una complicación significativa en el proceso de construcción de una estructura de representación

77 Abrams Harry N. Abstract Expressionism. Creators and Critics. An Anthology. Nueva York: Clifford Ross Ed. 1990. P. 182. 
dibujística, aunque por otra parte haya significado una revolución trascendental en la manera de concebir la pintura.

Las estrategias y acciones del dibujo como manifestación de la dinámica del trazo, la huella del corte lineal, el driping casi es más un trazo que una aplicación cromática. En su momento se señaló que estos movimientos pictóricos tenían un carácter fuertemente influenciado por la caligrafía oriental, agregaríamos que debido a esto, muchas de estas obras son pictogramas en alguna medida, aunque no guarden relación con un referente natural o ideográfico.

Un elemento típico consistió en formular composiciones que no guardara referencia con el plano poligonal que las contenía. La disposición de las partes del dibujo o pintura no obedecería a la métrica derivada del formato. La composición sería no relacional, esto es que, la estructura configurante derivaría de las relaciones que se fueran generando entre los elementos dispuestos en ciclos sobre el campo de la acción pictórica. Las consecuencias de esta formulación fueron radicales para la configuración de la pintura y el dibujo.

Franz Kline es un caso diferenciado, y aquí nos detenemos porque confrontando su trabajo se advierte lo importante del dibujo en su pintura, no como auxiliar, como agente de severidad constructiva. El proceso de Kline es muy sincero, a veces inicia la pintura sin ninguna idea previa y a veces retoma algún dibujo para abrir la pintura o para basarla en él. Los ciclos configurativos de las pinturas de Kline revelan una enorme sensibilidad hacia las acciones de construcción en el cuadro, por muy violentas que puedan ser, dentro de ese recio planteamiento al disponer la materia existe un respeto profundo por lograr un cuadro pleno de conciencia.

En la configuración se expresa el potencial de resolución de un concepto y la capacidad de ejecución del dibujante, este ejercicio tiene mucho de dramático, y no en el sentido común de la expresión. La ejecución es una acción en la que se actúa, y como toda actuación se conduce bajo una guía conceptual.

Parte fundamental de esta tesis es la consideración de la acción de dibujar, ya desde atrás hemos llamado a ello El Acto Dibujo. Esto lo relacionamos con una categoría más de importancia capital, El Carácter Proyectual del Dibujo. Nuestra tesis se funda en esas dos categorías y el desarrollo de su relación. Con ese análisis pensamos responder de alguna manera a la hipótesis formulada y que da pie a esta investigación, si bien nuestra hipótesis reconocía una triada de supuestos interrelacionados. El dibujo como promotor del pensamiento eidético y proyectual, la ruptura del vínculo sistémico que histórica y metodológicamente consolidó la relación funcional entre el dibujo y las artes visuales, y con la deriva de ese vínculo la crisis de la representación y el reciclamiento de los reservorios de imágenes de segunda y tercera generación.

Ya desde el planteamiento mismo del problema nos hemos dado a la tarea de esclarecer estas situaciones, pensamos estarlo haciendo a la luz del pensamiento histórico, teórico y formal del dibujo y del arte en general.

Como se aprecia, este capítulo está dedicado a las consideraciones del proyecto artístico en lo general, e intenta arribar a la particularidad de lo que hemos llamado el pensamiento proyectual del dibujo, aún tenemos algunas cosas más que agregar al respecto, pero hemos hecho este corte y resumen porque queremos puntualizar la importancia de con- 
siderar al dibujo como un Acto, en esta posición se comprende en mucho la orientación de las respuestas que deseamos aportar a los problemas planteados, si bien ya hemos depositado múltiples argumentos para su análisis.

Una postura de la crítica mira en la estrategia posmoderna de los artistas una raíz teatral y dramática. Pero en nuestra visión intentaremos expandir este análisis y marcar las distancias que nos separan de esa otra formulación. El análisis del acto dibujo nos remitirá a la interioridad de la acción de dibujar, a las conductas y estrategias desplegadas en ese momento, a la relación de identidad y causalidad que el pensamiento del dibujante establece consigo mismo, con el contexto y con los modelos que selecciona. A todo esto dedicaremos el cuarto segmento de esta investigación.

La ejecución lleva al dibujante al terreno del arte como forma de poder, ya decíamos algo al respecto anteriormente, agregaremos ahora que ese poder genera obras de autoridad que no pueden ser negadas porque su grado de consistencia y coherencia conceptual y objetual así como su potencia poética nos mantiene en su órbita gravitacional. Los dibujos más logrados se constituyen en obras que rebasan su circunstancia y desafían el paso del tiempo, porque contienen una potencia que nos habla desde su interior.

Para redondear diremos que las etapas del pensar el dibujo se corresponden con modos particulares de dibujar que son consecuentes con esa estructura reflexiva.

En última instancia la configuración consiste en dar disposición a las partes del todo según una organización estructural particular, confiriéndole un carácter específico.

La configuración es el tiempo del suceso del dibujo, tiempo de la vivencia pragmática, momento en el que la condición prefigurativa se torna condición fáctica. En la configuración dotamos de forma el concepto y el proyecto pensado, pero es el momento de la relación dialéctica y compleja entre el tema el contexto y el problema, ambiente en el que se sucede la vivencia del dibujante y en el que se ejercita el principio de autonomía generándose los desplazamientos abductivos.

Así la ejecución es el tiempo del acto dibujo, con esta consideración nos alejamos de las visiones tecnicistas, instrumentalistas y formalistas como consideración del trazar la imagen del dibujo, que ahora será el devenir del dibujar.

Esta expresión da sentido de pronto a todo lo comentado anteriormente. Al dibujar no hacemos sino dar disposición a materias, conceptos y partes según una estructura que pudo haber sido prefigurada en alto grado o liberada al azar.

De ahí que la formalización dentro del acto y el proyecto del dibujo no sea la conformación de la estructura del referente objetual, sino la construcción de la alteridad del pensamiento formalizado en un ente dibujo y suceso, que se integrará como condición de forma primera y alterna a lo ya visto y existente. Proceso endógeno de pensar haciendo el dibujo, recordamos a Hubert Damish, en su texto Ventana amarillo cadmio, cuantas críticas afrontamos al rehusarnos a los sistemas exógenos de análisis como inicio y fundamento del proyecto artístico.

La numerosa ecología de autores y teorías que brotan en el curso de esta investigación resuenan consonantes con nuestra antigua postura. Ya en el siguiente capítulo hemos de exponerlas. 
Esa disposición de interioridad disciplinar obedece al fuero interno autoral, a la decisión del dibujante que sabe la razón de cada elección, o en todo caso la intuye, la siente. Por eso la figura no corresponde sólo al terreno del contorno circunscrito, también compete a las figuras mentales estratégicas y metodológicas, a las causas subjetivas u objetivas que tienden puentes entre el contexto y el pensamiento del dibujante.

Esa particular disposición de partes que dan carácter a la cosa, nos habla de un dar figura bajo una definición particular.

La figura creada atañe al campo físico de existencia del objeto dibujo. Puede darse la situación de crear una configuración de conceptos, algunos de los cuales preexistían en nuestro ideario. Configuramos también el relato temático de nuestro dibujo, le creamos una sintaxis discursiva. La poética también es condición que se configura.

La configuración como acción en desarrollo es crear entidades, los dibujos pueden ser mapas de nuestro discurso, del viaje que emprendimos y deseamos reseñar, como en Jean Hendrix, pueden ser expresión de futuros proyectos, pero hay que decirlo alto, dibujar es construir entidades totémicas, piezas a las que tenemos que rodear porque recurrentemente se interponen en nuestro camino. El objeto, (sobre todo en el dibujo) mantiene un alto poder de invocación, nos reúne y nos conmueve o reta nuestro entendimiento.

Dibujar es fomentar nexos, entre las partes de la obra pero también entre nuestro pensar y el de los otros; vínculos de nuestra corporalidad, ubicada en el espacio que hemos determinado para la acción del dibujo, que puede ser la locación más agreste del paisaje o el café bohemio de los impresionistas, o cualquier otro.

Configurar es dejar huella, rastro del andar y de lo hecho, de sus razones y sus sentimientos. Dibujar exhibe el dibujo y con ello al dibujante, lo desnuda en su potencial o sus incapacidades. Al plantearnos la configuración entendemos un tanto a nuestros modelos y nos cuestionamos nuestros motivos, ponemos a prueba nuestras estrategias y con ello conocemos el mundo. El dibujo al hacerse es un bisturí que obra con agudeza sobre la realidad observada.

La conciencia incrementada en el dibujar nos coloca de frente a lo repetitivo de nuestros trazos, nos enseña el repertorio de formas y conductas estandarizadas a las que recurrimos, nos dice en silencio aquellas cosas para las que estamos menos dotados, pero también para las que si lo estamos.

Al configurar el dibujo, más que al pensarlo aprendemos a confiar en el encuentro de las soluciones y a no preocuparnos por el desenlace de la obra, porque nos educa la mirada para encontrar en los sucesos el orden del material y los procedimientos para organizarlo. Por eso el dibujar es configurarse uno mismo.

La configuración es un estado intermedio del dibujo, ahí se suceden los pensamientos que arman la disposición de las partes de la imagen y transforman nuestro pensamiento. La obra acabada genera otros pensamientos, pensamientos que tienen que ver con el contemplar e imaginar nuevos escenarios, pensamientos de la síntesis experiencial.

La teoría que ahora se construye en cuanto al dibujo, corre en el sentido de analizar su papel dentro de las artes y su situación como una expresión que se baste a si misma.

Como lo señala Gómez Molina, en el camino de liberar al dibujo perdieron sentido sus 
partes, el apunte el boceto y demás se convirtieron en componentes de los manuales más mecánicos que se editan, pero dejaron de operar con la lógica que les exigía una práctica del dibujo coherente con la estructuración del pensamiento eidético.

También se abandonaron con estos dibujos las prácticas analíticas de las que se derivaron. No perdimos o vulgarizamos una terminología técnica, en el camino extraviamos la posibilidad de conflictuar los conceptos de la plástica y la visualidad con el ejercicio sistematizado del dibujo.

La llamada autonomía del dibujo parece ser una convocatoria a las prácticas procedimentales más arbitrarias. La volitividad del dibujante corre por rumbos de irreflexión en aras de la libertad dibujística, las imágenes del dibujo ya no se construyen desde la tensión de la ejecución con toda la complejidad conceptual e interpretativa que esta encierra, se elaboran pensando que la voluntad de colocar elementos trazados en el plano es dibujar y por tanto significar, pensamiento bastante elemental. La disposición de elementos trazados en un formato no trae aparejada la acción enriquecida de dibujar, para esto se requiere la claridad de la acción que se emprende, el concepto que la organiza y que determina la manera de ser del trazo en cuestión, su tiempo y actitud de ejecución. Esto y tantas situaciones más son el tamaño de la pérdida que vivimos en busca de una independencia.

Se dice que la pintura está liquidada y que sólo puede sobrevivir diluida o asociada con otras artes. A cambio se plantea que el dibujo tiene un fortísimo potencial de empuje, para la vida actual de las artes plásticas, visuales e interdisciplinarias. Tenemos treinta años de escuchar ese discurso que más se asemeja a una profecía no cumplida. En su lugar, con un estruendo silencioso, a lo largo de casi doscientos años, pero sobre todo en los ocho últimos decenios la fotografía penetró la médula de todas las artes y sistemas comerciales de la cultura visual, causando una reestructuración lingüística y conceptual, así como la ruptura de los territorios disciplinares.

Pero en cuanto al dibujo, se olvida, que éste desde sus milenarios orígenes estuvo asociado al pensamiento en imágenes y a la representación del mundo. De manera natural el dibujo ayuda a organizar las acciones futuras, como el maestro Acha analiza en su texto, decimos que, las funciones proyectuales y comunicativas del dibujo son muchísimo mas extensas que la vanidad artística.

Los vínculos familiares del dibujo con otras prácticas productivas incluso externas a las artes lo fueron construyendo en toda su riqueza y complejidad, por eso buscar su autonomía es correr hacia la pérdida de su sentido.

El ánimo taxonómico y separatista parece campear el panorama, no creemos que tenga mucho sentido.

El dibujo también ha vivido la suerte de las artes a lo largo de la historia, pero sólo hasta el siglo XX se le intentó liberar de unas supuestas ataduras.

Claro que las funciones del dibujo en el arte del siglo pasado reportaron enseñanzas alternas. No creemos que estas propiedades emergentes hayan sido una piedra filosofal buscada, pensamos que son productos y funciones colaterales, efecto secundario del devenir de las artes.

Muchísimos de los artistas del siglo XX cuyas aportaciones y posturas artísticas fueron 
de lo más radicales con respecto a la tradición; vieron con genuino respeto el ejercicio del dibujo y nunca se apresuraron a derrumbar nada de su sentido.

Artistas neoconceptualistas como Kabakov, Muntadas o Irán do Spírito, incluyen el dibujo como parte sustantiva de sus proyectos. Cuando esto sucede, constatamos que la dinámica combinatoria de los elementos o unidades sintácticas es sumamente cuidada, a la vez que complicada; en ese sentido se plantea una apertura del discurso de la obra y dentro de esta, la función del propio dibujo. Pero no se varían sustantivamente las maneras y modos metodológicos de las partes del dibujo. En estas obras el Dibujo Interno de Zuccari sigue siendo tan vigente como en su formulación original. Un dibujo de Leonardo diseñando una maquinaria no dista nada de los bocetos de Kabakov para su Palacio de los Proyectos como lo vimos en las imágenes anteriores.

Los distintos modos del dibujo, los dibujos del dibujo siguen estando ahí, a disposición, los empleamos aleatoriamente según el proyecto lo requiera, mediante la práctica del dibujo solucionamos los problemas conceptuales de los proyectos, igual que hace miles de años. Pero no es posible usar simplemente una disciplina. El dibujo no es una agrupación de partes inventariadas de las que uno dispone con simpleza. Los distintos estratos técnico-metodológicos del dibujo se tienen que aprehender, los tenemos que asir, y esto solo es posible mediante un largo ejercicio.

Así cuando en el taller y la escuela dedicamos largos años al aprendizaje del dibujo soportamos el descrédito del calificativo de académicos, no se termina de entender que el dibujo es una disciplina fáctica, es un acto, no una acción simple. Claro que toda acción es una actividad intencional, pero el acto encara la completud del suceso, lo envuelve en su complejidad y hace al dibujante conciente de su hacer. El dibujante en el acto dibujo es responsable de generar el suceso de representación y configuración.

Es posible que el antiguo petroglifo, o la incisión en la madera y el hueso, fuera un acto sencillo, en el que sólo se buscara cuantificar una operación de trueque, pero la línea que contenía ya el concepto numérico o que significaba un ideograma, fue una violencia abstracta introducida por el hombre a este planeta.

La distancia conceptual que va del pictograma al ideograma nos mostró el crecimiento del intelecto humano auxiliado por el dibujo. Los sistemas del lenguaje escrito se desarrollaron a la par que el dibujo, por muchos siglos no existieron diferencias claras entre ellos, sus caminos no se habían bifurcado.

Las estructuras de la forma dibujo como formas del pensamiento, tenían códigos sistémicos rigurosos que no es posible alterar arbitrariamente, se aprenden, y en la historia fueron patrimonio transmitido de generación en generación. El olvido o abandono del patrimonio conceptual como cualquier otro, nos condena a su pérdida y a su reinvención.

Entre más sean los años de laxitud en la práctica del dibujo más se incrementa la distancia que lo lleva a su pérdida.

Parece asombroso que usemos con facilidad términos (que no conceptos) como el de hacer un apunte en dibujo o bocetar etc.

En las líneas siguientes intentamos reflexionar en estos conceptos tan manejados pero tan poco claros. No buscamos nuevamente la definición certera, sabemos que a las cualidades conceptuales que anotemos, y los adjetivos que señalemos hacen falta muchos más. 
Este es el inicio de una práctica reflexiva que invita a su continuación. Contiene ya desde ahora la base de una postura teórica; aquella que define las diversas actividades y dibujos del dibujo como la expresión de una cadena procedimental y metodológica en la que se observa la construcción del pensamiento eidético y su elaboración a lo largo de la historia.

Los dibujos del dibujo son la expresión concisa del pensamiento proyectual del dibujo, en ellos se baja al terreno de la concreción disciplinar las reflexiones teóricas generales del proyecto que hemos venido estudiando.

Intentaremos en las siguientes líneas definir esta idea, lo haremos con el intento de separarnos del pensamiento manual y procedimental mecánico, buscando el carácter que dote a nuestro pensamiento de un fondo metodológico y epistémico, pues consideramos que los dibujos del dibujo son la expresión de la cadena mental que manifiesta la postura cognitiva del dibujante como manera de relación con el contexto.

Se designa como Apuntes aquellos dibujos caracterizados por su sencillez. Su economía de trazo recuerda la norma poética en donde la expresividad certera aumenta partiendo de formas concisas evitando el pleonasmo.

Llama la atención el que los apuntes generalmente comportan una manera gestual de trazar. Habría que hacer una distinción entre un apunte rápido y un dibujo gestual rápido.

El apunte representa y configura algún personaje o suceso del contexto en su expresión vital, es un trazo emanado del contexto sucediendo. El apunte no puede ser inventado, parte necesariamente de la realidad contextual externa, es el asalto del mundo hacia el artista. Como lo decía Nicolaides el dibujo de gesto implica hacer comunión con la intencionalidad interna del modelo buscando una identidad. En el dibujo de apunte se tiene que asumir una acción veloz porque generalmente el decurso y decaimiento de los motivos que interesa dibujar se suscitan rápidamente y no esperan al dibujante, de ahí que el apunte desarrolle la habilidad como territorio de la práctica del dibujo.

Pero el dibujo de apunte es primordialmente la toma de información de la realidad, información que caracteriza el modelo y el acontecimiento y que no puede ser reducida ni suprimida en busca de un principio gestual de compresión formal. La relación entre el apunte y el modelo del que emana es la de las formas y sucesos contenidos en el contexto y su devenir. A diferencia de la gestualidad en la que se puede llegar a la obtención de una forma alterna, que si bien emana del modelo no contiene sino su esencia gestual en la que la información visual tiene que ser comprimida y en cierto sentido sacrificada.

Las consideraciones de Leonardo sobre la necesidad de hacer apuntes en el contexto urbano queda ya descrita en sus palabras. Una cita de Gómez Molina resulta interesante ya que marca un giro significativo en la manera en que se hace el apunte:

"Leonardo nos da de ellas siempre una visión matizada del discurso: para ello hay que fijarse en las acciones que se desarrollan en las calles, plazas y campos, anotando sus formas por una breve indicación, que llega a adquirir un valor casi taquigráfico: así, por ejemplo, para dibujar la cabeza hagamos una $O$, para un brazo, una línea curva, y lo mismo para las piernas y todo el cuerpo. Al volver a casa completemos las notas, dando forma a las figuras."78

78 Gómez Juan José, et al. Las lecciones del dibujo. Madrid España: Ed. Cátedra; 1999. P. 177. 
Notemos que la manera de captura de los datos en la imagen, no corresponde a la práctica que hoy aprendemos para realizar apuntes, las recomendaciones de Leonardo corren más en un sentido taquigráfico que gestual. Es importante apuntarlo porque marca un signo de la conducta metodológica en los sistemas de representación en el arte de la época.

El dibujo gestual rápido también da una respuesta veloz como trazo, pero en este caso el centro de interés se desplaza del modelo o suceso visto, a la conducta interna del dibujante, el dibujo gestual puede existir en ausencia de modelo o suceso alguno, se puede originar en el inconsciente. Su nexo con el contexto no requiere de asistir a él, no implica el estar ahí, el ver a, ni el asombrarse ante tal.

Es posible que entre ambos existan más similitudes que distancia, pero lo que aquí nos interesa es señalar prácticas del dibujo con funciones cualificadas que generan modos del hacer diferenciados y posturas epistémicas propias.

Para dibujar apuntes es necesario un trazo que consigne; esto es anotar, tomar nota, de lo sucedido, no de lo que necesito dibujar. Mediante el apunte se consigna, se transcribe la información del modelo en la circunstancia específica de ese momento. No serían posibles dos apuntes iguales dado que la realidad es infinitamente variada en su suceder. Por eso dibujar apuntes es dibujar la vitalidad de la realidad.

Todo es dibujable en apuntes, porque todo tiene una esencia que nos dice las causas de su actual estado, y en su concreción temporal todo lo visto vivido tiene cualidades que adjetivan su forma, esas cualidades son transcritas a información graficada en un proceso que se da estando ahí, siendo uno con el acontecimiento. En el apunte no hay testigos todos formamos parte del atentado.

Cuando se está dibujando apuntes se puede inventar la manera de trazar, pero no la información trazada, el dato visual siempre está ahí en presencia de todas las miradas.

Dibujar apuntes demanda una respuesta casi instintiva, trazar casi sin pensarlo.

El instinto es conducta que no pasa por el pensamiento lógico, es respuesta de la mente por vías cortas que aceleran la capacidad de respuesta.

Pero el hacer apuntes se puede aprender, por lo tanto no es instintivo, puede ser impulsivo eso sí. Mediante el trabajo desarrollamos la capacidad de acelerar el trazo y la respuesta de nuestros apuntes, los tiempos se reducen y la capacidad de síntesis mejora, pero esto sucede porque el apunte comporta un análisis del conjunto que se mira, en su estructura el apunte encierra un proceso de percepción discriminatoria aunque al suceder de modo tan rápido pensemos que no existe.

Fenoménicamente la postura que el dibujante guarda cuando realiza este tipo de dibujo es la de tener desplegado el contexto, el mismo dibujante está inmerso dentro de lo que dibuja, y lo que es dibujado se ve fuertemente afectado por el dibujante y el hecho de ser dibujado. Cuando hacemos apuntes Heisenberg está presente con su principio de incertidumbre, aunque suene de locura el decirlo, hacer apuntes nos hunde en el contexto y en un alto grado lo perturbamos.

Cuando dibujábamos en los bosques hace ya algunos años, todo a nuestra llegada estaba en silencio, creíamos que así era de manera natural, después de treinta o cuarenta minutos de dibujar concentrados, el bosque recuperaba sus voces y se animaba de nuevo. 
Las ligas que unen modelo y dibujante en el apunte son de estrecha cercanía.

En el apunte la realidad sienta su dominio como motivo de reflexiones, se impone al dibujante, hacer apuntes no es intervenir la realidad es conocer el contexto.

Por eso cuando hacemos apuntes, no solo la manera es importante, la función y la relación dibujante contexto también juegan un papel central.

El apunte es el dibujo más lejano a los cánones, porque al derivar del contexto que acontece, nos enseña que la realidad tiene pliegues y caracteres infinitamente ricos y sutiles que nuestra mente jamás puede imaginar.

No sólo es importante transcribir información, la actitud implicada en el acto de trazar así como la discriminación de los datos visuales confieren a nuestros apuntes una carga temperamental específica. El apunte condensa el carácter de lo visto y el estado de ánimo del autor.

El apunte se sustenta en un vínculo irrenunciable entre el contexto que transcurre, el dibujante y la imagen; mediante él aprendemos como la realidad tiene mucho para enseñarnos si decidimos mirarla. Dibujar apuntes es como salir al mundo a recoger sucesos, dejándolos consignados en una taquigrafía elemental que es ante todo trazo casi instintivo. En este tipo de dibujos se implica la inmersión del autor en el espacio vivencial del propio modelo o fenómeno, que al suceder es motivo de reflexión.

Dibujar apuntes nos permite a los dibujantes una particularización de las imágenes, misma que nos aleja de los peligros de la estandarización al construir nuestras obras. Es también una manera estratégica de relación con la realidad, es el imperio del contexto sobre lo prefigurado.

Parece que nuestra mente no puede imaginar dos dibujos encimados, o al mismo tiempo, y que contengan variaciones de ajuste.

Casi siempre se dice que un boceto es un dibujo o una construcción en la que intentamos planear la futura obra, esta es la acepción sobreentendida del término.

En 1976, Adolfo Mexiac en la Escuela Nacional de Artes Plásticas, uno de los mejores grabadores mexicanos y fundador del Taller de la Gráfica Popular, decía que el Boceto era un dibujo en el que se buscaba establecer las partes que integrarían una obra posterior, así como las variantes en su organización y estructura, para tener al frente varias opciones de solución a algún problema. También enseñaba que se pueden hacer bocetos de claroscuro. Es probable que esta concepción se debiera en cierta medida a su disciplina como grabador, pero independientemente de eso la lección es bastante clara.

Como es común en los talleres de grabado, sobre las pruebas de estado se trabaja con tinta líquida y diluida para analizar los posibles estados siguientes en la evolución de la placa matriz.

De ahí nos surge la idea de que al bocetar podemos visualizar una imagen sobrepuesta y su consecuencia constructiva con la imagen anterior.

Hasta que realizamos el primer agrupamiento de las partes de una composición trazadas en el papel, es cuando podemos visualizar las variantes encima de lo que estamos viendo.

Las variaciones que podemos observar en un dibujo de boceto no son lo mismo que los arrepentimientos, estos últimos son decisiones de rectificación sobre la obra definitiva o sobre el proyecto final. Los cambios en un boceto se deben a intentos de reajustar la 
imagen en función de adaptaciones casi siempre proyectuales y discursivas, estas variaciones son parte de la esencia de bocetar.

Nuevamente aquí existe una definición sencilla del común entendido, el boceto es uno o varios dibujos que se realizan antes de acometer de lleno la obra definitiva.

En el año 1500 la fabricación de papel se realizaba en condiciones artesanales todavía, la obtención de pliegos del metraje necesario para realizar las calcas en los murales, constituía una labor de amplia envergadura, por condicionantes como ésta, y las que se desprenden del ideal racionalista, era necesario llegar al estado de construcción de una obra con el mayor número de problemas resueltos, de ahí que dado el valor de lo que estaba en juego, el boceto constituyera una práctica de tanteo y acercamiento a las condiciones configurativas de la obra.

En el desarrollo del periodo barroco se generalizó la práctica de realizar bocetos de las obras tentativas para presentarlos como pruebas para la obtención de alguna encomienda y referencia para el contrato de la obra. El uso práctico del boceto empero comportó consecuencias estructurales relevantes en el proceso metodológico del dibujo.

Bocetar se fue conformando como la acción de primeridad imaginaria del proyecto y la obra. Como especulación mental que adaptaba el tema y su concepción inicial con una propuesta y posibilidad formal que se sabía debería ser ajustada.

Para el artista plástico específicamente el dibujante, es común realizar algunos Bocetos antes de acometer de lleno la obra definitiva.

Bocetar es tantear, ajustar, aproximar, variar, combinar, esto es, intentar posibilidades para el ensamble de los elementos constitutivos de una obra, es llevar las ideas de la mente al papel en esquemas simples, manchas o líneas sueltas que al producir formas casuales no obligan a una figura terminal, solo son el trazo de las figuras que pasan por nuestra mente al discurrir un proyecto.

Mediante los bocetos decidimos y ajustamos el peso, el número, la posición, el tono el contraste, la sintaxis, el tono dramático y conceptual etc. Todo esto habrá de integrar la composición.

Bocetando aplicamos la variación para generar oportunidades constitutivas, sintácticas y constructivas de una obra.

El boceto es una práctica de configuración porque en el buscamos disponer las partes de una obra bajo una organización conceptual.

Al comienzo de un boceto existe una visión prefigurada de lo deseado como imagen; los bocetos poco a poco dejan atrás la idea inicial y ceden frente a variaciones más ricas e interesantes abiertas en ese momento.

Puede definirse el bocetar como un constante plantear, negar, ajustar, acertar en los elementos integrantes de lo trazado.

Aunado a lo anterior el bocetar es una manera de pensar mediante imágenes.

Entendiendo los procesos de representación como las elaboraciones mediante las cuales rearmamos el mundo en nuestra mente, queda manifiesto su carácter de abstracción. A su vez esta consiste entre otras cosas en la disección de un todo en sus partes para mejor comprenderlo y hacerlo manejable. 
Roger de Piles, conocedor de la pintura en el barroco escribe en 1699 un texto que tituló Idea del perfecto pintor. Una breve cita de este texto arroja claridad sobre la variada gama de modelos que el pintor debía de saber dibujar del natural, de paso se advierte como ya estaba plenamente establecida la práctica del boceto, esta formaba parte del proceso de planear la obra.

"Los dibujos de los que se desea hablar aquí son las ideas que los pintores expresan generalmente sobre el papel para la ejecución de una obra que meditan. Se debe incluir en el número de los dibujos los estudios de los grandes maestros, es decir, las partes que han dibujado de la naturaleza, tales como cabezas, manos, pies y figuras enteras, ropajes, animales, árboles plantas, flores, y, en fin, todo aquello que puede entrar en la composición de un cuadro. Pues tanto si se considera un buen dibujo respecto al cuadro del que es la idea, como respecto a alguna parte de la que es el estudio, merece siempre la atención de los conocedores." ${ }^{79}$

El trabajo de bocetar es por tanto una operación eminentemente abstracta aunque represente imágenes reconocibles de nuestro entorno.

Bocetando comenzamos a dar consistencia a nuestros sueños. Si bien el apunte se ancla en la realidad circundante, el boceto posibilita el libre flujo de las ideas hacia el papel, por mas descabelladas que puedan parecer.

El boceto demuestra sin lugar a dudas que una obra asemeja la conjugación de los verbos en sus distintas posibilidades.

Suele confundirse la práctica del boceto con aquellas primeras manchas que se realizan al iniciar un cuadro, decimos que abocetamos la obra. Probablemente no sea necesario contrarrestar esa opinión, lo que interesa decir es que el boceto guarda una distancia mental con la realidad contextual, sus relaciones con el mundo y los modelos son las del pensamiento representacional, el plano de existencia del boceto es el de las posibilidades de especulación sobre el posible de la obra, su condición es la de una serie de estados alternos de organización posible, que en sus conflictos nos remite nuevamente al estudio de la realidad, lo cual lo diferencia del apunte.

Actualmente el boceto puede incluir procedimientos híbridos que involucran prácticas como las del collage, el montaje y otros, esto con la finalidad de construir la ruta de la obra que contenga la intención semántica que explicite el problema planteado por el tema.

El boceto más allá de su visión instrumental se hunde en el territorio de la especulación proyectual prefigurativa; insistimos, en este lapso del proceso, bocetar es un ejercicio de especulación flexible y desnaturalizadora de las prácticas significantes y de representación, es así porque en el se activan y cuestionan tanto los procederes como las estrategias y las estructuras de formalización del dibujo, y también porque en el bocetar se trabaja en la práctica constante del desplazamiento complejo.

El boceto es una práctica empleada desde el uso del dibujo en el Renacimiento, pero adquiere su completud como sistema en el arte del Barroco. Para ese momento el bocetar se redondeó como la práctica típica de prefigurar la obra y planear su decurso con un margen amplio de linealidad metódica. Esto no significó jamás una limitación metodológica y

79 Freixa Mireia, Garriga Joaquim, Yarza Joaquín, editores. Fuentes y Documentos para la historia del Arte. Renacimiento en Europa. Barcelona: Ed. Gustavo Gili; 1983. (VII). P. 203. 
epistémica, bastaría pararnos frente a cualquier obra de Miguel Ángel, el Greco etcétera para advertir de inmediato que la complejidad de la obra construida fácticamente ampliaba el territorio del proyecto hacia sucederes de una complejidad alterna que no es la del boceto típico. Queremos señalar la alteridad y distancia que existe entre la práctica del dibujo de boceto como acto prefigurativo típicamente mental y la ejecución de la obra final que interioriza y funde la conceptualización del dibujo dentro de la construcción fáctica de la obra que puede suscitarse en el terreno alterno de otra práctica disciplinar artística.

El apunte nos pone frente a los ojos lo que podemos aprender del contexto, los bocetos nos educan en la configuración de las obras y las ideas.

Cuando intentamos dinamizar un concepto o un sujeto en el boceto, caemos en la cuenta de que no sabemos como es éste ni como moverlo, tampoco sabemos de que manera recrear un espacio específico y menos aún de que modo podemos generar atmósferas y sensaciones en el cuadro que deseamos, nos queda claro el no saber. A veces lo que no podemos representar en nuestra mente es la manera de cómo construir una idea o una estructura plástica.

Los Dibujos de Estudio constituyen una estrategia para analizar mediante la observación detenida y la configuración dibujística de una imagen, la esencia estructural del sujeto o fenómeno.

Teniendo al frente el problema y requiriendo de su manejo para incluirlo en un proyecto nos queda clara la necesidad de estudiar para superar ese vacío.

Por eso el dibujo de estudio tiene ya una larga tradición.

La evolución del dibujo de Giotto a Masachio y después la explosión renacentista fue posible en gran parte gracias al cambio en la manera de dibujar, notamos la cualidad de las representaciones, pero estas son posibles debido a la flexibilización del dibujo.

El efecto naturalista del dibujo en ese proceso se debió a varias razones, entre otras a su uso para efectuar el reporte de los análisis que el dibujante realizaba de sus modelos.

Las disecciones que se efectuaban en los cadáveres, eran reportadas meticulosamente en dibujos de profunda atención a las partes que se iban revelando.

La acción quirúrgica traía aparejada la disección del modelo mediante el dibujo. Éste se fundió con el método experimental, el taller de dibujo tuvo mucho de laboratorio.

El naturalismo en el modelado de la anatomía de esas pinturas, se logró después de años de adaptación de la práctica dibujística al entendimiento de los fenómenos de la naturaleza. Esto fue posible no solo por la práctica reiterada, junto con ella el artista creó y adaptó conceptos técnicos y procedimentales que permitieron esa cualidad de la imagen y la materia.

El sfumato, el pasaje, el regatino, el relieve y el claroscuro fueron conceptos del dibujo y la pintura que modificaron su ingeniería y se convirtieron en útiles de análisis de los modelos.

El dibujo de estudios comprende un universo bastante complejo de variantes.

Por una parte se realizan específicamente estos dibujos para resolver alguna cuestión 
poco clara en los bocetos, posiciones de las manos, facciones de algún rostro etc. En este sentido los estudios representan un elemento integrante de una cadena configurante más amplia. Sin embargo los dibujos de estudio en el campo plástico y de la visualidad se pueden dividir en tres vertientes fundamentales:

A- Aquellos que analizan exhaustivamente las posibles combinatorias de los elementos formales constitutivos de la obra, así como su pertinencia, llamemos a estos dibujos de momento; estudios de abstracción configurante. Digamos también que tienen estos como cualidad esencial, el definir una estrategia de significación, como lo vimos en los distintos ensayos antes de la versión terminal del Salvamento de la Medusa de Gericault, o el dibujo "Nuestros dioses" de Saturnino Herrán Fig. 18

B- Aquellos dibujos de estudio, mediante los cuales se analizan con infinita paciencia y profundidad las partes de un sujeto entendido este como modelo. Puede calificarse estos trabajos como aquellos en los cuales la invención en un cierto sentido se comprime, puesto que en ellos rige el orden y la estructura constructiva del modelo estudiado. Llamemos a estos Estudios de análisis de estructuras formales en los modelos. Fig. 19

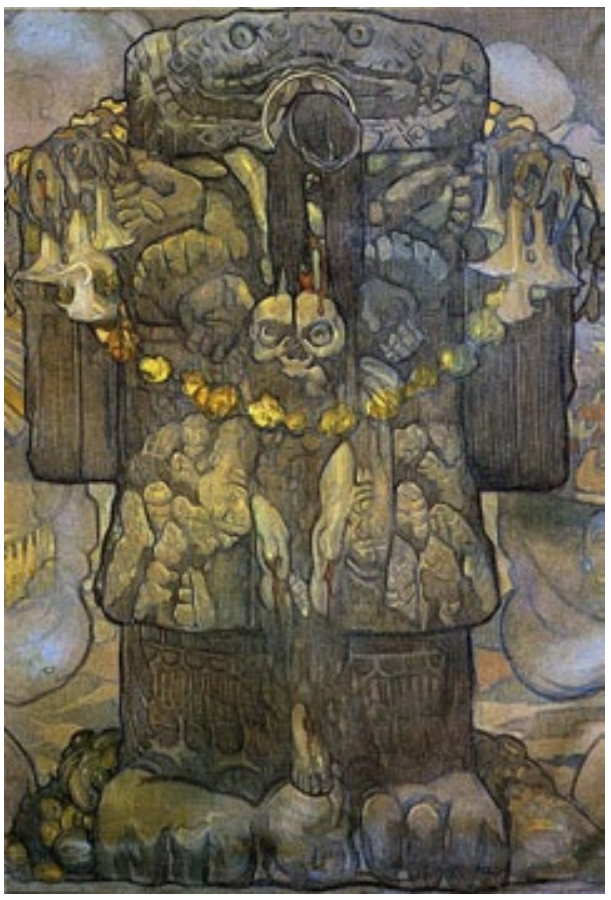

Fig. 18

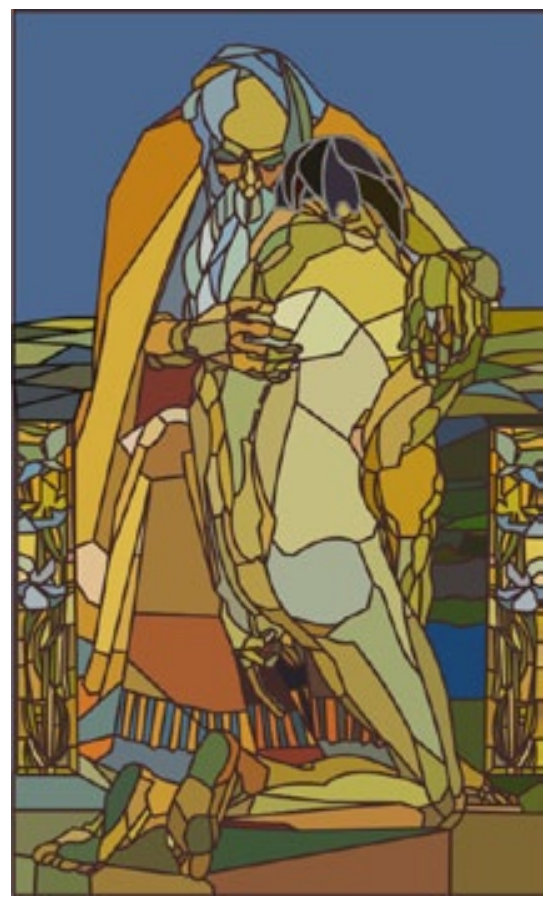

Fig. 19 Saturnino Herrán. Vitral

C- Dibujos de estudio de construcción formal de representación, dibujos de especulación formal, cuestionamiento y variación de las estructuras conceptuales del campo del dibujo. Fig. 20 

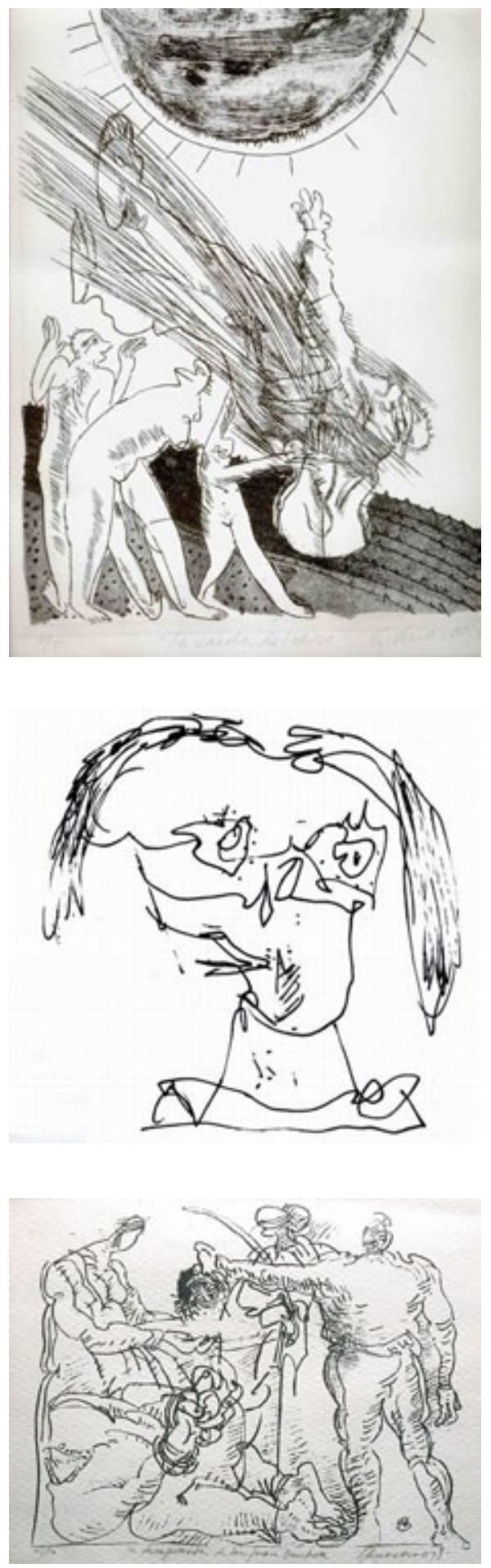

Fig. 20 Gilberto Aceves. Dibujos.
Es importante mencionar que estos estudios implican por una parte necesariamente el reconocimiento de la cosa real en el sentido físico, a manera de fuente de estructura de la forma plástica. Y por otra, la claridad conceptual y formal de la estructura del campo dibujo sobre la que se opera y configura la imagen.

Una vez señalada aquella división, digamos que en conjunto los dibujos de estudio mediante la reflexión insistente y el trazo reiterado, encuentran la estructura del sujeto o fenómeno y las posibles soluciones al problema estructural inicial.

Tenemos entonces que el dibujo de estudio implica una conducta reflexiva consistente y, en el plano resolutivo del trazar, una ejecución técnica altamente estructurante en cuanto al modelo y la conformación de la imagen. Sus tiempos de ejecución son necesariamente dilatados. El dibujo de estudio genera en consecuencia trabajos sumamente elaborados; demanda por lo general una motricidad intencional controlada. Implica (y esto es muy importante hoy día) la voluntad para construir una imagen que no se obtiene a la primera intención generalmente. El dibujo de estudio logra sus mejores dividendos en la mente del dibujante, pues al dejarle una experiencia estructurante sistematizada, este será capaz de utilizarla a voluntad en el futuro; es un bisturí para diseccionar el modelo dibujado, que posteriormente posibilitará la especulación plena de la forma.

Aquí la relación entre el modelo y el dibujante se da en términos de estudio. Para Leonardo y Rembrandt o Gericault, el cuerpo o la parte dibujada estaban bajo la lente, era el punto fijo de atención hasta que revelaba su razón. El dibujante era la inteligencia cognoscente.

En este punto la acepción que nos interesa del proyecto en el dibujo, es aquella que se refiere a los trazos mediante los cuales el artista elabora la representación y configuración de lo que tiene en mente realizar como obra terminal. 
La lección del informalismo trajo consecuencias y cambios radicales en el comportamiento metodológico de los artistas y dibujantes.

Parte de la propuesta y actitud de los expresionistas abstractos consistió en abordar la obra sin ningún boceto o proyecto previo, aunque esto no fue logrado en su totalidad.

Ahora es frecuente que este sea el procedimiento habitual.

Pero no en todos los casos es así. Los proyectos de Christo Javacheff denotan la actitud metodológica rigurosísima que lo lleva a realizar collages pinturas y dibujos antes de abordar sus intervenciones, cuyas magnitudes espaciales y geográficas implican una dimensión ética y política de gran responsabilidad, y por tanto exigen una planeación puntual. Dibujando proyectos definimos con claridad nuestras intenciones de construcción significante.

El proyecto puede estar tan certeramente finiquitado que de alguna manera nos pone frente a lo que sería la obra final aunque esta todavía no exista concretamente. Una cualidad del proyecto en el arte es su posibilidad de ser y de impactarnos aún dentro del terreno de la utopía. Cuando un proyecto acierta en la estrategia conceptual y de representación ha logrado su finalidad esencial; si bien al llevarlo a la acción configurante se agregaran situaciones fortuitas que posibilitan nuevamente su expansión significante.

La distribución, el peso, el número y el grado de los elementos que integran la obra quedan definidos en el Dibujo de Proyecto, en ellos se encuentra inmanente el principio de acción compositiva como fundamento reflexivo de significación.

También las relaciones de la obra con el entorno se resuelven en estos dibujos.

El emplazamiento de la obra como problema se resuelve en el trabajo del proyecto, así cuando se realiza en el contexto, la obra tiene un margen de certeza amplio, si bien lo fortuito comienza a intervenir en la deriva del proyecto.

Si en algún momento del dibujar, la forma obedece a una función consciente de representación, es en este tramo de la construcción de la imagen.

Es importante apegar la ruta configurante al plan determinado en el proyecto, evitando así fisuras que puedan llevar a desviaciones en la intención expresiva. En la historia del arte occidental encontramos con profusión dibujos de proyectos de los más variados asuntos, máquinas de todo tipo, tapetes, pisos, castillos, escenarios y escenografías, pinturas, esculturas etc. No sucede lo mismo con otras culturas y su construcción de la forma. Esto es así dado el carácter racional y lineal de occidente, nos caracteriza un pensamiento que pretende operar con márgenes amplios de certeza y predictibilidad. Proyectando una obra plástica, en realidad la organizamos desde su gestación hasta cada una de sus etapas fáctico-constructivas, pero también en el proyecto dibujado quedan finalmente establecidas las relaciones significantes del tema y las respuestas a su problematización.

Dibujar proyectos es el pináculo del pensamiento determinista y establece como tal, una secuencia metodológica unidireccional, por esto no es casual que en su origen hace 600 años esta ruta artística estuviera íntimamente ligada a la arquitectura, el diseño y la ingeniería.

El dibujo de proyecto define, no solo por tanteos, todos los factores implicados en una obra. Permite al autor enfrentarse al lienzo, la lámina, la madera, el espacio urbano etc. Con una certeza mayor. 
Con la secuencia de los dibujos del dibujo y sus funciones se formuló un paradigma metodológico y un sistema de representación en el arte de occidente, este, a lo largo del tiempo ha dotado a las artes plásticas y visuales de una herramienta de especulación formal. Los proyectos dibujados se han venido simplificando en su elaboración técnica, en una relación inversamente proporcional a la capacidad mental del artista, para representar en su imaginación los caracteres y condiciones formales del proyecto. La capacidad corporal de configuración dirige la idea y su forma al cuerpo de la herramienta encargada de realizar el depósito matérico en el soporte. Como lo dijeran los calígrafos chinos "es la idea que fluye a través del pincel. 



\section{CAPÍTULO III \\ LOS MODELOS DEL DIBUJO}

El modelo es el otro.

El modelo es la ficción que calza con la realidad.

El modelo es la estrategia del hacer.

El modelo es el pensamiento de la configuración.

El modelo es el gran otro.

El modelo es la presión de los otros que ocupa mi mente.

El modelo es nuestro deseo de construir al gran otro.

El modelo está en la interioridad del acto de dibujar.

Nuestra investigación se origina con la escisión problemática generada en la formulación posmoderna, que establece la quiebra de los modelos paradigmáticos formales y estéticos, mismos que hasta la modernidad operaron como relación sistémica que unió al dibujo con las demás prácticas artísticas.

Desde el momento que la realidad contextual externa pierde consistencia ontológica como otredad que funda el principio del acto dibujo para conocer al otro y a lo otro, se rompen las relaciones causales de la cadena epistemológica que organizó hasta ese momento la postura e intención del dibujante.

El inicio de este proceso se anuncia dentro de la postura romántica y su proyecto crítico de la cultura y la filosofía; con el Doctor Fausto aparece (o cuando menos es planteada claramente) la figura del ser dividido, que identifica dos vías para conocer la realidad, una, la del pensamiento racional y objetivo, frente a otra segunda, la del conocimiento sensible y vivencial. De ahí y hasta hoy tal escisión resulta ser el centro del proyecto artístico y la base de las estrategias de construcción del sentido significante; dicotomía prácticamente insalvable.

De este camino señalamos una consecuencia radical, la que se muestra en el corte de la modernidad de los años treinta del siglo XX, esto, al llevar el origen de la práctica del dibujo hacia la totalidad interior y subjetiva del artista, convirtiendo el acto de dibujar, de un trabajo disciplinar orientado a la construcción de una obra estética hacia el terreno de la acción del dibujo. Como veremos, en la interioridad del dibujo este proceso ya se había iniciado en las prácticas del movimiento romántico y en la estética sublime y pintoresca, pero marcamos como punto de giro radical el corte que las vanguardias establecen para los años 30 del siglo XX. 
Dedicamos un primer segmento de este trabajo a la tarea de posicionar el fenómeno, buscando establecer los cortes teóricos sustantivos derivados de esta formulación, viéndolos como núcleos problemáticos esenciales para el sustento de nuestra hipótesis y fundamento de la investigación.

Siguiendo esa dirección del análisis, y desde semejantes premisas nos abocamos a trazar una categorización de la disciplina del dibujo como una forma del pensamiento proyectual. Desde esa postura fundamentamos tanto la constitución del cuerpo disciplinar del dibujo, como su entendimiento y definición en tanto función proyectual, que lo enlaza con las demás artes plásticas y visuales. Intentamos demostrar como esa función se mantiene íntegra aún dentro de las estrategias y prácticas multidisciplinares de la posmodernidad. Si bien señalamos la quiebra de las prácticas de representación del dibujo como creadoras de imágenes de primera generación.

Hasta este punto formulamos nuestra idea del dibujo como disciplina proyectual, carácter y función que ha mantenido dentro del desarrollo del arte occidental. Iniciamos también la consideración teórica del dibujo como un acto; el Acto Dibujo.

Partiendo de estas dos vertientes intentaremos llegar a discurrir en la última parte de esta investigación sobre la posibilidad de establecer las bases para un análisis teórico formal y estratégico del acto dibujo.

Los dos tramos iniciales de esta investigación constituyen el marco teórico filosófico con el que fundamentamos nuestra reflexión. Pero a la vez integran el espacio y región temporal en el que se inscribe y sucede el fenómeno que analizamos. Esta resulta ser una característica peculiar que acaso sea interesante resaltar; marco teórico e histórico se transfunden como ubicación fenoménica del problema estudiado.

En esa línea metodológica es necesario introducir un material categórico y conceptual emanado de la interioridad del campo que estudiamos; y no porque nos interese mantener o defender la pureza de un área artística y su circunscripción; más bien resulta necesario tal trazo conceptual, como determinante metodológica obligada por la construcción sistémica de nuestro análisis. El centro temático que nos mueve es el de la situación del dibujo en el contexto de la modernidad y la posmodernidad, por eso nos remitimos a los contenidos conceptuales, teóricos, metodológicos y procedimentales cuya condición es la que intentamos analizar, así como la postura epistémica del sujeto dibujante.

La dirección metodológica que guía nuestra intención entonces, no se determina por la ruta analítica de la generalidad artística, ni por los problemas genéricos que en ello se suceden, aunque en cierta medida el dibujo esté impactado por la condición total de las artes. O bien forme parte integrante de un fenómeno de complejidad mayor que integra las regiones varias de las artes en una dialéctica que no reconoce límites de territorios modelísticos.

Ya desde este punto se visualiza una postura epistémica que determina una concepción del análisis.

Los modelos del dibujo no son solo entidades objetuales clásicas, se encuentran en la interioridad del pensamiento del dibujante desde el momento mismo en que se inicia la reflexión tautológica hacia el propio campo. 
La consideración del dibujo como práctica artística para analizar será abordada bajo el trazo orgánico del pensamiento del propio dibujo, sus sistemas de formalización, sus conceptos, sus posturas filosóficas y las estrategias que lo sustantivan y relacionan con las demás artes.

Pero la categoría de modelo en el campo del dibujo enfrenta una conceptualización múltiple y relativizante.

Hemos de referirnos a los Modelos del Dibujo a manera de concepciones paradigmáticas y cuerpos conceptuales de la forma del dibujo y sus sistemas. Una reflexión modelística empero implica también el entendimiento y estudio de los sistemas teóricos y epistémicos sobre los que opera y se desplaza la práctica y acción del dibujar. Son estos, modelos categóricos que realizan extensiones hacia campos diversos del arte, o que bien, como en este caso provienen de campos tangenciales y conexos, pero que penetran y reportan ideas útiles a nuestro análisis; son en cierta medida modelos de crítica de arte, de su historia etc.

El análisis de los modelos del dibujo no podría dejar de lado un territorio reflexivo sobre los sujetos, objetos y fenómenos que a lo largo de la historia han constituido la otredad ontológica frente y dentro de la cual se posiciona el dibujante.

Habremos de iniciar nuestra reflexión con una demarcación general sobre el concepto de los modelos como construcción teórica, social, artística y abstracta, que permite el entendimiento de fenómenos que acontecen en el orden contextual de la realidad, figuras creadas por el pensamiento que intentan reproducir construcciones y causas que determinan el devenir de los fenómenos, pero he aquí una cierta distancia con los modelos de las artes, en este campo los modelos como maquinaciones abstractas no intentan la explicación del orden natural, social o contextual para operar en su afectación y conducción, los modelos en el dibujo, como en el arte son figuras del mundo eidético formal, crean un territorio alterno que se sobrepone a la primeridad contextual.

Pasaremos a los modelos analíticos que se aplican en el estudio de las artes, será de esa manera ya que los estudios específicos sobre el campo del dibujo nuevamente son pocos. Por eso es que nuestra reflexión corre de territorios generales para dirigirse a la región del arte hasta puntualizar el territorio del dibujo.

El pensamiento teórico y la literatura que expresa las reflexiones del dibujante, así como el trabajo que la crítica aporta sobre el campo disciplinar, se encuentra disperso en el mar de material general de las artes, es tema recurrente para citar en el análisis que de los procesos artísticos se hace y dentro de los cortes paradigmáticos que se formulan. Pero este pensamiento que expresa una postura teórica con respecto al dibujo es sumamente fragmentario por decir lo menos.

La teoría del dibujo vive las determinantes de la secuencia modernidad posmodernidad; señalamos con esto la renuncia para construir un pensamiento sistemático e integrado en el que se base la determinación ontológica de la disciplina.

Los cortes históricos de la forma del dibujo y sus estados teóricos, siempre estarán en relación con el tiempo y la ubicuidad histórica en la que se suceden, esta es una formu- 
lación ingenua; lo que tenemos que remarcar es que el carácter de esa circunscripción no es lineal, se manifiesta en giros y modos particulares que son los que interesa referir y analizar en este estudio.

En gran medida la respuesta y satisfacción al problema planteado encuentra su solución en el estudio de esta secuencia histórica, epistemológica y formal del dibujo, La comprobación o disprobación de la hipótesis se haya también determinada en gran medida por este segmento del estudio.

Los sistemas modelísticos del dibujo y su trazo a través de la historia, y el establecimiento de cortes y secuencias paradigmáticas de este fenómeno nos revelará las características y funciones que operan como constantes del cuerpo del dibujo dentro del fenómeno general de las artes, nos permitirá establecer que elementos y conceptos de las formalizaciones dibujísticas y sus estrategias se someten a constantes y variaciones dentro de la sistematicidad del dibujo y la que se genera como función hacia las demás artes. Nos definirá con mucha claridad incluso el grado de esas variaciones formales y funcionales, nos advertirá sobre la emergencia de las funciones y características de nueva y primaria generación.

Los modelos del dibujo se relacionan íntimamente con el carácter histórico del proyecto artístico, como ya lo analizamos en el apartado capitular anterior, por eso decimos que el pensamiento proyectual del dibujo es una expresión modelística del dibujo interno zucariano. Los giros y recorridos de esta expresión son un territorio por explorar, aunque la tarea de este análisis esté iniciada. Pero sobre todo, interesa formular estos cortes modelísticos del dibujo basados en su integración como función histórica del dibujo, señalando los momentos de estabilización formal y epistémica, mismos que nos permiten hablar de periodos, que no son sino cierres temporales del pensamiento y la representación. Cortes, relatos, periodos, cualesquiera que sea la denominación que les asignemos.

Es esta una postura teórica basada en la necesidad metodológica de construir una agrupación del dibujo que nos posibilite el análisis que intentamos. Es pues una necesidad teórica, que sin embargo no desconoce, ni le interesa negar, la formulación de otros estudios que proponen diversos cortes paradigmáticos para el análisis del arte moderno y posmoderno.

Así, es necesario iniciar la construcción de un marco conceptual de la forma y los sistemas teóricos del dibujo, las estrategias de representación que analizan el propio campo y acción del dibujar, que hemos de entender como la manera específica del pensar dibujando.

En diversos puntos de nuestro análisis aclaramos e intentamos orientar la reflexión en una dirección que se origine desde la interioridad disciplinar; esto es, marcar la problemática inicial como una condición de existencia de la práctica del dibujo, que si bien reviste implicaciones filosóficas y de otros órdenes, es ante todo condición de la producción y ejecución del dibujo.

Lo anterior, pensamos, es una condicionante básica que determinamos, y aunque hasta este punto hemos discurrido por argumentos culturales e históricos del arte, intentamos siempre retornar a la ubicuidad puntual disciplinar. Marcamos con esto una postura metodológica clara y hasta cierto punto radical. Determinar los giros problemáticos que originan nuestro trabajo y su ruta de análisis desde una visión endógena del campo del dibujo. 
De modo que aunque muchos de los sustentos reflexivos se comparten y originan en disciplinas anexas, es el núcleo de la teoría del dibujo, sus formalizaciones y estrategias el centro gravitacional que organiza el análisis.

Los fundamentos de esta postura son ante todo epistémicos y metodológicos, aunque no faltan justificaciones que también orientan ese proceder.

Hace poco ya nos inclinábamos por esta ruta modelística, enfrentamos algunos desacuerdos con distintos pensadores.

A lo largo del trabajo de esta investigación fueron apareciendo nombres, posturas e ideas coincidentes con nuestro punto de vista. Alain Bois, Hall Foster, Marchan Fiz, Hubert Damish, todos ellos, nos enseñaron la posibilidad de desarrollar un pensamiento que se ubica en la interioridad del campo que se analiza, pero tomando siempre en cuenta las extensiones y contenidos tangenciales con la historia y el fenómeno general del arte.

La teoría de la modernidad Greengberiana hace centro de su elaboración crítica, el campo disciplinar de la pintura, en tanto que las construcciones reflexivas posmodernas se centran en el problema de la estrategia artística, objetivada en la cita y la apropiación, en el relato que justifica las artes pluridisciplinares e híbridas, la alegoría y la teatralidad, esto como respuesta a la crisis de la representación.

Cabe en este punto una distinción analítica, es importante señalar la distancia que existe entre la crítica posmoderna que fundamenta ese arte, y la producción de los artistas a quienes se deben las obras que motivan ese discurso.

Consideramos pertinente esta consideración, ya que tanto en un discurso como en otro (o en términos de Danto, tanto en el relato moderno como en el posmoderno) la práctica de los artistas pone en uso y se basa de manera recurrente en la disciplina del dibujo; aún así, el espacio que todos los autores teóricos y críticos de estos periodos dedican al dibujo es francamente insuficiente. Pero sobre todo no lo constituyen en punto de origen reflexivo, poniendo en su lugar formulaciones y posturas universalistas del dibujo que son originarias de aquellos relatos que se busca trascender.

En todo caso, aunque las prácticas del arte dentro de los últimos 80 años lo menos, se han dirigido al terreno multidisciplinar, ya se ha analizado la imposibilidad de trascender radicalmente el establecimiento de los límites de definición ontológica de los campos disciplinares. Agregaríamos que cualquier expansión en este sentido solo lleva más allá las fronteras del propio campo, o bien nos ubica en la zona del entre espacio donde se coloca la producción del híbrido.

No desconocemos aún así la posibilidad de emergencia de producciones artísticas con cualidades diversas que corren rápidamente a su establecimiento como regiones artísticas específicas, tal es el caso del video, como lo fue el de la fotografía o el cine. Pero no es este el asunto que interesa en este trabajo.

Mucho del transcurso de este camino lo hemos recorrido asistidos por el pensamiento de la crítica y la historia del arte, pero el giro que nos interesa es el que entiende los modelos del dibujo como formas de pensar el arte y el mundo mediante el ejercicio del dibujo. Puede esto sonar sencillo, pero lo mencionamos como supuesto categórico fundamental. 
Las lecciones de Hubert Damish estudiado a través de Alan Bois vinieron a dar certeza a nuestra intuición.

Pero también aludimos a los modelos del arte llevados al terreno de naturalizaciones culturales. Estabilizaciones de pensamiento que se emplazan en el imaginario colectivo y que operan como mecanismos de peso en el ideario e intenciones del dibujante. Los modelos del dibujo actúan como presión ideológica que determina el posicionamiento del dibujante frente al historicismo de su modelo. Hemos de dedicar algunas líneas a este punto.

Decimos nuevamente que entendemos los modelos del dibujo en una acepción que no solo es del orden racional y estratégico del dibujo, ni tampoco solo del mecanismo cultural e ideológico.

Para nosotros también, (y a riesgo de aparecer como tradicionales) los modelos del dibujo serán entidades ontológicas ante las cuales nos plantamos para realizar los diálogos del dibujo, otredades que activan los mecanismos complejos de la identidad y dan pie a la formulación de una fenomenología del acto dibujo en donde el sujeto se emplaza en una particularidad espacial y temporal, y en donde la vivencia primera se encadena con el plano experiencial, espacio y tiempo en el que se funda la historia como consecuencia del dibujar, más que como una historia en la que se basa y posiciona el proyecto del dibujo. La última parte de este capítulo trata sobre el recorrido de los modelos de representación formalizados del dibujo a lo largo de la historia. Queremos ver en ellos la concreción del pensamiento del dibujo que nos lleva al territorio de lo artístico, pensamiento que es la aportación de la disciplina y sus dibujantes al territorio de la teoría endógena de las artes.

Es pues este un segmento del análisis que corre de lo teórico general hacia el territorio particular del pensamiento del dibujo. Esperamos tener la capacidad para elaborarlo suficientemente.

\section{III-1 EL MODELO ES LA FICCIÓN QUE CALZA CON LA REALIDAD}

Los modelos son modos paradigmáticos del pensamiento humano. Son construcciones categóricas que emulan sujetos, fenómenos o procesos de la vida que se desea comprender; se adaptan a cada una de las regiones de la actividad humana. Se amplían conteniendo grandes esferas del saber, o bien se diversifican y subdividen en finísimas islas del conocimiento.

Aquí la noción de sistema, y ecología intelectual nos resulta indispensable, sobre de esa base estaremos trabajando y no es necesario puntualizarlo continuamente.

El pensamiento racional y experimental se auxilia de modelos estructurales y lógicos a manera de formulaciones abstractas que replican las condiciones de fenómenos u organismos. Aquí los modelos son entidades creadas para la investigación y el manejo de los fenómenos analizados. Estos modelos permiten la aproximación anticipada a los fenómenos reales del contexto, haciendo predecible el comportamiento y evolución de esos sistemas. Sin embargo el investigador sabe que estos modelos son estructuras abstractas creadas inteligentemente pero que guardan una distancia con el ser analizado, nunca el modelo en esta situación sustituye la realidad. Tiene por el contrario la necesidad de adaptarse a ella, en la medida de que su comportamiento modelístico debe ser similar al de los procesos 
estudiados cuando estos se manifiestan en la realidad contextual. Nuevamente el modelo es una construcción intelectual humana.

Una característica importante es que los modelos usados no tienen necesariamente que ser de las mismas dimensiones que el fenómeno u organismo que estudian, se pueden construir a escalas aumentadas o disminuidas drásticamente, porque se sabe que la normatividad que priva en el fenómeno es universal, independientemente del tamaño del cuerpo que la vive.

Ya que las pruebas se realizaron con modelos a escala, se procede como última etapa de la investigación a trabajar con modelos de dimensión real, de ahí se obtienen los últimos datos que hacen posible las conclusiones y el cierre del experimento.

El modelo como construcción teórica prefigurada, debe su rigurosidad a un orden lógico, la operación experimental y la comprobación empírica son los eslabones capitales del pensamiento racional occidental y del método científico. Su completud como la mencionamos, coincide con el periodo renacentista de las artes, las marca en su interioridad epistemológica. Por tanto su historicidad racional positiva coincide con la historicidad racional del proyecto como visión del mundo.

Este es el origen de las prácticas proyectuales observadas en varias áreas del quehacer humano, el arte entre ellas. Las distintas etapas en el avance de un proyecto son en realidad la construcción de un modelo que busca solventar las necesidades de una obra, para que esta finalmente cumpla con los objetivos para los que fue diseñada.

Para la ciencia el modelo es una figura teórica temporal, una explicación provisional en tanto se construye una más convincente. Para el dibujante, el modelo teórico es la entidad sistémica formalizada que objetiva la representación en un conjunto de categorías, conceptos, leyes técnicas y estrategias referidas al universo de la imagen.

La historia del dibujo muestra el proceso de cambio y ampliación del universo de modelos de que se ha servido el dibujante.

Con los cambios paradigmáticos en la concepción del arte viene aparejada la transformación de los modelos del dibujo, hasta llegar a la mitad del siglo XX en donde los modelos se convierten en expresión tautológica del arte y, por otra parte se transportaron también al interior de la subjetividad del propio dibujante.

Para el dibujante el modelo puede ser un pensamiento hecho formas, un ideal que gana consistencia en la medida que le atribuimos tiempos, acciones, actitudes y valores, así como técnicas y modos de dibujar.

Hacemos en este punto una diferenciación fundamental; la formalización, la forma a que aludimos no solo es la formalización trazada que nos remite al modelo referente objetual o ideado, esta es la relación directa que une signo y símbolo con un algo que es representado y que llamamos referente.

En este punto aludimos a la forma del propio signo, que puede variar en su cualidad formal y matérica, pese a seguir denotando un referente de manera directa o sintetizada 
como en el ideograma. La cualificación que se hace de la forma del signo trazado es principio fundamental en los procesos de conceptualización y teorización del dibujo; la forma del ideograma es variable aunque siempre se asocie con la forma del referente, esta consideración nos aleja de las visiones directas que hermanan fácilmente representación y mímesis, distinción que resultará esencial para el desarrollo de nuestro último capítulo en esta investigación. Situación teórica que por otra parte se halla en la base del proceso de abstracción que se inicia en la vanguardia del XIX y culmina en el proyecto del dibujo indéxico y formalista del $\mathrm{XX}$.

En el terreno de las artes y el dibujo, la visión ideal del modelo, se concreta en formas con razones compositivas y estructurales, plasmadas en un sistema métrico, el modelo del ideal se basa en la expresión mesurable de la belleza.

Dentro del dibujo los modelos se elaboran armando estructuras teóricas, formales, conceptuales y procedimentales, a las que se les confiere un potencial de importancia, el modelo no es el caso sino el sistema. Al artista interesa la posibilidad de que el sistema sirva no para producir el mismo modelo sino la variación en cada obra producida.

Los modelos en arte son también modos de expresión de los paradigmas de la época, y en ese sentido cristalizaciones del proyecto histórico, son modelos del pensamiento mediante los cuales se integra el imaginario colectivo. Estos se concretan en estructuras teóricas y metodológicas y en sistemas de representación globales, también en la consideración que el artista guarda del contexto que le antecede y del actual, en lo cual se basa la fundamentación del modelo histórico como forma del pensamiento del artista.

Los modelos del dibujo implican niveles teóricos de abstracción, se establece un recorrido de niveles teóricos modelísticos para el dibujo, desde el plano cultural general y su ecología como visión en la que la propia sociedad se auto representa, hasta el plano de la representación como traducción sígnica formal de los datos observados en la estructura visual de los modelos somáticos.

Una de las partes sustantivas del tratado de la pintura de Leonardo es la que dedica al estudio de la perspectiva pictórica, en esa parte el autor analiza el tratamiento espacial y cromático interrelacionados para generar profundidad por medio de recursos no geométricos; no analizaba cuerpos ni objetos, pone al centro del dibujo y la pintura un fenómeno físico, el del filtraje que la atmósfera y su densidad generan como reductores del color local y el contraste cromático de los objetos, la manera en que lo desmenuza en reducciones formales es maravillosa. ${ }^{80}$

La naturaleza se puso como modelo y centro del dibujo y la pintura. Esto favoreció en un primer momento la depuración de la experimentación como base del dibujo.

Después, la revolución del relato temático en el arte barroco desplazó otra serie de paradigmas del modelo, el exceso de formas ovoides multiplicadas intensamente generó su explosión en un campo atmosférico y lumínico, todo lo cual entre otros factores, terminó modificando el modelo paradigmático. 
Pero hubo una consecuencia o giro interesante, pintar y dibujar la naturaleza implicaba, tomándola como modelo, representar situaciones mucho muy complicadas porque el modelo estaba en continuo movimiento y cambio. Pintar un suceso en tiempo real implicaba su suceder fenoménico, una puntualización espacial y una demarcación temporal en la que se cobró conciencia de lo importante de la ubicuidad del dibujante como sujeto cognoscente. El sistema renacentista y manierista barroco, congelaba a los modelos y ofrecía una suspensión del tiempo que colocaba a los personajes detenidos en la fracción del instante representado.

Ésta es una de las circunstancias que se derrumban con Las Meninas de Velásquez, el tiempo es una condición de circunstancia natural del acontecer, todos comparten el instante, el pintor los modelos y el espectador.

Los fenómenos como modelo del dibujo, pusieron al dibujante en necesidad de adaptar las estrategias de acercamiento con la realidad, el apunte cobra muchísima importancia, el dibujo de estudio no decrece en su aplicación, pero su práctica se acelera incrementando la capacidad del dibujante en tiempos reducidos.

También el dibujo se desplazó hacia técnicas como la media tinta y la acuarela, porque los espacios del cuadro estaban dominados por amplios vacíos aparentes, muchos de los apuntes de campo de Rembrandt tienen bastas zonas de la imagen sin afectar por personaje alguno. La pintura de fines del Barroco, la de los flamencos naturalistas y la del pre-romanticismo se pobló de extensas zonas de color modelado, y el dibujo se comenzó a llenar de vacío. Fig. 21

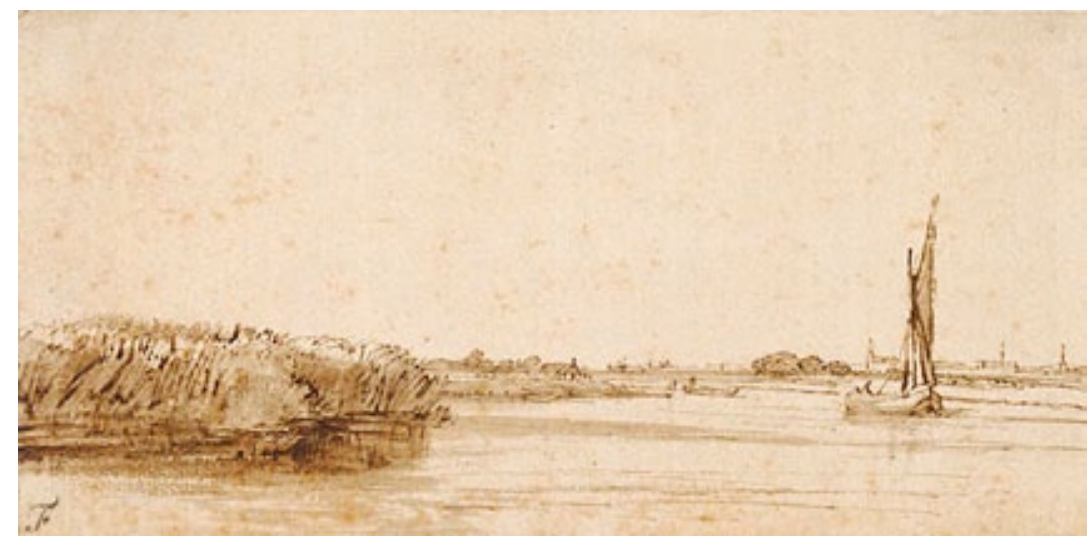

Fig. 21

Cuando los modelos se centraron en los fenómenos, el dibujo cedió terreno a la cromatización de la pintura, a la gestualidad y la densidad matérica de la superficie. La norma renacentista y del clasicismo definía el dibujo a partir del contorno como: circunscripción de los cuerpos por la línea, incluso el paisaje renacentista es de un purismo de contornos. Por otra parte la huella indexal del trazo y la pincelada hasta ese momento era subyacente en los estratos pictóricos y se buscaba su dilución en la apariencia de realidad, en ese punto, la pintura flamenca inicia la lectura perpendicular de los estratos pictóricos y la revelación de la huella indexal del trazo como gesto subjetivo y marca indicial del procedimiento operativo y mental. 
Esta condición de materialidad pictórica sensible y trazo emotivo animado por la subjetividad del artista será una de las características centrales de la forma expresionista, cualidad que se prolonga aún hasta hoy. Henri Moore, Kati Kolwitz, ambos en la primera mitad del siglo XX nos dan lecciones de magnitud insuperable. Fig. 22
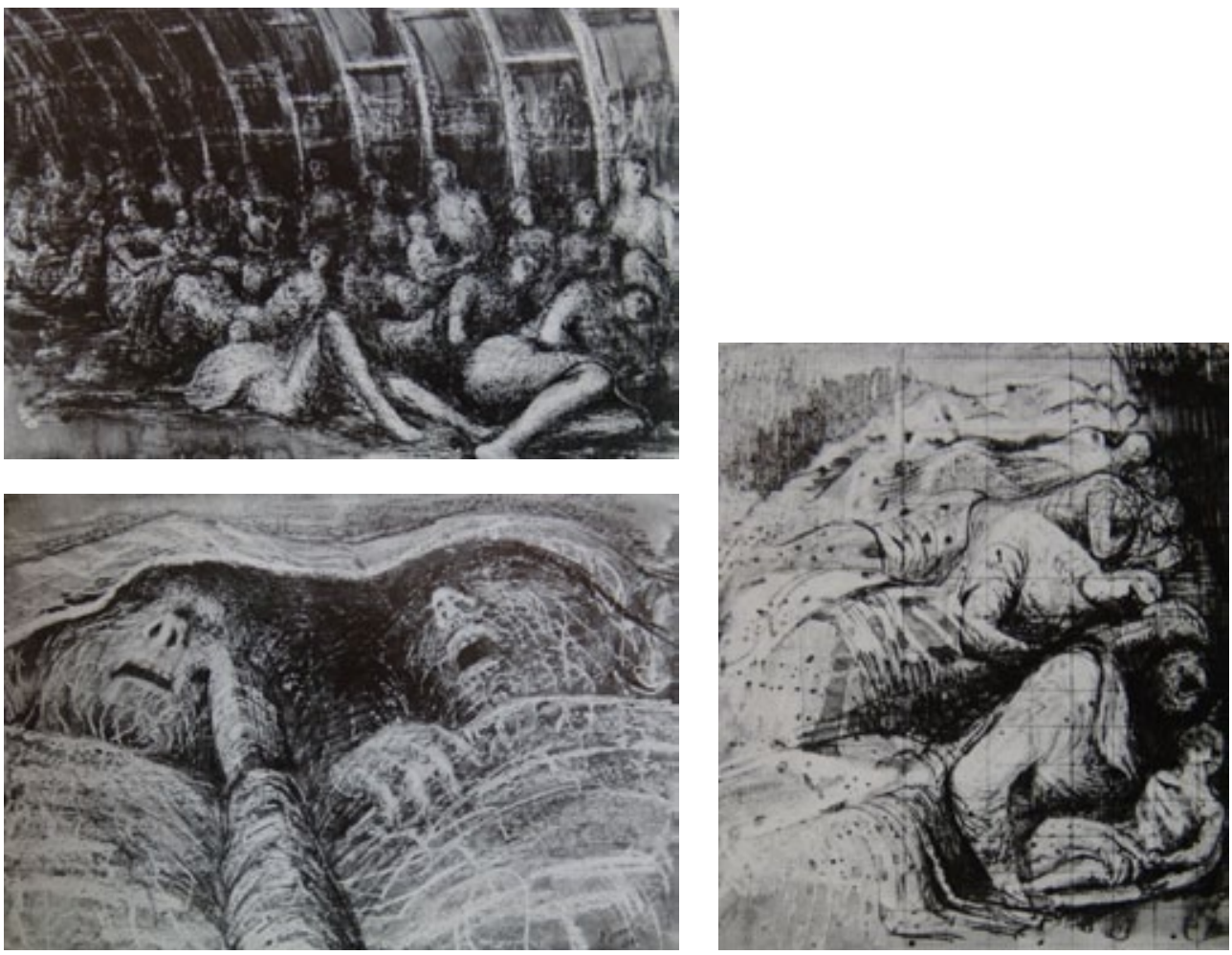

Fig. 22 Henry Moore

El gran pliegue del informalismo y el expresionismo abstracto consistió en retrotraer los modelos al interior de la psique del artista, el modelo estaba dentro del dibujante, no tenía que buscarlo para aprender de él, pero éste le seguía mostrando la coherencia de su trabajo con el norte conceptual y procedimental.

Muchos, por no decir todos los artistas informalistas y expresionistas abstractos guardaron una estrecha relación de pensamiento e imagen con las culturas tribales del mundo. Barnett Newman siguió con particular interés las exposiciones de arte polinesio y del pacífico del sur que se montaron en los años cuarenta en Nueva York, el mismo se encargó de redactar textos para las presentaciones y catálogos de esas muestras. Pollock, por su parte se adentró profundamente en el pensamiento de las culturas aborígenes norteamericanas como los Hopi, el pensamiento místico egipcio sustentó varias de sus primeras obras fundamentales.

El caso de Dubuffet en su búsqueda del pensamiento elemental primigenio es bastante conocido.

Ya desde finales del siglo XVIII el arte oriental, Chino y Japonés principalmente invadió el mercado y la cultura artística europea, la egiptomanía del XIX y el arte tribal africano signi- 

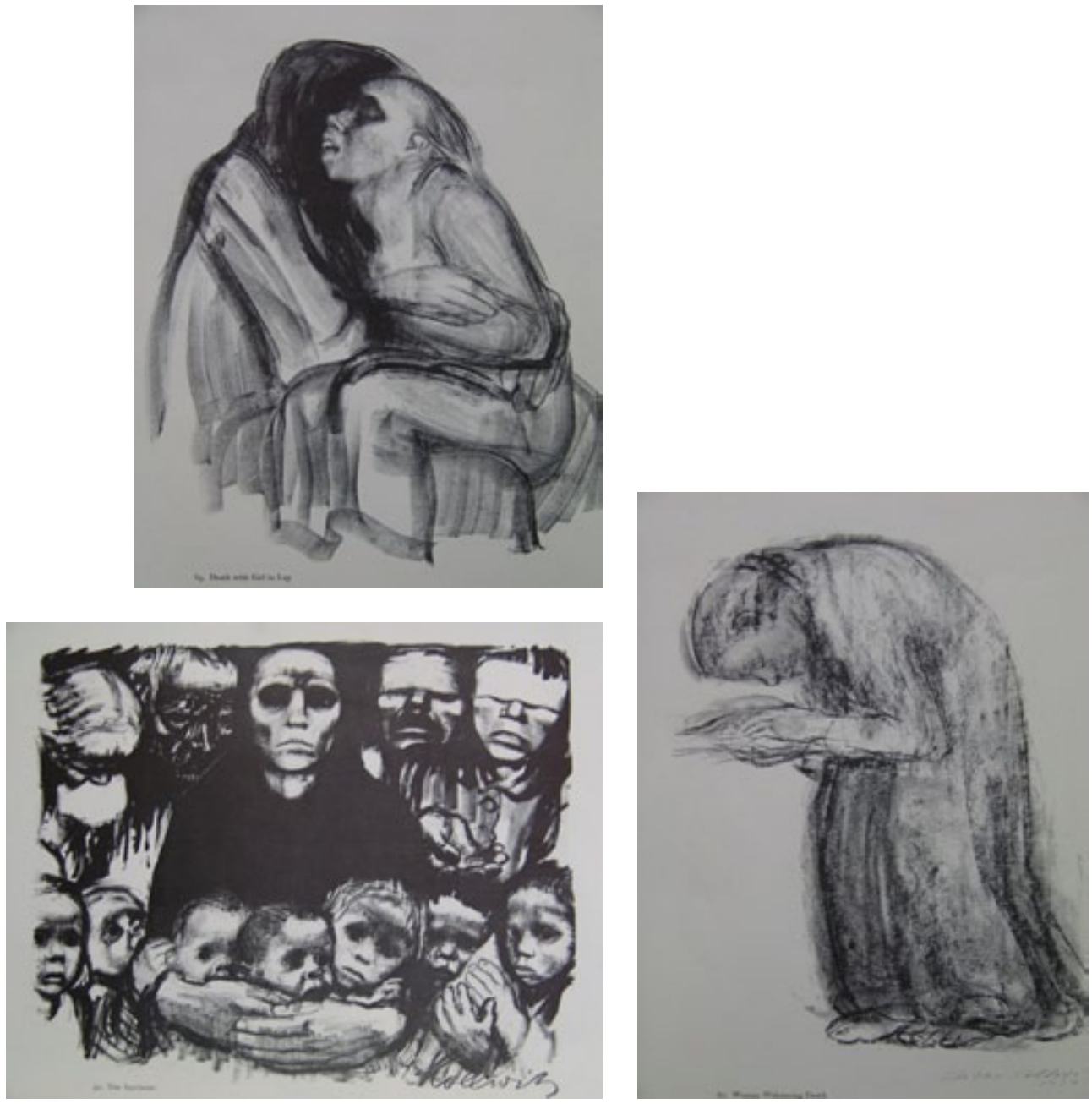

Fig. 22 Kati Kollwitz

ficaron una oleada que impactó el ideario representacional de occidente. En ese sentido y claramente se muestran como modelos que presionaron el imaginario formal del arte y del dibujo; no sabemos en qué medida, pero es claro que este repertorio formal marcó el rumbo del arte a partir de la vanguardia.

Podemos marcar con precisión el punto y las obras que ya en el arte informalista y expresionista, presentan huellas, puntos de giro, momentos de desviación de aquel imaginario formal representativo para construir el absoluto de cada uno de esos artistas, que a la larga los convertiría a su vez en nuevos modelos del dibujo.

Nos interesa señalar un apartado más; el que toca a la relación epistémica que el dibujante guarda con el modelo que dibuja. Pareciera ser que objetivamente el artista analiza lo que tiene enfrente para poder representarlo en la imagen, incluso hemos dicho que 
dibujar en un momento, consiste en recabar información de la cosa vista, y en ese sentido el dibujo es la transcripción del dato visual.

Esta posibilidad de definición del dibujo es en cierta medida acertada, pero comporta el riesgo de igualar la práctica del dibujo con la teoría de la comunicación en su sentido estructuralista más limitado.

El dibujante al posicionarse ante sus modelos ontológicos realiza una observación, acto mediante el que recaba una información visual, pero esos datos no solo se refieren a peculiaridades visuales, tienen que ver también con la apreciación subjetiva que el dibujante procesa partiendo de su vivencia, una extensión psíquica que no se agota en una acción de toma de información, ni de su codificación y transcripción en caracteres sobre el soporte del dibujo.

Por eso decimos que la relación del dibujante con sus modelos reviste un carácter epistemológico en el que se requiere la conciencia del dibujante, para ejercer un posicionamiento frente al problema que se ha trazado a resolver y la pertinencia del método y estrategia que se propone. La relación epistémica no se agota en la transcripción de datos visuales, es un acto cognitivo que pretende calar en la profundidad de lo analizado.

El hecho de trasladar el caballete a la campiña y llevar los útiles del dibujo a la calle o al campo, o como lo hiciera Daumier a la cámara de representantes, significó una revolución más profunda de lo que pudiera parecernos.

La relación que el dibujante establece con sus modelos no es un acto simple. Se llegan a desarrollar lazos de profundidad significativa. Esto entraña una definición epistémica y vivencial.

Cuando el modelo es fuente de conocimiento se desarrolla una pasión de investigador. Otras veces el modelo significa una entidad que tiene un poder por sobre el dibujante, entonces sobrecoge, y la relación de autor es de cautela y titubeo. Muchas veces se tiene la conciencia de estar dibujando lo sagrado, los valores nacionales o, nuevamente Daumier, el rey como Pera.

Diego Rivera pintó a sus modelos desde el amor infinito por su pueblo, por eso tomó de su carácter aquello sustancial, lo depuró formalmente hasta despojarlo de aquellos rasgos que lo enturbiarían, pero ese pueblo modelo nunca existió.

El fetiche es también un modelo, en él la realidad del otro se duplica, el fetiche es parte espiritual y sustancial del otro, si le hacemos cosas al fetiche se las haremos al otro, a no negar existen dibujos que se ensañan con el modelo, lo retratan porque morfológicamente toman la esencia de las formas que lo tipifican, pero lo destrozan o lo penetran en toda la gama de acciones y sentimientos humanos, recordemos los retratos que de los curas realizan José Clemente Orozco y Antonio Saura, o los Cuerpos de Damas de Dubuffet. Fig. 23

La potencia de este vínculo epistémico no se puede ocultar. Cuando esta relación se sustentaba en el acercamiento del dibujante a la naturaleza, era un vínculo romántico, positivista, o prerrafaelista.

Pero hay zonas tabú; la relación de Klimt con sus modelos femeninas es sencillamente sensual y francamente provocativa, la de Schiele con los desnudos que dibujaba sí que es per- 

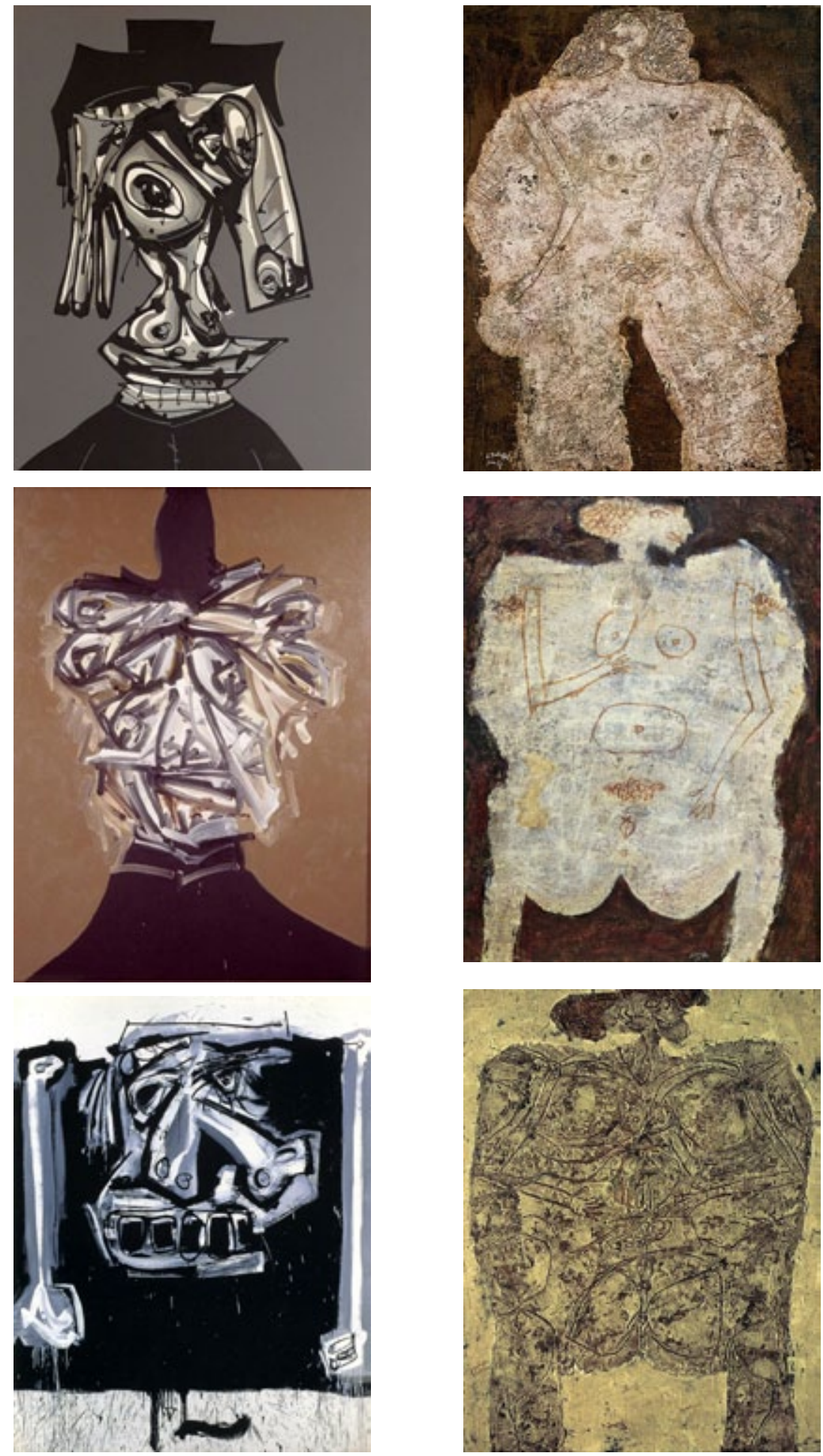

Fig. 23 "Curas" Antonio Saura

Fig. 23 Dibujos y pintura. Jean Dubuffet. 
turbadora, Oscar Kokoshka como maestro de la pintura y el dibujo simplemente destrozaba al personaje al retratarlo, las fotografías de Matisse dibujando mujeres en su estudio nos muestran un eterno amante de la mujer. Helga y Andrew White, Rembrandt y su esposa, Picasso y sus modelos. Rodolfo Nieto y los animales en el Zoológico de Basilea. Fig. 24
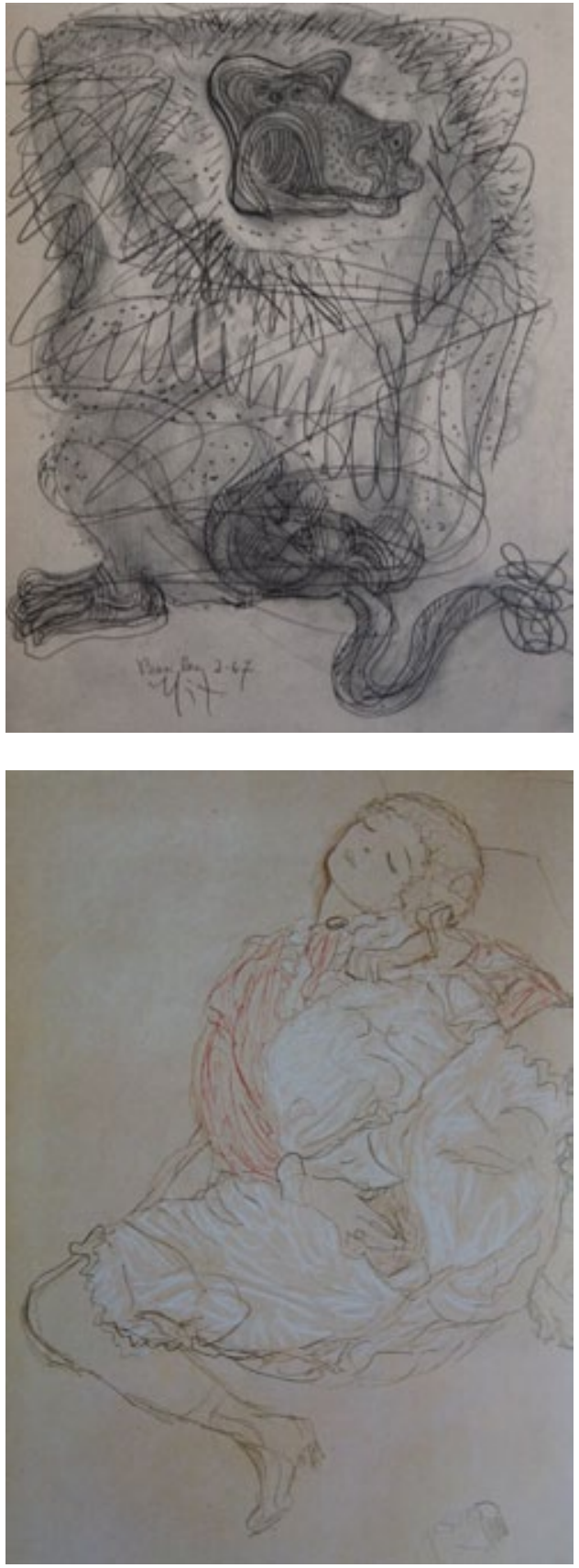

Fig. 24 Gustav Klimt. Rodolfo Nieto

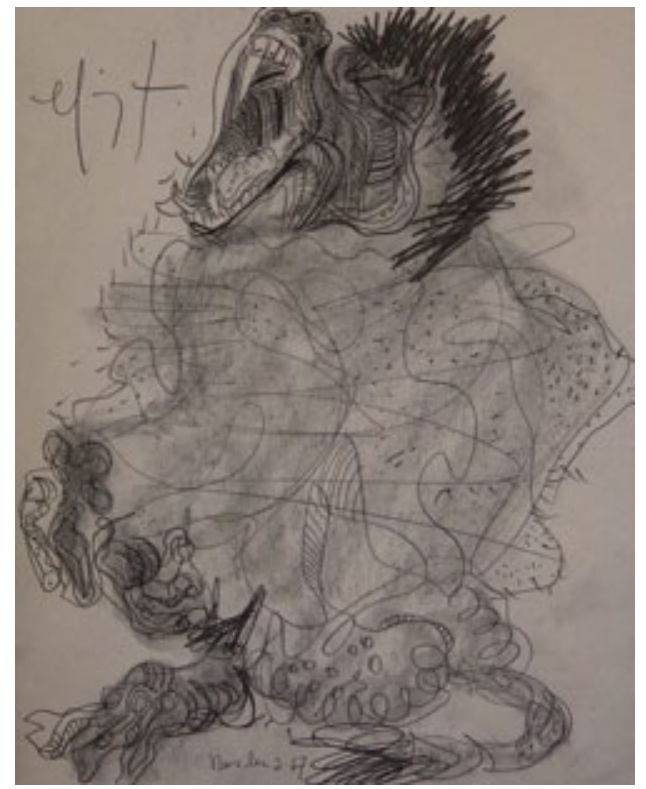

Por ahora es sumamente extenso el recorrer la variedad de estas situaciones, lo que podemos decir es que la relación abandona el plano metodológico para envolver al dibujante en la vivencia, en un diálogo intersubjetivo y en ese plano experiencial que muchos señalan como parte importante del proceso de generar un dibujo. La postura epistémica del dibujante junto con el vínculo vivencial, determinan el gradiente del impacto en el dibujante, esa será la provocación que impulse el proyecto de representación y su carácter, de ahí el sendero por el que habrán de discurrir.

Las posibles relaciones entre el modelo y el dibujante contienen la amplitud del gradiente sentimental humano, pero se inclinan básicamente por dos campos; el de la búsqueda objetiva del proyecto, y el de la compenetración del autor en la circunstancia del contexto. 
La raíz gnoseológica contenida en esa relación, es la que define el grado de identidad que el dibujante desea establecer con el modelo, cualesquiera que este sea.

Puede ser que el proyecto requiera una distancia teórica que aparte al dibujante de vivir la circunstancia del modelo, pero puede suceder que el dibujante busque integrarse con los modelos que dibuja.

Nuevamente decimos que a partir de 1940, con la consolidación del proyecto pictórico moderno, se inició un alejamiento del dibujante con los modelos, o cuando menos estos se transformaron en entidades lógicas de razón formal, maneras reflexivas del propio lenguaje del arte, en esta situación el vínculo epistémico y vivencial del dibujante con los modelos como sujetos se enfrió, por decirlo de alguna manera, fue así no porque la relación se hubiera visto suspendida, sino porque la calidad de ésta se orientó hacia la esfera sígnica y conceptual, en donde sus preocupaciones correspondieron más al proyecto histórico de las artes y en ese sentido se alejaron del proyecto existencial.

Para hoy nos encontraremos en posibilidad de estar dentro del modelo dibujado y ser parte del sistema en su estado actual; o podemos ser el ojo distante detrás del microscopio.

Entenderemos la historia del pensamiento teórico del dibujo y su concreción en sistemas formales, como la historia de los modelos teóricos del dibujo, en su interior se contiene como elemento causal las relaciones que el dibujante ha establecido con sus modelos como sujetos. Llamaremos a estos segmentos de historia modelos paradigmáticos del dibujo, no intentamos fundar un cuerpo analítico, acabado, ni siquiera decimos que está en construcción. Simplemente después de haber estudiado el fenómeno hemos encontrado situaciones y características en el propio curso del dibujo que nos permiten sostener aquellos pensamientos hipotéticos, en el sentido de que el dibujo tiene una secuencia en la historia del arte desde el renacimiento, que mantiene una raíz de carácter proyectual, y en ese proceso un devenir que lo ha llevado a variar el grado de esa relación epistemológica.

Pero también existe el modelo como un patrón que representa un ideal y por tanto un objetivo a seguir, un algo a lo que deseamos acceder y a lo que queremos imitar. La actitud conservadora en esta definición no estriba en el hecho de los valores que se desean, sino en el hecho de desear ser como algo, el deseo de ser nosotros a través de un ideal creado desde fuera de nosotros, o, acaso de una manera en la que muy lejanamente participamos en esa construcción.

Así, existen modelos ideales muy distantes en la historia y otros tan cercanos en nuestro tiempo. Una concepción idealizada del modelo para el dibujante reviste una postura ideológica en todos sentidos, hasta aquí hemos hablado de los modelos como segmentos teóricos del dibujo, o bien como entidades de la otredad con las que el dibujante se relaciona en el acto de dibujar.

Pero los modelos son también formas en que el status social y el orden dominante de una cultura se colocan sobre el sujeto individual. Ambiciones ideológicas, aspiraciones que desde fuera se nos imponen pero sentimos como nuestras y genuinas.

La modernidad desatada insistió en la inmediatez, alejó en ese momento el proceso artístico y en especial el del dibujo de las secuencias prolongadas de configuración. La urgencia por la expresión marcó una distancia con la historia y la negó tal vez precipitadamente. 
Se puso énfasis en la presencia misma del artista en la obra. La complejidad del acto expresivo como activación de un código social cedió terreno ante la autoexpresividad, que en ocasiones logró la construcción innovadora del sistema del dibujo, pero otras tantas se agotaron en la autorreferencialidad individual.

Tal como lo formulara Greenberg y Fried, el arte de vanguardia se convirtió en un ejercicio que solo hablaba de sí mismo, de sus reglas y procedimientos. Claro que esto suscitó una expansión técnica y estratégica, pero su resultado más negativo fue el establecimiento del paradigma que nos impele a buscar la novedad a toda costa, ésta se convirtió en un valor ideológico más que en la conclusión de un conflicto del lenguaje como acto de representación y significación. Thomas Lawson en su artículo "Última salida: La Pintura" del libro Formalismo e Historicidad de Benjamin Buchloh 1999 menciona como las pretensiones de la modernidad se agotaron en el uso excesivo de las variables de la forma, el procedimiento y las estrategias, reduciéndose a la mera representación del impulso, y no la disciplina reflexiva de la imaginación.

La función de los artistas después de la segunda guerra mundial se basó en sacar a la luz una nueva visión del arte y el sujeto común, alejándose del proyecto ascensionista de la modernidad primaria e iluminista, implantando una nueva idea de subjetividad artística. Así se desarrolló un espectro amplio de comportamientos irracionales y arcaizantes, Todo ello refleja en gran medida el fracaso de la integración positiva social y la búsqueda de una nueva integración social, un nuevo imaginario colectivo alejado de la razón occidental y mucho más cercano a la visión cosmogónica de las culturas periféricas.

Se denunció cada vez con más energía como las instituciones sociales asignan los roles de cada sector social y las condiciones de su consumo cultural. Se expuso la manera en que el sistema cultural dominante determina el marco paradigmático de la transformación y la producción artística, terminando éstas, transformadas en una herramienta de control ideológico. El sentido crítico agudo de Buchloh se muestra en esta cita de su artículo El arte conceptual de 1962 a 1969, compendiado en su libro Formalismo e Historicidad.

"O, peor todavía, Broodthaers muestra como el triunfo ilustrado del arte conceptual -su transformación del público y la distribución, su abolición del status objetual de la obra de arte y de la forma mercancía- solo podía ser un triunfo breve que de manera casi inmediata se vería obligado a dar paso a la fantasmagórica reaparición de los paradigmas pictóricos y escultóricos del pasado que habían sido (¿tal vez prematuramente?) Desechados. De esta manera, el régimen especular que el arte conceptual aseguraba haber desbaratado pronto se restauraría con renovado vigor. Y, como no esto es lo que ha pasado." ${ }^{11}$

Aquí sucede una mecánica teórica importante. Tanto el modelo de proyecto artístico histórico positivo, como el proyecto existencial crítico se basan en la conciencia del sujeto en su particularidad histórica.

El proyecto histórico positivo lo impulsa a la integración de un todo social ascendente, el proyecto crítico existencial le marca en su ruta de ruptura y crítica permanente.

Pero la presión ideológica que el modelo cultural ha determinado para el artista genera en el él un estado patológico, ya que por una parte sabe de su función como artista cons-

81 Buchloh Benjamin H. D. Formalismo e Historicidad. Madrid: Ed. Akal; 2004. Pág. 199. 
ciente que denuncia el estado dominante de la cultura, y su responsabilidad de mover el motor de su desarrollo, pese a entrar en conflicto con las fuerzas del status, pero por otra parte se mantiene en el sueño de la aceptación que el propio estatus al que critica reserva para el artista triunfador, sitial de aceptación y plenitud artística social. Esta razón es la que se muestra en el fondo de los activismos conceptuales radicales como es el de Joseph Kosuth. O bien el caso de Naum Gabo en su traslado a los Estados Unidos de Norteamérica en 1946. Éste puede ser un ejemplo claro del peso que el contexto ideológico ejerce sobre el proyecto y el actuar del artista. La exposición breve que realiza Buchloh de este asunto es precisa históricamente, dejemos que sea él mismo mediante sus palabras quien lo muestre, aunque dedica un espacio suficiente al particular tomemos algunas de sus líneas como ejemplo.

"La problemática recepción del Constructivismo en 1948 y la evolución de Gabo desde el vanguardismo hasta el neovanguardismo plantean dos cuestiones. En primer lugar, ¿Qué tipo de ajustes personales y estéticos y qué clase de adaptaciones históricas y políticas tuvo que realizar Gabo? Y, segundo, ¿qué factores críticos determinaron la recepción crítica de la obra de Gabo en la historia de la cultura de posguerra y, en particular, la acogida de Clement Greenberg, uno de los críticos más importantes de la neovanguardia americana? ¿Qué tipo de maniobras se vio obligado a realizar Greenberg para acomodar, en un primer momento, la obra de Gabo en el marco crítico, institucional y estético de la década de los cincuenta y para excluirla después de ese mismo marco?"82

La ideología es una marea social intangible, cúmulo de valores y preceptos creados por el núcleo social, generalmente sin una base objetiva de pertinencia en lo que se afirma. Se debe las más de las veces a una conveniencia política, pero se convierte en la determinación de paradigmas para cada segmento de la sociedad y para cada práctica humana. Es una construcción nuestra decimos, pero de tal magnitud y consistencia que opera por sobre la individualidad de los sujetos que la construyen, es el gran otro creado por nosotros. Por eso ideológicamente el modelo es la presión de los otros que ocupa mi mente. Y la ambición enfermiza y suprema, es el deseo incontenible que tenemos de llegar a ser los constructores y modificadores de ese gran otro.

En esta situación el modelo es una entidad que ya poca relación tiene con el estado del arte como primera instancia, pero nos determina una función en la vida y la cultura, éstas son las extensiones de la cultura naturalizada y dominante a las que el proyecto existencial tanto se ha opuesto.

El modelo como ideal es producto de la reflexión y actos sociales, pueden ser estos individuales o colectivos, pero lo que interesa es que son una visión idealista del mundo, existen como resultado del querer ser ideal, su condición no es natural, la idea y el rol que se nos asigna antecede a la producción de la obra.

\section{III-2 LOS MODELOS PARADIGMÁTICOS DE ANÁLISIS}

¿Podemos designar el lugar de la teoría en la pintura sin violentarla, sin, esto es, desconocer lo que la dota de su carácter específico, sin anexarle un discurso adaptado, cuyos

82 Buchloh Benjamin H. D. Formalismo e Historicidad. Madrid: Ed. Akal; 2004. Pág. 201. 
engranes son inadecuados y débiles para dotarlo de un sistema coherente de causalidades que aclaren la peculiaridad de su geografía reflexiva y procedimental?

Precisamente, en este punto se abre la posibilidad de relacionar todo esto que líneas arriba hemos expuesto como la sustancia que alienta la realidad de un pensamiento interior del dibujo, y que no es sino parte de los modelos de la interioridad teórica del arte.

En la mitad del siglo XX Barnett Newman y Marcel Duchamp retoman la idea renacentista del arte como una expresión intelectual, el arte debe estar al servicio de la mente, es decir, ser una operación intelectual. El arte no es la expresión directa de un pensamiento, es la resolución que aclara la relación de una idea y su representación, integrándolas en la obra o la relación estética.

Veamos ahora el pensamiento de algunos autores, mediante sus ideas llegaremos a una puntualización mayor que despeja el pensamiento hipotético de nuestra tesis.

Alain Bois, basado en Hubert Damish reconoce como central esta formulación, dedica un texto completo al estudio del asunto, su libro "Painting as model" se interna en las vertientes de modelos teóricos que constituyen la práctica de la teoría pictórica del siglo XX. Teoría que no emana de campos exógenos al arte sino que fluye de fuentes de la interioridad del fenómeno de la producción.

Nuevamente las ideas y estrategias reflexivas que encontramos se dirigen a dilucidar las prácticas pictóricas, son en ese sentido distantes un tanto del territorio del dibujo. Pero también en muchos de sus segmentos aluden a condiciones de similitud que se desarrollan en el territorio del dibujar. Por lo pronto tomamos estas ideas como inicio de nuestro estudio, esperamos a lo largo del trabajo ligarlas y encontrar su peculiaridad en el terreno que nos interesa.

Por otra parte, la necesidad de establecer segmentos paradigmáticos que operen como categorías trazadoras del análisis es reconocida frecuentemente. Rosalind Krauss en su artículo "LeWitt en progresión" incluido en el texto "La originalidad de la vanguardia" nos dice lo siguiente.

"En pocas palabras, Gablik defiende la existencia de tres periodos distintos en la historia del arte. El primero lo forman todas las representaciones visuales anteriores al descubrimiento de la perspectiva sistemática; el segundo, que se inicia en el Renacimiento, se caracteriza por el predominio de la perspectiva; y el tercero, el del arte contemporáneo, es anunciado por el advenimiento de la abstracción. Como se desprende del título de su libro, la autora considera que estas tres divisiones señalan una serie de fases en radical progresión, concebida cada fase como una sustitución y superación de la fase precedente." 83

Generalmente la demarcación de cortes y segmentos históricos que agrupan la historia del arte está en función de la orientación analítica que se busca fundamentar, por eso

83 Krauss Rosalind. La originalidad de la vanguardia y otros mitos modernos. Madrid: Ed. Alianza Forma; 1996. P.262. 
consideramos que no ha lugar para una discusión que busque negar las formulaciones de otros autores.

Pero así mismo vemos que otros cortes paradigmáticos establecidos (Danto, Greenberg, Gablik) no satisfacen los requerimientos de nuestro análisis, además de que dejan de lado el organigrama teórico y formal del dibujo a lo largo de la historia como eje metodológico para el análisis.

Los modelos analíticos de la crítica de arte operan como constructos a posteriori del hecho analizado, son un esfuerzo por explicar la dinámica y origen de fenómenos ya dados, la producción de los artistas. O bien son intentos de agrupación de la producción bajo criterios sistémicos que tienden a establecer denominadores comunes.

Hemos de diferenciar los segmentos y cortes formulados en el trazo de la historia del arte, con respecto a los modelos analíticos que se aplican para obtener esas agrupaciones. No es lo mismo aludir a los resultados de un análisis que a los modelos epistémicos usados en la investigación.

El caso arriba mencionado, que formula tres periodos básicos en la historia del arte de occidente es pertinente en lo general. Pero señalamos que en un arco tan amplio de agrupación se escapan muchos de los fenómenos y categorías que interesan en este análisis.

El periodo pre-renacentista, el del renacimiento con la perspectiva piramidal y el de las vanguardias del XIX con las que se inaugura la modernidad, la modernidad formalista misma, la abstracción Pospictórica y el inicio posmoderno del dibujo, constituyen el objeto de estudio que nos ocupa. La interioridad de lo acontecido en esos segmentos con respecto al devenir del dibujo y sus cuerpos teórico formales es nuestro objeto de análisis.

Nuevamente en este punto nos aqueja un problema; los estudios realizados en el terreno del arte visual corren en el sentido de postular una visión general que compete a la totalidad de territorios que integran este universo artístico, y no es que esto sea un error; pero en este caso lo que interesa es la reflexión sobre un segmento específico de estas artes, el del dibujo.

La tarea se complica un tanto más si consideramos las inflexiones del arte contemporáneo y moderno que corren sobre la disolución de los campos disciplinares clásicos de la plástica y la visualidad. Aunque ya hemos manifestado nuestras consideraciones en ese asunto, el aparato teórico e histórico del que se dispone emana fundamentalmente de ese territorio, el de la crítica moderna y posmoderna que borra las fronteras de los territorios de las artes.

En parte esta situación es la que origina nuestra tesis, el intento por iniciar una demarcación analítica e histórica del campo dibujo y sus aparatos formales y de representación. Con esto no desconocemos la utilidad y pertinencia de los modelos a los que habremos de aludir, solo señalamos la escisión teórico metodológica que se genera.

La búsqueda de material teórico, nos llevó (como es natural en toda investigación) al descubrimiento de autores y rutas analíticas que fueron aclarando las ideas. El pensamiento de Hubert Damish, aunque distante y de difícil acceso, significa para nosotros la posibilidad objetiva de tender un puente entre las disciplinas de análisis filosófico y teórico del arte y el pensamiento que se suscita en el tiempo y espacio del acto del dibujo.

Con el conocimiento de esta posibilidad reflexiva se salva y atenúa la distancia y división del ejercicio modelístico de la práctica de las artes, y con ello la del dibujo. 
Más abajo enunciaremos de manera sucinta la secuencia estructural de este pensamiento, pero en este momento señalamos puntualmente la coincidencia de estas premisas modelísticas como base de soporte de aquello que entendemos como el acto dibujo.

\section{III-2-1 EL MODELO HISTÓRICO}

El Modelo Histórico ha reportado gran utilidad para el estudio del fenómeno del arte, consiste en plantear como sustantiva la práctica del artista frente a la situación histórica y temporal en que se ubica, en él se considera el ejercicio del arte como un asunto que involucra las relaciones sociales en las que a su vez se inscribe, la forma, los procesos y los sistemas, se posicionan como una respuesta, comentario o manifestación ante esa perspectiva.

Parecería obvio recordarlo, pero la historia es una ciencia social; esto es, se ocupa de relaciones humanas vivas y dinámicas, hemos de separarla de ejercicios arqueologizantes en los que las obras y los objetos se distancian de las prácticas sociales que los originaron y determinaron. Así la historicidad del dibujo como modelo resulta ser la expresión de un pensamiento y filosofía sustantivado en las formas, las prácticas de representación y significación, referidas todas ellas a la emisión de una opinión o juicio histórico.

Cuando menos desde la revolución renacentista, el artista siempre se ha sabido consciente de su ubicuidad histórica y ha comprendido su praxis como una incidencia en ese contexto, incidencia que toma en cuenta su pasado cultural y las prácticas humanas en toda su amplitud. Su ser como artista muestra una voluntad de intervención en ese contexto, constituye una apuesta a la construcción crítica del futuro.

En este punto notamos como la historia entendida modelísticamente se funde con el trazo del pensamiento proyectual. El modelo histórico es la sustantivación del proyecto crítico, positivo o existencial subjetivo del dibujante y el investigador; no puede ser sino un ejercicio de la conciencia en su plena expresión.

En la medida que un hecho artístico se aleja de nuestro presente los caracteres fácticos y los actos que constituyeron un acontecimiento artístico social se disuelven en el tiempo.

La causalidad de las obras y las acciones de los artistas así como los efectos generados en su contexto se ven atenuados.

Aquí se origina la importancia de un modelo histórico de análisis.

La historia como ciencia se basa en el hecho y en el dato, el historiador no participa en los acontecimientos ni afecta los resultados, no corre los riesgos al no ser parte de lo acontecido; cuando menos eso era lo que se pensaba. En la distancia que el tiempo le confiere, establece formulaciones que determinan a las obras y los eventos como partes de una secuencia histórica, que al ser ensartada en una progresión, formula el trazo de la historia del campo analizado.

Pero el punto de que el historiador o el dibujante no participen de los hechos y fenómenos considerados no implica una objetividad absoluta como llegó a suponerse. Tanto la postura del dibujante e historiador, como el aparato modelístico que utiliza como método determinan el carácter y la sustancia de las reflexiones concluidas y las obras presentadas.

Al ubicar como capitales determinadas obras y acontecimientos, el historiador las coloca en posición de hablar por sí mismas, conteniendo en su interioridad las claves que desde 
su tiempo conservan y nos hablan de las condiciones sociales que las generan. Pero no sólo eso, el dibujante y el crítico al considerar determinadas obras y sucesos dentro de la historia, establecen cortes paradigmáticos que nos los muestran a su vez como ejemplos de pensamiento modelístico.

Para el modelo histórico (y para cualquier otro que analiza el arte) surge una fuerte condicionante problemática: los acontecimientos hacia el pasado no pueden ser presenciados de nueva cuenta, tienen una linealidad temporal imposible de revertir; así que sólo podemos acceder a ellos por medio de fuentes indirectas y testimoniales, lo cual genera una distorsión y distancia en el análisis, ya que las fuentes como documento siempre serán pregnadas por la postura de quien las consigna y en cierta medida por el carácter del medio usado en su registro.

Sumemos a lo anterior el que cada vez más accedemos a las obras de arte por la vía de reproducciones en imagen, que no pueden ser tomadas como la obra en sí, y que agregan cualidades que no participaron de la génesis inicial.

Diríamos que para cualquier análisis en el terreno de lo artístico, y bajo cualquier modelo que se utilice, es condición insalvable el enfrentamiento directo con la obra y de ser posible en las circunstancias primeras en que fue puesta en circulación y el evento mediante el cual fue presentada.

La falta de datos e información visual sobre el carácter y contexto de una obra, un artista o un evento pueden conducirnos a equívocos radicales en el análisis.

Diríamos que una condicionante del análisis histórico está dada por la completud y suficiencia de los datos disponibles, mismos que determinan la frontera de sus afirmaciones. El modelo histórico de pensamiento, reporta para el artista no sólo la dimensión de relación con los acontecimientos sociales en extenso; es también entendido como el conocimiento y posicionamiento del artista frente a la secuencia y devenir en el tiempo de las formas y pensamientos de su disciplina, bajo esta concepción la producción de las obras y el proyecto artístico es entendido como la construcción de un pensamiento histórico que concuerda, trasciende o niega el de su tiempo, expresado en la forma y representación de su campo artístico.

La proliferación que hemos vivido en los últimos dos siglos sobre la cantidad y canales de información ha traído como consecuencia una apertura potenciada en las derivas y prácticas artísticas, los artistas se informan de manera inusitada de lo que acontece en su territorio profesional; así, con fuentes indirectas se establecen lecturas varias sobre las obras y los fenómenos del arte que llevan la evolución del proceso sobre causes de apertura exponencial.

Aunque extensa, tomemos una cita del Benjamin Buchloh quien expone el punto.

"Obviamente, resulta poco menos que ridículo preguntarnos si los acontecimientos históricos podrían haber sido diferentes en el caso de que en determinado momento de la historia se hubiera recibido más información o una información diferente. Sin embargo, es preciso comprender hasta qué punto, en el contexto artístico de la posguerra, la historia de la recepción (y sus condiciones peculiares) se convirtió en la historia de la producción, y hacerse cargo del modo en que algunas entidades estéticas aparentemente autónomas reciben información artística y, por tanto, también histórica. En el contexto 
europeo actual comienzan a plantearse preguntas a cerca de los aspectos históricos de una parte del arte americano reciente. En efecto, con la perspectiva de los años, empezamos a preguntarnos si, a pesar de su incuestionable autenticidad y el impacto de sus innovaciones, no seguirá un patrón histórico cíclico en virtud del cual cada nueva generación -de los expresionistas abstractos a los minimalistas- pretende asimilar, desarrollar y ampliar un conjunto diferente de presuposiciones históricas a cerca de las prácticas artísticas del siglo XX. Por ejemplo, uno podría expresar dudas acerca de la supuesta radicalidad epistemológica de Sopas Campbell de Warhol (1962)"84

Así la información de que disponen los artistas los coloca en la situación de potenciar su discurso como una forma de mostrar la progresión histórica del pensamiento y la sociedad que lo posibilita.

Las actividades estéticas, y dentro de ellas las artísticas no serán entendidas como actividades autónomas, más bien siguiendo a Deleuze, acaso como una actividad desarrollada con causes epistémicos específicos; pero que no se desliga de las actividades políticas y sociales.

Y no es esto debido a la cualidad mimética y representacional de la imagen como narración de un segmento o acontecimiento histórico, ni a su capacidad estético formalista como evolución de un repertorio sígnico, lo que implicaría un reduccionismo del potencial artístico, visto como expresión de la complejidad histórica de las formas del pensamiento y su visión eidética del mundo, que no son sino la expresión de relaciones sociales transitando el ámbito del lenguaje.

Con la introducción del pensamiento racional dentro del territorio artístico, desde el renacimiento hasta el siglo XIX el trazo del modelo histórico en el arte dominó el panorama. No olvidamos la oposición clásica entre coloristas y dibujantes que permeó prácticamente todo este periodo de las artes, tomamos en cuenta así mismo (y es parte sustantiva de este capítulo) la diversidad de tensiones subjetivas que matizaron los momentos parciales en este trecho, desde la fe de Piero en el número y los cánones de Durero en el estudio métrico de la figura humana, hasta la estética sublime y pintoresca. Pero en todo ese decurso la postura del dibujante siempre lo posicionó frente a la historia mediante una forma de graficar la realidad, misma que definía su opinión artística.

No se trata en este momento de seguir un trazo cronológico, ya más adelante lo intentaremos. Por ahora destacamos como en todo el movimiento de esa complejidad que hemos dado en llamar modernidad, y que contiene diversos segmentos, la historicidad como modelo siempre acompañó de alguna manera el pensamiento del dibujante, del artista y pensadores del área en general.

Es de todos conocida la vocación histórica y social de las vanguardias artísticas de inicios del siglo XX. No decimos nada nuevo al mencionarlo, su heroicidad y la de sus autores radicó en la búsqueda de la trascendencia humana mediante sus formas, tanto como en la vocación de construir una realidad social justa y libre.

El giro que deseamos señalar es aquel que manifiesta en ese momento una actitud para remitir la investigación y el tema de las artes hacia su propia interioridad. La tautología del

84 Buchloh Benjamin H. D. Formalismo e Historicidad. Madrid: Ed. Akal; 2004. Pág. 11. 
lenguaje, la forma de la forma, las artes visuales y el formalismo, manifiestan la primera derivación radical del modelo histórico del arte hacia un pensamiento de causalidad circular retroactiva, el arte como discurso de las artes, el lenguaje como discurso del lenguaje y no solo como constructo codificado para disertar sobre una realidad externa y referencial.

Después del tramo informalista europeo de posguerra quedó terminantemente trascendida la postura ingenua de las artes, al revisar las presuposiciones epistemológicas de las prácticas artísticas, la diversidad de estrategias procedimentales del arte en la modernidad y las fuentes eidéticas de la pintura y el dibujo en ese periodo (Hartung, Dubuffet, Klein, Still, etc.) dejaron claramente sentada la firme convicción filosófica y epistémica del arte más allá de lo casual e ingenuo.

Con toda esa revisión (de la que por otra parte el dibujo formó piedra angular) se reconoció que la práctica del arte no se reducía al mero listado de sus catálogos formales ni a la investigación de su discurso tautológico, sino que estas se encuadraban en un marco contextual que obligaba su explicitación como parte de una realidad histórica en la que las prácticas y posiciones artísticas no eran una expresión dependiente, si no, un medio de producir ideología y una manera eficaz de incidir en el contexto mismo en que se generaron.

Si bien se puede señalar una actitud historicista, calificativo con el que se menciona a los artistas que con conocimiento suficiente de la historia y las prácticas artísticas, establecen una relación directa con las obras propias; esto es, un conocimiento de la historia del arte que entra en acción cuando se elabora una obra.

Nuevamente una cita de Buchloh.

"Esta sensibilidad frente a la historicidad, incluso respecto a la propia actividad del pintor (la capacidad para cuestionar el sentido de la propia práctica mientras uno la está llevando a cabo), permite afirmar que Richter es uno de los principales responsables de que la pintura mantenga su vigencia en la cultura contemporánea. En efecto, las actitudes formales de Richter son consecuencia de la historicidad de su propia práctica pictórica y, en ese sentido, suponen un frágil equilibrio entre el gesto subjetivo y el hecho objetivo." ${ }^{5}$

Podríamos mantener opiniones encontradas respecto a la distancia y prontitud con que los artistas asumen su relación con la historia, el desarrollo de las artes y el tiempo que les toca vivir, pero como anteriormente lo hemos señalado, cuando el dibujante traza una línea lo hace de cara a la historia y con conocimiento de lo que ha sido la práctica de otros artistas, aunque en ese trazo se manifieste lo profundo de su intención psíquica.

La historicidad como modelo del pensamiento en el dibujo se expresa en el uso de los sistemas mismos de representación, que no son patrimonio exclusivo de la individualidad, y también se sucede en la continuidad que la obra y acción del dibujante establecen como secuencia de ese reservorio histórico. Agregaremos que el ejercicio de la representación y el sentido significante son expresión social de un acuerdo lingüístico, en ellas se expresa la interacción de subjetividades y racionalismos que son la deriva pragmática de las formas y sistemas de representación. Nos inclinamos desde este punto por una concepción contextual e histórica que entiende la práctica del dibujo como una acción

85 Buchloh Benjamin H. D. Formalismo e Historicidad. Madrid: Ed. Akal; 2004. Pág. 53. 
humana de vocación social, en donde lo uno no es tan uno si no se olvida de sí mismo, y en la que sin embargo el todo social se ve enriquecido por el segmento del pensamiento particular del dibujante.

Más que optar por el historicismo como acto de fe, señalamos en este punto una relación triádica:

a) La historia (como aplicación de relaciones sociales)

b) El universo de lo artístico (y dentro de él la teoría y sistemas del dibujo)

c) Las pulsiones e intencionalidades del dibujante (como expresión de la subjetividad que permea lo histórico y lo artístico)

Estos constituyen los continentes de la relación histórica del dibujante con su contexto. Son tres campos que interactúan y se mezclan en el ideario e intencionalidad del dibujante, son los que entran en tensión con otros territorios para finalmente determinar los problemas nucleares formulados y las decisiones que frente a ellos toma el dibujante.

\section{III-2-2 PENSAMIENTO AUTORREFERENCIAL}

Entendemos los movimientos integracionistas de inicio del siglo XX como una segunda fase moderna de la vanguardia, ya en capítulos anteriores profundizamos sobre el sentido categórico de estos movimientos y su camino hacia las artes visuales en sustitución del paradigma plástico. Consideramos que en ese corte, la historia de las artes arriba a su primera formulación tautológica, la forma de la forma, el arte por el arte con Oscar Wilde, la gramática de las artes de Kandinsky, los Fundamentos para un Arte nuevo de Van Doesburg, todas estas son expresiones que nos hablan de un proceso auto reflexivo circular del arte. El arte como discurso del arte es un pliegue cognitivo que propone el lenguaje para reflexionar su propio territorio, de ahí que sea una característica más o menos general de la vanguardia la disección que hace de los procesos de formalización y las categorías del arte para tratarlos de forma separada y específica, como asunto de los movimientos que la integraron. Este es un primer sentido cognitivo de la abstracción y la vanguardia; la separación del todo en sus partes para mejorar su análisis y comprensión.

El modelo de pensamiento autorreferencial se irá definiendo por dos caminos que a la larga constituyeron modos diferenciados de plantear el arte, el modelo formalista y el modelo tautológico conceptual.

Ambos casos revisten importancia para el análisis que nos ocupa, pues en ellos los artistas hicieron del dibujo un territorio fértil de operación.

Ya desde el proyecto histórico del Romanticismo, entendido como un pensamiento no coincidente con el sistema; pasando por el Naturalismo y el Realismo del XIX, la Vanguardia de ese mismo siglo y hasta el periodo de entreguerras del XX, asumirá firmemente un estado de crítica social, manifiesto no solo en su expresión como voluntad reconfigurante de lo social, sino también en la expresión del lenguaje y los medios que el arte utiliza como vía de concreción.

La Vanguardia se soporta en una esencia dialéctica, se manifiesta en ella el par de contrarios y su unidad como opuestos insalvables. Se origina en la crítica del sistema cultural y social pero siempre será ese el territorio que habitará. 
Pero la característica sustantiva de la modernidad es su búsqueda formalista, en ella radica su esencia autorreferencial, en su capacidad de autocriticarse para conformar el camino de su propia construcción como lenguaje. Esta será una de las bases primordiales de la teoría del formalismo en el pensamiento de Clement Greenberg.

El proceso de alejamiento de la realidad natural como fuente referencial de las imágenes se había iniciado desde la vanguardia del XIX, Paul Cézanne dejaría a punto el problema para la irrupción cubista, Kandinsky, Mondrian y tantos otros alcanzaron la formulación de la imagen anicónica. Pero la característica agregada por los informalistas y expresionistas abstractos fue señalada por Greenberg como el desplazamiento que centra el problema de la pintura en el medio con el que se trabaja.

En su ensayo Hacia un nuevo Laoconte Greenberg define su concepción del medio artístico, categoría que será central en su pensamiento sobre las artes. Plantea que el medio son las condiciones específicas que diferencian una forma expresiva de otra; así la pureza de un campo artístico dependerá de la aceptación y entendimiento de esas delimitaciones, y con base en ellas es que las artes se definen como tales y diferenciadas.

En el caso de la pintura, el pensamiento formalista de Greenberg propone tres conceptos centrales, a) La planitud del soporte, el flatness b) La delimitación del cuadro mediante el marco y c) Las propiedades del pigmento y la palpabilidad de la pintura.

En este punto del trabajo nos mantenemos en una visión teórica y general del problema, ya que nos interesa tratarlo como modelo de pensamiento que permea el análisis de la historia del arte y así el pensamiento del dibujo.

Pero la posibilidad de amplitud que los conceptos mencionados introdujeron a la práctica de la pintura y el dibujo, resultó una revolución del pensamiento eidético y la gestalt de las formas artísticas. La teoría del accionismo psíquico, el proceso por sobre el resultado, la acción como representación, la teoría de la resistencia del medio, son parte del arsenal legado por este trecho de la historia del arte.

En este mismo capítulo, páginas adelante, dedicaremos un segmento a estas particularidades.

El modelo formalista, y la práctica de los artistas de aquellas décadas, no se proponen una ruptura con el pasado y las formas artísticas que heredan. En ese aspecto su pensamiento es en gran medida histórico; pero la paradoja se sucede porque al llegar al punto de giro radical de ese segmento de las artes, se aportan recursos y construcciones teóricas, formales y críticas que rompen con el pasado precedente, generando derivaciones abductivas de primera generación representacional, formas y maneras nuevas en el mundo.

Greenberg, basándose en T. S. Elliot, sostenía que el artista debe someter continuamente su trabajo a una valoración histórica frente a la suma de la teoría y forma del arte, sin buscar una personalidad propia sino un medio por el cual sus experiencias e impresiones encuentren vía combinatoria de manera fortuita e inesperada y diferente de cómo acontecen en la vida real.

El pensamiento formalista se separa un tanto de la historia al construir y buscar la autonomía artística. Aún en los textos más radicales de Mondrian, Realidad Natural y Realidad Plástica, la fuente de la pintura se encuentra en la abstracción y síntesis geométrica de la naturaleza, el siguiente paso lo aporta el pensamiento formalista al propugnar que la obra no debe 
reconocer un vínculo con la vida, entendida como fenómeno contextual, el aislamiento será condición necesaria para la generación del producto artístico y la experiencia estética.

En la medida que la producción del arte es un fin en sí mismo y que se entiende como autorreferencial y generadora de su propio sentido y medios, la comprensión utilitaria de la práctica del arte queda desplazada.

Por eso el artista que se inscribe en el modelo formalista busca su autoexclusión del ámbito público, se centra en la construcción de su absoluto formal.

De todo ese proceso resultó la reducción del tema como categoría contextual.

El contenido de la obra hasta ese momento era entendido como la narrativa del conflicto dramático e histórico desarrollado en la obra. Para el modelo formalista del arte, la obra no puede ser reducida y relacionada con nada que no sea ella misma.

La intención de los artistas por construir absolutos formales que sustantivaran la definición de su campo de práctica artística los colocó en posibilidad de generar sistemas formales de nueva generación.

La categoría de All-Over consistió en un recurso pictórico de expansión y distribución formal sobre la totalidad del plano soporte; con ella no se intentaba la consecución de la profundidad virtual mediante el recurso de los grises y el color local que construían planos y términos de profundidad. La planitud comentada por Greenberg se basa en esta práctica de formalización, con ello se salvaba a la vez que se generaba una distancia con la construcción pictórica de toda la tradición occidental.

Greenberg entiende el All-Over como la repetición de un mismo motivo pictórico sobre toda la superficie del plano pictórico. No coincidimos con esta apreciación totalmente. En las pinturas de Pollock y las de Tobey encontramos la construcción de una grafía gestual que se origina más sobre una base dibujística, es una reducción pictográfica cuyo referente objetual se ha disuelto o no existe, dada la naturaleza automática del gesto autográfico; se busca mediante el automatismo de acción la no repetición mecánica del gesto trazado, cada inflexión del dibujo buscaba la subversión de una plantilla mecánica lineal del trazo basado en el comparativo experiencial. Fig. 25
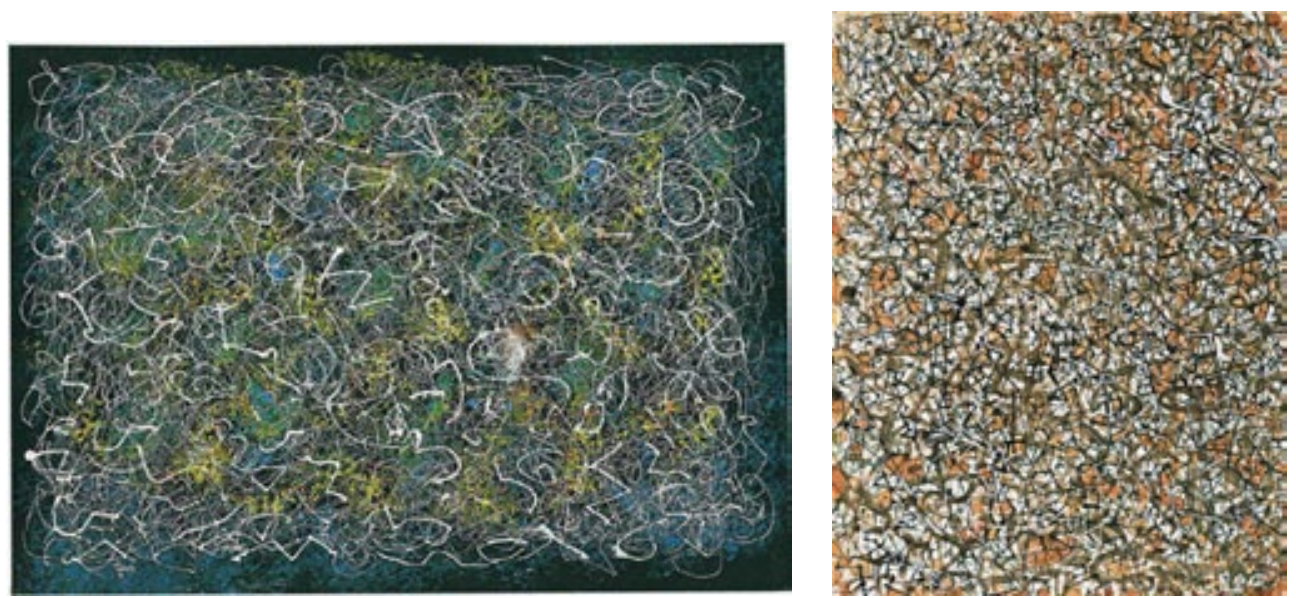

Fig. 25 Mark Tobey. El All-Over no es repetición de un mismo motivo gráfico. 
Aún adelantándonos diremos que el dripping se sustentaba en una base de dibujo porque desplazaba el elemento cromático y su tonalidad como elemento de construcción, de ahí que una buena parte de la obra del expresionismo abstracto se centre en la monocromía gestual.

El Color Field consistió en reconocer una característica inherente al plano de color, le confirió propiedades de extensión y con ello una personalidad ontológica como categoría pictórica. El campo cromático trajo como resultante la consideración de la extensión y límite del área asignada al campo, con esto la distancia entre dibujo y color comenzó a cerrarse, por eso señalamos que se generó como consecuencia del trabajo formalista la dibujización de la práctica pictórica. Ya adelante observaremos el trabajo de Franz Klein, Clifford Still y otros.

Sin embargo el pensamiento de Greenberg resulta muy interesante en muchos sentidos, tomemos sus palabras redactadas en su ensayo La crisis de la pintura de caballete, el cual se incluye en el texto que ya hemos mencionado.

"Para expresar mi pensamiento he pedido prestado deliberadamente el término polifónico a los señores Kurt Lizt y René Leibowitz... Del mismo modo que Schöenberg da a cada elemento, a cada voz y nota en la composición, la misma importancia -diferente pero equivalente-, también esos pintores ejecutan cada elemento, cada parte del cuadro por igual. Y tejen así la obra de arte en una espesa malla cuyo principio de unidad formal es contenido y recapitulado en cada uno de sus hilos, de manera que la esencia de la totalidad de la obra la hallamos en todas y cada una de sus partes." ${ }^{86}$

No es que los pintores hasta el Naturalismo y el Realismo del XIX no fueran conscientes de que la pintura y el dibujo comportaban una concepción de la forma como categoría plástica. Será con la revolución Cezaniana que la forma se constituya poco a poco en el eje de gravedad de la pintura y en la conciencia de que con ella se construye una entidad alterna a la del referente natural u objetual. En esto el dibujo y la visión geométrica de Paul Cézanne jugaron un papel importante.

El tema y el referente natural como hasta ese momento se consideraron fueron desplazados del centro pictórico, la pintura se alejó poco a poco del drama, la historicidad y el modelo de la naturaleza. Aunque irónicamente hasta el final de sus días Cézanne se consideró un aprendiz frente a la naturaleza, en su mente no se daba aún el gran salto.

La forma del arte y su disección se ubicarán desde entonces como el eje del trabajo pictórico, para ello el pensamiento del dibujo retoma el vigor disminuido en el que el Impresionismo parecía haberlo colocado.

Tomemos una cita de Greenberg que cierra esta idea.

"¿Cómo hubiera podido aventurarse el Impresionismo en la gran pintura, como lo hizo, si no hubiera tenido forma? En todo caso, lo que Cézanne buscaba era un tipo de unidad distinta, más enfática y supuestamente más permanente: más tangible en su articulación. Aunque su compromiso era con el motivo natural inmediato, se daba cuenta, pese a todo, de que este por sí mismo no suponía una base suficiente para obtener la unidad pictórica y que, si quería conseguirla, tenía que leer la naturaleza mediante una mezcla

86 Greenberg Clement. La pintura moderna y otros ensayos. Madrid: Ed. Siruela; 2006. P. 50. 
de pensamiento y sensación; un pensamiento que no fuera asunto de reglas extrapictóricas, sino de consistencia estructural interna, y una sensación que no fuera asunto de sentimiento, sino de percepción." ${ }^{87}$

Pero el modelo de la forma, como estado terminal de un proceso, significa no sólo el establecimiento de categorías formales (valga el pleonasmo) el pensamiento que subyace en esta intención reiterada es la intuición primero, y la conciencia posterior de que las artes consisten en una peculiaridad del pensar, que si bien hasta entonces (siglo XIX) la naturaleza como referente, modelo y fuente del proceso de representación mantenía un papel sustantivo en el acto de dibujar, este no se circunscribía a la lectura referencial de la imagen sino a la lectura indéxica o lingüista de los procesos de formalización y sus íconos resultantes.

Al distinguir la forma de la cosa modelo, de la forma del pensamiento hecho pintura, se logró finalmente aclarar la conciencia de que las prácticas artísticas se fundan en una región teórico-reflexiva particular, son una manera específica de pensar el mundo, por eso nosotros decimos que la representación no se circunscribe al ámbito limitado de la búsqueda mimética, la representación desde siempre (pero claramente desde el proyecto formal de la modernidad) ha sido el ejercicio de formalizar el mundo en estructuras de pensamiento, que no en formas de alusión a un referente (sobre todo considerando que desde antaño se entendió claramente la distancia existente entre el modelo sujeto y su imagen construida como obra de arte).

En este proceso el dibujo operó como disciplina que potenció el plano especulativo de la forma, su condición de campo que estructura el pensamiento en la imagen, y la organización del proyecto de la obra, le permitió al dibujante la especulación más abstracta posible. En el tramo de la modernidad que antecede al Informalismo y al Expresionismo Abstracto el dibujo continúa una diferenciación peculiar de la práctica pictórica; los dibujos mantienen una condición de existencia mental, pese a su objetualidad en el soporte, la aplicación pictórica, como momento subsiguiente del proceso, irrumpe como hecho o acontecimiento que introduce fácticamente circunstancias pragmáticas y vivenciales diferenciadas.

Hemos mencionado y nuevamente recordamos, como el dibujo se introdujo al cuerpo de la pintura de un manera particular, en su momento retomaremos este rumbo del análisis, bástenos por ahora decir que dentro del lapso histórico de la modernidad formalista el tiempo del dibujo y el de la pintura se sobrepusieron en una sincronía de acción, cuando hasta entonces el tiempo del dibujo era el del pensamiento proyectual y, el de la pintura, el del suceso fáctico, por más que el dibujo como pensamiento estructural y conceptual se mantuviera inmanente en todo el proceso.

La insistencia del pensamiento formalista en la vitalidad del momento del pintar y dibujar, llegó al extremo que lo distanció de la relación histórica como modelo del arte; fue así porque en su término radical operó sobre la base constructiva de la actitud personal del artista, la individualidad como vía para lograr una estrategia artística y un absoluto pictórico condujo a la desintegración del proyecto histórico como integración del todo social, fuera en sentido de relaciones humanas, o en sentido de un código común para el entendimiento del dibujo.

87 Greenberg Clement. La pintura moderna y otros ensayos. Madrid: Ed. Siruela; 2006. P. 54. 
La historicidad dentro del modelo formalista solo podría ser entendida en el sentido más general de su expresión; como postura extrema del principio de autonomía y volitividad del artista y como renuncia y denuncia a los intentos y fracasos de integración social de la modernidad iluminista.

El presente se convirtió en la presencia del artista en el momento de pintar y en su inclusión física en el espacio de la pintura, la expresión representacional cedió ante la autoexpresión individualizada.

En un sentido humanista esto puede resultar criticable, pero tal situación generó resultados de una apertura importante.

La búsqueda personalizada de un entendimiento de la pintura trajo consigo la apertura de una libertad técnica que multiplicó exponencialmente las rutas y estrategias del campo de la pintura.

La pintura y el dibujo desde entonces se aclararon su posibilidad como acto indéxico gestual o bien como búsqueda indexal del trazo graficado que muestra una definición estratégica del dibujo y su concepto; ambos sentidos, continentes paradigmáticos del dibujo hasta el día de hoy.

Como habremos de ver, el modelo formalista operó y consolidó la base de los territorios disciplinares diferenciados de las artes (dibujo, pintura, escultura, gráfica) si bien en las décadas de 1930-50 ya era de uso común la producción de obras híbridas objetuales que marcaron un derrotero alterno.

La interacción del dibujo con los demás campos disciplinares en el proyecto formalista, de lo que se ha llamado la modernidad Greengberiana es un fenómeno altamente interesante, pensamos que este tema solo se ha rozado por los analistas. Es nuestra intención marcar una pauta reflexiva con dirección específica al respecto.

Sobre lo anterior adelantamos una observación, es en la década de 1930 cuando se publica el texto que consideramos el último tratado de la forma y el proceso del dibujo.

El texto de Kimon Nicolaides The Natural way to Draw es el último tratado que expone una teoría particular y específica del dibujo, intentando constituir un cuerpo integrado de técnica y teoría. Sabemos y consideramos el hecho de que Nicolaides escribe el libro en su calidad de profesor de una escuela de arte, y que el tratado además está orientado al objetivo de aprender a dibujar, pero no deja de ser importante la relación que sus contenidos y principios guardan con el arte informalista y el expresionismo abstracto de la época.

Conocemos de la literatura y artículos que sobre el territorio del dibujo se ha escrito de entonces y hasta ahora, pero con todo, no se ha logrado la integración de un cuerpo teórico específico sobre la disciplina, acaso porque en la modernidad y la posmodernidad no se intenta ya más la construcción de los discursos totales e integrados como base de la práctica del arte y su filosofía.

El pensamiento de Nicolaides se centra en un entendimiento del dibujo basado en tres áreas conceptuales, la Gestualidad, el Contorno como observación sensorial y la Construc- 
ción Tectónica de la forma, es él quien más abunda en la reflexión sobre estas categorías. La concepción de Kimon observa una característica que lo diferencia de las posturas de la teoría del dibujo que le anteceden; se basa en una postura epistémica que comienza a distanciar el dibujo de una práctica eminentemente racional, para él el dibujo no se basa en el establecimiento reflexivo de la estructura abstracta de los modelos y la forma. Señala el momento de la acción de trazar como el centro del proceso y, dentro de éste la actitud subjetiva y de comunión empática con el carácter e intención del modelo. Para él, al dibujar un contorno se debe tocar casi literalmente la zona del modelo que se dibuja. En el terreno del relieve suceden cosas harto importantes en su concepción; es quien primero separa de modo preciso la relación entre el gradiente, la luz y el claroscuro de la construcción masiva de la forma. Es en el texto de Nicolaides en donde encontramos las bases del Dibujo Tectónico.

Podríamos entender el libro de Nicolaides como un modelo reflexivo del dibujo y la pintura en sí mismo, pero dada su relación conceptual y cronológica como antecedente del expresionismo abstracto hemos decidido ubicarlo como un segmento de los modelos formalistas de representación del dibujo.

La investigación de Nicolaides se desarrolla en la década de 1930, esto implica que sus formulaciones anteceden un tanto a las estrategias del informalismo y el expresionismo abstracto.

Aún con esto, la coherencia estructural y teórico-formal que se establece entre ambos sucesos del dibujo es mayúscula, un leve análisis comparativo de sus formas lo muestra prontamente; pero queremos destacar el sentido profundo de coincidencia dado por la concepción del dibujo como una acción, más que como una práctica generadora de objetos. Por otra parte se entiende el origen de ese ejercicio en el terreno profundo de la psique del dibujante y no en su campo racional como aplicación de una estructura métrica, este sería un gran desplazamiento conceptual cuyos impactos continuaron el trazo de las ideas de Alexander Cozens y después el dibujo romántico. La única divergencia que observamos en el pensamiento de Nicolaides y la modernidad formalista estriba en el hecho de que la consideración de Nicolaides sobre el dibujo supone un vínculo fuerte y profundo con los modelos que se dibujan, ya sea que estos correspondan al ámbito de lo llamado natural o bien lo industrial objetual.

El segmento de la modernidad formalista desembocaría paulatinamente en la aclaración del pensamiento y la vía tautológica del arte, la autocrítica de la pintura y la auto referencialidad del arte señalada por Greenberg son en sí ya la definición de esta postura.

Pero andando el tiempo y mirando las prácticas de los artistas, el pensamiento tautológico habría de generar al interior de su lógica un camino que a la larga resultaría francamente antagónico a la modernidad formalista; nos referimos al surgimiento de los procesos conceptualistas; prácticas también tautológicas pero que se basan en el rigor de la reflexión del concepto como soporte de la obra, pensamiento racional de disección teórica, el conceptualismo a la larga propondría entre otras cosas el prescindir de la huella gestual y constructiva de la mano del dibujante, depositando la tarea de la ejecución de la obra en el esfuerzo de los ayudantes, técnicos o artesanos. Con esto la huella indéxica apunta a su disolución en la lectura del concepto lógico racional del lenguaje y no a la marca personalizada del trazo a mano alzada y la pincelada personalizada. 
Entre la modernidad clásica de Greenberg y la aventura posmoderna se encuentra el enclave del arte conceptual y movimientos diversos que guardan una dinámica importante en el campo del dibujo, también más adelante nos centraremos en ellos, entendemos esta particularidad más como un entreactos que como un corte segmentario de la historia. $\mathrm{O}$, en todo caso un estado de la historia del arte y el dibujo en donde la imbricación de las prácticas artísticas y las obras que de ello emanan requieren de un modelo alterno de la historicidad del arte como vía de su explicación.

\section{III-2-3 EL MODELO RELACIONAL}

"Junto a esos dos géneros establecidos que son la historia de las cosas y la historia de las formas, queda por inventar una historia de los comportamientos artísticos. Es ingenuo pensar que la historia del arte constituye un todo susceptible de reemplazar de manera duradera esos tres componentes. Una micro biografía del artista revelaría los gestos que hizo en el espacio de su obra." ${ }^{8}$

Otra posibilidad que opera como modelo para comprender la práctica de las actividades artísticas, y dentro de ellas el dibujo es el pensamiento relacional, como se desprende de la cita anterior, en este modelo se coloca al centro del análisis el comportamiento del artista en la particularidad fenoménica del suceso.

Comenzaremos vertiendo en estas líneas una serie de reflexiones de Nicolás Bourriaud tomadas de su libro Estética relacional. Procedemos de esta manera porque en cierto modo no nos es un pensamiento ajeno. Primero habremos de exponer las ideas del autor para después plantear algunas consideraciones y precisar puntos que pensamos pertinentes.

Para Bourriaud el Arte relacional es el conjunto de prácticas artísticas que toman como punto de partida teórico el continente de las relaciones humanas y su práctica social, más que el espacio autónomo y privativo de la formalidad tautológica o la matematicicidad conceptual basada en el pensamiento racional. Así la estética relacional se basa en el análisis de las obras de arte en función de las relaciones humanas que suscitan o figuran.

De este modo las obras ya no tienen como intención el construir realidades imaginarias o utópicas. Buscan más bien construir modos de existencia y modelos de acción dentro de lo real ya existente.

El modelo relacional retoma la convicción de que el arte contemporáneo integra un proyecto cultural y político, que incluso manifiesta una intención crítica y subversiva con base teórica. Todo esto concierne tanto a las condiciones de trabajo como de producción del objeto cultural y se les entiende como formas cambiantes de la vida social.

"La forma que cada artista le da a esa producción relacional no es inmutable: los artistas encaran su trabajo desde un punto de vista triple, a la vez estético (¿cómo traducirlo materialmente?), histórico (¿cómo inscribirse en un juego de referencias artísticas?)

88 Bourriaud Nicolás. Estética relacional. Buenos Aires: Adriana Hidalgo Editora. 2006. P. 137. 
Y social (¿cómo encontrar una posición coherente en relación con el estado actual de la producción y las relaciones sociales?)."

Con esto se busca ir más allá de las luchas de la modernidad, intentando no la emancipación de los individuos sino la de la comunicación humana y así la de la dimensión relacional de la existencia. El aura de la obra de arte se disuelve en el mundo de lo representado y en su forma, para migrar hacia la forma temporaria de las relaciones que produce en el acto expositivo y su forma temporal y colectiva.

Este desplazamiento manifiesta un giro radical pues se salta la concreción de un objeto con intensiones estéticas para hablar directamente al público, quien participa e integra el acontecimiento artístico.

Las obras relacionales (Félix González torres, Rikrit Tiravanija) constituyen básicamente eventos colectivos y performáticos, independientemente de su validez como proposiciones artísticas, poco o nada tienen que ver con el dibujo. La forma de estas obras es la forma de una relación estrictamente social que no pasa por la constitución de un objeto estético formalizado, como es el caso del dibujo.

El interés que reportan a nuestro estudio dependerá de la extensión que hagamos de su soporte teórico, sin que con ello forcemos su lógica conceptual basada en una estructura de relaciones.

En el año de 1997 aproximadamente, la evolución de nuestros proyectos de producción nos condujo a la consideración del Dibujo y Pintura Contextual. Con ese término aludíamos a una práctica del dibujo y la pintura que encontraban su origen en las relaciones que el artista establecía con el contexto. Acudíamos al concepto de contexto como una extensión o ampliación globalizante que superaba los límites de lo que hasta entonces se entendía como naturaleza y realidad en el campo del arte. Por largo tiempo (como es sabido), el dibujo fue disciplina de análisis del modelo de la naturaleza, con el tiempo los modelos a dibujar rebasaron el ámbito de lo natural, las extensiones de campo se sucedieron hasta llegar al dibujo de fenómenos naturales, subjetivos y sociales, haciéndose necesario con esto la ampliación de los límites de la definición de los sujetos constituidos como motivo a dibujar. En sí, no es esta la lógica que interesa en este punto, lo es más bien la resultante de esta consideración.

El posicionamiento del dibujante frente a sus modelos conlleva un asunto de relaciones. El dibujo y la pintura contextual es ante todo y primeramente para nosotros un asunto de relaciones.

Pero no las consideramos solo en su índole social, sino en su carácter epistemológico total; esto es en la consideración que el dibujante hace de la relación que lo une con la otredad, la comprensión que de ella tiene, la formulación estratégica y metodológica que construye en esa relación y la construcción que él mismo sufre como resultado del proceso de apertura de la propia identidad.

Comprendíamos también que el orden de esta relación epistémica (que por sí misma es una forma de relación ontológica y cognitiva) potenciaba la configuración de estructuras formales del dibujo producto de esa relación, y que además, el conjunto de estas variables

89 Bourriaud Nicolás. Estética relacional. Buenos Aires: Adriana Hidalgo Editora. 2006. P. 55. 
integraba un acto de representación, que no es sino la forma de una relación que asume el carácter del Acto Dibujo. De ahí que para nuestro entender el Acto Dibujo no sea sólo la acción del dibujar (que por sí misma ya es bastante) sino la acción que representa y genera una tipicidad de relaciones marcadas y determinadas por la condición dibujística de la práctica disciplinar, misma que determina una vivencia primera y particular en su forma sustantiva. Forma de sustancia y relaciones epistémicas e intersubjetivas que dirigimos a la intencionalidad de una representación que busca su vía específica de formalización.

Por tanto, nos vemos interesados en la postura de Bourriaud, que señala la importancia de las relaciones sociales y de comunicación en el suceso artístico; más si las consideramos bajo el entendimiento de un intercambio de subjetividades, cosa a la que habremos de retornar. Pero como dibujantes nos ubicamos en el emplazamiento de la acción de trazar, en la que se inserta el comportamiento abstracto reflexivo y su consecuencia indéxica representacional en un algo llamado dibujo.

Como veremos, para nuestro entender, el Acto Dibujo es un suceso con particularidad espacio-temporal en el que se sustantivan las relaciones del dibujante con sus modelos ontológicos, con sus modelos estratégicos, con los modelos de la forma y la historia, relaciones además con la obra misma que configura y que a su vez lo construye. Relaciones múltiples y complejas que dan sustancia al acto de representación que intentamos dilucidar.

Desde la Estética de lo Sublime y lo Pintoresco se inicia la construcción de la plasticidad dramática de la materia, que se entendía no como la sustancia de la que se integran físicamente los modelos naturales sino como la materialidad organizada del dibujo y la pintura en la que se introducía el conflicto dramático que el artista buscaba expresar. En esta secuencia se mantenía como central la relación del dibujante con la poetización del código formal del dibujo.

El proyecto de la primera vanguardia del XIX se centró en el cuestionamiento de la relación de la forma plástica vs la forma del referente objetual.

La modernidad formalista nos trajo el concepto maravilloso de la resistencia de los medios artísticos hacia la voluntad configurante, con ello la obra redondeó su consistencia ontológica, convirtiéndose en otredad de sustancia inefable con la que sin embargo nos relacionamos.

En la visión posmoderna la interacción de los repertorios de imágenes concita una relación del artista con el pasado y sus maneras formalizadas.

Dentro de un recorrido apresurado del análisis, el dibujo y la pintura contextual se nos revelan plenas de relaciones que tejen la complejidad de una red, misma que articula el sentido de la acción de dibujar; desde la primeridad vivencial hasta el impacto de la presentación de la obra en el contexto expositivo.

\section{III-2-4 EL MODELO PERCEPTIVO}

La percepción ha sido institucionalizada y naturalizada como categoría que opera y fundamenta la práctica del la pintura y sin lugar a dudas del dibujo del siglo XX.

La percepción pareció de modo innegable el inicio del ciclo vital de la pintura; se convirtió en base de la representación, a su vera se entendió la representación como el hecho simple de volver a hacer presente la imagen perceptual mediante la imagen representada. 
El binomio percepción-representación se constituyó en uno de los más sólidos basamentos teóricos del arte.

En este modelo de pensamiento las operaciones del dibujar consisten en la formalización de lo percibido, mantienen por eso como relación indisociable el vínculo del dibujante con los modelos ontológicos que le rodean (valga la expresión, la naturaleza).

Hubert Damish debate la idea de Sartre en cuanto a que la percepción estética no es sino una especie de conciencia retrospectiva, una nueva y constante aparición del modelo pintado, provocado por la imaginería de la pintura como objeto artístico.

El carácter de mímesis y sustitución son evidentes en esta formulación. Pero muestra sus más graves conflictos al ser aplicada en el estudio de la llamada pintura abstracta.

Según el pensamiento perceptivo clásico, la pintura Black Square de Malevich no será sino un eclipse solar y el Broadway Boogie-Woogie de Mondrian una representación reductiva del mapa del subterráneo de Nueva York. Este tipo de interpretaciones abundan entre la crítica y aún los propios artistas, y es así porque son cómodos sustitutos de un esfuerzo reflexivo mayor. Un ejercicio de pensamiento que nos lleva a considerar la práctica del dibujo y la pintura como un sistema perceptivo de extensión, en donde la ejecución del dibujo y la pintura continúan los momentos reflexivos del acto perceptual y prefigurante en el tiempo reflexivo de la acción del trazar y pintar.

Damish señala que debemos estar atentos a la especificidad del objeto para dejarnos guiar de nuevo hacia su sistema, de ahí el interés en el detalle, en la textura, en todo lo pequeño y grande que no es sino huella indéxica de la intencionalidad y la conciencia de acción del dibujante y el pintor.

Así las lecturas abundantes pero simples en torno al caso señalado de Mondrian ceden su lugar a reflexiones vitales en las que el objeto obra no es algo irreal y representación sustituta, sino entidad dotada de particularidades cualitativas que denotan rutas de pensamiento expandidas.

El modelo perceptivo aplicado al dibujo nos llevaría a entender la acción de dibujar como un continuo pensar de manera alterna a los sistemas formales establecidos, no una práctica destructiva del dibujante hacia el pensamiento que le antecede, sino la búsqueda abductiva que expande las posibilidades de representación hacia sistemas de nueva y primera generación. Así la pintura ortogonal de Mondrian no es la negación del drama plástico pictórico solamente, es más la intención por lograr una pintura carente de líneas curvas que generan espacialidad y relaciones fondo figura, ya que la línea curva aplicada a la superficie del soporte define sus espacios concretos y vacíos, a los cuales el imaginario colectivo se encuentra fuertemente atado, constituyéndolos en unidades concretas que sustituyen la constitución conceptual de la línea que los origina.

Si el pintor escoge el camino de la negación del imaginario colectivo estabilizado para dejar fluir sus propias reflexiones, es en gran medida motivado por dar al espectador una señal de la inquietud con la que la percepción de la pintura debería ser acompañada.

Por eso más allá del placer sensorial se inicia una práctica elemental de la conciencia, sin un fin específico, contraria a la actividad de representación que reconstruye el objeto referencial. Ahora en cada oportunidad de percepción pensamos que se puede ir más allá de aquello dado para ver, internándonos en la posibilidad de nuevas constituciones de significado. 
Esto es lo que Hubert Damish llama el Modelo Perceptivo, tarea permanente del artista de perturbar las estructuras de percepción, y, más que nada la relación fondo-figura tan consistente en el campo del dibujo.

La oposición fondo figura y su integración en una imagen única es tema recurrente en la pintura y dibujo de la modernidad, los artistas centraron en gran medida su trabajo en esta integración. Con la consideración del modelo perceptivo se establece la posibilidad de comparar el trabajo de Pollock, de Mondrian y los pintores modernistas. Desaparecería de esta manera el problema de ligar los trabajos cromáticos de Pollock con sus series monocromáticas y sus trabajos últimos llamados figurativos. El modelo perceptual otorga la posibilidad de entender como trascendente la pintura y el dibujo de Dubuffet, ya que devuelve a la idea de forma su sentido primordial, en sus lienzos la forma no puede ser reducida al perfil geométrico de los sujetos dibujados, la línea no se posa sobre un plano abstracto, es parte integral de un campo de textura que se muestra integralmente a nuestros sentidos.

Así la operación destructiva del pintor se puede entender como una delicada empresa que gobierna la construcción de la pintura y el dibujo, y se dirige no sólo a la extensión de los conceptos y formas disciplinares sino hacia la totalidad del pensamiento y su gestalt eidética.

\section{III-2-5 EL MODELO TÉCNICO}

El Modelo Técnico para el pensamiento de Damish es en cierta medida una oposición a la formulación de opticalidad contenida en la estética formalista de la modernidad sostenida por Greenberg y Fried.

Una visión modelística de la técnica comenzará por considerar como esencial el espacio fáctico que se pone en juego por la obra en su condición objetual. De ese trasladar la reflexión a un nivel concreto surge una atención particular al proceso del trabajo como un lugar de formación del todo estructural de la obra, condición que antecede a los afectos y subjetividades a los que puede aludir en el acto de presentación.

En todo caso, el Modelo Técnico sienta las bases de una consideración histórica del campo del dibujo, secuencia de avances frente a los que se posiciona el artista.

Damish propone establecer y construir una cronología de la lógica técnica inventiva del artista; insistiríamos nosotros que esta lógica inventiva de la técnica se concatena con la intencionalidad conceptual prefigurante del dibujante, todo esto integrando el cuerpo de lo que llamamos el pensamiento proyectual del dibujo; pensar la técnica como la vía fáctica del concepto mediante la estrategia.

Pero en el caso particular del Modelo Técnico nos colocamos en la temporalidad del acontecimiento fáctico, del hacer en su sentido directo.

La técnica como modelo de pensamiento es la apertura a la dimensión de originalidad, entendida como la conexión nueva entre la intencionalidad conceptual y estratégica y la materia (pigmática o no) que da sustancia al dibujo, de modo tal que en esa materia y su disposición particular se funda el hecho indexal que permite la reconstrucción mediante la huella del acto dibujo; pero también su expansión hacia la dimensión perceptual antes aludida.

Manteniéndose en el significado fundamental de la huella indexal Damish estructura su 
comprensión de la pintura de Pollock, señala que entiende la disposición de cada trazo, cada toque de pintura y cada dripping como la negación y contraposición que busca destruir el sentido de lógica continua que guarda el trazo anterior con el concepto fundamental de la obra.

Esta comprensión de la mecánica conceptual de la técnica nos permite aclarar porque líneas arriba, no coincidíamos con la definición que Greenberg hace del All-Over, cuando lo define como la repetición constante de un motivo pictórico esparcido por toda la superficie pictórica. Damish observa cómo entonces las líneas y drippings en la pintura de Pollock surcan la tela de extremo a extremo en un contrapunto que ya no se desarrolla a lo ancho bajo las coordenadas cartesianas, sino en un espesor, y donde cada una de las cuales solo tiene sentido en relación al trazo que le precede como motivo de contraposición.

Este es el caso de Pollock, pero la dirección del análisis técnico aplicado a la multiplicidad de autores nos revela el universo de amplitud que esta formulación contiene como modelo de operación mental en la que se funda la práctica del artista.

El acto de dibujar como modelo de pensamiento, es el momento de la abducción creativa, tiene lugar cuando el artista inicia ese proceso conduciendo poco a poco materia y concepto en un acto de configuración, concepto que no fue a fin de cuentas sino el trazo de la línea que marca el inicio, pero en cierto sentido el territorio a negar. Concepto que de manera recursiva continua es sometido a reajustes bajo la presión que la técnica aplicada aporta al ofrecer configuraciones que muestran capacidad sistémica y estructurante a la secuencia de la obra.

Ya el pensamiento de Damish y Alain Bois nos llevan claramente a trascender una visión instrumentista de la técnica hacia una Epistemología de la Técnica en donde el pensamiento y la invención tienen lugar.

En este acto y momento entraría todo lo demás, el conjunto de técnicas que la historia nos pone a disposición, procedimientos tomados de la tradición; bases de arranque del proceso, pero, sistemas que serán trascendidos por la conformación del pensamiento actuante al configurar la obra.

El resurgimiento de significados inmanentes en Dubuffet, el intercambio de posición entre la superficie visible y la oculta en Klee, el entrelazado de la retícula discontinua en Mondrian, todo esto se convierte en modelos reflexivos que demuestran la práctica teórica de la pintura.

Las operaciones de veladuras, la mecánica de las imprimaturas y los aprestos, las transparencias y los barnices, el contorno como circunscripción de la forma, el claroscuro como base tonal de la profundidad dibujística, la perspectiva aérea, todo esto se vio sustituido por la teoría de los contrastes simultáneos, la pincelada indexal, la reducción de la línea a su carácter geométrico y matemático; en fin, la pintura y el dibujo con personalidad concreta diferenciada de la tradición, y claro que no entendemos el dibujo como un puro efecto de superficie o programa y boceto de la obra terminal. La técnica como modelo reflexivo nos conduce siguiendo a Damish hacia su consideración como universo episté- 
mico que cuestiona el método y sus procedimientos continuamente.

Reflexionar sobre la textura del plano en la pintura de la modernidad del siglo XX es para Damish un modelo técnico por excelencia, ya implica un conocimiento profundo de la pintura como práctica que formaliza y recrea una teoría, convirtiéndola en base de nueva especulación, quizá en este punto no sea tanta la distancia entre el pensamiento de Damish y las propuestas de Greenberg sobre una pintura autorreferencial.

Queda claro entonces que la pintura, y el dibujo (este último desde el entendimiento manierista de Federico Zuccari) son una maquinación productora de teoría, por eso para Damish el estudio sobre la textura del plano pictórico es un modelo técnico por excelencia, en su fondo topológico entraña el pensamiento pictórico típico del siglo XX.

Sin recurrir a la matemática, un pintor puede llegar a formular una problemática que logre ser traducida en otros términos.

Por eso en gran medida la pintura produce su efecto reflexivo a partir de sus productos, en su trama más íntima, sin la posibilidad de que se le otorgue un significado único.

Todo esto resulta coincidente con nuestro pensamiento de años atrás, en esta exposición de modelos encontramos la resonancia de nuestras ideas, y, claro está, la respuesta a muchas de nuestras interrogantes; pero también en esta postura se halla en parte la solución a una de nuestras hipótesis.

La respuesta y el entendimiento de la condición actual del dibujo habrán de basarse en el estudio de los Modelos de la Interioridad del Dibujo, que no son sino el conjunto de saberes y procederes emanados de la acción del dibujar.

Por eso en este capítulo nos orientamos hacia esa tarea; iniciar el trazo de los modelos del dibujo como construcción teórico formal que expresa el pensamiento dibujístico de los artistas. Y porque además no sería posible continuar sin la formulación de ese trazo inicial, ya que nuestra postura analítica se basa en la interioridad del pensamiento del campo disciplinar del dibujo.

No intentamos agotar esta tarea, pero mencionamos las cada vez más numerosas orientaciones en ese sentido. Nuestra intención consiste en formularla como parte indispensable de un trazo analítico, que hasta ahora se encuentra iniciado, pero que requiere a nuestro entender de una precisión y reorientación metodológica en el análisis.

\section{III-2-6 EL MODELO SIMBÓLICO}

Si bien la modernidad formalista operó sobre un pliegue tautológico autorreferencial de las artes, y en ese sentido el modelo de pensamiento técnico nos resulta óptimo para su comprensión; lo cierto es que la auto referencialidad nos lleva casi de modo ineludible a su dimensión como entidades sígnicas; complejos que son una estructura semántica y se organizan con un sentido sintáctico, nexos de sentido significante que se constituyen mediante códigos sistémicos. El dibujo puede hablar de algo fuera de él, o de sí mismo, pero es claro que para ello se integra en la dimensión sígnica.

Signo, símbolo y código tienen su ubicuidad en la dimensión social y cultural. 
La cultura pende sobre la cabeza del dibujante y opera al margen de su volitividad, aunque con el tiempo y la gravedad de su obra puede llegar a subvertirla.

La cultura organiza el juego, distribuye los roles y regula los intercambios entre lo visible y lo legible, entre lo dibujado y lo escrito, lo visto y lo escuchado.

De ahí que se haga necesario el trazo de un mapa histórico de las conexiones entre las prácticas y los sistemas reflexivos del dibujo.

Fue típico del siglo XX la relación entre las artes y el discurso, gracias a la ruta de la auto referencialidad artística y la introducción de la semiótica al aparato analítico del arte, esto constituyó un problema.

Específicamente el dibujo siempre había sido una disciplina de pensar y representar el mundo contextual, una manera de interpretarlo, no en el sentido mimético ni analógico, pero si con respecto a la propia ciencia o lenguaje dibujístico sígnico.

Hasta la revolución del Romanticismo y las vanguardias del XIX las matemáticas ocuparon un lugar importante dentro del cuerpo de las artes. Su capacidad cuantitativa organizó la métrica del espacio compositivo, marcó aún las divisiones cromáticas proporcionales en el sistema de Chevrel, de manera que la relación intralingüística de campos constituyó un factor de estructura en la obra.

Las matemáticas y la semiótica no solo guardan una relación con el dibujo en el sentido cuantitativo, ni como análisis de los tiempos y procesos de semiosis.

Ambas al igual que el dibujo, saben de la consistencia del lenguaje y su densidad como realidad mental, la no transparencia del lenguaje es condición compartida por estos campos. No hemos de caer en las relaciones simples y practicistas con bases denotativas y referenciales miméticas.

El ámbito del lenguaje como proceso simbólico se dirige a la construcción de realidades inventadas, mundos cuya particularidad se sobrepone a la realidad contextual externa, pero mundos finalmente en los que priva una condición de existencia subjetiva, posibilitada por la configuración perceptual del dibujo a la que ya aludimos en su momento.

Consideramos el modelo simbólico no sólo en su dimensión como constructor de unidades sígnicas visuales, o en su calidad de creador de obras que se constituyen en parteaguas simbólicos en la historia del pensamiento y las artes.

Una dimensión extendida de lo simbólico abarca también el conjunto de prácticas y estrategias que integran la acción del dibujar. No sólo la imagen icónica o la no referencial, o la reducción alfabética de la línea en los dibujos indexales de LeWitt son el resultado simbólico del dibujo.

Las prácticas de producción integran también parte del reservorio simbólico del campo del dibujo.

Ya el modelo técnico revisado anteriormente nos alerta sobre el particular.

La pintura prerenacentista fue por definición imagen sostenida en el espacio arquitectónico, en el altar portátil o el libro facsimilar. Con el renacimiento, el plano de cuadro, que es como sabemos el plano geométrico interpuesto entre el modelo y la visión del dibujante, 
se desprende de su realidad geométrica y cobra sustancia en el bastidor físico de la pintura portable. Plano vertical, cuya posición perpendicular a la horizontal se debe a su raíz geométrica. El cuadro se convirtió en la ventana que abrió la densidad y consistencia del muro que la soportaba, ventana al mundo, corte virtual en la arquitectura.

La condición de verticalidad del plano pictórico ganó consistencia y terreno, aunque la pintura en relación integrada con la arquitectura no dejó de realizarse. La pintura de caballete representó la manera de hacer viable las operaciones mentales (más que prácticas) especulativas sobre las que se basó la evolución de la protomodernidad.

Cuando el caballete se trasladó a la campiña, la pintura revolucionó en parte su carácter monárquico y la concepción simbólica del espacio taller del artista se desplazó hacia terrenos más mundanos.

El plano pictórico vertical simbolizó el campo de las convulsiones teóricas de la pintura por más de cuatrocientos años, cuando los pintores tendieron la tela sobre el piso y suprimieron el arriba y el abajo como referentes espaciales se sentaron las bases para una nueva simbología de la forma y el acto artístico.

Desde ese punto histórico hasta nuestra actualidad las consecuencias están a la vista, los soportes del dibujo tomaron por asalto la totalidad de espacios y superficies posibles, objetos (Gabriel Orozco), pizarrones (Beuys), montañas (Richard Long) etc.

Dubuffet consiente de esta situación entendía sus pinturas y dibujos como planos que forzaban la mirada para considerar la superficie pintada como un plano visto desde arriba y también lograr la elevación de un plano sobre el muro mediante un trazo o marca. Las propuestas de Niele Toroni interviniendo la arquitectura son una muestra inmejorable en ese sentido.

La penetración física de Pollock al pintar sus lienzos adentrándose en la interioridad del plano, simboliza una nueva relación con la pintura y con el mundo.

Aún los trabajos de Mondrian nos llevan al colapso del modelo taxonómico de la pintura, particularmente entre la acción y la representación, diluyendo la distancia que las separaba como operaciones fácticas y mentales.

La formulación de esta particularidad del modelo simbólico es una de las más trascendentes en el arte visual del siglo XX y nos acompaña hasta hoy.

\section{III-2-7 LA ESTRATEGIA COMO MODELO}

Alain Bois en su libro menciona cómo fugazmente y antes de morir Barnett Newman le refirió a Damish que todo lo que había hecho como pintor tuvo sentido solamente en relación con el trabajo de Pollock y en contra de éste.

Basado en esta puntualización podemos considerar un modelo teórico más dentro de la práctica de hacer la pintura y el dibujo.

Como elemento dentro de un juego, una obra o un conjunto de ellas, tienen un significado más que el que cada una integra como logro y formalización de un contexto.

Primero por lo que cada una es, pero también por lo que no es, por aquello a lo que se opone. 
Decimos que la obra tiene un valor por sí, pero también de acuerdo a su posición en el tablero que constituye el campo disciplinar y el territorio extenso del arte. En ese contexto la producción del dibujo es una postura que opera como entidad que juega una partida. Claro que esta ubicuidad particular requiere de la conciencia del dibujante en cuanto al proyecto de su trabajo y la situación general del campo que constituye la posición particular del estado que guarda la partida, el juego en su integración mediante las normas y condiciones que lo definen como tal. Esto se liga claramente con el modelo histórico.

Cada uno de los cortes paradigmáticos de la historia del dibujo y del arte, encuentran su lógica de gestación dentro de las estructuras del segmento que les antecede, y su concreción al lograr sistemas alternos de negación formal y estratégica plenamente diferenciados.

El interés del modelo estratégico no reside tanto en su capacidad diferenciadora como en su posibilidad de establecer vínculos de relación claros, ligas que se mantienen entre lo que hemos llamado estados temporales de un sistema, estados que explican de este modo y con este modelo en gran medida su línea de secuencia y al mismo tiempo sus cualidades diferenciadas.

Advertiremos en este momento que este modelo no se originó en la consideración individual de una obra. Sino en la conciencia del estado que guarda el tablero general del campo disciplinar y aún del resto de las artes.

Dentro del modelo estratégico encontramos ubicada nuestra noción del dibujo como sistema complejo. La posición particular de cada estado del tablero en el campo del dibujo nos marca en su secuencia el devenir del campo, pero también su tendencia, los puntos o zonas que operan como atractores del acto de dibujar; nos muestran igualmente la recursividad de los sistemas formales de representación que se operan. Al tener una claridad de la tendencia y sus bases estratégicas y de representación el dibujante y el analista advierten con claridad la aparición de una obra, o un signo dentro de ésta, un uso particular de sus tropos, que no se enmarca dentro de la tipicidad y comportamientos anteriores.

Así para dibujar no es suficiente tomar los materiales y herramientas, se requiere la conciencia de un norte estratégico, de nuestra posición en el juego al que nos integramos, algo que valga la pena; y, que más valioso que la posibilidad no sólo de ganar la partida sino reinventar el juego.

Tomemos una cita de Alain Bois, que aunque es larga expone de manera clara lo que nos preocupa, y dentro de ella misma, una referencia que a su vez hace sobre el pensamiento de Wölffing.

"Tomemos otra vez la metáfora estratégica por excelencia, la del ajedrez: Damish la utiliza para clarificar su punto de vista histórico. Supongamos que Newman y Pollock son oponentes, como podemos determinar por sus movimientos cual es el orden del encuentro en particular con su relación a sus nuevos aunque productivos desarrollos, ¿y que es del orden genérico del juego, con sus reglas asignadas? Uno puede ver que es sustituido por medio de esta clase de pregunta, al igual que el asunto de las repeticiones que tanto preocupa a Wölffing.

Es cierto que através de la problemática de la abstracción, de los pintores americanos (de la generación de los expresionistas abstractos), casi ya en los veintes los exponen- 
tes del suprematismo, neoplasticismo, purismo, etc.; pudieron alimentar la ilusión de que más allá de ser enganchados meramente en una simple contienda que tomaría su lugar en el escenario de las contiendas, estaban integrando o construyendo el juego de la Pintura, estaban regresando a los fundamentos del juego, a sus inmediatos elementos dados. El episodio americano representaría entonces menos un nuevo desarrollo en la historia de la abstracción que un nuevo inicio, un resumen -pero a un nivel más profundo y, teóricamente tanto más práctico, con medios más poderosos- del juego que empezaron bajo el título de abstracción treinta o cuarenta años antes"90

Aunque mantiene relaciones históricas, el modelo estratégico es en otro sentido antihistoricista, no cree en el agotamiento de las estructuras de representación ni en el de los sistemas estratégicos que constituyen los campos disciplinares, ya que está siempre atento, y de hecho se basa, en la posibilidad no sólo de deconstruir el juego sino de reinventarlo a partir de crearle extensiones o reducciones que terminan por modificar su esencia cualitativa, su definición e integración ontológica.

El modelo estratégico acepta las discontinuidades en el transcurso histórico del dibujo, no cree en un tiempo homogéneo sin rupturas. El juego del dibujo como planteamiento estratégico, opera en una particular temporalidad y en circunstancias específicas, bajo el peso de un contexto y ecología cultural, en relación con la conciencia epistémica remitida a la integración del propio campo dibujo.

La consideración arriba expuesta sería condición reflexiva aplicable a todos y cada uno de los modelos de la interioridad del campo del dibujo.

Como lo señala Alain Bois tal condición teorizante genera dudas de inmediato sobre un sinnúmero de afirmaciones que encontramos en el territorio de la crítica del dibujo y las artes en general.

¿Son la supuesta convención de profundidad piramidal, o la citada renuncia a la representación formal, realmente elementos prescindibles dentro del territorio del dibujo? ¿O bien sólo son parte de un momento estratégico que resulta fundamental para el desarrollo de una partida, pero no como elemento sustituible del territorio del dibujo?

Bajo el modelo estratégico tenemos la particularidad de concebir el territorio del dibujo como un campo de antagonismos, en donde nada está nunca terminado, ni decidido de una vez y para siempre. Pero este modelo es en esencia optimista al considerar siempre presente la posibilidad de apertura abductiva de los sistemas que interviene.

Tomamos el pensamiento de Bois, que a su vez repite a Damish, como conclusión parcial pero positiva de la intuición que alimentaba nuestra hipótesis inicial.

Damish mantiene una actitud irónica frente a los tonos apocalípticos que campean en el panorama del arte actual y sus atolladeros, momentos difíciles que deben ser tomados simplemente como uno de los muchos encuentros interrumpidos en el territorio del arte y a los cuales la historia y la crítica mantienen en cierta reserva.

90 Bois Yve-Alain. Painting as model. Massachusetts: MIT Press; 1990. P. $256 .$. 
Por eso para el dibujante la mejor aplicación de los modelos del dibujo no estriba en la posibilidad de historiografiarlos, sino en llevarlos al interior de la acción ejecutante, integrarlos como parte de su pensamiento proyectual que se dirige innegablemente al momento del acontecer fáctico configurante.

De esta manera convertimos el acto dibujo en un productor de modelos del pensamiento, siempre en relación con los modelos de consistencia ontológica concreta y subjetiva, entidades de la otredad con las que entablamos los diálogos de identidad.

Así el dibujo puede ser una maquinación que nos conduce a la filosofía pero para reelaborarla. La lectura de los modelos teóricos del dibujo permanecerá tan cercana y dentro del dibujo como es posible, centrándose en el corazón mismo de la invención dibujística.

\section{III-3 FORMALIZACIÓN E INTERIORIDAD DEL DIBUJO}

Todo lo anteriormente tratado, orbita en la línea que nos lleva a comprender la particularidad epistémica que considera los modelos del dibujo como una forma particular de teorizar desde el dibujo.

Esto sin desconocer las variaciones que se presenten desde una perspectiva histórica y lineal, o bien desde las consideraciones flexibles de las prácticas artísticas interdisciplinares contemporáneas,

En todo caso lo que resulta claro desde una perspectiva metodológica, ya sea lineal o interdisciplinar, es que se requiere el trazo claro y orgánico de una teoría de la forma y los sistemas del dibujo.

Sea cual sea nuestra postura frente al arte de nuestro tiempo, no es posible emprender un análisis teórico del dibujo y sus relaciones interdisciplinares careciendo de esta base analítico-formal y epistemológica del dibujo.

Pensamos que el trazo de ese estudio está aún por realizarse, el trabajo de los pensadores y la literatura española de 25 años hacia acá es significativo, en él nos basamos.

El giro que tipifica nuestro análisis consiste en sentar las bases para el establecimiento de cortes, periodos o momentos dentro del devenir del dibujo, que puedan marcar giros paradigmáticos basados en las estructuras internas de representación formalizada del propio campo.

Sabemos que esta es una empresa ambiciosa y acaso escape a nuestras posibilidades el concluirla de manera satisfactoria; pero solo habremos de enfocarnos en la consecución de una secuencia analítica de la historia del dibujo y sus sistemas como marco de comprobación o falsación de las tesis e hipótesis sostenidas en esta investigación.

El origen del dibujo, el de la pintura y la escritura comparten una vena común, el texto de A. C. Morhouse, "La Historia del Alfabeto"91 es particularmente claro en este sentido. Pero lo que de ese origen común nos interesa destacar es la función gestáltica del dibujo como translación del pensamiento hacia una región eidética. En ese camino, pensamiento, forma y concepto se integran en una unidad indisociable que sólo se particularizará con la aparición del alfabeto como cadena sígnica abstracta que ya no dependerá de la forma dibujo y las pictografías.

91 Morhouse A. C. Historia del Alfabeto. México: Ed. Fondo de Cultura Económica; 1982. (Breviarios 296). 
Pero en ese trecho del camino, tanto la escritura en ciernes, como el dibujo y la pintura operaron como procesos de formalización de una realidad contextual externa que se transformaba en la interioridad del pensamiento abstracto.

Surgen desde ahí los modelos de la exterioridad natural fenoménica, la otredad.

Pero de manera sincrónica se originan los modelos de la interioridad mental abstracta que desembocan en los procesos de codificación sígnica del contexto primario; los modelos del pensamiento eidético y su forma.

Un tercer continente acompaña este mapa mental, el de los modelos de la interioridad subjetiva del individuo y su colectividad, mismos que representan el acuerdo social del lenguaje y que se expanden hacia un pensamiento subjetivo y mágico religioso.

Por todo esto es que consideramos a los modelos del dibujo como formas de un pensamiento sistémico estructural eidético, cuyo trazo e historia es lo que ahora nos interesa analizar.

Los modelos del dibujo en tanto formas del pensamiento integran parte de la ecología cultural de la época y sociedad en la que se originan y dentro de la que operan, son la expresión del pensamiento naturalizado y se manifiestan por la vía de las operaciones abstractas y formales del dibujante.

Por eso es que su potencial dentro de un análisis teórico o bien formal debe tomar en cuenta ese marco histórico, ya que es en esa región en la que mejor operan estas categorías como bases de un análisis; en la medida que nos distanciamos de ese arco fenoménico estamos flexibilizando y ampliando las márgenes operativas de esos conceptos y con ello su capacidad para construir un análisis e investigación.

Los modelos del dibujo requieren de nuestra parte, el esfuerzo de ubicuidad analítica, para situarnos dentro del contexto artístico y del dibujo que los origina, mas allá de ello nuestro análisis comienza a perder sustento.

Tal vez desde este punto en adelante se haga necesaria una aclaración; las formulaciones que realizamos no intentan ser excluyentes, no buscamos con ellas la negación de cualquier otra suposición teórica, tampoco las entendemos como totales y acabadas, esto es que, reconocemos desde ahora su incompletud. Por eso pensamos que su valor consiste en manifestar un pensamiento metodológico y epistémico específico y en describir el trazo de una ruta de análisis; la de la reflexión endógena del pensamiento proyectual del dibujo y la reflexión sobre el acto del dibujar.

Con lo anterior no evitamos la responsabilidad de asumir lo formulado, puntualizamos mas bien el carácter disciplinar del trabajo.

\section{III-4 LOS MODELOS Y LA OTREDAD}

Hasta aquí podemos referirnos ya a la categoría de Modelo dentro del dibujo planteándonos dos campos generales para su entendimiento.

El primero, el Orden Teórico de los Modelos del que nos hemos ocupado hasta este punto. En segundo término, el Modelo como la Otredad Ontológica. El otro, el que no soy yo, sujeto, objeto o fenómeno frente al que me posiciono y que representa la entidad y misterio, para cuyo conocimiento inicio el dibujar.

Sabemos que con esta consideración nos ubicamos en una concepción que entiende la 
realidad como exterioridad a la conciencia cognoscente; mundo de existencia en el que los otros tienen principio de autonomía y autodeterminación. Concepción en la que los otros y la realidad son por si mismos y poseen su principio estructural y formal, su voluntad de agrupación y distanciamiento. En suma, una condición de ser y existencia que no depende de mi entender y para cuyo conocimiento desarrollo estrategias del dibujo, maneras que organizan mi relación con esos otros y el contexto. Lección que podemos leer en la historia milenaria de las artes y, específicamente en la de las formalizaciones del dibujo.

Sabemos que esta concepción ha sido cuestionada y que en términos constructivistas y gestálticos la realidad no es una región existente de por si, sabemos que en la medida que la percibimos la construimos, y que así toda realidad es en cierto sentido nuestra construcción formalizada y discriminada, jerarquizada bajo el orden de nuestro interés; precisamente ahí ubicamos nuestra concepción modelística, en el reconocimiento de la realidad como un contexto otro, que sin embargo sólo es en la medida que lo formalizo y en ese acto lo represento. Ya desde este punto nos orientamos hacia un entendimiento de la representación que trasciende una concepción mimética, más adelante volveremos a ello.

La relación que unió el pensamiento del dibujo con la naturaleza externa, con el contexto y las otredades como referente artístico fue condición milenaria, esta línea de conducción sólo se alteró en el proyecto de la modernidad del siglo XX, con el advenimiento de los modelos de la interioridad subjetiva de las artes, forma de la forma, pensamiento tautológico en el que el artista crea el espacio del propio lenguaje, que no alude sino a la posibilidad de una dimensión reflexiva que en si misma es prueba de humanidad.

Pero como ya lo hemos señalado, la emergencia de posturas epistémicas alternas no es condición de aniquilamiento del pensamiento anterior, es posibilidad de alternancia, escenario en el que una y otra desaparecen y se presentan en una condición de coexistencia sistemática y sistémica. Recordamos aquí el pensamiento de Damish. Así el proyecto de la modernidad muy pronto cedió paso al retomar el contexto como fuente de formalización y estrategia artística.

A esto es a lo que aludimos al mencionar a los modelos del dibujo como la consideración y relación con el otro.

Decimos que el modelo es el otro, la realidad con la que no puedo negociar, la que no tiene cauces estructurales y orgánicos que dependan de mi determinación, por más que mis acciones puedan afectarla inevitablemente.

En esta línea que débilmente separa lo real de lo construido desde una visión constructivista, es en la que se asientan los modelos del dibujo como consideración de la otredad.

Con Fausto y el pensamiento romántico se define claramente el ser dividido, sentimiento y razón, pensamiento y sensación comienzan a desdibujar y desintegrar la solidez de la naturaleza como unidad logocéntrica. El todo natural se ve fragmentado, escindido por la condición natural de la subjetividad interna del artista, una naturaleza otra, cuyos ordenes estructurales parecen determinarse por principios de interioridad psíquica. Pero el pensamiento interior del artista mantiene una división de origen, división que conlleva sustantivamente la fragmentación, y por decirlo así problematizada.

El pensamiento de la vanguardia nace escindido de la totalidad modelística que le antecede, pero no con ello abandona de tajo a la naturaleza y el contexto como base del pensamiento y el proyecto del dibujo. La vanguardia fragmenta la totalidad pictórica (por ejemplo) pero al hacerlo abstrae las partes del todo pictórico disciplinar, las separa para 
su análisis y estudio, pero sigue abrevando en la relación modelística y estratégica que lo une con la naturaleza. Solo de esta manera entenderemos a fondo la revolución abstracta de Cézanne, que sin embargo se basa en el estudio de unas cuantas manzanas y el paisaje. Por otra parte tomemos dos obras que en sí son el estandarte del romanticismo pictórico: Escenas de la matanza de Scio, de Eugenio Delacroix y nuevamente, El salvamento de la Medusa, de Teodoro Géricault. Fig. 26
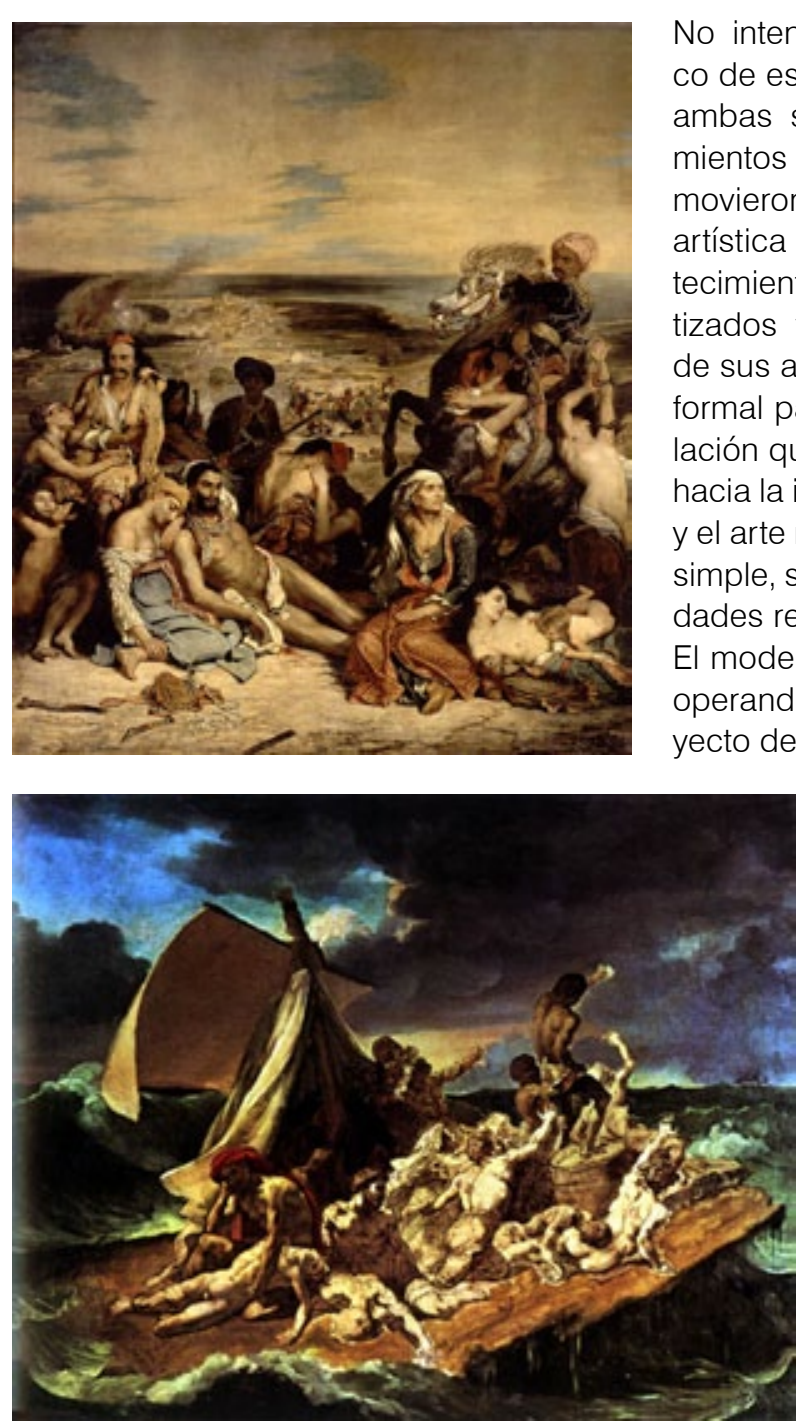

Fig. 26 Delacroix. "Escenas de la matanza de Scio" Géricault "Salvamento de la Medusa"
No intentaremos un análisis hermenéutico de estas obras, lo que decimos es que ambas se originan de sendos acontecimientos políticos y contextuales que conmovieron la opinión pública, la estrategia artística se basó de origen en esos acontecimientos contextuales, que al ser tematizados y problematizados en cada uno de sus aspectos logran una consecuencia formal particular de representación. La relación que conduce el pensamiento crítico hacia la interioridad del proyecto del dibujo y el arte no se expresa de manera directa y simple, se basa en el encuentro de posibilidades relacionantes de nueva generación. El modelo como entidad contextual siguió operando como centro detonante del proyecto del dibujo.

Ambos ejemplos, se basan en la historicidad del proyecto del dibujo a la que ya nos hemos referido, en su vocación histórica expresan una voluntad de ruptura y crítica de su contexto social y cultural. En el orden del pensamiento teórico, como ejemplo de modelos, son dos obras que se pueden considerar como los manifiestos de la teoría y la estrategia plástica del romanticismo. La ruptura de la base fija de asentamiento compositivo, la tonalización de las áreas de espacio cromático cobrando consistencia matérica y la subordinación de la línea y su disolución dentro de los planos de valor, que modelan la forma y la atmósfera, son estos de modo resumido la expresión del pensamiento romántico formalizado en la concreción de la imagen. 
El lienzo de Delacroix fue planeado, bocetado y corregido por más de un año, el autor realizó dibujos de estudio para la resolución de la composición espacial y cromática.

Pero lo que señalamos particularmente en este par de ejemplos es el que tales estudios se basan en la recurrencia y análisis de modelos naturales, aunque en la operación proyectual estos modelos y la imagen terminal se organicen mediante una formalización que transgrede el orden mimético y las apariencias naturales.

Hasta el pensamiento ilustrado se pensó en el orden natural como un todo articulado por un conjunto de leyes universales e inviolables, por tanto el proyecto del arte debería tender al establecimiento de sus propias categorías estables, que serían la expresión del orden natural llevado al dibujo.

Pero la relación del dibujo y los modelos naturales no resulta ser tan sencilla, ya desde el periodo renacentista se advirtió la distancia que existía entre el orden natural y el orden plástico, se menciona claramente el que la imagen dibujada era una transcripción modificada de las estructuras de los modelos naturales regulada por los cánones de proporción. Vale la pena recordar, para no establecer relaciones rápidas y violentas, que desde ese momento se fue consciente de que la pintura era un artificio, simio de la naturaleza, decía Paolo Lomazzo, aunque su finalidad fuera la de emular los principios de la visión humana. El dibujo de los modelos ontológicos y objetuales fue para el artista del renacimiento una mezcla basada en la razón métrica estructural y en la observación de la naturaleza.

La modernidad de la vanguardia en el siglo XIX continúa manteniendo una fuerte relación con la naturaleza, y dentro de esto en el terreno del dibujo, pero la variación consistió en buscar órdenes de formalización que se sabía ya, no eran la explicación de una estructura natural aparente, sino una construcción alterna que aludía a la organización interna de los modelos y que determinaba lo que nuestra mirada percibía.

Pero aún todo esto se originaba de la reflexión al asistir y posicionarse en el contexto mediante una particularidad fenomenológica, el ser del dibujante en un espacio y locación específica y en una particularidad temporal; estado fenoménico que determinó la consecuencia y propuesta del artista.

En el siglo XVIII el caballete del pintor se trasladó a la campiña, ya veremos las consecuencias que esto trajo al interior del dibujo, pero con Cézanne inicia su retorno al interior del estudio del pintor.

Para hoy la pregunta no es ya como lograr comprender el orden natural, y menos por medio del dibujo, ese fue en gran medida el ideal renacentista (que por otra parte pronto fue abandonado) pero el entendimiento del orden natural no fue una empresa de la que solo el dibujo se haya encargado, para ello se aplicaron una serie de campos del conocimiento dentro de los cuales el dibujo operó como herramienta de observación, análisis y registro de las observaciones.

Hoy nos interesa el como lograr que la experiencia frente al otro y la vivencia en el contexto se logre como pensamiento que no es el del orden natural sino el de lo que frente a el pensamos. Habitar la distancia que va del orden natural a la estructura de la imagen. Pensar sobre los modelos lo no pensado hasta entonces, encontrar la manera de un decir que represente la experiencia y vivencia, la opinión que de ese acto tenemos y no la expli- 
cación de los motivos del orden natural.

Citemos a Fernando Rampérez quien nos aclara este punto.

"El hombre es sólo un pliegue en el saber: nace a la vez que encuentra algo que desborda su propio proyecto; el hombre nace en la episteme renacentista con un proyecto de cuya imposibilidad surge nuestra situación de pensamiento actual: pensar desde los bordes de la racionalidad establecida esa vida que la desborda, irreducible, fuerza cercana que queda sin embargo más allá, al otro lado; incluso sabiendo que pensar ese otro lado, pensar lo no pensado, es lógicamente imposible, que constituye una tarea sin fondo precisamente porque lo otro se presenta como lo que no se deja pensar."92

Claro que al decir esto nos inclinamos por una postura artística y epistémica, una en la que consideramos a la realidad y sus otros como fuente del proceso de representación, aunque aclaramos, no es esta la única determinante modelística en la que habremos de basarnos.

Así pues una región de existencia de los modelos en el dibujo es la que compete a la existencia de las entidades ontológicas, contextuales o fenoménicas independientes del pensar y la intencionalidad del dibujante.

El modelo es e/ otro, el que existe fuera de nosotros y siempre ha sido motivo de la imagen, para conocerlo se inventó el dibujo, para representarlo, apresarlo un tanto, hacerle cosas y poderlo dominar, o hablar de él, o sacralizarlo junto con los otros.

El modelo es el otro que se resiste a ser como lo concibo, es la realidad en su negativa a ser comprendida y en su imposibilidad de ser abarcada.

El otro como modelo guardará siempre un ámbito de definición e intención al que no habré de acceder, será así una fuente constante de misterio parcial en el que nace lo inefable y la poética del acto dibujo, y en la que la expansión de las formas y los procedimientos tienen capital importancia. Entendemos así la formalización y la configuración como un acto de expansión del sentido dentro de la dimensión sígnica y del lenguaje, expansión generada por la vivencia en el modelo pero que se ubica en el inter-espacio entre modelo y proceso de configuración, el espacio de la experiencia.

El otro que represento y siempre cambia, obligándome a variar mi representación, cambia siempre, y en tal medida, que nos hemos visto impelidos a darle una forma estable, racional y mesurable, pensando que de ese modo lo apresamos y descubrimos su esencia.

Por miles de años el modelo del otro fue similar a nosotros en su morfología, los dioses tenían nuestra forma porque los habíamos creado. La forma de los modelos era humana y con eso los demás seres y objetos pasaban a segundo término. Los modelos fueron sujetos; lo demás, objetos.

Pero la historia de la imagen nos muestra claramente que el universo de los modelos representados siempre estuvo integrado por la totalidad de seres que coexistieron con el ser humano. No nos interesa ese señalamiento que por si mismo resulta simple, lo que nos inquieta es que, en ese universo ontológico el problema se desplaza hacia el ámbito de las relaciones, las interacciones ontológicas y como éstas son reflexionadas y canalizadas en la acción de dibujar.

92 Rampérez Fernando. La quiebra de la representación. El arte de vanguardia y la estética moderna. Madrid: Ed. Dykinson. 2004. P. 238. 
Mucho se puede discurrir y vagar hablando de los modelos en el campo del dibujo.

Para el estudio que nos ocupa no investigaremos la panorámica histórica como distinción de cánones para dibujar la figura humana.

No nos interesa el estudio de la métrica en relación a los modelos, ahí el terreno es amplísimo y apasionante. Tampoco nos interesa las distinción de género, femenino masculino, ni los estudios positivistas de los tipos fisiognómicos, ni la expresión en relación con la constitución anatómica de los sujetos, todo ello forma parte de la problemática de las representaciones de la figura humana en el dibujo.

No es que todo esto no sea importante, creemos que si lo es. Existe bastante terreno recorrido en ese tema.

Por esta ocasión lo que nos interesa es la postura epistémica en la que el dibujante se relaciona con el otro que le es igual, nos interesa considerar el dibujo como una reflexión del dibujante hacia el género humano, la naturaleza y el contexto, basados claro está en las consideraciones y las construcciones conceptuales fabricadas con esa finalidad.

El modelo del dibujante es en una de sus posibilidades el dibujo del otro, en el sentido de dibujar los sujetos del propio género humano.

Sería este un primer nivel de identidad entre el artista y sus iguales.

Pero se dibujan también modelos del mundo de los objetos, modelos a los que generalmente no se les concede un rango ontológico igual al de los modelos humanos.

El objeto entra tardíamente al primer plano de la pintura como región temática. Es hasta el barroco que la pintura de género se decanta con claridad meridiana. El retrato en Rubens, José de Rivera y Franz Halls, la naturaleza muerta nuevamente con Franz Halls, el paisaje como suma de seres no humanos en la pintura de Ruisdael etc.

Los objetos en la pintura barroca generalmente fueron considerados parte del entorno de la pintura histórica y mitológica, En lo referente a la consistencia como motivo de estudio se les concedió particularmente el interés de su cualidad matérica, el efecto de los distintos materiales, telas, sedas, cristales líquidos etc. Pero tardarían muchos años antes de que lograran la potencia del centro discursivo en la imagen. La ampliación del mercado del arte alcanzó a segmentos de la sociedad que plantearon sus propios valores y demandas, esto junto con la paganización de los temas terminó por asentar la amplitud con que los modelos fueron abordados.

Ya con el paisaje Holandés y la estética de lo pintoresco y lo sublime se pone el acento en la cualidad de suavidad o potencia de la materia de los modelos que se seleccionan como motivo del cuadro. Este será el inicio de una ruta que para fines del XIX concede a los objetos de la naturaleza una cualidad ontológica firme.

Duchamp habló del Gran Vidrio como una maquinaria, el Futurismo hizo del maquinismo el centro de su manifiesto. Los estudios de Ruskin en el paisaje nos hablan de la naturaleza como la reunión de personajes que se convierten en modelos del dibujo, su método de dibujo ${ }^{93}$ curiosamente inicia con un ejercicio de dibujar una piedra, para terminar dibujando la naturaleza.

Después de la revolución surrealista con sus ensamblados y cajas, los objetos no serían

93 Ruskin John. Elementos de dibujo colorido y composición. 
vistos ya como un segundo personaje en el dibujo, mostramos aquí unos objetos ensamblados de Alan Glass exquisitamente inquietantes, Fig. 27
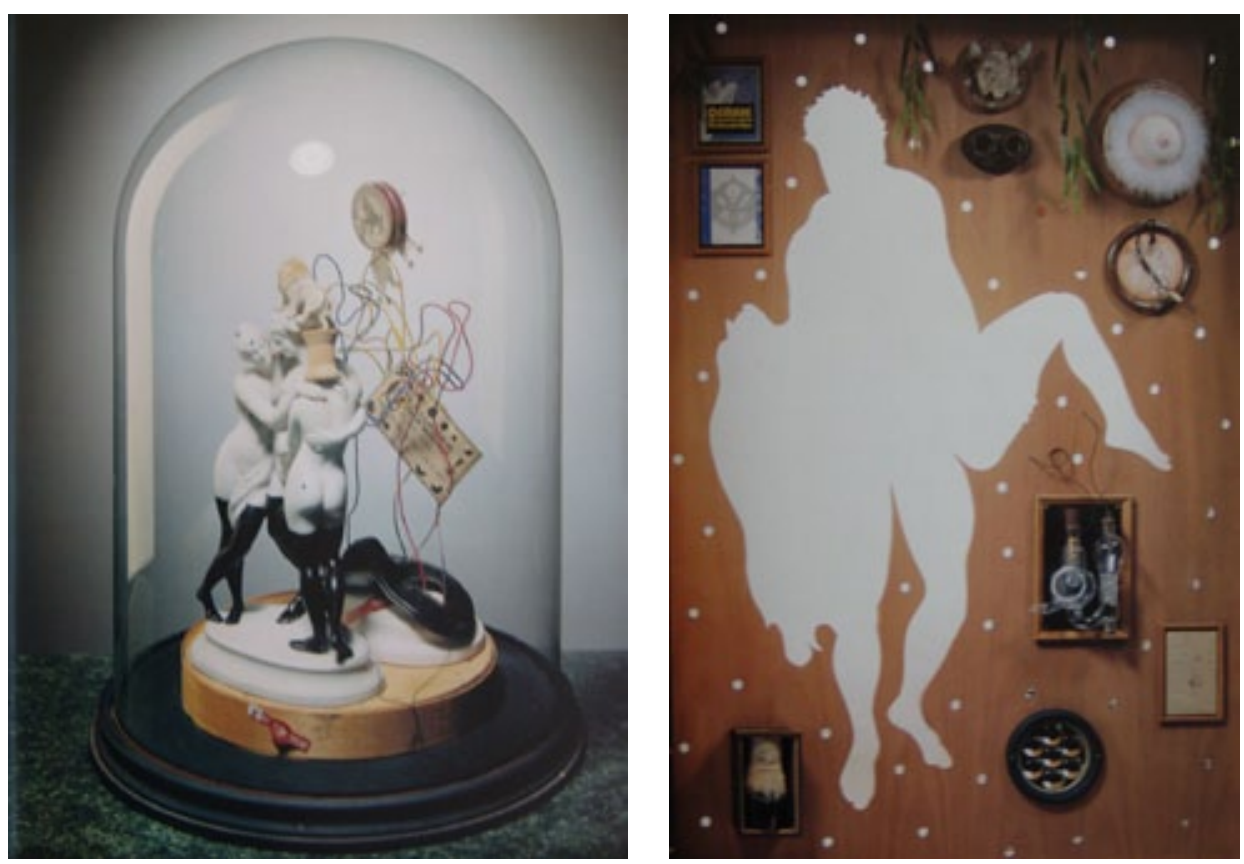

Fig. 27 Alan Glass

El objeto como modelo trastoca hasta el desequilibrio la integridad de la psíque humana. La práctica del cadáver exquisito con sus mezclas de modelos igualarían en el pensamiento los objetos con los sujetos, la línea divisoria desaparecería de una vez por todas. La imagen de la lata Campbells coloca el más trivial de los objetos en la punta del sitial de los modelos. Revolución iniciada por Duchamp y sus ready made.

El camino abierto por Duchamp y los collages cubistas tuvo un carácter diferenciado en al ámbito de los modelos del dibujo. En ese proceso se inicia la eliminación de las secuencias de representación, pues el objeto no se trató como fuente de estructuras eidéticas sino que vino a sustituir la imagen del referente representado por la presentación misma del objeto en el espacio expositivo.

Esta situación determinó un cambio esencial de estrategia, los objetos presentados constituyeron entidades sígnicas con un valor simbólico implícito, esta carga semántica es el detonante operativo de la nueva estrategia de relaciones simbólicas, en ella la forma del objeto es tal y casi siempre poco afectada en el proceso generativo de estas nuevas obras; con esto se sucede un desplazamiento del dibujo en su función proyectual como constructor del proyecto artístico, si bien mantiene en gran medida su estructura interna como sistema de formalizaciones. 
Actualmente las estrategias de significación están densamente pobladas por la irrupción de los objetos como modelo de la obra de arte, ya la revolución del capitalismo presentaba al objeto como un nuevo centro ontológico, quinientos años después el objeto habla mucho más de la condición humana cosificada y consumista que la misma imagen del hombre.

Hasta el último cuarto del 1600, la pintura y el dibujo tenían como centro temático el relato de lo sucedido en el campo de la mitología, la religión o las gestas heroicas de la monarquía. La vena flamenca de la pintura en Holanda descubrirá poco a poco a la naturaleza, plena de motivos como eje temático de la obra de arte.

En Inglaterra, Constable basado en las ideas de Sir Joshua Reynolds hace del paisaje el gran género de la pintura. Ya tendremos oportunidad de detenernos en esta circunstancia, por ahora digamos que al poner a la naturaleza como centro temático y modelo del dibujo cambiará abruptamente la postura epistémica en este terreno.

Dibujar frente a la naturaleza condujo al dibujante a la representación de los fenómenos como modelos del dibujo, esto a su vez llevaría a la conclusión de que la naturaleza es parte de un contexto, pero que los límites estaban rotos y la visión del mundo exterior se podía dilatar hacia un contexto en toda su complejidad y riqueza como el gran modelo, aquel que nos incluye a todos.

El Impresionismo inició la carrera de pintar las circunstancias del devenir como modelo de la pintura, la temporalidad y su consecuencia en el fenómeno lumínico son su gran lección, que se plasma en su teoría del instante impresionista.

Cuando el dibujante tomó por asalto a la naturaleza como modelo dio el primer paso en la conquista del contexto como modelo.

Los modelos desde la postura epistémica del dibujante, revisten el carácter de ser fuente del material necesario para formalizar una representación, con toda la riqueza que este acto contiene desde la parte meramente formal de la imagen, hasta aquello que constituye el ideario normativo de esa forma.

\section{III-5 EL MODELO INTERIOR DEL DIBUJO}

Un campo más, es el del Modelo Interior del Dibujo; el Dibujo Interno, como lo definiera Federico Zuccari, al cual complementó con su enunciado del Dibujo Externo, entendido este como la concreción fáctica del dibujo interno.

Forma del pensamiento que no es ya el otro sino una formalización que propone el dibujante. Modelo de la interioridad que reúne la subjetividad del dibujante y su reflexión más racional, todo esto expresado en sistemas del dibujo que serán validos aún en ausencia de la otredad, sistemas preicónicos que constituyen el dibujo en abstracto. Categorías, conceptos, leyes, procederes y estrategias que podemos reconocer como modelos del pensamiento del dibujo, y en los que se basa su potencial proyectual prefigurativo. En los parágrafos siguientes nos detendremos sobre este punto, que marcó una de las diferencias sustantivas entre la concepción del dibujo florentino del renacimiento y el dibujo manierista.

Podemos señalar un denominador común, una característica epistémica que une al dibujo del periodo renacentista, manierista y barroco; a lo largo de esos siglos se configuraron sistemas del dibujo, del color y la geometría, miles de páginas, que aunque guardan 
saltos cualitativos en sus concepciones, sin embargo constituyeron una secuencia de sistemas que integraron el dibujo y la pintura como entidades abstractas pero con una existencia consistente e intransparente como lenguajes, secuencias rigurosas de formalización independientes de las obras concretas que posibilitaron.

La teoría de Zuccari enuncia por primera vez con claridad la diferenciación entre El Dibujo Objeto, El Dibujante y El Dibujo Como Sistema Formal.

Pero en este punto queremos insistir en la relevancia de esta noción teórica. Al considerar desde el siglo XVI al dibujo como una disciplina teórico reflexiva se marca una ruta de ascendencia que une el dibujo manierista con las expresiones conceptuales más reductivas de Sol LeWitt o Piero Manzoni. Claro que sabemos de la distancia histórica que existe entre estos procesos, y entendemos sus profundas diferencias como modelos estratégicos del dibujo y el arte, como modelos técnicos y perceptivos. Pero en este punto marcamos insistentemente una huella, para señalar que en gran medida los andamiajes de conceptualización y formalización de la historia del dibujo, así como las estrategias conformadas a lo largo de los siglos, se filtran hasta las prácticas artísticas actuales y el pensamiento crítico que pretende demasiado rápido haberlas trascendido.

El modelo del dibujo interno es de naturaleza platónica, eminentemente racional, de ahí que se concluya que la pintura y en este caso el dibujo son una forma del pensamiento. El dibujo interno es un modelo porque logra constituir un conjunto categorial y conceptual como definición del dibujo, propone las reglas y procederes que guían la acción configurativa y de representación. Analiza también las relaciones de la disciplina con los campos anexos.

La interioridad del modelo del dibujo no solo será entendida como la manera de canalizar la subjetividad del dibujante, reúne las cualidades del pensamiento racional y objetivo, y esta característica es la que le constituye en entidad modelo. Porque mediante formulaciones abstractas se entiende al modelo de la realidad natural para estudiarlo.

La naturaleza en sentido extenso, los sujetos de distinto orden, los objetos que cobran consistencia ontológica, los fenómenos sociales y naturales del contexto, los sucesos históricos constituidos como relatos fundacionales fueron el modelo primario donde se originó el acto dibujo y la representación. En estos modelos se unía dialécticamente la realidad externa y contextual como región concreta y objetiva del mundo, con las determinantes internas y subjetivas del artista. Pensamiento racional objetivo, pensamiento intuitivo y pensamiento subjetivo configuraron una causalidad metodológica. Con el advenimiento de la artisticidad anicónica y la separación de la imagen de su referente modelo, se abre la puerta a los modelos tautológicos de los campos artísticos. Los modelos del arte por el arte, la forma de la forma, la alfabetidad visual y la pureza disciplinar establecida por la estética de la modernidad. Todo esto hasta llegar a los modelos del dibujo que formalizan la estrategia por la vía de la cita y la apropiación y la hibridación disciplinar.

Vemos así que los modelos del dibujo siempre aluden a la consideración de una entidad alterna, sea esta natural y material o de índole abstracta racional o bien subjetiva.

El otro, como modelo del dibujo ha variado a lo largo de la historia del arte. El interés que el dibujante y el artista pone sobre distintas entidades del contexto es muy variado a lo 
largo de la historia, y lo son también los modos y estrategias que se han puesto en práctica para aprenderlo.

Resulta claro que las formas del pensamiento dibujo también revisten una variación y cambios a lo largo de la historia, en si mismos, esos cambios y sus giros conceptuales y teóricos constituyen los modelos del dibujo, materia de este análisis, implican como lo hemos observado variaciones en la postura epistemológica del artista dibujante.

Con el pensamiento modelístico del dibujo interno podemos analizar su secuencia como disciplina proyectual, el origen de esta función y la variabilidad sistémica de esa integración que lo une con las demás artes.

"Siempre es necesario copiar la naturaleza y aprender a ver bien. Por este motivo es preciso estudiar a los antiguos y a los maestros, no para imitarles, sino, una vez más para aprender a ver. [...] Os envío al Louvre para que aprendáis de los antiguos a ver la naturaleza"94

"En otra cosa aún más importante se han diferenciado siempre entre si los pintores: en la investigación sobre el nivel de perfección de lo bello. Algunos, cuando imitan uno o más géneros de cosas, se dedican solo a reproducir aquello que normalmente percibimos con la vista, solo aspiran a imitar la naturaleza perfectamente tal como aparece a los sentidos sin buscar nada más. Otros en cambio alcanzan mayor altura con el entendimiento y comprenden en su Idea la excelencia de lo bello y la perfección a la que aspira la naturaleza, aunque nunca la alcance en un único sujeto, ya que lo impiden las circunstancias de tiempo, de materia y de otro orden... Los artífices, no contentos con imitar lo que ven en un único sujeto, van recogiendo las bellezas repartidas en muchos, las juntan con fineza de juicio y hacen las cosa no como son sino como deberían ser para ser perfectísimamente acabadas." 95

Las dos citas anteriores son las palabras de Ingres y de Agucchi, en ellas nos muestran el pensamiento de dos épocas con respecto a la concepción modelística del dibujo.

Nos vemos entonces en la necesidad de mencionar con puntualidad que el término de Modelo, encara acepciones múltiples.

En la cita de Dominique Ingres nos parece fundamental destacar el hecho intencional de aprender a ver, se recurre a la naturaleza y a los maestros para aprender a ver, no para copiarlos, se desprende de esto una primera distancia con la postura del ideal mimético, que de manera fácil se asume como crítica, la educación visual, el aprender a ver, es ante todo un hecho analítico de discriminación racional; proceso de elaboración de la gestalt. La mímesis entendida como copia nos lleva a la superposición de la imagen como sustituto de una realidad primaria.

Por otro lado en la cita de Battista Aguchi queda claro el entender el dibujo como una reunión abstracta de caracteres formales que no se encuentran como unidad en el modelo natural, entonces el dibujo es acto de integración de una forma que se sabe no es la natural sino la ficción formal que aunque se origina en el estudio natural corre en una distancia diferente.

94 Gómez Juan José, et al. Las lecciones del dibujo. Madrid España: Ed. Cátedra; 1999. P. 349.

95 Freixa Mireia, Garriga Joaquim, Yarza Joaquín, editores. Fuentes y documentos para la historia del Arte. Renacimiento en Europa. Barcelona: Ed. Gustavo Gili; 1983. (V). P. 33. 
Lo anterior explicita lo que habíamos mencionado, un campo paradigmático de regiones, una, la de los modelos como subconjuntos del campo teórico de las artes, que a su vez conforman modelos de pensamiento más globales; dos, la de los modelos como aquellas entidades ontológicas y contextuales que son asunto de análisis en el dibujo y fuente de conocimiento, estudio y sistemas de representación.

Hasta este punto nos hemos dedicado a exponer la categoría de modelo del dibujo como forma teórica particular del pensamiento, en segundo orden tratamos los modelos del dibujo como fuente ontológica primaria de la imagen. Como última parte de este capítulo estudiaremos las etapas paradigmáticas del pensamiento plástico, que se concretan en grandes capítulos de la teoría del dibujo. A ellos dedicaremos la segunda parte de este capítulo.

\section{III-6 LOS MODELOS FORMALES DEL DIBUJO EN LA HISTORIA}

Hasta este punto, hemos reiterado la necesidad de establecer cortes analíticos para el estudio del pensamiento proyectual del dibujo, su historia y su acción disciplinar. Mencionamos igualmente que diversos autores, si bien indirectamente, reconocen esta particularidad categórica, quizá lo realizan sólo como inicio de su propia reflexión, aunque rápidamente pasen a estructurar un modelo que deja de lado su necesidad inicial, condición típica esta, de la posmodernidad.

También a lo largo de nuestras líneas nos mostramos como quienes no solo reconocen la necesidad de una secuencia histórica que señale las variaciones y particularidades del dibujo y su pensamiento, sino que vemos esta como una posición teórico modelística sostenible.

Particularmente las palabras de Erwin Panofsky al inicio de su texto sobre el renacimiento del arte occidental exponen de manera muy clara, la postura que de tiempo atrás se fue conformando en nuestra mente sobre este asunto. Las líneas que siguen, antes de dar paso a el recorrido por la historia del dibujo y sus representaciones formales y estratégicas exponen mucho del pensamiento de Panofsky, quien sobre éste particular se mostró como una autoridad indudable.

Todo cambio o innovación, presupone la existencia de un algo establecido y delimitado, nos dice Panofsky, y aquí señalamos la coincidencia con Foster en el sentido que reconoce la imposibilidad de ubicar la interrelación de campos del arte sin recurrir a la necesidad de reconocer el propio campo que se trasciende.

Ese algo establecido puede ser tan amplio como la tradición o el ideario cultural, pero en el dibujo es claro que se trata del orden de representación en uso y heredado de la historia, por más reciente que esta sea. En fin, convención o paradigma formal, ésta es la constante de la que la innovación aparece como variable.

Para aclararnos si una solución o concepto del dibujo representa o no una innovación, se requiere ver con claridad la aceptación de una constante e intentar definir su trazo evolutivo. Igual, para dilucidar el grado de afectación que las variaciones dibujísticas introducen, tenemos que esclarecer si estas han logrado cambiar mediante su efecto y presión el trazo y estado del corpus dibujístico. 
La dificultad consiste en que este análisis nos invita a considerar el fenómeno pensado, inmerso en una particularidad histórica de tiempo y espacio, que amplía sus causas e influencias.

Tenemos que considerar que una extensión del periodo temporal analizado se entenderá como un corte paradigmático generalizante, pero que contiene en su interior segmentos y autores menos importantes, duraciones más cortas que pueden ser colocadas bajo el denominador común del corte mayor.

La tipificación cualitativa de cada segmento paradigmático será entonces delimitada en un tiempo y lugar, en éste se desarrollan las estructuras formales del dibujo, el avance de nuestro propio estudio nos permitirá cada vez un acercamiento y redefinición de esta ubicuidad formulada.

Sobre estos cortes, sus razones y expresiones es posible que no lleguemos a un acuerdo común sobre su inicio y término como un periodo o corte paradigmático, es así porque en gran medida el arco de delimitación se corresponde con el interés del giro estudiado y con la estructura analítica utilizada.

La propia definición de los modelos del dibujo como segmentos históricos de los cuerpos de representación formal, observa un cambio de dirección o emergencia de cualidades de alteridad (como lo expusimos anteriormente bajo los postulados de la complejidad), estas comprenden el sentido de continuidad del sistema y a la vez el sentido de divergencia o disyunción de las normas estructurales, lo que nos permite señalar su condición de primeridad emergente.

En el campo del dibujo estos giros dentro de los periodos, se originan por la acumulación de pequeñas variaciones graduales, modestas pero acumulativas (debidas tanto al desarrollo del pensamiento de cada artista como a la variedad de autores, cuyo trabajo puebla el territorio de ese periodo) o por el impacto de hallazgos mayores que trastocan radicalmente el modelo.

Dentro de la modernidad romántica los cambios se debieron incluso a posturas y factores críticos y negativos del proyecto. Un número cada vez más grande de autores acepta y desarrolla formas y procesos, estrategias antes no conocidas. Pero en el dibujo también ha ocurrido, y más en los momentos recientes de la tardo modernidad, que la generalidad de autores deja de desarrollar y olvida sistemas del dibujo que antes eran de uso familiar, situación que motivaba su evolución progresiva.

Pese a todo lo anterior, podemos observar y afirmar que cada modelo del dibujo y corte paradigmático, posee una definición teórica formal y estrategia que le es típica, aunque su análisis, fundamentación y aún su descripción nos resulte difícil.

Al estudiar los modelos del dibujo en la historia consideramos los puntos reflexivos que hasta aquí hemos vertido en este capítulo. Esto quiere decir que veremos en ellos la relación del dibujante con sus modelos objetuales u ontológicos, fenómenos, naturaleza y contexto. Pero igual nos referiremos a las formas del pensamiento interiorizadas en la ac- 
ción de dibujar. Estrategia, significación, técnica, historia, relacionalidad y formalizaciones representacionales son el contenido de nuestro trazo histórico.

\section{III-6-1 EL MODELO RENACENTISTA}

Tomando como base el texto de Erwin Panofsky Renacimiento y Renacimientos en el Arte Occidenta ${ }^{96}$ el movimiento renacentista es un fenómeno cultural que se genera en el pensamiento filosófico del siglo XIV, se extiende a la literatura hasta permear las artes visuales y la arquitectura.

Por causas que se ubican en una doble vertiente, el pensamiento clásico grecolatino vivió hasta ese momento un corte como base de la constitución cultural.

No es el interés de este estudio involucrarnos en este orden de motivos. Panofsky se centra en la intolerancia iconoclasta de la iglesia y en la destrucción generada por las invasiones bárbaras hacia la península itálica como el origen de ese corte cultural.

En el trabajo de Panofsky se expone como el propio Lorenzo Ghiberti (Florencia, 13781455) atribuye la decadencia de la pintura y la escultura a la ruptura de la tradición clásica, no por un acto de dios, sino debido a la voluntad humana, pensaba que esa ruptura podía ser enmendada, mediante una deliberada vuelta al pensamiento de la antigüedad.

Sabemos que una formulación conceptual generalmente tiene un origen secuenciado y que no se debe a la originalidad de un solo autor, pero en el tratado de Alberti se menciona con claridad las categorías de Circonscriptione (Circunscripción) y Compositione (Composición) que mas tarde para el 1500 serán enlazadas en la de Disegno (Diseño) Menciona también la recepción lumínica que después llevará a la formulación colorista al margen del dibujo.

Pero quizá una de las partes esenciales de su pensamiento sea la introducción del principio de Armonía, diciendo que el pintor debe ante todo procurar que las partes concuerden entre sí; y lo harían si, en cuanto a cantidad, función, clase, color y en todos los demás aspectos armonizan en una belleza común.

Esta búsqueda de la armonía se asentaría como pilar de la pintura y el dibujo desde entonces y tardaría más de trescientos años en ser cuestionada. Leonardo y Durero entre tantos más se acogieron a esta meta. Con esta postura se opuso el dibujante al postulado de una norma verosímil simple y sobreentendida, enfrentándole el criterio de unidad estética y racionalidad matemática, implicada en la base numérica de proporción como gradación de la relación entre las partes. La observación del color local de las cosas era un hecho simple, pero la formulación de un sistema armónico entre las partes y el todo del cuerpo humano (Alberto Durero) sin combinar la experiencia empírica con la investigación arqueológica y la cuantificación matemática, no sólo en el sentido aritmético, sino en la formulación de series discontinuas de progresión constante, era un proceso de formalización que sólo podía ser resuelto por el pensamiento racional. En este momento se inicia la contradicción entre la concepción platónica del dibujo y el pensamiento aristotélico sustentando la visión cromática de la pintura, y en todas las fuentes del siglo XV veremos como la función de la pintura pasa de una mera imitación de lo real al campo de

96 Panofsky Erwin. Renacimiento y Renacimientos en el arte occidental. Madrid: Ed. Alianza Editorial; 2006. P. 338. 
la representación asistida por la organización racional mediante las proporciones justas, cuyo secreto se encontraba en las perdidas razones métricas del arte antiguo.

Parece ser que Giorgio Vasari en su libro sobre biografías de arquitectos, pintores y escultores, publicado en 1550, es el primero en afirmar la unidad de las tres nobles artes, pintura, arquitectura y escultura sobre la operación mental del Diseño, que no era otro sino el dibujo en su concepción integradora del proyecto artístico y generador de las gestiones formales de la imagen, así como el estudio de las cosas mundanas mediante la razón proporcional. Vasari las integra en un solo volumen, contrario a lo que sucedía anteriormente, cuando encontramos tratados separados para cada uno de estos cuerpos de las artes.

Visto por Vasari ya en 1500 el renacimiento era un fenómeno cultural general, pero en el terreno de las artes que nos ocupan el veía una evolución dividida en tres segmentos. La primera etapa fue abierta por Juan de Cimabué 1240-1302 y Giotto di Bondone 12661337, la segunda etapa corresponde al periodo de Masaccio 1401-1428 y la tercera inició con Leonardo da Vinci y culminó con Miguel Ángel Buonarroti 1475-1564.

La segmentación que realiza Vasari puede ser criticada en términos de que hace a un lado personalidades importantes en el terreno de la pintura y específicamente el dibujo, pero pensamos que no es así. El criterio de organización de esta triada se corresponde con los cambios profundos que caracterizan las estructuras formales del dibujo y la pintura, si bien el periodo renacentista está poblado de personalidades fuertes que aportan valores formales importantes en el área.

El primer momento se inició al romper los preceptos medievales de representación en la imagen, esto se consiguió mediante el trabajo de enriquecimiento lineal y cromático en la pintura de Cimabué y Giotto (como se dijera en el 1500, ellos dieron inicio a la primera edad y la primera lección de pintura fue la lineal, nosotros hacemos notar la interdependencia de la pintura hacia el dibujo, en el sentido de asociar como parte del sistema de formalización a la línea, que ciento cincuenta años después fundamentaría la separación de esos campos. Al inicio del siglo XV la arquitectura desempeñó un papel motor esencial en el proceso y fue quien más asiduamente buscó la consanguinidad con el arte clásico, si bien la escultura corrió por un camino similar. El Renacimiento desde el 1500 integra la pintura, la escultura y la arquitectura bajo un entendimiento común, deja de lado la prelación de cualquiera como dominante en el terreno del lenguaje y se les entiende como campos que se tienen que ejercer al ritmo del desarrollo de un pensamiento general que las dota de una raíz filosófica común. El debate entre un arte basado en el análisis de la naturaleza y otro basado en el pasado clásico fue superado, o más bien integrado en una suma de métrica basada en la razón proporcional y experimentación que analiza los fenómenos y sujetos naturales para encontrar su estructura y razón fenoménica.

Nuevamente, Leonardo y Miguel Ángel en su obra y pensamiento muestran directamente esta conclusión. Fig.28

"Obró en esto Zeuxis como sabio; porque cuando los pintores no ponen a la vista lo que quieren imitar, sino que quieren hallar la belleza en solo su imaginación, y adquirir fama de este modo, no solo no la adquieren con semejante trabajo, sino que se acos- 

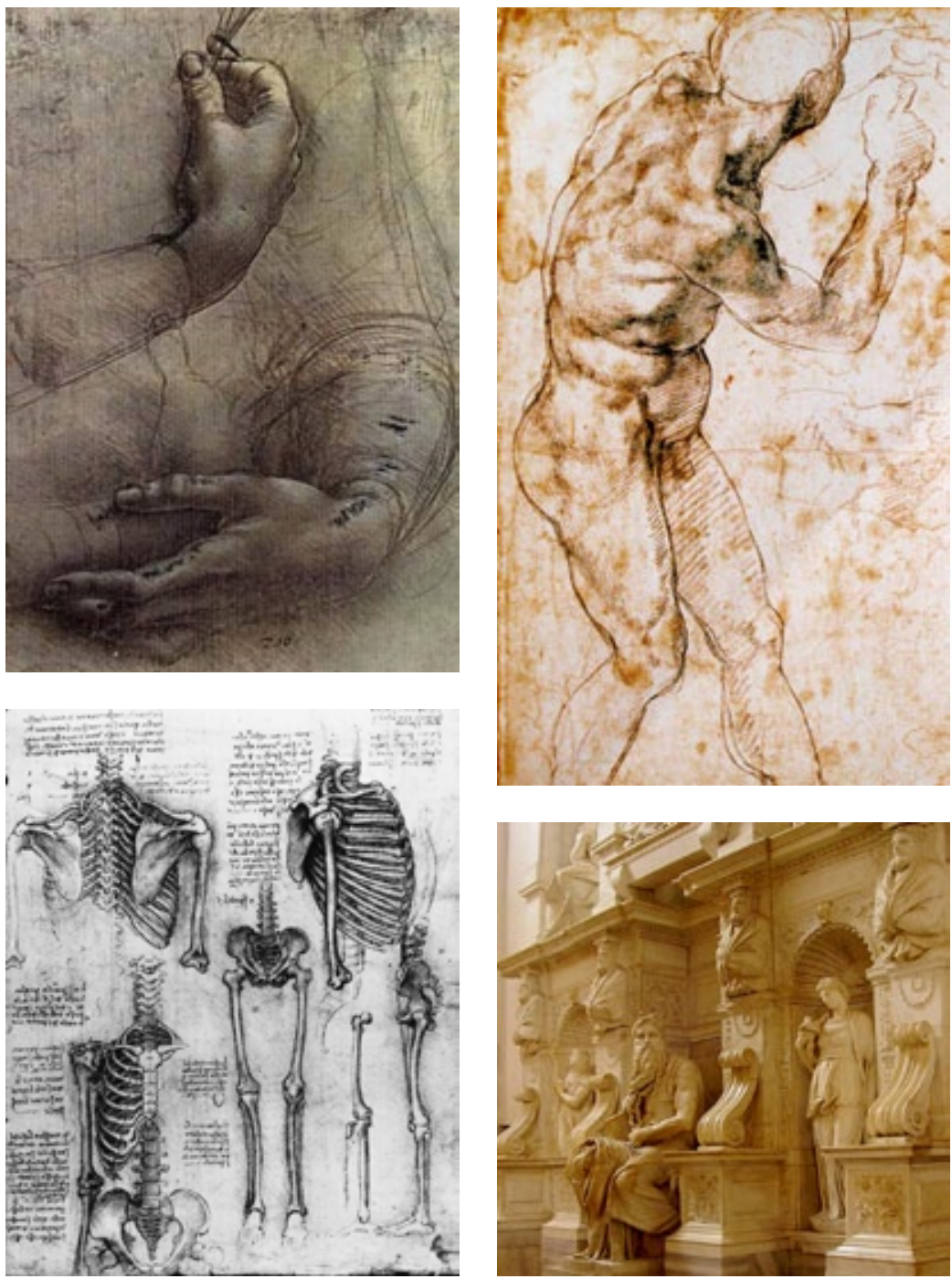

Fig. 28. Leonardo da Vinci, Miguel Ángel Buonarroti.

tumbran a una pésima manera de pintar, que después no la pueden dejar aún a costa de los mayores esfuerzos. Pero el que se acostumbre a hacerlo todo por el natural tendrá la mano tan hecha a lo bueno que todo lo que ejecute parecerá natural, que es lo único que se anhela en la pintura." ${ }^{\text {97 }}$

La representación y configuración dibujística del cuattrocento italiano se fundó sobre una base doble, como todo el fenómeno que llamamos renacimiento, una, la del pensamiento científico racional, la segunda, la recuperación del pensamiento clásico griego y romano.

97 Battista Alberti León. Tratado de pintura. México: Universidad Autónoma Metropolitana; 1998. (Coleccción Ensayos). P. 122. 
Su revolución humanista se planteó la recuperación del pasado histórico cultural, y la cercanía con la naturaleza como fuente de conocimiento verdadero.

Aquí se inicia el proceso de inclusión de la pintura la escultura y la arquitectura dentro de las artes liberales, artes del pensamiento. Proceso prolongado en el que el dibujo tendría un papel fundamental por ser disciplina reflexiva proyectual.

El desprendimiento del pintor y dibujante del gremio artesanal, fue posible por el carácter científico que tomó la pintura. Esto requirió para su realización de la integración con las matemáticas y la filosofía natural, como ellos mismos decían.

Los desarrollos matemáticos del tratado de perspectiva de Piero Della Francesca tienen un rigor científico, expresan una pasión por el criterio mesurable del espacio y el comportamiento de los cuerpos degradados en su dimensión, las referencias y citas con que contamos lo muestran como un trabajo rigurosísimo que ejemplifica la práctica artística en esos años.

El tratado de la Pintura de Piero (1416-1492) integra procedimientos de comprobación y falsación para las construcciones geométricas y perspectivas de la imagen, esta será una característica que tipifica el proceder metodológico de la pintura y el dibujo, Condición nueva en su rigurosidad y que separa el pensamiento y texto de Piero de los manuales técnicos de la época en los que el orden discursivo se orienta hacia el compendio de la experiencia del maestro en la práctica de taller como suma cognitiva empírica.

La definición de dibujo que aporta Piero es exactamente coincidente con las de Alberti y Leonardo, es entendido como el contorno que circunscribe la imagen del modelo, la línea como entidad abstracta, geométrica y no natural que determina la definición de la forma. Esta reflexión permite el acercamiento del dibujo al orden racional geométrico, la circunscripción lineal de los modelos les atribuye la posibilidad de cuantificar sus características somáticas, hasta afinarse en la construcción de los cánones de proporción.

La circunscripción de los modelos permite atribuirles una extensión de área, este será el plano general de la figura que posibilita su descomposición en múltiples subdivisiones. Los planos divididos constituyen la secuencia del relieve de una superficie, así, a la circunscripción de la forma se agrega una construcción topológica, cuya modulación mediante valores de gris desembocan en el modelado, relieve de la superficie del cuerpo y espacio.

Geometría, color y dibujo fueron las tres partes constantes de la pintura en los tratados de la época.

El dibujo es planteado como pensamiento y práctica paradigmática en la integración de la pintura, la escultura y la arquitectura.

La diferencia sustancial en los textos anteriores al 1400 y los renacentistas se aprecia en que los primeros tienen un carácter típicamente artesanal y de transmisión del oficio, las recetas y la experiencia aplicada del maestro como complemento del oficio tienen un valor significativo en ellos. Los textos clásicos de Piero y Alberti inauguran la era de los tratados, libros de disertación teórica, científica y experimental. Muchas de las teorías explicadas en ellos contienen sus prácticas de demostración o falsación como ya lo mencionamos.

Las matemáticas y la geometría como ciencias mesurables se utilizan para construir un método de representación coincidente con el orden visual que se tenía de la naturaleza. 
La perspectiva piramidal reprodujo el mecanismo proyectual de la visión humana, basada en el conocimiento de la física que se tenía en ese entonces, entre otros factores con ello logró el objetivo de dar carácter científico a la pintura.

La medida aplicada a las proporciones del cuerpo humano tuvo particular importancia, los estudios de Leonardo son significativos, pero el trabajo de Alberto Durero es total. La medida cuantificada justificó la importancia del número, expresado en razones de métrica compositiva derivadas del estudio del modelo humano. De ahí deviene la búsqueda de la armonía en tanto exista un ajuste con la norma.

El dibujo como eje constructor del pensamiento proyectual estaba al centro de las artes, además, su capacidad de permitir el acercamiento reflexivo a los experimentos realizados, le confirió una función nueva, la de estudiar y analizar las razones estructurales de la naturaleza.

El carácter formal del dibujo en el Renacimiento fue fundamentalmente lineal, el dibujo se entendió como la circunscripción del perímetro de los cuerpos, pensamiento fuertemente hermanado con la geometría.

El pensamiento de Alberti es claro en esta postura, veamos.

"Primero, al ver un objeto decimos que este ocupa un lugar en el espacio. Aquí el pintor, al describir ese espacio, dirá que la delimitación de un trazo con una línea, es una circunscripción. Luego, al volver a verlo, comprendemos que están unidos entre sí más planos del cuerpo observado, y aquí el pintor, al colocarlos en sus lugares, dirá que está realizando una composición. Finalmente, podemos definir con mayor claridad los colores y las clases de los planos. En vista de que todas las diferencias que existen entre ellos provienen de la luz, podemos llamar correctamente su representación como la recepción de la luz." ${ }^{88}$

En cuanto a la composición, que está fuertemente unida al dibujo nos dice lo siguiente.

"La composición es aquella regla de la pintura por medio de la cual los objetos observados encajan entre sí en la pintura. La obra más importante del pintor no es un coloso [o una pintura colosal], sino una historia [el tema]. La historia le da mayor reconocimiento al pensamiento que cualquier pintura colosal. Los cuerpos forman parte de la historia, los miembros forman parte de los cuerpos, y los planos son parte de los miembros. Por lo tanto las partes principales de la pintura son los planos." 99

Y el último componente del dibujo sería el del relieve, para tener un panorama general de las partes consideradas fundamentales en este sistema de pensamiento.

"En mi opinión a nadie se le puede dar el título ni aún de mediano pintor que no sepa a fondo la fuerza que tiene en todas las superficies cada luz y cada sombra. Siempre

98 Battista Alberti León. Tratado de pintura. México: Universidad Autónoma Metropolitana; 1998. (Coleccción Ensayos). P. 85.

99 Battista Alberti León. Tratado de pintura. México: Universidad Autónoma Metropolitana; 1998. (Coleccción Ensayos). P. 93. 
alabaré aquella cabeza que agradando así a inteligentes como a ignorantes tenga tal relieve que parezca que sale del cuadro; y al contrario para mí ningún mérito tendrá aquella en que sólo se conozca el arte en el contorno."100

Así tenemos los elementos centrales del pensamiento dibujístico; primero la importancia de la delimitación lineal contorneada de las figuras, esto permitirá su manejo certero en el espacio geométrico matemático. Será también la base del ejercicio compositivo y del entendimiento de los planos internos o de modelado y construcción de cada cuerpo, al final el manejo del modelado sirviéndose del claroscuro tendrá como consecuencia un dibujo que emula las relaciones visuales que observamos en la naturaleza.

Alberti pone especial atención a la manera de dibujar una grisalla, este será un concepto que unirá a la pintura y el dibujo cuando menos hasta fines del barroco.

La pintura modelada e iluminada por el dibujo y el claroscuro, será una de las revoluciones en el campo de las formas de representación del dibujo.

Se señala a Ghiberti como un coleccionista y admirador de la escultura clásica. Se dice que invitaba a sus colegas a inspirarse tanto en la naturaleza como en lo que subsistía del arte clásico.

Con esta referencia correspondiente al periodo de inicio del renacimiento tenemos clara ya la doble vertiente que animaría la base paradigmática de las tres nobles artes de ese entonces. Por un lado el estudio del arte clásico grecolatino y por el otro el estudio de la naturaleza mediante el pensamiento racional. El mensaje de Ghiberti se transformó en la doctrina sustancial y se prolongó en sus sucesores. León Battista Alberti en su tratado de la pintura (1435) aconseja al pintor el acercamiento con los intelectuales humanistas para tener una amplitud temática en el terreno profano.

Centrándonos en el terreno de la pintura y el dibujo, existe una postura analítica generalizada, misma que marca una línea de ascendencia y transmisión formal casi totalmente ininterrumpida entre el trabajo de Juan de Cimabué 1240-1302, Giotto di Bondone 12661337, Masaccio 1401-1428. Coincidimos en esta genealogía de la forma del dibujo, vemos en el trabajo de Sandro Botticelli un caso que redondea la siguiente etapa evolutiva en el sistema formal del dibujo.

Nos referimos al trabajo de estos pintores a manera de antecedentes de formalización en el dibujo, colocaremos después unas imágenes en las que se observa esta ruta de cambio progresivo, para centrarnos después en el trabajo propiamente del renacimiento.

Cimabue fue pionero en una tendencia al naturalismo, pues su dibujo introduce particularidades dramáticas y fisionómicas que rebasan la rigidez anterior. Si bien la distancia por lograr un naturalismo es aún mayor, precisamente aquí se inicia el camino de este análisis. Se sabe poco de Cimabué en cuanto a su vida y su actividad como pintor, más allá de las obras con que se cuenta. Incluimos aquí tres imágenes de sus trabajos, un crucifijo en el

100 Freixa Mireia, Garriga Joaquim, Yarza Joaquín, editores. Fuentes y documentos para la historia del Arte. Renacimiento en Europa. Barcelona: Ed. Gustavo Gili; 1983. (IV). P. 44. 
que se muestra el carácter plenamente bizantino, pero en la segunda imagen que es un detalle, se observa la pureza lineal que le es típica, así como la particularidad en el gesto del rostro, el modelado de la estructura anatómica se corresponde con masas volumétricas que permanecen aún separadas y no observan una correspondencia con la proporción y estructura mecánica muscular. Si bien las partes del torso están modeladas no se puede hablar de una secuencia de planos que establezcan un relieve, la figura contiene pocas secuencias de giro radicales, claro que tiene una estructura dinámica y espacial, es evidente, pero esta se resuelve mediante la sobreposición de las partes del cuerpo, no por la secuencia de planos diagonales que penetren el espacio y generen la ilusión de profundidad en el plano pictórico.

Aunque estamos en presencia de una linealidad dibujística y una limpieza de planos cromáticos, no podemos decir que esta línea sea aquella que muy poco más tarde construirá el escorzo, generando la perspectiva del cuerpo humano.

En la imagen de la Virgen María con el Niño se cumplen estas mismas características, a ellas se agrega el tratamiento compositivo del grupo de figuras. Este conjunto se rige por una subordinación proporcional basada en el criterio de grado y jerarquía, en el sentido del significado religioso, aunque su distribución se realice sobre una traza geométrica evidente, no se arma la escena por el orden de un criterio espacial compositivo propio de la ingeniería interna de la pintura. Fig. 29

Giotto fue discípulo de Cimabue, es maravilloso observar la continuidad formal que se establece entre la obra de estos dos autores y la manera en que Giotto tensa al extremo las estructuras del dibujo que se observan de manera inicial en el trabajo de Cimabue.

A Giotto se le considera como el último gran pintor de la tradición bizantina. El arte de ese periodo se caracterizó por regirse en el terreno del dibujo con base en cartillas que
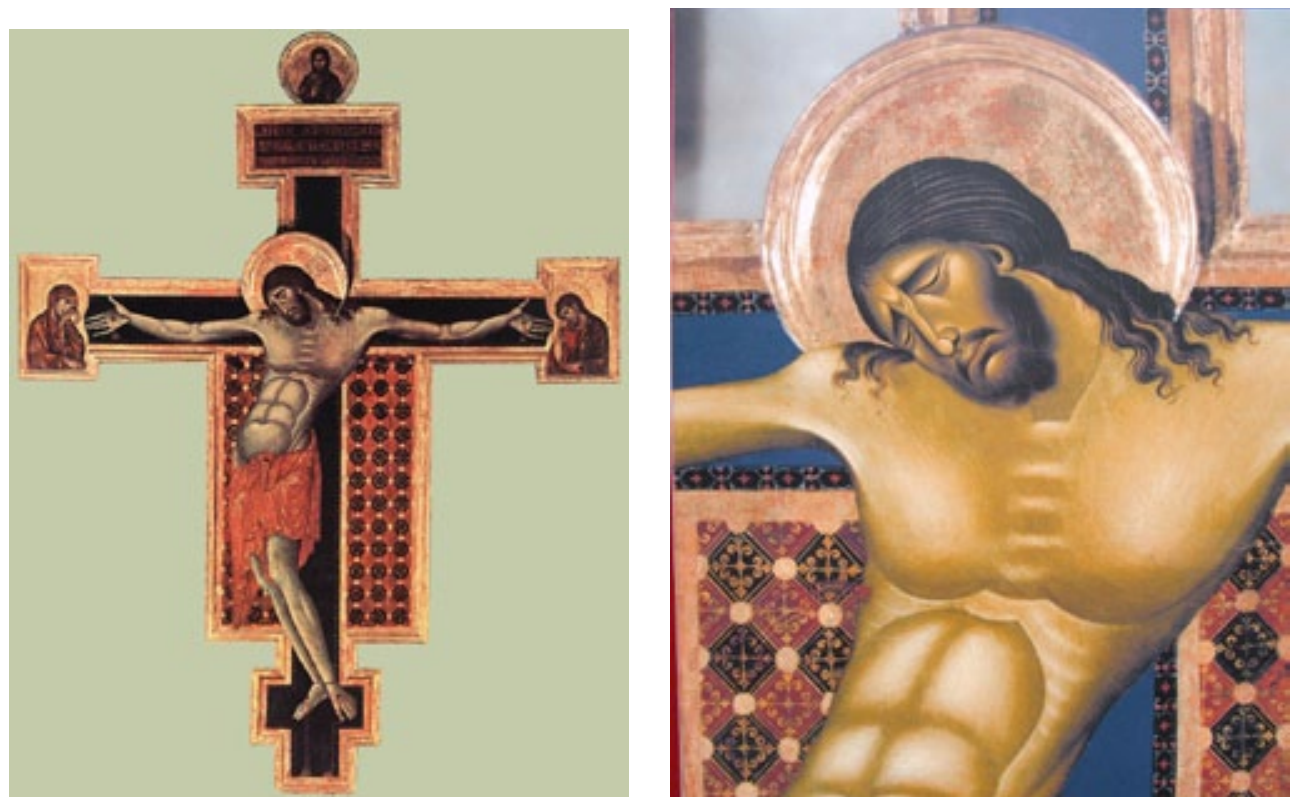

Fig. 29. Cimabue. Crucifijo y Madonna. 


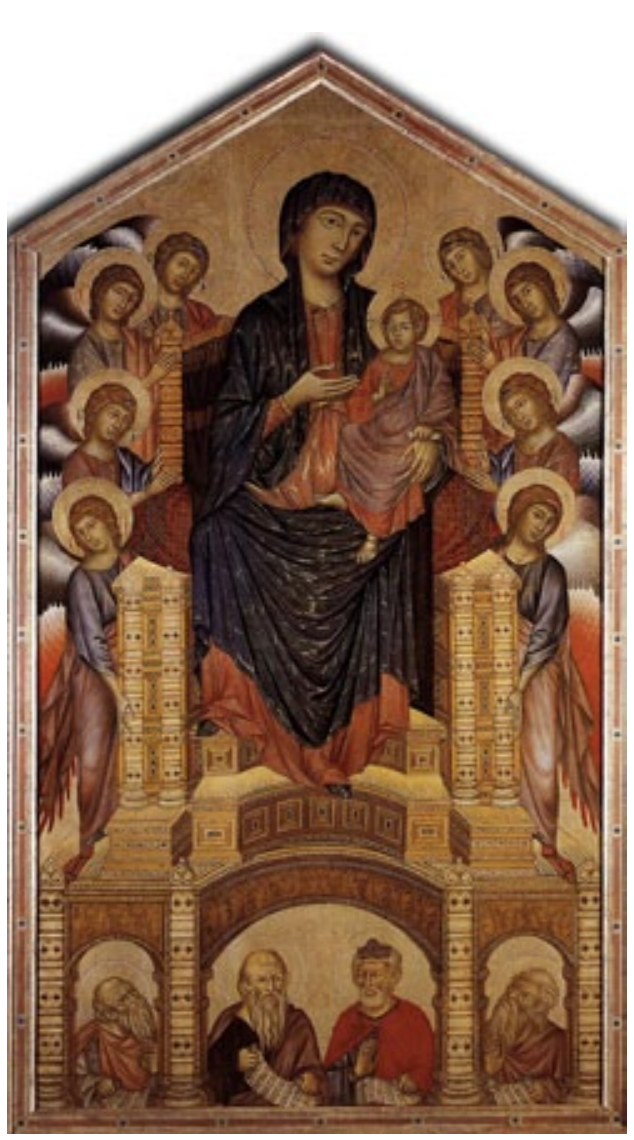

Fig. 29. Cimabue. Crucifijo y Madonna. (Cont.) contienen los conceptos establecidos para la forma de los modelos, escenas y formas que hoy nos parecen bastante planas y muy estilizadas. Al observar este tipo de figuras es evidente como no están construidas por medio de un análisis métrico de la proporción ni de la observación precisa de la estructura ósea y mielítica del cuerpo.

La concepción formal de Giotto, en el terreno de la pintura y el dibujo resultó extremadamente innovadora y es el precursor ya directo de la evolución que poco después llevaría al dibujo renacentista. Sus obras fueron el punto de inflexión entre el arte bizantino del fin de la Edad Media y el racional y naturalista que floreció en el Renacimiento.

Así la planitud y el simbolismo del arte Bizantino fue dando lugar al relieve y modelado en el dibujo. Sabemos que la perspectiva y la intelectualización racional del color fueron procesos que se sucedieron integrados consustancialmente al proceso del dibujo, aunque nos dirigimos especialmente hacia este último. Giotto adoptó el lenguaje visual de la escultura en cierto sentido al darles volumen y peso a los cuerpos pintados. Esta será una relación importante en la formalización sistémica del dibujo con las estructuras de otros campos artísticos.

Al igual que los demás artistas de su tiempo, Giotto carecía de los conocimientos experimentales de anatomía y una teoría de la perspectiva matemática que los pintores posteriores construyeron.

Giotto es el gran iniciador del espacio tridimensional en la pintura europea, basado tanto en la comprensión geométrica de la obra como en los recursos del dibujo y el color. En ese punto radica en gran medida el mérito que deseamos destacar. Su capacidad para lograr formalizar un pensamiento diferenciado en el terreno interior de las estructuras del dibujo. Sus obras primeras, muchas de ellas crucifijos, conservan una rigidez, el drapeado de las telas es marcado por hilos de oro, pero luego se desmarca de estos modelos, realiza un tratamiento más sutil, más suave, especialmente en las carnaciones; sustituye los hilos de oro en las telas por drapeados con pliegues profundos; utiliza un cromatismo mucho más delicado.

Lo anterior parece una consideración simple, pero tomemos en cuenta, por si fuera poco, que este proceso tuvo lugar en un espacio de treinta y cinco años aproximadamente. Nuevamente introducimos unas imágenes que muestran las cualidades que mencionamos. Fig. 30 

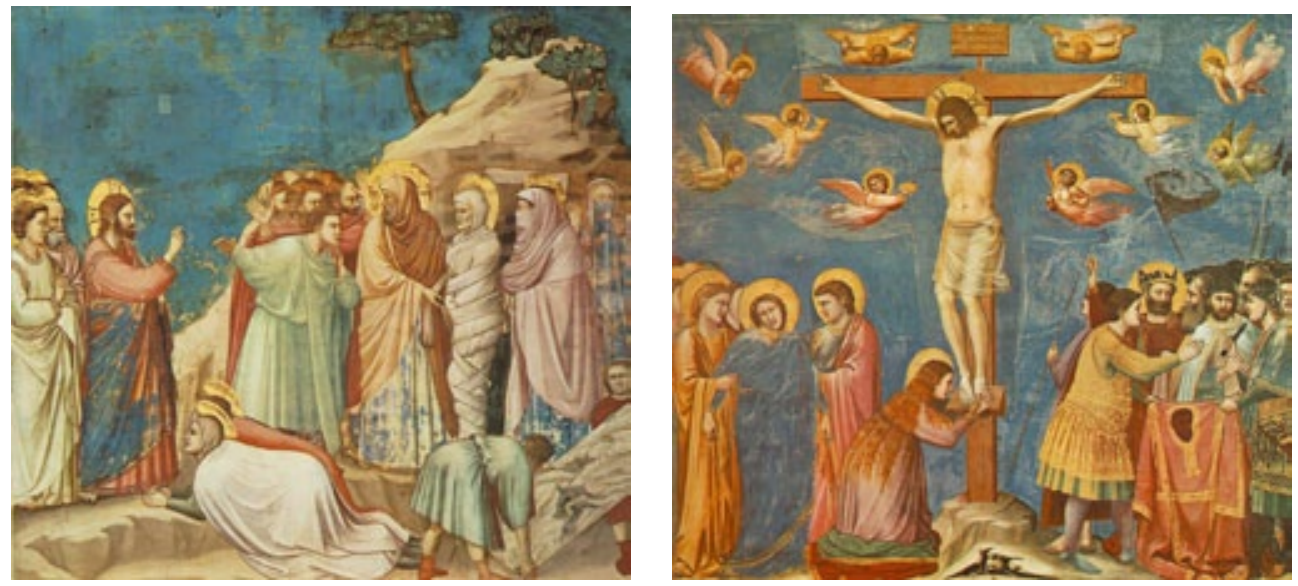

Fig. 30. Giotto. Frescos de la Capilla Scrovegni.

Estos frescos corresponden a las escenas de la vida de Cristo, se encuentran en la Capilla Scrovegni.

El ángulo inferior izquierdo en la pintura que trata la resurrección de Lázaro está modelado y resuelto sin recurrir a la demarcación lineal de contorno, el espacio y relieve se logran a partir de la altura tonal del color. Ambas pinturas son ricas en la construcción del relieve utilizando medios tonos de color, las profundidades en los pliegues prescinden también cada vez más del recurso contorneado.

Incluimos en este momento unos ejemplos del trabajo de Fray Angélico 1390-1455, esto con la finalidad de cerrar la secuencia progresiva que nos muestra el encadenamiento formal que habrá de madurar ya como renacimiento pleno. Fig. 31
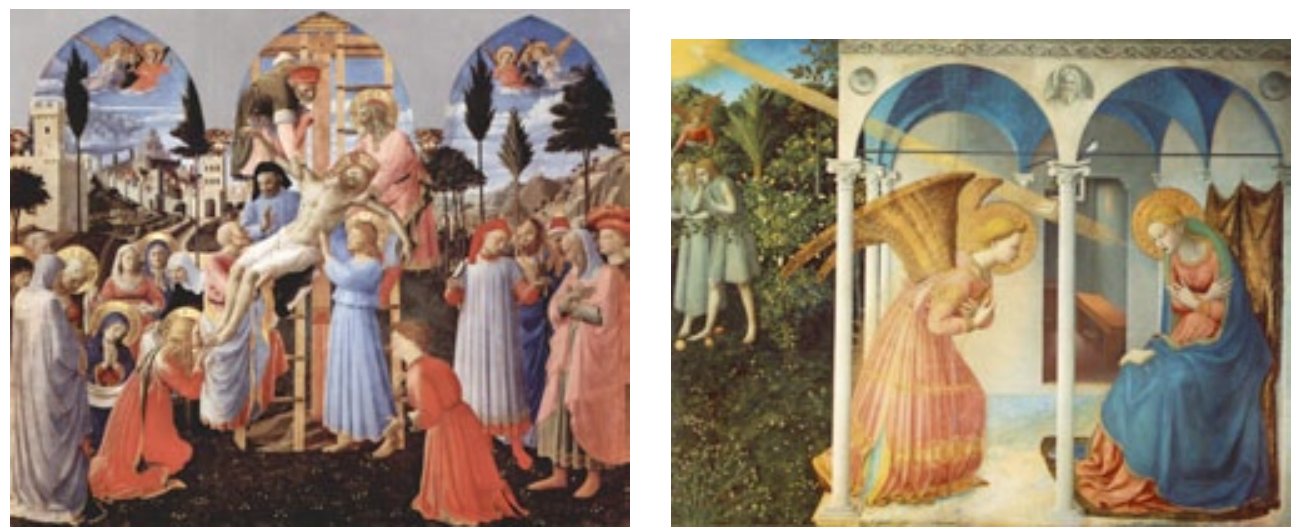

Fig. 31. Fray Angélico. Descendimiento y Anunciación.

Una vida casi sincrónica con la de Fray Angélico es la de Masaccio 1401-1428 este representa la irrupción de la expresión renacentista, los propios tratados del XV y XVI lo mencionan como el primero que realizó medias tintas con claridad, el primero en aplicar el escorzo en la figura y realizar construcciones anatómicas naturalistas. 

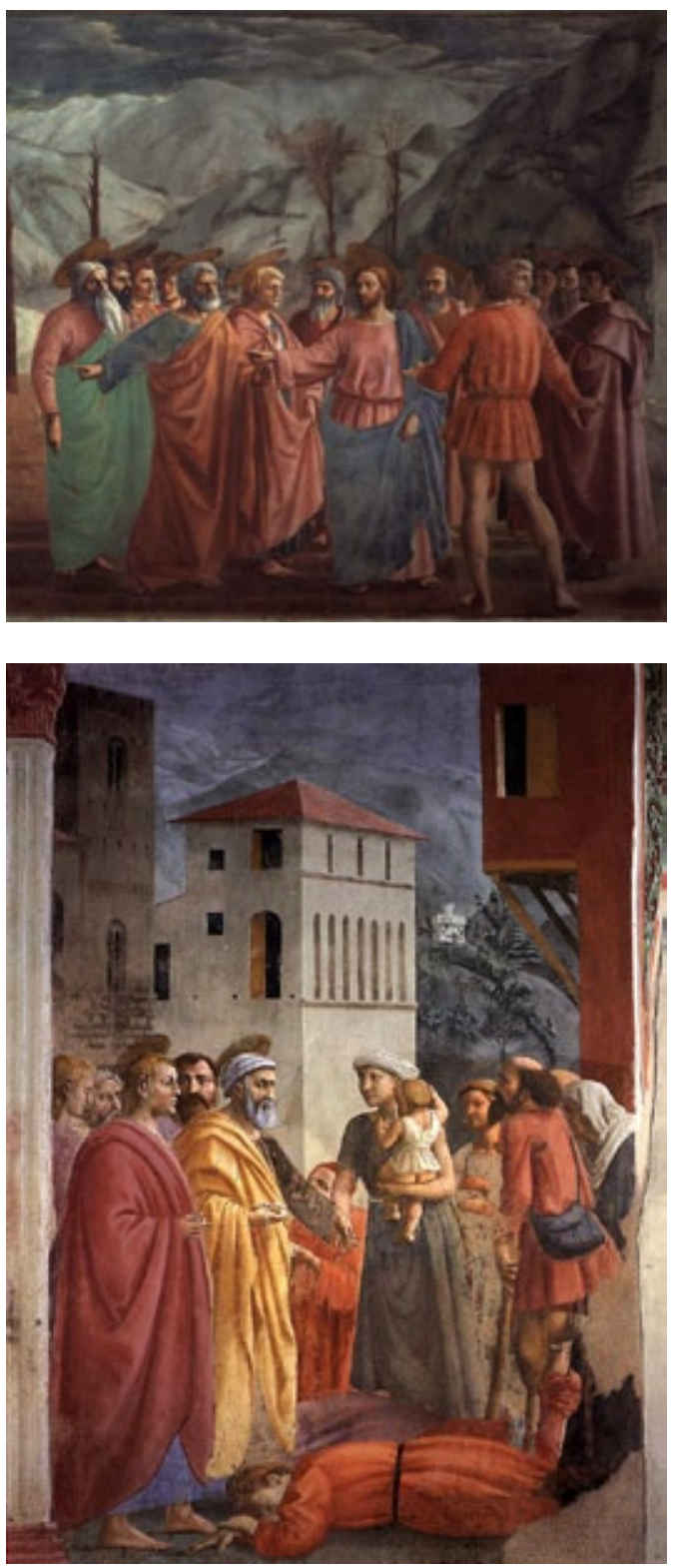

Fig. 32. Masaccio. Frescos, escenas de la vida de Cristo.
Ya de por si en el trabajo de artistas como Fray Angélico se muestra la consistencia de la forma renacentista, pero no podemos sino pensar en la corta carrera de Masaccio y la labor que deja interrumpida. Veamos algunas reproducciones de sus pinturas para realizar algunas reflexiones. Fig. 32

Sobre estas obras y su autor se ha dicho todo y más, resulta evidente la maduración de una nueva concepción de la forma, una cuyos paradigmas permean el arte visual incluso hasta nuestros días, una forma de representación visual que modificó la gestalt de la mente y el ojo humano, el arte de nuestros días se muestra deseoso de marcar una distancia con esta forma de representación, quizá en ese acto perdemos más de lo que ganamos, cuando menos en el terreno del dibujo.

Pero de todo lo dicho sobre Masaccio lo que nos interesa centralmente es destacar la maduración conciente y racional de una concepción artística. No nos dedicaremos a comentar de estas obras su secuencia técnica evolutiva, cuando menos no solo eso, que ya es muchísimo. Vemos en la obra de Masaccio una manera del pensamiento pictórico, una que genera sus propias formas de conceptualización y categorías dibujísticas, cristalización de un pensamiento pictórico, que no ilustración de alguna postura teorizante. El Renacimiento fue mucho de redescubrimiento del arte clásico grecorromano, pero sus autores tuvieron la capacidad de construir formas de representación con órdenes teórico

formales de primera generación, cadenas de representación con fórmulas no vistas hasta entonces. Por si fuera poco, en ese momento, alrededor del 1435 se tuvo la capacidad de explicitarlas en un discurso teórico escrito que no tenía sus bases sino en la comprobación empírica al construir la imagen. Esta aptitud para hacer de las artes un territorio del pensamiento y poderlo consignar en la letra escrita, con un rigor teórico científico fue lo que llevó a la consideración de las artes como un ejercicio noble, y al artista como parte del sector intelectual de la cultura, todo esto más allá de mitificaciones pseudo románticas 


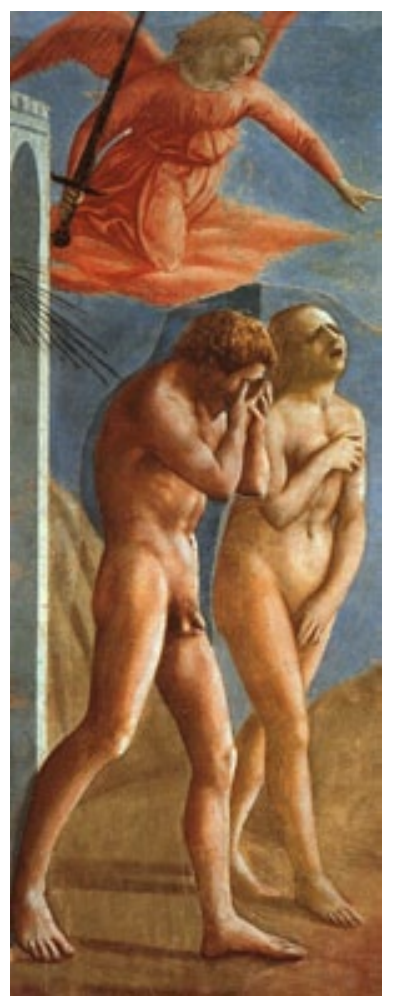

Fig. 32. (cont.)

que ven en los artistas de esa época portentos inexplicables. El logos del método y la razón se introducen claramente como estructura orgánica del dibujo.

Hasta este punto nos hemos centrado en el origen y antecedentes del fenómeno de la forma visual renacentista, pasemos a trabajar lo que consiste propiamente el cuerpo de sus formulaciones conceptuales.

Queremos referirnos a Sandro Botticelli, porque en su trabajo concreta lo que se puede entender como la definición Florentina del Dibujo para el tiempo del Renacimiento. Condición que se concreta tanto en el repertorio formal de representación como en la explicitación teórica de ese arsenal técnico que no es sino pensamiento fáctico.

Botticelli entró como aprendiz al taller de Fray Filippo Lippi, de 1464 a 1467 hasta alcanzar los catorce años de edad. Recibió una educación más completa que otros artistas del renacimiento. De este pintor recibe Botticelli sus mayores influencias: la síntesis entre el nuevo control de formas tridimensionales, la delicadeza expresiva en los rostros y los gestos, producto de un grado altamente refinado y conciente del ejercicio del dibujo y la técnica pictórica de los temples, teniendo al frente de si a los modelos vivos como fuente de construcción, de datos visuales y comparación reflexiva. La mecánica de formalización de los temples opera sobre el dominio del dibujo como constructor del relieve, ya adelante nos detendremos en esta relación estructural.

En menor medida, resultó influido por la monumentalidad de Masaccio. En 1467 Sandro vuelve a Florencia, frecuentando el taller de Andrea del Verrocchio, donde trabajó al lado de Leonardo da Vinci. De esta época data una serie de Madonas en las que se advierte el impacto de ese círculo artístico intelectual.

Para 1470 Botticelli establece un taller propio. Ya entonces encontramos las características típicas de su obra.

Con el trabajo de Botticelli tenemos frente a nosotros el resultado de la observación naturalista de los modelos, así no queda duda ninguna de que esos trabajos son dibujados frente al modelo en el estudio, esta experiencia se funde con la ortodoxia compositiva que basa la estructura interior de la figura, en el seguimiento riguroso de los cánones de proporción.

El Contraposto como sistema de balance para las figuras humanas, está organizado mediante el control contrastado de los ejes horizontales de movimiento articular del cuerpo humano. Esta fórmula de balance es producto de una doble observación. Se encontró que en gran parte de la estatuaria Griega este sistema permitía el desplante natural de la cadencia rítmica de las figuras verticales. También se observó que un cuerpo humano que se coloca de pie, tiende a descansar el total de su peso de forma alternada sobre una de las dos piernas, esto genera la tensión rectilínea de la pierna de soporte, a la vez que 
el elevamiento de la cresta de la cadera del mismo lado, con el consecuente descenso de los puntos opuestos del mismo eje, con esto se obliga a la horizontal de los hombros a ubicarse en una caída leve en sentido opuesto a la elevación del eje de las caderas. La distribución rítmica alternada de los ejes horizontales se realiza sobre una línea vertical imaginaria pero consistente, que se origina en la base del cráneo, en el Atlas y el Axis y toca indefectiblemente en el centro del tobillo interno de la pierna de soporte.

El rigor y purismo de estos sistemas de dibujo y composición, que no son en estricto geometría del espacio, sino en todo caso de la figura, es lo que separa el clasicismo típico del Renacimiento ya maduro, pero de una primera época; con el arte de dibujantes que radicalizan estos aparatos de representación y generan saltos de cualidad en el dibujo y todo el sistema de las formas visuales.

Tenemos entonces que el trabajo de Botticelli dentro del dibujo organiza la dinámica interna de las figuras, con base en sistemas complejos que depuran la observación de los modelos. Y retoman los cánones clásicos. Esto es lo que solemos encontrar de manera profusa como explicación de las formas en el Renacimiento, y es cierto, pero detengámonos a pensar un tanto más a fondo.

Cuando el dibujo y la composición renacentistas se basaron en el canon como estructura organizativa estaban determinando la preexistencia de una norma de razón métrica, estaban generando el nacimiento tanto de las disciplinas preicónicas (sistemas formales teóricos que existen con independencia de las obras fácticas, y que no son otra cosa sino cuerpos del lenguaje del dibujo y la pintura) y atribuyendo un valor numérico al canon (por más que este se basara y fuera producto de la observación experimental y la comprobación empírica en los modelos naturales); con la atribución cuantificada del canon, aparece la proporción, de peso, de número y de grado, el canon deja de ser una convención teológica y nace de la razón abstracta. También se establece mediante esta definición la Razón Proporcional, esto es la raíz numérica, que es la constante, entonces cada una de las figuras dibujadas serán casos y variaciones, que se atienen a la norma de proporción.

En gran parte, todo esto es el sistema de representación que define el Dibujo Florentino. Pero además esta concepción propone un purismo de contornos, Botticelli une la lección lineal iniciada por Cimabué con el naturalismo logrado mediante la observación empírica de los modelos naturales.

Pero esta demarcación florentina de los contornos no es solo intención técnica purista. Con la precisión lineal de la figuras se consigue la posibilidad de hacerlas operar en la lógica de la geometría del espacio compositivo, que compete no solo a las figuras sino a la totalidad.

Como es evidente en la temporalidad de Botticelli y específicamente en sus trabajos se depura la concepción del dibujo como constructor del Relieve, este concepto permitió a la pintura acercarse a su ideal mimético, mediante un recurso del dibujo, amén de toda la ingeniería que se fue armando.

Pero la construcción del relieve dibujístico adelantó un tanto al pensamiento escultórico, al que, hasta ese punto, tanto le debía.

Con el logro de las secuencias de relieve dibujado y la gradación del contraste entre los valores utilizados, así como con la conducción de los Pasajes (que son secuencias no radicales de transición de tono) se logró el entendimiento topológico de las superficies, una reflexión sobre la característica de la propia superficie de los cuerpos, mediante sus se- 
cuencias de planos, y no sólo el relieve como la cualidad somática de los modelos dibujados (de ahí el interés obsesivo de los pintores por estudiar los lienzos y telas, y hacerlos parte importante de la composición, más allá de decorativismos. Fig. 33

La luminosidad pictórica, la limpieza cromática y dibujística que observamos en El Nacimiento de Venus es sorprendente, en el detalle del rostro de Venus se observa aún el vestigio de la vieja concepción lineal delimitadora de los contornos, aunque estos casi desaparecen integrados a la altura tonal del plano de color. Algo que destacamos es el carácter del trazo y construcción de las cabelleras de las figuras y las ondas que figuran el oleaje en la superficie del agua, la manera en que los fustes y el follaje de los árboles es armada; las soluciones logradas muestran vestigios de un dibujo sígnico ideográfico,
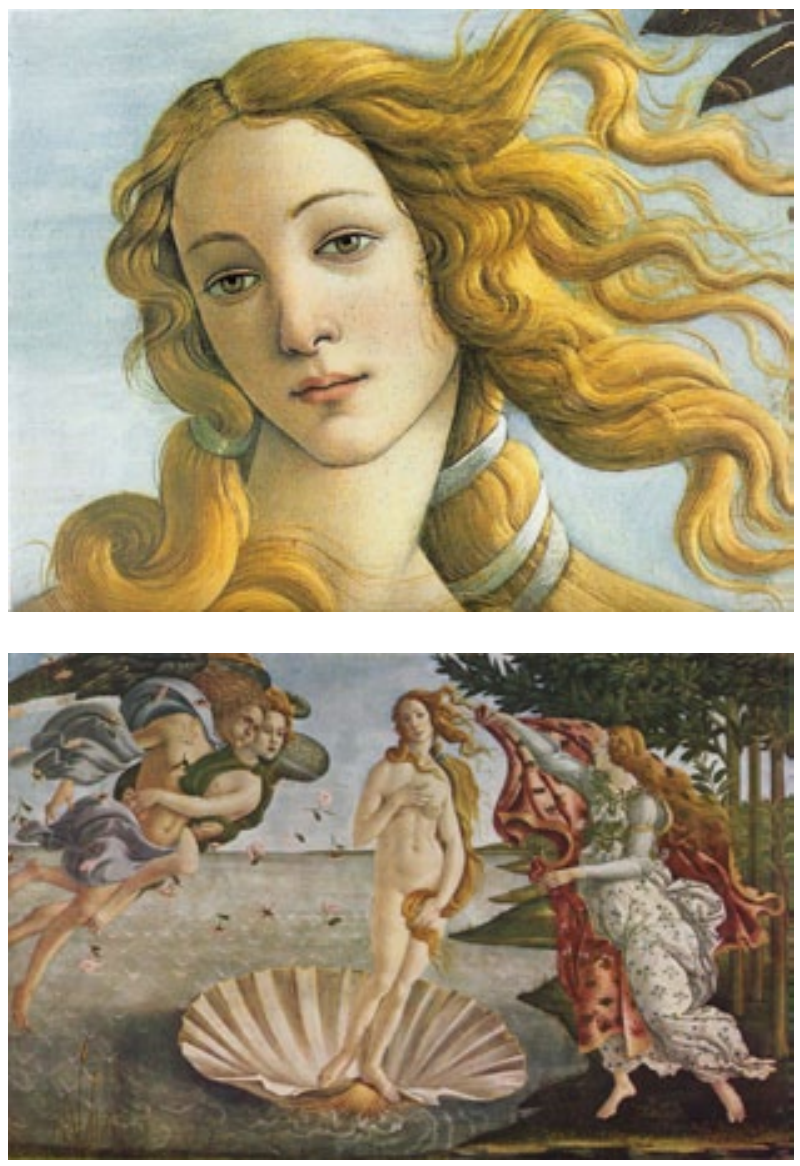
una reducción gráfico-sígnica

Fig. 33. Botticelli. "El nacimiento de Venus" Figura en "Contraposto" y detalle que se establece para designar un modelo, independientemente de su particularidad circunstancial. Digamos que es el dibujo de una sensación mediante un código gráfico y no el dibujo de una sensación mediante la construcción matérica de la sensación equivalente. Aunque podamos ponderar el naturalismo en el trabajo de Botticelli, circunstancias de esta naturaleza definen la forma de su pensamiento pictórico y dibujístico, y nos permiten establecer un comparativo con otros autores.

Los textos del Manierismo y el Barroco definen el inicio de una tercera edad de la pintura que se inicia con Leonardo da Vinci 1452-1519 y culmina con Miguel Ángel Buonarroti 1475-1564.

Pero el resumen de todo este aparato teórico no solo se expresa en razones conceptuales como estructura de la pintura y el dibujo. Mediante estas se logró otra realidad de plenitud sensible, que impacto en lo profundo de la psique y el imaginario colectivo.

La exacerbación de la técnica se convirtió en generadora de experiencias estéticas, para dimensionar estas apreciaciones recordemos nuestra propia experiencia al enfrentar directamente esas obras. En ese momento cobran la autoridad que su dimensión magistral les confiere, y se comprende como el pensar se encuentra en íntima relación con el mundo sensible. Fig. 34 

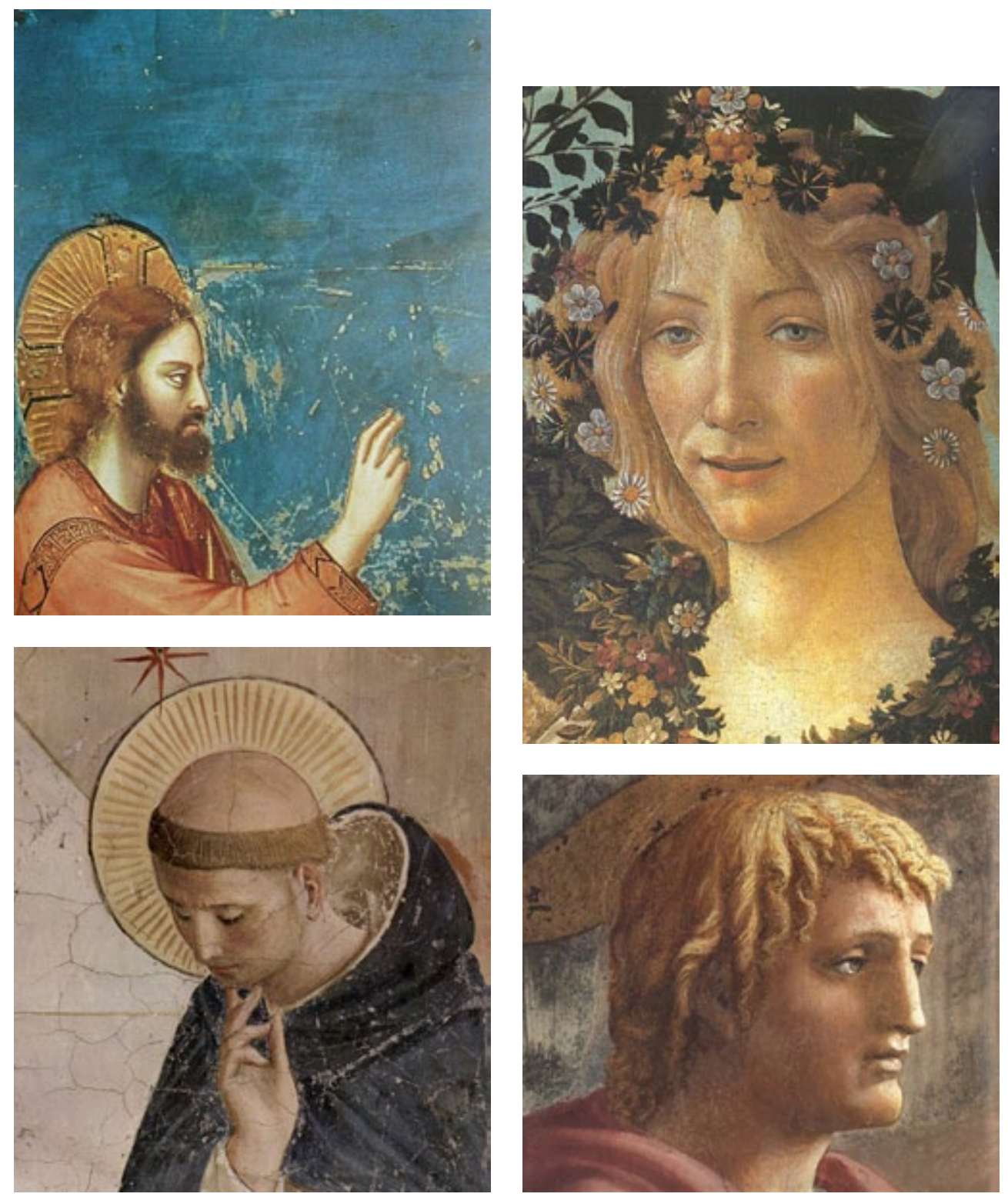

Fig. 34. Evolución del concepto de Dibujo renacentista, de Cimabué a Leonardo.

Leonardo siempre se manifestó por asumir la experiencia como madre de todos los conocimientos, basada en una búsqueda concreta de los sentidos sobre los aspectos ocultos y las facetas más variadas de la realidad y la naturaleza, entendió a esta como un sistema global dinámico de fenómenos y fuerzas, perceptibles y susceptibles de ser investigadas por parte del hombre; mediante sus sentidos organizados y dirigidos por la mente, como motor del sistema.

Este es el fundamento sobre el que Leonardo basó la relación entre arte y ciencia, que será también una relación entre mente y sentidos con la experiencia empírica en la rea- 

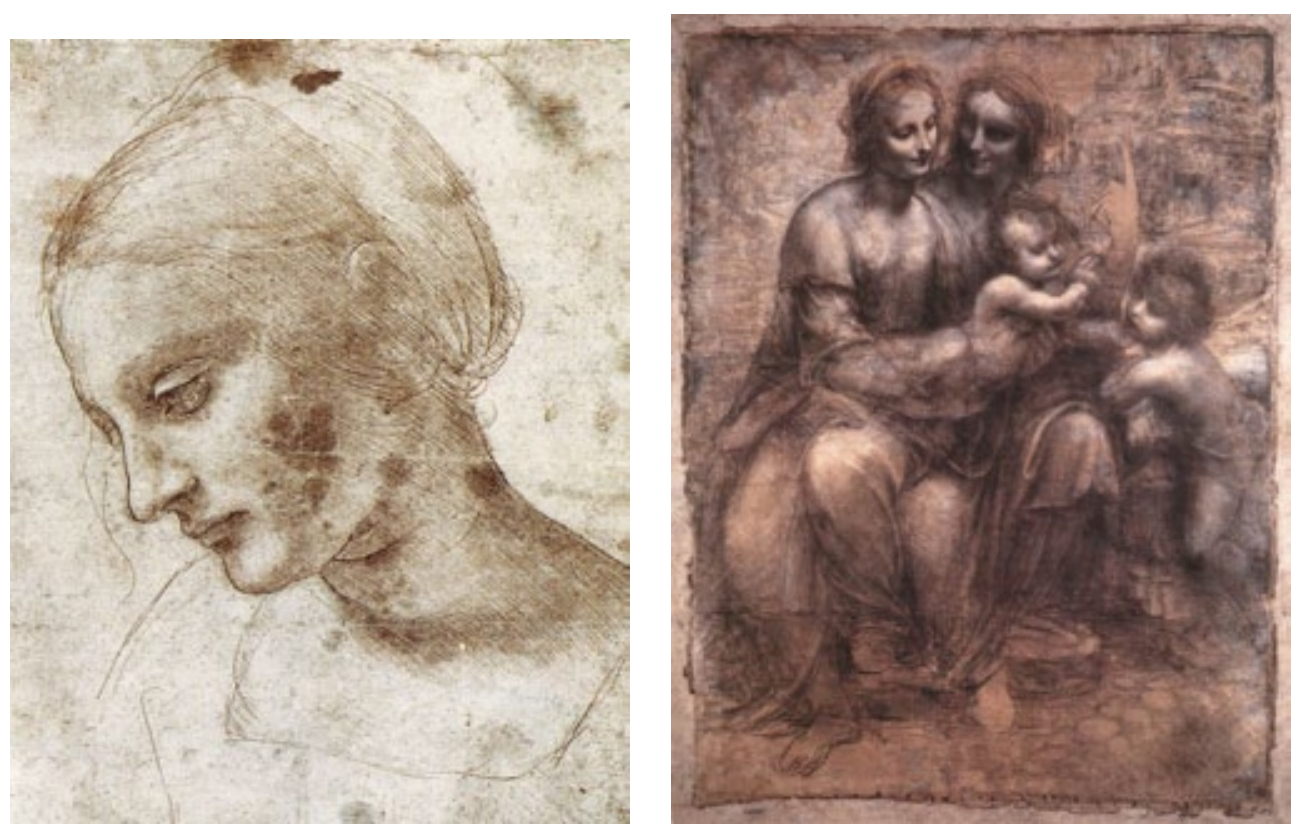

Fig. 34. Evolución del concepto de Dibujo renacentista, de Cimabué a Leonardo. (Cont.)

lidad natural, una conexión cognitiva que es posible mediante la analogía, operación artística de comprobación, de transcripción, de comunicación, gracias a la capacidad gráfica del dibujante.

Leonardo insiste en fundar su discurso en la experimentación, parece que era criticado por no basarse demasiado en la teoría precedente del dibujo la geometría y la pintura, puso por delante siempre el estudio del fenómeno o sujeto.

El método científico parte del paradigma de abstraer la realidad en las variables que la componen, para estudiar su comportamiento en distintas circunstancias. Se diseñan experimentos o procesos de observación en los que se lleva registro riguroso del proceso y las situaciones que se van presentando, así como su comportamiento.

Las notas de Leonardo pueden tener una doble lectura. La de un tratado que por otra parte nunca terminó ni publicó, y también la de una bitácora del proceso experimental.

En alguna ocasión a raíz de la exposición de estos dibujos en el Palacio de Bellas Artes de México el maestro Juan Acha redactó un artículo periodístico que ahora nos es difícil ubicar, en él planteaba que al mirar esos dibujos no estábamos ante la intención de crear obras de arte en el sentido estético actual de la expresión, nos invitaba a pensar esos dibujos como parte de un estudio de laboratorio en donde la imagen era un auxiliar metodológico.

El día de hoy la concepción del universo implícita en esos dibujos y la calidad formal que contienen, los hace arribar al terreno de la plenitud artística, desde su tiempo nos hablan de un pensamiento en donde el dibujo participó de la aventura experimental.

Lo interesante del comentario del maestro Acha es que nos coloca en el contexto que origina estos dibujos, y tal vez así se pueda extender el razonamiento no solo a Leonardo 
sino al artista de la época con las debidas diferencias. El plano del pergamino y el papel se convierte en lo que ya habíamos señalado, no es el espacio de la representación de una figura que terminará siendo pintada, es el espacio de la representación, pensamiento de un autor que desarma al modelo para comprenderlo. Esta postura no solo lo vincula con la investigación; estos dibujos son investigación en sí, en muchos de ellos encontramos gran cantidad de anotaciones correspondientes al análisis que se realiza, tal como nos lo enseñaron esto es parte del proceso de control en el trabajo de laboratorio, estas láminas son ciencia y arte integrados en una visión del mundo a través del dibujo.

Gómez Molina citando a Plinio nos dice.

"Los botánicos griegos comprendieron la necesidad de hacer manifestaciones visuales que confirieran inteligibilidad a sus declaraciones verbales. Y con este fin ensayaron el empleo de imágenes, pero los métodos con que contaban para ello eran tales que se encontraron absolutamente incapaces de repetir sus manifestaciones visuales de un modo completo y exacto... De ahí que finalmente los botánicos renunciaran incluso a describir sus plantas verbalmente y se contentaron con enumerar todos los nombres que conocían de cada planta, así como las dolencias humanas para las que resultaban beneficiosas." 101

Un caso similar es del Tratado de Herbolaria de Juan Vadiano en México. Este texto recopila la herbolaria tradicional del México prehispánico, pero las imágenes que contiene son de un carácter representacional tan típicamente Mesoamericano, que su identificación actual en la naturaleza ha resultado en todo un trabajo de investigación por sí mismo.

Esto nos lleva a concluir dos cosas, la primera es que; el código de representación es accesible al entendimiento del grupo humano que lo crea o lo maneja, después de eso, pierde su característica de sobreponerse a la realidad y ser leído como tal, se convierte en un misterio que hay que investigar.

La segunda es que el sistema de representación proyectual originado en el Renacimiento nos sigue siendo accesible al entendimiento, esto demuestra su continuidad en el imaginario de nuestra sociedad. Nos enseña también en qué medida el pensamiento renacentista cambió el ojo y la mente del hombre y con ello su manera de ver la realidad. Claro que este no fue un cambio logrado solo en los años del Renacimiento, sería un proceso que se proyectaría en el tiempo y se fue completando consistentemente.

La preocupación experimental de Leonardo repercutió en su formulación sobre una perspectiva atmosférica, un filtraje de la atmósfera que modifica las gradaciones tonales del color en relación a las distancias, esta circunstancia se integró con la formulación del Sfumato, las consecuencias constructivas de esta secuencia triádica serán fundamentales en la progresión del pensamiento del dibujo.

Debido a su postura como científico, Leonardo controla las etapas del trabajo, deja muy poco al azar y mantiene una postura analítica en todo el proceso, esto le permite crear estructuras formales que nos aclaran la región intelectual que las soporta. Establece una relación paralela entre el método experimental que usa para dibujar, y el pensamiento clásico idealista, en el sentido de que el patrón ejemplar es el producto de la síntesis de todos

101 Gómez Juan José, et al. Las lecciones del dibujo. Madrid España: Ed. Cátedra; 1999. P. 182. 

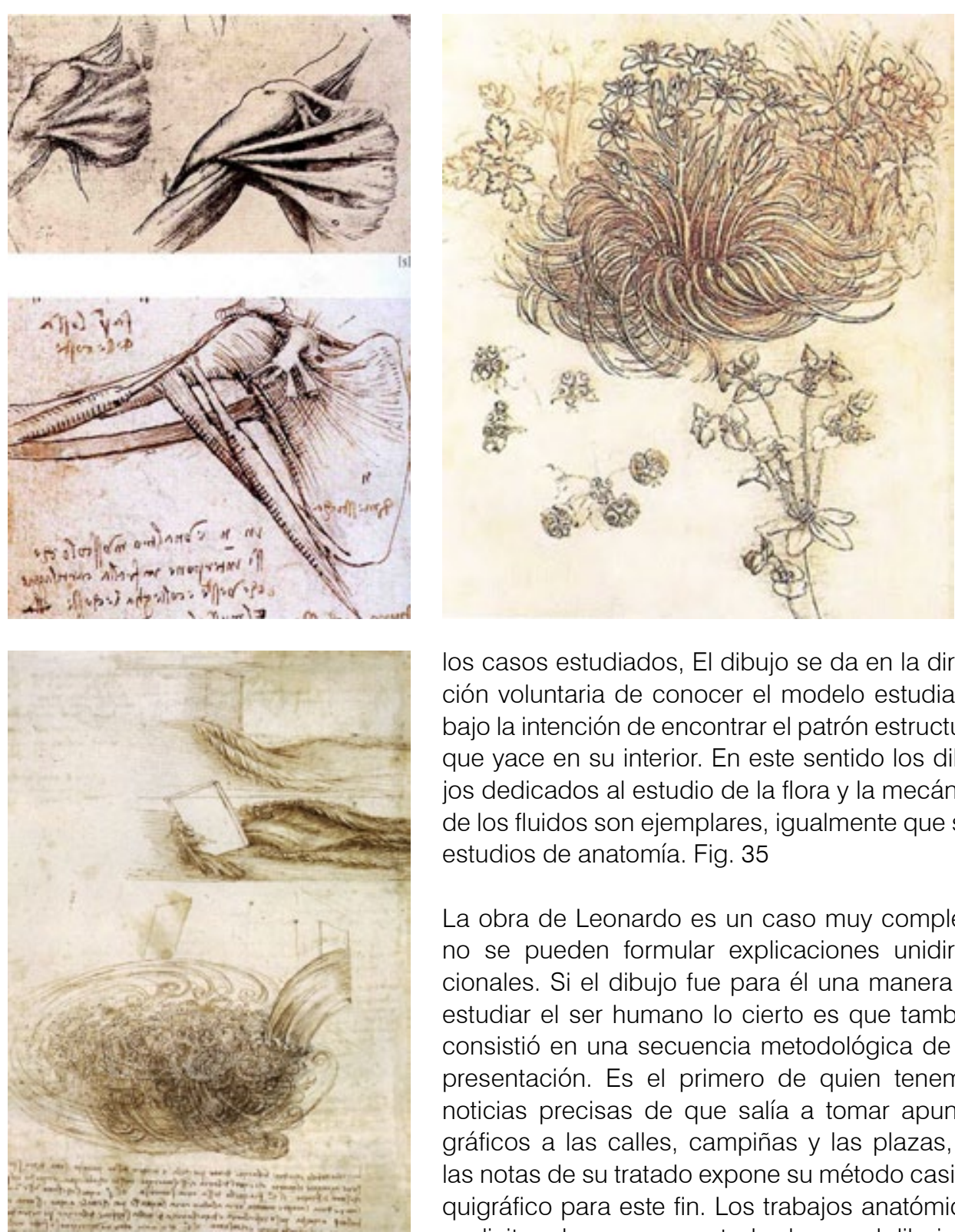

los casos estudiados, El dibujo se da en la dirección voluntaria de conocer el modelo estudiado, bajo la intención de encontrar el patrón estructural que yace en su interior. En este sentido los dibujos dedicados al estudio de la flora y la mecánica de los fluidos son ejemplares, igualmente que sus estudios de anatomía. Fig. 35

La obra de Leonardo es un caso muy complejo, no se pueden formular explicaciones unidireccionales. Si el dibujo fue para él una manera de estudiar el ser humano lo cierto es que también consistió en una secuencia metodológica de representación. Es el primero de quien tenemos noticias precisas de que salía a tomar apuntes gráficos a las calles, campiñas y las plazas, en las notas de su tratado expone su método casi taquigráfico para este fin. Los trabajos anatómicos explicitan de una vez por todas lo que el dibujo de Fig. 35. Leonardo. Dibujos de estudio. estudio puede ser, el estudio y boceto preparatorios para el cuadro de Santa Ana la Virgen y el niño, describen la secuencia de construcción configurante de sus pinturas.

La extensión del trabajo de Leonardo en el terreno del dibujo es muy extensa, más de 4000 hojas, entre dibujos sueltos hasta los que constituyen volúmenes integrados dedicados al estudio de diversos temas, sobre el vuelo de los pájaros, sobre anatomía, sobre mecánica fundamental y maquinismo o sobre estudios hidráulicos. 
Los cuadernos de dibujo de Leonardo nos trazan el camino de su pensamiento através de sus variadas etapas. Nuevamente, en ellos se muestra la relación entre dibujo y ciencia a la que ya nos hemos referido; su confianza en la experimentación y las matemáticas, ciencias a las que consideró verdaderas y pertenecientes al terreno de las mecánicas, ya que sólo logran su término mediante la actividad manual. Esta posición se relaciona con su entendimiento de la pintura cuando dice que esta existe inicialmente en la mente del artista y sólo alcanza su completud con la obra de la mano. Observamos aquí la semilla de la definición Zucariana del Dibujo Interno y el Dibujo Externo.

Así el dibujo se transforma en la conclusión y representación del proceso mental que organiza; pero que no es sino el pensamiento aplicado metodológicamente al estudio de los modelos naturales y contextuales. Es el documento probatorio del doble sentido, el del proceso racional y abstracto, como del método experimental aplicado.

En la Virgen con flor o Madonna Benois 1478, se observa el inicio de la disolución del asentamiento firme de las figuras al que nos referimos en el caso del trabajo de Botticelli, algunos llaman a este factor el inmovilismo gráfico, término con el que no estamos de acuerdo, pero el caso es que con esta obra se rompe el criterio de asentamiento planimétrico de la figura y el espacio, propio de Botticelli y de la tradición pictórico arquitectónica de Piero Della Francesca.

Esta imagen se basa en una estructura rítmica rica en diagonales compensadas y en un amarre de líneas que remiten siempre la lectura visual al interior de la pintura. Contiene igualmente el principio de demarcación piramidal para la composición, estructura triangular que junto con la forma ovoide dominará en la pintura del siglo XVI. La rítmica de movimiento de la composición y las figuras se dirigirá finalmente hasta el sistema del Contraposto agudo de Miguel Ángel y el Serpentinato típico del Manierismo y el Barroco. En este mismo trabajo se inicia el estudio de la gradación lumínica como factor constructivo del espacio y la profundidad, la dilución de los contornos y su penetración en el espacio; en pocas palabras el rompimiento de la concepción Florentina del dibujo.

Ya con Masaccio, Botticelli y otros se llegó a la organización tonal de los planos cromáticos, eso propició el surgimiento de una atmósfera sinestésica sugerida por el cuadro, pero en ella se mantenía siempre la delimitación de los cuerpos, la precisión de los cuerpos no se perdía sin importar su colocación en la profundidad virtual del cuadro, esta se construía mediante la ciencia perspectiva de esencia geométrica. Con los trabajos de Leonardo, la luz inicia su camino como elaboradora de la experiencia gestáltica de la imagen. Fig. 36

En la técnica del fresco los colores en polvo se tomaban de un solo lote, eran pesados y diluidos en un mismo volumen de agua; con esto se lograba igualar la profundidad tonal de los planos pintados. Las medias tintas se lograban con diluciones divididas regularmente de la base tonal original. Por eso esa pinturas eran básicamente modeladas y dibujísticas y evitaban las mezclas cromáticas, sobre todo las que se pudieran realizar en la superficie pintada. La grisalla y el modelado mediante el dibujo, eran los factores constructivos elementales de la pintura. La mezcla cromática directa en la paleta y el matiz como sistema ya definido serán introducidos en los frescos de Miguel Ángel y en la pintura manierista y barroca.

En el terreno del dibujo existe en este punto un factor más a considerar. Leonardo ya en su tiempo era considerado como el que primero pintó osadamente las sombras. 

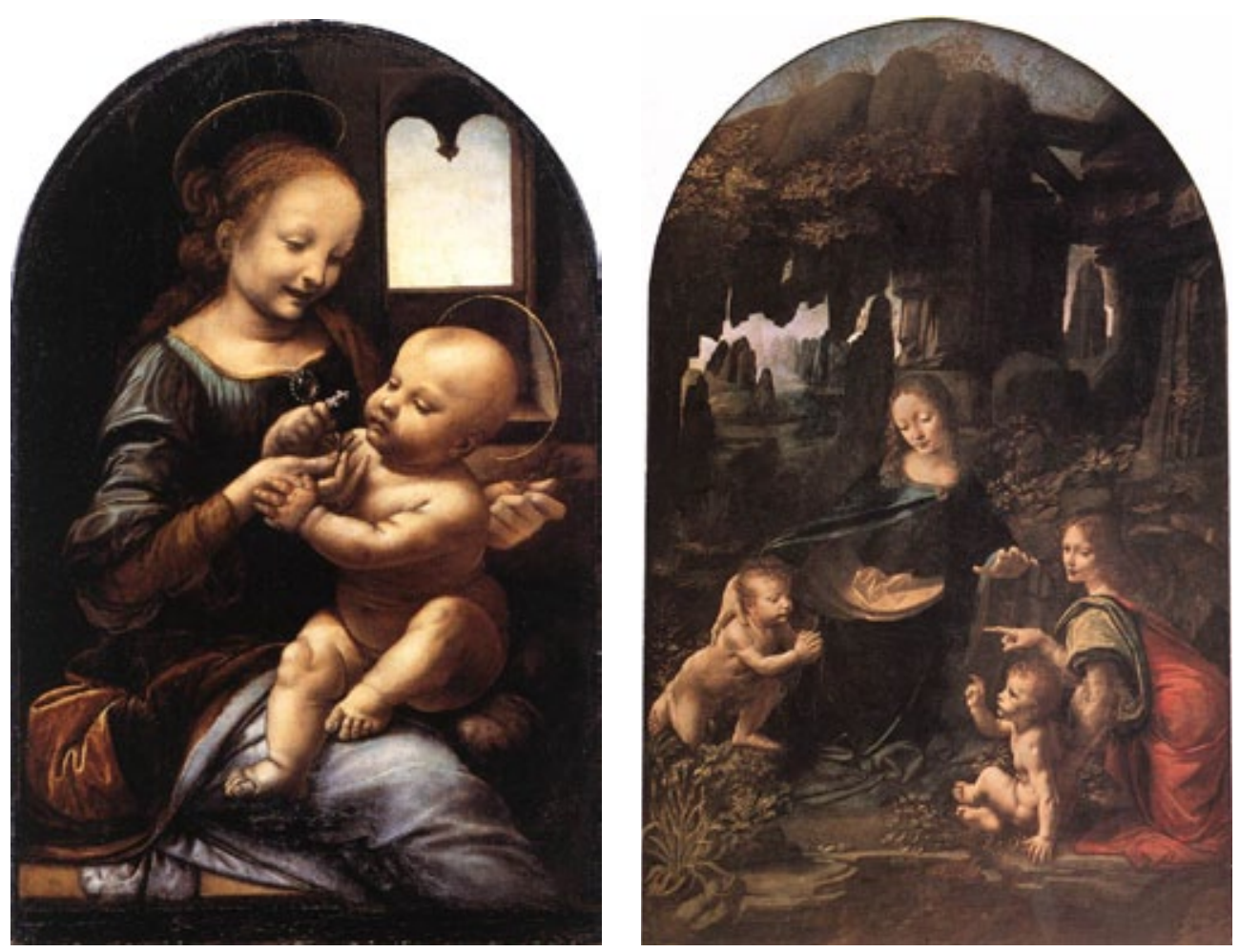

Fig. 36. Leonardo. Madonna y Virgen de las rocas.

A los tres elementos del dibujo renacentista, composición, contorno y relieve, Leonardo agregaría la explosión del claroscuro y la perspectiva atmosférica. Este concepto, el de la Perspectiva Atmosférica es interesante de reflexionar, no corresponde estrictamente al campo del dibujo, si consideramos la definición que en ese momento era vigente sobre esta disciplina, el dibujo como circunscripción de los cuerpos y ordenamiento de las partes en el plano compositivo, pero tampoco se ubica claramente en el terreno de la pintura, ya que la perspectiva atmosférica es la degradación del tono y el contraste cromático en función de la profundidad, además para conseguir este tipo de organizaciones del gradiente lumínico se hizo necesario implementar un procedimiento mecánico, el Sfumato junto con los Pasajes, modificó el pensamiento del dibujo, porque se requería tener presente la completud del modelo pero se requería igualmente y al mismo tiempo imaginar un sistema de proyección de rayos lumínicos extremadamente complejo, que además actuaría particularmente sobre la topología de los planos de las cosas y el espacio. Pero el asunto de este sistema formal y conceptual no se agotó en ese punto. Se dirigió también a considerar el efecto de las disminuciones y aumentos de luz y cómo estas afectaban la consistencia de los contornos y la línea. Podemos decir que estas pinturas de Leonardo y sus magistrales dibujos plenos de atmósfera son el inicio de un dibujo que logró la continuidad topológica de los cuerpos representados, figuras en las que no encontramos ya planos cortantes y separados por demarcaciones lineales. 
Este es un ejemplo de cómo el pensamiento de una época se concreta en principios formales que organizan una teoría desde la interioridad de un campo artístico.

El claroscuro por otra parte se usaba como un generador de relieve en la imagen dibujada, la saturación de los colores con el toque de negro en las sombras y de albayalde en las luces es un recurso del dibujo aplicado a la pintura. Por esto la pintura se asemejaba a la secuencia de modelado de la escultura; porque se basaba en el entendimiento de los planos internos del modelo. Y el espacio representado era resuelto con la aplicación de la perspectiva piramidal.

La propuesta de Leonardo lleva al dibujo a una concepción del espacio pictórico, construido mediante la mengua y regulación del gradiente lumínico y sus efectos en la superficie de los modelos. Es el primero en formular que la ausencia de luz degrada los colores, pero en las áreas luminosas de los cuerpos se genera también el efecto de dilución lineal.

La pintura de Rafael de Urbino, pese a ser más joven que Leonardo y la de Miguel Ángel es de una pureza de contornos exquisita, el dibujo florentino es distinto cuando menos en ese aspecto a la obra de Leonardo. Esa fue una revolución en el terreno del dibujo. Sentó el precedente para la escuela tenebrista y la materialidad en conexión con la pintura flamenca.

El tratamiento que Leonardo da a los contornos, se suma a la composición contrastada de planos extensos en tonos bajos, en ellos mantiene algunas áreas recortadas. A través de esas oquedades se distinguen fracciones del horizonte en una luminosidad extrema; con esto contradice una norma de términos espaciales de la pintura, en la que toda zona de carga matérica densa y luminosa, se proyecta hacia el primer término del cuadro. La ingeniería de Leonardo en su valoración lumínica del contorno y la construcción del espacio, acercaron a la pintura y el dibujo a extremos de un naturalismo que estaba más allá de las posibilidades de la geometría y la perspectiva piramidal solamente.

Los sistemas de representación alcanzan grados de perfeccionamiento en el periodo renacentista, basados en el conocimiento experimental y los procedimientos matemáticos, los cánones de la antigüedad grecolatina fueron puestos al día y sus autores actualizados. Los pintores renacentistas se sabían apoyados en la obra de Apeles y Zeuxis.

La grisalla era un recurso del dibujo y la pintura que se usaba hacia el final de la edad media, consistía en pintar partes de los muros con imágenes entonadas en grises que simulaban el color de las rocas empleadas para realizar las esculturas, de esta manera se obtenía una integración del conjunto visualmente. Pero la grisalla fue desarrollada mucho más para convertirla en un sistema de estructuración del orden lumínico y la cualidad de los sectores tonales en la imagen. Tenemos así que las sombras deberían ser modeladas y profundas, transparentes y penetrables, en ellas se usarían los colores que no tuvieran opacidad en su constitución, no deberían ser cortantes sino diluidas.

Las luces por su parte serían construidas con densidad, mates, pastosas y matéricas para promover su desplazamiento hacia los planos primeros de la imagen, tampoco deberían ser cortantes, salvo en los puntos donde se representaba el brillo de las superficies, tanto en las zonas de luces como en las tintas medias los colores se podían mezclar entre sí, pero solo mediante el procedimiento de transparencias, estas serán las áreas donde poco 
a poco se abre el concepto de mezcla cromática. Los tonos medios deberían ser tratados con continuidad, sin cortes, mediante la aplicación de Pasajes, en estas partes el Sfumato opera como concepto de construcción.

El dibujo del Renacimiento como pensamiento y estrategia constructiva de representación estableció los conceptos de Contorno, Modelado, Sfumato, Regatino Claroscuro, Escorzo, Anatomía, Relieve, Pasaje y Grisalla. Estos se proyectan y continúan en el ejercicio del Manierismo, donde se agregan variaciones que amplían el sistema formal.

Los conceptos de Contorno, Modelado y Regatino se originan y están en íntima relación con la mecánica pictórica de ese momento histórico, pero no son solo experiencia práctica, representan la especulación racional de las acciones técnicas.

Debido a dos o tres razones torales, la pintura al Fresco es quizá el procedimiento de mayor dificultad en cuanto a ejecución técnica. Primero, debe ser ejecutado en el periodo de tiempo cuando el muro aplanado con cal se encuentra en estado de fraguado receptivo, de modo que los pigmentos se integren en el cuerpo del estrato calcáreo, en segundo término se establece un problema contradictorio entre el avance para cubrir la superficie y la calidad y cualidad de las construcciones formales que se pintan; a mayor rapidez menor calidad formal (esto nos da una ligera idea de la complejidad de muchas de las obras de las que hablamos) por eso es que se fue logrando una práctica mixta en la que los muros podían seguirse trabajando con capas de temple sobre el aplanado ya fraguado.

El Temple fue una técnica de pintura mediante emulsiones que se aplicaban sobre tablas imprimadas. Todo esto lo sabemos, es común en cualquier tratado de técnicas de los materiales de pintura y son técnicas de uso frecuente entre los pintores actualmente.

Pero tanto el temple como el fresco son procedimientos en los que no se puede sobreponer estratos pictóricos densos ni pinceladas pastosas, ya que esto debilita su capacidad de adhesión, entonces para lograr un tono consistente de luz o color con saturación pigmática densa, se tiene que recurrir a la aplicación de capas muy delgadas que permiten el secado de los estratos inferiores. Por otra parte la fragmentación de la pincelada, obligada por el carácter matérico de las emulsiones, fue generando el Regatino, pinceladas cortas y agrupadas en una secuencia rítmica que se organiza en concordancia estructural con las cadencias de la topología de las superficies que se representan, esto posibilita con mayor ductibilidad el efecto de degradado del tono en una superficie. Esta fue la mecánica que observamos en autores como Botticelli y Fray Angélico y que llevó poco a poco a la disolución de la linealidad circunscrita en la continuidad de los planos de modelado. Todo esto es una operación que compete a la disciplina del dibujo, entendida como circunscripción de los cuerpos pero también como definición de la forma, así como la de generador de la estructura topológica en el modelado de las superficies.

Si bien el temple es una técnica de pintura eminentemente dibujística, tiene ciertas limitaciones en el terreno atmosférico y cromático, ya que la calidad de las sombras carece del espectro de profundidad que se alcanza con el óleo o el encausto. De ahí que la revolución de Leonardo en el terreno de la Atmósfera pictórica, del Sfumato y la Perspectiva Atmosférica se encuentre en relación con el desarrollo del óleo y las técnicas mixtas. El óleo al permanecer por mucho tiempo como superficie pictórica fresca y activa, posibilita operaciones mecánicas distintas a las del temple, como el ligamento de las zonas de contraste y la fusión de las mezclas cromáticas, así como el modelado y dibujo de las super- 
ficies con relativa independencia de la pincelada. Además de que la integración del aceite como aglutinante confiere a la pintura un índice de transparencia y profundidad mayor.

En la obra de Leonardo se integran las características más positivas de ambos procedimientos. No podemos más que reiterar la relación que se entabla entre una acción técnico-mecánica y el concepto, para integrar entre ambos un pensamiento pictórico que es una estructura de representación.

Un aspecto muy importante en este análisis consiste en señalar la intención que se marcó como meta en la pintura y dibujo del Renacimiento. Se venía desarrollando una práctica de representación que intentaba diferenciarse del arte bizantino, en éste, la huella de los trazos y acciones derivadas del proceso pictórico era muy cruda. El arte del Renacimiento en el dibujo y la pintura buscó la disolución de la huella del trazo y la pincelada indéxica para aumentar el carácter sensible de las imágenes y crear un mundo virtual a manera de una ventana como recorte de la realidad natural.

Se considera el espacio pictórico como un ámbito aparentemente tridimensional, integrado por sujetos y recortes espaciales, mismos que parecen extenderse indefinidamente aunque no de modo infinito, esto por detrás de la superficie pintada, que es objetivamente bidimensional. Entonces esa superficie ha perdido la materialidad que poseía en el arte del término del Medioevo. Deja de ser una superficie opaca de trabajo impenetrable dada por el soporte y se convierte en la famosa ventana renacentista que hemos descrito. Tomemos del tratado de Alberti ya mencionado las siguientes palabras.

"Deben saber los pintores, que con sus líneas recorren una superficie plana y que al rellenar de color las zonas así delimitadas, lo único que se trata de conseguir es que las formas de las cosa vistas aparezcan sobre esa superficie plana como si fuera de vidrio transparente. Trazo un rectángulo del tamaño que quiera, el cual imagino ser una ventana abierta por la que miro aquello que dentro de él haya de ser pintado"102

Este efecto de recorte virtual fue posible tanto por la estructura geométrica y la perspectiva, pero en íntima relación con el tratamiento atmosférico del color, con el espacio y con los recursos del dibujo que hemos descrito.

El dibujo renacentista dotó al método experimental de una herramienta de representación, suficientemente poderosa para consignar las observaciones de los experimentos que descubrían el misterio interno de los modelos.

El ímpetu de tomar a la naturaleza como modelo de conocimiento, combinado con el ideal abstracto de la belleza pura en el sentido mesurable, hacen del dibujo renacentista el conducto de realización mimética tan deseado por los pintores; desde ahí y hasta la aparición de la fotografía, el dibujo dota a la pintura y la escultura de una capacidad de representación para acercarse a la mímesis del mundo en la imagen.

Los artistas renacentistas no vacilaron, tenían claramente definido su objetivo, un arte humanista basado en la observación de la naturaleza y la herencia de la antigüedad grecolatina, había mucha competencia entre autores pero todos coincidían en el ideario colectivo.

102 Battista Alberti León. Tratado de pintura. México: Universidad Autónoma Metropolitana; 1998.

(Colección Ensayos). P. 69. 
Así la empresa se realizó con el concurso de todos, en interés de una visión colectiva del proyecto artístico.

La riqueza formal y compositiva del dibujo como sistema de representación solo reconocía la limitante del buen juicio, basado en la observación naturalista experimental y en la métrica de las proporciones. Con esto el dibujo renacentista partiendo de su precisión lineal mantuvo un carácter metodológico riguroso, la cadena de modos de dibujar para conseguir un proyecto se definió en sus partes fundamentales. El pensamiento proyectual prefigurativo del dibujo hizo su aparición en la escena artística.

Cimabué, Giotto, Masaccio fueron los precursores directos del carácter naturalista del dibujo del 1400, sus lecciones de anatomía y la variación de los ángulos de presentación de la figura, anunciaron el escorzo. El modelado de sus superficies plegadas introdujo el tratamiento de relieve a la superficie pictórica; pero el ingrediente sustancial del cambio se encontró en la convicción epistémica del pintor de enfrentar la naturaleza mediante un proceso experimental, de salir a la calle y al campo a observarla y en llevar el modelo sea cual fuere a la mesa de disecciones.

El poder de estas herramientas de representación fue tan poderoso que cuando menos los pintores tardarían 400 años en hacerles cortes y cambios radicales.

El dibujo renacentista es uno de los modelos de pensamiento cuya densidad es difícil remontar aún hoy día.

El manierismo, el Barroco y la historia subsiguiente agregarían giros epistémicos a esta función del dibujo pero será un proceso en el que los paradigmas no se desechan simplemente, de su interior surgen las variaciones que terminan proponiendo modos de pensamiento que nos parecen distantes, pero que mucho tienen del pensamiento anterior.

\section{III-6-2 EL DIBUJO EN EL MANIERISMO Y EL BARROCO}

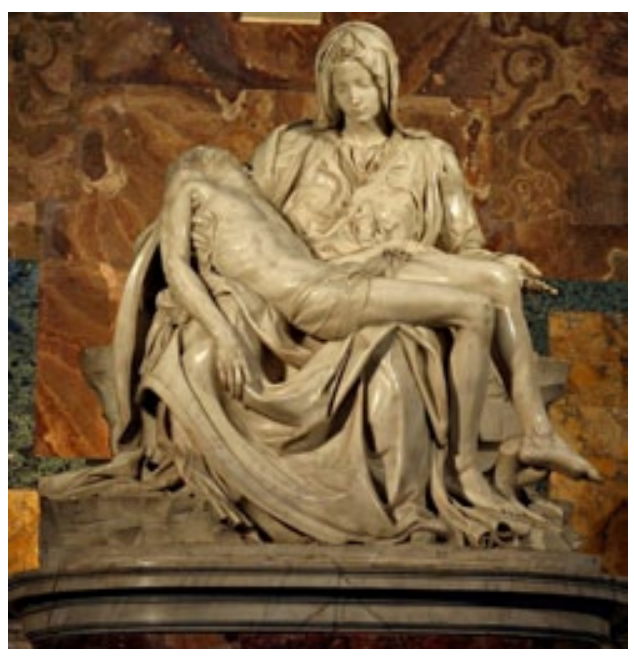

Fig. 37. Miguel Ángel. "La Piedad" 1498.

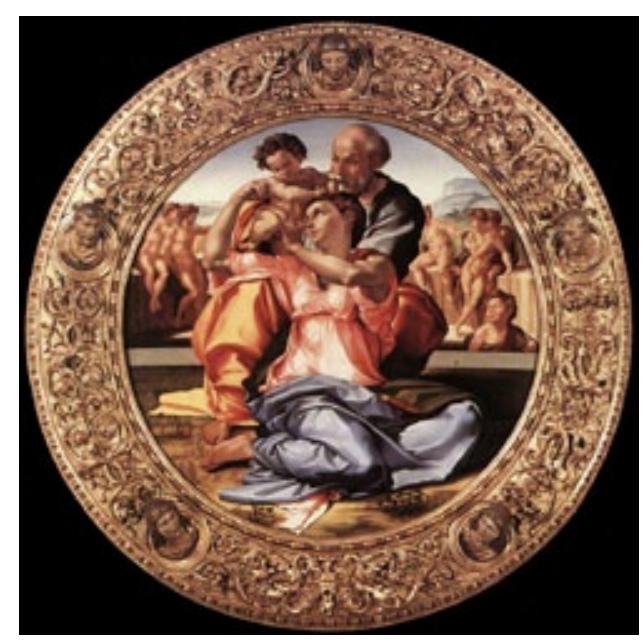

Fig. 38. Miguel Ángel “Tondo Doni” 1504.

Decidimos iniciar este apartado con la exposición de estas tres obras porque en ellas se muestra de modo claro y expedito el carácter del cambio radical que significó el inicio 

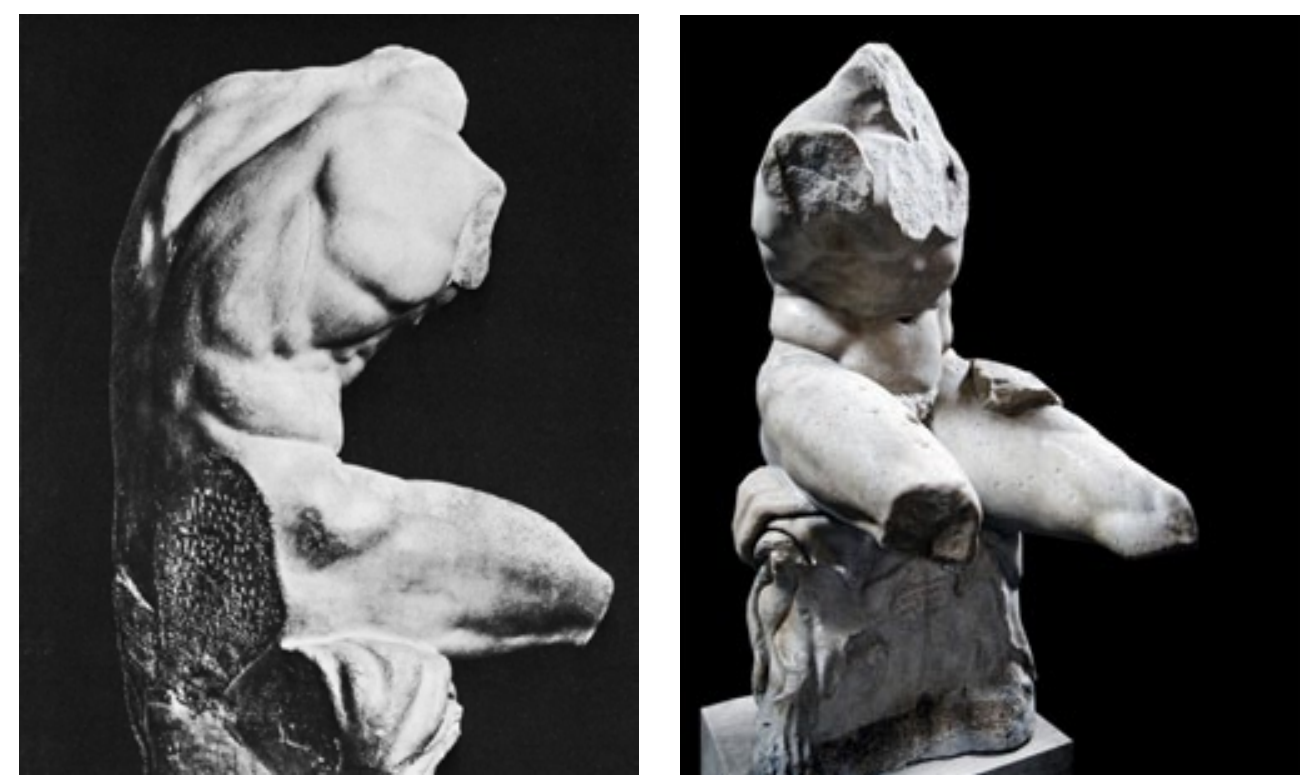

del manierismo como concepción artística. Líneas adelante regresaremos a ellas para ligar la continuidad de nuestro análisis.

Ya para mediados del siglo XVI la explosión de la literatura teórica artística es incontenible. En parte gracias a la difusión de la imprenta, ya que anteriormente la elaboración de una sola pieza de texto era trabajo de años. Pero sobre todo debido al ímpetu divulgador de quienes integraban los círculos culturales, por eso la teorización del hecho artístico se convirtió en parte del paradigma naturalizado. El hecho de exponer teóricamente los fundamentos de las artes se entendió como parte del sistema de su producción, en ello desempeñaron un papel central las Academias de Artes.

Los tratados renacentistas aconsejaban claramente basarse en la naturaleza como fuente de estudios y en los modelos de los antiguos como ideal ejemplar. Un elemento agregado será la inventiva del dibujante y el buen juicio para variar las composiciones y

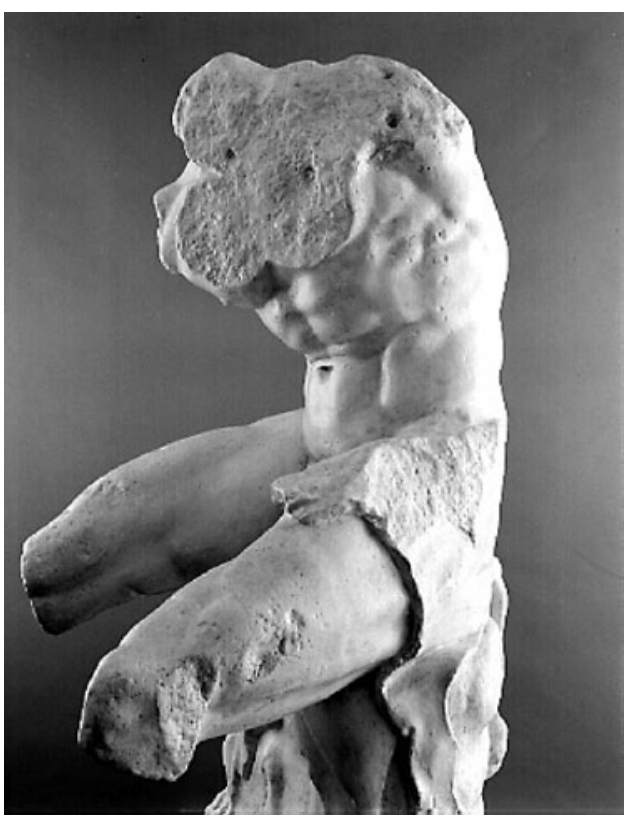

Fig. 39. "Torso de Belvedere" fragmento estatuario de un desnudo masculino firmado por el escultor ateniense Apolonio de Atenas. Fue descubierta en su estado actual en el Campo de' Fiore (campo de las flores) 1503-1513. Se pensaba era un original del siglo I A.C. Actualmente se estima que es copia de una estatua más antigua, probablemente datada en el siglo II A.C. no caer en una constante repetitiva. 
A través de todo el Renacimiento la postura objetiva y racional junto con la observación de los modelos naturales, operaron como contenedor de las prolongaciones de la forma que no tuvieran una base experimental.

Este es el punto de giro que marca el inicio de lo que será el Manierismo, una postura que traspone el cerco de la forma limitada por el juicio de la razón métrica del canon como estricta observancia y análisis de los modelos naturales.

Ya veremos como en palabras de algunos autores manieristas se inicia el proceso de alejamiento de la anterior teoría de la pintura, entendida como proceso fundamentado en las ciencias racionales y la filosofía natural.

Con el trabajo de Miguel Ángel, tanto en la pintura como en la escultura arranca un proceso de variación de esta causalidad como origen de las formas de representación.

En el aspecto teórico revisaremos el pensamiento de algunos tratadistas y artistas del movimiento manierista, en el terreno del dibujo y la imagen nos centraremos en el trabajo de Miguel Ángel, por una parte vemos en su obra la base del pensamiento manierista, y en otro sentido pensamos que compendia de manera excelente los elementos que nos permiten continuar el estudio que nos ocupa.

Muchos de los análisis históricos confieren al Manierismo un carácter de movimiento que marca el declive del pináculo renacentista. Lo denuncian como un exceso de formalismos que carecen de sustento filosófico y natural, vanidad y formalismo sensual. Pero en esta línea de análisis, el manierismo tendrá un lugar importante en la construcción del pensamiento del dibujo.

Este fue el origen de la postura manierista al recomendar la variación.

Habiendo sido perfeccionados los sistemas de representación del dibujo y la pintura al grado alcanzado, se disponía de una ingeniería formal enorme. Esto generó en los artistas la conciencia de que ese aparato formal podía ser la base de un arte que por sí mismo creara realidades alternas a la propia realidad objetiva y concreta de la existencia física. Si bien el Manierismo significa una aventura sobre todo de variación formalista, pensamos que con ello se abre el terreno hacia un universo de representación que madurará en una conciencia epistémica alterna del dibujo y la pintura.

No es que el Manierismo como acto del dibujo careciera de racionalidad, por el contrario, los tratados de sus autores insisten en la visión teórica y conceptual del dibujo, son quienes logran una explicitación clara y secuenciada del dibujo como operación intelectual, ligada a su praxis fáctica como acontecimiento que opera sobre la base proyectual teórica.

¿En dónde radica entonces el giro peculiar de este proceso del arte y particularmente del dibujo?

La caracterización que los propios autores del Alto Renacimiento hacen de sus artistas y la estructura formal que ellos crearon muestra una visión estilística, conceptual y formal ya muy clara, definían a Rafael como el mejor colorista, a Leonardo como el mejor alumbrador y a Miguel Ángel como el mejor diseñador. 
En 1550 se ha desarrollado claramente la polémica entre la escuela veneciana de vocación colorista y la postura florentina basada en el dibujo. Como hemos revisado, la definición florentina del dibujo se establece sobre un pensamiento racional que lo entiende como la línea que tiene esencia geométrica.

Dentro del pensamiento manierista la concepción del dibujo vive un giro teórico, en algunos textos y autores lo encontramos definido como Disegno, en otros más el dibujo es parte integrante del conjunto universo del diseño, veamos las palabras de Paolo Pino, pintor que escribe sus Diálogos de la Pintura en 1548.

"El arte de la pintura imita la naturaleza en las superficies, y para hacerlo entender mejor lo dividiré en tres partes, a mi modo: la primera parte será el diseño, la segunda invención, la tercera y última colorido. En cuanto a la primera parte, llamada diseño, quiero así mismo dividirla en cuatro partes: a la primera llamaremos juicio, a la segunda circunscripción, a la tercera práctica, a la última correcta composición... Poseyendo juicio adquiriréis la circunscripción, que entiendo que es perfilar, contornear las figuras y dar claroscuro a todas las cosas, a lo cual vos llamáis esbozo."103

En este orden de pensamiento encontramos dos cosas interesantes para el tema que nos ocupa; por una parte ya aparecen con claridad diferenciada los conceptos de Diseño, Composición y Circunscripción. La esfera del pensamiento del dibujo se expande de su anterior entendimiento que lo ataba solamente a su carácter de linealidad circunscrita. Estas tres nuevas prácticas disciplinares, con el tiempo se integrarán en el universo general de la definición del dibujo. Pero en segundo término vemos como en la postura manierista el dibujo se dirige hacia un territorio compositivo y diseñístico que resultará altamente acorde con la complejidad de las nuevas formas y estrategias de representación. Con base en lo anterior se comprende la consideración que ya en ese momento se tenía sobre Miguel Ángel como el mejor diseñador.

La pintura dentro del Manierismo asiste a una explosión cromática, esta postura no tiene nada de sensualismo simple, se fundaba en la visión aristotélica que consideraba el mundo como una comprensión de los sentidos, de ahí su oposición frente al dibujo como disciplina platónica del pensamiento racional de las formas.

El caso es que el dibujo y la pintura comenzaron a derivar por senderos de saturaciones formales, el dibujo se complicó en líneas que ya no se originaban en el modelo natural y que constituían excesos desde el punto de vista de no ser necesarias para construir la estructura sino como alegorías formales, pleonasmos que construían una estructura formal por sí misma, esto dotó al dibujo de artilugios más sensuales que racionales. El dibujo, la pintura y la escultura se saturaron de formas que no eran la forma de los sujetos de la imagen (como hasta ese entonces se pintaba y dibujaba) sino formas que construían una imagen que era marco de existencia alterna para el acontecimiento del tema.

El arte del Renacimiento occidentalizó la historia del Cristianismo, en términos de su caracterización iconográfica, cuando en realidad es un desarrollo del territorio y la cultura

103 Freixa Mireia, Garriga Joaquim, Yarza Joaquín, editores. Fuentes y documentos para la historia del Arte. Renacimiento en Europa. Barcelona: Ed. Gustavo Gili; 1983. (IV). P. 264. 
judaica. Podríamos considerarlo como una sobreposición que transparenta dos territorios representacionales, el de la cultura que fue nicho del suceso histórico, y el de la cultura que volvió a formalizarlo con otro aparato de representación.

Pensamos en el periodo manierista como un proceso de este tipo, uno en el que la imaginería formal se desborda creando mundos de existencia no mimética que se sobreponen sobre el mundo que percibimos.

Nuevamente; este es un punto de giro que consideramos sustantivo: comienza de manera consciente el distanciamiento de la búsqueda mimética representacional de la realidad, el cual fue uno de los paradigmas fundamentales del Renacimiento, iniciándose un proceso de búsqueda de las construcciones formales del arte como realidades sensibles alternas. La categoría mimética continúa apareciendo en los tratados manieristas, pero en la medida que estos avanzan en el tiempo esa preocupación se diluye.

El Manierismo y el Barroco siguieron siendo visiones del dibujo y la pintura basadas en la métrica y la geometría, pero el dibujo se concedió fundamentos para la composición que ya no emanaban del orden natural sino de la complicada maquinaria formal.

Este será un punto de giro epistemológico esencial, la forma como aspecto primario que se proyecta en el desarrollo interno de la obra, y la manera de los maestros como inicio de la especulación de la representación.

Paolo Lomazo con su tratado de la pintura es el ejemplo más claro de esta postura, haremos algunas citas y las comentaremos. Pasaremos luego a revisar la postura de Federico Zuccari, quien aporta el elemento teórico sustantivo que marcará el paso de avance y la distancia del dibujo del Renacimiento al Barroco.

En el Manierismo y Barroco el dibujo se basó en la invención como demanda de aceptación creativa.

Se introdujo una reflexión sobre el sistema de representación en sí y sobre el hecho del lenguaje como conjunto de formas, que consideran desde lo objetual hasta las figuras humanas y los conjuntos arquitectónicos y las ambientaciones de paisaje.

Esto requirió de un aumento acelerado en la variación de las imágenes y su tratamiento formal. De manera que los dibujantes se adaptaron y explotaron las partes del sistema de representación que más favorecían esta búsqueda. El escorzo como perspectiva de la figura humana se desarrolló ampliamente.

El Serpentinato es la estructuración de la figura humana dibujada en construcción piramidal y en sentido espiralado, semejando el movimiento de las flamas del fuego. Ya cuando hablamos de la representación en el capítulo Il tuvimos oportunidad de comentar estas estructuras.

También nos detuvimos en la exposición del Contraposto como la oposición alternada de los ejes horizontales de la figura humana, que en complemento con el serpentinato crean estructuras en la composición de un movimiento acelerado.

Pero Miguel Ángel y la secuencia manierista darán una potencia a estos conceptos al proyectarlos en una multiplicidad de vistas y direcciones espaciales. 
Ya en los trabajos de Leonardo domina la composición sobre áreas triangulares, esto es el sentido piramidal, también en sus grupos de figuras la dirección de los ejes de movimiento muestra una dinámica diagonal contrastada, pero sus resultados nos ofrecen imágenes que guardan un sentido de credibilidad natural; aunque las sabemos producto de la invención representativa nos ofrecen una realidad vivencial, una en la que podemos imaginarnos transcurriendo, su concepción es mediúmnica vivencial. En las obras de Miguel Ángel nos sentimos separados de esa realidad, es un mundo de figuras titánicas, no iguales a nosotros, sus proporciones y posiciones son antinaturales e imposibles de replicar por sujetos vivos, pero con eso y todo logran integrar un plano de existencia, una realidad en la que nuestro pensamiento se proyecta y nos hunde en un mar de reflexiones y experiencias estéticas, que nos retornan a nuestro propio plano vivencial con un espíritu transformado, y esto no es mera poética, quien se haya parado bajo los frescos de la Capilla Sixtina o frente a los mausoleos de la Capilla Medicea lo comprenderá perfectamente.

Por cierto al contemplar la Sixtina tenemos frente a nosotros la mejor explicación del salto renacentista manierista, el universo de Miguel Ángel en la bóveda y al frente, y en los muros laterales la lección renacentista clásica.

Sucede algo similar con la escultura de la "Piedad" (1498) comparada con sus trabajos de la "Capilla Medicea" (1520-1534).

En La Piedad se observan con rigor los cánones renacentistas clásicos y el naturalismo propio de esa concepción, no nos dirigimos a las lecturas interpretativas de la obra, señalamos como en este trabajo no se anuncian aún los caracteres formales de representación del Miguel Ángel manierista. Fig. 40
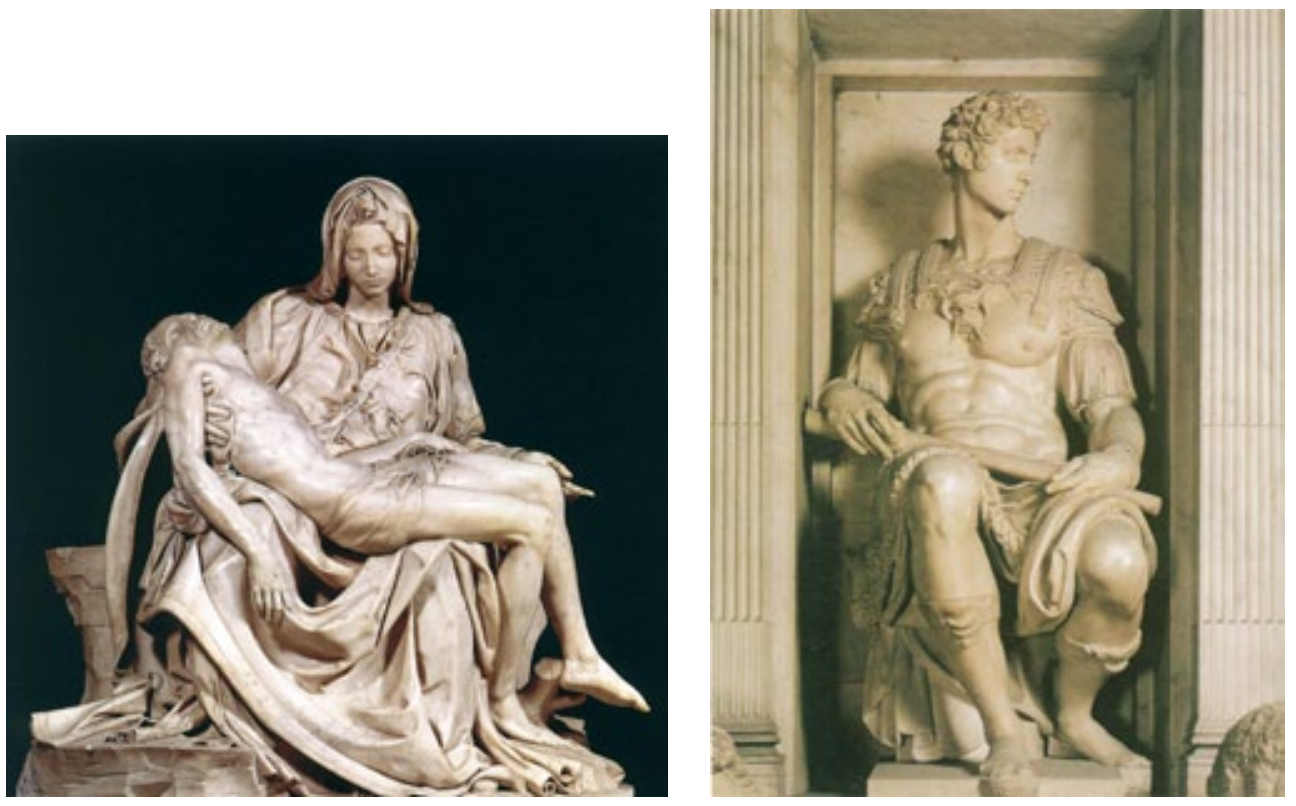

Fig. 40. Miguel Ángel. En estas imágenes se observa el estilo renacentista temprano en contraste con el logro de la dinámica manierista que caracterizará el dibujo y composición de Miguel Ángel.

Si el Renacimiento concibió el plano pictórico y compositivo como una ventana al mundo, no exageramos al decir que el Manierismo inició la colocación del punto de vista en un es- 

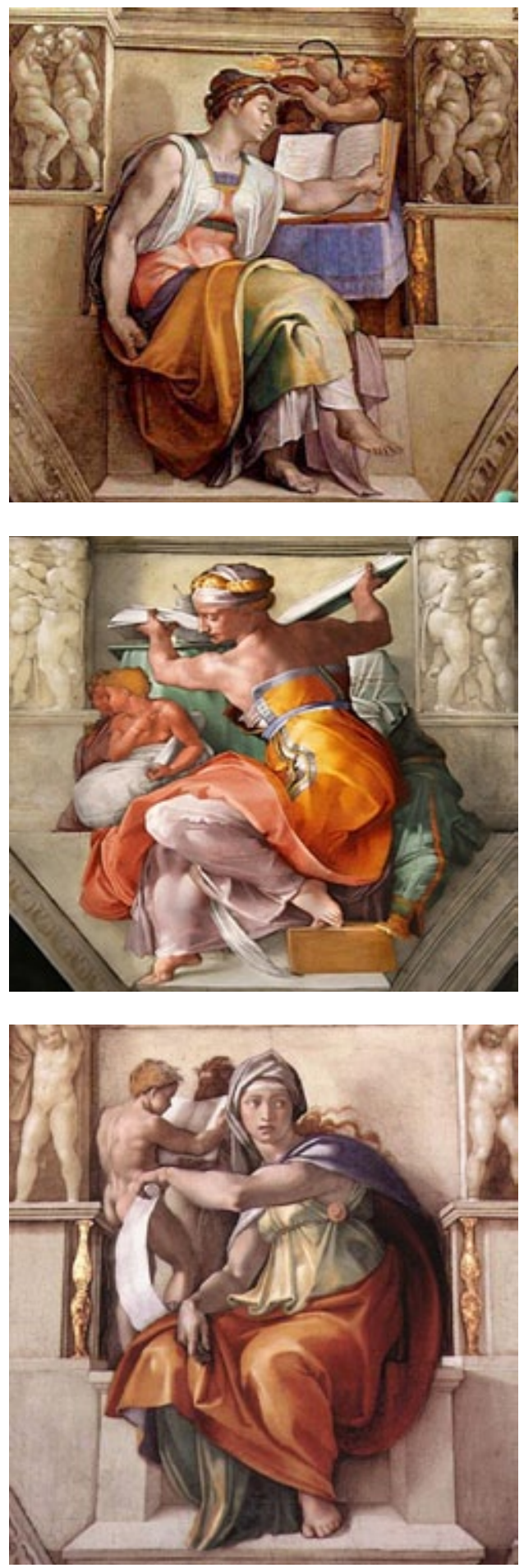

Fig. 41. Miguel Ángel. Sibilas. Sibilas de la Sixtina. Composición serpentinada y sombras de tono color. pacio poliangular. Esta es una innovación del manierismo, la tridimensionalización de las vistas de la figura sobre las que se ejecuta el Contraposto.

El Nacimiento de Venus pintado por Sandro Botticelli muestra un equilibrio calmo, pese a representar a Venus meciéndose sobre el oleaje, es el punto que se antoja más opuesto a la figura de La Sibila Delphica en los frescos de Miguel Ángel de la Sixtina. Fig. 41

Miguel Ángel es el iniciador propiamente de la inventiva manierista. Los frescos de la Capilla Sixtina son plenos de dinámica y son obra maestra del dibujo todavía no superada. Cromáticamente también son innovadores y muy adelantados para su tiempo, ¿porqué? Porque desplazan la concepción renacentista Albertina en la que el modelado, las luces y sombras en la pintura se representan mediante la adición de negro y blanco, según sea el caso, en los frescos de la Sixtina las sombras y las luces se pintan con tonos de color, no con saturaciones de valor, también vemos como el color local, entendido como el color de los objetos que se denuncia con claridad en las zonas más iluminadas de los modelos, es interpretado por combinaciones de tonos cromáticos. Esto hace que en el dibujo, pero sobre todo en la pintura de Miguel Ángel el modelado no se deba a las secuencias del Sfumato como en caso de Leonardo. Fig. 41

El color sustituye a la mezcla de blanco y negro para saturar o degradar el tono cromático, después de la restauración de que fueron objeto, estas pinturas se nos revelan plenas de colorido, el mito tenebrista de la Sixtina se derrumbó y en su lugar tenemos el anuncio de la postura típica del manierismo que se agudiza en el barroco. La pintura colorista veneciana en oposición a la pintura tonalista y dibujística florentina y toscana renacentista. 
Como comenzamos a ver, la pincelada en la pintura renacentista se encuentra en relación íntima con la mecánica de la construcción de la forma, en parte originada por el proceso técnico, en los frescos de la Sixtina notamos como áreas y superficies cada vez más amplias se cubren con un solo golpe de pincel, pero el efecto de construcción resultante mantiene una coherencia entre el golpe del pincel y la forma del modelo y la superficie que se representa.

Creemos que en parte esta situación es originada por el hecho de considerar la distancia a la que estas pinturas iban e ser observadas finalmente (poco mas de 20 metros) pero el caso es que ésta es una situación nueva que inicia una relación diferenciada entre el índex del trazo y la huella de la acción mecánica y mental del dibujo, en la pintura típicamente barroca éste es un factor fundamental que caracteriza una nueva visión del acto de representación. La pincelada con área, forma y extensión que modula la superficie en contraposición de la pincelada fragmentada y diluida propia del renacimiento. Quizá hasta este punto se ubique el inicio de lo que hoy llamamos Pintura Directa.

El serpentinato, el escorzo y el Contraposto sobre movimientos que se desplazan en tres dimensiones se sumaron al esfumato, el regatino (que pronto se diluiría en el golpe de pincel, típicamente manierista y barroco; que posibilitó el carácter cromático de esa pintura) y el claroscuro, para sentar las bases de la representación, usando estructuras de la forma dibujística que preexistieron en el intelecto del pintor ya de manera decidida. El tratado de Paolo Lomazzo escrito en 1584 es el ejemplo que mejor compendia este pensamiento.

Armado de estas herramientas de la visión, el dibujante enfrentaba los modelos, pero el resultado sería la exacerbación de algunas características formales en aras del esfuerzo expresivo.

El Manierismo y el Barroco siempre tuvieron reservas que contenían al dibujante evitando su libre desenfreno imaginativo. Se planteaba como necesaria la práctica reiterada de dibujar del natural y copiar los buenos maestros.

En realidad más que la postura moral que limita o desarrolla el estilo manierista, y más tarde el barroco, nos interesa lo profundo de la postura intelectual.

El método experimental para dibujar del natural y la razón numérica como soporte de la proporción, son fundamentos típicos del dibujo renacentista; se verán enfrentados al libre ejercicio del dibujo frente a la naturaleza. La invención es componente sustantivo del dibujo manierista y se basa en el ejercicio del intelecto prefigurador del dibujante. Tal como lo vemos en el Tondo Doni y en la Sixtina.

La distancia epistémica del Renacimiento, al Manierismo y el Barroco es más grande que los pocos decenios que los separan.

El Renacimiento basa la práctica del dibujo en la experiencia dentro de la realidad circundante, en el experimento controlado y mesurable como base de investigación.

El Manierismo se referirá cada vez mas intensamente al plano interno subjetivo de las formas de representación, como sentido del discurso dibujístico. El dibujo del natural se subordina al dibujo de la forma como sistema creado por otros pintores, el manierismo es el dibujo a la manera de... lo que importa es la elaboración de la manera, enriquecida con la construcción conceptual como guía del proceso. 
La ciencia, la filosofía, la pintura, y el dibujo renacentista construyeron una caja plástica basados en la experiencia y el método experimental, en ese espacio se concretaba una definición de la totalidad por medio de un ejercicio de representación, la razón matematizada reprodujo los mecanismos de la visión humana, cuando menos hasta donde se sabía en ese momento y los llevó metodológicamente al cuadro, la postura manierista hallará su clímax en el barroco con la pintura de Velásquez, Las Meninas significan la caída del punto de vista fijo y unitario, el rayo visual y la finestra perta se derrumban ante el acto de mirar y estar expuestos a la mirada múltiple.

El Manierismo y Barroco desarrollan el ámbito de movimiento de la caja plástica en una visión de $360^{\circ}$ y en las seis vistas del cuadrante espacial.

El punto intermedio de conexión lo constituye la postura de Lomazzo nuevamente, se basa en un idealismo teológico, mezclado con la visión racional de las ciencias matemáticas; es por eso que constituye el punto de paso, porque no abandona el racionalismo científico pero en el carácter del dibujo su postura es eminentemente manierista y barroca con la formulación del Serpentinato y el Contraposto sobre todo.

"Y que la pintura es arte se demuestra por la definición del mismo arte, que en definitiva no es otra cosa que una razón recta y regulada de las cosas que se han de hacer. Se demuestra también por ser todas las cosas naturales la regla y la medida de la mayor parte de las ciencias y las artes del mundo, ya que fueron hechas por Dios con suma sabiduría y poseen por consiguiente todas las perfecciones posibles de que son capaces; y por ello pueden ser norma recta de las cosas artificiales; de ahí se deduce claramente que la pintura es arte, porque toma como regla suya las cosas naturales; y es imitadora y como si dijéramos simio de la misma naturaleza, cuya cantidad, relieve y color procura imitar; lo cual hace con la ayuda de la geometría, la aritmética y la perspectiva y la filosofía natural, con tanta y tan recta razón que ya no puede pedirse más."104

El Manierismo tardío ya con las bases del pensamiento barroco en el dibujo, se redondea en la postura de Federico Zuccari (1540-1609). Su tratado de La Idea de los Pintores Escultores y Arquitectos, contiene la postura dominante en la academia Romana que presidió como primer director. La concepción de Zuccari se transmitiría al resto de Europa y la encontraremos en los textos de Pacheco y Palomino en España.

La necesidad de una pintura que se funda en el pensamiento matemático es ya rechazada por este autor. Propone a cambio una visión basada en la observancia de la naturaleza, y en el dibujo como expresión conceptual de representación partiendo de sus propios sistemas.

"Insisto, y sé que digo la verdad, en que el arte de la pintura no toma sus principios de las ciencias matemáticas ni tiene necesidad alguna de recurrir a ellas para aprender ninguna regla y procedimiento para su arte, ni siquiera para razonar especulativamente, puesto que no es hija suya, sino de la naturaleza y del diseño. Una le muestra la forma, el otro le enseña a operar, de modo que el pintor, además de los primeros rudimentos y enseñanzas recibidos de sus predecesores o bien de la misma naturaleza,

104 Freixa Mireia, Garriga Joaquim, Yarza Joaquín, editores. Fuentes y documentos para la historia del Arte. Renacimiento en Europa. Barcelona: Ed. Gustavo Gili; 1983. (IV). P. 312-313. 
por el mismo juicio natural con mucha diligencia y observación de lo bello y lo bueno, se convierte en hombre capaz sin ninguna ayuda ni necesidad de las matemáticas. También he de decir que es verdad que en todos los cuerpos producidos por la naturaleza hay proporción y medida, como afirma el sabio [Aristóteles]; y si, no obstante alguien quisiera dedicarse a examinar todas las cosas y conocerlas mediante la especulación matemática, para obrar conforme a ella, además del insoportable aburrimiento, perdería el tiempo sin conseguir ningún resultado apreciable."105

Zuccari concreta esta postura en la formulación del Diseño Interno y el Diseño Externo. Aquí se sientan las bases de un modelo de pensamiento para el dibujo, que operará hasta la llegada del modelo romántico, incluso, aún en ese momento, se prolongará dentro de la pugna Neoclásico-Romanticismo.

Tomemos en este momento la cita para redondear su definición.

"Por diseño interno entiendo el concepto formado en nuestra mente para poder conocer cualquier cosa y obrar externamente conforme a la cosa entendida. [...] Y antes que nada digo que diseño no es materia, no es cuerpo, no es accidente de sustancia alguna, sino que es forma, idea, orden, regla, término y objeto del intelecto, donde se expresan las cosas entendidas; y se encuentra en todo lo externo, tanto divino como humano, según expondremos a continuación. Ahora, siguiendo la doctrina de los filósofos, digo que el diseño interno en general es una idea y forma en el intelecto que representa expresa y distintamente lo entendido por este, que también es su término y objeto...Y empezando por aquí explicaré que entiendo con este nombre de diseño interno, y de acuerdo con el sentido común tanto entre los doctos como entre el vulgo diré que por diseño interno entiendo el concepto formado en nuestra mente para poder conocer cualquier cosa y obrar externamente conforme a la cosa entendida del mismo modo que nosotros pintores, al querer dibujar o pintar alguna digna historia,"106

Con respecto al Diseño Externo dice lo siguiente:

"Siguiendo pues nuestro planteamiento digo que, para clarificar este concepto y diseño interno y mostrarlo al sentido y al intelecto, es necesario darle cuerpo y forma visual; y para entendimiento nuestro mejor y mayor lo circunscribiremos y le daremos el ser, mostrándolo al sentido con varias delineaciones, asignándole también parte de sus propios instrumentos, según sus varias operaciones. Digo, por lo tanto, que diseño externo no es otra cosa que lo que aparece circunscrito de forma pero sin sustancia de cuerpo. Simple delineación, circunscripción, medida y figura de cualquier cosa imaginada y real. Este diseño así formado y circunscrito con línea es ejemplo y forma de la imagen ideal. La línea, pues, es el propio cuerpo y sustancia visual del diseño externo, de cualquier manera que esté formado;"107

Después de los escritos de la pintura, la perspectiva y el dibujo de Leonardo en 1518, cuando hace su exposición de la pintura como ciencia basada en demostraciones mate-

105 Freixa Mireia, Garriga Joaquim, Yarza Joaquín, editores. Fuentes y documentos para la historia del Arte. Renacimiento en Europa. Barcelona: Ed. Gustavo Gili; 1983. (IV). P. 336.

106 Ibíd., P. 330.

107 Ibíd., P. 335. 
máticas, los tratados tomarán el camino que los aleja de esa postura. Los pensamientos en torno a la belleza, lo inexpresable, la gracia, la imaginación, la dialéctica entre la naturaleza y el origen de la belleza, son incompatibles con la racionalidad sistémica del 1400. Los días de la fe en el número y la razón proporcional quedarían atrás. La pintura había iniciado una separación de las corporaciones gremiales y religiosas.

En la base del Manierismo y el Barroco se encuentra un pensamiento de ascenso aristotélico, en el sentido de ver el dibujo como la autorización del entendimiento para dirigir el discurso, bajo el cause del mosaico sentimental y sensible del gradiente humano, con él, los pintores y dibujantes están autorizados a generar variaciones al modelo natural originando la manera, cosa que no coincidía por supuesto con el planteamiento de demostraciones basadas en el número y la geometría, ni con el rigor científico renacentista y el dominio de la ldea de corte Platónico.

A esto se debe que los sistemas de representación en el Manierismo y el Barroco, si bien mantuvieron el soporte de la geometría y la composición, fue por la necesidad estructural de construir los proyectos que requerían un rigor organizativo proyectual, pero en el terreno estricto configurante, el relato, la historia, el tema del cuadro incitaría a los artistas a correr en el camino de la desbordada fantasía de las formas.

Una cita más de Felipe de Guevara pone en perspectiva precisa la postura manierista, en el sentido de crear un sistema conceptual que guarde la representación de la imagen concebida y la parte del dibujo que se avoca a su explicitación en el plano del papel.

“... es de saber que hay dos maneras de imitación: la una es cuando con el entendimiento y la mano imitamos lo que queremos y esta es el arte de pintar, y la que llamamos pintura. La otra es solo el entendimiento, cuando solo el pensamiento imita alguna cosa,... La más cumplida es la primera, cuando juntamente con el entendimiento las manos demuestran la semejanza de las cosas que están imaginadas. Esta que es de mayor cumplimiento sirve para mostrar las cosas que la imaginativa en su idea tiene concebidas."108

Es esta capacidad de tensar el concepto y someter el acto del trazo a la reflexión de la representación, la que ya no abandonará al dibujo en todas sus concepciones posteriores, el dibujo como el campo del debate de la idea, estará presente incluso en los momentos en que el arte linda con lo inefable y el terreno de lo emocional. La oposición florentina y veneciana, la manierista renacentista, la neoclásica romántica y todas las demás mantienen sin embargo la función proyectual del dibujo como el que centra el concepto de la representación en la construcción de la obra. Las maneras variarán, la postura con que se concibe la estructura de representación y las acciones de configuración también; pero la función de operar como directriz conceptual que busca los nexos de solidaridad en la obra como sistema inscrito en un pensamiento proyectual, indistintamente de la lógica casuística, será la constante del dibujo.

Decir Barroco es expresar un calificativo hasta hoy día, en él se comprende el significado de lo recargado y hasta el exceso de formas no necesarias a la construcción del mensaje, esta apreciación es coherente con el ideal que inicia el dibujo manierista y en los autores barrocos.

108 Freixa Mireia, Garriga Joaquim, Yarza Joaquín, editores. Fuentes y documentos para la historia del Arte. Renacimiento en Europa. Barcelona: Ed. Gustavo Gili; 1983. (IV). P. 47. 
A manera de comprobar que nuestras palabras no son excesos de invención citaremos un pasaje del tratado de Antonio Palomino, Museo Pictórico y Escala óptica en el que hace un comentario sobre la pintura de Doménico Teotocópulus, mejor conocido como El Greco, lo menos que colegimos es que le señala el exceso y la exageración de sus gustos en las licencias de representación.

“... fue gran pintor y discípulo de Ticiano, a quién imitó de suerte, que sus pinturas las equivocaban con las de su maestro; como se ve en muchas de las que ejecutó en España... Pero él, viendo que sus pinturas se equivocaban con las de Ticiano, trató de mudar de manera, con tal extravagancia, que llegó a hacer despreciable y ridícula su pintura, así en lo descoyuntado del dibujo, como en lo desabrido del color."109

Como estilo artístico el barroco surgió a principios del siglo XVII y de Italia se irradió hacia la mayor parte de Europa. Posteriormente fue revalorizado a fines de siglo XIX por Jacob Burckhardt y luego por Benedetto Croce y Eugenio d'Ors. Fue finalmente rehabilitado en 1888 por Heinrich Wölfflin (1864-1945), quién identificó al Barroco como oponente al Renacimiento.

Ya hemos señalado la mesura del Renacimiento y el inicio dinámico del Manierismo, en la Roma de los Papas se advierte la necesidad de un arte nuevo. Para mejorar el ejercicio de su gobierno, las altas esferas eclesiásticas dominantes en Roma hubieron de depurar su cúpula. La necesidad de reformar las estructuras del mundo católico es lo que conduce al Concilio de Trento y a la llamada Contrarreforma, que realmente es una Reforma católica, que no va contra algo sino en busca de la adaptación a los nuevos tiempos.

El impacto de todo esto sobre el arte genera importantes consecuencias desde el primer momento. Los teólogos reunidos en el concilio proclaman ciertos dogmas que han de ser representados dignamente por los artistas al servicio de la Iglesia: la virginidad de María, el misterio de la Trinidad, entre otros, pasan a protagonizar los lienzos. La Iglesia, fue la primera en comprender el poder ilimitado del arte como vehículo de propaganda y control ideológico. Por esta razón se convierte en un comitente que emplea grandes cantidades de artistas, para llevar a cabo un arte, directo, fácil de leer, que cualquier fiel que se aproxime a una iglesia pueda comprender de inmediato. Los santos dejan de vestir como cortesanos para aparecer casi como pordioseros, con rostros comunes. El énfasis de la acción ha de colocarse sobre el dramatismo. Las escenas se vuelven dinámicas, lejos del hieratismo intemporal de los estilos anteriores. Las composiciones se complican para ofrecer variedad y colorido. Las luces, los colores, las sombras se multiplican y ofrecen una imagen vistosa y atrayente. Fuera del patrocinio de la Iglesia, los mecenas privados se multiplican: el afán de coleccionismo incita a los pintores a llevar a cabo una producción de pequeño o mediano formato para aumentar los gabinetes de curiosidades de ricos comerciantes y alta nobleza.

La secularización de esta época propició que se revalorizaran géneros profanos, como el bodegón o el paisaje, que empieza a cobrar una autonomía inusitada. Las complejas composiciones del Barroco, la diversidad de focos de luz, la abundancia de elementos, todo, puede aplicarse perfectamente a un paisaje. El Barroco como estilo es tan sólo una intención de base. Las formas que adopte en la praxis serán tan variadas como se pueda imaginar.

109 Palomino Antonio. El Museo Pictórico y escala óptica. Madrid: Ed. M. Aguilar; 1947. P. 840-841. 
Dentro de la literatura satírica y burlesca de Italia el término Barroco se utilizaba en 1570 para designar una idea grotesca y graciosa. En los talleres y estudios de los pintores el término se aplicaba en la descripción de los contornos curvilíneos de los muebles y para señalar la disolución de los contornos firmes en la pintura.

Tenemos dos acepciones iniciales, una que se refiere al terreno de la pragmática como valoración de la forma, y la otra que precisa la relación ya no del término, sino del concepto baroquer como una situación formal de la estructura del dibujo.

La crítica comienza a usar el término frecuentemente desde mediados del siglo XVIII, pero lo hace como calificativo en el sentido negativo. Se dice que los artistas avanzados del XIX son los primeros en reconocer las características positivas y altamente valiosas de la pintura de autores como Diego Velázquez1599-1660, Rembrandt 1606-1669, Peter Paul Rubens 1577-1640 y Franz Hals 1591-1656

El Barroco es un movimiento íntimamente ligado al desarrollo de las academias, con sus teorías y discusiones, una de ellas particularmente que interesa en este análisis, la que busca aclarar la supremacía del color sobre la concepción lineal de la pintura.

Independientemente de los cambios formales de representación el Barroco desarrolla la revolución temática de la pintura y el dibujo. Los géneros como demarcaciones temáticas ya eran practicados desde el trabajo manierista, pero con el mercado y la expansión filosófica del Barroco se potencia su consolidación como centros autónomos. La práctica de dibujar en locaciones externas al taller del artista se vuelve ejercicio común y las partes estratégicas y metodológicas del dibujo se decantan claramente. El Apunte, el Boceto, el Estudio y el Proyecto adquieren definición metodológica en el ideario del artista y dibujante. Pero así mismo se les dota de una categoría ontológica que un poco más tarde los convierte en ejes de desarrollo de la interioridad teórica del dibujo.

Particularmente el Boceto se considera una aportación de la visión barroca del dibujo y la pintura. Consiste generalmente en trabajos pequeños preparatorios para obras mayores, sirviendo de base para el establecimiento de los contratos entre el cliente y el pintor, bocetos sobre los que se realizaban los ajuste convenidos por las partes.

El boceto lleva al interior de la obra una riqueza cromática nueva, una ligereza en el trazo del dibujo que se mantiene hasta la obra terminal, una subjetivación mayor de la imagen y una comprensión sensualista de la materialidad de la obra. Fig. 42
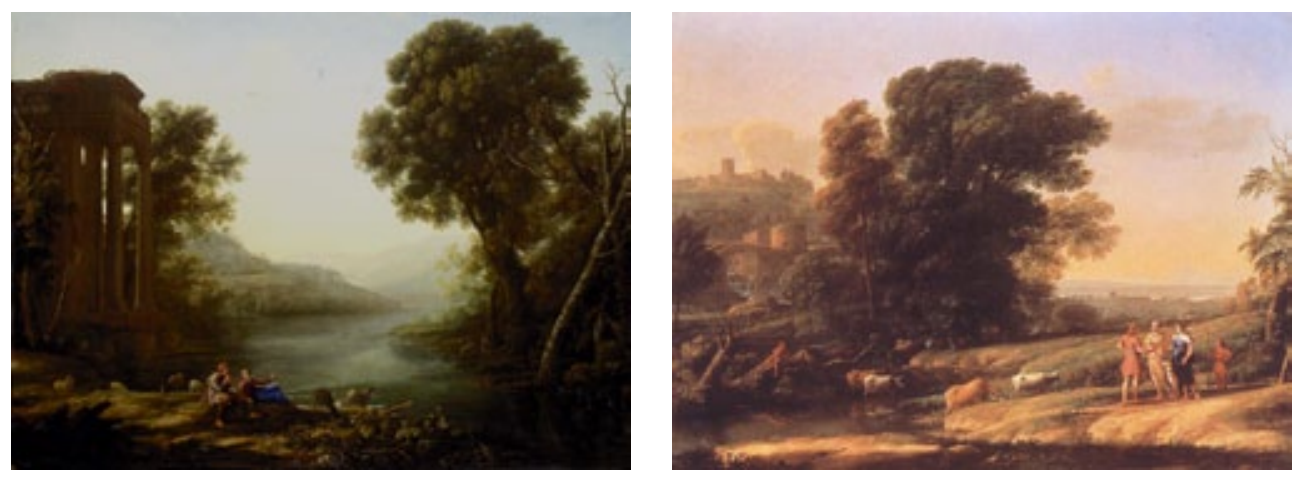

Fig. 42. Barroco y Paisaje como Pintura de Género. 
El ser humano no desaparece completamente de la representación de la obra, pero la naturaleza no domesticada por el hombre comienza a desplazar la visión antropocéntrica, para en su lugar cobrar un espacio distante de la función decorativa, en este punto arranca la postura Pintoresca y Sublime de la estética. El cuadro de género rebasa los límites del individuo para constituirse en un retrato social, en él se contiene una visión moral universal inmanente en las escenas de la vida diaria.

El Barroco desborda la iniciativa manierista y logra la sugestión de un espacio fantástico, en parte por la relación decorativa e integrada que la pintura había logrado con la arquitectura, la decoración de muros, tondos y techos es típica de ese momento.

Este es un punto que deseamos destacar. En la pintura barroca el dibujo mantiene una relación de lenguaje sobre la base de la dinámica compositiva y la estructura or-

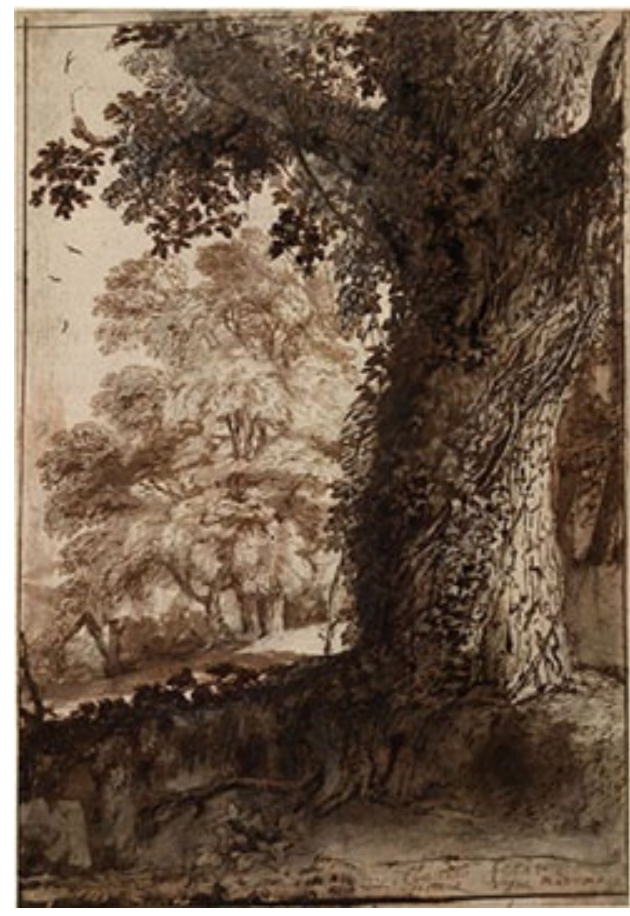

Fig. 42. Barroco y Paisaje como Pintura de Género. (Cont.) ganizativa de la figura humana, en parte como continuidad del dibujo manierista, este asunto ya lo hemos revisado.

Los pintores barrocos en el sentido anterior se mantienen en el desarrollo dramático de la composición sobre la base teatral lumínica, (Caravaggio, Zurbarán, Rubens, Rembrandt etc.) también mencionamos el periodo barroco como el tiempo de la explosión de la pintura de géneros, pero nos interesa destacar la relación del dibujo barroco en su unión con la pintura, la arquitectura (fenómeno que ya se inicia en los dibujos de proyecto y diseño de Miguel Ángel) y aún las artes decorativas. En este terreno se suscita el fenómeno de multiplicación exacerbada de las partes dentro de una composición y de las formas de estructura rebuscada Fig. 43

La primera obra es el Baldaquino, la segunda El trono de San Pedro y la tercera la Tumba del Papa Alejandro VII, las tres ubicadas en la Basílica de San Pedro en Roma, todas realizadas por Gianlorenzo Bernini.

Como se observa en las imágenes, y, como lo han señalado otros analistas la forma de los objetos se perfila de manera precisa y limpia, es un ejercicio del dibujo sumamente tectónico y escultórico, pero su carácter oval, serpentinado y múltiple, provoca un efecto de retroacción al convertirse en una explosión lumínica y atmosférica.

También se ha señalado el carácter cósmico en cierto sentido del espacio formal del Barroco y su proyección de mensurabilidad casi infinita.

Vemos el Barroco como un espacio de reflexión conceptual donde el dibujo potencia su 

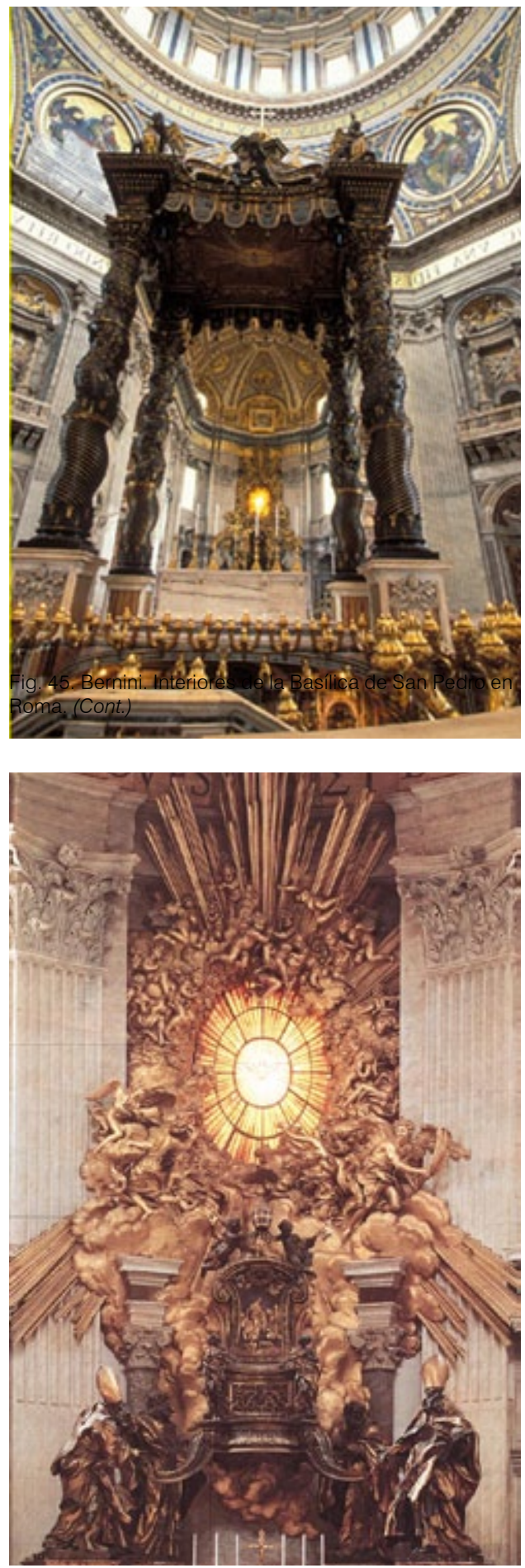

Fig. 43. Bernini. Interiores de la Basílica de San Pedro en Roma.

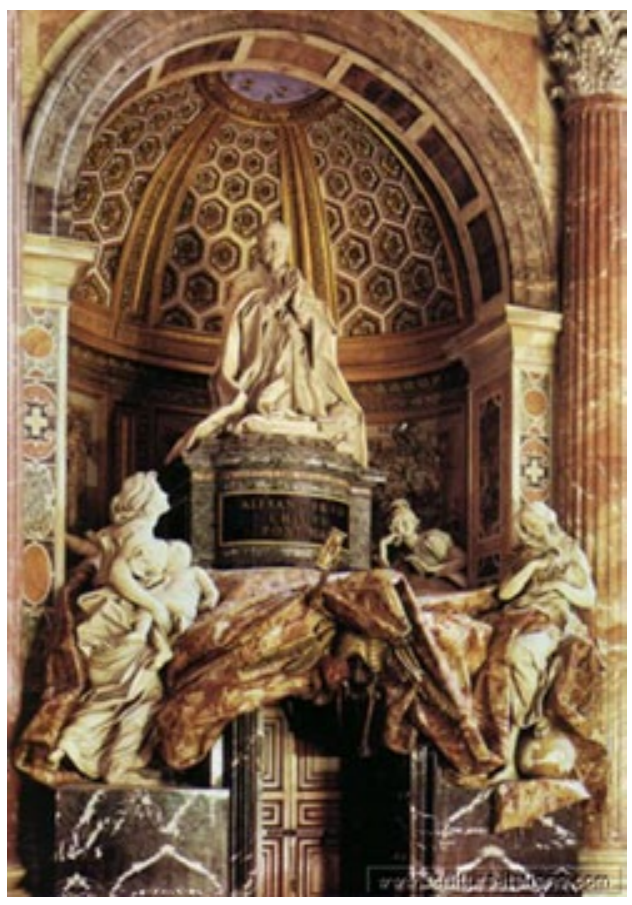

capacidad proyectual y retribuye ampliamente a otros campos del arte como pensamiento del proyecto histórico y artístico. El Barroco es una maquinaria formalizante de complejidad inaudita, que rebasa los límites de un adjetivo calificativo para expandirse al terreno de lo sustantivo.

En este punto de la historia del dibujo se inicia un concepto al que nosotros hemos denominado Masa Visual Retroactiva, formas de distinto peso y grado que se conjuntan constituyendo una forma aditiva nueva, esta se alimenta a si misma hasta conformar un conjunto de sensación inmaterial y no concreta.

Para nosotros el Barroco es un complejo de formas aditivas que se expresa en la forma arquitectónica integral compleja, resuenan en nuestros oídos las estructuras compositivas de los conciertos para órgano de Juan Sebastián Bach. 
Esta noción de masa visual compleja, se expresa en una diversidad infinita sobre la gama de autores del dibujo y la pintura, y en los conjuntos de soluciones formales que utilizan. Vemos al Barroco como la primera generación de una industrialización de la forma del dibujo y las artes, si es que se puede decir de esta manera. Una verdadera maquinaria formal y matérica.

Traemos a colación los bocetos de Rubens y algunos dibujos de Rembrandt. Ya más adelante terminaremos con el análisis de la relación entre el dibujo y la pintura que se muestra en la función indexal de la pincelada con la forma y el color dentro de la pintura de Velázquez, Rembrandt y Franz Halls, como ejemplos de la teoría estructural del dibujo en el movimiento barroco. Fig. 44

Una situación importante en el terreno del dibujo barroco es la relación que el claroscuro guarda como proceso dibujístico, pero que se introduce también en una complicada estructuración del fenómeno cromático. La Pintura Tenebrista constituye un núcleo esencial del periodo barroco, el claroscuro ya era muy bien entendido como un generador de relieve y estructura topológica, tanto como el verdadero organizador de la composición lumínica y la espacialidad virtual. En el Barroco el claroscuro se desliza desde las atmósferas apacibles y divinas de Leonardo hacia la liberación del conflic-
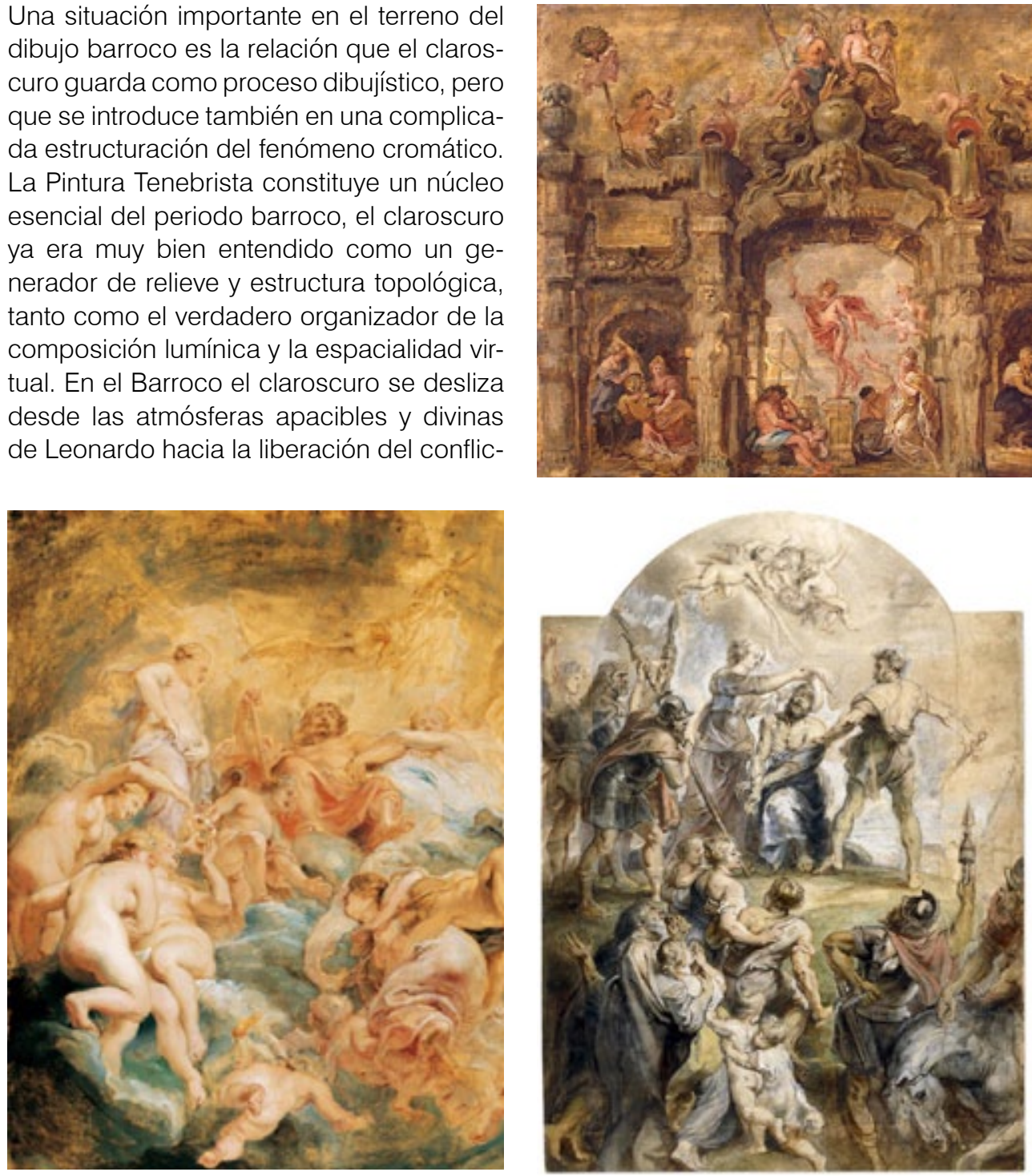

Fig. 44. Rubens: Bocetos. 

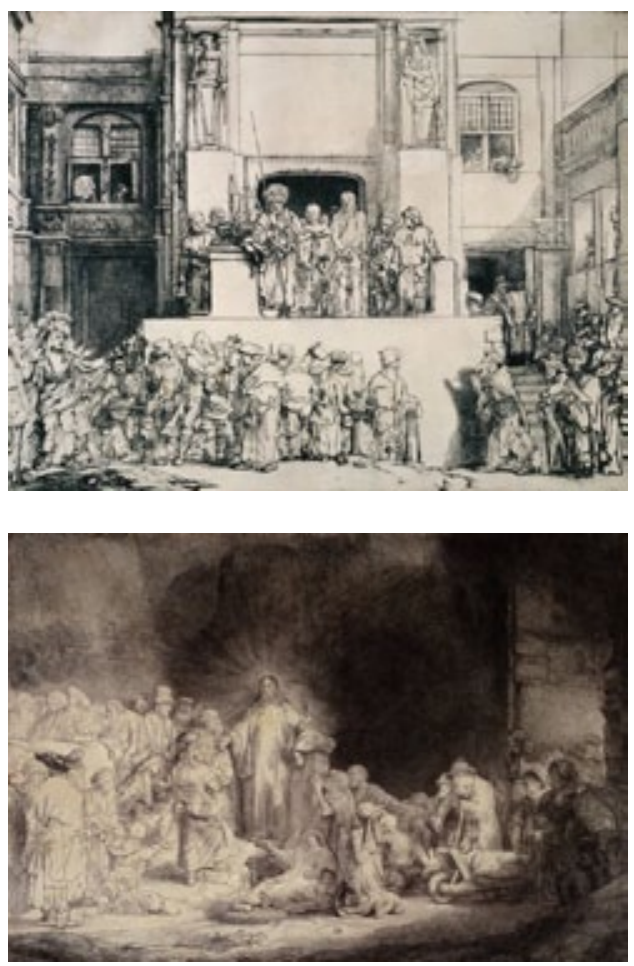

Rembrandt. Dibujo y aguafuerte

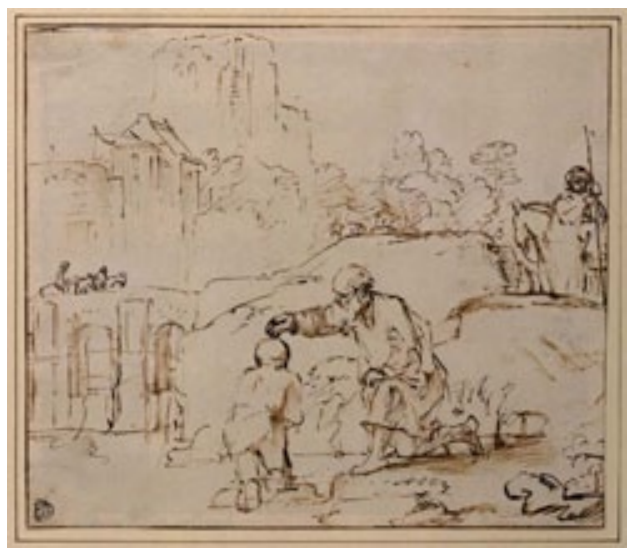

to dramático que se muestra no solo en la expresión fisiognómica sino en la tensión lograda mediante el gradiente lumínico. Es paradójico que dentro del mismo movimiento encontremos expresiones magistrales como las de José de Rivera de fuerte austeridad y la de Peter Paul Rubens con su explosión cromática.

Entre muchas variaciones, el Barroco presencia el ascenso de la crítica de arte como el territorio que se ocupa del análisis temático y su tratamiento acertado en la pintura y el dibujo.

Deja posicionado al dibujante y al artista en el terreno de la construcción de las formas como sistemas de representación, la configuración de la obra será la trinchera del dibujante en la que toma posición.

La anécdota de los hermanos Carracci es un ejemplo; Agostino disertando sobre las virtudes de Laoconte invitando a Annibale a emitir su opinión, este se limitó a escuchar y al final trazó de manera precisa la escultura en un dibujo sobre la pared, argumentando que los dibujantes deberían hablar con las manos; es el fin de la era de los artistas científicos que vuelcan su conocimiento en tratados de rigor teórico sistémico.

La consolidación de la pintura en un radio que se expande desde el epicentro italiano, será un proceso que llevará tiempo. La onda expansiva del renacimiento y sus bases clasicistas se prolongará de manera un tanto retardada. Pero en este fenómeno de ecología artística tenemos que considerar la visión de Panofsky, en donde el Renacimiento se sucede en zonas múltiples con afectaciones complejas, para nuestro punto de análisis, dentro de la Pintura Barroca comienza a darse un proceso en el que las aportaciones y causalidades de la pintura Flamenca toman el relevo en las variaciones sobre los sistemas de representación del dibujo.

Vicente Carducho, Francisco Pacheco y Antonio Palomino son los exponentes del manierismo y el barroco en España, son autores que tienen muy bien revisada la postura y los 
tratados renacentistas Italianos, su concordancia con el dibujo como ordenador de la idea y constructor de la secuencia formal es clara. Pensamos que con ellos prácticamente se inicia la sólida tradición del buen dibujo que permea el arte español desde entonces.

Las siguientes palabras de Vicente Carducho contienen una belleza transparente porque nos muestran como ya para 1633, año en que se publican sus Diálogos de la pintura, existía una conciencia clara del proceso teórico e histórico del dibujo desde el siglo XIII. Aunque abundan sobre puntos que ya hemos expuesto las incluimos como parte de una conciencia sobre los modelos históricos.

"El año de nuestro bien de 1240 nació en Florencia Juan de Cimabue de padres nobles y el que dio principio a la primera edad. Aprendió esta arte aventajándose a sus maestros griegos, aunque siempre en aquella poca noticia de la buena pintura [...]. Tuvo algunos buenos discípulos en aquella ciudad, uno de ellos fue Giotto, que así mismo dejó atrás a su maestro. El año de 1417 nació en Florencia Masaccio (admirable natural) que murió a los 26 años [...] este con pasmo de todo el arte reconoció la mala manera que hasta entonces se había practicado y supo advertidamente elegir una buena y dar luz para lo perfecto. Fue el primero que cual otro Cinón Cleoneo hizo escorzos, buenas proporciones y tintas; señaló pliegues en los paños con gracia y propiedad: mostró en los rostros la variedad de los afectos, no platicada hasta entonces [...] y dio principio a la segunda edad. Michaelangelo Buonarroti dio principio a la tercera edad y no se si ose añadir fin a ella, como término final de la excelencia científica destas artes y el non plus ultra de ellas." ${ }^{\prime 10}$

La secuencia de impacto de la revolución italiana del 1400-1500 y hasta adentrado el 1600 , provoca en otros países europeos un sentimiento de independencia cultural, las causas del desprendimiento del dibujo de una matriz italiana son muy complejas.

Analizando la evolución del pensamiento proyectual del dibujo, tenemos que el fenómeno de expansión de los cambios artísticos al dirigirse hacia el centro norte de Europa traerá como consecuencia cambios relevantes que impactarán el núcleo de la disciplina del dibujo en su carácter epistémico.

Las conferencias dictadas en el interior de la academia Francesa por Roger de Piles y Le Brun desatarán una oposición que surge por una diferencia de opinión sobre la obra de Ticiano.

El resultado será la polémica entre coloristas que toman a Rubens como bandera y los clasicistas que se arropan en la figura de Poussin.

La batalla se define a favor de los coloristas aunque para este análisis es poco relevante en si mismo el resultado.

Nuevamente el conflicto que se libra bajo esta disputa es el del color como elemento sensible y con mayor poder de representación y evocación, por sobre el dibujo que significa la postura del pensamiento abstracto y normativo. Los síntomas del conflicto entre coloris-

110 Freixa Mireia, Garriga Joaquim, Yarza Joaquín, editores. Fuentes y documentos para la historia del Arte. Renacimiento en Europa. Barcelona: Ed. Gustavo Gili; 1983. (IV). P. 162. 
tas y dibujantes en la pintura se anunciaron en el manierismo y maduraron en el Barroco, desde entonces, no dejará de ser un conflicto teórico disputado.

Ahora el dibujo y sus representaciones se flexibilizan hacia una postura hedonista que se impone sobre el idealismo racional del Renacimiento.

No se trata de un cambio radical, esos no existen al cien por ciento. Es un acento diferente. Con la ponderación del color sobre el diseño se le retira a la pintura la responsabilidad de ser fuente de enseñanzas didácticas y morales, en su lugar será fuente de sensaciones y poco a poco asumirá un papel lúdico, de ahí que los temas mitológicos comiencen a compartir espacio con la pintura de género, y especialmente el paisaje que a la larga sería el centro de las representaciones del dibujo.

Pero para nosotros, la relación entre la pintura, como arte del color y su visión sensible, hacia el dibujo como ciencia racional del concepto lineal, reviste un sentido teórico mucho más profundo, uno que no alcanzamos a detectar en los análisis que hasta ahora investigamos.

De hecho, ya desde puntos anteriores nos basamos en la relación sistémica que se establece entre los procesos conceptuales y formales del dibujo, junto con los procedimientos técnicos de la pintura, y de cómo esto implica una relación sustancial en la que el dibujo permea la interioridad de la acción pictórica, y ésta a su vez obliga a modificar la forma en que se conceptualiza la racionalidad del dibujo.

Para nosotros esta es una de las maneras en que trasladamos el hecho de teorizar a la interioridad del ejercicio disciplinar, al que en la parte inicial de este capítulo dedicamos largas líneas.

Al mencionar el trabajo pictórico de Miguel Ángel en la Sixtina, hacíamos mención a incipientes modificaciones en la huella estructural e indéxica de la pincelada. Situación que dio al golpe de pincel una autonomía constructiva sobre las prácticas técnicas procedimentales propias del Renacimiento.

En la pintura barroca este proceso se consolida y desemboca en una fusión conceptual, donde dibujo y pintura se integran para lograr una ingeniería nueva de representación formal del código visual y procedimental.

Particularmente en el caso de los trabajos de Franz Hals, Diego Velázquez y El Greco se aprecia el proceso al que nos referimos y que consideramos una de las características importantes del dibujo barroco y a la que hasta ahora se la había concedido nula atención. En lo general podemos decir que la pincelada en la pintura renacentista estaba reducida a toques de la herramienta, segmentos cuya forma era esencialmente lineal, agrupadas en bloques con ritmo que estaba en relación al modelado el sfumato y el relieve de las superficies. Con la pintura barroca la pincelada adquiere campo, extensión y forma de superficie, incluso inicia un proceso de disolución de la continuidad de las superficies que se modelan, deja toques sueltos de color y pincel sin una liga concreta a la continuidad de los planos del modelo, esto le confiere una cierta esencia gráfica.

Con el proceso que mencionamos se obliga al dibujante a adaptar la conceptualización de sus prácticas, ya que ahora el dibujo opera como estratega mental para determinar la estructuración del proceso que hemos mencionado. Pensamos que en un sentido tiene razón la reflexión teórica sobre la linealidad del dibujo y la esencia cromática de la pintura, 
pero vemos que existió en ese momento una integración de las estructuras codificadas del dibujo y la pintura que integró sus niveles de conceptualización.

La pintura modelada renacentista fue cediendo hacia una pintura modulada, de calidad más sensual y gestual, una donde la huella indexal del dibujo ya no se ocultaba dentro de la continuidad técnica de la superficie, sino que ahora se convertía en logro a perseguir, una pincelada del dibujo que mostraba claramente la estrategia de construcción y entendimiento de la forma. Fig. 45
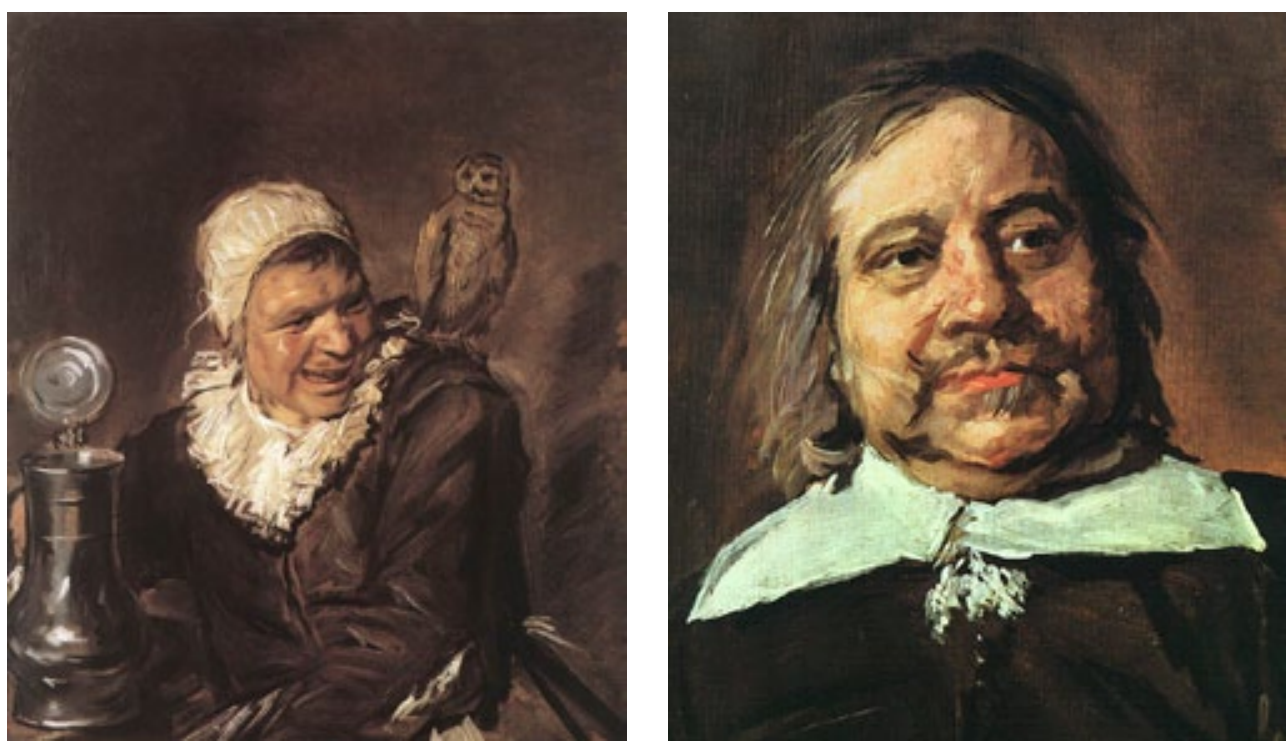

Velázquez y Rubens en sus dibujos se nos muestran claramente clasicistas, lineales y definidos en la forma, pero al realizar una visión macro de sus pinturas encontramos la interiorización del dibujo en una conceptualización que organiza la materialidad pictórica y la pincelada con sus atributos formales. Fig. 46

El desplazamiento geográfico del renacimiento desde Italia hacia Francia, Holanda Alemania e Inglaterra, traza una línea que lleva los valores del proyecto del dibujo desde el racionalismo experimental y científico, hasta la estética de la sensualidad

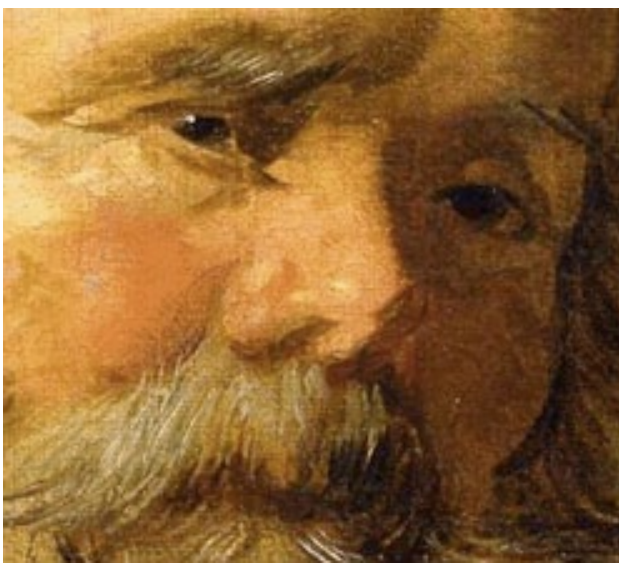

Fig. 45. Franz Hals. Detalles de retratos cromática tonal, el extremo de esta ruta lo constituirá la valoración de los motivos temáticos tomados de la naturaleza, pero no como el fenómeno de disección experimental, sino como la fuente de sentimientos subjetivos y estímulos al espíritu poético y sublime del dibujante. 

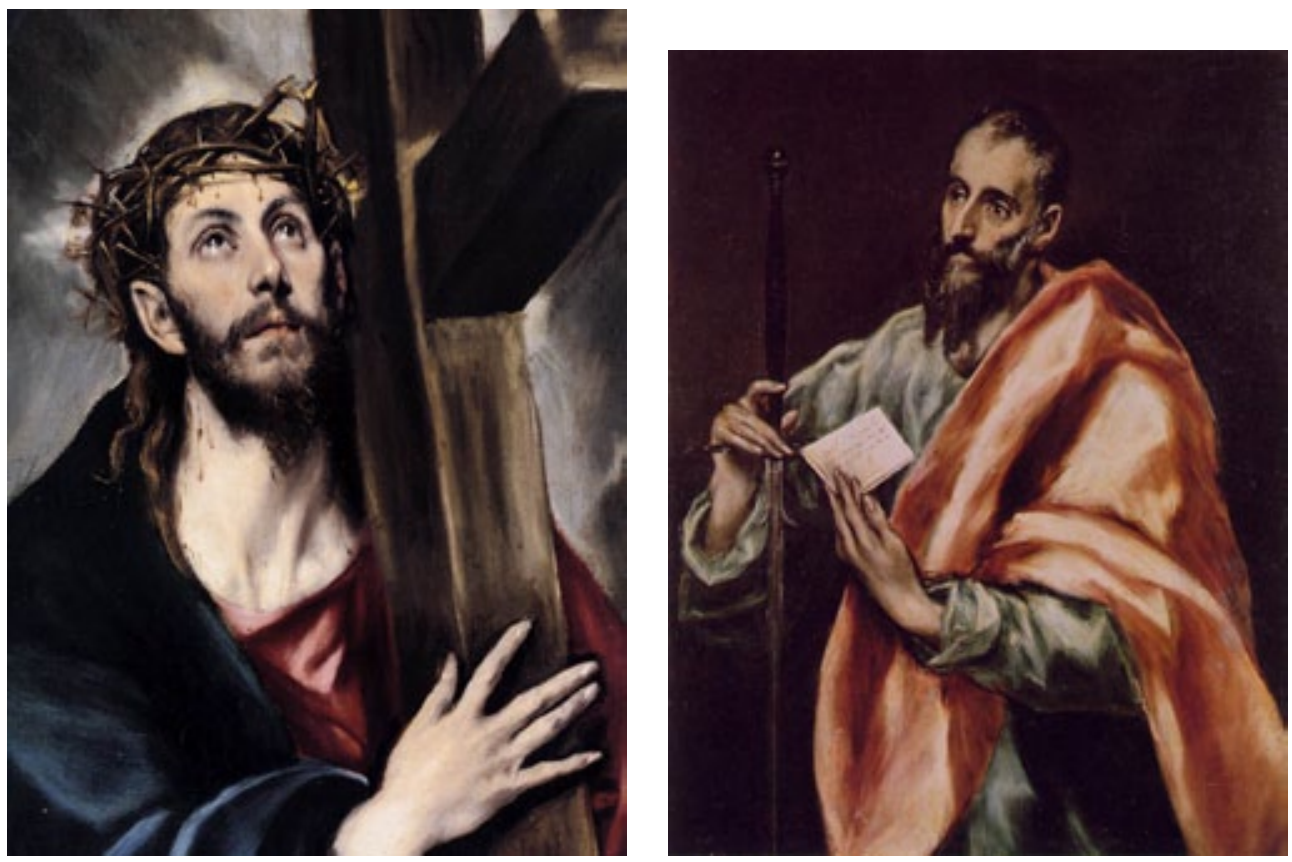

Doménikos Theotokópoulos. Cristo y Apóstol San Pablo
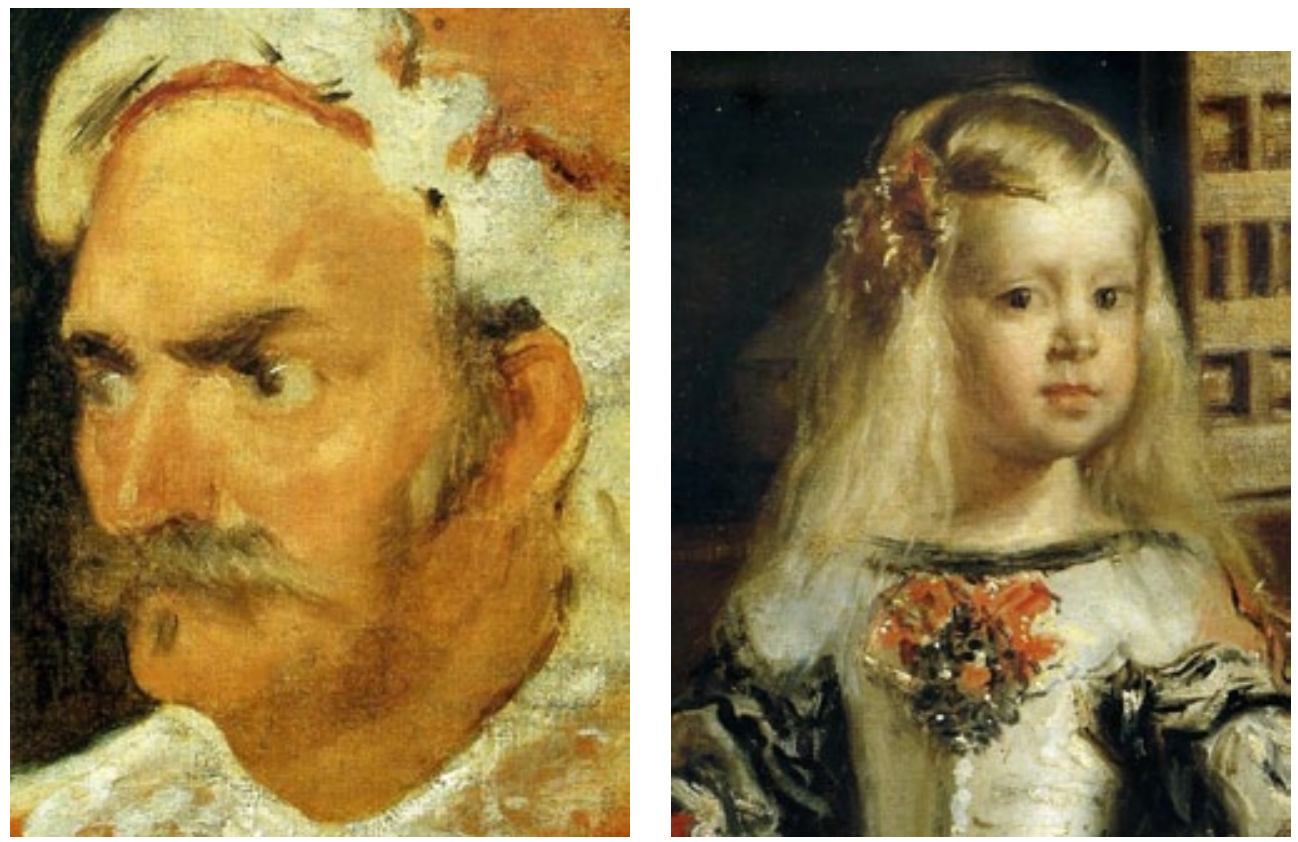

Diego Velázquez. Bufón e Infanta. Detalles 

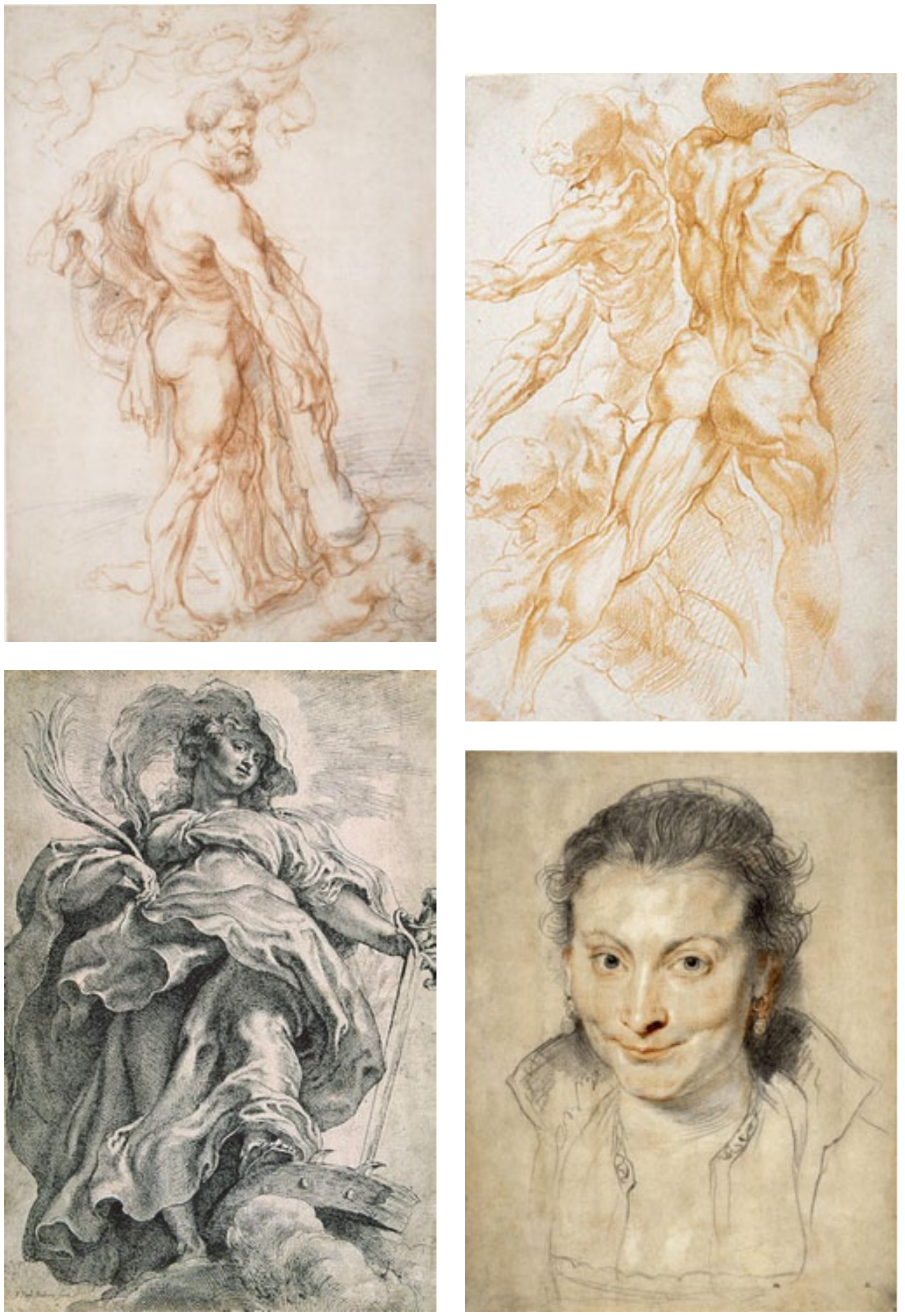

Fig. 46. Rubens. Estudios y retrato. 

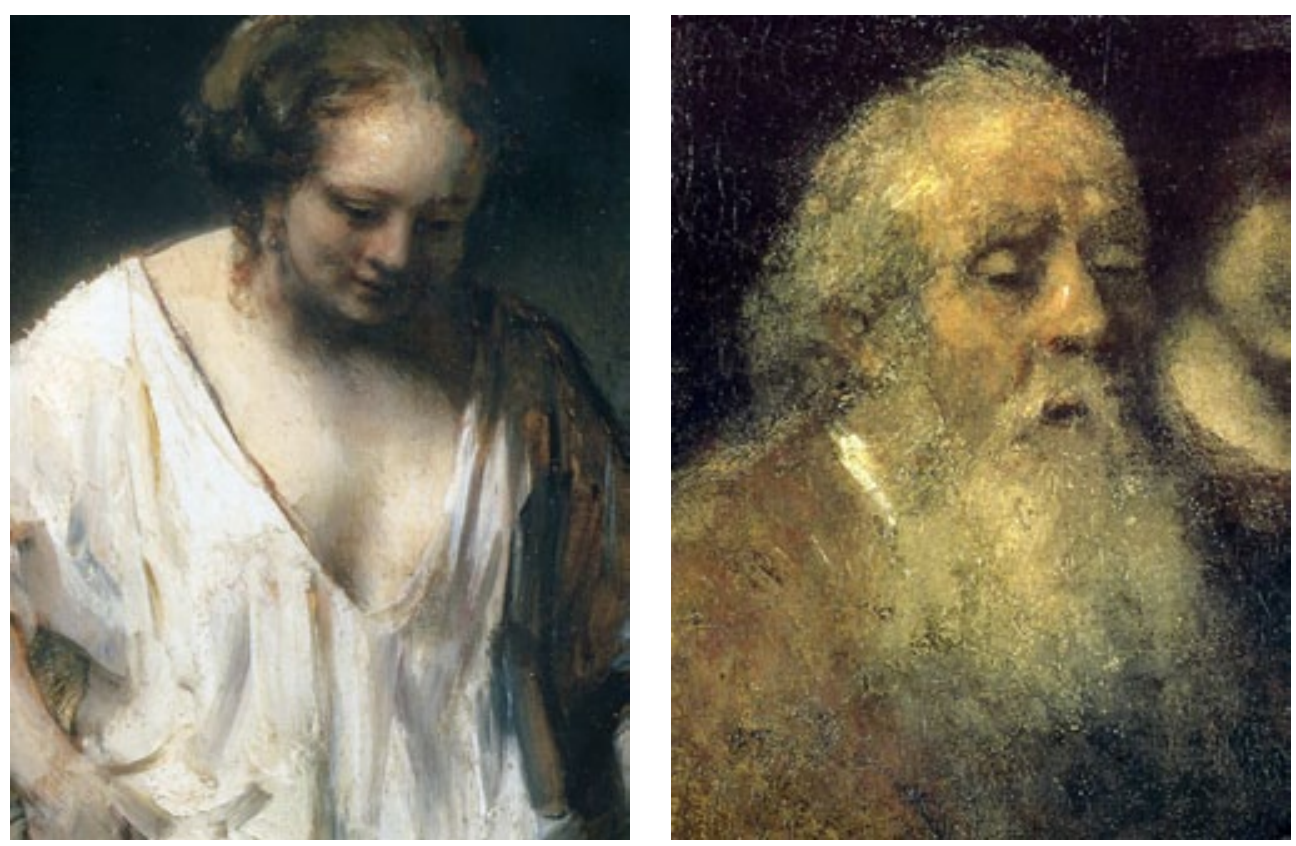

Rembrandt. Pincelada Indéxico Matérica con estructura de dibujo subyacente.

La selección de modelos femeninos que hace Rembrandt es por todos conocida, ninguna Venus puebla sus pinturas, la carnalidad mundana se muestra en toda su expresión, los temas bíblicos son parte considerable de su obra, pero tiene innumerables libretas de dibujos en los que analiza insistentemente el paisaje. Dibujo y paisaje fueron un polo de reflexión para este pintor.

No adelantaremos el análisis, pero este será el relevo en el nuevo modelo del pensamiento del dibujante en el siglo XVIII. Fig. 47

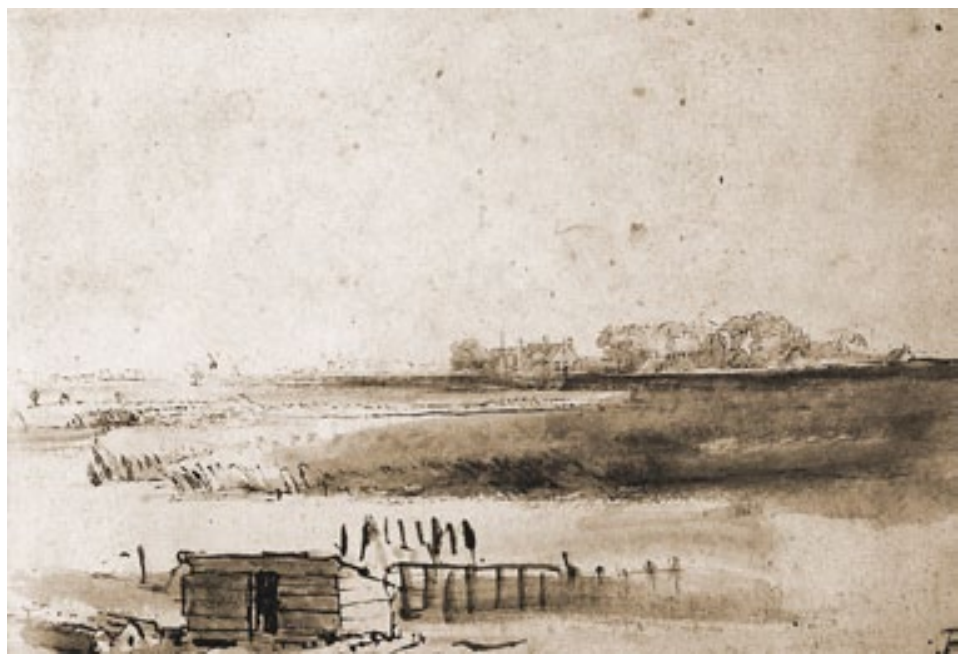

Fig. 47. Rembrandt. Tinta, dibujo de paisaje. 


\section{III-6-3 DEL NATURALISMO AL ROMANTICISMO EN EL DIBUJO}

El método comenzó a desviarse de la visión disciplinar ortodoxa y se dirigió poco a poco a la adaptación vivencial del dibujante, no se buscaría ya más el establecimiento de una senda lineal metodológica única y convenida casi siempre al interior de la academia.

Cuando el Barroco y sus teóricos plantearon el beber en la fuente de la naturaleza, aumentando las representaciones con la imaginería del dibujante, poniendo como único freno el decoro y el buen juicio, dejaron entonces la puerta entreabierta para que se perdiera el decoro y el buen juicio precisamente.

En el Renacimiento el arte sale del claustro monástico al gremio, su permanencia ahí es fugaz, las alcabalas y las limitantes estrangulaban al artista, los casos de pintores al margen del sistema gremial aumentaron. La academia nace con espíritu Platónico en el sentido de reunirse para discurrir el sentido profundo y último de la idea del arte. Pero también tiene el carácter de establecer un nuevo cerco a las liviandades del artista. El poder que Zuccari tenía como Príncipe de la primera Academia Romana llegaba incluso a poder decretar la prisión de alguno de los miembros. Fig. 48
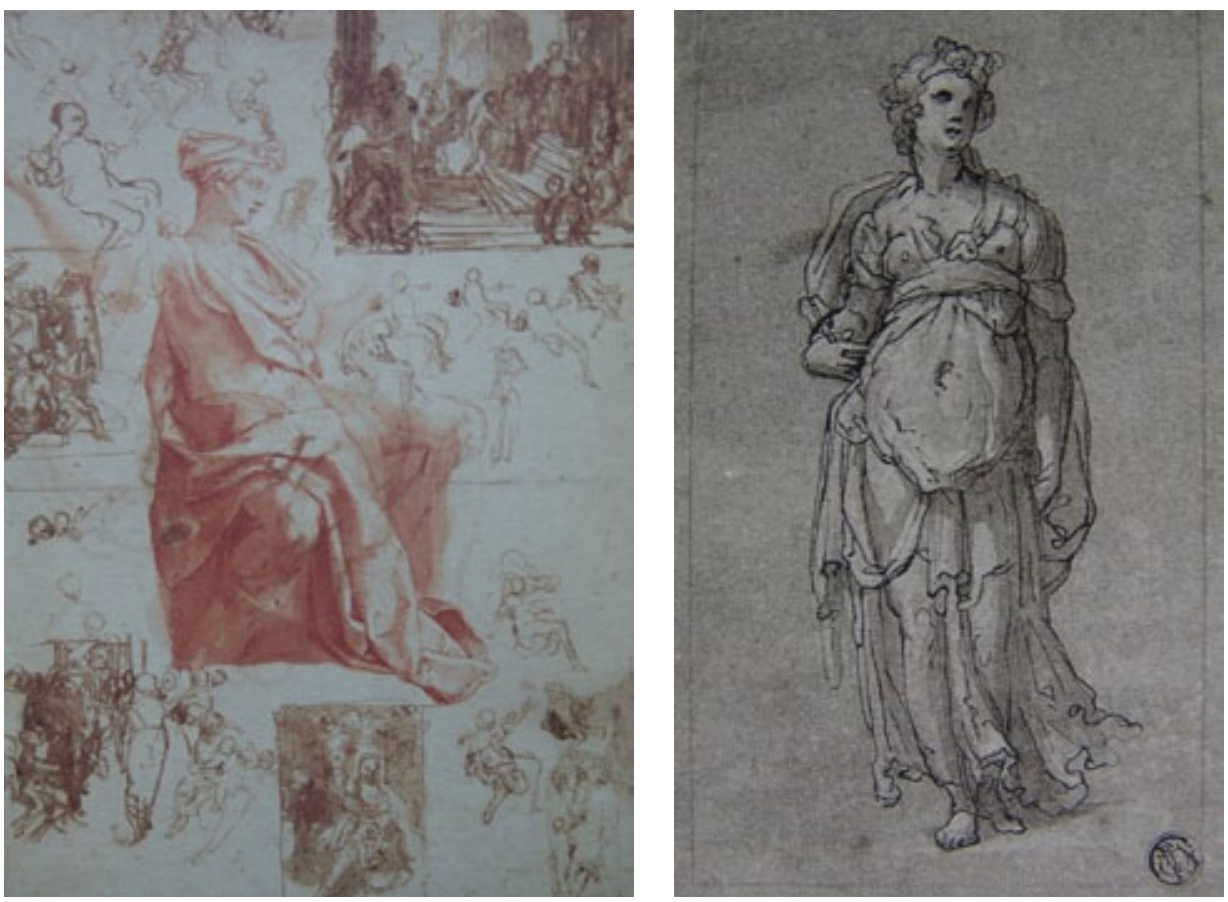

Fig. 48. Federico Zuccari. Dibujos.

No es muy conocida la rebelión del Greco hacia las alcabalas que se tenían que pagar en sus tiempos, como ahora, por la generación de la pintura; la solución: Empeñaba los cuadros y no los vendía.

Con la incidencia en las academias de personalidades que no producían dibujo, pero si producían discurso, se siembra uno más de los elementos que llevarán a la fractura de ésta, como factor unidireccional de creación del proyecto para el dibujo. 


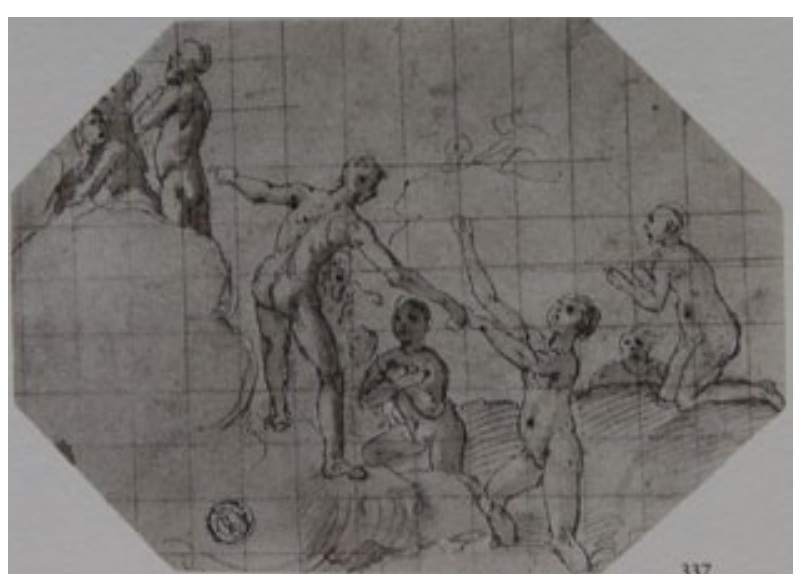

Fig. 48. Federico Zuccari. Dibujos. (Cont.)

Lo que acontecía en Holanda con el caso de Rembrandt pintando gente del vulgo, que por supuesto no coincidía con ningún canon de belleza clásico generó muchos escándalos. Varios de sus cuadros al igual que algunos del Greco fueron rechazados por quien los había encargado.

Vermeer van Delft 1632-1675 es también un pintor de la vida común, en su trayecto como artista no pintó ningún gran encar-
comunes como las que pueblan go, solo pequeñas pinturas destinadas a personas tan comunes como las que pueblan sus imágenes.

La medida del buen juicio exigida en el Barroco, se irá diluyendo poco a poco en una postura que prioriza cada vez más el carácter de las cosas tal cual se dan en su contexto natural, no se intenta ya asemejarlas a ningún canon de representación preexistente, se les tomará como generadores del propio sistema de valoración de las representaciones. Ya no se estructura a la naturaleza, podríamos decir que se desnuda a la naturaleza, se pone la mirada en su transcurso sin la afectación del dibujo métrico estructurante. El tiempo como circunstancia que marca un momento le da especificidad al dibujo, vuelve irrepetible cada momento como posible generador de una circunstancia plástica. La materialidad en su contraste se inclina por la exhibición y preferencia de aquellas cosas que tienen una materialidad contrastada, se les considera óptimas para la generación de sensaciones discursivas en el cuadro.

Rubens, Velázquez, El Greco, Franz Halls y Rembrandt constituyen un cuerpo de pintores barrocos. Pusimos nuestro interés en su trabajo porque ahí se encuentran los pasos de una secuencia traslativa de los conceptos del dibujo; y porque ellos particularmente dedican un espacio en su obra al género del paisaje. No nos interesa el género en sí; nos atrae reflexivamente porque dentro de su práctica se gestan circunstancias conceptuales y procedimentales que operan como el impulso de un nuevo pensamiento del dibujo.

Aunque su cronología no rebasa los años del 1690, en su trabajo tenemos ya redondeada la visión de una naturaleza que se potencia como centro semántico del arte.

El siguiente grupo y cadena de autores se sobreponen inicialmente a esta cronología, para después establecer una secuencia temporal bastante regular en la que cada uno se muestra como el corolario del que le antecede.

Al término de este apartado dedicaremos nuestra reflexión a plantear un conjunto de aspectos en los que esta secuencia de autores trastoca el pensamiento y la teoría del dibujo.

Jacob van Ruysdael 1628-1682 típicamente barroco pero básicamente orientado hacia la pintura de paisaje. En su trabajo la naturaleza inicia su colocación como centro temático del proyecto artístico. Figs. 49 

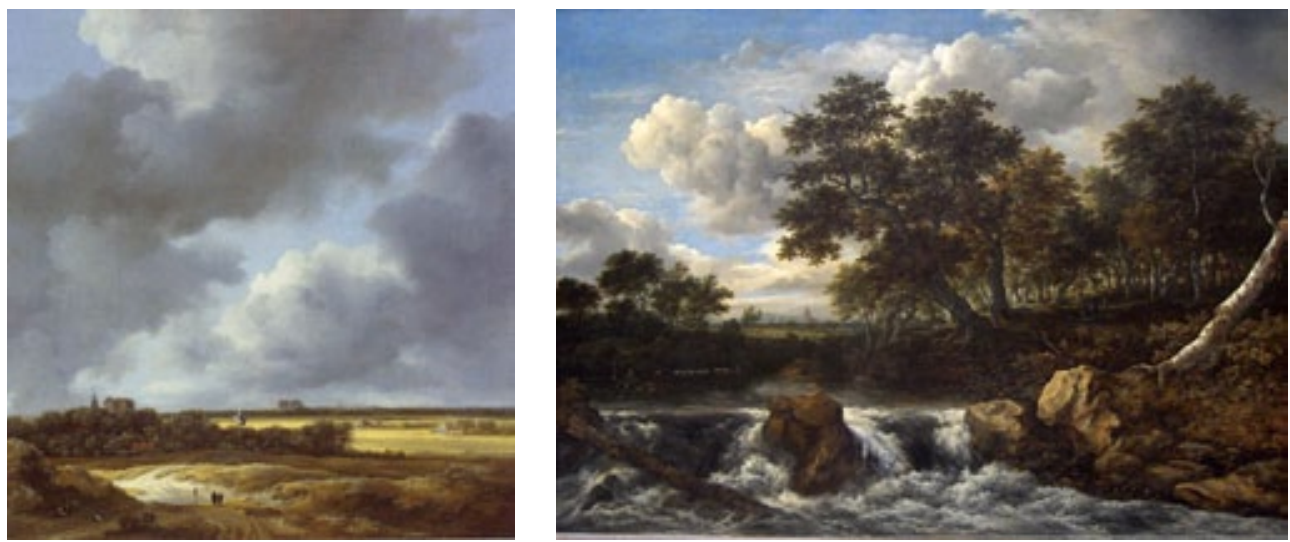

Fig. 49. Ruysdael, paisajes.

Claude Lorrain. 1600-1682. En sus pinturas de paisaje se advierte la inclusión de motivos arquitectónicos, así como composiciones en las que la perspectiva organiza el espacio total. El dibujo y la pincelada comienzan a interpretar formas de superficies texturadas y discontinuas. Figs. 50
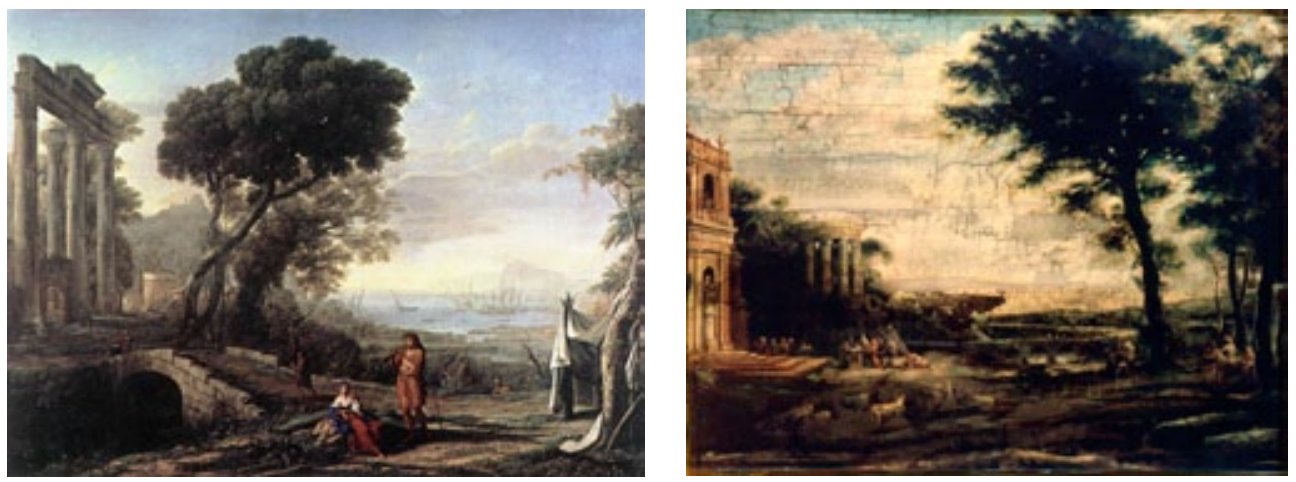

Fig. 50. Lorrain, antecedentes del Pintoresquismo y la Estética Sublime

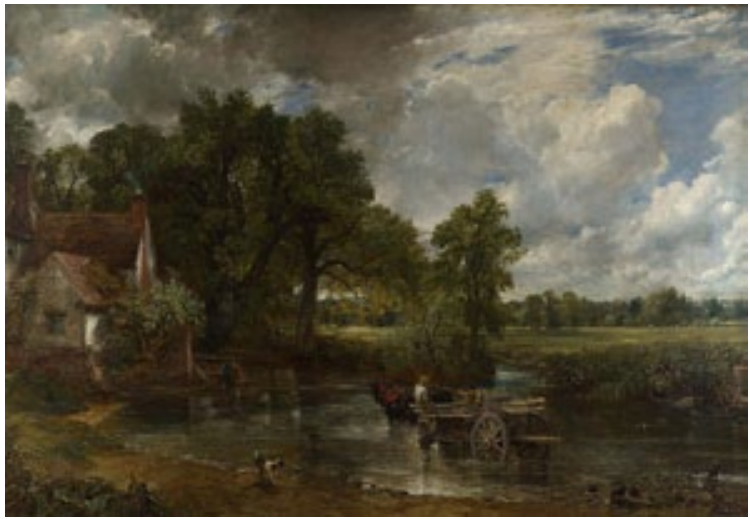

John Constable. 1776-1837 Artista de la Estética de lo Sublime y Pintoresco. En sus trabajos la naturaleza va más allá del marco bucólico para el costumbrismo, la intensidad subjetiva de la imagen es modelada no solo por la elección temática sino por la plasticidad de la forma y la materialidad pictórica. Fig. 51

Fig. 51. Constable. "El carro de heno" con esta pintura el autor ganó la medalla de oro en el salón de Paris en 1824. El campo del color, con su forma y extensión se equilibra con el modelado de los cuerpos como categoría constructiva. 
Joseph Mallord William Turner. 1775-1851 Primer autor en lograr la disolución de las formas corpóreas y plantear el cuadro como un conjunto plástico abstracto en relación al gradiente sentimental humano. Figs. 52
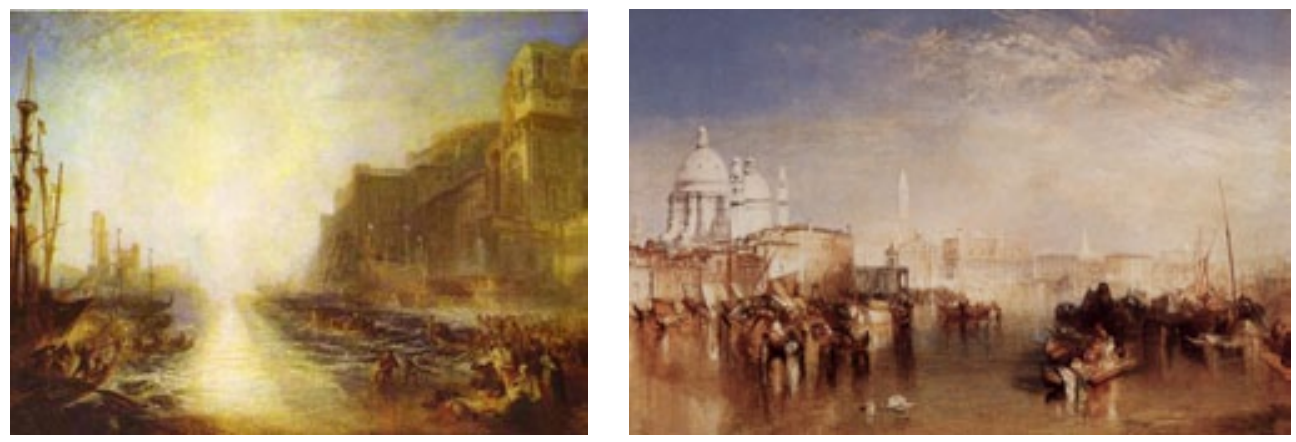

Fig. 52. Turner, en sus vistas de Venecia mantiene el modelo temático clasicista, pero en el tratamiento dibujístico y cromático las formas abandonan el patrón académico.

Jean Baptiste Camille Corot. 1796-1875 Pintor consolidado como representante del naturalismo, cierre del ciclo que coloca a la naturaleza como centro ontológico del arte.

En Corot, el tono del color, la materialidad pictórica como concepto, la atmósfera como construcción lumínica y la pincelada suelta, cuya extensión, dirección y cuerpo hacen el dibujo y la forma; integran un modelo de pensamiento dramático en cuya interioridad dibujo y pintura forman una unidad integrada. Figs. 53
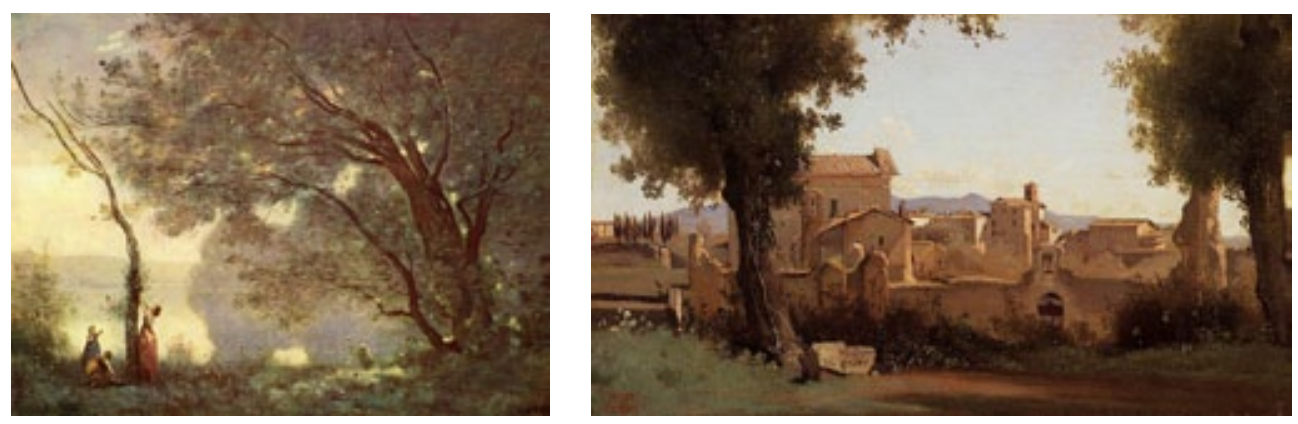

Fig. 53. Corot, paisajes.

La luz en Italia le enseñó a Corot otra de sus aportaciones fundamentales al lenguaje pictórico. "El dibujo -decía Corot- es lo primero que hay que buscar. Seguidamente, los valores cromáticos. Éstos son los puntos de apoyo. Después el color y, finalmente, la ejecución”.

Ilia Yefimovich Repin. 1844-1875 En este segmento incluimos a Repin porque además de ser un pintor enmarcado dentro del realismo del XIX, movimiento que agrega valores teóricos a la historia del dibujo y la pintura, realizó una serie de grabados al aguafuerte en los que las estructuras constructivas del dibujo adquieren peculiaridades conceptuales que nos resultarán importantes en el análisis. Figs. 54 

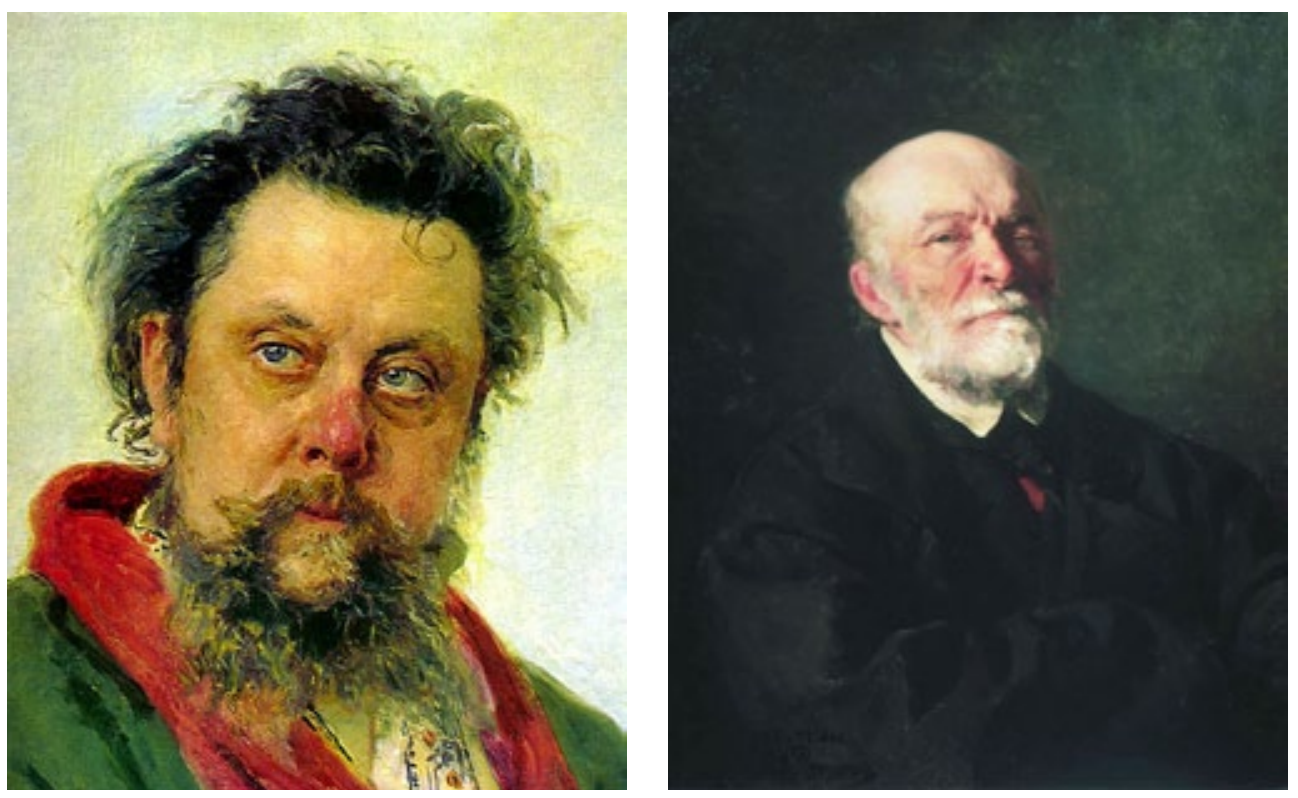

Pero retornando al punto de nuestro estudio; tenemos que el discurso del Barroco, maduro para los albores del siglo XVIII, inicia como contraparte de la pintura cortesana y mitológica una pintura de temas triviales y humildes, incluso comerciales, para un público no necesariamente culto. Pero así formará las bases de un pensamiento que opondrá la valoración de la naturaleza a la creación de normas académicas que limitan su

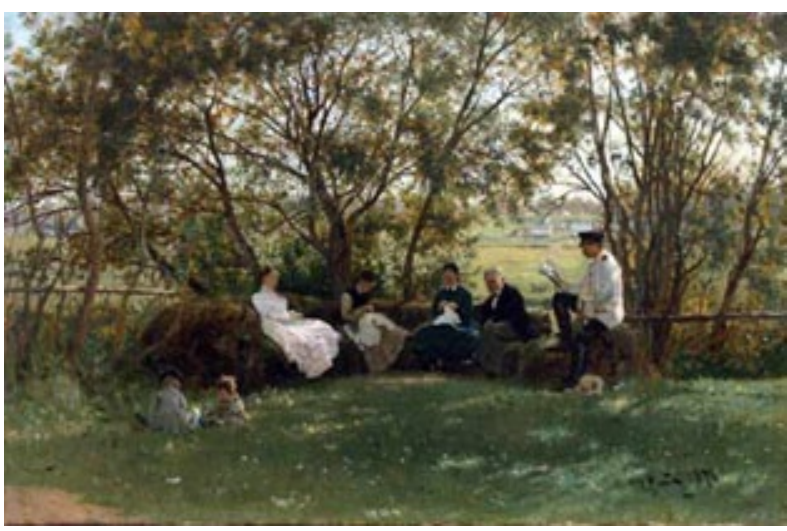

Fig. 54. Repin, retratos y paisaje. sentido ontológico.

La episteme que se introduce en esta visión es la de la particularidad temporal y espacial donde se desarrolla la vivencia del sujeto. Una particularidad que se opone a la visión atemporal mitológica y religiosa de la pintura que le precede, una en cuya concepción el instante del acontecimiento opera en una región del pensamiento abstracto y por ende de existencia en el campo de la idea.

Por otra parte hemos puesto particular atención a la indexalidad del trazo y la pincelada porque en ellas se observa la deriva del trazo lineal circunscrito hacia la muerte de la forma del sujeto, en aras de la forma plástica, de un índex que agrega valores cualitativos al discurso y a la opinión que de los modelos se expone como parte del sentido significante. 
tra solo indicios de subjetividad, nos expone también una ingeniería teórica del pensamiento del dibujo.

La Estética de lo sublime y lo pintoresco comprenden un espacio temporal que une la secuencia del dibujo entre el arte barroco y el inicio del Romanticismo.

En este camino que se recorrerá en casi 90 años se gesta la principal fractura del proyecto artístico histórico, y la escisión que consideramos el inicio del ser dividido de la Modernidad. La Ilustración, la Revolución Industrial, el Iluminismo, la consolidación del pensamiento determinista nacen ligados desde siempre a su par dialéctico opuesto; el ser cuyo proyecto histórico de vida es la crítica sistemática de la razón como absoluto, y su negativa a vivir y conocer el mundo por la razón intelectual, poniendo en su lugar el sentimiento y el conocimiento del mundo mediante los sentidos.

El proyecto histórico positivo, conocer mediante el pensar lógico; el proyecto histórico crítico, conocer mediante el vivir y la integración de los sentidos.

La revolución del Romanticismo imponiendo el sentimiento a la razón se estaba gestando, siempre llevará aparejado a su par dialéctico, a su opuesto, el dibujo neoclásico, freno y acicate a la vez de sus impulsos configurantes. La actitud con que se mira la naturaleza y la actitud con que se ejecuta el dibujo, son más importantes que la norma que los estructura.

Veamos el origen de esta historia, los personajes que la escenifican y los pensamientos que los animan.

Como un elemento fundamental para el periodo histórico que revisamos, es importante plantear que para el siglo XVIII, la geografía política europea estaba ya bastante definida sobre el concepto moderno de nación. Las fronteras eran sumamente móviles todavía, pero nos referimos a ese sentimiento de pertenencia e identidad que sumado a los intereses económicos e imperiales desembocó en las posturas nacionalistas.

Países como Inglaterra y Holanda, en franco ascenso económico se dieron a la tarea de fundar un discurso de identidad que se plasmara en las artes.

El fenómeno de los estilos y las maneras sería trastocado ahora por la definición de los nacionalismos estéticos.

Las estéticas regionales llevan a poner la mirada en el pasado arcaico de las naciones, lo medieval, en conjunto con lo natural agreste, aparece como elemento importante en una y otra de estas representaciones. Lo pintoresco en cada región era diverso y distinto. La identidad en ese momento se entendió como el carácter distintivo que dotaba a cada cultura de rasgos propios no compartidos.

El artista que mira la naturaleza como fuente de belleza que genera estructuras de representación, se opone a la postura romántica que considera la belleza producto de la exaltación espiritual provocada por el entorno.

Un cambio en la postura epistémica; ahora se dialoga con la naturaleza porque se le concede esencia ontológica propia, ya no sólo se le estudia y se le perfecciona en las representaciones, ya no se le considera incapaz de producir elementos perfectos en sus razones proporcionales, en donde se funda el pensamiento platónico de perfección en busca del ideal. 
La naturaleza como región de autonomía ontológica en su esencia, será el gran campo del proyecto del dibujo.

La exaltación de su espíritu, la turbulencia de sus fenómenos y la aspereza de sus personajes son los valores que privarán en las representaciones del dibujo.

"Lo sublime en pintura como en poesía, abruma de tal modo y toma tal posesión del espíritu entero que no queda sitio para atender a la crítica en detalle. Las pequeñas elegancias del arte, en presencia de estas grandes ideas expresadas con tal grandeza, pierden todo su valor, y se consideran por el momento al menos, indignas de nuestra atención."111

Este pensamiento de Reynolds deja clara la postura de fondo y el concepto de valoración. En la siguiente cita se advierte con precisión los valores que se deben tomar de los modelos, a fin de estructurar la configuración, cuyo carácter resultará de la adecuada selección, así como del manejo correcto de los elementos observados en el modelo.

La postura de lo sublime frente a la naturaleza se acompañó siempre en la pintura inglesa de esta época, de aquello que se denominó el Gran Estilo, que no era otra cosa que la búsqueda de transponer fronteras y límites en el arte, basados en una monumentalidad y contundencia formal.

"En un examen cuidadoso, encontramos manchas y defectos en todos los objetos que la naturaleza expone ante nuestra visión [...]. Pero no todos los ojos perciben esas faltas. Hace falta una vista acostumbrada a la contemplación y comparación de las formas, y que, a través de un largo hábito de observación de lo que tienen en común cualquier grupo de objetos de una misma especie, ha adquirido el poder de discernir lo que desea de cada individualidad. Esta larga y laboriosa comparación debiera ser el primer estudio del pintor que anhela el great style."112

En su décimo discurso, Reynolds deja asentada con claridad como la búsqueda de lo sublime pertenecía al territorio del idealismo, y no sería la búsqueda objetiva de valores en la naturaleza.

"El arte que profesamos tiene la belleza como objetivo; nuestra tarea es descubrirla y expresarla; pero la belleza que buscamos es general e intelectual, es una idea que subsiste solo en el pensamiento: el ojo nunca la vio, ni la mano la ha expresado."113

Así pues estamos frente a una definición en la que el terreno de la representación prefigurada estructura los sistemas formales y su aplicación, postura emparentada con la concepción del diseño interno de Zuccari.

La valoración de los modelos, para desencadenar los procesos de representación no es tanto un cambio de sujetos, ni siquiera de su carácter, es la postura epistemológica la que varía, el punto de vista desde el que miramos las cosas determina lo que de ellas vamos a observar, así la Postura de William Gilpin (Inglaterra 1724-1804) no busca nuevos mo-

111 Freixa Mireia, Garriga Joaquim, Yarza Joaquín, editores. Fuentes y documentos para la historia del Arte. Renacimiento en Europa. Barcelona: Ed. Gustavo Gili; 1983. (VII). P. 108.

112 ĺdem.

113 ĺdem. 
delos, se basa en la naturaleza pero selecciona aquella parte de las cavernas, las rocas musgosas, las irregularidades del relieve rocoso, las quebradas de la montaña con sus caídas de agua. Aquellas partes salvajes de lo natural en donde el hombre no ha puesto su mano, por esa inquietud de representar la virginidad del mundo natural es que no ha de ponerse orden en la construcción de la estructura de los modelos.

Gilpin hace una valoración de la arquitectura palaciega, ahí plantea el conflicto de exceso de formalización cuando esa arquitectura es dibujada, entonces pierde, según él, su capacidad plástica y se vuelve chocantemente rígida. La arquitectura en ruinas muestra el poder del paso del tiempo y nos remite a reflexiones filosóficas por distintas rutas. Plásticamente la rudeza de la erosión se opone a lo terso en la pintura y el dibujo.

Ésta es la formulación de la estética pintoresca, con ella el repertorio de representaciones de los modelos del dibujo se abre a formas muy diferentes de las del Barroco propiamente. Los jardines del 1600 representaron el prototipo de orden impuesto a la naturaleza, la estética de lo pintoresco quita el freno al orden natural y las imágenes del paisaje que prohíja viajan por las zonas agrestes del espíritu.

El dibujante emprende la aventura de viajar, esto en parte animado por la visión enciclopédica y economicista, pero al fin y al cabo el dibujo acompaña a los pintores viajeros del 1700, algunos como Moritz Rugendas Ilevarán su aventura hasta otros continentes. Lo que ahí descubrieron y mostraron al mundo eurocentrista quedó latente como filón para nuevas experiencias en el dibujo.

El punto de giro en la estética pintoresca será dado por el trabajo de Alexander Cozens, ya que no solamente pone la mirada en valoraciones matéricas y temáticas del modelo, en este caso la naturaleza. A esto agrega lo que él llamó su Nuevo Método para la invención de Paisajes.

Con este método la teoría de la representación se convierte en una acción de configuración artificial, en donde la imaginación interviene no como un modificador del estilo sino como el elemento inicial del planteamiento.

Aparentemente el parecido con los modelos se mantiene pero asistimos a la propuesta de operaciones intelectuales del dibujante que no tienen el mismo inicio que un dibujo de análisis de las formas del paisaje.

El pintor se haya trabajando en el paisaje, pero lo primero que hace son unas manchas iniciales sin más que una vaga intención, el concepto de estructura será sugerido por esas manchas y acentuado un tanto más, después de eso se tiene que encontrar el acabado, de acuerdo con las coincidencias con un paisaje del natural.

La estética pintoresca criticó el que la pintura de corte histórico se basara en imágenes tan lejanas de hechos que no se sabía bien a bien en qué contexto se situaron, desde ese punto de vista hacían el parangón diciendo según la idea de invención de Cozens, que ellos arrancaban también de una región mental igualmente evocadora.

Si atendemos al propio Cozens, el método de trabajo de invención, se le ocurrió una vez que no podía dar a entender a un alumno en el paisaje la razón de componer de manera fluida el vigor del cuadro, basándose en la dinámica del paisaje; por eso le sugirió que simplemente manchara y notara el vigor de las manchas al fluir, y de igual manera buscara ese gesto inicial en su dibujo del paisaje. 
Las consecuencias de esta postura en términos de un sistema de representación serían importantes. La pintura y el dibujo no partirían ya de un modelo natural estricto, todos los objetos son fuente de análisis del dibujo, la relación entre procedimiento y modelo objetual como un par indisoluble quedó rota. La cercanía con la pintura de fines del XIX y las corrientes de la modernidad del XX se había planteado.

"Componer paisajes por invención no es el arte de imitar la naturaleza individual; es más: es formar representaciones artificiales de paisajes según los principios generales de la propia naturaleza, fundados en la unidad de carácter, que es la verdadera sencillez; concentrando en cada composición individual las bellezas que la imitación juiciosa seleccionaría entre las que se encuentran dispersas en la naturaleza."114
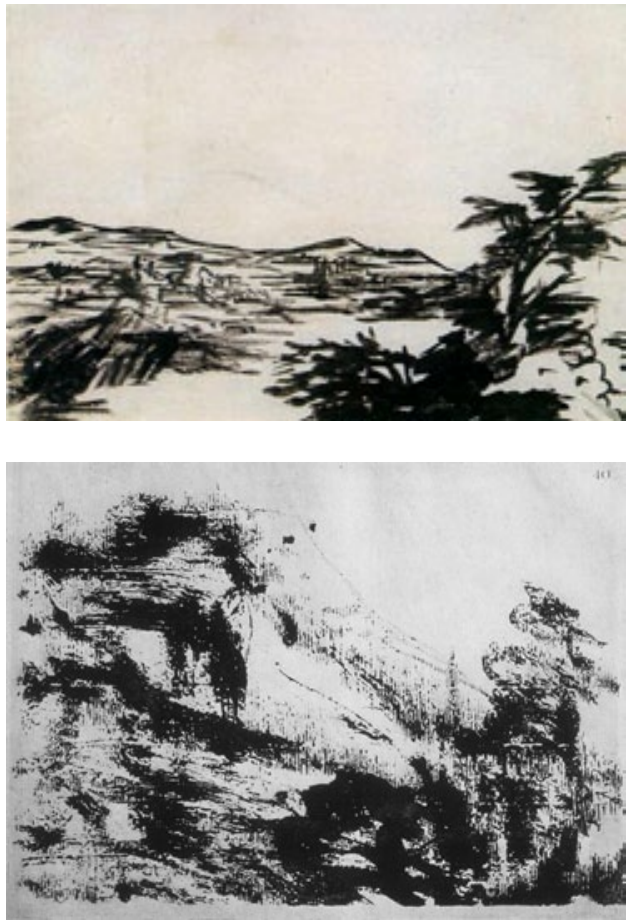

Fig. 55. Cozens, paisajes por invención.

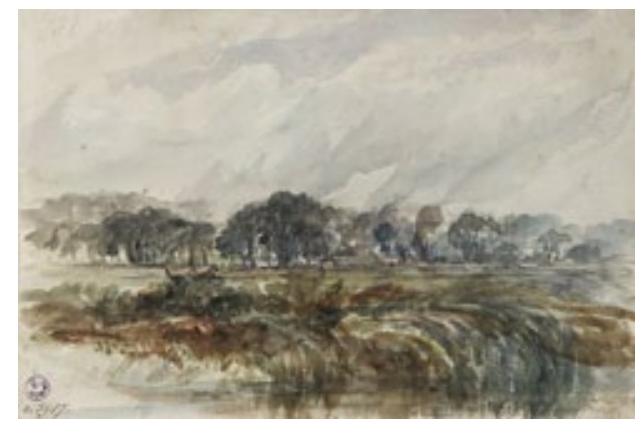

Después de Cozens, John Constable, se adentra en el tiempo del Romanticismo, su pintura no tiene ya ningún límite a lo sublime como sentimiento provocado por la representación de la naturaleza, y el asistir a la maravilla del paisaje. Se dice que Constable fue el primer pintor que definitivamente trabajó la pintura al exterior del estudio, buscando con ello penetrar la esencia que va más allá de lo dibujable.

Reynolds, William Gilpin y Le Brun insistieron en posicionar a la pintura sobre una
sus argumentos son más bien morales que base filosófica sólida, hoy nos parece que sus argumentos son más bien morales que filosóficos, se orientan hacia el deber ser, le dictan al arte un camino y función preestablecido, vemos en este asunto un problema típico que se gesta en el Barroco, con la consolidación de las prácticas de la crítica de arte, con los conocedores y teóricos del arte se inicia el proceso de presión de campos externos al arte sobre el establecimiento de su proyecto.

Pero muchos de estos autores eran también artistas, lo que queremos plantear es que al aplicarse el artista a la práctica de producción y configuración se establecen de por si sistemas y procesos propios del campo que se ejerce.

114 Freixa Mireia, Garriga Joaquim, Yarza Joaquín, editores. Fuentes y documentos para la historia del Arte. Renacimiento en Europa. Barcelona: Ed. Gustavo Gili; 1983. (VII). P. 272. 
Hacemos notar que en las obras de los autores que arriba reseñamos el dibujo tiene una importancia sustantiva como organizador ya no sólo del proyecto sino del acto configurante, y que dentro del sistema formal recompone una serie de factores que lo llevan a un giro como lenguaje plástico visual.

El arte barroco monárquico siguió siendo en lo general una creación de estudio, de taller. Pero el segmento del Barroco que sale del ámbito cerrado para estructurar una nueva representación de la naturaleza creará toda una revolución epistémica de la pintura y el dibujo.

Esto es así porque el posicionamiento del artista cambió de manera radical su ubicación, los fenómenos que ahora le interesaba representar tenían una dinámica diferente a la que estaba acostumbrado a dibujar, fue consciente de que el cambio de ubicación y de modelos requería de la construcción y adaptación tanto de sistemas de formalización, como de estrategias metodológicas coincidentes con los nuevos intereses.

Diríamos incluso que en ese momento se incrementó dentro de esa sociedad europea la conciencia sobre la importancia del método en todos los campos del hacer humano.

La pintura que cobró importancia como centro temático comportaba nuevos modelos ontológicos a representar. El paisaje al convertirse en el género integral de la pintura fue sometido a un despojo de visiones costumbristas.

Los personajes del paisaje fueron entonces los componentes de la geografía y la naturaleza, comprendiéndose incluso el conflicto de oposición entre la civilización humana y el desarrollo del ser natural.

El dibujo y la pintura permitieron llegar a una demarcación del paisaje con sus modelos divididos en la dimensión celeste, la terrenal en toda su orografía e hidrografía y la relación mediante la que el ser humano se integraba en ese nuevo contexto de la existencia.

Las rocas, la orografía, el agua, los ríos, el mar, la vegetación, los bosques y los celajes eran modelos para los cuales las anteriores formas del dibujo resultaron insuficientes en el momento de la toma de datos y la estrategia de configuración.

El dibujo como circunscripción está ligado a la construcción de formas cerradas y de relieve en los cuerpos. Con el dibujo barroco y naturalista romántico se fue construyendo una ingeniería formal y conceptual de representación que posibilitara el armado del nuevo modelo del dibujo. La irregularidad de los nuevos motivos tanto en su forma como en su superficie y partes llevaron al dibujante a la extensión del sistema modelístico del dibujo.

Es sencillo comprender lo que planteamos, pero una sola mirada comparativa a un paisaje fragmentario renacentista junto a un cuadro de Constable explica claramente el cambio de la forma y el sistema en este viaje del dibujo. Figs. 56

Incluso tomando como ejemplo a Leonardo, quien en su virgen de las Rocas ya se internaba en el terreno de la perspectiva atmosférica, vemos como el dibujo es de una pureza en la definición de las formas de los modelos, independientemente de los factores espaciales y la distancia.

Tomamos nuevamente un dibujo de Leonardo sobre el comportamiento de un cauce de 
agua para compararlo con un cuadro de Ruysdael. Observamos en Leonardo vestigios de un pensamiento ideográfico del signo, en tanto que en el cuadro de Ruysdael se muestra la intención constructiva de la forma del agua más allá incluso del pictograma, intentando la representación del cuerpo líquido con caracteres que se dan a la sensación más que a la reducción sígnica. Figs. 57
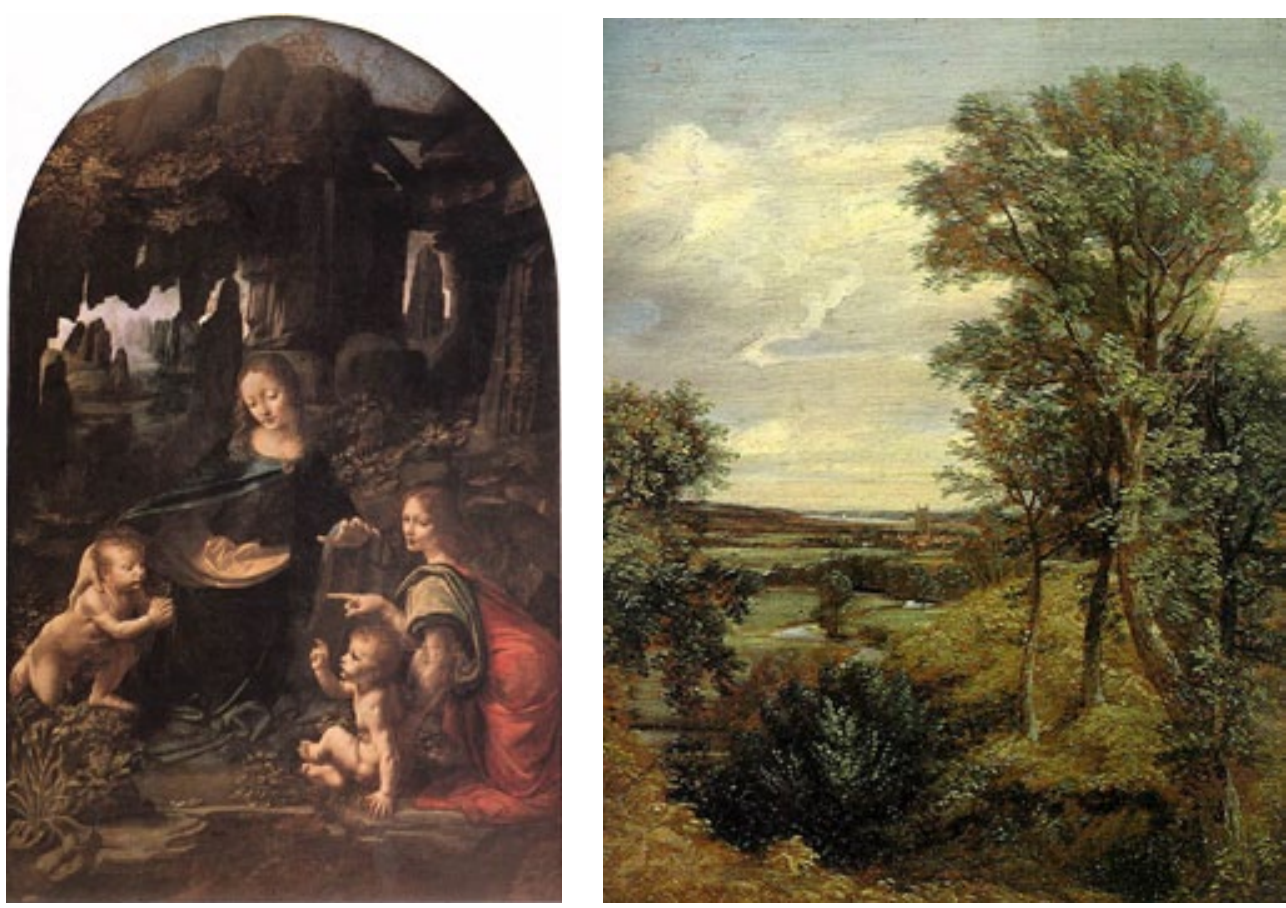

Fig. 56. Leonardo, Constable. Rompimiento de la circunscripción dibujística de la forma.
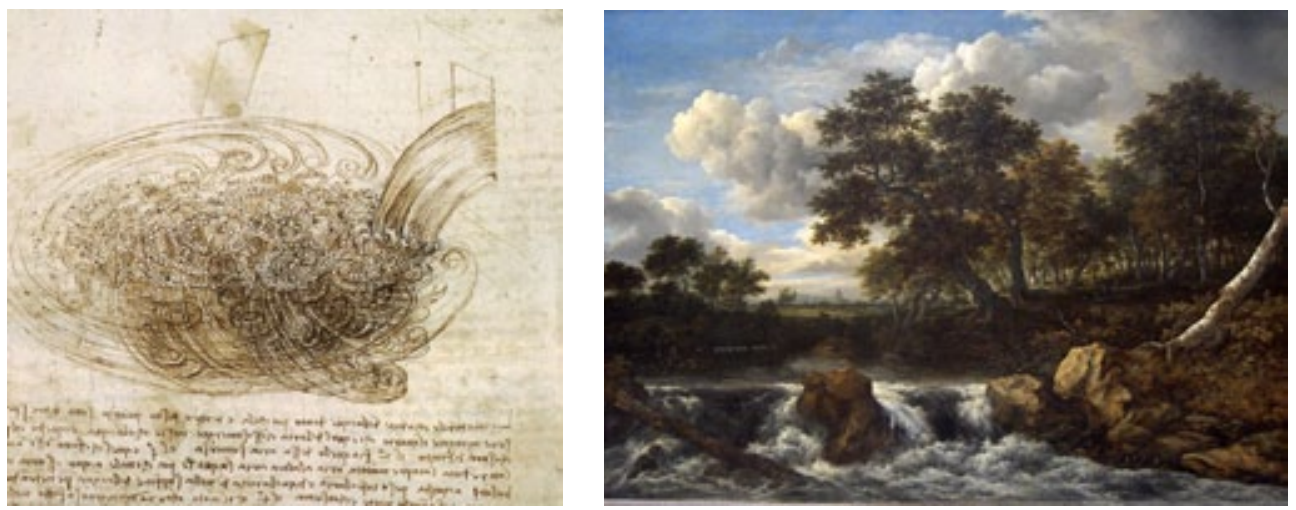

Fig. 57. Leonardo, Ruysdael. Representación diagramática ideográfica y naturalista del movimiento acuático.

Vemos en el dibujo de este periodo un entendimiento de la noción de vacío, que se opone a la idea de la forma cerrada y circunscrita del Renacimiento. El vacío es un campo espacial que se activa mediante la composición cromática y tonal, por tanto su sustancia es 
inmaterial y no concreta. Estas áreas generalmente se trabajaron con armonías tonales de poco contraste, ya sea en el gradiente bajo o alto de la escala lumínica, continuaron con el desarrollo de un doble sentido para el trazo y la pincelada, el de su disociación matérica y textural y el de su carácter gráfico gestual.

Al avanzar este proceso el claroscuro también habría de desarrollarse de manera expandida, mucho más allá de la función generadora de relieve y de base tonal para los colores. El concepto de masa aparece como intención de construcción, aunque no lo encontramos explicitado. Se diferencia del concepto de forma precisamente porque es difícil y en algunos casos imposible de determinar la circunscripción geométrica de los modelos, pero se ve evidentemente que constituyen conjuntos de materialidad y corporalidad penetrable.

Hemos dicho que en este trecho de la historia de los modelos, se dibujó recurrentemente el agua, las rocas, la vegetación etc. Podría parecer una mención simple, pero quien haya intentado dibujar un arbusto o un árbol más allá de una traducción esquemática, sabe del problema que tratamos. Intentemos dibujar entonces un bosque, o una secuencia rocosa en un acantilado, así nos daremos cuenta de la medida de los conceptos generados por el dibujo, y no como un truco mimético, sino como la concreción de sistemas y conceptos que operan como organizadores gestálticos de la imagen.

En este punto del estudio insistimos en una consideración que anteriormente señalamos; muchas de estas circunstancias son estrategias estructurales de configuración, operaron no en el momento de dibujar un apunte o estudio de paisaje, se activaron asociadas al acto de pintar, y esto fue una revolución típica del Barroco, que se exacerba potencialmente en los años que le siguen. La acción de pensar el dibujo y trazarlo no fue solo una etapa previa a la aplicación del factor cromático. El apunte el boceto y el estudio de dibujo se siguieron practicando, pero la acción configurante terminal del dibujo se realizó entonces en sincronía con el acto de pintar, ahora bajo una gestalt en la que la forma cerrada del modelo y los planos no era precisada, ambos continentes conceptuales poblaron la mente del artista en un tiempo simultáneo.

Esta es una relación que se observa cuando colocamos dibujos de estos autores junto a imágenes de pinturas en proceso o terminadas. Figs. 58
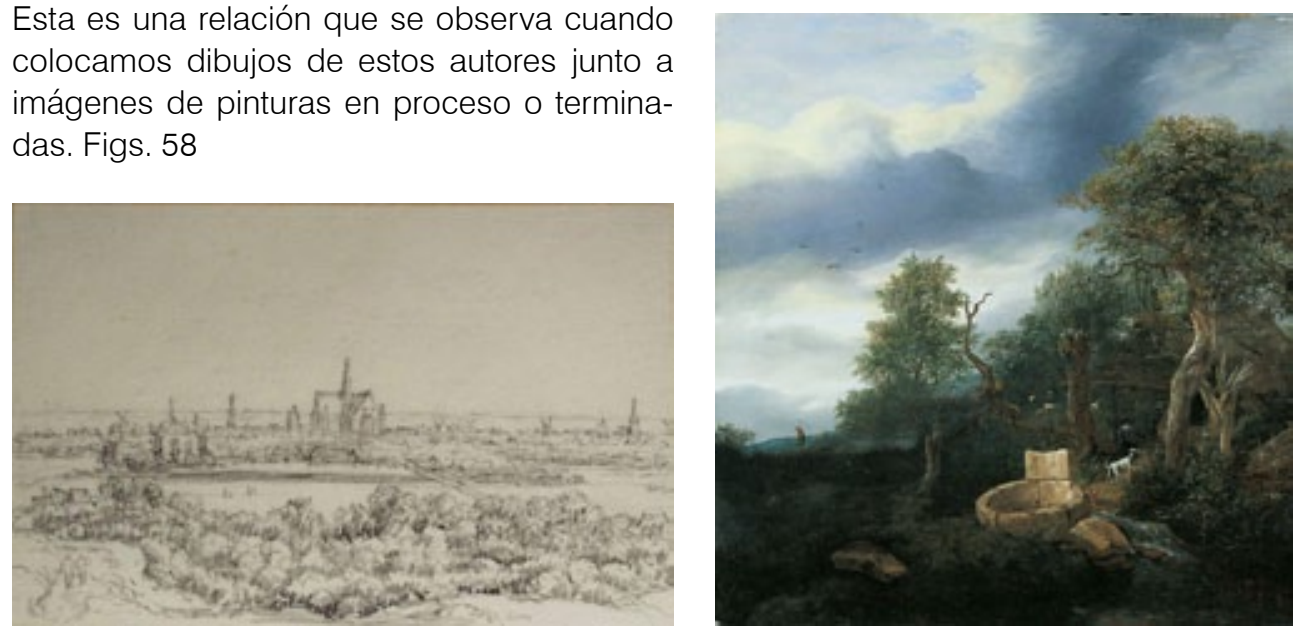

Fig. 58. Ruysdael. Dibujo y pintura 

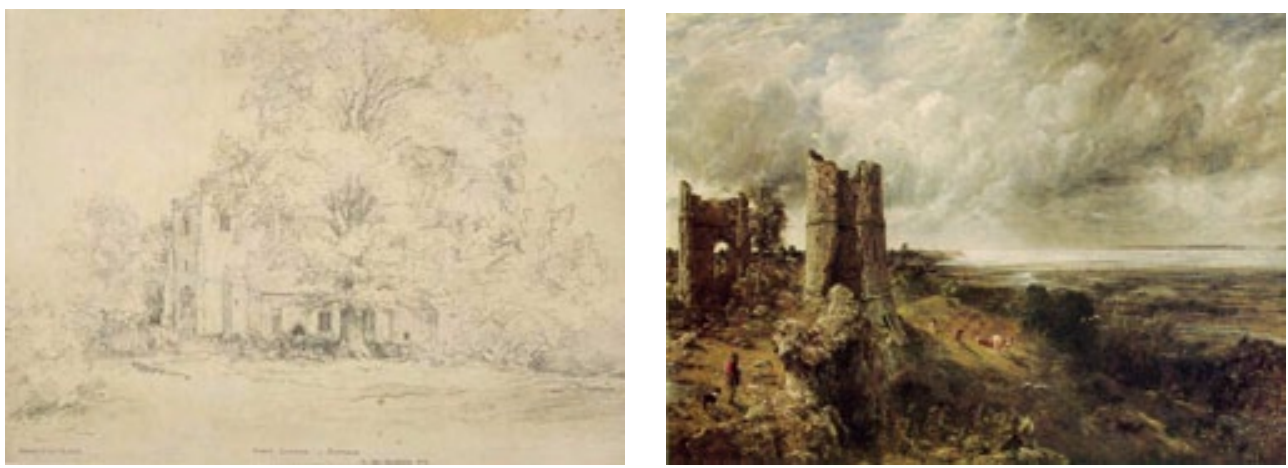

Constable. Dibujo y pintura

Pero en el caso de los pintores ingleses observamos un fenómeno interesante, al trabajar sus apuntes de viaje y campo y sus bocetos con acuarela, desaparece esa condición divisoria de un dibujo típicamente lineal junto a un dibujo interiorizado en el pensamiento pictórico, y este suceso es posible debido a la personalidad física del medio, que potencia una construcción formal particular. Si el Renacimiento vio alumbrar el Dibujo de Relieve de la forma, con el Barroco se inicia la gestación de lo que se dio en entender como Dibujo Pictórico. Figs. 59
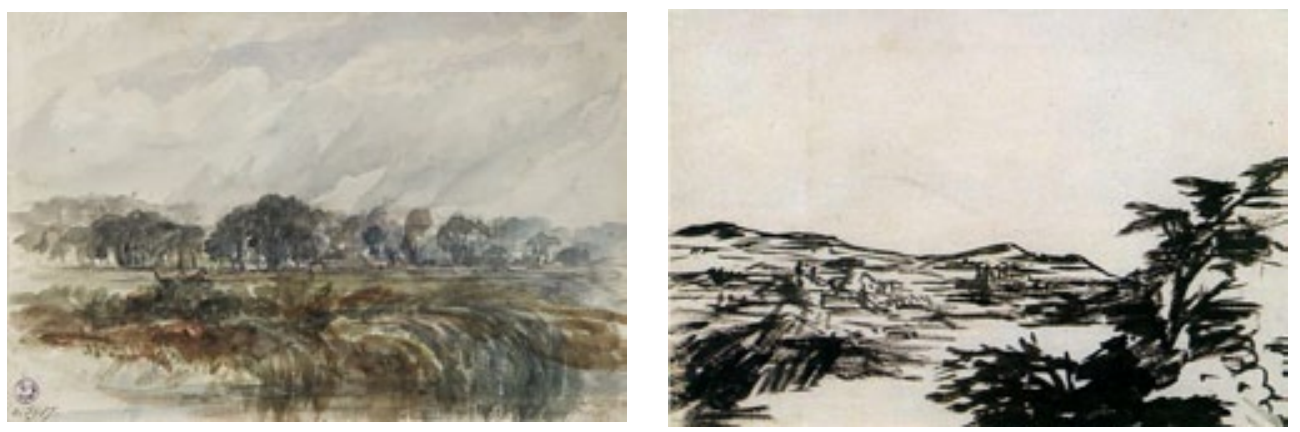

Fig. 59. Alexander Cozens. Acuarela y dibujo a tinta.

Antes de concluir esta parte del trabajo incluimos una selección de grabados de llia Repin, forman parte de una carpeta que constituyó una bitácora de viaje. En estas obras se concreta la visión del movimiento Naturalista del XIX, pero también se observa claramente la evolución de las estructuras del dibujo. Estos grabados no deben de ser vistos como intención mimética y realista del dibujo, en su interior contienen una organización ejemplar de los conceptos de masa, claroscuro, modelado, espacio y tono. Llamamos a observarlos con atención, su riqueza es enorme, en muchos de ellos el fuste de un árbol sufre dos o tres variaciones constructivas, se inicia en valor de modelado, se transforma en plano de tono y luego se convierte en parte de una masa penetrable de follaje. Ese es en parte su misterio, bajo una apariencia mimética opera una composición formal que no es sino la activación de una estrategia mental, la cual además no se repite, sino que varía en cada lámina del conjunto. Figs. 60 

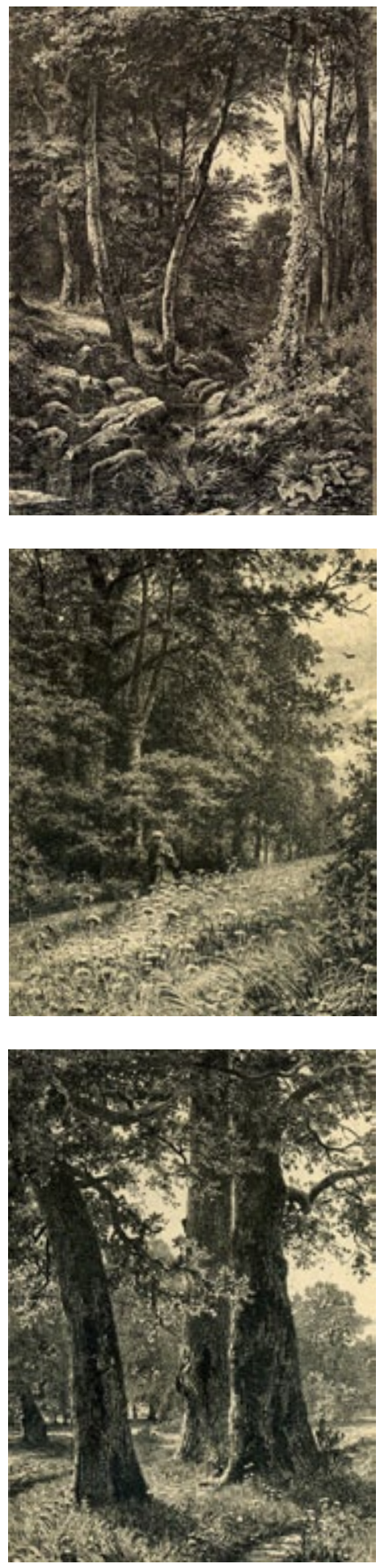

Fig. 60. Ilia Repin. Aguafuertes.
Una consecuencia más de todo este proceso fue el desplazamiento de la pintura desde el interior de un gabinete o estudio del pintor hasta la amplitud de las locaciones culturales. Esta fue una característica de este segmento del Naturalismo y el Romanticismo, la pintura y el dibujo al aire libre iniciaba su camino como centro motriz de las revoluciones formales de la vanguardia.

Pero el dibujo realizado en un espacio interior, como lo es el taller del pintor todavía tenía mucho que decir sobre el particular, y un papel sustantivo dentro de los modelos teóricos del dibujo.

El movimiento romántico será siempre poblado por la presencia de Eugenio Delacroix, no importa tanto su figura en este trabajo, pero es interesante que en la etapa temprana de su formación viajara a Inglaterra a estudiar la pintura de Turner y Constable, interesado por dos cosas; su color y el tratamiento de la luz. Con este viaje se inicia la influencia de la escuela inglesa de dibujo sobre la pintura y el dibujo franceses deI XIX. Incluimos en este capítulo algunas imágenes de dibujos de Delacroix porque según miramos desencadena dos campos de interés en las construcciones configurantes del dibujo y en la manera de crear las estructuras formales. Son muestra también de la operación del dibujo como constructor del proyecto artístico, en ellas reconocemos los bocetos y estudios de sus obras significativas. Figs. 61

Las operaciones configurantes que varían la estructura conceptual de la forma se agregan a la función proyectual prefigurativa, no existe conflicto metodológico en el proceso, más bien una continuidad estratégica.

El boceto tendrá una potencia casi salvaje en sus dibujos, las conductas gestuales se muestran aquí en su doble sentido, el de responder al impulso instintivo que se da en la primera mirada al modelo, y dos, el trazo desbocado corriendo tras la idea en una linealidad cuya dinámica nunca antes había sido vista, y que jala a la mano detrás del sentimiento. El segundo punto generado por las consideraciones del dibujo romántico resulta de su interés central por el color.

Una de las propiedades del color es su campo, el que a su vez puede ser modelado, una postura colorista dará importancia al campo cromático, la circunscrip- 

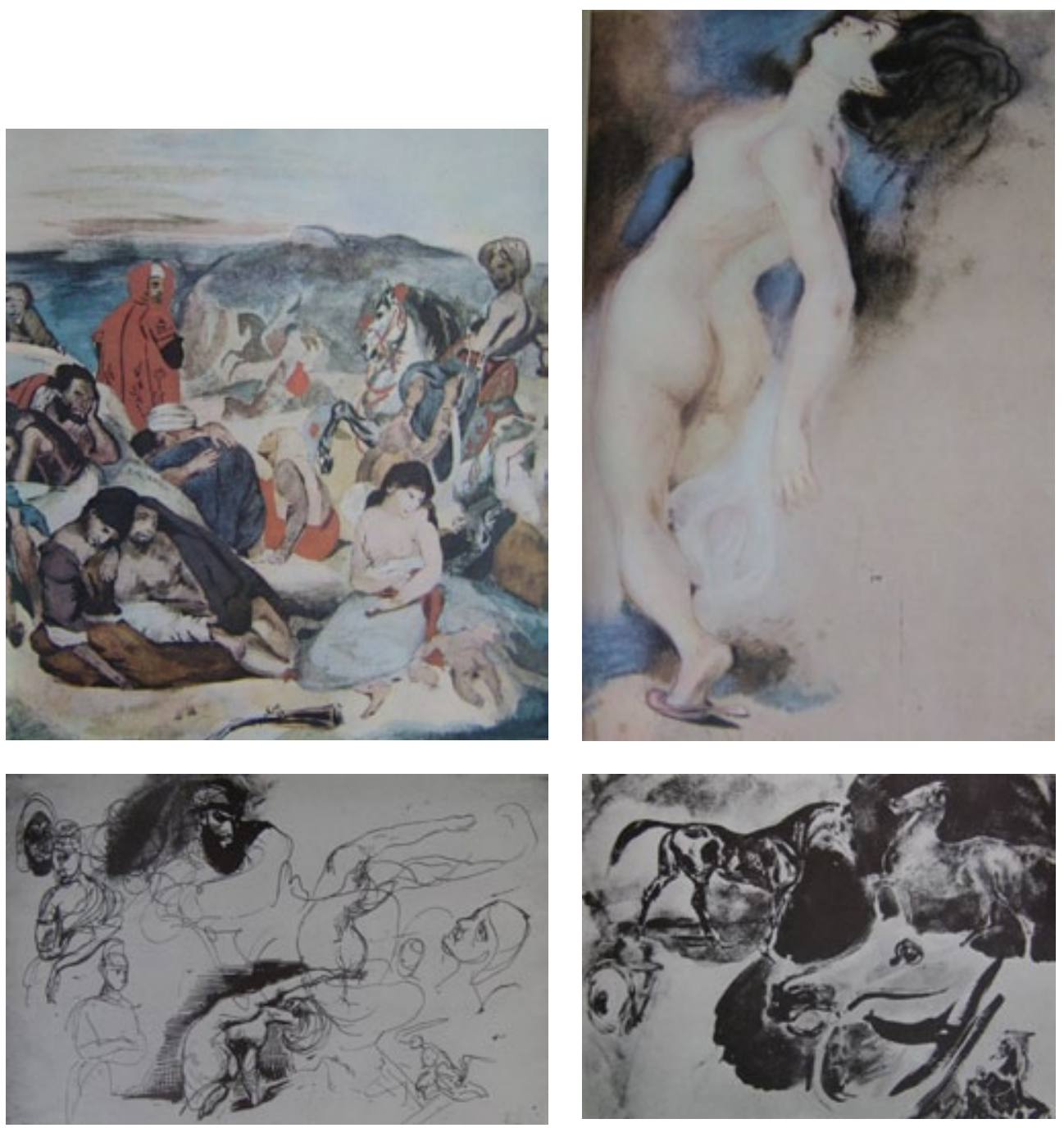

Fig. 61. Eugenio Delacroix. Bocetos y apuntes.

ción lineal será más el resultado del manejo adecuado de los tonos.

Cuando el dibujo se aplica al campo de color se crean planos yuxtapuestos, y dependiendo del manejo correcto del tono y su área, el resultado son los perfiles que dibujan las figuras. Lo anterior parecería un discurso arriesgado, pero es el mismo Delacroix quien nos lo asienta en sus letras.

La postura filosófica y metodológica del dibujante en el Romanticismo, es componente fundamental que determinará el sentido de sus representaciones, por otro lado, el sistema de formas y conceptos que esto propicia, es un giro en el carácter y funciones del dibujo dentro del proyecto artístico. Interesa aquí la actitud del dibujante romántico porque se traduce en acciones que causan virajes en el dibujo y su papel dentro de las artes plásticas.

Esta actitud se concreta en el dibujo de Delacroix específicamente porque en su caso se 
salva la dicotomía a la que aludíamos cuando hablábamos del paisaje sublime y romántico; aunque la línea es recurso esencial en el dibujo de Delacroix, ya no es aplicada como delimitación contorneada de la forma, se le entiende como asociación a la distensión del plano tonal y matérico, así la línea en sus dibujos amplía su espesor hasta adaptarse a la forma de los modelos dibujados, en cierto sentido es un retorno a los recursos caligráficos del dibujo, en razones de esta índole es donde se basa la polémica frente al pensamiento racional del dibujo neoclásico.

Cuando la actitud se concreta en procesos y formas del dibujo, genera la oposición del Romanticismo con el Neoclásico, es curioso que entre Delacroix y Gericault no existiera ningún ataque directo a la obra o la persona de Ingres. Los datos que tenemos son de una consideración y respeto entre ellos. Aún con eso su trabajo de dibujo corre por caminos diferentes. Una cita de Ingres da lugar a precisar la idea que tenía sobre el dibujo y el color.

"La expresión, parte esencial del arte, está íntimamente ligada a la forma. La perfección del colorido tiene tan poco que ver con el asunto, que los pintores de expresiones excelentes no han tenido como coloristas un talento equivalente. Quién se lo reproche es que apenas sabe de arte, no se puede exigir a un solo hombre cualidades contradictorias. Por otra parte, la rapidez de ejecución que exige el color para mantener su prestigio no se acomoda con el profundo estudio que exige una gran pureza de las formas." 115

El trabajo de Ingres como el mayor exponente del neoclásico desafió toda crítica, incluso la afilada pluma de Baudelaire quién era el ardiente defensor de los románticos lo respetó, decía de él:

"Me gustaría creer que su ideal es una suerte de ideal hecho mitad de salud, mitad de calma, casi indiferencia, algo parecido al ideal clásico, al que ha añadido las curiosidades y las minucias del arte moderno. Este ayuntamiento es el que a menudo da a sus obras un cierto encanto extraño."116

Delacroix tampoco tomó en sus manos la defensa y el ataque a los neoclásicos, las personalidades y la obra de Louis David no eran cosa de tomarse como menores.

"Yo llamaría de buen grado clásicas a todas las obras equilibradas, esas que satisfacen al espíritu no solo por una pintura exacta o grandiosa o estimulante de los sentimientos y las cosas, sino también por la unidad, el orden lógico, en una palabra, por todas esa cualidades que incrementan la impresión y alumbran la simplicidad."117

Realmente la disputa entre los coloristas y dibujantes en el Romanticismo y el Neoclásico se puede entender como dos concepciones de la construcción de la forma. El neoclásico dibujaba tomando como base el estudio de los modelos escultóricos y los relieves de la antigüedad clásica, pero en el fondo teórico se animaba sobre el entendimiento de un pensamiento centrado en la forma racional de los sujetos y el espacio, el color era para

115 Freixa Mireia, Garriga Joaquim, Yarza Joaquín, editores. Fuentes y documentos para la historia del Arte. Renacimiento en Europa. Barcelona: Ed. Gustavo Gili; 1983. (VII). P. 297.

116 Ibíd., P. 296.

117 Petrova Eva, Delacroix y el dibujo romántico. Barcelona: Ed. Polígrafa; 1989. P. 8. 
ellos un efecto actuante sobre la estructura objetiva de los modelos. De ahí su carácter fuertemente contorneado y la observancia del modelado para generar la sensación de relieve, dado que lo que interesaba era el modelado en la secuencia continua de los planos, era fundamental no cortar abruptamente las secuencias, era necesario también evitar el contraste cromático mayor, para lograr el aire y la atmósfera calma que requería el equilibrio de las posturas del modelo.

El dibujo de Gericault o Delacroix también consideraba importante la linealidad, pero el suyo no era un concepto neto del contorno, en este caso debería de sujetarse o dejarse llevar por el impulso interno del autor, o por el ímpetu de los modelos que se encontraban en la realidad circundante, la linealidad y el trazo para los románticos sentaba la esencia de los ritmos visuales y las tensiones compositivas que eran la base primera del conflicto dramático expresado en la pintura, no se regía sólo por una idea de equilibrio existente en la mente o fundada en la métrica.

En el capítulo anterior incluimos los estudios y bocetos preparatorios para El salvamento de la Medusa pintado por Gericault, ahora agregamos unos dibujos de Delacroix en los que señalamos como era práctica común el aplicar el dibujo a la especulación para fijar el concepto y la composición de obras finales. Fig. 62
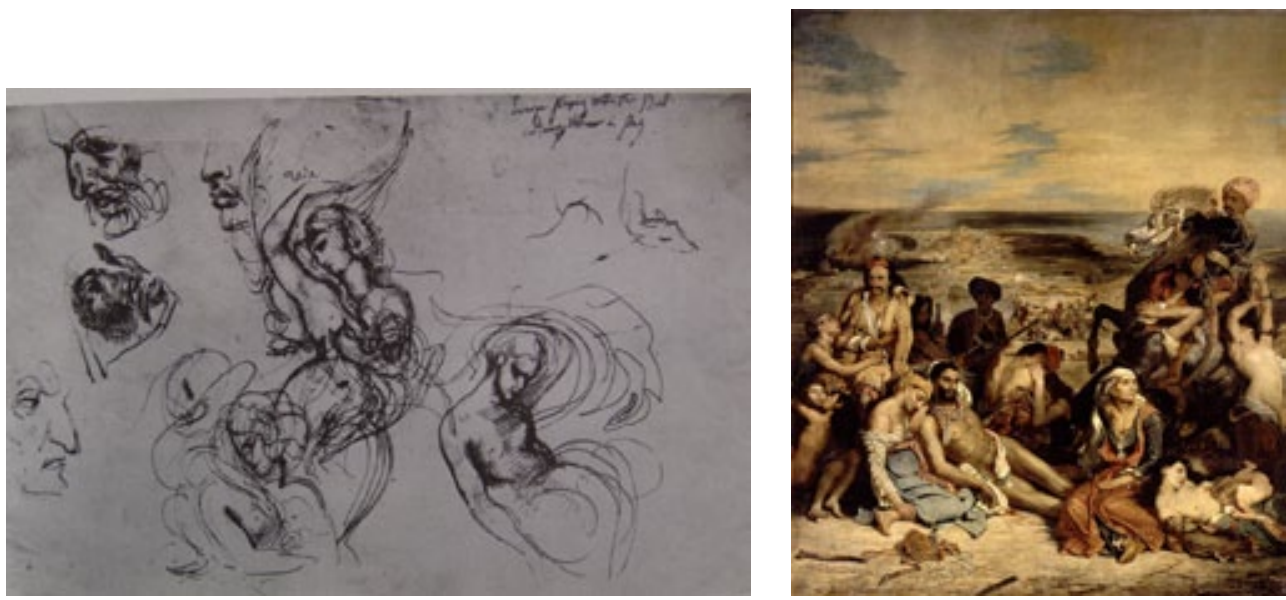

Fig. 62. Delacroix. "Escenas de la matanza de Scío" Estudios y obra terminal.

Con ello aclaramos la postura, en el sentido que las variantes del dibujo romántico, se dieron sobre la base de transformar la actitud del artista como contenido del discurso, mediante la adaptación de los procesos de trazo y el carácter de la manera técnica y formal. La función especulativa proyectual del dibujo se mantuvo constante, incluso diremos que se reforzó dado el carácter del dibujo en el sentido de permitir rápidos bocetos con variantes violentas en el tratamiento de una idea o sus partes.

Incluimos una cita que aunque extensa muestra con precisión y claridad lo dicho líneas arriba. Se trata del proceso para la elección del tema y la realización del cuadro, Escenas de las matanzas en la isla de Scío pintado por Delacroix.

"En enero del año siguiente [1824] aparecen consignadas por primera vez sus im- 
presiones sobre el encuentro con el coronel Voutier, testigo ocular de las luchas del pueblo griego por su independencia. Las matanzas en la isla de Scío empezaron en abril de 1822 y se prolongaron por espacio de un mes. Los turcos mataron entonces a veinte mil griegos e impusieron la esclavitud al resto de la población. En Europa, los acontecimientos de Grecia conmovieron a todas las personas amantes de la libertad, especialmente la juventud. [...] Lord Byron, ya en vida poeta legendario, partió para Grecia y con su ejemplo hizo que el gran público se pusiera a favor de la causa griega. Así, Delacroix no pudo elegir un tema más trágico y más actual, siguiendo los pasos de Gericault [se refiere al formato del salvamento de la Medusa] El formato de la tela era tan ambicioso como el mismo tema, pues tenía más de cuatro metros de alto.

Conceptualmente la composición estaba elaborada desde 1823. Su plasmación sobre la tela estuvo precedida de dibujos de toda índole. Delacroix plasmó su primera idea en un rápido dibujo a pluma. En los esbozos siguientes dispuso los diferentes personajes, concretó las relaciones entre ellos, sus gestos y sus actitudes. En una acuarela estudió la armonía de los colores. Esta acuarela da ya una idea general de la tela y produce una magnífica impresión por su rico colorido, pero no deja de ser una etapa en el proceso de creación, que aún habría de sufrir innumerables modificaciones antes de alcanzar la versión definitiva. Las páginas del diario dan testimonio de un trabajo apasionante, a menudo también agotador. En el transcurso de los días al pintor se le iban ocurriendo ideas que sabía se perderían si no las recogía en ese mismo momento en que aún estaban cubiertas de ese encanto que les prestaba la imaginación y el humor pasajero. A veces, cansado de la tela, la dejaba a un lado y se dejaba ganar por el deseo de hacer una serie de cuadros pequeños. Pero la gran verdad dantesca siempre terminaba imponiéndose y obligándolo a concentrarse en su trabajo hasta terminarlo."118

Aparte de Las Matanzas de Scío un cuadro más, redondea la concepción del dibujo en Delacroix, se trata de La Muerte de Sardanápalo, en él, los principios de asentamiento de las figuras en una base fija desaparecen, en su lugar el movimiento de rotación que les imprime es una nueva visión del dibujo. Fig. 63

La sala de Pintura Francesa del Siglo XIX en el Museo del Louvre representa de modo sumario el análisis que nos esforzamos en plantear, En dos grandes muros

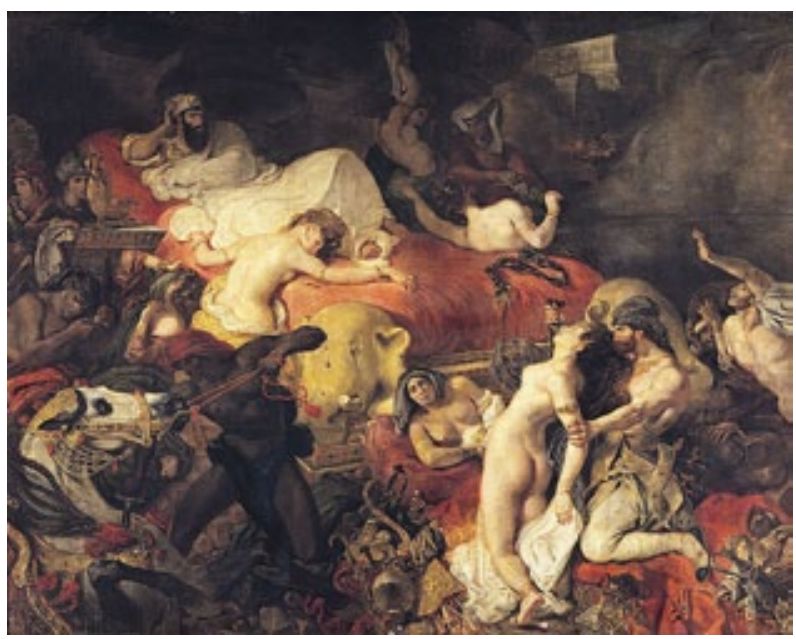

Fig. 63. Delacroix, "La muerte de Sardanápalo" frente a frente dialogan en mudo estruendo las obras de Ingres, Delacroix, Luis David y Gericault, entre otros. Desde que posamos los pies en el umbral de este espacio cedemos ante la conmoción, pero al mirar pensando estas obras concluimos con certeza lo

118 Petrova Eva, Delacroix y el dibujo romántico. Barcelona: Ed. Polígrafa; 1989. P. 38. 
que hemos planteado con tanta limitación.

Incluimos aquí otros dibujos que muestran las continuas reflexiones y ajustes dramáticos y compositivos preparatorios del trabajo final de Gericault. Figs. 64
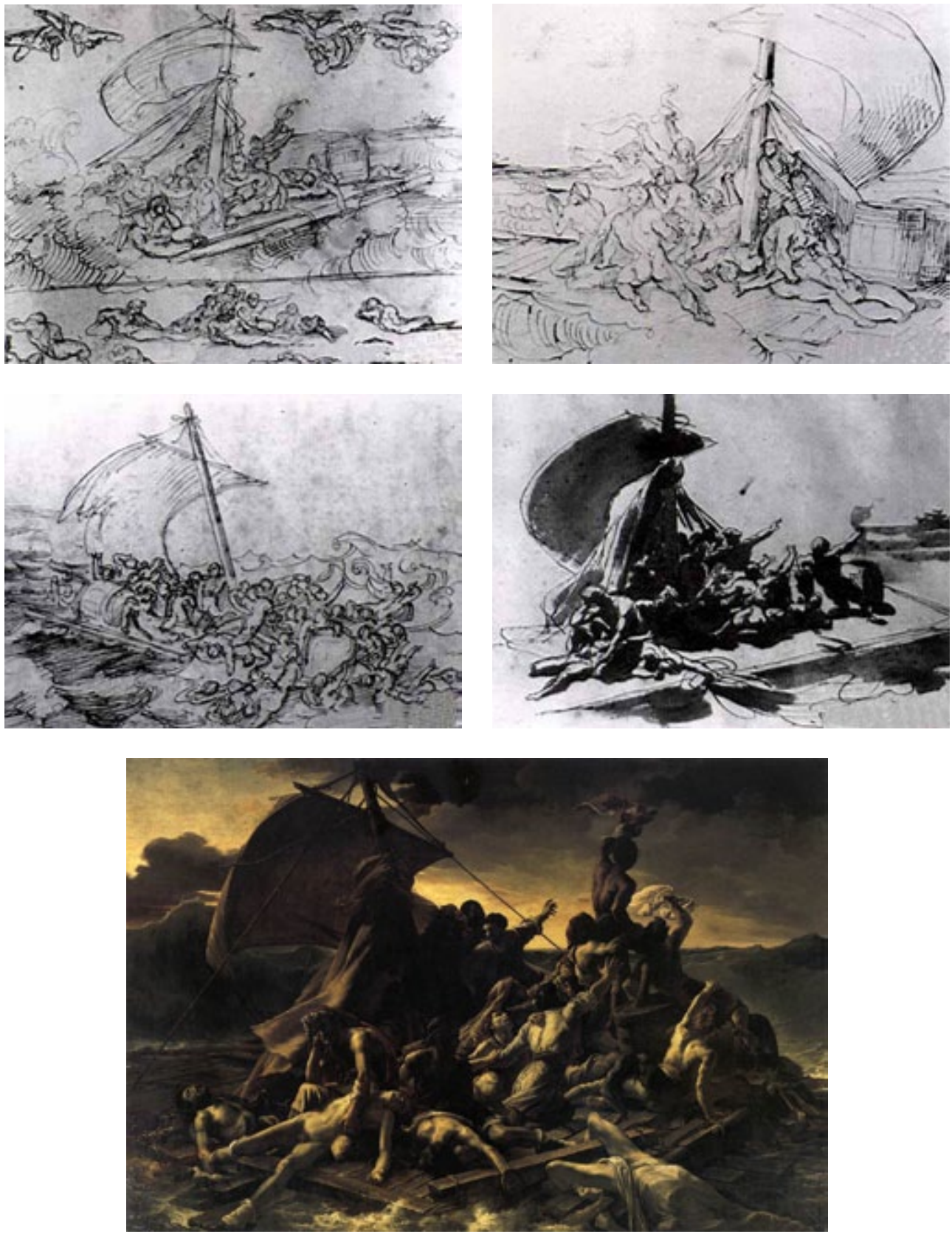

Fig. 64. Teodoro Gericault. Bocetos y obra terminal, "El salvamento de la Medusa" 
Los cambios en el ideario artístico y las variantes del dibujo en el Romanticismo son la culminación de un viaje mental de los dibujantes, iniciado con la apertura conceptual y la ingeniería constructiva del Barroco en su madurez, estas variaciones alcanzan plenitud en las formalizaciones del dibujo del 1700. Como todo proceso, en la maduración de la teoría del dibujo del Naturalismo se plantea el umbral para la explosión del dibujo romántico, en este corto periodo se alcanza la posibilidad de expandir en la práctica la antigua concepción italiana del dibujo, tanto en su esencia lineal circunscrita como en el entendimiento Zucariano del dibujo Interno que era la expresión del pensamiento racional, frente a éste, la emoción, la subjetividad y la emotividad encuentran cauces que los formalizan como actitud del dibujante, Este será el punto importante, el que la actitud se cristalice en aplicaciones formales y procedimentales específicas, y por tanto analizables bajo órdenes teóricos objetivos, modelos del dibujo en su definición teórica y epistémica, que es el asunto que centralmente nos ocupa.

Los artistas románticos dejan listo el panorama para el Naturalismo y el Realismo que ocupa un trecho del siglo XIX. Claro que hubo muchos espacios de producción entre esos años que no citamos, muchos autores que trabajaron el dibujo con particular intensidad, Daumier, Perov, Millet y tantos otros. Pero hemos puesto interés en puntos paradigmáticos de la representación en el dibujo y sus configuraciones de imagen como modelos del pensamiento, nos interesa la relación que guarda en la cadena constructiva del pensamiento de la forma.

Dos grandes artistas "torpes" de fines de siglo XIX, Cézanne y Vincent Van Gogh son personalidades de transición, despejarán el panorama y pondrán las piedras de toque para la revolución de la forma en el primer cuarto del siglo XX. Particularmente Cézanne tiene un sitial en el proceso de cambio hacia la pintura moderna del siglo XX. Para nuestra secuencia causal, ambos, desde sendas distintas aportan elementos de giro en la construcción indéxica del dibujo.

\section{III-6-4 EL DIBUJO DE LA FORMA}

Por momentos la secuencia histórica que determina nuestro trabajo se corresponde con los cortes clásicos de la historia del arte y la pintura, pero en otros casos como éste, parece que se establece sobre secuencias un tanto distintas. Esto es así precisamente porque vamos ordenando nuestra estructura de análisis sobre las causalidades relacionantes que el modelo analítico propuesto nos muestra. Y en ese sentido encontramos que en ciertos momentos las relaciones del dibujo y su proceso de construcción modelística muestra sincronías pero también desfases y relaciones diferentes a las que se nos proponen dentro de una historia del arte editada con su propio sentido.

¿Cuáles son las características conceptuales que observamos en Cézanne y Van Gogh y Georges Seurat, tres artistas que desde el sentido de la pintura resultan ampliamente distantes?

Y no es que en sus dibujos sean similares, ni en sus formas ni en su intención.

Pero descubrimos en ellos el inicio de los dos apartados estructurales que marcarán el cambio paradigmático conceptual del arte del siglo que se inauguraba.

Benjamín Buchloh plantea que el arte del siglo XX se desarrolla sobre la base de tres categorías cardinales: la factura, la no relacionalidad y la indexalidad. 
La No relacionalidad, o mejor, en términos que en adelante usaremos, la Composición No Relacional, reviste gran importancia para el proceso del dibujo y la acción, que es parte central del segmento siguiente de análisis.

Para el punto en que nos encontramos, la categoría de lo indexal aporta el eje analítico que expresa las relaciones conceptuales que organizan la función del dibujo en este segmento de la historia como cualidad emergente dentro del sistema. Ya un poco arriba formulamos nuestra consideración de la línea del dibujo como sistema indexal que manifiesta la huella del pensamiento del dibujante y que se aleja de la función clásica de contornear, nos revela la naturaleza de sus operaciones prefigurantes, pero también desnuda la interioridad subjetiva y psíquica del ejecutante en el acto de trazar, mediante la huella resultante de la actitud vuelta ejecución.

Tomemos las palabras de Buchloh para redondear este planteamiento, que es la base del corte paradigmático del dibujo en este segmento histórico que nos ocupa.

"La liberación de la línea de la tarea de la figuración -por utilizar la expresión que popularizó Michael Fried para designar uno de los principales logros de las pinturas de Pollock y su seguidor Morris Louis- fue, al igual que el monocromo, una de las metas que los pintores poscubistas persiguieron con más ahínco. A partir de 1913, los artistas más avanzados se habían dedicado a abolir todas las funciones icónicas de la definición lineal (la línea como contorno, que envuelve o describe figuras o configuraciones espaciales) por medio de la definición de la línea como formación espacio-temporal o como rastro inmediato de un proceso. Se concibió como una estructura que existe por sí misma, independientemente de la creatividad, expresividad o destreza del autor, la patte, como lo llamó Feneón. Esta mecanización del dibujo... se desarrolló a través de dos estrategias complementarias: la primera mostraba la fuerza de la gravedad como el primer factor determinante en la ubicación de estructuras y materiales sobre las superficies planas... La segunda estrategia se desarrolló principalmente en el contexto ruso y soviético a través de la exploración de la factura por Olga Rozanova y Lyubov Popova así como del uso que hizo Rodchenko de herramientas de dibujo como el compás y la regla, la brocha del pintor de paredes y el rodillo que durante siglos habían estado vetados del dibujo artístico"119

La Forma Indéxica Conceptual y la Indexalidad Gestual de la Acción, llevaron al reconocimiento del índice como un fundamento semiótico del dibujo y la función lineal dentro de la pintura, proceso y función que se aclara y agudizan con la decisión de fragmentar la línea y la pincelada como unidades singulares; remarcamos la gravedad y el peso de esta nueva función teórica en la que el dibujo operó como eje de construcción. Con este parteaguas se llega a la plenitud de la modernidad en los sistemas formales y de pensamiento del dibujo y la pintura.

Estas operaciones modelísticas teóricas surgen de la convicción política del Constructivismo por lograr un arte nuevo para su naciente país, un lenguaje que fuera consonante con la actualidad que estaban construyendo. Pero se origina también del ejercicio interno de la práctica de configuración artística, como de la asimilación racional de su inmediato pasado histórico y la sensibilidad de los artistas hacia las obras de su pasado aún fresco.

119 Buchloh Benjamín H. D. Formalismo e Historicidad. Madrid: Ed. Akal; 2004. Pág. 236. 
Todo este proceso teórico dentro del cual el dibujo se mantiene como factor capital, es el eje de análisis que opera en este inciso, de su muestra en la obra de algunos artistas y sus consecuencias sobre la teoría de las artes tratan nuestros párrafos siguientes.

La Forma de la Forma, la Tautología del Dibujo y la Pintura, el Artepurismo y la Autorreferencialidad del arte y el dibujo, son lo que consideramos la irrupción de la Primera Modernidad del siglo XX. Se basan en la división categórica que abre el principio de indexalidad en el dibujo.

Aquí aclaramos que nuestro corte modelístico se basa en un giro teórico que diferencia estos movimientos con claridad de aquello que más adelante se sucedió como la Modernidad Greengberiana correspondiente al Informalismo y el Expresionismo Abstracto. Situaciones en las que se puede aplicar el modelo de análisis de la indexalidad aunque los resultados del análisis nos lleven sobre rutas disyuntivas aunque no necesariamente opuestas.

El dibujo siempre había tenido su relato, trataba de algún tema, el Barroco denominó a esta circunstancia, la historia del dibujo.

Después del trabajo de Braque y Picasso que culminaría con la propuesta Cubista quedó listo el panorama para que Mondrian y Kandinsky dieran el gran salto; un arte que prescindiera de la evocación directa del referente dibujado y reconocible en la imagen del dibujo y la pintura.

La forma de la forma como relato de la obra. Llevar a una línea de paseo como Klee lo dijera. Colocarse en la punta de la pirámide del arte según la tesis de Kandinsky.

Pero antes de entrar de lleno a este panorama queremos detenernos en el dibujo de Cézanne, en el de Van Gogh y en la función de la pincelada dentro del trabajo de Seurat.

Los dibujos tempranos de Van Gogh lo muestran cercano a las inquietudes del Naturalismo, sus escenas encajan en la novelesca de Émile Zola, a quien frecuentó, en sus cartas hace referencia a su visión del campesino evocadora del trabajo de Millet.

En sus primeros encargos, aún viviendo en Holanda, pesa sobre él la demanda del mercado y el gusto comercial el auge del Realismo y el Naturalismo.

Pero al dirigirnos a sus dibujos de paisaje realizados con tinta y caña de caligrafía se nos abre un abanico complejo de calidades lineales, que si bien se originan como intención de formalizar relaciones espaciales y de relieve del paisaje, rebasan este plano y construyen un repertorio casi alfabético de la línea. Figs. 65

En estos dibujos la relación indéxica se establece en el sentido que formula valores conceptuales al trazo, y que se advierten diferenciados de la actitud gestual con la que se considera siempre el trabajo de Van Gogh.

Es conocido el interés de Van Gogh por el grabado japonés, lo coleccionó y lo expuso ocasionalmente, tanto en las herramientas utilizadas para dibujar como en las resoluciones constructivas es clara la intención de establecer una ingeniería lineal particular. 

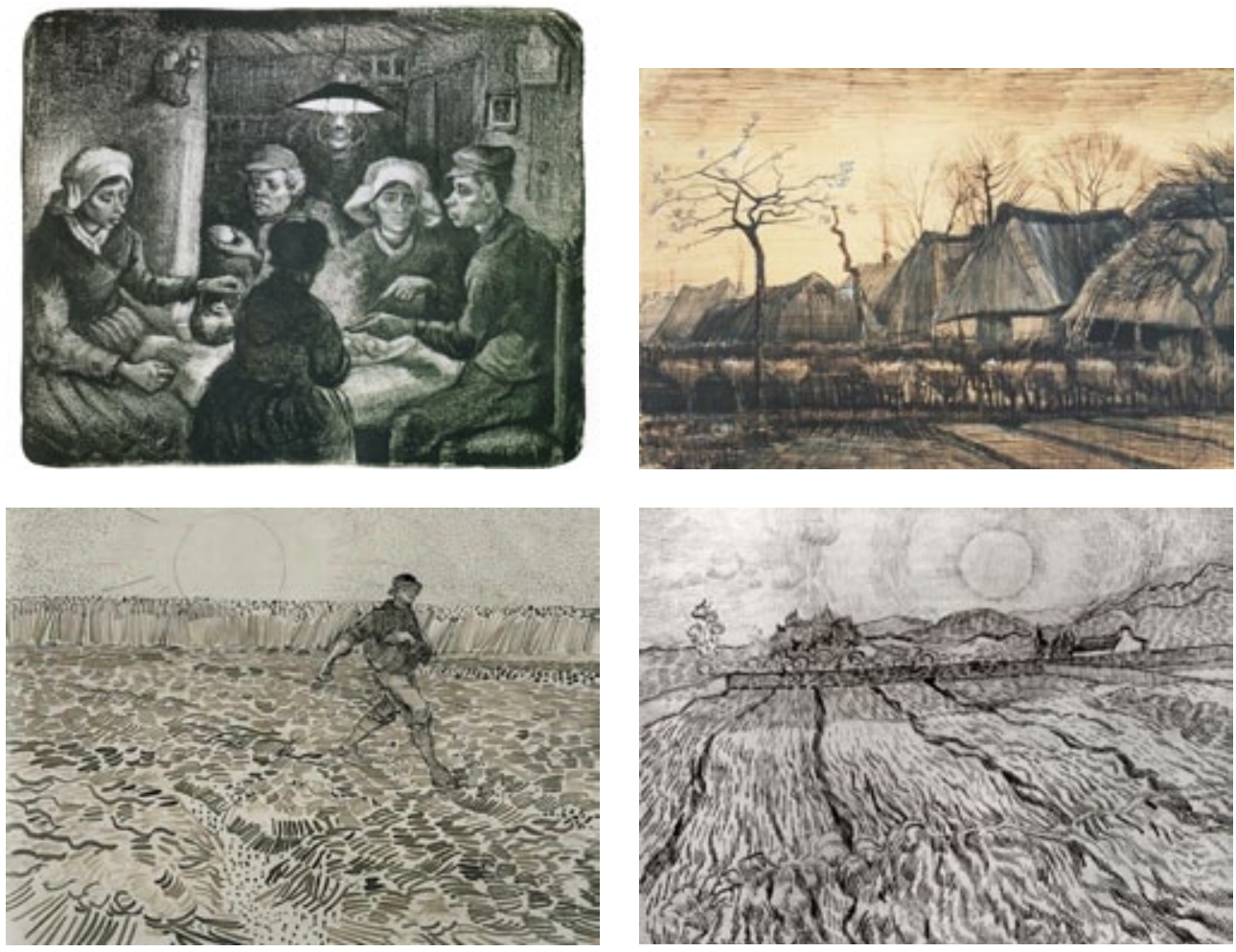

Fig. 65. Van Gogh, dibujos a pluma y caña de bambú.

La coherencia que alcanza a lo largo de su trabajo en esta búsqueda del dibujo estructural con una función lineal alterna es maravillosa.

Pero precisamente, al trasladar el autor sus proyectos a la pintura no se pierde esta cualidad en la que la pincelada es huella de un concepto y se integra plenamente a la intensidad subjetiva de la pincelada y su carga textural. Figs. 66

Fig. 66. Van Gogh. Inicio de la pincelada indéxica, huella de la acción física y el concepto formal.
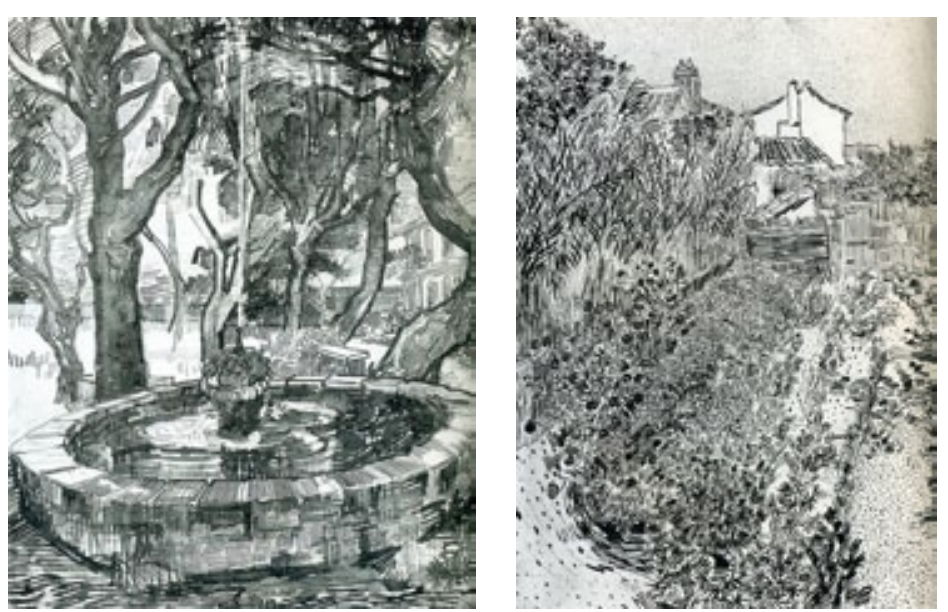

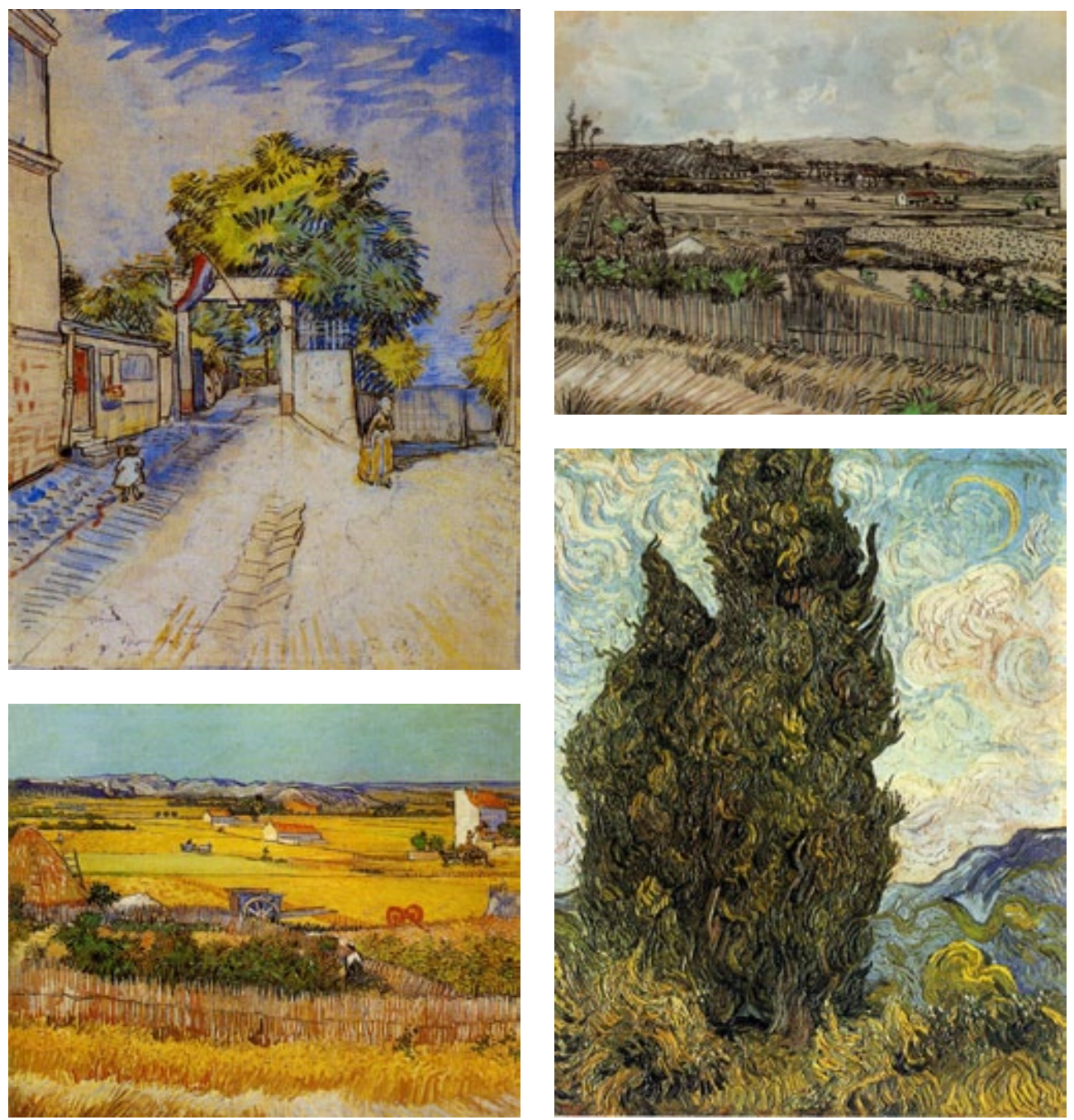

Fig. 66. Van Gogh. Inicio de la pincelada indéxica, huella de la acción física y el concepto formal. (Cont.)

En el trabajo de Seurat notamos como mantiene una estrategia metodológica dentro del proceso de trabajo. Realiza estudios previos a las pinturas finales, su dibujo es limpio en el aspecto lineal y contorneado. Pero en el momento de organizar la aplicación del color opera sobre la base de dividir las áreas de tono mediante pinceladas que segmentan los planos y dejan ver la operación conceptual que organiza la estructura, es como si el dibujo operara en una siguiente fase del proceso, interiorizado en la construcción cromática. Esta fusión interna del dibujo en la acción de pintar representa una operación mental que no obedece a los causes del modelo natural. Su existencia se da en la posibilidad de imaginar una estructura propia del pensamiento dibujístico, esta es la huella que nos denota la operación mental. Figs. 67

El trabajo de Paul Cézanne constituye el punto de cierre circular del proceso seguido por el arte del siglo XIX. Fue el artista más crítico en la reflexión de los mecanismos que 

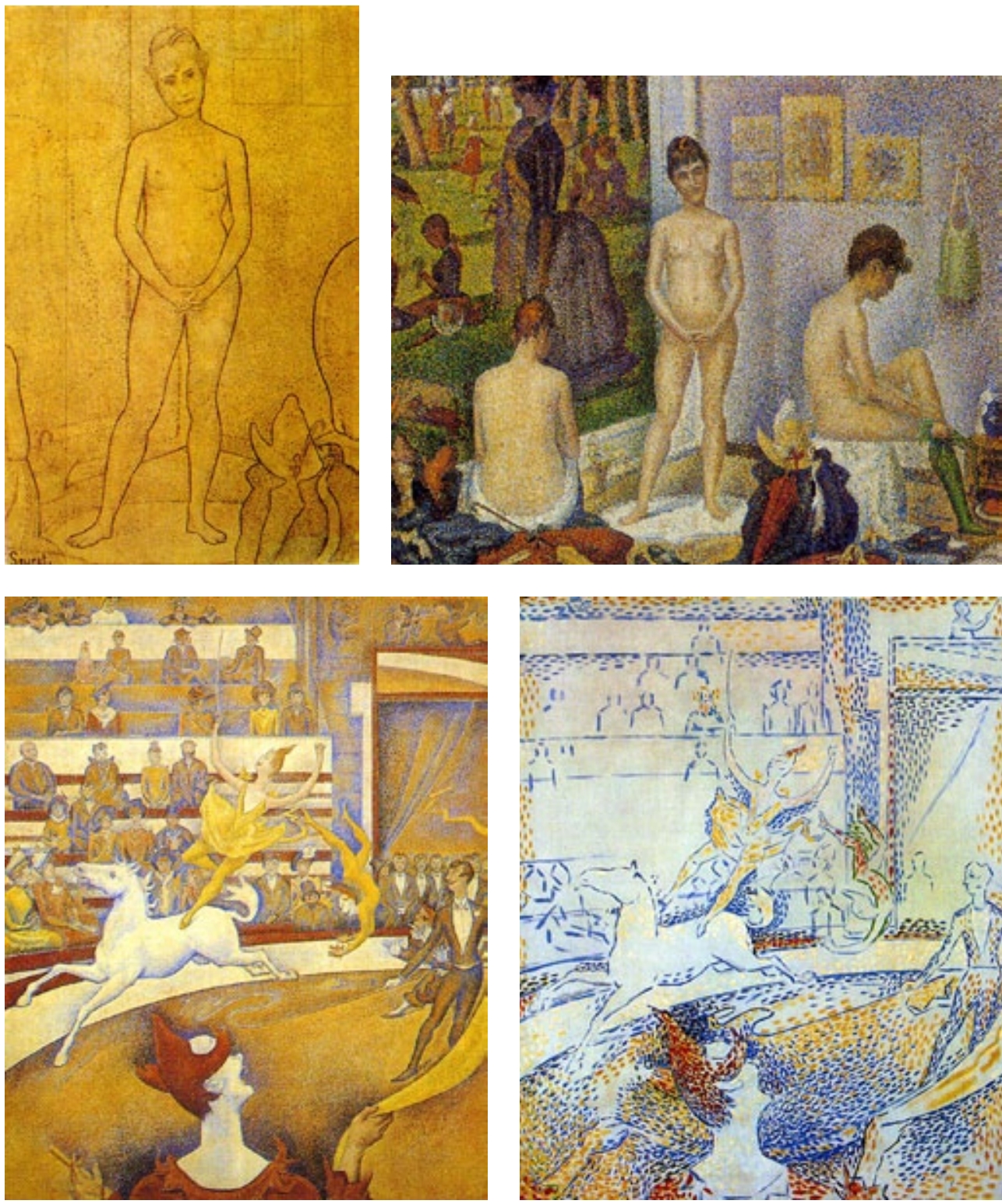

Fig. 67. Seurat, estudios y pinturas.

definen la pintura y el dibujo como formas de modelos perceptuales y de representación. En sus trabajos vemos más claramente que en ningún otro el sentido de la categoría de Observación. Mediante el estudio visual de los modelos es el primero que inicia el proceso de abandono del referente modelístico como asociación al resultado icónico del dibujo.

Para lograr esta meta era necesario ir dejando a un lado todas las categorías del dibujo aplicadas hasta ese momento, para en su lugar construir las partes de un vocabulario visual y un entendimiento alterno del espacio y la solidez de los modelos.

Ya comprendemos que esta era una labor gigantesca. 
"Soy el primitivo del camino que he descubierto, le dijo Cézanne a Émile Bernard al final de su vida. Pero el nuevo idioma que hablaba era tan articulado y convincente que después de él pocos podrían siquiera recordar el antiguo y mucho menos hablarlo"120

En Cézanne destaca su actitud para usar el dibujo como una manera de investigación, pero ya no tanto, o tan solo de la naturaleza, sino de la forma visual y plástica en sentido estricto. Una actitud que busca fervientemente la manera de lograr conclusiones.

Teodoro Adorno y Maurice Denis destacan en la obra de Cézanne su construcción como objeto autónomo, una representación no equiparable con cualquier imagen que pudiéramos remitir a la naturaleza, aquí la obra logra una consistencia ontológica de una vez por todas.

Los trabajos de madurez de Cézanne significan lo que en el siglo XX se denominó la creación autónoma, y ésta, siguiendo a Adorno, no está mediada sino por la forma de la obra misma. Objetos que no son del reino natural sino claramente construcciones que obedecen al reino del pensamiento.

En el estudio de Eiseman Stephen se resumen tres categorías de análisis que marcan pauta estratégica del pensamiento de Cézanne en la organización formal.

Primero, se construye una ilusión espacial que no depende de la perspectiva piramidal sino de los juegos de desdoblamiento que realiza con los planos de los modelos.

Ya de por si esta es una situación en la que el dibujo cobra sentido elemental.

En segundo término, la utilización de una estructura tectónica como base de la construcción de la superficie del cuadro y los modelos representados. En esta estructura, la forma, el tamaño, la dirección y delimitación de las pinceladas no dependen de la textura ni las dimensiones que tienen en los modelos que se toman como base de la observación.

En tercer lugar, y ésta es una característica en la que el dibujo fue un operador fundamental, las partes esenciales de la imagen estarán en los sitios donde los objetos y los modelos en general se acercan hasta encontrarse, llegan a compartir un sólo contorno.

En estas zonas Cézanne comprendió que la línea ya no tenía sentido, sino que la forma se construía partiendo de la definición de los planos de color y su correcta disposición pero también de su altura de tono y matiz, nuevamente, el dibujo se integra en la construcción cromática y aunque pareciera desaparecer, esto solo sucede en su carácter lineal, pero se expande hacia comprensiones tectónicas nuevas.

La pincelada que modelaba las formas y el relieve de los objetos pasó a ser parte de la historia, en su lugar se inicia el camino de la modulación como estrategia de construcción de la forma del modelo somático y el modelado del relieve.

El mismo Cézanne decía que no debería usarse el término Modelar, en su lugar debería decirse Modular. Figs. 68

Los fenómenos tratados en estas últimas líneas se unen con el trabajo de Picasso, Braque, Mondrian y Kandinsky en lo que será el paso hacia la abstracción pictórica.

La ruta que nos interesa seguir en este caso es la del pensamiento del dibujo y la evolución de su función indexal, la que lo conducirá hacia la formulación del lenguaje de la visión.

120 Eiseman Stephen F. Historia crítica del arte de/ siglo XIX. Madrid: Ed. Akal; 2001. P. 354. 

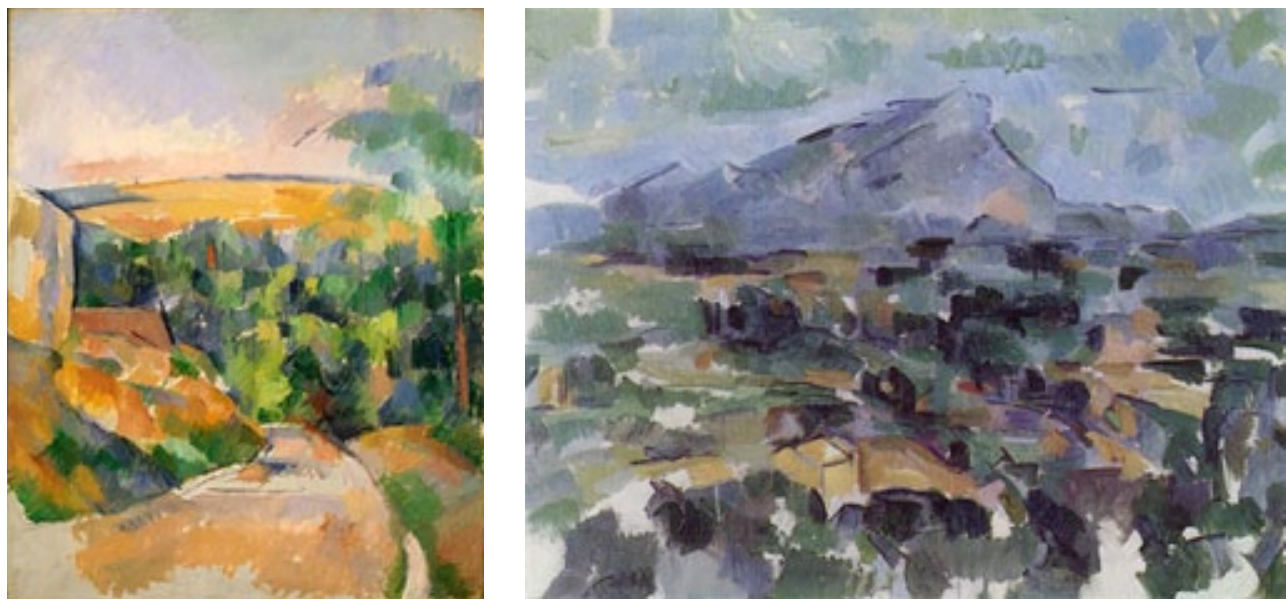

Fig. 68. Paul Cézanne, modulación pictórica.

El momento histórico al que nos referimos se desarrolla en cuatro décadas apretadamente, es una dispersión de inquietudes en toda Europa. En Austria el movimiento de la Secesión de Viena con Gustav Klimt a la cabeza, en Rusia el Constructivismo y el Suprematismo. De estos últimos movimientos artísticos culturales incluimos una serie de obras con las que se cierra el principio de indexalidad conceptual y la definición ontológica de la línea, conclusiones sobre las que se funda el desarrollo del arte en ese momento. Fig. 69
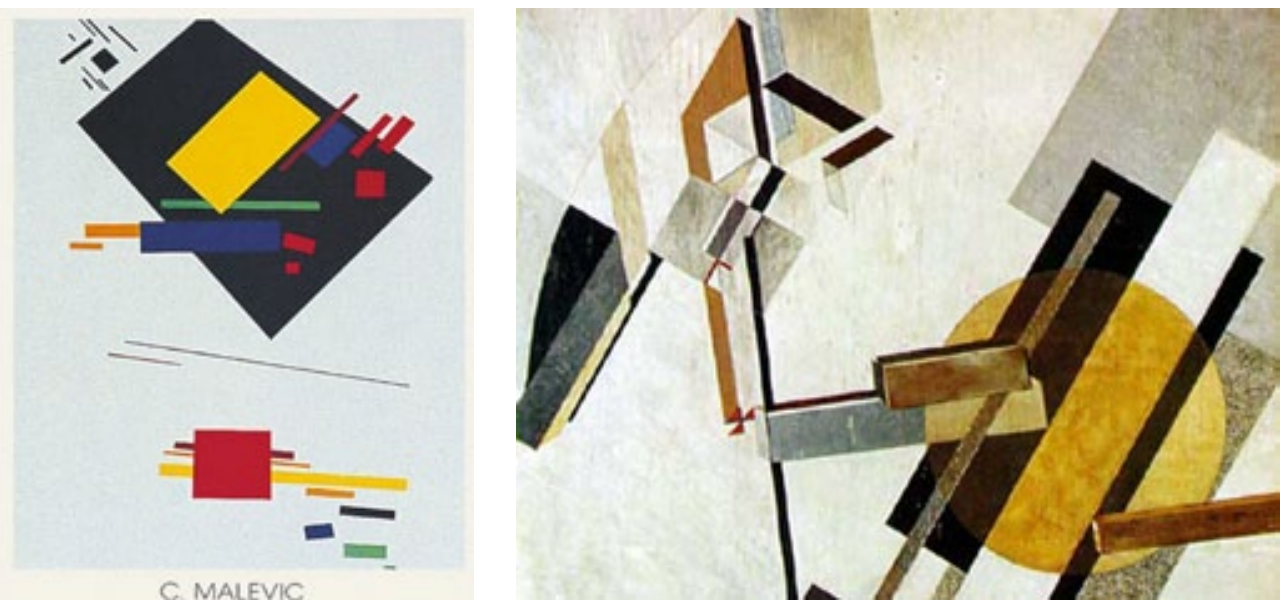

Fig. 69. Suprematismo y Constructivismo. Línea indéxica geométrica de carácter no autográfico.

El siguiente corte relevante en el proceso del dibujo y las artes en general lo constituye el Integracionismo y los segmentos que dentro de él se manifestaron.

Nos referiremos al Movimiento del Stijl y la Bauhaus como centros que representan con claridad una postura de los artistas, que por otra parte se integraron a veces, tanto a la revista y también al cuerpo docente de la Bauhaus, además de trabajar por su cuenta proyectos personales y encargos. 
Hemos separado también estos dos casos de movimientos abstraccionistas de la historia del arte, porque en ellos se decide el camino de la enunciación de un lenguaje visual de las artes.

Aquí la categoría de la Plástica es cuestionada radicalmente. Probablemente no de manera intencional pero si como consecuencia de sus formulaciones, Piet Mondrian, Theo van Doesburg, Vilmos Huszar, George Vantongerloo, Gino Severini, dentro de la revista Stijl, y Walter Gropius, Mies van der Rohe, Vasili Kandinsky, Oskar Schlemer y demás miembros de la Bauhaus, abrieron para siempre el espectro de la categoría definitoria del arte de la imagen. Esto traería consecuencias radicales en todos los órdenes; como es de suponer la lectura de la obra ya no será la del discurso dramático contenido en la imagen y mostrado mediante la configuración plástica de la materia y la huella subjetiva del temperamento del artista, expresada mediante la regulación de las descargas e inflexiones del trazo y la materia, ahora lo que interesa es un arte purista, en el que las formas aludan al nuevo lenguaje, el de la nueva sociedad, el del equilibrio y las formas absolutas.

Los textos de Mondrian, Realidad Natural y Realidad Abstracta y Arte Plástico y Arte Plástico Puro contiene sin equívocos esta postura. Los primeros treinta años del siglo XX fueron más prolíficos en teoría de las artes que los cien años precedentes.

Solamente el recordar el título de los textos nos habla de la intencionalidad epistémica de sus autores.

Este proceso ya ha sido señalado por otros investigadores, no somos los primeros en anotar el fenómeno de retroacción del lenguaje de las artes para convertirse en su propio relato, el lenguaje que habla del lenguaje, la forma de la forma como el discurso central de la obra.

Pero la faceta que nos interesa en este mar teórico, es la de ubicar la situación del dibujo dentro de estos proyectos de reconstrucción artística. Intentaremos seguir los pasos de las funciones desarrolladas por las prácticas del dibujo y colocarlas en su dimensión dentro de los procesos de representación.

Se partió de la idea de que los sistemas compositivos son la expresión organizada de los elementos que los integran, por lo tanto intentaron reducirlos a números más o menos fijos de componentes. Se podía entonces enunciar las leyes que determinaran su combinatoria. De esta manera el estudiante aprendería el alfabeto visual y después lo aplicaría en un ejercicio de apertura individual, tal y como sucede con la escritura.

Es el momento de realizar una puntualización:

La mención de la Línea, el Punto y el Plano como base de la teoría de la forma visual la encontramos tanto en Kandinsky como en Klee en sus textos, Punto y línea sobre el plano (1926) y Bases para la estructuración del arte, (¿1921-22?) Pero también se les halla dentro de los programas formulados para el Kontsentr Gráfico de la Unión Soviética (1923-26) En este grupo de escritos se mantiene la idea de que la Forma es el resultado de la interacción de estos tres factores geométricos. Sobre la base reductiva de estos tres principios, de manera contrapuesta se logra la apertura del sistema en una secuencia sólo explicable sobre la base de una alfabetidad. Esta cadena constructiva generó un paradigma geométrico, racional y categorial de los campos del arte visual que hasta hoy día norma nuestra estructura gestáltica, perceptual y conceptual; nos referimos a las categorías de división de las artes visuales en las Bidimensionales y Tridimensionales. 
Este patrón se basa en la enunciación del punto como forma primaria, a la que paradójicamente no se le puede atribuir forma alguna. La Línea, que resulta del desplazamiento del punto y es la huella indexal que describe la naturaleza de su comportamiento. Y el plano, que es el cierre de un circuito lineal. Al agregar un punto más en relación y posición cualquiera al plano generado, las líneas que trazan su comportamiento establecen la formación de la figura tridimensional. Este es el inicio del modelo teórico de la visualidad, su gramática se basa en el estudio y desarrollo de sus posibilidades combinatorias constructivas y las leyes que las vuelven operativas.

La primera modernidad integracionista del XX se sustenta en esa teoría general, parece que significa una razón modelística de primera generación; pero nos anima una inquietud, una duda, ¿hasta dónde este sistema lógico constructivo y geométrico tiene relación con la teoría del Tetraktis pitagórico como fundamento del mundo y el cosmos? En ese pensamiento el Uno corresponde al Punto como unidad primera, el Dos como existencia doble del punto trae en consecuencia la Línea, Tres Puntos permiten la demarcación del Plano, el Cuatro es un punto más que forma el tetraedro, cuerpo geométrico elemental.

Sobre la base anterior comprenderemos porqué dentro del Suprematismo, Constructivismo y Bauhaus el dibujo con instrumentos geométricos cobró relevancia. Bajo esta secuencia formal cualquier modelo a dibujar sería sujeto de simplificaciones y reducciones geometrizantes en busca de su estructura analítica mínima.

La narración tenía ahora poco sentido, el objetivo se basaba en dar estructura a la visualidad, se podía desarrollar la gramática de la forma desde la aplicación del alfabeto visual, el dibujo se distanció de la naturaleza y se confinó en los rincones de la proyección geométrica, en todos los casos se dibujaba para realizar la famosa síntesis geométrica de los modelos. El resultado de los ejercicios de los alumnos y aún el de sus profesores se asemejaba demasiado.

Con esto, las Artes Plásticas iniciaron su camino hacia las Artes Visuales.

Las dinámicas proyectuales cobraron nueva importancia ya que la pintura la escultura y demás artes se acercaron nuevamente al diseño, pero ahora desde la perspectiva de un diseño maduro, como disciplina que atendía los requerimientos de la industria y la propaganda.

Los propios integrantes del Stijl y la Bauhaus advirtieron este fenómeno y postularon su tesis integracionista; la reunión de las artes del espacio, la imagen y el diseño bajo un solo sistema de estructuras.

Denominaron a esta iniciativa Integracionismo, propusieron también, en especial Mondrian dentro de la revista Stijl el Neoplasticismo y el Elementarismo. Los términos de un arte nuevo y radical menudearon: Contraconstrucciones, Construcciones, Arte Concreto. Pintura Ortogonal etc.

La tesis de que todo arte era reductible a un número finito de elementos, y que éstos se podían cargar de un valor codificado, los llevó a pensar en la integración no sólo de las artes del diseño y la plástica tradicional. La música especialmente los sedujo en un intento por lograr obras interdisciplinares, basadas en el principio de sinestesia que después de todo sí tiene un origen neurofisiológico.

El estilo único y universal de compatibilidad lingüística sería el nuevo estilo moderno. El 
estilo moderno era impersonal, como lenguaje, escapaba a las distorsiones personales aplicadas sobre el código, la incidencia personal estriba en la utilización del sistema como aplicación individualizada a la solución del problema enfrentado en cada caso.

El proyecto del dibujo en los movimientos modernos, se convierte en estrategia de solución de problemas, mediante el ejercicio de la razón de las formas aplicadas como elemento de respuesta a esa necesidad. Aquí quedaba abierta la puerta para el Funcionalismo que más que mística tenía convicciones políticas.

Aun así esto es perfectamente coincidente con la función del dibujo como campo del planteamiento del concepto de la obra. Ese carácter cognitivo y proyectual será el que dos décadas más tarde sea fuertemente cuestionado cuando el arte se pare sobre territorios que rescatan la espiritualidad y el sentimiento, basándose en la emoción y la intuición como parte sustantiva del dibujo.

La reducción formal del Neoplasticismo se expresaba en los siguientes principios: universalidad del lenguaje, pureza de la forma, esencia espiritual, monumentalidad, equilibrio y armonía.

Estos principios eran el soporte de un lenguaje con elementos básicos de la forma, reducción de los colores a los primarios, uso de los grises al centro de la escala cromática como elemento de armonía y equilibrio, y muchas formulaciones más.

En el planteamiento neoplasticista vemos con claridad la influencia de Mondrian, los elementos de la teoría formal neoplástica están sacados de su texto Realidad natural y realidad abstracta, que se publicó en entregas en la misma revista Stijl de junio de 1919 a julio de 1920.

El desacuerdo surge cuando Van Doesburg plantea que el arte moderno y contemporáneo no podía ya basarse en la postura estática y tranquila, porque la vida en ese momento era todo lo contrario. Propuso la necesidad de incluir el tiempo y la cuarta dimensión en la obra artística y con las Ilamadas Contraconstrucciones se separa del Neoplasticismo y propone un arte de diagonales y desequilibrio.

Gyorgy Kepes haría la invitación clara un tiempo después a la alternativa de un arte actualizado con el fluir veloz del mundo contemporáneo.

"En la actualidad, los artistas creadores tienen que cumplir tres tareas para que el lenguaje de la visión pase a ser un factor poderoso en la remodelación de nuestras vidas. Los artistas tienen que aprender y aplicar las leyes de organización plástica que son necesarias para el establecimiento de la imagen creadora sobre una base vigorosa. Deben ponerse en armonía con las experiencias espaciales contemporáneas a fin de aprender a utilizar la representación visual de los actuales acontecimientos espacio-temporales. Por último, deben liberar las reservas de imaginación creadora y organizarlas en giros dinámicos, es decir, desarrollar una iconografía dinámica contemporánea."121

Pero los dibujos de proyecto menudean por todo este movimiento y la obra personal de sus autores.

121 Kepes Gyorgy. El lenguaje de la visión. Buenos Aires: Ed. Infinito; 1969. 
El dibujo dentro del proyecto de la Bauhaus se concretó en la expresión de sus clases y los objetivos que se propusieron. Estos programas nos muestran que el dibujo tuvo una importancia relevante, pero no como producto artístico autosuficiente, siempre se colocó en las asignaturas en un plano sumamente capital, en cada clase que se impartió de dibujo, se llegó a un cuestionamiento profundo de la función conceptual que desarrolla, dentro de la cadena de representación en la estrategia metodológica.

Se impartió dibujo analítico, dibujo técnico y de proyectos, dibujo escenográfico, se impartió también una clase en torno a la integridad del ser humano, en ella Schlemer ponía a dibujar a los alumnos buscando la síntesis formal del ser humano.

Existió un curso preliminar obligatorio en el que también se dibujaba mucho. Itten al impartir ese curso ponía ejercicios de estudio de montaje de objetos que servían de modelos. Eran armados con materiales diversos y después se les dibujaba, buscando con ello lograr el análisis de los distintos materiales que podían componer una obra, sus cualidades físicas y sensoriales. Los dibujos tenían la obligación de basarse en las características de las partes y materiales del modelo armado.

Las estrategias de proyección de la obra de arte serán enriquecidas y ampliadas en estos movimientos artísticos. Para bien o para mal, la obra, que ahora podía ser un objeto o cosa, bastante peculiar; se podía diseñar, y por primera vez esta palabra designaba una práctica diferenciada del dibujar, claro que el diseño incluye al dibujo en su horizonte disciplinar. Pero ahora se podía proyectar una obra construyendo un objeto armado de manera tridimensional, sin pasar necesariamente por el dibujo, las palabras de Moholy Nagy dan fe de esta postura, que además se asentaría como un paradigma de las artes visuales.

"La figuración, obtenida por estos medios técnico-mecánicos, de objetos naturales, fantástico-utópicos, de sueños y entidades irreales, se ha adelantado tanto, incluso con ayuda de circunstancias favorables, y ha alcanzado tal eficacia, que intentos similares realizados con medios manuales solo pueden comparárseles en contados casos. Gracias a las ilimitadas posibilidades de representación de que dispone, el procedimiento fotográfico está destinado a alcanzar la victoria en esta competición.

Solamente la visión fetichista del trabajo a mano puede levantar objeciones contra esta aserción. El que, al mirar una imagen, sea capaz de prescindir completamente de que la ha realizado una mano espiritual o un aparato sin alma, y sea capaz de ver las fuerzas creadoras del artista, más allá de la imagen, sin duda no va a preferir el pincel al aparato fotográfico. El hecho de que los resultados de la fotografía para los que tienen ojos para ver hayan alcanzado tantos progresos en los aspectos de claridad, precisión, luminosidad, inmaterialidad, y además de realidad de la representación, nos obliga a aclarar que el pintor naturalista haría bien en dedicar sus capacidades a la fotografía, que, entre todos los procedimientos de representación, es el más susceptible de desarrollo, el más versátil y el más espléndido."122

Gómez Molina ya analiza el problema de esta cita, cuando en la misma página señala que no es la representación lo que se cuestiona, sino la responsabilidad de quién realiza 
el acto. Estamos de acuerdo, pero agregamos además que es una falacia el supuesto desplazamiento del dibujo por el medio tecnológico de la fotografía.

La representación no es el acto simple de mimetizar la realidad en imágenes de segunda temporalidad.

Hemos insistido en calificar la representación como el hecho de rearmar la realidad y el modelo en la mente del sujeto cognoscente, esto para construir otra realidad inventada con sus propias características, que pueden no ser referenciales al mundo que nos rodea, pero también señalamos que éste es un proceso que se cristaliza mediante la aplicación de estructuras formales ideadas por el artista, principalmente no es un asunto de herramientas, aunque éstas estén involucradas en la realización de la configuración y el acto de representación. Bien haríamos en iniciar el desarrollo de una teoría de la herramienta en los procesos de representación artística.

He ahí la importancia de la distinción entre el tiempo de la configuración como posterior en el arte, al tiempo de la representación como conjunto unitario que contiene sus etapas.

Ésta aparece como primeridad en la mente del dibujante cuando imagina el modelo en determinada estructura formal, la representación repitámoslo, no es posible en el éter del pensamiento, siempre se plasma en estructuras abstractas que son tan variadas como la historia de la imagen y del lenguaje lo demuestra.

La mímesis o copia de la imagen visual perceptual, es una de las opciones de representación, el objetivo buscado en los 250 años del Renacimiento al término del Barroco.

La fotografía rearma el mundo ante nuestros ojos, no cabe duda, pero tampoco es la única manera de pensar el mundo, y hoy sabemos que tampoco es la traslación mimética del contexto.

Por eso es que los modelos del dibujo no son sólo los sujetos que se han de dibujar, lo son también los modelos del pensamiento que son leídos como el mundo reconstruido, para eso el dibujo dista mucho de haber sido desechado. No estamos diciendo que el dibujo sea condición indispensable para representar, porque de hecho cada arte y campo del conocimiento humano han creado su propio sistema estratégico para invocar y evocar la realidad y volverla a presentar como ellos la proponen.

Es sumamente polémico lo que aquí se afirma, pero es una de las razones para que muchos de los artistas consideraran que la obra podía ser planeada con un mínimo de dibujo y entregarla al artesano para su producción sin que la mano del artista interviniera.

Si en algún momento el dibujo fue descargado de alguna función constructiva del objeto y el concepto que lo anima, fue aquí.

Claro que la postura era sumamente radical y excluyente, por eso es que la reacción que suscito lo fue de igual violencia. El Informalismo, el Surrealismo y el Expresionismo abstracto en gran medida fueron respuestas a los proyectos integracionistas de la modernidad, la cual, después de la segunda guerra mundial perdió su cauda de convencimiento.

El debate entre geometría, fotografía, dibujo y modernidad fue extenso, pero la realidad en su terquedad se impuso, el dibujo se realizó y con abundancia tanto en la Bauhaus como en el Stijl, ya hemos señalado como, otras estrategias de configuración de la idea se generaron en este periodo, pero el dibujo reforzó su condición proyectual. Podríamos decir que incluso después de la flexibilidad del dibujo dentro del siglo XIX, el Integracionismo y el Neoplasticismo, precisarán las secuencias constructivas del dibujo, el boceto, 
el estudio, el apunte, el proyecto se decantan con una precisión taxonómica que antes no habían tenido, pero es interesante que el dibujo en su desnudez como resumen geométrico de los modelos, sentó bases paradigmáticas de representación que no eran las de la tradición mimética; tan fuertes fueron que incluso ahora son la base de los sistemas y manuales de dibujo convencionales.

Nadie cree que realmente un animal o un cuerpo humano sea una suma de triángulos y elipses, pero al presentarlos dibujados de ese modo todo mundo lee con claridad animales y cuerpos humanos.

Las imágenes que adjuntamos dejan claramente asentado el punto. Fig. 70

El Constructivismo Ruso, el Suprematismo, el Stijl y la Bauhaus se plantearon un proyecto para rehacer al artista, el hombre y
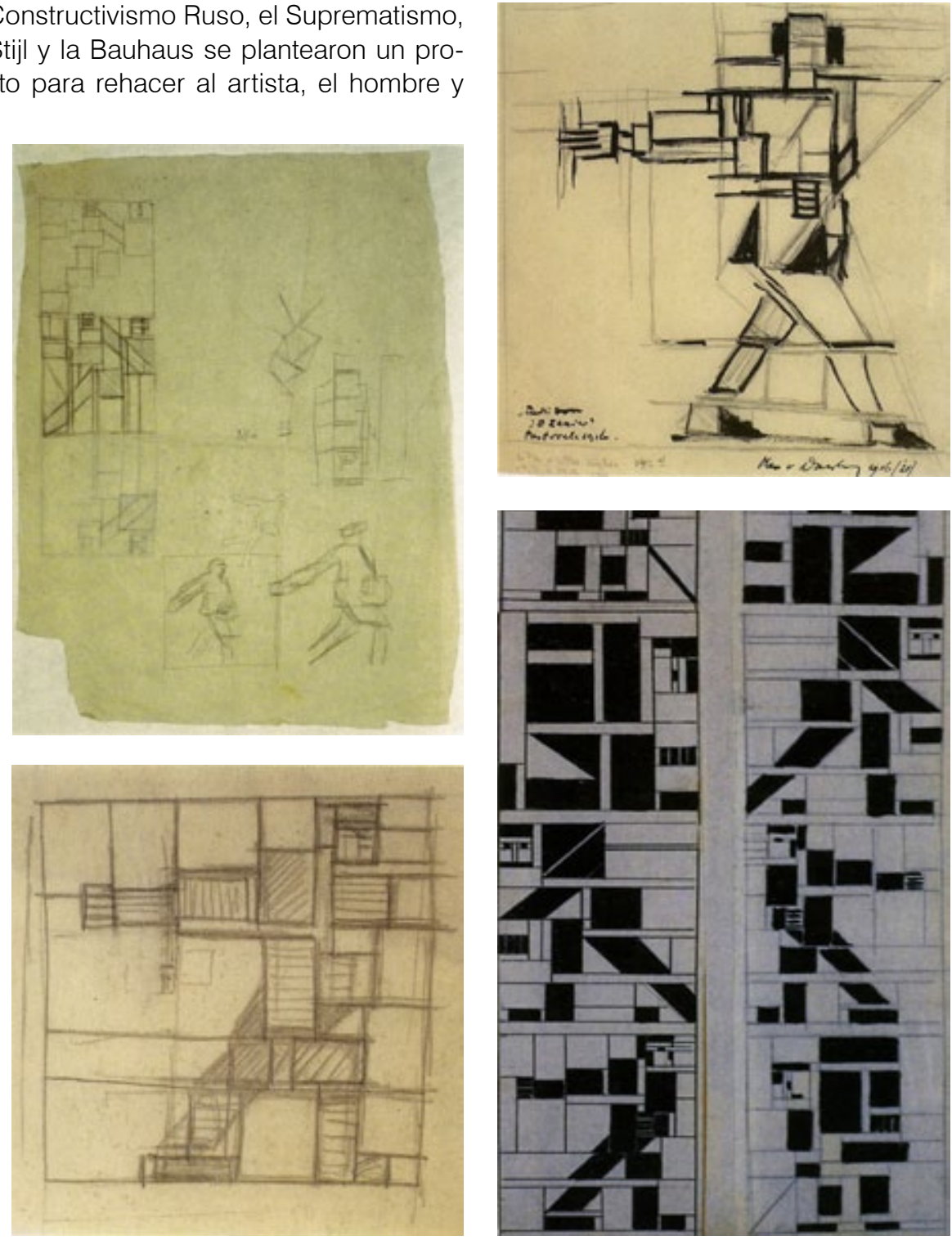

Fig. 70. Teo Van Doesburg. Proyectos para el Vitral "Gran Pastoral" 

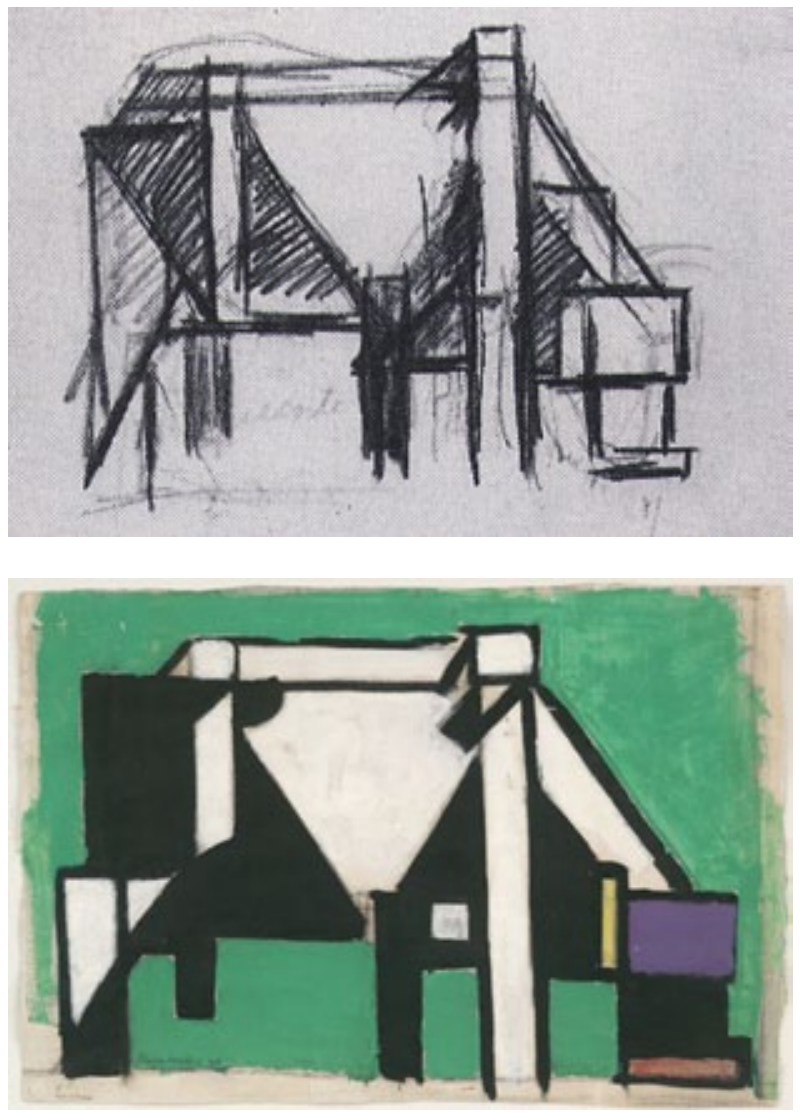

71. Teo Van Doesburg "Composición" (La Vaca) la sociedad, para ello definieron una actitud de desapego a la mímesis naturalista del dibujo y las artes, ahí radicó en cierta medida una esencia romántica.

No se trataba tanto de representar imitando como de representar bajo reestructuraciones de concepción.

Los propios artistas creadores del proyecto recapacitarían a medida que la experiencia avanzaba. Se dieron cuenta que en el correr del nuevo arte se había dejado de lado una antigua cuestión, se preguntaron si era posible realmente una imagen cuyo origen fuera sólo interior, con ello cayeron en la cuenta de que tenían que repensar el vínculo de la representación con la naturaleza, asunto nada nuevo por cierto.

Terminemos con una cita de Gómez Molina, en ella se aclara la pérdida de sentido en las representaciones cuando estas rompen su vínculo experiencial

con el contexto, para aludir solamente a la estructura misma, entrando en una carrera de sustracción que de manera inevitable agota el sistema, las combinaciones de los elementos del alfabeto visual pueden ser amplias, pero indefectiblemente empiezan a parecerse unas a otras y a caer en un agotamiento.

"La pérdida del modus integral en la abstracción formalizadora rompía el propio sentido de estructura que le había dado su valor. La estructura liberada iba a iniciar un proceso constante de desmaterialización significativa, los motivos objetuales se convierten en un proceso de composición fundamentalmente sintáctico-formal que constituye únicamente una comunicación visual. El nexo de integración ya no constituye la cualidad de un orden total, sino solamente mera integración formal."123

\section{III-6-5 LA ACCIÓN DE DIBUJAR}

Las vanguardias de la modernidad inicial del siglo XX resultaron mucho más normativas de lo que al inicio se plantearon. En su interior teórico conceptual se gestó el conflicto de

123 Gómez Juan José, et al. Las lecciones del dibujo. Madrid España: Ed. Cátedra; 1999. P. 133. 
que sus representaciones y los sistemas de estructuración de la imagen, constituyeron un cerco para expresar el material contenido en la experiencia sensible del artista.

Los instrumentos para el trazo exacto, humanizaban los dibujos como la expresión del pensamiento racional, pero los deshumanizaban en el sentido de alejarlos del mundo exterior y contextual, que transcurría en un convulsionado devenir.

El material de las experiencias convertidas en sentimientos y las pulsiones que pugnaban por manifestarse y salir de la psique del dibujante, terminó por romper el dique, el torrente de problemas no resueltos corrió y abrió una vía más para el proyecto del dibujo.

Los proyectos basados en la reconstrucción del todo social, llevaron a la insatisfacción de las pulsiones individuales, implantaron la representación como una acción basada en un sistema de estructuras formales convenido colectivamente. Pero al fin y al cabo la representación es un acto realizado personalmente, determinado por la aplicación del principio de autonomía del dibujante que busca la manera de formalizar su vivencia.

Por lo tanto el camino estaba más o menos abierto para la disidencia.

Buscar aquellas maneras de representar en donde lo establecido no negara la expresión individual.

El yo colectivo tenía su contraparte en el yo interno, en esa región interior existía un particular mundo de imágenes y asociaciones libres, que no habían sido censuradas por el consciente cultural y colectivo, por el gran otro.

La representación comenzó a contemplar métodos y sistemas como los del dibujo automático, el frotage, el gratage o el cadáver exquisito. El Surrealismo fue un movimiento artístico, en el que particularmente el dibujo destrabó el problema en cuanto a realizar imágenes que no fueran filtradas por el pensamiento consciente.

Las técnicas de trabajar el dibujo basándose en imágenes aleatorias obtenidas por medios variados no eran realmente nuevas, a lo largo de la historia del dibujo fueron notadas una y otra vez. Será propiamente hasta la propuesta de Cozens que se tomen como una fuente regular de representación.

Hemos iniciado aludiendo al Surrealismo porque en él se encuentran elementos de oposición al modelo del dibujo aplicado en las vanguardias de la normatividad visual, se partió como ya se dijo del fuero interno y vivencial del artista, se buscó penetrar la mente por rutas de exclusión del pensamiento lógico, se intentó encontrar la vía para conectar la subjetividad interior del dibujante con la producción de un objeto dibujo que representaba la expresión de una voluntad proyectual. El azar comenzó a tener peso en la representación y parecía un contrasentido a todas luces.

El saldo dejado por el Surrealismo repercutió en ondas cuya expansión trastocó los cimientos de los códigos de representación estabilizados.

El Surrealismo sobre todo en sus momentos tempranos, mantuvo una vocación icónica, esto es que se mantenía la identificación de elementos referenciales del mundo circundante, la clave consistía en darles asociaciones inverosímiles que provocaran el desfase del pensamiento consiente. La decalcomanía entre otras técnicas aportaría elementos anicónicos a la imagen. El surrealismo desplazó poco a poco el centro del problema desde el objeto dibujo hacia la acción de dibujar, la manera en que se realizaba el acto de dibujar, traía como consecuencia particularidades en las representaciones que de otro 
modo no eran posibles, así la estrategia más que la capacidad manual se colocaba como parte importante del proceso.

El material mental básico y necesario en todo acto de representación, no estaba o no era pasado por el consciente de la mente del dibujante, se restaba de esta manera valor a la voluntad configurante, sobre todo en la apertura de la etapa prefigurativa. Como consecuencia se le retribuyó importancia al recurso del objeto plástico en su resistencia a la configuración, o a la manera en que mostraba posibilidades no consideradas de estructuración. Se planteó como importante, que el método no fuera una expresión de la búsqueda de equilibrio y racionalidad configurante. El mensaje de los dibujos surrealistas resuena todavía hoy cuando los miramos, no son objetos dibujados, son sujetos dibujo con su propia voz. Figs.72

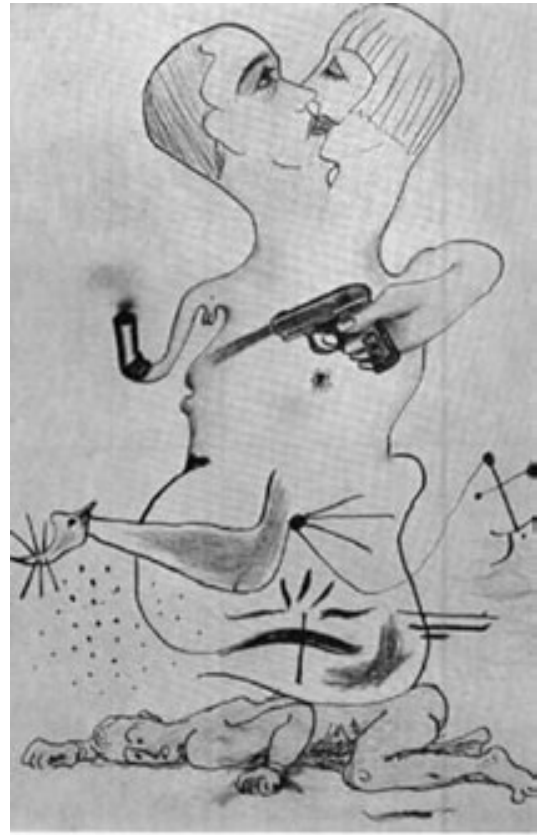

Man Ray, Yves Tanguy, Joan Miro, and Max Morise Cadavre exquis. 1928

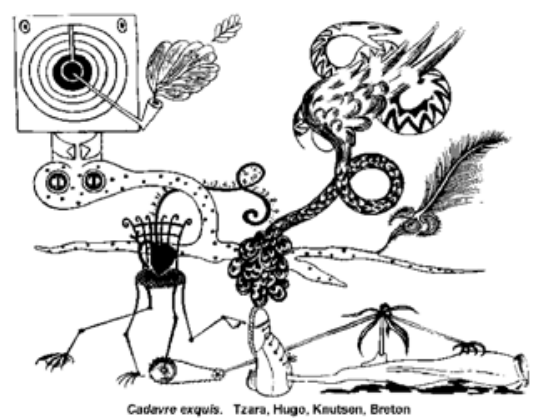

Fig. 72. Cadáveres exquisitos surrealistas.

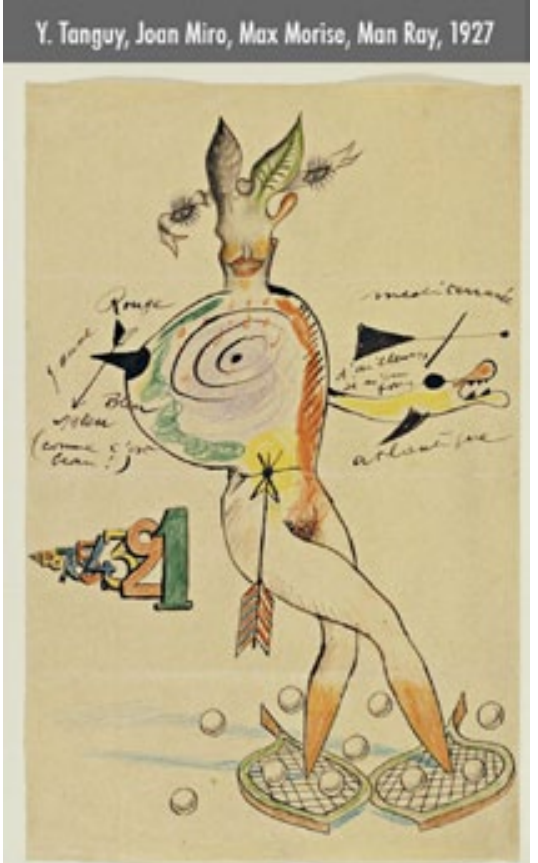

Todas éstas son las bases del nuevo desplazamiento del dibujo que se gestaba, y sumemos a ello el desacuerdo con la ruta modernista visual.

El fracaso de los proyectos integracionistas como constructores de una nueva sociedad, quedó evidenciado por una guerra que puso de manifiesto el espíritu más oscuro del hombre. Con todo esto, el Informalismo en Europa, y su correspondiente en América, el Expresionismo Abstracto irrumpieron derribando paradigmas. 
El Informalismo no existió como movimiento unificado, siguió una dinámica diferente a la de las vanguardias de preguerra, ni manifiestos, ni reuniones con idearios comunes. El movimiento se caracterizó por la individualidad de sus integrantes y lo relativo de sus tiempos de duración y término.

Fue la crítica de arte al notar similitud en las intenciones y las cualidades de la obra de ciertos artistas la que decidió agruparlos en un movimiento. Se le ubica desde mediados de 1940 hasta 1960 en general. Francia, España, Alemania, Italia, Bélgica, Holanda, Dinamarca entre otros fueron países en los que se dio el movimiento.

El nombre de Informalismo lo usó primeramente Georges Mathiew para referirse a una obra en la que los medios pictóricos carecen de significado. En 1951 los pintores Georges Mathiew, Henri Michaux, Jean Fautier, Jean Dubuffet, Jean Paul Riopelle, laroslav Serpan realizan una exposición en el Studio Facchetti de París. Entonces el crítico Michel Tapié vuelve a usar el término Informalismo, aunque prefirió llamar a ese movimiento El Arte Otro.

En el Informalismo, según Tapié, no son las formas el inicio de la organización espacial, sino el espacio pleno el que da pie al principio organizativo.

Pero si la composición relacional, en el sentido ortodoxo, establece vínculos entre la forma del plano espacial y las partes que se organizan en él, entonces pensamos que la situación generada en los trabajo de Dubuffet y Hartung es una no relacionalidad, en el sentido de que los trazos realizados en el espacio van trabando sus propias relaciones estructurales, vemos nosotros el espacio en esa situación más como un campo, pero que por sí mismo no es generador gestáltico.

Nos resulta esencial esta consideración, porque bajo esta premisa entendemos la dinámica de azar, accidente e imprevisto, tan recurrente en estos movimientos, en relación con un proceso estratégico que va dotando de sentido estructurante los resultados continuos.

Para nosotros, las relaciones causales aleatorias en relación a la conciencia estructurante que no fue prefigurada, son el centro de la configuración dentro del Informalismo y el Expresionismo Abstracto. De ahí la génesis e importancia de la gestualidad. Todo esto como base originaria de la marca indéxica particularizada en el caso de cada artista.

Y es este fenómeno de no relacionalidad con el plano o el espacio como entidad racional, el que nos permite comprender la importancia del dibujo en estos movimientos, ya que en el curso del trazo pictórico y su resultado se encuentra la valoración constructiva de la acción como estado presente que sugiere la secuencia próxima, pero cuya aplicación no es determinable con precisión.

Sobre esta base operativa es que se funda el principio de acción de estos pintores, por eso se les considera correctamente espontáneos y con recurrencia al accidente. Pero no porque sus formas y estructuras no emanen de lo natural, sino porque incluso no existen en el momento inicial de la obra, ni el mismo pintor podía visualizar las características ni cualidades, ni estructuras de lo que iba a suceder en el cuadro.

Por eso es que vemos en la obra de Dubuffet una larga prolongación del espacio en todas direcciones, en tanto que en muchos de los trabajos de Mathiew se observan vestigios 
arquitectónicos o estructuras que mantienen la huella de la gravidez matérica que determina la orientación verticalizada con que fue construida, nos remiten a las tensiones de las obras de ingeniería. Figs. 73
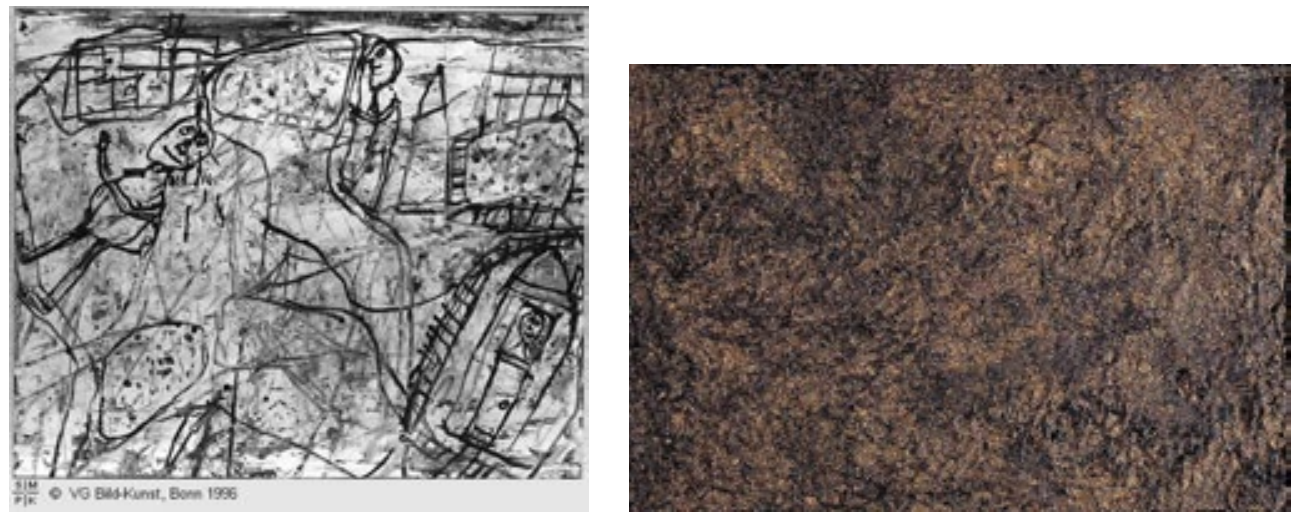

Fig. 73. Jean Dubuffet
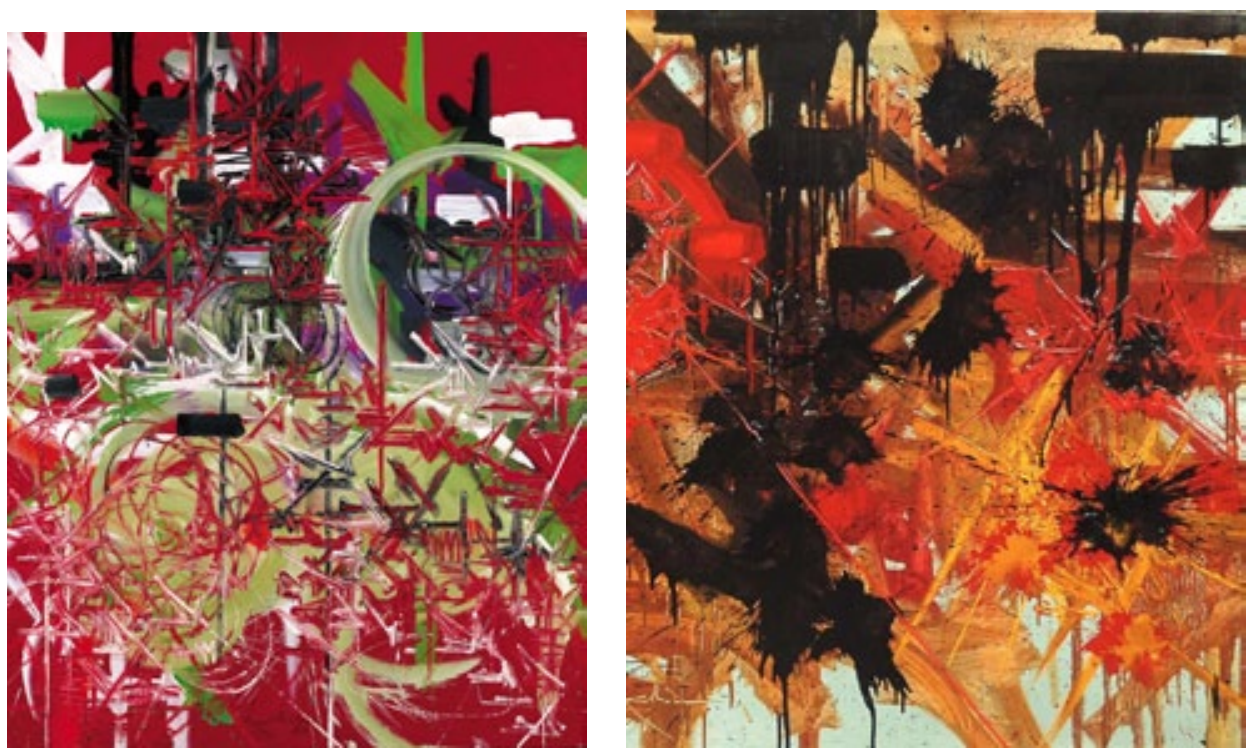

Fig. 73 George Mathiew

El público estaba ya más o menos asimilado a presenciar las propuestas del arte abstracto, y las dislocaciones mentales del Surrealismo, pero lo que ahora presenciaban no tenía forma simplemente, y rechazaba totalmente la idea del arte como una búsqueda de la armonía. De hecho este sería el común denominador de los artistas informalistas, el rechazo a todas las estructuras proyectuales y compositivas de la tradición y de las vanguardias de entreguerras.

No trabajarán ya partiendo de un proyecto prefigurado o un método enunciado con anterioridad a la obra, los sistemas preicónicos de proyección dejarán de ser utilizados. El método será asunto de construcción en el momento de hacer la obra. Incluso al configurar 
el cuadro el artista intentará negar los procesos lineales de causalidad, para buscar una construcción de la imagen mediante procesos no controlados por la voluntad configurante. En este momento el cuadro ganará una total autonomía ontológica, se le considera como una entidad con personalidad y presencia propia. Ya no alude a ningún ser sino que ahora es el ser de la representación.

Así podemos entender el distanciamiento con la realidad natural u objetual.

Los elementos que integran el dibujo informalista ya no serán elementos de la forma de la estructura de un sujeto, ahora son entidades que habitan el espacio de la obra, ya sea que tengan un carácter icónico referencial o anicónico abstracto.

La materia y la manera de disponerla en el plano pictórico fueron dos elementos sustantivos en el Informalismo.

Mathiew menciona tres características esenciales de la pintura informalista, que aplican correctamente al Expresionismo americano. $1^{\circ}$ La primacía unida a la ligereza de ejecución. $2^{\circ}$ Ausencia de premeditación de las formas y los gestos. $3^{\circ}$ Necesidad de un segundo estado de concentración. ${ }^{124}$

Surge en este punto una situación importante, las tres categorías mencionadas por Mathiew se orientan al terreno de la Acción de Pintar, de Dibujar, y son los componentes centrales de la estrategia procedimental de ejecución, Desde entonces constituyen un territorio definido dentro de la fenomenología de la pintura y el dibujo.

Pero dentro de ese mismo terreno de los acontecimientos se aborda la parte correspondiente a la huella indexal depositada en los soportes, esta nos revela la maquinación compleja de la acción configurante, esboza incluso el estado psíquico del artista.

Como un valor ligado intrínsecamente a este proceso, la posibilidad de la marca indéxica, dirigida a la extensión y apertura de la taxonomía de las formas del dibujo, se multiplicó grandemente.

Los procesos de aleatoriedad aunados a la comprensión de los resultados, fueron en gran parte los que hicieron de ese periodo y esos movimientos las prácticas autorreferenciales de las que Greenberg nos habla.

Los materiales de estos artistas fueron todos los de la tradición pictórica. Pero comenzaron a aparecer en la superficie del cuadro las materias más extrañas y raras que se pudiera pensar, alas de insectos, trapos, maderos carcomidos y toda suerte de materiales despreciados por la pintura.

Interesa aquí particularmente la manera de disponer la materia en el cuadro, en ella estará una fuerte inclusión del dibujo en la teoría informalista. Dado que se trataba de poner diques al pensamiento consciente, se puso particular importancia a la velocidad y el comportamiento del dibujante en el momento de trazar, como se citó líneas arriba.

Así tenemos dos puntos capitales en el análisis, primero, la obra no podía ser trabajada lentamente ni ser planeada (aunque como ya sabemos este precepto no sería aplicado por todos los artistas ni en su acepción más radical) esto llevó las cosas a una valoración 
mayor del proceso y la acción ejecutante por sobre el sistema lógico de las estructuras formales y aunque el informalismo dotó a la obra objeto de una calidad ontológica, el devenir del cuadro haciéndose fue la siguiente categoría en importancia.

Segundo; el comportamiento del dibujante partiendo más de la corporalidad que de la estrategia reflexiva asumió valores capitales. La gestualidad encontró finalmente su campo pleno de expresión. Ya desde el Manierismo se suscitó el volar de la mano haciendo el trazo, el Romanticismo rompió la norma del asentamiento fijo para las figuras y llevó el trazo a una conexión con el estado de ánimo del dibujante, pero hasta el Informalismo, la gestualidad conjunta la actitud del artista con una estrategia procedimental para crear la expresión acabada. Figs. 74

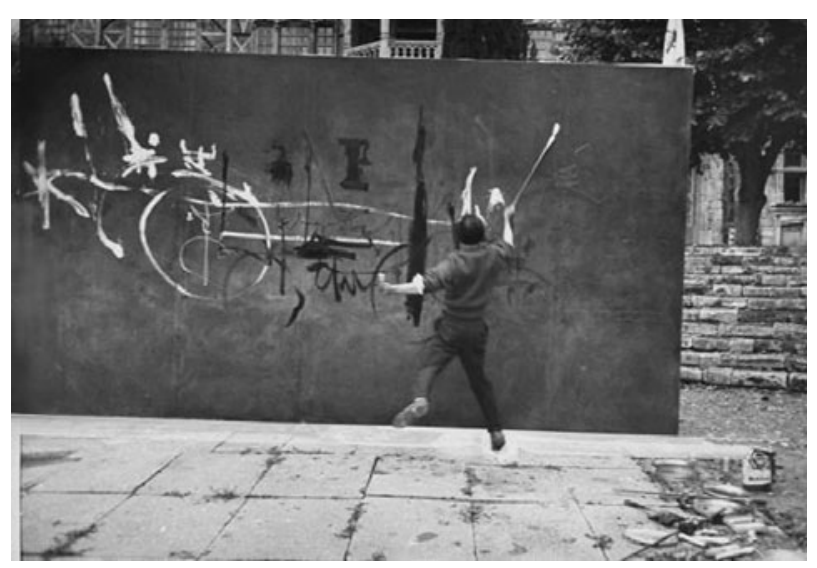

Fig. 74. Mathiew

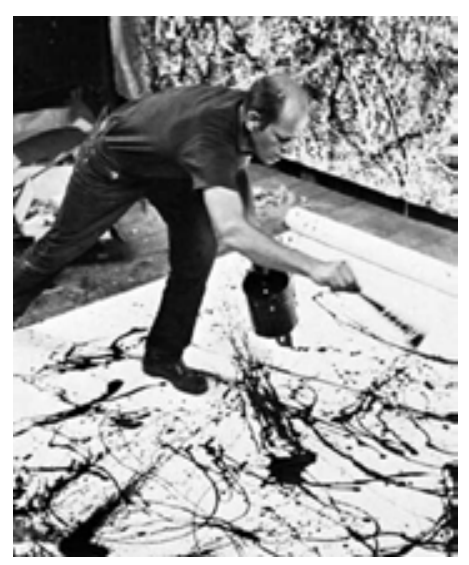

Pollock

El automatismo latente en mayor o menor grado en los procesos informalista y expresionistas conducía inexorablemente a la inclusión de la espontaneidad, y ésta en parte a los resultados accidentados. Meyer Schafiro aclara que lo no previsto forma parte integral del proceso artístico en general, igualmente que la sujeción conceptual de la estructuración. Pero pone como distintivo en este caso el hecho de que ahora el ordenamiento dado a la obra como estructura no deviene del análisis de lo natural, cuya existencia antecede al suceso pictórico.

Si bien es cierto que para ese momento el arte ya tenía clara su posibilidad de origen en un territorio no natural ni objetual externo, consideramos que el giro epistémico consistía en advertir y eliminar la existencia previa de un sistema preicónico disciplinar como marco de acción del proceso configurante.

El poder iniciar una obra sin sistema previo, sin tema histórico ni metodología construida se convirtió en la búsqueda estratégica de ese momento.

Pero la dinámica fenoménica contenida en este proceso llevaba en su interior la propia lógica de su crecimiento y disolución.

Esto porque se partió de la intención de apertura formal y procesual, el antiproyecto, el proyecto era carecer de proyecto, pero con el trabajo se mostraron las rutas particulares 
mediante las cuales se conseguía este objetivo, y las formas matéricas con las que cada uno creaba un mundo representacional, esto llevó a una etapa de estabilización, la curva de la gráfica de desarrollo entro en meseta y significó la naturalización de un pensamiento que buscaba la apertura a toda costa. Ésta fue una visión clara en cada uno de esos artistas, hecho por el cual notamos una migración en cada etapa de su proceso. Situación que se demuestra si observamos simplemente la secuencia de sus etapas y los trabajos que las constituyen, Hartung, Newman, son ejemplo de un proceso evolutivo ascendente, pero tendríamos en el otro extremo a quienes mostraron una voluntad más o menos constante de migración epistémica, Pollock De Kooning. Figs. 75
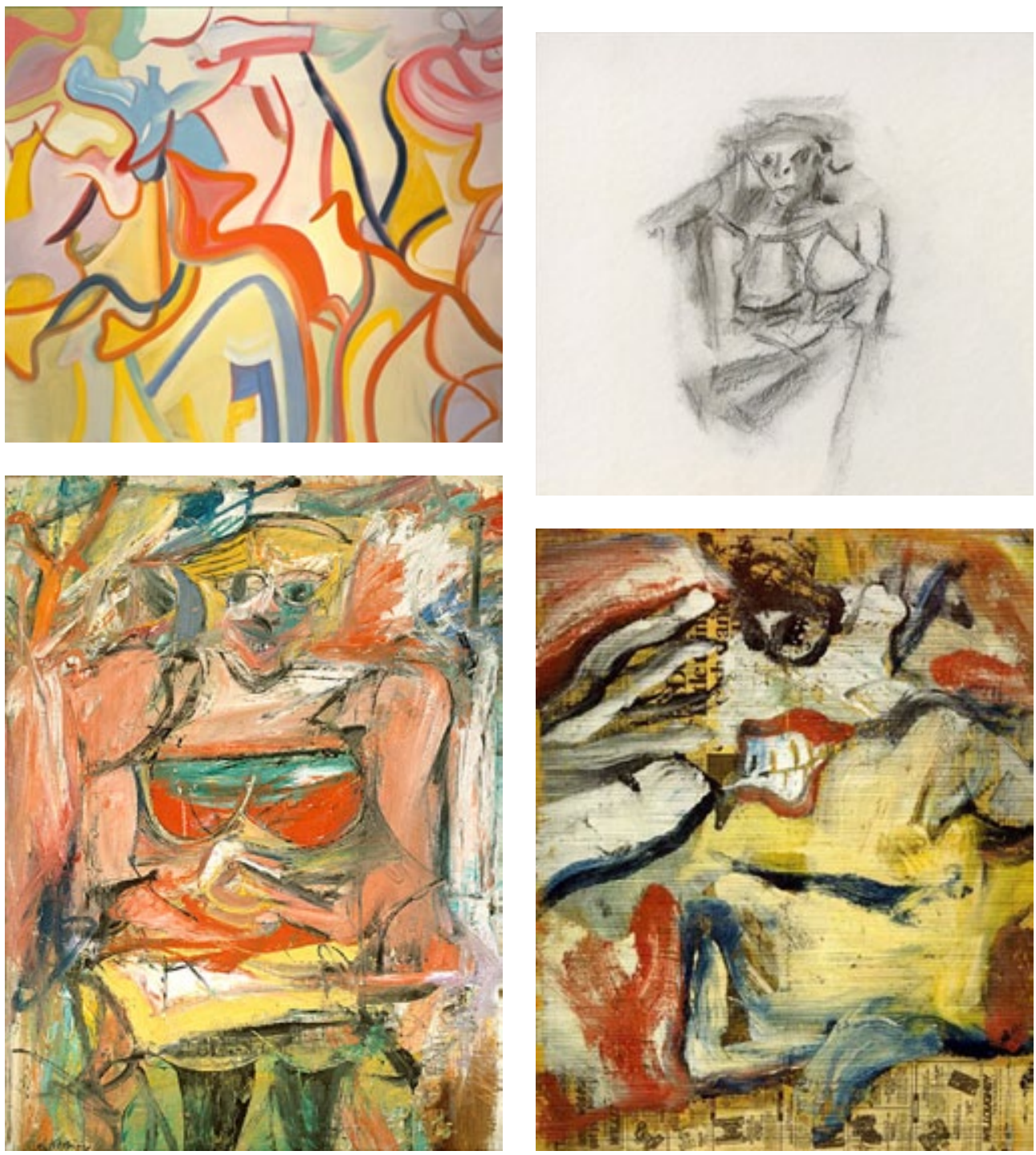

Fig. 75. Willem de Kooning 
Los rastros de la presencia del artista en la obra no son necesariamente signos en estricto, si entendemos el signo en su acepción de carácter gráfico en este caso, con una unidad de contenido semántico que es establecida por el pensamiento racional, (una extensión del concepto signo hacia su acepción relativizada mezclaría la posibilidad de entendimiento diferenciado de lo que resulta una práctica que genera huellas, como consecuencia y no como intención primera, de una práctica en la que la huella tiene un contenido seminal teorizante de primera intención, esto es, se instituye como causa y no como efecto del proceso.) serían huellas, que permiten una lectura reconstruida y arqueologizante del proceso e intenciones del autor. De aquí la división de Dorfles en el sentido de artistas Sígnicos y Gestuales, según se orienten hacia un grafismo caligráfico de unidades sígnicas, ó, hacia la construcción de una estructura expandida mediante el All Over.

Por más que se busca no es posible encontrar definiciones directas precisas de lo que se considera la gestualidad, se le menciona eso si reiteradamente pero sólo en el libro de Nicolaides ya comentado se le plantea con mayor detenimiento, si bien no de manera acabada. Lo anterior es debido en gran medida al clima de dispersión y la falta de voluntad de los informalistas y los expresionistas abstractos para reunirse y establecer marcos teórico normativos comunes. Se dice que la gestualidad es la comunión del dibujante con la intención interna del modelo, conectarse con el impulso que lleva al modelo a hacer lo que está haciendo, y trazarlo de manera salvaje e impulsiva, sintiéndolo y no pensándolo. El gesto es conducta instintiva, no aprendida, o sea que no pasa por el consciente. Pero la gestualidad también se dibuja en ausencia de modelos, puede llegar a ser la más pura expresión del impulso interno del dibujante, una estrategia de la acción consistente en contravenir los dictados del pensamiento consciente en el momento mismo de su brotar para guiar la acción. La manera en que la gestualidad se hace forma y trazo, es solo por la acción del dibujante, vertiendo, o tal vez distribuyendo el material sobre el formato. Las acciones de ejecución y su cualidad como gestos dramáticos revistieron fundamental importancia desde entonces.

La acción de hacer era la acción de decir, representación mediante una conducta, no solo a partir de las formas, el cuadro era el campo fenoménico de ese suceso, área de depósito de las huellas de esa batalla, el testigo mudo que no podía decir el total de lo sucedido, aunque sí una muy buena parte.

El Informalismo y el Expresionismo Abstracto, junto con la Abstracción-Pospictórica logran la decantación del principio de indexalidad hasta su clarificación en el sentido doble de su contenido, más adelante pondremos en ello nuestro interés.

El proceso semiológico que lleva el trazo del dibujo y la pintura desde la linealidad que construye una forma, hasta la línea que es la huella de la acción de dibujar, tiene en los momentos del Informalismo y el Expresionismo Abstracto una relevancia clave.

Nos parece en este punto coincidente con nuestro análisis la explicación que muestra el proceso de la indexalidad como el viraje de lo automático a lo autográfico.

La constitución de lo autográfico se manifestó en la voluntad de configurar y establecer como constante una identidad particular en la forma de la línea y en la manera de su depósito y aplicación, procedimiento y manera que volvieron inconfundible el bagaje formal 
de cada artista. Repertorio que lleva las emociones internas y privadas al campo material del soporte pictórico sin la necesidad de ningún contenido icónico referencial externo.

La categoría de automatismo estaba indisolublemente ligada a los procesos surrealistas, tenía en su interior la definición de una región inconsciente que sin embargo permanecía de alguna manera en el proceso de estos nuevos artistas.

En mucho la afirmación de estos dos movimientos descansó sobre la base de diferenciarse del surrealismo y crear su distancia estratégica.

El considerar lo autográfico como huella indexal venía a salvar el problema del automatismo.

No era necesario el acceso al inconsciente sino al proceso fortuito individualizado.

Con el caso de Pollock se abre un giro importante para el análisis de los proceso del dibujo, el de la autoría, la huella que depende del contacto corporal y manual del artista en la acción de configuración y trazo.

Leemos en el texto Arte desde 1900 lo siguiente:

"Aunque hoy podemos maravillarnos de la asombrosa pericia técnica de Pollock para entretejer numerosas mallas de colores, y de la notable convicción con la que alternaba entre las gotas tan finas como hilos y los gruesos charcos de pintura húmeda, lo cierto es que en sus pinturas de goteo renunciaba en parte a su autoría. Al evitar todo contacto directo con el lienzo extendido en el suelo, al dejar que la gravedad y la viscosidad de la pintura desempeñen un papel protagonista en el resultado de sus obras, y al abandonar el pincel, Pollock perdió la conexión anatómica que había vinculado tradicionalmente la mano del artista, el pincel y el lienzo. Titubeó en la cuestión del control, dependiendo de la respuesta crítica («Yo soy la naturaleza» frente a « iNada de caos maldita sea!») 125

Pero si bien es cierto que mediante este procedimiento se suprimió el toque directo de la mano y la herramienta sobre el soporte pictórico, sólo se aumentó la distancia entre la mano del dibujante y el soporte y se eludió la marca regular del trazo y su estandarización de lo que era el Dibujo a mano alzada, aunque la herramienta en sí no desapareció, ni dentro del trabajo de Pollock, ni dentro de cualquiera de los artistas informalistas.

El trazo y el dripping mantenían constante la intencionalidad estructurante conceptual y la disposición conformante lograba la integración de la forma resultante con el norte mental de inicio.

La importancia de este tipo de procedimientos se fincaba no en la eliminación de la autoría corporal de la mano, como se ha visto de manera mecánica, sino en la distancia causal configurante, lo que agregó elementos nuevos a una teoría de la técnica, y dentro de esta las herramientas y el tacto corporal y visual en la acción.

Es complejo, pero en gran medida esta situación tipificó la fenomenología del trazo y la acción, integrando lo aleatorio y accidental con la intención configurante en el sentido más abierto del método. Ni que decir que esto representó una postura epistémica del dibujante con respecto a la conciencia del método, la estrategia y los procederes.

125 Foster Hall, Krauss Rosalind, Bois Yve-Alain, Buchloh Benjamin. Arte desde 1900. Madrid: Akal Editores; 2006. P. 350. 
Por eso la pintura y esta manera particular de dibujar concretaron la libertad del individuo profundizada en la realización y el compromiso con la obra. Nuevamente una cita del texto Arte desde 1900.

"La conciencia de lo personal y espontáneo en la pintura y la escultura estimula al artista a inventar mecanismos para manejar, procesar, revestir, que confieren en grado máximo el aspecto de lo hecho libremente. De ahí la gran importancia de la marca, la pincelada, el pincel, el goteo, la calidad de la sustancia de la pintura misma y la superficie del lienzo como una textura y campo de operación; todos son signos de la presencia activa del artista. La obra de arte es un mundo ordenado de naturaleza propia en el que somos conscientes, en todo momento, de su devenir."126

En la medida que el trabajo de estos artistas maduró, la importancia de la espontaneidad se dirigió hacia la consecución de la unidad autográfica, el absoluto de cada uno de ellos; se migró del gesto básico hacia la marca autoral perfectamente reconocible, lo que en gran medida implicaba la consecución estabilizada de su propio sistema y estrategia, de este modo la indexalidad nos revela tanto el mundo de formas y huellas como el repertorio estratégico diversificado en cada autor.

Precisamente el carácter hermanado del trabajo de los informalistas y su vocación gestual, los introduce a una zona en donde la representación, pese a no reflejar una asociación con imágenes de contexto circundante se asemeja a los trazos de ideogramas y pictogramas de la escritura del oriente. Después de integrar extensiones de este análisis podemos ampliar nuestra comprensión de la gestualidad.

En lo referente a la gestualidad la definición se inicia con los pensamientos de Dorfles, contienen elementos agregados a la visión de Nicolaides, acaso porque tenía que responder a las exigencias de los movimientos emergentes dentro de la pintura y el dibujo.

"GESTO (adjetivo, gestual): pintura que se basa sobre todo en la actividad miocinética elemental y a menudo no controlada racionalmente; que se confía, por tanto, a un impulso creador que trata de lograr la expresión a través de la articulación dirigida del brazo (o también del cuerpo-Shiraga-). Esta pintura se remonta con frecuencia a orígenes, presuntos o reales, extremorientales e invoca vínculos con el cenismo, o sea con la pintura japonesa influida por la doctrina Zen."127

La mayor parte del informalismo basa su trabajo en estrategias caligráficas, aunque los trazos no corresponden a ningún signo de escritura en ellos se advierte la influencia de la estrategia de la caligrafía.

Según Dorfles, y concordamos, los artistas informalistas y los de la escuela americana expresionista abstracta, se dividen en aquellos que dan mayor importancia al impulso cinético y gestual, y aquellos que valoran la forma resultante como un signo con poder de representación. Las representaciones del Informalismo no aluden a ninguna circunstancia que no sea la del

126 Foster Hall, Krauss Rosalind, Bois Yve-Alain, Buchloh Benjamin. Arte desde 1900. Madrid: Akal Editores; 2006. P. 351.

127 Dorfles Guillo. Ultimas tenencias del arte de hoy. $5^{a}$ ed. Barcelona: Ed. Labor; 1987. P. 214. 
fuero interior del artista. Gestuales o sígnicos, los informalistas también son llamados tachistas, por recurrir constantemente a la mancha como recurso de configuración. Las cualidades de la mancha como elemento de formalización de una idea, coincidían con el objetivo de esos artistas, en el sentido de escapar a la órbita de la composición y representación tradicional. La materialidad de la mancha, su contorno irregular y su flexibilidad representativa.

Éste es el primer elemento que podemos resumir; los artistas informalistas al orientar su trabajo pictórico hacia lo sígnico y lo gestual, hicieron centro en procesos fuertemente dibujísticos, la pintura se inclinó notoriamente hacia el dibujo. Pese a no hallar fácilmente dibujos independientes o bocetos en esta etapa, lo cierto es que las propias pinturas son un dibujo dimensionado en lo pictórico.

Al hacer hincapié en la gestualidad, se introduce el elemento de la ejecución más o menos veloz del dibujo y la pintura como parte de la definición conceptual.

En los sistemas de caligrafía y pintura orientales se comprende claramente el principio de la gestualidad y la base del dibujo como creador de signos. Pero hay dos formulaciones que amplían el territorio de la acción del Dibujo. Primero lo que denominan "El Tubo de tinta reventado", con esta expresión se quiere decir que una vez que la acción del trazo se ha desatado no se debe detener por ningún motivo, como si fuera un flujo líquido que mana y al que no se puede poner una oclusión y al que sólo nos queda ir conduciendo urgentemente, lo cual deja al dibujante en una situación peculiar que lo integra y compromete en el acto del trazo.

La segunda es una norma conceptual, pero que se sucede en el momento de la acción fáctica, Ilaman a ello "La Idea que corre delante del pincel", la manera en que este pensamiento está enunciado es maravillosa y no requiere de mayor explicación.

Pero con estos puntos mencionados, junto a los principios de gestualidad y caligrafía sígnica advertimos la complejidad de la acción pictórica y dibujística como expansión dentro de los movimientos que analizamos.

De esta manera quedaba colocado al centro de la configuración de la obra el propio proceso. La actitud, el estado mental y emocional que guardaba el autor durante la acción tuvieron como vemos un peso importante.

Los artistas informalistas, Mathiew entre ellos; decían no planear nada al hacer sus obras, ni siquiera la manera de terminarlas, lo cierto es que en la secuencia de sus trabajos y en los de estos artistas notamos primero una fase de ajuste, después se van definiendo elementos recurrentes, así como acciones y procedimientos, que nos muestran la tendencia que cada autor fue estableciendo dentro de su propio proceso de configuración.

La existencia de esos síntomas metodológicos y formales en cada autor aclara como se gesta en ellos una manera de interiorizar el mundo, incluso como una lejana y remota opinión, el ideario colectivo dentro de la propia rebelión, se percibe en una apagada voz pero no cesa de susurrar.

Es básica la idea anterior para plantear como dentro de estos movimientos por más radicales que fueron se logró un ejercicio de representación del contexto. Podemos afirmarlo basándonos en el hecho de que cada autor generó un sistema de representación formal y procedimental, mediante el cual exteriorizaba su estado interno y la opinión que del contexto tenía. 
Esto, si nos referimos a la representación, como un acto básicamente de formalización, que en este caso trasciende la intención mimética.

Pero estas obras son representaciones del carácter del proceso, representan al sujeto en un acto de apertura social e histórica de su propia disciplina. Y representan también el sentido del pensamiento modelístico como expresión teorizante de la pintura y el dibujo.

Por eso los artistas informalistas y expresionistas abstractos, no fueron tan disímiles como al inicio lo pareció, pese a su voluntad de no ser más que ellos mismos comenzaron a parecerse entre sí, la crítica advirtió de inmediato los vínculos formales o conceptuales, sus teorías y prácticas y los convirtió en un movimiento pese a su voluntad.

El abandono de la naturaleza como origen del proceso de representación y significación es tomado como una constante típica de estos movimientos; pero la obra reflexiva y plástica de artistas como Saura, De Kooning y Dubuffet se plantan dentro de este ambiente para inquietar las reducciones analíticas. Cumplen con todos los preceptos enunciados pero se vinculan profundamente con la naturaleza hasta llegar a lo más hondo de su esencia.

La obra de Mathiew nos muestra una clara idea de construir estructuras espaciales de recia organización. No puede uno dejar de pensar en sus pinturas como estructuras de cierto valor urbano, si bien es cierto que contienen una velocidad y certeza de ejecución muy fluida.

Otro caso diferente es el de Hans Hartung, se decía que en ocasiones dibujaba con los ojos cerrados. Al mirar sus obras son mucho menos tensas que las de Mathiew, las líneas no unen puntos ni distancias, cada vez recurre menos al ángulo recto y a la propia línea recta. La ingravidez está dentro de sus trabajos. Pero en este caso una situación importante a la que se llega es a la de lograr con la línea un cuerpo ontológico que por sí mismo crea la pintura. Hartung se ubica como un autor en el que la línea muestra tanto el carácter de la huella directa de la acción, como el vestigio de una interioridad psíquica. Sus trazos en la mayoría de las obras no pueden ser estrictamente cercanos al ideograma ya que no contienen una reducción que los defina como unidades sígnico alfabéticas. Tampoco se acercan demasiado a la caligrafía porque su rítmica estructural y de trazo muestra más una síncopa de subversión que una búsqueda armónica. Fig. 76

Dentro del informalismo, Dubuffet aporta la idea de que el pensamiento no artístico también configura formas de representación, la mente de los locos y criminales genera imágenes que son una reconstrucción del mundo contextual.

Plantea que el material posee una voz propia que se tiene que expresar, coincide con la idea de la plástica como materia que se resiste a ser conformada, entonces la configuración es una lucha profunda entre la materia y la voluntad configurante, el hacer la obra es el tiempo de la acción de esta lucha. En Dubuffet la huella es el rastro de la acción y herramienta, dejadas en la materia y la superficie de la pintura, esos rastros dicen tanto como las inflexiones de los lenguajes no verbales.

El Informalismo es un movimiento en el que el hacer la obra ocupa el centro del proyecto artístico.

La ejecución como categoría de lo artístico implica el proceder del autor, la actitud es- 
tratégica inmanente y el estado mental y anímico del dibujante. De esta manera la representación del contexto está contenida en la actitud epistémica que el dibujante guarda con el acto de dibujar, y las fuentes y motivos de la acción.

Esto no es otra cosa que la completud del proyecto artístico y del dibujo frente a su tiempo histórico y su matriz filosófica.

En este movimiento y en sus autores el color se orientó hacia la constitución de campos espaciales en los que se suscitara la acción gestual del trazo, o bien la línea se cromatizó. La acción de colocar el trazo y la materia llevaban implícita la rapidez para evitar la reflexión sobre lo que se hacía, esto trajo como consecuencia el que la pintura generalmente se soportara sobre la base del trazo, la mancha, y los grafismos. Estos trazarán la dirección, la estructura del gesto, o de la cosa, realizarán penetraciones a grupos más compactos de líneas y en fin, el dibujo penetró la pintura, no es que se pueda hablar de dibujo dominando nada, es interesante el hecho de que el dibujo deje un tanto su carácter de proyectar para construir en el momento mismo la pintura. Las estrategias de representación sufrieron una desviación abductiva que llevó al dibujo no a su separación de las artes sino a una nueva transdisciplinariedad.

Robert Coates escribió en 1946 sobre una exposición de Hans Hoffman que se realizó en Te Mortimer Brandt Gallery. En ese artículo llama a la obra de Hoffman la pintura del Expresionismo Abstracto, aunque el término ya se había aplicado para el trabajo de Kandinsky en un texto anterior, quedó en este caso muy adecuado para la obra de Hoffman y los artistas Neoyorquinos.

Harold Rosenberg llamaría a este movimiento el Action Painting, en español Pintura de Acción. Generalmente se pintaron cuadros de dimensiones mayores, esto para procurar la inmersión del pintor dentro
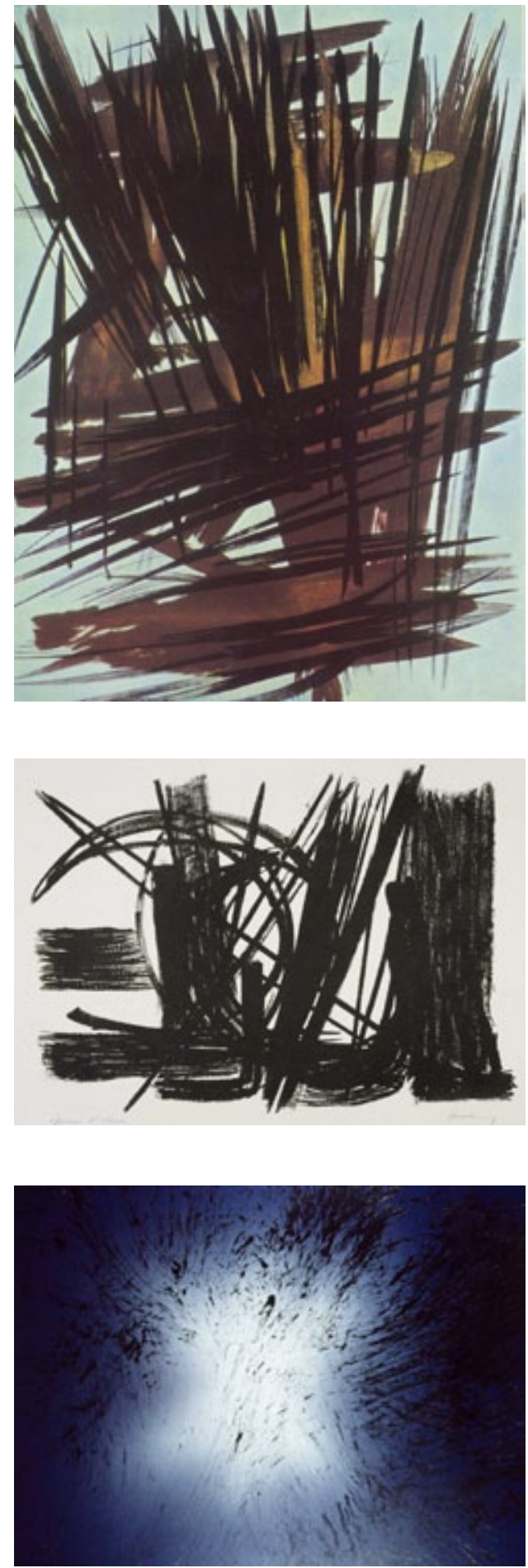

Fig. 76. Hans Hartung 
del espacio de la obra, pintar un cuadro de esas dimensiones no fue la imagen de una suma experiencial, fue una vivencia en sí. Rothko decía que al pintar en ese formato no se domina el cuadro.

Rosenberg también dice que dentro de la pintura de acción se establece un diálogo entre el autor y el cuadro que se hace, el autor plantea las primeras manchas, el cuadro responde con situaciones no contempladas, el autor trata de integrarlas e integrarse en el hacer y se da una dinámica de réplica continua.

Los conceptos de Campo y All Over tendrán una importancia en este movimiento al igual que la gestualidad.

Son términos ya utilizados por David Anfam y Anthony Everitt.

Anteriormente nos habíamos referido al término All Over, es una pintura que se aplica por toda la superficie de la tela, sin dejar ningún rincón o espacio sin cubrir, pero el concepto no es tan simple. Esta definición implicó una pintura que transcurre, y no que se coloca. Es un sistema de composición no relacional y al enunciarlo simplemente aludimos a un contrasentido, una paradoja; no es posible una composición que no contenga normas relacionantes entre el plano soporte y los elementos que se disponen, de ahí su importancia, el All Over sustituyó la norma por la estrategia. En la medida que los elementos de la imagen se distribuían y se iban sumando de manera isómera sobre el plano, generaban lazos de afectación y estructuración entre ellos, las imágenes resultantes serán expansiones cósmicas que no se limitan por la forma del cuadrángulo, esto porque en general las pinturas de all over son realizadas colocando el soporte de manera horizontal y atacándolo por todos los flancos laterales, sin generar lecturas cartesianas referenciales.

Los vínculos estructurales que se generan de esta manera no obedecen a factores geométricos, cuando menos en el sentido cartesiano y euclidiano. Es una pintura de carácter orgánico y cósmico, en contraposición a los principios estables y equilibrados de la composición con una métrica rítmica mesurable.

El Campo será la noción, más que la definición del espacio compositivo de la pintura. Es el campo del suceso de la pintura de acción, no es un plano geométrico platónico, no es la suma de un número de ángulos. Es el espacio en el que transcurre el movimiento corporal del dibujante pintor. Es un campo fenoménico porque es tiempo de sucesos, está plagado de valores subjetivos y metafísicos porque no se ordena a la lógica del plano prefigurado. El campo deja de ser una entelequia poligonal, se convierte en una manera de sentir el espacio y prolongarlo indefinidamente. Así como de trabar relaciones causales y casuales entre los elementos que se van agregando al cuerpo de la obra, elementos que por cierto no representan entidades de modelos referenciales sino segmentos icónicos por sí mismos, cuya forma gráfica y extensión determinarán el grado y tipo de relación configurante y estructurante de la obra.

La No Relacionalidad es una de las tres categorías que Benjamin Buchloh señala como centrales y paradigmáticas de la pintura de la modernidad y en general del siglo XX.

Sí existió la práctica del dibujo en el expresionismo abstracto, aunque al igual que en el Informalismo no fue bajo el patrón metodológico anterior sostenido hasta la modernidad integracionista, también se introdujo nuevamente al ejercicio pictórico dotándolo de un vigor gestual, pero con todo y eso disponemos de algunos dibujos en los que se advierte que los autores buscaron probar el carácter de los drippings, que utilizarían en obras definitivas, la práctica del estudio de alguna manera se mantuvo aunque soterrada en estos movimientos. 
Parece que el asunto de los bocetos si fue advertido por los críticos, su preocupación fue mayor que la de los propios artistas, al respecto Rosenberg dijo que el dibujo también era una acción aunque se tratara de un boceto como acción previa a la pintura. Dice que el boceto es un enfrentamiento anterior a la pintura, y esto es interesante ya que se corresponde con la visión clásica del boceto como el intento de ajustar lo que será la imagen definitiva. Figs. 77

David Smith ve al dibujo como si tuviera autonomía ontológica, dice que se resiste a dejarse hacer y que trata de imponer su voluntad propia sin que la ejecución lo afecte. Smith describe al dibujo como lo más cercano y directo a la verdad misma, como la más natural liberación del hombre. Pero cuando habla de la actitud del dibujante señala situaciones peculiares que se relacionan con maneras conceptuales más estables. Esto es así porque dice que el dibujante no ha de dejarse perder por las derivas de la imagen y la línea, dice que ha de dominarlas y someterlas al dictado del concepto buscado, o sea que debe oponer un tanto resistencia al dibujo que deviene del azar de la configuración.

Dice que la línea debe hacerse con convicción, no dejar la línea de la historia. Una línea trazada con claridad conceptual será más recta que una línea trazada con la regla.

Jackson Pollock es un artista que cumple con todo lo analizado anteriormente. Agrega algunas variables al proceso de la acción pictórica y del dibujo dentro de este movimiento. Lleva el cuadro a una postura horizontal mientras lo construye, y hay quienes ven en este hecho una modificación sumamente importante, ya que los principios de la historicidad humana se unen a la verticalización de las imágenes.

Pollock trabaja grandes superficies que luego cortará en tamaños y formatos que hasta ese momento no tenía dispuestos, es
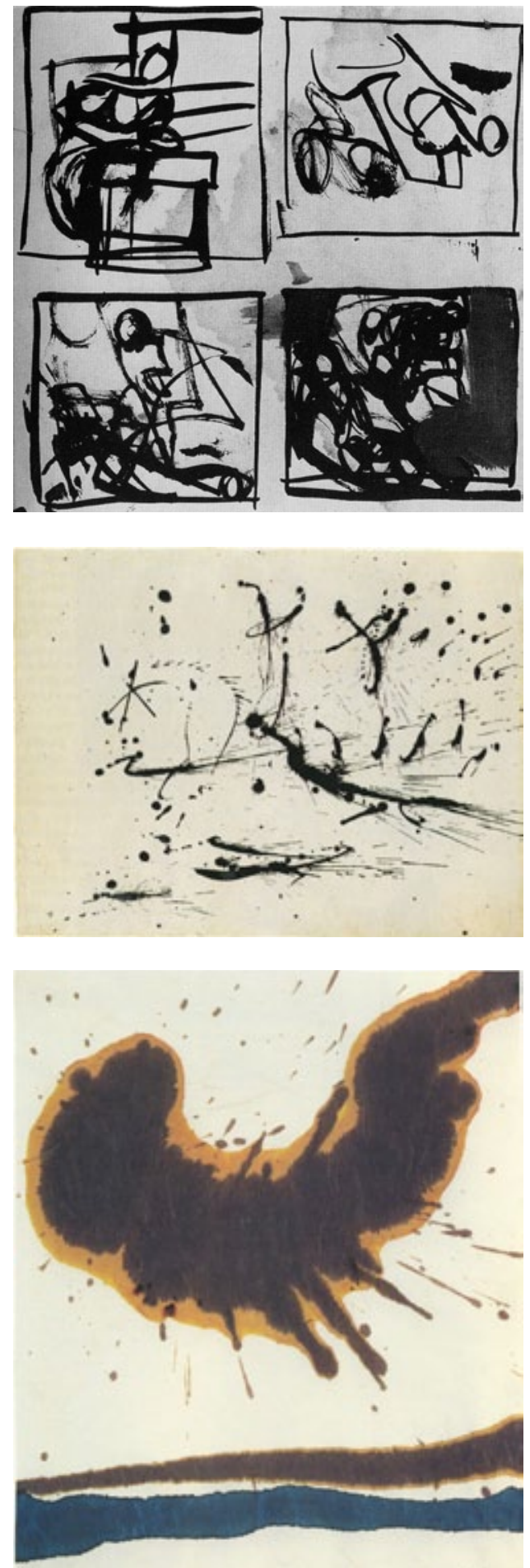

Fig. 77. Franz Klein. Jackson Pollock. Robert Motherwell. 
quien más utiliza el dripping y con mayor rigor ya que en muchos casos su mano no hace contacto con la superficie trabajada. De hecho la práctica de recortar era recurrente en él, a veces pintaba rollos de tela que luego dividía para estudiar el resultado espacial, pero a veces las continuaba pintando, ésta fue una pintura sin referentes cartesianos, las coordenadas espaciales simplemente no tienen sentido en la obra de Pollock, y esto se demuestra en el hecho de que al ser expuestas en planos verticales, aún así los depósitos y huellas de los drippings mantienen su carácter de derrames sin orientación de coordenadas, discurren ingrávidos y solo muestran su forma determinada por el propio peso.

David Anfam señala el talento gráfico de Pollock, porque su pintura es rica en grafismos y su obra sí contempló la realización de dibujos en los que se aprecia el estudio de los problemas de construcción de la pintura ya en su época de madurez.

El estado ejecutante de Pollock fue característico y casi legendario de lo que implica la inmersión en el acto de pintar y trazar. Pollock se adentraba en el espacio de la pintura y el tiempo del hacer, sus palabras citadas en Ross dejan clara su intención.

"Cuando estoy dentro de mi pintura, no estoy al tanto de lo que estoy haciendo. Es sólo después de una especie de periodo de tomar familiarización que veo en lo que he estado. No tengo temores sobre hacer cambios, destruir la imagen, etc. Porque la pintura tiene una propia vida." ${ }^{28}$

Frente a la obra de Pollock se pierde la razón de hablar de pintura y dibujo, la imbricación de uno y otro es tal, que de verdad no tiene sentido intentarlo. Habíamos comentado ya la penetración de la pintura por el dibujo en el Informalismo y el Expresionismo Abstracto y como la pintura se marcó de carácter dibujístico, Ben Heller tuvo que escribir para la exposición de Pollock presentada en 1990 que contenía dibujo y pintura de la serie blanco y negro. Los problemas curatoriales del caso fueron mayúsculos, dibujos pictorizados y pinturas dibujadas y en fin, la división pintura dibujo se convirtió en una zona muy blanda y elástica. Heller comenta que Bernice Rose escribió que el dibujo desapareció en la pintura, se volvió uno con la pintura.

La obra de Pollock no habla más que de Pollock, de su mundo interno como artista, no se tiene ya que buscar un tema fuera de uno mismo. Para él el método es algo que tiene que ser construido sobre la base de la necesidad expresiva de cada artista, esta irá determinando los procedimientos y la selección de herramientas y materiales que se adecuen a la circunstancia expresiva. En el expresionismo de Pollock el método es la estrategia del sentir del autor, la manera en que se adecue en el proceso lo lleva a introducirse en la obra y a sentirse cómodo en ella. Sólo de esa manera podrá mediante la práctica comprender la esencia del material y su personalidad y entonces manejarlo. Fig. 78

Franz Kline es un caso diferente, para él la pintura será la expresión del acto de vivir intensamente fuera de la pintura, pero también la intensidad de vivir al hacer la obra. Para él la pintura no es conocimiento ni tiene que ver con él; pero si es pensamiento, y este es el que se debe concretar en la obra, para Kline la emoción era la prueba final de la pintura, debería aparecer al dar por terminado un cuadro, este es un bello pensamiento sin duda

128 Anfam David. El Expresionismo Abstracto. 1ª ed. Barcelona: Ed. Thames and Hudson, Ediciones Destino; 2002. (Serie el Mundo del Arte 68). 

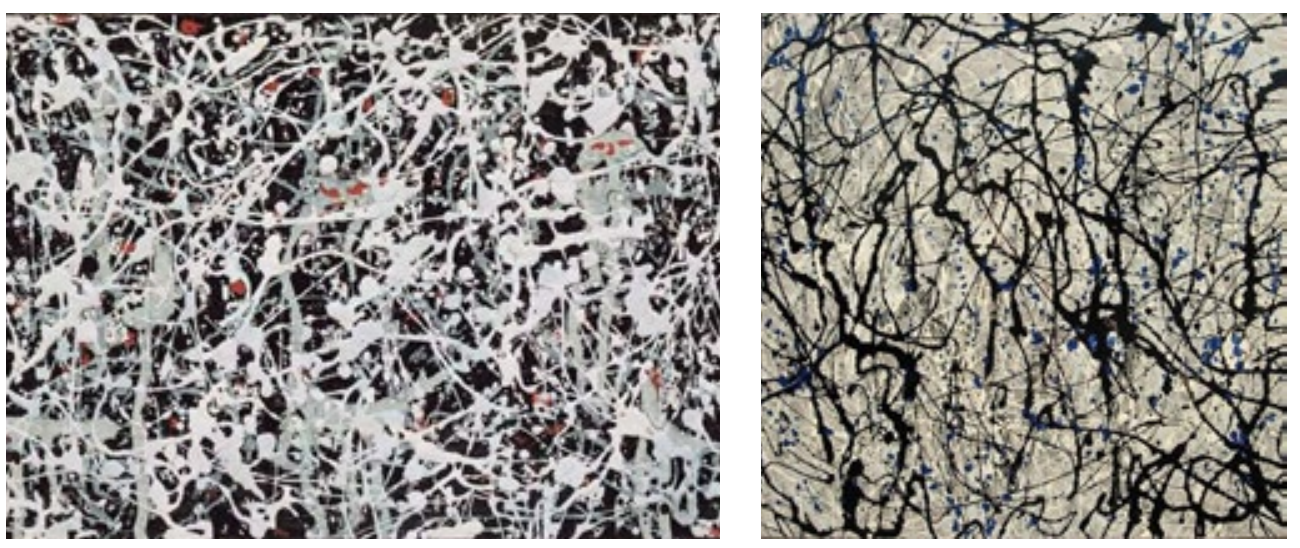

Fig. 78. Jackson Pollock

y con el coincidimos desde nuestra modesta estatura, el cuadro decimos es una forma de poder, entre otros el poder de conmover, el poder de la poética, el poder del hacer, el poder de la acción, el poder del sentido significante integrado en la obra.

Kline decía que no era su emoción la que quería introducir en la obra, sino la emoción que quería que la obra comunicara, para esto era fundamental el proceso. Iniciaba los cuadros sin una idea definitiva del proceder, decía que desde el origen éste era asunto de asociación libre, así de abierto, asociación libre.

La categoría de asociación libre resulta demasiado imprecisa, no podemos fundar análisis sobre de ella. Pero en las líneas siguientes aportamos varios elementos reseñados en el libro de Ross, en los que queda bastante reconstruido el proceder de Kline al trabajar la obra. Señala como acciones estratégicas la eliminación, la agitación y la simplificación en el momento de la experiencia de pintar.

Kline podía encontrar afortunadamente el cuadro acertado, pero en ocasiones había que desechar para seguir buscando. Iniciaba en ocasiones sin nada de por medio, pero en otros casos retomaba dibujos antiguos y los revaloraba tomando ideas que ahora le parecían pertinentes, otras veces haría algún dibujo para fijar alguna idea y ensayarla hasta que le pareciera adecuada. A veces los dibujos iniciales son varios para distintas áreas del cuadro, en el momento de pintar la obra sumatoria los dibujos iniciales son modificados en el proceso de hacer una sola entidad.

Nuevamente la opinión del artista corrobora la concepción de un dibujo unido a la pintura. Pero también la de un dibujo que es campo de pruebas previo a la gran contienda.

\footnotetext{
"Yo más bien siento que la pintura es una forma de dibujo y la pintura que a mí me gusta tiene una forma de dibujo con ella. No veo como es que puede ser desasociada de la naturaleza del dibujo." 129
}

Kline buscaba los cuadros de gran formato como los demás expresionistas abstractos, pero a diferencia de los otros él decía no saber a ciencia cierta el porqué de esa elección. Lo que sí es cierto e indudable es que una pintura de tres metros por lado demanda una

129 Abrams Harry N. Abstract Expressionism. Creators and Critics. An Anthology. Nueva York: Clifford Ross Ed. 1990. P. 99. 
acción corporal mayor, no es suficiente la acción del brazo y el antebrazo. Sus cuadros nos muestran una pintura potente y vigorosa pero no demasiado azarosa, él mismo manifestó pintar organizaciones que se hacen pintura, de ahí y del mirar sus obras, concluimos que se desarrolla un sentido constructivo de la pintura, los momentos intermitentes de ataque y reflexión muestran una obra que no es casual, es el resultado de varios momentos reflexivos de configuración. Figs. 79
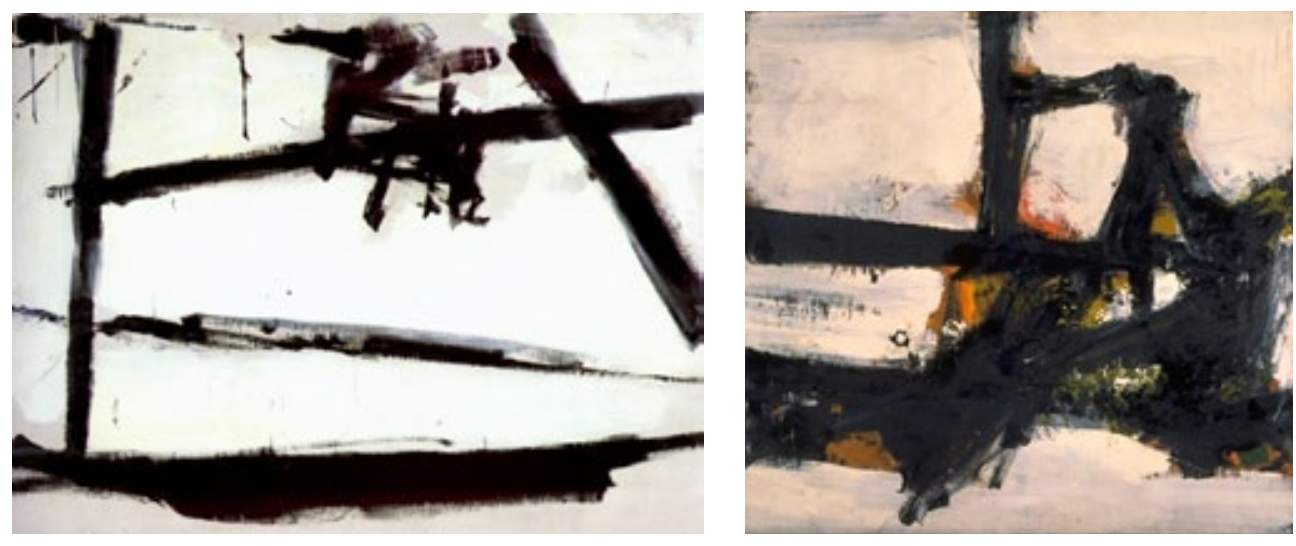

Fig. 79. Franz Kline

Willem de Kooning es el niño terrible del Expresionismo Abstracto, leer sus opiniones en las entrevistas que se le hicieron raya en la comicidad, como él mismo lo dijo del tratamiento de sus temas en la obra.

Revisar sus respuestas lo único que aclara es que era un nihilista, no le interesaba casi ninguna causa, quizá por esto representó el mejor prototipo del artista americano, aunque él fuera holandés. Prácticamente negó cualquier intento de teorizar su trabajo. Lo hemos incluido en este análisis porque es uno de los dibujantes más potentes y poderosos del siglo XX. Su caso evidencia la carencia de sentido para hablar de un retorno del dibujo a la pintura o de una pintura basada en el dibujo etc. Simplemente al mirar sus trabajos acerca de la mujer es evidente la contundencia del dibujo y la pintura fuertemente unidos, sus trabajos dejan sin sentido los intentos de separar ambas disciplinas.

Antes que él nadie había maltratado de tal manera a la mujer en la imagen, incluso lo grotesco de los Corps de dame de Dubuffet se basaba en la fértil evocación de la Venus del Auriñaciense y el Magdaleniense.

De Kooning es la definición de la gestualidad en la imagen, la acción y el expresionismo. En este autor se reintegra el dibujo en todo su poder dentro de la representación, conjuntado con lo más flexible de las estrategias del expresionismo abstracto. Cabe señalar que las etapas de su producción nos muestran un de Kooning de vocación fuertemente cromática, cuando así lo decidió, realizó series de pinturas en donde el sentido del dibujo cedió ante el impulso de lo especialmente pictórico, lo informe si es que se puede decir, por eso mismo es que sus ataques dibujísticos a la figura significan una voluntad de representación inequívoca, y aún en sus pinturas anicónicas la funcionalidad formal múltiple de la línea, nos lleva a un análisis profundo de la categoría que se atribuye al Expresionismo Abstracto como el movimiento de la línea pictórica, como la línea gestual salvaje que recompone el dibujo una y otra vez y como una línea que amplía su campo hasta integrarse 
en la indefinición con los planos del campo pictórico. Ateniéndonos a la propuesta de, de Kooning veamos algunas de sus obras, entendámoslas en el contexto del movimiento expresionista abstracto y bajo los conceptos a los que nos hemos referido. Figs. 80
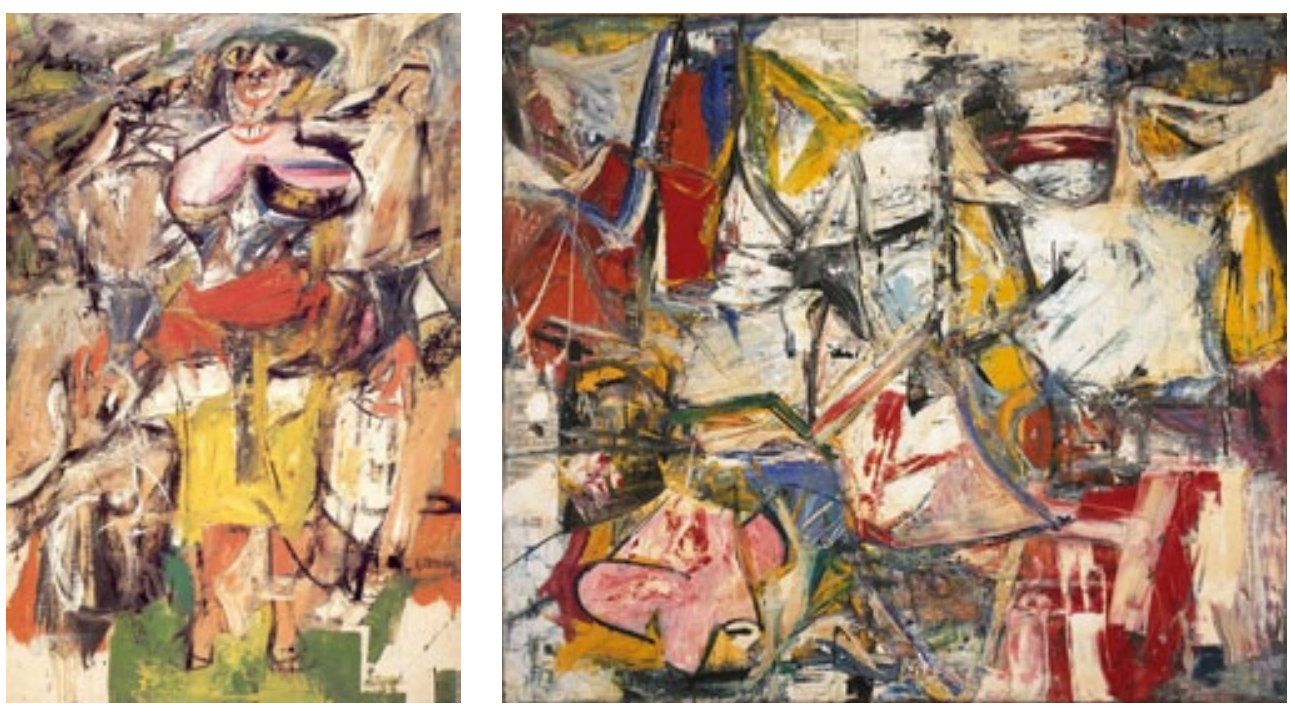

Fig. 80. Willem De Kooning

La teoría del accionismo psíquico, el proceso en igualdad de relevancia junto con el resultado objetual, la acción como representación del proyecto histórico del artista, la teoría de la resistencia del medio, la linealidad pictórica, la indexalidad como huella autográfica y automática. En el arte pictórico de este segmento paradigmático se logra concretar una forma espacial que rebasa la visión de la ventana renacentista y la perspectiva piramidal. Éste es un corte de relevancia profunda en el modelo de pensamiento de las artes. Pero sobre todo la capacidad de lograr un trazo y un dibujo más allá de la delimitación de la forma del modelo, constituyen parte del arsenal teórico legado por este trecho de la historia del arte y los autores que llenaron con sus obras y trabajo este espacio.

Al naturalizarse las revoluciones formales logradas, se llegó a un momento de estabilización, los cortes innovadores se integraron como fórmulas que cada vez más se repetían. Éste no era sino el proceso natural de la historia. Por tanto la intención y la obra de las generaciones en ascenso, se centraría en una búsqueda de extensión y abducción de las recientes fórmulas paradigmáticas. Ese es el centro de estudio de nuestro parágrafo siguiente.

\section{III-6-6 EL DIBUJO DE LA MODERNIDAD A LA POSMODERNIDAD}

"Las actividades pictóricas de principios de los años sesenta (como sucede en todos los momentos relevantes de la pintura radical) deconstruyeron las convenciones de la contemplación (de los cuadros) al tiempo que reconstruían nuevos parámetros que permitían percibir la pintura como algo significativo. Para cumplir con sus intenciones «rupturistas», estas prácticas tuvieron que atacar un sistema de convenciones semióticas desde posiciones que se pretendían tan originales como definitivas. No obstante, ese 
tipo de gestos son de naturaleza necesariamente mítica ya que dependen de que el espectador tome la decisión de suspender su conocimiento de la historia del signo pictórico a fin de experimentar este episodio concreto como una «ruptura» en el presente." 130

La Pintura y el Dibujo que se suceden en general desde mediados de la década de 1950 y alcanzan hasta las postrimerías de los años 70 de ese mismo siglo, se sobreponen al periodo de auge de la modernidad típica a la que nos hemos referido, como es común en los procesos históricos, las características de un nuevo segmento teórico y epistémico del dibujo y el arte, emanan del ámbito de acción de la plenitud artística estabilizada. Esto en parte debido a la relación compleja de causalidad, que contempla la emergencia de características nuevas de un sistema, sólo como derivación relativa al orden estructural de ese cuerpo complejo. Y en otro sentido, como manifestación de la voluntad crítica del proyecto histórico existencial del artista, misma que lo impulsa a la detección y crítica de las prácticas y fundamentos conceptuales, que habiendo surgido como manifestaciones de ampliación, sin embargo se estabilizan y restringen el desarrollo de los sistemas de representación del campo disciplinar.

Como habremos de ver, al igual que sucedió con el Informalismo y el Expresionismo Abstracto, en la pintura de este segmento histórico el dibujo permaneció en muchos casos integrado al ejercicio de la pintura, esta ruta de fusión se prolongó en el desarrollo del llamado Arte del Concepto y en muchos de los trabajos de las artes que integran prácticas disciplinares múltiples.

En este punto en particular, el trazo de los modelos de representación del dibujo, no se corresponde con los cortes y segmentos analíticos que la crítica viene trazando para la organización de la historia del arte de las seis últimas décadas. Pero pensamos que esta particularidad no reviste ninguna disfunción en el análisis, ya que los pormenores y giros que nos interesan, definen una tipificación que varía un tanto los criterios establecidos de estudio.

Si bien la producción madura de artistas como Frank Stella, Kenneth Noland y Robert Ryman se ubican dentro del arco temporal de la tardomodernidad, lo cierto es que encontramos en ellas, características que depuran y precisan para el Dibujo la consecución de un modelo de pensamiento, mismo que se liga de manera natural con la función de esta disciplina dentro del marco epistémico del Arte Concepto. Serán estos perfiles precisados, los que a su vez nos permitan ver claramente el corte suscitado con la irrupción de las estrategias posmodernas y su impacto dentro del campo del Dibujo.

Lo que suele llamarse el periodo moderno en el que nos detuvimos para analizarlo, constituye un movimiento de vanguardia, representa la punta de un pensamiento avanzado que culmina en producciones relevantes para el desarrollo del fenómeno artístico y su lenguaje. Pero eso no implica que fuera la práctica generalizada de todo el territorio artístico.

Al mismo tiempo que el Informalismo y el Expresionismo Abstracto, se desarrolló el camino del Arte como Proceso, este es un modelo estructural y estratégico distanciado de la estética de la modernidad formalista. Por otra parte el impacto de lo que se denominó la Escuela de París, fue significativo en el arte latinoamericano de ese tiempo.

130 Buchloh Benjamín H. D. Formalismo e Historicidad. Madrid: Ed. Akal; 2004. Pág. 223. 
Con todo lo anterior, lo que concluimos, es que la función del Dibujo que analizamos como típica de la modernidad significó una expansión del modelo teórico proyectual del dibujo, amplió sus posibilidades formales de representación y las estrategias y prácticas de la disciplina; pero además de estas extensiones relevantes el Dibujo continuó operando en el resto del contexto artístico bajo la estructura modelística proyectual estabilizada desde el inicio del siglo XX sobre todo en las regiones culturales periféricas que en las décadas de los 60 y 70 realizaron un arte de resistencia en el que el Realismo Crítico y el Expresionismo dieron fuerza y empuje a las funciones conceptuales y formales típicas del proyecto del dibujo.

Todavía en la década de 1970 la corriente de dispersión de los modelos proyectuales del dibujo y las artes seguían un patrón regido por la vanguardia, pero precisamente al finalizar esa década la producción modelística y formal de las artes se pluralizó, se atomizó exponencialmente y una multitud de obras totalmente diferenciadas en su modelo conceptual y procesual compartieron los espacios de distribución artística.

La cauda expansiva de este fenómeno permanece activa aún en nuestros días.

El dibujante actual y el artista en general, dispone de una serie de mecanismos y medios que le informan de la situación actual del arte, ya mucho se ha señalado esta circunstancia, con ello, como consecuencia, se abre su abanico de autonomía para el ejercicio del dibujo, junto a esto su conciencia histórica frente a la práctica y teoría del dibujo debiera expandirse.

La consecuencia final de este fenómeno de globalización es que para nuestros días la práctica del dibujo es un territorio de la más variada y compleja diversidad, lo cual vuelve altamente difícil su estudio, pero pensamos que toda esa diversidad de producción, no necesariamente implica una ampliación del sistema modelístico del dibujo, son pocas las extensiones epistémicas y cognitivas agregadas al campo disciplinar, y mucho menos las ampliaciones de su formalización como sistema de representación.

Continuaremos nuestra exposición de los modelos del dibujo refiriéndonos a algunos autores de lo que se llamó la Post Painterly Abstraction. No es de nuestro interés el estudio del movimiento en sí, importa en nuestro caso la producción de algunos de sus artistas porque desde nuestro punto de vista guardan íntima relación con el pensamiento del dibujo.

Para mediados de los años 50 del siglo XX y dentro de la década de los años 60, con el arribo de la Abstracción Pospictórica y el Minimalismo se gestó la oposición a los procesos típicos de la modernidad analizada por Greenberg y Fried.

Si bien estos movimientos son considerados como parte de la tardomodernidad, lo cierto es que ya contenían principios de formalización y procesos de producción y exposición que significaban giros radicales a las prácticas modernas típicas.

El Minimalismo como arte literal y con su dimensión fenoménica temporal. La Abstracción Pospictórica sostenida en la negación de la Huella Indexal Gestual, con su propuesta del Índex Lineal Conceptual, con la No Relacionalidad compositiva centralizada y con la pureza de superficies y perímetros de la forma se definió como un modelo de pensamiento pictórico bien diferenciado del Informalismo y el Expresionismo Abstracto.

Su estrategia de acción se dirigió al terreno de la formalización como oposición al lenguaje establecido, también su base estratégica dentro del proceso de realización se definía por oposición, lo industrial y prefabricado por sobre lo gestual autográfico. 
Estos pintores entonces mantienen una tendencia general a la ruptura, Fried considera que esa tendencia es el producto de la conciencia autorreferencial de los procesos propios de la pintura y no solo la evolución particular del lenguaje individual, lo cual hace esta situación coincidente con el modelo histórico de pensamiento al que ya nos referimos.

Dejemos que sea el propio Fried quien resuma esta postura.

"Una vez que un pintor que acepte las premisas básicas del Modernismo llegue a ser consciente de un problema concreto suscitado por el arte de nuestro pasado más reciente, su acción ya no resulta gratuita, sino impuesta. Puede estar equivocado en su valoración de la situación. Pero mientras cree que dicho problema existe y es importante, se enfrentará a una situación de la que no puede pasar, sino que debe pasar a través de ella, de un modo u otro, y el resultado de ese paso forzado será su arte. Eso significa que, mientras que la pintura modernista se ha divorciado progresivamente de los intereses de la sociedad en la que precisamente florece, la dialéctica real por la que surge ha adoptado, cada vez más, la densidad, la estructura y la complejidad de la experiencia moral, es decir, de la propia vida, aunque de una vida vivida como pocos estarían dispuestos a hacerlo: en un estado de permanente alerta intelectual y moral."131

Post Painterly Abstraction fue el título de una exposición en Los Angeles County Musem of Arts de Los Ángeles California, los artistas que se reunieron en esa muestra fueron conocidos como los pintores del Hard edge o del Color field painting, es interesante observar que los sustantivos que se les otorgan aluden a conceptos formales del lenguaje de la pintura, y así es, como veremos, su pensamiento se mueve sobre el interés de hacer un desmontaje de los conceptos y procesos de la pintura americana que en ese momento ya se encontraba establecida.

Por otra parte fue el propio Greenberg quien redacta el escrito de presentación para esa muestra. En ese ensayo Greenberg recuerda las características de lo que él había definido como pictórico: las líneas pictóricas que no definían contornos ni cuerpos, el color fuera de toda referencia a la relación local de los cuerpos, el dripping, la mancha sin delimitación precisa. Pero menciona las características de esas nuevas imágenes como construcciones de lo No pictórico, pinturas con delimitaciones de área cromática precisa y con perímetros y aristas regulares y con pureza cromática. El color en estas series se utilizó en su estado primario, sin mezclas prácticamente y sin diferencias de textura, los bordes de las áreas de color fueron tratados con dureza y precisión.

Con estas características plásticas y visuales se buscaba renunciar a la huella autógrafa típica del Expresionismo Abstracto y a la huella indexal del Informalismo.

Como se ve, la abstracción pospictórica operó sobre la lógica de negación de las estructuras y procesos de la pintura inmediata anterior; partiendo de esa situación, el dibujo retomó características que ya se habían tratado dentro del Suprematismo y el Constructivismo, particularmente la inclusión de la factura como elemento racional e industrializador del trabajo pictórico, lo que motivó a estos pintores a utilizar herramientas y tipos de pintura comerciales e industriales, así como lo expone Buchloh en el ensayo sobre la factura dentro de su texto Formalismo e Historicidad, que ya hemos citado.

131 Fried Michael. Arte y objetualidad, Ensayos y reseñas. Madrid: Ed. A. Machado Libros; 2004. (Colección La balsa de la Medusa 141). P. 264 


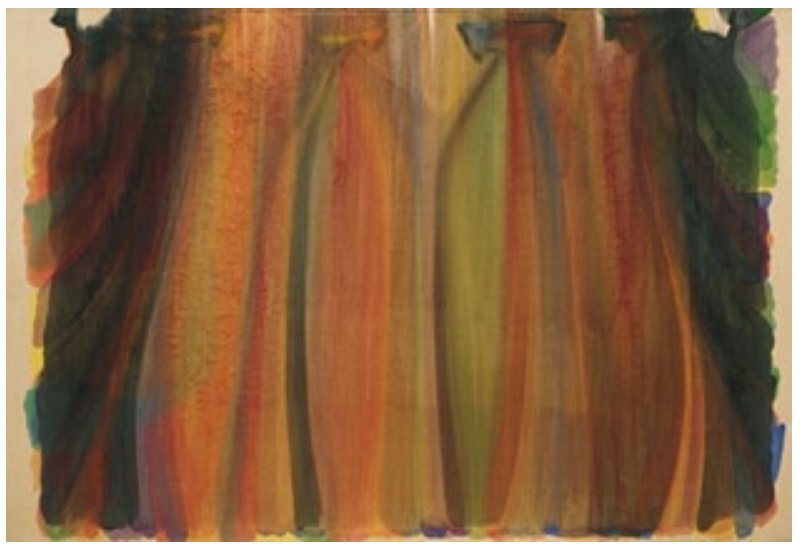

Fig. 81. Morris Louis. Pintura

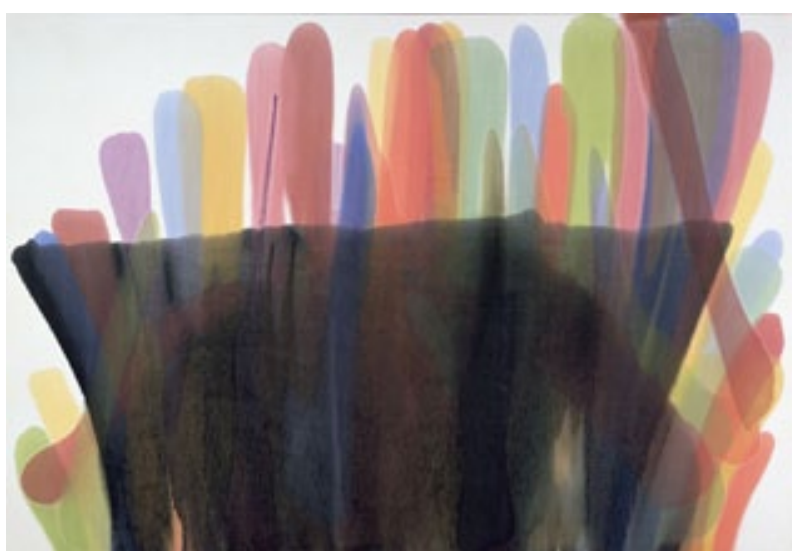

Fig. 82. Morris Louis. Índex como huella matérica y acción física sin signos gestuales.
Mencionaremos primero a Morris Louis, este pintor trabajó con diluciones de pigmento que después vertía sobre telas sin imprimatura, tensadas y humedecidas. Restregaba la aplicación pigmática luego de haberlas vertido, consiguiendo un resultado de alta dispersión tonal y un reduccionismo de lo que pudiera ser la forma, tanto de una inexistente figura, como de la huella violenta de trazo manual o gestual. Figs. 81

Los límites del área tintada son generalmente dispersos, aunque logra determinada precisión, o bien, debido al efecto acuarelado resulta un halo de frontera en la mancha pintada, pero en todos estos casos la huella no denota operaciones de construcción gestual.

Fried señaló en su análisis como la tinción terminó identificando el color y la acción de pintar con la trama del lienzo utilizado.

La relación conceptual que une la consideración física de la tela sobre la que la pintura se cons-

truye, es un asunto en verdad antiguo, y en ello el dibujo desarrolló una función importante. Ya nos detuvimos en señalar como la relación entre material pictórico, pincelada y dibujo como huella indéxica directa y visible, fue una revolución que se inicia dentro del arte Barroco. Para todo pintor resulta familiar la consideración del carácter físico del soporte como parte del léxico y el texto pictórico, en esto no consistió la innovación; ésta se logra al radicalizar la idea, en realidad la imagen teñida opera como fondo y viceversa, variación provocada por los momentos de contemplación, las pinturas de Louis generan obras ópticas pero también resultados que se acercan a la indexalidad del Dibujo. Fig. 82

De manera que el resultado conceptual de estos trabajos es lo que pudiéramos llamar un no dibujo, desde nuestro punto de vista este artista se acerca al grado elemental del dibujo, reduciendo forma, ritmo, línea, plano como figura racionales métricas, no prefiguración proyectual, no contorno que delimite para generar planos de superposición, etc.

Pero una vista primera del trabajo de Louis muestra de modo evidente una reflexión sobre la organización cromática, construida bajo el procedimiento de las transparencias. El análisis estructural de esta obras comportaría la necesaria extensión del campo disciplinar 
del dibujo y su práctica, condición sobre la cual guardamos aún reservas.

Kenneth Noland comparte la convicción moderna de no considerar definitiva ninguna formulación conceptual establecida. Inicia su proceso como pintor usando también la estrategia del teñido del lienzo. El arranque de su revolución formal parece estar determinado en un sentido abierto pero profundo, por su contacto y amistad con Morris Louis.

Una diferencia importante entre el trabajo de ambos la constituye la verticalidad gestáltica de los lienzos de Louis, en tanto que en el trabajo de Noland el teñido mantiene mucho más de irregularidad en los bordes tintados, pero genera un sentido no direccional en el que no se sugiere ninguna indicación cartesiana de lectura, situación que se ve reforzada por los subsiguientes estratos pictóricos, que en general son círculos concéntricos realizados con mayor precisión.

Aunque las imágenes de Noland muestran contornos de anchas líneas con bordes fragmentados y residuos de huellas indexales de la mano y la brocha, estos no tienen un concepto propiamente caligráfico ni gestual autógrafo.

Pero el corte radical de estos trabajos consiste en el abandono del sistema All Over típico de la composición expresionista todavía en boga por ese entonces, a ese sistema, Noland y otros oponen el concepto de campo cromático, extensiones de color con propiedades formales y gestálticas totalmente diferentes. La saturación del plano pictórico en Noland se construye con el recurso del campo de color y no con la progresión saturada de una malla de grafismos gestuales.

Podemos decir que con Noland se camina hacia una disminución del dibujo como personalidad ontológica presencial en la imagen y se le convierte en una función gestáltica ubicada en las zonas de contacto cromático o en el entre-espacio de las mismas.

Aunque por otra parte Louis y Noland coquetearon continuamente con una serie de escurridos de pintura que se asocian con el manejo de los depósitos cromáticos del Informalismo y el Expresionismo Abstracto; este es un factor del dibujo que se mantiene aunque con voz apagada dentro de esta estrategia, pero señalamos como estos fluidos de color no guardan el mismo concepto del dripping, en el sentido que no se generan como una estrategia de subversión a la linealidad del pensamiento del dibujante, parecen ser más bien una manifestación de autoconformación del campo de color con base en el depósito líquido de la pintura, tanto el teñido como el escurrido, en estos casos nos parecen una manera de construir sin la intervención manual configurante, cosa que no sucede en el dripping. Hemos señalado algunas ideas que establecen una relación del Dibujo en estas obras, son el resultado de la observación de los trabajos de Noland, pero pensamos que su mayor solidez se logra en el terreno disciplinar de la pintura, como el propio Fried lo reseñara.

"Esta interpretación queda reforzada por la eliminación progresiva por parte de Noland, durante aquellos años, de cualquier cosa que no fuera absolutamente esencial para esa clara estructura deductiva a la que parece haber aspirado. Por tanto, su liberación de los últimos vestigios del dibujo y la pintura tradicionales, tales como los propios motivos estructurales imprecisos y el desorden, surge del color..."132

Frank Stella también participó en la muestra de la Abstracción Pospictórica, las pinturas de Stella obtienen su estructura partiendo literalmente de la forma geométrica perimetral del soporte

132 Fried Michael. Arte y objetualidad, Ensayos y reseñas. Madrid: Ed. A. Machado Libros; 2004. (Colección La balsa de la Medusa 141). P. 282. 

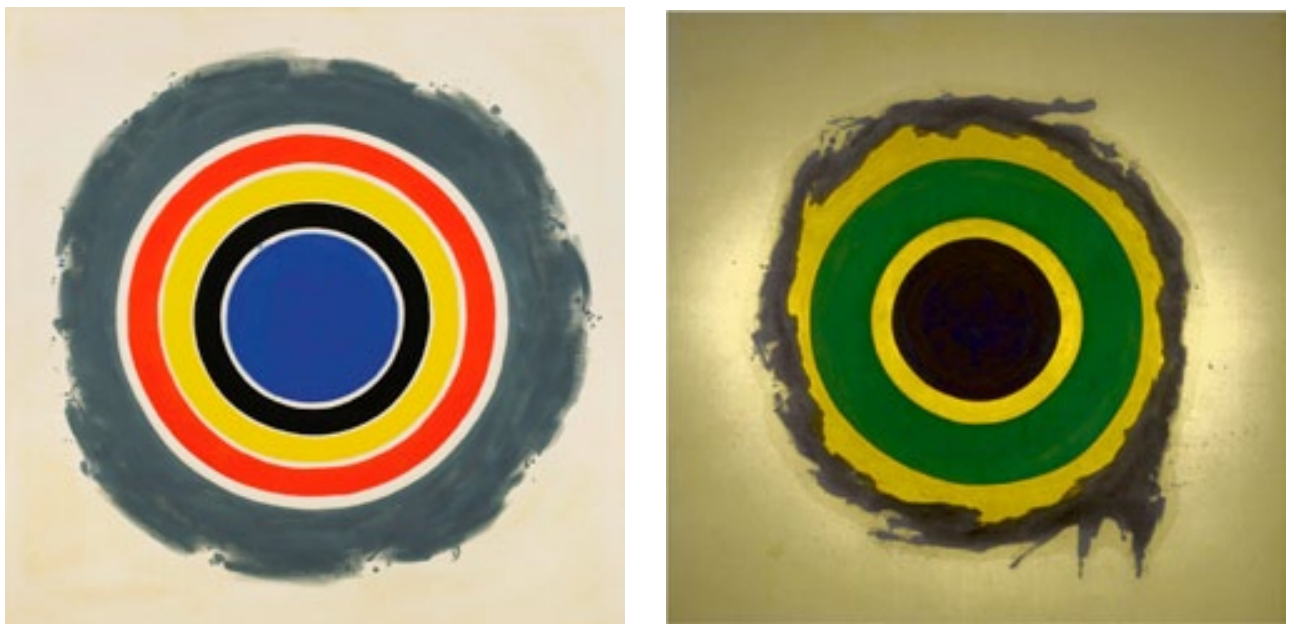

Fig. 83. Kennet Noland.

del cuadro, pero declara que la propia deducción de este formato es suficiente para construir la completud de la pintura; no solo la sintaxis de las partes de este tipo de entidades.

El trabajo de Stella también es una estrategia de reacción a la institucionalización de los abstraccionismos en boga por aquel momento.

Sus pinturas consisten en series de bandas lineales regulares y paralelas, monocromas, con una separación mínima entre sí, pero también paralelas a las aristas del plano que es formato del soporte de la pintura. Se originan en los márgenes y se replican al interior del plano hasta saturarlo generando una confluencia geométrica concéntrica.

Esta relación entre la forma del plano soporte y la estructura derivada, fue entendida como la más estricta literalidad pictórica y estructura deductiva.

El propio Stella en su conferencia de 1959 en el Instituto Pratt aclara la manera en que llega a esta formalización.

"Tenía que resolver dos problemas, uno espacial y otro metodológico. En primer lugar tenía que ocuparme de la pintura relacional, es decir, del equilibrio de las distintas partes entre sí. La respuesta obvia era la simetría: hacer lo mismo por doquier. No obstante, aún quedaba la cuestión de cómo llevar esto a sus últimas consecuencias. Una imagen o una configuración simétrica dispuesta sobre un fondo abierto parecen descompensadas en el espacio ilusorio. La solución a la que llegué -probablemente hay más, si bien yo no conozco otra: la densidad de color, consiste en eliminar de la pintura el espacio ilusorio mediante el uso de un patrón regulado. Tan sólo quedaba encontrar un método de aplicar la pintura que siguiera y complementara esta solución. Esto se logró utilizando las herramientas y las técnicas de los pintores de brocha gorda."133

A partir de esa conclusión las obras que siguen en la secuencia evolutiva de Stella son el desarrollo de una estrategia de variaciones sobre el principio original para tensar la consistencia de sus formulaciones. 
En esta dinámica que muchas veces se basó en la monocromía, y otras posteriores en la segmentación cromática mediante franjas cuyo ancho les confería campo y extensión, el dibujo fue el operador holístico que permitía la delimitación de la forma color. Figs. 84
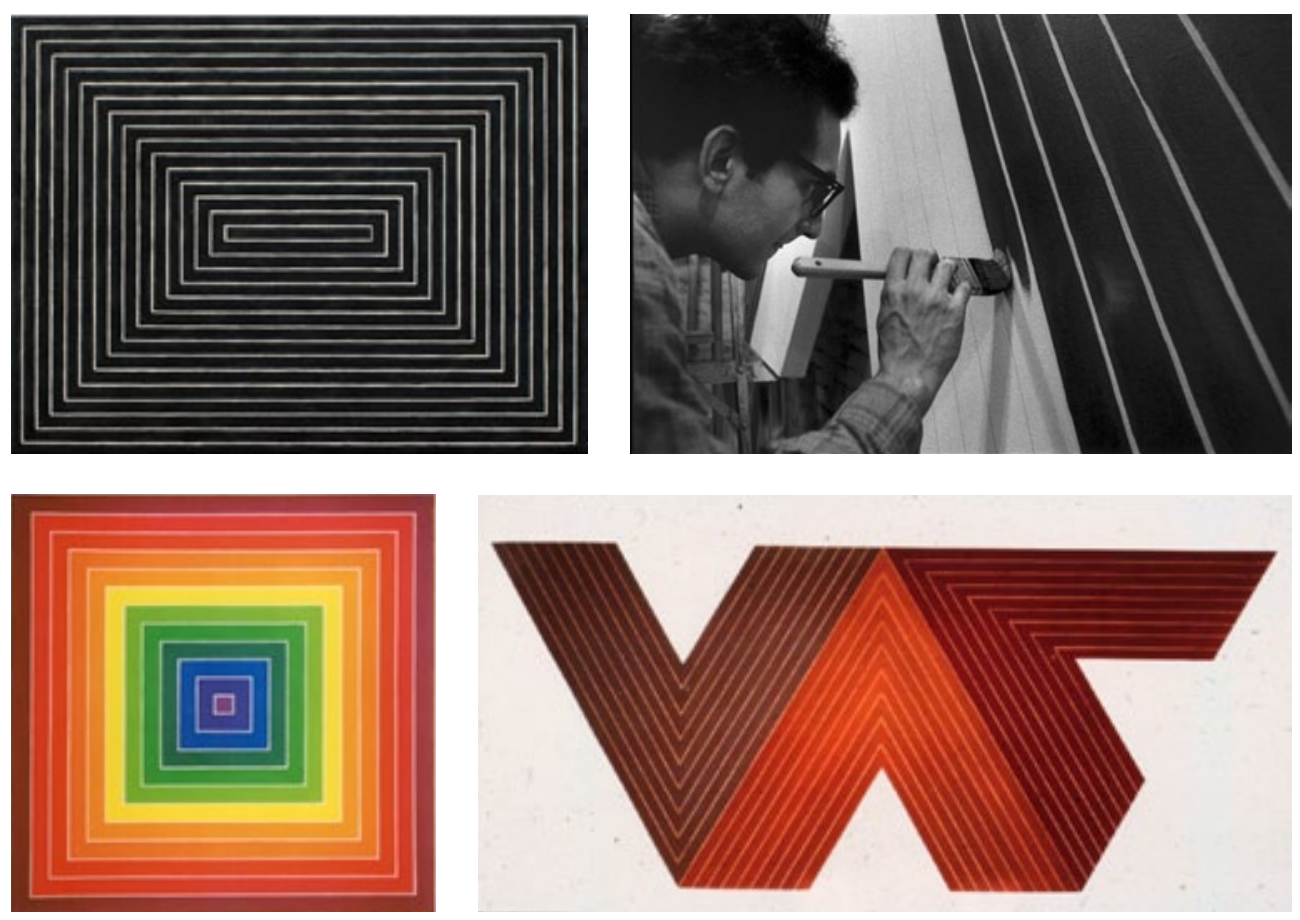

Fig. 84. Frank Stella trabajando. Pinturas del Color Field y Hard Edge.

Las reflexiones que Buchloh realiza sobre el trabajo de Robert Ryman, Niele Toroni y Piero Manzoni en su texto Formalismo e Historicidad nos parecen relevantes y coincidentes con el análisis que nos ocupa, habremos de operar sobre esta base para desarrollar nuestras ideas en este punto.

En otro sentido esta triada de artistas complementan el círculo de estudio del problema que tratamos; el de la Estructura Indéxica del Dibujo como recurso de organización en la pintura de la abstracción pospictórica.

Materia, Materialidad Pictórica e Índice del Dibujo serían las tres categorías que desde nuestro punto de vista ocupan la centralidad del trabajo de Ryman.

Señalamos directamente el hecho de que la materialidad pictórica en este caso nos interesa como asociación íntima con el principio de indexalidad derivada de la huella visible, en relación con el factor físico o acción metodológica que la genera; elemento que por otra parte no es sino la aplicación estructural de la disciplina del dibujo.

Si en las pinturas de Noland y Stella el dibujo se dirige a una reducción de la huella autográfica en pos de un rigor geometrizante, con Ryman se abre la posibilidad de continuar la práctica del dibujo como un proceso de ampliación que no necesariamente tiene que pasar por la gestualidad del Expresionismo. Figs. 85 

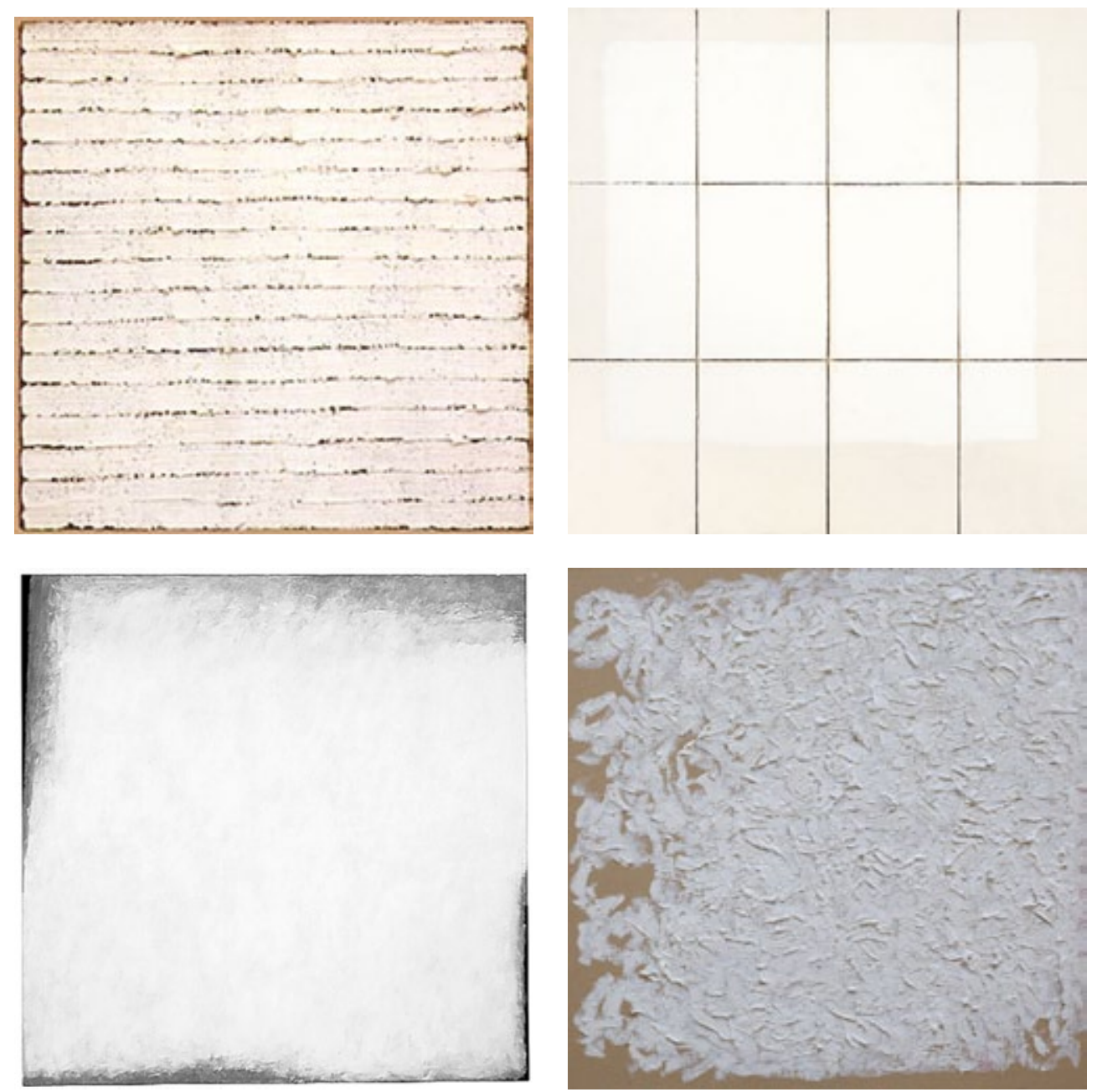

Fig. 85. Robert Ryman. Es el pintor de la Abstracción Pospictórica que más profundizó en la construcción de trazos y pinceladas indéxicas.

En el trabajo de este artista destaca la conceptualización que realiza de la pincelada al convertirla en todo un arsenal taxonómico del lenguaje, es esta operación en la que el dibujo se mantiene como factor de estructura y apunta a la intención de una sintaxis, sobre todo cuando el total de la obra se soporta en el principio serial de la pincelada, lo que la lleva también a una búsqueda de la factura como un factor que media entre la expresión de la gestualidad llevada hacia una regularidad casi industrial, que al igual que en el Informalismo y el Expresionismo Abstracto permitía la identificación autoral inequívoca.

Ryman construye un repertorio de recursos facturales, pinceladas reguladas en longitud y anchura, control de la carga de pigmento y materia en las aplicaciones sobre la tela y regulación consciente de los movimientos mediante los cuales la mano y el brazo realiza su depósito.

De ahí que el caso de Niele Toroni resulte totalmente distinto, ya que recurrirá a una marca o índice único, generalmente puntiforme, para dejar el peso de la apertura constructiva a 
su destreza en la conciencia y manejo del espacio y la arquitectura, ya que muchos de sus trabajos intervienen directamente en el espacio de la galería. Figs. 86
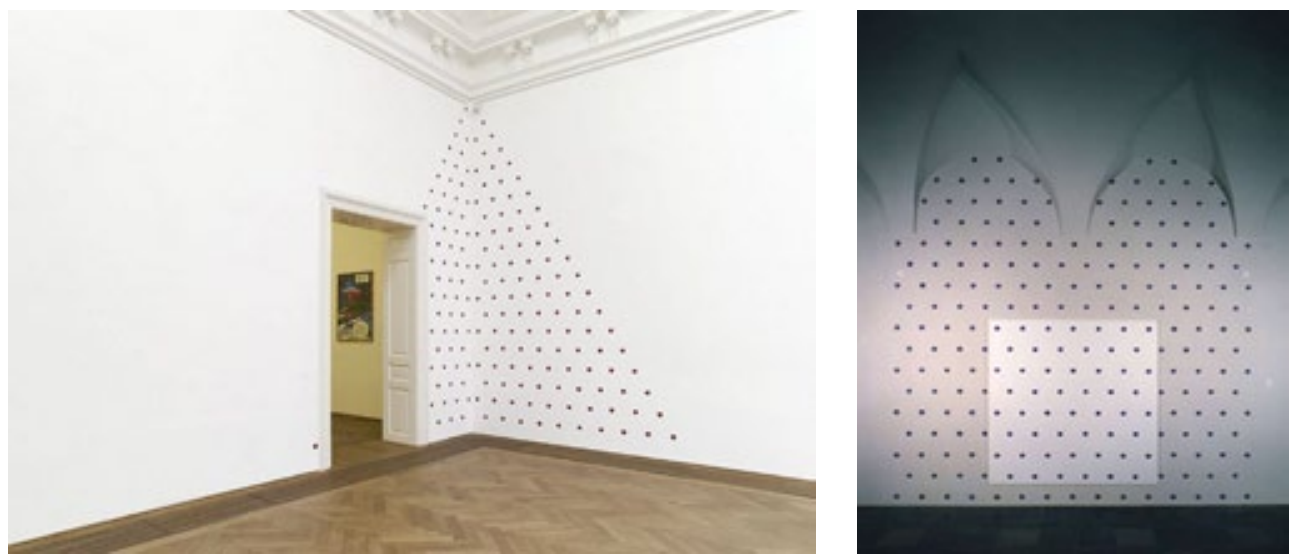

El planteamiento original de Toroni es la realización de una huella regular mediante la aplicación de pinceladas de color con un pincel de mismo número siempre, a una distancia alternada de treinta centímetros, sobre la superficie pictórica, lo cual genera una impresión reticular, pero el artista se las ingenia para no obstante este efecto, crear subversiones y cortes espaciales que confieren un sentido amplio y abierto a cada obra.

Toroni llamó a este procedimiento de aplicación regular de la pintura la Empreinte, con él, logró separar la acción de aplicar el color, de la de distribuir el color, mostró de

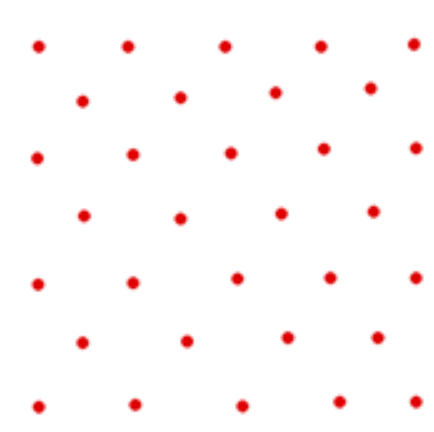

Fig. 86. Niele Toroni esta manera que la materialidad de la pintura no se identifica con su extensión espacial y temporal. Para él la forma espacial y temporal se concreta en el intervalo abstracto de 30 $\mathrm{cm}$. Y el color se transforma no en un campo sino en una marca, situación que lo acerca fuertemente a la condición de dibujo, aunque es claro que en la magia y creatividad de Toroni, el punto o pequeño cuadrado puntiforme, adquiere cualidades gestálticas diferenciadas en función del tono cromático que lo constituye, y en gran medida de esto depende su operación espacial en el sitio de montaje.

En este grupo de pintores encontramos una mecanización del dibujo, pero esta opera no como signo de estandarización, se basa en una claridad conceptual que es producto de un modelo mental.

Así el índice se colocó como el fundamento semiótico del dibujo y la línea pictórica, se convirtió en una de las características típicas de la pintura moderna y la abstracción pospictórica. La opticalidad de la modernidad formalista se continuó en la abstracción pospictórica, pero se amplió mediante la aportación del dibujo en la elaboración clara del índice como huella de la acción física, huella de la materia y organización sintáctica del repertorio de líneas y pinceladas. Mediante estas aproximaciones se generó un proceso analítico claro y transparente, la interacción entre herramienta, material, superficie y estrategia procedi- 
mental y gesto, integraron un proyecto completo para la pintura, en el que el dibujo operó como elemento integrador y estructural en la pintura de mediados de los años 50 y hasta la década siguiente.

Piero Manzoni es uno de los artistas que inician la deriva del arte hacia las prácticas del arte del concepto. Este corte de la historia del arte nos interesa en el sentido de que nuevamente el dibujo se introduce en esta práctica como elemento que organiza el proyecto, y no sólo a manera de posibilitar los bocetos, sino como la expresión acabada de la idea artística que ya desde ese momento muestra la completud, la estrategia y el sentido de la obra, haciendo en ese sentido y sólo en ese, innecesaria la realización de otro objeto que no sea el proyecto como realizador de la idea.

Manzoni realiza en 1959 lo que llamó sus obras lineales; consistían en líneas de extensión cada vez mayor, hasta llegar al infinito. Estas eran trazadas al centro y a lo largo de rollos de papel, que después eran envasados en cilindros de madera de 20 a 26 centímetros de alto. En estos trabajos el autor definía el dibujo como una extensión espacial y temporal pura, no se requería figura, la propia línea no era una unidad formal del lenguaje, ni requería de una norma sintáctica para regular su combinatoria, era sólo un concepto que hablaba de la categoría de extensión, Lo elemental de los dispositivos de montaje y presentación de estas obras dejan claramente al centro lo complejo de su concepción reflexiva. Se señala el dispositivo de montaje (los cilindros de madera) como cercos que limitan la experiencia fenoménica perceptual de la noción espacial, pero esa es precisamente la estrategia, el espectador sólo construye esa noción de extensión en la región mental propia, son dibujos dirigidos al intelecto y no a la visualidad con un transcurso temporal teatralizado, con esto se inicia tempranamente la retirada de las prácticas de la percepción como centro de la experiencia artística; que ya no estética. Figs. 87
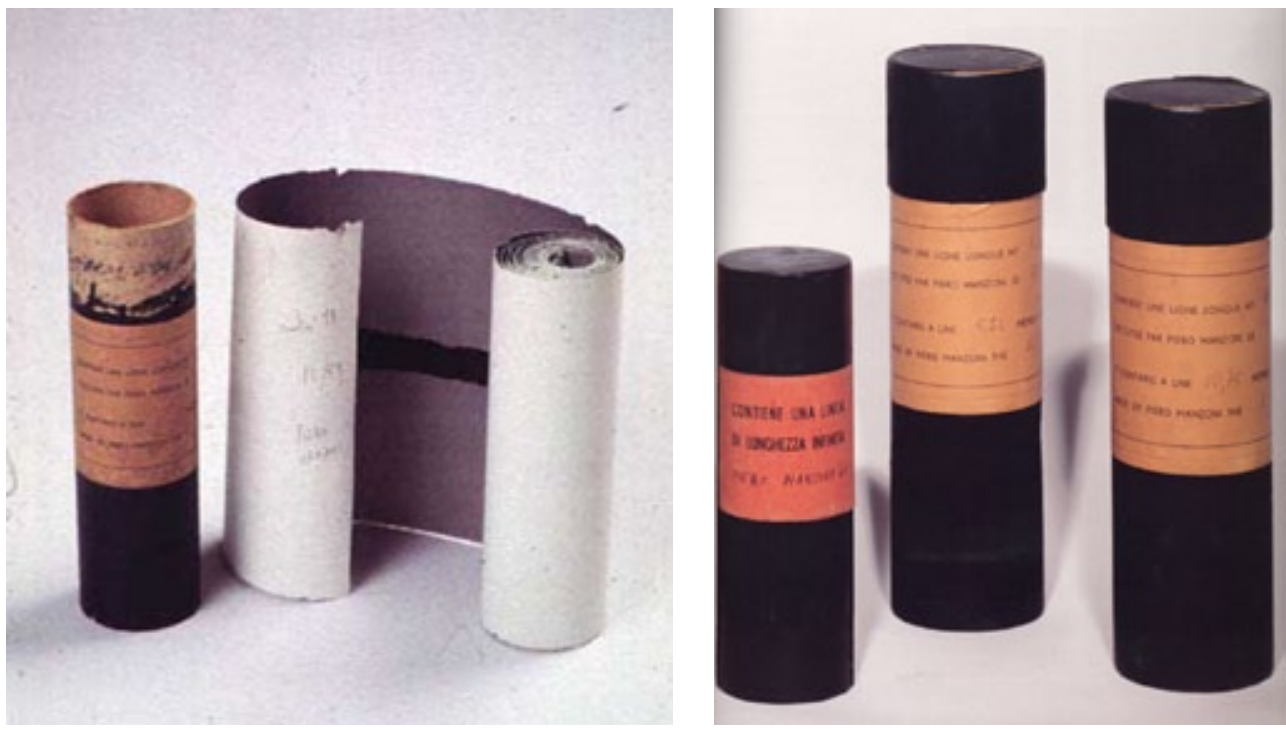

Fig. 87. Piero Manzoni "Línea infinita" 
El trabajo de Manzoni no se redujo a estas obras lineales; mostró una capacidad para plantear prácticas de apertura a la creación artística. Señalamos dos campos más dentro de su trabajo.

Uno en donde la obra es realizada mediante el plegado de materiales textiles o papeles sobre bastidores de lo que ya no se puede llamar pintura, no hay color, no se traza con ningún pigmento, pero hay líneas claramente definidas que integran una lectura topológica del plano, a veces en sentido puramente horizontal y en ocasiones generando subdivisiones cuadrangulares con diferencias rítmicas, en estos trabajos la pureza de la indexalidad como huella de la acción física, que sin embargo evidencia un comportamiento altamente racional, se muestra de manera magistral, quizá en estas obras se inicia la aventura de la expansión del campo disciplinar del dibujo. Figs. 88
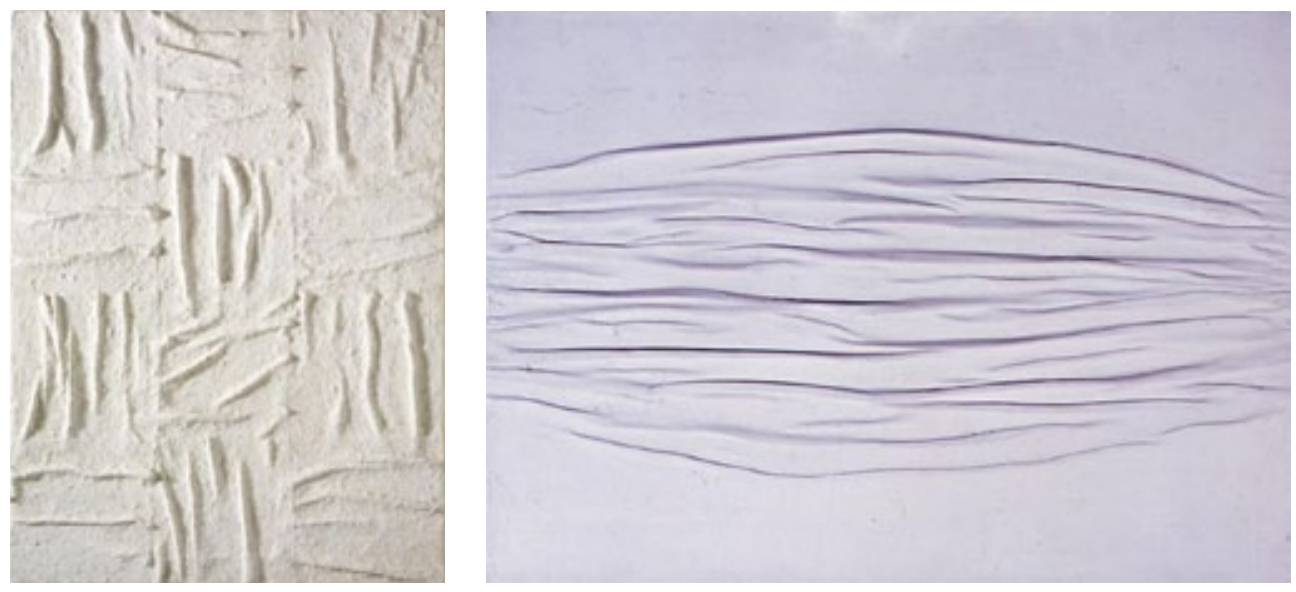

Fig. 88. Piero Manzoni.

En segundo lugar nos llama la atención un dibujo realizado en lo que parece una hoja extraída de un cuaderno de apuntes, es claramente la organización dibujada de un proyecto denominado Placentario, no logramos obtener mayor información de este dibujo, pero es clara su concepción como proyecto de lo que después se convertirá en la estrategia típica de muchos conceptualismos y géneros híbridos del arte. Fig. 89

El lirismo espiritual de Kandinsky y el rigor reflexivo purista y anti dramático de Mondrian no son en última instancia sino el conflicto con el que se divide el arte plástico visual desde el inicio del siglo XX. Lo específico de una estructura como razón conceptual y la posibilidad de que lo fortuito y la organización azarosa se tornen en poder generativo dentro del proyecto artístico y del dibujo.

Este es el dilema al que las obras de Sol LeWitt parecen dar salida.

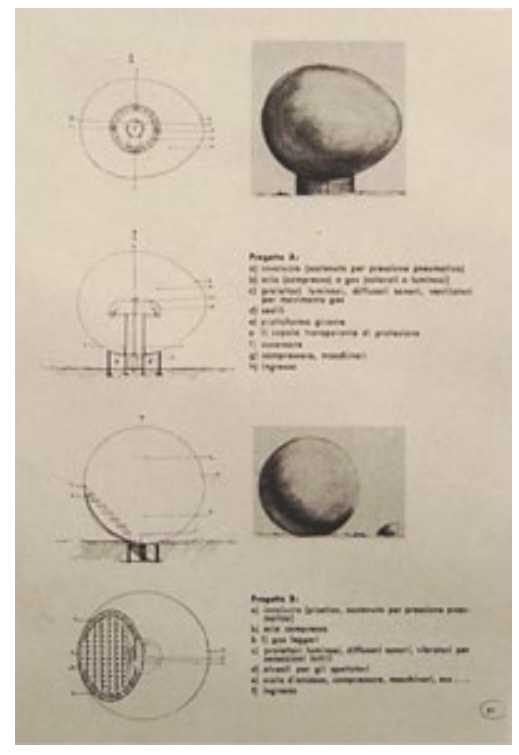

Fig. 89. Piero Manzoni Placentario. 
El caso de LeWitt es ejemplo de operación estratégica y proyectual donde el dibujo resuelve la integración del proyecto artístico como vía del arte del concepto.

Tal vez nuestras palabras no se extiendan largamente en este asunto, pero queremos destacar la importancia del punto; ya que desde la concepción Zucariana se aclara la naturaleza teórica de la disciplina del dibujo, pero vemos en el corte de este segmento histórico, 1961, un relevo y continuación de esta línea de pensamiento.

Diríamos que la distancia que diferencia el pensamiento manierista del protoconceptualismo y el conceptualismo maduro, se expresa en el sentido de que la operación mental del dibujo ahora se remite a la lógica interior del propio dibujo, pero no como formalismo, sino como detonante en el espectador de operaciones reflexivas, estas expanden o sustituyen la experiencia estética, en ausencia de una causalidad epistémica nacida de un vínculo modelístico con la realidad concreta.

Esta meta fue lograda en las obras conocidas como Estructuras, realizadas por LeWitt en 1961 y 1962. Eran obras que incluían elementos del lenguaje escrito integrados al sistema formal perceptual de la pintura.

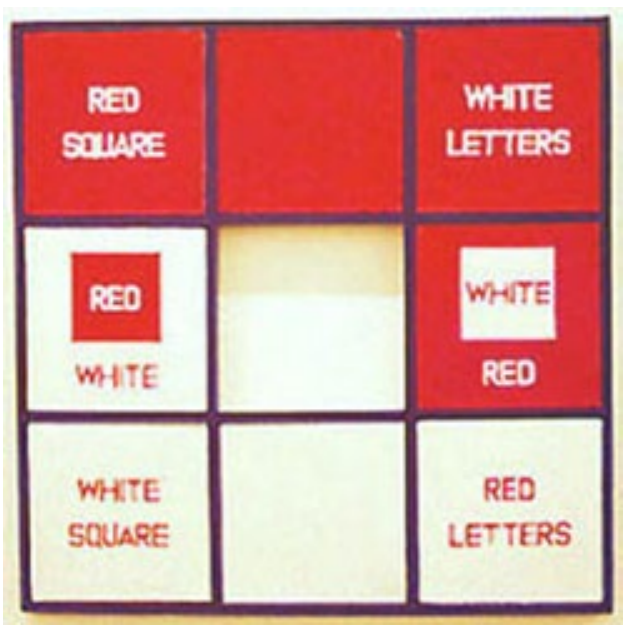

Fig. 90. Sol LeWitt. "Cuadrado Rojo"
La crítica a la visualidad pura aparece en el Cuadrado rojo de Sol LeWitt (1963), con la estrategia de cuestionar la autorreflexividad visual y formal, al usar inclusiones literales, lingüísticas, palabras y definiciones que contenían también cargas visuales, colores y formas cuadrangulares en este caso, pero colores y formas a los que aludían las definiciones literales mismas. Así LeWitt transformaba al espectador en lector simultáneamente, la acción de contemplar se tornaba en acción performática, lo cual constituye un cambio del objeto visual a un objeto que detona la dinámica de su comprensión en el plano no estético sino conceptual. Fig. 90

Mediante esta estrategia se generaba una sobreposición del plano lingüístico sobre el perceptivo, no para analizar la primacía de ninguno de los dos, pero tampoco (y esto es muy relevante) para formular la obra como una proposición analítica. Con esta conmutación se introducía al espectador no a una toma de partido sino a realizar la integración de todas las lecturas y combinatorias posibilitadas por los planos semánticos de la obra, texto pictórico y texto literal asociados.

Nos interesan también de este autor sus dibujos sobre las posibilidades de los cubos abiertos o inacabados, y sus murales soportados solo por el dibujo, pero tomemos del propio LeWitt tres postulados que nos permiten redondear el pensamiento básico del proceso conceptual para dirigirnos hacia las obras que nos ocupan. 
1- Los artistas conceptuales son místicos y no racionalistas. Llegan a conclusiones que la lógica no puede alcanzar.

2- Los juicios racionales repiten juicios racionales.

3- Los juicios irracionales conducen a nuevas experiencias.

En estas afirmaciones de LeWitt se muestra el carácter epistémico no lineal de su lógica de pensamiento, esto es importante porque cuando menos el caso de LeWitt como conceptualista; no se basa en la definición de un concepto y una lógica matemática que opera como demarcación cerrada. El elemento conceptual es en cambio la enunciación de una lógica estocástica, aleatoria y entrópica, de ahí su carácter abierto y generador como sistema dentro del arte.

Rosalind Krauss en el análisis que hace de LeWitt lo había observado y con ello deslinda de los entendimientos lineales y las lecturas cerradas de LeWitt que la crítica postulaba. En su ensayo "LeWitt en progresión"134, específicamente señala la desviación de entender las series de Variaciones de cubos abiertos incompletos que se integra de 122 unidades, bajo un orden deductivo inferencial y axiomático, para llegar a un principio central que explique lo múltiple de la experiencia.

Krauss cita la opinión de Donald Kuspit, quien establece el parentesco de esta obra con la amplia tradición occidental griega y renacentista, que busca el entendimiento del mundo mediante sistemas de razón matemática.

Ver a LeWitt y sus series de cubos incompletos a través de Descartes o Euclides implicaría la cita del principio central axiomático que opera en esas construcciones, el cual no existe, o, cuando menos no es una formulación de ese tipo, en segundo lugar se tiene que recordar que en la lógica matemática y científica en general, la formulación y encuentro de la norma reguladora, se orienta a la estrategia generalizadora, para que no sea necesaria la búsqueda y realización del número infinito de casos que constituyen el sistema; cuando en el caso de LeWitt, señala Krauss, lo que interesa es la realización de múltiples casos que son los que pueblan el universo de la mente, es importante que cada uno de estos 122 casos sean construidos.

A poco de pensar en estas estructuras notamos que no son la secuencia ordenada producida por la aplicación de una fórmula. Es más bien un universo incompleto de posibilidades. Un mundo generador de pensamiento aleatorio y no el cierre determinista de un concepto.

Pero al mirar tanto los dibujos como las piezas terminadas de estas series, surge con claridad un factor; ya desde la cartela dibujada se consolida la estrategia conceptual y su formalización, así, el proyecto opera de manera completa y se da a la experiencia expositiva, pero las fotografías de las piezas terminadas y expuestas plantean una relación temporal fenoménica dilatada, una en la que el tiempo de la vivencia de la pieza invade la temporalidad y la espacialidad sensible, no solo racional. Figs. 91

Los trabajos murales de LeWitt en varias ocasiones llevan a la pared la estrategia de los cubos incompletos, como es el caso de los Círculos incompletos organizados en las es-

134 Krauss Rosalind. La originalidad de la vanguardia y otros mitos modernos. Madrid: Ed. Alianza Forma; 1996. P. 259. 


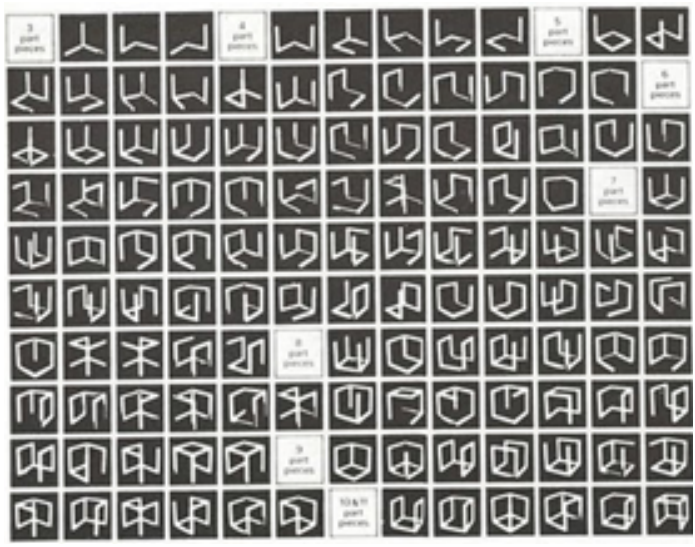

quinas, del que incluimos un proyecto que sirvió en el cartel de su exposición de 1976 y una fotografía del mural en exposición. Figs. 92

Otro tipo de murales realizados por LeWitt mediante el dibujo, eran proyectos en los que se intentaba generar construcciones espaciales, volumétricas y de relieve, separadas de representaciones objetuales, murales que buscan la lógica interna del concepto formal de manera tautológica.

En todos los trabajos murales tenía sobre el muro una cartela con el proyecto e instrucciones para su realización, decía que esto era para ayudar a comprender la idea, precisamente porque LeWitt fue de los artistas que se desligaron de la ejecución de las obras que ellos mismos concebían, con esto dejaban el proceso de la factura en manos de los ayudantes o realizadores, distanciándose así de cualquier implicación autográfica en el trazo efectuado, las líneas realizadas sólo eran la huella de una acción física, sí, pero no de la manifestación corporal sino de la guía del concepto. Figs. 93
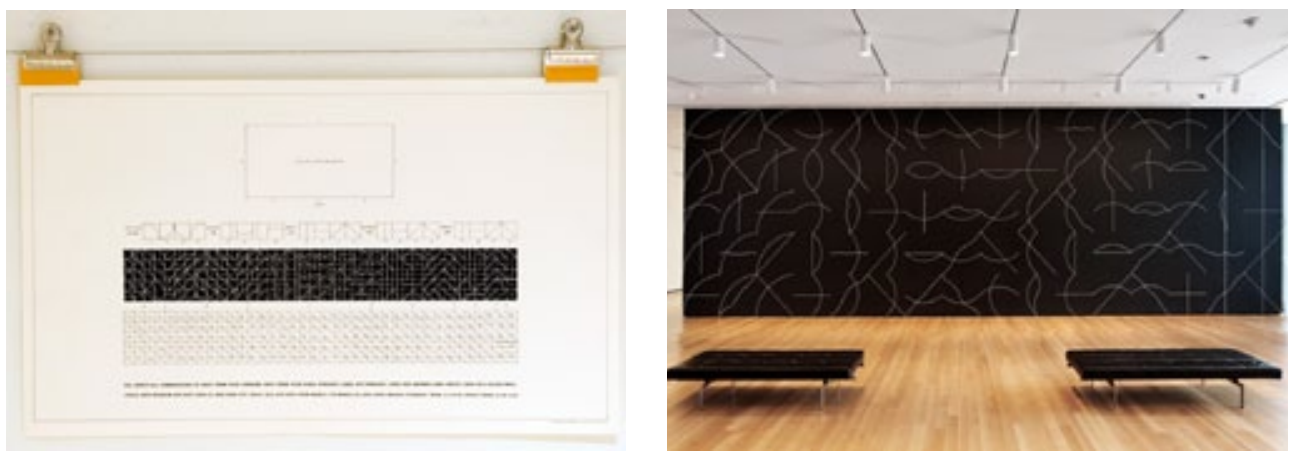

Fig. 92. LeWitt, proyecto y mural "Wall Drawings" 


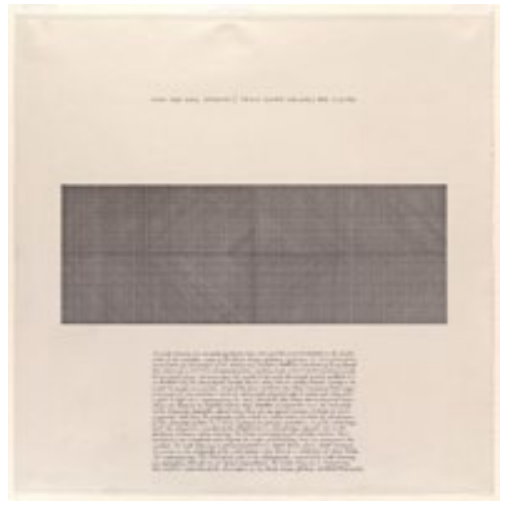

Fig. 93. LeWitt, instrucciones y Wall Drawing.

Este mundo de relaciones teóricas era al que nos referíamos al señalar la vía de ascendencia del dibujo como campo reflexivo, que en este punto se expande hacia estrategias de conceptualización, que enriquecen el sistema de la disciplina en su terreno mental.

Rechazando la opticalidad como categoría formal de la modernidad, y elaborando una estrategia reflexiva que involucró el texto plástico y visual con el texto literal, el arte del concepto incluyó al dibujo como parte del proyecto general de las artes, en esta situación el dibujo a su vez, amplió nuevamente su operación proyec-

tual y su consistencia ontológica. Se mantuvo ligado íntimamente al proceso generativo de las obras y el sistema que las soportaba.

Por más extremas que puedan parecernos las estrategias conceptualistas, se mantuvieron dentro del territorio de lo artístico, participaron del corte paradigmático de la modernidad artística, pero ya la emergencia de un nuevo segmento de artistas y prácticas con carácter distinto hacía tiempo que se venía gestando.

La tipicidad de ese nuevo estrato histórico ha sido puesta en perspectiva cuando desarrollamos el Planteamiento del Problema en este estudio, pasemos a realizar un recorrido de ese segmento que termina por redondear la secuencia del pensamiento modelístico del dibujo.

"El término «posmodernidad» se utiliza en crítica de arte de un modo un tanto promiscuo, a menudo como una mera indicación de lo no-moderno o como sinónimo de pluralismo. En 
este sentido sus pretensiones son modestas - se limita a expresar que nos encontramos en un período reaccionario en el que la modernidad parece algo distante, y la recuperación de modas pasadas demasiado próxima. Por una parte, esa distancia constituye la condición de posibilidad de la posmodernidad; por otra, la tendencia a recuperar elementos del pasado hace necesario concebirla como algo más que mera antimodernidad.

Por supuesto, la definición que se postule de la modernidad determinará hasta cierto punto una u otra comprensión de la posmodernidad. Cuando se entiende en sentido cronológico, la modernidad a menudo se restringe al periodo comprendido aproximadamente entre 1860-1930, aunque muchos la hacen extensiva al arte de postguerra o modernidad «tardía». En cambio, como término epistemológico la noción de modernidad resulta más difícil de especificar (por ejemplo, ¿hay que aceptar la ruptura entre clasicismo y modernidad tal como la define Michel Foucault?, ¿hay que atribuirla al criticismo kantiano, como hace Clement Greenberg?). En cualquier caso, cuando se explica la posmodernidad en relación a la modernidad, hay cierta tendencia a reducir esta última. ¿Se puede delimitar con tanta precisión la modernidad? Si es así, ¿en qué consistiría una ruptura respecto a ella?"135

Desde la postura posmoderna se asume la modernidad en su fase tardía, cuyo desarrollo se encuentra básicamente en los escritos de Clement Greenberg y Michael Fried. En esta visión, la modernidad equivale a la búsqueda de la pureza de los campos artísticos y a la autocrítica que cada uno de ellos desarrolla, para encontrar dentro de sus estructuras formales los factores conceptuales de autosoporte y desarrollo, como ya lo hemos visto. Así la pintura, la escultura y la arquitectura serían definibles e inconfundibles.

Pero ya desde aquí se observa el problema que esto reviste para la disciplina del dibujo, cuya relación con las artes particulares es de carácter sistémico como hemos venido revisando; sobre todo en las prácticas informalistas, del Expresionismo Abstracto y de la abstracción pospictórica.

En su momento esta posición mantuvo un carácter crítico, en tanto que significó una apertura de los procesos de representación formal de cada una de las áreas de las artes, y porque más allá del pensamiento de Greenberg y Fried, se generaron desplazamientos de la consideración formal de la obra hacia las prácticas, procesos y estrategias de la ejecución configurante.

Pero el proyecto rupturista y crítico de los artistas comenzó a cuestionar esas prácticas propias; utilizó dentro de la concepción y configuración de sus obras mezclas de procesos y componentes formales así como estrategias que traspasaron las fronteras de los campos formales y puros del arte recién enunciados, la necesidad expresiva del artista, como siempre, no reconoció limitantes impuestas y corrió sobre las conclusiones que la necesidad expresiva y la historia de los propios procesos le ponía a disposición.

La inserción de las rupturas de la modernidad formalista dentro de los espacios oficiales del sistema cultural (museos, galerías y circuito comercial) significó el desmantelamiento de su capacidad de ruptura y las convirtió en el arte oficial, de ahí que las prácticas del arte posmoderno se dirijan a espacios alternativos y adopten formas múltiples y mixtas, en las que medios de realización artística se funden para lograr el sentido significante, La

135 Wallis Brian. Arte después de la Modernidad. Madrid: Ed. Akal/Arte Contemporáneo; 2001. P. 189. 
mezcla y el híbrido se oponen a la pureza de los campos del arte.

De ahí que la primera condición del arte posmoderno sea la del desmantelamiento del territorio cultural.

Y, aquí surge un primer conflicto.

Existen dos posturas para considerar el inicio del arte posmoderno, o post-arte, aunque en ese sentido la cuestión aún no se haya explicitado abiertamente, ni sus autores hayan tomado posición manifiesta y puntual.

Un grupo de analistas, Foster y Krauss, se inclinan por ubicar el inicio de las prácticas posmodernas en las obras de autores que transgreden la delimitación de los campos disciplinares, esto bajo los supuestos que hemos mencionado, en el sentido del desmantelamiento de la geografía artística oficial y sus circuitos de distribución y legalización.

Hasta hoy, el artículo de Krauss sobre la Escultura en el Campo Expandido, opera como un paradigma de análisis. Pero en este punto tenemos que precisar; el esquema lógico de campos de pertinencia y su negatividad sobre el que se basa el análisis de Krauss es un modelo analítico del pensamiento estructuralista, su transposición como aparato de reflexión en el campo del arte nos impone cuando menos ciertas precauciones.

Por lo demás, parece que el resultado de la aplicación del modelo del campo expandido en el caso de la escultura, arroja resultados positivos para el entendimiento de las prácticas que migraron de la escultura hacia el terreno multidisciplinar de 1950 hasta hoy.

Pero el problema se complica cuando se intenta aplicar este modelo al caso de las demás artes, ya nos referimos al artículo de la revista October $N^{\circ} 114$ del año 2005 titulado LA Fotografía en el Campo Expandido.

El resultado de esos análisis no nos parece que resuelvan con claridad meridiana el análisis emprendido.

Intentar la aplicación directa de ese esquema para el campo del dibujo nos obligaría de inicio a determinar una serie de categorías del campo del dibujo y sus exclusiones lógicas, asunto que pensamos demasiado forzado.

En el primer capítulo de nuestro estudio nos detuvimos en la problemática teórica de la determinación de los campos del arte y su posible dilución, entonces nos inclinamos por el análisis de Hall Foster en el sentido de la imposibilidad teórica y lógica de trascender la categoría del campo en el arte que nos ocupa, aunque no con ello se pueda negar la emergencia del dibujo en distintos territorios del arte.

Una segunda posición establece el inicio claro de la prácticas artísticas posmodernas en el arte de la imagen desde la realización de la exposición Pictures de 1977 realizada en el Artist Space en Nueva York con obras de Troy Brauntuch, Jack Goldstein, Sherrie Levine, Robert Longo Philip Smith.

En los trabajos presentados en esta exposición se aplican ya claramente lo que serán las estrategias propias del arte posmoderno, la cita, la apropiación, el plagio, el desmontaje del significado previo de la imagen para sobreponer una nueva lectura y sentido, el uso de las producciones e imágenes de la historia del arte renunciando al ejercicio de la re- 
presentación como relación del artista con la realidad para generar un resultado formal. $Y$ en general el entendimiento del artista como un semionauta y subversor del significado original de la imagen.

Pero en cualquiera de estas dos posibilidades, definitivamente los artistas y los críticos posmodernos entienden su ruptura tanto con los medios del arte como con el historicismo secuencial que organiza los cortes en el devenir del arte.

Con todo y tener un principio causal que los emparenta, sin embargo no cuentan con una línea teórica unificada ni con categorías comunes para fundar su modelo, en parte porque han renunciado a ello desde el inicio, al oponerse a los discursos integrados y totales.

Para Krauss el advenimiento de la posmodernidad se basa en la expansión de los campos del arte. Para Crimp, sería un retomar características de la teatralidad y para Owens el lenguaje bajo un impulso alegórico y deconstructivo.

Por nuestra parte, vemos en el trabajo de artistas como Robert Smithson, Dennis Oppenheim y Richard Long una ruta estratégica que amplía las posibilidades de un campo del arte y lo interconecta con los modelos de pensamiento de otros territorios también artísticos, esta sería una expansión del campo en su sentido más sencillo, pero altamente significativa, en tanto que enriquece la forma del pensamiento artístico, lo concreta en imágenes o producciones formalizadas de primera generación, cosas, obras o imágenes no vistas anteriormente y que fortalecen nuestra visión eidética del mundo. Mientras que vemos la especificidad y puntualización de la práctica posmoderna como la irrupción de las prácticas de apropiación, cita, montaje y desmantelamiento de los sentidos originales de las imágenes recicladas.

Nos inclinamos por esta separación porque entendemos este problema bajo la consideración de los Modelos del Dibujo, formas del pensamiento particularizadas en diferencias formales y estratégicas que definen sus segmentos de corte y sus aportaciones y extensiones al territorio del dibujo.

Bajo esta perspectiva revisaremos algunos autores que en su trabajo mantienen un ejercicio del dibujo como factor sustantivo y función organizadora del proyecto y configuración terminal de la obra, aunque en sus procesos se manifieste con claridad una migración de la concreción de la obra hacia campos no ortodoxos del dibujo.

Dennis Oppenheim (1938) realizó en la frontera entre Estados Unidos y Canadá la obra Anillos Anuales en 1968. Esta obra es un dibujo sobre la nieve, consiste en una serie de elipses concéntricas atravesadas por el río Saint John. El dibujo representa los anillos anuales de crecimiento de los árboles, los cuales muestran la edad de los mismos, de ahí el título de la obra.

Oppenheim recopilaba información climática y topográfica sobre las locaciones en las que planeaba desarrollar sus trabajos, a esta información la llamaba pensamiento preliminar. Con esta suma de datos se trasladaba al sitio específico de las obras para iniciar el proceso de configuración propiamente dicho.

A la etapa de transformar esa información inicial en una configuración artística particular Oppenheim lo llamaba Gestos Abstractos sobre la tierra y pensaba que esos trazos 
solo aludían a su propia condición sígnica, pero que debían considerar su relación con la esencia geográfica de su lugar de emplazamiento. Esto permitiría lograr una relación entre la obra y los aspectos climáticos, lo que resulta claro en el caso de Anillos Anuales. Oppenheim decía que en esta obra intentó expresar la sensación de estar dibujando en la nieve, sintiendo el frío en el momento de estar dibujando, en esta declaración indirecta se filtra la intención que nos aclara el hecho de que el autor concebía esta obra como una manera de dibujar.

Esta obra es un diagrama que nos habla de distintas formas del concepto de frontera, pero nos interesa señalar que la manera en que continuamente es percibida, independientemente de las fotografías de registro o de la posición del espectador, es la de un diagrama del dibujo, una figura abstracta de corte geométrico con escaso o nulo valor escultórico, si bien es la marcación de un sitio específico, esta marcación se logra mediante la intervención de trazos lineales carentes de cualquier otro elemento formal, por eso la consideramos una intervención dibujística en el sentido nítido del campo del dibujo, sin

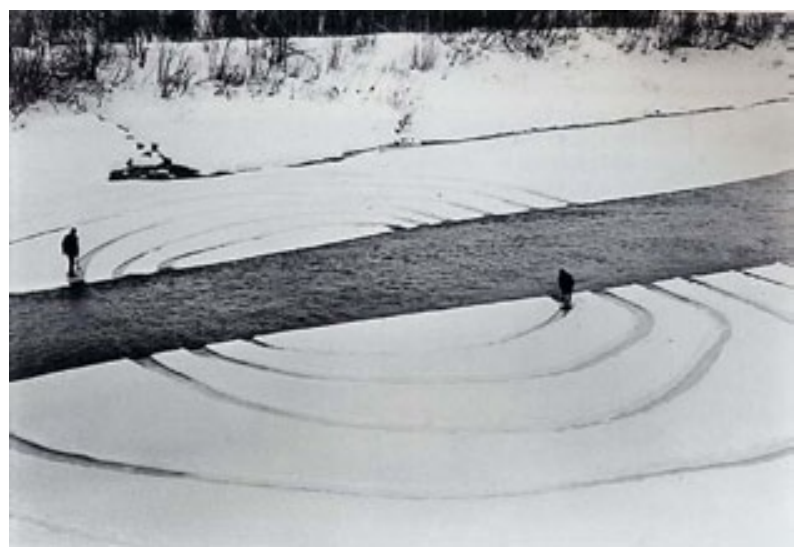

Fig. 95. Denis Oppenheim. "Anillos anuales" importar el transcurso fenoménico temporal en el acto de su contemplación; la forma del trazo de las elipses es constante sin importar los desplazamientos del punto de vista del observador, diríamos que tiene una consistencia terrenal mínima y una existencia conceptual máxima, la planitud de la superficie en la que las elipses están trazadas se mantiene como entidad abstracta y los surcos existen gracias a su condición lineal. Fig. 95

Generalmente el Land-Art se entiende como una ampliación del problema escultórico y su expansión. Pero pensamos que las obras como Anillos Anuales y Whirpool Eye Storm, se colocan dentro del territorio del dibujo. Esta forma de arte es una reflexión topológica, un tomar en cuenta ante todo el lugar para el emplazamiento y secuencia

"Mientras miraba el sitio, el lago reverberaba en el horizonte, haciendo pensar en un ciclón inmóvil, la luz parpadeante creaba la impresión de que el paisaje entero se estremecía. Un terremoto silencioso se extendió hacia la quietud palpitante, en una sensación giratoria sin movimiento. El sitio era un orbe que se envolvía a sí misma en una gigantesca curvatura. De ese espacio giratorio emergió la posibilidad del Spiral Jetty. Frente a esa evidencia ningún concepto, idea, sistema, estructura o abstracción podía mantenerse en pie. Mis dialécticas de Site y Nonsite se arremolinaron y tomaron una forma indeterminada, en la que lo sólido y lo líquido se perdían uno en el otro."136

El Spiral Jetty de Robert Smithson fue realizada en 1970 en la ribera del Gran Lago Sala-

136 Smithson Robert. Selección de escritos. México: Ed. Alias, 2009. P. 161. 
do de Utah. Tiene su origen en la inquietud de Smithson por el color rojizo de los lagos salados. Antes de conocer el lago y decidir el sitio para realizar la obra, no tenía una idea específica sobre el proyecto a desarrollar, solo sabía que quería realizar un trabajo en el lago. Como se desprende de la cita anterior, la forma de la espiral para el malecón fue resultado de una vivencia personal del lugar y se basó en motivos totalmente subjetivos.

La locación y la forma de la espiral inversa al movimiento de las manecillas del reloj, se basaron en el pensamiento de los Site y Nonsite que por ese entonces preocupaban a Smithson, un conjunto de negaciones y formulaciones entrópicas cuyo interés era el señalamiento de una subversión espacial.

La intención de Smithson era que los cristales de sal repitieran la espiral de manera creciente, como un enrejado o eco reverberante. El relacionaba la idea de repetición con los conceptos de escala y tamaño. Según su pensamiento, el tamaño determina los objetos, en tanto que la escala determina la noción artística, porque la escala opera sobre la noción de incertidumbre y depende de la conciencia que percibe las realidades, por eso según él, la escala no depende del tamaño del objeto, por eso las cosas pequeñas pueden percibirse magnificadas en su tamaño, ya que la escala no es fija, sino que depende de la percepción.

Particularmente, en el caso del Malecón Espiral, según Smithson, la escala depende del sitio o lugar desde el que es vista, así el espectador la percibe en múltiples escalas.

Desde su concepción y realización es difícil entender esta obra asociada al campo del dibujo. Sería una producción más relacionada con la escultura y la arquitectura, en tanto prolongación del hábitat humano, y aunque existen algunos dibujos previos a la obra, ésta se diferencia sustancialmente de los anillos de Oppenheim.

El terreno sobre el que se realizó el malecón no puede, ni fue considerado como un plano abstracto racional de soporte para la obra, los escritos de Smithson nos dan la certeza de que lo consideró en su sustancialidad geográfica como un lugar geofísico, la fenomenología desde el inicio de la obra se dio en el plano vivencial y bajo la subjetividad particular del autor, la sustancia del lugar mantuvo siempre una consistencia ontológica no abstracta.

Sumado a lo anterior, el propio autor manifiesta la importancia que tiene en la apreciación de la obra el punto de ubicación del espectador, como modificador fenoménico de la escala perceptual, y debido a esto el carácter relativo y cambiante de la consistencia de la obra.

Este Malecón Espiral sólo podría apreciarse como una línea espiral pura y abstracta si se le observa desde una altura considerable.

En todo caso, la Spiral Jetty es un trabajo del Earth Work, aunque su trazo elemental corresponde a una espiral, la concreción matérica de la obra la distancia de un carácter platónico como entidad lineal abstracta. En todas las fotografías que se revisen se advierte que el curso de la espiral corresponde más a una banda que tiene dimensión a lo ancho, a tal grado que su carácter lineal se compromete por la característica de extensión bidimensional. A lo anterior se agrega la intención que desde un inicio se tuvo de que la espiral guardara una condición cambiante por las afectaciones del medio ambiente, lo cual sin lugar a dudas ha venido sucediendo (ver imágenes). No la entenderíamos como una marca sobre la tierra sino como la construcción de un túmulo, aunque su forma no sea la típica de esas construcciones. 
En la compilación de textos de Smithson que revisamos, no encontramos alusiones puntuales que nos permitan acercar esta obra al territorio del dibujo, si bien tampoco la entendemos como una práctica típica de la posmodernidad, ya que su gestación no utiliza conceptos o imágenes de segunda generación de la historia del arte. La asociamos al carácter indéxico del dibujo, en el aspecto de ser una huella producto de la acción física al intervenir una superficie, quizá esta sea la manera de conectar el Spiral Jetty con el campo del dibujo. Figs. 96
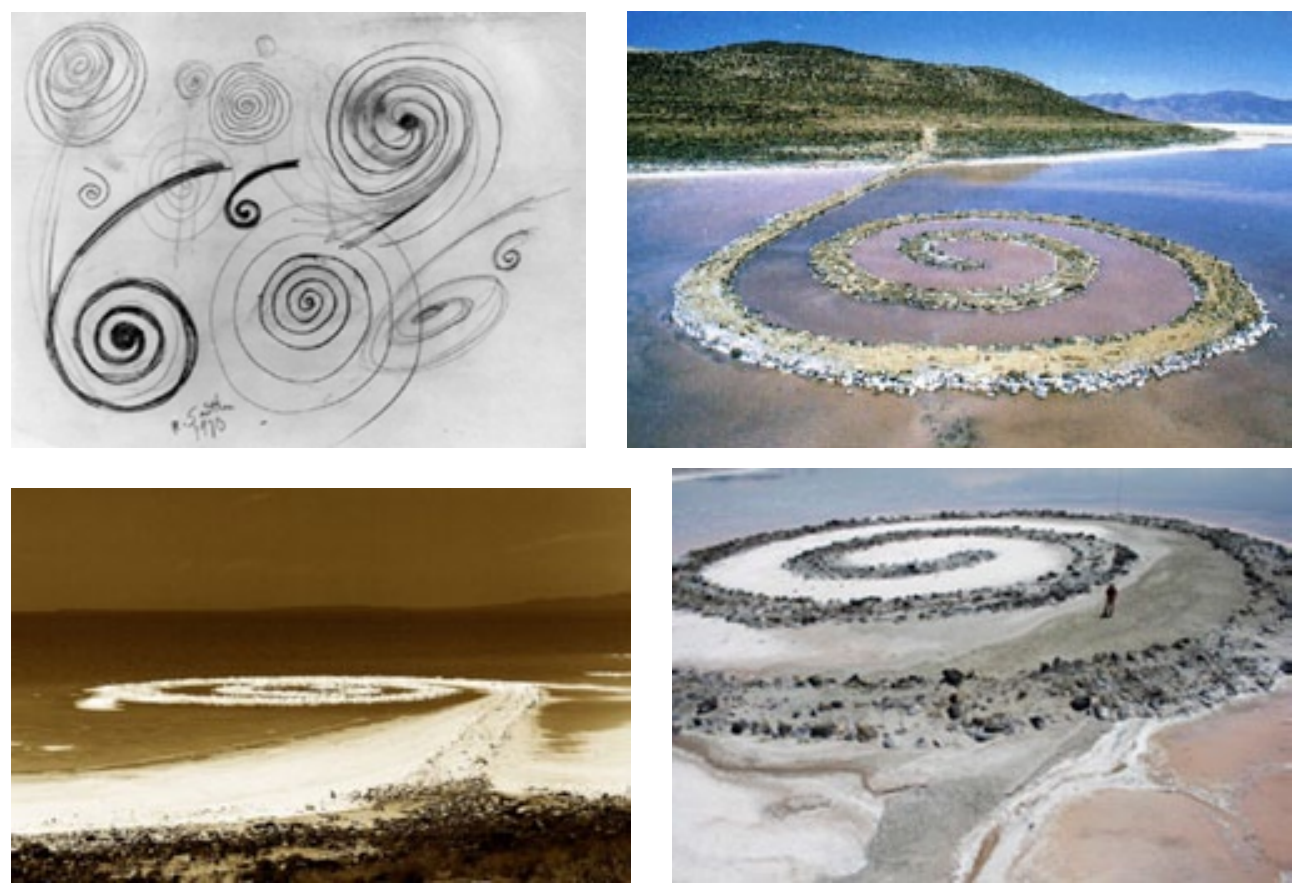

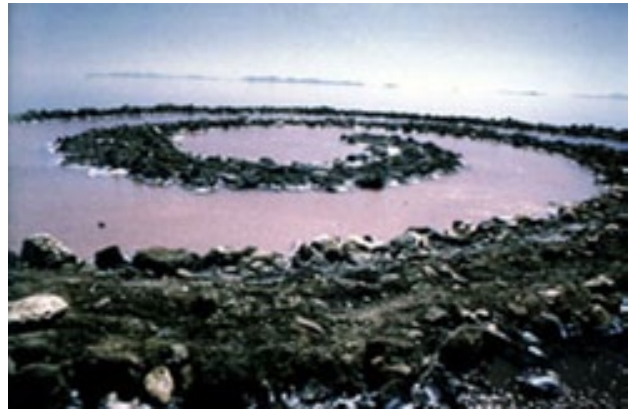

Fig. 96. Robert Smithson, dibujos y fotografías del "Spiral Jetty"
El lugar y la locación cumplen un papel primordial en este tipo de obras y su proceso. La naturaleza no es el modelo mimético sino el punto de emplazamiento donde se registra un acontecer; el ser y el estar en un espacio y tiempo específico, que confiere particularidad fenoménica al acto del dibujo. Mediante el estar se detectan características del sitio que inician el proceso de conceptualización de la obra.

Los trabajos de Richard Long no son transformaciones de la naturaleza, acciones uni-

ficadas en el entorno. El juego mutuo de arte y espacio deriva de la experiencia en el lugar. Por eso sus obras no son la conquista del territorio sino la encarnación de sus condiciones de existencia, así cada obra no es pertinente sino a un lugar específico.

Este acontecimiento en su sencillez implica una operación intelectual hacia el lugar, de ahí 
que estas obras casi siempre se traten de elementos lineales básicos, que operan como marcadores que revelan el lugar a la conciencia.

Caminar es parte central del método de trabajo de Long, acción física despojada de lo superfluo, con ello no intenta crear cambios abruptos en el paisaje, simplemente dejar huellas, no construcciones, solo rastros gráficos de la acción de vivir el lugar al recorrerlo, este es un vínculo que relaciona la acción del desplazamiento corporal con la de dibujar, acto que deja huella y que nos permite tanto la reconstrucción de la experiencia como el descifrar una variedad de significados en el trazo resultante.

El propio Long entiende su trabajo como un equilibrio entre las formas de la naturaleza y las ideas abstractas de lo humano, como líneas y círculos. Es donde él dice que sus características humanas se encuentran con las formas del mundo. Tal como lo expresó en la entrevista con Richard Cork para la Hayward Gallery de Londres en 1991.

A Line Made by Walking, de 1967 fue realizada en Somerset Inglaterra, mediante la acción repetida de caminar sobre un prado, hasta lograr el trazo de un sendero rectilíneo, que luego fue registrado mediante la fotografía. Años después realiza otra versión de la línea del caminar en Perú. Figs. 97
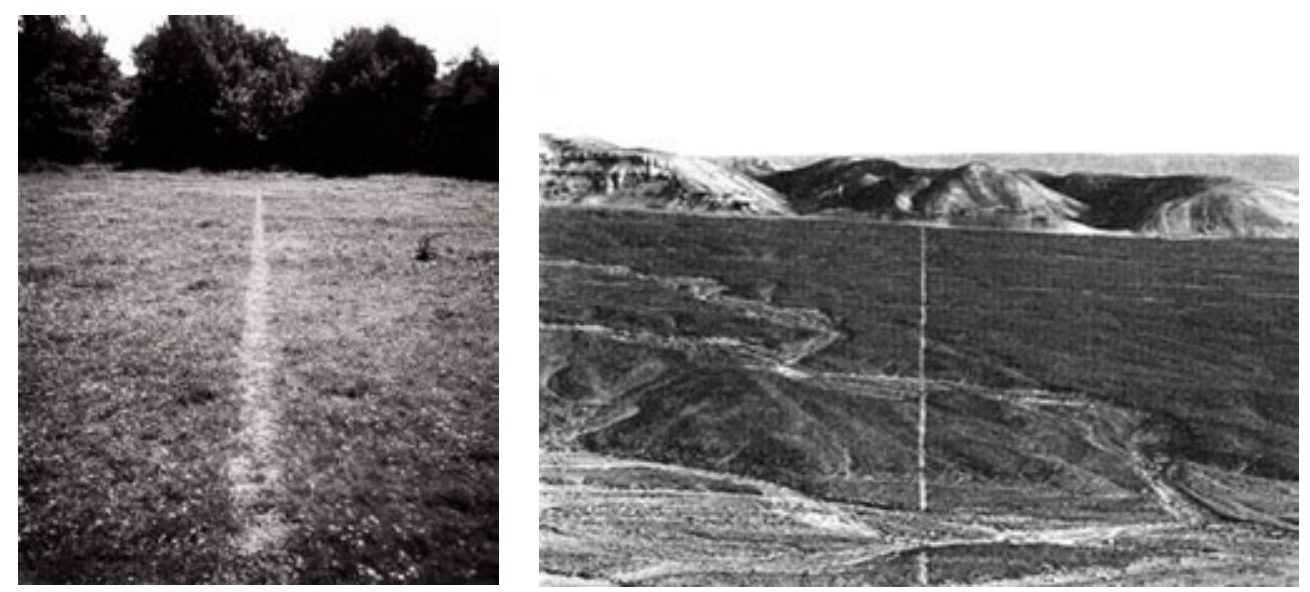

Fig. 97. Richard Long. "Walking the line" y "Walking the line in Perú"

En otros casos el autor realiza el marcaje de las figuras mediante la acumulación de rocas dispuestas con coordinación geométrica, como en el caso del círculo en el desierto de Mongolia en 1996. En este caso también la alineación de las rocas constituye un círculo claramente definido como una entidad geométrica sobre el plano del terreno.

Pero en múltiples trabajos el agrupamiento de las rocas no solo constituye una huella lineal, sino que el conjunto adquiere consistencia volumétrica con lo que se inicia un desprendimiento de lo esencialmente lineal. Figs. 98

Si pensamos el sentido gráfico en las obras de Richard Long y, en otro aspecto, su sentido como intervenciones localizadas (lo cual comporta una violencia reflexiva), podríamos 

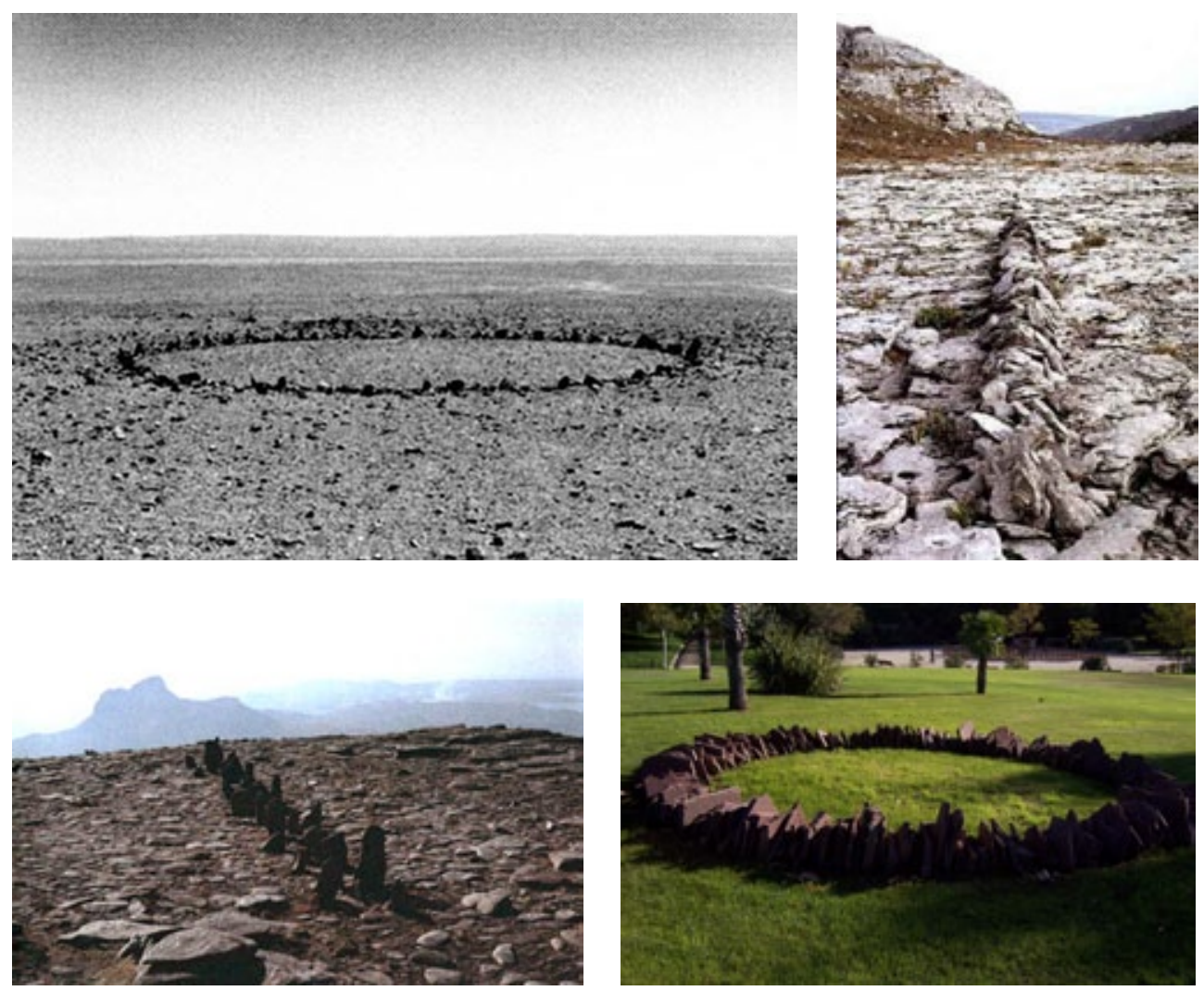

Fig. 98. Richard Long.

observar que en algunos de estos trabajos se realizan trazos lineales de carácter virtual y en otros se efectúa realmente el trazo de líneas como entidades geométricas. Esto es así porque en las versiones de las líneas hechas al caminar, o en el caso del círculo en el desierto de Mongolia, asistimos estrictamente a una huella de carácter lineal, cuya comprensión se da en el plano del pensamiento abstracto, el que nos permite reducir el mundo en entidades geométricas racionales de la forma. Cuando los trabajos de Long agregan características que los elevan sobre la topología del terreno aparecen no sólo los caracteres volumétricos sino que generan una apreciación fenoménica diferente, la del tiempo de la experiencia al recorrer la obra, ya sea físicamente o con la mirada y la del tiempo particularizado en una concreción climática, lo que agrega a estas obras una variabilidad fenoménica, pese a mantener un sentido estructural constante como figuras racionales.

Por si todo esto fuera poco, vemos en las otras imágenes incluidas un factor sumamente bello e inquietante. Las rocas verticalizadas son colocadas en secuencia circular o rectilínea pero mantienen un espacio entre cada una de ellas, distancia que se vuelve significativa porque logra la unidad del trazo partiendo de secuencias virtuales discontinuas, ya que el interespacio en cada bloque no es constante. Pero además al colocar los monolitos en posturas que no corresponden a las de su posición de gravedad adquieren una consistencia ontológica, se convierten en sujetos no humanos con una vocación de movimiento, marcha y éxodo o confluencia concéntrica. 
La disposición secuenciada de elementos líticos construye sucesiones lineales virtualmente, pero la posición y la forma de cada elemento les confiere un carácter fáctico presencial, esto es, existen en la mente del espectador como unidades lineales, pero también se generan en su experiencia vivencial fenoménica como sujetos con los que nos vemos forzados a dialogar en silencio, antes de dársenos a la experiencia reflexiva abstracta.

No es desconocido el carácter místico y Zen que subyace en el trabajo de Richard Long, de ahí que las conclusiones y razonamientos a los que hemos aludido no resulten desviaciones arbitrarias, vemos en este autor un pensamiento integral dentro del territorio de los campos del arte, pero indefectiblemente irrumpe con claridad en el campo del dibujo, y lo hace curiosamente mediante una integración del pensamiento nuevamente con la naturaleza como fuente del proyecto artístico del dibujo, situación a la que la vanguardia en la modernidad y la posmodernidad han renunciado, indudablemente una postura sobre la que hemos de reflexionar.

Pensamos que todo esto ha significado la expansión de los límites del campo del dibujo, pero manteniendo su configuración disciplinar, lo que nos permite observar las relaciones de penetración e incidencia, así como las contribuciones de recursos conceptuales y estrategias de distintas disciplinas.

El espacio de representación de estas obras perdió concreción y se convirtió en entidad virtual, tan amplia como el espacio geográfico en el que se emplazaron. Se relacionaron con formas rituales de arquitectura y construcciones antiguas. Pero operaron integrando los elementos del paisaje y el no paisaje mediante las estrategias del dibujo. Esta expansión permitió la interacción de territorios diversos del arte, el purismo positivista tardío de la modernidad cedió ante las prácticas de transgresión de los artistas, en ello el dibujo operó en muchas ocasiones como hasta entonces lo había hecho históricamente, como el gestor del pensamiento proyectual y sus estrategias de concreción dentro de las obras fácticas.

Recordemos nuevamente el año de 1977, cuando Douglas Crimp fue invitado por la directora del Art Space de Nueva York para organizar la exposición "Pictures".

Robert Longo, Troy Brauntuch, Jack Goldstein, Sherrie Levine y Philip Smith fueron los artistas que integraron esa exposición. Pero lo cierto es que en esa muestra la integración del dibujo como parte y estrategia del discurso estuvo casi ausente, si acaso en las fotografías de Levine recortadas con la forma de los perfiles de presidentes encontramos rastros elementales del dibujo. Figs. 99

Debido quizá a la integración de un grupo de artistas bajo una estrategia común en la construcción del discurso, y por recurrir a medios semejantes (video, fotografía, instalación y films stills) esta exposición se toma como el arranque abierto del arte posmoderno; aunque los procesos de cita y apropiación ya habían sido utilizados con anterioridad por artistas como Robert Rauschenberg y Nancy Spero.

Como ya hemos visto, con el uso del concepto de imagen, Crimp buscaba trascender las limitaciones de cualquier campo cerrado del arte, aludiendo tanto a la producción de imágenes como a los procesos mentales involucrados. Casi en su totalidad las imágenes empleadas por los artistas eran apropiadas o encontradas. No se buscaba la originalidad, sino estructuras y relaciones de significación, mediante el uso del repertorio que los medios masivos de 

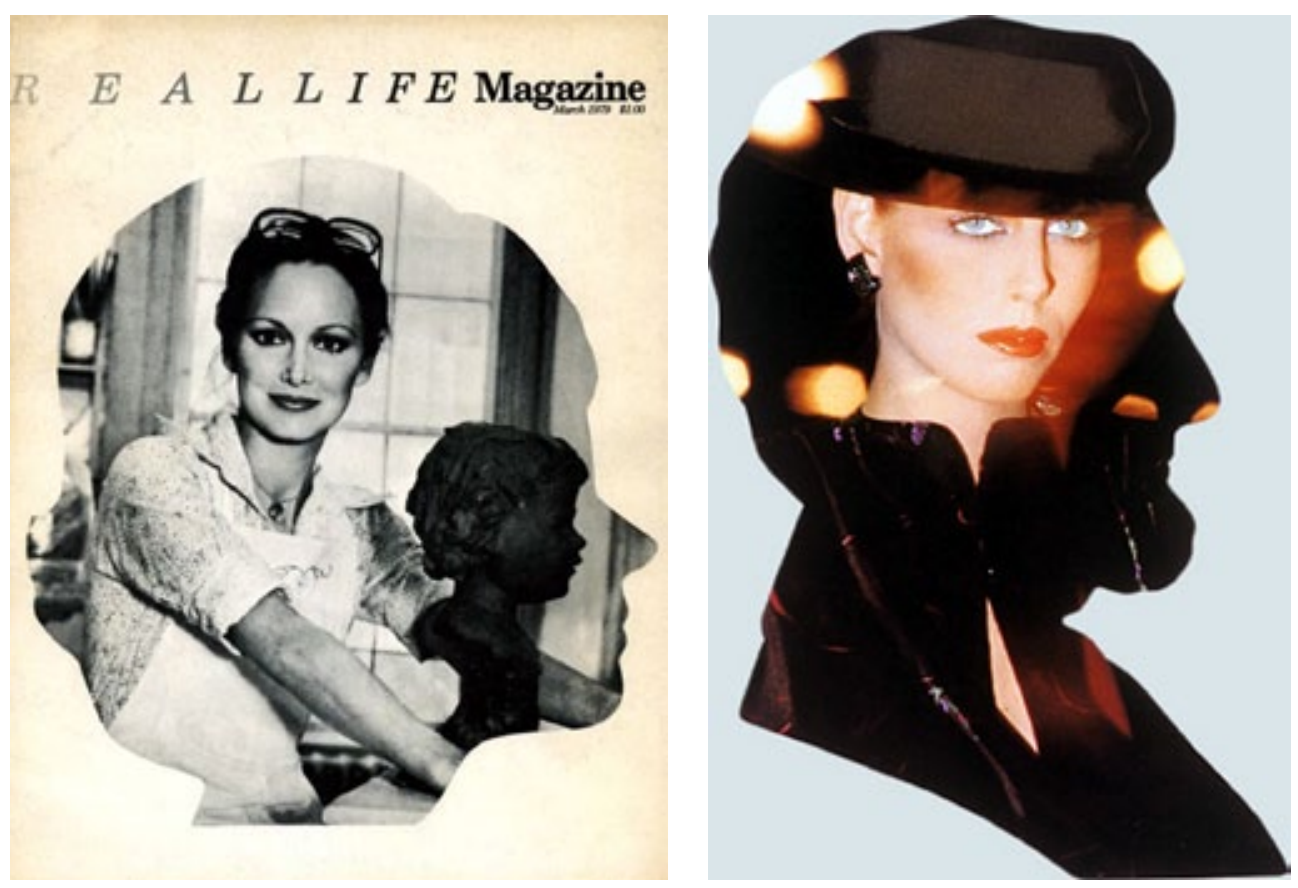

Fig. 99. Sherrie Levine. "Sin título"

comunicación ofertaban en ese terreno. De ahí nuestra consideración inicial para diferenciar la producción de artistas como Smithson y Long del terreno de la postmodernidad.

Aunque sea reiterativo, en este punto precisamos una de las ideas hipotéticas que animan esta investigación: las estrategias del arte posmoderno presuponen una estructura de significación discursiva en la que se opera sobre la base de utilizar el sentido semántico de una imagen histórica, para desmantelar ese sentido y crearle una nueva relación significante mediante la sobreposición de un contenido crítico nuevo, aquí la sintaxis como estrategia significante resulta esencial, tomando como postura asumida la valoración pragmática que socialmente ya tienen esas imágenes.

Esta era una de las suposiciones que nos animaban al inicio de este trabajo; conforme la investigación fue avanzando corroboramos en el pensamiento de otras fuentes la corrección de esta hipótesis.

Formular una tipicidad del dibujo como arte posmoderno, pensamos sería un equívoco, dado que dentro de este modelo posmoderno del arte no se busca la construcción de definiciones formales y disciplinares, por tanto el modelo del dibujo en la posmodernidad no presenta variaciones en sus cuerpos de representación formal, utiliza los repertorios de la forma y las teorías que la historia que hemos revisado le oferta.

Por más que busquemos, no hemos de encontrar sino mínimamente, imágenes de primera generación, en este segmento de la historia del arte de nuestros días.

El espacio que el dibujo ocupa dentro del arte posmoderno sigue siendo el de una función prefigurativa del proyecto artístico, como desde antes ya lo era. Opera también como 
función estratégica al permitir la permeabilidad de los campos del arte reunidos en una práctica multidisciplinar, pero sólo en el sentido de integrar segmentos de varios campos del arte (foto, video, dibujo, instalación, pintura etc.) y no en el de permitir el concurso de sujetos varios en la construcción del proyecto y su concepción.

En resumen, el papel del dibujo en la posmodernidad es el de lograr la posibilidad estratégica del proyecto artístico, pero no la de ser una disciplina de representación que se ocupe de las relaciones con los sujetos y modelos ontológicos del dibujo en una práctica generadora de imágenes de primera generación y sistemas formales.

La temporalidad fenomenológica implicada en el minimalismo encontraría su extremo en la Performance, ejecución o realización con una duración particular en tiempo real, tiempo que no se suspende como en la imagen fija, en lo general las artes de los años 1980 correrían por esa ruta. Esto colocó a las anteriores Artes Visuales, ahora Artes de la Imagen, en cercanía peligrosa con las Artes Dramáticas, el Teatro específicamente.

Con respecto al dibujo, su campo se pobló de innumerables eventos performáticos en los que el artista saltaba al espacio de configuración, ahora convertido en escenario, para ejecutar una serie de trazos y grafías pensando que con ello se realizaba una acción del dibujo. La duración literal de la acción del dibujo como performance requería la asistencia del público al evento, que se constituyó así mismo en suceso de representación, cuyo resultado siempre fue una imagen, ahora con el añadido de la experiencia psicológica al haber asistido a su realización.

Juan Martín Prada en su texto, La apropiación posmoderna, señala la existencia de una práctica posmoderna artística carente de sentido crítico, una postura que piensa que la simple combinatoria de imágenes del pasado del arte, en comunión con otras tomadas del presente, posibilitan la consecución de un sentido discursivo, que resulta ser, él mismo, una parodia de lo artístico, frente a un universo de artistas y producciones de sentido radical en su visión histórica del proyecto crítico existencial.

Pensamos que muchos de los artistas que enlazan la práctica del arte conceptual con el posmoderno, generaron su visión proyectual como fruto de una postura eminentemente radical hacia el contexto social e histórico que vivían.

Cildo Meireles, Louise Bourgueois, Sherrie Levine, Iran do Espíritu Santo y un largo etcétera lo ejemplifican; con esto queremos decir que las interacciones disciplinares a que sus obras llegaron son el resultado de necesidades expresivas y la búsqueda para encontrar construcciones artísticas que muestren claramente su opinión sobre ese tiempo histórico y social. Serían mucho menos un purismo artístico y una práctica tautológica autorreferencial, aunque esa sea una más de las consecuencias obtenidas, de ahí que las aperturas logradas en la estrategia y el proceso del arte sean un plusvalor colateral que se agrega al valor histórico de esos procesos.

En esta línea de artistas que caminan siempre con una conciencia de su tiempo, Nancy Spero, 1926-2009, sería una de esas mujeres que encarnan el ejercicio temprano de las estrategias de apropiación de las imágenes históricas, para convertirlas en obras de alto sentido antroposófico. La claridad de esta autora frente al momento de crisis que le tocó vivir la llevó a construir una obra de continuo sentido social, sin por ello perder lo profundo de una revolución artística. 
Su trabajo involucra lo textual literario con la pintura y el dibujo, como en el caso de LeWitt. Frente a las obras de Spero el espectador se convierte en lector simultáneamente, sólo mediante la percepción de lo visual y lo literal se logra la integración y la posible lectura de su trabajo.

Desde finales de la década de 1960 dejó de pintar sobre lienzos, para utilizar solamente el papel como soporte de sus obras, por considerar que las telas eran el soporte de la pintura masculina por excelencia, mientras que el papel se relacionaba mucho más para ella con el sentido frágil de lo femenino.

En el transcurso de los años sesenta del siglo pasado, su trabajo se dirigió centralmente hacia el cuestionamiento de la guerra de Vietnam, una guerra incoherente para ella y en la que habrían podido ser incluidos sus hijos. Figs. 100
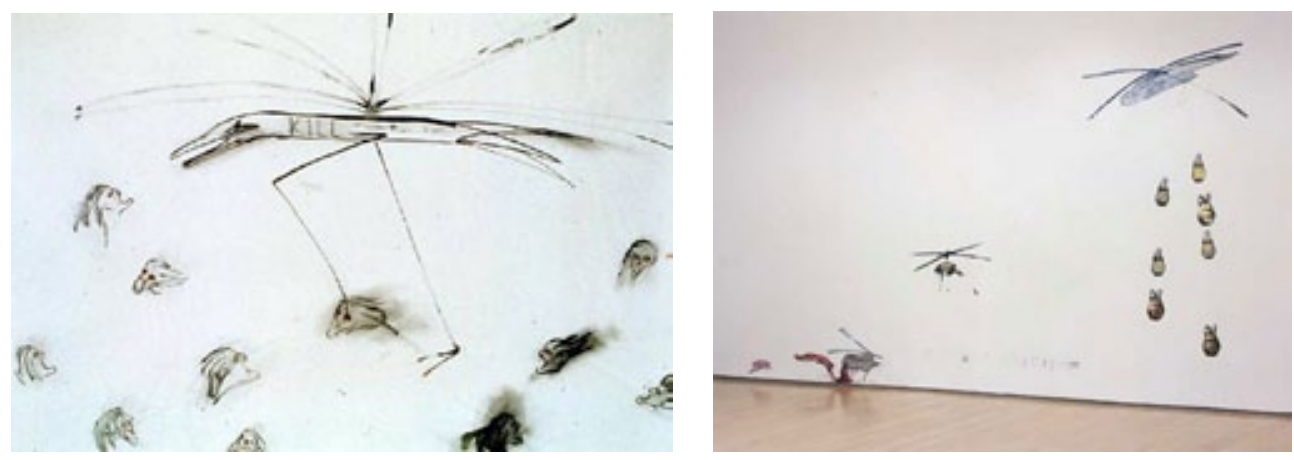

Fig. 100. Spero, dibujos sobre la guerra de Vietnam.

Tomaremos de ella su trabajo conocido como el Codex Artaud, obra de 1972 que consiste en 34 rollos de papel pegados entre sí, este trabajo contiene elementos de diversas disciplinas del arte, las integra en un producto unitario, que en este caso se construye tomando como eje rector el ejercicio del dibujo sumado al valor del símbolo gráfico escrito y la palabra fragmentada.

"Artaud es excepcional porque suyas son las expresiones más extremas de dislocación y alienación de todo el siglo XX.

Se presenta como la violencia por excelencia. Violento en el gesto y en el lenguaje, es masoquista y pasivo. Y con todo, el juega el papel de la mujer víctima.

Muchas veces, las mujeres son despreciadas como plañideras o irracionales, caracterizadas como alguien que chilla pero es incapaz de actuar. A la estigmatizada como loca se la excluye de toda clase de participación en el mundo exterior. Mediante esta clase de acusaciones dejan a las mujeres impotentes.

Artaud odiaba a las mujeres y tal vez no se ha reconocido que juega el papel de la mujer porque su valor simbólico se muestra bajo apariencia masculina. Sus gritos le aseguran valor masculino, como macho rebelde.

Yo me identifiqué con la conciencia de victimismo de Artaud -utilizando su lenguaje para ejemplificar mi pérdida de la lengua-, fracturando sus ya fracturados textos, porque me sentía víctima como mujer y como artista. Utilicé a Artaud durante cuatro años, en la serie Artaud Paintings (1969-1970) y en el Codex Artaud (1971-1972) para explorar 
los límites del victimismo (imaginario y real), aunque me imaginaba como habría detestado Artaud que una mujer reutilizara su lenguaje y alterase sus implicaciones.

Pues esos fragmentos de textos en tensión con mis imágenes pintadas y recortadas, para ejemplificar a la artista (yo) rechazada por una sociedad burguesa."137

Al utilizar el trabajo de Artaud como motivo generador de su propia obra Spero intentó migrar de la temática general de la guerra hacia el ámbito personal, pero también como expresión de una crisis y discriminación, en este caso de la mujer, decide hablar de sí misma pero se proyecta hacia el todo social.

Las obras de Spero se inician como un diálogo de oposición manifiesta a la consolidación institucionalizada del Expresionismo Abstracto, ella como algunos otros autores asume una posición estética marginal con respecto a la Escuela de Nueva York. Lo hace manteniendo la representación figurativa como eje pictórico y con la inclusión del texto escrito en la superficie de la obra. Ambas situaciones se orientaron hacia la elaboración de un modelo alternativo de formación eidética.

Pero la inclusión del texto escrito y grafiteado en la pintura era un proceso iniciado ya por Jasper Johns en los tempranos años cincuenta de ese siglo y se concretaría en las equivalencias lingüísticas sobreponiéndose a lo pictórico en las producciones del arte concepto, como lo revisamos en Sol LeWitt en 1968-1970.

Pero la obra de Spero, coincidente cronológicamente con esos años, saltaría la órbita de los límites conceptualistas al recuperar el valor poético del texto escrito y convertirlo también en forma de lo visual, y viceversa, lo visual se elabora como construcción poética de resonancia psíquica.

Un tercer elemento que suma a los dos anteriores en la postura de Spero como crítica del expresionismo institucional, es la relación directa y explicita que mantiene con la historia y con el mito.

La escuela de Nueva York generó una pintura de interioridad subjetiva, sus fuentes eran autorreferenciales y automatistas, cortaban radicalmente la historicidad secuenciada de sus formas e implicaban la ausencia temática como condiciones para lograr una pintura autorreferencial autocrítica, en términos de Greenberg.

En el Codex Artaud se retoma la tradición discursiva de la pintura y el dibujo insistiendo en una profunda fuente común que los enlaza con la historia, el pasado y los mitos. De aquí surgiría en parte el concepto de códice como libro, dentro del pensamiento arcaico, y por tanto la posibilidad de integrar la lengua como una forma del lenguaje que comporta una forma visual intrínseca.

Es conocido el encuentro que esta artista tuvo con los textos de Antonin Artaud en 1969, en su primera traducción al idioma inglés editada por Jack Hirschman.

En sus primeras pinturas comenzó trabajando con esa edición de los escritos, sobreponía fragmentos del texto de Artaud en el papel de la pintura, pero agregaba frases obscenas propias, entrecortando y limitando una lectura directa del texto de Artaud.

Muy pronto concluyó que era esencial recurrir no a las traducciones, sino al texto en su idioma original para acercarse al susurro inicial de la palabra. Para ese momento decidió

137 Spero Nancy. Artaud Paintings. The Cooper Union, 1989 Oct; Nueva York. 1989. 
mecanografiar el texto de Artaud que incluiría en cada página del Codex, organizándolo en bloques no lineales, áreas de texto que serían leídas pero que también operaban como espacios compositivos de lo visual; en cada una de estas inclusiones aparece el nombre de Artaud como autor del segmento.

En el uso de las citas literarias Spero trabaja pictóricamente y con el dibujo para que la voz del texto se apague, evitando la lectura fácil y logrando un murmullo.

La estrategia de significación en el Codex superpone una amplitud de conceptos e imágenes. La del códice como libro ritual, que en su forma plástica se desenvuelve en una secuencia continua, en relación al libro moderno que contiene los textos de Artaud.

La lengua en su sentido primigenio y gutural, que no acepta traducciones y que supone un esfuerzo para entender al otro en su origen, la lengua de lo escrito y el sentido lingüístico de lo dibujado y el graffiti, la lengua como órgano del habla y como elemento fálico de penetración y dominio masculino, la lengua con la que el animal se lame para curarse a sí mismo. Y la lengua como grafismo formal constante en el Codex.

La forma y la técnica de Artaud intentan salvar a la literatura de una muerte, a la que la conduce el refinamiento estético de un producto bien logrado; mediante la destrucción de la maestría y la estética literaria se intenta su salvamento.

Esta es centralmente la estrategia de Spero en el Codex, quitar lo sublime en la obra mediante la adición de textos, mecanografiados y trazados con la mano izquierda a modo de graffiti, cuyo contenido obsceno es constante a lo largo de todos los paneles.

El Codex está realizado en papel utilizando una forma híbrida de dibujo, escritura y collage, desarrollando una imaginería sexual directa, que logra la humillación de la propia pintura, desmitificándola como arte excelso mediante su acercamiento a fuentes recónditas del mito como las de Libro de los Muertos del antiguo Egipto, combinado esto con referencias a los manuscritos medievales y la poesía concreta.

En su Codex, Spero reproduce una carta en la que Artaud desde su internamiento en el hospital psiquiátrico de Rodez, se autodefine como letra muerta, la incorpora en el papel como un bloque de dibujo geométrico, visto de cerca es una gran firma, que revela en su laberinto tipográfico el nombre de Artaud, como si fuera el equivalente fonético de un grito o chillido, el de la mujer histérica.

La protesta de Spero en el Codex Artaud es clara, feminismo y gritos contra el silencio, utilización del lenguaje poético de Artaud fundido con la forma visual, a esto se suma la decisión de utilizar la forma ritual del libro como Codex, para llevarnos de la mano en el curso del desarrollo de la historia.

El expresionismo lírico que soporta el dibujo de Spero se mueve constantemente en un gran vacío espacial, cuya proporción en la composición permite la secuencia temporal de lectura y se convierte en elemento de tensión.

En el trabajo de Nancy Spero están ya presentes las estrategias típicas de la postmodernidad artística, la cita, la apropiación, el desmantelamiento de la imagen histórica para retribuirle un sentido alterno y actual, así como una estructura sistémica entre varias formas del lenguaje, la literatura y la del arte visual; el resultado, una obra de gran capacidad de denuncia, actualidad histórica y potencia expansiva del territorio del Dibujo. Figs. 101 

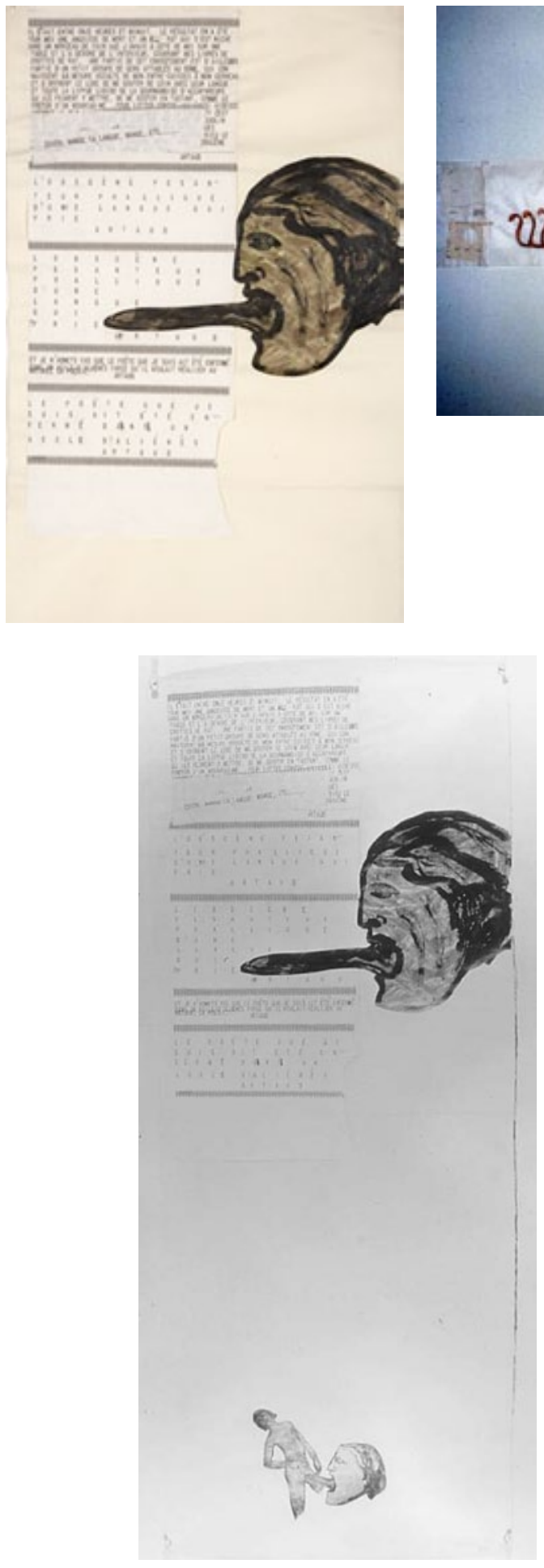

Fig. 101. Spero, láminas del "Codex Artaud" 


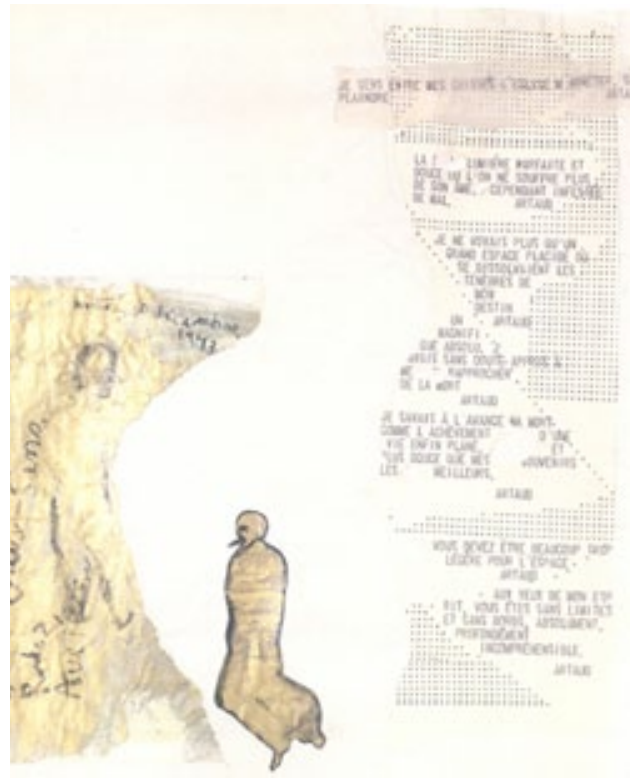

Fig. 101. Spero, láminas del "Codex Artaud" (Cont.)
Aproximadamente desde 1989 el artista brasileño Vik Muniz (Sao Paulo, Brasil, 1961) irrumpe en la escena artística.

Radicando en Nueva York inicia una serie de pequeñas esculturas en plastilina utilizando el total de un bloque de material, al terminar una pieza la fotografiaba para destruirla y realizar una nueva con la misma masa de plastilina, luego de varios ejercicios en este sentido advirtió que las imágenes fotográficas daban cuenta del proceso y las piezas de una manera diferente a la de la propia pieza volumétrica.

Al fotografiar esos modelados buscaba el ángulo correcto y la iluminación que diera cuenta del sentido que imaginaba en su mente para sus esculturas, pero resultó que el registro fotográfico trascendía la propia pieza modelada y era lo único que quedaba como testigo y realidad de las piezas.

Por ese entonces sucedió también que a su llegada a Nueva York consiguió un libro de fotografías de la revista Life, libro que extravió; para retomar algunas de las fotografías contenidas en el libro comenzó a dibujarlas de memoria, pero cuando gentes cercanas le pidieron que los expusiera sintió que los dibujos carecían de una serie de detalles y resultaban en cierto sentido burdos, por eso decidió fotografiarlos también, como en el caso de las esculturas, pero ahora filtró la imagen con una pantalla de saturación de puntos como en las fotografías impresas en los periódicos, además al realizar las ampliaciones decidió dejar un pequeño grado de desenfoque con lo que terminó generando imágenes de una alta versatilidad, creando una confusión, pues cuando miramos estas obras tomamos los dibujos fotografiados como si fueran impresiones directas de la placa fotográfica, este sentido de mentira y realismo virtual será desde entonces el eje del trabajo de Muniz, abandona la fotografía como captura de una realidad circundante para internarse en el objeto mismo que es la foto, creando para ello la situación que habrá de ser capturada, una construcción separada de lo cotidiano. Figs. 102

Muniz lleva este planteamiento al extremo, fotografiando construcciones de dibujo realizadas con un altísimo grado de meticulosidad y verismo mimético, lo que él considera una realidad artificial.

Para esto recurre a imágenes de segunda generación, trabajos realizados, ya vistos, citas visuales de artistas y obras reconocidas, Warhol, Piranesi, Gericault o Leonardo da Vinci. Sustituye la realidad, que en ese caso sería una copia de esos originales, fabrica una trampa semántica al volver a configurar esas imágenes con materiales irreverentes en el sentido artístico, jarabe de chocolate, azúcar, polvo, diamantes etc. En ese momento es en el que acontece el desmontaje del sentido original de las imágenes para sobreponer un nueva dirección semántica, basada en la implicación significante contenida en el material utilizado para dibujar; la acepción común o social del material se introduce como 

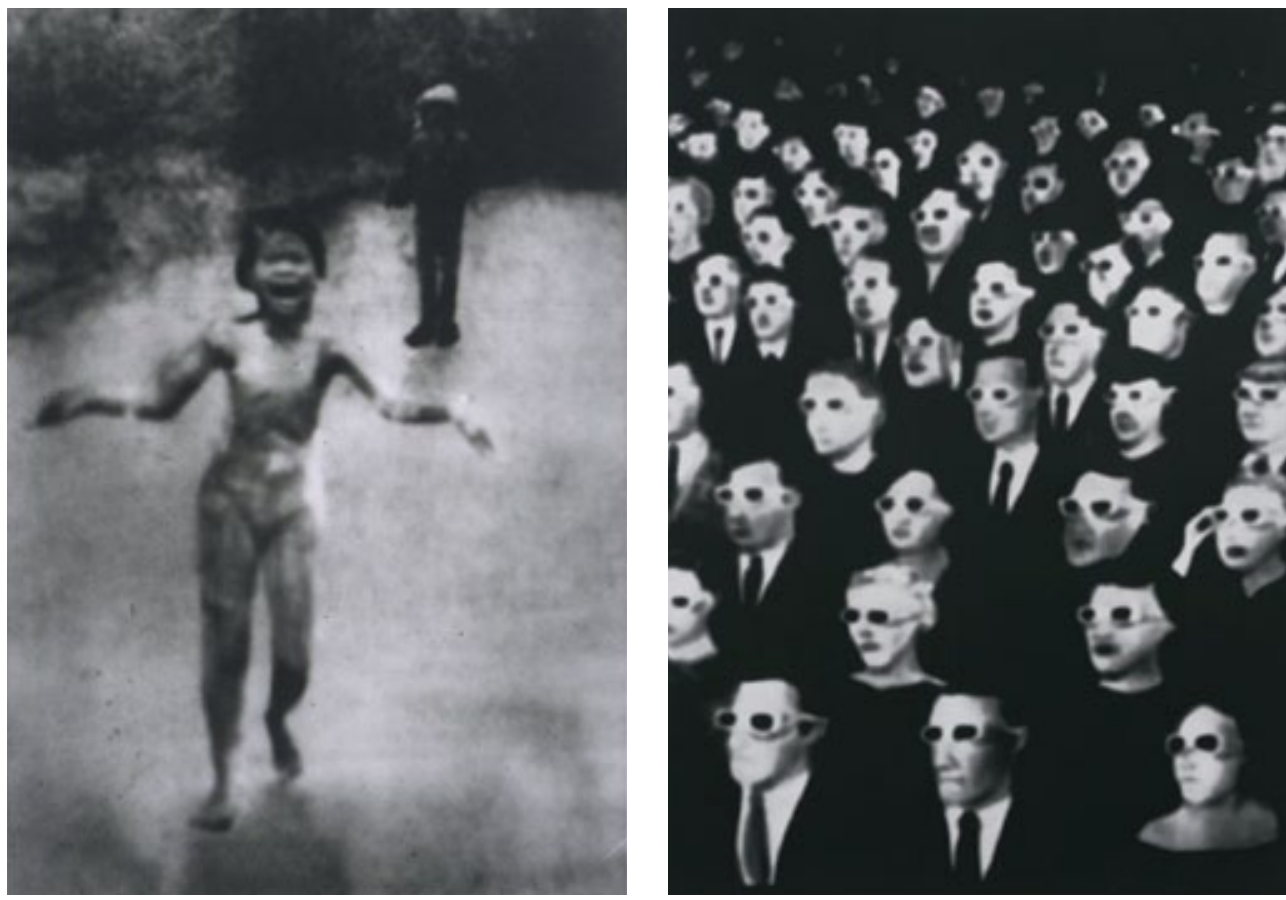

Fig. 102. Muniz, dibujos-fotografía de la serie "The Best of Life"

fractura al sentido original de las obras clásicas o establecidas, desmontándolo para reorientar su posibilidad discursiva, por eso es que decimos que la estrategia posmoderna organiza la estructura conceptual de esas obras.

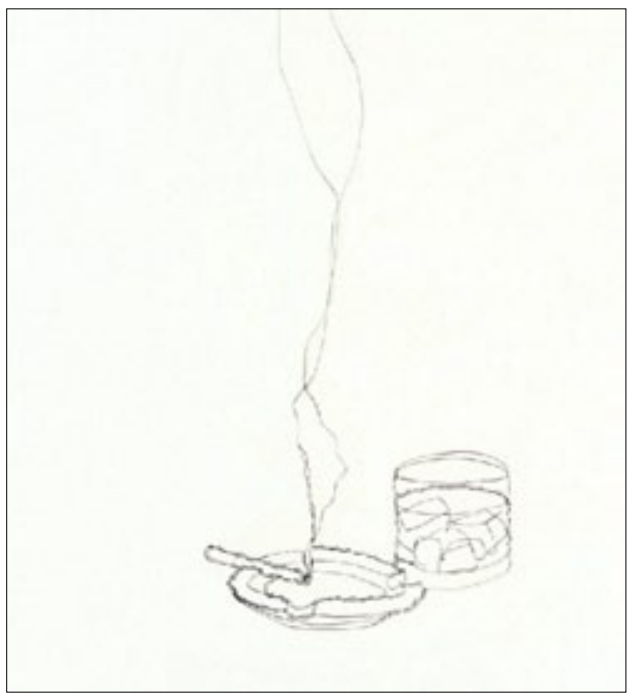

Fig. 103. Muniz. "Relaxation"
En su serie Imágenes de alambre, intenta trabajar con un recurso que se puede emparentar con la línea como elemento del dibujo por su carácter filiforme, pero que es un material no apto para el dibujo por su resistencia a la conformación mimética extrema, Es lo que Muniz llama un mal actor, uno que nos da cuenta siempre de la trampa superpuesta y que no permite al espectador perderse en la imagen como confusión mimética, en sus propias palabras: la peor ilusión posible, las cosas no son lo que parecen. Fig. 103

En su serie de Imágenes de hilo sustituye el alambre por el hilo como material de mayor flexibilidad.

Muniz comenta que pensó esta serie par- 
tiendo de varias asociaciones; la del elemento lineal filiforme que relacionó con su pasatiempo de la infancia, cuando volaba papalotes y el hilo desplegado le sugería la distancia, desenrollando cientos de cordón a medida que el papalote se alejaba. El nombre de estas obras alude al número de yardas de hilo usadas en la elaboración de cada dibujo. Pero en esta serie hay que puntualizar que Muniz trabaja retomando imágenes de autores paisajistas capitales en la historia del arte, generalmente Corot, a quien reconocemos por su genialidad en el tono lumínico del color, y la manera en que construyó el espacio en una particularidad temporal, con lo que se convirtió en el precedente directo del Impresionismo.

Cuando Muniz realiza sus versiones de estos cuadros surge una violencia semántica y de representación formalizada, los dibujos de hilo obviamente guardan un sentido lineal, lo cual ya es contrario a la pintura de Corot, sí logran una estructuración espacial y una profundidad atmosférica, pero la distancia no se basa en la profundidad y control del tono cromático, se logra partiendo del despliegue lineal del continuo de la hebra de hilo y en la sobreposición de capas de material, así en el trabajo de Muniz reconocemos las vistas históricas de Corot, pero su sentido conceptual y constructivo es otro bastante diferente. En esta serie particularmente no encontramos claramente el sentido crítico que lleva al autor a realizar la apropiación de esas imágenes de paisajes, ni vemos claramente la opinión manifiesta en el nuevo sentido semántico construido; estas series se sostienen en una estructura conceptual cuyos resultados son eminentemente formalistas. Figs. 104
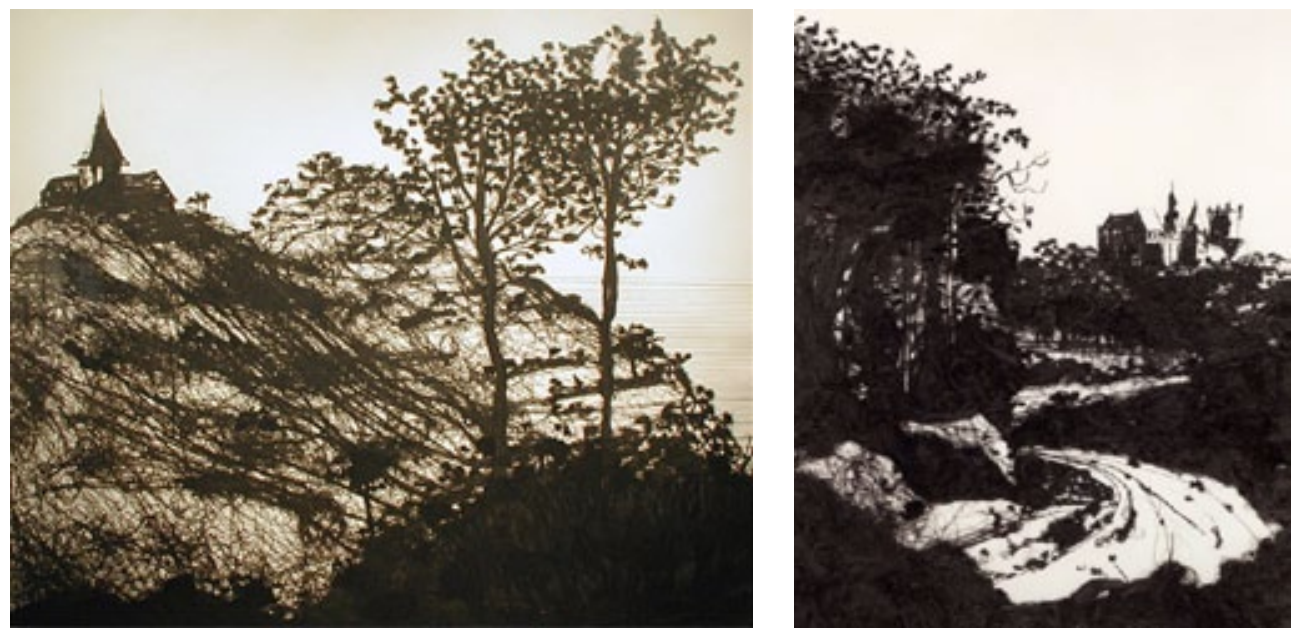

Fig. 104. Muniz, dibujos de paisaje realizados con hilo.

Algo similar sucede en la serie Cárceles, esta se desprende de la serie de aguafuertes Cárceles de la imaginación de Giovanni Battista Piranesi, arquitecto del siglo XVIII, aquí Muniz retoma el grabado arquitectónico, la disposición de los filamentos no se realiza mediante su depósito fláccido, en esta serie se establece un zigzag que semeja el carácter de las líneas de incisión del aguafuerte. El patrón de tendido lineal se establece clavando alfileres en puntos estratégicos, que también aluden a la punta de acero utilizada en el grabado para generar la traza que se somete al ataque del ácido. Los resultados son nuevamente unas fotografías amplificadas en gran formato que nos dan cuenta de la imagen que ha sido apropiada, pero a medida que nos acercamos senti- 
mos la distancia de representación formalizada que se logra por el uso de la estrategia del tendido de los hilos. Figs. 105
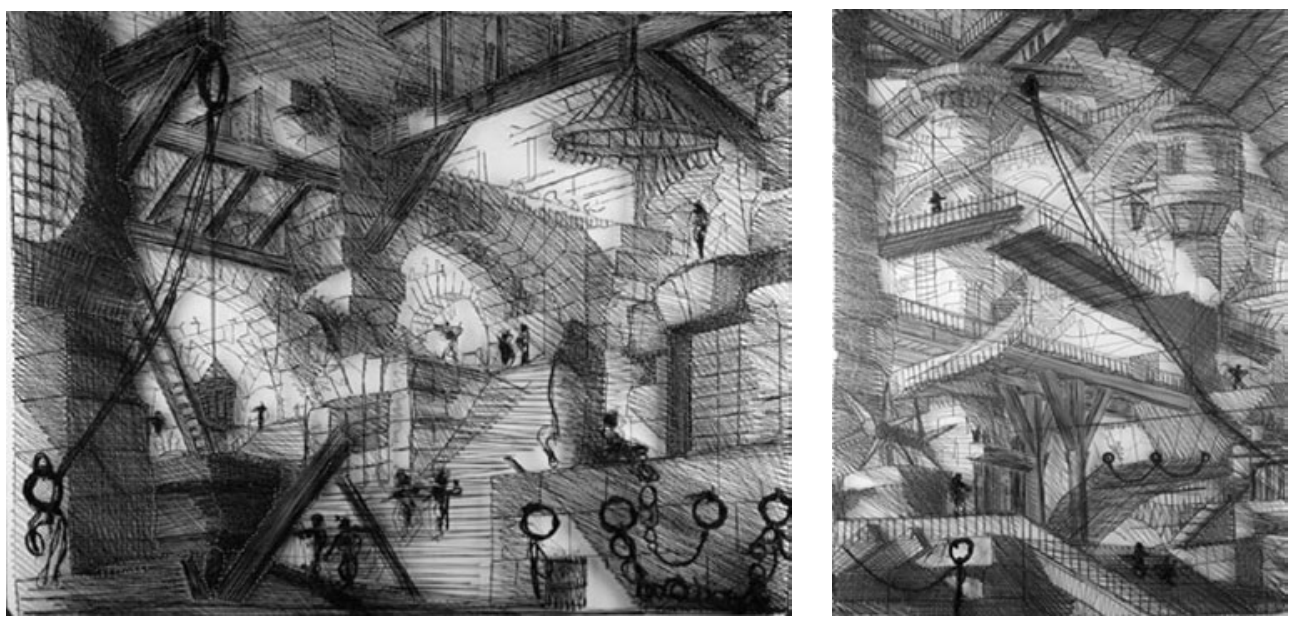

Fig. 105. Muniz, dibujos con hilo tensado, apropiación de los grabados de Piranesi S. XVIII

Tanto en la serie de dibujos de estrellas de cine realizados con diamantes, como en la de los monstruos cinematográficos trazados con caviar, pero específicamente en los Niños de azúcar, se consigue un sentido crítico en el que la materialidad del dibujo construido asimila la carga simbólica del material empleado, a manera de expansión poética o paradoja alegórica que construye un discurso no lineal, este enriquece y recrea el discurso de las imágenes apropiadas. Figs. 106
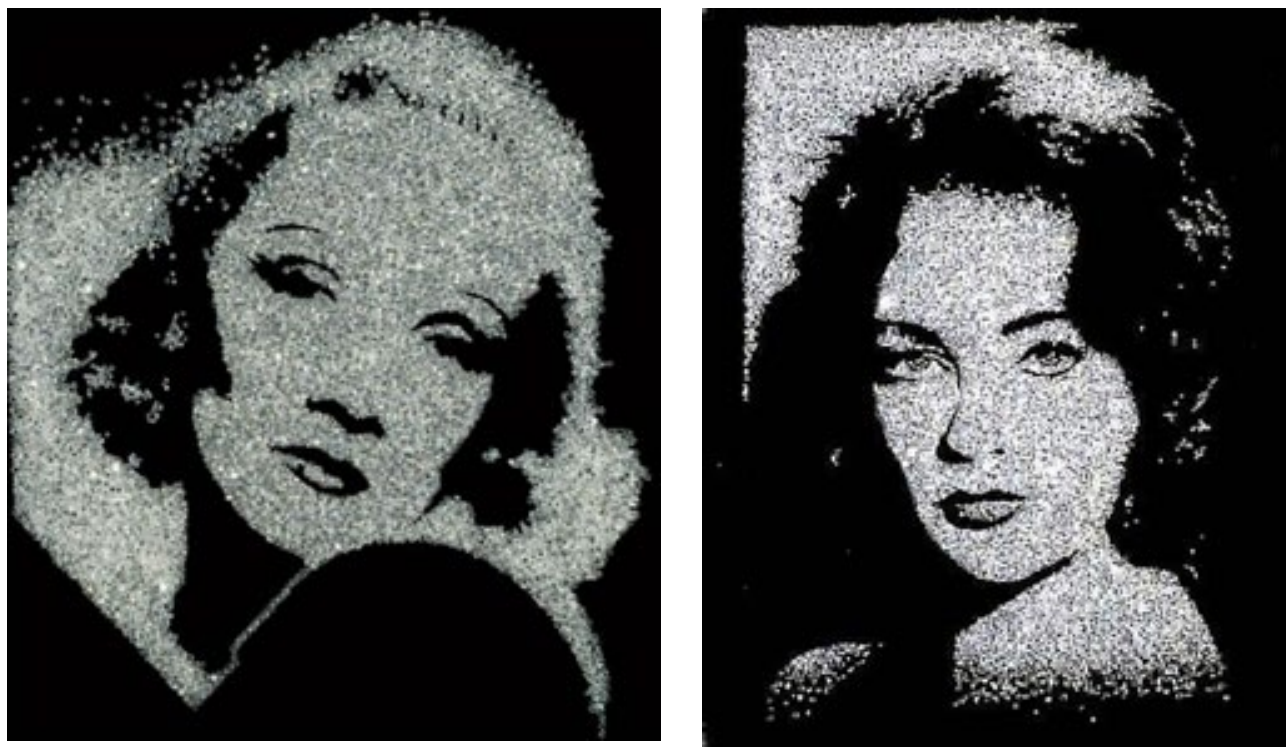

Fig. 106. Muniz, dibujos realizados con diamantes, caviar y azúcar para ser fotografiados. 

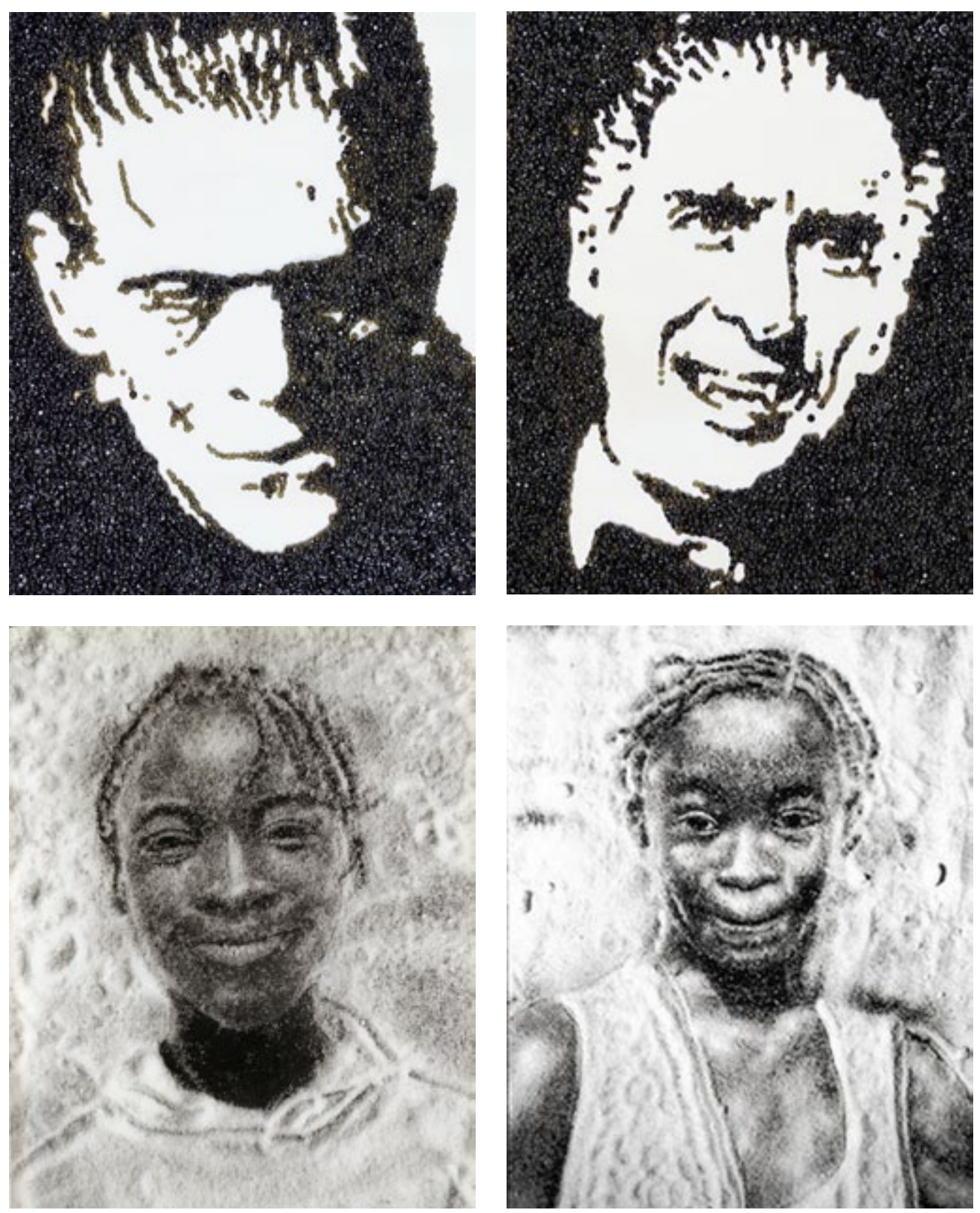

Fig. 106. Muniz, dibujos realizados con diamantes, caviar y azúcar para ser fotografiados. (Cont.)

Muniz asoció el brillo de los diamantes al crear un dibujo, con el brillo de las estrellas de cine, su glamur seductor y la manera en que conservamos estas personalidades en nuestro recuerdo. En los trabajos con caviar también dibujó estrellas de cine, pero en este caso eran monstruos, personajes que implicaban muerte, transformación y deterioro de ahí que el material orgánico resultara también una metáfora de esas condiciones, en los niños de azúcar, como es sabido se retrata a personajes infantiles de una isla en el Mar Caribe, la infancia, la 
personalidad ingenua y tierna de estos infantes contrastaba con el cansancio y deterioro de sus padres debido a largos años de trabajo en las plantaciones azucareras, este conjunto de relaciones subjetivas y sociales son las que armaron el discurso en esta serie de dibujos.

Ya hemos dicho que todas las construcciones de Muniz eran fotografiadas finalmente, redondeando con ello la significación de cada serie de obras, por lo anterior, suele considerarse a este autor dentro del género de la fotografía, pero su trabajo incluye una diversidad de campos artísticos y como hemos visto, estrategias mucho más complejas.

La complejidad del arte en la época posmoderna es un fenómeno irreductible históricamente, cuando menos hasta que no medie una distancia temporal que nos permita un análisis más objetivo, Pero podemos afirmar que este segmento del arte, es ante todo distinguible por sus operaciones estratégicas, no por la compartimentación de sus territorios artísticos. Aunque el dibujo ha sido práctica integrada en este proceso del arte, vemos como se centra en las mezclas de prácticas artísticas derivadas ya sea de la fotografía o de los medios masivos y electrónicos de comunicación.

Los modelos del dibujo han sido formas del pensamiento paradigmático; como cuerpos conceptuales formales históricos al fin, han tenido configuraciones diferenciadas, tal vez contrapuestas. Pero todos estos modelos crearon un mundo de representación en el que pudimos rearmar el universo en estructuras diversas. Son expresión cristalizada del pensamiento eidético.

El dibujo como actividad reflexiva se corresponde con el pensamiento de Damish, es una particular forma teórica, una que se relaciona con los distintos campos del saber humano pero que no requiere de basarse en otro continente que no sea el de su interioridad y particularidad epistémica.

Los modelos del dibujo nos muestran el trazo de su propia historia, la de una teoría de la representación, que en gran medida ha significado el entendimiento del dibujante, tanto de los modelos que son la otredad, el otro ser, sujeto, objeto o fenómeno al que se dibuja para establecer un diálogo, como de los modelos de la forma autorreflexiva del propio campo y su acción.

Los modelos del dibujo son también como lo expusimos, las formas del pensamiento estabilizado socialmente que operan como presión sobre el ideario del dibujante, determinando el carácter existencial de su pensamiento y proyecto, ya sea en el sentido positivo o en el de una dirección de pensamiento crítico.

Con la concreción de los modelos del dibujo, la visión que tenemos de la realidad ha sido modificada, nuestra mirada es ahora la suma y mezcla compleja de todos estos modos de ver y de representar el contexto, la mímesis como ideal renacentista basada en la razón y la experimentación fueron el inicio de la aventura, la estrategia compleja y la carencia de alusión a los referentes naturales en la abstracción y los informalismos, nos mostraron otro horizonte y cambiaron nuestra mirada. El viaje de la expansión de los campos disciplinares fue el preámbulo de la posmodernidad artística, esta irrumpió con su mezcla híbrida interdisciplinar; pero ni eso alcanzó para desplazar al dibujo como eje conceptual reflexivo al seno de los procesos de representación y organizador prefigurativo del proyecto artístico. 


\section{CAPÍTULO IV \\ EL ACTO DIBUJO}

La postulación de la autonomía del Dibujo dentro de las artes Plásticas y Visuales fue un tema recurrente en el medio artístico del fin de siglo pasado. Pero con precisión no encontramos ningún autor o escrito que se extienda en el análisis de ese problema, contamos con el punto de vista de Juan José Gómez Molina (q. en p. d.) quien se manifestó al respecto con una visión que desconfiaba de tal autonomía. Si bien la obra de muchos artistas de las últimas décadas se dirigió hacia un abordaje del Dibujo como producción que alcanza a completar el sentido expresivo del dibujante.

La literatura y los proyectos reflexivos de Gómez Molina son ricos como una vertiente que no se tenía hasta entonces para reflexionar sobre el campo del dibujo.

Nos hemos beneficiado profusamente de ellos, pero su carácter es eminentemente histórico, se basa en la fuente, el dato y el hecho, pensamos que a estas alturas nuestro corte reflexivo se manifiesta ya con sus diferencias hacia ese modelo, sin por ello menoscabar su importancia.

Poco a poco se ha mostrado el filo y la orientación particular de nuestro pensamiento; cuando menos esperamos que se haya hecho presente. Es así porque nos acercamos a la zona de redondeo, el cierre del trabajo en el que nos obligamos a mostrar nuestra visión, aunque con ello el riesgo de la apuesta sea mayor.

Todo esto ustedes sabrán notarlo, contamos con ello y con su consideración hacia estos intentos de pensamiento propio.

Nuestro planteamiento hipotético consistió en ubicar el problema de la llamada autonomía del Dibujo como consecuencia derivada de la ruptura paradigmática de los proyectos artísticos de la modernidad del siglo XX y la tardomodernidad de la Abstracción Pospictórica, que todavía mantuvieron un carácter formal y estético frente a la emergencia de las estrategias de flexibilización y expansión de los campos disciplinares en las artes en las últimas cuatro últimas décadas.

Bajo ese sentido hemos orientado nuestro estudio y análisis dentro del planteamiento del problema y creemos haber aportado algunos elementos que fundamentan positivamente nuestra hipótesis.

En algún momento mencionamos que nuestra investigación no se dirige a establecer una crítica a las prácticas artísticas posmodernas, el proceso de expansión de los campos artísticos y la cultura visual se debe a sus propias causalidades y sería equivocado negarlo como acontecimiento artístico que abre las posibilidades de expresión; pero no por ello el desarrollo del campo del Dibujo tuvo que ser convergente con esa orientación aunque como disciplina guardó en múltiples ocasiones relaciones sistémicas con ese devenir.

Por eso es que la orientación de la expansión de los territorios artísticos no excluye la consideración del Dibujo como un acto de representación, como muchos de los autores 
de la crítica posmoderna concluyen al asumir la quiebra de la representación y el fin de la estética como condición general en el arte.

El Dibujo como disciplina eidética se orienta a la construcción de la esencia formal de los modelos y del proyecto artístico, así se genera consecuentemente una apertura de los Sistemas Formales de Representación vigentes dentro del campo de la cultura visual, esperamos haber fundamentado lo suficiente esta idea.

Para el desarrollo de las tesis anteriores marcamos como necesidad el estudio de la categoría teórico formal que subyace en la interioridad del campo del dibujo, misma que le permitió a lo largo del tiempo y la práctica artística, ubicarse como gestor del pensamiento en imágenes y constructor del proyecto artístico. Llamamos a esta categoría El carácter Proyectual Prefigurativo del Dibujo. Con ese análisis intentamos desarrollar las condiciones estratégicas y epistémicas que operan en el pensamiento y la práctica del dibujante en los procesos de Prefiguración y Configuración, que en sí, integran los primeros momentos de lo que enunciamos como el Acto Dibujo.

El pensamiento modelístico teórico y formal del Dibujo a lo largo de la historia del arte es la definición del territorio sobre el que se desarrolla este proceso, y que particulariza el problema sobre el ser del Dibujo, de ahí que nos orientáramos en el capítulo precedente en esa dirección.

La construcción de un análisis del Acto Dibujo tiene la finalidad de extender la comprensión del fenómeno hacia una serie de regiones que pudieran ampliar el espacio reflexivo de la disciplina, más allá de las posturas formalistas e instrumentalistas o bien pragmáticas. Comporta su entendimiento como una práctica proyectual prefigurativa que se extiende y flexibiliza en el momento de la configuración fáctica y la presentación terminal del proyecto realizado.

El acto dibujo es la vivencia del dibujar, situación que se extiende tanto a la experiencia conceptualizante, como a la resonancia psíquica subjetiva del artista, en las que se decanta la organización territorial del pensamiento hecho imagen.

En este momento hacemos una mención que consideramos sumamente importante, y que deseamos no se pierda en las líneas de este trabajo.

Las categorías del Acto Dibujo, el Carácter Proyectual del Dibujo, la certeza de la vigencia del Acto de Representación, los conceptos de Vivencia, Experiencia, Prefiguración y Configuración surgieron y fueron tomando forma dentro de los procesos de producción de varias series de dibujos que nos ocuparon a lo largo de 7 u 8 años. Las rutas de pensamiento de este trabajo y su estructura se inician dentro de la producción del dibujo mismo, ahí se manifestaron las zonas oscuras por investigar y las hipótesis elementales.

Pero así también manifestamos que con este trabajo, y sobre todo en este capítulo no formulamos una teoría general del dibujar; es más una teoría que organiza el territorio de nuestra experiencia, que puede ser extensiva en cierta manera, pero que no agota posibilidades alternas dentro de nuestro campo y disciplina. Esperamos la comprensión de todos ustedes como lectores, no para disculpar nuestras carencias sino para comprender el sentido de nuestro análisis. 
Pensamiento Proyectual, Vivencia, Prefiguración, Experiencia y Configuración son puntos de apoyo para desplazamientos estratégicos, y todo ello como nuevo suceso vivencial recursivo y eje de un otro desplazamiento, son continentes que integran el acto dibujo entendido como práctica de representación.

Como primer asunto, dedicamos un espacio a la reflexión para extender el concepto de representación más allá de los límites en los que lo han cercado las concepciones posmodernas del arte.

Expresaremos nuestra visión de la acción de dibujar desarrollada como práctica de representación, remitido ya en este momento a la interioridad de ese acto.

La estructura y la forma de este capítulo es la de una exposición que vierte la secuencia de ideas que desplegamos en el decurso de nuestra producción como dibujantes, tiene entonces una lógica inmanente que no es arbitraria ni carece de sentido, es asistida claro está por los estudios que hemos realizado; pero no será la construcción de una teoría total bajo el orden de un pensamiento lógico deductivo, ni tampoco una suma de estudios y lecturas para ser ilustrados mediante la acción de dibujar.

Nuestra reflexión de los primeros núcleos temáticos de este capítulo se relaciona con un grupo de ideas esbozadas por J. F. Lyotard y su análisis sobre la fenomenología, Gilles Deleuze y su visión de la pintura, Philippe Dubois y su estudio a cerca de la fotografía, Humberto Chávez Mayol y su formulación del Tiempo Muerto y el trabajo de Fernando Rampérez sobre la quiebra de la representación en el periodo de la estética moderna. A lo largo de nuestro estudio encontramos en estos trabajos en particular, análisis que se remitían tanto a la secuencia como a la naturaleza del problema que nos ocupaba. El contenido de estos estudios aportó elementos a nuestro pensamiento, el carácter de esos autores está presente en estas líneas, ustedes sabrán advertirlo; pero hacemos una aclaración, nuestro pensamiento no es coincidente del todo con la postura de esos ensayos, mantenemos distancias, desviaciones, precisiones, matices, o incluso algunas contradicciones que son las que pensamos definen nuestro pensamiento particular y el centro de este estudio, creemos modestamente haber ido bastante más allá. De aquí en adelante lo formulado en los capítulos precedentes será la base operativa en la que descanse el flujo del análisis, también esto podrá ser advertido por el lector sin la necesidad de puntualizarlo recurrentemente.

\section{IV-1 EXTENSIONES DEL CONCEPTO DE REPRESENTACIÓN}

"Doble derivado de una imagen primera, imagen, imitación, expresión, representación, el libro tiene su origen ( $y$ el dibujo igualmente, decimos nosotros), que es también su modelo, fuera de sí: la "cosa misma" o esa determinación de lo que es que se llama "realidad" tal como es o tal como es percibida, vivida y pensada por quien describe o quien escribe. Realidad presente, pues, o realidad representada, esa alternativa deriva a su vez de un modelo anterior... La naturaleza era también una totalidad ordenada, el volumen de un libro cargado de sentido, dándose a leer, lo que debe querer decir a escuchar, como un habla, de entendimiento a entendimiento." —Derrida, La diseminación, pp. 67-68

Hay que extraer, sin embargo, sin culpa ni carencia, la últimas consecuencias de lo que Dostoievski afirmó: que si Dios no existe todo está permitido. Que no hay un fundamento 
absoluto que representar e imitar, no hay un fondo valorativo previo, y que incluso el relativismo tampoco tiene sentido porque se mueve en la misma lógica de ese universo de la representación. Solo queda (por fin) el acontecimiento singular (subrayado nuestro) la producción (creación estética, diría Nietzsche, con voluntad de poder) de ámbitos de sentido y valor. ${ }^{138}$

"La mímesis es un concepto deudor del de physis. Hay en la naturaleza cierto orden, cierta regularidad o necesidad expresada en el logos, que constituyen aquello que se debe repetir o representar mediante la mímesis en el arte. Solo puede ser mimetizado lo que tiene una lógica: es esa lógica lo repetible, no lo que de singular tenga un objeto o un acontecimiento."139

Iniciamos estas líneas con un sinsentido, el de la simple mención de un correr de enunciaciones, no vemos el guión que las engarza, pero sospechamos que esa lógica existe.

Ese fluir de sinsentido aparente, es sin embargo el modo en el que el discurso naturalizado del pensar y de la crítica se nos revela y pesa sobre nosotros; renuncia a la construcción de un discurso integrado, que desde sus bases organice el sentido del imaginario colectivo, característica privativa de la quiebra del proyecto moderno.

Como primer asunto nos ubicaremos en el terreno de la representación, tenemos aquí un núcleo conflictivo inicial que ya fue mencionado al plantear el problema, una visión que formula la quiebra de la representación al término del proyecto moderno del arte y su superación dentro de la estrategia posmoderna, Danto, Kuspit, Crimp, Krauss y Rampérez la plantean y proponen la formulación de categorías sustitutas.

En el terreno de la representación, referido al campo de las artes visuales y los procesos generadores de la imagen, como en el del acto de dibujar, tal ruptura se plasma en dos situaciones particulares que impactan directamente la práctica del campo disciplinar del dibujo: la primera se deriva del asumir la relación directa entre la categorías de Representación como Mímesis de la realidad exterior al sujeto artista. La segunda comprende la aceptación tajante de que la representación es una categoría superada, en tanto que corresponde al pensamiento proyectual occidental que madura en el corte de la tardomodernidad, cuya operatividad hace crisis en la condición de la existencia posmoderna y su pensamiento. Estos son los términos conflictivos que originan nuestra investigación y a los que aludíamos en el planteamiento del problema.

Nuestro pensamiento no concuerda con esa posición, ya a lo largo de nuestras páginas se advierte ese escenario.

Para los fines que animan nuestro trabajo resulta necesario plantear una serie de precisiones en torno a este conflicto, esto es así porque como dibujantes entendemos el ejercicio del Acto Dibujo como una práctica de representación, un acto que rebasa la búsqueda mimética basada en la existencia física objetual, que tanto nos ata a la naturaleza, proponemos un acto en el que los procesos de formalización significan construcciones representacionales que proponen nuevos órdenes gestálticos, elaboraciones que se des-

138 Rampérez Fernando. La quiebra de la representación: El arte de vanguardia y la estética moderna. Madrid: Ed. Dykinson; 2004. (Col. Comentarios y monografías) P. 289.

139 lbíd., P. 248. 
plazan desde lo lógico racional formalizado hasta el campo de las resonancias psíquicas intersubjetivas, órdenes en los que se recrea nuestra visión de la realidad contextual en un sentido que se expande más allá de lo natural; conflicto que marcó la diferencia entre el pensamiento filosófico del arte en el paso de la modernidad del XIX a la de inicios del XX.

Una cita de Fernando Rampérez nos resume la perspectiva filosófica de la representación en el marco de la modernidad inicial del siglo XX.

"Heidegger, mejor que nadie, ha subrayado la clave del enigma de la representación, planteado en los términos que se derivan lógicamente del divorcio ontológico mencionado: el fenómeno. La idea, o el concepto, entendidos como representación en el sujeto de un objeto exterior, ajeno y esencialmente distinto al perceptor, muestran a la vez que ocultan esa realidad ajena: y esto es así porque la representación solo es tal en la medida que no es el objeto, en la medida que lo suple o está por él, y, por tanto lo mismo que nos acerca la presencia del objeto nos subraya su ausencia... puesto que no hay verdad sino para un sujeto y porque, para una separación radical sujeto/ objeto, el sujeto siempre piensa solo representaciones (configuraciones formales decimos nosotros), jamás la realidad misma. Así las cosas, la mediación problemática lo es doblemente, doblemente mediación y, por tanto, doblemente problemática: de la realidad a la representación, y de esta a la supuesta realidad objetiva." ${ }^{140}$

El propio Rampérez completa el sentido anterior cuando remite la mímesis a un origen ritual, asociado a las prácticas mágicas arcaicas en donde los dobles de un ser actuaban como mediadores con su espíritu. En este orden de ideas la mímesis es un modo de recuperar la presencia de lo ausente, hacer presente lo que es pretérito. El acto de representación es entonces un ritual, pensamiento mágico cuyos tiempos, acciones y formas reproducen el origen y la presencia deseada.

Pero es necesario precisar que para el pensamiento lógico racional, la mímesis no es una sustitución mágica sino una representación formalizada del sujeto ausente, es en este sentido que opera el pensamiento platónico, formulando que la idea de un objeto es la réplica de su idea original, así entendemos las imágenes de la representación a manera de un sustituto o mediador, una presencia que se coloca en el espacio entre lo real objetivo y lo real imaginado, esto es lo que nos lleva a concluir el principio de diferencia, lo representado no es lo mismo que el sujeto ausente o el acontecimiento original, su tiempo es el de un después de aquella presencia primera.

Para la crítica posestructuralista y posmoderna la representación siempre será un doble, pero a nosotros no nos resulta adecuado el concepto de doble, un otro que intenta sustituir lo ontológico inicial concreto u objetivo. Pensamos en la representación y sus imágenes como una región de existencia diferenciada, no pensamos que hoy alguien asuma la imagen como sustituto mágico de una presencia ausente; estamos de acuerdo en entender las formas de la representación como presencias alternas que se sitúan con esencia particular entre el contexto y el pensamiento, formas y presencias de la realidad vivencial primera que es ausente y pasada. En términos de Derrida la representación es siempre

140 Rampérez Fernando. La quiebra de la representación: El arte de vanguardia y la estética moderna. Madrid: Ed. Dykinson; 2004. (Col. Comentarios y monografías) P. 257. 
ya otra cosa, habitada en su interior por la ausencia, y es este sentido de ausencia que se traduce también en carencia.

Esta precisión entre el pensamiento racional y el mágico religioso en lo referente al concepto de representación nos resulta esencial y fundamental para basar nuestra extensión de la representación y particularizar las acciones del dibujo como procesos formales que le construyen ampliaciones sistémicas.

Pongamos por caso la transición del dibujo entre el Renacimiento y el Manierismo; llegó el momento, cuando los artistas y entendidos reconocieron la inclusión de elementos y caracteres formales no contenidos en el eidos del sujeto modelo observado en la naturaleza y las reducciones métricas proporcionales establecidas, esos agregados eran libertades formales que corrían hacia la construcción de alegorías, eran producto de la lógica diferida del lenguaje y las formas, eran fácilmente identificables como inclusiones producto de la razón reflexiva y formalizada del dibujante, pero arbitrarias en tanto no era posible resumirlas de los modelos naturales. Esta dinámica epistémica sentó las bases de la definición del Dibujo Interno manierista.

La mímesis opera en el pensamiento de la imagen por semejanza o analogía de formas, es la lógica estructural del modelo la que se intenta llevar al terreno de la imagen, por eso es posible la repetición en este orden de pensamiento, se intenta reproducir el ser dibujado mediante la estructura eidética que se piensa le es constante.

En la modernidad tardía del Dibujo y la pintura, se advierte ya que esa lógica no es constante, en el momento en que los modelos dejan de ser entidades objetuales o sujetos para entenderse como fenómenos, esto es, circunstancias particulares de existencia de los sujetos o la naturaleza, que rompen la posibilidad de estabilizarlos en formalizaciones constantes o estilísticas.

Para hoy, es el pensamiento racional el que permite conceptualizar la realidad y su configuración en la acción de dibujar, aunque esta racionalidad no se exprese en sistemas métricos matemáticos como en otro tiempo.

Esta reflexión es la que mencionamos como base del pensamiento experiencial, el que muestra la diversidad de lo dibujado, sus intenciones iniciales y la distancia con el comportamiento del objeto configurado; y, aunque se aplique una lógica de la razón métrica y estructurante, el dibujante advierte con claridad el principio de variación, es esta conciencia experiencial la que le permite sintetizar y tender hacia la estabilización de la representación, como una delimitación que marca constantes identificables en la vanguardia y sus periodos, pero igual lleva al dibujante a la inestabilidad constante al buscar la continua variación que niega la tendencia estabilizadora. En efecto es esta una conciencia empírica, acompaña la diversidad de la representación en sí misma. Pero esta conciencia del hacer no basta en su simplicidad, hace falta que el dibujante una y confronte uno y otro resultado de la representación y que sea consciente de la síntesis posible (el modelo histórico nuevamente), así la diversidad del resultado del acto construye el pensamiento experiencial comparativo que concita la diversidad mediante la unidad analítica.

Pero el acto de la conciencia dada en la representación sólo es posible por la mediación y contraste con el modelo causal, sea este el de la porción de la realidad que funciona como referente o el del modelo interior y tautológico del dibujo que también puede funcio- 
nar como inicio abductivo de la extensión del lenguaje.

La representación dentro del acto dibujo opera también sobre la base de subjetividades que casi anteceden a los conceptos, ya que estos son operaciones conclusivas producto del plano experiencial, el que se deriva de la vivencia. El análisis del dibujante sobre sus formalizaciones se vincula con lo subjetivo de la psique y con la cultura, los conceptos como base de las acciones técnicas e instrumentales son desbordados.

El propio Rampérez introduce una cita de Kant extraída de su Crítica del juicio.

"Cuando bajo un concepto se pone una representación de la imaginación que pertenece a la exposición de aquel concepto, pero que por sí misma ocasiona tanto pensamiento que no se deja nunca recoger en un determinado concepto, y, por tanto extiende estéticamente el concepto de un modo ilimitado, entonces la imaginación, en esto, es creadora y pone en movimiento la facultad de ideas intelectuales para pensar, en ocasión de una representación (cosa que pertenece ciertamente al concepto del objeto), más de lo que puede en ella ser aprendido y aclarado"141

Ya desde entonces se comprenden dos momentos de la representación, el primero que atañe a la relación del pensamiento y las formas con la realidad en extenso, y dos, la que se ocupa de pensar la representación en su interioridad, un para sí de esa conciencia. Con esto se desplaza el centro de atención en las operaciones del Dibujo de lo estrictamente objetual del mundo externo hacia la objetualidad de la obra dibujo y sus procesos generativos; sin embargo no es este un evento intelectual de sustitución, resulta en un continuo ir y venir de un objeto a otro mediante la acción reflexiva y configurativa del dibujante. Situación originada en un vivir el mundo como primeridad y que ahora es otro vivir el mundo y el acto de dibujar dentro de una segundidad temporal.

Lo general estético como relación con el mundo se desplaza hacia la estética de la obra como producto y representación, entonces el asunto de la mímesis se entiende en su sentido fundamental como preocupación de la filosofía del arte pero con una dinámica más extensa al interior de la acción de dibujar.

Mientras que la representación inicialmente se basa en una correspondencia del pensamiento y sus datos con el mundo, en un segundo momento se transforma en una construcción que se ubicará siempre en un campo específico de la praxis humana, particularmente el Dibujo, formalizaciones que se abren a la interpretación, en este último espacio de la representación el foco de atención se centra en el lenguaje y la expresión, para lograr construir una nueva realidad mediante la obra, realidad que se origina en el mundo y contexto primero pero que ahora puebla también el contexto y su ecología como un nuevo ser, el de la diferencia aludida anteriormente; ser formalizado que genera su propia relación con el espectador en el que produce efectos alternos a los suscitados por la realidad referencial primera.

La representación se extiende hacia lo estético como ampliación de lo estrictamente lógico conceptual, por eso decimos que la lógica de la representación al dibujar comporta extensiones epistémicas que no tienden hacia lo absoluto de un método que opera como rector de las formalizaciones, pero no por ello dejan de ser manifestaciones de la con-

141 Rampérez Fernando. La quiebra de la representación: El arte de vanguardia y la estética moderna. Madrid: Ed. Dykinson; 2004. (Col. Comentarios y monografías) P. 261. 
ciencia experiencial. Este carácter es genérico de la representación en el arte, pero específicamente de manera sobresaliente dentro del Dibujo como disciplina eidética, apunta siempre hacia lo aún no determinado ni resumido, lo que está por manifestarse, sea estrategia, forma, acción o poética del acto dibujo.

Una postura estrictamente gnoseológica insistiría en lo imposible de concluir lo estético bajo conceptos lógicos; aquí se genera una fisura de importancia esencial. No es que la acción del dibujar no se oriente sobre conceptos o que no busque su enunciación, lo que sucede es que las operaciones lógicas de representación en el dibujo hace tiempo que dejaron de intentar la consecución de un sistema modelístico consistente y duradero. Hoy se dibuja aplicando los conceptos formales y teóricos del Dibujo a manera de reflexiones que alientan la intuición y logran con ello la producción de obras y formas que llevan inmanente su propia lógica, la que les permite una densidad y operación dentro del contexto o caso en el que se inscriben, son resultado de reflexiones e invitaciones a pensar el mundo y el arte de una nueva manera, pero no intentan ya constituirse en definiciones del todo del dibujo y sus partes.

La representación entendida como mímesis, vínculo que une a significante y significado y, por tanto al objeto dibujo con aquello a lo que alude, sufre un quiebre epistémico al interior del arte en la modernidad del XX, y no tanto por su distanciamiento icónico que permitía identificar el modelo dentro de las formas del dibujo, sino por la inclusión de fragmentos concretos de la realidad como parte de la facticidad de la obra, Duchamp y Picasso entre tantos, iniciaron la apertura de la experiencia que presenta fragmentos concretos de la realidad en la interioridad de la obra, el rumbo de esta revolución determina el carácter del arte en los últimos 100 años lo menos; pero si bien estos cambios impactan la práctica del Dibujo, no podemos por ello concluir que son totales o que dejan inactivas definitivamente la funciones constructoras del Dibujo en el proceso de la representación.

Los intentos por llevar la vida como tal, al interior de la obra, significaron un fuerte cuestionamiento a la concepción del arte dentro de la modernidad, pero es en este punto donde se origina la derivación problemática que nos ocupa; este cambio epistémico en el entendimiento del fenómeno artístico desplazó al Dibujo de su posición y función sistémica que lo relacionaba con el campo de las artes visuales y plásticas, entendemos la relativización estructural que esto significó, y que la obra plástica y visual se puede pensar y estructurar desde territorios que escapan al dibujo, pero desde entonces y hasta ahora el Dibujo generalmente continúa siendo el ejercicio proyectual del pensamiento del artista y el constructor de las tensiones dentro del proyecto, así como productor de imágenes de primera generación y prácticas estratégicas complejas que ahora entendemos como productos de la representación.

Aquí insistiremos en plantear claramente este punto como un conflicto irresoluble desde la teoría y la crítica del arte; sólo desde el campo de la producción artística se puede decantar una salida a esta falsa oposición.

La crítica posmoderna asume la apertura del fenómeno artístico hacia una quiebra de la representación, generada entre otras cosas por la inclusión de fragmentos vitales concretos de la realidad contextual en la obra, o bien al generar el hecho artístico sobre prácticas sociales relacionales más que en categorías objetuales. 
Veamos el pensamiento de dos dramaturgos que en su campo trascienden la modernidad.

Artaud citado por Foucault nos dice: "La representación ya no tiene porqué ser creída. El teatro es teatro. Artaud, justo en el momento de la vanguardia, rompe la ingenuidad, quiebra el velo mismo de la confianza en el seno mismo de la escena: grita que o nada es teatro o todo lo es. Nada hay que representar o todo es representación."142

Pero sobre el mismo punto Peter Brook, director teatral, puntal sustantivo del teatro posmoderno se sostiene en una posición divergente.

"Con todo es imposible afirmar que no existen diferencias entre el teatro y la vida. En 1968 aparecieron quienes, por razones muy válidas, hastiados de tanto $<<$ teatro absoluto $>>$, insistían en que $<<$ la vida es un teatro $>>$ y, por lo tanto no había necesidad de arte, artificio, estructuras, etc. $<<$ El teatro se hace en todas partes, el teatro nos rodea $>>$, decían. $<<$ Cada uno de nosotros es un actor, podemos hacer cualquier cosa delante de cualquiera, todo es teatro. >> ... Uno va al teatro para encontrar vida en él, pero si no hay diferencia entre la vida dentro y fuera del teatro, éste no tiene ningún sentido. Es absurdo hacerlo. Pero si aceptamos que la vida en el teatro es más visible, más vívida que fuera de él, veremos entonces que es lo mismo y simultáneamente algo diferente.

Concretemos algunos detalles. La vida en el teatro es más entretenida e intensa porque está más concentrada, La acción de reducir el espacio y comprimir el tiempo crea un concentrado." 143

Esto es posible en el terreno artístico porque su lógica estructural no es excluyente, puede trabajar el artista por oposición histórica y estratégica (Damish nuevamente) pero el resultado de su acción y su postura no aniquila la existencia de cualquier otra manifestación existente que haya probado en los hechos su capacidad de generar resultados artísticos valiosos.

¿Cómo entonces se declara concluida la esencia de la representación en la interioridad del acto de dibujar?

Entendemos la práctica de la representación en el dibujo como un ejercicio complejo que no solo consiste en el hecho de la mímesis formal, sino que se extiende a la práctica del hacer el dibujo en sí, a sus acciones, actos, estrategias y pensamientos que nos colocan frente a posturas epistémicas que ya nos hablan del carácter ampliado del sentido de la representación. Insistimos en el término sentido, como un concepto que alude a relaciones sistémicas obligadas por la coherencia del proyecto y no en su acepción simple y coloquial.

La categoría de representación se desprende del análisis filosófico que busca comprender el mundo; éste la entiende como expresión formalizada de la realidad, lo que provee al intelecto de una estructura reflexiva trascendente. En este orden de ideas la representación es el cuerpo formalizado del mundo que opera mediando entre la razón conceptual y la realidad objetual del contexto, es una re-presentación de aquello que existe en la exterioridad del sujeto cognoscente, de ahí que mímesis y representación en la historia de la filosofía occidental se encuentren ligadas íntimamente.

142 Rampérez Fernando. La quiebra de la representación: El arte de vanguardia y la estética moderna. Madrid: Ed. Dykinson; 2004. (Col. Comentarios y monografías) P. 231.

143 Brook Peter. La puerta abierta. Barcelona: Alba Editorial; 2004. P. 17. 
Bajo esta perspectiva es que se deriva la concepción que entiende la caída de la representación como parte de la crisis del pensamiento moderno, y que por tanto se proyecta en el arte y dibujo donde la imagen artística no guarda relación mimética con su referente objetual modelístico.

Cuando llevamos directamente al interior de la estrategia artística conceptos y categorías de otros territorios para establecer un análisis, suele suceder este tipo de situaciones, corremos demasiado directamente hacia conclusiones deterministas y cerradas.

Por eso es que decidimos caminar sobre los modelos de la interioridad del pensamiento artístico y del Dibujo, para tomarlos como campo de cruce de los conceptos en cuestión y poder tal vez generar visiones particularizadas que operen dentro del campo que nos interesa.

Así en este primer segmento de nuestro capítulo reflexionamos sobre posibles extensiones de la categoría de Representación, y no porque busquemos con ello construirnos variables o conceptos arbitrarios y a modo conveniente, sino porque estas extensiones se originan en fracturas y preocupaciones suscitadas dentro de nuestro ejercicio como productores del Dibujo, buscamos extensiones que satisfagan nuestro planteamiento hipotético, o que nos muestren las precisiones que debamos de contemplar.

A nuestro entender el problema consiste desde el terreno del Dibujo, (más que desde la filosofía) en analizar la posible extensión del concepto de representación, basándonos en la observación de los procesos y modelos de la interioridad del Campo del Dibujo a lo largo de la historia, como fue nuestra intención hacerlo en el capítulo precedente, y desde las bases analíticas del proceso generativo del Dibujo entendido como un acto, precisamente un acto de representación que comprende tiempos y aconteceres mucho más ricos que los que pueden animar una definición mimética.

La ruptura inaugurada por la vanguardias históricas a inicios del siglo XX y que hemos descrito como las primeras vanguardias del 1900 que culminan con los integracionismos, es una nueva etapa en los procesos de representación, la que corresponde a la disociación de la imagen de su referente objetual, ahí se inicia el plegamiento de la práctica del Dibujo hacia una reflexión del propio lenguaje de la forma y la categoría de Artes Visuales en sustitución del paradigma plástico. Este corte marcará el desarrollo de una buena parte del arte desde entonces. En ese momento se cuestiona radicalmente el concepto de mímesis asociado al concepto de representación, si bien nosotros anotamos que esa ruptura es histórica y se inicia desde el corte del arte manierista que propone la imagen del dibujo como una libertad formal no emanada de las fuentes modelísticas observadas en la naturaleza.

Si desde el siglo XIX con el trabajo del Romanticismo, Goya y Turner la imagen del arte mostró disidencias con la realidad percibida, será en el corte de la primera modernidad del XX cuando el ojo humano obligue a la conformación de una nueva gestalt para pensar el mundo mediante formas alternas y categorías sustitutas.

Por eso es que este giro comportó modificaciones epistémicas, cuestionamientos propios de lo que eran los modelos del Dibujo y los modos de relación del dibujante frente a ellos.

El espacio epistémico y la unión entre mímesis y representación finalmente tuvieron que ser revisadas. 
La relación del arte como imitación de lo real se fracturó, si bien este era un proceso que en el dibujo contaba con largos antecedentes. Pero la consistencia ontológica de lo real, lo externo al dibujante se debilitó, de ahí que el Dibujo se sumara a la postura tautológica del arte vuelto hacia sí mismo en una reflexión de sus estrategias y formas.

Pero si bien la categoría de mímesis pierde centralidad, esto no implicó que las formas y prácticas alternas del Dibujo no pudieran ser entendidas como un ejercicio de representación; y pensamos esto basados en el hecho de que los proyectos de la modernidad integracionista y los de la modernidad tardía Greengberiana fueron procesos que finalmente ofrecen como resultado formalizaciones y obras que posibilitaron la apertura de los códigos internos de los campos disciplinares artísticos. Todos los autores, analistas, críticos y teóricos coinciden en el hecho de que aún la modernidad tardía (la de 1945-1968) opera sobre el soporte de un proceso que valida la estética y la forma tautológica y autorreferencial, así como la estrategia de la acción a manera de ejercicio de representación formal que deriva hacia el acontecimiento como parte de una representación, que se extiende (decimos nosotros y Gómez Molina) hacia el terreno de las prácticas como conciencia epistémica del hacer del dibujante.

La acción y la estrategia representan al sujeto en el momento de ejercer su práctica desde posturas alternas que expanden la definición de representación más allá de la pura plasticidad de la forma en el sentido clásico del pensamiento griego. Autorreflexión que vuelca el dibujo sobre la historicidad de su propio lenguaje, los dibujantes cobran conciencia de que el lenguaje es en gran medida quien configura la realidad interiorizada, al ser el mediador entre el pensamiento trascendental del artista y la realidad contextual.

Si bien la historia del proceso de extensión de la categoría de la representación se inicia según nosotros claramente en el dibujo manierista con sus derivas formales no naturalistas, aunque si referenciales a los modelos objetuales, será en la vanguardia del XIX donde se geste el punto crítico del proceso, el que desembocará en la abstracción de corte anicónico y no referencial del siglo XX.

El tiempo lineal determinista cede ante la visión de una temporalidad vital y existencial que se desprende de la lógica dialéctica. La representación deja de ser una mediación entre la realidad externa y el pensamiento del dibujante, misma que opera sobre una lógica binaria de oposición entre la realidad y la imagen como símil que nos la reconstruye.

Pensamos que en ese momento funciona ya claramente una relación terciaria, la que involucra la realidad como modelo, el dibujante como forma del pensamiento y postura epistémica y la obra del dibujo que en adelante cobra su ser ontológico y da peso a nuevas relaciones pragmáticas de interacción con el espectador. En esta lógica terciaria se derrumba la mediación de la obra como entidad que sustituye la ausencia de lo real primero.

En la representación del dibujo, la obra cada vez menos puede ser tomada como aquello que llena el vacío de lo ausente; cada vez es más clara su calidad de diferencia, la que la define como algo no confundible con lo real primero.

La lógica terciaria no será entendida como un abandono de las prácticas de representación sino como una alteridad a la conciencia unívoca que sirvió de base a las formalizaciones del dibujo como expresión de la representación.

Pero no es la realidad física, referencial y contextual la que se fractura, es la construcción subjetiva que de ella hace el dibujante la que explota en un mundo de posibilidades que 
expanden el territorio de la representación de lo estrictamente formal hacia el terreno de las prácticas configurantes y las estrategias epistémicas mediante las cuales el dibujante se relaciona con el mundo, tanto el de la exterioridad física contextual como el de su interior, que por otra parte comporta y es marcado por el pensamiento cultural de las otredades y la historia, como ya lo hemos analizado.

Hay quienes entienden la formulación autorreflexiva del Integracionismo, el Informalismo y del Expresionismo Abstracto como la separación definitiva entre la representación y la realidad.

Este es uno de los puntos en los que el concepto de representación debe ser extendido. En primer lugar, los movimientos integracionistas que culminan con la ruptura icónica que relaciona la forma de la imagen con su referente, son producto de un proceso de reducción y síntesis formal de los modelos objetuales, la fuente de la imagen y el proceso siempre es un objeto, sujeto o fenómeno que tiene consistencia ontológica en el contexto externo al dibujante, su vínculo con esa parte de la realidad es sustantivo y causal, por tanto su representación formal, aunque ha diluido visualmente al referente de la forma, mantiene con él un vínculo determinante.

Como segunda situación tenemos los casos del Expresionismo Abstracto y la Abstracción Pospictórica, en ellos la referencialidad objetual y la asociación icónica sustituta no existen, ni se derivan de modelo objetual alguno. Pero estas prácticas del arte en las que el dibujo tuvo un papel relevante se basaron sobre los principios de la Indexalidad, operación epistémica que entiende la huella como rastro físico de una acción ejecutante, producto de la prolongación de una corporalidad autógrafa, o bien como huella de la operación mental que cifra códigos de representación analizando la estructura del lenguaje mismo; parte de lo que vemos representado en estas obras es al sujeto autor del dibujo, al dibujante como entidad específica, que ahora se incluye como parte de la representación formalizada, dibujante que se integra en plenitud al proceso de la representación abandonando su condición de espíritu rector externo de la forma pero paradójicamente excluido hasta entonces en la interioridad de la obra lograda.

No vemos en este punto un quiebre que anule la representación, de no ser acaso el del binomio histórico mímesis-representación.

Y aquí es necesario elevar el tono del discurso; la extensión del dibujo hacia el plegamiento autorreferencial de su lenguaje no significa un juego fácil ni una postura ingenua de sencilla reducción.

Si el lenguaje dejó de ser entendido como una formalización lineal del mundo aludido, para convertirse en la construcción subjetivada múltiple de ese mundo al que se hace referencia, nos puso en la dirección de comprender las estructuras del dibujo como un mundo por sí mismo, uno en el que las operaciones conceptuales y los intercambios de subjetividad son posibles sin por ello perder una consistencia ontológica humana, objetual y como lenguaje.

En este giro la dimensión poética y metafórica del dibujo se expandió, ya que las construcciones metafóricas no debieron pasar por asociaciones sígnicas referenciales de los elementos icónicos, la poética y la metáfora se ampliaron hacia el territorio de la más extensa subjetividad, indexada en el abanico de huellas, prácticas y mundos depositados 
por el dibujante, las que no solo permitieron una arqueología del Dibujo sino una expansión subjetiva del sentido de lo representado.

Con todo esto quedó salvado lo que desde antes se vislumbraba, la representación no era sólo una intención de volver a presentar la realidad externa, era un ejercicio de construcción de una realidad alterna y un evento, acontecimiento, rito y acto al que se desea llevar al espectador; ya no con la finalidad de la trampa de ojo, sino con la clara intención de colocarlo en otra realidad. ¿Porqué entonces entender que esa nueva realidad subjetiva, formal y construida tiene que ser mímesis de una primera?, la que existe en la exterioridad ¿por que no aceptar que puede tener su propia forma y condición de existencia? Así la representación para nosotros será una presencia diferida de lo real primario, pero al mismo tiempo una existencia ontológica cuyo ser no nos remite de manera lineal a reconocer en la imagen el mundo en el que se origina y del que parte; es también un acto, pero no por ello carente de formas, sus pasos, secuencias tiempos estrategias e implicaciones corporales y psíquicas expanden la representación más allá de la lógica objetual formalizada en un objeto bidimensional.

Aquí es importante incluir que con la aportación de las vanguardias puristas del XX y su posterior extensión formalista, maduró entre otras cosas el entendimiento de que la realidad subjetiva interior del dibujante era un asunto cuya complejidad era más profunda de lo que hasta entonces se había sospechado.

La subjetividad del dibujante determina su principio de autonomía, su capacidad para adoptar estrategias y cierres conclusivos dentro del acto de dibujar, le permite hacerlo bajo una conciencia histórica de la forma y el proceso, o bien dando cause a la intuición gestual primigenia, pero a todo esto se suma la consideración de que la subjetividad vista como expresión individual no lo es tanto, sabemos que también esta es una marca cultural en la que el proyecto social hunde sus raíces.

Pero con todo y esto la tarea del dibujante desde siempre y más claramente desde el inicio de las vanguardias, es la de realizar una glosa de la realidad y la formalización de otra nueva.

Esta disyunción es la que diferencia la primera vanguardia abstraccionista del XX de aquella vanguardia de la posguerra y la modernidad tardía. La primera mantuvo el nexo representacional originado en una reducción de la naturaleza, si bien el resultado de la imagen ya no hacía evocación del modelo referencial, por eso el proceso mediante el cual Mondrian y Kandinsky llegan a la abstracción anicónica es gradualista, se basa en una lógica de reducción sintética, pero mantiene el nexo entre lo real primero como base de la imagen de la representación.

La abstracción de la modernidad tardía hunde su origen en el pensamiento interior subjetivo del dibujante y el artista en extenso, la única naturaleza introducida en el evento de dibujar es la del dibujante mismo como integridad subjetiva, somática y psíquica. Esta segunda etapa de la abstracción no parte de un modelo ontológico externo al dibujante, es en términos de Greenberg referida a su propia interioridad lingüística, sus operaciones representan el pensamiento referido al dibujo mismo, así como a la vivencia integrada del configurar la obra.

La obra configurada en este corte no sustituye a ninguna presencia primera, ya no suple una ausencia, es en sí misma primeridad alumbrada. 
Siempre se llegó a una obra de presencia fáctica, somática, que era la huella formalizada del evento. Es en este momento que se vuelven significativas las formas de registro de la acción configurante, filmar al artista en el acto de dibujar y pintar, no solo comportaba el registro arqueológico de lo sucedido para una posterior reconstrucción y lectura, el registro era la comprensión de que sólo de esa forma se podía asistir a un corte temporal diferido de la acción, que en sí mismo era parte de la obra y no sólo su proceso técnico de configuración.

En este fenómeno que liga ambas partes de la vanguardia del XX se afina la certeza de la singularidad, el dibujo interiorizado en la práctica de la pintura no se diluyó, antes bien se convirtió (desde nuestro punto de vista) de una nueva manera en el eje vertebral de la acción pictórica. En ese espacio expandió sus resultados y reflexiones formales hacia una ampliación maravillosa de la representación, que se continuó hasta la experiencia de la Abstracción Pospictórica.

Con la definición de lo singular se cobró conciencia plena de lo irrepetible del acto del dibujo, acontecimiento único que no busca remitir a presencias perdidas sino que es en si una representación en la que el dibujo vuelve a suceder y a cobrar sentidos expandidos y diversos.

Sobre estas bases es que se aclara el concepto de diferencia remitido al terreno de la representación.

La diferencia nos conecta con el carácter dual de la modernidad, dualidad del proyecto positivo que afirma la construcción del orden social y de su contraparte, la del proyecto crítico existencial nacido de la postura romántica. Ambas caras del proyecto se profundizan en el pensamiento del arte del siglo XX y trastocan la representación, no sólo en el orden de la imagen y la obra sino en el de la estrategia del dibujo, que traza una ruta de comportamientos diferenciados de lo que hasta ese entonces se entendía como práctica del dibujo y las artes; además de que el repertorio formal y conceptual del arte se extiende hacia modelos de representación que superan con claridad el sentido mimético de esa categoría.

Las vanguardias históricas continúan con ambas vertientes del dualismo en el pensamiento proyectual del dibujo, pero los procesos de formalización y las prácticas estratégicas y de configuración de esta disciplina en ese momento significaron una revolución epistémica, esto es, un replanteamiento del dibujante sobre sus modelos constituidos como realidad, la relación que le unía con la naturaleza, los procesos que ponía en práctica para conocer su contexto y llevarlo a los terrenos de la configuración.

En suma, el dibujante se replanteó su relación cognitiva con la realidad en sentido extenso y la manera en que obtenía conocimiento de ella, y los cauces de formalización mediante los cuales la representaba.

Esto ya es materia conocida por la historia, pero sobre esa base agregamos la puntualización en el sentido de que la revolución anicónica y abstraccionista del XX no puede ser entendida como un abandono de la categoría de representación; si no más bien como una extensión epistémica, en la que el dibujante deja finalmente de posicionarse frente a su modelo, asumiendo una posición dual de distancia que colocaba al artista en el lugar de supremacía como inteligencia exterior al modelo dibujado y como conciencia ordenadora de los cauces del acto de dibujar. Esta era una dicotomía dialéctica en el sentido clásico, la oposición de los contrarios insalvable. 
Pero además era dialéctica y materialista porque mantenía el principio de una realidad objetiva que existía al margen de la conciencia cognoscente.

Vemos en el proyecto del Dibujo de la vanguardia que se gesta desde el XIX y que estalla en 1947 la construcción de una lógica terciaria como ya dijimos, una situación que posiciona tres entidades ontológicas definidas: el dibujante, la obra dibujo que en determinada medida es una otredad pero también es la proyección del psiquismo y deseo del dibujante, y el contexto como modelo de la otredad; asociados en el tiempo sincrónico de la acción representativa del dibujo pero mediados por la categoría de diferencia a la que alude Derrida.

Pero además entendemos la lógica que los relaciona no como un sistema de contradicciones de oposición excluyente, pensamos en esa relación tríadica como en una zona permeable, un área o campo construido por esos tres puntos. Esas tres entidades son a nuestro entender las que posibilitaron un enfoque epistémico alterno para la representación, ya que ésta deja de ser un asunto de oposición insalvable entre realidad primera exterior y una imagen formalizada de ese mundo.

En esta nueva relación se tiende un campo triangular que será en nuestra visión la arena del acto dibujo, el territorio más allá de lo físico en el que se suscitan los acontecimientos trascendentales del dibujar, por eso entendemos esto como una flexibilización no lineal del carácter proyectual del dibujo.

Y es en este territorio tríadico en el que se emplazan los órdenes del pensamiento experiencial.

Como ya se observa, esta lógica involucró sistémicamente a las tres entidades integrantes. Y aquí habría tanto que analizar; para empezar el objeto dibujo ya no fue visto como la obra resultante de la voluntad lineal configuradora del dibujante, y aunque éste desde hacía mucho ya intuía que el dibujar no era formalizar con exactitud lo prefigurado, sino que esto se entretejía con las formas alternas que se suscitaban en el momento de la configuración, y que eran éstas las que más capacidad de enriquecimiento ofrecían al juicio del dibujante y a sus consecuencias en la formalización, es hasta los accionismos de la modernidad que se adopta plenamente la consistencia ontológica de la obra como parte de un sistema causal recursivo.

En esta lógica terciaria la posición del dibujante dejó de ser la del sujeto analítico, la inteligencia objetiva que se mantenía al margen de lo dibujado y pasó a ser impactado por el modelo y el proceso, como por la obra misma que paradójicamente era su creación, de ahí que el proyecto moderno de la representación se extienda hacia una consideración del acto dibujo como un fenómeno de causalidad retroactiva en el que el creador y la creación se auto determinan, pero siempre conteniendo una mezcla interiorizada de lo que contextualmente pesa como realidad. Por eso para nosotros, la representación deja de ser una mera forma mimética referencial de un modelo objetual, y pasa a ser entendida como un suceso convocado por el dibujante en el que tres entidades ontogénicas interactúan en un evento de autoconstrucción, generando un suceso temporal y espacial que es el acto del dibujo, de ahí se entiende la cualidad auto generativa del pensamiento proyectual del dibujo y su circularidad retroactiva coincidente con el pensamiento constructivista al que antes aludíamos. 
Aventuramos aquí una extensión analítica: la lógica terciaria del acto de dibujar que hemos mencionado, y en gran medida varias de las ideas que habremos de exponer, no las entendemos como posibilidades de deconstrucción del proceso del dibujo y la representación; ya que no se basan en una descomposición de las partes que los integran para establecer una posibilidad de recombinación estructural alterna, sino que nos centramos en la formulación de categorías y conceptos que resultan nuevos para el sistema, elementos que generan una posible lógica analítica distinta y una serie de relaciones epistémicas también diferentes, se han incluido fichas nuevas al juego, quizá su sentido esté cambiando.

La liga que unía mimesis y representación termina por disociarse en el siglo XIX, esto ya es una convención analítica, pero fue así porque la misma consistencia ontológica de la realidad dificultó su definición, el modo de existencia de las cosas se relativizó y por tanto su representación mimética comenzó a carecer de sentido; en su continuo devenir cambiante, la realidad y las cosas, el contexto, escaparon de la antigua manera de representación que tras siglos se había ido construyendo. Pero no vemos ese proceso histórico de formalización de la representación como la construcción del espacio cartesiano con sus referentes ortogonales, ni como el modelo perspectivo renacentista, tal como la crítica lo entiende en un aplanamiento fácil del análisis.

Ya nos hemos dedicado a la mención de los modelos del dibujo como formas del pensamiento, en ese análisis dejamos en claro que la relación mimética como posibilidad de unión del referente modelo con su imagen representación, en realidad es más un proceso de construcción de sistemas formales que derivan hacia un ejercicio de relativización y enriquecimiento de este postulado inicial.

Por eso es que al referirnos al giro de la representación del 1800, nosotros aludimos a un proceso en el que la lógica de la representación cobra poco a poco una conciencia tautológica que termina por entender la autonomía ontológica de la obra, su proceso y sus estrategias como parte del sentido de la representación.

Más allá del ámbito de lo estético, este plegamiento del lenguaje sobre sí mismo que volvió consciente al dibujante de la mediación de sus formas como lenguaje, implicó un cambio epistemológico que impactó radicalmente el sentido y definición de la representación. Al hacerse el lenguaje un asunto en sí mismo, la noción de lo real, vive una extensión y se problematiza, y con ello la relación que unía históricamente al dibujante con sus modelos. Por situaciones como estas es que anteriormente nos hemos referido a los modelos de la interioridad del dibujo, aquellos cuya existencia ocurre en el ámbito de lo abstracto y subjetivo del lenguaje formalizado, y los que corresponden a las formas psíquicas que pueblan la mente del dibujante.

Ya con el Romanticismo la estética abandona cualquier referencia a una naturaleza no humana, pero esta noción de lo humano reconoce su condición escindida y fragmentada y la imposibilidad de una integración bajo el concepto de totalidad integrada.

Los fragmentos de una naturaleza y realidad rota cuestionan la consistencia de la representación dentro del dibujo bajo una intención mimética, como ya la aventura de Cozens lo ejemplifica, a la vez que abren la puerta finalmente a una concepción de la representación como un mundo de formas otras, que se originan en la gestalt experiencial del dibujante, por tanto, representación no será más ya, símil de lo referencial aludido sino la 
construcción de una estructura de formas cuya lógica se debe al pensamiento abstracto pero particularizado en cada artista.

Todavía en el XIX y sus vanguardias, la representación del dibujo y la pintura mediante sus formas permitían una alusión a lo natural como modelo de origen, pero el efecto de las formalizaciones era a no dudarlo el de la conciencia de estar ante una alteridad ontológica de la imagen.

Las vanguardias del XIX y más específicamente las del XX operan sobre una disección de las partes del lenguaje plástico y visual, esto es coincidente con el proceso de fragmentación de la realidad, desintegración que a partir de ahí no será revertida ya en la búsqueda de una estructura total integradora, ni del modelo natural ni del logos que de sentido a la totalidad de fragmentos que integran las parcialidades del lenguaje.

La vanguardia termina por concluir el conflicto iniciado en el Manierismo, cuando se advertía la distancia existente entre las libertades formalistas que no emanaban del análisis riguroso de los modelos naturales, como hemos visto el conflicto se resolvió por la ruta del imperativo de la forma disociada como proceso de plegamiento del lenguaje por sobre la referencialidad icónica de la representación.

Pero la diseminación del lenguaje y sus formas de representación siempre operó sobre una individualidad creciente del artista, la unidad del estilo dominando la individualidad se desplazó hacia la firma autógrafa del dibujante, situación que resultó fundamental en el proyecto del dibujo del siglo XX y sus procesos de representación, y no porque estos dejaran de serlo, sino porque se desplazaron hacia una expansión potencial en razón de la diversidad implicada.

Así la transformación del pensamiento representacional del dibujo es el correlato de una transformación más profunda acontecida en lo social, la que corresponde al periodo de maduración de la modernidad, la que antecede a su quiebra como proyecto de institución en la segunda mitad del XX.

Pero el hecho es que en ese corte histórico, al dispersarse el sentido unívoco de lo que se entendía por realidad, la conciencia filosófica trascendente concluyó el sinsentido de la lógica mimética de la representación, para dirigirse paulatinamente hacia el entendimiento de ésta como una mediación entre la realidad concreta referencial y el pensamiento del sujeto cognoscente.

Por eso en la imagen del dibujo crece la desconfianza entre lo trazado como correspondencia de lo visto vivido, la representación titubea y esa biunivocidad se rompe. Los procesos de cambio y deriva de las formas representativas que otrora acontecieron en espacios de tiempo dilatados se sucederán en ese momento con prontitudes aceleradas, cosa que por si misma no valoramos como un ejercicio positivo del proyecto moderno.

Nuevamente Fernando Rampérez puntualiza la exigencia de un sistema de análisis que se corresponda con la génesis interior del fenómeno a revisar, (Rampérez, La quiebra de la representación Pág. 45) señala la dificultad de tomar el pensamiento de Foucault directamente como soporte de análisis para la quiebra de la representación, debido a su carencia de particularidades para extenderlo a todos los campos de la cultura. 
En el fondo éste es un reconocimiento de las diferencias, las particularidades que una misma categoría asume al introducirse en distintos campos. Como parte de estas variaciones en el terreno del dibujo, la representación es una apertura que disocia la imagen referencial del modelo al que alude, pero no rompe el vínculo sustantivo de ser una realidad formal creada como resultado de un entendimiento eidético del contexto.

La representación se entendió también como la repetición del objeto o la naturaleza representada; éste es otro punto en el que es importante hacer distinciones, ya desde que entendemos la representación como la construcción de una segunda realidad formalizada se comprende que esto no es una repetición de lo original, es una presencia distinta, lo es porque su naturaleza no es del mismo orden estructural del modelo del que parte como realidad externa. Su esencia o eidos se desprende del pensamiento que la determina y su lógica reflexiva, así como de lo aleatorio del proceso de configuración, es la búsqueda de una estructura no conocida, una cuya forma no sabemos, pero de la que tenemos la certeza de que es posible.

El pensamiento eidético determina y da sentido a la representación, la lógica de la estructura y su forma es la esencia representada, por eso es que para el dibujante la representación pierde sentido como repetición de la realidad; la mímesis como reflejo de una manifestación primera, revelación de lo natural a la conciencia y su deseo de reproducción, es trascendida en el ejercicio del dibujo.

¿Cómo entender entonces el dibujo y la representación como repetición? El dibujo es disciplina del pensamiento eidético, por tanto se dirige a la esencia del modelo y a su expresión formal, pero ahora no a la de la cosa vista, sino a la de la obra que se busca elaborar. El arte de la vanguardia dejó esto bien en claro, el problema del dibujo y la representación no era solo la ruptura del vínculo que lo acercaba a la realidad natural y contextual sino el de la representación como búsqueda de mundos de primera generación para el pensamiento visual.

Tal vez el pensamiento del dibujo desde hace lo menos 200 años no sea ni siquiera interpretación de lo real, puede ser más una recreación, en el sentido que anexa cualidades a una realidad perceptual, cualidades no vistas en el sujeto sino conjeturadas en el proceso de prefigurarlo y configurarlo en la acción del dibujar.

Este es un pensamiento estratégico que flexibiliza el método, rompiendo su carácter positivista, pero que no renuncia a la construcción de una lógica que busca su formalización, y por tanto una racionalidad, razón que entiende que la forma de la representación no solo es la forma del modelo objeto sino la forma del pensamiento del dibujo, forma del lenguaje, tanto de sus signos como de sus prácticas y procesos, formalizaciones que no corresponden sino a una abstracción objetiva experiencial, una que no existe en el mundo de la exterioridad, la forma del pensamiento, y dentro de este la del dibujo, no tiene porque ser entendida como la forma del mundo objetual; así como sus maneras procedimentales y estratégicas representan formalizaciones de prácticas, así su referencialidad no nos remite nuevamente a un mundo objetual sino a un mundo del pensamiento y prácticas relacionales.

Dado lo anterior, el concepto de Presencia, que resulta capital en el análisis de la representación vive también una extensión flexible, la presencia deja de ser la otredad ontológica 
modelo del dibujo, para extenderse hacia la presencia de una subjetividad que entiende la forma del dibujo como campo del lenguaje y la presencia del pensamiento contextual sobre el dibujo manifiesta en el ideario colectivo.

No es solo el modelo frente al dibujante, son también las presencias interiorizadas las que operan como otredad en la subjetividad y que inician en él el camino de la formalización de la representación.

Esta suma de presencias no es sino la diferencia de aquello que alterna con el dibujante y que provoca la búsqueda de lo no presente, lo que escapa al propio sentido, sujeto forma o pensamiento.

Por eso en una lógica tríadica de la representación aparece la obra como una entidad de diferencia y presencia ineludible, ya que su estado inicial es de la prefiguración, idea e intención, que puebla la mente del dibujante en la primeridad del acto dibujo, después, el tiempo y espacio del fenómeno se llena con el dibujo objeto que se va haciendo, con su plasticidad, visualidad y condensación conceptual, cuyo sentido es el del querer decir del dibujante, pero que se nos revela con su propia autonomía, sobre todo desde una perspectiva de apertura compleja en el entendimiento del proceso. Pero al fin y al cabo la obra es el anclaje sin el que nos perderíamos en la mera intención sin llegar a sopesar los resultados fácticos de la representación. A este trecho del proceso lo entendemos como la mecánica del acto dibujo.

La obra dibujo se constituye en realidad alterna mediante la representación, se coloca en nuestra subjetividad junto con la realidad contextual, cuya descomposición y fragmentación se incrementa con el ejercicio representacional del dibujo.

Esta alternancia de realidades es un trabajo de producción e interpenetración, no de repetición, como mucho se ha entendido, producción de visiones nuevas de lo natural, lo cultural, lo conceptual del dibujo y del mundo psíquico, todo ello dentro de una representación que propone formas nuevas o variaciones que integran el lenguaje como mediación intersubjetiva.

La representación es la manifestación del sentido de las cosas, pero expresada o condensada en una visión formalizada en el campo del dibujo, ya desde esta posición se concluye que las formas de la representación mantienen el principio de variabilidad tanto como el pensamiento que las anima y que se encuentra enmarcado y determinado por su particularidad histórica, pero dentro de este marco contextual se mantiene siempre la vocación del sentido crítico existencial que orienta al dibujante en la dirección de construir abducciones a las estructuras puestas en juego.

Las variaciones abductivas dentro de la representación del dibujo son deudoras en parte del sentido experimental de la vanguardia. La experimentación fue una categoría y estrategia (casi método) central del arte de vanguardia. Se experimentó tanto con la investigación previa en que se funda el pensamiento del proyecto, como con la obra misma y su acontecer temporal como evento, en ese punto es donde aparece y cobra peso la accidentalidad como manifestación estocástica propia del dibujar y hacer el arte. Partiendo de esta oposición ineludible es que se logran las extensiones abductivas en los procesos de presentación del dibujo. Esas tensiones irreductibles nos gritan el sentido 
siempre abierto y variable de las prácticas y formas de la representación. A diferencia del pensamiento filosófico que intenta un entendimiento general de la representación en su nexo con la realidad y el sujeto, la representación del dibujo se basa recurrentemente en el cuestionamiento continuo del sistema y en el entendimiento del mundo contextual, aunque su tendencia sea la de lograr estabilizaciones de modelos formales, el dibujante sabe de antemano lo perenne de las formas, que una vez alcanzadas en una coherencia sistémica contienen en sus relaciones de estructura y estrategia el semen de lo no coincidente, lo que basará la nueva operación representacional, resuenan aquí las líneas del pensamiento de Damish.

La representación comprende ahora el ámbito de lo formal, tanto de lo visual como de las acciones, pero también el pensamiento que rebasa lo natural y se desplaza hacia lo antes no pensado en el campo ampliado de lo que rodea al sistema del dibujo y su relación con su territorio conceptual en íntima relación con el campo de lo existencial y subjetivo.

El dibujante solo es en este tiempo un pliegue en el conocimiento del dibujo, pliegue que será más significativo en tanto rebase su propio proyecto y penetre en la episteme del territorio general de la disciplina.

Las cosas a representar se nos escapan en su verdad fundamental, de ahí la imposibilidad de representarlas de manera mimética definitiva en el espacio del dibujo, pero ya que éste ha sido siempre una práctica del pensamiento, busca ahora como entonces una manera procedimental y formalizada de poner en la imagen aquello que signifique una articulación del contexto en el que la acción y el dibujante están inscritos. La representación como práctica proyectual se hunde ahora en lo imposible de definir, el modo de ser común de las cosas y la exterioridad, solo aspira a la formulación particular de una visión interiorizada, que sin embargo continúa expandiendo el horizonte reflexivo y subjetivo de quienes asistimos a la presencia de esas obras.

Es característico de la representación actual la aceptación del tiempo sólo como condición existencial, renunciando con ello a la búsqueda del absoluto general de ese tiempo como concepto racional generalizante.

Lo real se divide y multiplica en infinitas parcelas que se pluralizan todavía más en las subjetividades de los espectadores, de manera que el humanismo moderno cede frente a una antroposofía de lo múltiple infinito.

Para el dibujante el encuentro con lo otro, los otros, que antes eran sus modelos fuente original, es indefinible, aunque sigue siendo enunciable, tanto en lo estrictamente icónico como en lo tautológico que se hunde en la propia forma y proyecto del dibujo y el lenguaje.

La temporalidad es para el dibujante el arco del acontecimiento de la acción configurante, pero igual es una dimensión reflexiva en la que ubica sus fundamentos y conceptos en un acto histórico comparativo (el modelo histórico) que lo coloca en la posición de optar por la no repetición y buscar el logro de la diferencia.

Al reconocer el tiempo y el pensamiento precedente, el dibujante hace consciente su finitud y particularidad, pero con ello implica la necesidad de lo otro, lo que no siendo él no se deja representar, así la forma de la representación es una diseminación y apertura que se orienta desde el sentido del lenguaje hasta el de las prácticas que lo engendran. 
Lo otro y los otros se encuentran en la región de lo exterior al dibujante, se relacionan mediante fuerzas y presiones hasta adquirir estados temporales de estabilidad (recordando a Morin), existen en la interioridad del dibujante como presencias subjetivadas, pero no solo están ahí, ejercen su fuerza y presión en la autonomía y psique del dibujante. Esto es lo que entendemos como presión interiorizada del contexto y que marca en cierta medida la intencionalidad autónoma del proyecto del dibujante. Por eso vemos en la representación algo más que una operación de captura de información de los modelos sujetos, para luego configurar una formalización.

Para nuestra visión de la representación resulta esencial mantener la demarcación de lo que conforma la exterioridad, el campo de existencia de modelos y otredades que entendemos como unidad ontológica diferenciada de la del dibujante, y aunque puede esto parecer un enredo tenemos que agregar todavía la existencia sustantiva de la obra dibujo como entidad participante en el juego, de esta circunstancia es que derivamos una lógica terciaria de relaciones como generadora del espacio no físico de la representación, llamamos a este espacio la arena del dibujo, acaso esta región sea parte de lo que se ha dado en llamar los no lugares.

La representación en el dibujo hace tiempo que dejó de ser intención mimética, no buscó más reproducir lo visible sino producir otra realidad, que aunque concreta en la facticidad de la obra, sin embargo se debe al pensamiento abstracto, subjetivo y estratégico del dibujante. Y no fue una operación lógica matemática y filosófica la que aclaró esto al entendimiento del dibujante y el artista, fue, en el caso de la pintura y el dibujo la construcción de los collages cubistas, la pintura de Magritte hasta llegar a LeWitt, lo que condujo a la ruptura del paradigma de la referencialidad de la imagen, con estas obras la separación entre el signo lingüístico escrito y la imagen representada fue superada, ampliando con ello el campo epistémico de la representación y colocándolos en una dinámica recursiva y circular.

Cuando la acción se colocó como eje capital de las obras, estas tuvieron que ser entendidas como una práctica extendida, de lo estrictamente objetual al de la estrategia y el pensamiento que la anima, esta es otra de la extensiones a que se vio sometido el concepto de representación, ya que resultó evidente que el mensaje contenido en la obra se ampliaba al tiempo y espacio del acontecimiento.

La siguiente extensión sería dada al incluir una estrategia semiótica para estructurar la huella indexal autógrafa del dibujante en un abanico de formulaciones icónicas que organizaron la pincelada en todo un sistema sígnico (Ryman, Toroni, Manzoni).

Con las reflexiones anteriores se inicia el trazo de un mapa extendido del territorio de la representación, para configurar una concepción en la que esta abarca tanto el campo de la imagen como el de las prácticas y estrategias del dibujo y su hibridación con otras lógicas del lenguaje; territorio mediado y configurado bajo la presión del contexto que marca el principio de autonomía del dibujante.

Extender la categoría de representación hacia una concepción que la entienda como una función; aplicación del pensamiento que solo se concibe en el tiempo de la acción que implica memoria y tiempo.

La representación al ser operada en el dibujar es conciencia del pensamiento y las prácticas mediante las cuales se objetiva la obra configurada, pensamiento que hace posible la reflexión del acto de conocimiento. Por eso para nosotros la extensión de la represen- 
tación atañe tanto al logro del objeto dibujo como al de las propias prácticas dibujísticas; en términos de Gómez Molina la representación nos representa en el acto de representar el mundo, la representación expresa el acontecimiento específico del dibujar sin llegar jamás a agotarlo.

Pensamos que para este momento la representación abarca una lógica tanto del campo de los modelos contextuales en su proceso de ser formalizados mediante el dibujar, como otra que se refiere a la interioridad autorreferencial del proceso y la acción de representar; lógica de una función y sentido de una obra dibujo.

Rampérez introduce en este punto dos conceptos que nos resultan importantes y que ya desde antes bordeaban nuestras reflexiones; son el de acontecimiento y el de sentido.

Recuperando nuestro pensamiento de líneas arriba, resulta más o menos claro el porqué entender la representación como un acontecimiento, no solo pensamos en análisis de operaciones conceptuales y de lenguaje enmarcadas en la inmaterialidad del pensamiento lógico, la representación para el dibujante es siempre una ubicación espacial y temporal fenoménica, una que particulariza el acto dibujo. Y es esta particularidad fenoménica de la acción la que da sentido lógico al decurso de la configuración y a las reflexiones estratégicas, sentido que en su ausencia convertiría la representación en mera parodia de lo ilógico y solo casual.

Tomemos una cita de Lyotard incluida en el texto de Rampérez que precisa la centralidad del acontecimiento en el terreno de la representación.

"Si (...) es un acontecimiento, lo es ante todo como tensor o pasaje intenso, y ese tensor requiere, no el espacio tridimensional euclidiano del volumen teátrico y del cuerpo social organizado, sino el espacio ene dimensional, neutro e imprevisible de la película libidinal engendrada por el propio acontecimiento tensor de su singularidad."144

Agregamos ahora un segmento de Rampérez que completa la exposición.

"La clave está en la ruptura de un espacio previsible que provoca un acontecimiento que provoca el nombre de tal; el espacio (libidinal o no) es engendrado por el propio acontecimiento. No solo Deleuze o Lyotard, también por ejemplo Levinas o Derrida tratan de él (y lo convierten incluso en política). Sólo es acontecimiento lo impredecible que estábamos sin embargo esperando, lo no derivable; sólo es una actitud abierta (y esto no nos deja lejos de la ética) la que está abierta a lo inesperado, la dispuesta a experimentar lo imposible. No se trata de una estética de lo novedoso, ya gastada; lo que llega es distinto a lo esperado y siempre lo mismo otra vez; pero sin sorpresa, el acontecimiento no es tal. Eso queremos decir al afirmar que el sentido está siempre por producir, siempre por hacer: sin constituir nunca el resultado previsible de una maquinaria mecánica, la obra nueva y repetida sorprende cada vez con la singularidad del instante eterno reclamado por Nietzsche."145

\footnotetext{
144 Rampérez Fernando. La quiebra de la representación: El arte de vanguardia y la estética moderna. Madrid: Ed. Dykinson; 2004. (Col. Comentarios y monografías) P. 275. 145 ídem.
} 
Por eso cada acto del dibujo produce y contiene su sentido y es una apertura del juego de la representación, uno que formaliza sus analogías en las que navegamos perdiéndonos sin que tengamos un hilo que retomar necesariamente. La obra acontece: tiene lugar, da lugar, ha lugar, genera su espacio, en términos de Rampérez; genera el acontecer del acto de representación decimos nosotros.

Y, como lo dijimos al referirnos a la abducción, se trata de encontrar lo mismo de otra manera o bien de llegar a lo no pensado y no enunciado en las formalizaciones representacionales que nos anteceden como dibujantes.

Representar es buscar la construcción de formas bajo la coherencia de un sentido ya enunciado pero con la dirección de su extensión, su negación o su contraste ante formas y sistemas de lo no visto hasta ese entonces, con la conciencia de lo imposible de formalizaciones definitivas. Esta es la tarea del dibujante

El sentido causal de la representación será siempre el producto cuya coherencia se deriva de la estrategia de la acción del dibujo, está siempre dado por el uso de nuevas maquinarias epistémicas de representación; las que operan el juego entre el contexto, la obra y el autor. Por eso extendemos el concepto de representación desde su entendimiento semiótico inicial que la veía como la operación que relacionaba el objeto nombrado con su expresión formal, hacia una representación que formaliza estados del mundo, un contenido cultural para exponerlo.

Esta ruptura entre referente y sentido nos lleva a la extensión esencial de la representación, hacia las prácticas culturales más que a la búsqueda de la semejanza.

El espacio y el tiempo del acontecimiento, que nosotros llamamos el acto dibujo, son los de la representación en sí, constituyen el ámbito de una nueva vivencia, la del dibujar, la del vivir en tiempo real y en tiempo muerto, un vivir no tanto los términos de unas definiciones precisas y racionales, como la modernidad naciente y el determinismo lo pensaron. Sujeto y acción extienden la definición temporal llevándola hacia un relativismo incierto pero mucho más fecundo. Sujeto, objeto y contexto se interpenetran junto con la obra dibujo en una causalidad retroactiva que es la que hemos dicho corresponde a una lógica terciaria demarcadora de un espacio para el acto.

Este espacio generado no está vacío en su inicio, se puebla por el preexistente modelístico de los dibujos históricos y por la presión que el gran otro contextual ejerce sobre el dibujante; es aquí donde nuestro pensar se desprende una vez más de lo investigado por otros autores, el espacio y tiempo fenoménico del acto dibujo se satura desde el inicio de presencias que lo marcan y determinan, aunque en su vocación el dibujante siempre se ha de orientar hacia la variación de lo pensado y lo aún no formalizado; tratar de esta dinámica es de por sí un tema particular, uno que resulta fundamental en la reflexión del acto dibujo y que lo lleva más allá de lo que se enunció en la modernidad tardía como la pintura de acción y por extensión la acción de dibujar.

Pero el pensamiento proyectual del dibujo es ya un acontecer de la representación, desde la gestación del proyecto puebla el territorio mental y la intencionalidad del dibujante, 
este estado de prefiguración representacional existe tanto en intenciones y estrategias que son formas integrantes del acto como en formas referidas a lo conceptual disciplinar. Todo esto integra un conjunto que se coloca entre la realidad contextual y el dibujante, y el espectador en extenso. Es una entidad que media nuestro entender del mundo, pero nos detenemos un tanto antes de asumir esta mediación como un suplemento de la realidad. Pensamos el devenir del arte occidental como un viaje que se origina en la intencionalidad mimética del dibujo pero que se desplaza hacia la construcción de una entidad que se alterna con la realidad contextual y natural pero que se sabe otra. Este seria el viaje que se completa en la autorreflexividad tautológica de las artes en la modernidad integracionista y que se continúa en el análisis de Greenberg hasta la mecánica del conceptualismo y la abstracción Post pictórica.

La inclusión de lo supletorio en la realidad la sentimos asociada al sentido de carencia y pérdida de lo real, para nosotros la representación no suple la realidad, aún en el viaje mencionado pensamos la representación como un mundo construido, pero del que se sabe que por más similitud que hubiera llegado a tener en la imagen, ésta siempre fue un símil de lo real, otra realidad que por ser diferente a la causal natural sorprendía por su parecido, pero desde el manierismo (lo hemos mencionado) el carácter mediúmnico mimético de la representación vive sus derivaciones que lo llevarán siglos más tarde hasta la conformación de un mundo alterno, uno que coexiste con el social, el natural y aún el del pensamiento objetivo.

Pero en el pensamiento de Derrida se introduce la idea de différance, lo diferente, la representación como algo diferente a lo originario, concepto que nos permite comprender el carácter generador de la representación y que organiza en gran medida el rumbo flexible del acto dibujo sin por ello renunciar a la consecución formal.

La representación buscó la restitución de la cosa misma en su eidos, su lógica estructural que la determina, muy temprano, para 1500 el dibujo abandonó tal proyecto, cuando el dibujante renacentista declaró la inexistencia de la razón proporcional numérica en el orden de la naturaleza, y su posibilidad de existir solo en el orden arbitrario del concepto mental, concluyó con claridad la diferencia existente entre la cosa y su representación, por más que visualmente se hablara de una mímesis.

La diferencia abre el sentido singular del acto de representar, lo entiende como irrepetible aunque el pensamiento modelístico tienda a su generalización.

La singularidad del acto dibujo es importante porque, en su reconocimiento lleva la posibilidad de subvertir la tendencia estable de las formas y prácticas de la representación.

Esta es una mecánica fundamental; hasta el término del siglo XIX y aún dentro del Neoplasticismo y los purismos formales del XX, la estructura conceptual compositiva y sus leyes estaban enunciadas antes del acto de configurar la obra, eran pre icónicas, antecedían a la obra y la determinaban, el método operaba sobre lo representado.

Los conceptos de la acción, diferencia y singularidad terminan por redefinir la práctica de la representación. Acción que ya no opera con las formas y sistemas preexistentes como determinantes sino como inclusiones iniciales a las que la representación intenta desnaturalizar en una práctica flexible. 
Cuando aceptamos la carencia de absolutos en la representación del dibujo, sea en el accionar o sus formas, definimos el acto de dibujar como un continuo sin término, pero que sabemos se llenará de formalizaciones diferentes, tanto a las de lo real desplegado ante nuestra percepción como a las de la historia, sea esta la de las propias formas o la del repertorio modelístico que nos antecede.

Siempre que dibujamos estamos traduciendo, lo pensado, lo visto, lo vivido, lo histórico. Llevamos el sentido del decir de aquella realidad hacia otro discurso que sabemos imperfecto e incompleto, sabemos incluso que existen otros traductores y que su sentido nos es diferente. La representación es una traslación de sentidos que formalizamos, no una mímesis que en el dibujo descansaría sobre la habilidad manual más limitada. Nos permite investigar y probar géneros, estilos, procesos y estrategias, pero no cierra nunca estas categorías ni las relaciones sistémicas que se puedan lograr.

Porque la única manera de experimentar un mundo es habitarlo, quedarse a vivir en él, así la representación en el dibujo no es asunto de declaraciones restrictivas; siempre será ejercicio posible en tanto exista un dibujante que lo penetre, cargado no de la arbitrariedad, sino de la conciencia teórica e histórica de su campo como con el poder de la configuración, rebasando la estrategia de las asociaciones sígnicas elementales como estructuradoras de una sintaxis del decir, pero no alumbradoras de las imágenes de nueva generación.

\section{IV-2 VIVENCIA Y EXPERIENCIA EN EL ACTO DIBUJO}

Mediante la extensión de la representación, llegamos a la formulación del acto dibujo como una puesta en acción de la representación. Mencionamos que este acto se basa en las relaciones complejas que se generan en la triada ontológica constituida por el modelo, la obra en proceso y el dibujante. Al aludir al acto de dibujar como una práctica ampliada de la representación nos hemos adentrado en algunos desplazamientos, que a nuestro entender aclaran en parte nuestro pensamiento hipotético (el de la vigencia del dibujo como práctica de representación).

Antes de adentrarnos en la reflexión de la interioridad del propio acto de dibujar es necesario exponer algunas demarcaciones dentro de las que se da la relación tríadica que ya mencionamos. Consideramos importante este espacio reflexivo no porque intentemos lograr absolutos filosóficos, sino porque en este campo se desarrollan las relaciones que unen al dibujante con la realidad contextual y la obra que se prefigura, y que, ya en su configuración integran lo propio de la acción de dibujar.

La representación en el Dibujo a diferencia de la fotografía, el teatro, la pintura u otras artes se manifiesta en tres posibilidades de relación ontológica, la primera que lo liga sistémicamente con los modelos que son parte de la naturaleza o el mundo objetual y que muchas veces son la fuente de su interés, en segunda instancia y sin que esto comporte un orden de prelación, el dibujante guarda relación con la obra en proceso como integración del pensamiento autocrítico del lenguaje, plegamiento autorreferencial y en tercer lugar el dibujante se autogenera en la aplicación del acto de dibujar, obra y lenguaje construyen al sujeto que los configura. 
Antes de una mecánica de la interioridad del acto dibujo se requiere precisar un tanto la lógica de relación de los sujetos implicados que se interpenetran en el suceso del dibujo.

El estudio del acto-dibujo significa pensarlo como fenómeno, como algo que sucede y se despliega en una dimensión de espacio y tiempo particular y en la conciencia del dibujante. Este acto se inicia en el momento que el dibujante pasa de la vivencia primera al estado de una vivencia intencionada que es el inicio del pensamiento proyectual. Se trata de pensar en ese acto por sí mismo, y no como la vía para la expresión, situación que ya lo traslada a la exterioridad.

En este segmento dejaremos para un futuro las explicaciones generalizadoras, nos mantendremos en el nivel de la observación de lo acontecido y en cierta medida en su descripción, pero al hacerlo no marcamos objetivos limitados, nos inclinamos por el contrario hacia una lógica que al describir lo acontecido en el acto del dibujo se torna fuertemente irrebatible y con potencial de convertirse en base de construcciones conceptuales ulteriores. Si ya con esta investigación buscábamos internarnos en la reflexión particular endógena del dibujo es en este punto en donde se precisa el objetivo.

La observación de los modelos del dibujo y las relaciones que determinan su interioridad marcan la esencia eidética del suceso.

Pensamos que el acto-dibujo se llena en sus primeros momentos de un pensamiento pre-racional, pero no hemos dicho que tenga vocación anti racional. Es una vocación de mantener activo ese primer estado acontecido, el de la vivencia, prolongarlo lo más posible en el tiempo del hacer, dejando para un después el estado de la experiencia, que ya se distingue del vivir el fenómeno para en su lugar hacerlo pasar por cualquier modelo de pensamiento, buscando con ello su reducción lógica y el establecimiento primero de causas y factores comunes y reductibles.

En primera instancia nos interesa el dibujar como un relación particularizada con el mundo, cultural objetual conceptual y subjetivo.

Buscamos quizá inútilmente mantener fresca la vibración psíquica y los aromas de una vivencia primera, la del dibujante como ser humano, aquella en la que entabla sus primeros diálogos de identidad con los otros. Acaso frente al proyecto crítico y el proyecto positivo del arte nosotros estemos hablando de la vivencia como ese estado del vivir que diferencia la postura fenomenológica de aquella racional como esencia del pensamiento filosófico.

El arranque del acto dibujo se puede dar ya sea como manifestación de relación vivencial en un sentido de identidad entre el sujeto y su contexto, bien se puede iniciar como acto de vocación histórico recursivo y tautológico, en esta segunda instancia la vivencia se inicia como el vivir pensando para desembocar en el vivir ejecutando.

El acto dibujo continua siendo un vivir incluso en el momento de configurar, cuando el dibujante se posiciona frente a los sujetos o vive la inmersión dentro del modelo dibujado, todo esto antes de dejar caer sobre su análisis el peso de la crítica, la teoría del arte, los estudios visuales o cualquier otro aparato reflexivo emisor de juicios.

Aquí tenemos claro que lo que decimos se puede entender como un estado imposible de 
vivir en ausencia de pensamiento, pero el dibujo y su historia nos han demostrado que esto es posible; en ese sentido se relaciona profundamente el dibujar con una concepción fenomenológica.

Con esta idea de la vivencia tenemos una visión que tiende a lo empírico del acto dibujo, porque basa su origen en el retorno a los modelos mismos y a la práctica ejecutante del dibujar. Todo basado en una vivencia del ver y la mirada, el ver como experiencia racionalizante y el mirar como el sentir de nuevo el mundo con la mirada.

La visión asociada a la experiencia conformando una maquinaria intelectual; y la mirada unida a la vivencia, estado del pensamiento pre sígnico y la reflexión trascendente del dibujar llevan al dibujante a la conciencia del acto-dibujo.

La esencia o eidos desde una posición vivencial empírica se extiende al territorio de a) lo material, b) lo regional como marca cultural y c) la esencia del objeto en general, misma que siempre es asunto de una formalización. Sobre este triple territorio formulado por la filosofía es que se desenvuelve el proceso experiencial del dibujar, y aquí señalamos la coincidencia de esta formulación con el pensar que desde momentos anteriores anima nuestra tesis, en los parágrafos siguientes retornaremos a este particular sobre los argumentos vertidos por Deleuze al revisar la mecánica del acto de pintar.

Pero en el acto-dibujo no es posible arribar a la esencia del modelo ontológico o del autorreferencial sin considerar de modo sustantivo la importancia de la vivencia.

Para nosotros y desde hace mucho, la vivencia es la vocación del estar ahí, voluntad que va más allá de lo empírico que no es arbitrariedad, reflexión que se basa en la consideración que la realidad como modelo y otredad en el acontecimiento del dibujar, binomio que comporta tanto una esencia de lo general estructural y trascendente como una particular y fenoménica que les es dada por lo contingente y emergente de cada caso.

En todos los campos empíricos del conocimiento humano se encuentra implicada una esencia particular de la conciencia, ya Husserl lo anotaba y dedicó a este estudio una parte de su trabajo, así de esta manera, las reflexiones sobre el acto-dibujo son coincidentes con esta visión, y dentro de ella la consideración de la vivencia es nuestro punto fenoménico de arranque.

Pensamos en la vivencia como en la región de la intuición sensible (introyección del mundo al vivirlo), la cual tiene un carácter eminentemente subjetivo y psicológico, y vemos en la experiencia el terreno de la intuición lógica categorial que se desarrolla sobre el fondo vivencial de la acción de dibujar.

El dibujante es un sujeto específico que existe siempre configurando en una puntualización espacial y temporal, no es una definición abstracta, funda su ser en el hacer el dibujo aunque se posicione siempre de cara a la historia y la teoría del arte y de su campo.

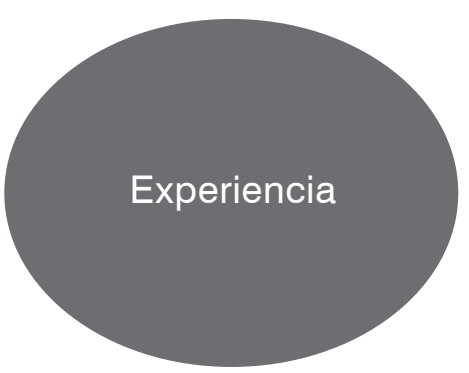

Vivencia 
Bajo una consideración fenoménica, la aniquilación del dibujo como acto, significa la interrupción del flujo de vivencias que son la fuente del pensamiento experiencial empírico del campo disciplinar, por eso es que al remitir el dibujo a una práctica de asociaciones sígnico semánticas se corre hacia el territorio de su disolución disciplinar dentro del territorio de la estrategia global de las artes.

Cada vivencia actual del dibujante al trazar se encuentra inscrita en el cúmulo de vivencias pasadas, pero que son vivencias en tanto que aún palpitan en las resonancias psíquicas y no pasan a ser desarmadas por el pensamiento experiencial, solo entendiendo esta relación compleja y quizá un tanto absurda podemos considerar el porqué el dibujar es una forma de vida.

Pero este vivir y estas vivencias no son idénticas a las del vivir de todo el mudo, ya Lyotard nos recuerda la huella intencional de toda vivencia (Lyotard, La fenomenología Pág. 41), en este caso la intencionalidad de las vivencias se encuentran desde su inicio enmarcadas por la ponderación que las une y dirige hacia lo interior de un campo que es el del dibujo y a la búsqueda para desatar el caos del cual ha de emerger la forma nueva, el diagrama según las palabras de Deleuze. Esto significa que el repertorio vivencial del dibujante no se separa del cúmulo experiencial lógico que opera al mismo tiempo en el acto de dibujar, sino que ambos se transfunden en un pensamiento que formula lo trascendental del acto dibujo, su teoría.

La vivencia del dibujar sucede siempre en tiempo presente, al conectarse con el cúmulo de vivencias anteriores nos remite a un presente poblado igual de las ausencias constituidas en huellas psíquicas, estas son esencia del motor del dibujar; remite también al plano experiencial reflexivo. El comparativo consciente que une vivencia y experiencia del dibujo se suscita en el presente y es a la vez una vivencia, la de la conciencia que nos revela la configuración posible de las formas y estrategias de la representación, pero que si bien implica lo conceptual no es una premisa que deba determinar primeramente la acción del dibujo.

En ese presente vivencial y experiencial del dibujar nos autocorregimos y nos construimos en la aplicación del pensamiento proyectual; por eso la consistencia de lo pensado y alumbrado al dibujar solo acontece en la realización del acto de dibujar en primera persona; aunque en la acción se vean involucradas presencias ontológicas varias.

Los aportes del acto-dibujo no se fundan tanto en la estrategia de relación semántica entre los signos incluidos en la imagen citacionista posmoderna, se fundan en las posibilidades configurantes que la vivencia ofrece, en las que dibujante, modelos, estrategia y configuración resultan concordantes en una obra que es representación formalizada.

La vivencia como campo temporal tiene dos momentos en el conocimiento experiencial del dibujar, el de la conclusión conceptual racional y el del acontecimiento objetivo que refuerza, amplía o niega la apuesta conceptual.

Esta es una dinámica recursiva, en ella no prescindimos de las operaciones conceptualizantes, pero no las establecemos en una linealidad operativa como fue el caso de muchas obras conceptuales, recordemos el cuadrado blanco y rojo de Sol LeWitt. 
El acontecer del acto-dibujo puede partir tanto de la región teórica conceptual del sistema modelístico del dibujo como de la asistencia vivencial frente a los modelos ontológicos. Tenemos que recordar que el concepto al dibujar no es ajeno al modelo que dibujamos, el modelo al dibujar es sujeto conceptualizado tanto como detonante psíquico; el pensamiento experiencial que el dibujante manifiesta en ese acto es también modelo formal de una manera particular reflexiva.

Se hace necesario hasta cierto punto (y si fuere posible), disociar la lógica general del arte contemporáneo, de la lógica específica de lo vivido en la acción de dibujar. Para el dibujante, el dibujo no es objeto teórico centralmente, éste es asumido como vivencia en la que busca encontrar sentido a la acción y formalización a lo pensado.

La existencia de paradigmas y tendencias consistentes en el arte en general no nos deberían bastar por sí solas para determinar la práctica del dibujar.

La forma del pensar en la acción es relación sistémica interpenetrada con la forma del modelo contextual que se dibuja; esto sólo es posible en el tiempo vivencial del dibujar. De ahí la importancia de una descripción casi enumerativa de lo acontecido en el acto del dibujo, descripción que trata tanto de la relación intersubjetiva de los modelos y el dibujante como de la conceptualización elaborada en esa acción.

"El mundo no es un objeto cuya ley de constitución poseo a través de mi yo, es el medio natural y el campo de todos mis pensamientos y de todas mis percepciones explícitas. La verdad no habita solamente en el hombre interior, o mejor dicho no hay hombre interior, el hombre es el mundo, y es en el mundo donde se conoce" (Merleau Ponty, Fenomenología de la percepción, Pág. 9). Así el mundo es negado como exterioridad y afirmado como medio, el yo es negado como interioridad y afirmado como existente." 146

Los modelos en sentido amplio son punto de partida en el que se inscribe la vivencia, arranque para la generación de formas, tanto del pensar como de la imagen, el dibujante no ha de asumirlas como norte de determinación lineal, el dibujar no debe ser la graficación simple desprendida de una cierta consideración sígnica proyectada; porque los modelos para el dibujante son más bien entidades con las que vive una relación, otredades con principio de autonomía que lo afectan tanto en su presencia como en su ausencia.

La reflexión experiencial del acto dibujo trata de aclarar las situaciones constantes dentro de esa práctica.

Tanto en las disonancias y variaciones, como en las recurrencias se detectan ligas de condición, esa constancia de factores en el seno del campo del dibujo nos conduce a su teoría, objetivo poco considerado en la condición de lo posmoderno.

El conjunto de síntomas observados en la práctica histórica del dibujo no nos conduce sin embargo a una constante metodológica determinista, sino a un mapa que muestra la geografía del campo y sus pobladores, geografía que se particulariza y reconstruye en la vivencia como categoría indispensable en el dibujar. La importancia del concepto dibujístico emanado de la experiencia no depende de la amplitud de casos operados, como de la efectividad configurante que una estructura dibujada muestra al estructurar

146 Lyotard J. F. La fenomenología. Barcelona: Ed. Paidós Studio; 1989. P. 72. 
sistémicamente la obra del dibujo; formas o estructuras que muchas veces pasan y cambian lo prefigurado.

Cuando anteponemos el pensamiento conceptual y la experiencia al momento de dibujar, estamos prejuiciando nuestra práctica, limitamos en muchos sentidos las posibilidades de apertura de la acción. Por eso el pensamiento proyectual es considerado en el dibujo un norte estratégico más que un trazo procedimental, este es el verdadero sentido objetivo del pensamiento teórico y conceptual del dibujo, que habrá de ser relativizado en la vivencia dentro de la realidad contextual y la acción configurante.

El núcleo asertivo de la configuración pocas veces se alcanza al primer intento, por eso la práctica del dibujar es recurrente, requiere de una suma de vivencias que desemboquen en el plano experiencial, en un reservorio de vivencias que pueden desplegarse en la sincronía temporal del pensamiento y no por mera gimnasia psicomotriz.

Pero aquí recordamos que el plano de la vivencia no se centra en un solipsismo, ni existencial ni reflexivo, es un terreno de indivisión con lo otro y con los otros, ya sea mediante su pensar expresado en las formulaciones del dibujo, tanto como en su presencia existencial directa. En esta relación es en la que podemos entrever porqué consideramos el acto dibujo como una forma de diálogo en sentido múltiple.

Cundo prefiguramos y configuramos al dibujar, el pensamiento y las formas históricas del dibujo se despliegan en tiempo presente, son un ahora del pasado, buscan en ese presente las formas y pensamientos de lo que aún no arriba, las representaciones futuras, que en cuanto se concretan se instituyen en pasado, esta complejidad temporal es la constitución de la temporalidad de la vivencia al dibujar, bajo sus preceptos podemos entender porqué las formas y el pensamiento del pasado del dibujo se relacionan sistémicamente con las formas que se encuentran en configuración.

La historia de la representación y sus modelos conceptuales en el campo del dibujo, es una forma de conciencia experiencial, la que el sector de los artistas tienen de sí mismos y de su práctica.

Pero esta conciencia experiencial integra un universo de vivencias acontecidas en lo particular del dibujante y su acto, suma fenoménica de riqueza expandida que opera como base de las futuras generalizaciones teorizantes.

Todo este acontecer es inseparable tanto del seno histórico contextual en el que se genera y de las formulaciones experienciales, pero no vivenciales de otros sectores que analizan el fenómeno del dibujo, circunstancia epistémica que define el ser de esas prácticas.

Quizá recordando a Lyotard, en un sentido fenoménico, el acto-dibujo sea la conciencia experiencial de una corriente de vivencias.

\section{IV-3 EL ACTO DIBUJO COMO UN ACTO DE REPRESENTACIÓN}

"Propongo aquí una suerte de síntesis reflexiva sobre los fundamentos de la fotografía, tanto sobre la imagen como sobre el acto que la definen, y sin que se pueda disociar uno de otra. Pues la fotografía, ya volveremos sobre esto, no es sólo una imagen producida 
por un acto, es también, ante todo, un verdadero acto icónico $<<$ en sí $>>$ es consustancialmente una imagen-acto (véase como epígrafe la cita de Denis Roche). En otros términos, la separación tradicional entre el producto (el mensaje acabado) y el proceso (el acto generador realizándose) ya no es aquí pertinente. Con la fotografía, ya no nos resulta posible pensar la fotografía fuera de su modo constitutivo, fuera de aquello que la hace ser como tal, dando por supuesto por una parte que esta $<<$ génesis $>>$ puede ser tanto un acto de producción propiamente dicho (la toma) como un acto de recepción o difusión, y por otra parte que esta indistinción entre el acto y la imagen no excluye en modo alguno la necesidad de una distancia fundamental, de una desviación en su núcleo mismo (volveremos sobre esto). Se ve que, en este contexto, la dimensión pragmática aparece como el inevitable punto de fuga de toda perspectiva sobre la fotografía... Se tratará aquí de concebir ese $<<$ fotográfico $>>$ como una categoría que no sea tanto estética, semiótica o histórica como fundamentalmente epistémica, una verdadera categoría de pensamiento, absolutamente singular y que introduce a una relación específica con los signos, con el tiempo, con el espacio, con lo real, con el sujeto, con el ser y con el hacer." ${ }^{147}$

Considerar el dibujo como un acto de representación es una posibilidad teórica en la que se estudia tanto la historia del pensamiento dibujístico como la construcción de las bases de un análisis particular al interior del campo disciplinar del dibujo y su práctica como producción artística hoy día.

Como se advierte esta postura del análisis se liga con el modelo analítico de Damish y con el de Dubois. El trabajo de Damish data de medio siglo atrás, el de Dubois de hace veinte años; en este punto de la investigación ese material nos reporta una utilidad invaluable, pero mencionamos que nuestra concepción del dibujo como un acto no está dada por el conocimiento del material de estos autores, esta idea se fue configurando en nuestro pensamiento a partir de 1992, cuando realizábamos la producción de una serie de pinturas y dibujos sobre el tema del bosque como modelo de estructuras espaciales y compositivas no lineales, trabajo que nos ocupó varios años; nos surgió también como conclusión paulatina elaborada en el ejercicio como docentes del dibujo.

Pero es claro en todo caso que, la lucidez del pensamiento de esos pensadores al analizar el tema que nos ocupa opera como línea conductora, aunque en el proceso se marquen las distancias con nuestra propia visión.

Pensamos que esta tarea puede ser abordada bajo la consideración del dibujo como un acto, un suceso que implica la conciencia epistémica del dibujante, el análisis del artista en una particularidad espacial y temporal y el devenir fenoménico del proceso. Las posibilidades modelísticas enunciadas por Damish y que constituyen una forma específica del pensar (dibujísticamente en este caso) se trasladan al espacio y tiempo de la acción prefigurativa y ejecutante del dibujar, particularizando una mecánica sistémica que se diversifica en cada ocasión que el dibujar acontece. Sin embargo lo que hemos tratado como modelos del pensamiento del dibujo en el capítulo anterior al referirnos a Damish, en el análisis de Alain Bois se remite al plano general trascendente del pensamiento del artista, no se desarrolla como red de trazos finos que particularicen la mecánica del acto de dibujar en relación con la representación, ese es el segmento que intentamos continuar. En lo referente al trabajo de Dubois sobre el Acto Fotográfico se mantienen esencialmente

147 Dubois Philippe. El acto fotográfico, de la representación a la recepción. Barcelona: Ed. Paidós Comunicación; 1986. P. 54. 
dos variantes con nuestro campo analítico, una en el sentido de que la práctica de la fotografía mantiene diferencias epistemológicas sustantivas con el ejercicio del dibujar, lo cual imposibilita la traslación directa de los conceptos y método de ese análisis al del territorio del dibujo; centralmente Dubois analiza el acto fotográfico como un acto icónico, pero en nuestra reflexión nos encaminamos a entender el dibujo como un acto de representación centralmente, lo que cambia radicalmente la estructura teórica del discurso. En segunda instancia la tesis de Dubois desarrolla un planteamiento que incluye fundamentos semióticos como marcadores del análisis, en nuestro caso no es así, aunque en momentos recurramos sobre todo a la noción de índex y mencionemos el proceso del dibujo como una posible estructura semántica intersígnica.

Pero como sea, reconocemos la importancia del trabajo de estos autores dentro de nuestra propia reflexión.

El dibujo objeto no es solo una imagen, resultado de una habilidad en el trazo y la técnica de elaboración como la idea común lo sugiere. Es el resultado de un acto intencionado desde el inicio, en él se integra la visión histórica que el dibujante tiene, su estrategia y proyecto frente al sistema mismo del dibujo así como la búsqueda subjetiva de lo poético.

Definir el dibujo como una acción, podría llevarnos al plano práctico y empirista, si bien podemos entender que toda acción en el terreno del dibujar es antecedida por un norte reflexivo que la origina, pero esa intencionalidad no se basa en una operación experiencial dilatada necesariamente, ni en la certeza y confianza total del dibujante en el material perceptual que le proveen sus sentidos. Por eso hablamos del dibujo como un acto, para introducirnos en una dimensión de causalidad intencionada en la que las partes y estrategias del proceso son consideradas como esencia del proyecto desde su inicio, y en donde la parte empírica es la comprobación, pero sobre todo la apertura pragmática del supuesto proyectual prefigurado, una intención que no está reñida incluso con la búsqueda de procesos emanados de lo profundo de la subjetividad cuya lógica no sea formal en el sentido clásico.

La pintura de acción y el Informalismo en buena parte, desplazaron el centro epistémico del proceso hacia la figura del artista, pero consideraron ya como un núcleo de resistencia a la obra misma en su proceso de construcción, esto aclaró la existencia de una lógica dialéctica, la que opone la obra y el artista, mediada por un proceso de lucha, en el que era obligada la victoria del pintor, o como en el caso de las opiniones de Pollock, si el pintor lograba el estado de interpenetración con el proceso, nada podía estar mal y todo era incluido dentro de la obra.

Pero en esta lógica dual, el tercer factor, el de el modelo como región ontológica constituyente de la acción de dibujar se vio disminuido o diluido en la presencia del propio artista, su peso como constituyente de la operación representacional fue desplazado.

$Y$ no es que todo esto haya significado un equívoco dentro de la historia del dibujo, lo que sucede es que para hoy el espacio de la representación se extiende hacia una lógica sistémica, donde las entidades que lo ocupan se definen hacia una triada entre cuya área triangular acontece el acto del dibujo.

Pensamos en el acto dibujo como un acto de representación; la base sobre la que se asienta es el campo de relación que se establece entre tres entidades, la del Dibujante, el contexto y la obra dibujo. 
Puede parecer una idea simple en extremo, pero el acto dibujo, implica la primeridad vivencial de el dibujante, es este quien personifica la vivencia primera, vivencia ya interesada en el carácter del dibujo, relacionado con el contexto en el que se ubica, la primeridad del dibujante da lugar al pensamiento del proyecto específico, que se inicia con la comprensión del tema (ya se precisó sobre el particular, de como el tema es la primera expansión del conflicto dibujístico y trasciende la anécdota narrativa), así el proyecto ya es estrategia explicitada, obra existente en la utopía, pero que desde ahí mantiene un peso conformante. El dibujante también se asume como la entidad de cruce entre lo vivido en el contexto y las operaciones gestálticas, perceptuales y experienciales; prefiguración y configuración que se relacionan en la estrategia del dibujar y mediante la cual se desencadena la secuencia del acto de representación; en términos de la lógica semiótica, el dibujante es el espacio de la segundidad, espacio en el que se da forma y constitución sígnica a lo concebido en el encuentro con el mundo.

Mediante el momento y la acción de la experiencia, lo pensado en el mundo se constituye en obra, suceso, imagen y signo.

Entenderemos la naturaleza y la realidad como modelos del dibujante, forman parte de la realidad contextual, objetos, sujetos, fenómenos y ecología cultural. Todo aquello que no siendo el dibujante es el espacio concreto, objetivo y subjetivo, mundo en el que se encuentra inmerso.

Si bien este contexto solo existe para el dibujante en el espacio de su vivencia y en el plano experiencial, tiene la conciencia de que se encuentra frente a o dentro de una alteridad, un otro que existe con independencia y que guarda su propio principio de autodeterminación y autonomía.

Todo dibujo obra y toda acción de dibujar se origina y se refiere a un contexto que es su espacio y tiempo de existencia. Aún los modelos tautológicos y auto referenciales del Dibujo existen como una forma contextual del pensamiento trascendente.

Para el dibujante, la obra dibujo puede ser la expresión de una combinatoria sígnica o diagramática, construcción sintáctica que permita el ejercicio de la consecución expresiva, puede ser también la acción que representa las prácticas de la representación y su pensamiento estratégico, en ocasiones es un suceso de acciones que lindan con lo inefable, cosas, formas y situaciones de explicación imposible pero que aparecen con claridad en el pensamiento experiencial del ejecutante. Pero en un sentido extenso la obra es una presencia ontológica con la que intentamos la configuración formal imaginada en el proyecto, en su acontecer muestra la resistencia a ser como su definición inicial le requería, esa particularidad de ser en tanto acontece la constituye en una presencia, lo que en sí es interesante, ya que de origen se debe a la intención y acción del dibujante, pero en su tiempo de configuración adquiere una forma de ser con la que se entabla un diálogo profundo. Pero después de la modernidad la obra del dibujo se extiende hacia la esencia de un acontecimiento, su ontología se desplaza hacia la de un suceso en el que no solo lo objetual es materia del sentido significante. La obra del dibujo puede ser pensamiento, forma, objeto o suceso base del proceso empírico (que no empirista) del dibujo y espacio de las aperturas abductivas de la estrategia y la experiencia del dibujante.

Para el dibujante, el referente no será ya visto como la presencia a sustituir en el acto de dibujar; sus referentes operan como núcleos ontológicos de alteridad frente a los que se 
posiciona, sea para formular formas y estructuras o para subvertir la lógica que los define como modelos de pensamiento. Hoy la relación con los modelos no es más ya una cuestión de naturaleza o sujetos solamente; es asunto de prácticas culturales y subjetivas en sentido extenso.

El acto dibujo es la representación en acción, genera y estructura formalmente huellas indexales y psíquicas, imágenes complejas y sistemas sígnicos o actos performáticos.

Cuando pensamos en el dibujo como un acto, no nos interesa solo la imagen o la obra como representación, nuestro interés se dirige igual hacia la acción que los genera, el hacer mismo y sus modalidades de acontecer y constituirse. La riqueza del dibujo está más en la historia de sus prácticas y repertorios formales que en la suma de los objetos generados. La consideración del dibujo como fenómeno se dirige a pensar las relaciones triádicas entre el contexto, el dibujante y sus actos de formalización. En su génesis siempre manifiesta la existencia de un referente, objetual o teórico, frente al que se posiciona para desmantelarlo en un proceso de formalización, ya sea de las prácticas o de la imagen.

En el acto dibujo se asumen posturas flexibles sobre la representación, puede esta ser pensada y operada por el dibujante como un volver a hacer presente el referente del que se parte, pero igualmente al dibujar se puede construir una imagen distante formalmente del modelo que la origina, también puede ser aplicada como la gestación de un sistema autorreferencial de las formas y repertorios del dibujo, así se observa que el dibujante opera sobre una práctica flexible que da vigencia y apertura a la categoría de representación.

La relación que al dibujar se asume con la realidad, es la de una selección parcial y arbitraria, un recorte de lo real, esto es factible ya que al dibujante no le interesa la obtención de la verdad, cuando menos no la verdad en el sentido generalizante y objetivo, le interesa aquella parte o región de lo real que es vivida con particular cualidad y que desencadena el pensamiento de la posibilidad para configurar un algo.

Por largo tiempo en la historia y aún en nuestros días, el dibujar fue considerado como una manera de tomar información y datos de la naturaleza y la realidad, para luego llevarlos a una graficación formalizada; esto constituyó una postura epistémica de la acción de dibujar que más o menos operó desde el trabajo renacentista hasta la maduración de las ciencias positivas y su nexo con el dibujo, observar al dibujar, fue sinónimo de muestreo de datos visuales que determinaban la esencia formal de lo observado.

Pero ya en el siglo XIX la representación en el dibujo se desplazó hacia ordenes estructurales y formales que se encontraban en planos mucho más profundos de los modelos y que no se ofrecían a la percepción visual simple; a lo anterior se sumó la visión cada vez más clara de que la estructura de la forma en las artes no tenía porqué ser coincidente con la de lo observado en la naturaleza, el dibujar para tomar datos de lo real se extendió hacia una relación epistémica diferente hacia los modelos.

En efecto, el dibujar negó desde ahí su búsqueda de lo especular como reflejo de los modelos, ya que no podía aspirar al logro de la verdad empírica, el dibujo naturalista de Millet y Corot manifiesta por ejemplo la semilla de formas muy distantes de lo mimético en comparación del dibujo realista de Illia Repin o de Antón Perov. 
El dibujo dirige sus intenciones de representación hacia diversas actitudes que van todas en el sentido de desplazar la búsqueda de la verdad o la estructura y el sistema absoluto, cuya base se encuentra en lo real natural y objetual como modelo para las formas, para asentarse sobre todo en el sistema mismo del dibujo y sus procesos, lo que Deleuze analizó en sus últimas cátedras que impartió sobre la práctica de la pintura y que se publicaron en su libro "Pintura, el concepto de diagrama"148 agregamos nosotros que aquella apertura teórica de la representación es la que nos conduce a la relación triple que exponemos y que genera la construcción del suceso del dibujar así como una forma representacional y una obra que abren y actualizan el sentido de la práctica de dibujar.

Esta relación del dibujante con sus modelos o referentes se orienta tanto en el sentido de posicionarse frente a, lo que se quiere dibujar o dentro de, lo que se está dibujando, pero también hacia la posibilidad de carecer de referentes objetuales u originar sus formalizaciones tanto de procesos y estrategias como de segmentos de la realidad subjetivos o abstractos, regiones puras del pensamiento modelístico.

Vemos el acto de dibujar como el territorio de la construcción de estructuras conceptuales y formales de representación, igualmente, actos que nos hablan de una postura frente a la historia y la realidad, aparatos de relaciones sintácticas, constelaciones intersígnicas que organizan un discurso, pero también ejercemos el dibujar como un continuo depositar huellas indexales, sedimentos físicos y psíquicos de la acción y el pensamiento, fijados en lo concreto de la materia y sus estratos y de los trazos realizados, este es el territorio de poesía inefable dirigido a la subjetividad de los otros.

El acto de dibujar oscila en la configuración desde la huella de la herida y la incisión, hasta la huella de la línea como pensamiento, pasando por las huellas indecibles de la psique, para dirigirse a la búsqueda de una estructura formal de primera generación, el diagrama que renueva el pensamiento eidético visual de lo humano.

Cuando dibujamos se manifiesta la condición que Peirce atribuye a los signos indiciales. Las construcciones formales del dibujar son huellas que posibilitan una conexión física con el acto que las generó, nos hablan de su tiempo vital y el estado psíquico del dibujante, también contienen las claves codificadas que permiten la visión del pensamiento conceptual que las soporta, y si es el caso, nos hablan de un modelo sujeto, pero llevando implícita la opinión que de él tiene el dibujante.

En segundo término el dibujar es un acontecimiento siempre singular, por más que se engarce en una secuencia de casos y aconteceres que establezcan una tendencia, tanto al suceder y ser una vivencia, como al lograr una particularidad formal estabilizada es siempre un caso irrepetible en sí mismo, esto es lo que le confiere en parte su esencia como práctica performática. Quizá en tercer lugar el acto de dibujar no designe tanto un referente, sino una práctica que muestra una postura compleja del ejercicio de dibujar, diríamos que los referentes del acto del dibujo se expanden mucho mas allá de lo objetual para hundirse en el territorio de lo subjetivo y el contexto cultural.

La cualidad de atestiguamiento para el acto del dibujo no se dirige a dar fe de un referente vuelto signo en la representación, es el vestigio que permanece cuando el acontecimiento

148 Deleuze Guilles. Pintura, el concepto de diagrama. Buenos Aires: Ed. Cactus, Serie clases; 2007. 
ha pasado, atestigua el acto y proceso complejo de dibujar, pensaríamos en este dibujo obra como una entidad totémica más que como testigo de una presencia referencial evocada.

Cuando el dibujante desarrolla la configuración piensa lo trazado en un sentido triple, es consciente de que traza y configura una imagen, produce huellas indiciales que muestran no sólo el sentido conceptual de las formas y su estructura sino que abren la lectura subjetiva del dibujo, sabe también que lo trazado configura un conjunto sígnico y simbólico en el que se explicita su postura histórica frente al contexto en el sentido amplio.

Partimos de entender el acto dibujo como una práctica de representación centrada en la estructuración de una imagen que integra una suma de huellas indexales, diagramas y relaciones metafóricas. Ponemos atención no solo a las obras resultantes como hasta la modernidad tardía había venido sucediendo, también lo hacemos en el proceso que es el que conduce a esos resultados, lo que constituye un desplazamiento epistemológico, situación que es la que en el fondo anima este capítulo; la reflexión nueva de la relación establecida entre el dibujante y sus modelos en un contexto determinado mediante una conciencia estratégica.

Cuentan en esta visión los niveles de la técnica como vía fáctica de concepto y como conciencia somática que marca las huellas indexales en el dibujo. Tomamos en cuenta también el conjunto de datos y operaciones reflexivas que relacionan la imagen en proceso con los modelos de que parte, el gesto de la mirada del dibujante puesta como vivencia sobre el contexto. Este desplazamiento epistémico estará cargado de consecuencias diversas. Una de estas es la de ser un acontecimiento que lleva implícita la singularidad y la irrepetibilidad, lo que es coincidente con la idea del signo indicial.

El acto de dibujar puede estar orientado en un cuádruple sentido;

a) El de contener al centro del proyecto un conflicto dramático como eje de las tensiones significantes y sintácticas.

b) El de la configuración de una entidad cargada de huellas indexales que contienen una dimensión formalizada, sensible y subjetiva dirigida al plano estético, poético, filosófico o bien arqueológico.

c) Puede también dirigirse con la intención de organizar un conjunto sígnico abstracto destinado a la centralidad del lenguaje y su teoría, dimensiones del pensamiento tautológico.

d) El acto de dibujar continúa hoy siendo una posibilidad del pensamiento proyectual, situación que le permite operar como el prefigurador del proyecto artístico, tanto en el terreno del dibujo como en el de terrenos múltiples e interdisciplinares.

El dibujo en nuestros días, como acto, recupera y mantiene vigente la formulación de Zuccari en tanto Dibujo Interno como expresión del pensamiento abstracto; pero se ubica también plenamente en el territorio del acontecimiento pragmático, esa zona de la semiosis en donde los signos y el lenguaje viven su deriva práctica social, de donde habrán de obtener en gran medida las extensiones de su propia definición y ser.

Aquí decimos nosotros que, en gran medida el dibujo de nuestros contemporáneos que se basa en la estrategia posmoderna ha sustituido la centralidad de la mímesis por la de 
referencia icónica dada, como categoría fundamental en el proceso del dibujo; no importa tanto ya la copia fiel de la imagen del modelo o figura referente pero sí, el que se haga alusión clara a su presencia y acción, no interesa tanto la forma gráfica en que se le representa (generalmente muy elemental) como la función sintáctica referencial que desarrolla en el proyecto. Nuevamente este es un desplazamiento epistemológico en el que se basa en gran medida el problema que hemos enunciado del dibujo en el ámbito del proceso posmoderno del arte y que es contrapuesto a la función de apertura formal de la representación, postura que Deleuze asigna a la práctica de la pintura y que extendemos al dibujo.

Buscamos ir más allá de ese conflicto pensando en el acto dibujo como una acción consciente en la que se intenta la elaboración del sentido artístico, sea en dirección estético-poética, simbólica-conceptual o simplemente proyectual. Con ello pensamos ahondar y explicitar la formulación de Juan Acha que dirige el dibujo hacia una forma de artizar la visión de la realidad.

Existe una distancia, o mejor dicho un espacio que media entre la vivencia del dibujante acontecida frente o dentro de su modelo y el resultado configurado ya como imagen del dibujo. En ese entreactos es cuando se suscitan las desviaciones abductivas o las intuiciones que iluminan, se sucede con plenitud de conciencia a veces, pero en otras ocasiones se da por mera sospecha y carencia de razón lógica. Son esos parajes, esos desplazamientos, esos ires y venires los que hacen el juego del acto dibujo y le dan sentido vital de mil formas diferentes, distancia entre lo visto vivido y lo intocable dibujado.

Es una escisión temporal entre lo visto y lo prefigurado que operan como modelo y lo que ahora vemos como obra dibujo.

Sabemos que lo que se nos muestra es una imagen que remite tanto a la realidad exterior, pero más, a la de la psique del dibujante y al tiempo que se extiende desde la vivencia primera en el contexto hasta la última etapa vivida en el acto de configuración. Todo ello dando sustancia a una nueva presencia que vemos como un presente simultáneo, pero que contiene el abismo enorme de lo acontecido en el trayecto.

Tenemos el principio de una separación en el tiempo y el espacio, una distancia entre el modelo referente dibujado y la imagen obra realizada, este principio es fundamental, muestra insistentemente que por más que la imagen del dibujo se nos aparezca similar al referente, es una presencia alterna, precisamente eso, un otro que campea con lo real que miramos, algo que al no ser lo mismo ni su sustituto intenta manifestarnos lo que se encuentra en la intencionalidad del dibujante.

A la falsa correspondencia mimética de la representación, el acto dibujo opone una escisión constituyente, distancia que cambia la relación misma del modelo con la imagen del dibujo y, en consecuencia nuestra relación con uno y otro.

Por más que nuestra lógica involucre tres sujetos esenciales (obra, modelo, dibujante) el acto dibujo siempre es acontecimiento en el que el dibujante ocupa la vivencia primera y es el autor de la acción, el espacio de cruce y voluntad autónoma configurante, aunque en algunos de nuestros últimos proyectos hayamos introducido a dos ejecutantes de la acción del dibujo involucrados en la consecución de un mismo acto y una sola obra.

En esa fisura que distancia la obra de su proyecto primero, generalmente el dibujante no realiza un solo dibujo, no considera que en una sola configuración logre alcanzar la idea 
prefigurada, trabaja en series, cadenas de intentos que lo acercan a la imagen pensada y que en cada ocasión le abren posibilidades de rutas o formas estructurales diversas, aprovecha todas las ocasiones y cada vez que ha jugado repite la apuesta de manera compulsiva, dibujar es la vivencia satisfactoria, mucho más que un producto terminado. Cada acto de dibujar puede reconfigurar todos los datos y pasos del proceso, esa es la lógica del acto, transitoria y singular, siempre por rehacer como acto pre-formativo. Claro que en esta perspectiva el acto de dibujar es un juego no exento de reglas, implícitas y explícitas (y quizá esto es lo que la posmodernidad como condición ha olvidado o hecho a un lado) códigos aceptados por el dibujante y la crítica y que son los que posicionan el proyecto del dibujar ante lo histórico y lo autorreferencial.

La temporalidad en la ejecución del acto dibujo puede marcarse en múltiples dinámicas, algunas más sincopadas, otras mas lineales.

Cuando el concepto o la estrategia del proyecto ha sido elaborada de manera completa, cuando el proyecto del dibujo ha considerado las partes y formas del sistema, la ejecución es un acto más lineal que intenta apegarse al programa diseñado.

Como hemos visto el dibujar también puede ser un acto instintivo y gestual de carácter expresionista; pero igualmente es una secuencia de ataques alternados, tanto en el tiempo como en la reflexión, suma de estratos que construyen una estructura sistémica con consistencia geológica para la imagen. El dibujo puede ser trabajado por días y después dejarse reposar, para volver a él con mirada crítica que recomponga lo no conveniente o que advierta relaciones alternas al pensamiento experiencial.

Pero el tiempo del dibujar es una vivencia que en su suceder nos representa en el acto de vivir una sincronía de momentos, los ya pasados y que se hacen presentes en la ausencia, uniéndose con la temporalidad presente, la de la historia y el contexto penetrando la conciencia experiencial.

No pensamos en alguna de estas dinámicas como la mejor dentro del dibujar, tampoco suceden separadas o en estado puro dentro del proceso del dibujo de cualquier autor. Pero es importante considerarlas como cortes metodológicos que nos llevan a una conciencia de lo que estamos realizando y las bases teóricas sobre las que opera nuestra práctica artística.

La dinámica temporal del dibujar permite la recomposición de lo previamente configurado, su negación o su afirmación mediante la insistencia en formas y estructuras que nos lleven a lo estético sublime, o a la cadena sígnica de citas o apropiaciones para lograr el constructo significante del proyecto. Este sería un vivir del dibujante a través de su pensar objetivo, pero la temporalidad del acto dibujo se manifiesta igual en la vivencia subjetiva, en la que afloran las pulsiones y el psiquismo, las ausencias tanto como las presencias desplegadas en el diálogo de identidad que es el dibujar.

Precisamente porque la temporalidad del acto del dibujo también es un asunto en el que se suscita la relación entre el dibujante, su modelo y la obra, en una dinámica no lineal el dibujante va y retorna a su modelo, el contexto o la obra las veces que considera necesarias, puede retomarlos una y otra vez; como fuente de información o para un análisis 
estructural, o bien como la otredad con quien se comparte un vivir que deja huellas psíquicas, las que construyen nuestra arqueología subjetiva, las que después se transmutan en estratos de la imagen y las formas de la representación.

El acto de dibujar maneja una temporalidad en la que cada trazo puede variar el carácter de la acción, y el de la imagen que está en construcción, cada grafismo es un compendio de tiempo que habla de por sí y dentro del conjunto, de manera permanente hasta que el dibujante decide que ha logrado la estabilización conceptual que considera pertinente mostrarnos o la imagen que arriba a la forma significativa, la que analiza Suzan Langer.

Ya el tiempo de la vivencia primera del dibujante dentro de un contexto o ante sus modelos comienza a diferenciarse del tiempo continuo de la vida en general, es el tiempo de una vivencia parcial y con un cierto interés, pero todavía transcurre en la línea cronológica común, en la ejecución se gesta y combina tanto el tiempo físico general como el tiempo contenido y suspendido dentro de los estratos y huellas indexales de la imagen. Cuando la obra sucede y cuando es concluida expresa una temporalidad alterna a la del decurso común de la vida, ya no es presa del tiempo cronológico evolutivo, pasa a la región del tiempo simbólico, siempre contenedor y detonador de vivencias, tiempo y suceso al que podemos recurrir una y otra vez sin necesidad de los recuerdos.

El tiempo del acto dibujo es el tiempo de la acción que detiene el devenir lineal y lo inscribe en la representación, para llevarlo a una temporalidad mayor y extendida, la que nos coloca hoy frente a las visiones y el pensamiento de hace siglos, o las de hace apenas unos años, tiempo integrado de muchos tiempos, sincronizados ahora en un mismo acontecer. El tiempo del acto dibujo es el tiempo que se detiene por un instante en el momento de la estabilización conceptual y en el del logro del sentido significante representado en la imagen o la acción performática; pero que se reanuda en el psiquismo intersubjetivo del espectador. Pero dejamos para un poco más adelante el continuar reflexionando sobre la temporalidad intrínseca del acto dibujo.

"Y este obstáculo, esta falla, este desfase... ineluctablemente conduce al sujeto al movimiento, al desplazamiento, a la travesía. Confrontado a dos universos que no coinciden, el sujeto, primero asombrado, intrigado, luego inquieto, angustiado, por fin perdido, preso cada vez más en una vertiginosa espiral, se pone a ir y venir sin descanso primero por la imagen, luego entre las imágenes, luego de la imagen al objeto, en el dispositivo, como si corriera tras una adecuación imposible, como si se tratara de atrapar un retardo por principio irrecuperable. Pues, evidentemente, cuanto más va y viene intentando unir los dos cabos, más se abre el abismo, más se amplía y profundiza la grieta, hasta el punto en que el sujeto solo puede literalmente hundirse en ella y perderse ahí para siempre..."149

\section{IV-4 EL ACTO DIBUJO COMO UN ACTO DE APERTURA Y ABDUCCIÓN}

Aún antes del primer trazo, el soporte del dibujo no está en blanco ni vacío, se encuentra habitado por el gran otro que llena el ideario del dibujante; o por el proyecto crítico que

149 Dubois Philippe. El acto fotográfico, de la representación a la recepción. Barcelona: Ed. Paidós Comunicación; 1986. P. 155. 
se encamina a su ruptura. Así pesan en el soporte y la mente, el conjunto de formas de la representación que son las que buscamos trascender.

Se dice que en el acto de dibujar trazamos el mundo de la manera en que lo miramos, pero nosotros decimos que, en ocasiones dibujamos el mundo sólo de la manera en que podemos rupestremente representarlo, o de la manera en que los diagramas introyectados culturalmente nos llevan a hacerlo, nuestro interés sería dibujar el contexto como una expansión del pensamiento eidético y como una extensión de las imágenes primeras, las que aún no han sido vistas porque no han sido dibujadas.

Hemos aludido al acto dibujo como un acto de representación; ahora nos referimos a él como un acto de apertura y abducción. Esto no quiere decir que sea una definición alterna. Pensamos el acto dibujo como un acto de representación, pero la interioridad de esta, es habitada por su esencia como práctica abductiva que expande los sistemas formales de representación y las estrategias del campo del dibujo.

La abducción y la apertura de los sistemas del dibujo puede ser el objetivo del acto de dibujar como acción de la representación.

En el capítulo Il de nuestro estudio nos detuvimos a precisar el sentido de la lógica abductiva y sus grados de profundidad gnoseológica.

La descripción que hace Deleuze de la práctica de la pintura se basa en una visión abductiva, en ella nos explicita el sentido profundo que anima al artista en la búsqueda patológica de las imágenes de primera generación, y nuevamente, es un análisis que se origina en la interioridad de la acción disciplinar de la pintura.

Este trabajo de Deleuze orientó la organización de nuestras ideas sobre este punto, lo tomaremos como apoyo y se advertirá su presencia en estos renglones..$^{150}$

Pero el entendimiento del dibujo como una práctica de abducción se originó en nuestro caso como una sospecha al realizar un trabajo de producción dibujística que terminó incluyendo la pintura y el grabado.

En este proyecto iniciamos la representación de los bosques basados en la búsqueda de estructuras espaciales y compositivas no lineales. Intentamos la organización de las imágenes sin recurrir a la perspectiva piramidal y al espacio cartesiano ortogonal.

Desde entonces nuestros proyectos de dibujo de una u otra manera se han orientado en la búsqueda abductiva de construcciones formales de representación. Pero esto lo mencionamos como fuente, como dato, y no porque pensemos haber arribado a ningún puerto o porque estemos emitiendo una propuesta. Fig. 107

Entonces: ¿Qué significa la abducción en el acto de dibujar? Significa formar conceptos que están contenidos y relacionados centralmente con los sistemas de representación del dibujo, y significa construir derivas y modificaciones a las estructuras ya dadas, todo esto dirigido hacia la búsqueda de una nueva visión eidética del contexto.

Por eso decimos que al iniciar el proyecto del dibujo la mente del dibujante se halla poblada por todo un ideario cuyos sistemas son los que se busca desplazar o revolucionar. 

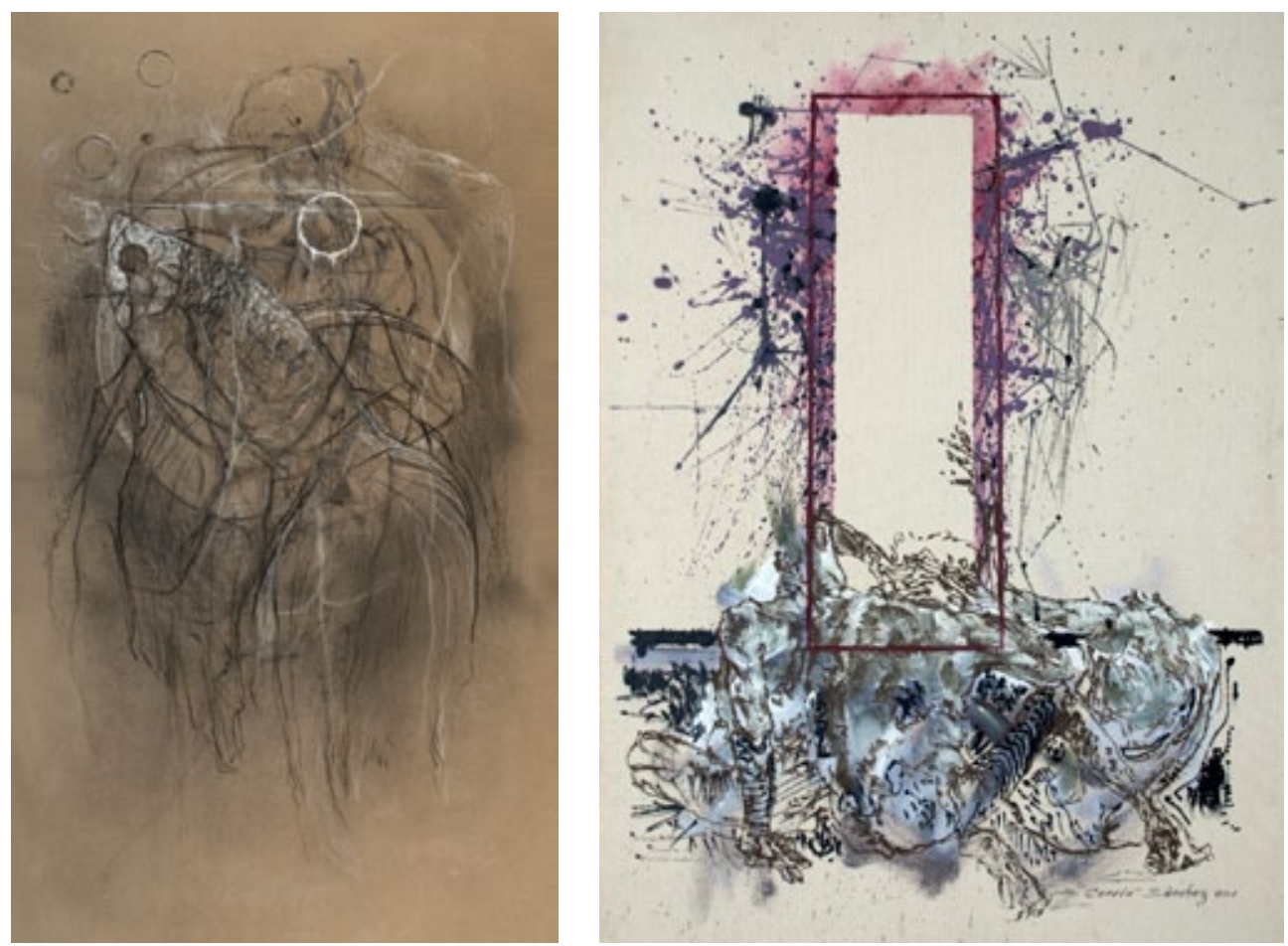

Fig. 107 Aureliano Sánchez

La búsqueda abductiva de los sistemas de representación es un proceso continuo de humanización gestáltica, incrementa nuestro entender el mundo, el lenguaje y la subjetividad alterna; quizá en ese sentido no sea tanto una parte del proyecto existencial crítico sino una simple expansión gnoseológica.

Este sentido abductivo que expande y transforma la esencia del lenguaje y el dibujo es un continuo movimiento de desplazamiento un constante emplazarse sobre ejes que también se hayan en desplazamiento; una relativización rizomática constante.

Las desviaciones abductivas de la forma y la representación llegan a ser en esencia radicales, por eso es que el acto del dibujo lleva en su interioridad el germen de la catástrofe, como lo señala Deleuze para la pintura. Catástrofe que a nuestro entender rebasa la deconstrucción para figurar un nuevo paisaje y no solo la reconfiguración de formas dadas en la naturalización anterior del sistema dibujo.

Ya el propio Deleuze se encarga de hacer una separación que entendería la catástrofe como tema narrativo literal, de aquella reflexión que entiende la catástrofe referida al propio acto de dibujar, una catástrofe que trastoca el sentido del acontecimiento del dibujo y genera sus desplazamientos relativizantes, catástrofe interna, telúrica y secreta.

Búsqueda abductiva que desborda la imagen sencilla del referente objetual aludido en el dibujo, para instalarse y hacerse visible en aquellas inflexiones de la forma cuyo motivo normativo se nos escapa. 
En el proceso productivo de los dibujantes asiduos podemos advertir esos momentos que constituyen puntos de giro abductivos, casi podríamos fechar como lo dice Deleuze los momentos en que arriba la nueva forma.

El acto de dibujar busca entonces la desestabilización de los sistemas del dibujo en aras de su propia expansión; una extensión del lenguaje que puede llevarnos a ver y entender el contexto de otra manera. Así la búsqueda del caos se remite a la intencionalidad de un nuevo origen, el germen de un dibujo que busca sentidos analógicos expandidos.

Es muy importante plantear en este punto que la alusión al tema del dibujo debe sufrir una consideración radical, desprenderse de su sentido anecdótico para convertirse en el planteamiento problemático central del proyecto, el problema será entonces el tema profundo del acto dibujo. Todos los conceptos, leyes, categorías, técnicas y estrategias del dibujo serán sometidos a una convulsión, quizá no todas al unísono, pero esencialmente de eso se trata, de generar un sisma del que pueda emerger la forma y la estrategia enriquecida, la que en adelante será patrimonio del todo social y correrá a fijarse en el imaginario colectivo.

Cuando esta esencia cuestionadora de la acción se aplica, generalmente se desata una inestabilidad que puede no llegar a resultados estructurantes en lo inmediato, es necesario entender esta acción como una lucha secuenciada en la que poco a poco se muestra el sentido configurador de nuestros actos y estrategias.

Aquí es donde el acto dibujo entendido como un proceso cobra su sentido profundo y radical; el dibujante puede estar imbuido de las mejores ideas e intenciones, pero no por ello lo dibujado será un acierto, las más de las veces eso resulta en una imagen carente de poder sobre el espectador, una imagen de la cual demasiado pronto no guardamos ningún recuerdo.

Al provocar una desestabilización cuando dibujamos, corremos el riesgo de trazar solo una masa informe, pese a la espectacularidad performática que se pueda efectuar.

El dibujo sometido a la estrategia citacionista y al proyecto alegórico casi se puede resolver en su inicial prefiguración; pero el acto dibujo siempre será una práctica de alto riesgo, una que demanda el poder ejecutante del dibujante en todo sentido.

De ahí que Deleuze afirme que la catástrofe y el caos tienen un sentido incluso pre pictórico.

"Hay una síntesis de tiempo propiamente pictórica y el acto de pintar se define por ella. Sería una síntesis de tiempo que no conviene más que a la pintura.

¿Y si me pregunto como encontrar y como llegar a definir -si esta hipótesis era justa- la síntesis de tiempo que podría llamar propiamente pictórica? Comenzamos a darnos cuenta. Suponemos que el acto de pintar remite necesariamente a una condición pre-pictórica y que, por otra parte, algo debe salir de lo que ese acto afronta. El acto de pintar debe afrontar su condición pre-pictórica de tal manera que algo salga. Tengo ahí una síntesis de tiempo, una temporalidad propia a la pintura. ¿Bajo que forma? Bajo la forma de un pre-pictórico, antes de que el pintor comience, de un acto de pintar y de algo que sale de ese acto. Y todo esto estaría en el cuadro, sería su tiempo propio. A tal punto que ante cualquier cuadro -no son en absoluto categorías generales- tendría el derecho de preguntar cual 
es su condición pre-pictórica. Muéstrenme el acto de pintar en ese cuadro y que es lo que sale de ese cuadro. Tendría entonces mi síntesis de tiempo propiamente pictórica."151

Ya en nuestros propios términos; la prefiguración en el acto dibujo se visualiza con un sentido abductivo hacia la representación y sus sistemas.

Es en este punto donde se aclara el sentido del modelo histórico como conciencia del dibujante hacia los sistemas de representación del dibujo, los que constituyen una forma de conciencia, misma que se busca subvertir.

Es importante comprender que la ruptura de las acciones del dibujo no se dirigen hacia un sensualismo personalista de la materia y sus accidentes.

"El mundo de las ideas completamente hechas es eso que tenemos en la cabeza, sean ideas colectivas, sean incluso ideas personales. Una idea personal no por eso es una buena idea."152 Son estas ideas naturalizadas las que son puestas en tensión por el acto del dibujo.

La representación formalizada del dibujar es siempre un proceso reflexivo en el que la vivencia se dirige hacia su forma experiencial consecuente, forma que es la expresión definida de un concepto originado y referido en relación a su contexto.

Esta diferencia radical nos lleva a comprender porqué de los primeros encuentros en el acto de dibujar queremos que emane el inicio de una estructura que formaliza nuestra subjetividad y vivencia y no un accidente de diletante.

Porque la vivencia primera, al arribar a una forma se dirige a un destino semántico, el de la segundidad experiencial, origen a su vez de una sintaxis particularizada y de una relación no lineal entre lo vivido y su concreción como configuración del dibujo, terceridad que se ofrece a la consideración pragmática frente al espectador.

Y todo esto no es sino una nueva etapa de la vivencia, vivir que solo es posible como circunstancia de un sujeto acontecida en una particularidad espacial y temporal; de ahí que en las líneas que quedan por venir habremos de referirnos no a la construcción de un sistema y método del dibujo, sino a la reflexión del tiempo y el espacio en que ese acontecimiento se desarrolla, así como a la triada de entidades ontológicas que en él participan.

Y es por esto que aún antes de comenzar la configuración ya han pasado muchas cosas, y siguiendo a Deleuze es por eso que dibujar comporta una catástrofe que nos dirige al caos; ¿por qué? Porque en el soporte del dibujo y en su temporalidad buscamos desembarazarnos de todo el peso del contexto y los requerimientos ideológicos, del fantasma, de aquello que Deleuze denomina "cliché", Ios clichés están ya sobre el soporte antes de que la configuración se haya desatado.

Así, al seguir a Deleuze en su libro sobre la pintura y el diagrama encontramos la corroboración de una de nuestras ideas; aquella en la que entendemos el dibujo como una práctica contextual en la que el gran otro como incidencia ideológica e histórica marca el proyecto del dibujo y las pulsiones del dibujante.

En las secuencias de imágenes y obras que emanan del acto de dibujar podemos notar

151 Deleuze Guilles. Pintura, el concepto de diagrama. Buenos Aires: Ed. Cactus, Serie clases; 2007. P. 37. 152 Ibíd., P. 54. 
esa lucha del dibujante frente a los convencionalismos, e identificar las imágenes que verdaderamente buscan la forma eidética nueva de aquellas que se basan más en una fundamentación y argumento.

Por eso es que el acto dibujo es un diluvio, una avalancha que se requiere para arrasar con esa suma de clichés, en un sentido procesual esto sería la abducción.

El dibujo expresionista y el dibujo mimético conservan su capacidad de asombrar aún a los espectadores expertos, así se manifiesta la fuerza del paradigma naturalizado; pero el dibujante consciente sabe que está parado sobre una base de formulismos convencionales.

De ahí que al dibujar en muchas ocasiones se efectúan ataques violentos y radicales a la imagen, se le mancha, se le esfuma etc., con el fin de abrir nuevamente la imagen a lo no convencional, mas allá de lo que siempre es nuestra manía configuradora, estas aperturas y negaciones resultan sustantivas en los procesos caógeneos al dibujar, porque rompen con las guías lineales del autor.

Pero en este proceso abductivo experiencial el dibujante si busca conceptos, definiciones y configuraciones formales de representación, Deleuze lo llama la búsqueda de diagramas, en el informalismo y el expresionismo moderno se les llamó la búsqueda del absoluto en cada artista. Esto nos acerca a la definición misma de cada autor sobre el dibujo, esa estabilización formal de la representación ambicionada. Algunos artistas arriban a ella y se mantienen investigando todas sus posibilidades (Newman) otros, varían de tanto a tanto y logran distintos estados de concreción abductiva a lo largo de su vida (Picasso).

Algo importante es que incluso dentro de una corriente histórica y estilística, podemos advertir la búsqueda individual de cada dibujante.

La abducción particularmente en el dibujo es totalmente variable, es la posibilidad de obras infinitas, no es para nada una idea general ni generalizante, sería entonces una zona y operación de remoción, para dar paso a la renovación de lo dibujístico, su carácter y sus categorías.

Como reflexión metodológica contamos ya con una secuencia:

- El tiempo y pensamiento pre-figurador.

- La tendencia formal de representación generada por las aperturas abductivas.

- El acto propiamente en el que esto acontece.

Deleuze nos señala la pertinencia de entender separadamente los datos de los hechos, esta distinción nos sirve y es interesante, el territorio de los datos corresponde al del pensamiento abstracto conceptuante, el de los hechos, al terreno del acontecimiento fáctico vivencial, estado pre-sígnico.

El terreno de los datos es la zona donde se enraízan los pensamientos naturalizados dominantes, clichés mentales. La zona de los hechos corresponde en el acto dibujo, al inicio de la nueva vivencia y abducción experiencial.

Los pensamientos naturalizados o clichés se manifiestan tanto en el imaginario colectivo como en el imaginario personal del dibujante y su repertorio de soluciones plásticas y 
visuales. Por eso es necesario desatar una avalancha, para conjurar los pre establecidos que amenazan con generar solo obras aceptables.

Pero así como hemos dicho que existen acciones de apertura al intervenir la obra en proceso, tenemos que decir que no todo vapuleo técnico a la imagen es un acto de reapertura.

La negación y la apertura que se busca es la del pensamiento actitudinal, el que define la postura y conciencia experiencial epistémica del dibujante; es la negación a repetirse uno mismo en sus prácticas hasta el infinito, por más afortunada que pueda ser su recepción. Pero entendemos ya entonces, que los simples dramas espontáneos son la más vacía expresión de la representación.

Nos referimos en este punto a la actitud honesta de artistas como Alberto Giacometti; en la imposibilidad de trazar la línea correcta en sus retratos repetía el trazo buscando acercarse a la certeza del dato visto, cosa que sabía, nunca iba a suceder; el resultado... lo inefable de esas obras. Fig. 108
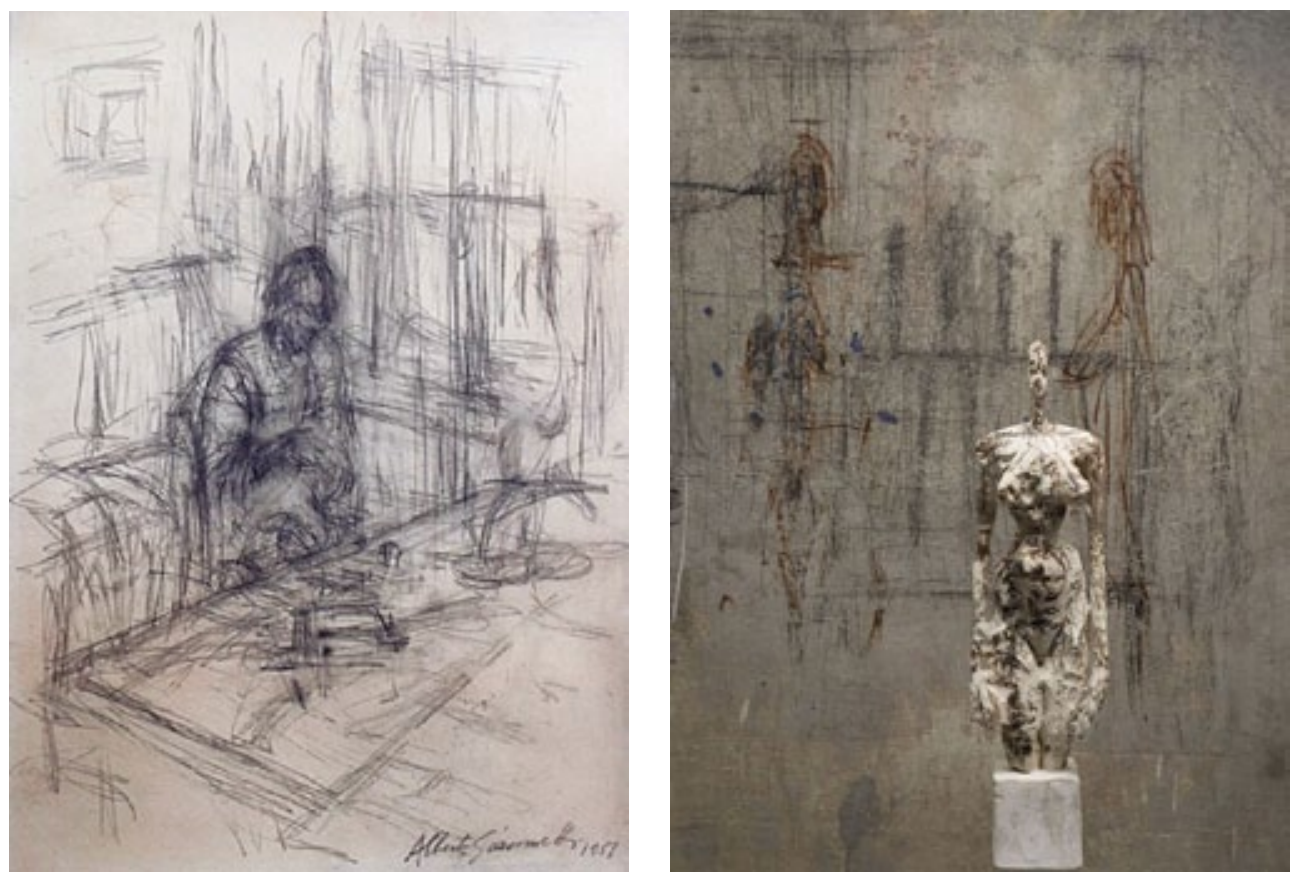

Fig. 108 Giacometti, dibujos.

Aquí podemos ya separar con claridad la habilidad, como concepto mecánico de la actitud en tanto conciencia epistémica.

Porque la actitud es base del logos y el método, en el terreno del dibujo es la conciencia del sistema de representación y la estrategia que operamos en el acto; y es la claridad abductiva que desata la avalancha inicial en contra de lo pre establecido.

Como acto y principio de actitud que se basa en las formas de representación del dibujo, se desarrolla y busca sus términos y resultados en cristalizaciones del campo del dibujo, en un 
pensamiento representacional dentro de ese campo; así la abducción deviene pensamiento y hecho dibujístico. Tomamos una cita de Deleuze que ejemplifica lo que aquí exponemos.

"Cézanne ha comprendido pictóricamente el hecho de la manzana. Eso, la manzana. Ha comprendido la manzana. Nunca nadie ha comprendido así una manzana. ¿Qué quiere decir comprender en tanto que pintor? Ese va a ser nuestro problema. Comprender una manzana quiere decir hacerla advenir como <hecho $>$, lo que Lawrence llama <el carácter manzanesco de la manzana> Eso es lo que Cézanne supo pintar como resultado de esa lucha contra el cliché, de esa búsqueda en la que nunca estaba satisfecho. ${ }^{153}$

Pero llegar a la consistencia de una estructura formal nueva es tarea de mucho tiempo y esfuerzo; cuando se logra, es sumamente difícil recomponer el proceso, volver a iniciar y ofrecer nuevamente formas de representación no vistas.

Precisemos; el momento pre figurativo del dibujo se basa en los datos previos del pensamiento contextual naturalizado; mientras que el momento de la configuración es la operación experiencial y configurante del acto dibujo.

Es importante que Deleuze excluya la narración y la figuración del hecho pictórico, dejando para ese fin el uso de otras disciplinas.

"..., diría que la lucha contra el cliché es la lucha contra toda referencia narrativa y figurativa. Un cuadro no tiene nada que figurar y nada que contar. Es la base. Si quieren contar algo, es preciso adoptar otras disciplinas, disciplinas narrativas.

...Suprimir la narración y la ilustración. Ese sería el rol del diagrama y del caos-catástrofe. Y por tanto suprimir, todos los datos figurativos, pues las figuraciones y las narraciones están dadas, son datos. Así pues, se trata de hacer pasar los datos figurativos y narrativos por el caos-germen, por la catástrofe-germen, para que salga de ahí algo completamente distinto: el hecho.

¿Qué es el hecho? Bacon lo define muy bien y vale realmente para toda la pintura. El hecho pictórico sucede cuando ustedes tienen varias Figuras sobre el cuadro -puede verse mejor a nivel de varias- sin que eso cuente ninguna historia."154

En este espacio de relativismo narrativo es que el lenguaje de la forma y la imagen, se distancian del texto literal, y se abren a la intersubjetividad interpretante, basada en visiones nuevas del mundo hechas representación.

Deleuze en sus reflexiones sobre la pintura sin embargo nos conduce maravillosamente por el territorio de la acción del dibujo. Advertimos que ponemos en juego pensamiento pictórico hacia el campo del dibujo; pero esto es posible dado que la actitud del artista y la mecánica estratégica operan sustantivamente en ambos territorios. El rango de este segmento estratégico es categorial, corresponde a una de las operaciones generales del método y las artes; la particularización se presenta al llegar al plano de los conceptos y formalizaciones referidos con mayor especificidad al territorio del dibujo.

153 Deleuze Guilles. Pintura, el concepto de diagrama. Buenos Aires: Ed. Cactus, Serie clases; 2007. P. 61, 62. 154 Ibíd., P. 65, 66. 
Nos hemos detenido a plantear esta aclaración porque el siguiente punto en el análisis de Deleuze resulta capital para entender tanto la abducción formal dentro del acto del dibujo como la manera en que lo inefable y la experiencia se plasman en la interioridad de la forma de la representación.

No se busca hacer visible lo visto físicamente (como la idea ingenua de representación lo implicaría) se trata de hacer visible la vivencia y la forma aún no vista, hacer visible la batalla del dibujar, el poder del dibujante y las fuerzas liberadas en ese suceso.

Estas fuerzas; la voluntad del dibujante de romper lo preestablecido, el buscar una nueva manera para hablar del mundo, son el verdadero continente y contenido del acto y la obra del dibujo; de modo que la obra resultante es un territorio rico y fértil saturado de huellas que expone a los otros las intenciones y las fuerzas que al operar en el acto configuran las formas de la representación.

Por eso en el dibujo trabajamos con la forma de los modelos para lograr una forma deformada, la que resulta de la aplicación de las fuerzas que operan en el acto del dibujo, y solo en esa concreción el espectador accede a la fuerzas no tangibles.

"La deformación como concepto pictórico es la deformación de la forma, es la forma en tanto que una fuerza se ejerce sobre ella, La fuerza, por su parte, no tiene forma. Es por tanto la deformación de la forma lo que debe volver visible a la fuerza que no tiene forma." ${ }^{155}$

Así la deformación hace visibles las fuerzas de la configuración, estas fuerzas y la estrategia prefigurada transforman el sistema de representación dibujística.

Cada vez más frecuentemente se hace una diferenciación entre lo visual y la mirada.

La visión asociada a los mecanismos lógicos de racionalización del mundo, una idea platónica, y la mirada entendida como el sentir el mundo por los ojos.

Aunque en ambos casos el imaginario colectivo pesa en el dibujante como cliché de prefiguración.

Esta relación de potencia tremenda solo puede ser subvertida en el momento en que la corporalidad del dibujante se desvincula del pensamiento racional metodológico prefigurante. Como si el cuerpo y la mano pudieran operar por una ruta reflexiva alterna a la del pensamiento prefigurado; y quienes dibujamos modestamente, sabemos que esto es posible, de ahí que Deleuze ponga especial interés en hablar de una mano que se desencadena de la mirada.

Parados en el absurdo diremos que se puede pensar mirando y de otro modo se puede pensar por la vía manual y somática.

Cuando la mano y el cuerpo siguen el mecanismo de la visión se establece la linealidad, pero cuando actúan de manera sincopada respecto a lo visto, se establece la posibilidad de un acto abductivo configurante.

Este es el estado convulsivo del dibujar, del que emana la nueva deformación de la representación; tanto en sus estrategias y sus procesos como en sus sistemas formales.

Para quienes dibujan es claro que también la manualidad y la corporalidad se sostienen en concepto técnica y método; esto es, en cierto sentido, en un universo preicónico.

155 Deleuze Guilles. Pintura, el concepto de diagrama. Buenos Aires: Ed. Cactus, Serie clases; 2007. P. 69. 
Pero los dibujantes son capaces de abrir el proceso abductivo porque pueden lograr el derrumbe de las coordenadas visuales que operan históricamente como generales contextualmente.

No hablamos desde una perspectiva técnica instrumental, la que promueve universalmente la habilidad manual como categoría suprema del dibujante, la que por cierto campea siempre y actualmente, aún dentro de la posmodernidad artística radical, y no se diga en los neoconceptualismos. Muniz, Nerdum, Freud etc.

Pensamos en una manualidad y corporalidad integrada también por el psiquismo del sujeto, condición y vía de su vivencia, reflexión experiencial contaminada por el sentir. Corporalidad del acto dibujo que no utiliza repertorios dados, sino que elabora su propia técnica y estrategia, la que da vía a su vivencia y la que desarma la estructura de la vieja representación.

Basados en estas premisas de análisis es que definimos el dibujo como un acto, un acto de representación y abducción, por ello no intentamos la formulación de un tratado del dibujo, ni queríamos enunciar sus leyes y conceptos, ya que al intentarlo estaríamos determinando unos límites y buscando una definición que resultaría en consecuencia excluyente; por eso nos dirigimos hacia el análisis de la posición epistemológica del dibujante y a lo sucedido en la fenomenología del dibujar.

Esperamos que en este momento comiencen a quedar explicadas nuestras hipótesis.

La conexión de esta concepción de lo corporal con la materia y los trazos que entendemos como huellas del psiquismo y el estado pre-sígnico nos permiten ubicar el momento vivencial del acto dibujo, ese momento en que la experiencia aún no establece principios de organización y proyecto. Si la fenomenología intenta la prolongación del estado vivencial antes de que la lógica filosófica abstraiga el mundo, este sería un estado fenomenológico del dibujo en su sentido más profundo y con mayor potencia abductiva.

\section{Como lo dice Deleuze:}

"... hay siempre un momento en la pintura o en un aspecto de un cuadro en el que la mano y el ojo se enfrentan como enemigos. Y es quizá uno de los momentos más interesantes de la pintura." ${ }^{156}$

Recurrimos a la noción de los trazos como índex y huella para ubicarnos en un estado todavía indefinido conceptualmente, un momento en el que el signo no se establece aún como concepto convenido, como estado codificado de lo trazado. Recordemos que índex y huella nos permiten la reconstrucción de hechos y actos mediante las marcas de la acción física, pero se diferencian del signo porque no establecen todavía esa reducción experiencial que trae como consecuencia el signo en tanto entidad que alterna con la huella, los hechos, los sujetos y su subjetividad.

El signo conlleva una dimensión subjetiva, y su entendimiento no es lineal y directo, pero con todo esto la tendencia de la imagen signo es la del logro de un sistema codificado formalmente que nos permite la lectura de la realidad y el mundo. 
Al referirnos a el acto dibujo, en su estado vivencial queremos señalar que es una práctica que se dirige a la remoción de las convenciones formales de representación en el dibujo y a la gestación de pensamiento eidético que se plasma en iconos que deforman la forma del referente, que ante todo rompen la semejanza icónica, tanto con el modelo referente como con las maneras de representación históricas.

El acto dibujo busca la creación de imágenes analógicas sin semejanza; las que guardan parentesco primordial con lo dibujado pero cuya forma deformada nos lleva a condiciones de existencia de ese modelo bajo una ontología alterna.

Es imprescindible romper esa semejanza para que el dibujar alumbre una verdadera imagen, la que brota y da sentido al dibujo como práctica de la representación y la concepción eidética.

El ícono logrado es el peso de la presencia de la imagen sin semejanza.

El acto dibujo es la acción con la cual borramos la semejanza mimética de la representación para producir una imagen nueva de presencia fáctica, y mediante la cual el dibujar ya no es la aplicación de ningún código o sistema exógeno que pese con determinación pre icónica.

\section{IV-5 ESPACIO Y LOCACIÓN; TIEMPO Y VIVENCIA EN EL ACTO DIBUJO}

La representación es la formalización tanto de la totalidad contextual como de sus parcialidades específicas; en ella el dibujante se relaciona tanto de modo sensible y subjetivo con el entorno, como de manera racional e inteligible; así, el contexto se constituye en presencias para la receptividad de nuestras vivencias.

En su sentido teórico profundo, la representación como una manifestación eidética de nuestro pensar y vivir el mundo se explica y desarrolla en una integridad espacio-temporal.

Todo nuestro vivir y nuestra experiencia del contexto se suscita en ese par fenoménico categorial; por un lado: nuestra captación y vivencia en el espacio, dirigida a su reflexión experiencial; una práctica que conceptúa el todo contextual y los sistemas del dibujo, la totalidad sólo se nos despliega como acción del intelecto.

Por otra parte, el tiempo como condición del vivir sintiendo; más que como objeto de definición teórica o formalizada.

El tiempo al dibujar, es sincronía en la que el presente se integra tanto de lo vivido, de las ausencias, del decurso de la vivencia del dibujar y el vivir en presente el pasado como activación de las huellas psíquicas y la historia.

La visión temporal en la que nos interesamos es una que se ubica fuera de las representaciones formalizantes maquinizadas en la imagen, como en el caso del Futurismo, o el Orfismo. Es un tiempo que opera en la vivencia, ante las presencias del modelo, tiempo interiorizado en el psiquismo del dibujante, tiempo de linealidad subvertida.

El total de la complejidad vivencial, sensible y abstracta del acto dibujo se entreteje espacial y temporalmente. Estos dos factores constituyen un par fenoménico esencial del acto dibujo y la representación; pero ambos elementos son acontecimiento; en tanto actuar y devenir de un sujeto, el dibujante, nuevamente una triada que genera un campo de sucesos. 
Siempre entendimos el estar aquí como una condición necesaria del dibujante, la inmersión fáctica del sujeto en el contexto con el que trabaja, de esta manera llegamos a comprender lo que para la fenomenología significa la particularidad del aquí y el ahora, la que genera una formalización puntual necesariamente, la forma deformada a la que alude Deleuze.

El aquí y ahora en tanto formalización dibujada, es la configuración experiencial particular de una cierta materia del contexto, de una porción del espacio en un lapso temporal transcurrido.

Pero lo particular de cada dibujo configurado se contrapone a la generalidad totalizante de la teoría del dibujo y el arte, tal es la dialéctica experiencial abductiva del acto dibujo, la de una particularidad espacio-temporal vivida, frente a la de la globalidad contextual teórica e histórica del sistema del dibujo.

Anteriormente planteamos como primer diagrama general del acto dibujo el que contempla: el contexto - el dibujante - la obra.

Esto como primer triada ontológica generatriz de un campo de sucesos.

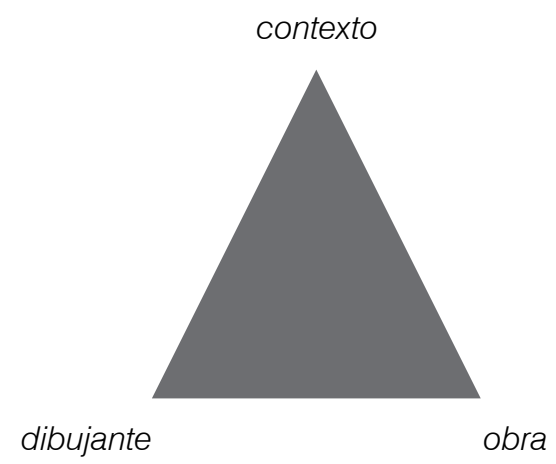

Nuestro segundo plano de relación tríadica estaría integrado por el espacio - el tiempo el dibujante interrelacionados en la acción del dibujar, referidos al acto en sí.

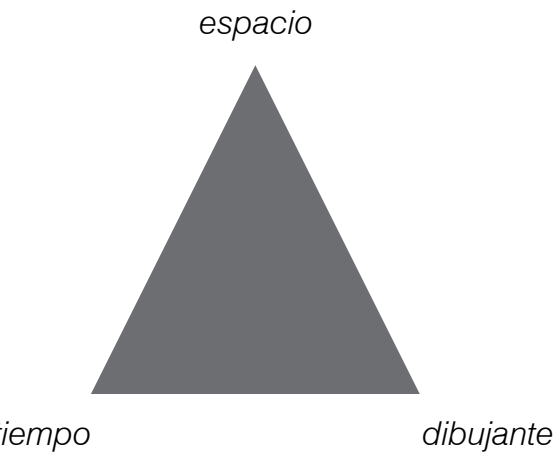

El espacio como reflexión problematizada y parte del dibujo, se hizo presente como una preocupación a partir del proceso en el que realizamos nuestras series de dibujos. 
Poco a poco nos encaminamos a su elaboración conceptual, pero ante todo, el espacio se nos desplegó siempre en dos sentidos; como componente de las construcciones formales compositivas y de las locaciones puntuales en que trabajamos.

La conciencia del espacio en el acto dibujo requiere del conocimiento de sus sistemas formales históricos de parte del dibujante, no sólo de manera teórica, sino de su conocimiento en la práctica del dibujar y en su manejo y dominio en la configuración de la obra.

Sabemos que la ficción espacial del plano de cuadro renacentista, lo es en tanto reducción geométrica del mecanismo de la visión, recorte que encuadra un segmento del mundo externo; es esencialmente la misma retícula que asiste la práctica del dibujo, la cámara fotográfica, las pantallas del ordenador; ventana que separa y delimita.

Pero esta tesis no es el lugar para intentar un cuerpo taxonómico del espacio a la manera de Wucius Wong; además de que no buscamos rediscutir una vez más la consabida entronación del espacio de la perspectiva piramidal renacentista y su negación a partir de los proyectos de la modernidad plástica y visual del siglo XIX y el siglo XX.

Ese filón analítico ha sido intensamente trabajado.

En este punto nos interesa mirar el asunto del espacio y el dibujo desde una doble variación que acaso resulta poco usual, el espacio psíquico como interioridad del dibujante y el espacio como locación o puntualización contextual. Ambas variaciones desde la complejidad que ya hemos venido exponiendo.

Pensemos el espacio como locación, desde una postura que no se funde solo en supuestos racionales prefigurados, que sea más una conciencia del estar aquí, en gran medida como nos lo revelara Lucy Lippard (mirando al derredor, en donde estamos y en donde deberíamos estar), un estar en la locación mirando al derredor, cuestionándonos nuestra identidad, un saber en donde está situado temporal y puntualmente el dibujante, esto como vivencia de un contexto físico, social y natural; un habitar los territorios. Acción y vivencia que depositan un caudal de huellas en la memoria pero sobre todo en el psiquismo de nuestro dibujante.

Ya el situacionismo utilizaba el término "deriva" para referirse a la vivencia del sujeto en el espacio del paisaje. Se buscó la formulación de una psicogeografía como manera alterna de entender los efectos del medio espacial sobre el sujeto.

El espacio como locación es una unidad psicoambiental y cultural, sus componentes como parte del contexto generan la identidad de los individuos con ese entorno.

Las distancias al dibujar no son solo objeto de dimensiones y proporciones, son igual distancias entre polos emotivos generados en la vivencia del entorno.

El espacio en el acto dibujo, no es tanto un mapa con señales claras de recorrido, pero si acaso ese espacio puede ser cartografiado, contendría las puntualizaciones emotivas de las huellas psíquicas.

La causalidad que estructura el espacio del acto dibujo; más que compositiva es aleatoria sobre una base emocional y política.

Solo el espectador especializado compartiría con el dibujante una lectura formalizada y compositiva del espacio; el resto, quienes nos miran, interiorizan la imagen propuesta 
operando por empatía, pasión y tacto de la mirada. Cundo buscan la lógica de la visión solo encuentran la falta de entendimiento.

La forma empática del espacio dibujado es intersubjetiva, no es lineal ni continua.

Esta construcción y lectura del espacio que buscamos, es irreductible, fragmentada por atracciones y rechazos, lo que consiste en la apertura constante de la experiencia estética. De ahí que nuestro proyecto mantenga vocación estética formalizadora, para trascender solamente las reducciones del tema en unidades sígnicas asociativas que reciclan y generan la alegoría como estrategia artística.

Así nuestra visión espacial se dirige hacia lo etéreo del viaje subjetivo del dibujante, ya sea en el interior del taller o del estudio como en el interior del paisaje, el espacio del dibujar es la locación concreta de la que partimos hacia la región del ensueño, la de la mirada de la imaginación creadora que sin embargo retorna a lo puntual de un espacio (Bachelard, "El derecho a la ensoñación").

Para nosotros, en el acto dibujo, el espacio y la locación siempre serán la ubicuidad del dibujante que se encuentra en un particular estado de conciencia vivencial, el de la ensoñación, un saberse en la vigilia experiencial tanto como en la ensoñación poética, la de la expansión subjetiva y relativa del lenguaje y el dibujo.

Pero igual, el pensamiento del modelo histórico obliga al dibujante al conocimiento de los sistemas formales de la representación del dibujo; el modelo estratégico lo coloca de frente a la claridad teórica de la producción de los diversos autores dentro del campo disciplinar y a posicionarse coincidentemente o de modo divergente ante todo esto.

En resumen, para el dibujante maduro, el espacio y su locación son materia tanto de la reflexión experiencial como de la vivencia preicónica y la vivencia de la configuración dibujística.

La segmentación que hace Philippe Dubois cuando se refiere al espacio dentro del acto fotográfico se orienta en un sentido de agrupación interesante. El menciona cuatro categorías para el espacio implicadas en la acción de la toma. El espacio referencial, espacio representado, espacio de representación y espacio topológico.

El espacio referencial, como el continuo de espacio en el que se inscribe el artista y que nosotros hemos introducido en nuestra noción de contexto. El espacio representado que es el recorte seleccionado en la obra. El espacio de representación que es el espacio conceptual que opera como composición, organización o sintaxis de la imagen y el espacio topológico, que es el ámbito de operación de la imagen con sus comitentes.

De manera general esta segmentación teórica del espacio dentro de la fotografía se desarrolla consistentemente dentro del campo del Dibujo, pero igualmente es necesario particularizar el concepto como espacio del dibujar.

El espacio referencial es para nosotros el espacio del contexto, sea físico fenoménico o cultural subjetivo, es el territorio en el que acontece la vivencia del dibujante y donde este comparte presencia con el universo de sujetos y objetos que se integran como alteridades, buscadas o no para ser tratadas en la configuración, espacio de relaciones afectivas y subjetivas, espacio de la identidad y las distancias ontológicas. 
Espacio referencial y espacio contextual se constituyen en espacio vivencial, espacio que define nuestra vocación del estar ahí, el ver y asombrarse, pero que comporta tanto la dimensión física como la subjetiva incuantificable.

Es el espacio de la vivencia inicial el que ha sido desplazado por las estrategias de la cita y la apropiación como categoría fundamental dentro de la representación y que ha sido confundido con el espacio del acontecer peformático.

El espacio representado, como recorte seleccionado para ser tratado en la obra implica la discriminación, la exclusión de aquel espacio y personajes o fenómenos que no resultan esenciales dentro de la intención proyectual, es el marcaje del interior y el fuera de cuadro dentro de la obra, es el trazo del límite de pertinencia, fuera del cual todo es irrelevante, es la frontera que nos aclara las relaciones que se pueden establecer entre nuestro pensamiento y el suceso sin llegar a extensiones de gratuidad.

El espacio de la representación es para Dubois el espacio teórico, conceptual y formal en el que se soporta el ejercicio compositivo de la fotografía, pensamos que así es, solo que tenemos que considerar como particularidades a esta propuesta el hecho de que para el dibujar, el espacio de la representación es el espacio de la construcción, formalización o pertinencia representacional, que son estrategias añadidas al sentido compositivo clásico. Es el espacio de la acción performática del dibujo, la que en su suceder representa al dibujante mediante sus actos.

Cuando dibujamos, el espacio recortado dentro del continuo para ser llevado a la representación, se organiza y se separa de manera autónoma, bajo cauces sistémicos que ya no son los de la realidad contextual sino los de una realidad alterna y alterada por el pensamiento de la representación.

Muchas veces para el dibujante, el espacio será un recorte segmentado de lo real visto, puede ser también un ámbito de acontecimiento de algún fenómeno, natural o social que es difícil entender como un despliegue de extensión de un área o tri-dimensión, es una situación que constituye una pluralidad dimensional y de direcciones, que por si fuera poco está penetrada por la sensación y la subjetividad.

Trasladamos la definición del espacio de la representación en el dibujo, desde el plano formal estructurante y abstracto de la imagen hacia el de la condición fáctica del dibujar, este espacio puede ser o no el de la vivencia primera, pero es el espacio en el que acontece el acto de la configuración que en sí, es una nueva vivencia.

Esta es una particularidad epistemológica en la que insistiremos, el espacio seleccionado como motivo del dibujar, tanto como el espacio en el que se decide dibujar determina las condiciones en que acontece el acto dibujo en gran medida, puede estar dado natural o contextualmente, pero puede igual ser una combinación de lo dado con lo construido como expresión del proyecto del dibujo. En él se expresa el pensamiento del dibujante y su postura frente al dibujo mismo, frente a los modelos de pensamiento metodológico y las definiciones disciplinares. La reconsideración del espacio de la representación en el campo del dibujo ha sido una de las experiencias más enriquecedoras para el arte desde los inicios de la modernidad y hasta hoy. 
Ya el espacio de la representación de manera central en el dibujo es alusión temática y conceptual desde la primera modernidad del XX hasta la abstracción Pos-pictórica.

Dentro de la mente del dibujante el espacio de la representación se extiende hacia una posible conciencia teórica, esta se va logrando mediante el ejercicio serial y recurrente de dibujar; no todo dibujante se orienta en esta dirección, pero sí, todos operan sobre una concepción implícita del espacio geométrico representacional, esta es una de las búsquedas que más disminuyen con el quiebre del proyecto de la representación en el arte contemporáneo.

El espacio de la representación del dibujo es tanto el espacio aludido conceptualmente como el espacio fenoménico en el que se configura la imagen, a esto se suma también el espacio del proyecto expositivo, ya que históricamente la realización del dibujo como proyecto se definió categóricamente en relación con la locación espacial a la que estaba destinado.

A diferencia de Dubois, referimos la topología espacial a las características conformadas de la obra que significan su estratigrafía su riqueza y complejidad matérica, indexal y ontológica.

El espacio de la representación en el dibujo, como en la cultura en lo general es el territorio de las prácticas sociales naturalizadas e ideológicas del status, como bien lo ha señalado la posmodernidad y sus críticos.

Pero en el acto de dibujar, el espacio de la representación es el terreno de las presencias psíquicas, las que pesan tanto como las de la ecología cultural y las de la teoría del arte. Es el espacio de cruce intersubjetivo que opera como mediación de la identidad, la del dibujante con su tiempo y la historia, y con sus modelo que son los otros y con el público.

Mencionamos varios continentes generales como parcialidades del espacio dentro de la acción del dibujar

- El espacio vivencial del dibujante como particularidad fenoménica puntualizada.

- El espacio de la representación como continente teórico, histórico y formal.

- El espacio de la representación como dominio de las prácticas culturales estabilizadas.

- El espacio de la representación como locación física del acontecimiento del dibujar.

- El espacio expositivo del acto dibujo o de las obras motivo de la producción.

- El espacio psíquico-racional del dibujante como campo del acontecimiento abductivo de la representación.

Espacio-tiempo y pensamiento-concepto son el devenir del dibujante, todo ello se relaciona en el acto de dibujar. Lo esencial es que, tomando del mundo una porción de realidad contextual y fundiéndola con el mundo interiorizado, ese acto logre la consistencia de una nueva entidad cuya ontología esté dada por la operación del acto dibujo y que su formalización sea una imagen deformada por las presiones de la acción configurante.

El espacio casi siempre es referido como asunto de la física, al ser llevado al dibujo se intentó graficar esa condición, de ahí que el espacio desencadenara la ambición de lo mesurable, la proporción y la estructura geométrica en el arte. Y también por esta asociación se construyó un modelo que conceptualiza el espacio en un cuadrante de tres ejes de co- 
ordenadas ortogonales. No habremos de retomar este giro temático; solo reconocemos la amplitud de la deuda que guardamos con este modelo espacial. Aunque ahora es tan criticado, cuando menos a lo largo de cuatrocientos años fue la base del desarrollo de una serie de campos del conocimiento y dentro de ellos el de las artes.

Pero también puntualizamos nuestro interés por la postura del minimalismo, con respecto al espacio y la temporalidad que la obra puede generar; en esos trabajos el tiempo y el espacio se dirigieron más al decurso del espectador al vivir y habitar la obra que hacia el aspecto estable de la representación. Ya la pintura y el dibujo para entonces habían caminado un tanto ese sendero, pero no deja de ser maravilloso ese giro espacial, que fue de la forma estática de la representación hacia el espacio fenoménico vivencial ante la obra.

Pero el espacio es una demarcación política, económica, cultural, psicológica y social, nos determina individual y colectivamente. Esto ha llevado a diversas perspectivas y clasificaciones; espacio vital, espacio geográfico, espacio exterior, espacio íntimo, espacio público etc. Así el espacio es objeto de diversos acercamientos y posibilita múltiples maneras de entenderlo en función de la disciplina de que se trate.

Para este trabajo el espacio es el campo del acontecimiento dibujístico, locación de la vivencia, la prefiguración, la configuración ejecutante y el proyecto expositivo.

Como parte formalizada de la representación, el espacio del dibujo es una entidad, un concepto y elemento de la forma; pero también es el operador de las relaciones que se suceden entre las partes de la obra y la estructura que de ello resulta.

Para el dibujante maduro el espacio también se manifiesta como la región histórica, ideológica y cultural en que su proyecto se inscribe; y en las resonancias psíquicas que la vivencia marca en su mente.

La conciencia espacial se inicia con el propio cuerpo; este conocimiento se desarrolla a través del movimiento. El espacio al dibujar es una proyección de la corporalidad humana y su vivencia; eso es común saberlo; pero consideremos que esta situación plantea el acto de dibujar como una estructuración espacial inmediata que el hombre desarrolla partiendo de lo corporal; la ejecución del dibujo es la conciencia ganada por la acción y reflexión proxémica corporal y por el dominio de la quinesfera; que es conciencia del alcance de nuestro cuerpo y su potencial ejecutante.

Muchas veces lo que vemos en las acciones performáticas dibujísticas es un cuerpo desarrollándose en simples y elementales movimientos; vemos un intento desesperado por expresarse sin que ello garantice una representación renovada.

Pero en el acto dibujo no basta el reconocimiento de nuestra corporalidad desplegándose en el espacio; es necesario llevarla al nivel de un ejercicio de poder, el poder positivo de la configuración bajo concepto y estrategia. El dibujante experimentado da vía a su corporalidad integral, psique y soma se desenvuelven en una conciencia espacial que puede desbordar las dimensiones y proporciones que rebasan su propia escala.

La capacidad dibujística configuradora siempre ha sido terreno de difícil consecución, es educación complejísima que se logra solo mediante la práctica asidua, lo es porque 
implica la transformación de patrones corporales y gestálticos que el sujeto tiene profundamente arraigados. Esto es lo que ha hecho del aprender a dibujar una práctica heroica. Para la posmodernidad ese objetivo no tiene sentido, y eso ha traído como consecuencia que dentro del dibujo y el proyecto artístico muchas veces se recurra a graficaciones esquematizadas del referente y el contexto, o que se utilicen recursos de la imagen de las ingenierías y otras disciplinas como la señalética. Esto dirigió el campo del dibujo hacia una supuesta expansión; cabría reflexionarlo.

Los últimos 500 años de dibujo occidental han sido el viaje de la espacialidad racional mesurable geométrica, de la cualificación topológica de las superficies mediante el relieve y el modelado, y del escorzo como profundidad del cuerpo proyectada en el espacio. En muchas de las prácticas posmodernas y actuales del dibujo y el proyecto artístico, priva una visión que generalmente se basta con las reducciones diagramáticas propias de los ideogramas. Los ideogramas hace miles de años significaron un salto cualitativo en la construcción del signo y el pensamiento abstracto, pero ahora al recurrir a repertorios dados y repetirlos infinitamente solo se corre hacia el empobrecimiento del pensamiento y la mirada.

El espacio representado puede ser profundo, cuando es la ilusión de un campo que tiene penetrabilidad, puede ser plano y logrado mediante la relación gestáltica fondo figura, forma y contraforma, puede ser atmosférico cuando se obtiene partiendo de estructuraciones lumínicas y tonales, y puede ser matérico cuando se crea como percepción de la estratigrafía de los depósitos de material que van construyendo perpendicularidad en la imagen. Pero como lo expuso Bachelard, existe también un espacio que es el de la resonancia psíquica de las vivencias y las imágenes poéticas.

La consideración interiorizada del espacio suma tanto su entendimiento racional como su comprensión psíquica, esta visión de un espacio racional y subjetivo simultáneo al dibujar, nos enlaza con una idea del tiempo que posibilita la conciencia y las resonancias psíquicas de las vivencias.

El Tiempo es una presencia tangible en muchos terrenos del arte; el teatro, la danza la música, el cine. Pero en las artes plásticas y visuales la representación del tiempo siempre guardó una consistencia virtual. Sería hasta los experimentos de la escultura cinética y los primeros accionismos (Calder, Pollock, Klein, Mathiew etc.) que el tiempo en su acontecer físico se introdujo en el acontecimiento dibujístico; pero fue siempre más una condición procesual que un elemento dado a la forma de la representación, aunque se entiende que guardara un relación sistémica en el proyecto integral.

Nos referimos a la condición temporal en este punto porque al introducir nuestra idea del acto dibujo, tal categoría es consustancial a la acción que configura el dibujo; y también se une de modo indisoluble al integrar la vivencia como parte de la primeridad y la segundidad experiencial configurativa que hemos descrito como parte del dibujar.

En una de sus acepciones, abstraer significa separar el todo en sus partes para arribar a su comprensión; La temporalidad integrada al proceso del acto dibujo se realiza en las etapas que ya hemos venido aludiendo: 
- La primeridad y vivencia en el contexto.

- La segundidad proyectual prefigurante.

- La terceridad y la configuración experiencial.

- El cuarto momento del acto expositivo.

Cuando enumeramos estos momentos lo hacemos desde la perspectiva del pensamiento teórico, solo podemos aludir separadamente a las partes de un proceso dentro de un esquema mental, porque al suceder dentro del contexto es imposible señalar la separación entre cualquier etapa; su interpenetración y sucesión es gradual y permeable. Como fenómeno, la temporalidad del dibujo no se da a los cortes de un tiempo lineal; pero con todo y eso es posible identificar cuando en plenitud hemos accedido a uno u otro segmento. Esta sería la sucesión de los cortes metodológicos de la acción del dibujar.

En el inciso anterior, cuando nos referimos a los procesos de abducción y representación dentro del acto dibujo, operamos también sobre una base analítica temporal, desde la prefiguración saturada de visiones ideológicas en el supuesto vacío del soporte, hasta las rupturas formuladas en la imagen y su forma nueva.

Pero esta temporalidad implicada en la abducción se para sobre una base epistemológica, la de la actitud del sujeto, el dibujante. No es tanto el tiempo de una secuencia lineal de pasos; sino el tiempo de la estrategia que se adecua al suceso aleatorio de la configuración del dibujo.

Tenemos entonces el tiempo como secuencia metodológica en el acto dibujo; también el tiempo como postura epistémica y estratégica.

Pero el tiempo dentro del acto dibujo es una dimensión psíquica; el tiempo como dimensión subjetiva de la vivencia del dibujante; tiempo generado por el deseo como vocación del proyecto. También como tiempo de la presencia del dibujante frente a los otros y las vivencias que con ellos comparte, y el tiempo del dibujante viviendo ya la ausencia de los otros. Complejidad temporal que genera un universo interior de vivencias en pasado que se integran con el vivir en presente.

El exceso de estrategia conceptuante del posmodernismo paradójicamente ha venido despojando al proyecto artístico y sus obras de su condición humanizada, nos interesa el tiempo de la configuración formal, pero siempre entrelazado e imposible de separar del tiempo de la vivencia que resuena en la psique del dibujante.

La formulación del Tiempo Muerto que propone Humberto Chávez Mayol, nos resulta interesante; aunque no establecemos una relación directa de discursos, recuperamos y adecuamos aquellas líneas que aclaran el trabajo del dibujar tal como lo habíamos venido realizando, reconocemos su influencia y agradecemos la claridad que nos aporta, pero igual extendemos las formulaciones y con ello asumimos los riesgos.

La temporalidad en el acto dibujo se desplaza, se mueve en un trazo rizomático permanentemente sincrónico de lo metodológico y representacional hacia el ámbito de la vivencia. El vivir nos llena de deseos que orientan intenciones, proyectos; visiones de futuro, maquinaciones deseantes. Este es el material del que llenamos nuestros dibujos, deseos en 
el sentido más extenso. Pero ese vivir también nos llena de huellas, marcas que rebasan lo físico y configuran el mapa psíquico de cada uno de nosotros.

Y tenemos aquí un primer punto de expansión; la huella, en cualquiera de sus sentidos, es un rastro físico que permite la reconstrucción del suceso que la genera; dándose así tanto a la lectura lineal como a la dilatación hermenéutica. La huella se deposita generalmente en una superficie, el soporte del dibujo o del signo. Pero la huella psíquica no es visible físicamente; es la marca interna, que nos genera la vivencia. No es visible ni siquiera para quien la lleva interiorizada, no se le puede conferir una lectura unidimensional ni lineal, siempre se debe a la interpretación relativa; pero sobre todo, como no es un rastro físico no puede ser tomada como modelo. Solo aflora al soporte del dibujo mediante la acción del dibujante; pero el espectador se encuentra imposibilitado para obtener el sentido primario de esa huella, el deseo original que genera ese trazo se ha perdido y ha muerto, solo podemos crearle un nuevo sentido de lectura, pero ahora basado en nuestro propio deseo, el que le atribuye una actitud significante alterna.

Tratamos aquí del tiempo del acto dibujo, en adelante simplemente mencionaremos la temporalidad del dibujar o el tiempo de la acción.

El dibujante vive el tiempo de su acción como un espacio en el que se recicla y a la vez se transforma el deseo y se agregan otros más, esto puede parecer un enredo, pero a la luz del pensamiento complejo comprendemos que esta es una dinámica no lineal que abre exponencialmente las rutas de la acción y el proyecto.

En esta dinámica, las imágenes y los modelos resucitan en el presente y se abren a la invención.

Es una temporalidad sensitiva vivencial, es perceptiva porque se orienta al pensamiento experiencial y es prospectiva porque se dirige al proyecto y al futuro, como ya lo mencionamos, a la transformación de la imagen y la memoria.

"En el tiempo muerto hay un conjunto de marcas invisibles que atraviesan la conciencia creando sutiles transformaciones en la vida cotidiana. Inexplicables rutas secretas se extienden en forma de ritornelo; juego de desplazamientos múltiples que configuran territorios de acción y reacción, y que lentamente, al paso del tiempo, se naturalizan como una suerte de memoria sin recuerdos." 157

Este tiempo se constituye de efectos, líneas formas y acciones, huellas depositadas; solo los resultado se nos dan a la vista, las causas y motivos son asunto de reconstrucción especulativa, deseamos conocerlas; pero si lo hiciéramos perderían su sentido.

El tiempo del dibujar y la representación, crea un ámbito que se asemeja seductoramente a lo real primero, pero en verdad es un tiempo segundo, el de la mezcla compleja de sincronías psíquicas vivenciales. Es un ámbito temporal de verdadera irrealidad que se inscribe naturalmente en el tiempo común de la vida, crea configuraciones significantes no vividas que estructuran una nueva memoria, por eso es que el buen dibujo es en parte

157 Chávez Humberto. Tiempo muerto. Toluca, México: CONACULTA; 2005. P. 112. 
aquella imagen que suscita un acontecimiento, imagen a la que asistimos y que ya nos resulta imposible de olvidar.

Dibujar es la fractura en el desplazamiento de la voluntad proyectual, su tiempo es el del relato múltiple de los deseos no logrados y las nuevas visiones que se colocan ahora como deseo y proyecto, pero también como la nueva memoria de las configuraciones alternas que se van logrando. Es una temporalidad formada en la vivencia del deseo.

"En un sentido común, podríamos creer que el transcurrir del tiempo es independiente de nuestras vidas y esto, de alguna manera es cierto. Sin embargo, aquí no hablo de la maquinaria temporal conformada por la convención social sino, mas bien, del transcurrir de la conciencia, en la intención vital de llegar a algún punto, de encontrar a alguien, de comprender algo, de descubrir la sensación inesperada en el logro esperado. Esta intención es, al final de cuentas, una manera (no la única, por supuesto) de distinguir el deseo. Mover el cuerpo y la conciencia en una dirección implica construir la espacialidad receptora de ese proceso y también dar ritmo a todas las expansiones y retracciones del cuerpo configurando la vivencia íntima del presente prospectivo."158

Pero ese deseo y voluntad se ven violentados por una barrera, los acontecimientos de la configuración y el devenir del proyecto; cuando esto sucede esa escisión temporal detiene o desvía el deseo original.

Esto afecta nuestra vivencia de las cosas, de los modelos y todo lo que en el acto se ve involucrado y marcado por la ausencia y la no consecución de lo deseado.

La construcción de nuestro proyecto crea niveles de objetivos deseados, su temporalidad se configura con la potencia de lo buscado pero igual de las esperanzas y huellas latentes.

Cuando el dibujante decide concluir un dibujo, el tiempo de la configuración se ha detenido, tal vez logró el deseo inicialmente prefigurado, o quizá arribó a mejores configuraciones. Pero ese dibujo al ser presenciado por los otros, se mueve desde la pérdida del deseo que impulsó su origen, y se abre a una nueva temporalidad interpretante.

Muchas de las vivencias que activamos en la acción de dibujar son parte de un pasado y quizá de una carencia. Podemos estar presentes frente a nuestro modelo, pero en muchos casos no es posible reencontrarnos con ellos, esa falta coloca al dibujante reconsiderando la pérdida, y creando el dibujo como mecanismo de restitución. En este plano, el dibujo da al dibujante la capacidad de trabajar con los modelos que estando ausentes habitan la dimensión de su memoria pasada. Huellas psíquicas en ausencia concreta de referentes.

Frente a la ausencia, nuestra conciencia proyectiva arroja un caudal de metáforas transfiguradoras de aquello que fue nuestra vivencia primera. Estas metáforas reconfiguran la memoria al inventar múltiples formas de la representación, las que ahora incluso a nosotros nos despliegan las vivencias pasadas en una dimensión y posibilidad distinta; múltiples dinámicas del tiempo pasado, cuya forma ya no es la esencial de lo pasado sino una nueva vivencia presente con memoria de lo ausente.

158 Chávez Humberto. Tiempo muerto. Toluca, México: CONACULTA; 2005. P. 19. 
Nuestra búsqueda al dibujar quizá se centra en asistir nuevamente a los lugares, los objetos y los sujetos, para que desde nuestro ahora reordenemos los ires y venires, no de las cosas, sino de nuestras marcas del tiempo y lo vivido. Por eso la temporalidad del dibujar opera sobre huellas psíquicas que determinan nuestras percepciones presentes como vivencia nueva.

La temporalidad del dibujar se asemeja al principio de acumulación de capas, cada vivencia y su intento de ser formalizada se coloca sobre el intento y la construcción anterior, y vendrán nuevos intentos y vivencias que al sedimentarse irán creando a la vez que modificando lo antes configurado y vivido, la topología del acto dibujo.

Este entendimiento estratigráfico y topológico de la acción y lo configurado nos revelará la diferencia entre un dibujo que obedece directamente a un dictado proyectual (Sol LeWitt, Wall drawings 2005) y otro que se nos revela como un territorio que contiene infinitos acontecimientos y estados psíquicos, aunque estos se nos oculten a un entendimiento total.

La sintaxis que intenta organizar tal cúmulo de pasados y presentes es ya una integración de territorios múltiples, no reproduce miméticamente las imágenes de lo pasado y ausente, organiza la conciencia de las ausencias y la dimensión de un nuevo presente metafórico que les creamos. Los sujetos y acontecimientos recordados ya fueron, pero poco importa, puesto que los significantes que ahora integran la obra, operan solos, y los efectos de su construcción tienen una posibilidad generativa independiente.

El acto de dibujar cuando se ubica en la conciencia del contexto no puede ser corregido, sólo el dibujo que se apega a un patrón proyectual de representación estricto es depurado hasta conseguir la forma óptima.

El dibujo contextual es consustancialmente temporal, siempre cambia en relación al devenir circunstancial, no puede ser corregido, su configuración depende de los hechos y pensamientos suscitados, es un acontecimiento siempre abierto, ya que se basa en la esencia del contexto como conjunto de circunstancias y entramado de relaciones. El acto dibujo en tanto proceso contextual depende de la realidad total entretejida, sus formas están determinadas por las distintas apariencias del mundo en movimiento en donde lo accidental cobra categoría de esencia.

El tiempo del acto dibujo es la claridad del vivir frente a sus presencias y las ausencias interiorizadas, pero es intención orientada prospectivamente ya que de manera instantánea traslada las huellas psíquicas hacia la visión de un hacer el dibujo y sus formas.

Cuando el dibujante acierta en su acto de dibujar, logra una concreción temporal formalizada que contiene una gramática rica en vivencias; estabiliza una burbuja psíquica que permite a los otros asistir a las subjetividades sin haber vivido la falta y las ausencias generativas de ese acto; pero el carácter indexal de las marcas permite la sospecha de la intensidad de la lucha.

La ligereza y el poder evocativo de las obras del acto dibujo reemplaza la pesadez de la pérdida y nos instala en la nostalgia y la ensoñación. 
En esta nueva estabilización que el dibujo les confiere, las vivencias y los sujetos están descontextualizados ya que fueron arrancados de su circunstancia original, la que les confiere su sentido significante; ahora quedan en posición para ser dotados de otras cualidades y afectos, adquieren evidentemente nuevas significaciones. Esa es la cualidad temporal constructiva del acto dibujo; y es una condición inimaginable de oportunidad abierta a la abducción libre y creativa.

Las vivencias contenidas en el acto dibujo son tan poderosas que muchas veces no las soportamos directamente, las presenciamos sublimadas en las formas de la imagen y su poética, o en la mecánica de su concepto.

En el carácter proyectual prefigurativo del dibujo hemos visto como se gesta y desarrolla la fuerza del proyecto; su temporalidad, si bien es enmarañada y compleja como el contexto nos lleva a la plenitud. Ante la pesadez de la ausencia y las huellas del vivir, sigue el gozo de la plenitud en donde las coordenadas del espacio y el tiempo de la acción y la representación se desvanecen en beneficio de una obra, cuya ontología lleva en su interior una nueva presencia cualitativa indiferenciada; y a favor de un tiempo otro de la vivencia, ambos, elementos de un estado de primeridad vivencial, momento que antecede al pensamiento taxonómico articulado.

La temporalidad del acto dibujo es la de la vivencia y sus reviviscencias múltiples, colocadas en una suerte de presente intemporal que rebasa el tiempo cronológico y el de los tiempos del método riguroso como lo conocimos.

\section{IV-6 LA MECÁNICA DEL ACTO DIBUJO}

Puntualizamos brevemente, no nos interesa el mecanicismo como doctrina filosófica, que surgida en el siglo XVII afirmó que la influencia física era la única causalidad de los fenómenos que conforman el mundo material. Esto supuso la negación del territorio de lo espiritual y subjetivo de lo humano, situación que con el paso del tiempo y los análisis posteriores fue modificada.

Conocemos los riesgos de incluir el término, más cuando generalmente se le utiliza como calificativo o sinónimo de una actitud irreflexiva.

Pensamos el acto dibujo como una maquinaria puesta en marcha, nos interesa internarnos en el juego de sus partes y en las fuerzas que originan y determinan su movimiento, este es un tanto el sentido de la mecánica como parte de la física. Insistimos en las relaciones de afectabilidad que se establecen entre las partes que constituyen el territorio del dibujar.

Así pues, queda claro que nos dirigimos a un ejercicio reflexivo que reconoce la necesidad de trabar relaciones entre partes, lo cual es claramente coincidente con la visión del dibujo como práctica compleja.

Todo análisis que busque entender la mecánica de un cuerpo disciplinar y sus dinámicas está obligado a incluir el tramo que corresponde a la metodología, la estrategia y el pensamiento proyectual de esa disciplina. Precisamente el reconocimiento de esa nece- 
sidad nos llevó a proponer sendos capítulos de este trabajo orientados al análisis de esas categorías, recordamos lo escrito en esos espacios y lo unimos con los continentes que enumeramos acto seguido.

El sentido de lo que en adelante referimos toma en cuenta la complejidad que intentamos esclarecer sobre esa temática, la que relaciona método y estrategia con el pensamiento proyectual.

Los modelo universalistas fueron un común denominador de los proyectos de la modernidad, esa es una de las circunstancias que se pierden dentro de lo posmoderno. No vemos en esta situación motivo de debate, más bien hoy resulta condición ineludible y hace imposible la formulación de un modelo teórico total del dibujo; no nos paramos en la discusión o no de tal objetivo, sino en su imposibilidad, dado que no estamos en condición de construir acuerdos fundacionales.

El problema no es sólo de lógica teórica estructural, sino de convenio social. De ahí entendemos la formulación de Derrida del principio del desorden taxonómico. Sumamos a lo anterior el hecho de que no nos mueve el espíritu de un proyecto positivo ascendente como el que animó a las vanguardias, por eso es que no lanzamos nuestras reflexiones como propuestas de integración social y solución a las disyuntivas del fenómeno artístico.

"Este desorden alude a la existencia de una pluralidad de discursos sin dominancia. Derrida argumenta que más que teoría o teorías, hay jetties teóricos, es decir, muelles en los que atracan diferentes discursos que mantienen entre si una relación de conflicto y de competición." 159

Nuestra investigación se orienta en el sentido de una reflexión teórica del acto de dibujar, ese es uno de nuestros objetivos; pero la lógica que constituye el centro gravitacional de nuestro sistema está dada mayormente por el pensamiento experiencial suscitado en el transcurso de nuestra práctica como dibujantes, lo cual la marca en cierto sentido como lo que hemos denominado, un modelo de interioridad del campo dibujo; no se rige por la determinante de un modelo teórico taxonómico piramidal; aunque ya por otra parte algunos tratados típicos de la modernidad como el de Nicolaides formulan su propia lógica estructural.

Vemos nuestros pensamientos y diagramas más como desplazamientos nómadas dentro del territorio del dibujo, una diáspora expansiva que contiene vínculos sistémicos de relación, pero estos vínculos se deben más al trabajo de la experiencia y la estrategia configurante que a la consistencia de un método con lógica deductiva.

Por todo esto enunciamos el acto dibujo a manera de una función relacionante, la que traba nexos entre el dibujante y el contexto con la mediación de la obra dibujo.

Los tiempos del acontecimiento vivencial y experiencial de este campo de acción son los de la:

Vivencia - Prefiguración - Experiencia - Configuración - Presentación

Pero la dinámica que determina su tiempo de acontecer no es lineal ni totalmente sincrónica; ya hemos dicho que es una dinámica temporal sincopada y generalmente recursiva, acontece en múltiples direcciones e interpenetra causa y efecto. Esta sería un verdadero diagrama de estructura rizomática. 


\section{EL DIBUJO COMO OBRA:}

Casi podemos decir que la Obra realizada en el acto dibujo es una entidad con definición propia.

Pero al detenernos en esta expresión nosotros afirmamos categóricamente que la obra del dibujo se inicia como intención proyectual del artista.

La obra no se genera por sí misma, no se piensa a sí misma, ni tiene por tanto una voluntad de autodeterminación ni principio de autonomía.

¿Cuál es entonces la consistencia ontológica de la obra dibujo?

Quizá estrictamente no sea posible hablar de una ontología del dibujo como sujeto; quizá su ser sea el de un acontecimiento desatado por la voluntad actuante del dibujante.

Entendemos el dibujo como obra en términos de un acontecimiento y un fenómeno, como tales se inician con la acción del dibujante pero al comenzar a suceder se liberan al flujo estocástico de todo fenómeno. No es posible gobernarlos totalmente por la voluntad proyectual; y más en este caso, ya que al sustituir el método ortodoxo por la estrategia emergente se aumentan los márgenes de aleatoriedad en el suceso.

El acto dibujo como acontecimiento sucede entrópicamente, eso lo sabemos, pero lo que puntualizamos es que el decaimiento del proyecto que vuelve difícil la configuración, y lo que desata el caos tomando toda la imagen como lo señala Deleuze, es la circunstancia de que el dibujante incluye factores y variables en cantidad desmedida, incrementando con esto las afectaciones interdependientes entre la estructura que se intenta organizar. De ahí que la norma poética compositiva y configurante con la que fuimos enseñados a dibujar tomara como punto central, la síntesis formal y la reducción de los elementos compositivos.

Las formas y elementos que introducimos al dibujo en proceso se deberán a una necesidad significativa, de no ser así los excluimos de la imagen. Al agregar elementos gratuitos nos dirigimos a un formalismo decorativo cada vez más distante de la consistencia significativa.

La obra como algo dado es continente de un sentido significante que esta integrado por las relaciones generadas entre:

- Teoría

- Concepto

- Tema

- Forma

- Técnica

Pero en un sentido de cualidades y adjetivos, la obra tiene una resistencia a la configuración proyectual, como ya se ha dicho, esa resistencia constituye una voz, el dibujante la escucha y entabla el diálogo que transcurre por todo el cariz de temperamentos imaginables. Tiene también una historia propia y se enmarca en la historicidad del campo y la cultura, en él encontramos sus parentescos, fuentes y similitudes y frente a ellas notamos sus cualidades emergentes. Posee carácter y cualidad sensible dados por la configuración, este carácter y cualidad era territorio obligado dentro del paradigma de la forma plástica significativa y visual, en la aleatoriedad contemporánea de la forma dibujística, el carácter se genera en lo fortuito de la configuración. Finalmente la obra puede tener poder de ensoñación poética, o en el otro extremo una concisión conceptual bien lograda. 


\section{EL CONTEXTO COMO CIRCUNSTANCIA Y COMO RED DE RELACIONES}

El dibujo contextual de manera simple sería aquel que traba relaciones circunstanciales con su entorno y el que se inscribe en un entramado de relaciones que van más allá de la propia acción de dibujar. Y eso es correcto, pero hablar de relaciones contextuales nos coloca necesariamente en el plano sociológico del asunto.

El acto dibujo comprende una dimensión fuertemente individual, cosa que no es difícil comprender, al fin y al cabo es una interiorización psíquica y experiencial; pero siempre sucede como internalización de las relaciones ideológicas y culturales en el sentido más amplio. El acto dibujo es la revelación de una gama de relaciones sociales que los sujetos establecen en la dinámica diaria de su ejercicio como integración de grupos humanos.

Decimos lo anterior porque básicamente nos interesa la acción de dibujar no como la expresión arbitraria de la voluntad del dibujante sino como ejercicio de su principio de autonomía ante a esa condición contextual.

Dibujo y Contexto traban una relación dialéctica como par de oposición, ejemplifican la ley de unidad de los contrarios; incluso en términos de la sociología de Zizek (El sublime objeto de la Ideología 1992), el acto dibujo sería la revelación del dibujante frente al gran otro, pero es también el deseo de reconocimiento por ese gran otro al que intenta recomponer. Esta lógica binaria motivada por el contexto genera un cierto estado patológico o de resistencia (el proyecto artístico existencial) consustancial a la acción de dibujar.

Incluso en una lógica terciaria, el contexto opera, junto con la obra y el dibujante, como punto para triangular un área de acontecimientos en el fenómeno de la representación.

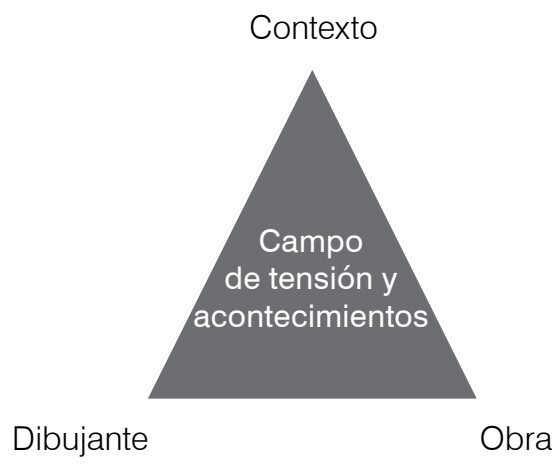

Ya dentro de las notas de Leonardo a fines del siglo XV encontramos la referencia del dibujante transcurriendo en el espacio público para observarlo y dibujarlo; pero indudablemente que la acción de construir las imágenes de la representación era un trabajo que se realizaba dentro del espacio del taller. Aunque la distancia histórica entre el espacio del contexto y el espacio del taller comenzaba a cerrarse, faltaba mucho todavía para que el artista trasladara el espacio del dibujar al seno mismo del espacio contextual en su sentido amplio. Los términos de construcción localizada, emplazamiento e intervención, entre otros, dan cuenta de este paso.

El dibujo contextual es la historia del viaje que se inicia con la relación entre dibujo y naturaleza, obsesión del artista renacentista, después, la estética pintoresca reconoció el orden de la sensibilidad humana, que junto con lo natural constituyó el conjunto del paisaje; la revolución dadaísta y surrealista dotó a los objetos simples de tensión y contenido como 
parte de un contexto que se introdujo en el territorio del dibujo, desde el fluxus y el situacionismo hubo que dilatar la noción anterior de lo natural y lo social, ahora hacia lo contextual en el sentido más amplio, como espacio epistémico del acontecimiento artístico.

Actualmente tenemos que entender la relación del dibujante y el dibujar con el contexto partiendo de un análisis multinivel, el que comprende la categoría de lo contextual desde el espacio natural y físico que nos rodea, pasando por el ámbito del taller, lo urbano etc. hasta la cultura interiorizada en la mente del autor.

Hoy en día el dibujante reflexivo entiende el contexto tanto como condición histórica, cultural, como el espacio y suma de modelos, todo esto operando dentro de su acción ejecutante. Pero no solo mira el contexto como zona de acontecimiento del dibujo, lo traduce en reconocimiento de una vivencia que es llevada hacia un plano problemático como motivo de formalización y estrategia dibujística; su postura epistémica se orienta hacia la forma y sistemas de la representación y no sólo hacia la denuncia ideológica.

La conciencia contextual del dibujante determina la claridad para entender dos factores problemáticos e históricos que acompañan el ejercicio del dibujar, y que generalmente se reflexionan de manera aislada: el de la Actitud y el de la Aptitud. Al analizar este binomio dentro del terreno de la técnica, se imposibilita su explicación más allá de lo instrumental. La actitud será definida como postura y conciencia epistémica del dibujante dentro del acto de dibujar. La despojamos de sus implicaciones éticas y morales, la llevamos más allá del terreno del deber ser.

Actitud es claridad de postura en su relación con el contexto como modelo y motivo, claridad también ante la pertinencia y consecuencia del método y la estrategia aplicada y frente al sistema formal de representación con que se trabaja.

Pero la actitud que toma el dibujante marca también el carácter de la relación y el diálogo establecido con el contexto y sus sujetos. La actitud como conciencia epistémica es el saberse del dibujante en una puntualización espacial y temporal, generando las estrategias con las que relaciona contexto y obra en ejecución.

Podemos decir que el contexto ha sido la condición generadora tanto del proyecto ascendente positivo, como del proyecto crítico existencial desde el arranque de la modernidad ilustrada y el romanticismo. Esta fue la disyunción que caracterizó el proyecto artístico desde la escisión del romanticismo; ya lo mencionábamos anteriormente en otro capítulo. Pero para la apertura metodológica y epistémica del acto dibujo, se abre una variedad de alternativas.

La epistemología corre el peligro de ser entendida como postura personal arbitraria del sujeto dentro del proceso cognitivo; no es así, para que verdaderamente se hable de una epistemología es necesario que la reflexión del sujeto se coloque en un plano sobrepuesto de conciencia cognitiva, esto es, que realice una meta-reflexión sobre el proceso que ejecuta.

A través de la historia, los dibujantes han construido una serie de posibilidades epistémicas paradigmáticas para la práctica del dibujo, como acción de la representación:

- El dibujo se integra como parte de una práctica ritual.

- El dibujo es una forma de estudio y análisis de los modelos naturales y objetuales.

- El dibujo es una práctica alegórica formalizada.

- El dibujo es la transcripción y síntesis de los datos visuales. 
- El dibujo es una respuesta gestual graficada del dibujante ante el contexto.

- El dibujo es una conceptualización formal de la vivencia y la experiencia.

- El dibujo es la construcción de una entidad fáctica alterna.

Quizá el espacio correcto para referirnos ahora a la aptitud sea el de una posible teoría de la técnica del dibujo, pero como lo mencionamos, en contraste a la actitud del dibujante, expresamos aquí nuestra visión sobre ese punto, que se ligará al referirnos a la técnica como la vía que grafica y explicita el concepto problematizado de la representación.

La aptitud la remitimos al poder de configuración de la obra, y al poder de poner en forma la materia, el poder de generar la fuerza que hace evidente la deformación abductiva de la forma.

Si la actitud se remite al plano estratégico y epistémico, la aptitud nos lleva a considerar el dibujo como una forma de poder, el poder de sublimar lo directamente contextual en una problematización temática formalizada.

La práctica del dibujo históricamente tenía tres niveles de apropiación de las habilidades: introducción, manejo y dominio; con esto se llegaba a la maestría, que en parte significaba vencer la resistencia de la materia para ser puesta en forma conceptual y poética.

La aptitud es la manualidad; pero una manualidad liberada del imperio de los datos visuales, es conformadora de estructuras extrañas, logra la plasticidad que contiene el conflicto dramático puesto en la forma significativa, es una conexión experiencial lograda gestualmente y alterna y paralela a la reducción experiencial conceptuante.

La aptitud es la corporalidad desatada en conjunción con la estrategia actitudinal.

Dentro del acto dibujo reconocemos nuestro potencial y nuestras carencias. La aptitud dentro del dibujar es la conciencia de una gran parte de nuestro ego.

La aptitud se concreta en el manejo pleno de la conformación de la materia, en el manejo de las formas y estrategias de la representación y se convierte en una práctica de la teoría y los conceptos de la obra.

\section{LOS MODELOS COMO ENTIDADES ONTOLÓGICAS DE LA OTREDAD:}

Ya en el capítulo anterior nos detuvimos en este punto; iniciamos con un listado puntualizado de los modelos en el acto de dibujar, expusimos estos como función teórica y estratégica del arte, finalmente realizamos un recorrido general por las etapas paradigmáticas dentro de la historia de los modelos formales de representación en el dibujo.

Retomamos el tema en este espacio porque en un momento específico de la acción de dibujar, los modelos representan una parte importante sobre la que queremos puntualizar. Ya nos detuvimos en el parteaguas epistemológico que significó la revolución de las vanguardias anicónicas de principios del siglo XX. Reconocemos la importancia del pensamiento tautológico y autorreferencial de los modelos formalistas abstractos, y la revolución que esto significó en la evolución de la visión y la gestalt del ojo humano.

Pero ese no es el punto, queremos retomar como una relación de gravedad, la que se establece en el acto de dibujar entre el autor y los sujetos de la otredad.

El artista al hacer, dialoga con la historia, con su contexto; estratégicamente se posiciona frente a la postura de los demás dibujantes; pero la relación del dibujante al pararse frente a los sujetos, objetos y fenómenos para dibujar es un asunto que nunca perdió relevancia. 
Esta relación corre en un sentido hacia la interioridad de la acción del dibujar, mientras que de alguna manera la relación del dibujante con los modelos de lo histórico y lo social se extrovierten a partir de la representación.

Nos inquieta que históricamente los modelos del dibujante (más los modelos humanos) se hayan entendido como elementos pasivos y sujetos a la voluntad del dibujante. Nos inquieta esto porque puede ser tomado como un sometimiento, y lo es, porque la voluntad e intención del dibujante no es algo explicitado, así que escapa al entendimiento del modelo dibujado, ¿cómo entonces podemos relacionarnos con ellos en un plano de igualdad para realizar un flujo de entendimiento vivencial e intersubjetivo?

En nuestra experiencia, esta relación se puede basar en una amplitud de estrategias, pero en todas ellas hay que tomar a los modelos como entidades cuya intención autónoma y sentido significante inicial está dado, es con ese sentido que trabajamos alegóricamente; trabajamos también con fenómenos sociales, ambientales, generalmente encontramos en ellos una causalidad y devenir fenoménicos; el dibujo como intervención toma ese sentido de lo dado para resignificarlo mediante la práctica.

Pero, ¿que sucede cuando nuestros modelos mantienen un principio de autonomía y autodeterminación actitudinal?

Dibujar seres humanos es una experiencia siempre abierta.

El modelo toma una actitud de entrega al saberse dibujado, el dibujante lo percibe y ambos entran en un plano de relación.

El modelo se sabe dibujado y se resiste porque lo considera una invasión, el plano de relación ahora contiene una tensión producida por el no acuerdo de voluntades.

El modelo se encuentra dentro de un espacio y tiempo intencionales para dibujar. El modelo colabora, cree saber la intención del dibujante y actúa a modo, pero entre más aporta más se desdibuja su esencia corporal, deja de ser lo que es y se convierte en lo que cree que el dibujante necesita ver de él.

Es necesario entonces, en cualquiera de las situaciones anteriores que el dibujante construya estrategias de relación y diálogo, técnicas de interacción con los modelos que incrementan el falso entendimiento.

Los modelos creen entender el sentido y la intención del dibujante, pero este sabe que en verdad solo tienen una idea equivocada de su búsqueda, fomenta entonces ese mal entendido y provoca situaciones que serán leídas y reforzadas por el modelo en una dirección, que no es la que interesa al dibujante, pero generan consecuencias en movimientos, situaciones o expresiones que el modelo no podrá controlar, ya que ni siquiera advierte la lectura oculta del suceso.

Este tipo de relación mantiene un entendimiento que no pasa por lo verbal y en el que la integridad de ambos, dibujante y modelo se mantiene de alguna manera, el modelo nunca es lo que el dibujante quiere y el dibujante siempre abre al modelo a una experiencia dentro del acto ejecutante.

Nuevamente decimos, los modelos pueden ser algo dado como situación contextual, en ese caso tienen una autodeterminación sistémica, ofrecen una riqueza de posibilidades dentro de las que actúa el dibujante, linealmente se piensa que en esta situación el dibujante es una presencia neutra que no debería trastocar el devenir contextual, sería más un testigo que un sujeto activo; pero nosotros pensamos que no existen los testigos asépticos, la presencia del dibujante en una locación para dibujar es ya como una piedra que cae en el agua y genera sus perturbaciones. Esta situación es un ir y venir del dibujante 
hacia el contexto y también en sentido inverso, esta es una forma de diálogo que se abre a lo nuevo y sensible más que al entendimiento racional.

Pero cuando los modelos forman parte del acto dibujo en un espacio organizado para ese efecto, la estrategia se convierte en un acto de diálogo con un carácter diferenciado del anterior, modelos y contexto entran en acuerdo y colaboración; el gradiente de la subjetividad y sentimientos intercambiados representa un filón interminable y un reto a la capacidad de dirección del dibujante.

\section{MATERIALIDAD Y MATERIA:}

Buscar mediante el dibujo una definición física y científica de la materia resulta para hoy un sinsentido.

Desde el inicio comprendemos que el orden de la materialidad dentro del dibujar es lo que nos interesa.

La materia en su estado físico es el material que habrá de ser trabajado en la acción de dibujar, mediante la configuración de la representación la materia física se estructura bajo órdenes que se proyectan dilatando lo físico material.

Ya desde el informalismo y el expresionismo se sabe con claridad de la resistencia que la materia elemental guarda para ser conformada dentro de la personalidad estética de la obra; así dibujar es poner en forma representacional a la materia, configurar y conformar constituyen el eje de lo que Langer determina como la forma significativa. La materia para el dibujante es el correlato de la vivencia puesta en la forma de la representación.

Al realizar el dibujo sentimos una contradicción inestable entre el peso de la materia sobre la configuración de la forma. La materialidad cuando es trabajada con habilidad técnica, se orienta con facilidad hacia una percepción sensible de la imagen, que cala en la subjetividad; en tanto que la configuración que busca la construcción formal se basa en el entendimiento racional de la estructura, tanto del modelo como de la nueva imagen.

El problema es que la materialidad, por ello, puede devenir pura sensibilidad carente de sentido semántico en estricto, y la pura forma se hundiría en la exigencia de una construcción racional.

En los proyectos del dibujo de la modernidad hasta los años 60 del siglo pasado, la materialidad cedía bajo la presión de la forma y la composición. El dibujo se entendió como el territorio platónico racional frente a lo sensible aristotélico del color y la pintura; pero en el panorama que delineamos, la materialidad del dibujo cede ante la presión de la forma plástica o la forma del referente representado.

Las estrategias posmodernas (que hemos revisado, cita, alegoría etc.) lateralizan la importancia tanto de la forma nueva configurada, como de la materialidad en tanto metalenguaje; al hacer a un lado la vocación estética y la representación.

Pero siendo consecuentes con el pensamiento de Deleuze, tanto la materialidad de la obra, como la forma dibujada, nos rebelan la presión de la fuerza aleatoria que la configura, la intención diagramática del artista.

Podemos decir que la materialidad del dibujo en un plano radical se puede guiar por la deriva entrópica del suceso dibujístico; en este sentido es una función resultante y negativa de la presión del dibujar que se basa en la estructuración formal de la imagen.

Esto quiere decir que la materialidad al dibujar se puede liberar al acontecer de los resultados casuales de la configuración. Pero el factor relacionante que traba vínculos entre la materialidad estocástica y la forma lógica proyectual es la relación poetizada y la sublimación metafórica del tema del dibujo, o bien la intención significante. 


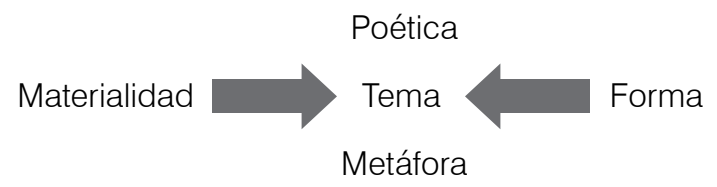

Así vemos que la obra del dibujo es un estado temporal de lo formal con un grado de presión de lo matérico, situación estabilizada por el manejo poético, problematizado y significante del tema.

Decimos entonces que el acto dibujo lleva la materia a un estado inmaterial; esto mediante la espiritualidad y el psiquismo, mediante la organización poética del tema. Todo esto sería la materialidad en la representación.

Así, la materialidad dentro del dibujar es también forma experiencial conceptualizada en la representación; forma y concepto que se relacionan contextualmente con el pensamiento físico y filosófico, pero que se orientan en su propia búsqueda epistémica y en su particular definición.

El dibujo lleva al museo, a la galería y al espacio expositivo la materia, la saca del laboratorio y el experimento científico.

El cúmulo de reflexiones sobre la materialidad que venimos exponiendo transcurren dentro del pensamiento experiencial del dibujante, muestran una madurez intelectual.

Pero nos interesa redondear nuestra idea de la materialidad en el dibujar estableciendo una relación que dirigimos poco a poco en el sentido marcado por Bataille y que retoma Herman Parret.

Un materialismo bajo y elemental que nos humaniza al extraer la materia de sus causes sistémicos culturales, una materialidad más cercana al sentir y el vivir, materia que aún no sea la de los conceptos codificados.

Analogía matérica que nos vuelve conscientes de lo corporal, un poco antes de llegar a su proposición conceptual.

Bataille separa nuestra relación con la materia a partir de la "apropiación" y la "excreción". Mediante la apropiación establecemos el sentido social y cultural a las cosas, ciencia religión, instituciones. Pero en la excreción nos relacionamos con todo aquello que no podemos asimilar a través de las formas codificadas y convenidas. Desde esta perspectiva, la homogeneidad material tiende a establecer un equilibrio estático, mientras que la materia elemental mantiene un sentido heterogéneo que se resiste a las reducciones codificadas y cala directamente en nuestra subjetividad.

Nos interesa, si esto fuera posible, una materialidad al dibujar que aluda al sujeto o al tema dejando de lado su consistencia icónica formal. ${ }^{160}$

Porque la materia heterogénea carece aún de sentido, y su significado está por construirse. La materialidad extraña, al dibujar, indica analogía elemental subjetiva, no puede ser asimilada mediante la razón y el entendimiento, esos dibujos estarían dentro del territorio de la materia heterogénea y solo nos quedaría asimilarlas mediante nuestra subjetividad, desde el primer instante hasta nuestra última mirada.

Junto con la visión que hemos expuesto sobre el tiempo y el espacio en el acto dibujo,

160 Bataille Georges. El valor de uso de D. A. F. De Sade (1), Obras Escogidas. México: Ed. Fontamara; 2006. 
esta orientación de la materialidad constituye una triada reflexiva categorial, la de los tres continentes teórico-formales centrales del acto dibujo. Pero pusimos suficiente interés en hacer una formulación de estas tres categorías desde una perspectiva que incluye lo formal pero que se expande hacia lo contextual y psíquico subjetivo.

La relación que determina los vínculos sistémicos entre esta triada reviste un carácter complejo, y en este momento se advierte ya el porqué pusimos énfasis en relacionar el método y la estrategia como partes de una complejidad en la acción de dibujar.

Esta complejidad determina vínculos de interdefinición sistémica, no sistemática, flujos constantes de causalidad que corren en tiempo y direcciones múltiples y de desplazamientos relativos, que también generan un campo de acontecimientos.

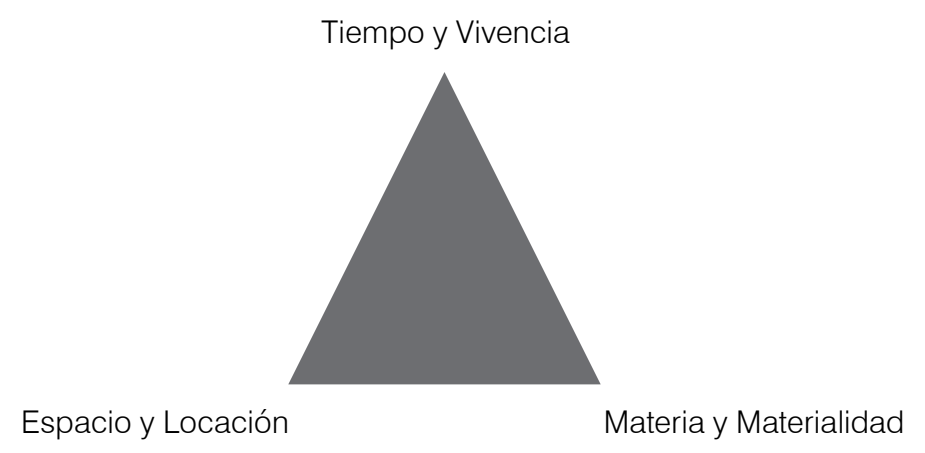

La manera en que hemos entendido estas tres categorías suma la visión formalizada de la representación con su parte subjetiva, ya lo mencionamos; pero lo que ahora planteamos es que esta ruta de análisis deja en claro la importancia de la corporalidad, del dibujante en este caso; como la vía de suceder fáctico de aquellas categorías.

Para nosotros desde hace mucho (cuando realizábamos nuestros propios dibujos, y cuando intentábamos nuestras primeras reflexiones) la corporalidad del dibujante es una unidad somática, psíquica y reflexiva, que guarda relación con el contexto en sentido amplio.

Es esta corporalidad del dibujante y solo ésta, la que vive en primera persona la fenomenología del dibujo.

Esta es la cadena reflexiva inicial de nuestro entendimiento de la ejecución del dibujo.

La siguiente triada de la complejidad dibujística sería la que interrelaciona concepto, materia y técnica mediante la ejecución.

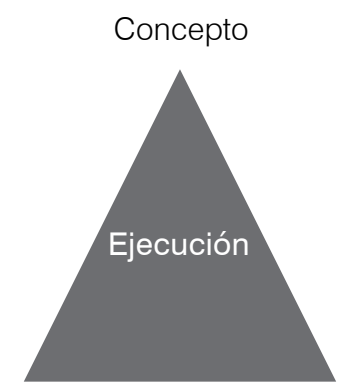


Pensamos que la visión que entiende al dibujante como un semionauta organizador de significados, lo despojó de su riqueza corporal y muchas veces redujo el acto ejecutante a una acción inerte que paradójicamente intenta hablar de lo humano vivencial.

Cuando exponemos este último esquema no queremos reducir la corporalidad dentro del dibujar a un enunciado racional, por eso decimos que la corporalidad en el acto ejecutante de dibujar, implica estados corporales vivenciales de ejecución, el cuerpo no sólo es el que dibujamos y del que hablamos, es también el de nosotros que dibujamos.

Aquí recordamos lo expuesto en el capítulo de los modelos del dibujo, en ellos encontramos la diversidad y riqueza estratégica y metodológica con que el dibujante atacó la corporalidad en la configuración del dibujo.

\section{LA TÉCNICA Y SUS CAMPOS TEÓRICOS DE ACCIÓN}

Porque la huella es tanto rastro de un accidente como efecto dejado por la intención, pero también rastro que marca la psique.

Por eso la técnica abarca tanto la manera de hacer, como la intención de crear sentido significante, es la elaboración de un discurso, que involucra desde lo estrictamente lingüístico hasta lo subjetivo informe.

Así la técnica opera siempre para el dibujante entre lo casual aleatorio y lo intencional significante, entre el simple ser de un acontecimiento físico y el trazo que revela una lógica no natural.

Etimológicamente se nos revela el sentido literal del término técnica;

"Del griego Téchne. Relativo a un arte u oficio. F. Conjunto de procedimientos para el aprovechamiento industrial y científico de los recursos naturales." 161

Tenemos entonces un conjunto de procedimientos, normas o protocolos con el sentido de una acción ordenada que buscan resultados determinados.

El sentido lineal de la definición supone que en situaciones similares, un procedimiento igual produce los mismos resultados positivos. Por tanto la técnica dictaría el orden de los pasos, los materiales y las herramientas dentro de la acción de dibujar.

La técnica además, incluye un conjunto de saberes variados y es transmisible socialmente. El dibujante la aprende de otros pero su fin último es el de modificarla y reinventarla.

Pero la historia de la técnica en el arte en general, y dentro de ella la del dibujo, ha revisado profusamente también su visión tecnológica e histórico-económica, la que traba lo técnico con los sistemas de producción en un contexto determinado.

Particularmente la historia de los materiales y las herramientas del dibujo nos revela la manera en que se fueron introduciendo, no sólo en el sentido productivista, sino como parte del lenguaje plástico de la disciplina.

Técnicamente se construyó una voz para cada material y para la conformación dada por la herramienta en los procesos dibujísticos como lenguaje.

Como manera de hacer, la técnica del material y las herramientas hizo posible una configuración estructurada de la materialidad y la forma de la representación. 
En el capítulo anterior nos referimos a las variaciones de la pincelada que hicieron posible operaciones conceptuales y de representación en el ámbito del dibujo y la pintura, desde el regatino renacentista hasta el catálogo de la pincelada como huella pictórica en Robert Ryman pasando por la pincelada gestual ya en el barroco.

Existe una profusión de literatura tecnicista que nos indica como se dibuja de acuerdo a cada material utilizado.

Pero ya se advierte que el sentido verdadero de la técnica es el que organiza la mecánica de las partes bajo una intención significante profunda.

La técnica del dibujo es la graficadora teórica y conceptual de la representación.

Nos encontramos en este punto tratando sobre la dinámica de la acción de dibujar.

"El dibujo es un acto; tiene que suceder".

Dentro de ese acto, la técnica y la estrategia del dibujo son las vías para poner en forma y concepto la obra, son la ruta que construye la poética y el psiquismo de la imagen, parada en el sentido deseante del dibujante.

Es la manera de hacer que estructura el acto y el proceso.

No de manera limitada, pero el proyecto y la estrategia operan principalmente en el proceso de la prefiguración, mientras que la técnica campea en el tiempo de la configuración; aunque ambas mantienen un sentido causal dentro del acto de dibujar.

Precisamente basados en estas peculiaridades distinguimos entre el dibujo como un acto y una acción, la acción al dibujar contiene un sentido proyectual elemental, el que apenas se manifiesta como pensamiento de intención antes que conciencia epistémica; al entender el dibujo como un acto nos trasladamos al terreno de la abstracción, la que realiza una disección del todo y sus partes y que trae como consecuencia el trazo reflexivo y organizado de todas ellas.

\section{Proyecto y prefiguración}

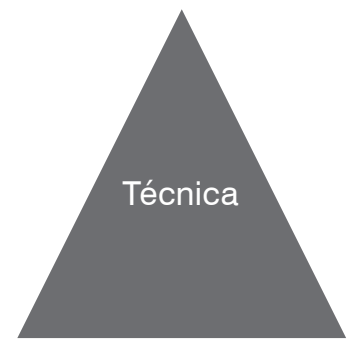

Acontecimientos

Vivencia

estocásticos

La técnica al dibujar es la manifestación de una forma de poder del dibujante, el poder de la poética y la configuración conceptual, el poder de poner en forma y discurso la materia y la canalización tensa y afortunada del deseo.

Podemos caracterizar la técnica dentro del dibujo como la conciencia epistémica circular y retroactiva del dibujante frente a los campos de: 
- La Estrategia

- Los Procesos

- La Forma

- Los Soportes

- Los Materiales

- Las Herramientas

Estrategia y proceso han sido expuestos anteriormente con mayor profundidad.

La técnica opera bajo una intencionalidad conceptuante, la que genera la fuerza de intención que deforma la forma vista y percibida de los modelos. Pero el resultado es una forma deformada, forma alterna de una nueva entidad ontológica. Forma de la nueva representación que nos abre la mirada y que nos habla de otras maneras de entender el mundo y contexto, forma hasta entonces no vista que expande nuestra concepción eidética y que continúa dando sentido al acto dibujo como acto de representación.

La técnica como manifestación compleja se desprende del practicismo y se hunde en la operación abductiva de los sistemas formales y procesuales del dibujo, y en la vivencia plena de la configuración.

El formalismo técnico se convirtió en calificativo despectivo, se le despojó de su sentido primario como generador del proceso semántico, el que construye el sentido de la imagen signo.

Para nosotros, en nuestra concepción procesual del dibujo, la técnica va construyendo el sentido significante de la obra y el relato de un tiempo y las vivencias; en la estrategia posmoderna de asociación sígnica, la técnica aporta pocas posibilidades de rupturas abductivas ya que el eje de la construcción está dado no por la forma y la representación como categorías de lo estético, si no por el sentido teleológico estable contenido en esas imágenes y lo que representan.

Como discurso de significación la técnica se concreta en acciones configurantes y performáticas que dan forma y cualidad matérica a la obra. Son ataques de intervención prefigurados hacia la intención de construir discurso; por eso gradúan y atemperan la gravedad del resultado conformante y la cuantificación de los cambios en la imagen y su materialidad.

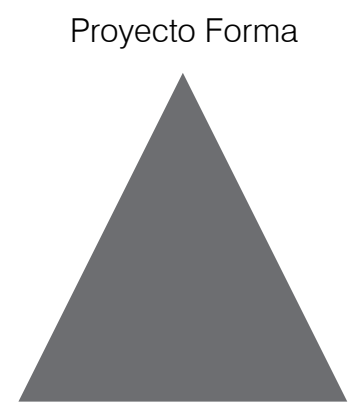

Forma Materialidad Procederes Conformantes

Campos de interacción retroactiva de la técnica 
Sabemos que los soportes del dibujo pueden ir desde el plano del papel hasta la superficie de la playa, el paisaje nevado etc. Pero antes que nada los soportes del dibujo son el campo de acontecimiento del acto dibujo y elemento sustantivo del espacio fenoménico. Tradicionalmente los soportes se incluyeron como parte de la materialidad de la obra y como espacio del pensamiento abstracto, así fue históricamente; pero el soporte del dibujo después de las vanguardias del siglo XX se ofrece como campo social, contextual y como territorio de una psicogeografía determinante en la acción performática, la técnica es un orden de relación con todo ello.

Sobre la visión clásica de los soportes del dibujo queremos precisar que constituyen parte sumamente importante de la materialidad y del carácter aptico del dibujo. Tuvieron su importancia fundamental dentro de la cadena de producción de las artes y del propio dibujo, la historia de las formas y la representación se liga indisolublemente con el desarrollo de los soportes del dibujo.

Pero sobre todo, el papel, el papiro, el pergamino etc. representan superficies que dan vía a la abstracción, en las que se desarrolla una operación mental, el clasicismo del dibujo significa el orden del pensamiento abstracto colocado en un trozo de papel que contiene lo ilimitado del pensamiento de la representación.

La relación compositiva y estructural entre las formas y el soporte se organiza en un sentido relacional, cuando los elementos de la imagen y la composición guardan relación y se derivan de la forma geométrica del soporte; o de manera no relacional, cuando los elementos incluidos en la composición generan sus propios vínculos de estructura y se expanden más allá del espacio perimetral del plano soporte.

Así como la línea no existe en la naturaleza y es una violencia mental introducida al mundo por el intelecto humano, el soporte del dibujo es el campo del pensamiento racional, y para la modernidad es también el espacio de la fenomenología del acto, campo del suceso y el acontecimiento del dibujo.

El soporte y sus dimensiones se encuentran en íntima relación con la corporalidad del dibujante, la escala determina la dificultad y el grado de relación ejecutante.

Los materiales del dibujo son el cuerpo físico de la obra, se entienden como elemento de su materialidad, constituyen parte de la cadena significante del discurso.

Pero para el dibujante formado en la técnica y su poder, la cantidad de posibilidades intelectuales, constructivas y sensoriales que ofrecen los materiales del dibujo es infinita y mantiene los órdenes de relación mas sutiles que podamos imaginar.

No terminaríamos en este espacio si nos adentramos por ese camino particularmente.

La materialidad del dibujo es el reservorio técnico de la huella indexal que contiene las intenciones profundas del acto ejecutante.

El dibujante puede asumir una postura exquisita o bien rupestre frente al manejo matérico de sus dibujos, eso depende de su intención significante; pero su capacidad configuradora del material y la forma le posibilita realizar el dibujo requerido por la intención proyectual, no sólo el dibujo que sus limitaciones ejecutantes le permiten.

En general la materialidad del dibujo se puede orientar hacia tres órdenes categóricos:

- La Maleabilidad Plástica.

- La Materialidad Conceptual Homogénea.

- La Materialidad Elemental Heterológica. 
O bien puede ser un orden conceptual significante que no cobre relevancia dentro del proyecto.

Pero en cualquier caso la materialidad del dibujo es una cualificación que el dibujante configura como intención significante y discurso.

Pensar la herramienta en el acto de dibujar la coloca en un plano de mediación. Es una entidad que se ubica entre la obra que se construye y la corporalidad y el psiquismo del dibujante.

La teoría de la herramienta del dibujo es la reflexión de esta distancia que se acorta o se extiende según la estrategia aplicada al dibujar, y de la cualidad y el carácter de la huella indexal producida.

Desde este orden técnico de la herramienta, la historia del dibujar ha sido una ruta que, en ocasiones busca eliminar la distancia creada por la herramienta entre el cuerpo del dibujante y el dibujo, otras veces se parte de una visión que pondera la cualidad del resultado al aplicar la acción de la herramienta a la superficie del dibujo.

Los dibujos y las pinturas de Dubuffet intentaron borrar la huella indexal que se dirigía al signo abstracto no referencial, buscando más la huella de un estado que antecede al signo.

Pero como sea, la herramienta puede ser la extensión de las acciones corporales del dibujante, un multiplicador de sus capacidades autorales.

Paradójicamente la herramienta nos vuelve conscientes de nuestra corporalidad cuando reconocemos en los trazos, variaciones indexales que distorsionan nuestra sensación.

La herramienta es un canal que permite la conexión que hace fluir la idea desde nuestra mente hacia la superficie del soporte. Pero es también un modulador del psiquismo descargado en el acto de dibujar.

Encontramos generalmente un sentido para las herramientas del dibujo que las coloca como medio de actualización histórica y tecnológica.

Desde la Cámara Oscura y el Velo Albertino hasta los Ordenadores de hoy día, el dibujo siempre ha mantenido una cercanía con las revoluciones tecnológicas, situación que le ha valido la expansión de sus sistemas formales. En este sentido, las herramientas dentro del dibujo, son un auxiliar para la visión y los sentidos perceptuales del dibujante. Pero como lo mencionamos, la herramienta es generadora de configuraciones conceptuales y diversidad de huellas indexales.

De ahí que la historia del dibujo este llena de casos en los que el autor inventa o modifica sus propias herramientas, buscando la configuración del sentido deseado. Generalmente se quiere evitar los mecanicismos que permiten la reconstrucción de las acciones, en aras de una estética que genere más deseos de mirar y sentir, se intenta evitar la visión como proceso lógico de entendimiento.

Analizando atentamente las imágenes de Franz Halls y Diego Velázquez encontramos en ellas claramente la huella del trazo revelada en las características de la pincelada, su dirección y amplitud puestas en relación con la dirección y el relieve de la superficie que modelan y construyen. Pero en los trabajos de Francisco de Goya y los de Turner es totalmente imposible descifrar claramente las acciones técnicas y manuales. Esa es una diferencia entre el pensamiento racional del dibujo en el barroco, ante la sensación emotiva que se abre a la modernidad en un dibujo que mantiene pese a todo su trasfondo estructural. 
Estructura racional y huella indexal como categorías de configuración determinan los campos de interacción compleja de la técnica, en un sentido muy cercano al de su proceso de formalización eidética graficado en el esquema anterior:

\section{Idea sensible prefigurada}

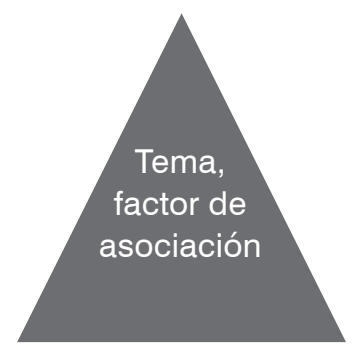

Materia Materialidad

Praxis y Procederes

Acción ejecutante

\section{DEL HACER EJECUTANTE Y SU RAÍZ EPISTÉMICA}

Según el diccionario de Nicola Abbagnano (FCE, México 2004) la Epistemología es el campo de la filosofía que se ocupa de la teoría del conocer, las definiciones del saber, sus fuentes y los conceptos formados en ese acto, así como de las diferentes formas del conocimiento, no solo el científico; como en determinado momento se pensó. También estudia la relación entre el sujeto cognoscente y el objeto conocido.

Actualmente el término recurrente es el de epistemología, pero se entiende la Gnoseología como uno de los tres órdenes categóricos de la filosofía, el que se ocupa del análisis sobre los procesos cognitivos del sujeto. La Gnoseología da pie a la construcción de la Teoría del Conocimiento.

Hasta donde revisamos, existe una diferencia sustantiva entre la Epistemología y la Teoría del Conocimiento; la Teoría del Conocimiento es el análisis filosófico riguroso del proceso del conocer y se organiza en secuencias y procesos metodológicos generales que operan por sobre la postura del sujeto, en tanto que la epistemología es la flexibilización metodológica que se determina en función de la postura variable del sujeto frente al contexto a conocer.

No contamos con los elementos teóricos para adentrarnos en este debate, ni nos resulta imprescindible, ya que lo que nos interesa es precisamente la particularidad del dibujante en una puntualización espacial y temporal frente a la que debe responder.

Se comprende entonces porqué nos referimos a una postura epistémica en el acto dibujo; entendida como la conciencia que el dibujante tiene de su objeto de análisis, del problema que ese conocimiento le plantea y de la claridad que tiene sobre el método y la estrategia que construye para disipar esa incógnita y configurar la forma conceptual imaginada.

Haciendo un ejercicio de generalización y ya dentro del campo particular del dibujo podemos mencionar tres órdenes epistémicos categóricos que agrupan la postura del dibujante como sujeto cognoscente. 
Primeramente y desde hace tiempo consideramos que el acto dibujo comporta una serie de características que lo acercan al acto ritual; nunca nos dirigimos estrictamente en una línea de análisis antropológica o etnológica del pensamiento mágico religioso, lo que planteamos es que en toda definición del rito está implicada la necesidad de su realización fáctica porque en ella está contenido el renacimiento del proceso vital, para nosotros el dibujo es algo de lo que mucho se puede hablar (y aquí lo hemos hecho) pero necesariamente es algo que hay que realizar, ejecutar. El dibujo en la posmodernidad con las estrategias de cita, alegoría y apropiación poco tiene de ritual.

Todo rito tiene normas y se estructura en tiempos y espacios de representación que no son arbitrarios, están determinados por la significación que ese acto reviste.

Los tiempos y las formas dentro del ritual representan las formas del cosmos, el universo y su orden esencial, las formas y tiempos del dibujar no necesariamente representan esas esencias, pero se hayan en íntima relación con lo fundamental de la estructura de la representación, así como con las formas que el contexto y la realidad propician.

Dibujar con un sentido ritual implica también una especial compenetración, un estado mental del dibujante que lo involucra como sujeto integrado en el acto, ya no como entidad racional al margen del proceso.

El rito nunca ha sido una práctica estrictamente constante, ha variado a lo largo del tiempo, asimilando la actualidad de las formaciones sociales que lo practican. Pero de cualquier manera, el ritual como práctica invariable y repetitiva no interesa al dibujante, ni tampoco hoy, como visión mágica de la realidad; pensamos en un rito del dibujo como una práctica ejecutante por la que hemos de atravesar a manera de condición para establecer un ser ontológico, el ser dibujante, ser que se gana en la vivencia de ese acto y en la consecución de un poder.

Mediante la acción ejecutante del dibujo ganamos un conocimiento del mundo y de nosotros mismos, en el sentido constructivista más pleno, el dibujar no solo define lo dibujado sino que construye al propio sujeto de esa práctica.

Desde la postura renacentista y sus antecedentes en el 1400, el dibujo se fue perfilando como una manera de conocimiento, al definir la naturaleza como un territorio independiente de la voluntad humana y con sus propios órdenes estructurales, y al retomar la razón intelectual como la herramienta para acercarse a ese universo, el dibujo se desarrolló como sistema basado en la observación y el comparativo experiencial que se dirigió a establecer cánones proporcionales que eran la reducción promedio de lo observado.

Desde entonces se reafirmó con claridad teórica la relación entre el dibujante y la naturaleza, (que no era sino la manera de decir mundo o contexto) mediada por la práctica del dibujar.

$$
\text { Naturaleza -------- Dibujo -------- Dibujante }
$$

Dibujar como estrategia del conocer, contiene una serie de segmentos metodológicos. El Observar, convertir lo percibido y mirado en una reflexión experiencial de la forma, toma de información y datos visuales. Prefigurar y configurar, esto es, dar lógica, estructura y forma a la imagen representación, tanto en presencia del modelo que opera como determinante del límite del proceso de formalización, como en su ausencia, basados en las reducciones constantes que se establecen a modo de resumen ya en nuestro pensamiento experiencial y la memoria, en este proceso de prefiguración proyectual se gesta el nuevo 
ser que alude a la realidad vivencial primera, se concreta con la aparición de la nueva entidad de la representación lograda en el proceso configurante.

Dibujar es conocer, pero solo en tanto que nos exija la compenetración con el contexto y los modelos que se dibujan, establecer con ellos una relación fenoménica presencial, compartir la locación y la temporalidad, basar esa relación en una intención eidética, un entendimiento del mundo en imágenes que tienden a ubicar una esencia estructural. Ver y mirar dibujando, sentir en el acto de dibujar una relación de intercambio con los otros, la otredad que cuenta con su propio sentido de autonomía.

Pero es cierto que hoy podemos dibujar en ausencia del contexto primero y basarnos en el reservorio de imágenes que el mundo global nos pone a disposición; las imágenes de segunda y tercera generación constituyen ahora un filón estratégico para construir el sentido significante dentro del acto dibujo.

Pero retornando a lo general del tema; el dibujar como forma de conocer, solo consiste en una estrategia de relación con el contexto y la otredad, no podemos engañarnos pensando que lo dibujado es la esencia de la naturaleza desplegada, solo es el resumen experiencial y formal que nosotros realizamos de ella, el dibujar nos lleva al conocimiento de que lo dibujado es la construcción de una presencia alterna de aquella que vemos como contexto.

Esta estrategia de relación entre el dibujar y el contexto no es una posibilidad metodológica cognitiva generalizante, cuando menos en el sentido de la ciencia. Y ya que esta construcción de la representación se debe a la volatilidad del dibujante, a su particular punto de vista epistémico, se reconoce en ella una posibilidad de mentira, algo que no explica lo real desplegado sino sólo la esencia de la imagen de la representación. Pero como sea, la relación entre el dibujante y el contexto que se despliega en el acto dibujo es de una gran profundidad.

Tenemos entonces que, conocer e investigar, pueden estar remitidos hacia el contexto en que estamos inmersos, este es un primer orden de relación epistemológica.

Pero en segundo orden el conocer se remite al análisis del propio sistema metodológico, el del campo puesto en acción, del dibujo en este caso. Sería esta una meta-reflexión, la que atañe al pensamiento tautológico autorreferencial.

El dibujante investigando la posibilidad de abducir, deconstruir, extender etc. Los propios sistemas formales, estrategias, y modelos teóricos de la disciplina. Esta es una práctica constructivista circular retroactiva en esencia, desde la vertiente de Watzlawick y Foerster. El proyecto autorreferencial del dibujo en tanto reflexión que se pliega sobre el propio campo del lenguaje no es un mero juego formal, en el fondo implica la reconstrucción de los aparatos formales mediante los cuales representamos el mundo. Los sistemas visuales y sus prácticas de representación, impactan de manera consistente en el modo que la sociedad manifiesta y configura su imaginario colectivo.

Los procesos de socialización de las formas y la apropiación que los grupos humanos realizan de las propuestas visuales del arte, terminan por modificar la gestalt cultural y perceptual; el proyecto tautológico del dibujo encaminado a la expansión y abducción de la forma visual de la representación es por tanto un orden epistémico, que se conecta directamente con el contexto cultural y le reporta una utilidad sustantiva. 
Como tercera posibilidad epistémica, el acto de dibujar permite en cierta medida el autoconocimiento.

No hablamos en este punto estrictamente de investigación, nos referimos a una manera de autoconocimiento.

La investigación implica un pensamiento hipotético con respecto a la posible explicación de un problema, se define por la claridad metodológica y proyectual, se desencadena como ruta de solución al problema y la incógnita iniciales.

Pensamos no tanto en un dibujar para investigarnos a nosotros mismos, sino el dibujar como forma del conocernos. Este es un supuesto de flexibilización compleja relativizante; estaríamos en el terreno de la epistemología más que en el de la teoría del conocimiento. En este caso se acepta un margen de indefinición. Por motivos como este, desde hace más de diez años sentimos la necesidad de internarnos en el pensamiento constructivista, sospechábamos que de alguna manera al dibujar nos adentramos en un proceso que nos llevaba a conocernos a nosotros mismos.

Cuando el dibujante ejecuta se le aclaran antes que nada sus incapacidades, no sólo las que le impiden formalizar con precisión el dibujo proyectado en su mente; se vuelve consciente de aquellas acciones y trazos que le es imposible ejecutar, se le despliegan insistentemente sus formas repetitivas, las mañas a las que siempre recurre para organizar un espacio, una estructura, una forma etc. Todo el abanico de clichés de los que no puede desprenderse. Cuando se dibuja se es consciente de que muchas veces el proyecto y lo configurado obedece a nuestro deseo de reconocimiento social, o que realizamos más la obra en función de un estado social del dibujo del que poco creemos, pero que nos condiciona como peso contextual. Dibujando somos conscientes también con precisión de la capacidad de concentración que tenemos, del tiempo que trabajamos en la imagen y nuestra compenetración en el acto. Notamos como nos desconectamos de lo real que nos circunda y nos relacionamos con la historia intemporal mediante el trazo o entramos en un estado de ensoñación.

En el acto dibujo, puede suscitarse un auto reconocimiento profundo del dibujante, en sus potenciales y sus debilidades, pero también acontece en esta acción la superación de esas limitantes y la expansión del potencial reconocido; en esta situación, el dibujante y su objeto de estudio se auto compenetran y se construyen uno a otro, en el acto de conocer la realidad el sujeto se auto analiza y se conoce, lo cual es coincidente con la visión de un aprendizaje constructivista genético.

Quizá en el acto dibujo, el sujeto no pueda investigarse a sí mismo, pero en él encuentra una vía de autoconocimiento profunda, no desde una perspectiva mística, si no desde una claridad epistémica experiencial.

En términos de territorios cognitivos podemos expresar la siguiente triada:

Conocer el mundo

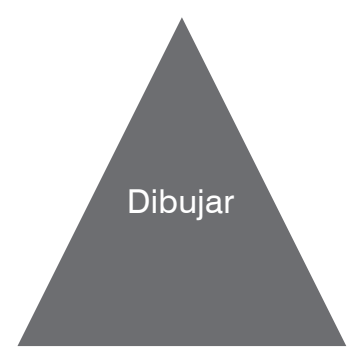

Conocerse a si mismo

Conocer el dibujo 
En términos de la representación constructivista se expresaría de la siguiente manera:

Construir el mundo

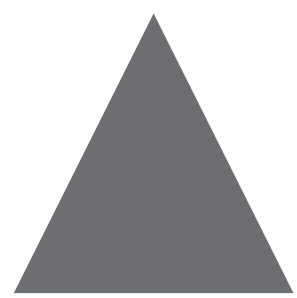

Construir la

Autoconstruirse representación

Del hacer ejecutante y su raíz epistémica:

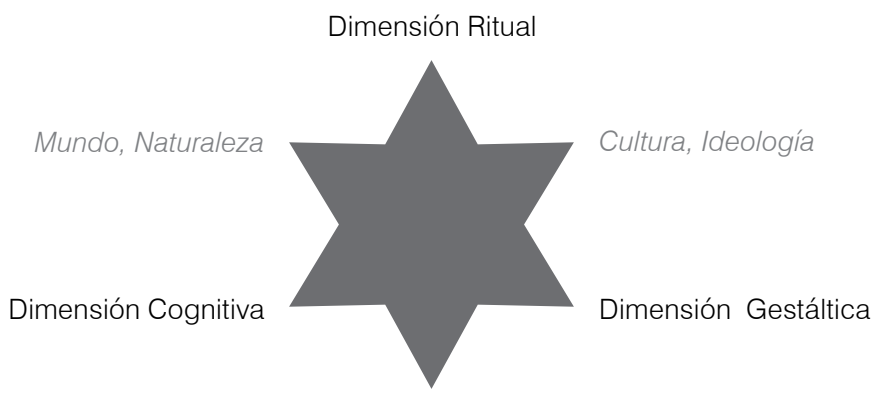

La Otredad, Ios otros, Interdisciplina

Del hacer ejecutante y sus circunstancias aleatorias y la intencionalidad proyectual:

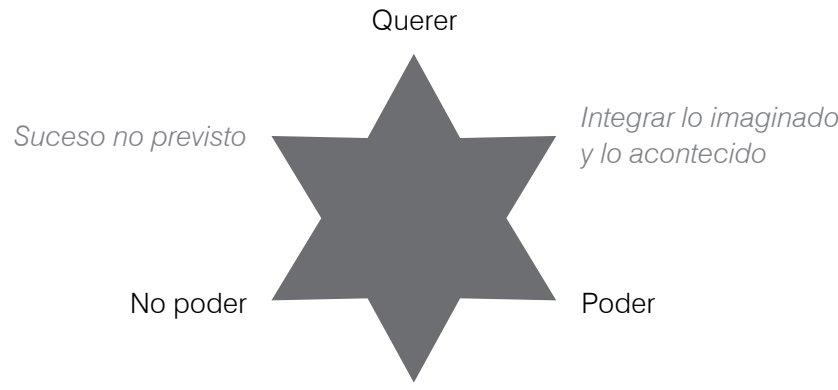


Del hacer ejecutante, los medios y la técnica:

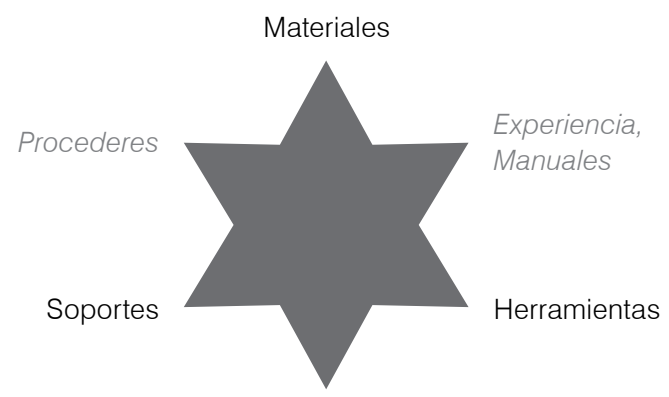

Métodos, sistemas de representación

Del hacer ejecutante y la construcción del sentido significante:

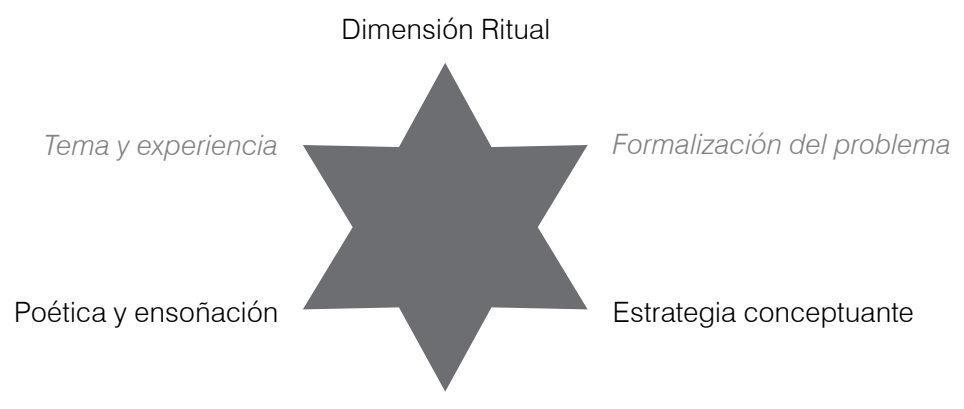

Metarelato

Finalmente y de manera sencilla el acto dibujo es el viaje que se origina en la vivencia vuelta proyecto, que al ser problematizada busca en la ejecución el encuentro con su forma sistémica, la de la representación eidética del contexto.

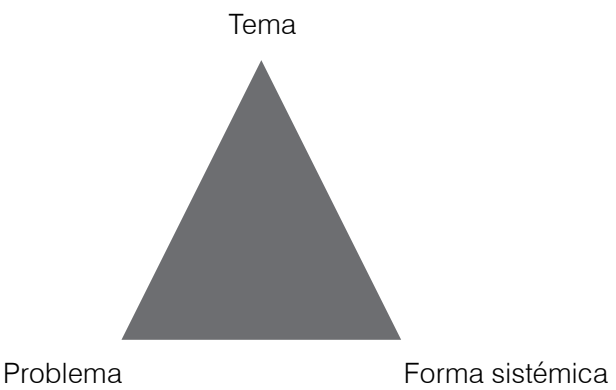





\section{CONCLUSIONES}

La euforia que se desató en los últimos treinta años al hablar del dibujo y sus perspectivas dentro del panorama de las artes, se dirigió hacia una mal entendida autonomía disciplinar. Más que ver en el dibujo un campo potencial de renuevo para las artes, en realidad lo que se manifestaba era un hartazgo de la crítica y los artistas con respecto a la entronación de la pintura como eje del fenómeno artístico, y hacia la comercialización y asimilación de la objetualidad artística.

Intentamos como una de las direcciones centrales de este trabajo, la elaboración de un trazo teórico del dibujo a lo largo de la historia, al revisar el material acopiado pudimos advertir que por mucho tiempo el dibujo y sus modelos teórico-formales se encuentran entrelazados con los de la pintura sobre todo. Esto sucedió así porque el pensamiento central se posicionaba desde lo conceptual pictórico hacia la organización del proyecto, por más que se utilizara un campo del dibujo dentro del proceso artístico. Pero también fue de ese modo, dado el carácter esencial del dibujo como una disciplina que se dirige al pensamiento de la forma y a la gestación de un mundo de imágenes; bajo ese carácter, demostramos en esta investigación el vínculo sistémico que unió al dibujo históricamente con el conjunto de las artes.

Aunque logramos desprender poco a poco un conjunto de visiones formales y teóricas del dibujo a lo largo de la historia, sería equivocado entenderlos separados del pensamiento integrado en el que se originaron. Tampoco pensamos haber concluido el tema en ese sentido; en su momento dijimos que intentábamos las bases de un trazo de la historia del dibujo y sus sistemas, no pensábamos lograr su completud y así ha sido.

Sinceramente pensamos que al redireccionar el análisis y la investigación histórica en relación al desarrollo de un pensamiento dibujístico, contribuimos al inicio de esa ruta de análisis.

Precisamente esta investigación demostró la centralidad del pensamiento del dibujo como eje del proyecto artístico y el pensamiento generador de la representación y la imagen en un largo trecho del camino de las artes, aunque se estuviera trabajando en el campo de la pintura la escultura o la estampa.

Iniciamos nuestra investigación con una formulación que operó como nuestra hipótesis: ¿La postulación de la autonomía del dibujo dentro de las Artes Plásticas y Visuales, es consecuencia de la ruptura paradigmática de los proyectos artísticos de la modernidad del siglo XX, frente a la emergencia de las estrategias de flexibilización y expansión de los campos disciplinares en las artes de las tres últimas décadas?

Por esa razón dedicamos el primer capítulo al planteamiento de ese problema.

Al final y luego de investigar las fuentes, pensamos que efectivamente así sucedió, y que el contenido de nuestra investigación lo expone, aunque en el espacio de estas conclusiones habremos de puntualizarlo. 
El desarrollo de nuestras conclusiones seguirá la estructura de este trabajo, de esa manera se mantiene un orden expositivo y se puntualizan los resultados.

La ola que impulsó a los artistas en el tránsito de la modernidad a la posmodernidad, fue la de ser coherentes con su tiempo histórico y con el pulso del devenir de las artes; formularon sus propuestas y emitieron su opinión en ese contexto. Como lo expone Lucy Lippard al hablar de la desmaterialización del objeto artístico; mucho del proceso conceptual en el arte de los años 1960-70 se originó como una manifestación política asociada a las rupturas sociales que poblaron el contexto de esa época.

No fue su interés central, pero dentro de todo ello, generaron repercusiones fundamentales que modificaron los paradigmas artísticos y las relaciones orgánicas de integración de la obra y el proceso artístico.

Dentro de esas consecuencias, el vínculo sistémico que unía el dibujo con el cuerpo de las Artes Visuales se fragmentó y modificó.

Por tanto, la llamada independencia del dibujo está relacionada más bien con los factores de desintegración de los campos disciplinares en el terreno del arte posmoderno y con el proceso de hibridación de los lenguajes del arte.

En ese sentido no tratamos sólo con un asunto del campo del dibujo sino con un tema relacionado con el complejo general de las artes.

Parte de las operaciones proyectuales ortodoxas del dibujo se dirigían a pensar las partes del proyecto y la forma de los elementos de la obra, por ello se decantaron las etapas de prefiguración y configuración del proyecto. Pero con el giro semiológico estratégico en el arte posmoderno esta función quedó parcialmente desplazada.

La estrategia de dislocación sígnica ganó terreno frente a la labor de representación estética formal del dibujo. Al atacar la originalidad se renunció en cierta medida a la búsqueda de imágenes de primera generación.

La llamada autonomía del dibujo es una consecuencia y no una intención propuesta, la expansión disciplinar fue el corolario del proceso artístico del siglo XX, trastocó la función metodológica del dibujo en el arte pero no alcanzó a liquidarla totalmente.

Aún la propia crítica posmoderna señala la necesidad de establecer cortes paradigmáticos significativos en el proceso del arte

Intentamos demarcar espacios de territorio históricamente, en los que se estabilizaron los modelos formales sobre una concepción del dibujo en particular y su concresión como sistemas de representación. Estos cortes permitieron figuras de análisis que muestran el desarrollo del fenómeno.

Para ello insistimos y tomamos la dirección de un análisis que se originara desde una visión que interesa a la interioridad del pensamiento dibujístico. Aquí el trabajo resultó bastante difícil; pero su validéz se demostró al encontrarnos con la postura de Foster (Arte después de la modernidad), Deleuze (Pintura, el concepto de diagrama) Damish y Alan Bois (Painting as model)

Dentro de todo el material revisado encontramos la alusión insistente al dibujo como una actividad que permite el desarrollo del proyecto artístico y su prefiguración; también se le 
definía como elemento vertebral en las "operaciones de elaboración conceptual del proyecto". Ésta es más o menos la postura clásica que se tiene de la disciplina. Pero no se llega a precisar la base de esa afirmación y la mecánica sobre la que opera.

Este trabajo se desarolló en ese sentido. Elaboramos una definición provisional que no es excluyente; consideramos el dibujo como disciplina eidética, un campo de trabajo dirigido a la elaboración del pensamiento en imágenes y la esencia formal del mundo percibido; esto es lo que nos permitió afirmar la vigencia del dibujo como proceso generador de sistemas alternos de representación. Creemos haberlo dejado claro más allá de una postura volitiva.

Históricamente establecimos tres estados sustantivos en el proceso de flexibilización metodológica del dibujo que anteceden al corte de su función gestáltica dentro de la posmodernidad.

Recordamos que esta secuencia es un proceso gradual, pero pensamos haber marcado suficientemente sus etapas.

Nos referimos a los procesos de giro en el carácter proyectual del dibujo y en su carácter icónico referencial de representación.

Primero: La postura del Dibujo Romántico que subjetiva y poetisa la forma y la composición oponiéndose a la razón neoclásicista. En esta concepción neoclásica la materia y sus acciones conformantes se orientan a la construcción racional de la forma, mientras que en el dibujo romántico la materia se configura en razón de la forma plástico-dramática.

Segundo: Los abstraccionismos neoplasticistas del XX. En ellos se corta con el referente icónico, el dibujo abstrae la estructura del modelo aunque se mantiene la función proyectual prefigurativa. Pero sobre todo se postula la posibilidad de un alfabeto de la forma visual, cosa que nunca se concluyó, pero que abrió la puerta para relacionar el dibujo con operaciones de conceptualismo purista radical (Manzoni, LeWitt etc.).

Tercero: El corte de la modernidad formalista Greenberiana y la Abstracción Pospictórica, en donde el dibujo permea lo pictórico y dibujiza la pintura (Franz Klein, Still etc.); o bien se convierte en el campo que debe ser eliminado de lo pictórico (Newman, Morris Louis, Rimman etc.).

Éste es el proceso que detenidamente desarrollamos dentro del último trecho en el capitulo de los Modelos del Dibujo.

Dentro de la modernidad formalista que comprende el Informalismo y el Expresionismo Abstracto es prácticamente imposible separar el proceso del dibujo de lo pictórico.

En segunda instancia podemos afirmar que en ese corte histórico se mantiene y consolida el proyecto estético de la forma como eje del proceso de representación.

Hasta ese momento la prefiguración se mantenía como una parte sustantiva del proceso artístico, en ella el dibujo tenía su lugar preponderante. Pero de ahí en adelante, la configuración sin proyecto previo se convirtió en el eje de la estrategia técnica ejecutante del acto pictórico.

La mímesis fue dejada de lado para ser sustituida por la pincelada, la línea y la mancha distendida como huella psíquica autógrafa del dibujante pintor. 
Casi inmediatamente y como parte de un accionar y un pensamiento modelístico estratégico de oposición, la pintura de la abstracción pospictórica negó la huella como vía del psiquismo y la remitió hacia el terreno de la alfabetidad conceptual, éstos fueron los pintores del color field y el hard edge, quienes paradójicamente necesitaron hablar del dibujo para sustentar sus tesis.

Con todo esto la estrategia se fue colocando como el eje del proyecto artístico.

Cuando el dibujo se fundió en la acción pictórica, en lugar de la pureza del campo buscada en términos de Greenberg, lo que sucedió fue una fusión transdisciplinar; una en la que el dibujo continuó con su tarea reflexiva de tensar el concepto y lograr estructuras de representación formales alternas.

Aquí resulta importante señalar que en ese momento se disoció la representación como simil mimético de lo real externo; pero no para desecharla como se ha querido ver, sino para extenderla al terreno de las prácticas de configuración y al de las estrategias que trazan el rumbo conceptual de la obra. Por eso no entendemos la representación sólo dirigida a la forma referencial sino a las propias prácticas y trazos mentales del dibujante.

Para la modernidad, el dibujante era un monstruo sagrado, para la posmodernidad el artista renunciaría a la centralidad autoral, solo constituyó un elemento más del discurso. Pero nosotros definimos al dibujante como una presencia que se constituye en espacio vivo y región mental subjetiva en la que acontecen los cruces eidéticos de la representación.

La condición fenoménica del Minimalismo dotó a la obra de una teatralidad, con ello se rebasó el carácter meramente visual y la opticalidad señalada por Greenberg, desde entonces esta relación teatral acompañará a la vivencia temporal dilatada del espectador frente a la obra, situación que será esencial dentro del dibujo y las obras posmodernas.

Dado que ya no interesa sólo la huella autógrafa del artista sino la experiencia dilatada del espectador frente a la obra, la centralidad autoral pierde sentido, situación que se anexa al plagio, la cita y la apropiación como ejes de la estrategia posmoderna y negación de las prácticas de representación.

Recordamos en este punto, como la cita, la apropiación, la alegoría y el montaje generan estratos de representación en términos de Douglas Crimp; vemos en ello una aportación al territorio general del arte, pero puntualizamos que esta operación discursiva se basa en la estructuración del sentido semiológico de la obra, atiende a las relaciones semánticas de las partes de la imagen; o sea, las que tratan de los nexos entre el signo y su significado, el que lo relaciona con lo real original, a las relaciones sintácticas que trabajan la trama entre las partes constituyentes del discurso y a las relaciones de orden pragmático cuando el discurso sígnico posmoderno opera en su deriva contextual.

En todo caso, si el dibujo como práctica de la representación puede ser asociado a los procesos de semiosis, se encontraría ubicado en el estado de gestación que antecede al signo, en el momento de la primeridad.

Por eso es que si la estrategia del arte posmoderno busca la dislocación de los sistemas de representación entendidos como formas de legitimación cultural, pretende un objetivo político artístico legítimo.

Pero si actualmente el proyecto del dibujo puede involucrar las estrategias posmodernas 
del dicurso, esto no excluye la posibilidad de su función eidética gestáltica como disciplina de representación.

Si e/ sistema se apropia de las imágenes y cargas culturales de los diversos grupos periféricos, el artista plagia en segunda instancia las imágenes naturalizadas por el status, lo hace para devaluar semióticamente esa cultura y sus propuestas de imágenes como creaciones originales. Así, con la estrategia alegórica se desmantela políticamente y se denuncia el sentido pervertido de la cultura dominante.

El problema estriba en tomar esa posición política a manera de negación de una práctica como el dibujo, que se funda en un orden conceptual y formal de la representación; actividad eidética que puede entenderse como un estado cualisígnico.

Esto genera desplazamientos categoriales de lo estrictamente formal a lo político y filosófico; por ejemplo, categorías como la del espacio, hasta la modernidad tardía eran un asunto formal de configuración, para la posmodernidad el espacio se extiende desde lo formal hasta las esferas de lo político cultural. La composición, dentro del mismo giro histórico, fue desplazada desde una función que lograba la integración simbólica y formal de la obra, hacia una sobreposición de capas semánticas que no buscan su integración sino la fractura del sentido.

Las estrategias posmodernas generaron obras que rebasaron los géneros, los estilos y los propios campos disciplinares, ahí se origina el híbrido como espacio de escición, en donde el dibujo no opera como formalización de un referente sino como armador de capas semánticas en lo que se denominó el texto imagen.

Con la desaparición de la obra de arte como objeto, propuesta en el arte-concepto, se inició en parte el camino de la dilución de los campos disciplinares, pero también se abrió un interespacio para el dibujo en el que fungiría como eje de la reflexión conceptual (de nuevo recordamos a Manzoni, LeWitt etc.).

Dentro del tránsito, modernidad posmodernidad, el dibujo arribó al terreno de la reflexión tautológica, la autorreferencialidad, ahí colmó su carácter platónico; pero rápidamente, los artistas que rebasan la posmodernidad toman de nuevo la práctica del dibujo referida a la graficación de elementos denotados de la realidad tangible. Hablamos de los trabajos de los últimos quince años, aún es demasiado pronto para afirmar algo al respecto.

Pero en tanto, el arte posmoderno, en palabras del propio Danto, se poblaba cada vez más de una pléyade de artistas que había desdeñado, u olvidado dibujar.

Dentro del universo de la filosofía, la posmodernidad se caracteriza entre otros factores por el abandono de las lógicas binarias. Así, en el terreno de las artes, la posmodernidad se marca categóricamente por la disolución de los campos disciplinares, como lo expusimos anteriormente.

Es difícil evidenciar el dibujo como una práctica de expansión disciplinar aplicando el esquema del grupo de Klein que Rosalind Krauss introdujo en el análisis de la escultura. Por lo tanto, basados en un esquema lógico riguroso no podemos concluir el dibujo como una práctica de campo expandido.

Pero es claro dentro de la historia tardomoderna, que las obras de los dibujantes corrieron básicamente hacia dos variaciones fuertes: una, la de su realización sobre soportes no convencionales que rebasaron la superficie del papel, y dos: la de resaltar como central el momento y las prácticas performáticas de ejecución de la imagen. 
Nosotros llamamos a esto una flexibilización disciplinar, más que una expansión del campo. Y es que resulta imposible (y lo decimos como una conclusión) hablar de una expansión del campo artístico cuando en la modernidad del XX nunca encontramos descrita o enunciada la taxonomía y definición de los campos en cuestión, más allá de los intentos limitados de Greenberg por marcar las partes de la Pintura (planitud, materia, color etc.). Por tanto y bajo un rigor lógico, no se puede afirmar una conclusión en ese sentido, cuando se carece de premisas enunciadas claramente. Esto desde una posición teórica, pero en el terreno pragmático (que no practicista) el artista como siempre recurrió a la diversidad de medios y estrategias que dieron coherencia a su búsqueda significante.

Coincidiendo con Foster; resulta imposible una definición tajante y general del llamado "Campo Expandido" porque ya desde la experiencia posestructuralista y después la posmodernidad, se renuncia a la búsqueda y construcción de los discursos totales, aquellos que contenían las definiciones universales del campo y sus partes; entonces ¿cómo pararnos en una afirmación que desconoce y renuncia a la lógica que le daría sentido?

Por eso hablamos de una flexibilización del dibujo, una que modifica sus contornos y límites de polución pero que al fin y al cabo mantiene y reconoce su territorio disciplinar.

Por eso es que el dibujo todavía dentro de una condición posmoderna retribuye al territorio del que emerge, y se define utilizando los términos que históricamente le han sido legados; términos que no pueden ser modificados sino desde la interioridad de un proceso de representación que concluya nuevas formas sistémicas gestálticas.

Hasta la modernidad tardía, el ser dibujante se ganaba como una condición de esfuerzo superlativo, aprender a dibujar era tarea de toda la vida, así nos lo dejaron claro nuestros maestros, ahora se puede dibujar al tener un tema que organiza la reunión de partes integradas de la realidad cotidiana.

Las flexibilizaciones del dibujo en los últimos cuarenta años lo menos, aportaron posibilidades de expresión y ruptura al proyecto del arte conceptual y posmoderno, pero esto es posible dado su carácter de disciplina tensora del pensamiento en imágenes y de su esencia proyectual prefigurativa, y no porque se haya dirigido hacia prácticas que relumbran por su novedad.

La mezcla de prácticas y recursos dentro del fenómeno del arte introdujo al análisis la categoría de Interdisciplina, esta mención se volvió moneda corriente en nuestro medio.

En este espacio de conclusiones lo decimos directamente: la categoría de Interdisciplina no es una definición teórica emanada del territorioo del arte, debe su origen a los congresos que estudiaron el terreno pedagógico al final de los años sesentas en Suiza, pasarían lo menos quince años para que esa perspectiva teórica cobrara claridad y se concretara en vías de aplicación práctica dentro de la investigación.

Entonces, estamos ante un un conflicto epistemológico, la interdisciplina como integración de disciplinas que estudian el campo del arte, o bien como posición autoral desde la que se produce el arte.

Como parte de un problema general epistemológico, estamos de acuerdo con la postura de Rolando García, la interdisciplina es la integración de un grupo de investigación que da sentido a la teoría de la complejidad, es una voluntad metodológica y no una característica de la naturaleza. 
Ahora, dentro del terreno del hacer el arte y el dibujo, pensamos que la interdisciplina es un conflicto de integración de lenguajes, de repertorios gramaticales (situación que desde luego reviste una alta complejidad) o en un segundo sentido, la interdisciplina dentro del arte, (igual que en otros territorios del hacer humano) implica la integración de un equipo de trabajo que concita especialistas de distintos terrenos, todos reunidos para la solución de un problema que rebasa la capacidad disciplinar de una orientación.

Esto implica problemas estructurales y metodológicos fuertes, lo vemos claramente, aunque ello rebasa el marco de estas conclusiones.

Pero con todo, la práctica del Dibujo continuó desarrollándose analizando sus conceptos, las estrategias, las técnicas, los sistemas procedimentales etc. Estos elementos constituyen las fronteras que limitan el ejercicio del campo del dibujo y su apertura.

Esta mecánica determinó un pensamiento y fenómeno homeopático con la interioridad del campo, aunque no se renunció a una práctica crítica y reconstituyente del mismo.

La posmodernidad terminó por evidenciar que, dentro del terreno del arte y el dibujo, nunca se contó con una teoría unificada que delimitara la territorialidad de los campos artísticos, este fue más bien un entendido tácito pragmático que se asumió como acuerdo, pero que representa un problema cuando se quiere realizar un análisis objetivo.

Por eso es que al no existir una enunciación sólida, la determinación de la expansión de un campo artístico se realiza sobre bases relativas; o sobre parcelas teóricas sumamente fragmentadas y opuestas como lo anota Derrida.

Pero al margen de las definiciones teóricas que nunca se terminaron de enunciar, lo cierto es que el artista en su actuar fáctico deja de lado muchas veces las definiciones predeterminadas, para en su lugar reconocer posibilidades alternas de configuración formal y estratégica; en esta situación lo que tiene que ampliarse es la definición del término teórico, basándose en la práctica del arte y no a la inversa como se sugiere, y como el propio dibujante lo asume al dirigir su proceso sobre la tendencia marcada por el contexto.

Muchas veces es el propio dibujante quien genera las definiciones de su campo, en otros casos, éstas se desprenden como ejercicio teorizante emanado del hecho artístico. Por ello la teoría del dibujo guarda un margen relativo de independencia con respecto a la práctica que lo genera, la ontología del dibujante se deriva del ejercicio pragmático del campo.

Para hoy ya es claro que ni el arte, ni la estética llegaron a su extinción, como apocalípticamente se afirmó, actualmente podemos decir que lo que se modificó fueron los contornos de sus definiciones teóricas; basadas en las prácticas y procederes del artista, quien pasó por alto el límite de polución que era necesario para determinar la pureza y definición de un campo, Greenberg en ese punto quedó atrás en el tiempo.

Con la hibridación indiscriminada en lo posmoderno la pureza de los campos perdió sentido, en consecuencia su opuesto, la impureza disciplinar también quedó fuera de razón. Ya no es asunto del dibujo, pero en la hibridación interdisciplinar del lenguaje y la imagen, aparecen obras cuyas características no se emplazan en el terreno de ninguno de los campos originales, la suma resultante es algo más que la reunión de las partes, asistimos a un estado alterno de la ontología de la obra.

El híbrido posmoderno se rebela a la ubicuidad dentro de algún campo, se coloca en el interespacio de las fronteras disciplinares, terreno lineal de "entre zonas", emanado de los campos que lo originan pero con personalidad alterna, de ahí que la flexibilización 
del dibujar se observe en la irrupción de medios y estrategias atípicas dentro del dibujo hasta entonces.

La desterritorialización del campo del dibujo renuncia a las definiciones duras, en su lugar se dirige hacia una vocación que prioriza los nexos y relaciones de todo tipo, los absolutos del arte de la modernidad quedan en el pasado. Esta es la red interdiscilinar que complejiza el estado posmoderno del arte.

Ya expusimos cómo los conceptos formales del dibujo se adaptan al ser aplicados en la configuración de distintos terrenos del arte visual, por eso desde la modernidad se enfrentaron serias dificultades para circunscribir conceptos privativos de lenguajes particularizados.

Casi al final de nuestra investigación demostramos cómo el papel proyectual del dibujo se mantiene vigente dentro del arte neoconceptual (Spírito, Kabakov etc.) pero no sólo eso, una ojeada a los catálogos compendiados de las galerías internacionales y a las publicaciones especializadas muestran la actualidad del dibujo como práctica de formalización eidética y estética.

Los autores del periodo moderno muchas veces redujeron el factor cromático y acercaron la imagen y el proceso al terreno del dibujo, lo tonal, lo caligráfico, el dripping y el esgrafiado de aquellos trabajos constituyen un texto que permite una lectura formal interna de ese proceso.

Los cambios cualitativos entre la modernidad y la posmodernidad representan un salto filosófico, pero en la interioridad del dibujo se generó un doble proceso que mantuvo tanto el sentido proyectual disciplinar como su carácter eidético formal.

La entropía, lo aleatorio y el accidente, fueron conceptos que aparecieron dentro del proceso pictórico de la modernidad formal abstraccionista, ocuparon las reflexiones fuertes en ese momento, aún hoy son parte de un eje que permite el análisis de ese periodo.

Revisten importancia para nosotros porque produjeron un giro radical en la relación que unía el dibujo con la pintura.

Al introducir el azar y lo no previsto al momento de configurar la obra se estaba negando la definición clásica de composición, proyecto y prefiguración; lo cual contenía parte de las funciones históricas del dibujo. Pero los artistas no negaron ese sentido neciamente, en su lugar armaron la representación formal del dibujo construyendo categorías nuevas, el all over y la no relacionalidad compositiva junto con el dripping, posibilitaron una personalidad visual para la imagen que era nueva al ojo humano. Era éste un proyecto estético y formalista de la representación; en este sentido la forma estética no era la forma de una experiencia sensible solamente sino una forma del pensamiento típicamente artística. Mientras que el arte posmoderno considera la forma como algo dado; tanto en las imágenes que se apropia como en los fragmentos de realidad que introduce en la obra y el espacio expositivo.

Pero ya en los informalismos y el expresionismo abstracto se plantó la semilla de la flexibilización dibujística.

Primero: el asunto central del proceso seguía siendo la forma estética, en ella se exteriorizaba la postura estética y filosófica del dibujante; pero parte importante del fenómeno era la acción ejecutante del dibujante, tomada en el sentido de una acción performática de la representación tanto como el origen de una obra que contenía un universo de huellas indexales que se referían al psiquismo del autor y ya no a la forma del referente objetual. 
En la modernidad, la forma la estrategia y la acción son la opinión significante.

Para la posmodernidad la forma del tema y la que los sujetos presentan en la vida real y cotidiana es tomada como su forma sustantiva, aquella que lo muestra como se despliega en el mundo. De ahí que cualquier proceso artístico que reinterprete esa forma es tomado como un acto de falsificación.

La Estética no llegó a ningún final, como en la posmodernidad lo afirmó Danto, pero para esa concepción, fue dejada de lado como esencia del acto artístico.

He aquí un conflicto para el pensamiento eidético, el dibujo y la mirada.

Es comprensible la actitud de los artistas posmodernos de la imagen, en lo que se refiere a su interés por desmantelar los procesos de representación típicos de la cultura de su tiempo. Esto se observa en la lista de autores y las obras que se presentaron en la exposición "Pictures" de 1979, como lo analizamos en el capítulo tercero.

Pero cuando esta actitud de desmantelar discursos se generalizó, lo que se nos ofertó fue un panorama de aislamiento, y lo imposible de construír acuerdos de integración; dentro de ello se volvió imposible hasta ahora alcanzar una definición del dibujo que permita entender lo sucedido en este tiempo. Se piensa incluso que éste es un problema teórico; no es así, es un problema de desintegración contextual, la libertad de dibujar llevada al extremo, priorizó el proyecto individual por sobre la construcción de figuras del imaginario colectivo que representen al todo social por encima del sentimiento individual de libertad.

Con esto se dificultó la definición del ser del dibujo, de su sentido, sus contenidos disciplinares y su papel en el concierto del arte actual. No basta con saber lo que ahora sucede en el dibujo dentro del terreno del arte, no es solamente un asunto de estar informados; nos referimos a la postura convenida que pudiera ubicarlo con claridad dentro del proyecto artístico inscrito en su contexto con la vocación de construirlo y no sólo de trastocarlo.

El artista posmoderno trabaja sobre una base que opone estrategia a representación. Su orientación es de base discursiva y desestabiliza el plano semántico de las imágenes apropiadas mediante una organización sintáctica atípica. En esta operación se funda la asociación del arte posmoderno junto al sentido de Deconstrucción.

Con la deconstrucción (aunque no todo arte posmoderno es deconstructivo) se rompe el orden significante del discurso estable; se reagrupan sus partes junto con las de otros repertorios no sincrónicos, ni en sentido estilístico ni en sentido identatario social. Todo esto arma una malla sintáctica de relaciones que cuestiona de fondo la cultura hegemónica. No repetiremos aquí lo ya expuesto, sólo concluímos que es esa esencia de ruptura la que origina y orienta el proyecto posmoderno del arte, como un terreno en el que la estrategia se erige centro de gravedad proyectual; esto es lo que genera repercusiones en la fenomenología del dibujo.

No diremos de ninguna manera que la estrategia posmoderna no reviste importancia en la ontología del arte contemporáneo, pero tampoco se puede concluir de ello la invalidez del sentido capital que la representación guarda en los procesos del dibujo como generador y modificador del mecanismo de la mirada y las formas.

La estrategia posmoderna utiliza imágenes de segunda generación y construye imágenes de tercer orden, ya vimos suficientemente porqué esta construcción tiene sentido.

Basados en una estrategia de exclusión, concluímos que el dibujo en su función eidética esencial se sigue ejerciendo, podemos verlo en aquellas obras que dejando a un lado las imágenes dadas de segunda generación nos ofrecen visiones raras, formas o construc- 
ciones que algo tienen de no vistas (Julie Meheretu, Judy Pfaff) Aunque dado lo reciente de este proceso es dificil teorizarlo y ofrecer conclusiones terminadas.

Pero retornando a la estrategia posmoderna centrada en la cita la apropiación y el desconocimiento del plano estético y formal como objetivos del trabajo artístico, es ya un territorio convenido que esto amplió el trazo de nuevos alcances para los campos disciplinares que anteriormente fueran el centro del proyecto moderno.

Con la renuncia y la crítica a los sistemas formales de representación y con la hibridación de los campos disciplinares, se generaron las situaciones que precipitaron los cambios parciales en la función proyectual del dibujo.

Éste no ganó autonomía artística, ni se constituyó como un arte en sí mismo; lo que sería contrapuesto a la visión posmoderna que niega la pureza de los propios campos disciplinares.

Pensamos que la práctica del dibujo está en una situación relativa de ubicuidad. Los dibujantes somos conscientes de ese estado, nuestra posición en esta región relativa, es una potencia expansiva para nuestro ejercicio.

En esta investigación tratamos la crisis de la representación dentro de la esfera posmoderna del arte. Primero, nos orientamos en el sentido de ubicarla como parte del problema que repercute en el campo del dibujo. En segundo término, al mantener nuestra visión que sostiene la importancia de la representación dentro del acto dibujo, esta categoría se extiende bajo preceptos que aclaran su sentido como parte de la fenomenología del dibujar. Tratamos entonces la representación dentro del planteamiento problemático para después en su momento retomarla como parte de las extensiones teóricas que realizamos. En ambos términos radica la apuesta que como conocimiento nuevo aventuramos en esta tesis.

La Representación en el sentido sociológico es parte del sistema ideológico mediante el cual los grupos humanos se definen, marcan su intención de ser en sí y su proyecto. En ella justifican sus aparatos sociales de representación (estado, moral, ética, orden jurídico etc.) Cuando el arte posmoderno se manifiesta crítico hacia la cultura hegemónica se orienta a la institución de la "polis", trata de las relaciones sociales establecidas por el grupo humano cuando se reune bajo intereses comunes, cuando cobra una conciencia del "ser para sí".

Ésta es una de nuestras conclusiones, la crítica posmoderna (en los autores que revisamos y que se integran en nuestra bibliografía) traba relaciones directas entre el campo sociológico de la representación para establecer su invalidez en el terreno de la gestalt de las formas.

Vemos en ello un error teórico, aunque en el terreno de la crítica social reconozcamos la importancia de esa posición política que se identifica por otra parte con el proyecto crítico social del arte.

La representación, en el sentido que nos ocupa, es función teórica y epistemológica del lenguaje; aunque en cualquier ubicación contextual se entrelace con factores políticos y de diverso orden.

Al dejar de lado la representación como proyecto estético formal del dibujo, lo limitamos en varias de sus capacidades epistémicas, las que integran la riqueza de su función como vía gestáltica de la mirada.

Desde el inicio de esta investigación, y como parte del problema original, señalamos la correspondencia demasiado rápida que la crítica posmoderna establece entre representación y mímesis. 
Después de haber estudiado el asunto ratificamos aquella que era nuestra postura hipotética: La relación entre mímesis y representación se corresponde específicamente con algunos periodos históricos. Particularmente en el caso del dibujo, sólo en un segmento del pensamiento renacentista se pensó en identificar a plenitud la imagen con su referente, pero muy rápido se percibió que las figuras como suma de razón proporcional guardaban una distancia severa con los modelos referentes; en todo caso el modelo era una entidad racional abstracta y no un sujeto creado en la naturaleza.

Conociendo medianamente la historia del dibujo y la pintura sabemos que desde el arte manierista y el barroco, la forma y la materialidad de la imagen obedecen a un orden de significación determinado por operaciones mentales como proceso de construcción del lenguaje no verbal, si es cierto que la imagen se constituye como texto no literal, y que la poética implica una relación indirecta entre la forma y el sentido subjetivo; ¿cómo entonces sostener al binomio lineal mímesis-representación?

Nuestros dibujos no sustituyen una realidad natural o social no artística; por sí mismos integran una región alterna, la del arte, que efectivamente nos hace retornar al contexto primario pero no como sustituto sino como opinión crítica o poética, como plano transparente de sobreposición.

Esto sólo se logra construyendo sistemas formales de representación que nos llevan a comprender el mundo, pero no de la manera naturalizada por la cultura emplazada. Por eso concluímos que la representación no es sólo el establecimiento de relaciones de poder político en las que grupos sociales dominantes se erigen y justifican socialmente.

Posmodernidad y estrategia dejaron de lado la formalización y la estética del trabajo artístico. Usan una mirada de diseñador que opera sobre la suma total de las artes y sus estilos, la abducción eidética se sustituye por el cliché cultural.

La revista "Octubre" fue desde siempre el eje de la crítica posmoderna; en sus páginas se escribieron artículos clásicos del pensamiento posmoderno del arte. Uno de ellos sobre "La originalidad de la vanguardia y otros mitos modernos"

Recordamos este artículo nuevamente porque podemos concluir una contradicción que hemos encontrado insalvable, la que se establece entre la no originalidad vs desplazamiento abductivo.

Expusimos la lógica abductiva como base y proceso gradual de la creatividad, y como el giro y el desplazamiento de los sistemas del dibujo, de ser cierto el pensamiento de Pierce y Ángel Herrero, invalidaría la afirmación posmoderna que niega la originalidad y con ello la vigencia de la representación renovada.

Hasta aquí lo que toca a la representación como el problema que originó nuestro estudio; ya regresaremos a ella como parte de extensiones reflexivas previas a nuestra idea del acto dibujo.

Iniciamos nuestra investigación con la visión del dibujo como una forma del pensamiento proyectual, misma que da sustancia a su función como eje del proceso de representación; llamamos a esta categoría El carácter Proyectual Prefigurativo del Dibujo. A lo largo del trabajo fue quedando clara esa tesis.

Pero en el camino encontramos como el carácter proyectual del dibujo se bifurca en una visión ordenadora del método y el proyecto, y en una flexibilización de la estrategia proyectual. En todo este segmento de la investigación cobró relevancia el estudio del pen- 
samiento complejo y la lógica abductiva. Basándonos en esas dos vertientes pudimos explicar la ruta del dibujo que permite a la vez tanto una visión metodológica prefigurada como sus variaciones creativas emergentes. En este terreno pensamos modestamente haber aclarado nuestra idea inicial positivamente.

El proyecto del dibujo es la reflexión inicial que recuerda la intención significante primaria, frente a la que quedan claras las abducciones que abren la ruta de la representación.

Pero en el proceso de la investigación surgió un elemento agregado que vino a enriquecer nuestra concepción del carácter proyectual del dibujo.

Nos referimos al texto de Santiago Vera Cañizares "Proyecto artístico y territorio".

Ya desde el inicio intuíamos que el proyecto del dibujo aparte de ser el ámbito creativo de la obra y de ser él mismo parte de la propuesta, traba relaciones con el contexto histórico cultural y social en el que se inscribe.

Encontramos en esas líneas claramente la dimensión histórica del pensamiento proyectual, como visión ideológica y como práctica política.

El propio Vera Cañizares engloba el proyecto del arte desde una doble posibilidad; la del Proyecto Positivo Moderno, como ideal ascendente y constructor de la sociedad moderna; y la del Proyecto Crítico Existencial surgida de la modernidad industrial del siglo XVIII, que señala y denuncia las certezas rigidizantes del totalitarismo social.

El pensamiento proyectual coloca al artista de frente a la fragmentación del corpus y el individuo social, no le permite evadirlo como ya dijimos, frente a esa disyuntiva el pensamiento proyectual se dirige a calar en esa disyunción histórica.

Esta es la relación que une desde siempre el pensamiento del proyecto moderno con la vanguardia artística, como positividad ascendente o como negatividad crítica existencial. Ésta sería la expresión contextual del pensamiento proyectual artístico.

Pero en la interioridad del campo formal del dibujo, la cadena metodológica de lo que se ha dado en llamar "Los Dibujos del Dibujo" se inicia típicamente en el Renacimiento y madura para mediados del 1600 en el arte Barroco. Apunte, Boceto, Estudio, Proyecto y Obra terminal, comprenden la cadena que expresa las etapas metodológicas de la representación en el dibujo occidental moderno.

Esta secuencia proyectual y su carácter metodológico se mantienen a lo largo de 400 años en general; pero la postura epistémica del dibujante frente a los modelos, las formas de la representación del propio dibujo y el contexto social variaron constantemente. Esto es lo que motiva los cambios formales de la representación y la deriva del lenguaje del dibujo.

Podemos ver en el Romanticismo una crítica a la Modernidad Ilustrada ascendente; en ese corte se divide ya claramente el proyecto del arte y el del dibujo. Una visión ascendente que aspira a fundir armónicamente arte, cultura y sociedad; en ésta la representación se dirige hacia formas y sistemas positivos de la cultura. Visión que podemos rastrear hasta Bauhaus y el Neoplasticismo.

El artista rebelde y escindido de la sociedad es consecuencia del pensamiento romántico, pero eso sólo nos interesa en el sentido que desde entonces tal rebeldía se cuaja en una epistemología que genera sistemas de representación del dibujo que trastocan el pensamiento en imágenes.

Centralmente se desplaza la atención del pensamiento proyectual hacia la parte metodológica formal del dibujo, o bien, hacia la parte crítico social. 
Pero desde nuestra perspectiva, y coincidiendo con Vera Cañizares, el Tema se constituye en categoría relevante dentro del proyecto del dibujo.

El tema de la obra es la región circunstancial y mental en la que se cruzan las reflexiones procesuales y pragmáticas del acto prefigurante y ejecutante. Es quien determina la suerte crítica, conceptual o poética del dibujo.

El verdadero tema es una función problemática y no una certeza, por ello opera como impulsor del proyecto y el dibujar. La conciencia del problema define el tema del proyecto. Consideramos relevante la demarcación que hacemos del tema como el área problemática que resulta al relacionarse el contexto, el dibujante y la obra en construcción.

Igual que el proyecto, el tema se dirige tanto a la esfera de lo cultural y lo social como al campo de la interioridad del propio dibujo; así la crítica se ejerce desde el plano sociológico y desde el plano formal de la representación.

Éste es el sentido del núcleo del proyecto; la relación entre el tema vuelto problema y su transmutación conceptual en una forma sistémica que da estructura a la representación. Pero además el tema del dibujo es la entidad atravesada por la vivencia del dibujante, la del vivir prefigurando como la del vivir configurando; y esto le confiere ya al proyecto un sentido no lineal de comportamiento.

Al definir el tema del proyecto como región de vivencias, introdujimos elementos categoriales nuevos, la Vivencia con un sentido fenoménico teórico. Sumamos a ello la inclusión del Pensamiento Experiencial, como segundo término de un pensamiento procesual que desarrollamos como parte de lo que llamamos en un inicio el Acto Dibujo. No repetiremos en este espacio lo que ya hemos expuesto, esperamos haber sido claros solo lo puntualizamos como parte significativa de nuestras conclusiones.

Tenemos entonces que el pensamiento experiencial es la reducción reflexiva constante que el dibujante realiza frente a la suma vivencial del acto de dibujar y los preceptos contenidos en el pensamiento proyectual inicial. Por eso el proyecto construye continuamente el plano experiencial del artista. En ésa dinámica, el proyecto opera conscientemente en la planeación y configuración del dibujo, momento de diálogo en el que adquieren profundidad constructiva tanto los sistemas representacionales como las estrategias puestas en juego.

El pensamiento proyectual del dibujo es en sí mismo una obra que nos representa a nosotros mismos en el acto de representación, como lo señaló Gómez Molina; pero en términos metodológicos es un sistema orientado hacia la construcción de otro sistema que es la obra y en este caso el dibujo.

El proyecto del dibujo tiene como un primer núcleo de intención (no decimos que sea el más importante) atacar las resonancias culturales naturalizadas, incluso como un pensamiento que mina las reflexiones e intensiones iniciales del dibujante. Esto porque en segunda instancia el proyecto del dibujo busca las formas nuevas, lo no visto, la nueva constitución de la mirada el sentimiento y el pensar. Como ya lo decíamos el proyecto del dibujo se dirige a la región mental y psíquica profunda, aquella de los diálogos que iluminan y modifican la topología de la representación.

Para nosotros el pensamiento proyectual del dibujo es el viaje vivencial que se dirige al pensamiento experiencial. También aquí reconocemos el peso del texto de Santiago Vera. Cuando enunciamos nuestra visión del acto dibujo, consideramos el proyecto orientado a 
trascender la realidad inmediata y aparente, la que tanto pesa en la posmodernidad; buscamos dirigirnos hacia estados experienciales de conciencia representacional. El pensamiento proyectual es conciencia epistémica, tanto como un proceso de formalización que concluye en una visión que representa la realidad y a nosotros mismos, aunque también lo vemos como un ejercicio alterno de deconstrucción sígnica.

Desde su inicio el proyecto reconoce el tiempo y el plano fáctico del proceso, en ese momento acontece la materialidad configurada del dibujar, ésta es la forma fáctica constituida.

La forma nueva es el imperio de la mano y la corporalidad modificando la mirada y el pensamiento, en términos de la manualidad expuesta por Deleuze. Por eso la forma nueva de la representación es implícitamente crítica, porque pasa por encima tanto del pensamiento social establecido y dominante como del propio cliché del dibujante.

Por su parte, las emergencias de la estrategia constituyen un desarrollo cognitivo, que es extensión de la conciencia epistémica.

Dentro del paso a la posmodernidad el proyecto del arte y del dibujo se caracterizó más como un terreno de la intervención y la estrategia, que como una práctica de la formalización estética.

Pero el comportamiento programático, tanto de los procederes y estrategias, como del repertorio conceptual utilizado puede ser leído en la suma indexal que constituye el texto imagen, así como en los registros recabados de la acción al configurar el dibujo (videos, fotos, películas), de donde se concluye la postura epistémica asumida. La historia de esta fenomenología es el relato de las fuerzas liberadas en el acto configurante.

El pensamiento proyectual y la conciencia estratégica toman a la obra y los modelos del dibujo como otredades ontológicas con las que se entablan los diálogos del silencio.

Aunque éste sea el espacio de conclusiones introducimos de nueva cuenta una cita de Santiago Vera, lo hacemos porque en ella se aclara la intención que en un inicio sospechábamos en lo referente al aspecto de estrategia y pensamiento proyectual, sus palabras concluyen de manera inmejorable este punto.

"El proyecto creativo, como promotor previo y protagonista de las evoluciones artísticas, tiene la facultad de convertirse en instaurador metodológico y programático del lugar discursivo y simbólico para el Arte, merced al establecimiento de relaciones íntimas e intensas con el tema, fomentadas como una estructura rizomática, donde todos y cada uno de sus componentes (elementos vivos dentro del circuito rizomático artístico) establecen vías de comunicación con todos los demás, creando a modo de un sistema de vasos comunicantes; no eximiendo la posibilidad de actuaciones independientes o aisladas. Estas relaciones íntimas, biocenóticas, acogen aspectos multisemánticos (metáforas, símbolos, arquetipos) alcanzando contenidos, tanto denotados (con significado estable dentro del sistema cultural donde están insertados), como connotados (con significados variables según contextos o grupos o grupos culturales)"162

El pensamiento proyectual del dibujo se fue decantando como ruta metodológica de con-

162 Vera Santiago. Proyecto Artístico y Territorio. Granada: Ed. Universidad de Granada; 2004. P. 113. 
figuración formal; pero se colocó finalmente como vía de transformación y construcción social, y también como posibilidad de apertura estratégica en el proceder del arte.

Aunque el proyecto del dibujo implica su dimensión abstracta, igual decimos que manifiesta un ámbito vivencial desde el momento en que el dibujante se inserta en el contexto original y luego en el acto ejecutante, incluso en su dimensión expositiva.

La actitud en el proyecto define la postura epistémica. Da sentido al sistema estratégico y teórico en operación, posiciona al dibujante dentro de las formas de pensamiento universal. El proyecto en su profundidad requiere el conocimiento suficiente de la historia del arte y los sistemas del dibujo. Con la pérdida del sentido integrado del dibujo, se diluyeron los acuerdos que permitían la demarcación de sus conceptos y prácticas. Por eso la práctica actual del dibujo vive una dispersión en lo referente a los cuerpos formales de representación que se utilizan.

Nuestra hipótesis partía de un supuesto triádico interrelacionado. a) El dibujo como promotor del pensamiento eidético y proyectual, b) La ruptura del vínculo sistémico que histórica y metodológicamente consolidó la relación funcional entre el dibujo y las artes visuales, c) La crisis de la representación y el uso de las imágenes de segunda y tercera generación. En el proceso del dibujo, la formalización rebasa la forma de lo somático para hundirse en la construcción de la alteridad del pensamiento formalizado en el dibujo como objeto y como suceso. Forma primera que se suma a lo ya visto. Proceso del pensamiento dibujístico, recordamos a Hubert Damish, en su texto Ventana amarillo cadmio.

Basados en todo esto definimos el carácter proyectual del dibujo como la función que le ha permitido ser el integrador del proyecto artístico y el motor del pensamiento en imágenes y la esencia estructural de las formas, premisas que lo integran como un campo disciplinar particular de pensamiento.

Al revisar las fuentes que tratan el análisis de la representación encontramos la mención recurrente de la pérdida de consistencia de la realidad contextual. Éste es terreno de la filosofía en el sentido más claro de la expresión; no es ahí a donde nos dirigimos para concluir. Pero en ése mismo discurso se alude a la carencia de sentido de dibujar o pintar posicionado ante lo que se había dado en entender como modelos.

Como se ha visto, uno de nuestros capítulos de investigación se dirigió intensamente en el sentido analítico de esa categoría.

En este espacio conclusivo puntualizaremos lo que aportamos como extensiones teóricas de la categoría de modelos. Varias de esas extensiones se basan o se deben al pensamiento de otros autores, volveremos a puntualizarlo; pero en una parte concluimos sobre la base de ideas propias.

La acción de dibujar las más de las veces fue asumida como una mediación cognitiva entre un sujeto llamado dibujante y la otredad, la de la naturaleza, la realidad o el contexto. Luego de haber investigado concluímos que no es tanto una disolución de los modelos lo que acontece sino una desviación epistémica en la que el artista ya no dibuja para conocer al otro, ahora se sirve del reservorio de imágenes de la historia.

Válida o no esa situación, lo cierto es que no puede operar como premisa general que concluya con el sinsentido del encuentro del dibujante con sus modelos. 
Deseamos poner énfasis especial en este punto, muchos autores aparecieron en la investigación (Alain Bois, Benjamin Buchloh, Craig Owen, Hall Foster, Douglas Crimp, Marchan Fiz, Hubert Damish) varios de ellos manifestando la pertinencia de un pensamiento endógeno de los campos artísticos, y por extensión del dibujo, de manera que esta idea que nos animó desde el principio no es sólo nuestra. Pero modestamente pensamos haber realizado una serie de extensiones sobre la categoría de modelos en el terreno del dibujo. Esta afirmación está desarrollada en el cuerpo de esta investigación, ustedes sabrán valorarla. A esta organización de los cuerpos teóricos de la categoría de modelo en el dibujo se debe agregar nuestra exposición de lo que llamamos el Acto Dibujo; juntos, estos dos apartados sustantivan en gran medida nuestra respuesta al problema inicial, es una reflexión basada en la historia del arte y en el pensar de varios autores.

Muchos de estos argumentos emanan de la crítica del arte, ahí existe un problema, suenan un tanto distantes al dibujar, se obligan demasiado por el derrotero global del arte visual. Pero otros autores como Foster, Deleuze, Michael Fried, Alan Bois y Hubert Damish comprenden mucho más internamente los conflictos de la configuración. Incluso se manifiestan claramente por una tipicidad particular del pensamiento ejecutante. En gran medida con ello se prueba positivamente parte de nuestro pensamiento hipotético.

Pero además de su vertiente teórica, los modelos del dibujo siguen siendo las entidades ontológica o fenómenos del contexto ante las que nos posicionamos para realizar los diálogos del dibujo. El modelo es la otredad que activa los cuestionamientos de la identidad. Junto con nuestros modelos nos emplazamos en una locación que instaura la particularidad espacial y temporal fenoménica del dibujar, en donde el vivir se enlaza con la reflexión experiencial.

El modelo es la ficción que calza con la realidad en el más puro sentido constructivista. Para el dibujante el modelo abstracto es una entidad formalizada y sistémica que objetiva la representación, es claro entonces que el modelo, ni es la realidad primera ni su sustituto como se ha querido ver, el modelo es una ficción que se constituye en realidad inventada, no vemos nosotros ahí ningún problema, lo interesante se suscita en la cualidad y variables de esa relación, la manera en que la ficción del dibujo se relaciona y alude a la realidad primera es el terreno de la apertura de identidades.

Para las Artes Plásticas, el modelo era la realidad alterna de la Forma Significativa, en donde la materialidad y la forma sustantivaban el sentimiento. En la categoría de las Artes Visuales el modelo era la alfabetidad del lenguaje visual, que tampoco era lo real primero. Para la modernidad formalista el modelo fue la consecución del absoluto personal, la objetivación de la visión propia de la pintura y el dibujo. En la posmodernidad el modelo es la entidad a trascender, lo que es deseable no necesitar.

El Modelo como entidad teórica y ontológica se diversifica en categorías paradigmáticas de la interioridad artística, en gran medida planteadas por Damish. No hemos de repetir lo ya desarrollado, realizaremos solamente una puntualización seriada.

El Modelo Histórico es el posicionamiento del dibujante ante el repertorio histórico de sus sistemas y de la condición temporal de su contexto, no tanto de las circunstancias sociológicas de la historia.

Este modelo es la sublimación de las particularidades históricas en aparatos formales 
y prácticas estratégicas del dibujo. Por eso es que determinadas obras marcan cortes paradigmáticos en la secuencia del arte.

En este modelo resulta capital la información de todo tipo de que dispone el dibujante para traducirla en una postura estratégica.

En el curso de la investigación nos hemos detenido suficientemente en lo que consideramos el Modelo Tautológico Autorreferencial, lo definimos como el plegamiento retroactivo del uso del lenguaje para constituirse en su propia causalidad.

Elaboramos nuestra idea haciendo mención de la crítica de Clement Greenberg, pero basándonos sobre todo en la postura constructivista de Watzlawick.

Señalamos este modelo como una característica general de toda la vanguardia anicónica y la disección que realiza de los elementos de la forma y el lenguaje visual.

El pensamiento tautológico desembocó en dos vertientes, la del arte conceptual y la del modelo formalista.

La forma del modelo se separó de la forma del concepto y el lenguaje, de una vez por todas quedó clara la idea de que el dibujo es una manera particular de pensar el mundo y no una reproducción mimética.

Apareció entonces la visión indexal del dibujo que lo llevó a establecerse como parte de un texto no escrito.

Ya mencionamos que para Bourriaud el Arte relacional es el ejercicio de prácticas que toman como eje el continente de las relaciones humanas y su introducción en el evento expositivo. Este modelo tiene particular importancia en el terreno del dibujo, ya que desde hace décadas el acontecimiento del dibujar es un evento al que concurre el público y se lleva algo más que la experiencia de la obra terminal. El flujo de interacciones entre autor y asistentes es manifestación de la intersubjetividad. El aura de la obra se disuelve en la colectividad catártica o emotiva del evento.

Nuestra definición del modelo relacional no se agota en los nexos interpersonales del dibujante con el público, ya en los catálogos de nuestras exposiciones de 1997 hablábamos del Dibujo y Pintura Contextual, esta definición tiene como eje una forma de relación, la que el dibujante establece con el contexto.

El Dibujo Contextual es el reconocimiento de la otredad y su comprensión, así como la formulación estratégica y metodológica que de esa relación se desprende.

Damish expone el Modelo Perceptivo; éste se basa en la personalidad áptica y visual de la obra. Ésta es el repertorio indexal de la intencionalidad del autor y el flujo de acontecimientos de la configuración.

El modelo perceptivo rebasa el mero plano sensorial e inicia una práctica de la conciencia que expande el sentido de la representación.

En este modelo lo dado a la mirada se convierte en la construcción del pensamiento mediante la visión.

La intención del modelo perceptivo sobre todo en el dibujo es la perturbación del orden naturalizado en la gestalt común y en la relación clásica fondo figura.

Precisamente el sentido perceptivo del dibujo requiere de otro modelo, el Modelo Técnico; este modelo es el proceso de configuración como un suceder en el que se organiza el ser estructural del dibujo. 
Ya dijimos que la técnica es la vía que explicita el concepto, así es, pero este sentido se expande hasta una amplitud significante que comprende el amplio abanico de la constitución fáctica del dibujo; el modelo técnico organiza y produce la imagen como texto no escrito pero aún así dado a la lectura y a la sensación. Situación que nos explica porqué el dibujo objeto, como hecho indexal permite una cierta reconstrucción del acto de la representación.

Las prácticas estratégicas y los repertorios formales llegan a convertirse en símbolos paradigmáticos; la verticalidad del plano pictórico, la mímesis y la forma etc. Son modelos que simbolizan cortes históricos en el proceso del dibujo y el arte.

Existen artistas, obras y movimientos artísticos que tipifican estos estatutos simbólicos y son los referentes a trascender; desde la posibilidad de la estrategia, la forma, el proceso o cualquier parte de lo que constituye la sustancia del dibujar.

La estrategia se yergue como modelo en el momento que rebasa su plano operativo dentro de la configuración para colocarse como posición teórica y epistémica del dibujante frente a las prácticas que operan dentro del campo disciplinar.

El Modelo Estratégico es la posición del dibujante dentro de la partida histórica que se juega en el dibujo; define el rumbo del enfrentamiento del dibujante con sus iguales, con la teoría y la historia. Por lo que la obra es, y también por lo que no es, como lo dijimos.

Como modelo, la estrategia traza vínculos, mapas de relación claros entre lo que llamamos los estados temporales del sistema del dibujo.

El modelo estratégico es antihistoricista, simplemente porque no acepta la cancelación del flujo histórico del proceso. Niega la decadencia de la representación y la estructura formal del campo disciplinar. Porque este modelo se basa en la deconstrucción del juego y en la posibilidad de reinventarlo con bases estructurales diferenciadas en su cualidad ontológica.

Basados en la lógica de un modelo estratégico nos podemos preguntar con toda gravedad: ¿Es la renuncia a la representación formal, realmente un elemento prescindible dentro del territorio del dibujo? ¿O bien sólo es parte de un momento estratégico en el curso de una partida del arte, pero no por eso resulta sustituible del territorio del dibujo?, ya sabemos que dentro del terreno del arte la respuesta tiene que ser positiva y abierta, porque no podemos negar anticipadamente ninguna ruta epistémica.

El mismo Damish se muestra desconfiado ante el tono apocalíptico reiterado de la crítica; el prefiere pensar en esos atolladeros como casi interrupciones en los encuentros del juego del arte.

Para el dibujante su mejor filón de oportunidad no es la reseña histórica de sus modelos, sino su activación o negación en el terreno fáctico de la partida ejecutante.

Tomando todo este panorama modelístico como el universo de operación, se observa porqué es necesario el conocimiento de un marco teórico e histórico de los sistemas de representación y la teoría del dibujo.

Y éste es el desarrollo del pensamiento que nos anima desde hace tiempo, es la respuesta que construimos en parte al problema de esta investigación. El operar dentro de la actualidad del campo del dibujo se basa en el conocimiento de Los modelos del dibujo, cuerpo de saberes formados en el acto dibujo. 
Pero el dibujo es un cuerpo disciplinar teórico y formal de mediación, un territorio que ocupa la posición entre la ontología del dibujante y la del contexto, es la región por la cual accedemos al contexto y con la que incidimos en él perturbándolo.

Hemos puesto énfasis en el carácter de los modelos del dibujo como entidades teóricas y estratégicas. Definiciones abstractas como procesos de codificación eidética del contexto. Estos son parte de un acuerdo social de lenguaje que se expande hacia el mundo subjetivo y espiritual.

Pero al pensar el dibujo como una mediación aparece con claridad la figura de aquello que está al otro extremo de la mediación; por eso decíamos y ahora concluimos que los modelos del dibujo continuarán siendo las otredades ontológicas a las que accedo mediante el dibujar.

La categoría de Modelo dentro del dibujo se coloca entonces sobre dos campos generales.

\section{El Orden Teórico de los Modelos y el Modelo como la Otredad Ontológica.}

Los modelos interiores del dibujo son de carácter abstracto, se deben al pensamiento, son operaciones de disección conceptual que separan en partes lo que en el acontecer fenoménico siempre está integrado. Estos modelos construyen categorías y paradigmas que analizan la relación de la disciplina con respecto al contexto y a sus formas de representación, son igual la ruta que canaliza y encausa la subjetividad del dibujante y la sustantiva como parte de la obra.

Con la exposición de esta serie de variaciones de la categoría de modelo aclaramos una parte de nuestro problema inicial, aquel que aludía a la pertinencia de un pensamiento teórico y metodológico de la interioridad del dibujo, al margen de la problemática global del arte. El hecho de que varias de estas posturas sean planteadas por autores de talla teórica da consistencia a nuestra conclusión, que prueba la hipótesis de arranque.

Al término de todo el cúmulo de reflexiones anteriores se comprende porqué concluimos el que los modelos del dibujo en su visión más general son los cortes históricos de los cuerpos de representación formal de la disciplina. Mediante ellos observamos el comportamiento y la tendencia del proceso del dibujo y el arte. Sus cadencias sus fragmentaciones y sus rupturas. Esto es, el sentido del dibujo como un sistema complejo con sus divergencias, sus conjunciones y disyunciones en el cuerpo de sus normas estructurales.

Así, podemos afirmar que cada modelo formal del dibujo, como corte paradigmático, posee una definición teórica formal y estratégica tipificada.

Para el desarrollo de nuestro recorrido histórico por los modelos formales de representación del dibujo tomamos (como se advirtió en el cuerpo capitular) seis segmentos generales en los que observamos posibilidades de agrupamiento cualitativo del problema estudiado.

III-6-1 EL MODELO RENACENTISTA

III-6-2 EL DIBUJO EN EL MANIERISMO Y EL BARROCO

III-6-4 EL DIBUJO DE LA FORMA

III-6-5 LA ACCIÓN DE DIBUJAR

III-6-6 EL DIBUJO DE LA MODERNIDAD A LA POSMODERNIDAD 
Ya hemos dejado suficientemente claro que la condición del dibujo del fin de milenio debe ser leída más como una circunstancia de movilidad paradigmática del proceso de las artes que como una libertad del campo disciplinar. Y también que la quiebra de la representación y el modelo estético es una particularidad de la condición posmoderna del arte, pero que difícilmente se puede asumir como característica permanente, ya que hasta la tardomodernidad, que se traslapa temporalmente con lo posmoderno, se concreta la vía de las artes en obras que son formalizaciones de la representación.

Entonces la premisa de la expansión de los campos disciplinares no necesariamente implica la exclusión del dibujo como función del pensamiento eidético.

Llamamos a esa función eidética el Acto Dibujo.

El Pensamiento Proyectual, la Vivencia, la Prefiguración, el Pensamiento Experiencial y la Configuración, son los elementos categoriales que entendemos como el cuerpo del dibujo en tanto proceso de representación.

Esta parte de nuestras conclusiones es más una posibilidad que una solución.

Por lo anterior no queremos derivar un cuerpo taxonómico de aquello que nombramos el acto dibujo; menos cuando ya expusimos su contenido en el último trecho de nuestro escrito.

Orientamos esta parte a puntualizar algunos elementos previos en los que se basa el desarrollo de nuestra definición, pensamos mejor que, en esas reflexiones se muestra el fundamento mediante el cual desalojamos finalmente la problemática inicial en la que ubicamos el territorio del dibujo.

Aún entrando en franca contradicción con la mayor parte de las fuentes estudiadas, definimos el Acto Dibujo como una práctica de representación.

Y pensamos haber demostrado que en ese acto se rebasa la imposición de la mímesis como eje de la representación.

Fundamentamos esa afirmación en la premisa que precisa el entender la representación tanto en el sentido de una práctica social ideológica, pero también como un proceso eidético de origen gestáltico.

En la representación se significan las práctica sociales mediante las cuales se justifica el sistema. Pero la representación también construye los nuevos órdenes de la imagen en los que introduce las resonancias psíquicas intersubjetivas del vivir y en las que se fundan las imágenes de primera generación.

Ya que la representación se objetiva en sistemas formales, y ya que opera en el intercambio de subjetividades y la sensibilidad, es por tanto un segmento del campo estético, incluso dentro de los proyectos de mayor rigor lógico conceptual.

En el acto dibujo, las formalizaciones son una explicitación de la conciencia experiencial. Se dirigen hacia lo aún no determinado ni resumido, lo que está por manifestarse, sea estrategia, forma, acción o poética.

El corte paradigmático introducido por las Artes Visuales y los primeros Integracionismos es el primer gran cuestionamiento radical al concepto de mímesis asociado a la representación. Aunque nosotros anotamos que esa ruptura se inicia con las libertades manieristas de la forma y el concepto de alegoría.

La deriva de la representación que va de la mímesis a lo no referencial es un proceso de 
más de tres siglos, pero tiene su primer corte radical en la modernidad inicial del XX, en las obras que obligaron al ojo humano del todo social a la modificación de su gestalt y a sus cánones de representación.

Se modificó la postura epistémica del dibujante frente a sus modelos y los procesos del dibujar, a partir de entonces, la forma, pero también la acción y la estrategia representan al dibujante y a su postura artística y política.

Se concibió al dibujo como el lenguaje que configura la realidad interiorizada y como el mediador entre lo contextual como real primero y la vivencia del dibujante trasladada al pensamiento experiencial.

El dibujo dejó de ser el descriptor del mundo y se convirtió en su construcción subjetiva. Al acercarse al lenguaje, el dibujo nos hizo claridad sobre su propio sistema y el plegamiento tautológico que refuerza su ontología y la nuestra. Y todo esto no es sino parte de la mecánica de la representación.

La poética, la metáfora y el concepto (si es que pudiera ser definido al margen de la poesía) se expandieron hacia la posibilidad expresiva ejecutante del dibujante. Cosa que hoy parece no tener sentido o que no se quiere ver.

La ejecución y la obra dibujo se pueblan de huellas y rastros indexales que amplían los mundos construidos por el poder del dibujante.

La representación y la obra del dibujo se dan a la lectura, desde lo arqueológico de su topología hasta lo psicoanalítico de sus pulsiones.

Por esto concluímos que la representación no es un volver a hacer presente el sujeto ausente. Es el acto de construir otra realidad, cualificada con diferencias que no permiten el confundirla; como se asume demasiado fácil.

El acto dibujo crea una representación en la que desea introducir al espectador, sea para reflexionar sobre la primera realidad o para ubicarlo en aquello que Bachelard llamó la región del ensueño. Para nosotros en esta investigación han quedado muy atrás los mecanismos de la trampa de ojo tan socorridos en un eterno retorno.

El concepto de Diferencia, introducido por Derrida nos resultó altamente significativo. Tanto porque resuelve de una vez por todas la distancia entre el modelo y su representación como entidades diferentes a las que no debemos confundir. Y porque implica como consecuencia que, ambas entidades al ser diferentes se constituyen en estructuras formales también diferenciadas, la forma de la imagen del dibujo no es la forma del modelo referente.

La representación parte de encarar una realidad primera para construir una segunda. En ese recorrido es que caben las operaciones reflexivas que aludimos; pero la representación como acto fenomenológico es la conciencia e interiorización de una vivencia primera, la que busca prolongarse en la vivencia de la configuración que es el inicio de la formalización del contexto, en este punto se inicia la segundidad del pensamiento experiencial; aunque en su tiempo ambas acontecen casi de manera sincrónica.

Es importante al concebir el dibujo como acto, tener presente que en sí, no carece de formas, de tiempos y secuencias, estrategias, manifestaciones de la corporalidad y el psiquismo, condiciones que lo acercan a un carácter ritual y no solo a una formalización mecánica de la realidad. 
Los repertorios y códigos formales, los signos, el dibujo como texto indexal no son solo las partes de un proceso de semiósis (lo que resulta capital en la operación estratégica posmoderna) son también la dimensión fenomenológica del dibujar. Fenomenología porque se centra en la puntualización espacial y temporal del dibujante como sujeto de una vivencia cognitiva, que busca mantenerse activa antes de dar paso a las reducciones teorizantes de la experiencia. Por eso es que frente a esta concepción la negación posmoderna de la representación significa una antítesis.

Para 1947 en el proceso del arte se definen claramente la obra, el artista y el contexto como sujetos ontológicos de una relación terciaria. Entre ellos se genera un campo de interacciones complejas y que nosotros Ilamamos los diálogos del dibujo, aconteciendo en una temporalidad y locación compartidos.

Destacamos como giro importante el que en esta lógica terciaria no se opera sobre una base de términos excluyentes como en la lógica binaria y dialéctica. En esta postura se trabaja dentro de una zona permeable que facilita las relaciones osmóticas.

Basados en esta lógica terciaria afirmamos que la representación no se dirige hacia la deconstrucción del campo del dibujo, la rebasa porque no intenta el reordenamiento de los sistemas de representación, busca su ruptura y modificación sistémica; le interesa la gestación de imágenes de primera generación que trascienden la partida y modifican la definición del juego, el lenguaje, el campo. Esta sería una postura epistémica radical del dibujante.

Cuando el lenguaje se torna el tema de la obra en sí mismo, la noción de lo real se problematiza, claro está, pero en esa problematización se aclararía de una vez por todas la falsa relación obligada entre mímesis y representación, y con ello el vínculo profundo que une al dibujante con los modelos en el sentido más amplio de la definición.

La fragmentación de la llamada realidad se relaciona con la disección del lenguaje visual que introdujo la vanguardia. Simplemente la riqueza de la representación formalizada que eso generó es maravillosa; y claro que esas imágenes resultaban diferentes a la visión perceptual de los modelos referenciales, no es la mímesis lo que prevalece como categoría en ese trecho histórico, es la traba entre referente e imagen la que se sostiene.

Mondrian observó atinadamente que en esa operación, aunque la obra se originara en la naturaleza, debía dejar de denotarla para atravesarla y crear estructuras del absoluto plástico, formas de la forma, que no formas dramáticas o políticas del mundo externo a la plástica.

La diseminación del lenguaje en la vanguardia de la preguerra tenía un proyecto social positivo de ascenso, cosa que en la posguerra se desdibujó dentro de lo múltiple infinito de la huella autógrafa del dibujante.

El pensamiento eidético se orienta hacia la esencia estructural de las cosas, esto se concreta en las formas de los modelos, abstractos o somáticos. Por eso es que la vanguardia dejó en claro que la representación se orienta hacia la primeridad de la imagen y lo no visto, anexa cualidades a una realidad perceptual, cualidades no propias del sujeto sino conjeturadas en la prefiguración y configuración.

La mecánica de la filosofía se basa en el nivel más alto de abstracción y generalización de lo real, pero el acto del dibujo, como el de todo arte, trabaja sobre la apertura y des- 
estabilización permanente del sistema, y en el replanteamiento de su vena epistémica. El dibujante asume lo temporal de su imagen lograda, al ganar esta un emplazamiento social, elabora su propio límite que debe ser rebasado.

Ubicados en esta particularidad, planteamos una conclusión surgida en el curso de la investigación: El acto dibujo puede estar orientado en un sentido autorreferencial, y trabajar sobre una lógica compleja retroactiva, quizá hasta llegar al concepto puro. Pero esto lo coloca en una órbita gravitacional que termina por agotar sus posibilidades expansivas de lo eidético; lo transforma en un juego del lenguaje que no alude, ni puede, a nada que esté más allá del cerco del lenguaje.

Sólo en las relaciones del dibujante con el contexto en que se inscribe, e introduciendo su práctica como parte de ese ejercicio contextual de relación, se potencia el sentido profundo de la representación.

Nosotros ratificamos en este momento la vocación del dibujante como entidad que tiene que buscar la otredad, el sujeto o el contexto con el que entabla las relaciones de identidad vivencial.

El acto dibujo es el acontecimiento que media entre el dibujante y la realidad.

$Y$ aquí se comprende claramente el fundamento de los esquemas que pueblan nuestra exposición del acto dibujo en el último capítulo de este trabajo.

Los conceptos de acto, diferencia y singularidad pueblan esta mediación, sustantivan a la representación como un proceso dado a la reflexión y no solo al acontecimiento práctico.

Cuando dibujamos dejamos marcas; líneas, huellas cicatrices incisiones; todo un universo de registro del pensamiento y el estado psíquico dado a la sensibilidad.

Pero es esencial que el dibujante así lo sepa y tenga la capacidad configurante de moverse dentro de ese territorio del decir haciendo.

El dibujante es el inicio del proyecto y el eje fenoménico de la acción ejecutante. Ocupa la vivencia primera, su psiquismo y su mente son el territorio de cruce de la voluntad configurante y el proceso experiencial, que arroja la forma como consecuencia y discurso contenido; forma originada y puesta en relación al contexto.

Mucho más allá de la palabra, en la obra del dibujo y su secuencia, advertimos esa lucha librada contra los clichés, vemos las imágenes y los actos que verdaderamente desatan el caos y la lucha. Pero como lo señala Deleuze, esta tormenta desatada, la mano que se revela en contra de la visión, busca el establecimiento de diagramas, nosotros les llamamos sistemas formales del dibujo y la representación.

Este trabajo no buscaba la formulación de una definición del dibujo en el sentido clásico, y tampoco se dirigió a la formulación de un cuerpo taxonómico correspondiente. Esperamos que quede claro que ésa no es nuestra orientación porque consideramos que una postura tal en el contexto actual, no tiene sentido dada la disgregación de los autores del campo, quienes estamos parados en la más pura individualidad y rechazamos como acto de convicción cualquier integración fundacional.

Por eso es que no pensamos en escribir un tratado del dibujo, porque estaríamos exponiendo una definición excluyente que generaría sus propios límites, de ahí que buscáramos en su lugar el análisis de aquello que acontece en el acto de dibujar. 
En una postura de esta naturaleza, lo corporal, la materialidad, y el trazo son un intento de significación semántica, pero también son la revelación del cardiograma emotivo del dibujante. Husserl pensó que la fenomenología tendría que hacer énfasis en el estado vivencial del sujeto, antes de que el pensamiento experiencial racionalizara el vivir; nuestra idea del acto dibujo sería un estado fenoménico del dibujo que se orienta con un fondo eidético y abductivo.

Nuestro análisis del dibujo considera tres categorías básicas en su proceso, el tiempo, el espacio y el sujeto emplazado en esa particularidad.

Por eso nos orientamos a pensar el espacio no sólo como una categoría formal del dibujo. El espacio ha sido siempre una categoría formal en el arte; pero lo extendemos hacia el terreno psíquico interior del dibujante, y hacia el espacio como locación contextual geográfica y cultural intangible.

El espacio es el recorte contextual como motivo del dibujo, es también el espacio seleccionado para emplazar la obra. Ambas partes espaciales determinan el carácter del acontecimiento. Este puede operar sobre las condiciones significantes de lo dado contextualmente, o bien generarlas como propuesta de lo construido. O bien integrar ambas circunstancias en una unión semántica.

Tal como la materia vive un viaje desde su condición física hasta la materialidad significante en el acto de dibujar, el cuerpo del dibujante igual lo pensamos en un desplazamiento relativizante.

Dentro de la concepción plástica se entendió el cuerpo y la manualidad como el espíritu rector de las acciones conformantes, en la modernidad formalista se reconoció la corporalidad como el despliegue del sujeto en la quinesfera espacial y la superficie del dibujo, pero también se introdujo la corporalidad como un estado vivencial y psíquico particular del artista en el acto ejecutante.

Estas fueron ya extensiones flexibles de lo corporal; nosotros agregamos que la corporalidad conduce a un estado de poder; lo que llamamos el estado de poder configurante del dibujo, poder de configuración bajo concepto y estrategia.

Para nosotros el dibujo como forma de poder es la capacidad de poner en concepto la obra y su materialidad, pero también el poder de modelar el gradiente sentimental en la imagen y en lo interior de la subjetividad del espectador; de ahí que concluyamos nuevamente la importancia del plano estético en el proyecto del dibujo, aunque para la crítica posmoderna ese objetivo no tiene sentido.

En esta orientación, la técnica sería una manifestación de ese poder poético y de configuración conceptual.

La técnica es una forma más de conciencia epistémica circular y retroactiva del dibujante que opera sobre las categorías de:

- La Estrategia

- Los Procesos

- La Forma

- Los Soportes

- Los Materiales

- Las Herramientas 
Una tercera categoría fenoménica es la del Tiempo.

Las artes plásticas y visuales en algún momento fueron entendidas como las artes del espacio, porque lo ocupaban de facto de manera concreta. Pero más allá de Calder y los cinetistas, el tiempo fue una ambición e ilusión para el dibujante; aunque las artes de hoy (cine, video) replantean esta anterior problemática.

Pero no quisimos ubicarnos en este panorama que el arte contemporáneo resolvió con las aportaciones interdisciplinares; al margen de estos procesos retornamos a la temporalidad pensada para el dibujar.

Al abstraer separamos la unidad en sus componentes para acceder a su análisis.

La temporalidad en el acto dibujo se realiza en las etapas que aludimos:

- La primeridad y vivencia en el contexto.

- La segundidad proyectual prefigurante.

- La terceridad y la configuración experiencial.

- El cuarto momento del acto expositivo.

En el curso de la investigación encontramos una variación que nos llevó a comprender la dimensión subjetiva del tiempo como vivir del dibujante dentro del proceso.

El tiempo es la vivencia del dibujante frente a los otros y lo que con ellos comparte.

Pero también es el tiempo de la ausencia y el deseo que se manifiesta en el proyecto como vocación deseada.

El dibujo es disciplina eidética porque es un arte que puede hurgar en el pasado, en la ausencia y el deseo y elaborar ese tiempo muerto, sublimarlo en formalizaciones, huellas de lo ausente, huellas psíquicas de referentes que ya no están, huellas además dejadas por el vivir.

El tiempo del pasado y la ausencia coexiste con el tiempo presente de la configuración, reviviscencia y vivencia.

Las huellas del tiempo y lo vivido solo afloran al dibujo y la mirada externa mediante la acción configurante, en ese repertorio indexal el espectador lee el orden semántico del discurso; pero el sentido original de esas huellas, lo vivido por el dibujante y las ausencias que pueblan el tiempo muerto es algo que se le escapa. La esencia inicial de esas marcas-huellas, el deseo original que las generó se ha perdido y ha muerto, ahora les fabricamos un nuevo sentido de lectura, basado en nuestro propio deseo, el que le atribuye una actitud significante alterna.

Cuando el dibujante clausura el proceso de una obra, estabiliza temporalmente una forma. Esa gramática es rica en vivencias y genera una burbuja psíquica; los otros asisten a la obra sin haber vivido la falta, el deseo y la lucha, y las ausencias generadoras del suceso dibujístico.

Estas posturas basadas en un orden categórico de la vivencia y la experiencia dentro del acto de dibujar, son tal vez una particularización de lo que Derrida llama el principio del desorden taxonómico, la imposibilidad dentro de lo posmoderno para fundar discursos teóricos generales y rigurosos, como consecuencia de la desintegración de la institución imaginaria social. 
Para entender la práctica del dibujo actualmente, es necesario un ejercicio de análisis multinivel, un viaje cognitivo transversal o vertical que penetre la producción del dibujo desde lo contextual hasta la interioridad psíquica del dibujante, pasando por la realidad como modelo, los sistemas de representación, el espacio de la producción la técnica y la estrategia utilizada.

Todo esto al ser racionalizado por el dibujante y, al tomar posición ante ello, nos manifiesta su actitud, que es la conciencia epistémica frente al método, la realidad y el conocer.

Dentro de la estrategia posmoderna se deja de lado la importancia de la forma nueva de la representación, la materialidad y la acción corporal como esencia del metalenguaje plasmado en el cuerpo estético del dibujo.

Por eso ahora frecuentemente al dibujar, la organización plástica y visual de la materia sufre y disminuye ante una disposición casual en el soporte, pero sin un factor conceptual fuerte que opere como eje de causalidad proyectual.

Nos acercamos al término de nuestra investigación; por última ocasión retomamos el plano general del discurso para cerrar el plantemiento problemático que originó esta reflexión.

Consideramos el artículo de Rosalind Krauss "La escultura en el campo expandido" aparecido en el año de 1979, "La originalidad de la vanguardia" 1981, y los de Douglas Crimp "Pictures" publicado en 1977 y reelaborado en 1979 y "Sobre las ruinas del museo" como parte sustancial de los ejes y ejemplos paradigmáticos de la crítica del arte posmoderno. En ellos se observa un modelo teórico para el arte, generado en parte desde el interior de la revista "Octubre" y que se generaliza en el pensamiento de los Estados Unidos de América, si bien su onda expansiva se desplaza hasta alcanzar en cierta medida los escritos europeos (Brea, Juán Martín Prada). Hoy podemos agrupar en esta corriente a pensadores como: Brian Wallis, Douglas Crimp, Rosalind Krauss, Arthur C. Danto, Benjamin Buchlo, Craig Owens.

En el cuerpo de la investigación y particularmente dentro de las conclusiones, marcamos la importancia de los procesos artísticos de la posmodernidad dentro del concierto general del arte y la cultura.

Pero hemos de señalar que independientemente de ello, dentro de este modelo crítico se comete el error de extender afirmaciones y formular predicciones, particularmente para el terreno del dibujo; ni el fin del arte, ni el de la estética, ni la caída de la representación se pueden concluir necesariamente como totalidad para el arte, sólo porque una vía estratégica haya encontrado posibilidades de realización alternas en el proceso del arte.

Vemos en el trabajo de estos autores una corriente crítica; a treinta años de su conformación podemos decirlo. Pero no extendemos su visión como una teoría general del territorio artístico que clausure rutas distintas en el ejercicio del arte. Basados en esta lógica es que concluímos la viabilidad del campo del dibujo como un proceso artístico formal de representación. Tendencia que se muestra en el trabajo de los dibujantes, quienes desde la interioridad de la práctica marcan la tendencia del acontecimiento.

Dentro de la confusión general posmoderna se entiende por igual el trabajo de la crítica del arte como constructora del sentido del proyecto artístico; pero la crítica trabaja sobre el hecho artístico una vez que ha sido dado. Los artículos de estos autores que revisamos en la investigación carecen de análisis puntuales sobre el dibujo, pero ocasionalmente se 
emiten opiniones al respecto sin que medie un rigor teórico e histórico.

Esta visión americanizada del arte posmoderno se caracteriza por su sentido antiesteticista, efectúa una mezcla del ejercicio de la teoría con el de la crítica del arte; renuncia a la novedad en el pensamiento eidético y a la originalidad. Pero lo grave es que extiende su posición al terreno total del arte, lo hace a manera de conclusiones lógicas teorizantes, cuando en realidad son posturas (legítimas) para asumir una convicción del deber ser del arte.

Los artistas y la crítica posmodernos construyeron una ruta más para el arte como proyecto crítico social, al igual que el arte llamado conceptual y el de la desmaterialización objetual, con ello se ampliaron las estrategias del arte.

Pero no nos equivoquemos, así como el conceptualismo no aniquiló el arte de la imagen y la representación, la estrategia posmoderna y la expansión disciplinar no terminó con el dibujo como gestor del pensamiento formal, perceptual, estratégico y técnico en imágenes, y como mediador entre el dibujante y el contexto.

En la condición posmoderna, se confundió en extremo la reflexión del crítico con aquello que se supone es la postura epistémica del artista, aunque en muchos casos (Lucy Lippard, Sherrie Levine) el autor de la obra haya explicitado su desacuerdo o su visión particular. Bajo este panorama, la acción de esta oleada de autores conserva mucho del carácter y vocación de la vanguardia al actuar casi bajo un programa manifiesto.

Todos sabemos que el arte es el terreno de las posibilidades en el que se trabaja con lo imposible; en él, la única verdad general es aquella que niega cualquier totalización excluyente.

No decimos lo anterior a modo de opinión, lo hacemos basados en la práctica de una pluralidad de dibujantes que en todo el orbe trabajan el territorio del dibujo como disciplina del proyecto, la forma y la representación. Por ello es que afirmamos que la producción de la disciplina corre por su propio camino, que no es necesariamente el que la crítica limitante le ha señalado. Hoy el dibujo se realiza integrado a otras artes, por convicción expresiva del artista; pero igual se ejecuta como una disciplina que por sí ahonda en la reflexión teórica de todo el universo que constituye la totalidad artística, por otra parte sigue operando como gestor y prefigurador del proyecto de las demás artes, tesis a la que dedicamos un capítulo de nuestro estudio.

Dentro del curso de la investigación se fue perfilando otra posibilidad teórica diferente y un tanto distante del pensamiento posmoderno.

Esta orientación resultó coincidente con nuestro pensamiento hipotético inicial, aquel que basaba el análisis teórico del dibujo en una interioridad disciplinar; en un aparato conceptual y formal emanado de la propia práctica del dibujar.

Esta postura se comprobó en su término general, a partir de la enunciación de diveros autores.

Pero también encontramos al investigar, que la teoría del dibujo a lo largo de la historia del arte de occidente, en muchos periodos se funde transdisciplinarmente con la de otros campos del arte, sustancialmente el de la pintura. Tal es el caso de la visión renacentista que formula tres cuerpos constituyentes de la pintura, El Color, El Dibujo y la Geometría. O dentro del Expresionismo Abstracto en el que analizamos el dibujo como un cuerpo teórico y estratégico que permeó la pintura. 
Así, una teoría del dibujo y sus modelos formales de representación es en parte el análisis de esta relación simbiótica.

El problema al que aludimos se refiere al flujo formal y liguístico entre territorios artísticos, pensamos en esta investigación haber abundado en ello.

Pero la perspectiva de una teoría endógena, es también un problema teórico epistémico; en el sentido de una construcción teórica que se soporte desde la práctica disciplinar homeopática y no desde el territorio de la crítica y la filosofía como peso ideológico contextual de presión sobre el dibujante.

En este sentido encontramos varios autores que se manifiestan con claridad por una forma del pensamiento y la teoría típicamente artística y gestada desde su práctica disciplinar.

Aunque tenemos que aclarar que en todos los casos esta formulación se basa en el territorio de lo pictórico y no del dibujo.

Concluímos que la posición epistemológica es susceptible de extenderse hacia los diversos campos del arte y en particular al dibujo; lo que no se puede extender o extrapolar es el aparato conceptual integrado de un campo a otro, cuando menos no en su totalidad, ese es precisamente el trabajo del dibujante, el de construir sus estrategias, formas y sistemas de representación.

Para el esclarecimiento de esta ruta modelística, dos textos resultaron básicos dentro de la investigación: "Pintura. El concepto de diagrama" de Gilles Deleuze 2007 y "Painting as model" de Yve Alain Bois 1990, dentro de éste último el capítulo que analiza el trabajo de Hubert Damish en su texto "Ventana amarillo cadmio".

Otros autores como Hall Foster y Luigui Pareyson se inclinan en este mismo sentido.

La interioridad de una construcción teórica de las artes y su calidad epistémica como una forma del pensamiento se desarrolla en esos trabajos. Los autores no coinciden cronológicamente, ni tampoco en la perspectiva con la que desarrollan el análisis, no podemos decir que formen parte de una corriente en el sentido formal; pero precisamente vemos en ello parte de su valor, insisten en lo particular del pensamiento en el arte y sus estrategias teóricas.

Este modelo destaca esencialmente las rutas estratégicas, perceptuales, técnicas, formales y estéticas como núcleo reflexivo del acto artístico; de ahí que resultara ampliamente coincidente con nuestra ruta de investigación y análisis.

Finalmente cerramos nuestra investigación con una serie de reflexiones sobre la mecánica y estrategia del "Acto Dibujo", nuevamente decimos que no ofrecemos esas construcciones como una nueva teoría del dibujo, no son una propuesta, no pensamos que nadie debiera seguirlas, ellas no sustituyen el acuerdo fundacional que creemos necesario para construir un imaginario del dibujo. No constituyen la prueba de nuestra hipótesis, no pueden serlo puesto que obedecieron más a la lógica derivada de la producción particular de nuestros dibujos.

Pero los diveros conceptos organizados a lo largo de estos años y emanados originalmente de nuestra acción como dibujantes muestran una coincidencia con los órdenes reflexivos que fueron apareciendo a lo largo de la lectura. 
Dialogar implica ejercitar la opinión del otro, para arribar al conocimiento de aquello a lo que solos no hubiéramos acertado.

Al dialogar nos dejamos traspasar por la voz del otro, reconocemos su autonomía ontológica y nos identificamos con aquella parte de su esencia que nos puede construir.

Esta investigación es un diálogo en el que convocamos a todas las voces y presencias involucradas en la fenomenología del acto dibujo, sólo si escuchamos su voz será clara nuestra conclusión.

Existe una incómoda memoria histórica de las formas, y peor si uno es dibujante. En cuanto miramos una imagen, nuestra memoria saca del cajón del análisis formal y la representación aquel autor o estructura a los cuales nos asemejamos.

Pero cuando esa voz interior, que no sabemos de donde viene, nos indica el carácter exacto del trazo, su velocidad y su inflexión o la estrategia pertinente; entonces el dibujo resultante tendrá un cierto aire de algo desconocido y nunca visto.

Sumado a todo esto, la experiencia de cursar este programa doctoral y realizar este estudio nos ha enriquecido sustancialmente; sin embargo... quedamos a su consideración.

Aureliano Sánchez Tejeda

Enero de 2012 



\section{PROLEGÓMENOS}

En este espacio se presentan cuatro proyectos de dibujo realizados a lo largo de algunos años; como ya se ha mencionado no se incluyen como premisas lógicas para derivar alguna conclusión, son segmentos de trabajo en los que se fueron generando las inquietudes y conceptos que después animarían los estudios doctorales; Es pertinente que ustedes puedan ver y valorar los procesos en los que se inicia esta ruta de investigación.

Estas obras integraron el cuerpo de cuatro exposiciones; entre los trabajos exhibidos en aquellas muestras y las imágenes que aquí mostramos, se encuentran muchos dibujos que constituyen la base del proceso y la selección final.

Se han producido varios proyectos más que no se incluyen en el cuerpo de esta tesis; aún ahora la producción de obra visual corre por rumbos diferentes a los que competen a esta investigación; como sea, los dibujos que a continuación se presentan, fueron el semillero en el que brotaron los conceptos y las posturas de un ideario como dibujante.

No se cometerá el error de tratar de explicar estos trabajos, menos cuando pensamos que la obra debe darse por sí misma a la sensibilidad y el entendimiento; si es que alcanza ese grado de concreción, y porque se pecaría de soberbia al pretender haber demostrado algún punto de la investigación con estos dibujos. Estas obras son origen más que conclusión.

Pero también es cierto que en el transcurso de estos proyectos de producción se reafirmaron conceptos y categorías de la interioridad del dibujo, como también se fueron forjando adaptaciones emergentes y definiciones formales un tanto particulares expresadas en términos alternos dentro de los sistemas de representación formal. En ese sentido el ejercicio del dibujo fue una práctica siempre asistida por la reflexión y la reducción experiencial.

Las cuatro series de este apartado tienen como ejes categoriales el momento de la vivencia, el de la reflexión experiencial y el de la acción ejecutante, las más de las veces acontecidos en una sincronía y no en una secuencia lineal metodológica.

- "Cuentos del bosque sombrío" Julio 1995 y "El aliento del caos" Marzo de 1997.

- "Los Testamentos de Cornelius Castoriadis" Diciembre de 1998.

- "Tótem y Tabú" Diciembre 2004, Enero 2005.

- "Lo que nunca termina" (Masa visual, sincronía espacial y temporal) 1994- continuo.

Estas palabras son más un marco introductorio que una fundamentación teórica de los dibujos, sirvan entonces sólo como breve relatoría del camino en el que se fueron gestando las ideas.

Consideramos la producción de los dibujos como un ensayo visual, e insistimos en ello, ya que el orden de las reflexiones obedeció a los cuestionamientos que el proceso de producción fue generando pero sin un rigor sistemático como premisas de un análisis intencionado. 
Estrategia, metodología y proceso fueron tensados libremente en estos trabajos. Precisamente, los conceptos de prefiguración, configuración, dibujo contextual forma y representación se hicieron recurrentes en el curso de la acción ejecutante. Comenzó a gestarse la convicción de una visión formal estética y la certeza de la posibilidad de la representación como renuevo de la visión y la mirada.

"Cuentos del bosque sombrío" fue una exposición presentada en 1995. En ella se concretó una visión que apostaba por una racionalización del ejercicio del dibujo frente a los excesos existenciales que por aquellos años poblaban el arte mexicano.

Esta postura racional de la forma se cristalizó en la búsqueda de sistemas compositivos y estructurales que operaran al margen de la perspectiva piramidal y las coordenadas cartesianas; o sea, de todo el aparato preicónico del dibujo. El sentido aleatorio de la estructura se convirtió en el factor organizativo de los nexos compositivos, la razón matricial no se planteó como razón anterior a la construcción de la imagen sino que fue su resultante. Cada dibujo representaba una carta geográfica puntual de la locación seleccionada como modelo para dibujar; con esta situación se reafirmó la convicción de un dibujo contextual que sustraía sus cauces estructurales del entorno.

Estructura y estabilidad eran el binomio toral de la composición clásica, después de esta serie de dibujos se pudo generar una dinámica de trabajo en la que se fracturó ese par categorial.

Los proyectos de dibujo y paisaje realizados mantenían vigente el nexo entre forma, modelo y representación dibujística en el sentido clásico; sinceramente esto resultaba un tanto molesto, pero al llevar el dibujo y el paisaje a terrenos y modelos variados, este problema se resolvió al expandir la categoría de modelo no sólo a la naturaleza sino al contexto en el sentido más amplio de la expresión, desde lo concreto de las locaciones hasta lo intangible de las prácticas culturales.

Empíricamente se generó la convicción de un dibujo realizado en el "estar ahí" se pasó de una visión panorámica y viajera del paisaje a una concepción en la que se buscó introducirse en el espacio dibujado para integrarse como parte del contexto trabajado, se intentaba disolver la distancia epistémica tradicional entre el dibujante y sus modelos como entidades lejanas y ajenas. No se vería el modelo como un objeto ni se estaría sentado cómodamente frente a él; no ser un testigo sino parte del atentado.

En este proceso se comenzó a introducir la fotografía como parte de un marcador espacial de locaciones y un archivo de situaciones contextuales peculiares para el dibujo. Nunca desde entonces y hasta ahora, las placas fotográficas sustituyeron a los modelos concretos como fuente del proceso y del dibujo, solo constituían un reservorio de datos visuales e información para tomarse en cuenta dentro de la estrategia de configuración. Todos los dibujos eran iniciados trazando directamente en la locación contextual, esto es muy importante ya que la mirada primaria de la visión humana difiere sustancialmente de la captura lumínica del lente de la cámara, así los dibujos eran marcados por la percepción y deformación de la mirada en el lugar, aunque posteriormente la fotografía operara como parte del análisis y archivo de casos espaciales.

Caminando y fotografiando se iniciaba un proceso de representación mental prefigurativa, 
al tomar esas placas se hacía ya con la intención de rearmar formalmente ese lugar, la foto no era parte del modelo sino un registro estructural que después sería analizado.

A lo largo de todas las series de trabajos, tanto de figura humana como de paisaje, siempre se puso énfasis en el obstinato, el ritornelo y la seriación como estrategias de penetración para profundizar en las posibilidades de un concepto y en las variaciones estructurales de un problema.

Caminando se penetraba el modelo, tanto físicamente como de manera reflexiva.

Comenzó a surgir la idea de la vivencia como categoría fenoménica capital en el proceso del dibujo. Y esta visión se concretó en estrategias precisas; el hecho de caminar el bosque por largas horas, sin la intención todavía de dibujarlo y pintarlo, sólo para reflexionarlo, para mirar lo que se ofrecía a la vista; para vivirlo.

Por aquel entonces cayó en nuestras manos un catálogo con la obra maravillosa de Agustín de Ibarrola, y dentro de ella, particularmente su trabajo en "El Bosque de Oma" de ahí se aprendió en muchos sentidos, temáticamente, formalmente, en cuanto a la estrategia, conceptualmente etc.

La caminata se transformó en estrategia y en acción performática necesaria como parte del dibujar.

Caminando nos internábamos en el modelo y la locación, la conciencia y la mirada se alteraban y quedaban dispuestas a un estado perceptual particular. Al caminar de regreso se retornaba al pensamiento lineal.

Se comprendió el suceso artístico como algo que sucede en el espacio social y pragmático del acto expositivo, pero también y de manera importante, en la lejanía ignorada de la espesura del bosque mientras era dibujado.

En este proyecto se utilizaron puntas de plata, papeles y tablillas preparadas. Sabemos que esa técnica requiere de una precisión y decisión al trazar, y que el resultado es de un nivel descriptivo mayor y por ello fueron seleccionados, por lo cortante de su linealidad. No interesó en este proyecto la sensualidad matérica de esta técnica, se veía el dibujar como una transcripción de información, de lo visto a lo trazado en el soporte, de ahí surgió la formulación del dibujar como transcripción del dato visual y la necesidad de un modelo exterior para realizar ese análisis formal.

Esta exposición, junto con "El Aliento del Caos" de 1997 fueron generando la conciencia de que el carácter procesual del dibujo se orientaba hacia una visión formalizada de la representación y hacia derivas abductivas de los sistemas estructurales. Surgió de ahí la necesidad de estudiar con mayor precisión la historia del arte y del dibujo, particularmente dentro de los procesos de la Vanguardia en el siglo XX. También se fue gestando la idea de la vigencia del dibujo como práctica eidética de las formas en contradicción a las estrategias posmodernas.

La exposición "El Aliento del Caos" aportó una característica fundamental al proceso, misma que opera dentro de esta tesis. Al trabajar con suficiente intensidad y frecuencia el tema y modelo del bosque, se fue creando en el ideario interior una visión abstracta del mismo, 
una conciencia eidética del bosque basada tanto en lo concreto del modelo como en lo volitivo y experiencial de nuestra representación. Así en esa exposición se integraron series de pinturas y dibujos anicónicos, realizados en el espacio del taller sin asistir al bosque.

Cuando los dibujos mostraron la posibilidad constructiva en ausencia de un sistema previo de composición surgió la idea de realizar una serie de grabados como experimento de composición aleatorio. Pero las imágenes se mantendrían siempre en relación icónica y estructural con las locaciones tomadas como modelo. En los grabados existe un mayor rigor geométrico, pero esto permitió la distorsión formal de las estructuras tomadas del dibujo, siempre buscando una lectura y recuperación del referente del bosque.

Se hizo evidente la relación de este proceso con el fenómeno de la vanguardia purista del XX, reconocimos el carácter formal del proyecto y cómo estaba basado en la posibilidad de cambio del lenguaje del dibujo, con esto se planteó el conflicto entre la modernidad y posmodernidad en términos de la originalidad y la representación.

Fue particularmente en esta etapa del proyecto cuando se abrió a la reflexión más honda el momento técnico y de configuración ejecutante como un tiempo sustancial en la significación de la obra.

Esto ya lo sabíamos; pero no es lo mismo haberlo estudiado que vivirlo en primera persona en el tiempo de la configuración. Se nos reveló el sentido de la técnica como vía del concepto y la huella como parte autógrafa y testigo del acontecimiento, la herramienta como modo de gradación de la calidad de esos estratos matéricos; conceptos que serían investigados en los capítulos de esta tesis.

Nuevamente lo decimos, todo esto apareció más a manera de sospecha para estudiar que como teoría acabada.

Pero supimos que en ese momento, el de la configuración, el pensamiento prefigurado en realidad se hace acontecimiento y forma-imagen en el soporte, ahí la estrategia cobró nuevos tintes.

Cuando se dibuja, la imagen trazada se nos viene abriendo, uno decide el momento en el que quiere detenerse, o el rumbo y carácter que quiere dar a la obra, Entonces se hace un tanto el dibujo a voluntad, el dibujo de habilidades manuales simples va quedando atrás.

Ya desde los trabajos de paisaje en el bosque, el tema fue ganando importancia dentro del proceso de trabajo; pero en las series de dibujos sobre el cuerpo humano terminó por mostrar el peso que guarda como factor potencial dentro del proyecto.

En ese momento (1996-2000) esto no aparecía con profundidad conceptual, eso vendría a raíz de estos estudios.

Pero sucedió que las estructuras compositivas formales de los dibujos comenzaron a relacionarse con temas, autores y posturas externas a los propios modelos dibujados; no eran conexiones del todo arbitrarias, sino en relación a visiones distintas y de otros autores pero sobre el mismo tema, o bien literatura cine o música que trataba temas similares y los desarrollaba formalmente como asunto de las obras.

Cuando los trazos evocaron circunstancias, ideas y sensaciones que no existían en el lugar dibujado, entonces apareció la metáfora y la dilatación poética; situación que igual entró en conflicto con la alegoría, la cita y la apropiación posmoderna y con su negación de la originalidad, nuevamente comenzó a mostrarse una contradicción que tendría que ser investigada. 
Revisamos entonces los textos de Gastón Bachelard, "La poética del espacio" "La poética de la ensoñación" "El aire y los sueños" "El árbol aéreo" etc.

Tomamos como eje de trabajo el proceso del dibujo, la fenomenología del acto y buscamos que la imagen llevara un tanto al espectador a la región del ensueño.

En este punto se inició la sospecha de la posibilidad de un estudio del acto de dibujar basado en el análisis fenomenológico del proceso.

Aquí también recurrimos a material bibliográfico y hemerográfico referido a los procesos no lineales y a la teoría constructivista radical de Watzlawick.

Ya desde ese momento se renunció al traslado directo de conceptos y categorías de otros campos cognitivos para sostener el ejercicio del dibujo; lo estudiado daba claridad al acto de dibujar, pero en ese trazar surgieron las nociones de estado, tendencia, curvas positivas y negativas, multiposición, dibujo y pintura perpendicular, grados de libertad variable, dibujo contextual y varios elementos más que nos permitían precisar las operaciones que realizábamos en la imagen.

Muchos de estos términos eran ligeras variaciones a los conceptos formales del dibujo; pero en algunos casos constituían enunciados propuestos de modo emergente para designar acciones o maneras en las que estábamos dibujando, nuevamente eso animó nuestra intención de investigar, no nos apresuramos a mencionar todo aquello como el inicio de una forma del dibujo.

Trazar, representar y pensar se integran en un mismo acto y obra; se reflexionó simultáneamente el modelo, su estructura, su poética, el trazo y la manera, la composición y la forma. Comenzaron a saltar las relaciones históricas del proceso y su particularidad endógena como campo disciplinar... nuevos asuntos a investigar.

En los dibujos y grabados del bosque se puso especial interés en los factores geométricos estructurales y en la relación de las masas, se generaron direcciones diagonales y profundidad mediante los pasajes de tono hacia el relieve, se iniciaba dibujando un plano en contraste de tono para irlo configurando hacia el relieve y el volumen, todo como constructor de un modelo espacial.

Generalmente interesó muy poco la cualidad somática de los sujetos, en parte debido a eso, dentro de los proyectos siguientes la orientación contempló significativamente la corporalidad como categoría central.

Las imágenes del bosque resultantes en los dibujos, los grabados y las pinturas mostraban ya una consistencia formal, pensamos en ese momento que eso podría ser un modelo espacial y compositivo y una visión particular del dibujo; pero sabíamos que bien podía consistir sólo en una manera particular para evocar el bosque como conjunto de formas. Para saber si aquellas composiciones eran sólo un caso, o si verdaderamente se dirigían hacia un modelo de representación decidimos cambiar de tema y sujetos de estudio, trabajamos el cuerpo humano y su estructura somática como fuente de composición.

Los conjuntos gráficos trazados no tocaban ni dependían de la forma del polígono en que eran colocados, en ese sentido no se estaban realizando composiciones relacionales, la forma de la imagen dependió de la estructura entre los elementos que la constituían sin atender al polígono de soporte, se operó sobre núcleos de atracción compositiva en lugar de métricas rítmicas y distributivas. 
Ahora se buscaba una espacialidad perpendicular para la imagen, una que no se basara en el gradiente y la escala de valores que en el dibujo clásico establecen la profundidad. Desde los dibujos del bosque se pensó en lograr imágenes que disolvieran la relación gestáltica clásica fondo-figura, éste fue uno de los planteamientos que intentamos poner a prueba al realizar ahora dibujos de figura humana.

Por aquel año de 1997, en el mes de diciembre sucede la muerte de Cornelius Castoriadis, sus trabajos sobre "La Institución Imaginaria de la Sociedad" y "El ascenso de la insignificancia" nos conmovieron por su gran estatura humana. Por aquel entonces trabajábamos con un modelo de desnudo en las clases de dibujo, su imagen era la expresión más contradictoria a cualquier idea de clasicismo que pudiera pensarse.

Es así de casual, pero de esas dos cuestiones fuimos gestando un proyecto de dibujo que luego terminaría en la exposición que llamamos "Los testamentos de Castoriadis" (por cierto, diez años después, en Julio de 2007 tuve la oportunidad de visitar la tumba de este filósofo en el cementerio de Montparnasse, un laurel joven fue plantado a los pies de su sepulcro.)

El tema de lo múltiple como conjunto de individualidades se unió a la idea de institución del vínculo social. Éste es un tema que Castoriadis trató en el texto sobre la "Polis" y "El imaginario político griego y moderno" Su análisis sobre la Falange como conciencia de la fuerza resultante de la acción unitaria originó el concepto central del nuevo proyecto. Todo resultó coincidente con la idea formal de eliminar la relación fondo figura e integrar con todos los sujetos una sola forma, la que aludía subjetivamente al tema problematizado. Los cuerpos como ideal de proporción perfecta fueron sustituidos por la representación generada en las poses de Clemente que era nuestro modelo.

Buscamos establecer una crítica a los sistemas clasicistas de composición y a las estructuras de contraposto manieristas. Si no se logró la ilustración de ese fondo temático, sin embargo se consiguieron estructuras que dieron continuidad a los planteamientos formales que se habían iniciado al trabajar las composiciones del bosque.

Se buscaba la consecución de nuevas formas, pero siempre en concordancia con el tema nuevo, el que se conectaba con la coyuntura contextual e histórica.

En aquel momento se pensó que la visión humanista contenía un engaño; tanto se hablaba del ser humano, que este terminaba siendo una entidad abstracta imposible de aterrizar. Nos interesó entonces una antroposofía que concretara al ser en condiciones corporales tangibles, cuerpos llenos de sensación aunque no carentes de definiciones.

Queríamos imágenes y representaciones que aludieran a la humanidad toda, pero en una condición tangible de existencia.

Se trataba de crear la visión no de una figura sino de una masa visual, un conglomerado formal aditivo capaz de asimilar los trazos subsiguientes.

Sobreposición, multiposición, interpenetración y yuxtaposición generaron escenas unitarias, pero no exaltando la apariencia corporal externa sino el sentido de un conglomerado humano.

Incluimos aquí unas palabras que Carlos Blas Galindo escribiera para el catálogo de la 
exposición "El impulso del tiempo" realizada en 1999, lo hacemos porque pensamos que en ellas se muestra el origen de algunas de las preocupaciones que animaron tiempo después esta tesis.

"Y si es verídico que al género humano le compete comprender a la parte de la naturaleza que no es humana, no es menos cierto que le urge incrementar su comprensión sobre si mismo. Más allá del incremento de la pluralidad (que es permisividad). Más allá del ejercicio de la tolerancia (concepto demasiado cargado de esa caridad que no subsana las causas de los hechos sino que, ocasional y selectivamente, atiende algunas de sus consecuencias). Por eso Sánchez Tejeda invoca en sus vigorosos dibujos a la democracia verdadera... Mediante sus formas, que atañen tanto a la sensibilidad como al raciocinio."

Ahí se decantó ya claramente la interrogante sobre el tema como categoría del proyecto del dibujo, en relación a la estrategia formal y significante.

Pero entonces se comprende también porque para nosotros, el modelo, en tanto otredad que genera el acto de dibujar, surgió como centro de gravedad y entidad de diálogo.

Basados en estas reflexiones imaginarias, comprendimos que la calidad del vínculo que como dibujantes manteníamos con los modelos tenía que ser revisada; no podíamos seguir entendiendo este nexo basados en una vocación de servicio.

Aquí se abrió un espacio de riqueza y diversidad en la calidad de esa relación.

La comunicación no verbal entre el modelo y el dibujante. Lo que el modelo tenía para mostrar y el conocimiento que podía enseñar al dibujante. La personalidad e intimidad, el mundo psíquico del modelo que determina su acción en el acto de ser dibujado. La naturaleza de sus respuestas al saberse dibujado. El mundo de malos entendidos que deben ser fomentados y en los que se basa la comunicación entre el modelo y el dibujante, lo que el modelo cree que el dibujante quiere de él, frente a lo que el dibujante verdaderamente desea y que sabe que el modelo no dará, pero en su lugar, la apertura de ambos sujetos que genera un acontecimiento vital como acto del dibujo.

Concluímos que el acontecer del acto de posar puede correr en un sentido muy similar al de la teoría dramática de la actuación, en ese terreno, el factor técnico es muy importante. Pero el suceso del posar puede por otra parte acontecer como una manera simplemente vivencial entre el modelo y el dibujante.

Desarrollamos esos dibujos en una secuencia sugerida que aludiera al sentido de los frisos griegos clásicos.

Decidimos que las figuras y el formato rebasarían un tanto la escala humana, para involucrar de manera plena la corporalidad del dibujante en la acción de trazar y para establecer una dinámica específica de contemplación en el espectador, de ese modo complementaríamos la corporalidad de el modelo y la de su conceptualización.

Intentamos activar la corporalidad ejecutante en el ataque a la quinesfera y en la penetración del espacio real del soporte. Buscamos que las líneas y la manera de trazar discurrieran por un repertorio indexal y sígnico que trasladara el sentido de diversos estados 
de ánimo al soporte; no porque de manera simplista pensáramos que el estado anímico se penetrara en las imágenes, sino porque el manejo técnico de la ejecución, permitiría la variación ejecutante del repertorio indexal sígnico.

Las huellas matéricas en estos dibujos van desde la evidencia directa de la mano hasta las herramientas más sutiles que fuimos adaptando (como en general siempre lo ha hecho el pintor, el dibujante, el artista), pero ese repertorio sígnico fue pensado como función cualificante de la forma en relación a un potencial indéxico y sensible.

En este proyecto se concluyó positivamente la posibilidad de generar líneas forma, líneas testigo y líneas dato visual, comprendiendo así un tanto más a fondo la dinámica de representación de la acción del dibujo.

Todo esto fue lo que sucedió en aquellas sesiones y que se agregó a lo que los proyectos anteriores habían generado.

La exposición "Tótem y tabú" se originó como secuencia proyectual de los factores que hemos reseñado, pero se detonó con la lectura del texto de Castoriadis "Freud, la sociedad, la historia" incluido en el libro "El ascenso de la insignificancia" 1996.

Básicamente intentamos una historia involutiva de lo humano, escenas en las que coexisten hombres y animales.

Pero el fondo temático real era el que buscó una consecuencia de esas ideas en imágenes y estructuras formales basadas en la concepción que veníamos desarrollando; un tema referido al texto dibujo, al lenguaje de la forma y la estructura de representación.

El último cuerpo de imágenes de este anexo corresponde a una libreta de apuntes de dibujo; se llama "Lo que nunca termina"

Cuando éramos estudiantes en la academia, los profesores nos impusieron la tarea y costumbre de dibujar fuera del taller, para ello cargábamos siempre con una libreta específicamente para esa labor, en ella desarrollábamos la habilidad de trazo y la observación frente a los modelos y situaciones más rápidos y variados. Cada cierto tiempo los profesores revisaban nuestras libretas y analizaban los dibujos y nuestro avance. De manera que entre más libretas agotábamos en esa tarea, era mayor el desarrollo, deseábamos llenar y llenar cuadernos de apuntes.

Como todo dibujante (de antaño), conservamos esa costumbre para siempre. En nuestro caso no esperábamos a terminar un cuaderno, comprábamos varios por gusto, por sus distintos papeles y formatos, por la calidad de sus superficies que permitían distintos resultados en la materia y las formas.

En 1994 obtuvimos una libreta más para ese fin, solíamos llevarla cuando viajábamos o tomábamos café en cualquier lugar.

En determinado momento, debido a circunstancias personales miramos esas páginas como un registro de huellas vitales, pensamos que no había una razón específica para terminar de llenar cada hoja de la libreta y guardarla para siempre. Coincidiendo con las ideas que veníamos aplicando en los demás proyectos, decidimos no avanzar adelante en los folios de la libreta, nos regresaríamos dibujando sobre las páginas ya utilizadas, 
pero lo haríamos imaginando que aún estaban vacías; al llegar al inicio de la libreta volveríamos a trazar ahora nuevamente en el sentido acostumbrado, pero siempre imaginando las páginas en blanco.

Esa libreta que incluimos en este anexo, representa y contiene la lectura de momentos muy diversos, de modelos, de técnicas y estados de ánimo que ofrecen una lectura sumaria de rastros múltiples, como un palimpsesto interminable, pero que se basa en la sincronía de vivencias que se despliegan sincrónicas en el tiempo muerto de nuestras huellas psíquicas.

Ahí terminó por redondearse nuestra idea de una Masa Visual en sincronía espacial y temporal. Como ustedes pueden apreciar, en muchas láminas el resultado en devenir es formalmente inquietante, en muchas otras las disonancias se contradicen ya al observarlas en conjunto.

Pero es el momento de suspender la palabra; nada de lo dicho en estos prolegómenos es ofrecido como prueba o teoría concluida, sólo intentamos narrar las fuentes del problema y de los conceptos que animan esta tesis.

Estas fueron las exposiciones y los proyectos que nos orillaron a investigar aquello que ustedes amablemente han leído, lo hicimos como necesidad para poder sustentar nuestra producción como dibujantes y pararnos en una claridad histórica solo un poco mayor. 
CUENTOS DEL BOSQUE SOMBRÍO Punta de plata 


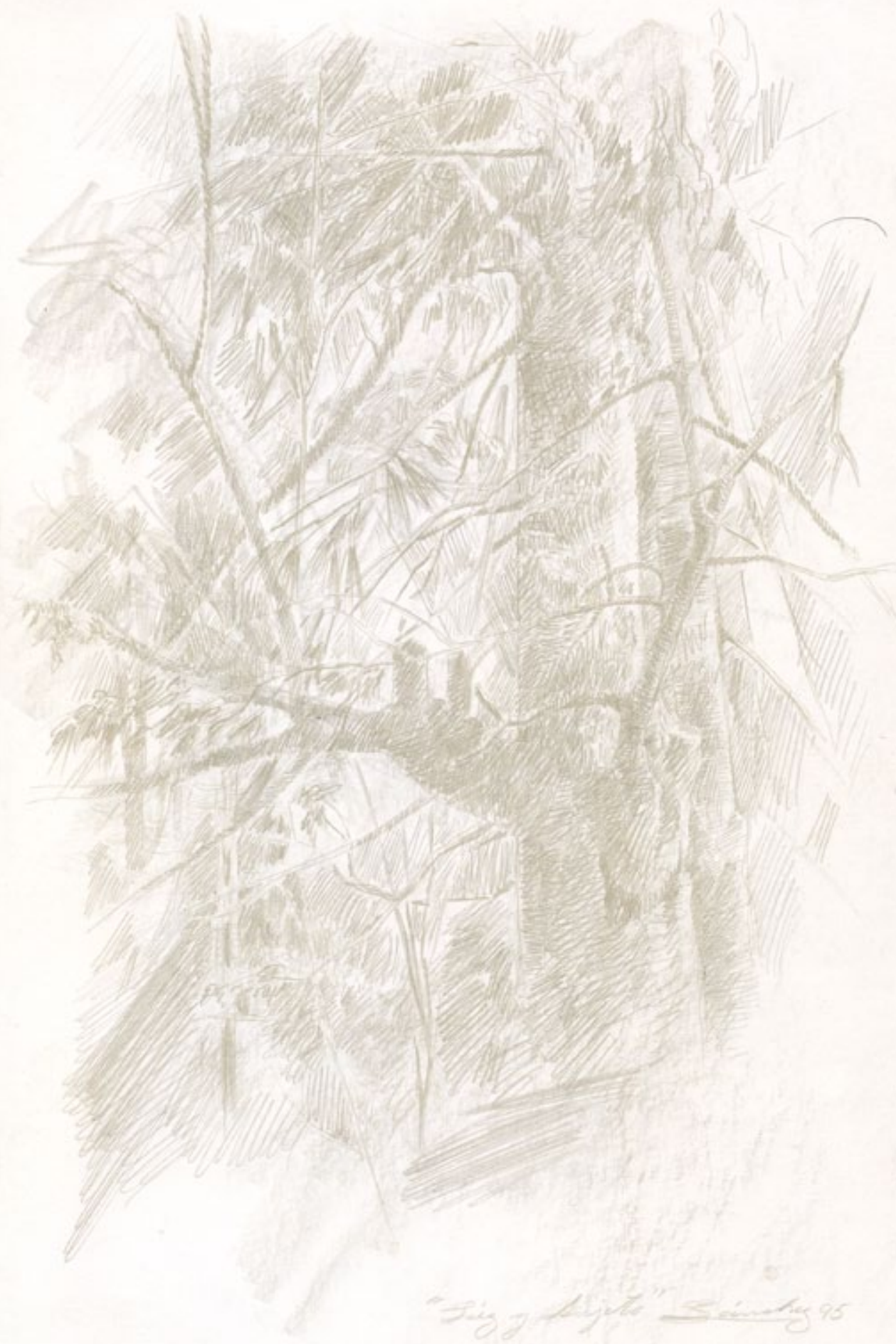




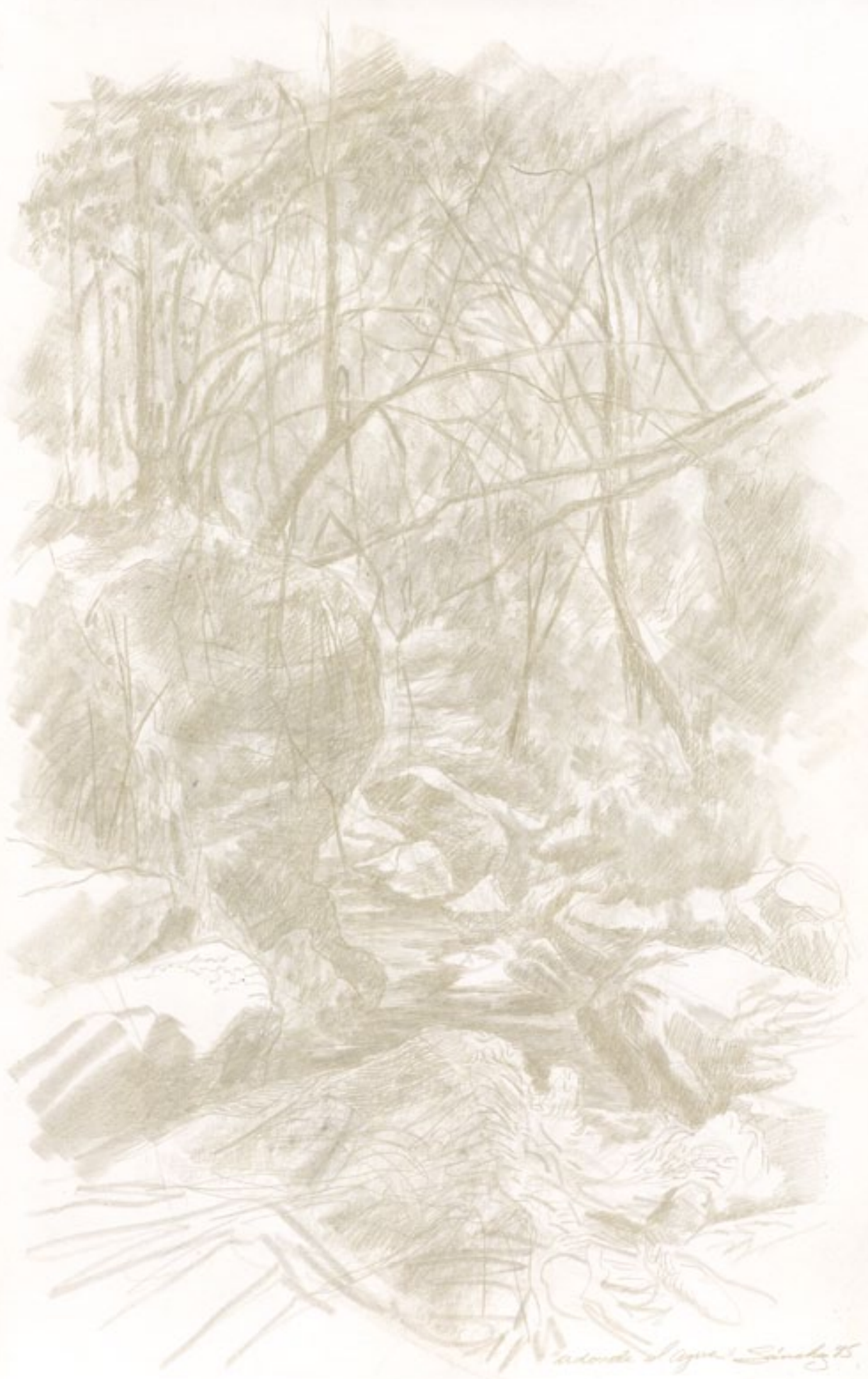




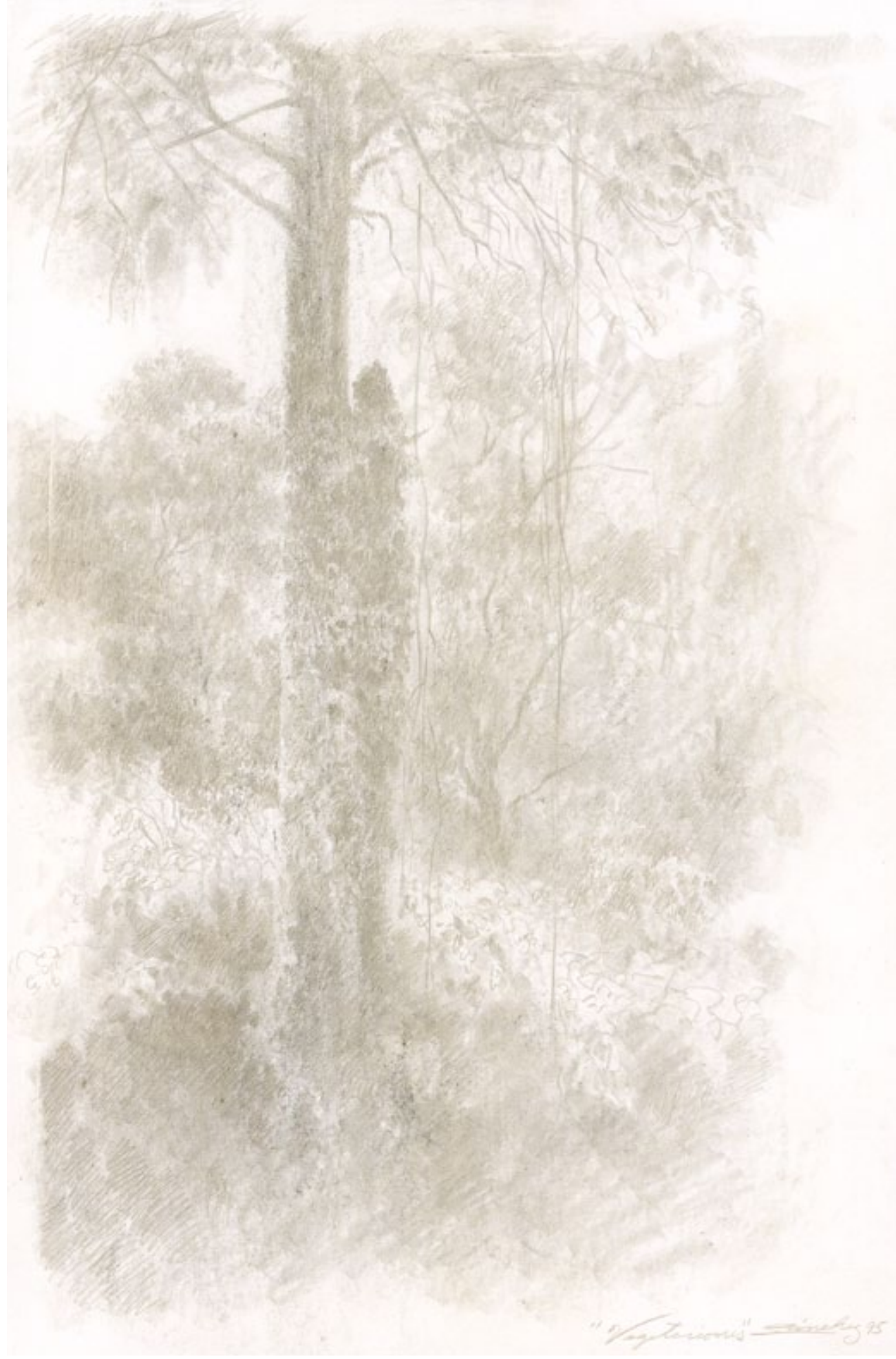




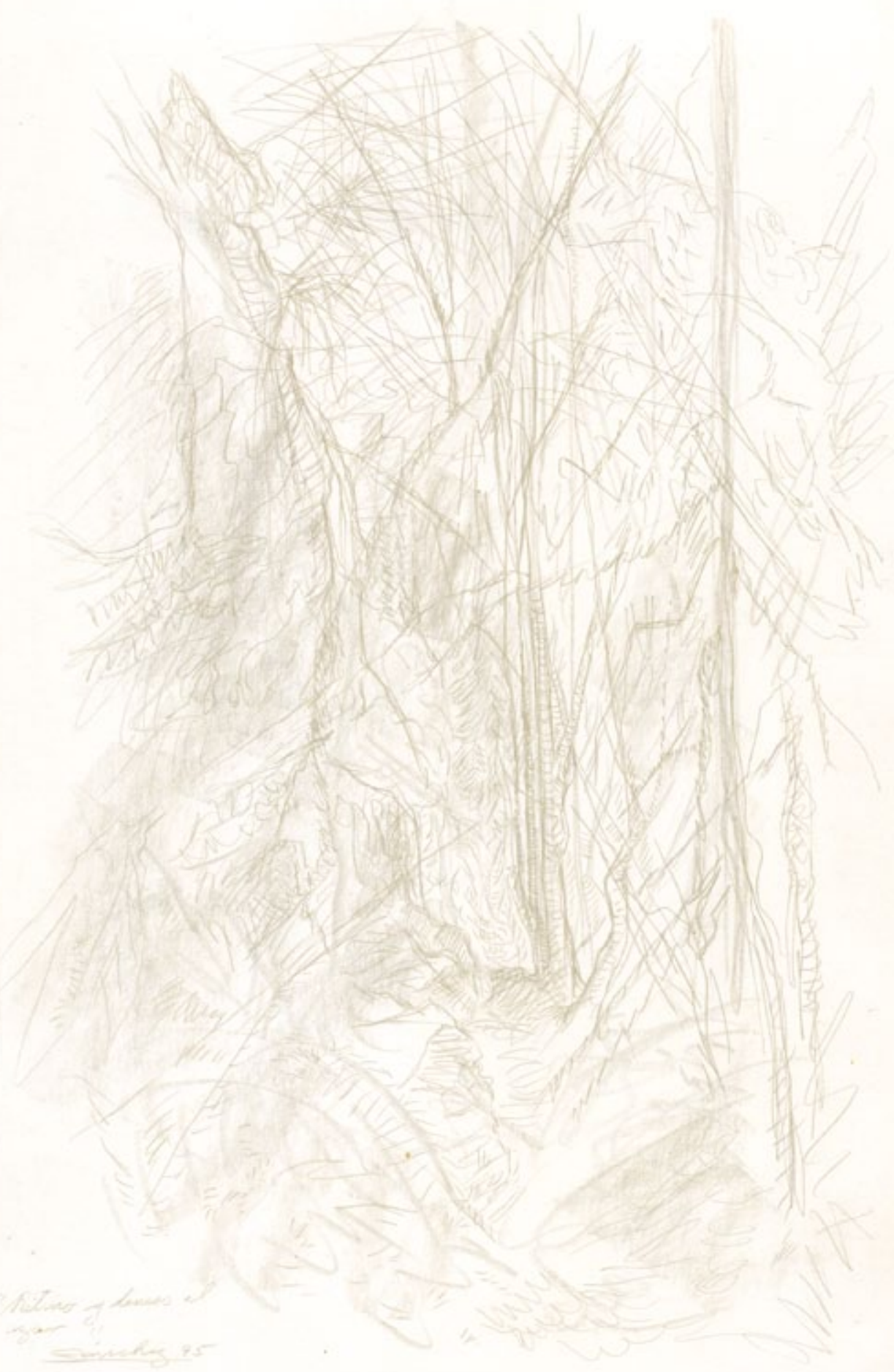




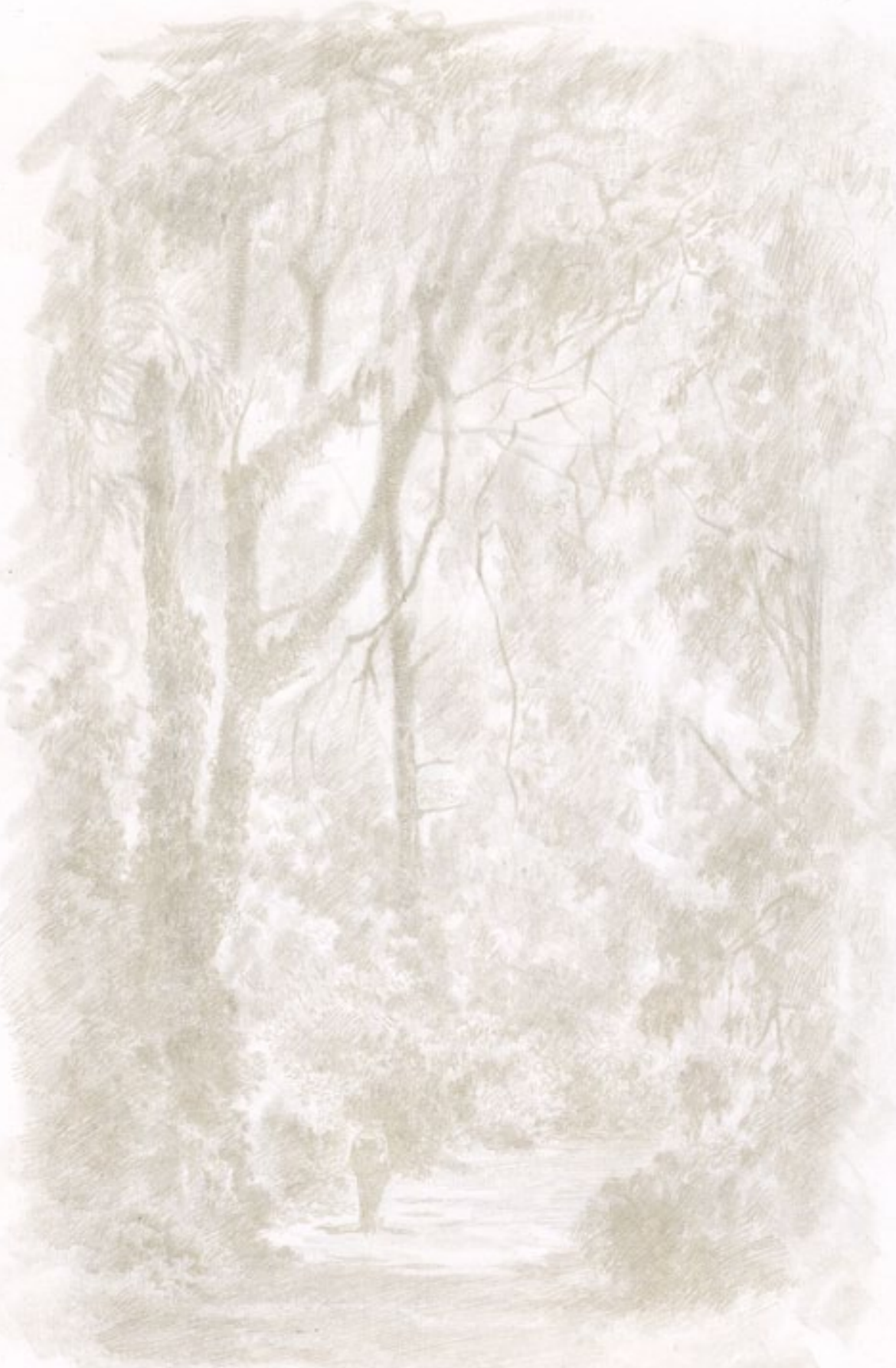




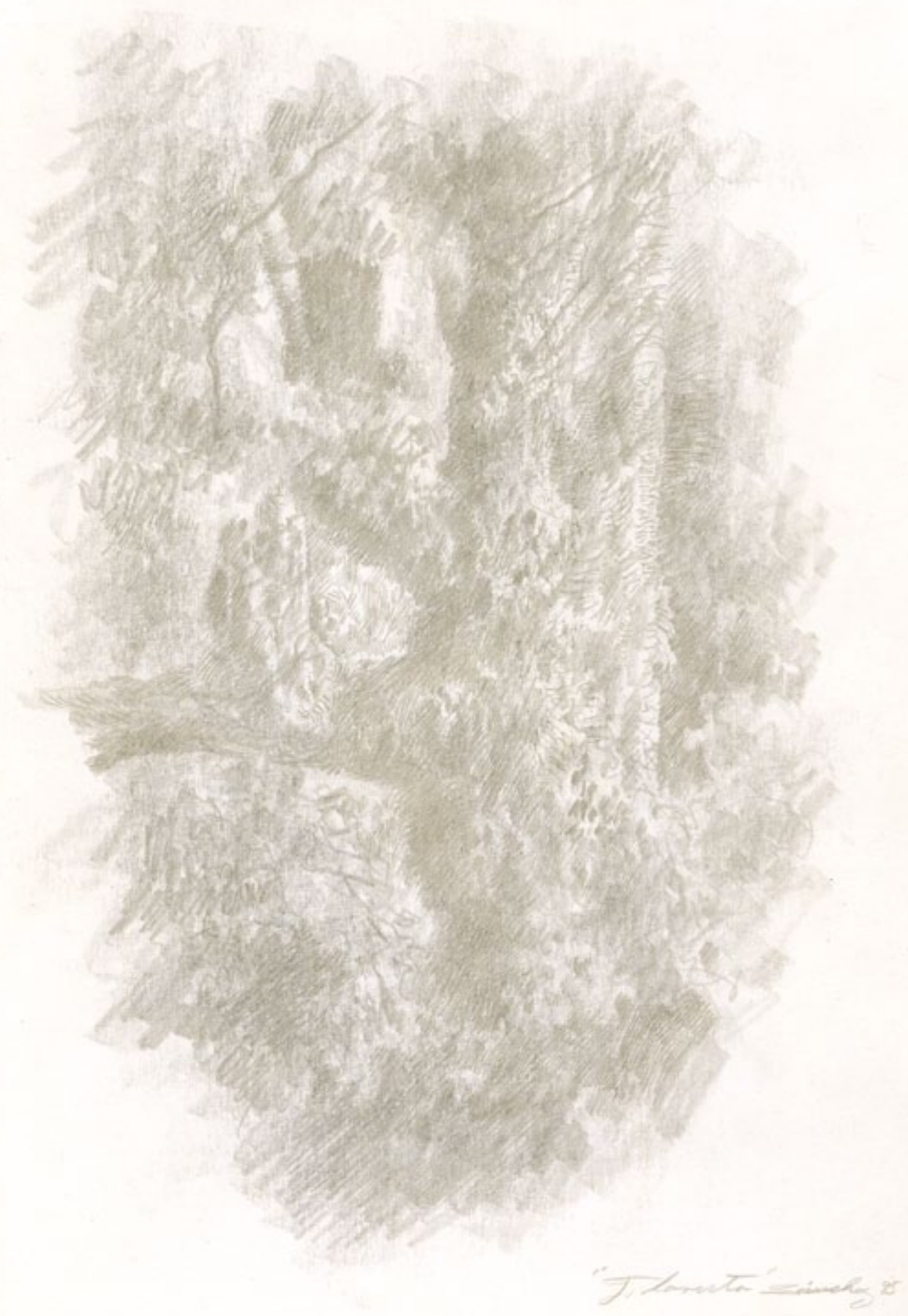




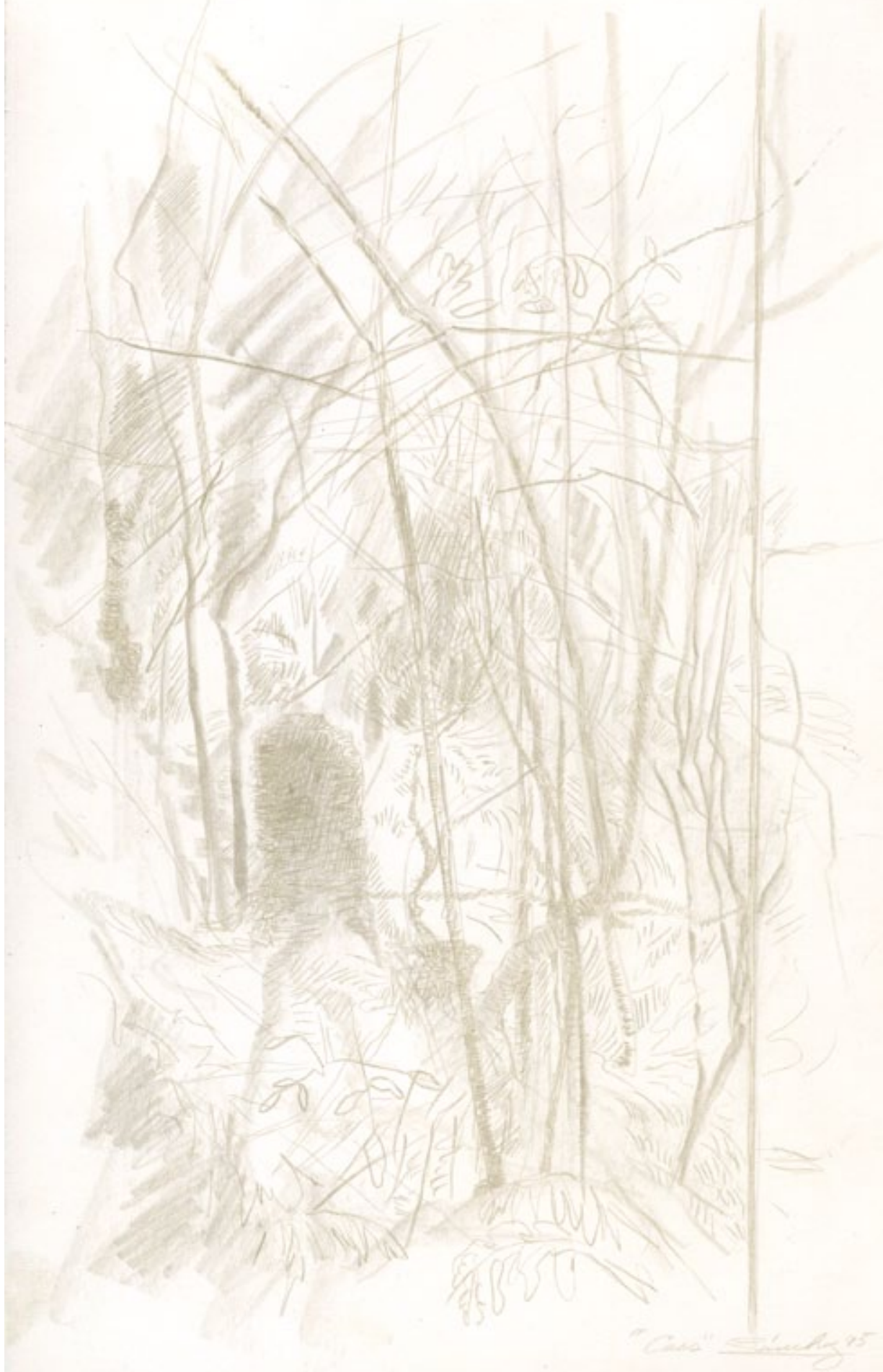




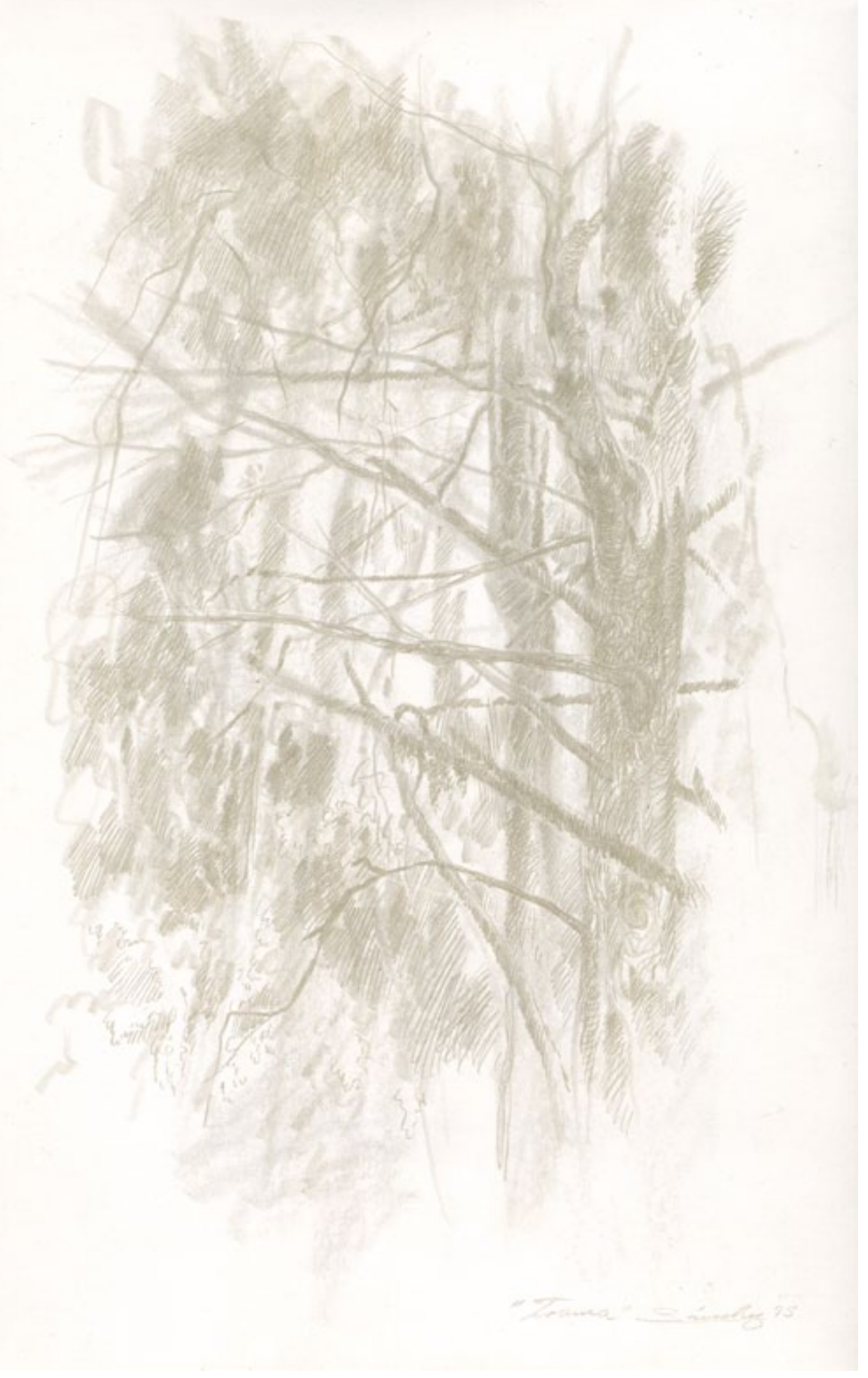




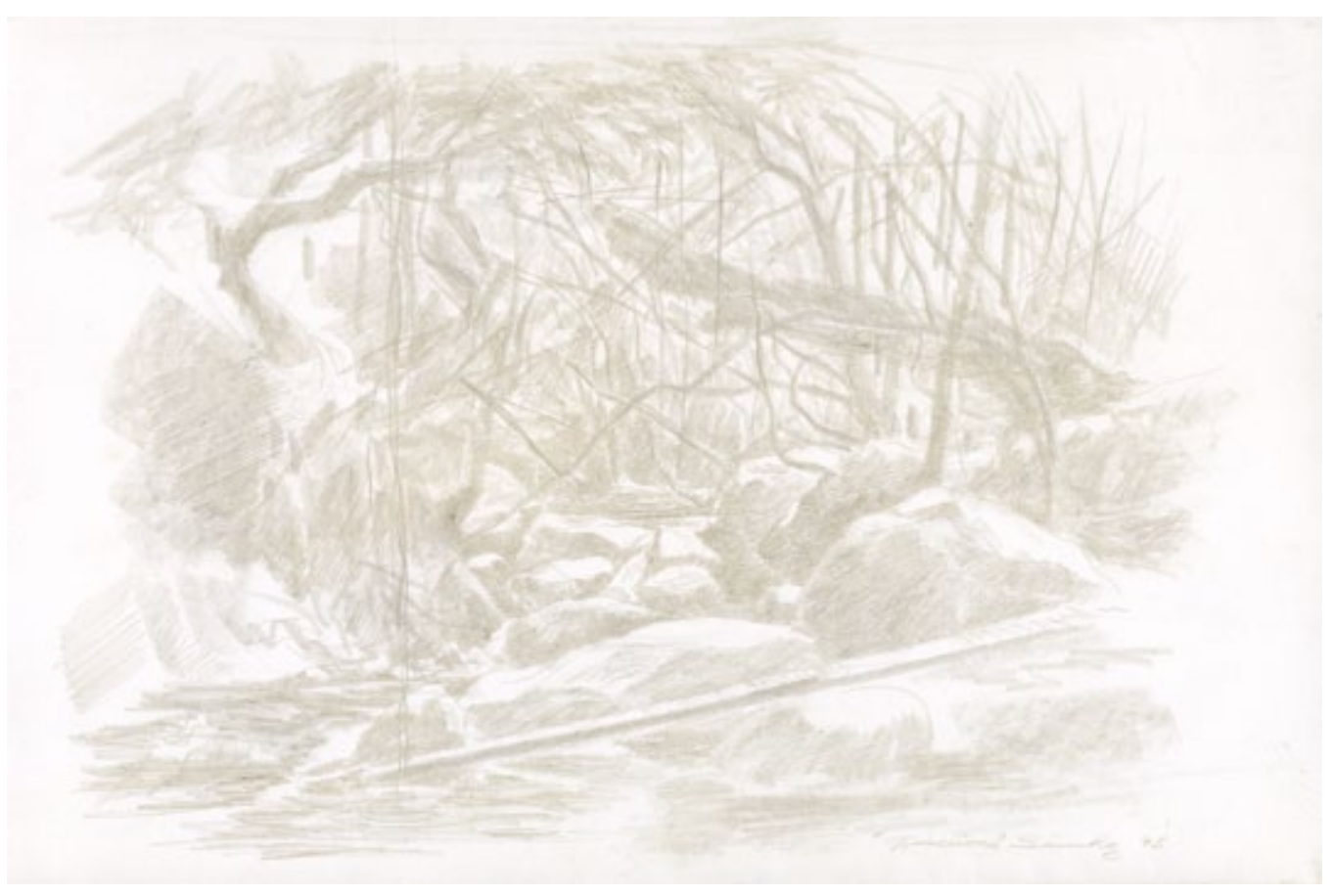


CUENTOS DEL BOSQUE SOMBRÍO Grabado 


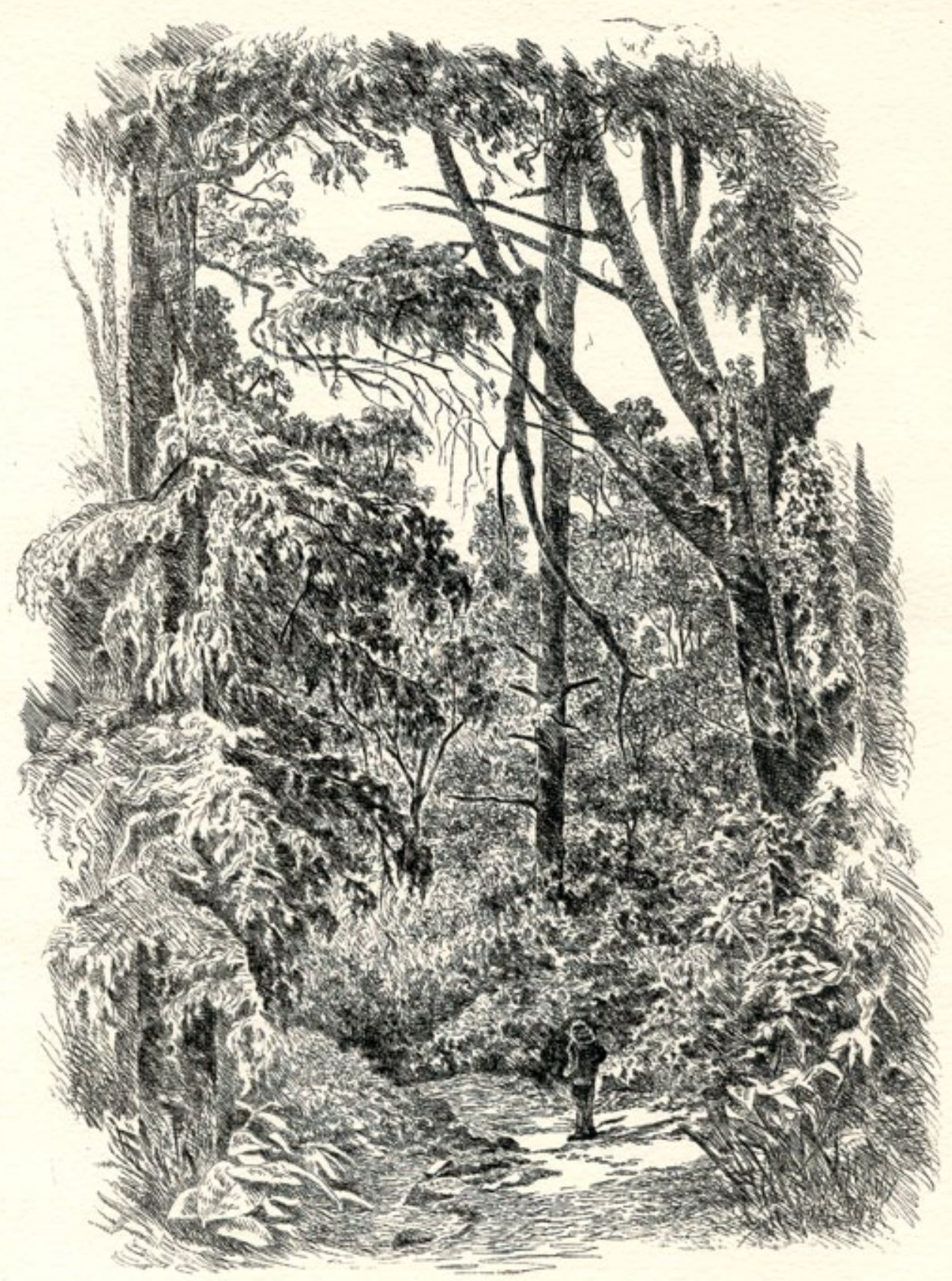




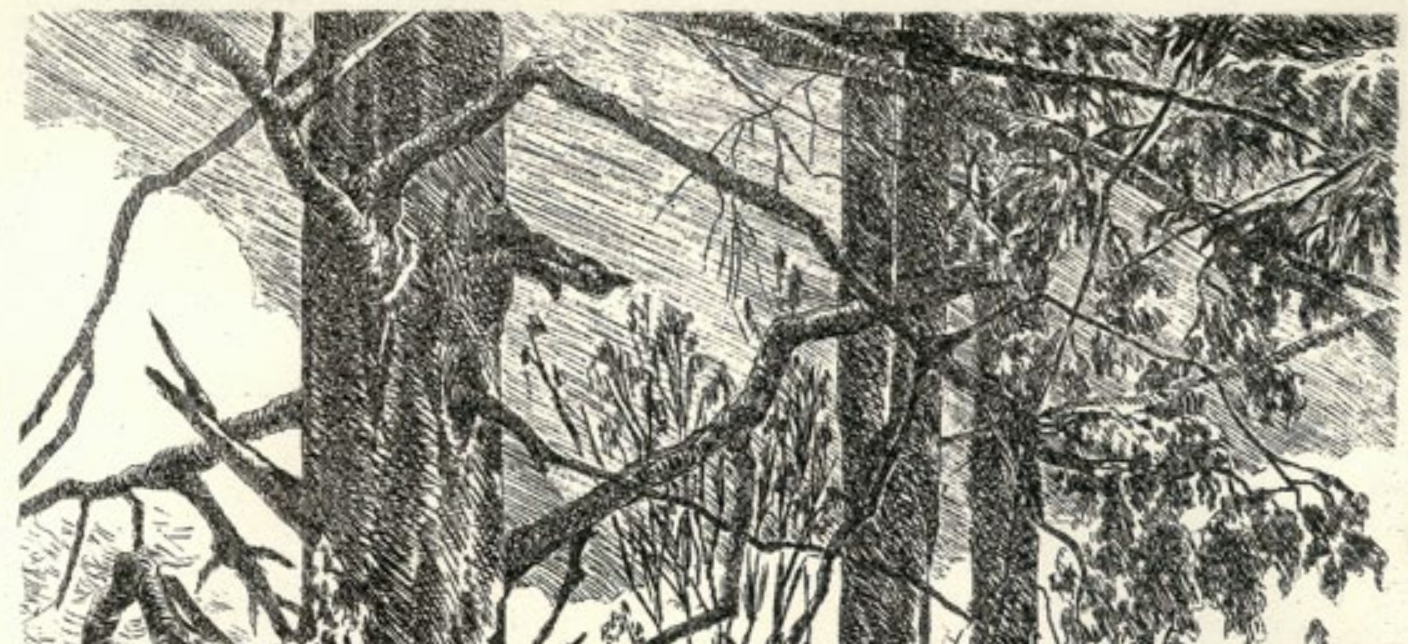

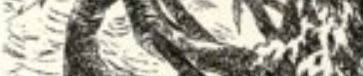

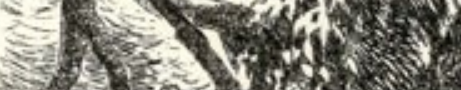

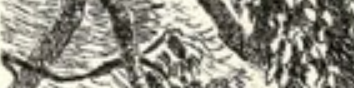

3 to 1 .

ind

(A) $3 \times 1 \times$ (6) onst. (this) Now * 30 . 1.10.

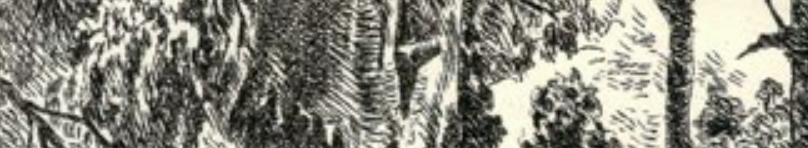

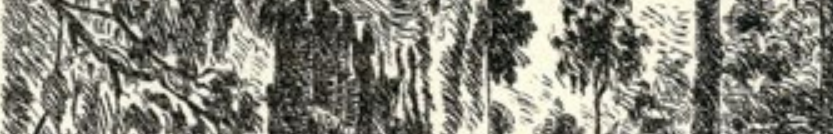
1. (1)

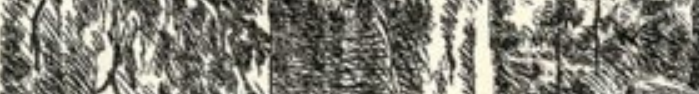
3 .

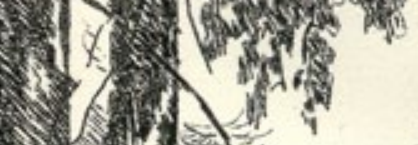

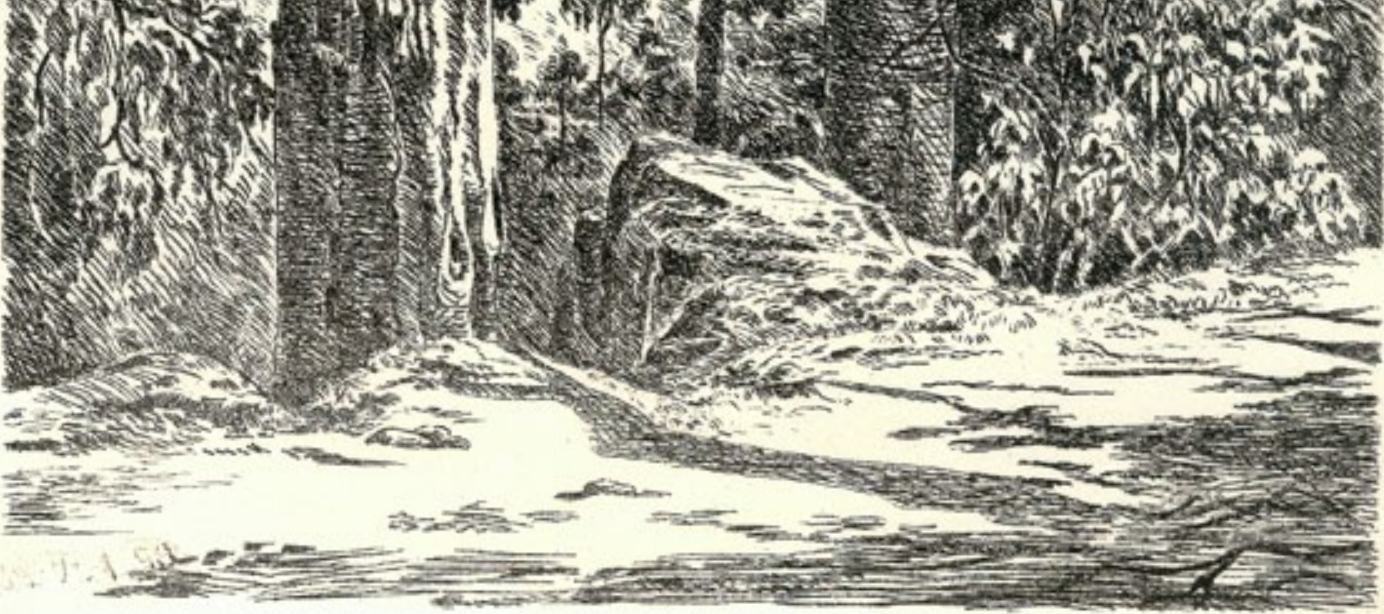




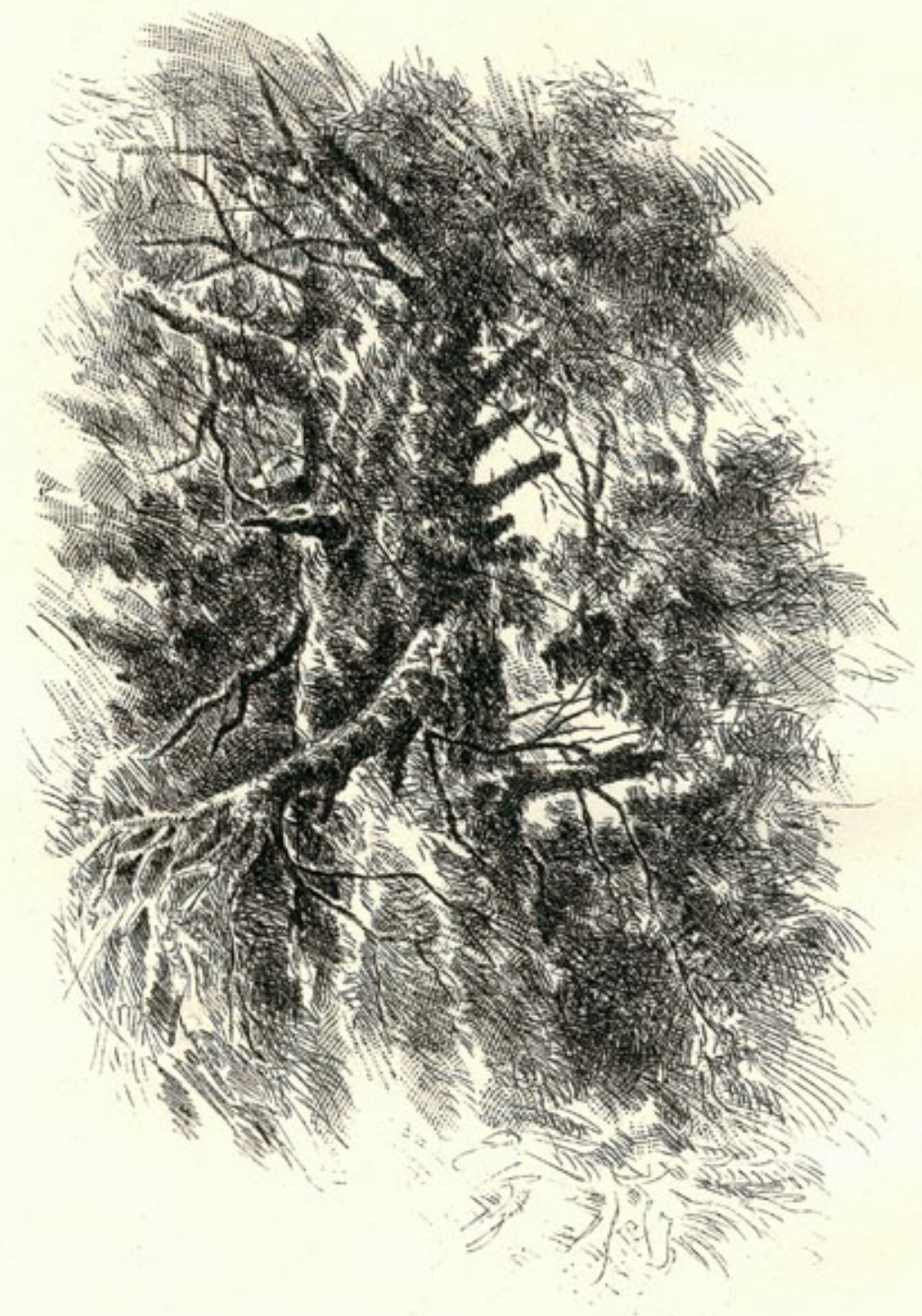




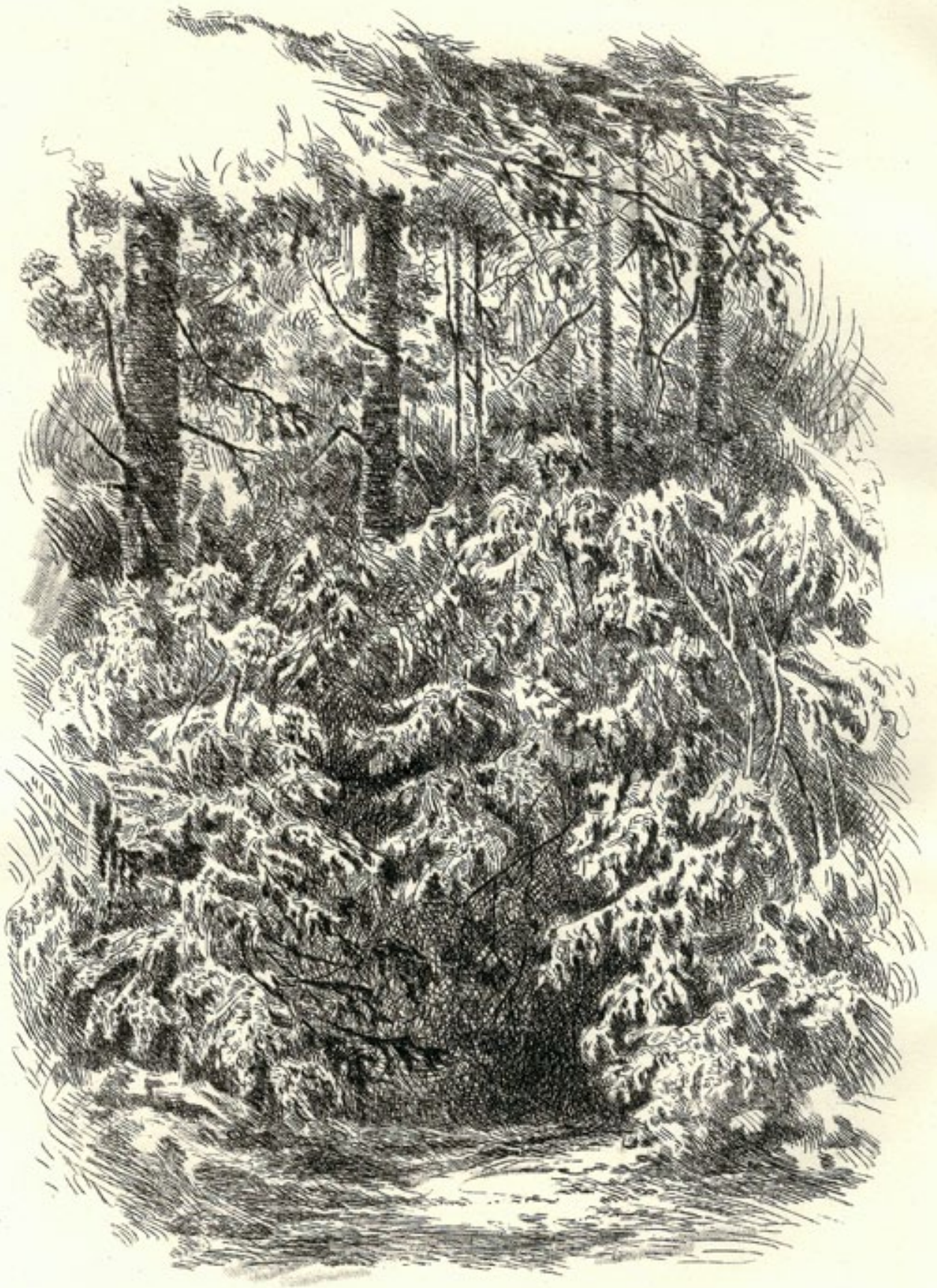




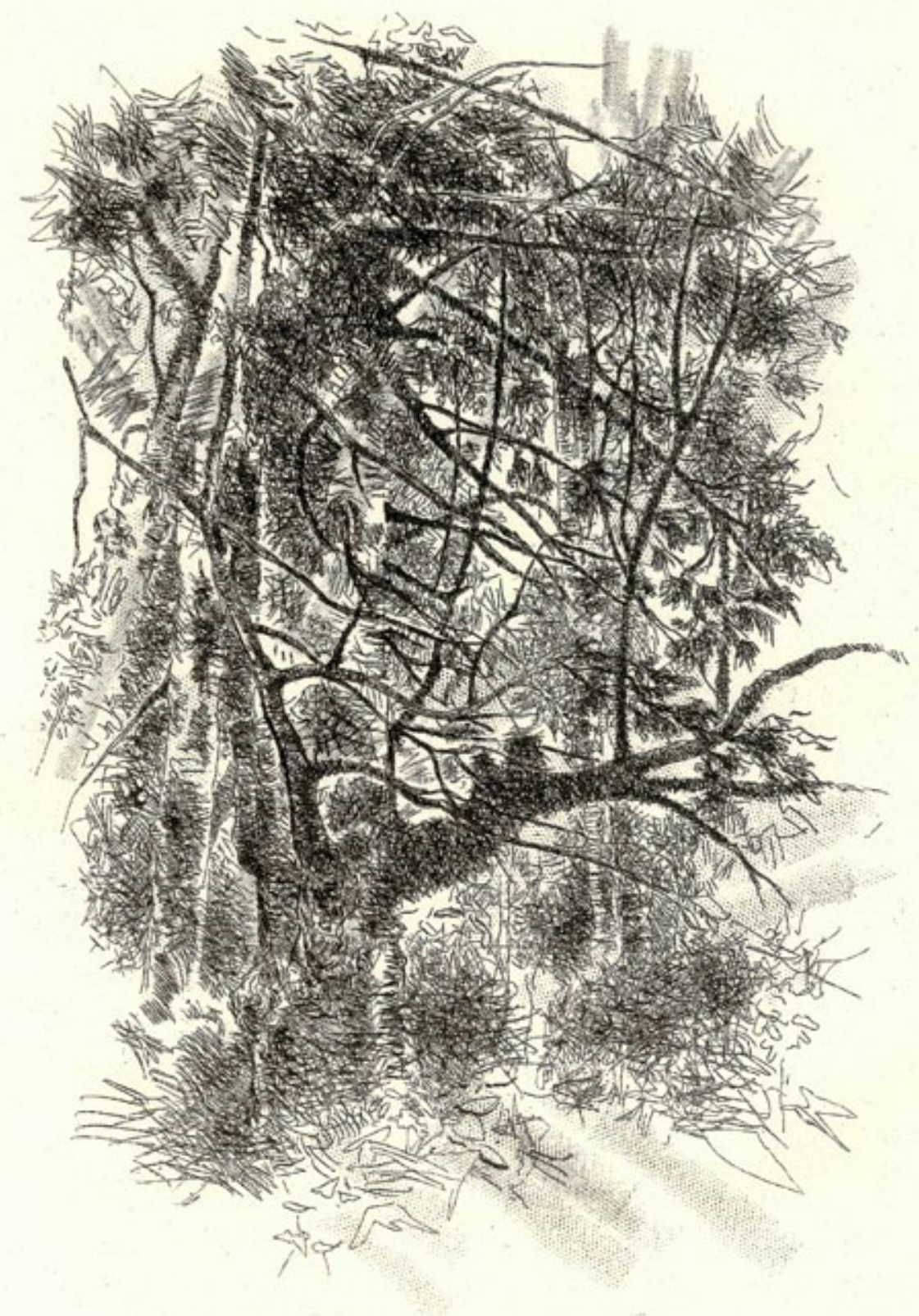




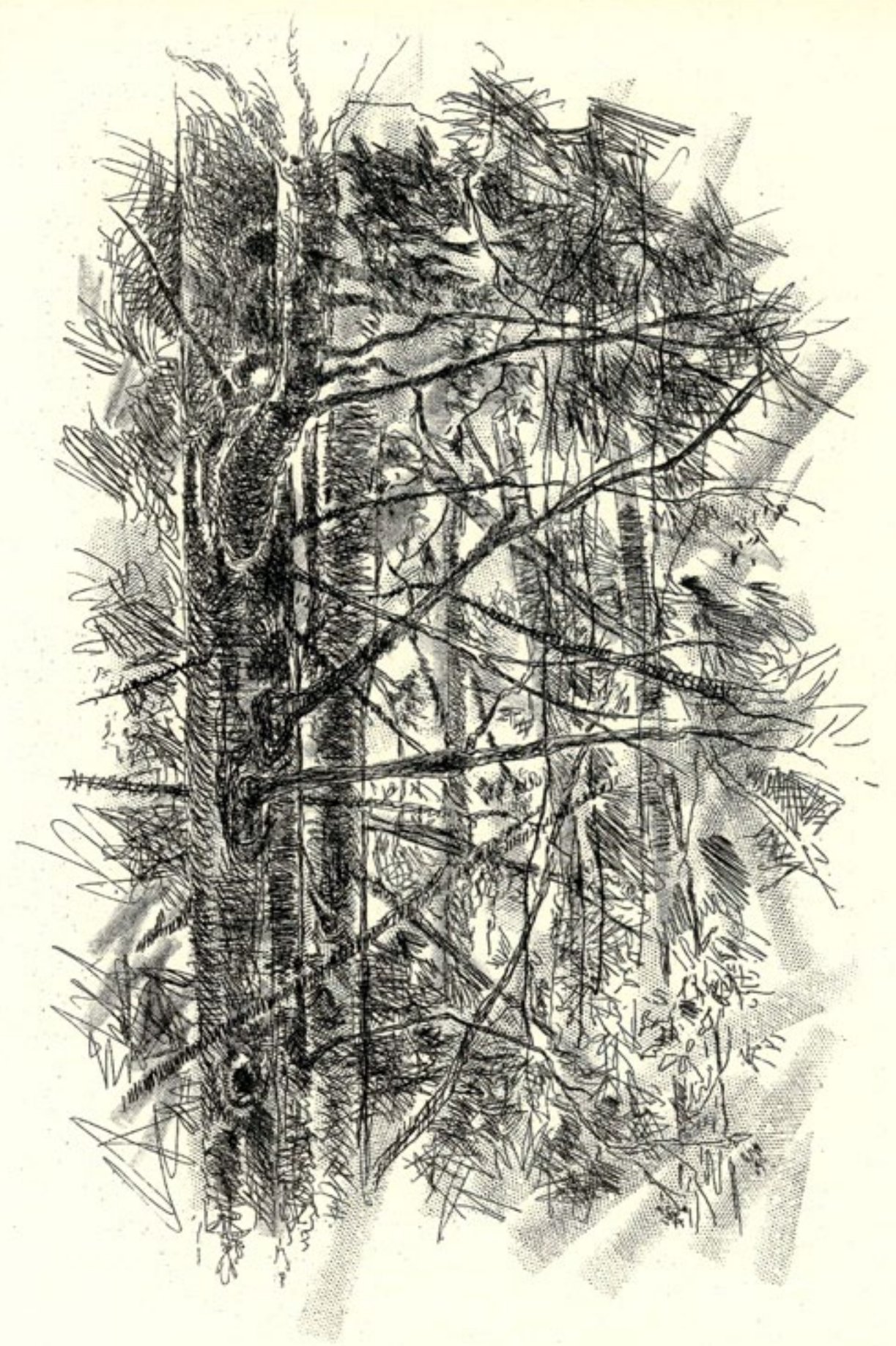




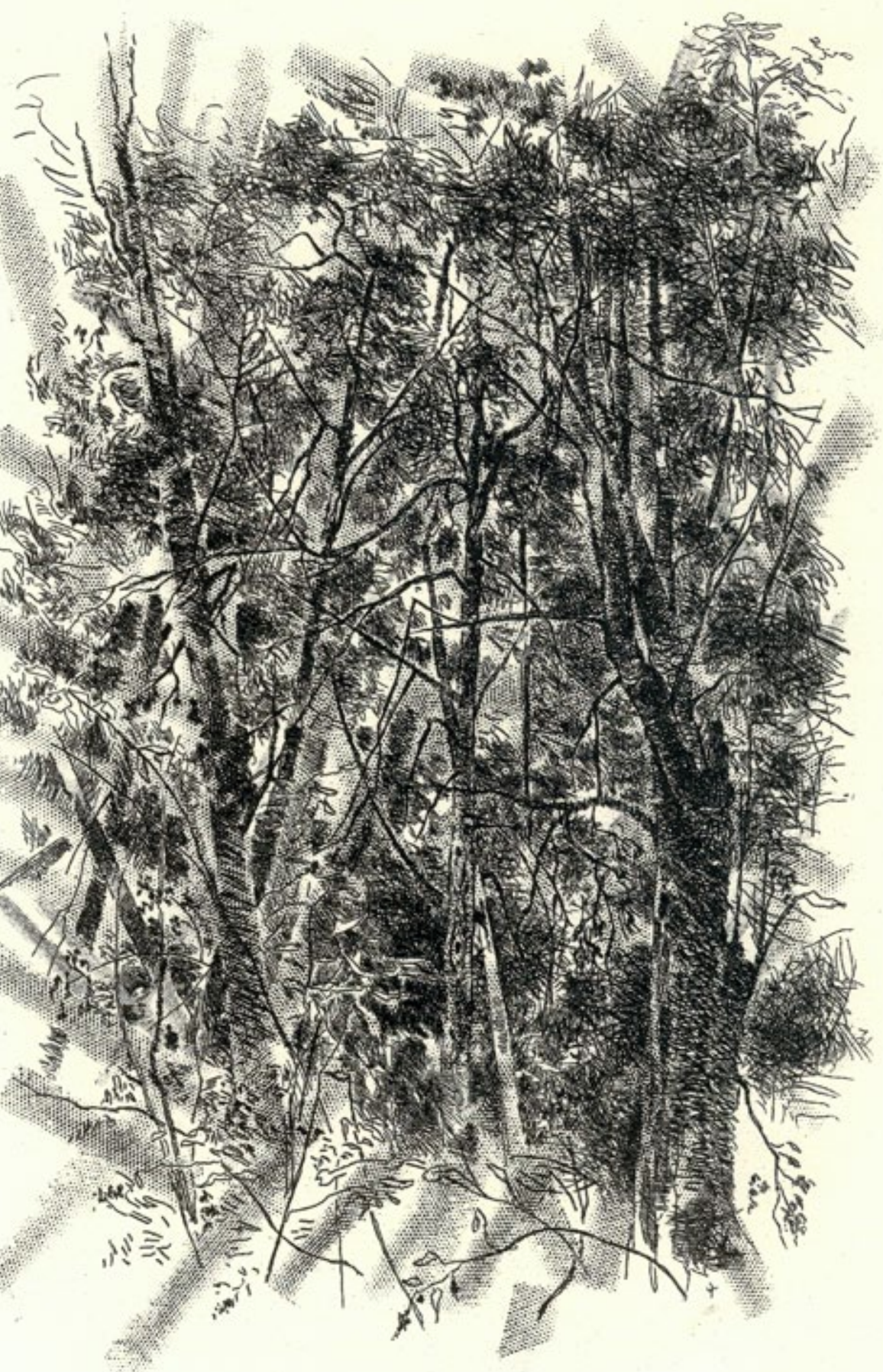




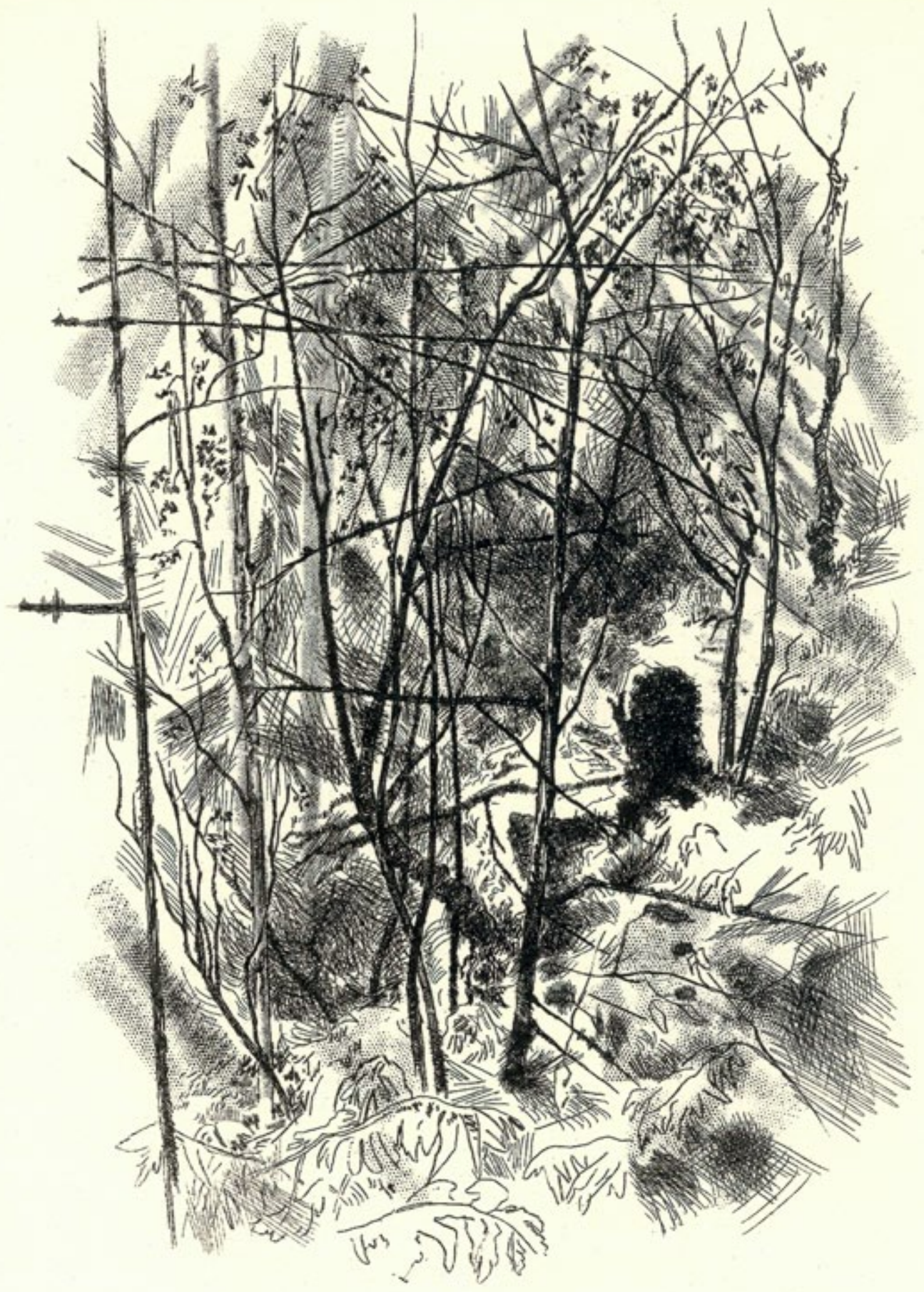




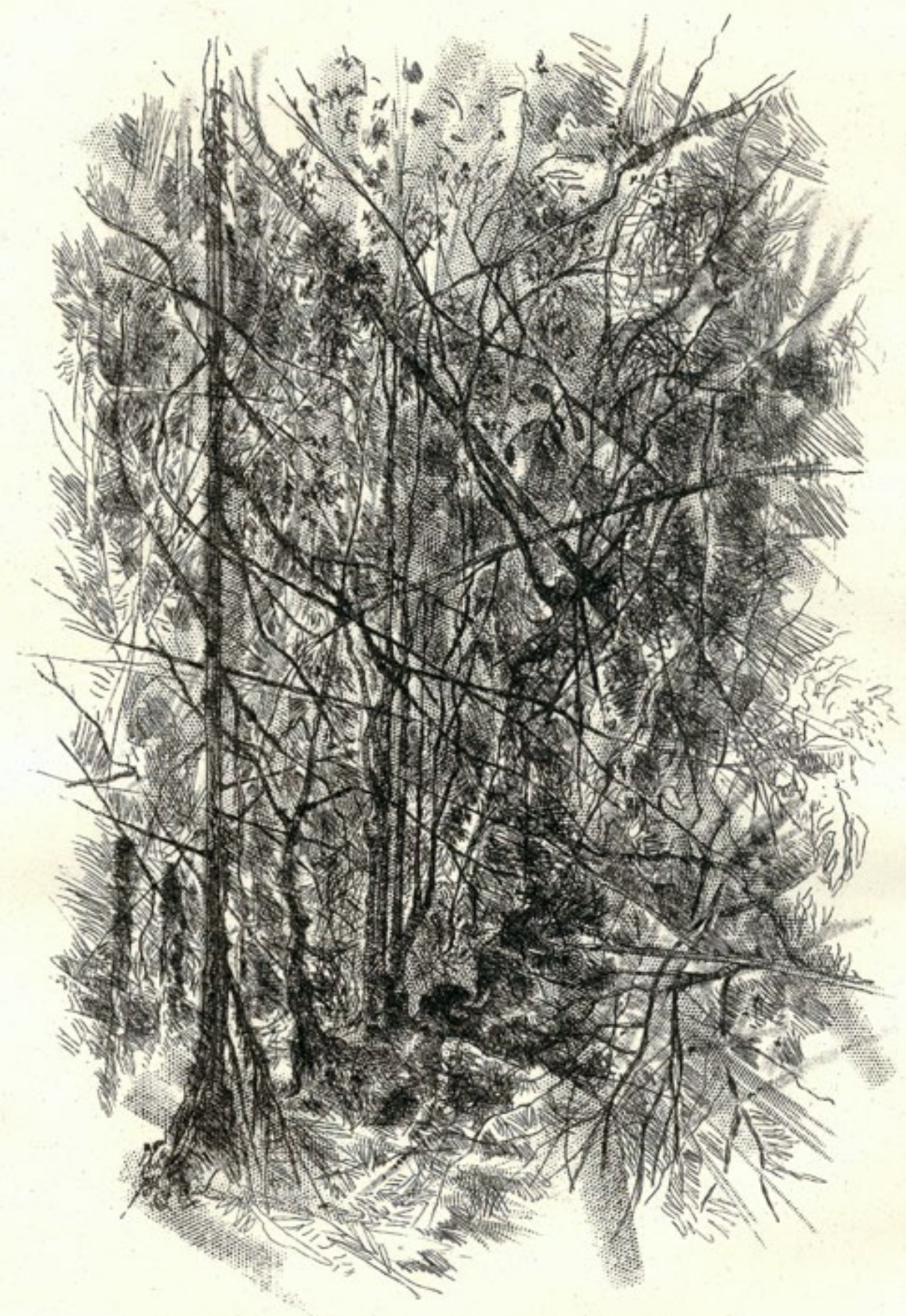




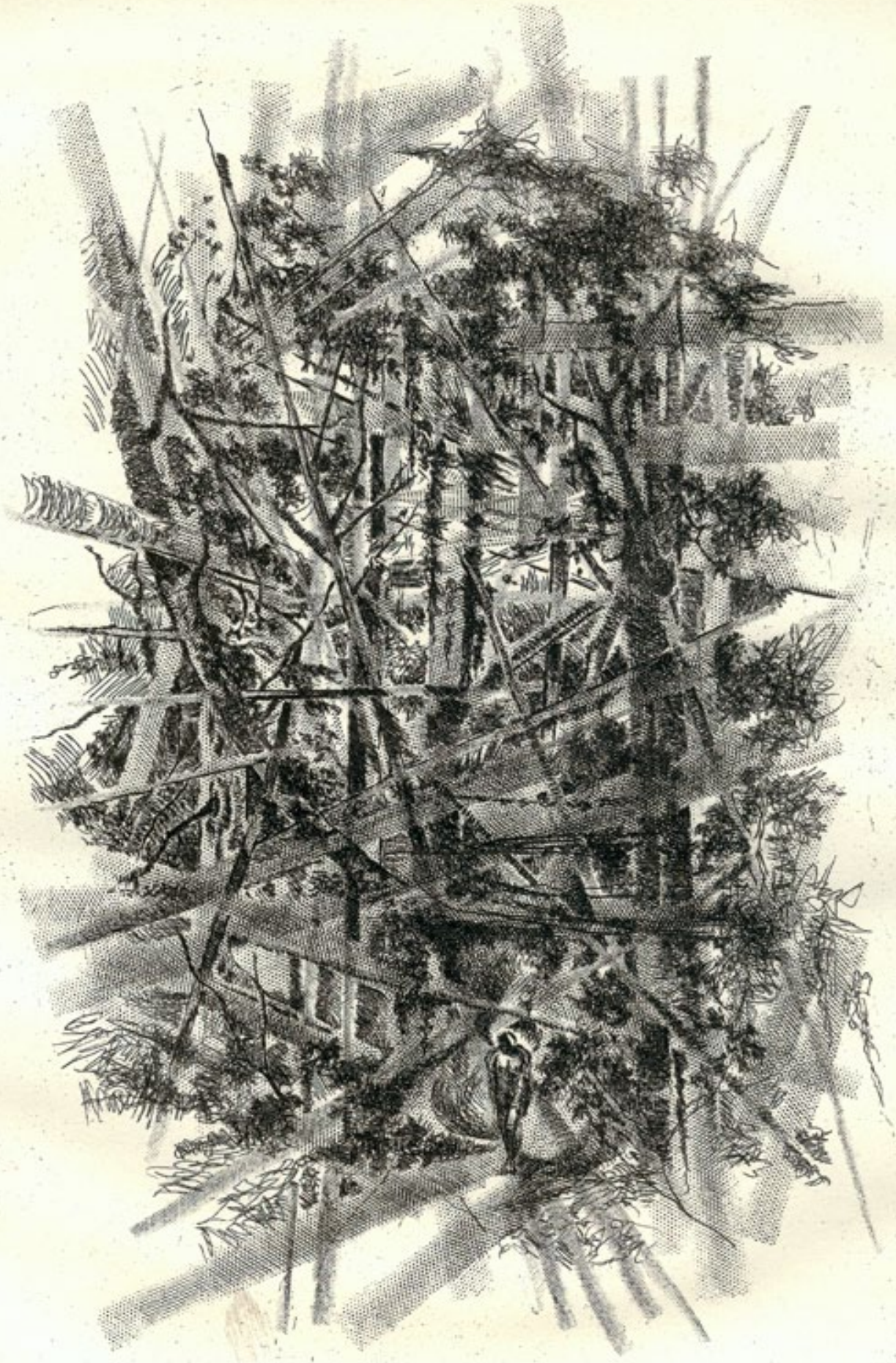


CUENTOS DEL BOSQUE SOMBRÍO Temple 


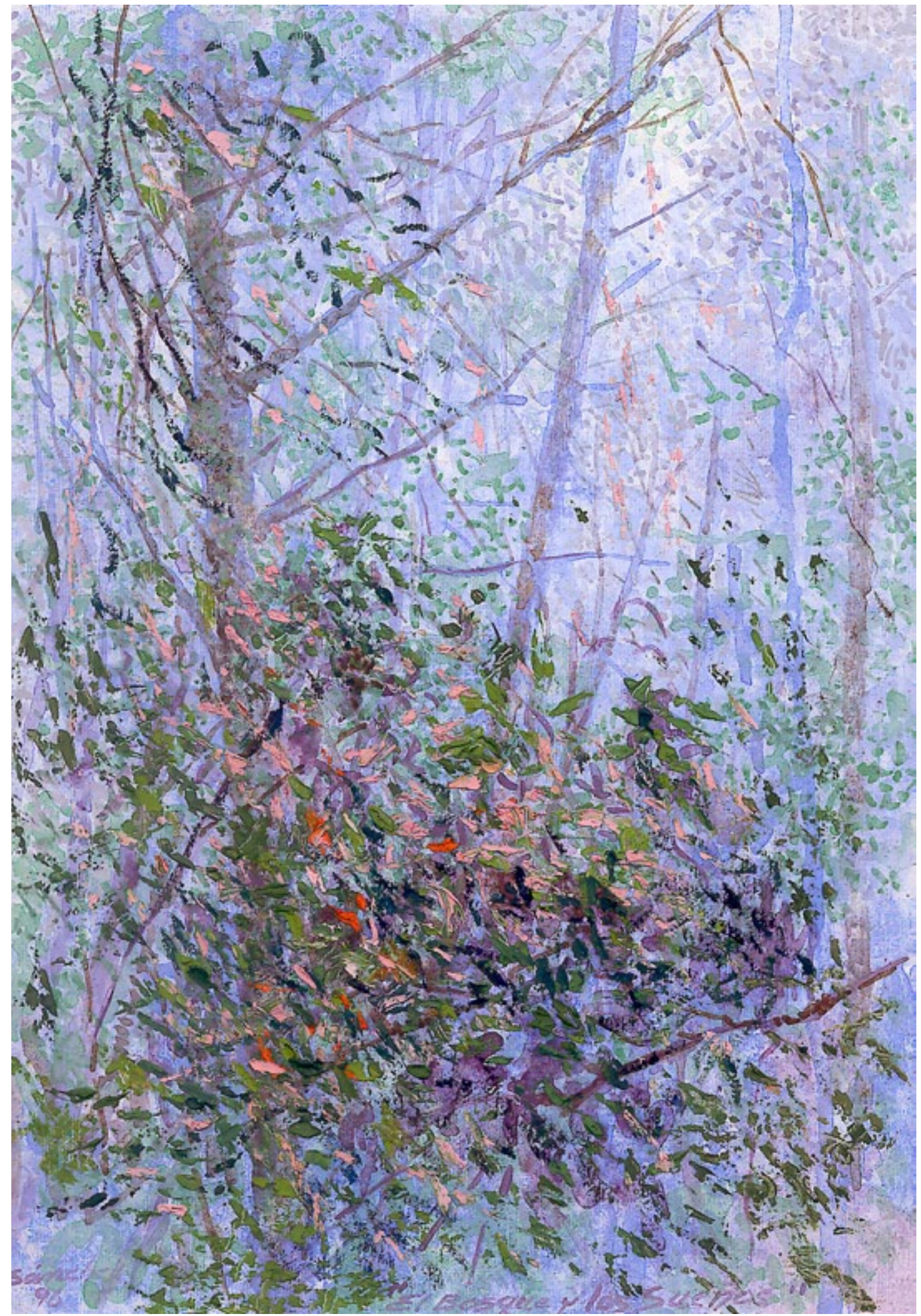




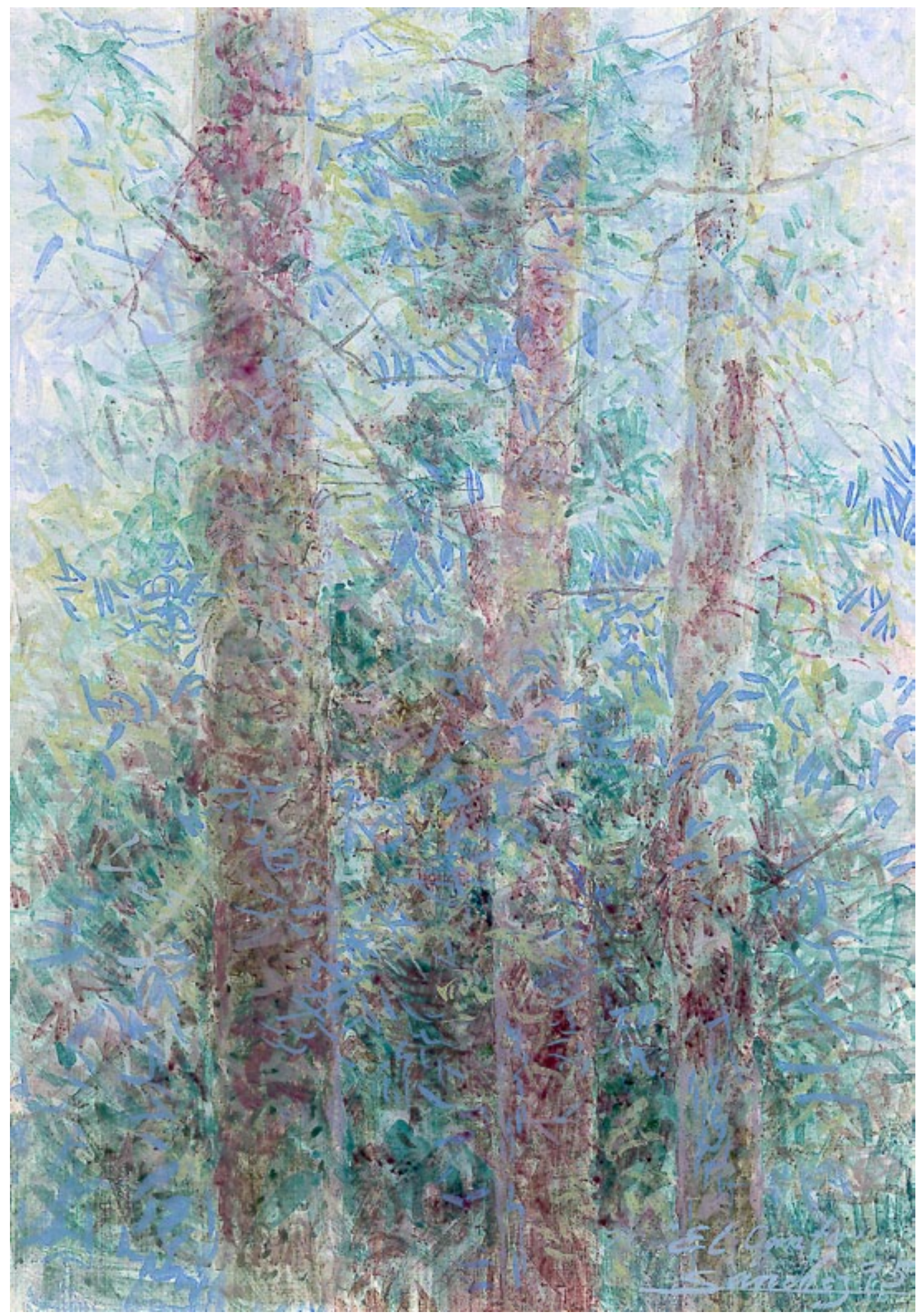




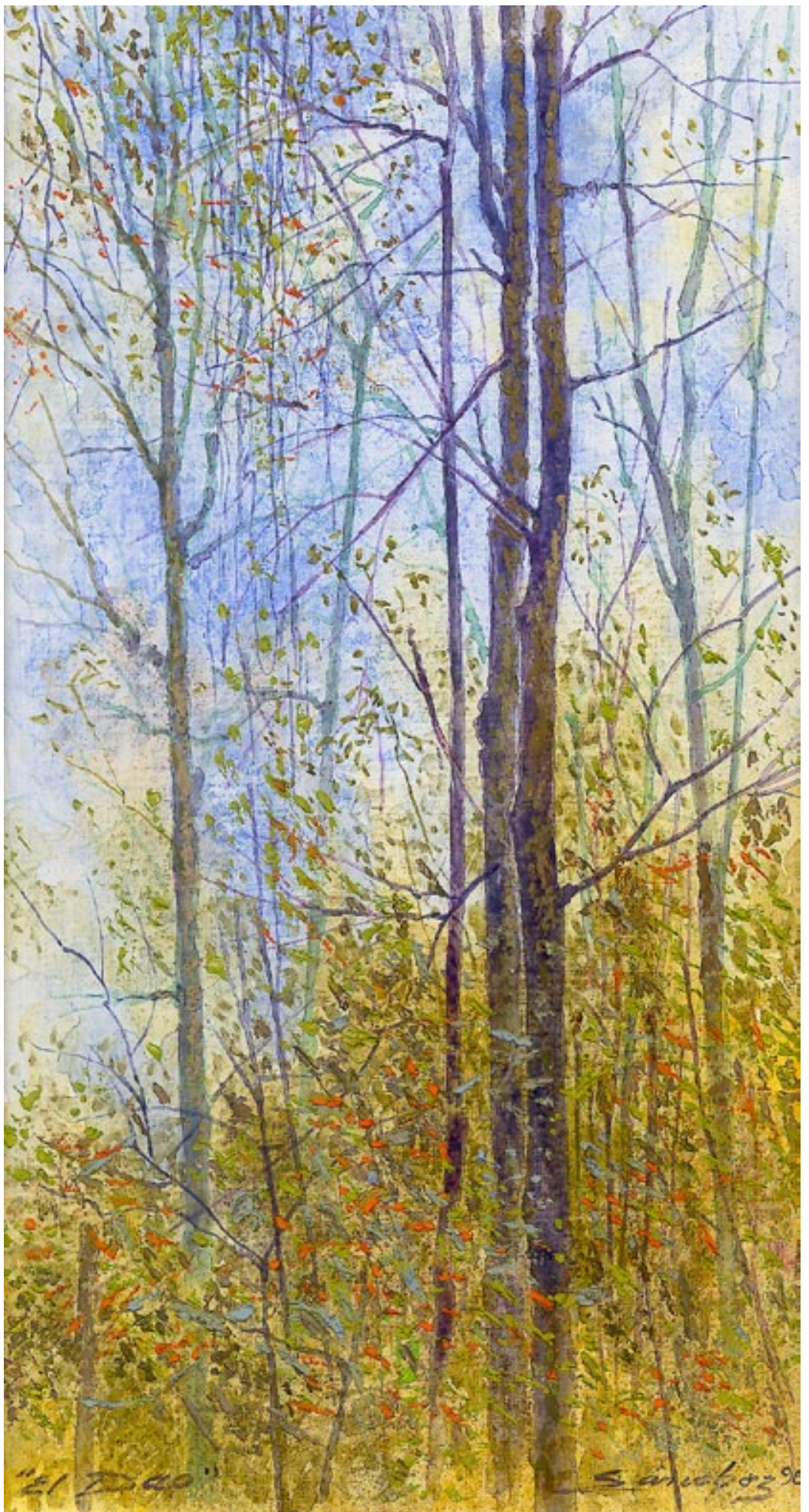




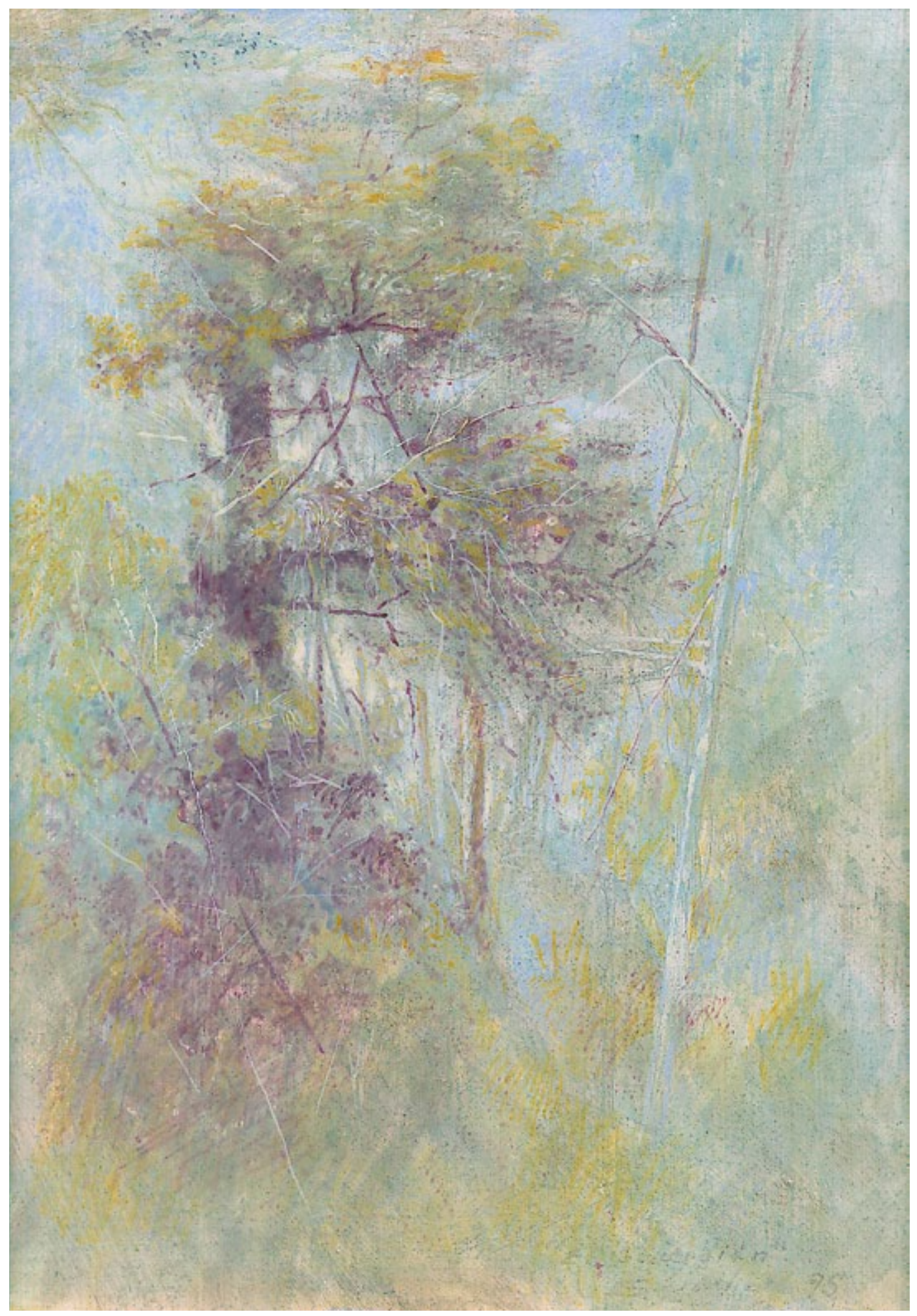




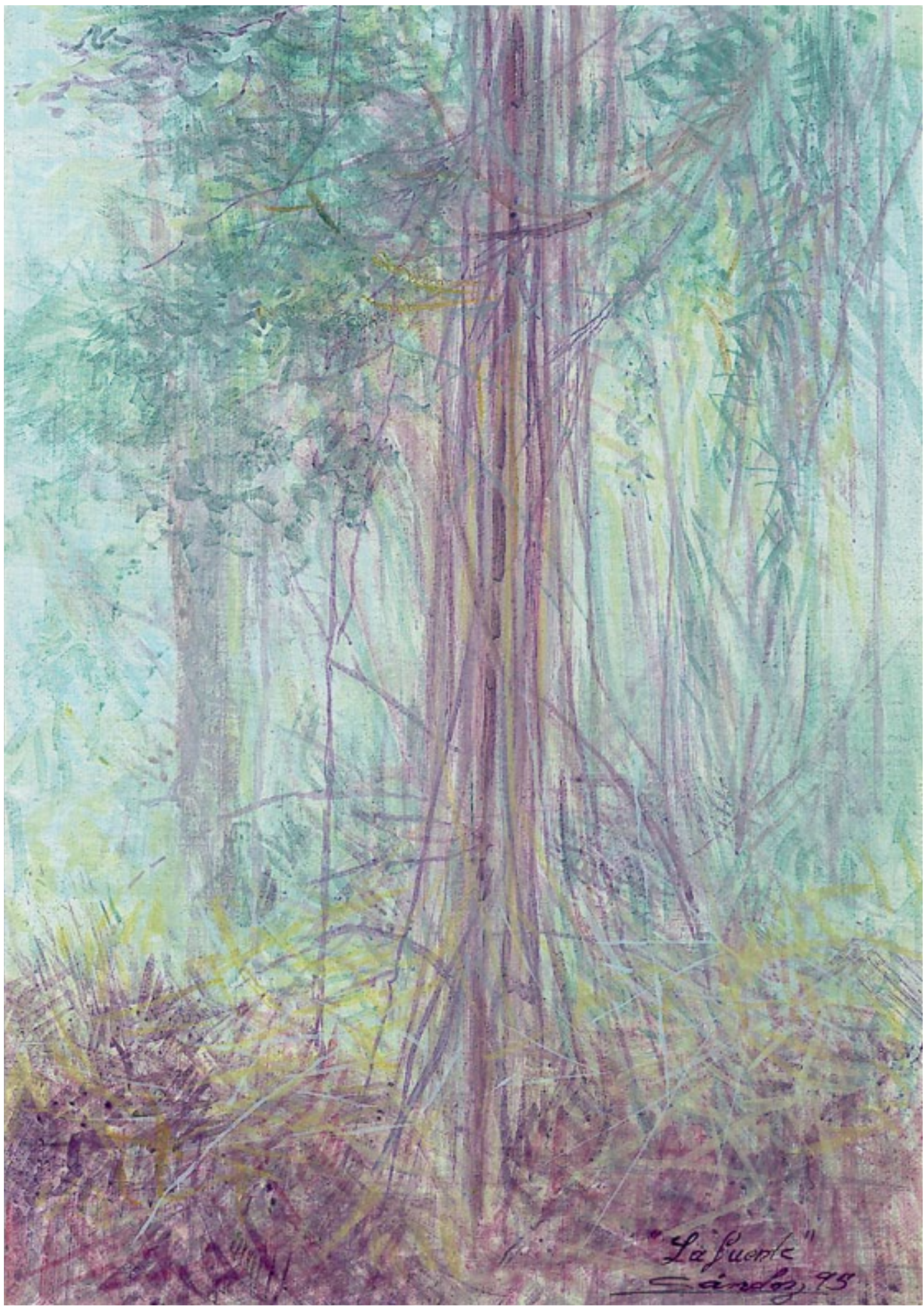




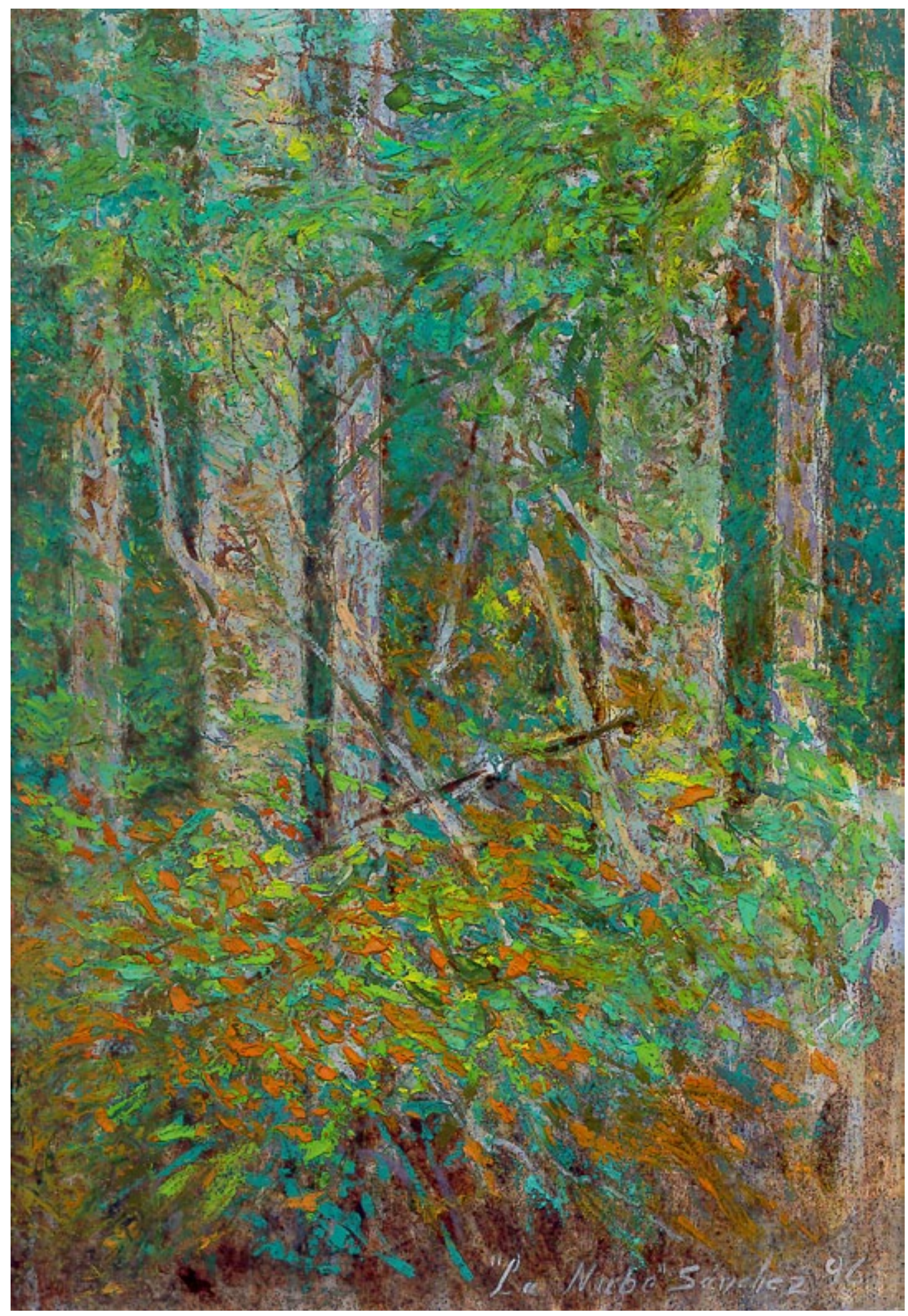




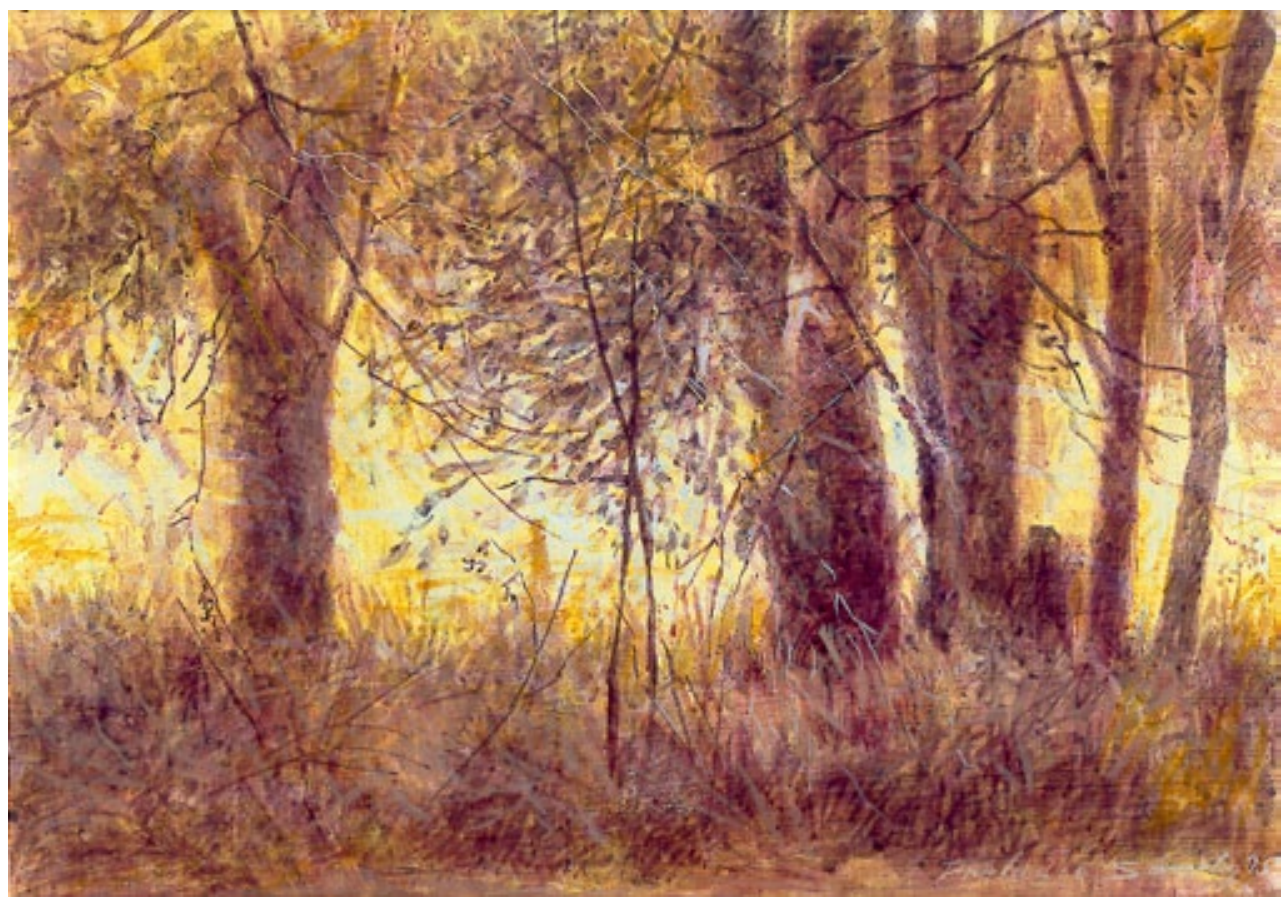




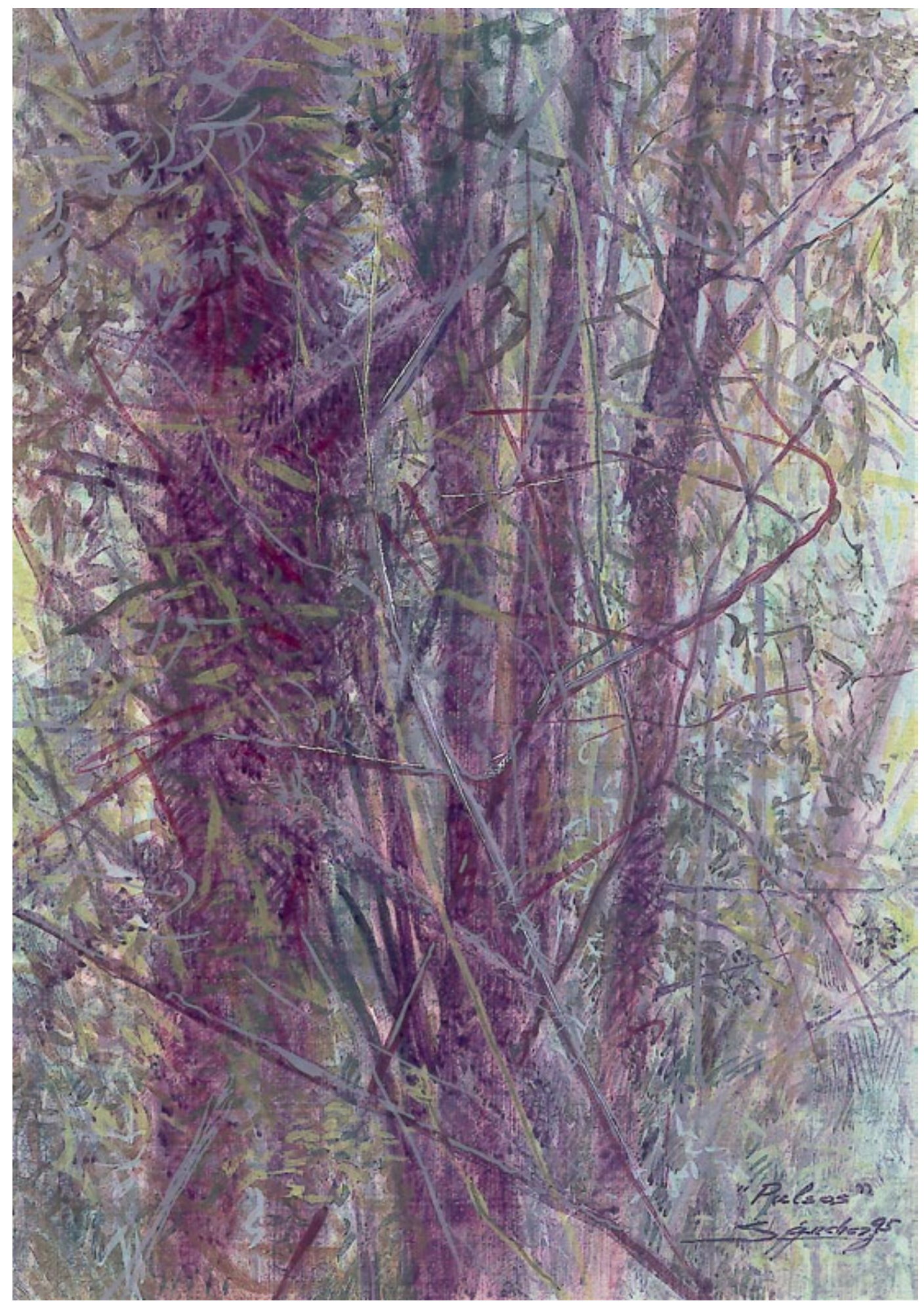




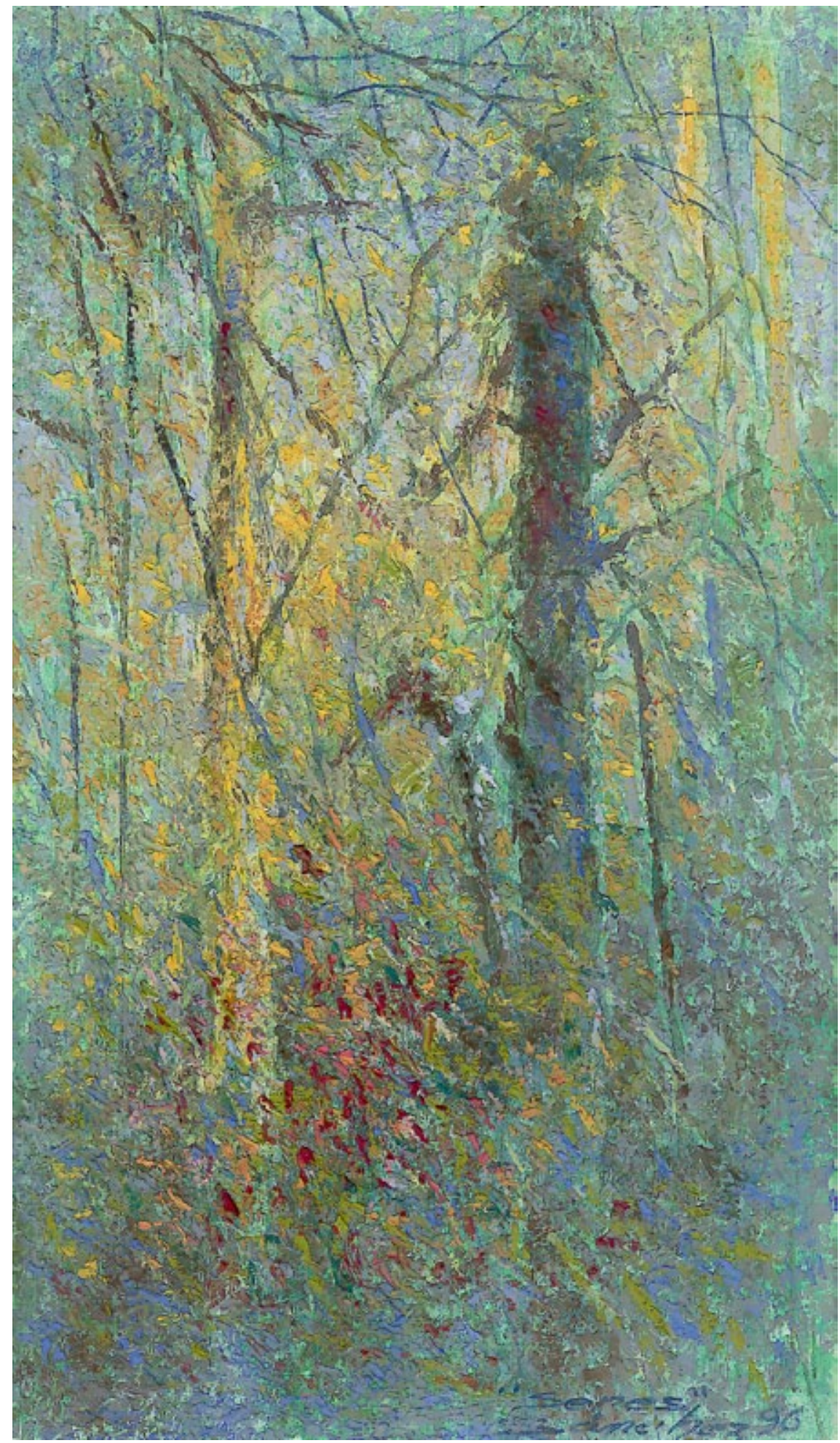




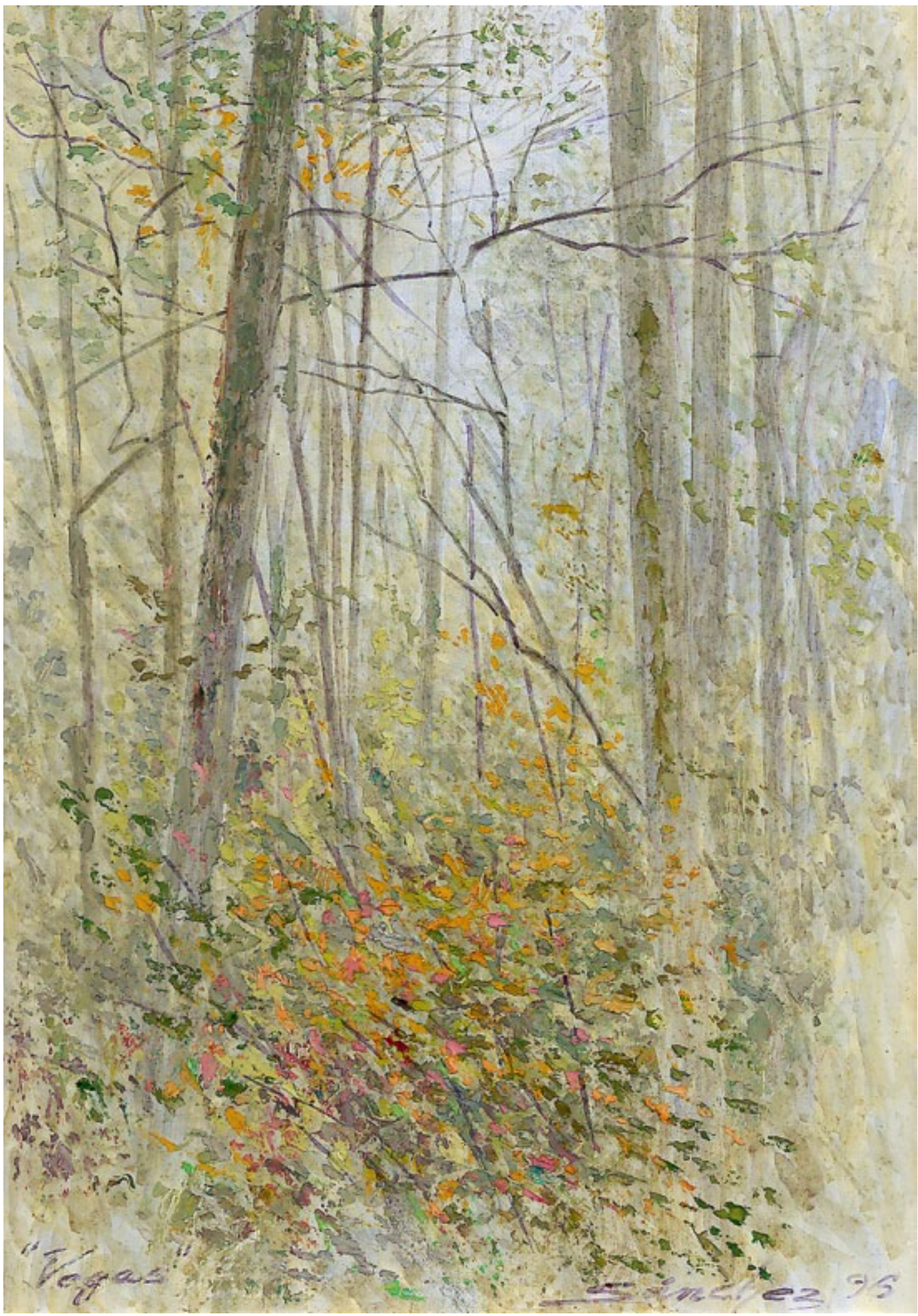




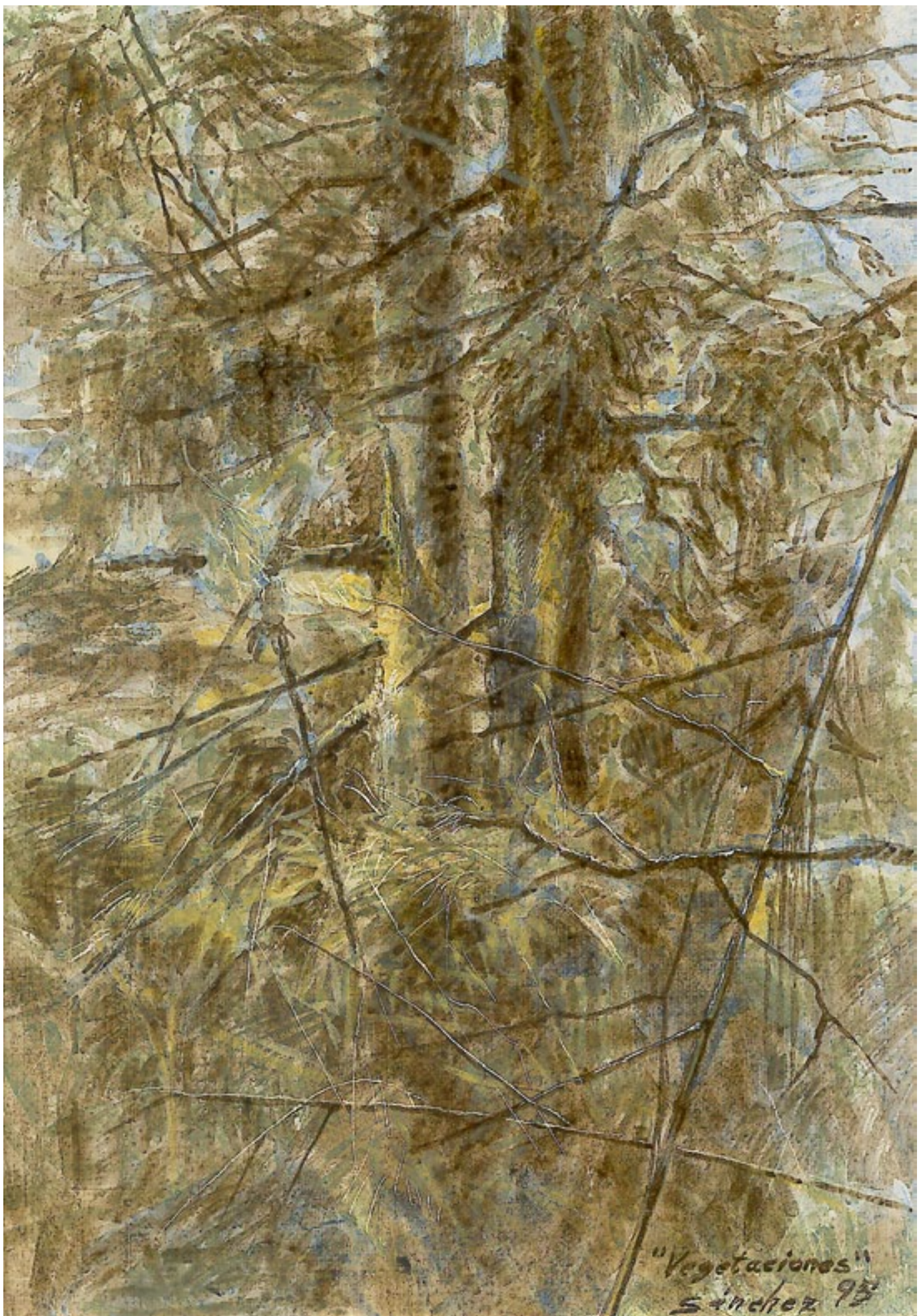




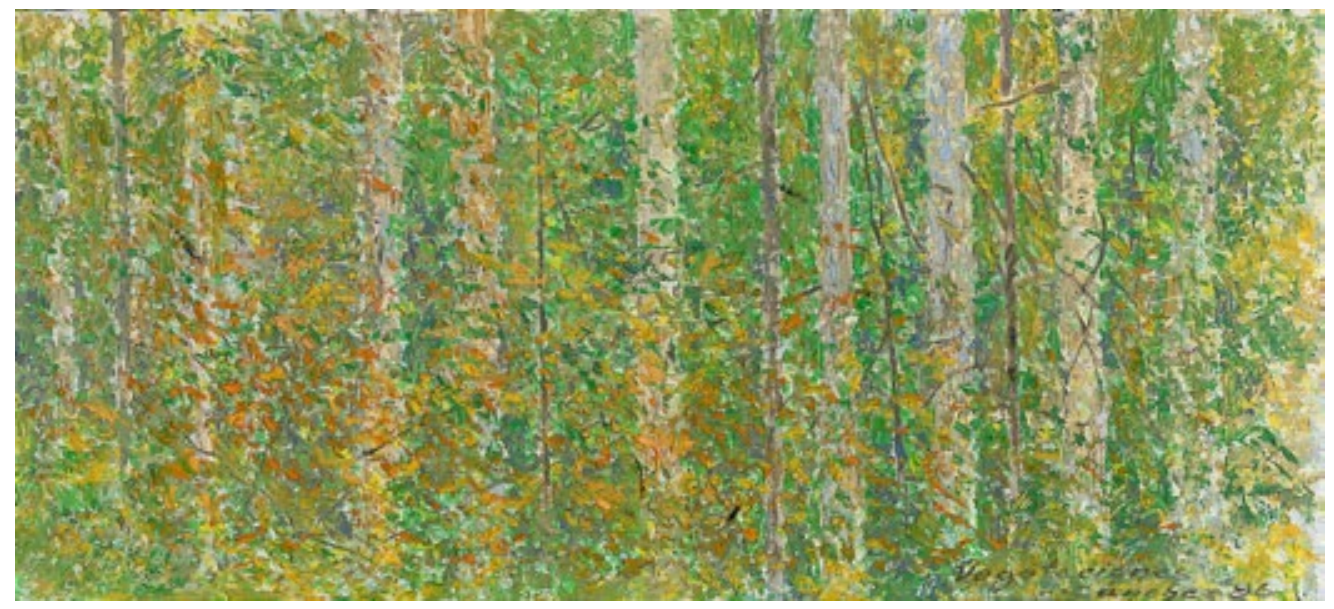


TÓTEM Y TABÚ 


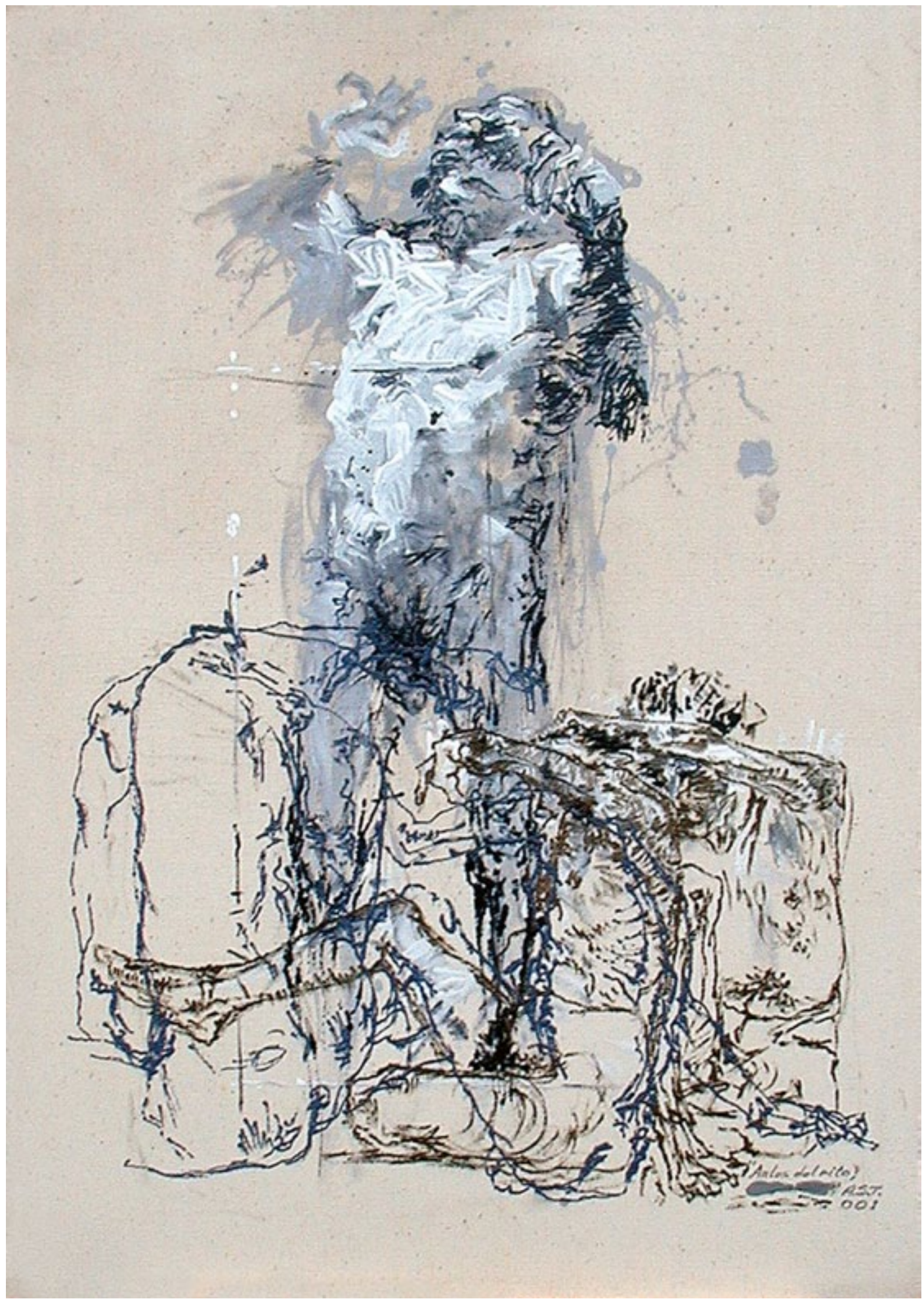




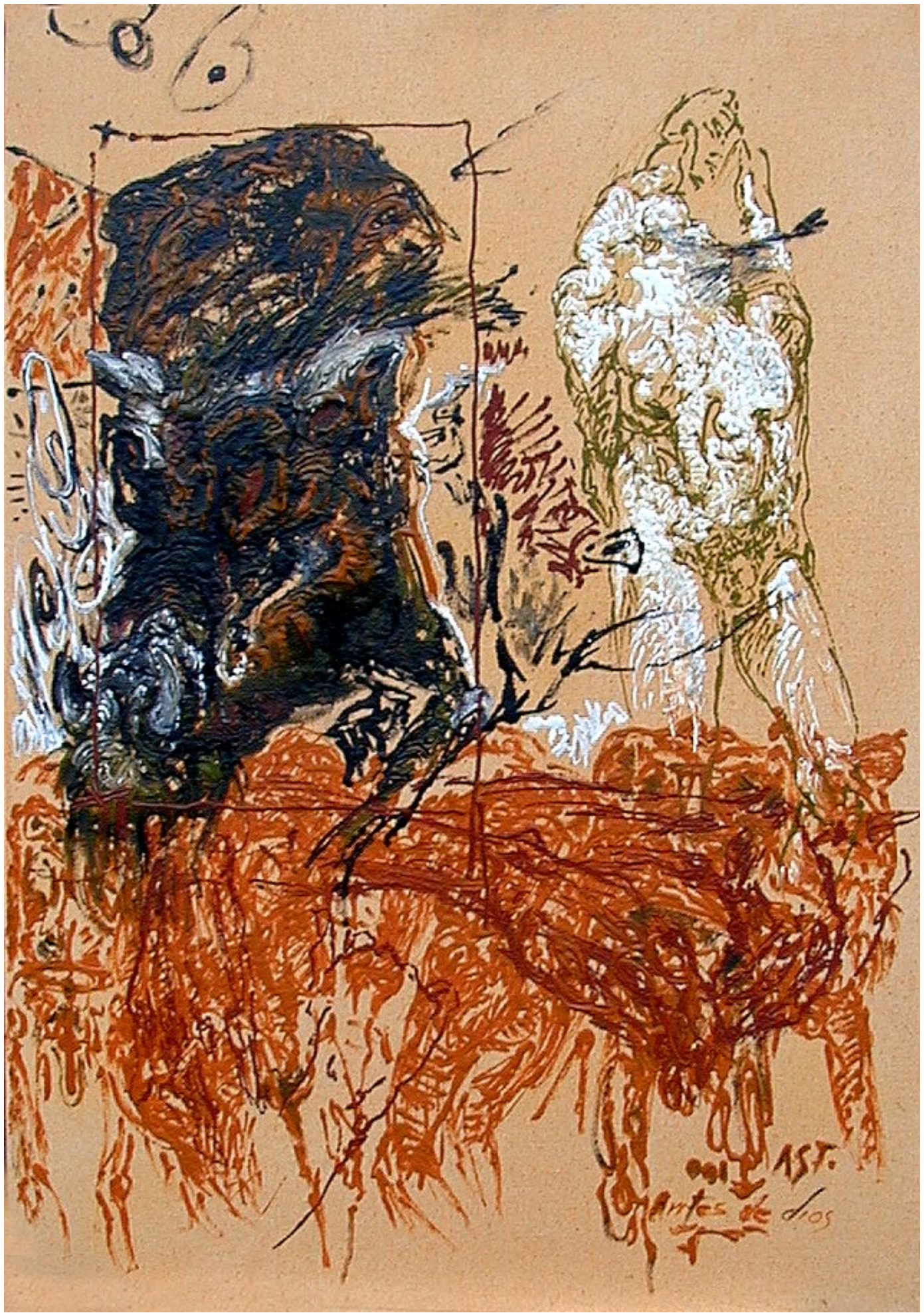




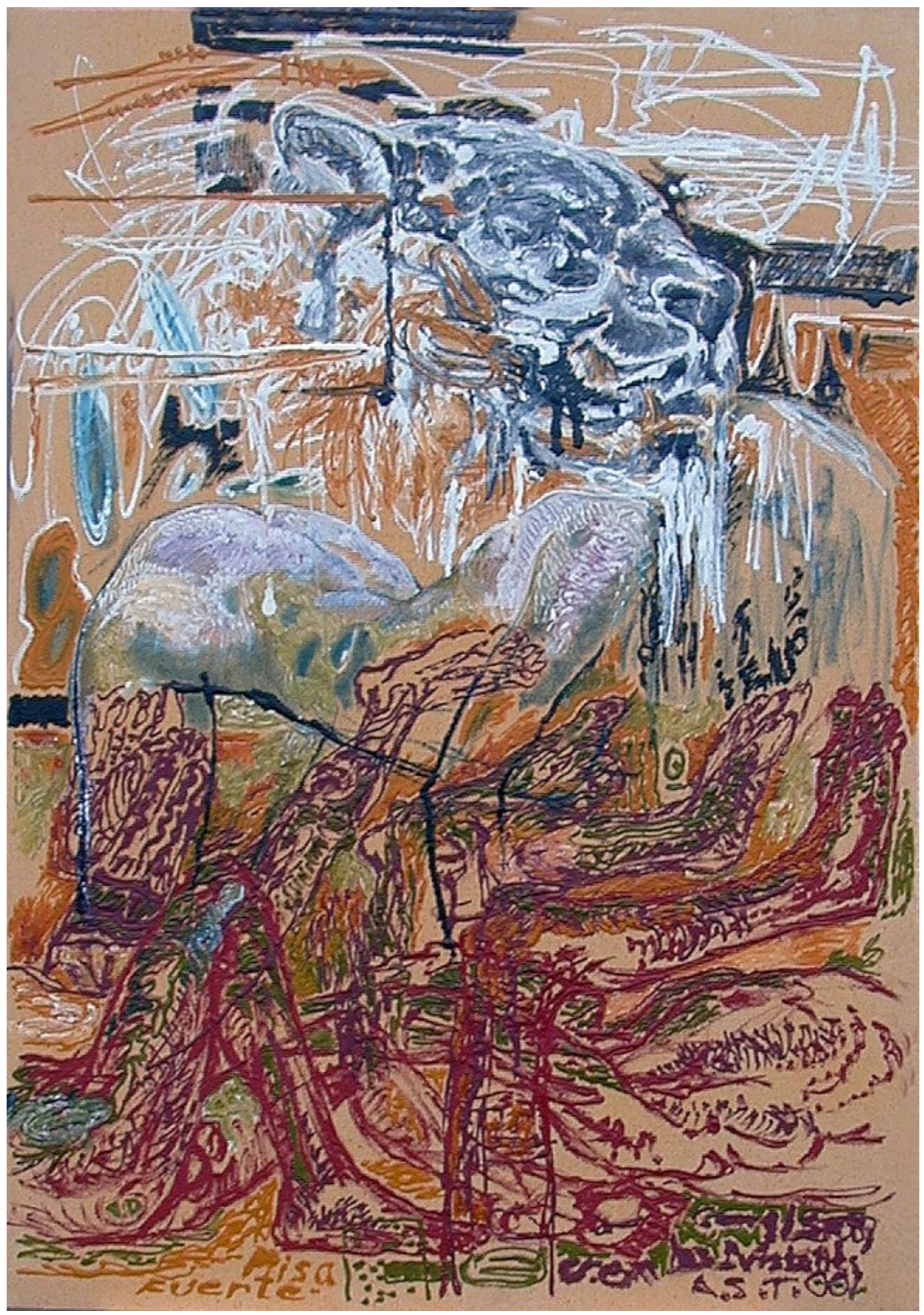




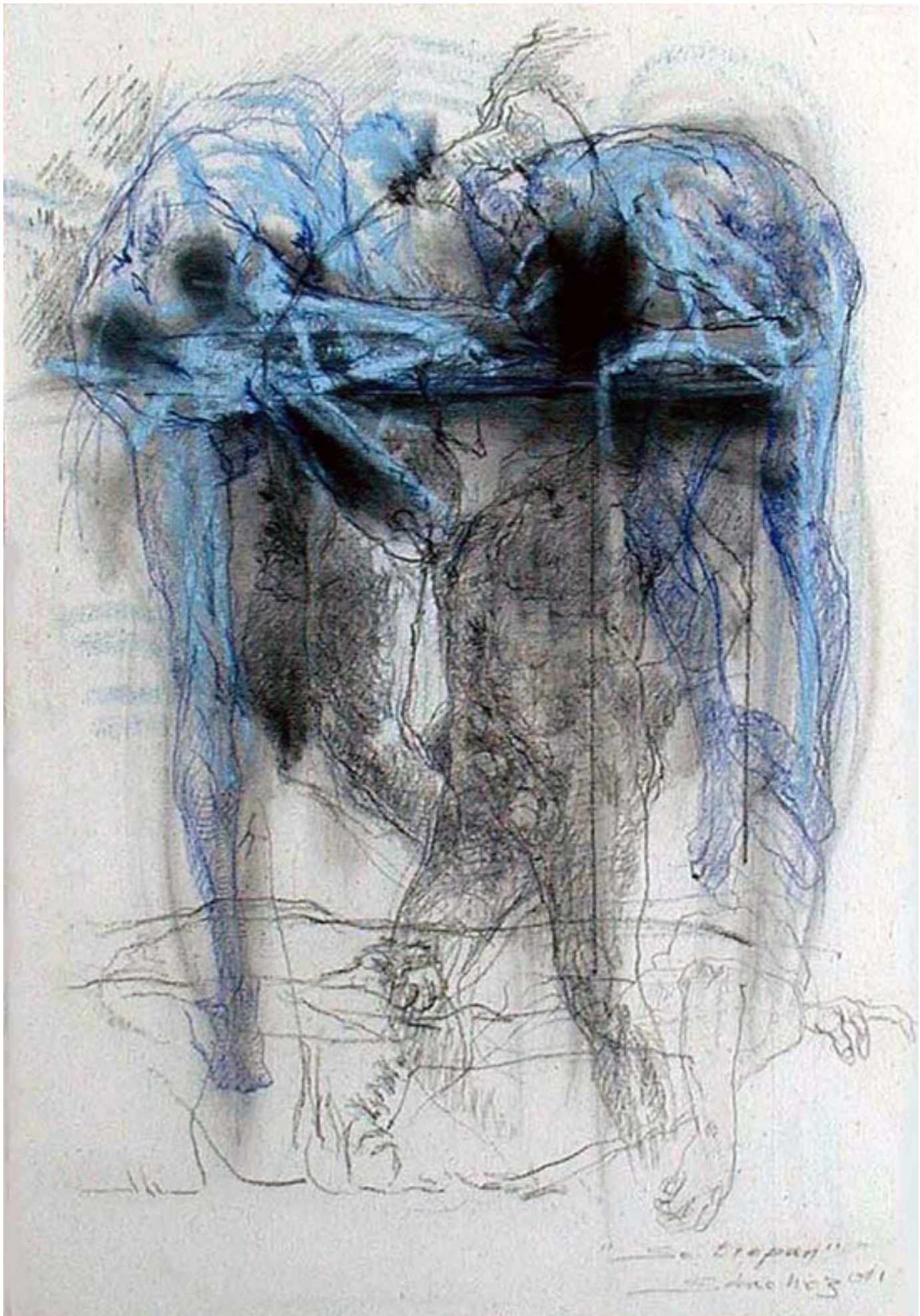




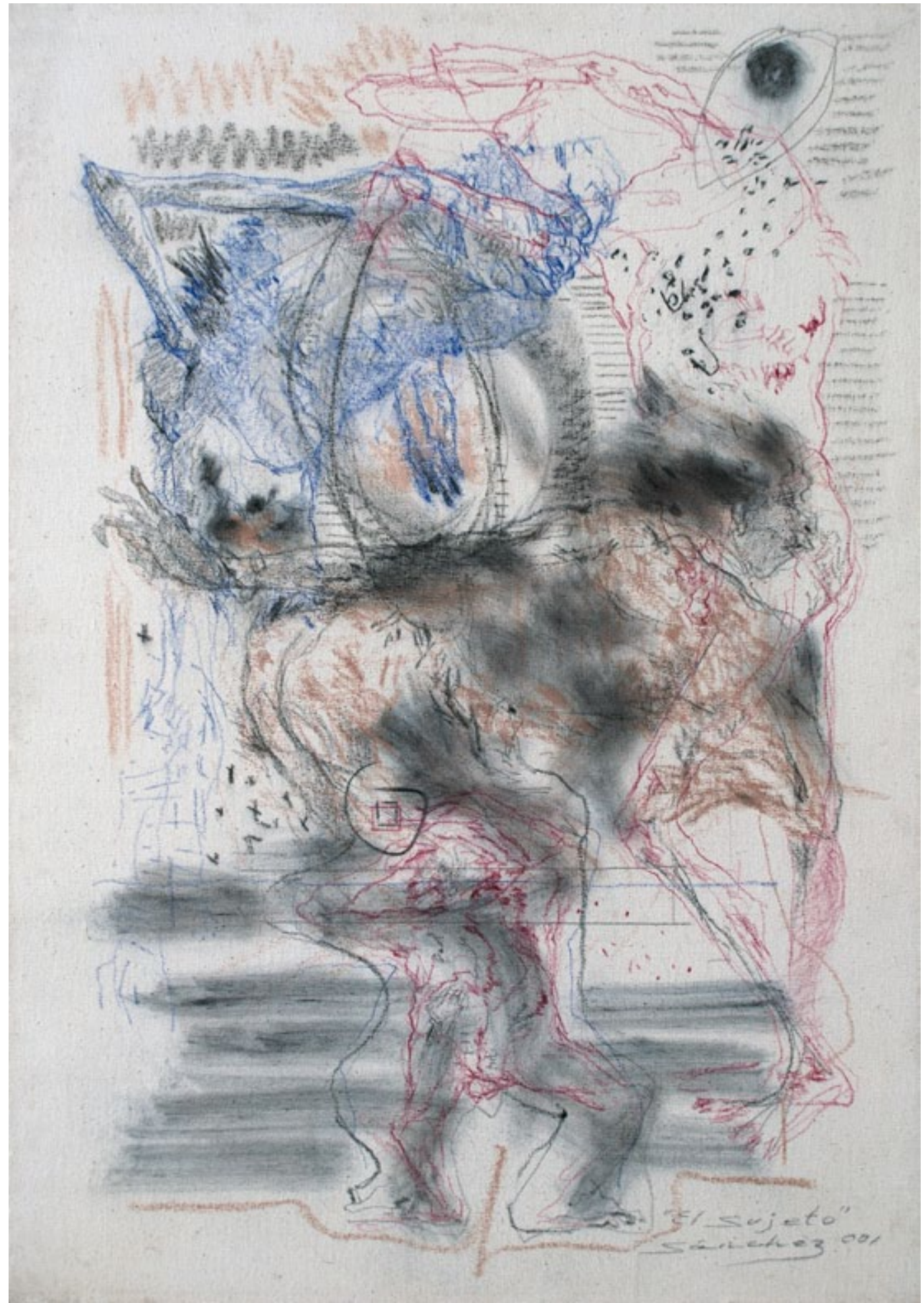




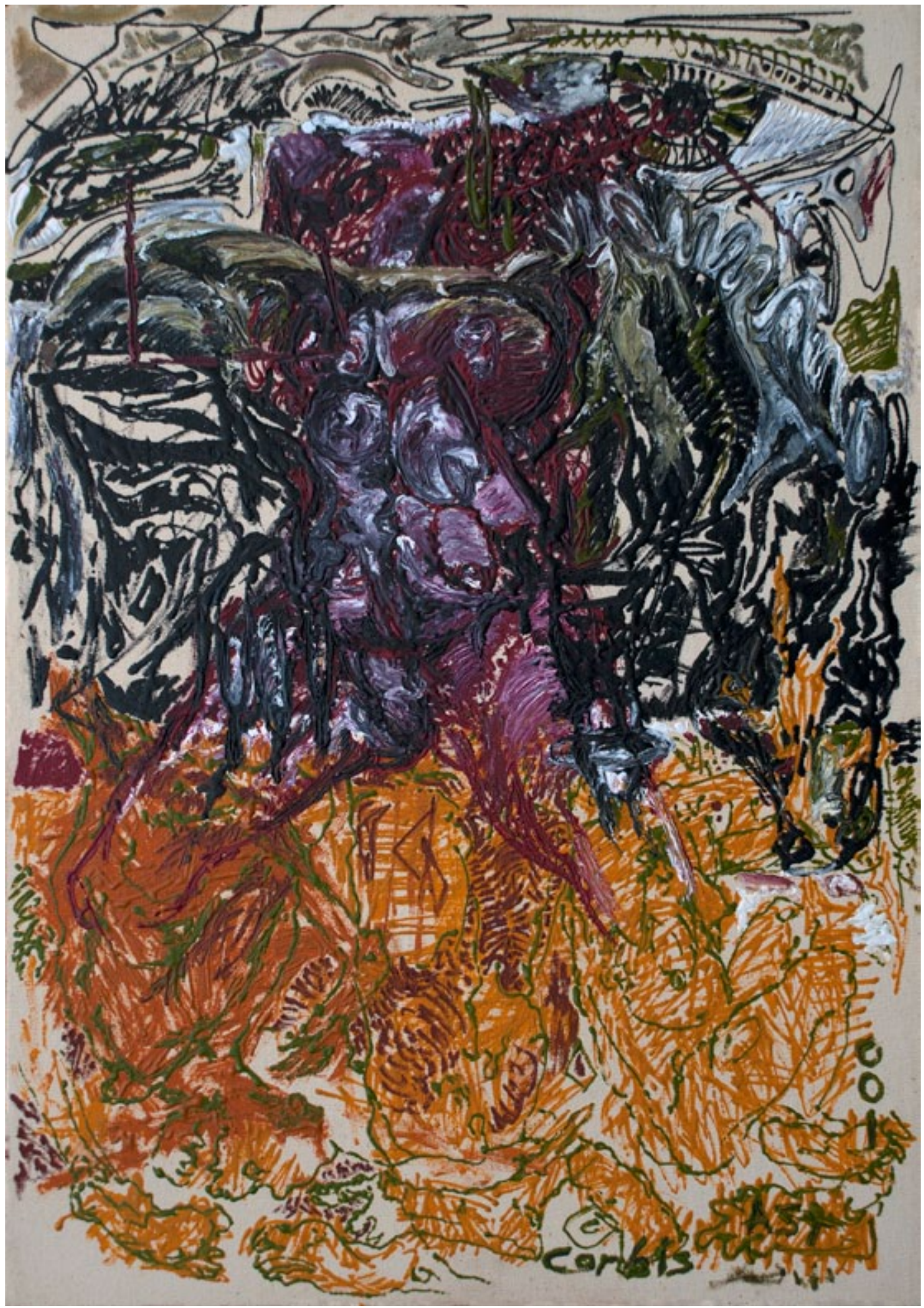




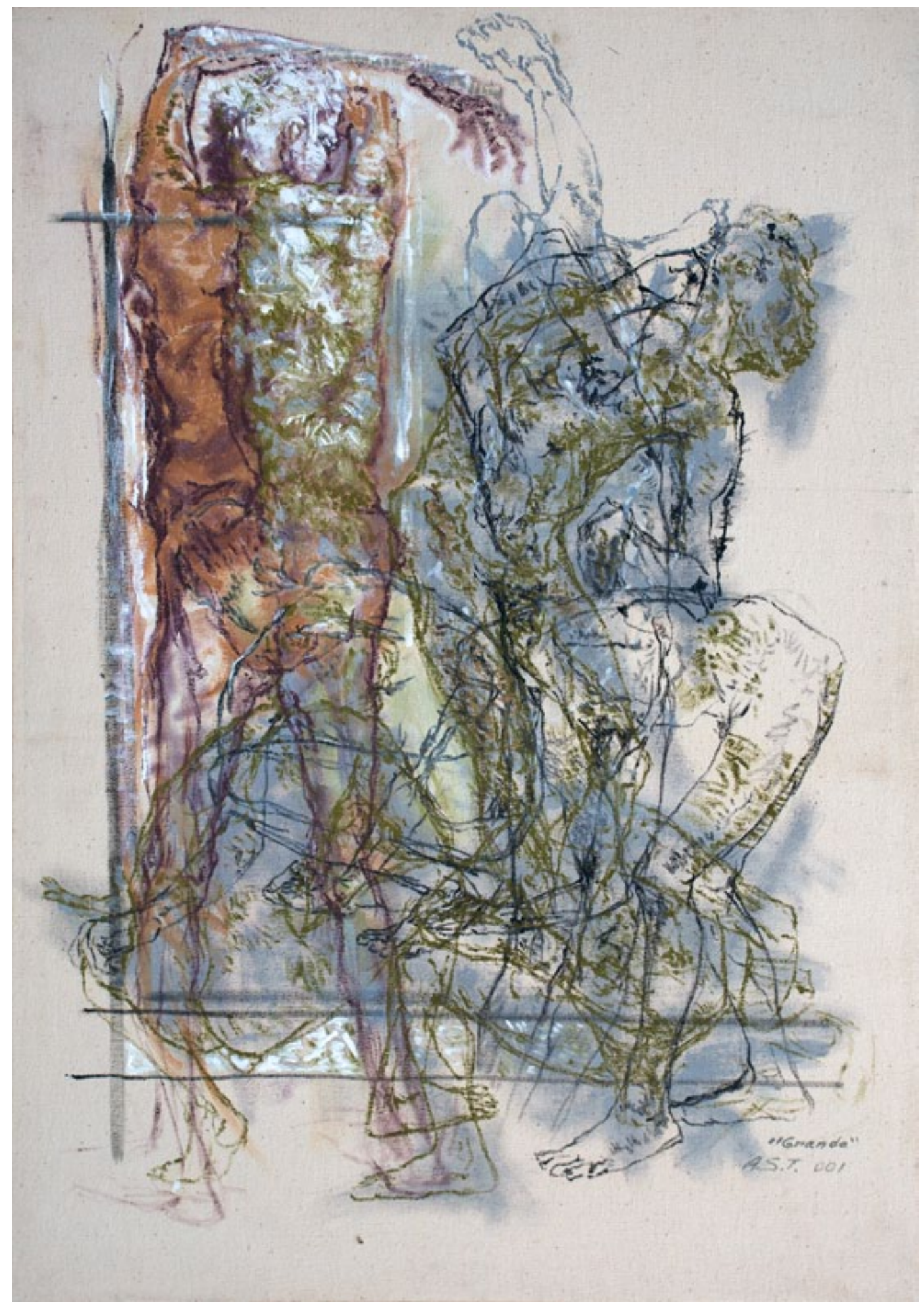




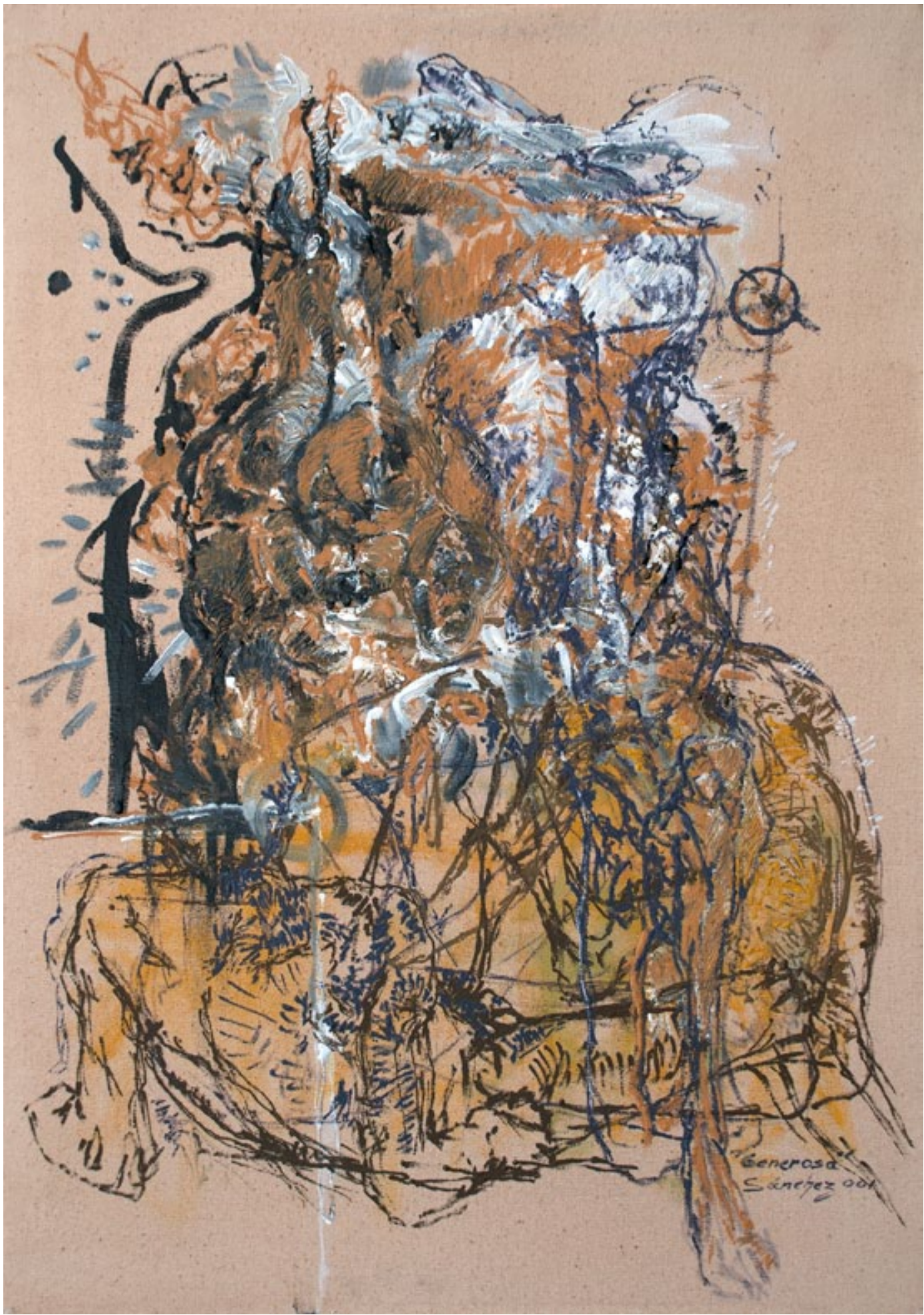




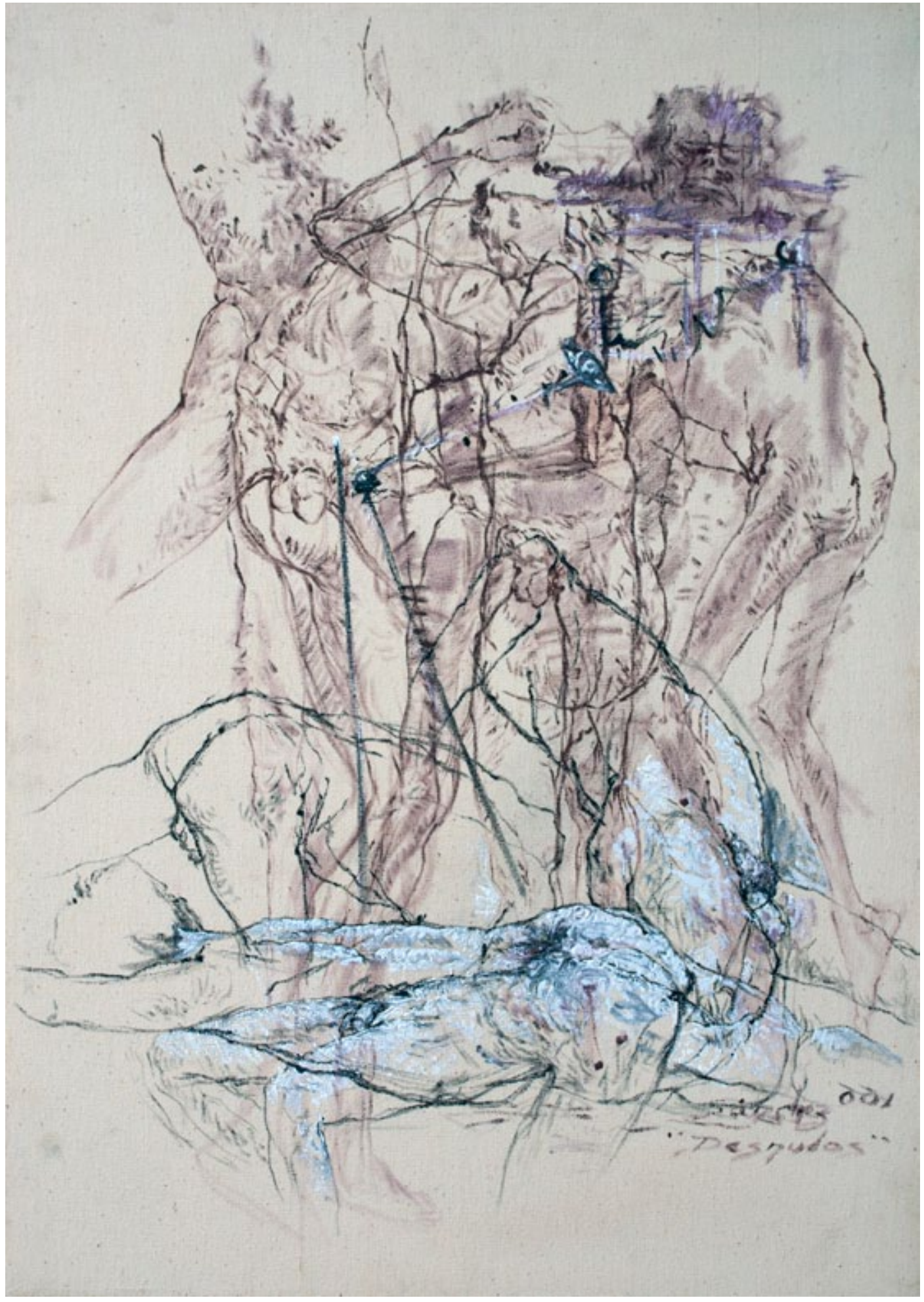




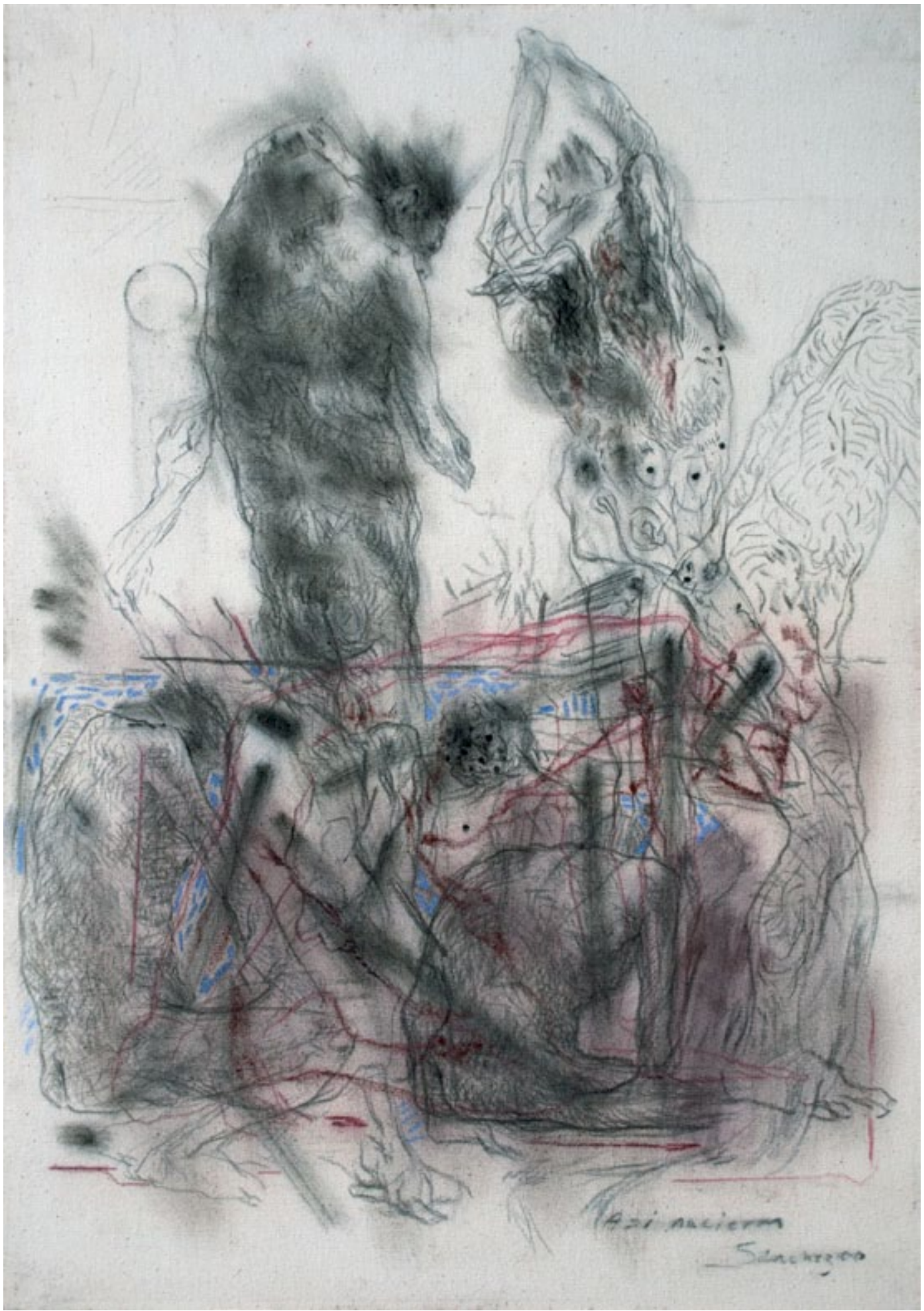




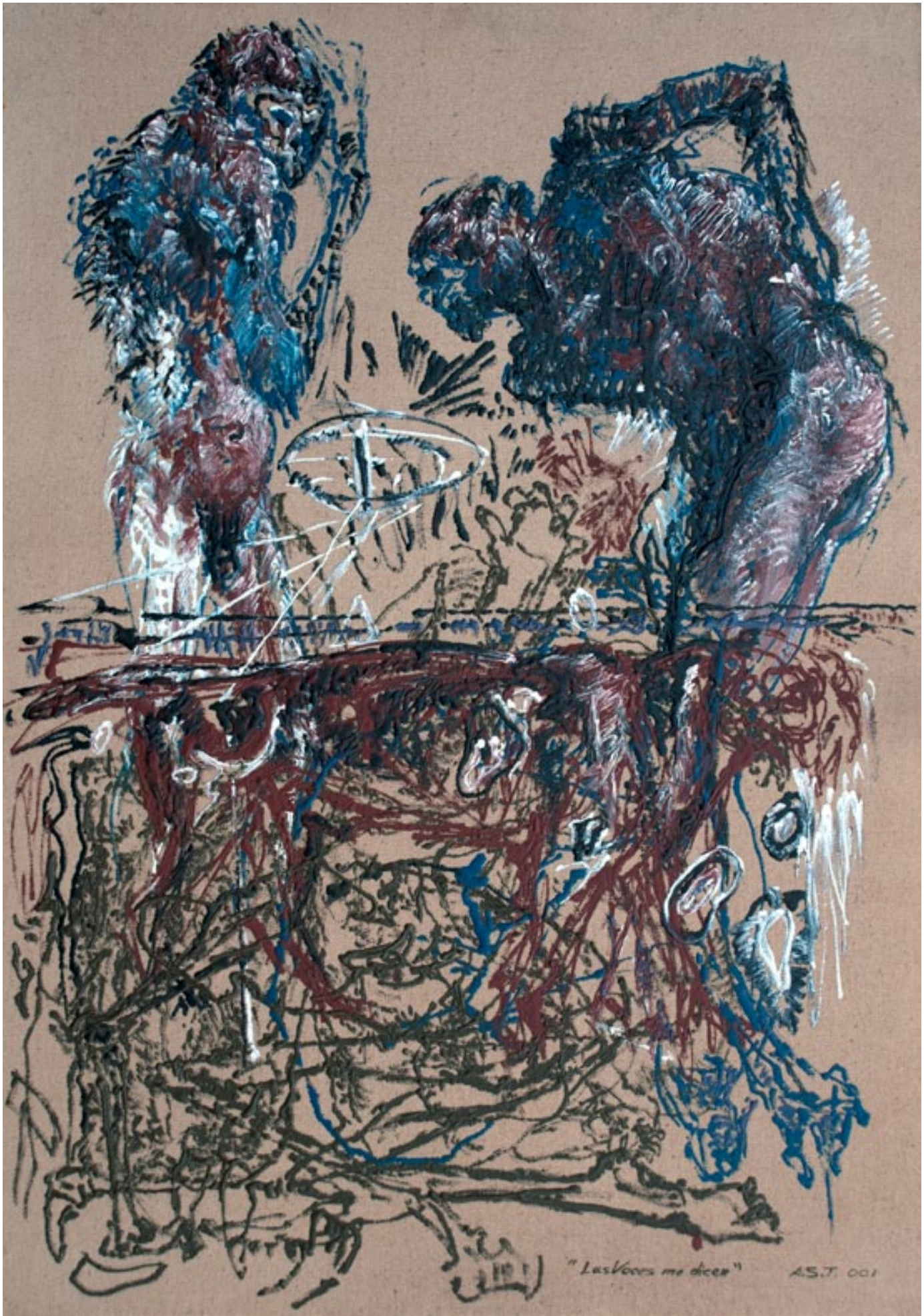




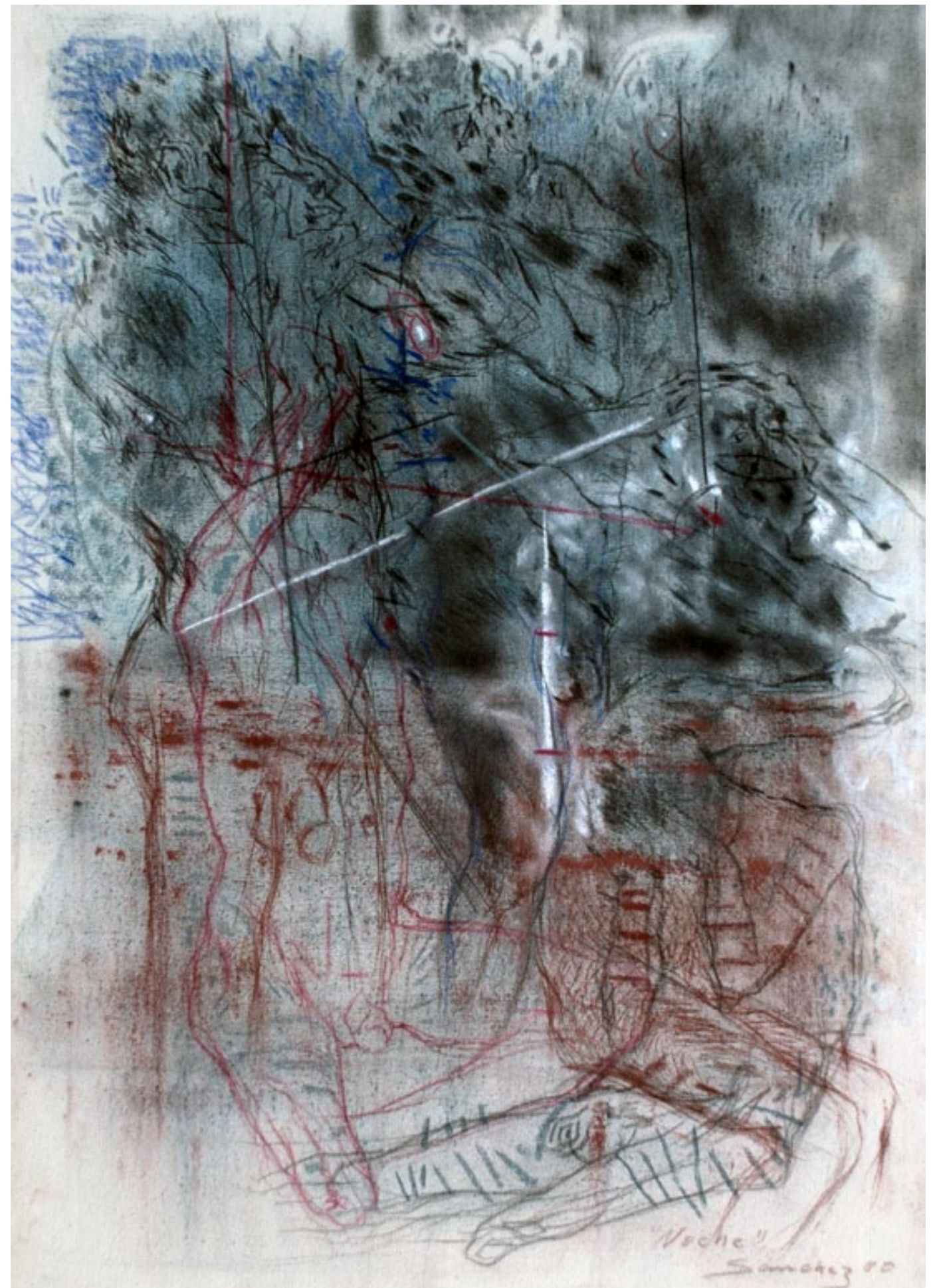




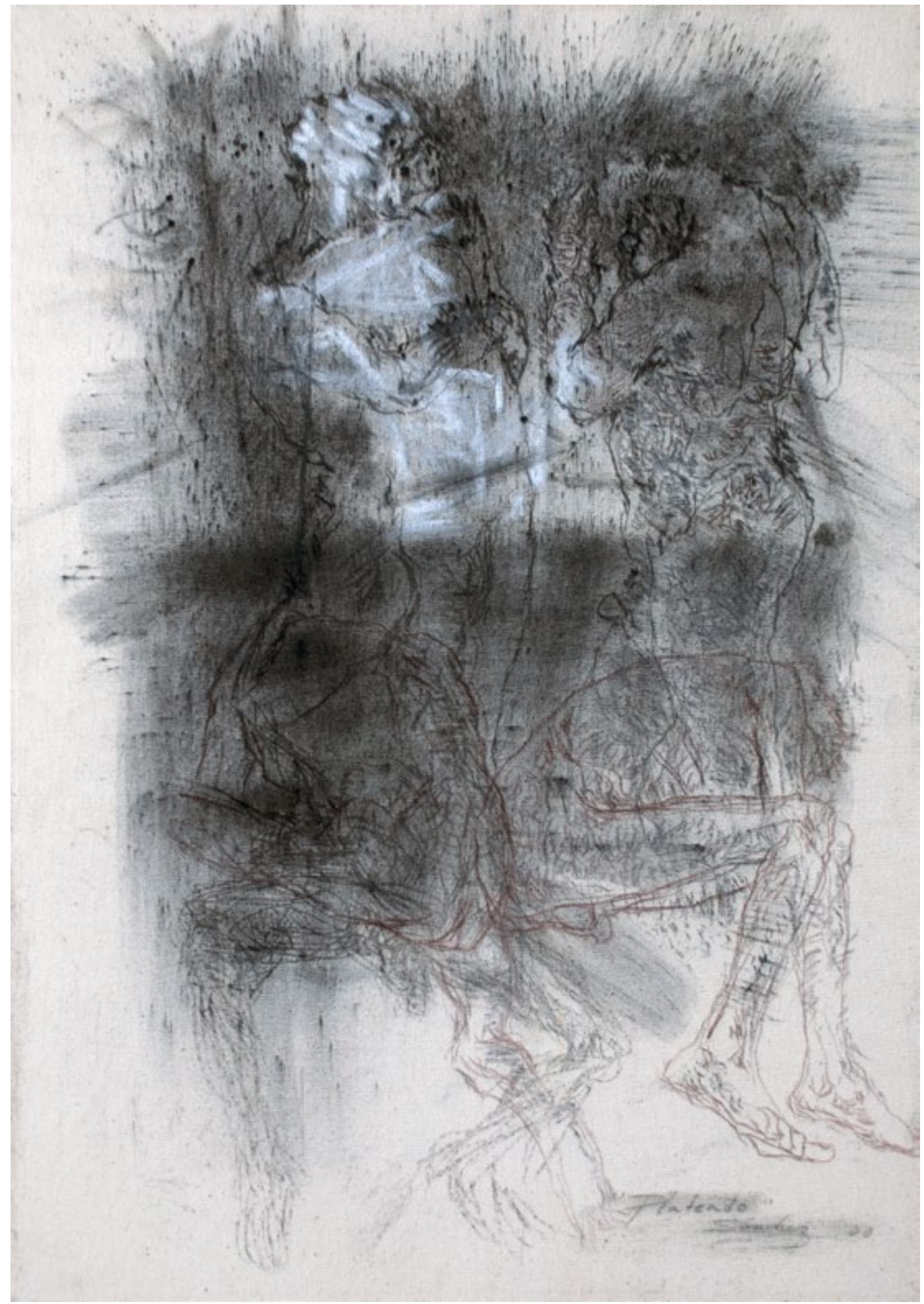




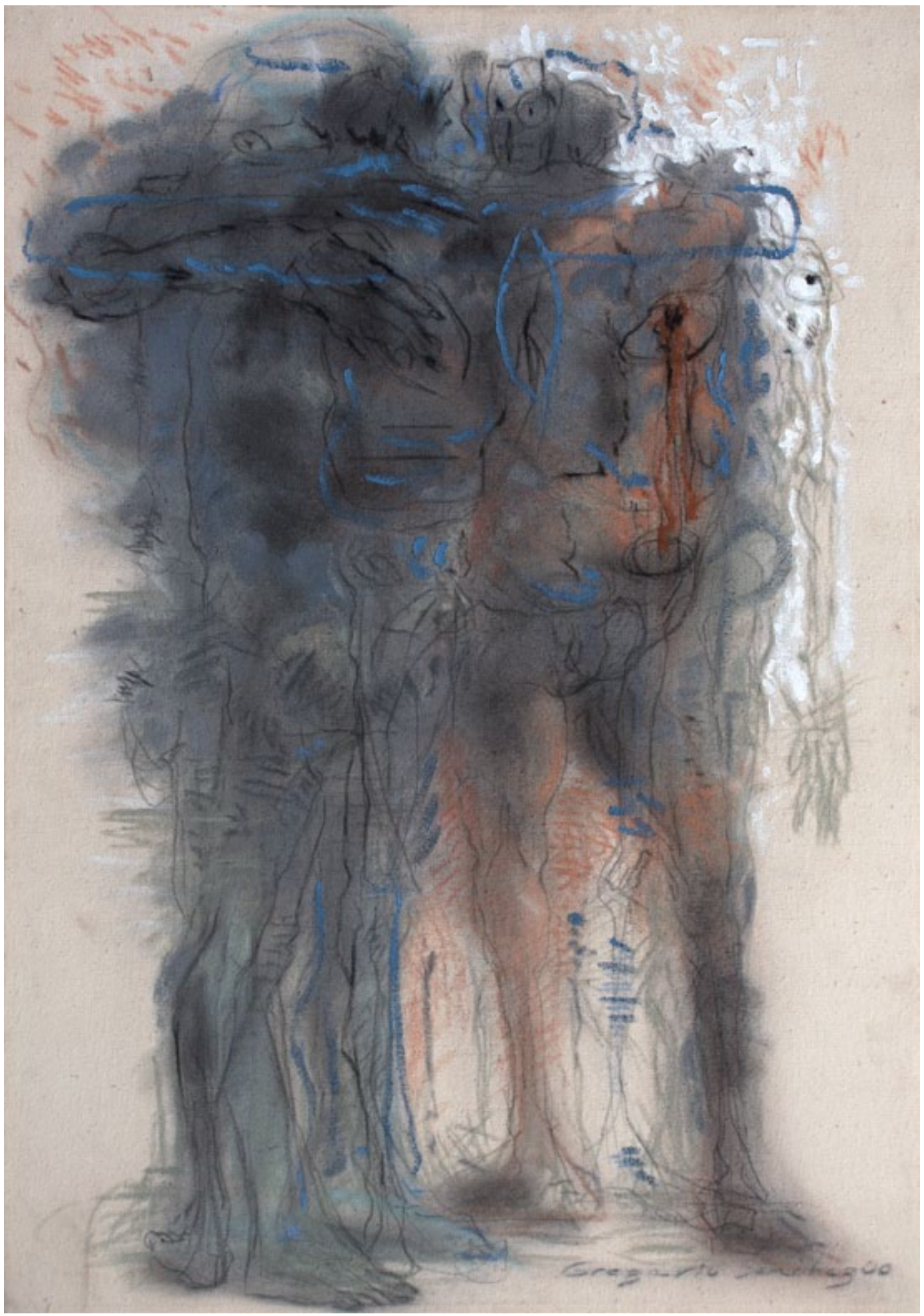




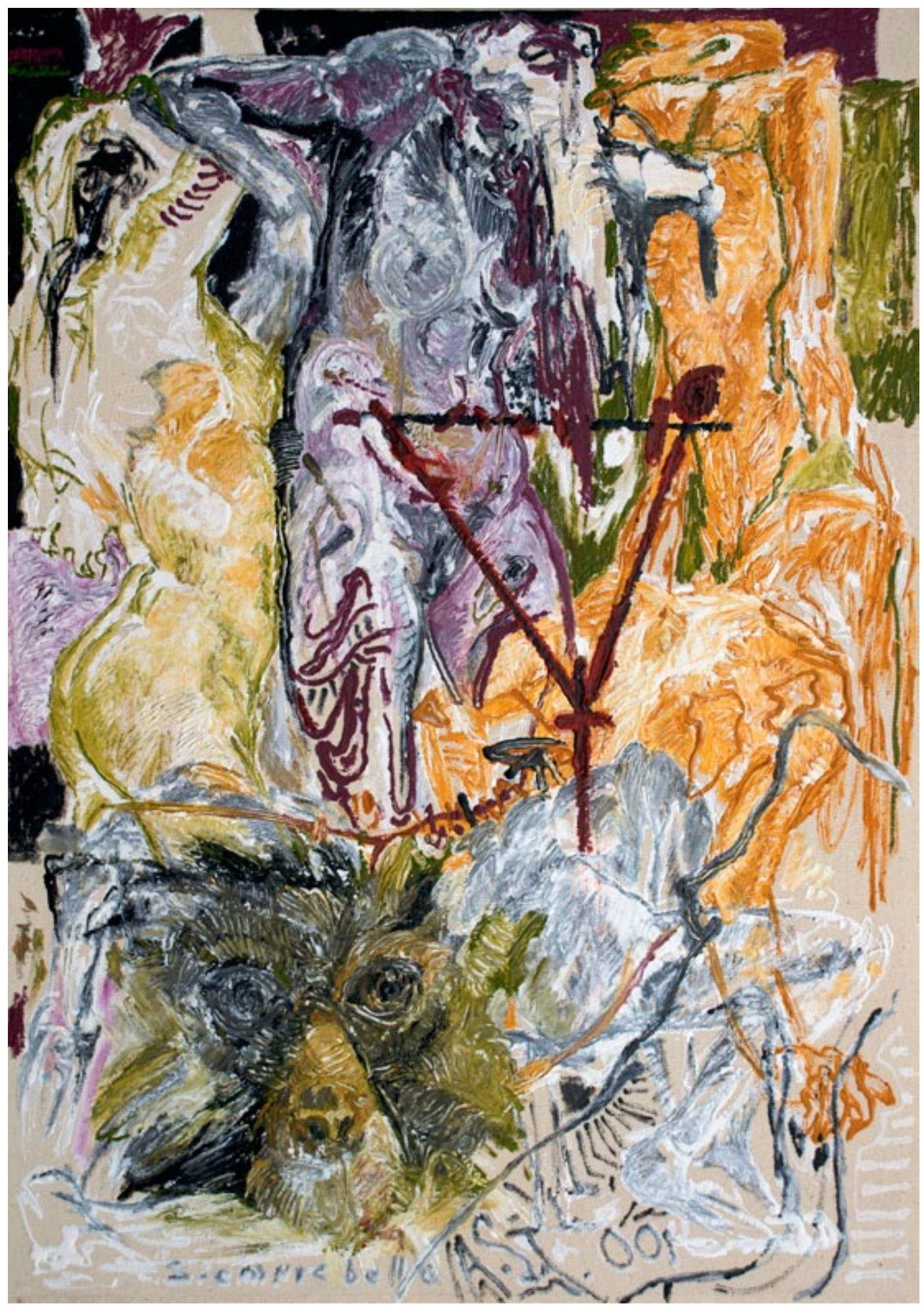




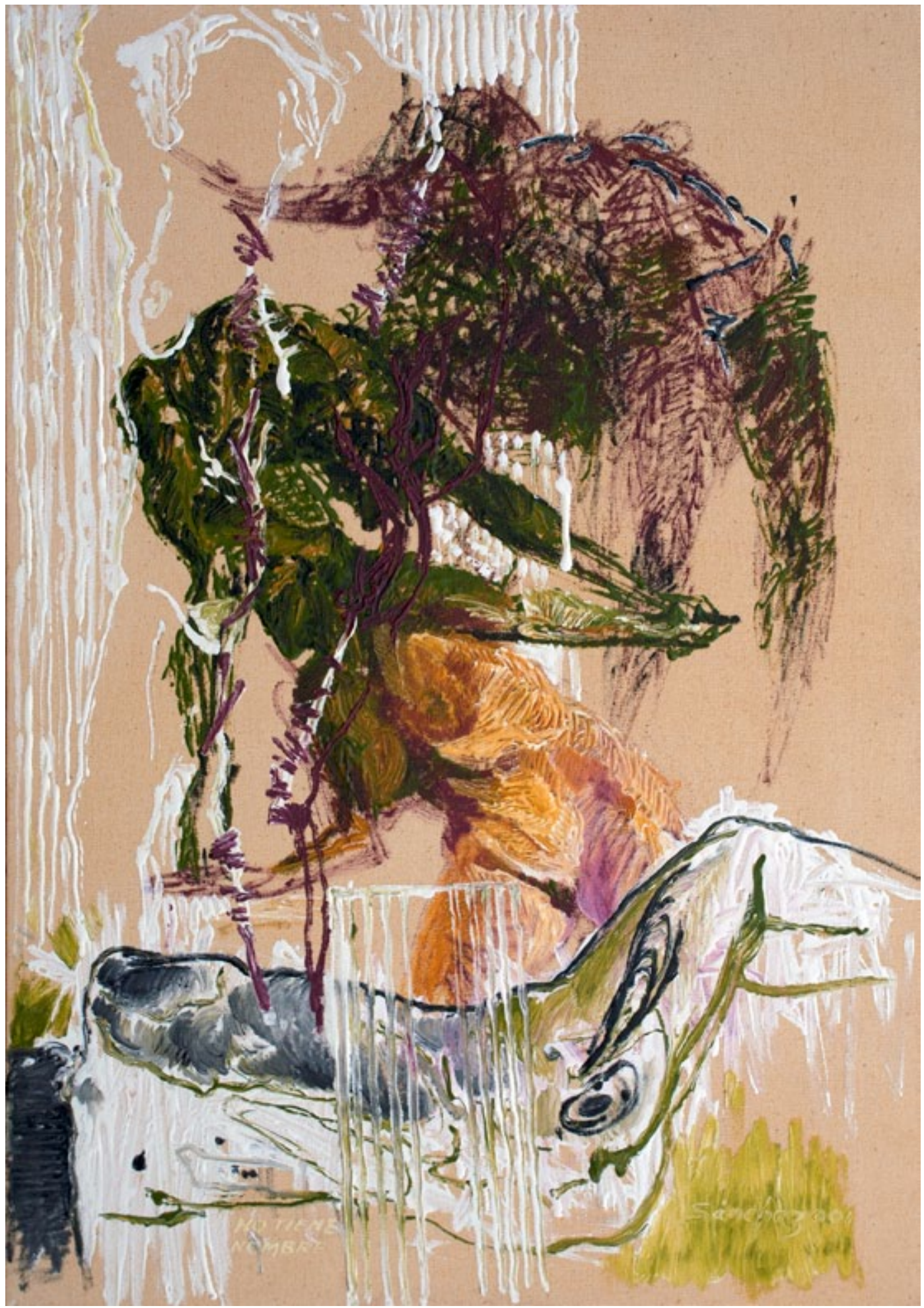




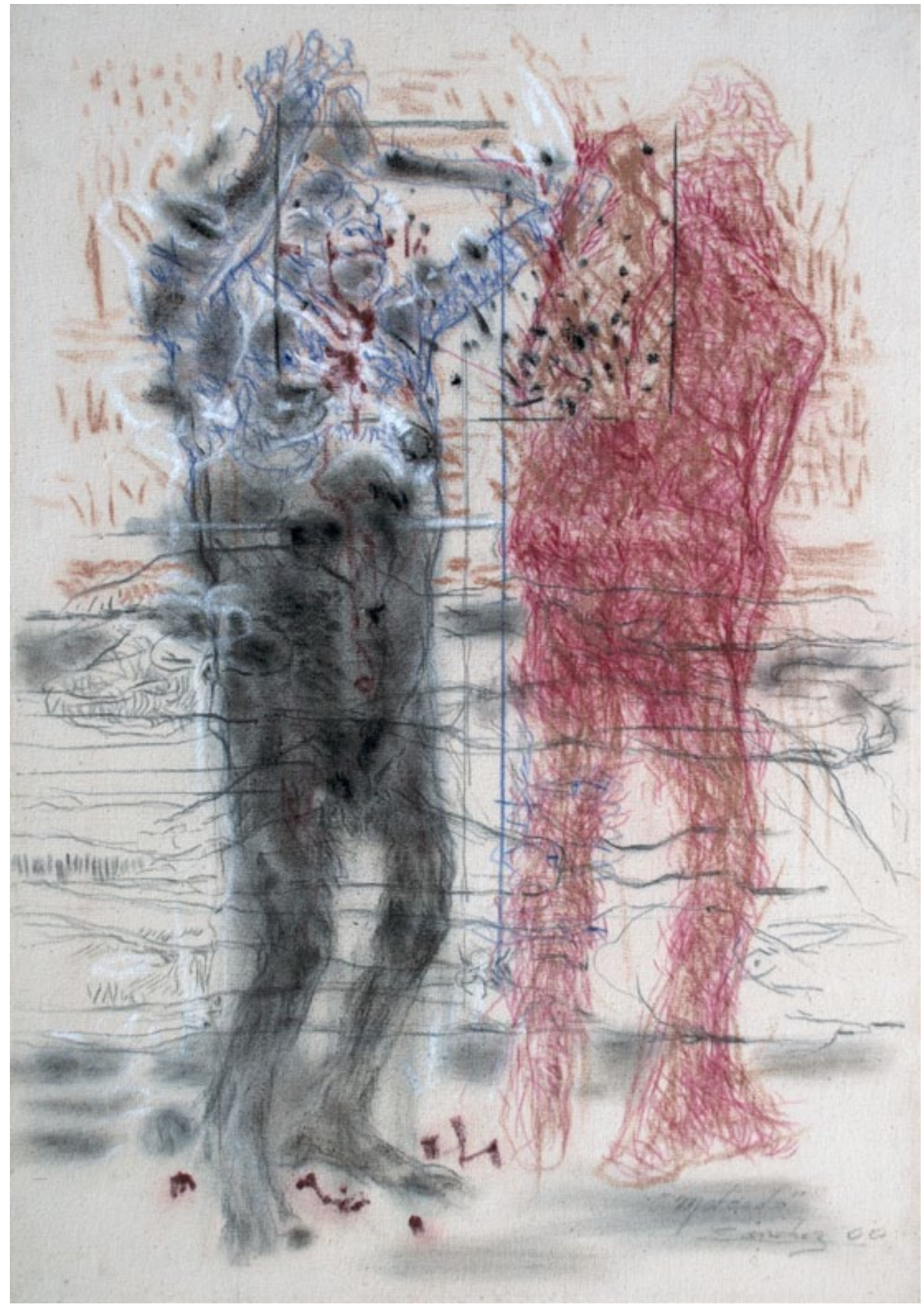




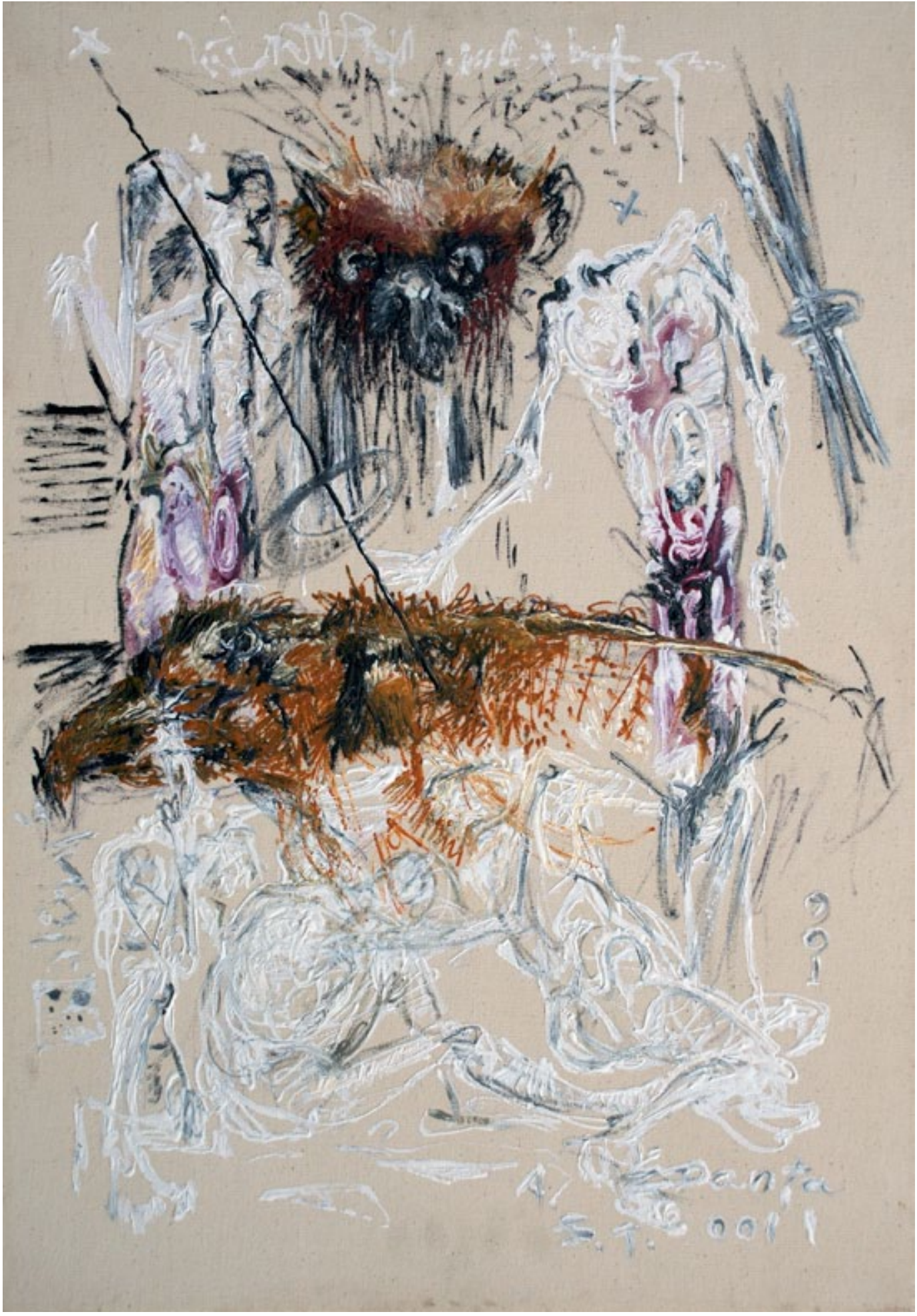




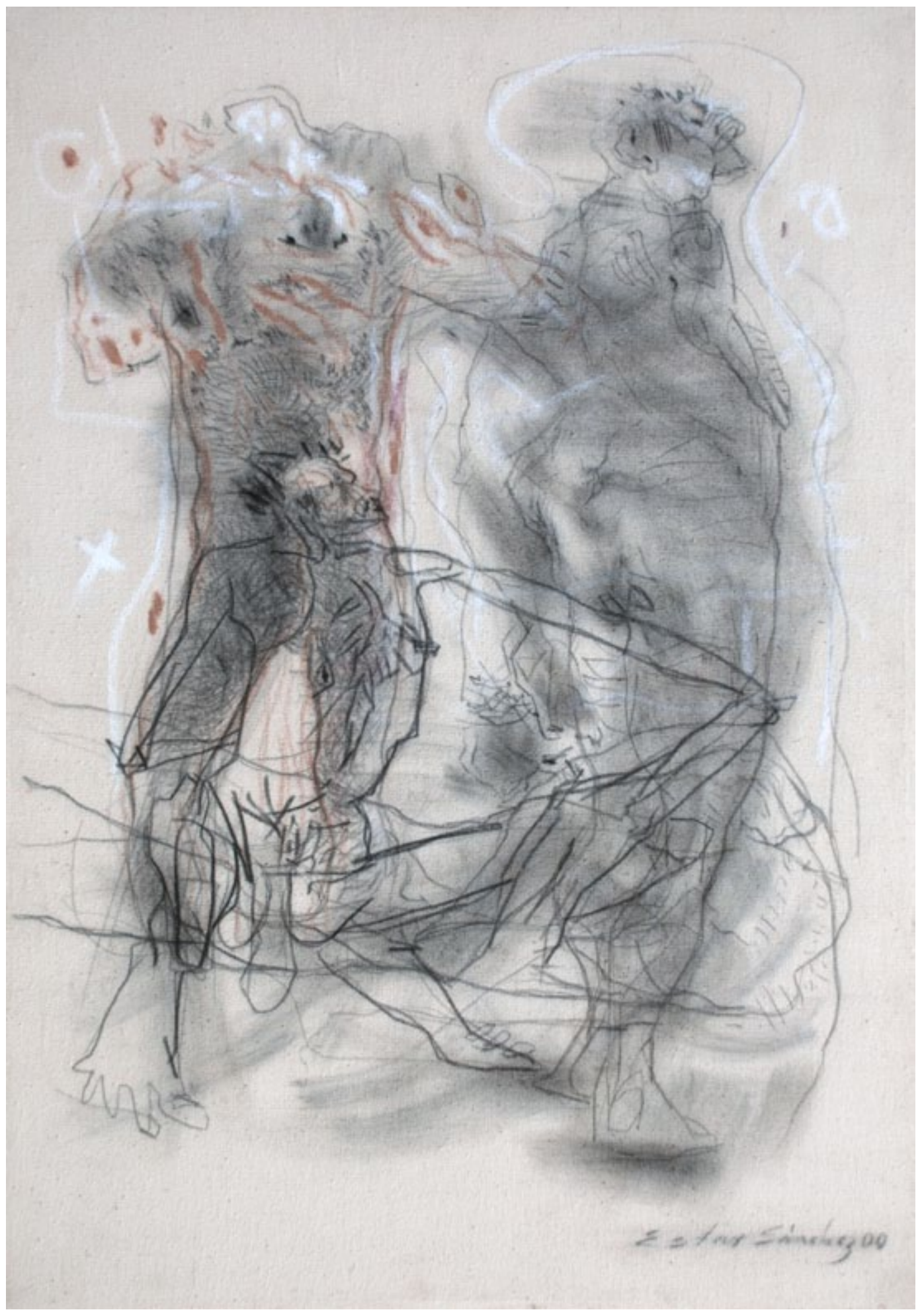




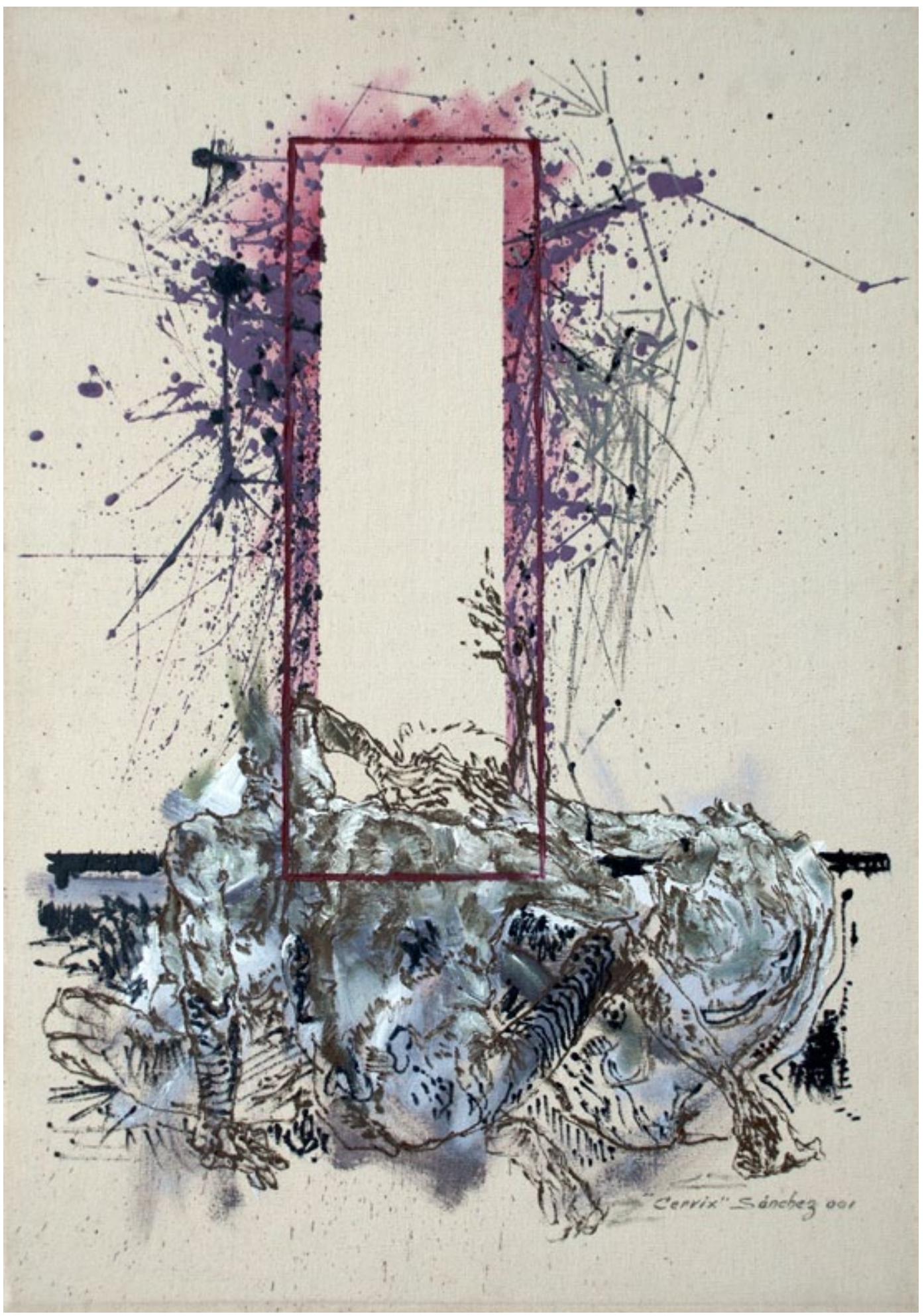




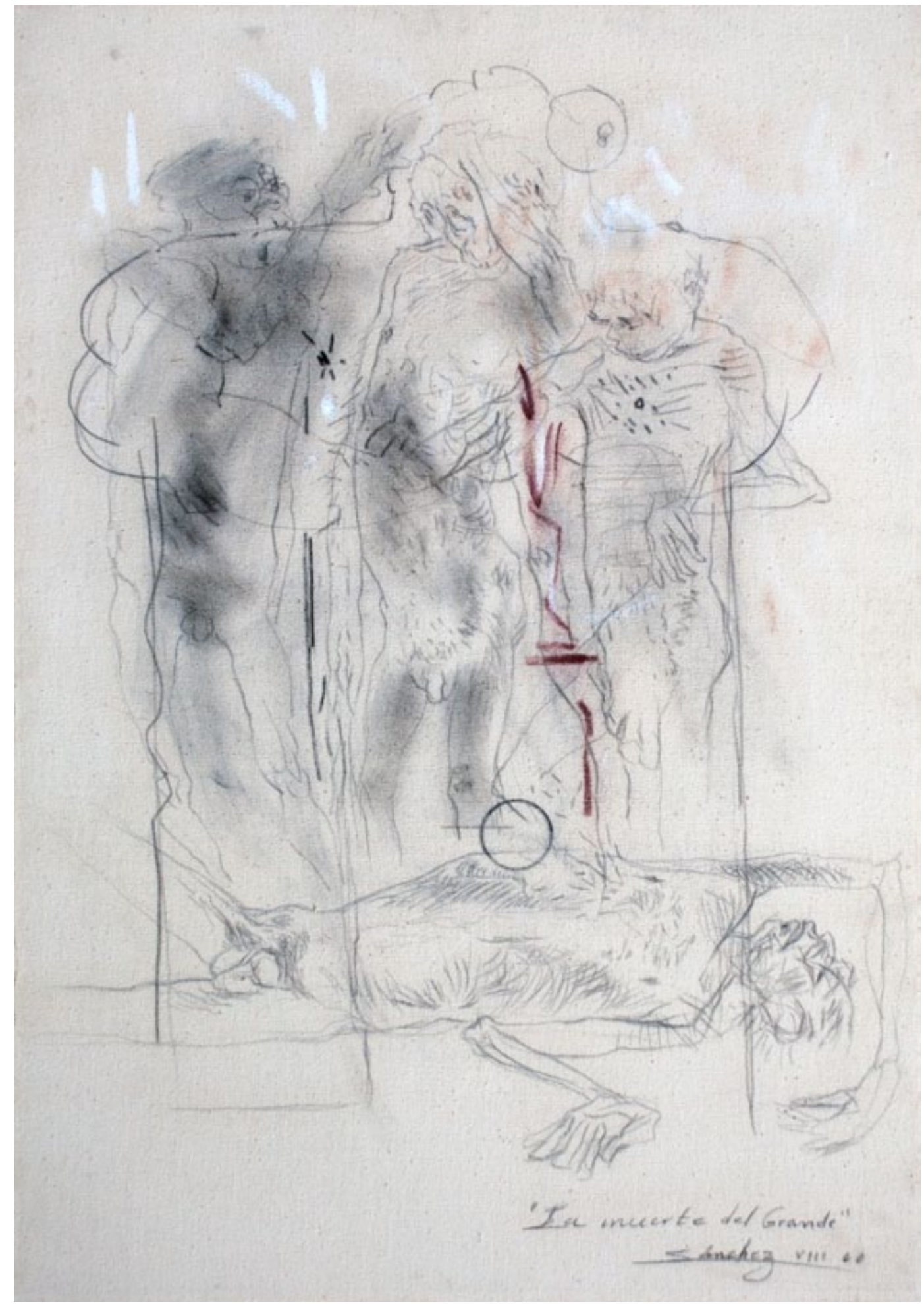




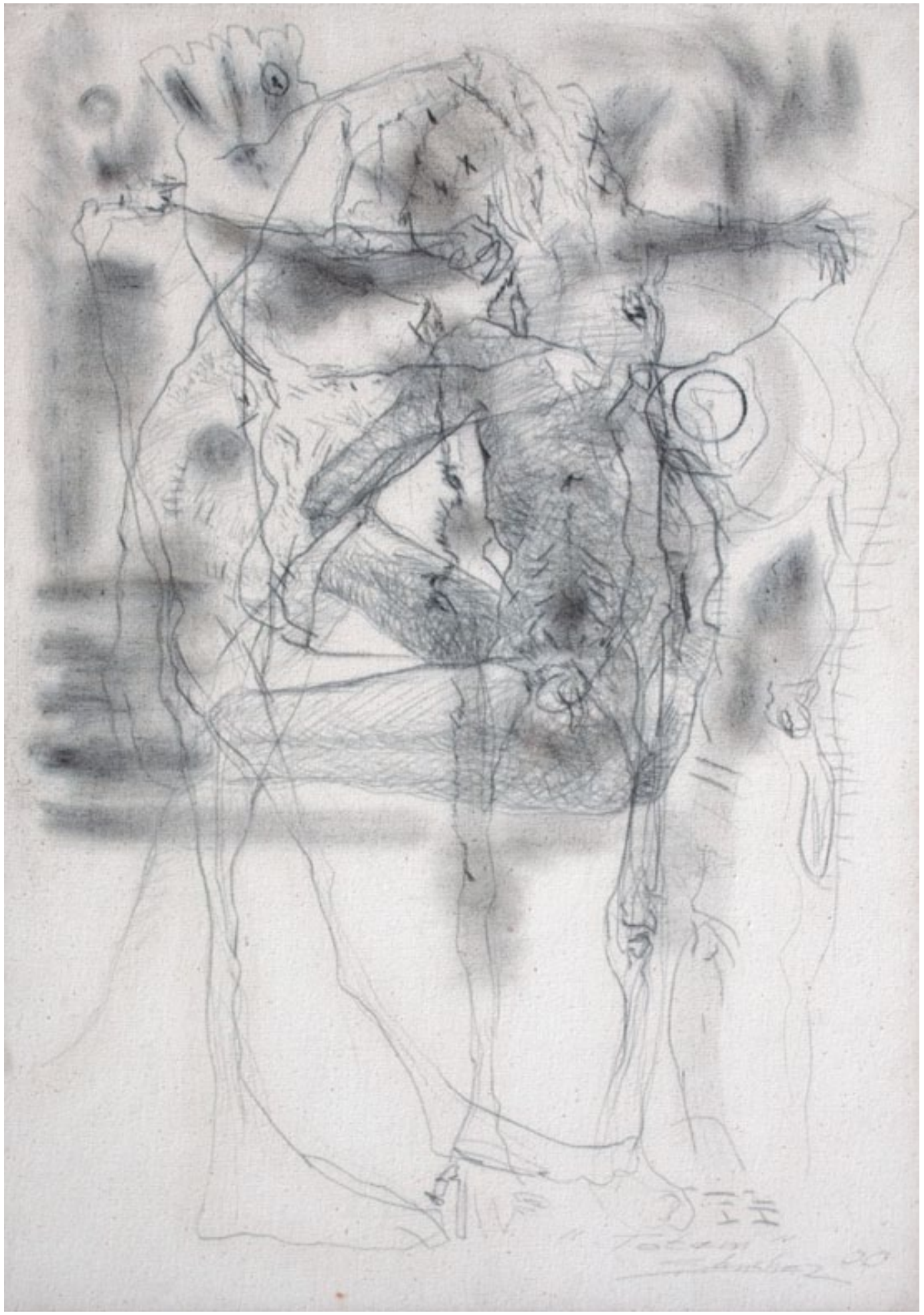




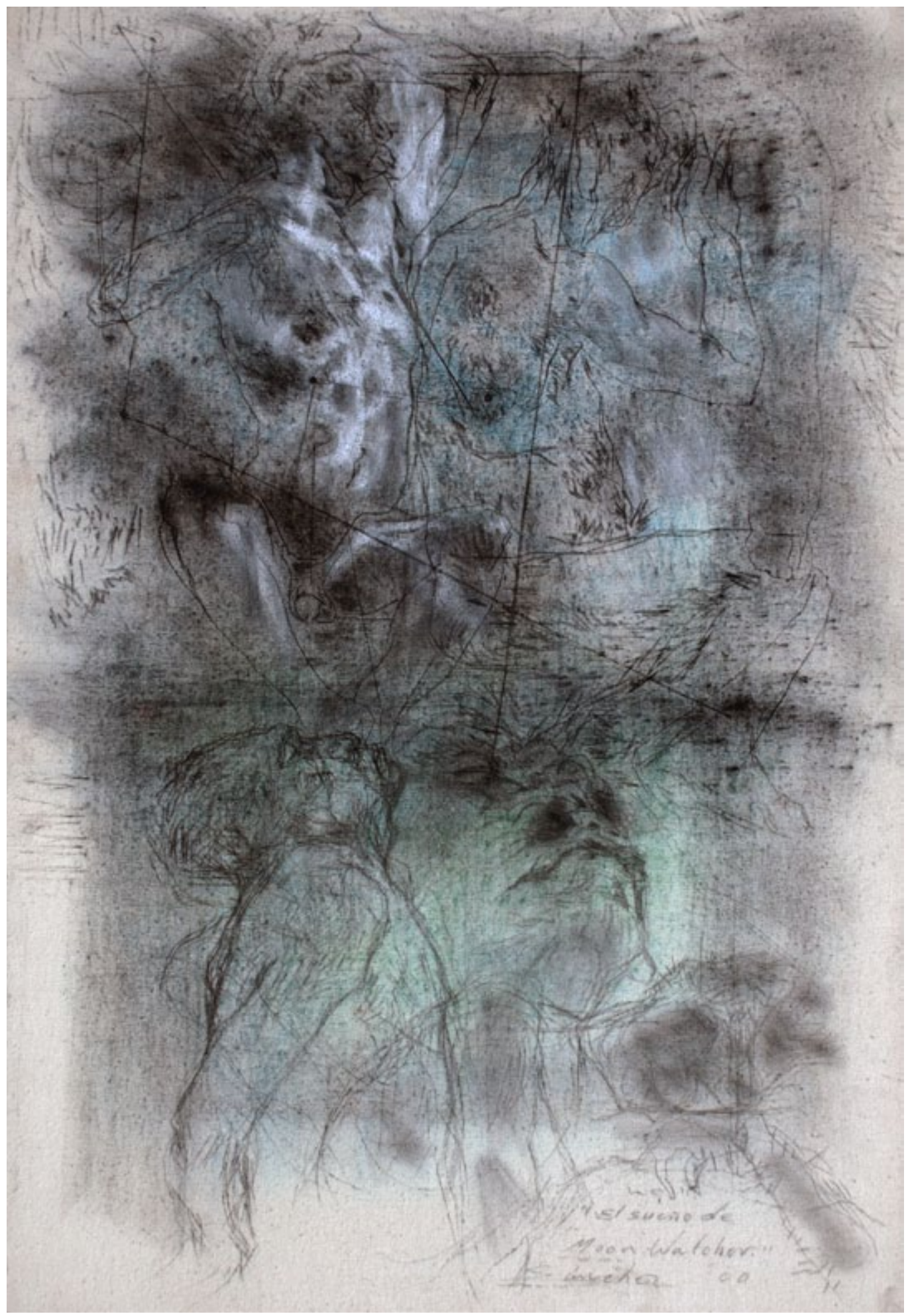




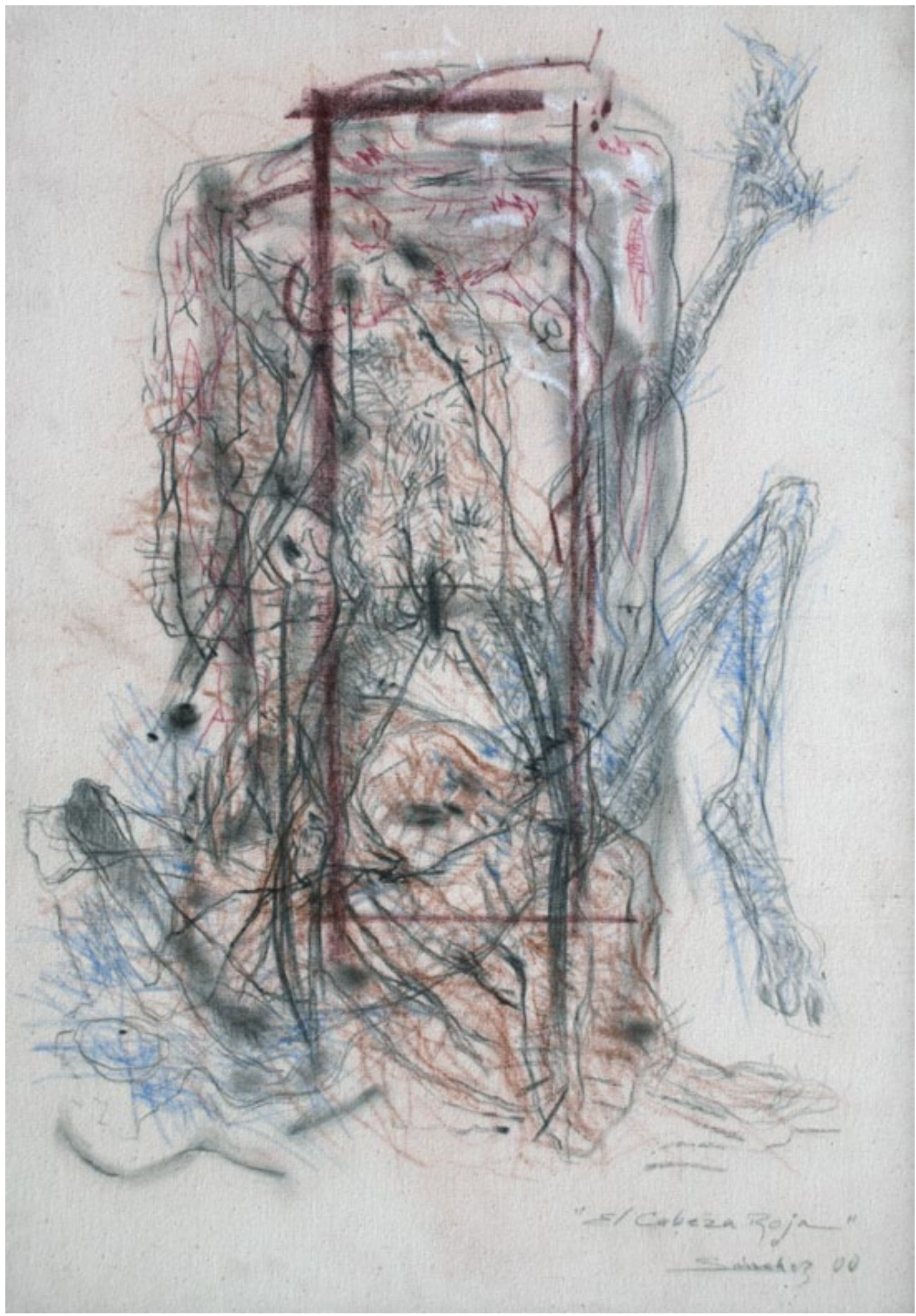


LOS TESTAMENTOS DE CORNELIUS CASTORIADIS 


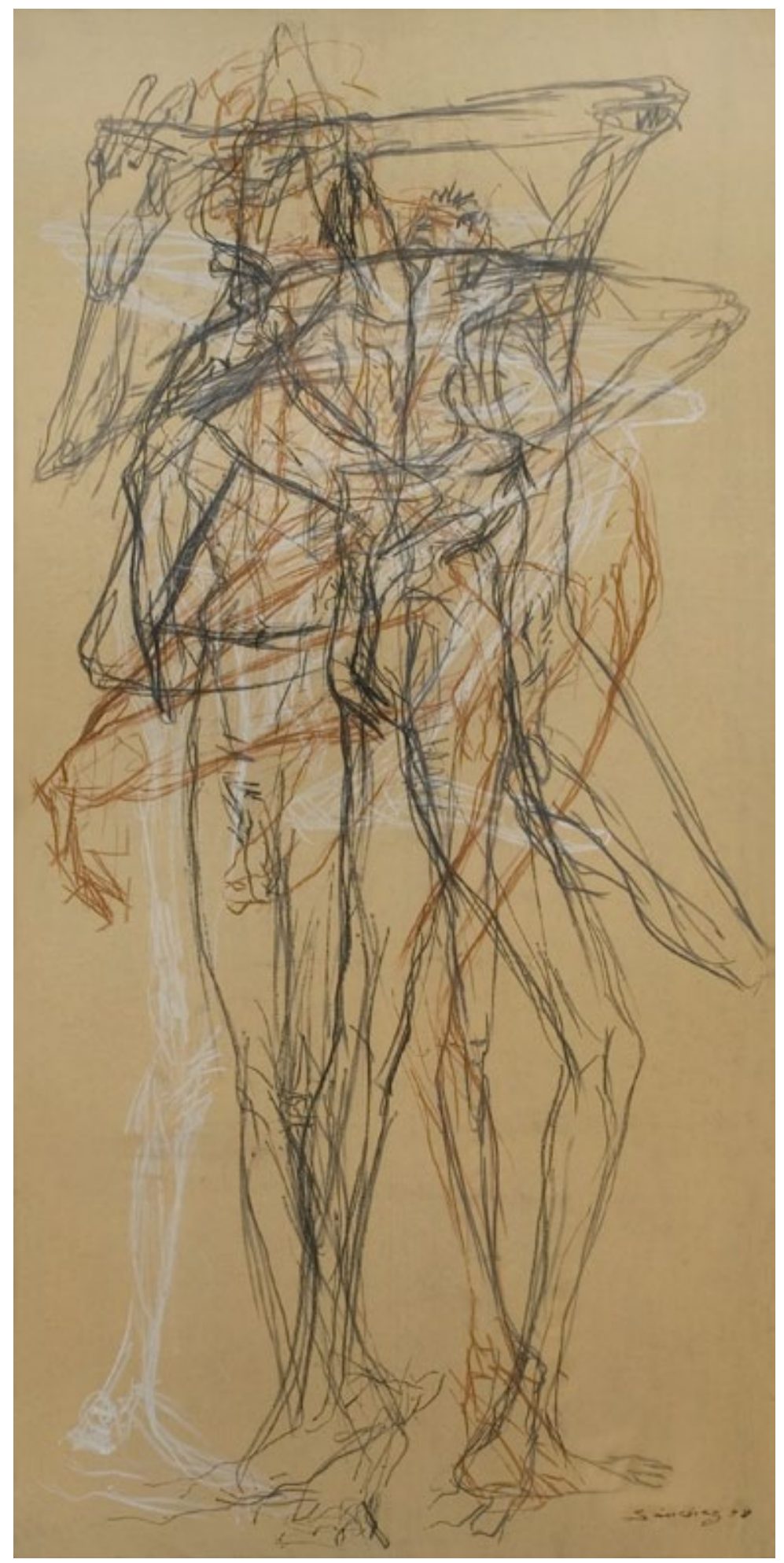




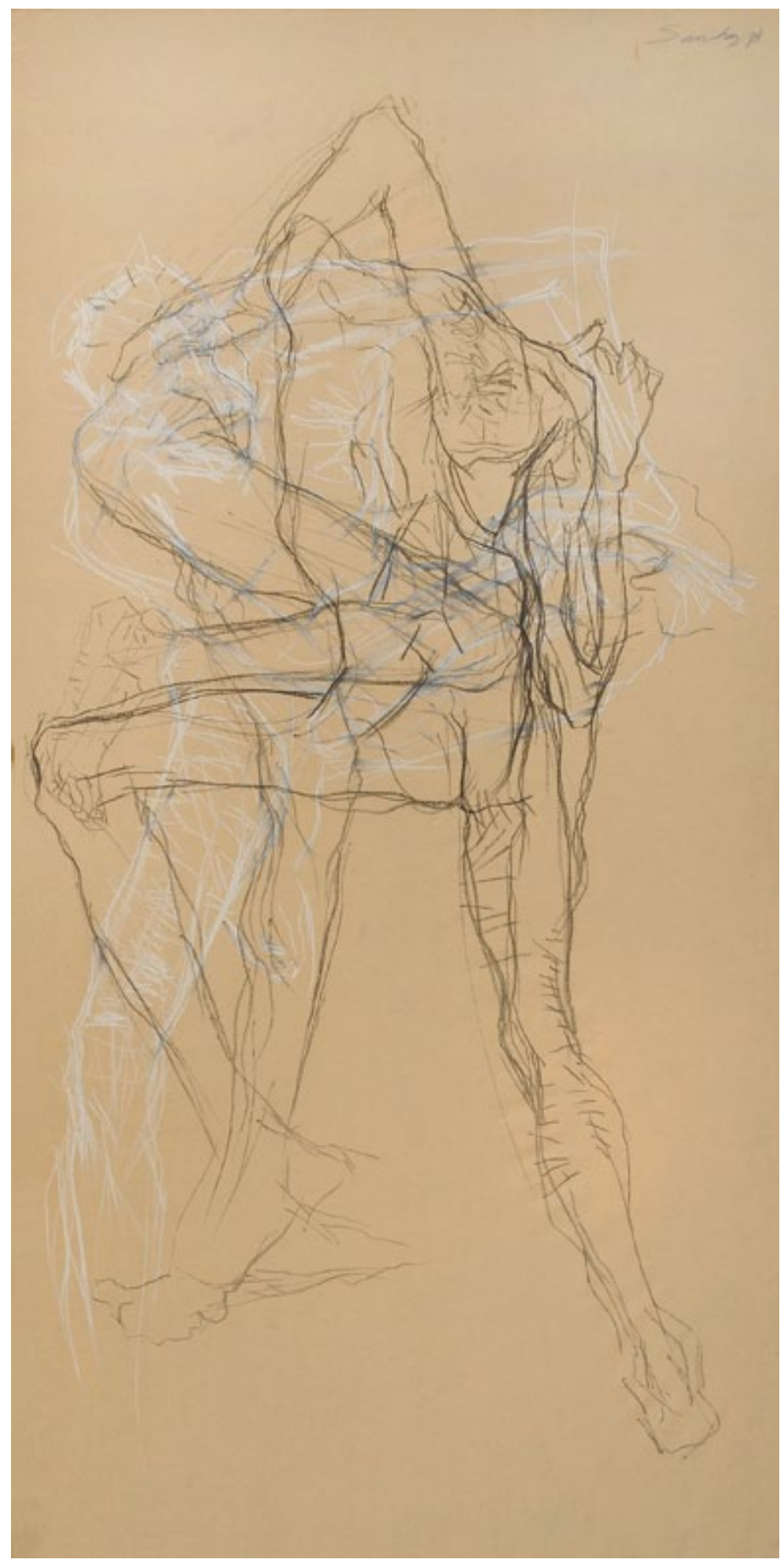




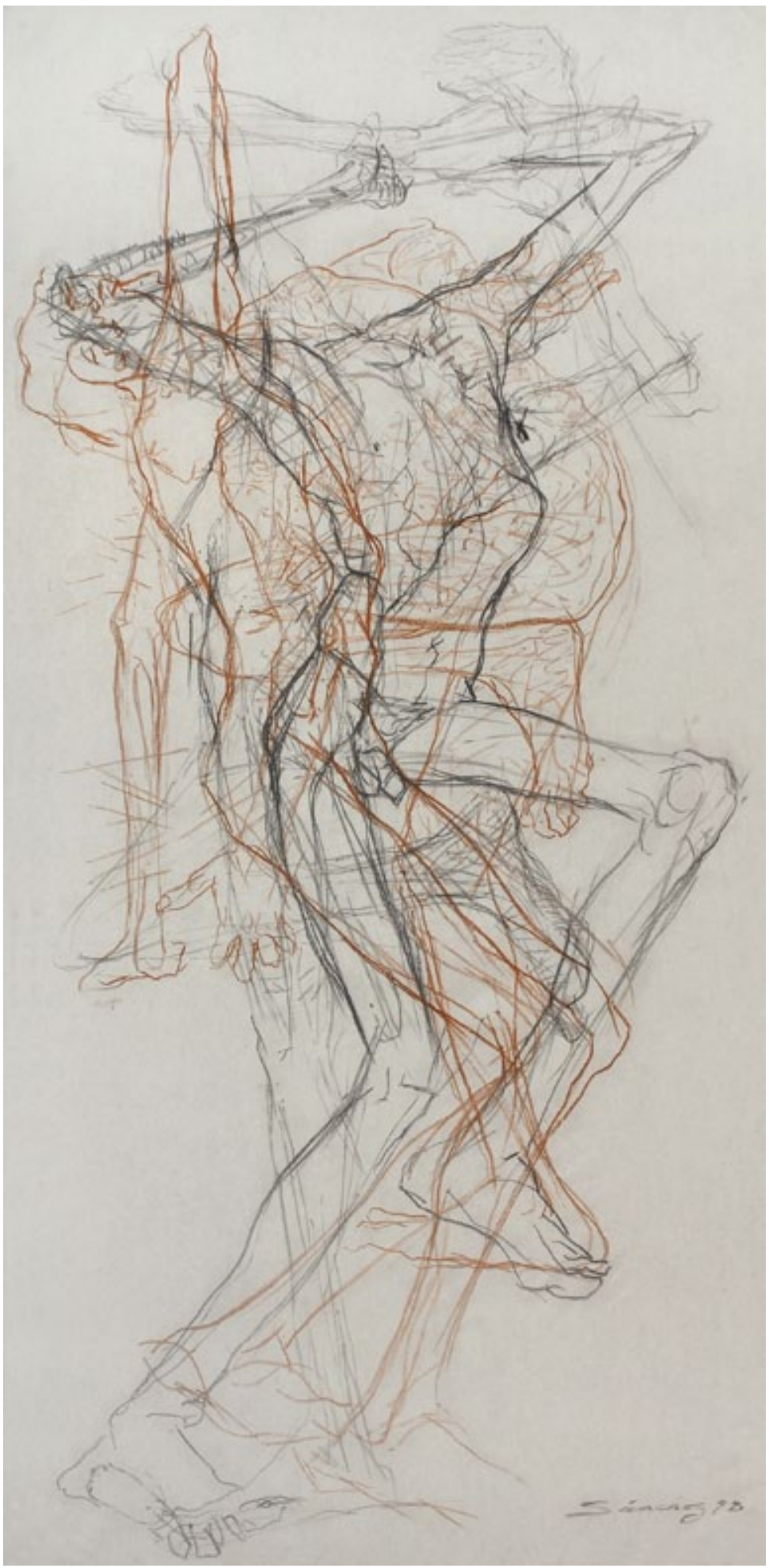




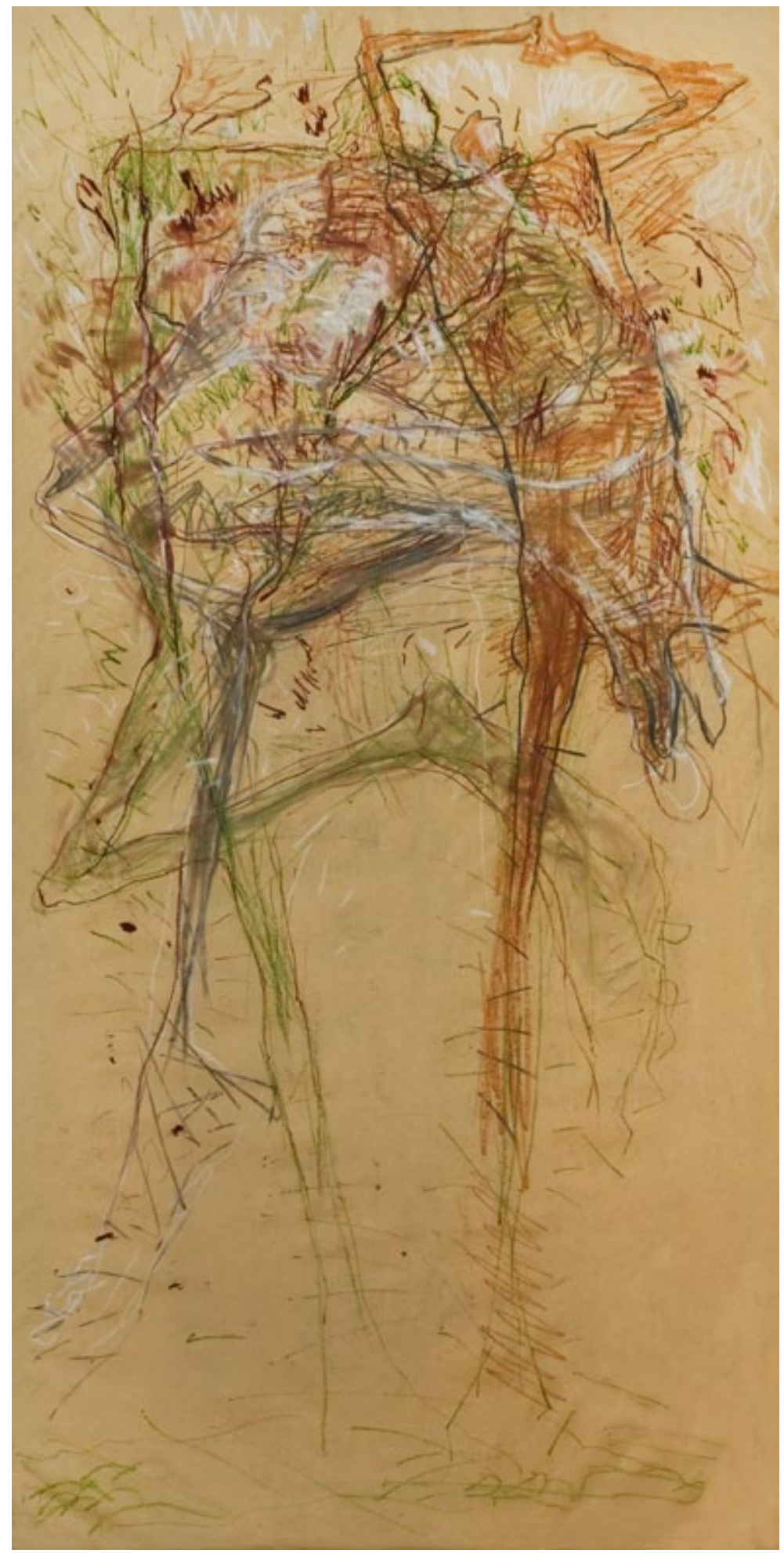




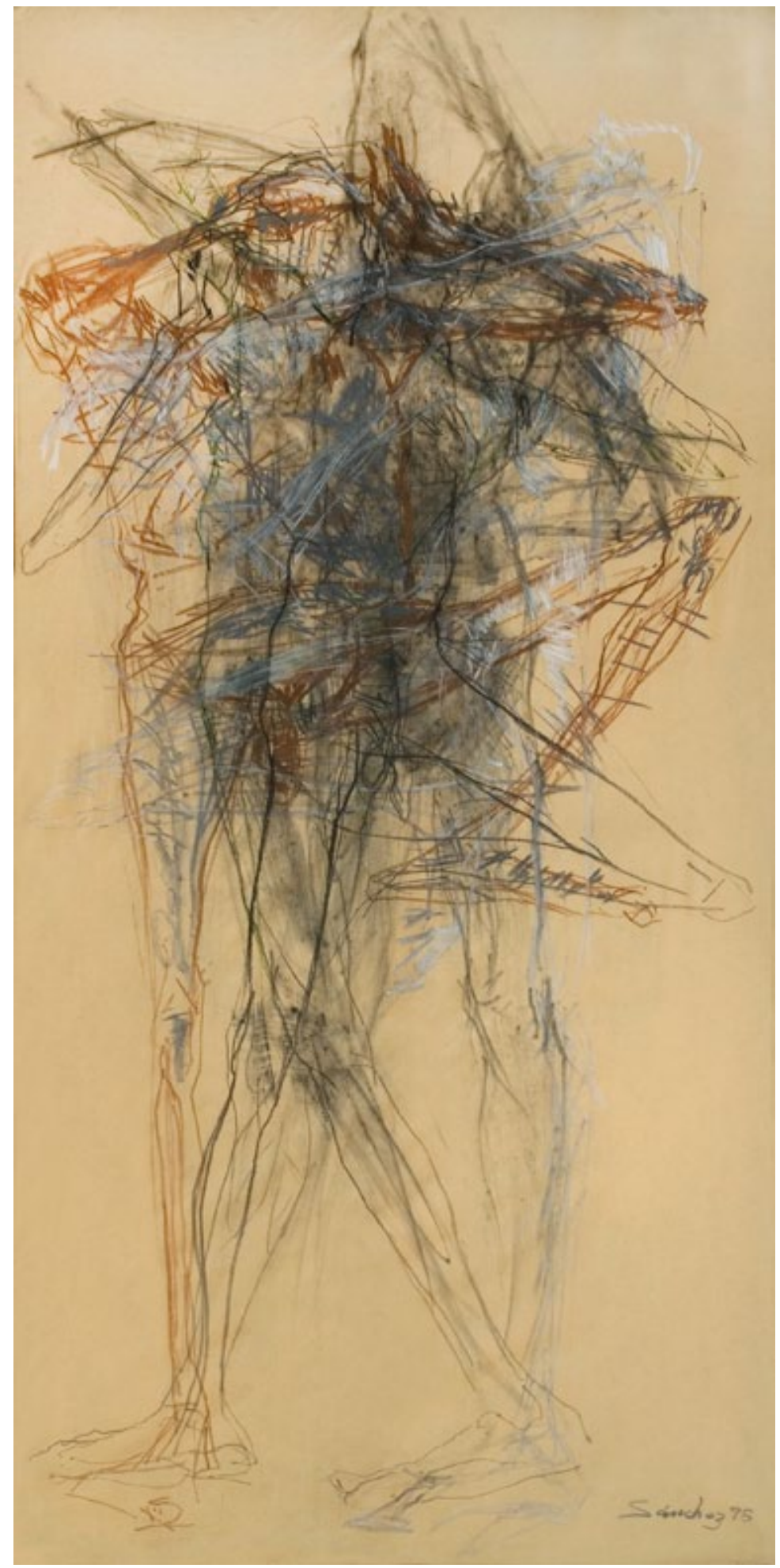




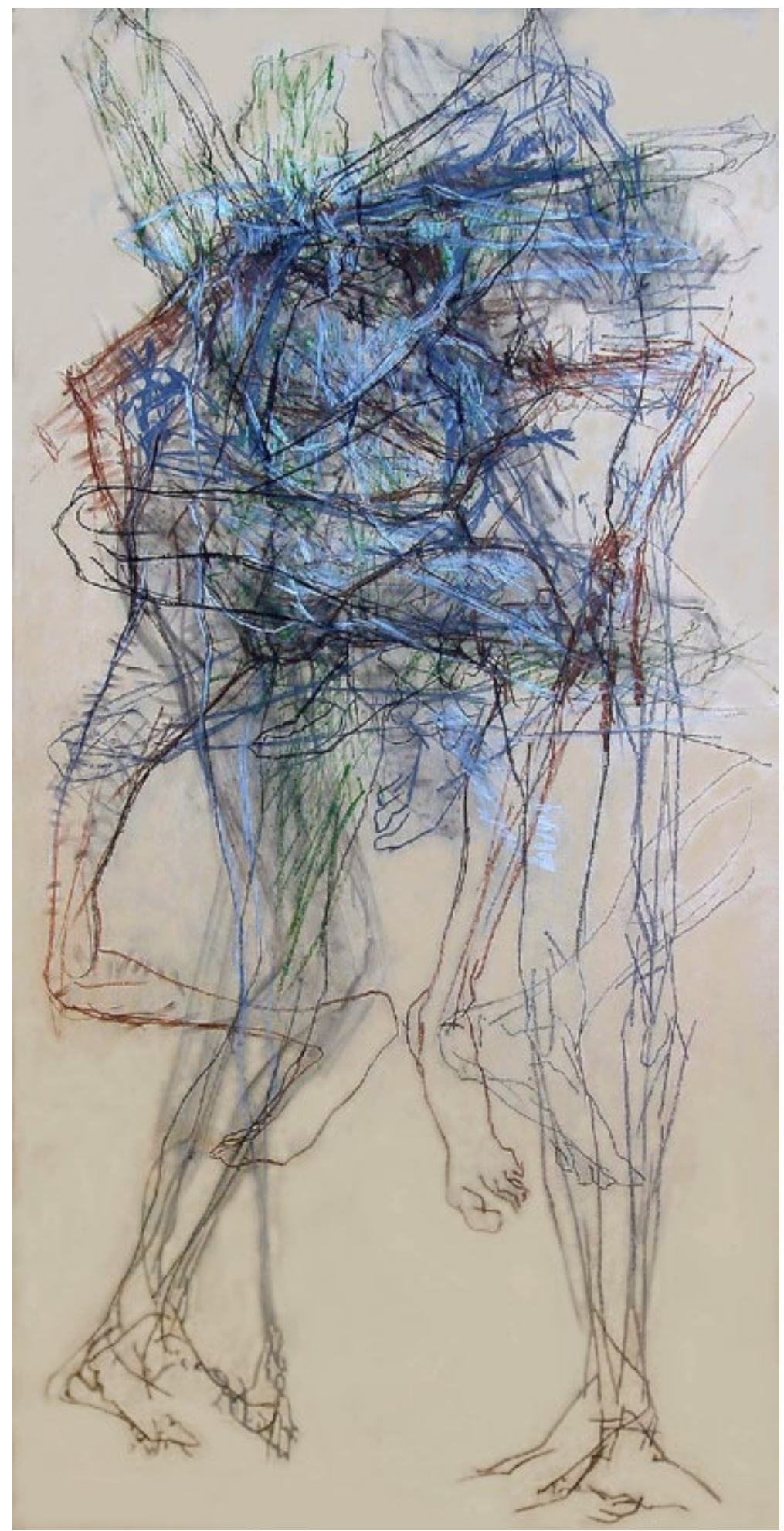




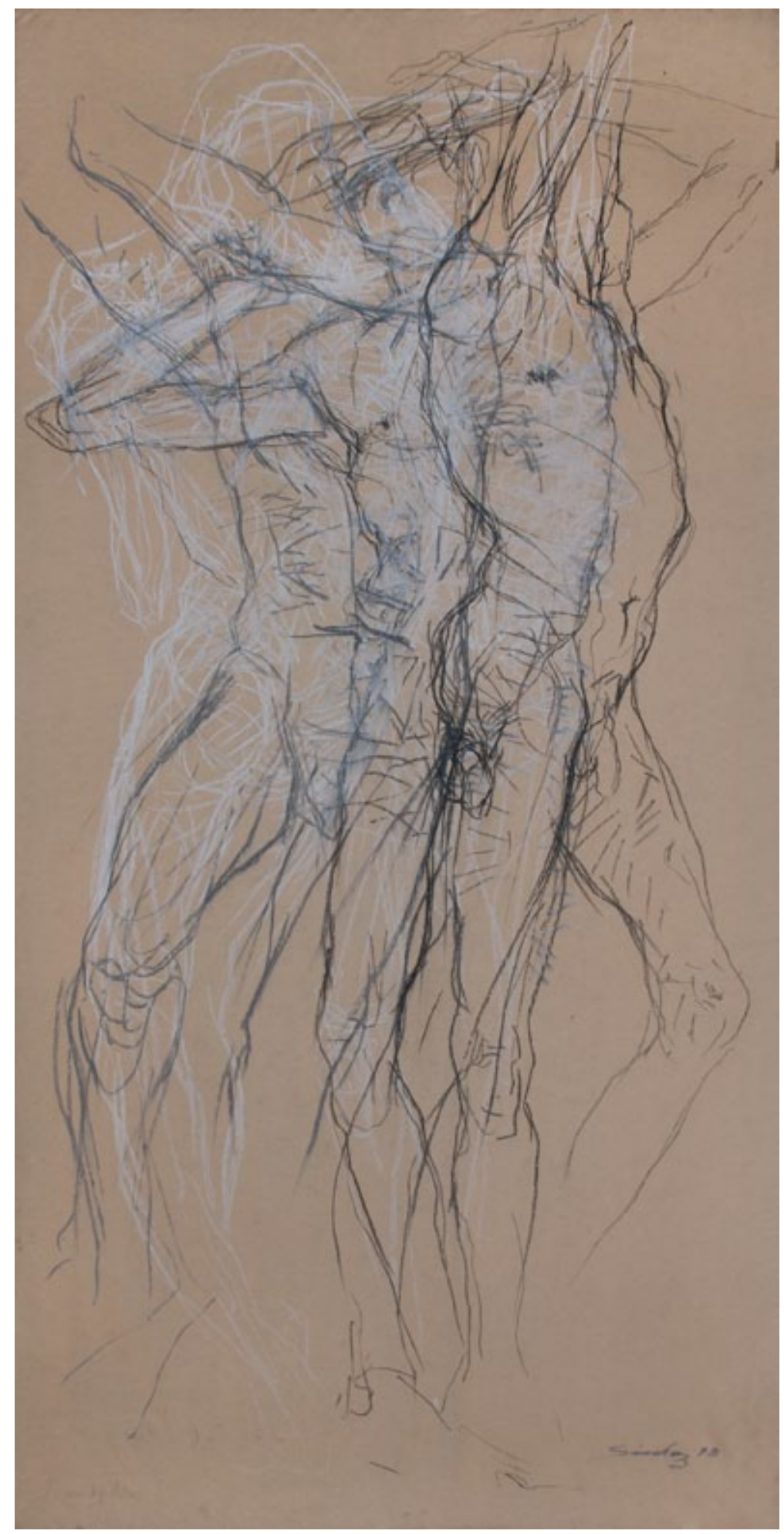




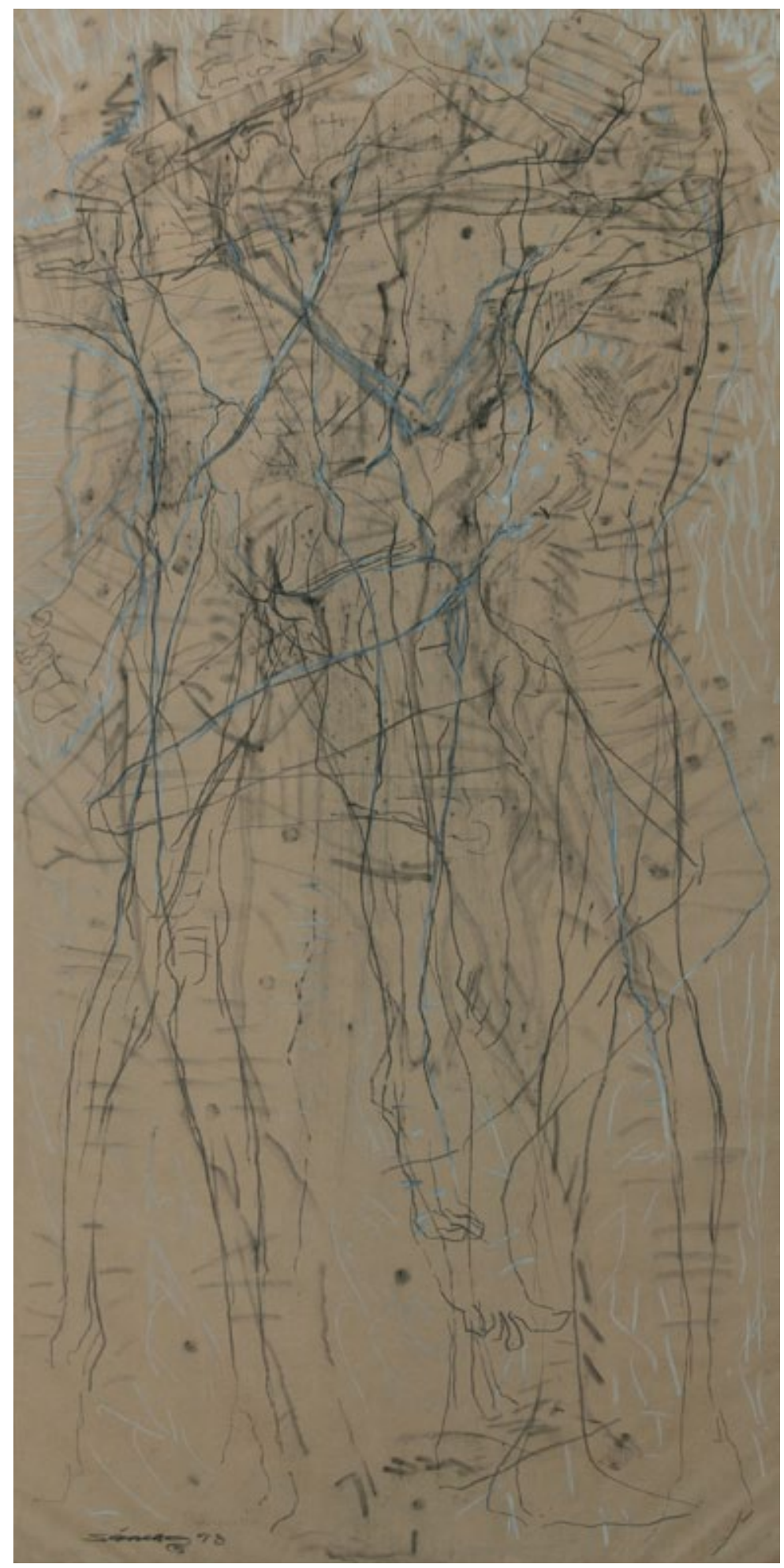




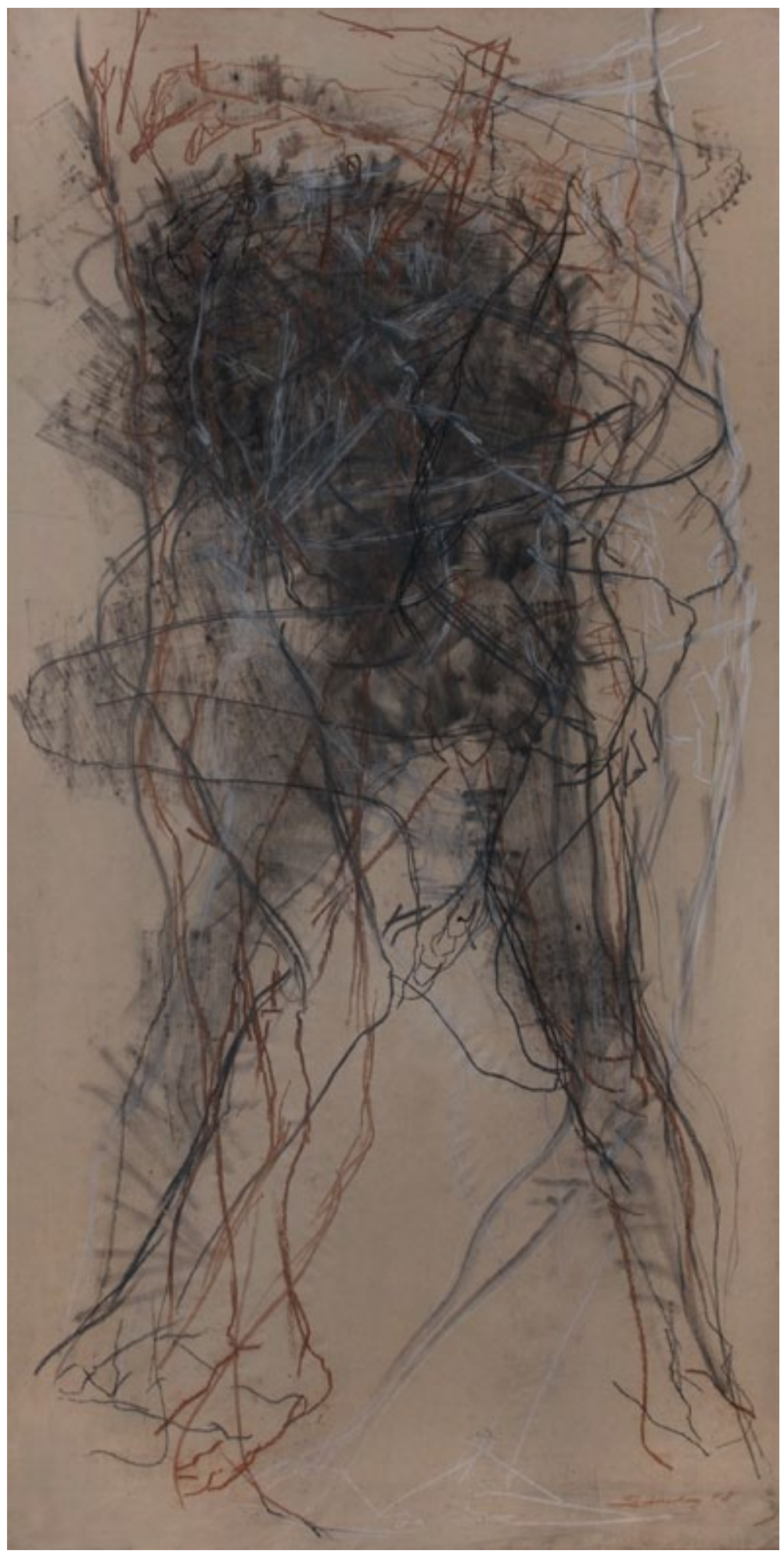




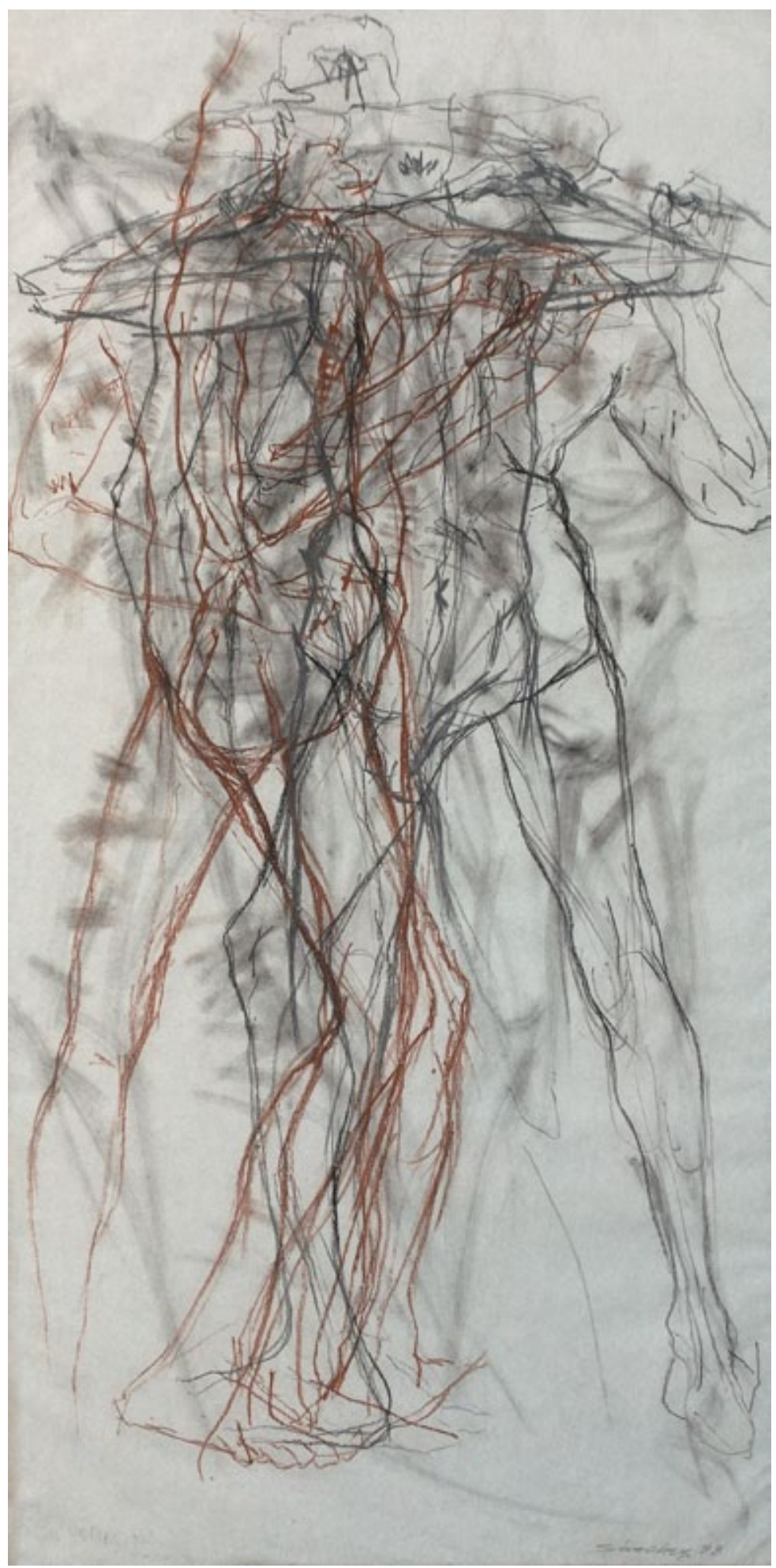




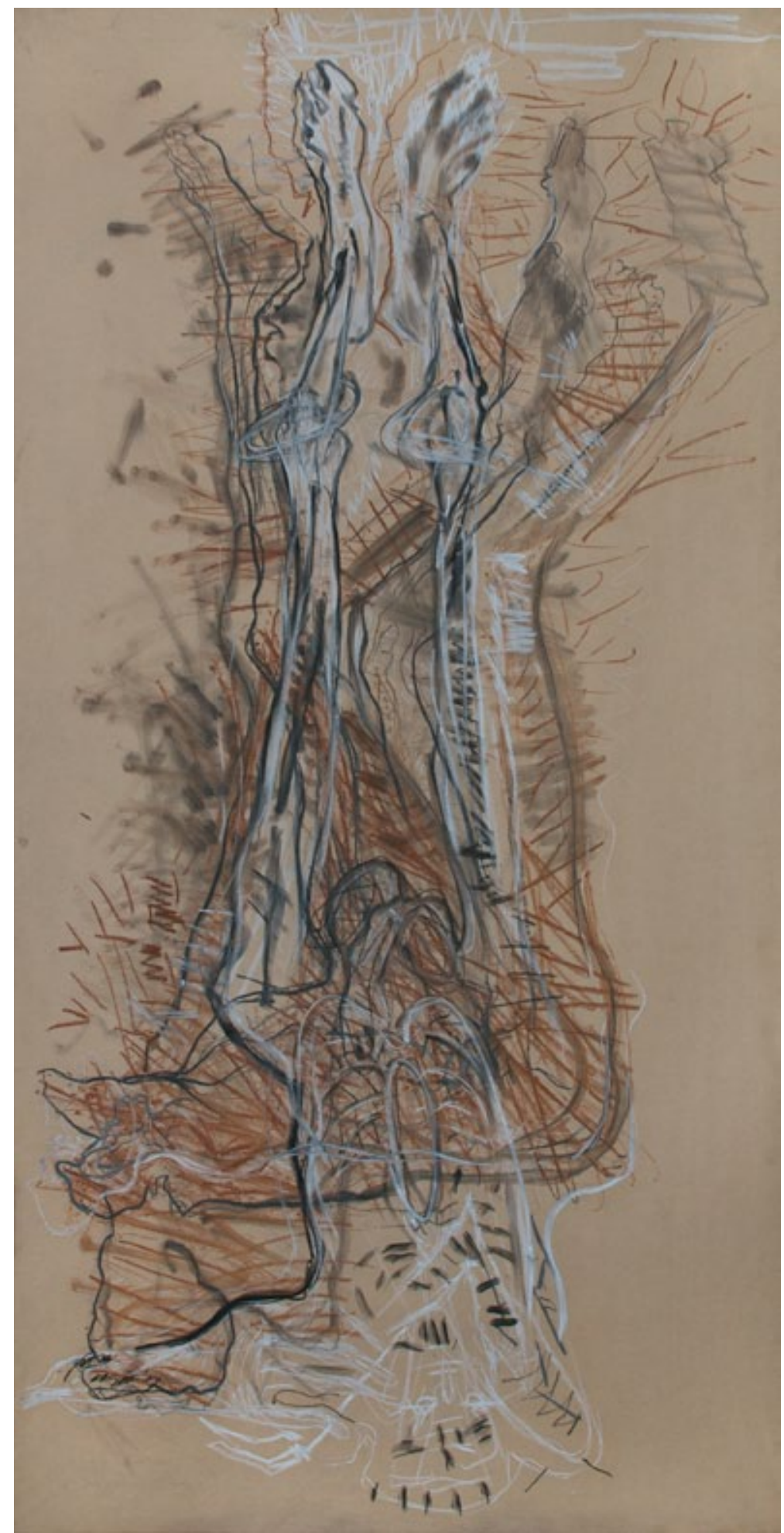




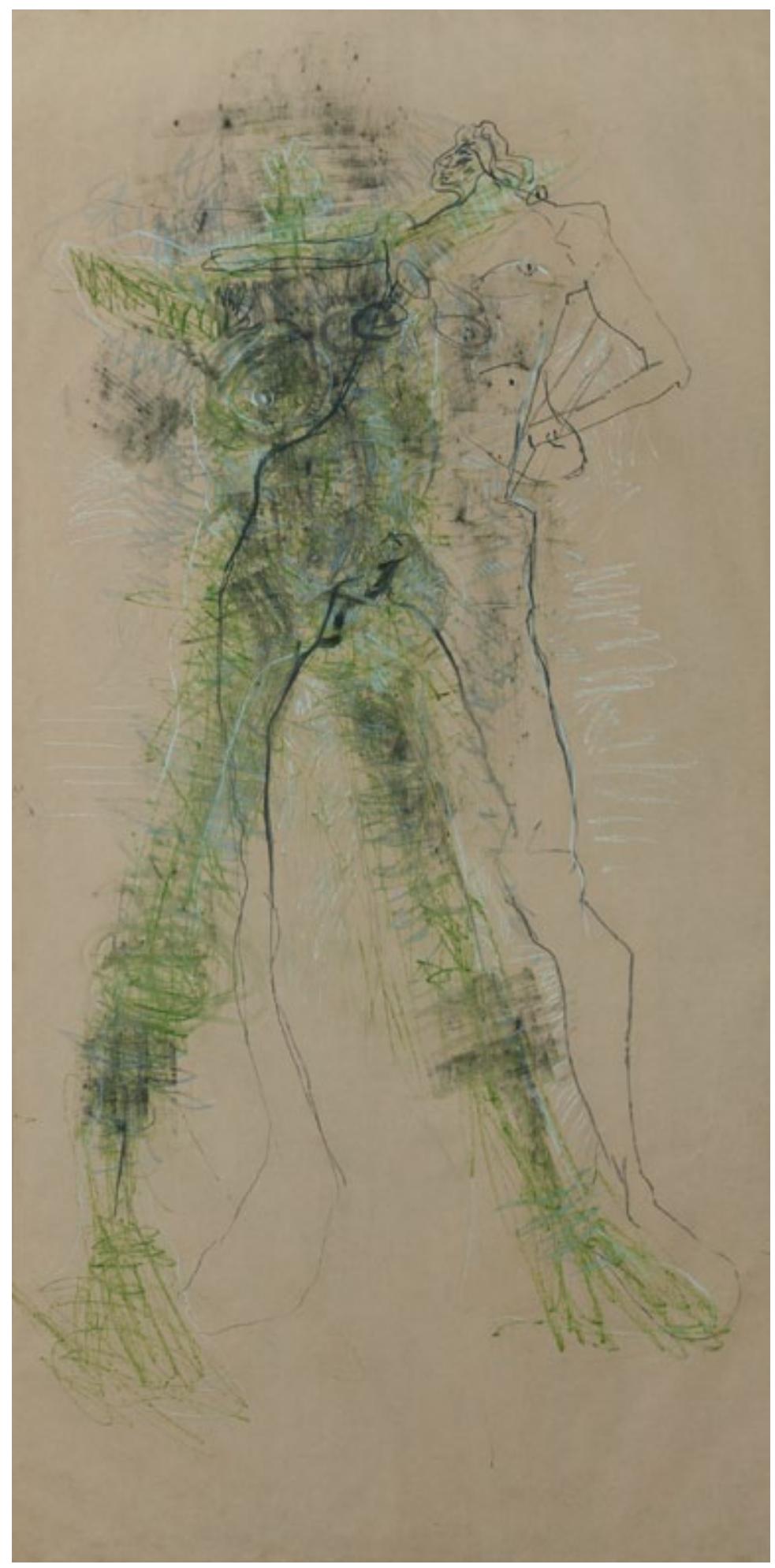




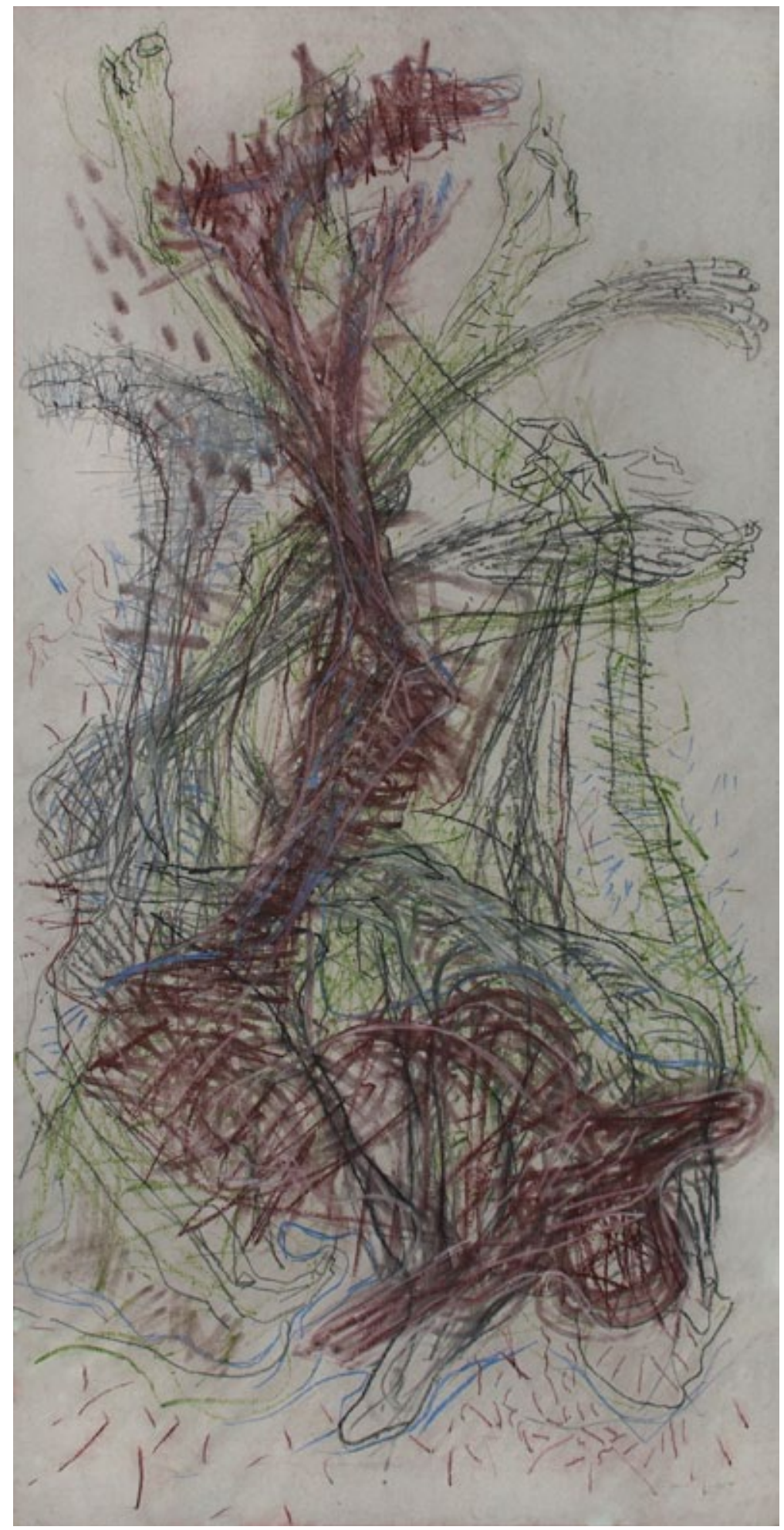




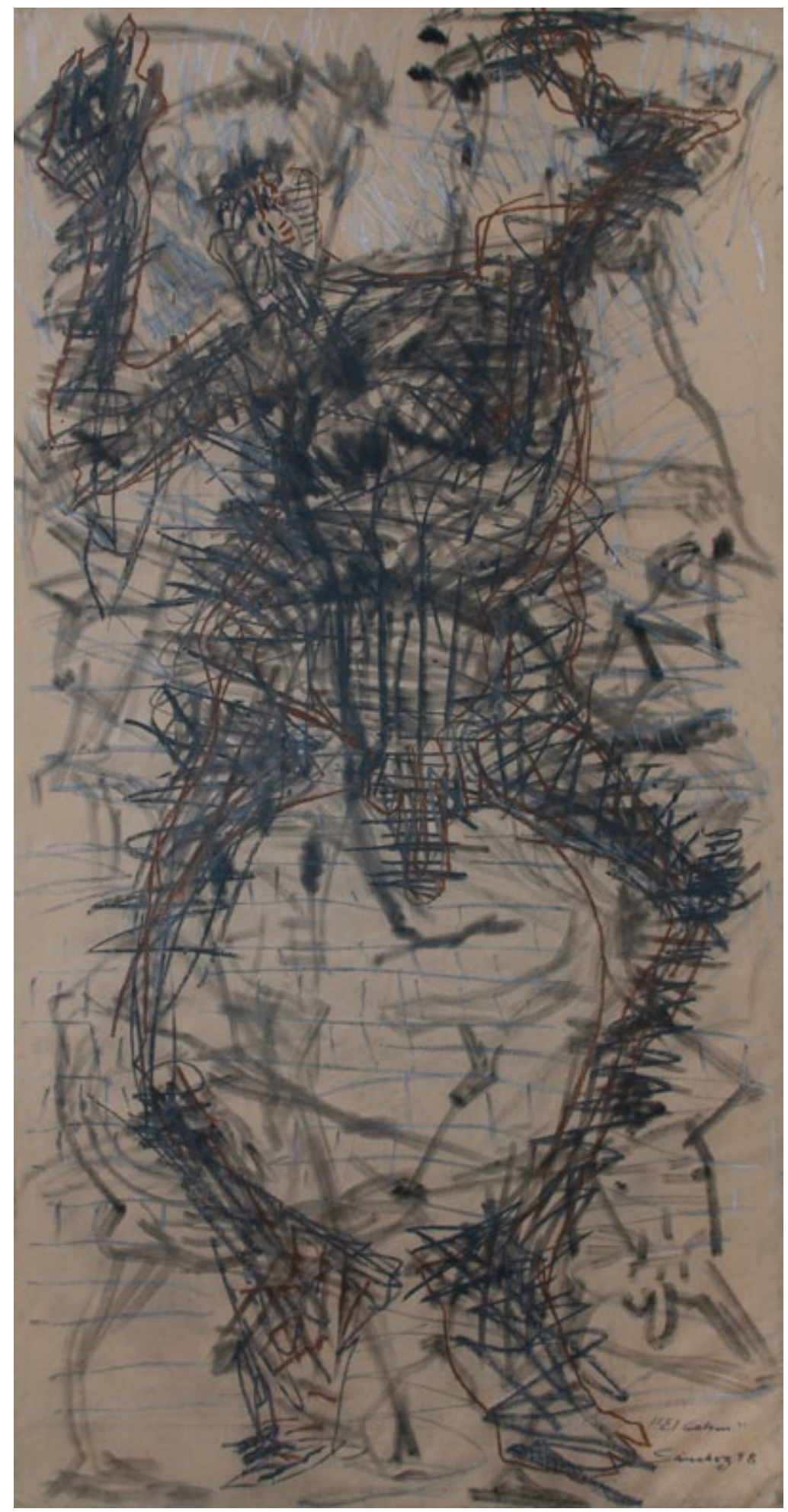




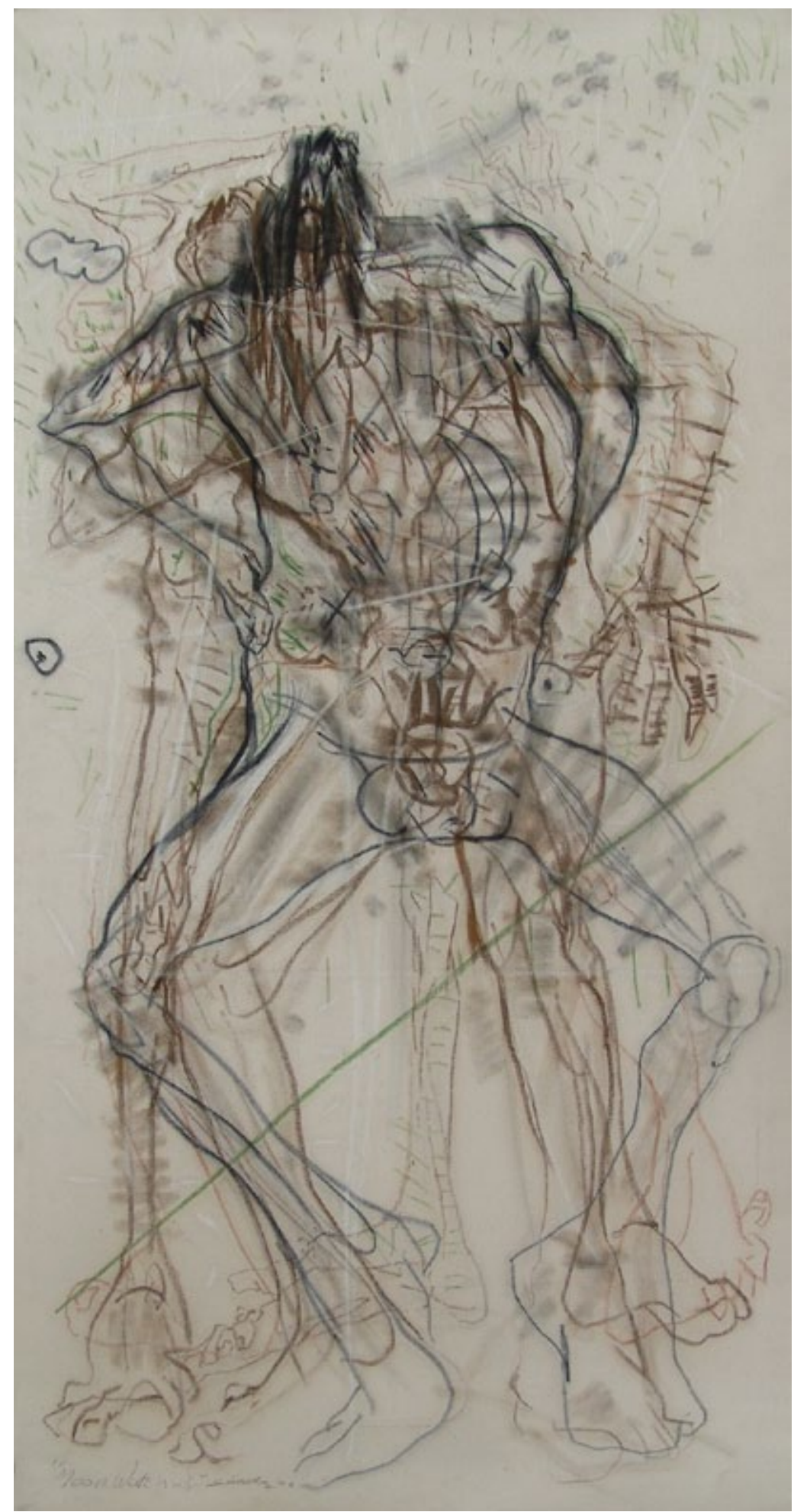




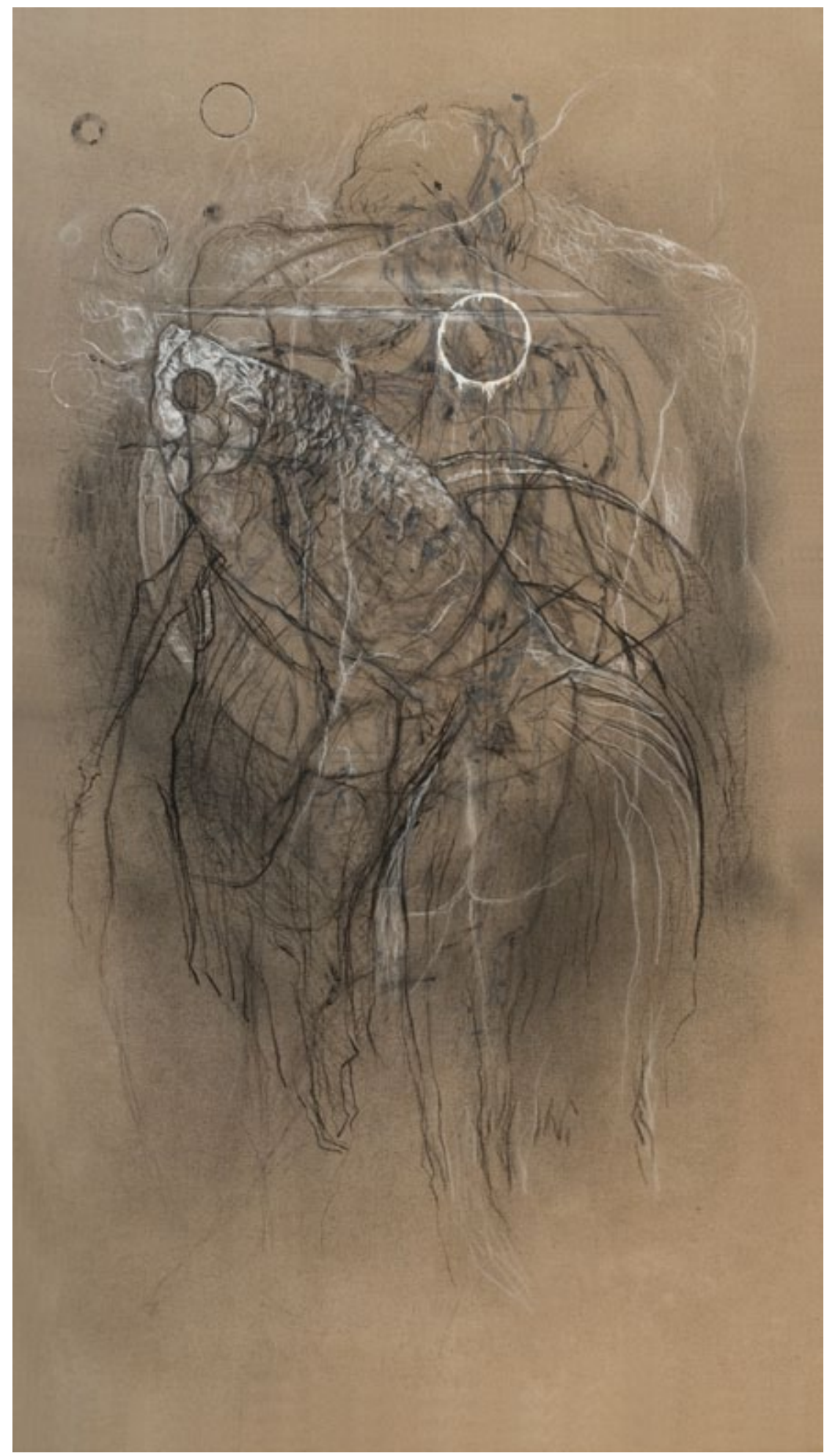




\section{LO QUE NUNCA TERMINA}

(MASA VISUAL, SINCRONÍA ESPACIAL Y TEMPORAL) 


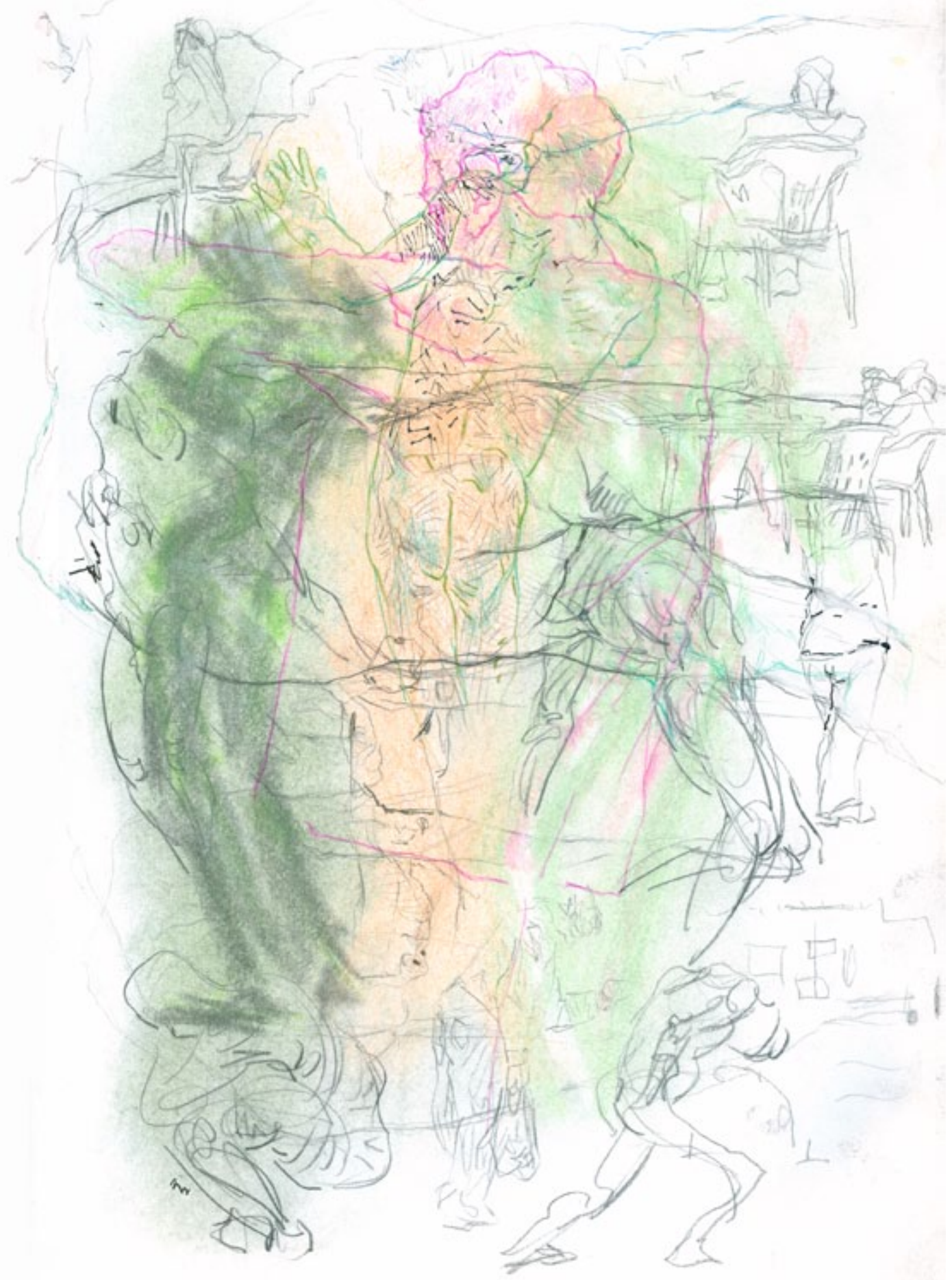




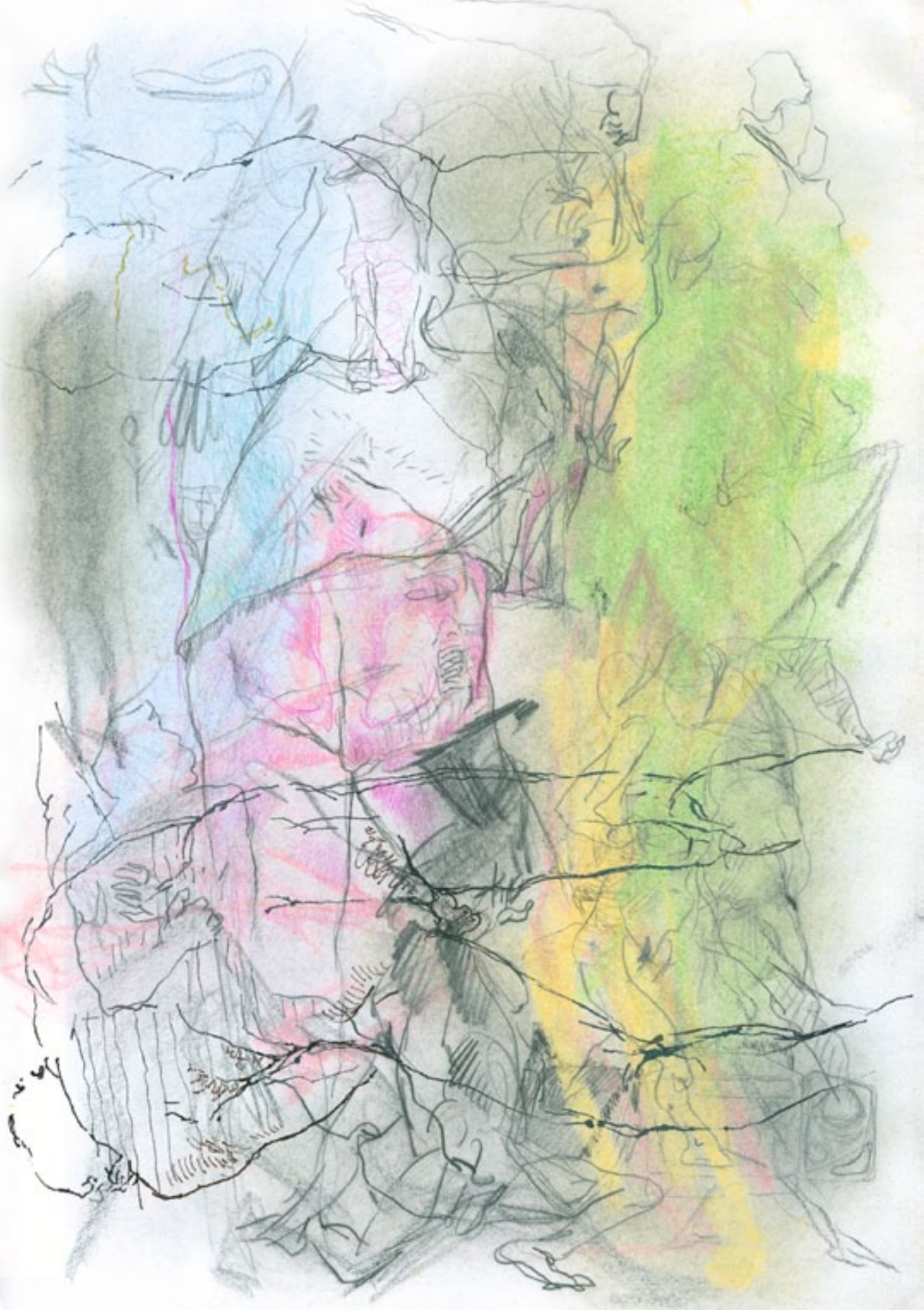




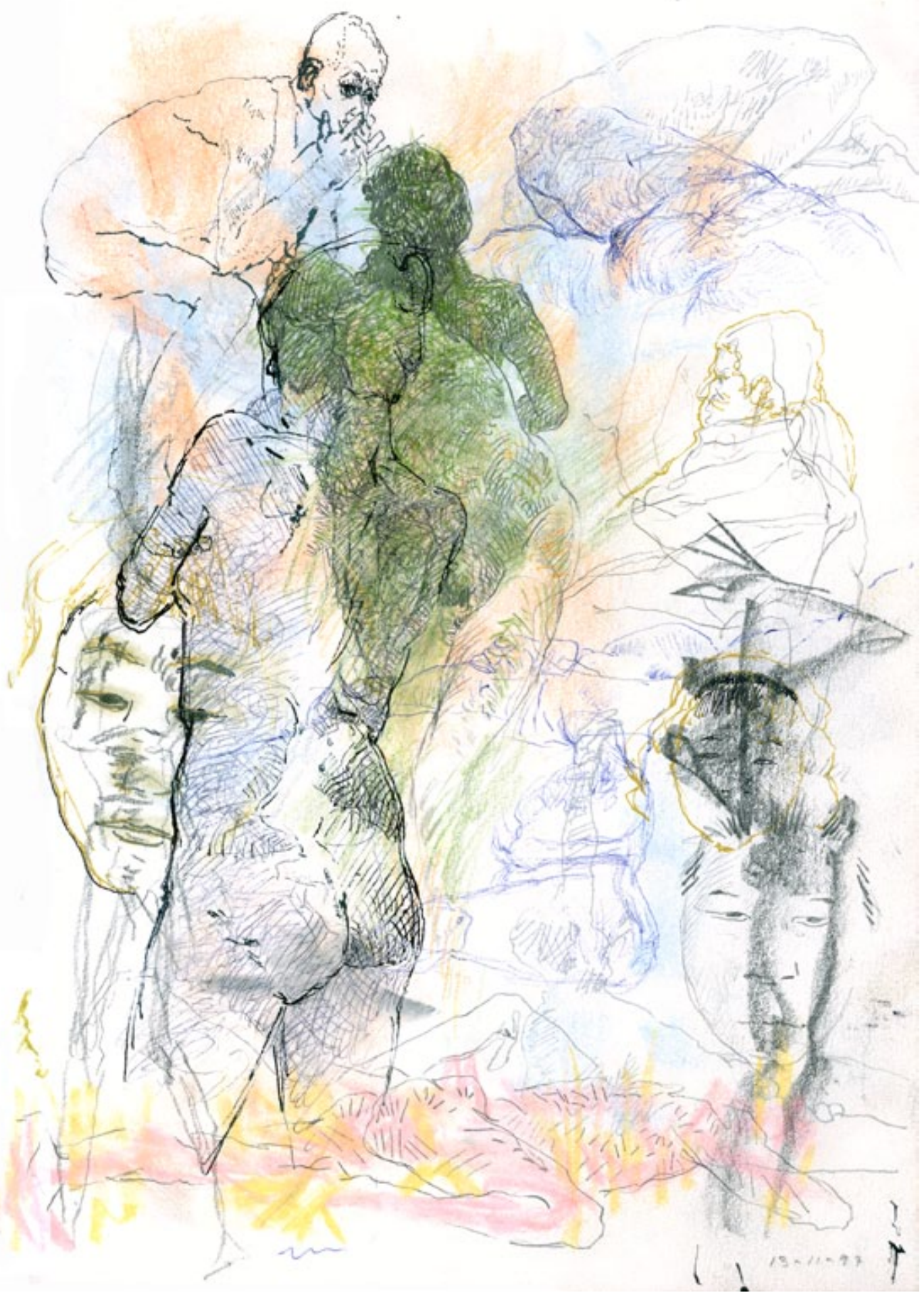




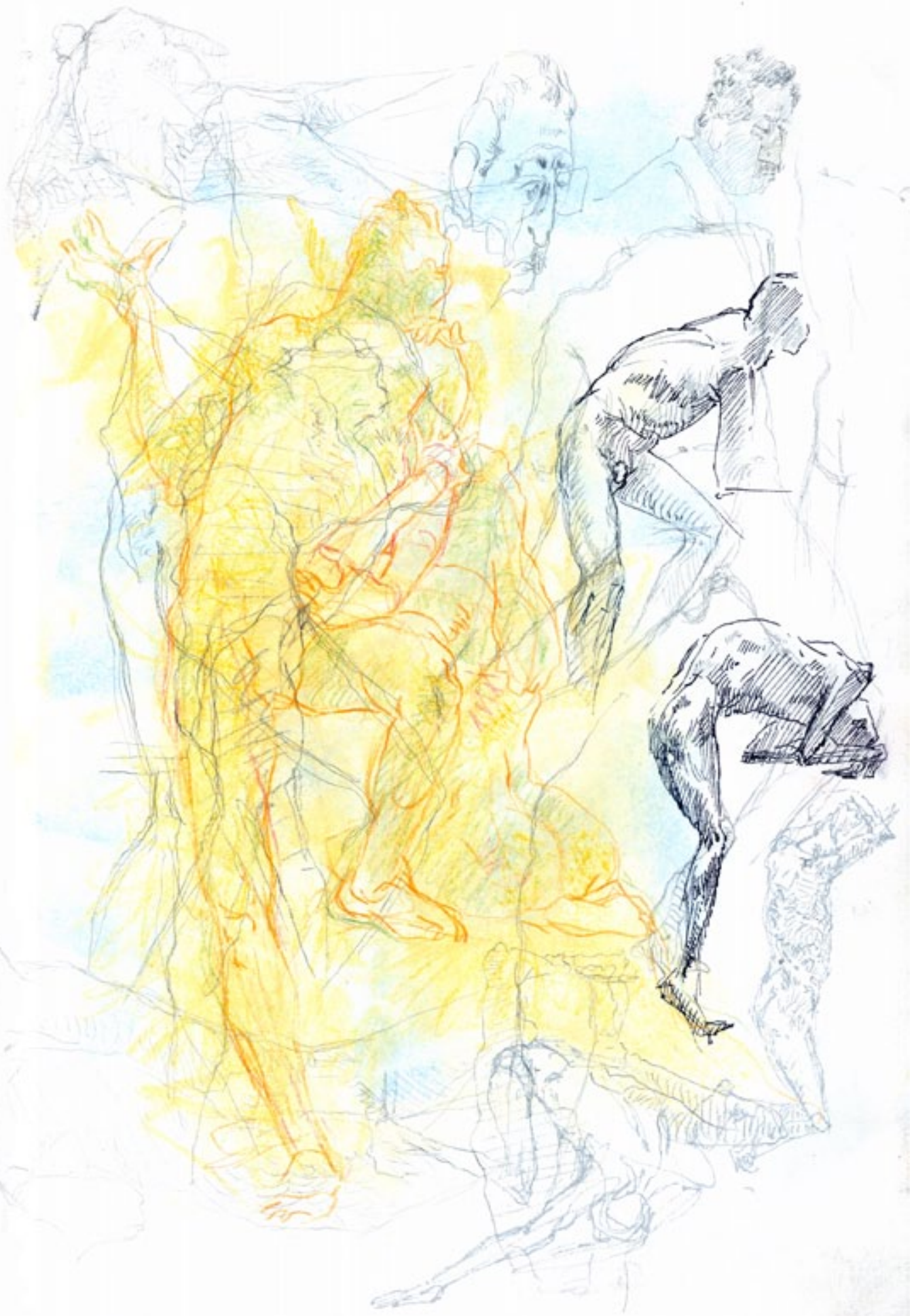




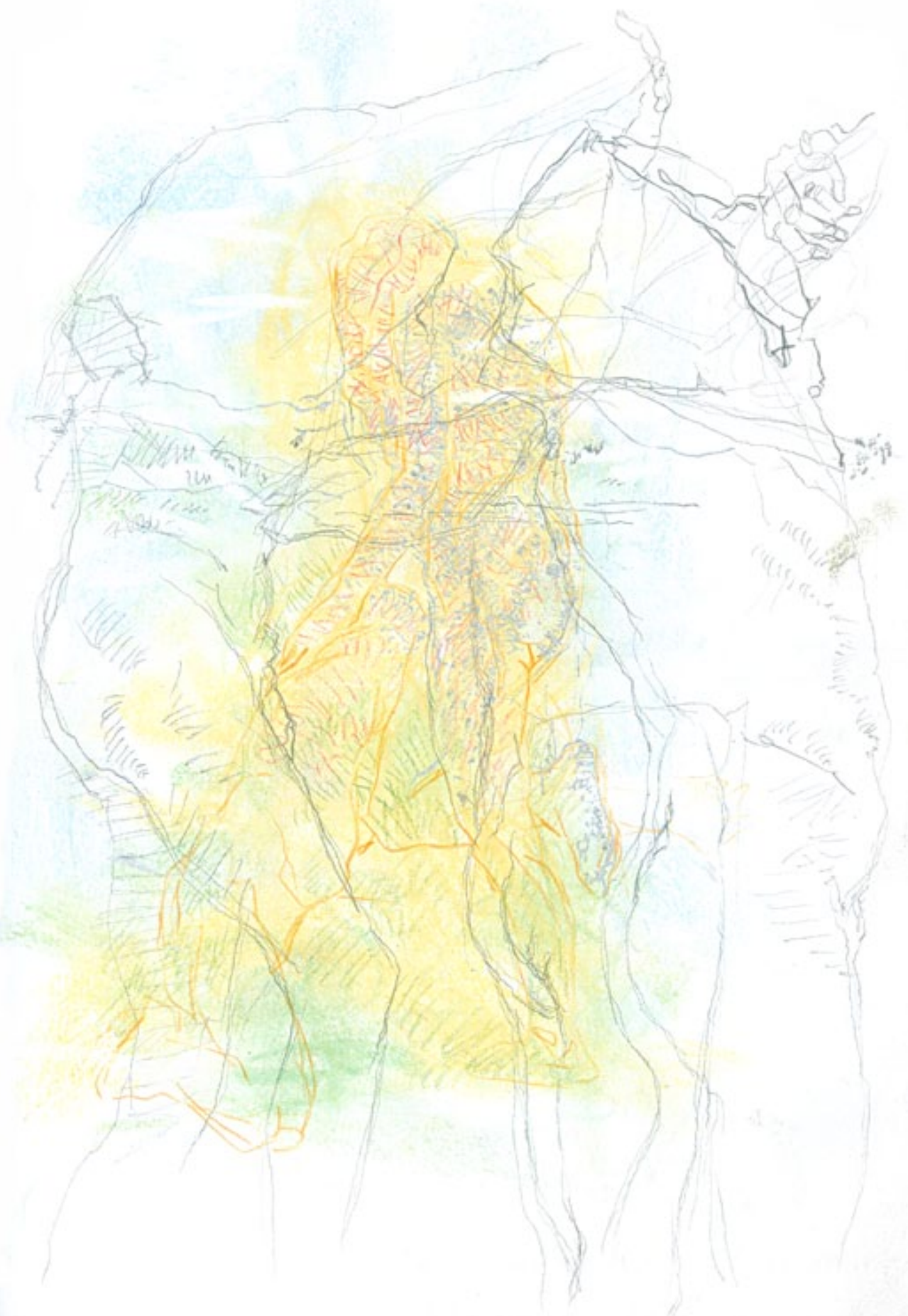




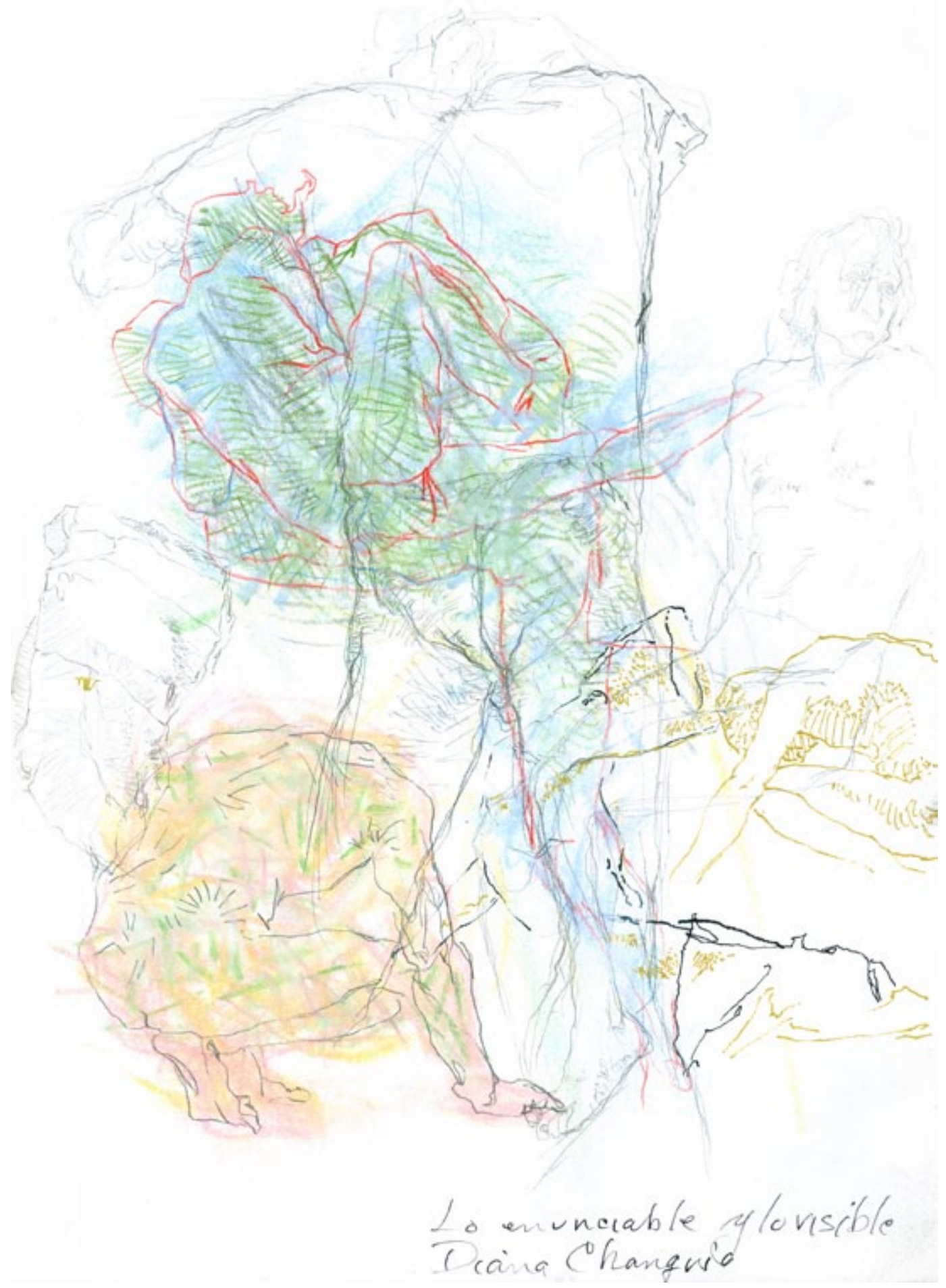




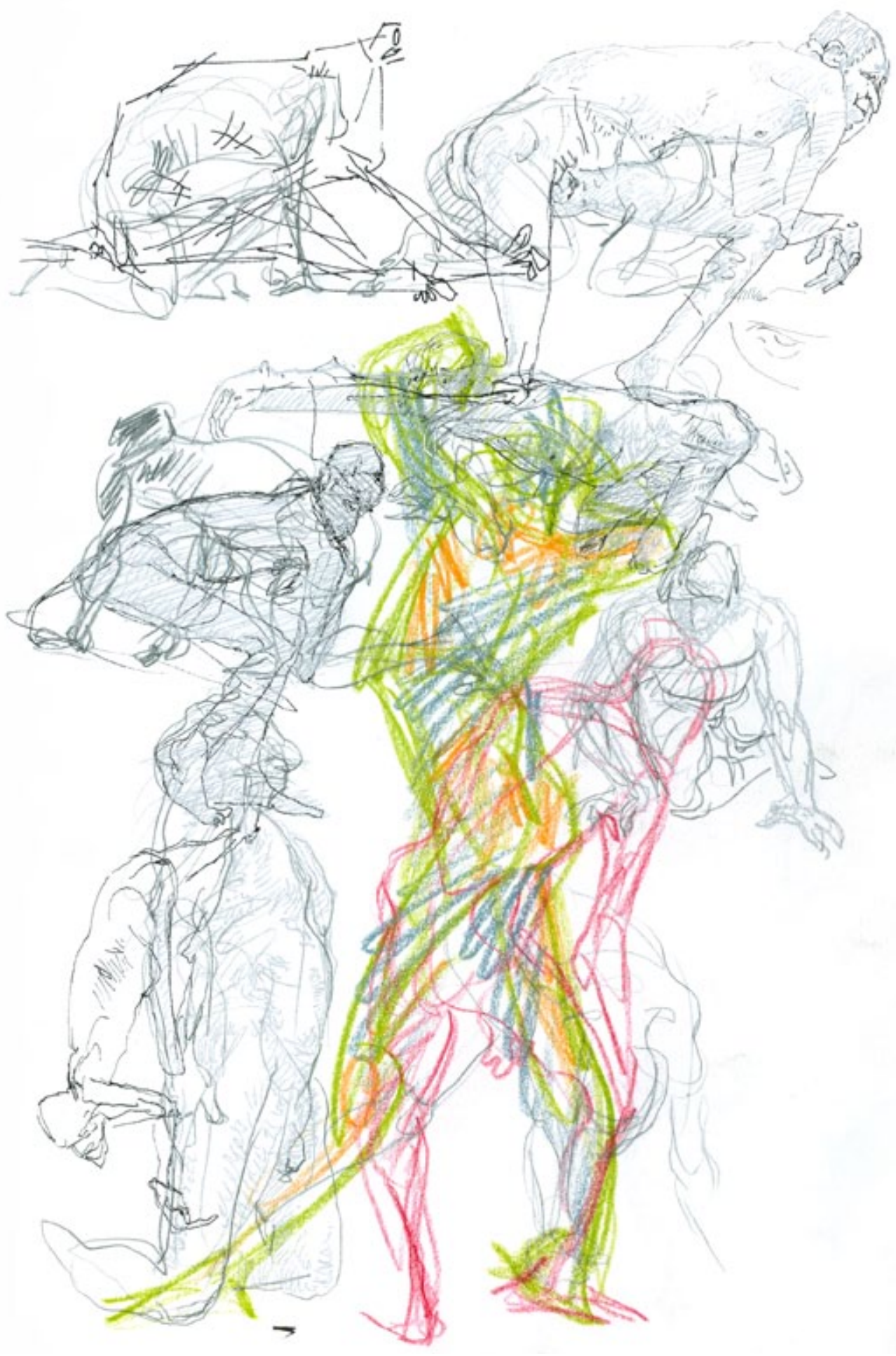




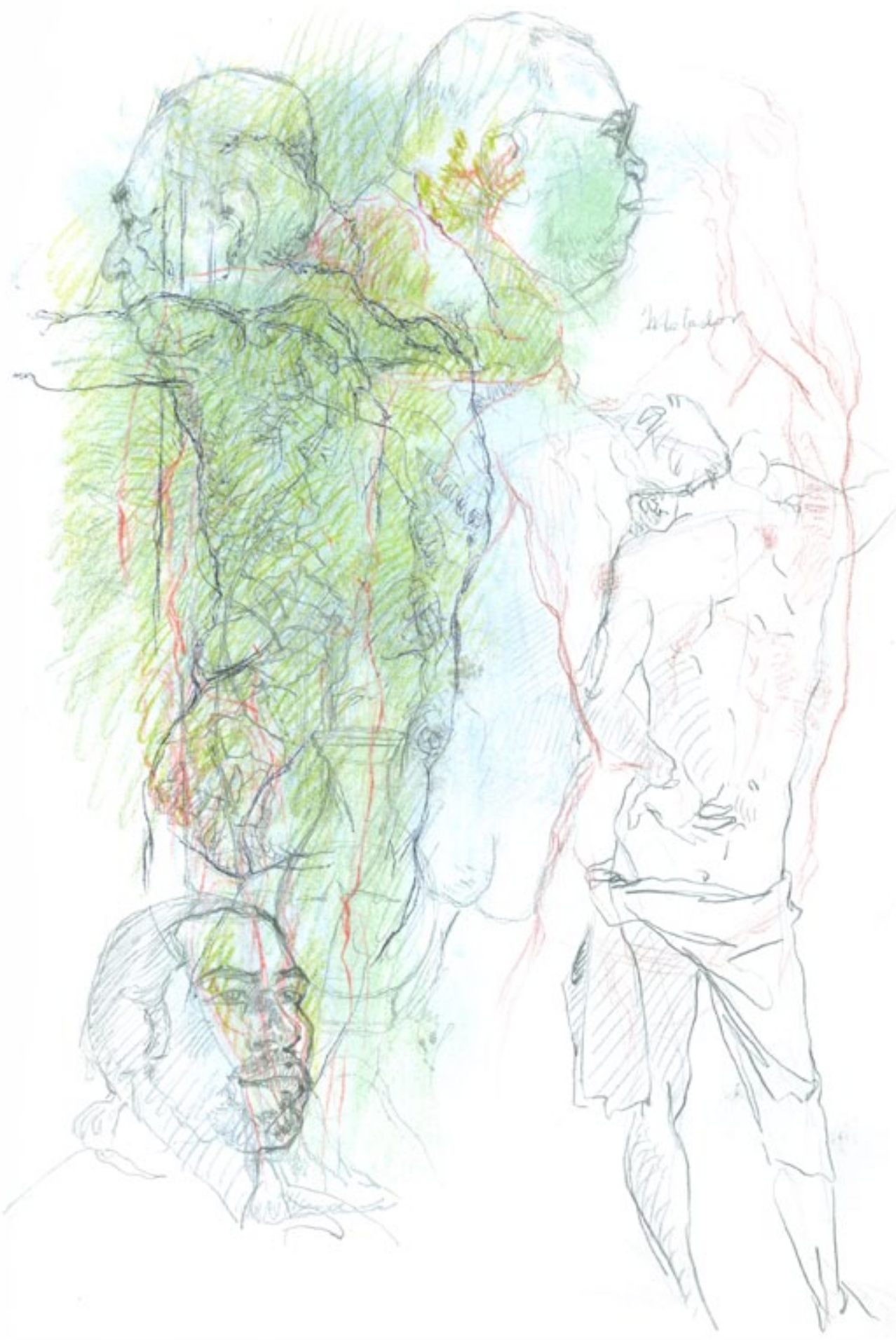




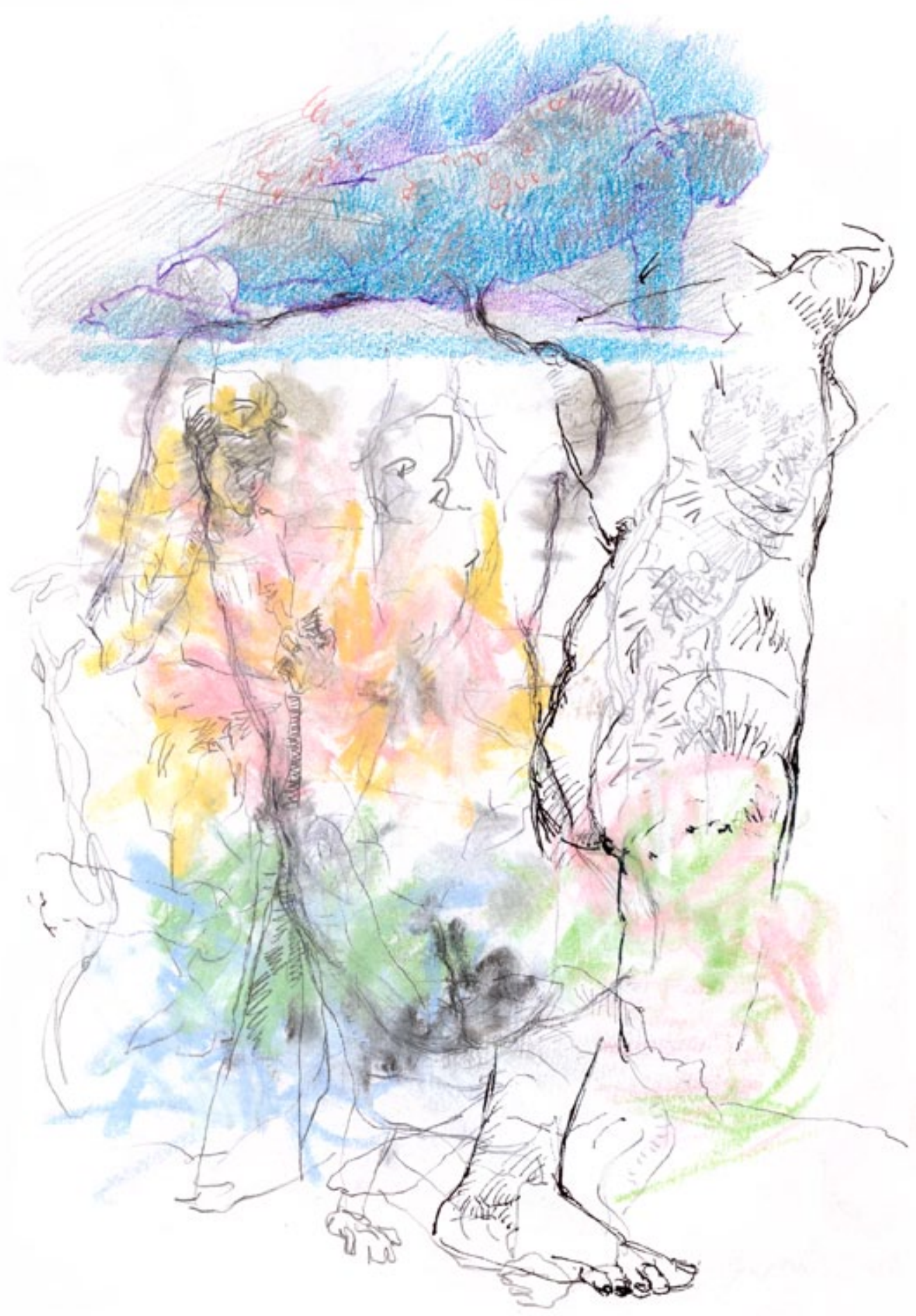




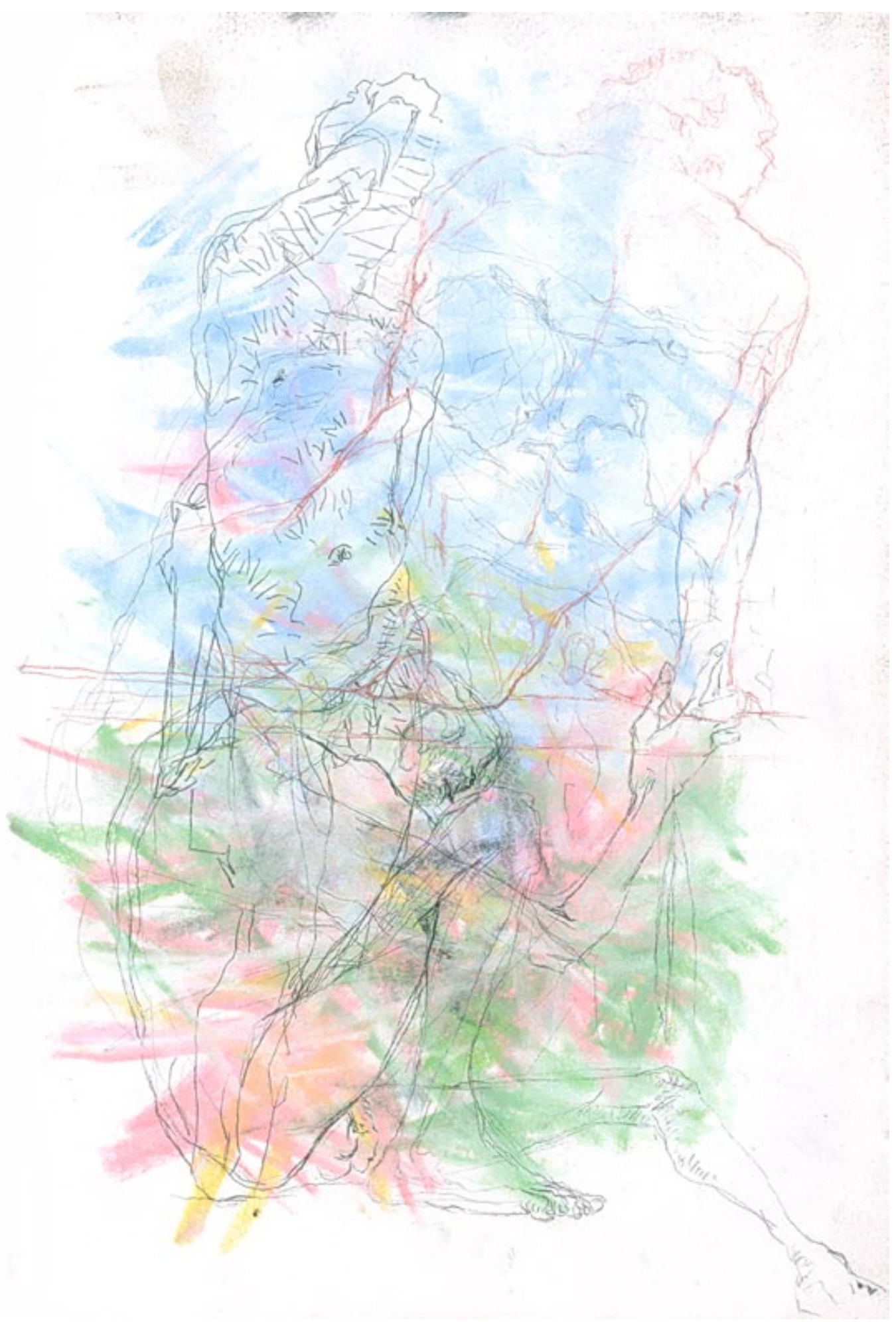




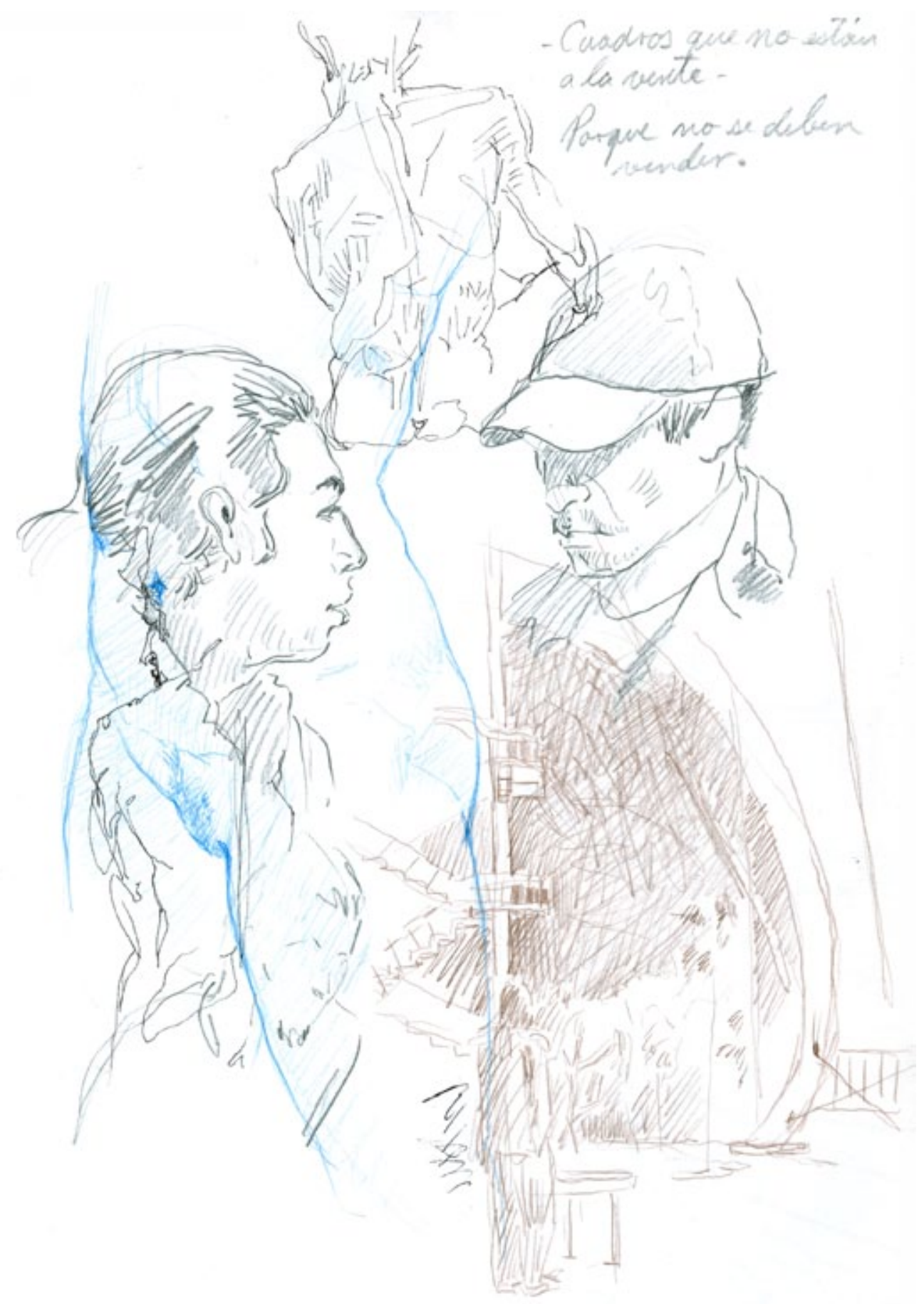




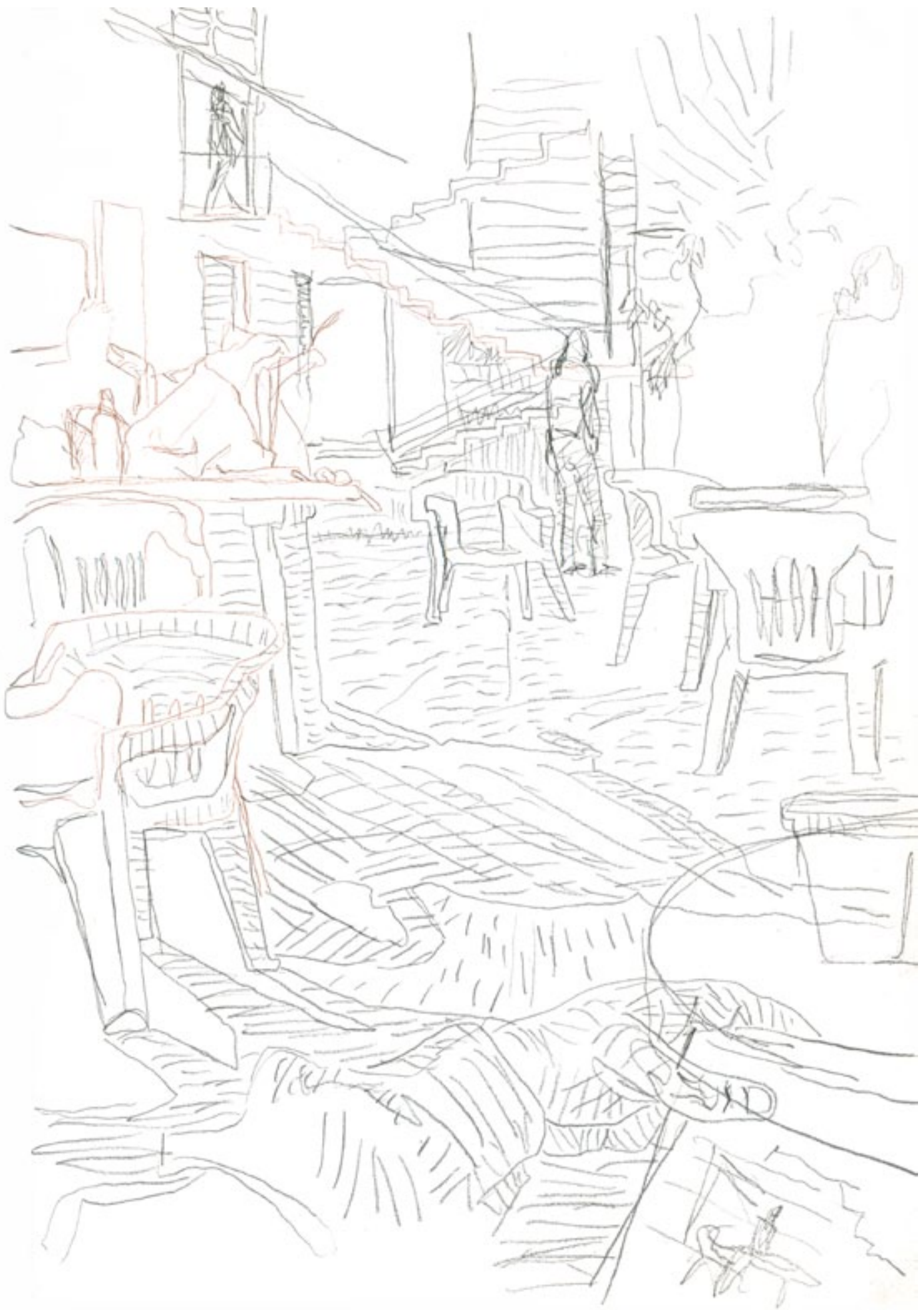




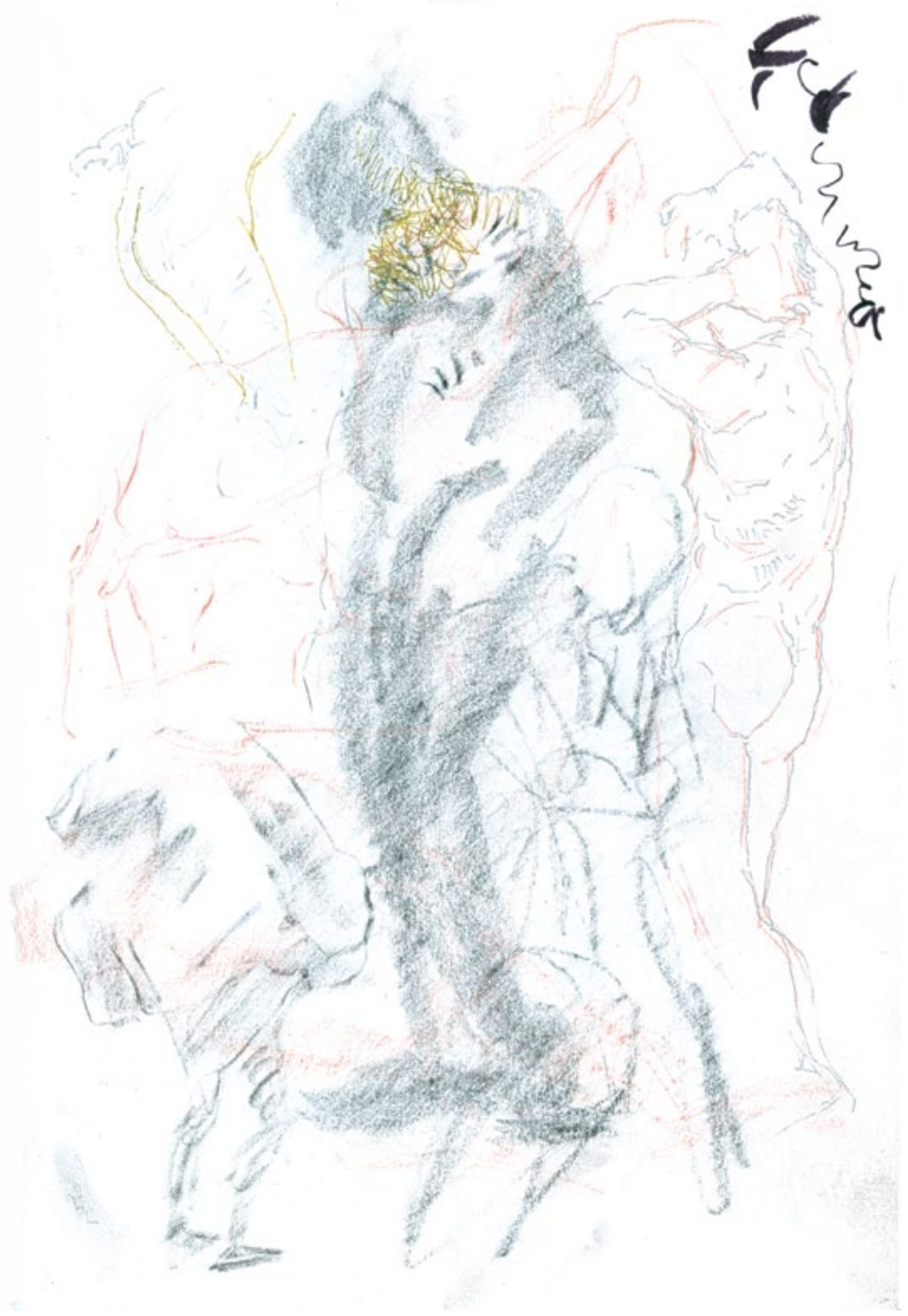




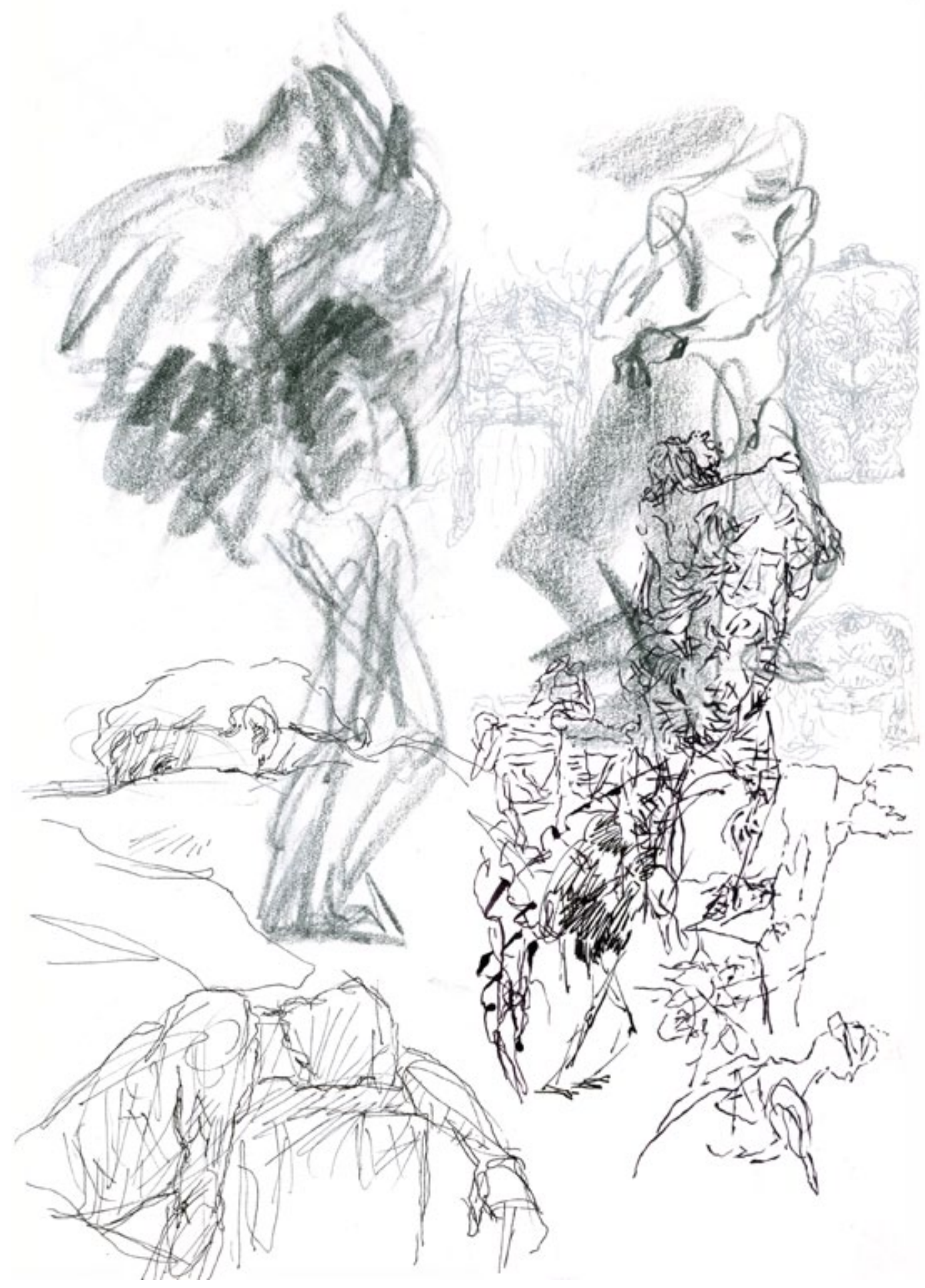




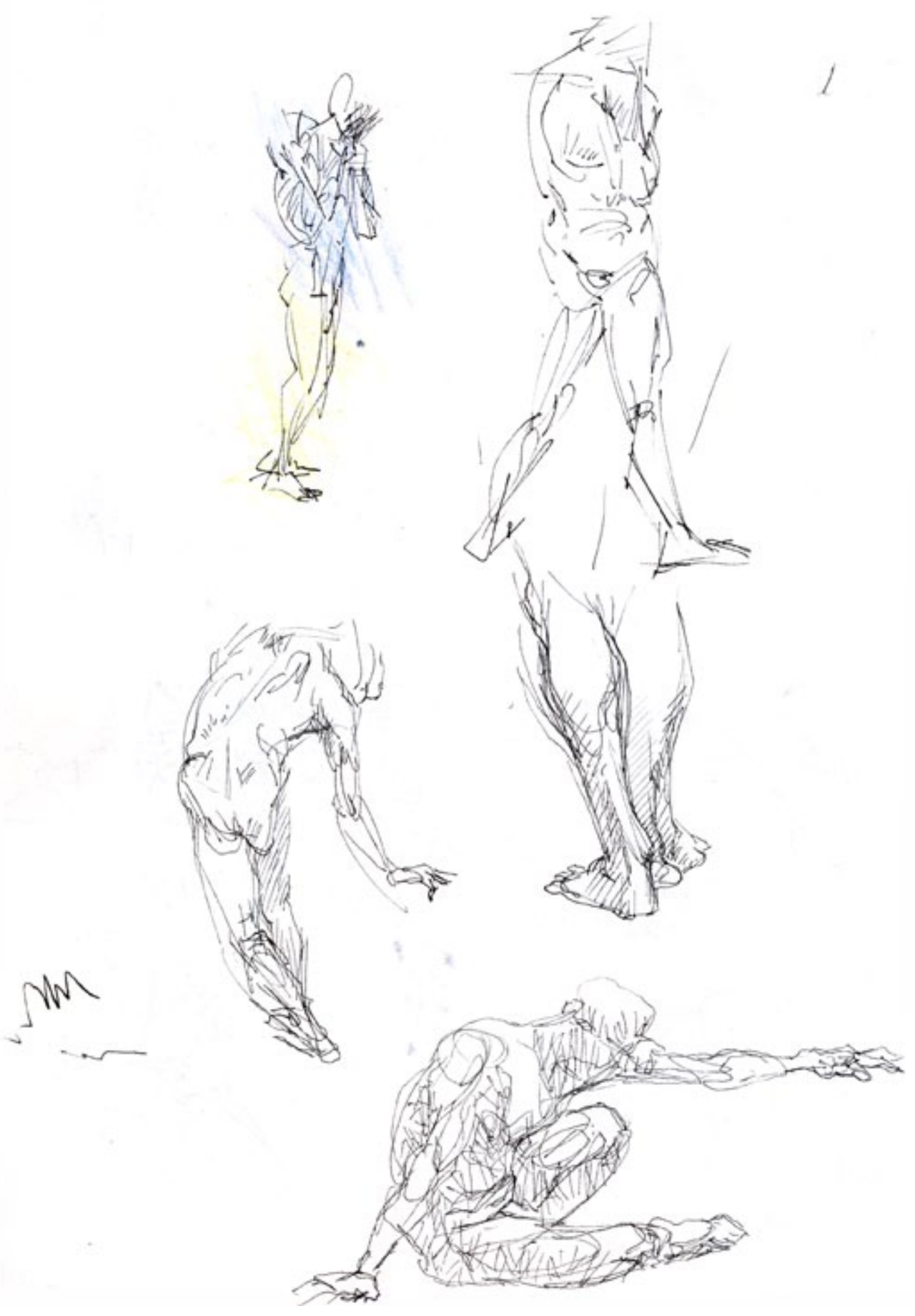




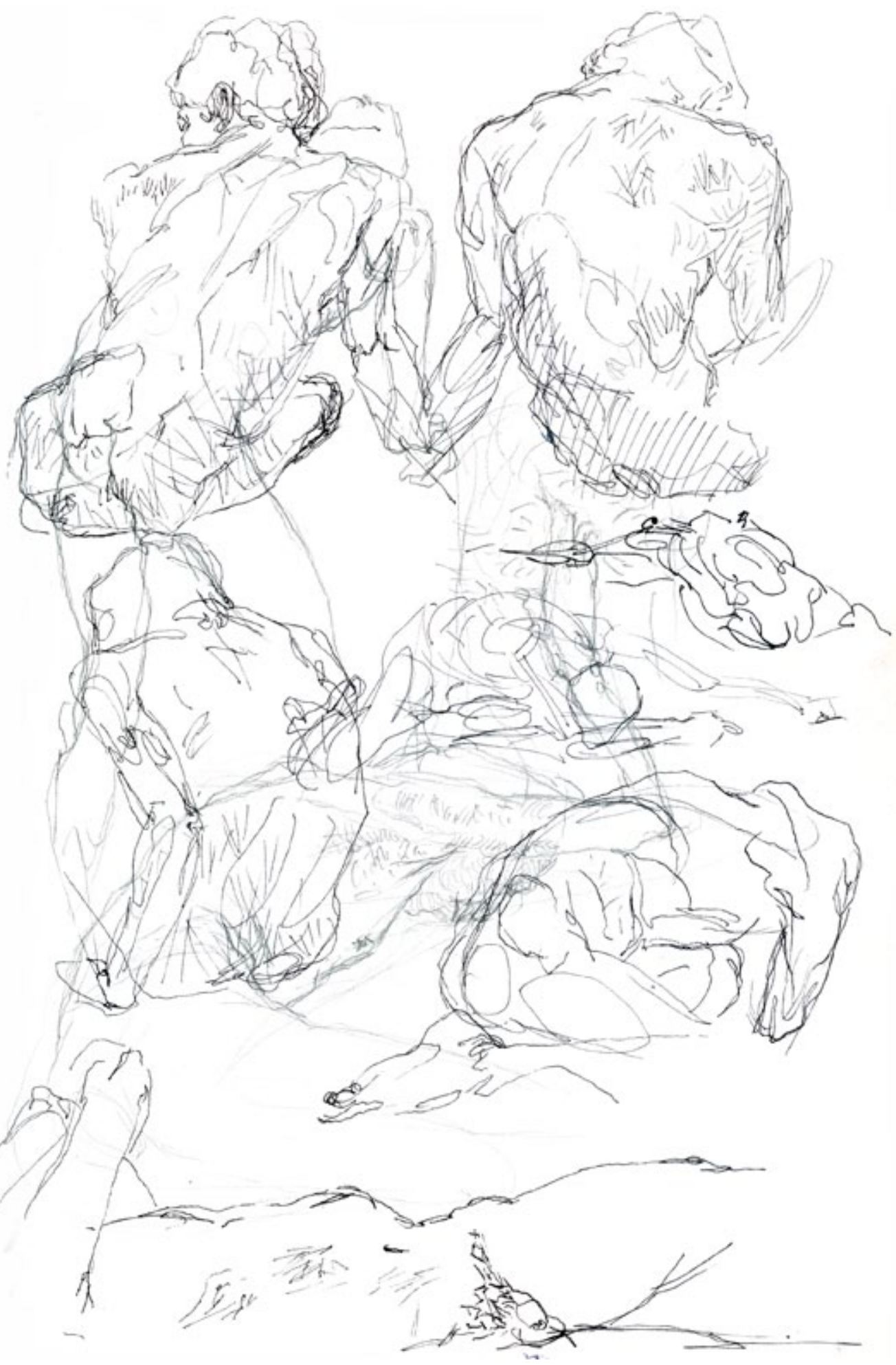




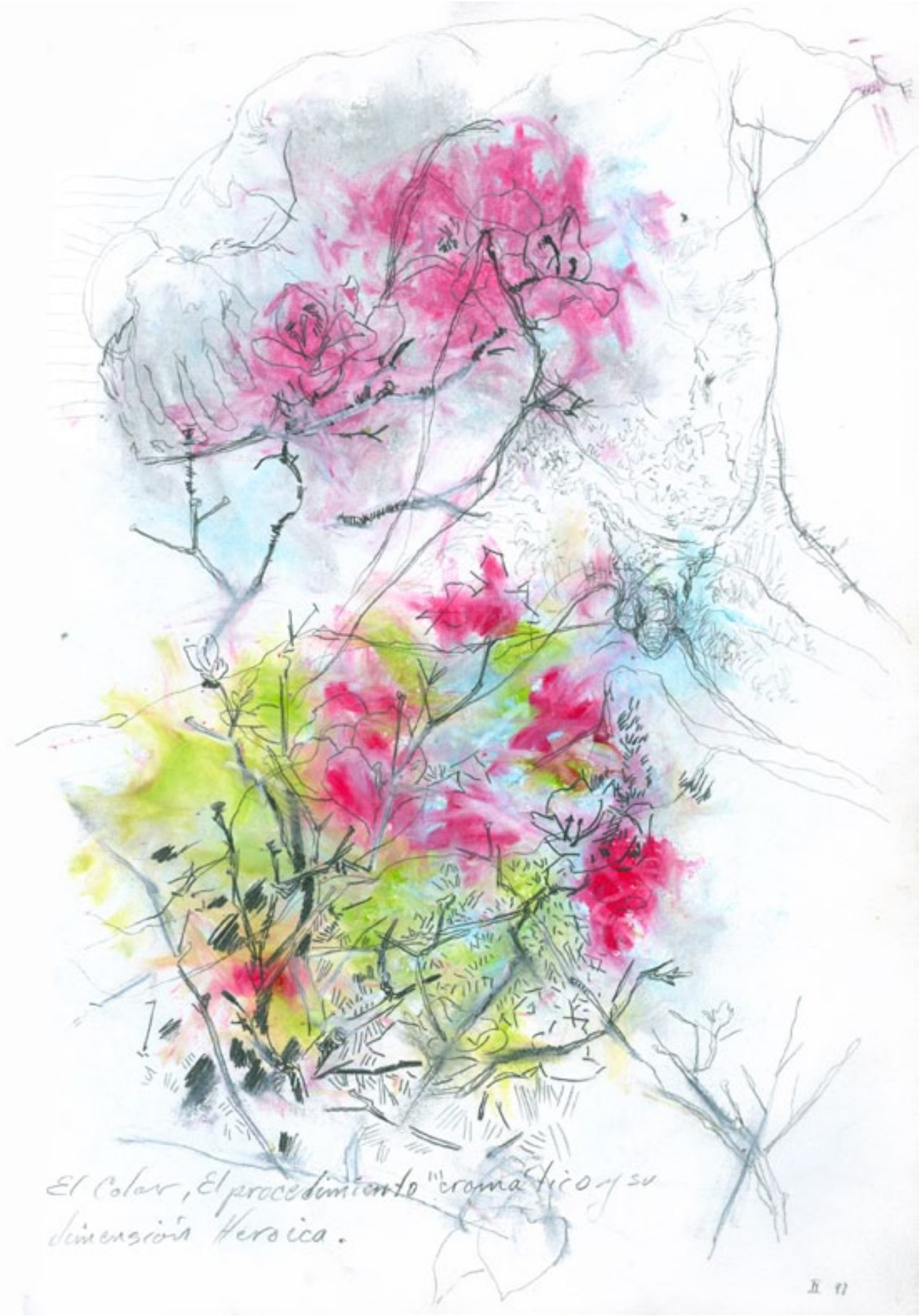




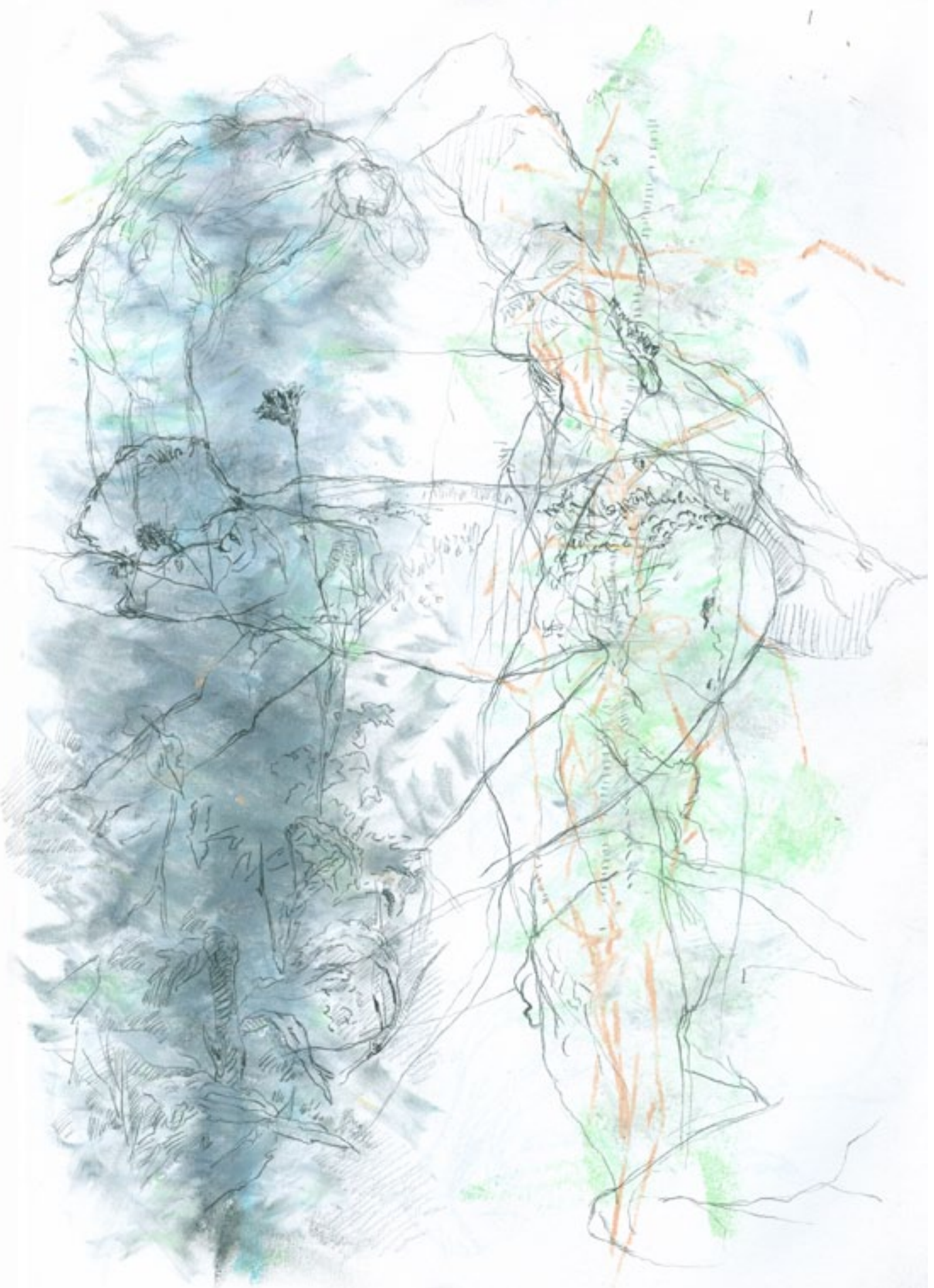




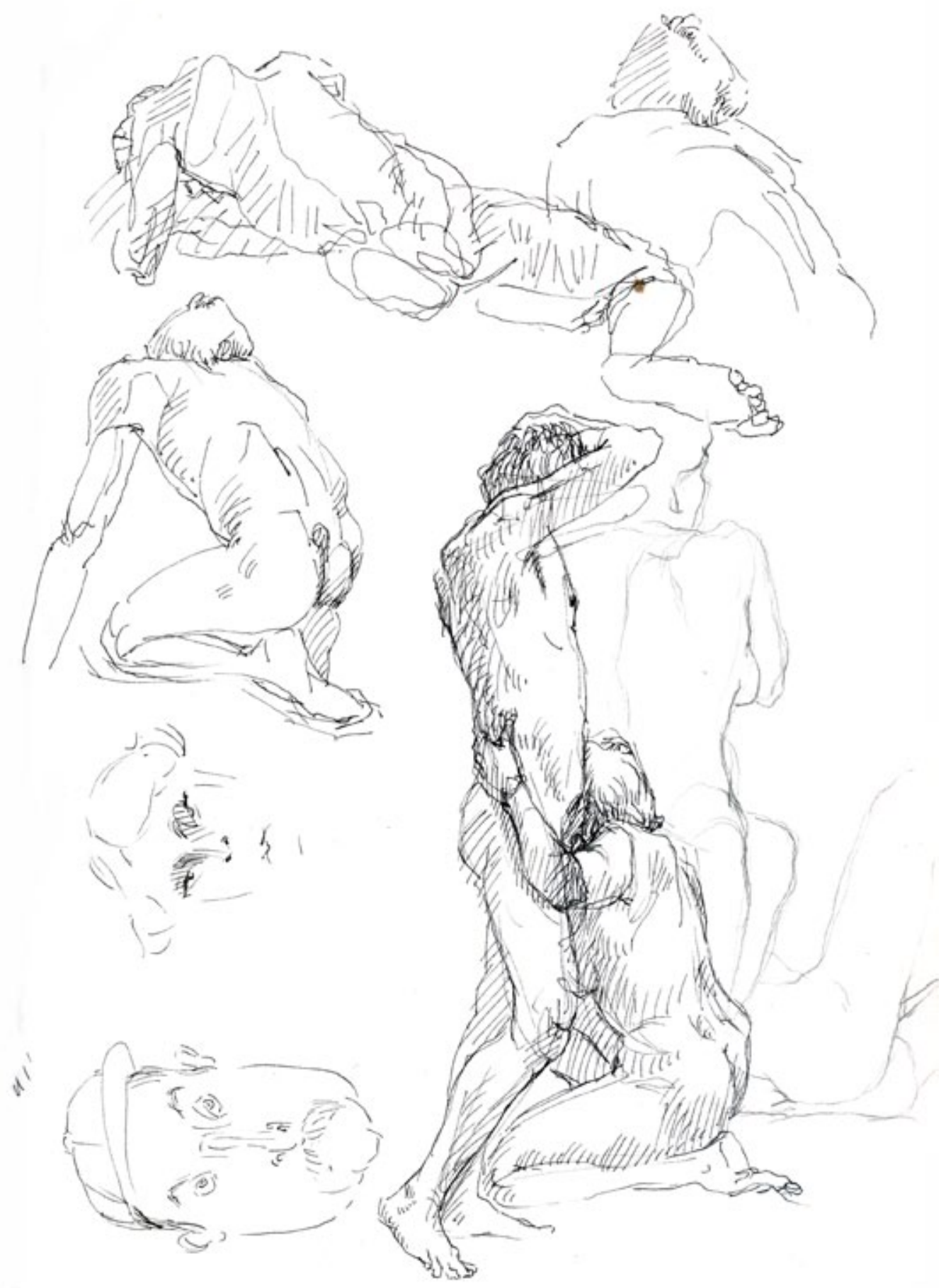




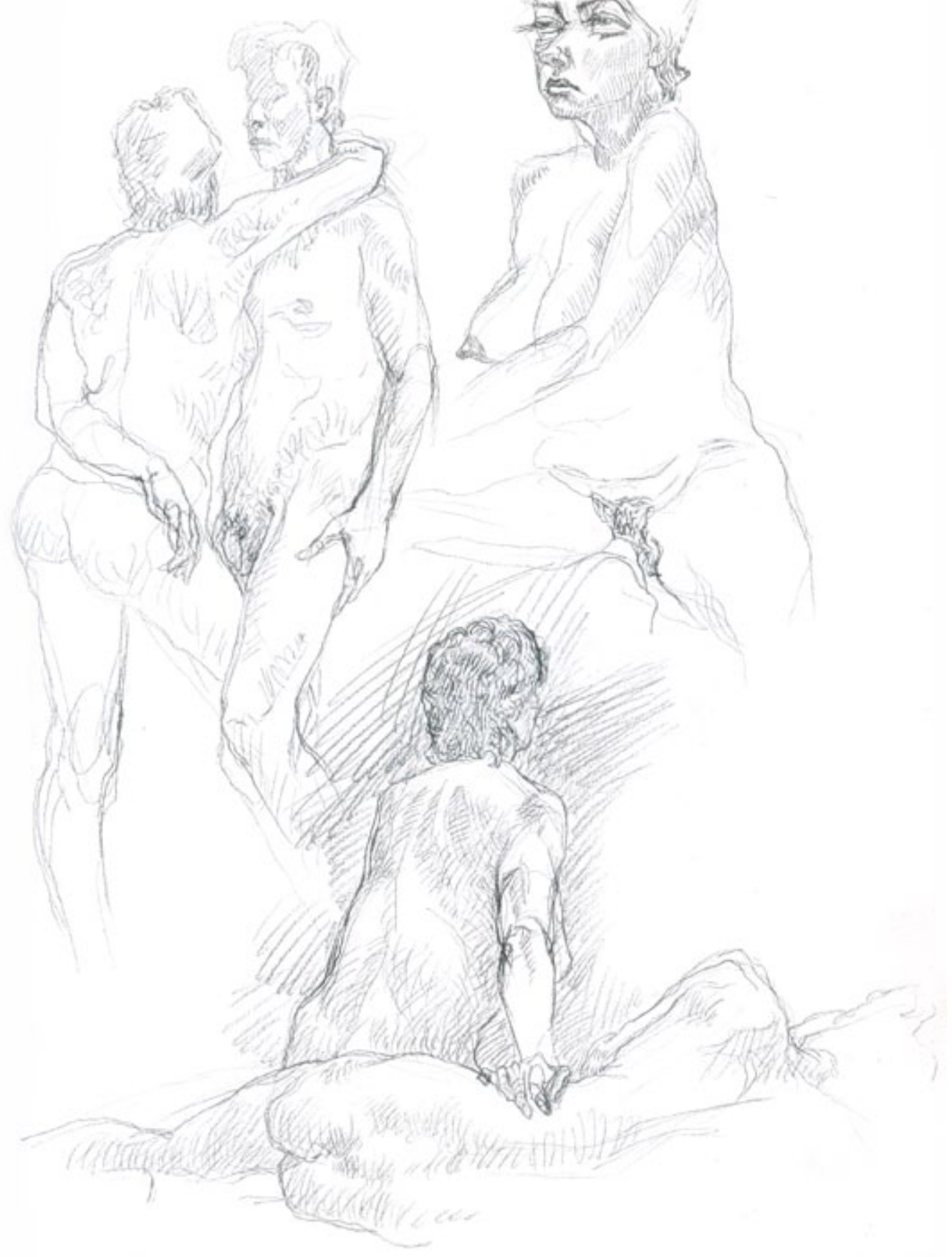



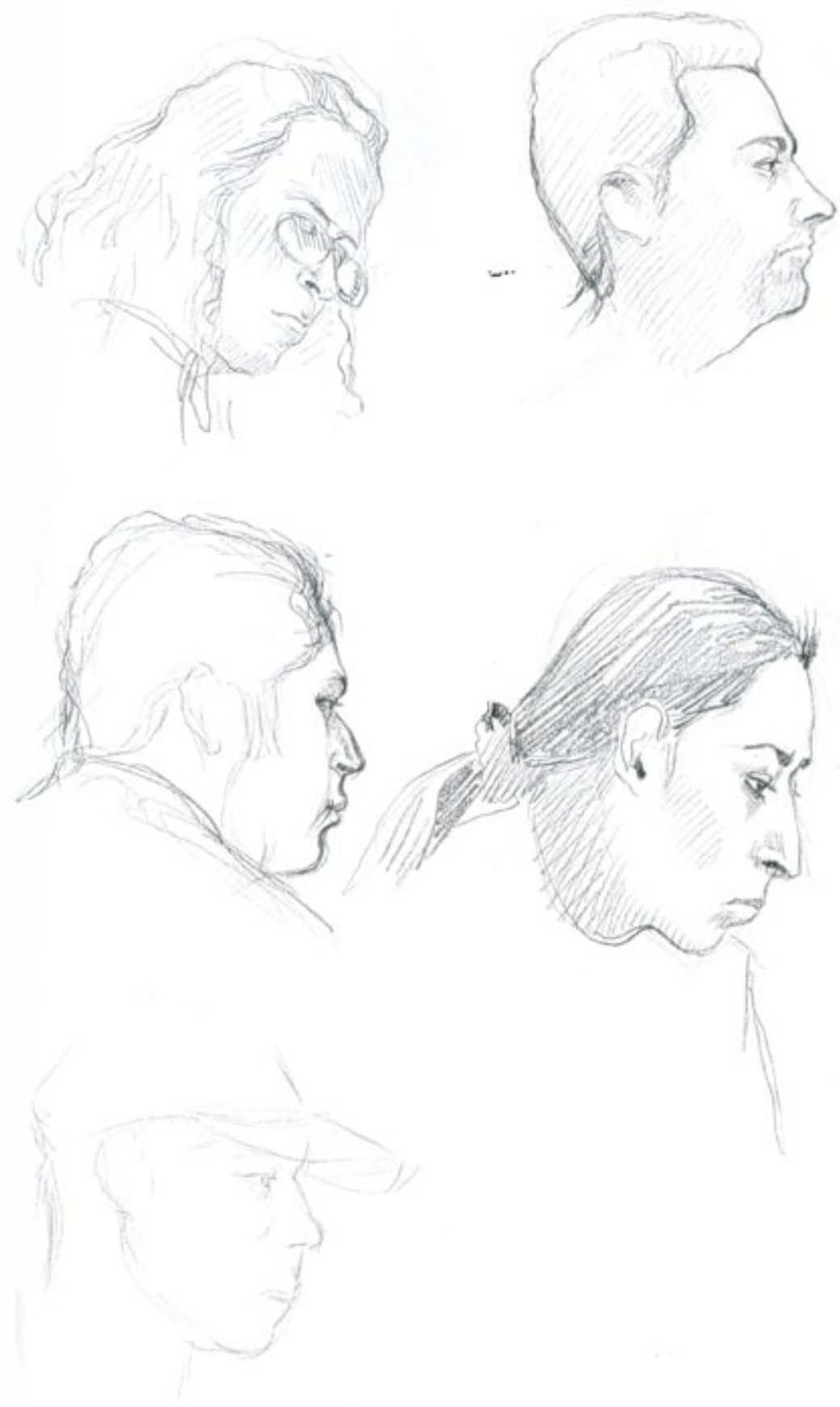

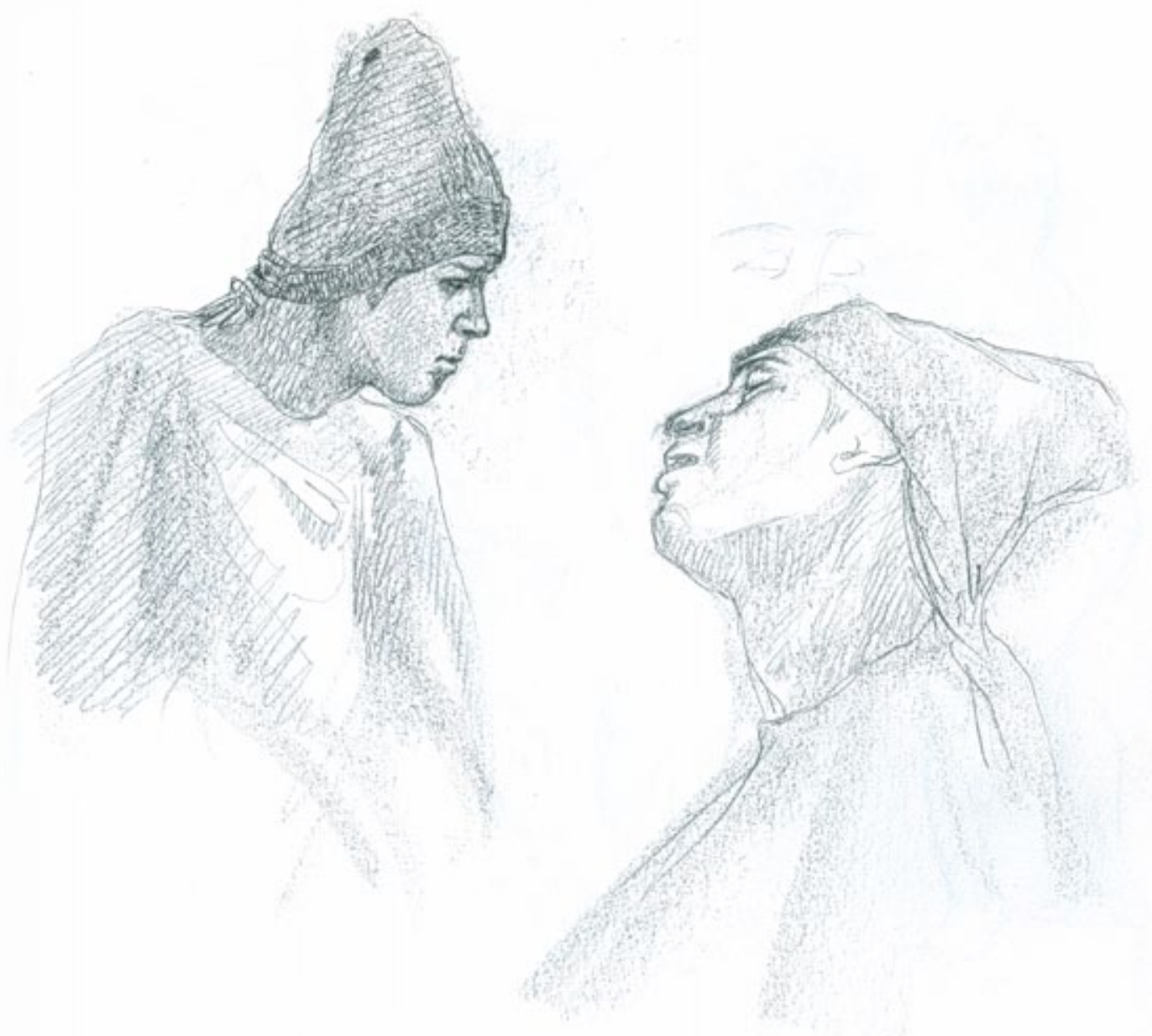


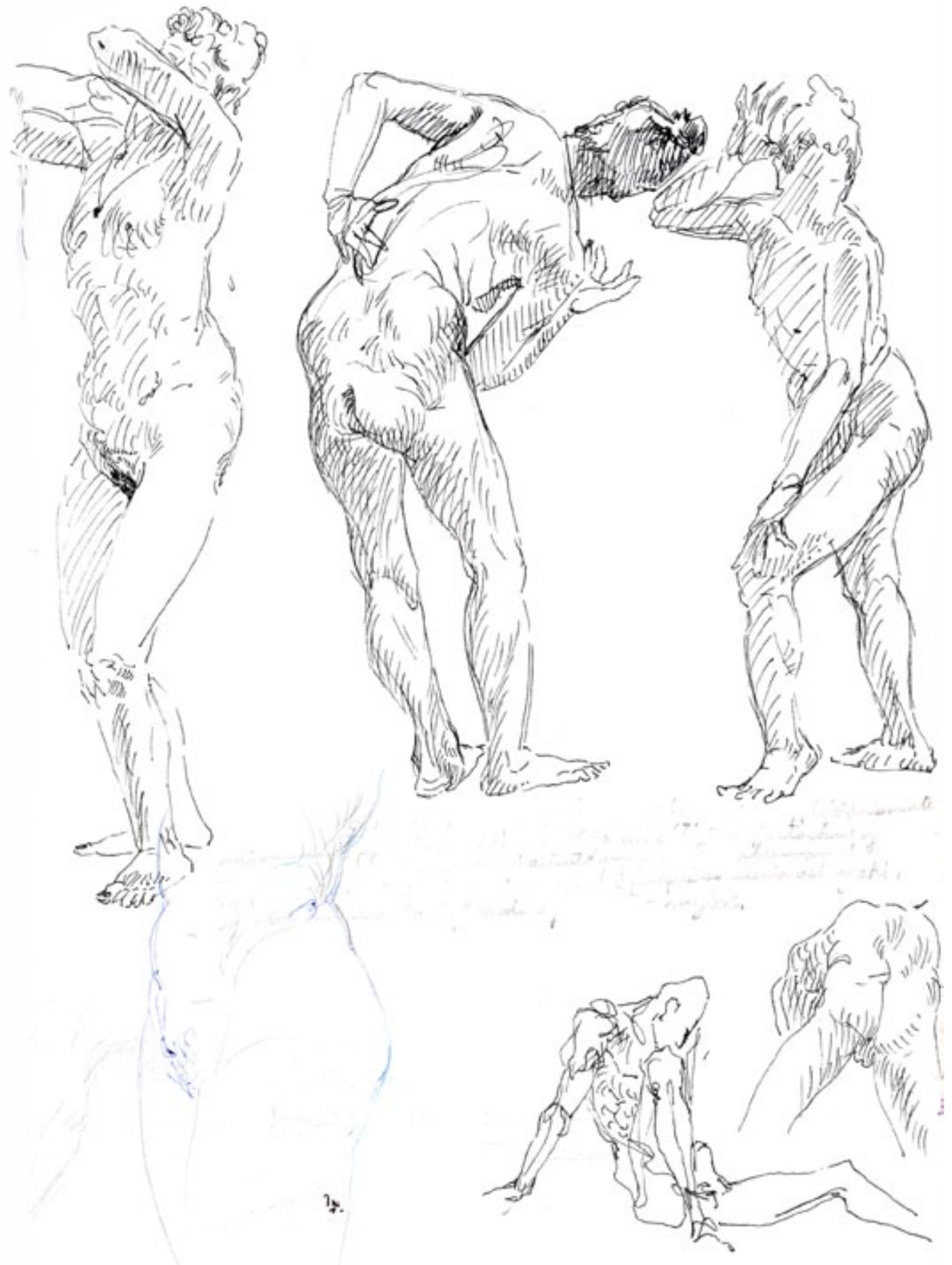




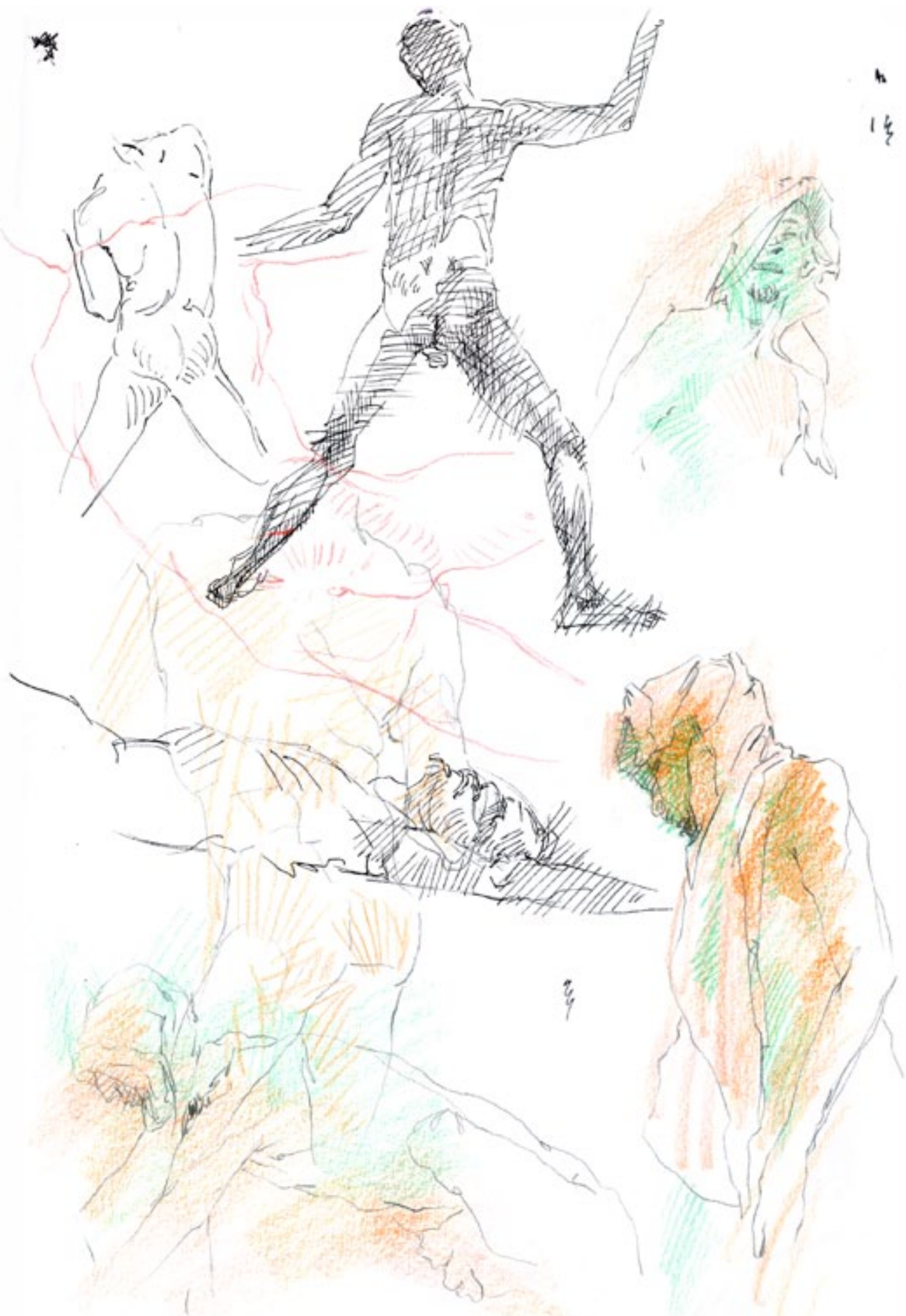




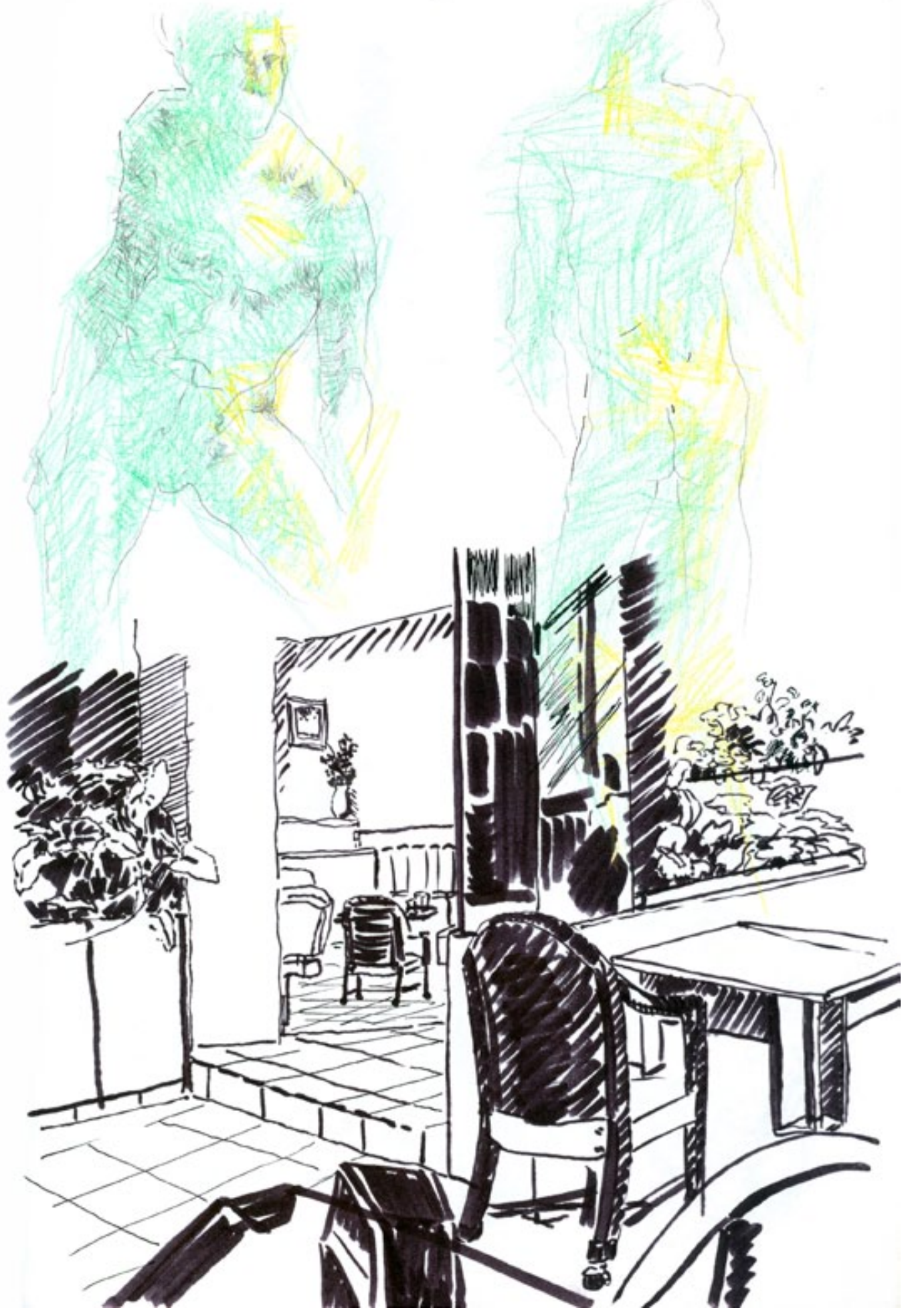




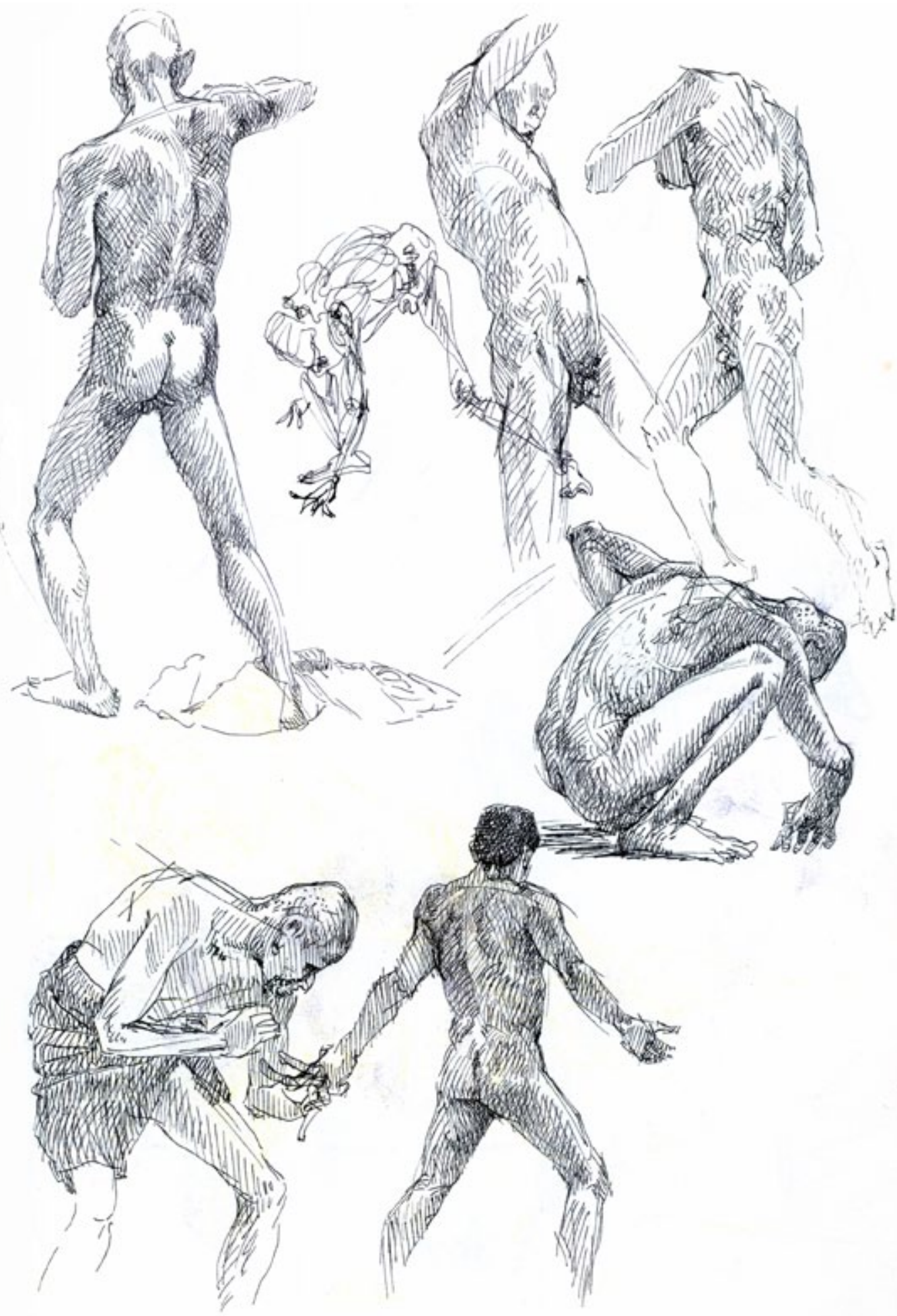




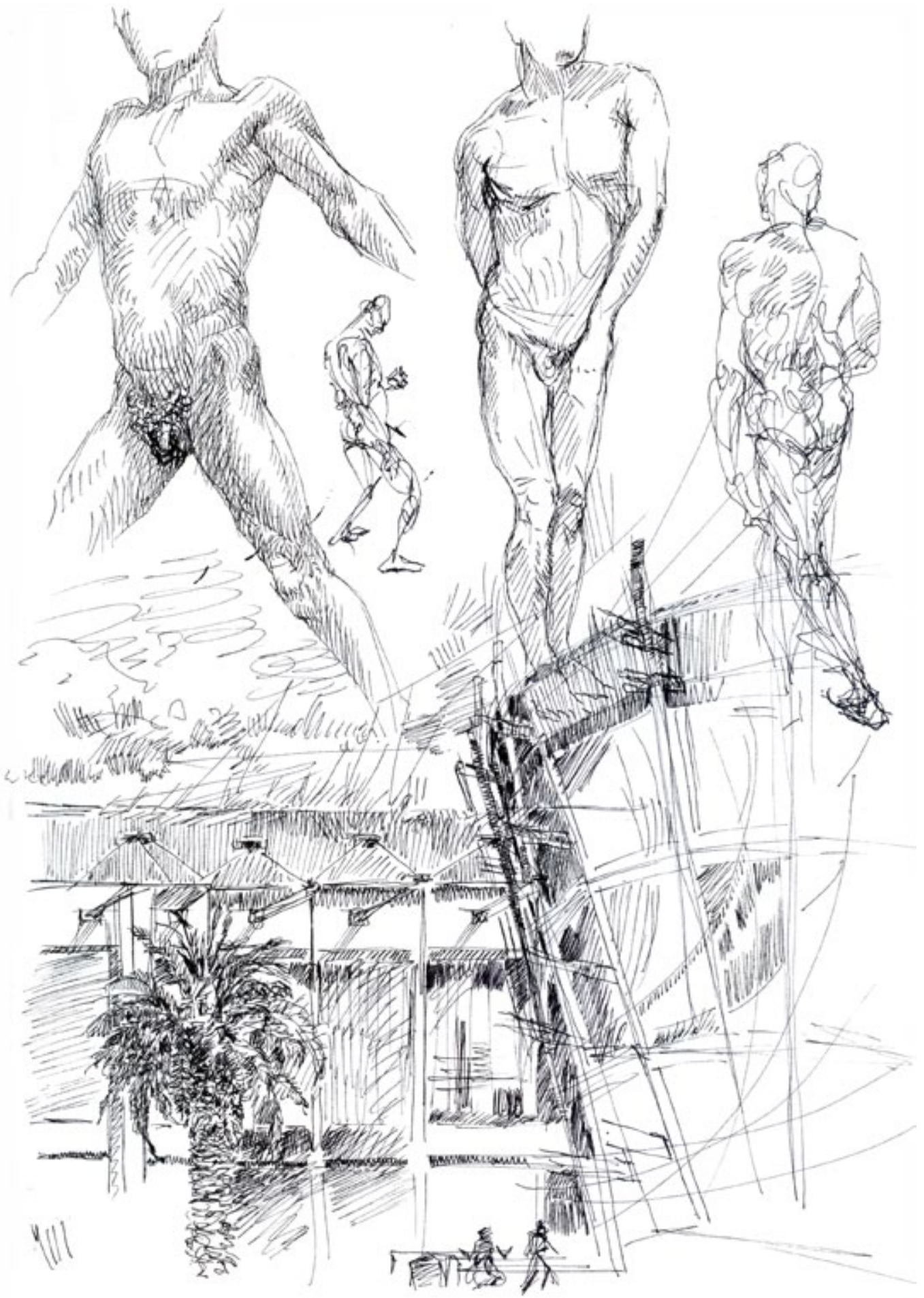




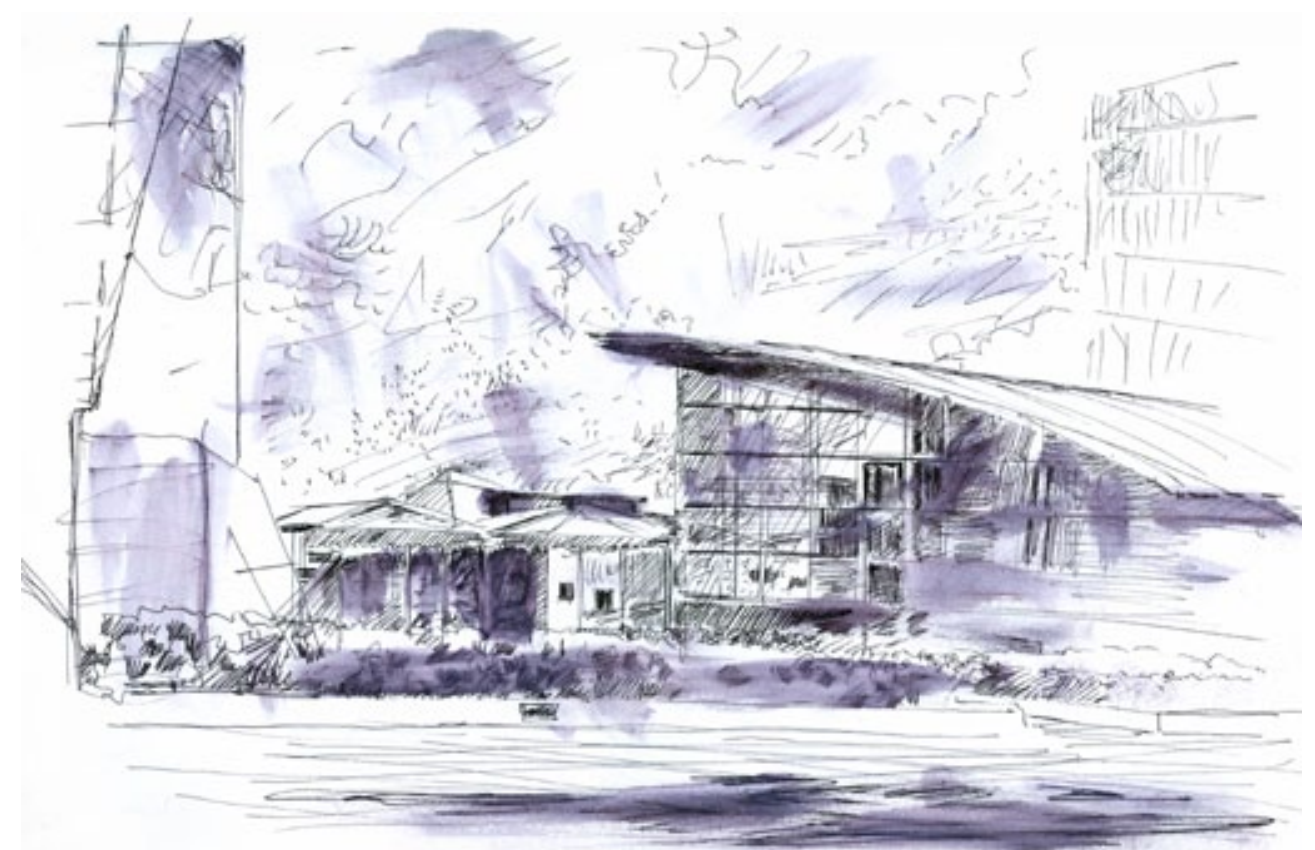




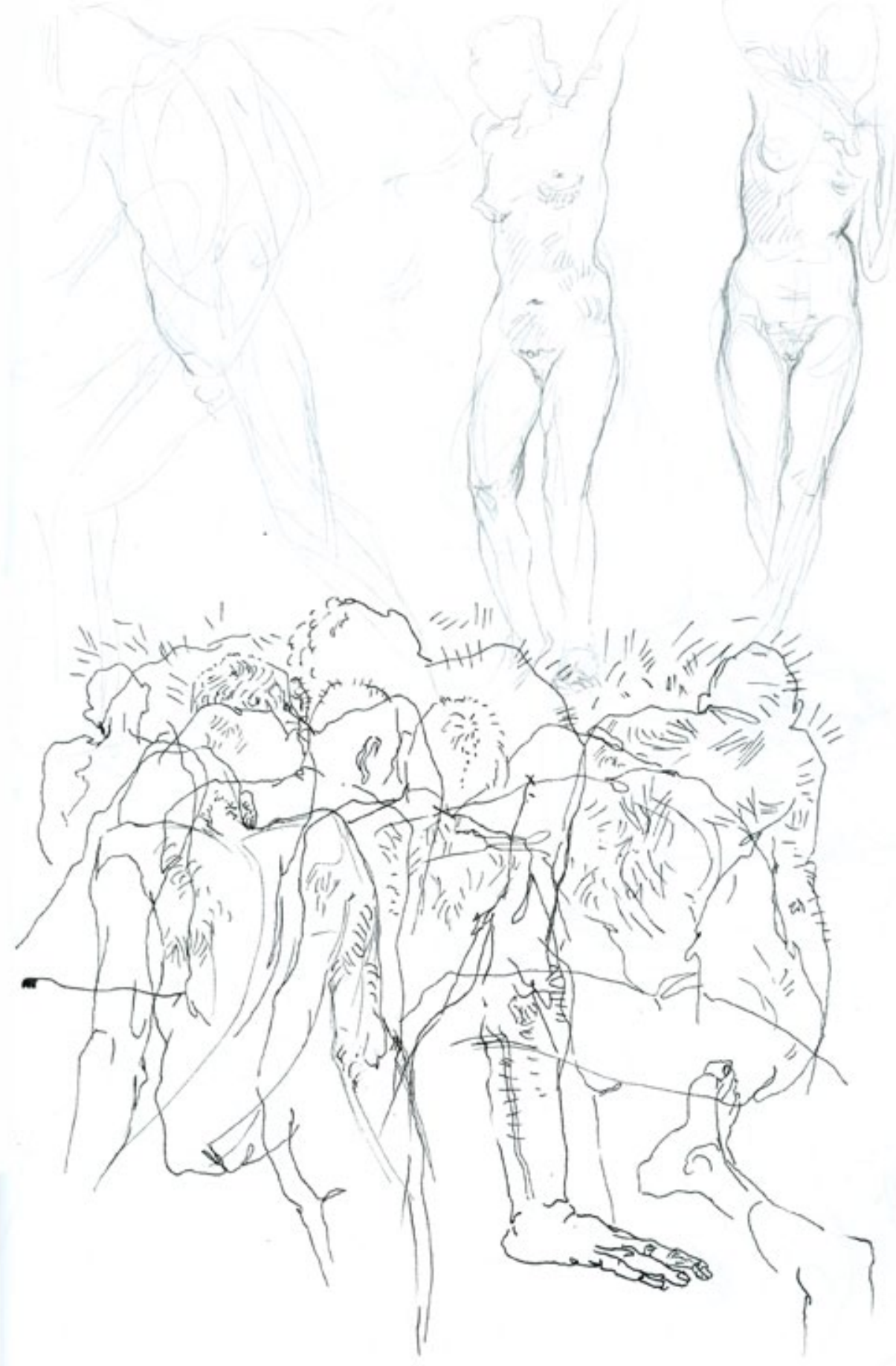




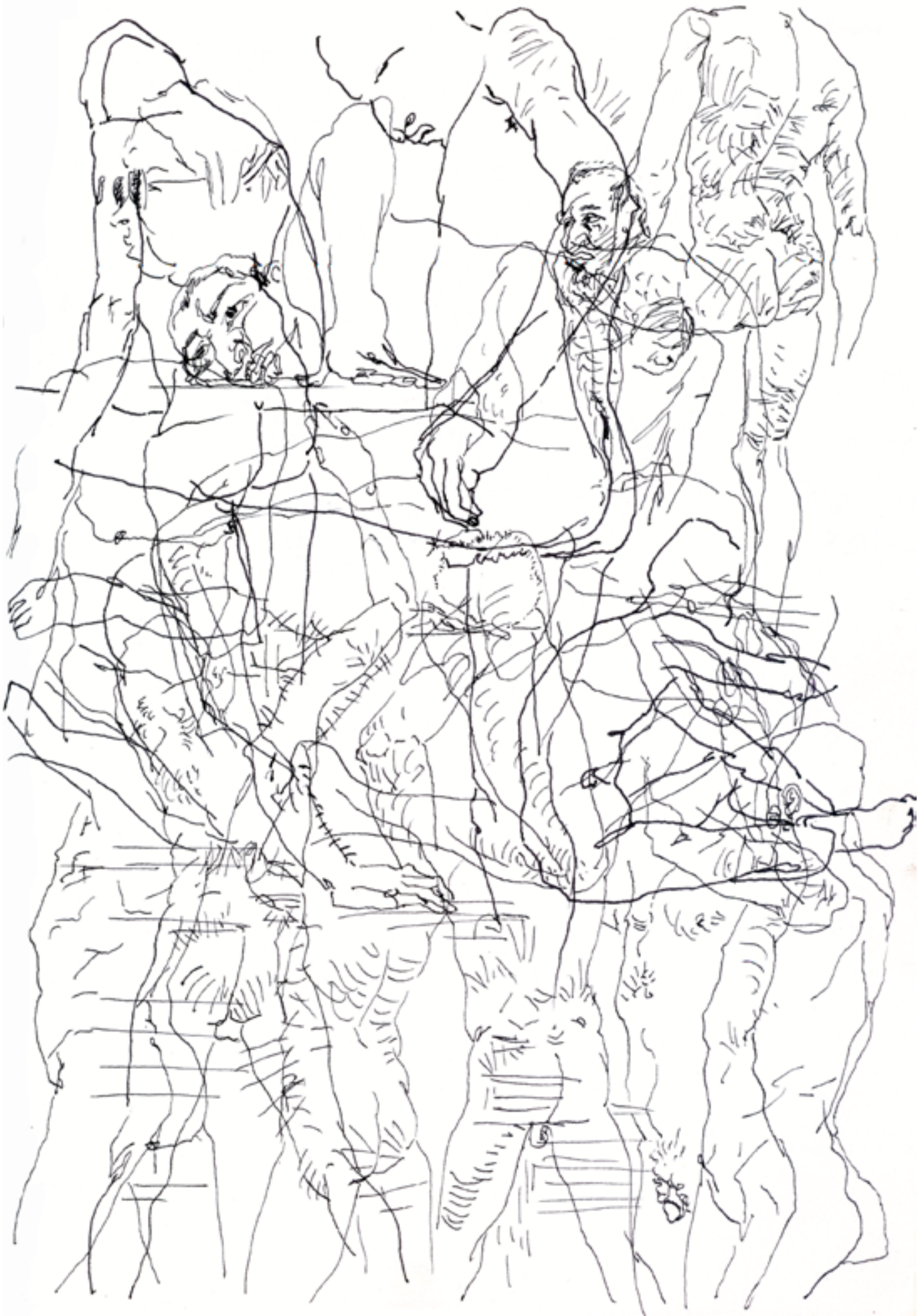




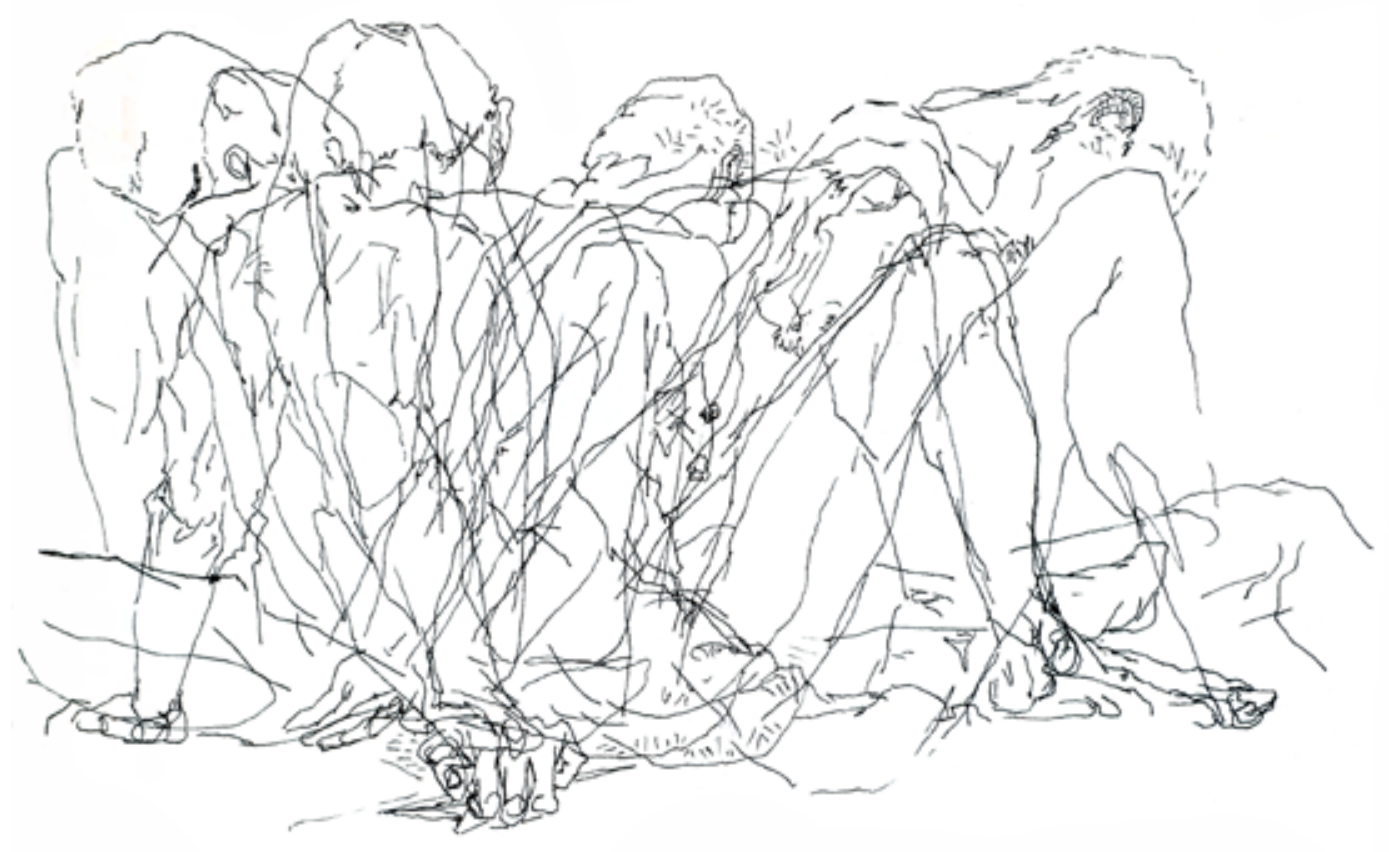




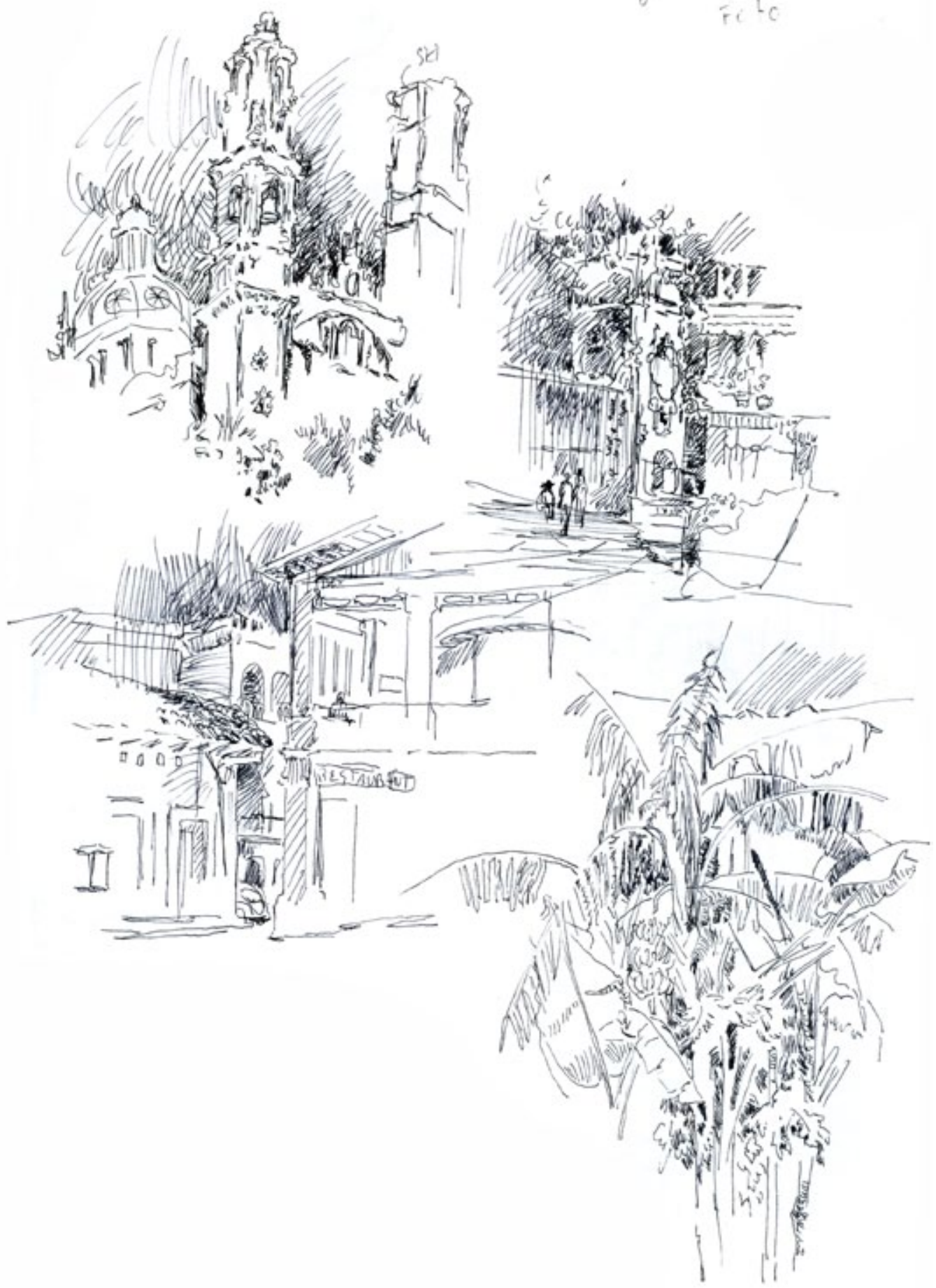




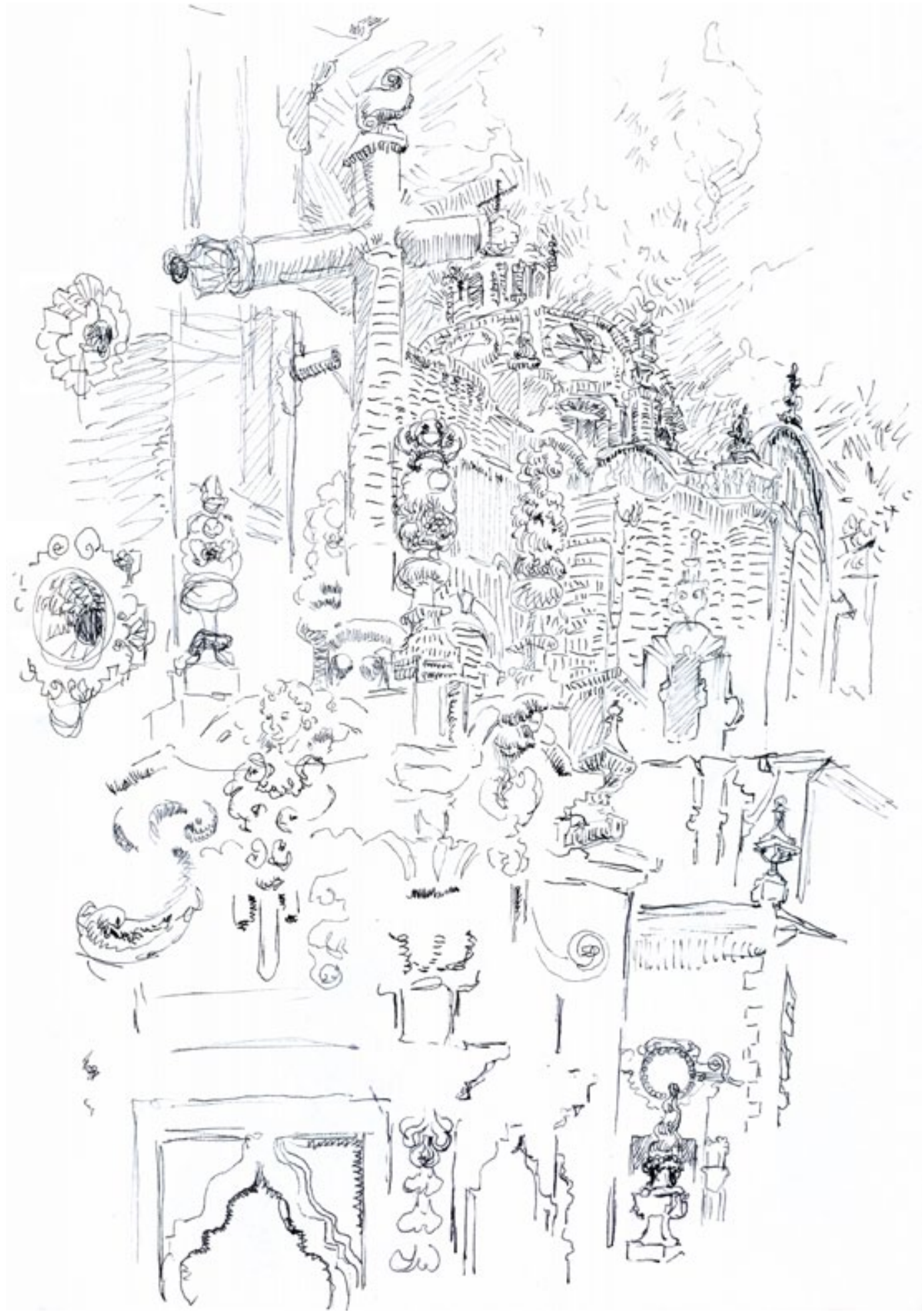




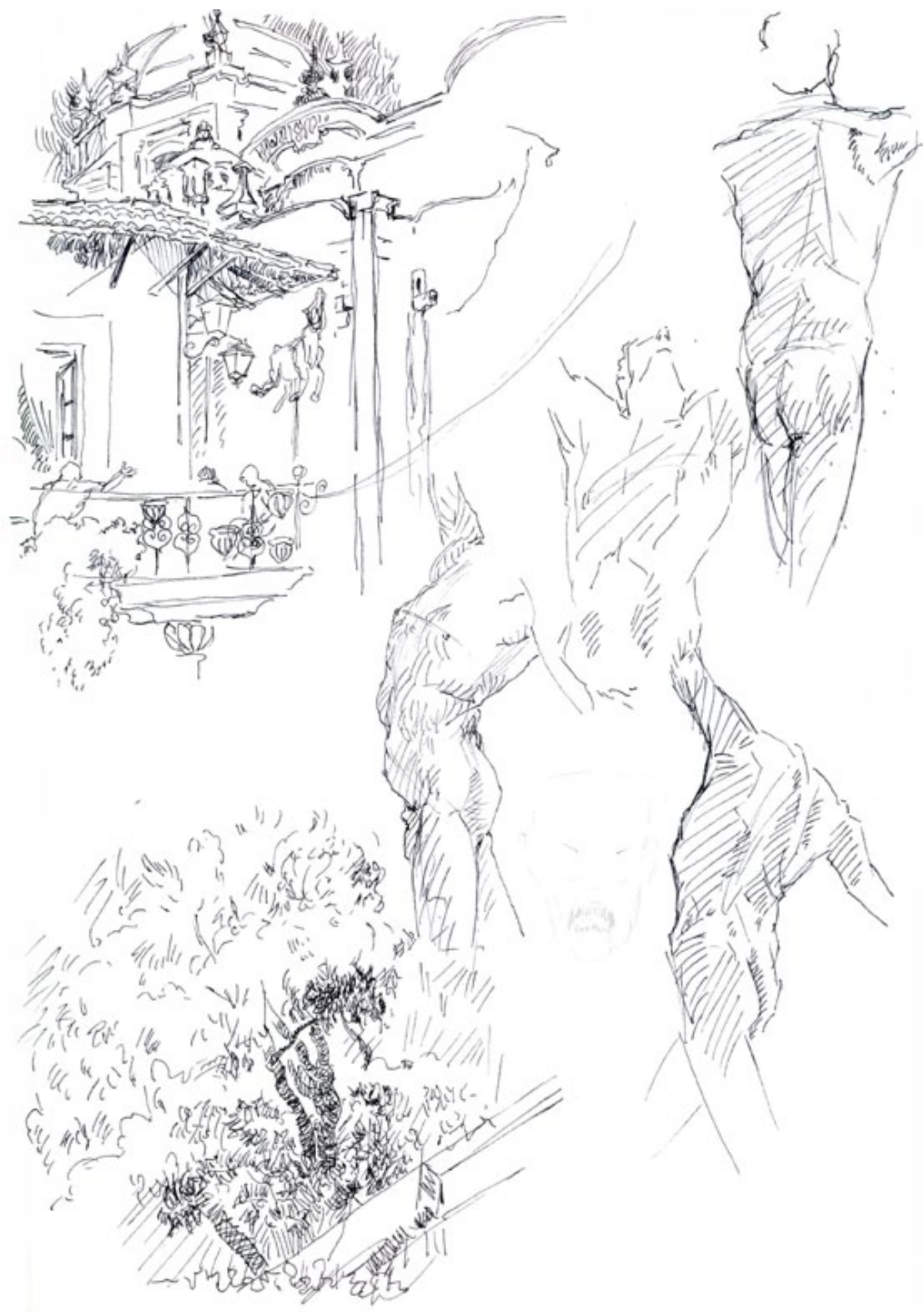




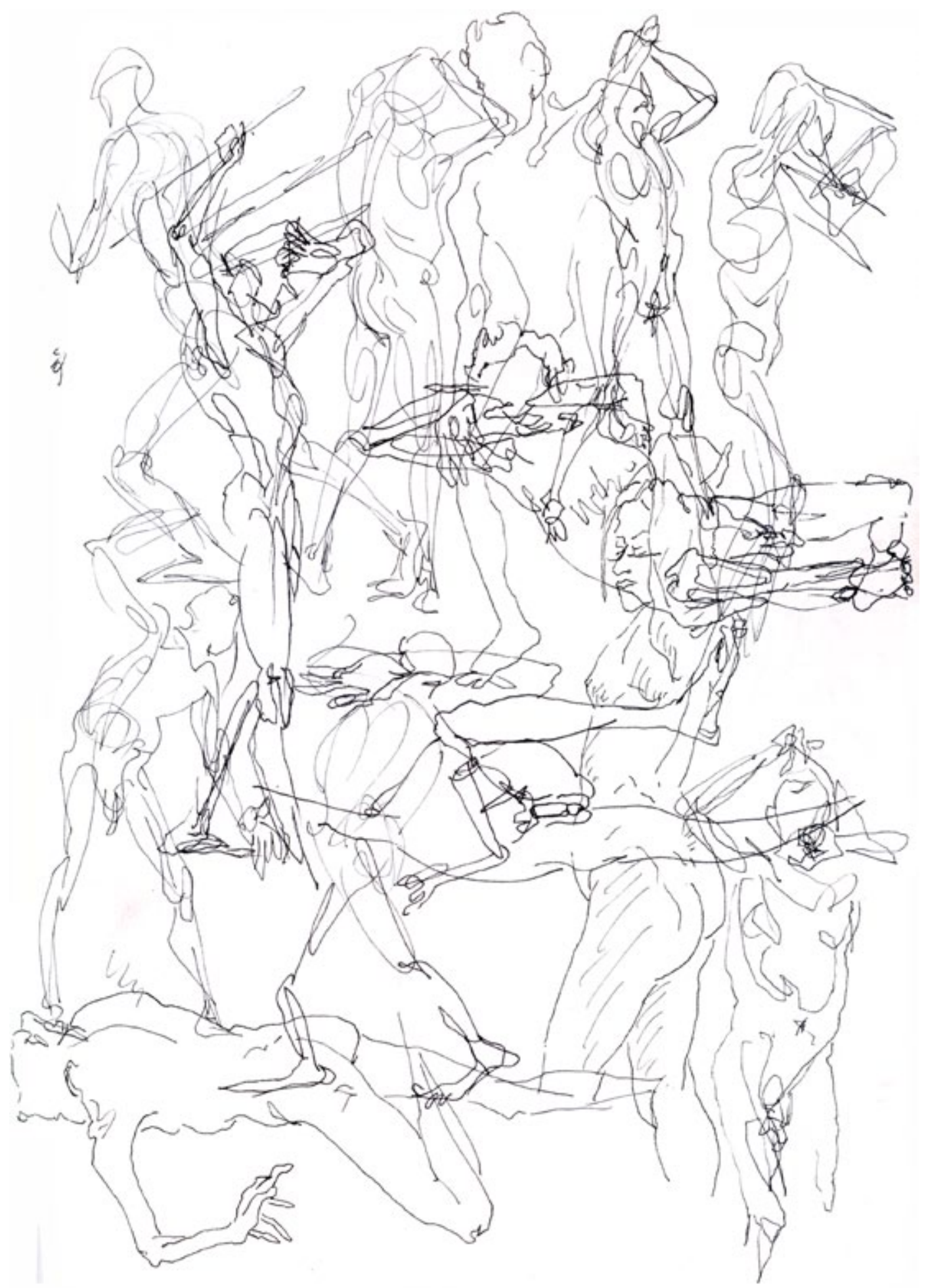



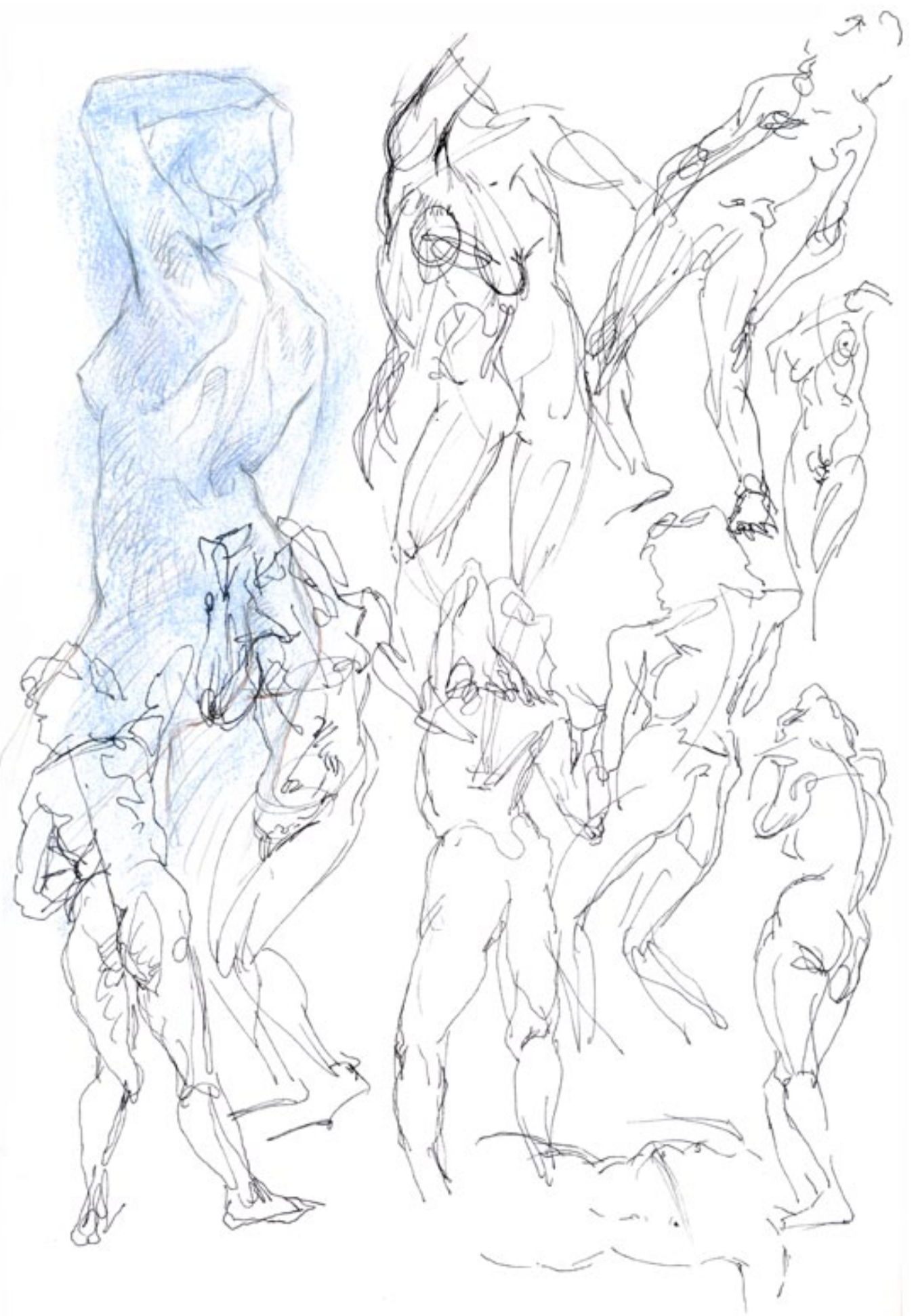


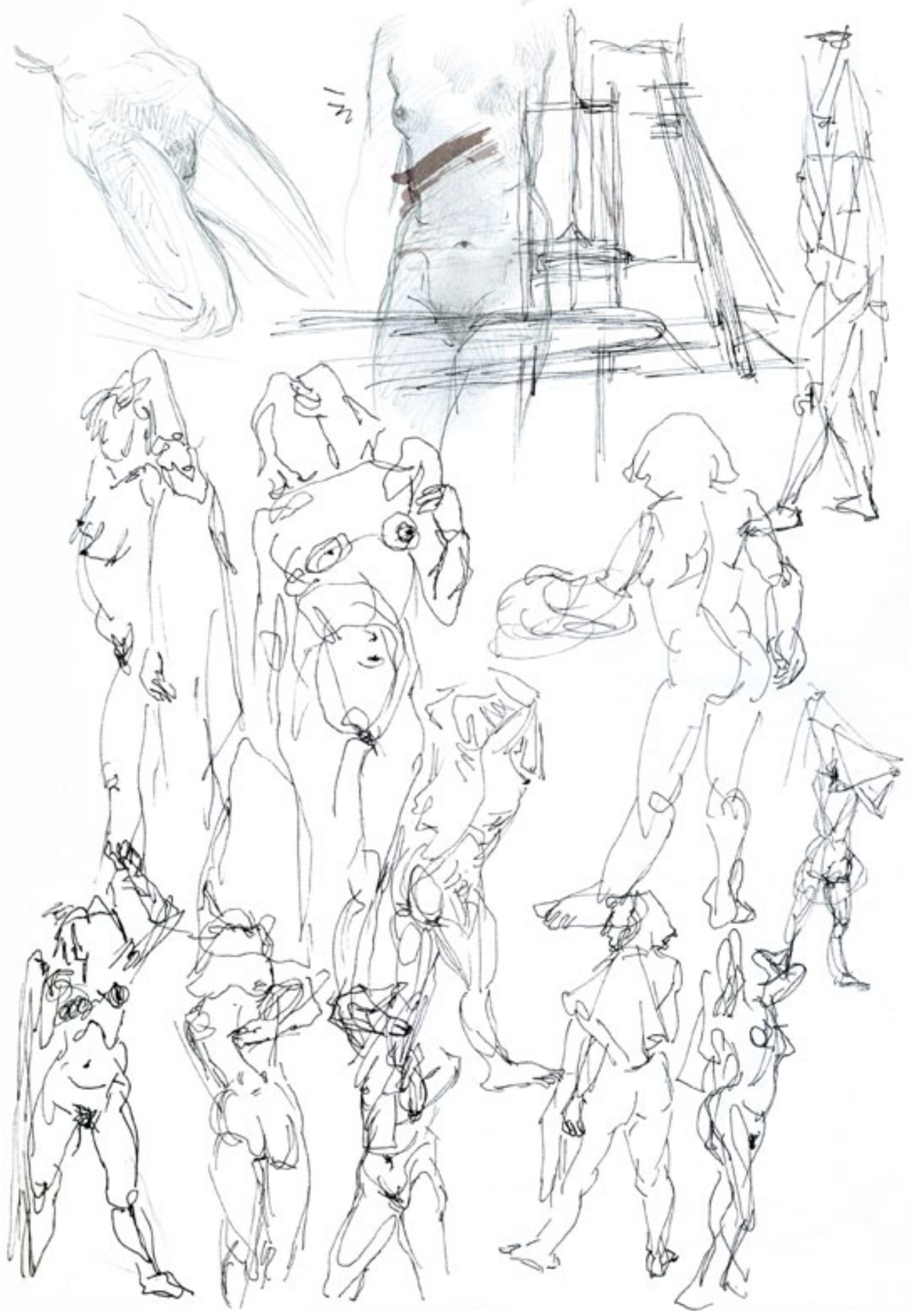




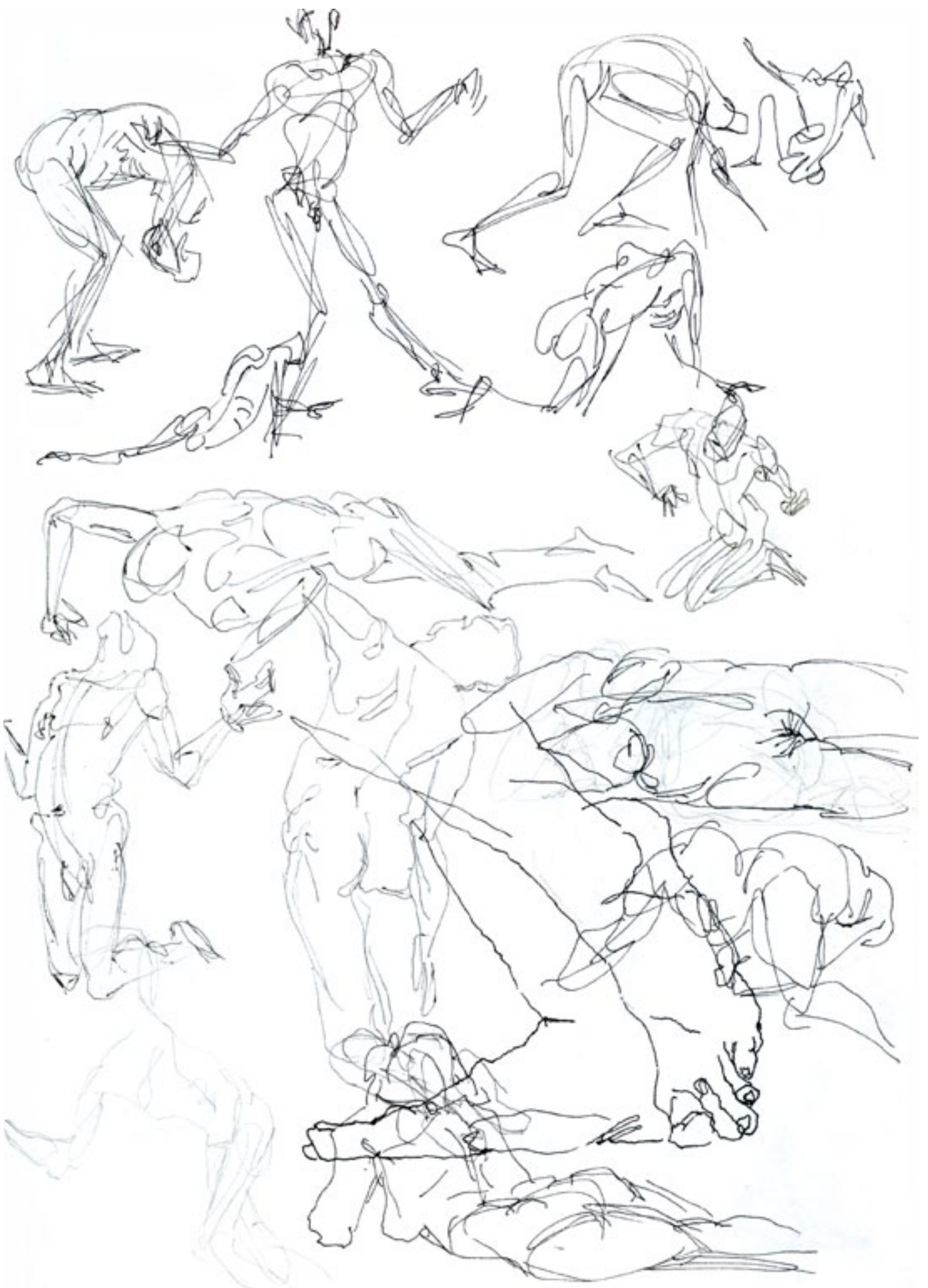




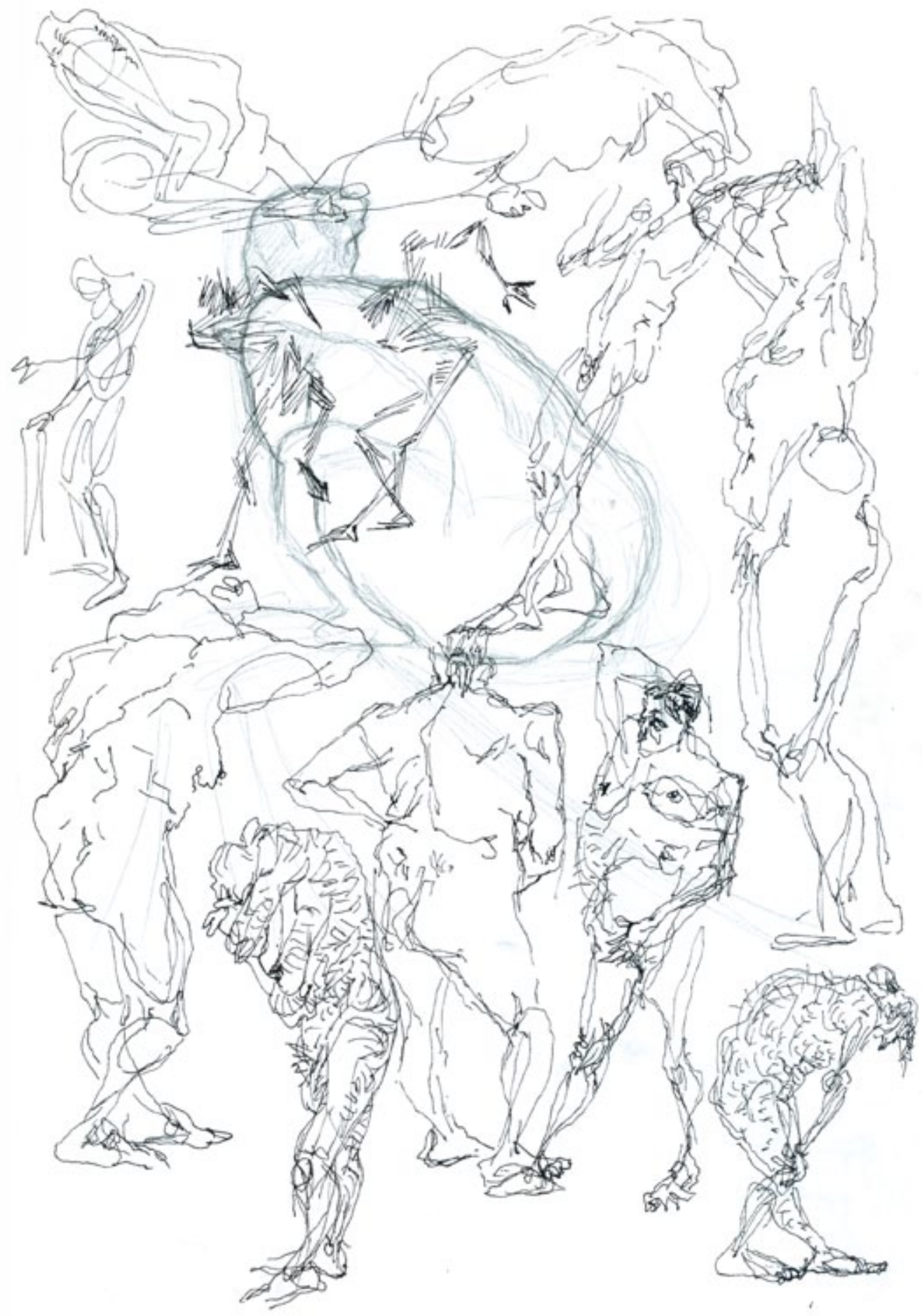




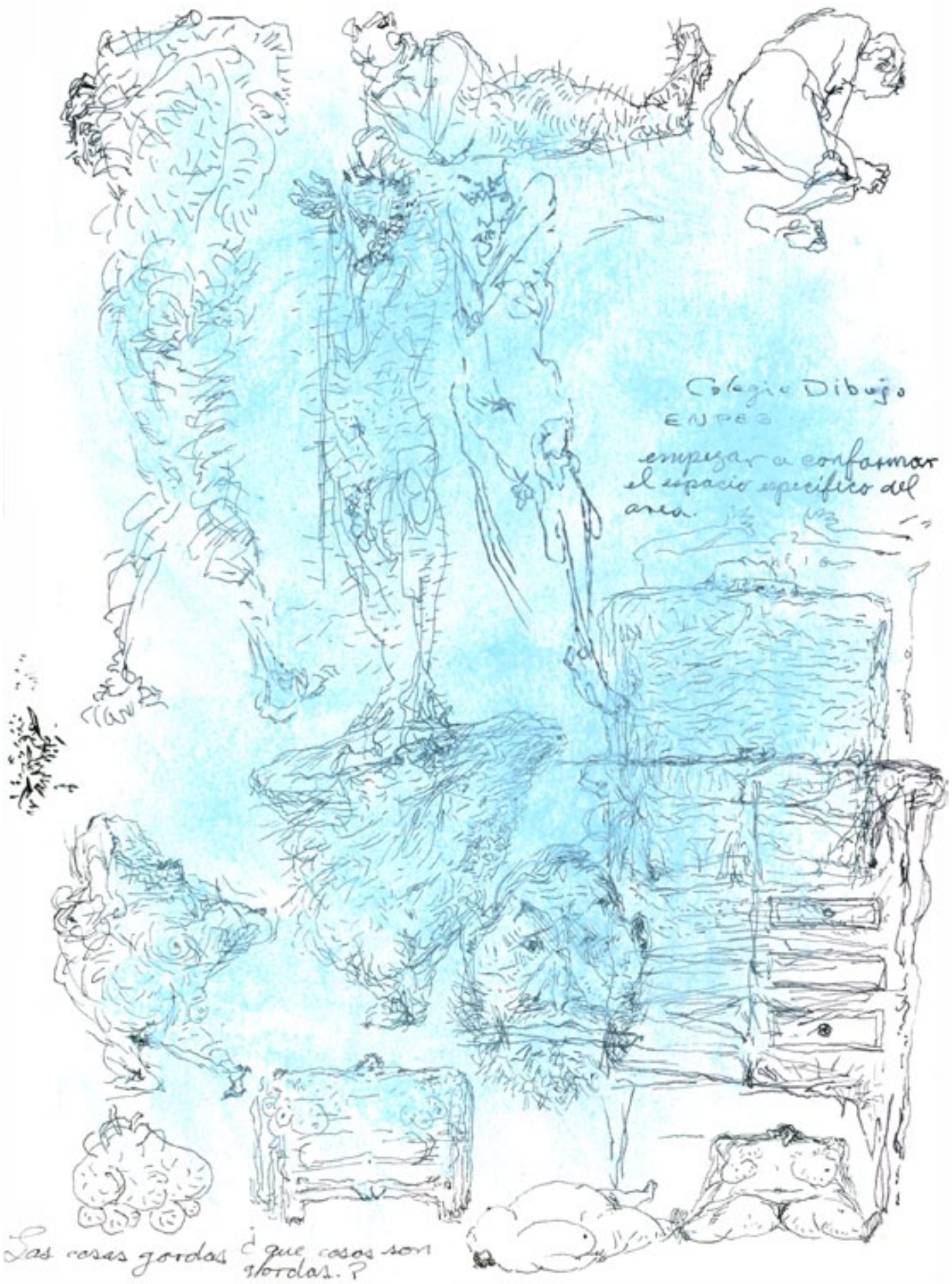


¿sue cosas san yurdas?

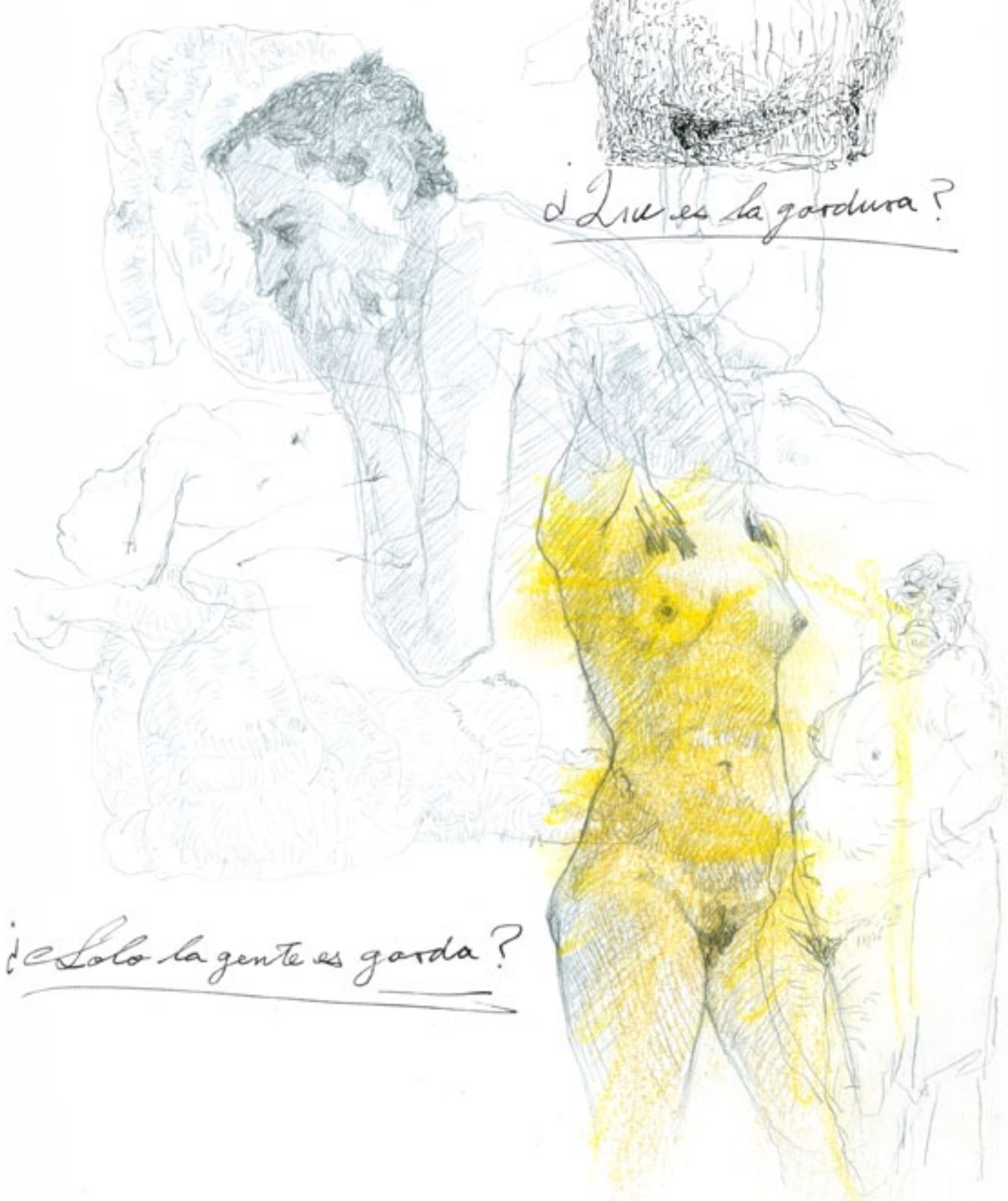




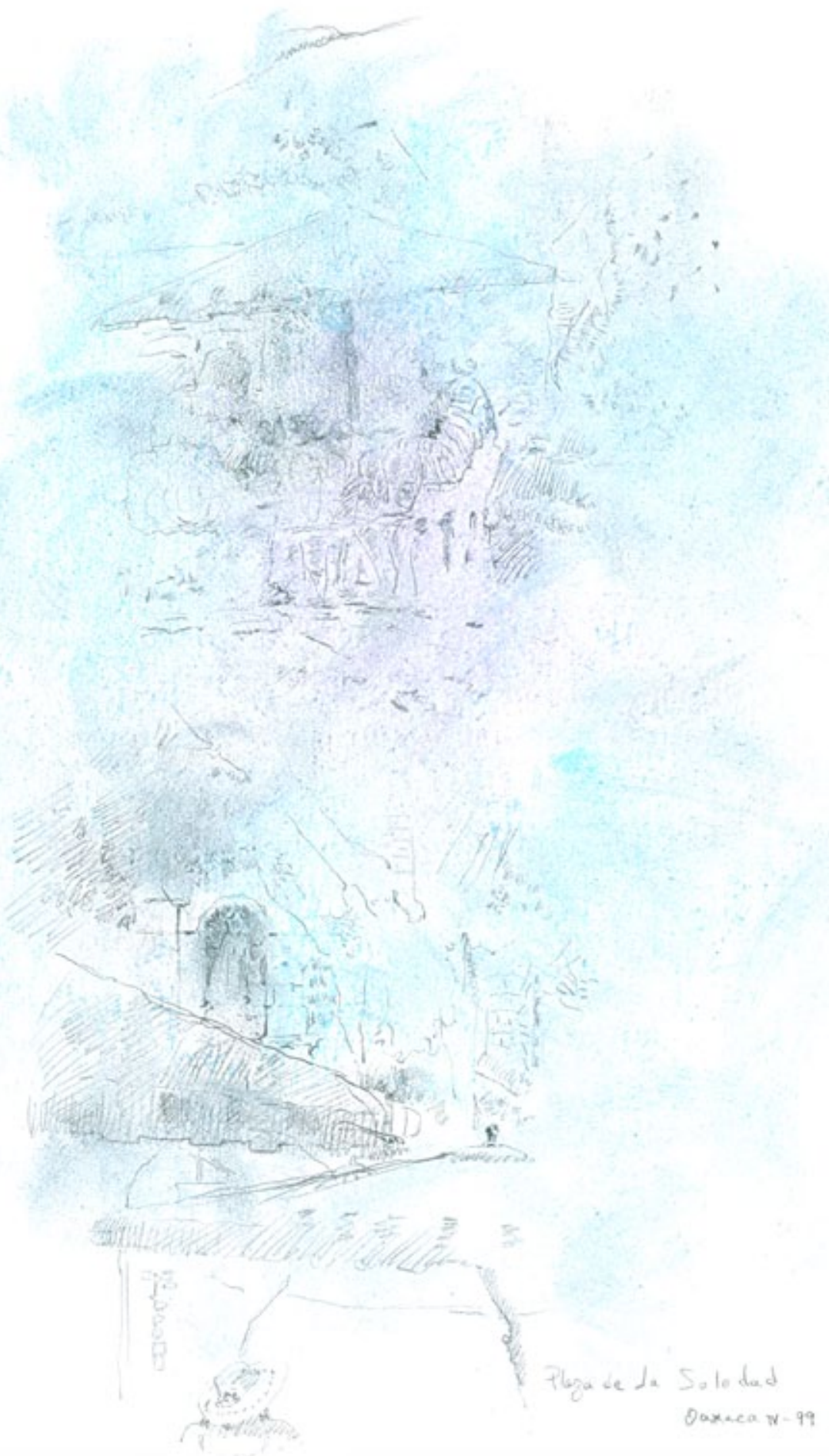




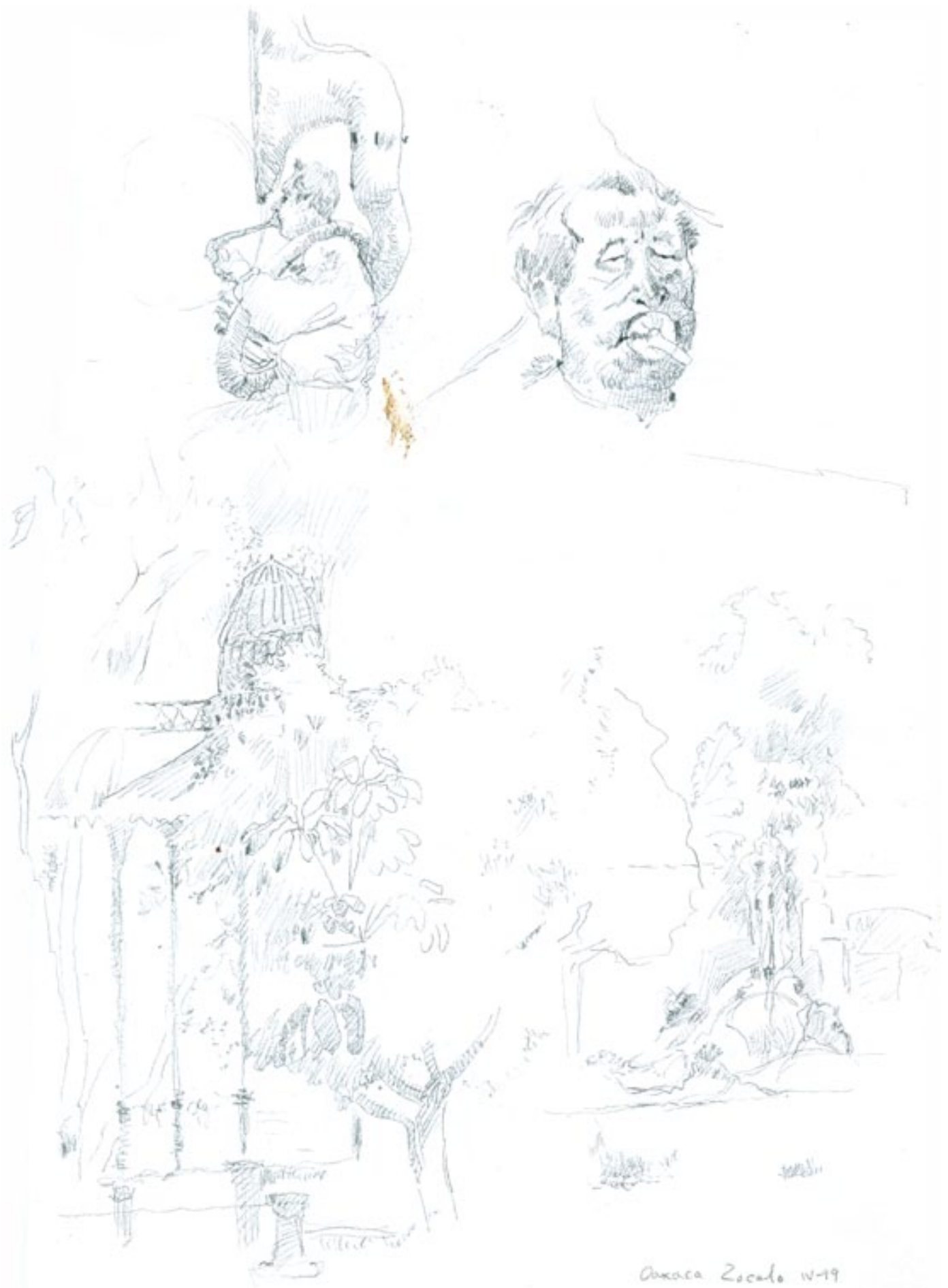




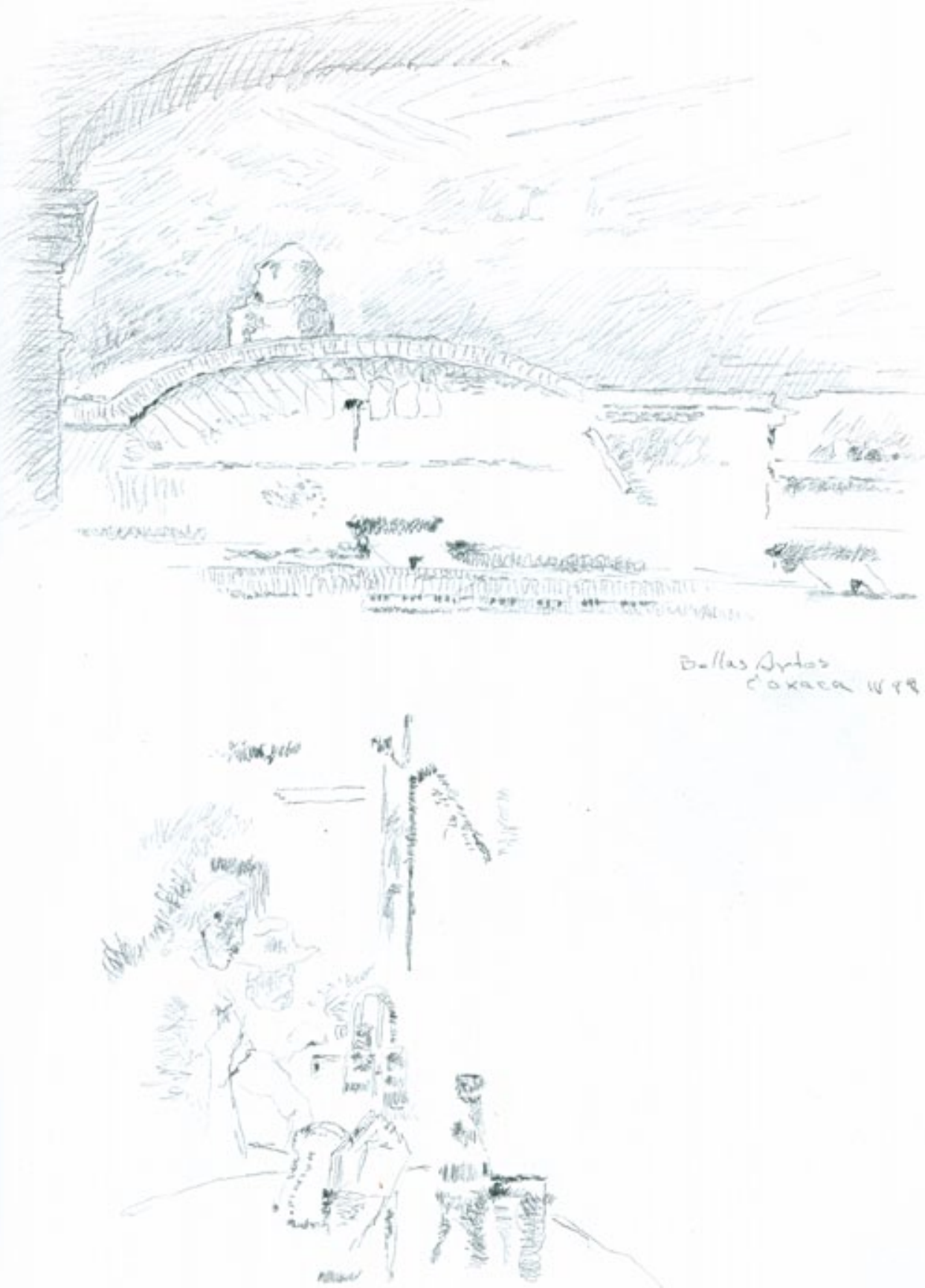




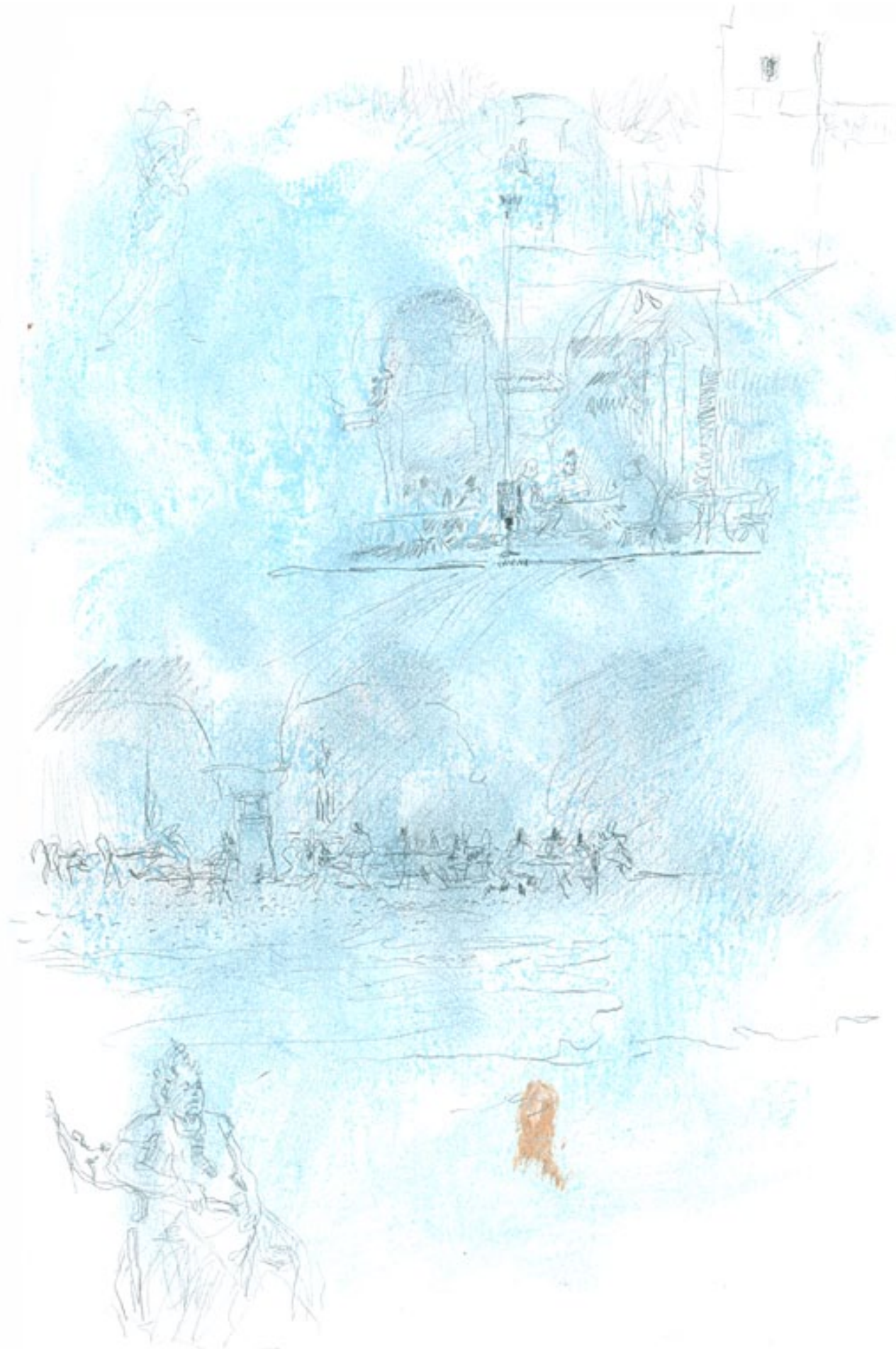




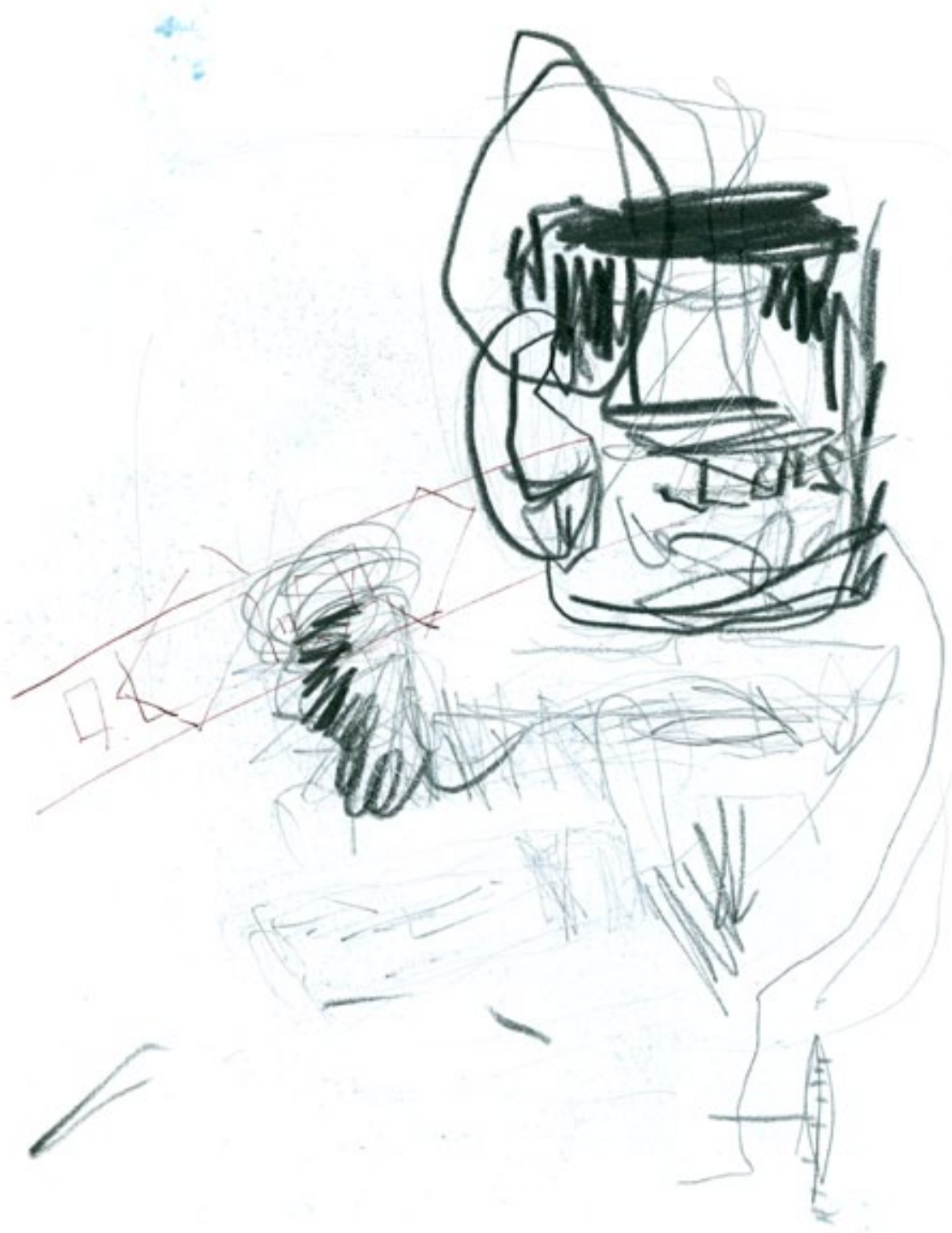




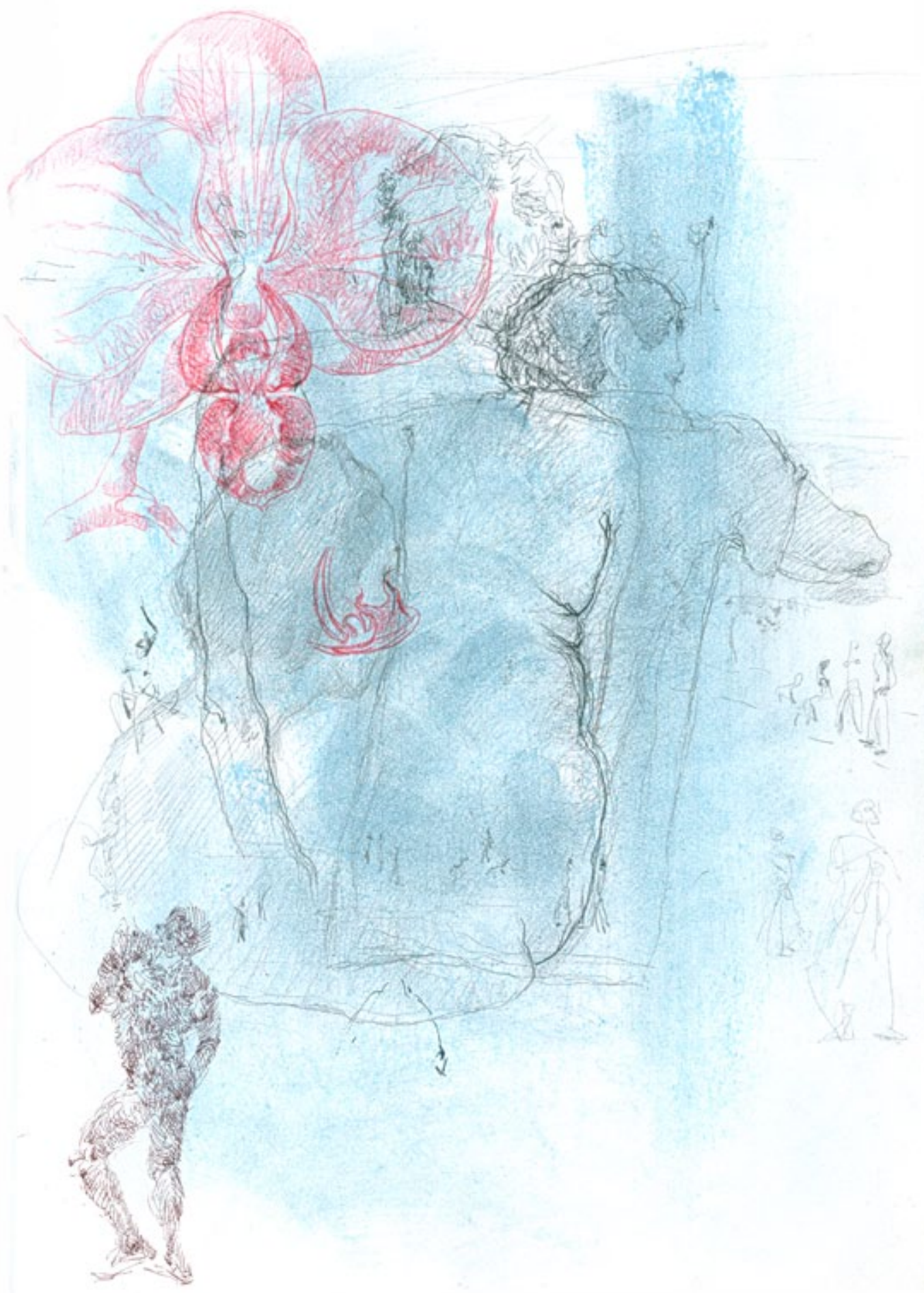




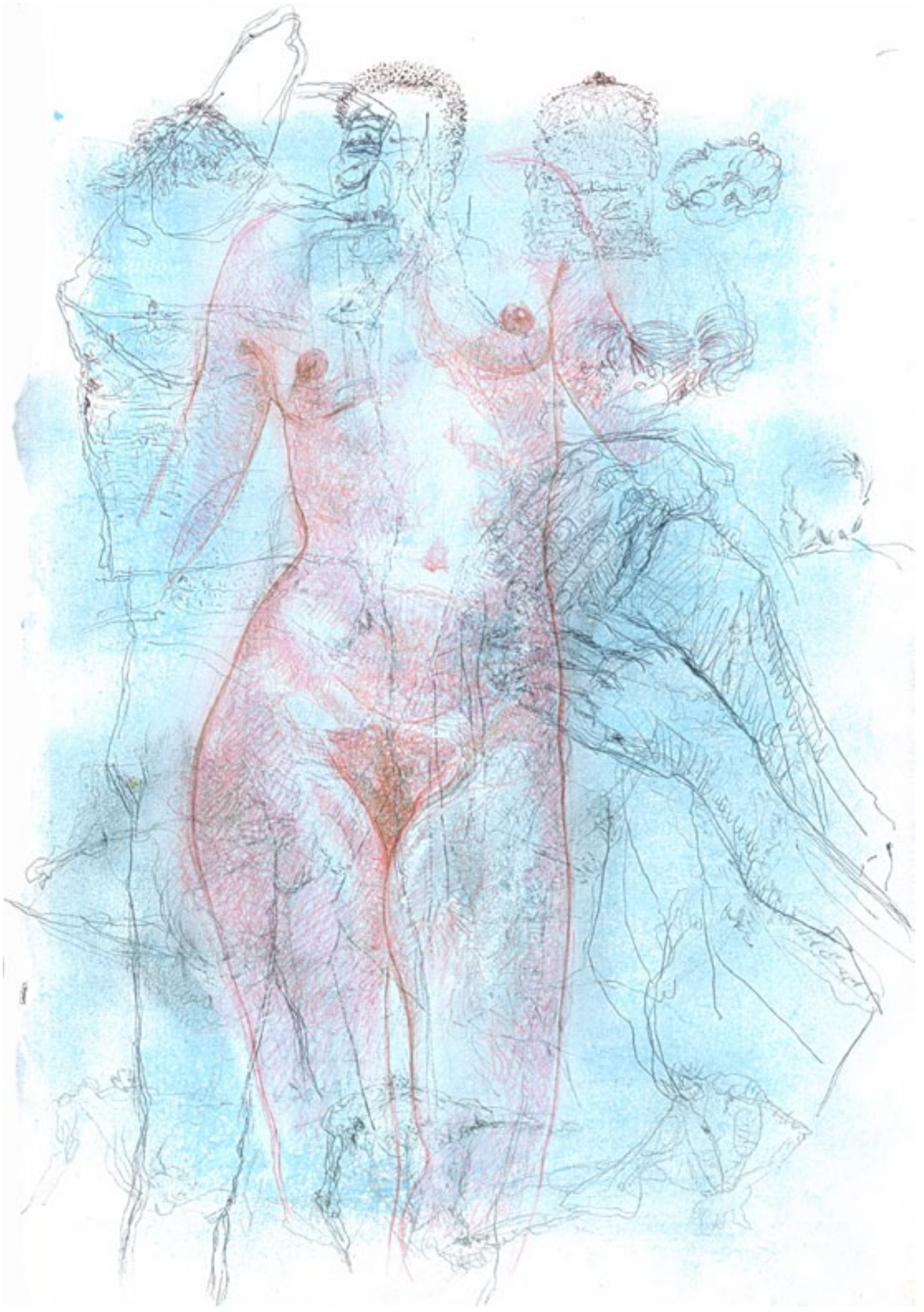




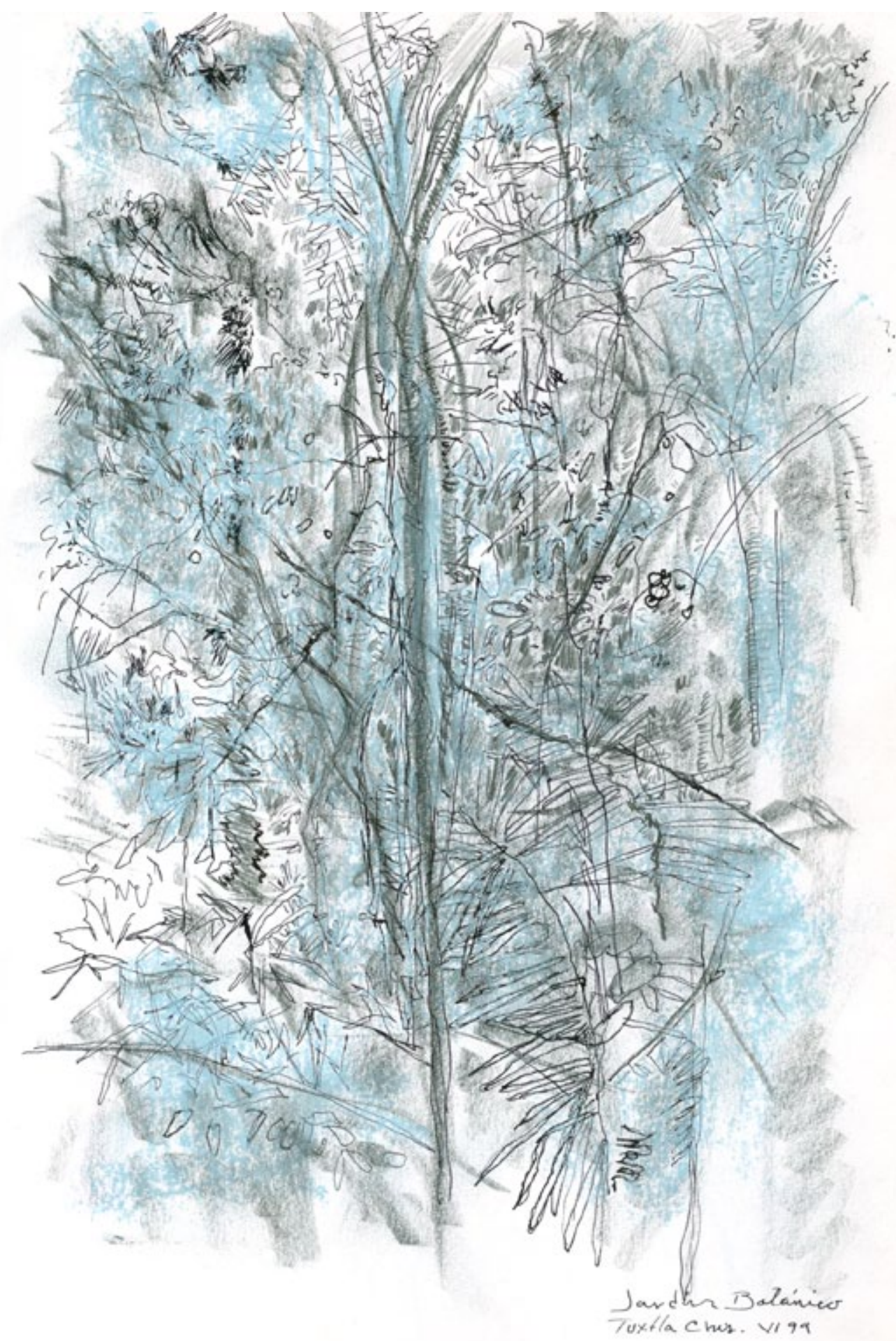




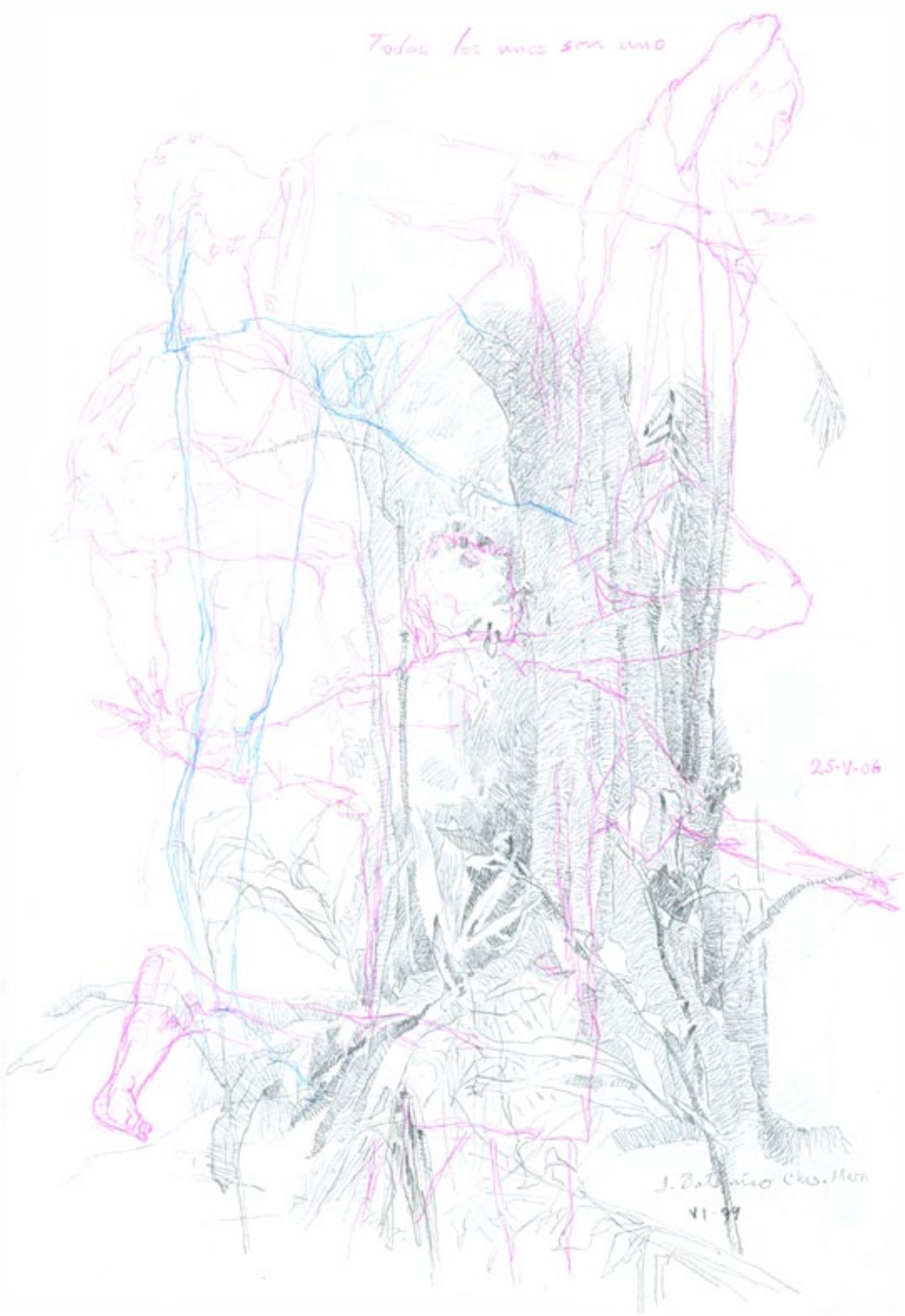


LO QUE NUNCA TERMINA (MASA VISUAL, SINCRONÍA ESPACIAL Y TEMPORAL)

653

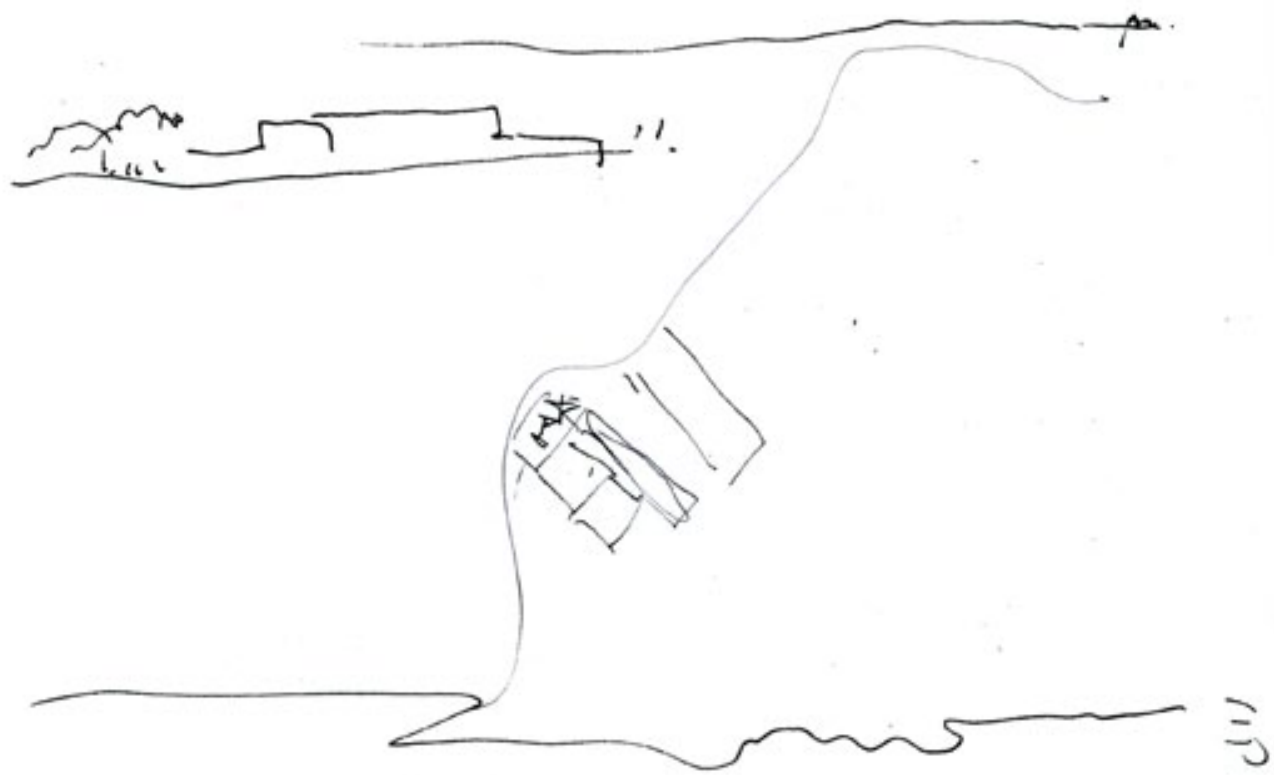

"Pifyar los cosos" "s"

"Ciajar los suasos." 


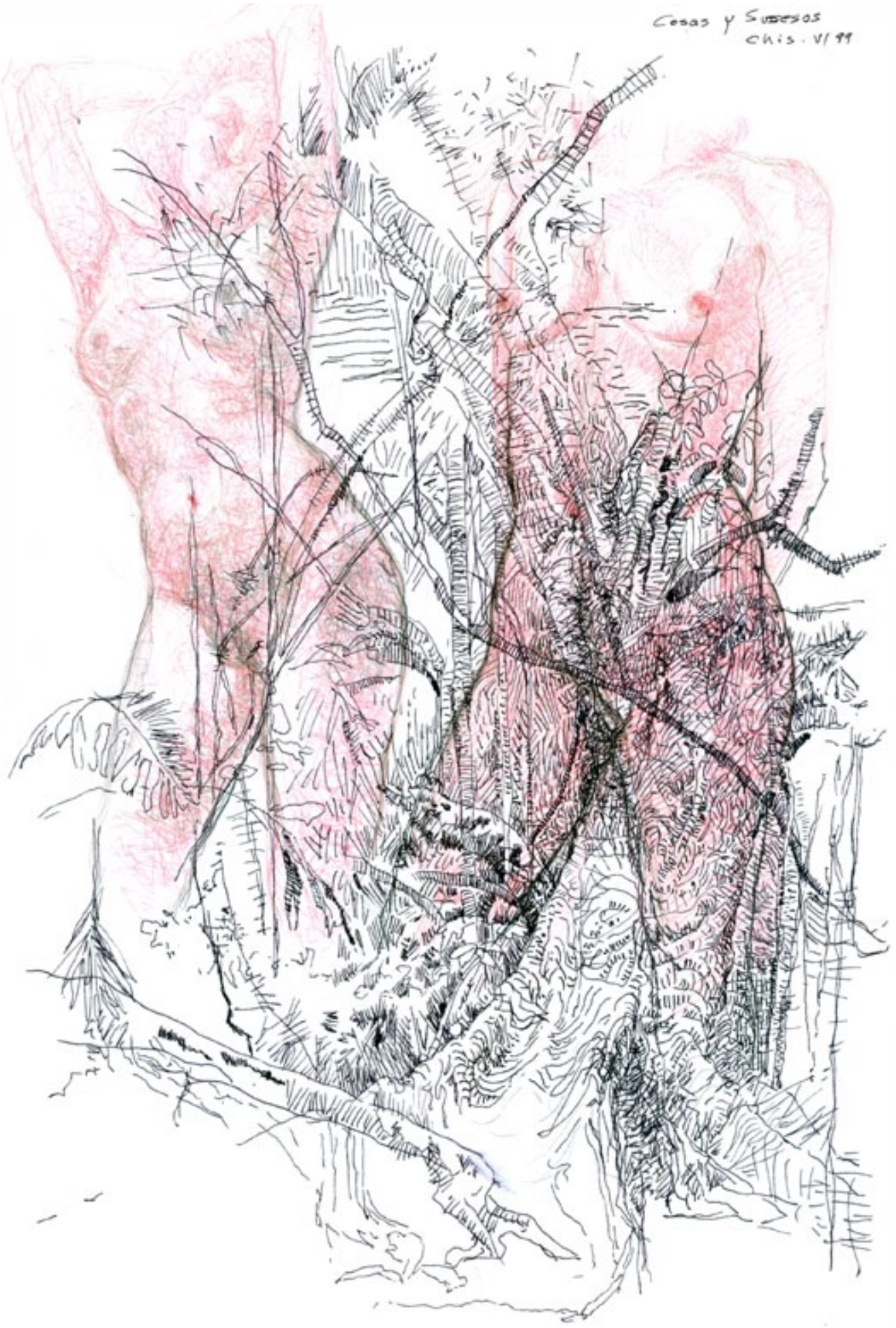




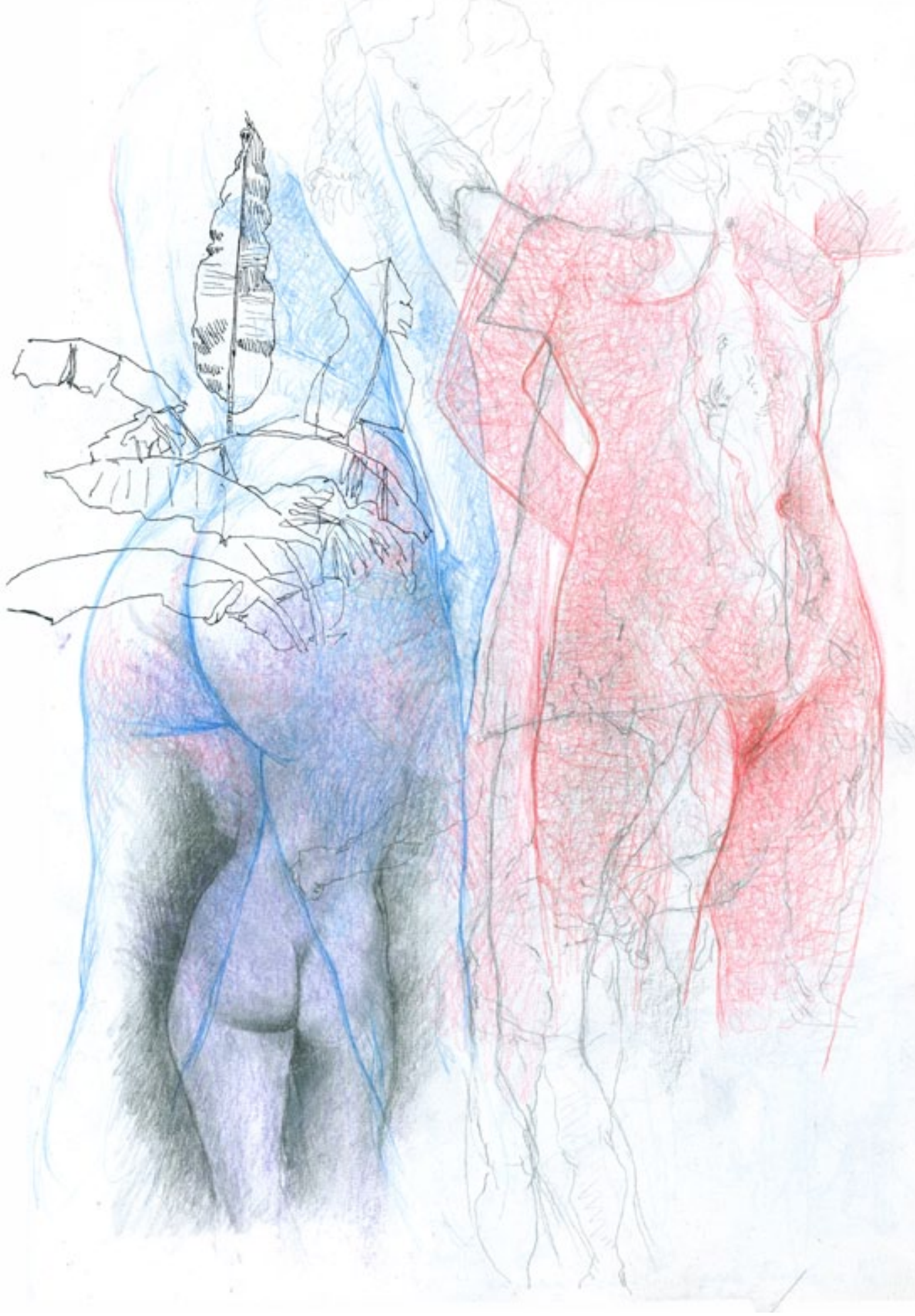




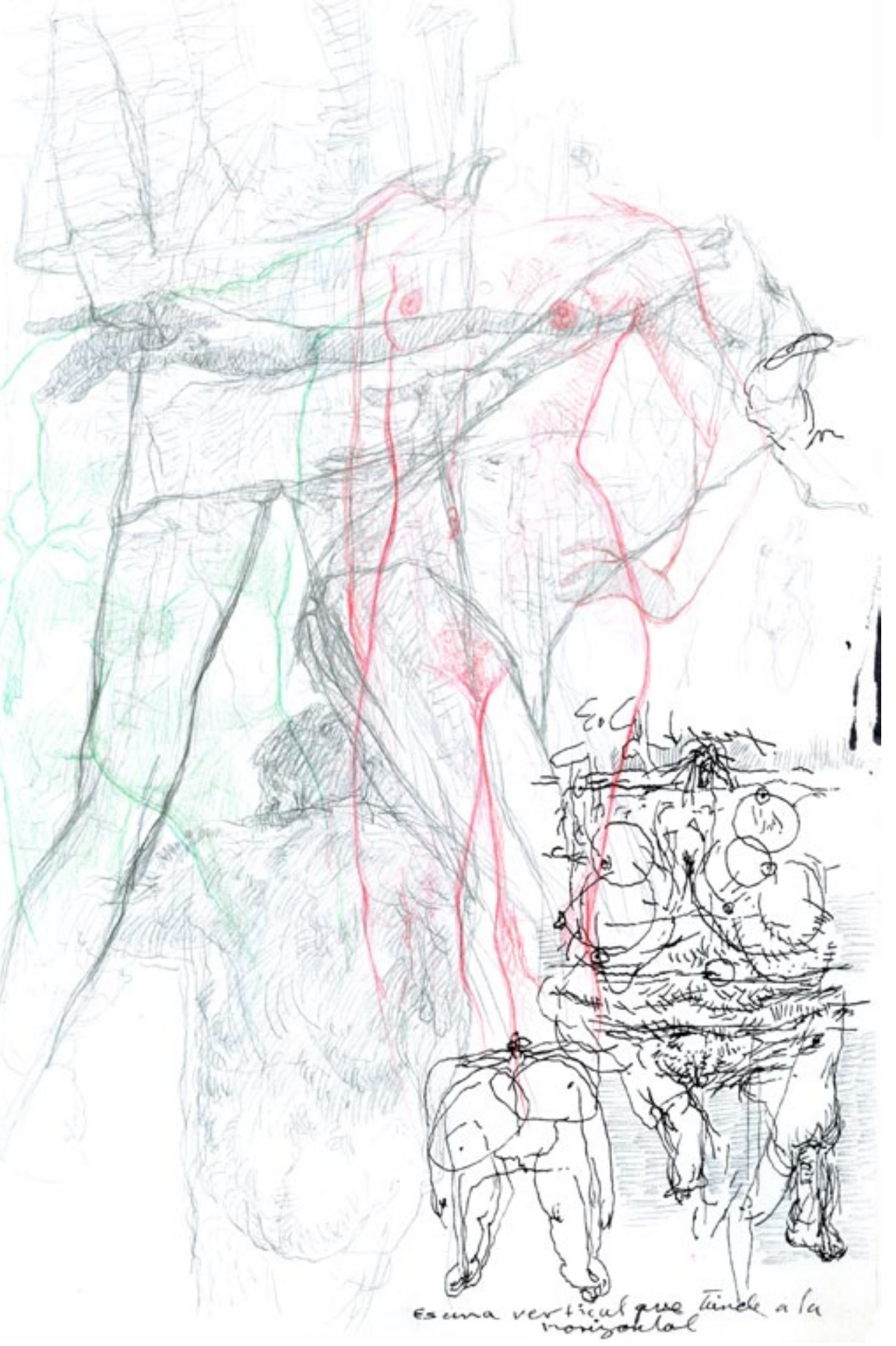




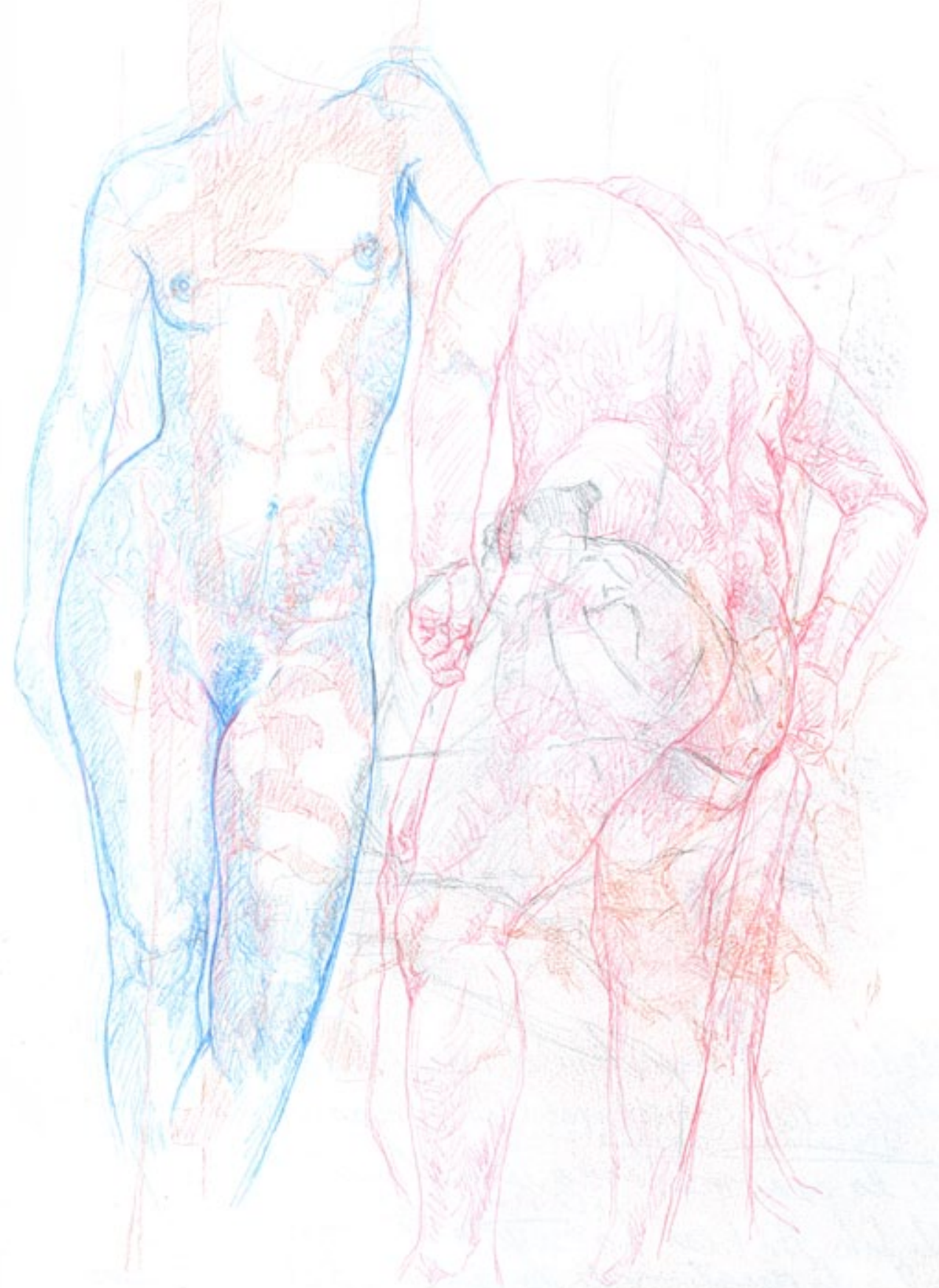



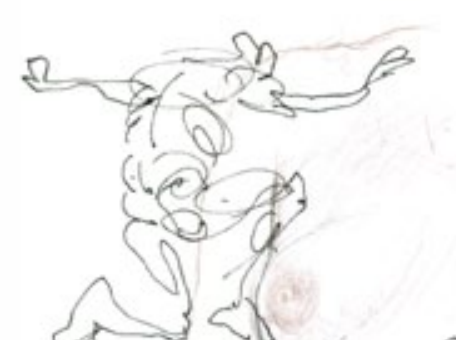
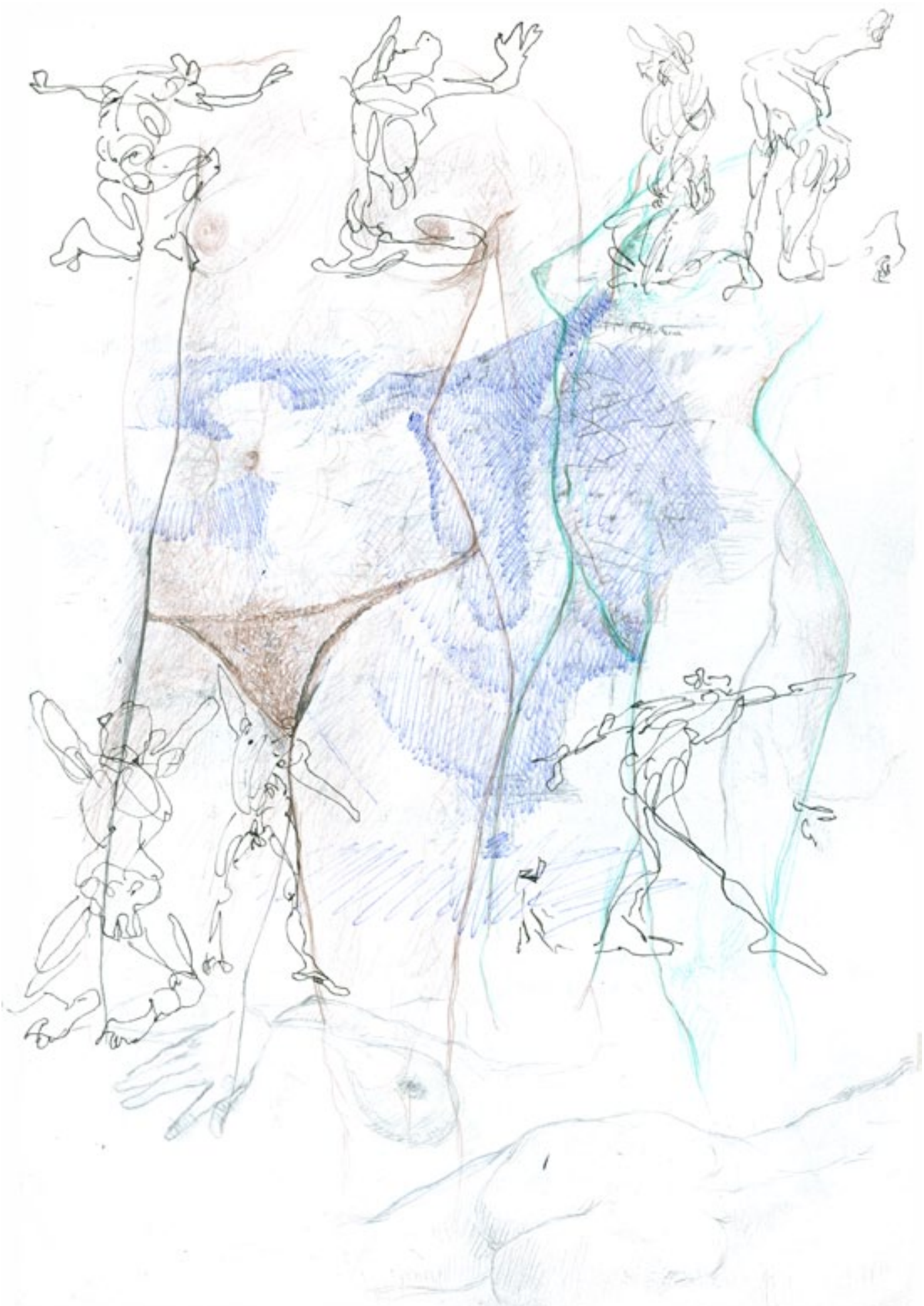


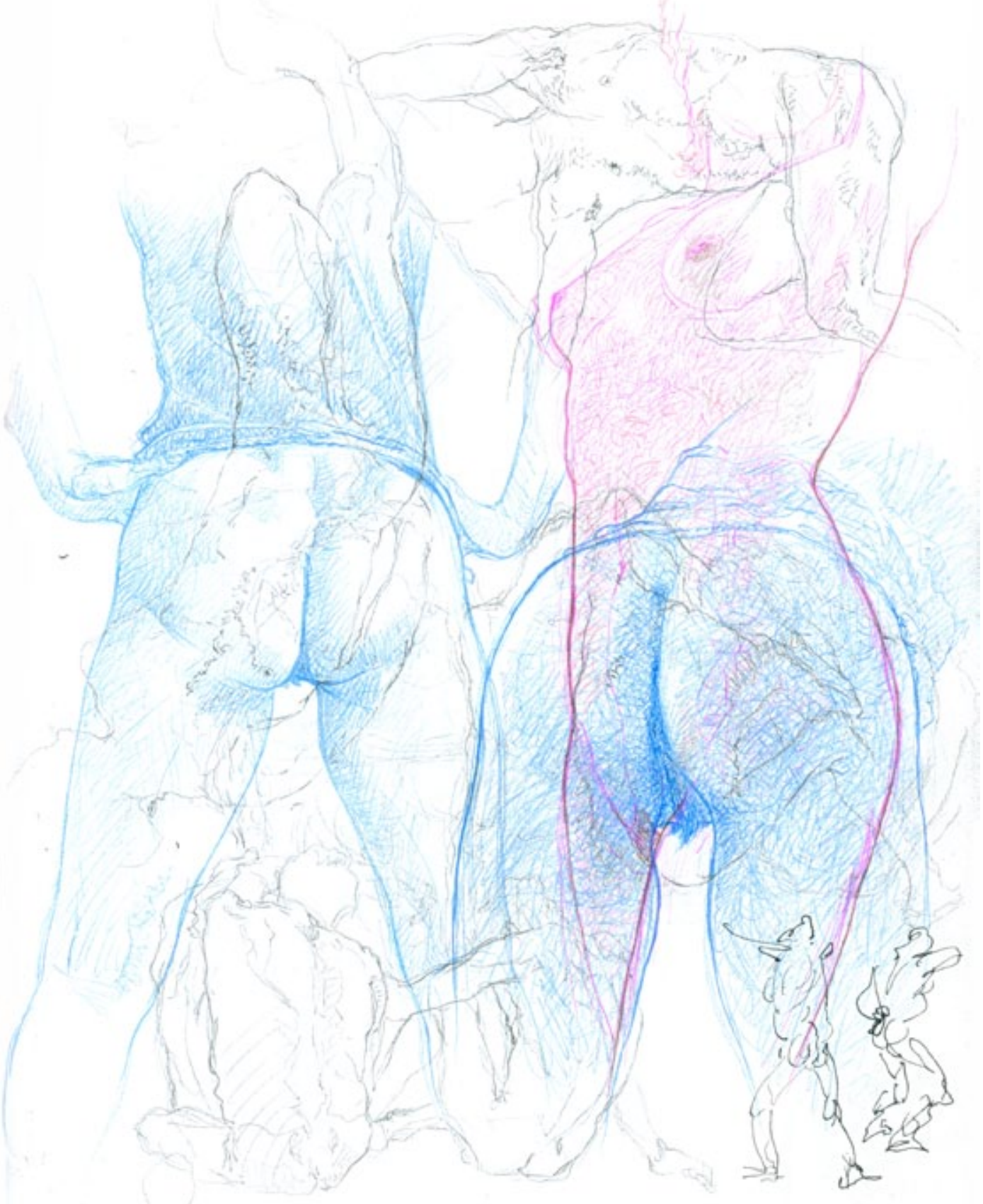




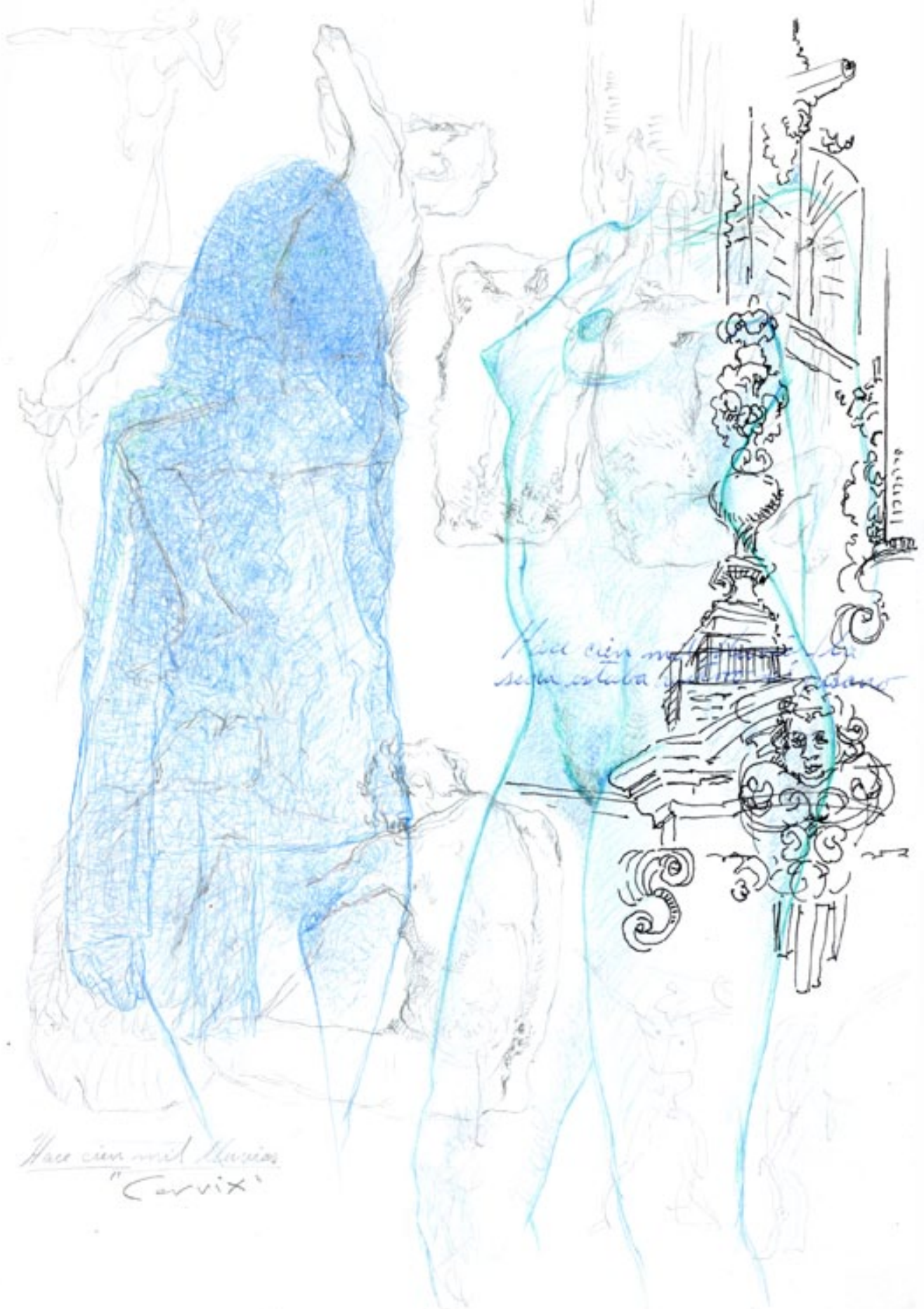




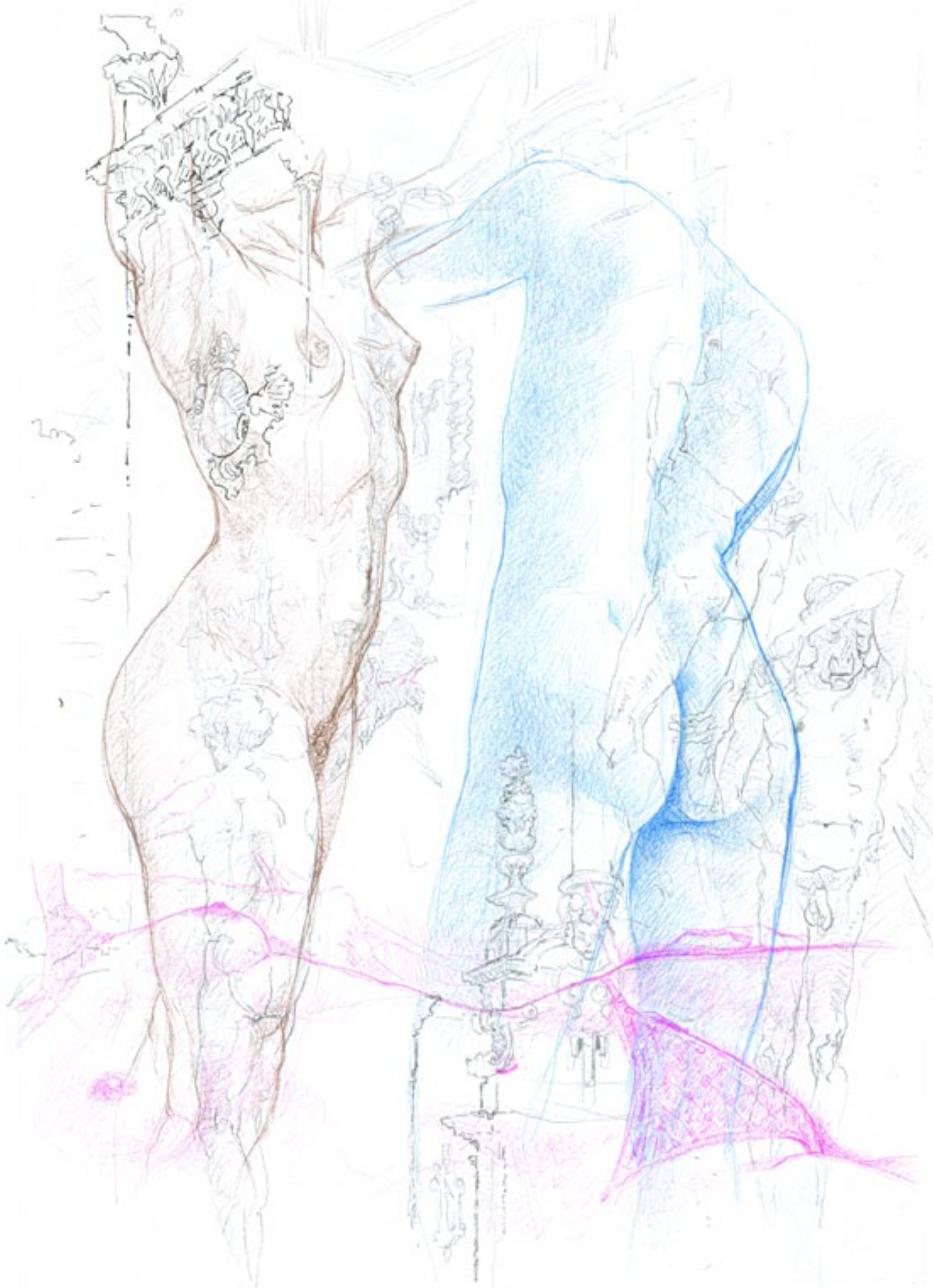




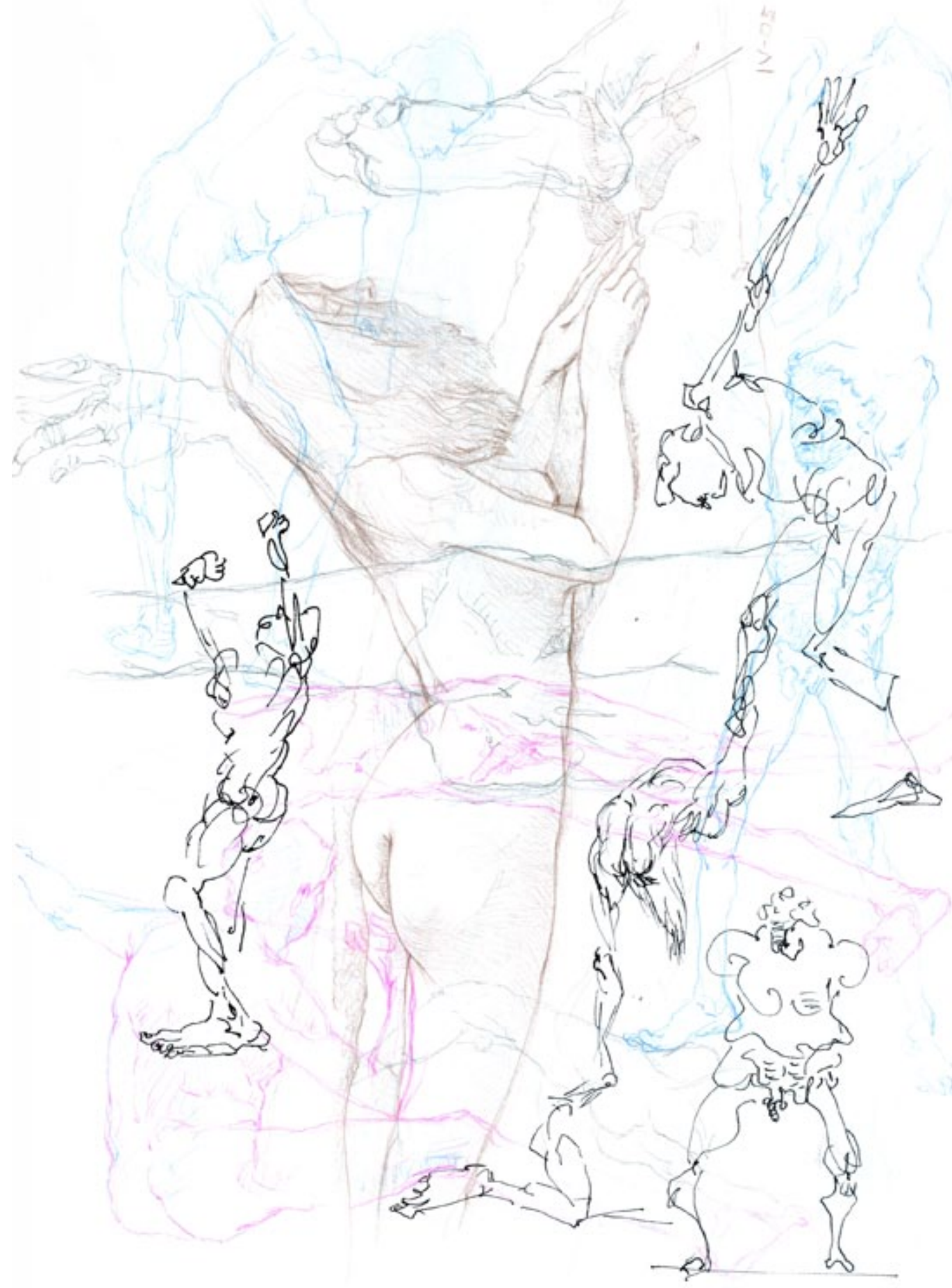




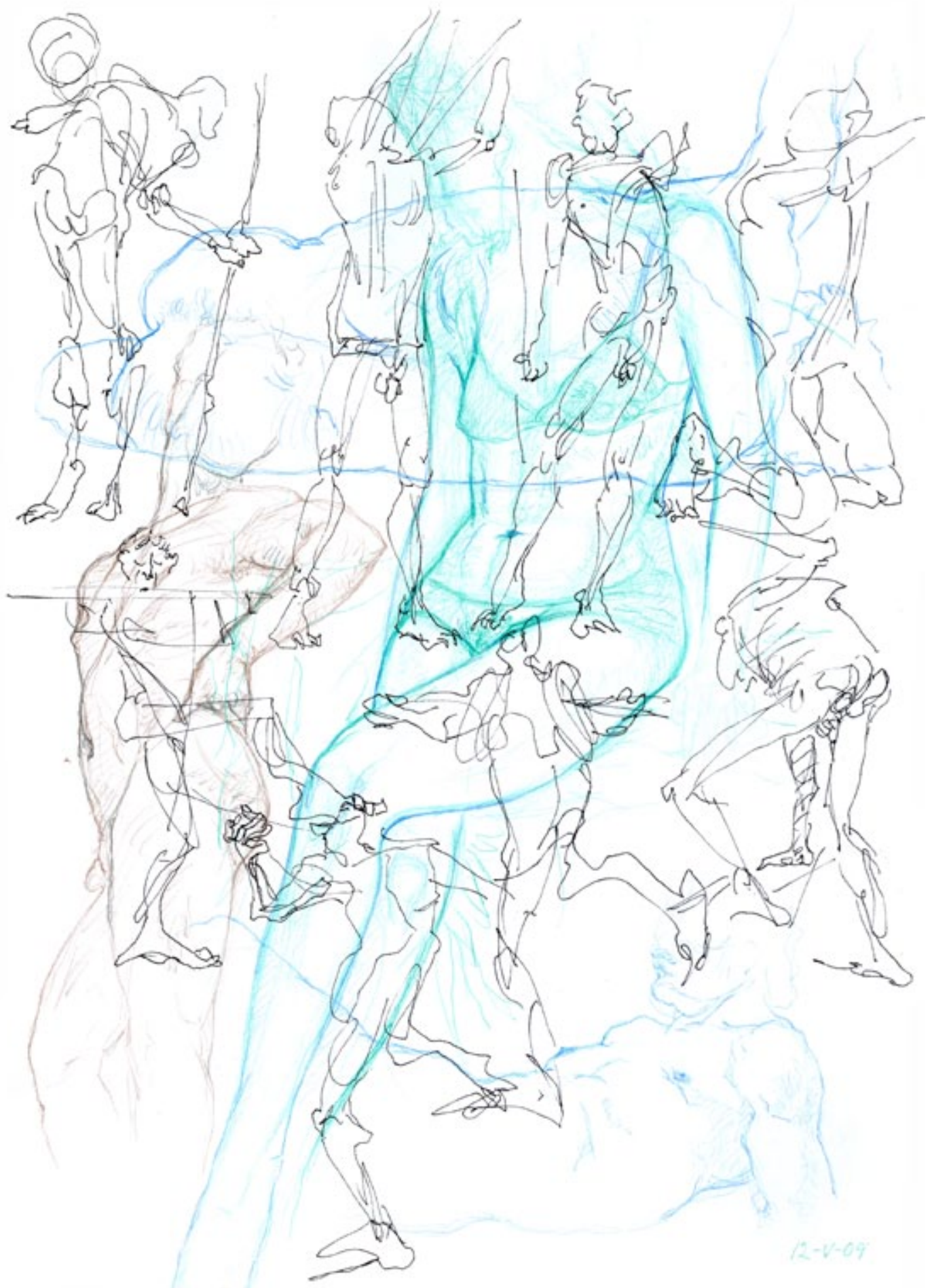





\section{BIBLIOGRAFÍA}

1. Abbagnano, Nicola, Diccionario de Filosofía, México, Fondo de Cultura Económica, 2008, pp. 1103.

2. Acha, Juan, Teoría del Dibujo. Su Sociología y su Estética, México, Ediciones Coyoacán, 1999, pp. 151.

3. Ades, Dawn, André Masson, $1^{a}$ ed. Nueva York, Rizzoli, 1994, pp. 128.

4. Adorno, Th. W. Teoría Estética. Obras completas, Madrid, Akal, Básica de bolsillo 7, 2004, pp. 512.

5. Aedo, Tania, Tekhné 1.0 Arte, pensamiento y tecnología, México, CONACULTA. CENART, 2004, pp. 170.

6. Andreotti, Libero y Costa, Xavier Editores, Teoría de la deriva y otros textos situacionistas sobre la ciudad, Barcelona, Museu d’Art Contemporani de Barcelona, 1996, pp. 172.

7. Augué, Marc, Los no lugares. Espacios del anonimato. Una antropología de la sobremodernidad, Barcelona, Editorial Gedisa, 2008, pp. 125.

8. Anfam, David, El Expresionismo Abstracto, $1^{\mathrm{a}}$ ed. Barcelona, Thames and Hudson, Ediciones Destino, Serie El Mundo del Arte, no.68, 2002, pp. 216.

9. Bachelard, Gaston, La poética del espacio, México, Fondo de Cultura Económica, Breviarios 183, 1997, pp. 281.

10. Bachelard, Gaston, El agua y los sueños, México, Fondo de Cultura Económica, Breviarios 279, 203, pp. 295.

11. Bachelard, Gaston, El aire y los sueños, México, Fondo de Cultura Económica, Breviarios 139, 1993, pp. 328.

12. Bachelard, Gaston, La poética de la ensoñación, México, Fondo de Cultura Económica, Breviarios 330, 1997, pp. 321.

13. Baker, George, Photography's Expanded Field, Ney York, October No 114, March 5 to April 3. 2004 , pp. 120.

14. Barney, Matthew, Drawing restraint. Vol / 1987-2002, Germany, Verlag der Buchhandlung Walther Köning, Köln, 2005, pp. 93.

15. Barthes, Roland, La cámara lúcida, Barcelona, Paidós Ibérica, 2007, pp. 188.

16. Bataille, George, Obras escogidas, México, Fontamara, Filosofía, 2006, pp. 531.

17. Battcock, Gregory, Ed. La idea como arte. Documentos sobre el arte conceptual. Barcelona, Gustavo Gili, 1977, pp. 156. 
18. Battista Alberti, Leon, Tratado de Pintura, México, Universidad Autónoma Metropolitana. Colección, Ensayos, 1998, pp. 135.

19. Baxandall, Michael, Modelos de intensión. Soibre la explicación histórica de los cuadros, Madrid, Herman Blume, Colección: Arte, Critica e Historia, 1989, pp. 170.

20. Berganza Gobantes, Pilar, Vanguardias y Artistas de/ Siglo XX. Notas de Arte, Godella, Valencia, Edetania, 1994, pp. 216.

21. Best Maugard, Adolfo, Método de Dibujo. Tradición y resurgimiento del Arte Mexicano, México, Departamento Editorial de la Secretaría de Educación, Manuales y Tratados, 1923, pp. 135.

22. Blok, Cor, Historia del arte abstracto, 1900-1960, $2^{a}$ ed., Madrid, Cátedra, Colección Cuadernos de Arte, 1987.

23. Bois, Ive-Alain, Painting as Model, Cambridge, Massachusetts, The MIT Press, An OCTOBER Book, 1993, pp. 327.

24. Bomford, David, Underdrawings in Renaissance Paintings, London, Nacional Gallery Company, 2002, pp. 192.

25. Bonet Correa, Antonio (Coord.), El surrealismo, Madrid, Universidad Menéndez Pelayo, Cátedra, 1983, pp.230.

26. Bourriaud, Nicolas, Estetica relacional, Argentina, Adriana Hidalgo editora, 2008, pp. 143.

27. Brereton, Richard, Los cuadernos. Bocetos de diseñadores, ilustradores y creativos, Londres, China, 2009, pp. 239.

28. Breton, André y Eluard, Paul, Diccionario abreviado del surrealismo, Madrid, Siruela, Serie La Biblioteca Azul, Serie mínima, 1, 2003, pp.170.

29. Breton, André, Manifiestos del Surrealismo, 6ta ed. Barcelona, Labor, Colección Labor, Nueva Serie, no. 12, 1995, pp.338.

30. Brea, José Luis, (ed), Estudios Visuales. La epistemología de la visualidad en la era de la globalización, Madrid, Akal, Estudios Visuales, 2005, pp. 244.

31. Brook, Peter, La puerta abierta. Reflexiones sobre la interpretación y el teatro, Barcelona, Alb a Editorial, 2004, pp. 141.

32. Buchloh, Benjamín H. D. Formalismo e Historicidad. Modelos y métodos en el arte del siglo XX, Madrid, Akal, 2004, pp. 246.

33. Burgin, Victor, Ensayos, Barcelona, Gustavo Gili, 2004, pp. 255.

34. Calabrese, Omar, Como se lee una obra de arte, Madrid, Cátedra, Signo e imagen, 1999, pp. 124.

35. Calabrese, Omar, La era neobarroca, Madrid, Cátedra, 2005, pp. 209. 
36. Calvo Serraler, Francisco, Coordinador, Ilustración y Romanticismo, Colección Fuentes y Documentos para la Historia del Arte VII, Barcelona, Gustavo Gili, 1983, pp. 408.

37. Carl, Zigrosser, Käthe Kol/witz, New York, Dover Publications, 1969, pp. 97.

38. Cabezas, Lino, El Dibujo como invención, idear construír dibujar, Madrid, Cátedra, 2008, pp. 399.

39. Castoriadis, Cornelius, El ascenso de la insignificancia, Madrid, Cátedra, 1998, pp. 238.

40. Castoriadis, Cornelius, Figuras de lo pensable, México, Fondo de Cultura Económica, 2002, pp. 302.

41. Castoriadis, Cornelius, La institución imaginaria de la sociedad, Barcelona, Tusquets, 1989, pp. 334.

42. Castro, Sixto J. Vituperio de obranejas, México, Herder, 2007, pp. 215.

43. Cellini, Benvenuto, Tratados de la Orfebrería y de la Escultura, México, Leyenda. Colección Atalaya 7, Sin fecha, pp. 157.

44. Cennini, Cenino, Tratado de la Pintura. El Libro del Arte, Barcelona, Meseguer Editor, 1979 pp. 152.

45. Chávez Calderón, Pedro, Historia de las Doctrinas Filosóficas, México, Addison Wesley Longman, 1998, PP. 320.

46. Cávez Mayol, Humberto, Tiempo muerto, México, Conseil des arts et des lettres du Québec y el Fondo Nacional para la Cultura y las Artes de México, 2005, pp. 419.

47. Cheng, Francoise, Vacío y Plenitud, Madrid, Siruela, 1993, pp. 129.

48. Christo and Jean Claude, Early Works, Germany, Taschen, 2001, pp. 276.

49. Cirlot, Lourdes, Primeras Vanguardias Artísticas. Textos y documentos, Argentina, Terramar Ediciones, 2008, pp. 219.

50. Cirlot, Juan-Eduardo, El Arte Otro. Informalismo en la escultura y pintura más recientes, $1^{\text {a }}$ ed. Barcelona, Seix Barral, Colección Biblioteca Breve, 1957, pp. 133.

51. Cirlot, Juan-Eduardo, Informalismo, $1^{\text {a }}$ ed. Barcelona, Ediciones Omega, 1959, pp. 84

52. Cortés, Valeria, Anatomía, Academia y Dibujo Clásico, Madrid, Cátedra. Ensayos Arte, 1994, pp. 411.

53. Crego Castaño, Charo, El espejo del orden. El Arte y la Estética del Grupo Holandés «De Stijl», $1^{\text {a }}$ ed. Madrid, Akal, 1997, pp. 295.

54. Dantzic, Cynthia Maris, Como Dibujar. Guía completa de sus técnicas e interpretación Madrid, H. Blume, 2004, pp. 336. 
55. Danto, Arthur C. Después del fin del arte. El arte contemporáneo y el linde de la historia, Barcelona, Ediciones Paidós Ibérica, Transiciones 16, 2005, pp. 254.

56. Delacroix, Eugène, El puente de la visión. Antología de los Diarios, Madrid, Tecnos, Colección Metrópolis, 1998, pp. 151.

57. Deleuze, Guilles. Guattari, Felix, Mil mesetas, España, Pre-Textos, 1997, pp. 522.

58. Deleuze, Guilles. Guattari, Felix, ¿Qué es la filosofía?, Barcelona, Anagrama, Colección Argumentos, 2005, pp. 221.

59. Deleuze, Gilles, Pintura. El concepto de diagrama, Buenos Aires, Cactus, Serie Clases Volumen 4, 2007, pp. 290.

60. De la Cruz, Martín, Libelum de medicinálibus indorum herbis, México, Fondo de Cultura Económica, 1996, pp. 258.

61. Dery, Mark, Velocidad de escape. La cibercultura en el final del siglo, Madrid, Siruela, 1998, pp. 397.

62. Descargues, Pierre, Hartung, $1^{\text {a }}$ ed. Nueva York, Rozzoli, 1977.

63. Dewdney, A. K., Recreaciones Matemáticas, Scientific American, Mayo de 1990.

64. Díaz, Padilla, Ramón, El dibujo del natural en la época de la postacademia, Madrid, Akal, Bellas Artes 4, 2007, pp. 326.

65. Doesburg, Theo, Principios del nuevo arte plástico y otros escritos, $1^{\mathrm{a}}$ ed. Murcia, Colegio de aparejadores y Arquitectos Técnicos de Murcia, Colección Arquitectura 2, num.18, 1985, pp. 210.

66. Dorfles, Gillo, Últimas tendencias del Arte de hoy, 5ta ed., Barcelona, Labor, Colección Labor 205, pp. 279.

67. Dorfles, Gillo, El devenir de las artes, México, Fondo de Cultura Económica, Breviarios 170, 2004, pp. 318.

68. Doyne, J., Packard, N., Shaw, R., Caos. Barcelona, Investigación y Ciencia, № 125, Febrero, 1987, pág., 16, 29.

69. Dubois, Philippe, El acto fotográfico. De la representación a la Recepción, Barcelona, Paidós Ibérica, 2002, pp. 191.

70. Dupin, Jacques, Antonio Saura. Damas, Bilbao, Museo de Bellas Artes de Bilbao, 2001, pp. 62.

71. Edwards, Betty, Aprender a dibujar. Un método garantizado, Madrid, Hermann Blume, 1985, pp. 207.

72. El Arcoiris Nocturno. Obra de Alan Glass, México, Galería López Quiroga, 2003. pp. 60.

73. Eisenman, Stephen F. Historia crítica del arte del siglo XIX, Madrid Akal, Arte y Estética 59, 2001, pp. 415. 
74. Esteve de Quesada, Albert, Creación y Proyecto. El método en Diseño y otras Artes, Valencia, Institución Alfonso el Magnánimo. Diputación Valencia, 2001, pp. 156.

75. Everitt, Anthony, El Expresionismo Abstracto, $1^{\mathrm{a}}$ ed. Labor, 1975, pp. 71.

76. Facundo Mosi, Alberto, El Dibujo. Enseñanza Aprendizaje, Universidad Politécnica de Valencia, 1999, pp. 376

77. Fernández Arenas, José, Coordinador, Barroco en Europa, Colección Fuentes y Documentos para la Historia del Arte V, Barcelona, Gustavo Gili, 1983, pp. 477.

78. Fernández Arenas, José, Coordinador, Renacimiento y Barroco en España, Colección Fuentes y Documentos para la Historia del Arte VI, Barcelona, Gustavo Gili, 1983, pp. 269.

79. Fliedl, Gottfried, Gustav Klimt, Berlin, Benedikt Taschen, 1991, pp. 239.

80. Folds Suzanne, and Laura M. Giles, Italian Drawings before 1600 in The Art Institute of Chicago, Vermont, 1997, pp. 455.

81. Fontcuberta, Joan, El beso de Judas. Fotografía y verdad, Barcelona, Gustavo Gili, 2007, pp. 191.

82. Foster, Hal, El retorno de lo real. La vanguardia a fines de siglo, Madrid, Akal, 2001, pp. 235.

83. Foster Hal, Krauss Rosalin, Bois Yve-Alain, Buchloh Benjamin H. D. Arte desde 1900. Modernidad Antimodernidad Posmodernidad, Madrid, Akal, 2006, pp. 704.

84. Foucault, Michel, Esto no es una pipa, Barcelona, Anagrama, Colección Argumentos, 2001, pp. 93.

85. Fried, Michael, Arte y objetualidad. Ensayos y reseñas, Madrid, Antonio Machado Libros La balsa de la medusa 141, 2004, pp. 364.

86. García, González Angel, Calvo, Serraller Francisco, Marchán, Fiz Simón, Escritos de arte de vanguardia 1900-1945, Madrid, Istmo, 2003, pp. 543.

87. García, Rolando, Sistemas complejos. Conceptos, método y fundamentación epistemological de la investigación interdisciplinaria, Barcelona, Gedisa, 2008, pp. 200.

88. Garriga, Joaquim, Coordinador, Renacimiento en Europa, Colección Fuentes y Documentos para la Historia del Arte IV, Barcelona, Gustavo Gili, 1983, pp. 606.

89. Gastón, Guirao, Cristina, Mies: el proyecto como revelación del lugar, Barcelona, Fundación Caja de Arquitectos, 2005, pp. 247.

90. G. Durozoi-B. Lechebonnier), El surrealismo. Teorías, temas, técnicas, $1^{\text {a }}$ ed. Madrid, Ediciones Guadarrama, Colección Punto Omega, Colección Universitaria de Bolsillo, 1974, pp. 305

91. Geelhar, Christian, Paul Klee. Dibujos. Barcelona Gustavo Gili. Colección Comunicación Visual, 1972, pp. 212. 
92. Gilpin, William, 3 ensayos sobre la belleza pintoresca, Madrid, Abada Editores, 2004, pp. 173.

93. Ginzburg, Silvia, Turner, Italy, Arch Cape Press, 1990, pp. 99.

94. Glimcher, Marc (ed.), et alterus, Jean Dubuffet. Towards an alternative reality, $1^{\mathrm{a}}$ ed. Nueva York, Pace Publications y Abbeville Press Publishers, 1987, pp. 312.

95. Golding, John, Caminos a lo absoluto, México, Fondo de Cultura Económica. Turner, 2003, pp. 237.

96. Gómez Molina, Juan José, Coordinador, Las lecciones del Dibujo, Madrid, Cátedra, 1999, pp. 618.

97. Gómez Molina, Juan José, Cabezas Lino, Bordes Juan, El Manual del Dibujo, Madrid, Cátedra, 2001, pp. 654.

98. Gómez Molina, Juan José, Coordinador, Estrategias del Dibujo, Madrid, Cátedra, 1999, pp. 662.

99. Gómez Molina, Juan José, Coordinador, La representación de la representación, danza, teatro, cine, música. Dibujo y profesión 1, Madrid, Cátedra, 2007, pp. 371.

100. Gómez, Molina Juan José, Coordinador, Los Nombres del Dibujo, Madrid, Cátedra, 2005, pp. 576.

101. Gómez Molina, Juan José, Coordinador, Máquinas y Herramientas del Dibujo, Madrid, Cátedra, 2002, pp. 657.

102. Greenberg, Clement, Arte y cultura, Barcelona, Paidós, Estética 32, 2002, pp. 305.

103. Greenberg, Clement, La pintura moderna y otros ensayos, Madrid, Siruela, 2006, pp. 127.

104. Groys, Boris, Ross, Davis A. Blazwick, Iwona, llia Kabakov, London, Phaidon Press Limited, 1998, pp. 160.

105. Guasch, Ana María, El arte último del siglo XX. Del posminimalismo a lo multicultural, Madrid, Alianza Forma, 2007, pp. 597.

106. Guasch, Ana María, Los manifiestos del arte posmoderno. Textos de exposiciones 1980-1995, Madrid, Akal, Arte contemporáneo 5, 2000, pp. 398.

107. Harrison, Charles \& Wood, Paul, Art in Theory 1900-2000. An Antology of Changing Ideas, United Kingdom, Blackwell Publishing, 2002, pp. 1258.

108. Hartmut J., Dietmar, El lenguaje de los Fractales, Scientific American, Agosto, 1990.

109. Hayles, Catherine, La evolución del Caos, Barcelona, Gedisa. Límites de la Ciencia, 1998, pp. 382.

110. Heidegger, Martin, Arte y Poesia, México, D. F. Fondo de Cultura Económica, Breviarios 229, 1997, pp. 148. 
111. Henry Moore en México. Escultura, Dibujo, Gráfica de 1921 a 1982, México, Instituto Nacional de Bellas Artes, Noviembre de 1982-Enero 1983, pp. 104.

112. Herrero, Ángel, Semiótica y Creatividad. La Lógica Abductiva, Madrid, Palas Atenea, 1988.

113. Hollis, Jill and Cameron, lan, Pasaje. Andy Goldsworthy, Verona, Hrry N. Abrams, 2004, pp. 168.

114. Husserl, Edmund, Ideas relativas a una fenomenología pura y una filosofía fenomenológica. Libro segundo: Investigaciones fenomenológicas sobre la constitución, México, Fondo de Cultura Económica, 2005, pp. 519.

115. Interdisciplina, Escuela y Arte, Tomo I. Antología, México, Consejo Nacional para la Cultura y las Artes, 2004, pp. 272.

116. Interdisciplina, Escuela y Arte, Tomo II. Antología, México, Consejo Nacional para la Cultura y las Artes, 2004, pp. 304.

117. Jameson, Fredric, El posmodernismo o la lógica cultural del capitalismo avanzado, Barcelona, Paidós, Estudio 83, 2002, pp. 121.

118. Jones, Amelia, El cuerpo del artista, Hong Kong, Phaidon, 2006, pp. 204.

119. Kandinsky, Wassily, Cursos de la Bauhaus, Madrid, Alianza, 1983, pp. 187

120. Kandinsky, Wassily, De lo espiritual en el Arte, Premia, La Nave de los Locos, México, 1981, pp. 132.

121. Kandinsky, Marc, Franz, El Jinete Azúl, Barcelona, Paidós Estética 19, 1989, pp. 326.

122. Kandinsky, Wassily, La Gramática de la Creación. El futuro de la Pintura, Barcelona, Paidós Estética 10, 1987, pp. 162.

123. Kandinsky, Wassily, Punto y línea sobre el plano. Contribución al análisis de los elementos pictóricos. Barcelona, Paidos, 1996, pp. 159.

124. Kepes, Gyorgy, El lenguaje de la visión, Buenos Aires, Ediciones Infinito, 1976. pp. 301.

125. Klee, Paul, Bases para la estructuración del arte, México, Ediciones Coyoacán, 1998, pp. 71.

126. Krauss, Rosalind E. La originalidad de la vanguardia y otros mitos modernos, Madrid, Alianza Forma, 2006, pp. 320.

127. Kuhn, Thomas S. La estructura de las revoluciones científicas, México, Fondo de Cultura Económica, 2000, pp. 360.

128. Kuspit, Donald, El fin del Arte, Madrid, Akal, Arte Contemporáneo 18, 2006. Pp. 159.

129. L'opera completa di Gericault, Milano, Rizzoli Editori, 1978. pp. 164. 
130. Lambert, Susan, El dibujo Técnica y Utilidad, Madrid, Herman Blume, 1985, pp. 144.

131. Landesio, Eugenio, Compendio de Perspectiva lineal y aérea,sombras, espejos y refracción con las nociones necesarias de geometría, México, Portal del Águila de Oro, 1866, pp. 46.

132. Langer, Susanne K. Sentimiento y forma. Una teoría del arte desarrollada a partir de una nueva clave de la filosofía, México, UNAM, Centro de Estudios Filosóficos, 1967, pp. 403.

133. Lhote, Andre, Tratado del Paisaje, Buenos Aires, Poseidón, 1973.

134. Lippard, Lucy R, Seis años. La desmaterialización del objeto artístico de 1966 a 1972, Madrid, Akal, 2004, pp. 377.

135. Lucie, Smith, Edwars, Artes Visuales en e/ Siglo XX, Londres, Laurence King Publishing, 1996, pp. 398.

136. Lyotard, J. F. La fenomenología, Barcelona, Paidós Ibérica, 1989, pp. 158.

137. Maldonado, Tomás, Vanguardia y racionalidad, Barcelona, Gustavo Gili, 1977, pp. 271.

138. Manni, Marcella, Villirillo, Giuseppe, Sol Le Witt. Wall drawings allo Studio G7, Bologna, Damiani, 2006, pp. 101.

139. Marin Vidael, Ricardo, De Laiglesia González de Peredo, Juan Fernando, Tolosa Marín José Luis, La Investigación en Bellas Artes. Tres aproximaciones a un debate, Granada, Grupo Editorial Universitario, 1997, pp. 328.

140. Maris Dantzic, Cynthia, Como Dibujar, Madrid, Herman Blume, 1999, pp. 336.

141. Martínez Fernández, Maritere, iCambiamos por favor!, Diario del taller del maestro Gilberto Aceves Navarro, México, Consejo Nacional Para la Cultura y las Artes, 2003, pp. 365.

142. Maynard, Patrick, Drawing distinctions, London, Cornell University Press, 2005, pp. 266.

143. Meyrink, Gustav, La casa de la última farola, Madrid, Ediciones Felmar. Colección La Fontana Literaria, 1976, pp. 240.

144. Michaud, Yves, El arte en estado gaseoso, México, Fondo de Cultura Económica, Breviarios 555, 2007, pp. 169.

145. Moles, Abraham, Las Ciencias de lo Impreciso, México D. F. UAM, colección las Ciencias Sociales, 1995, pp. 430.

146. Mondrian, Piet, Realidad Natural y Realidad Abstracta, Madrid, Debate, Serie Arte, 1989, pp. 139.

147. Morgan, Robert C. Del Arte a la Idea. Ensayos sobre Arte Conceptual, Madrid, Akal. Arte Contemporáneo 13, 2003, pp. 156. 
148. Morhouse, A. C., Historia del Alfabeto, México D. F. Fondo de Cultura Económico, Breviarios 160. 1982, pp. 306.

149. Morin, Edgar, El Método I. La naturaleza de la Naturaleza, Madrid, Cátedra, Colección Teorema, 2001, pp. 448

150. Morin, Edgar, Introducción al Pensamiento Complejo, Barcelona, Gedisa, 2001, pp. 167.

151. Morris, Charles, Fundamentos de la teoría de los signos, Barcelona, Paidós, Comunicación14, 1994, pp. 122.

152. Nadeau, Maurice, Historia del Surrealsimo, $1^{\text {a }}$ ed., Barcelona, Ariel • Esplugues de Llobregat, 1972 (reimpresión 1975), pp. 259.

153. Nancy Spero. Disidanzas, Madrid, Museo Nacional Centro de Arte Reina Sofía, 2008, pp. 191.

154. Newman, Barnett, Escritos escogidos y entrevistas, Madrid, Editorial Síntesis, 1990, pp. 365.

155. Nieto, Rodolfo, Bestiario, México, Galería López Quiroga, 1993, PP. 39.

156. Nicolaides, Kimon, The Natural Way to Draw. A Working Plan for Art Study, Boston, Houghton Mifflin Company, 1969, pp. 221.

157. Norden Linda, Danto Arthur, Sara Sze, China, Deborah Aaronson, 2007, pp. 223.

158. Oida, Yoshi, Un actor a la deriva, México, Ediciones El Milagro, 2003, pp. 255.

159. Palomino, de Castro y Velasco Antonio, El Museo Pictórico y Escala Óptica, Madrid, Aguilar, 1947, pp. 1222.

160. Panofsky, Erwin, Renacimiento y Renacimientos en el arte occidental, Madrid, Alianza Editorial, 2006, pp. 338.

161. Pansu, Evelyne, Ingres Dibujos, Gustavo Gili. Colección comunicación Visual, Barcelona, 1981, pp. 220.

162. Parret, Herman, De la Semiótica a la Estética; enunciación, sensaciones, pasiones, Buenos Aires, Edicial, 1998, pp. 194.

163. Parret, Herman, Las pasiones. Ensayo sobre la puesta en discurso de la subjetividad, Buenos Aires, Edicial, 1995, pp. 263.

164. Pérez, Alfonso, Historia del dibujo en España de la Edad Media a Goya, Madrid, Cátedra, Cuadernos de Arte 19, 1986, pp. 510.

165. Petrova, Eva, Delacroix y el Dibujo Romántico, Barcelona, 1989, pp. 189.

166. Polcari, Stephen, Abstract Expressionism and the Modern Experience, London, Cambridge University Press, 1993, pp. 408. 
167. Porlán, Rafael, Constructivismo y Escuela, Sevilla, Diada, 1993.

168. Prada, Juan Martín, La apropiación posmoderna. Arte, práctica apropiacionista y Teoría de la Posmodernidad, Madrid, Fundamentos, Colección Arte, 2001, pp. 205.

169. Radaña, A., Movimiento Caótico, Barcelona, Investigación y Ciencia, № 114, Marzo,1986, pp. 23.

170. Ramírez, Juan Antonio, Corpus Solus. Para un mapa del cuerpo en el arte contemporáneo, Madrid, Ediciones Siruela, 2003, pp. 355.

171. Rampérez, Fernando, La quiebra de la representación. El arte de vanguardia y la estética moderna, Madrid, Dykinson, Colección Comentarios y Monografías, 2004, pp. 305.

172. Ross, Clifford (ed.), Abstract Expressionism: Creators and Critics. An Anthology, $1^{\mathrm{a}}$ ed. Nueva York, Harry N. Abrams, 1990, pp. 304

173. Ruskin, John. Los Pintores Modernos, Pamplona, Aguilar, 1963, pp. 227.

174. Ruskin, John. Elementos de Dibujo Colorido y Composición, Pamplona, Aguilar, 1963, pp. 235.

175. Ruskin, John, Sobre Turner, México, UNAM, Colección Poemas y Ensayos, 1996, pp. 267.

176. Sander, L., Crecimiento Fractal, Barcelona, Investigación y Ciencia, N 126, Marzo, 1987, pp. 73.

177. Sandler, Irving, Judy Pfaff, New York. Manchester, Hudson Hills Press, 2003, pp. 145.

178. Saura, Antonio, Note Book. Memoria del tiempo, $1^{\mathrm{a}}$ ed., Murcia, Colegio de Aparejadores y Técnicos de Murcia, y Librería Yerba, Colección de arquitectura 3, num. 24, 1992, pp. 165.

179. Schapiro, Meyer, El Arte Moderno, Madrid, Alianza Forma, 1993, pp. 207.

180. Schlemmer, Oskar, Escritos dobre arte: Pintura, teatro, danza, cartas y diarios, Barcelona, Ediciones Paidós, 1987, pp. 190.

181. Seymour Anne, Moorhouse Paul, Hooker Denise, Long Richard, Richard Long. Walking the line, Great Britain, Thames and Hudson, 1996, pp. 326.

182. Smithson, Robert, Selección de escritos, México, Alias, 2009, pp. 186.

183. Stangos, Nikos, Conceptos de arte moderno, Madrid, Alianza Forma, 1994, pp. 336.

184. Stiles, Kristine, and Selz, Peter, Theories and documents of Contemporary Art. A sourscebook of artists'writings, Berkeley and Los Angeles, California, University Of California Press, 1996. Pp. 1003.

185. Sureda, Joan, Guasch A. M. La trama de lo moderno, Madrid, Akal, Arte y Estética 14, 1993, pp. 248. 
186. Tekhné 1.0 Arte, pensamiento y tecnología, México, CONACULTA. CENART,

187. Valéry, Paul, Teoría poética y estética, Madrid, Visor, Colección, La balsa dela Medusa, num. 39, 1990, pp. 207.

188. Vecchi, Pierluigui. Colalucci, Gianluigi, Michelangelo. The Vatican Frescoes, New York. London. Paris, Abbeville Press Publishers, 1996, pp. 271.

189. Vélez Cea, Manuel, El Dibujo de Fin de Milenio, Granada, Universidad de Granada, 2001, pp. 188.

190. Vera Cañizares, Santiago, Proyecto Artístico y Territorio, Granada, Universidad de Granada, 2004, pp. 150.

191. Vilchis, E. Luz del Carmen, Método de dibujo de Gilberto Aceves Navarro, México, Universidad Autónoma Metropolitana, 2008, pp. 258.

192. Vinci, Leonardo, Tratado de Pintura, Madrid, Nacional, 1983, pp. 509.

193. Vitamin D. New perspectives in Drawing, New York, Phaidon, 2005, pp. 352.

194. Vitamin P. New perspectives in Painting, New York, Phaidon, 2004, pp. 352.

195. Wallis, Brian, Arte después de la modernidad. Nuevos planteamientos en torno a la representación, Madrid, Akal, Arte Contemporáneo 7, 2001, pp. 467.

196. Warncke, Carsten-Peter, El arte de la forma ideal. De Stijl. 1917-1931, $1^{\text {a }}$ ed. Alemania (Köln), Benedikt Taschen, 1993, pp. 216.

197. Watzlawick, Paul, La Realidad Inventada, Barcelona, Gedisa, El Mamifero Parlante, 1994, pp. 278.

198. Wentworth, Nigel, The phenomenology of Painting, United Kingdom, Cambridge Universiti Press, 2004, pp. 268.

199. Wick, Rainer, Pedagogía de la Bauhaus, $1^{\mathrm{a}}$ ed. Madrid, Alianza Forma, 1986, pp. 317.

200. Wilson, Brent, La enseñanza del Dibujo a partir del arte, Barcelona, Paidós, 2004, pp. 210.

201. Wingler, Hans M., La Bauhaus. Weimar, Dessau, Berlín. 1919-1933, Barcelona, Gustavo Gili, 1962, pp. 585

202. Wood Paul, Frascina Francis, Harris Jonathan, Harrison Charles, La Modernidad a debate. El arte desde los cuarenta, Madrid, Akal, Arte Contemporáneo, 1999, pp. 271.

203. Yard, Sally, Willem de Kooning, $1^{\text {a }}$ ed., Barcelona, Ediciones Polígrafa, 1997, pp. 128.

204. Yutang, Ling, Teoría China del Arte, Buenos Aires, Sudamericana, 1968.

205. Zizek, Slavoj, El Sublime objeto de la Ideología, México, Siglo XXI, 2001, pp. 3002. 


\section{FICHAS BIBLIOGRÁFICAS DE PÁGINAS WEB CONSULTADAS}

Christo y Jeanne-Claude. Christo and Jeanne-Claude [sitio web en línea]. s.l., 2003, (c 2003 Christo [citado el 18 de junio de2009]. Disponible en <http://christojeanneclaude.net/>.

«Early Works». En Christo y Jeanne-Claude. Christo and Jeanne-Claude [sitio web en línea]. s.l., 2003, (c) 2003 Christo [citado el 19 de junio de 2009]. Publicado originalmente en Bourdon, David, Christo, Nueva York, Harry N. Abrams Publications, 1970. Disponible en < http://christojeanneclaude.net/early.html >.

«Dockside Packages, Cologne Harbor - 1961». En Christo y Jeanne-Claude. Christo and Jeanne-Claude [sitio web en línea]. s.l., 2003, (c) 2003 Christo [citado el 19 de junio de 2009]. Disponible en <http://christojeanneclaude.net/dp.html>.

Christo y Jeanne-Claude. «Wrapped Coast, Little Bay, Australia, 1968-69». En Christo y Jeanne-Claude. Christo and Jeanne-Claude [sitio web en línea]. s.I., 2003, (c) 2003 Christo [citado el 19 de junio de 2009]. Disponible en <http://christojeanneclaude.net/wc.html>.

Christo y Jeanne-Claude. «Wrapped Monuments, Milano, Italy - 1970». En Christo y JeanneClaude. Christo and Jeanne-Claude [sitio web en línea]. s.l., 2003, (c) 2003 Christo [citado el 19 de junio de 2009]. Disponible en <http://christojeanneclaude.net/wm.html>.

Christo y Jeanne-Claude. «Valley Curtain, Rifle, Colorado 1970-72». En Christo y Jeanne-Claude. Christo and Jeanne-Claude [sitio web en línea]. s.l., 2003, (c) 2003 Christo [citado el 19 de junio de 2009]. Disponible en <http://christojeanneclaude.net/vc.html>.

Christo y Jeanne-Claude. «The Umbrellas, Japan - U.S.A., 1984-91». En Christo y Jeanne-Claude. Christo and Jeanne-Claude [sitio web en línea]. s.I., 2003, (c) 2003 Christo [citado el 21 de junio de 2009]. Disponible en <http://christojeanneclaude.net/umFiles/umUSA.html>.

Christo y Jeanne-Claude. «Wrapped Reichstag, Berlin, 1971-95». En Christo y Jeanne-Claude. Christo and Jeanne-Claude [sitio web en línea]. s.l., 2003, (c) 2003 Christo [citado el 21 de junio de 2009]. Disponible en <http://christojeanneclaude.net/wr.html>.

Christo y Jeanne-Claude. «Wrapped Trees. Fondation Bayeler and Berower Park, Riehen, Switzerland, 1997-95». En Christo y Jeanne-Claude. Christo and Jeanne-Claude [sitio web en línea]. s.l., 2003, (c) 2003 Christo [citado el 21 de junio de 2009]. Disponible en <http://christojeanneclaude.net/wt.html>.

Christo y Jeanne-Claude. «The Gates, Central Park, New York City, 1979-2005». En Christo y Jeanne-Claude. Christo and Jeanne-Claude [sitio web en línea]. s.I., 2005, (c) 2005 Christo [citado el 21 de junio de 2009]. Disponible en <http://christojeanneclaude.net/tg.html>.

Christo y Jeanne-Claude. «Over The River, Project For The Arkansas River, Colorado. In Progress». En Christo y Jeanne-Claude. Christo and Jeanne-Claude [sitio web en línea]. s.l., 2003, (c) 2003 Christo [citado el 21 de junio de 2009]. Disponible en <http://christojeanneclaude.net/ otr.html>.

Christo y Jeanne-Claude. «Biography. Christo and Jeanne-Claude». En Christo y Jeanne-Claude. Christo and Jeanne-Claude [sitio web en línea]. s.I., 2003, (c) 2003 Christo [citado el 21 de junio de 2009]. Disponible en <http://christojeanneclaude.net/bio.html>. 
Christo y Jeanne-Claude. «How To Read The Art Works by Christo \& Jeanne-Claude». En Christo y Jeanne-Claude. Christo and Jeanne-Claude [sitio web en línea]. s.l., 2003, (C) 2003 Christo [citado el 21 de junio de 2009]. Disponible en <http://christojeanneclaude.net/howTo.html>.

Christo y Jeanne-Claude. «Bibliography. Books, Catalogs, Film/Video». En Christo y JeanneClaude. Christo and Jeanne-Claude [sitio web en línea]. s.l., 2003, (c) 2003 Christo [citado el 21 de junio de 2009]. Disponible en <http://christojeanneclaude.net/bibli.html>

Nurture New York Nature. Christo and Jeanne-Claude: 40 Years of Public Art [sitio web en línea]. Nueva York, Nurture New York Nature, Inc., s.f. [citado el 21 de junio de 2009]. Disponible en <http://www.40yearsofpublicart.org/>.

Nature. Christo and Jeanne-Claude: 40 Years of Public Art [sitio web en línea]. Nueva York, Nurture New York Nature, Inc., s.f. [citado el 21 de junio de 2009]. Disponible en <http:// www.40yearsofpublicart.org/index.html?catg $=34>$.

Public Art Fund. «The Palace of Projects by llya \& Emilia Kabakov». En Public Art Fund [sitio web en línea]. Nueva York, Public Art Fund, mayo de 2000 [citado el 10 de julio de 2009]. Disponible en <http://www.publicartfund.org/index.htm>.

Ilya Kabakov, Ilya \& Emilia Kabakov [sitio web en línea]. s.I., 2001, (c) 2001 Ilya \& Emilia Kabakov [citado el 16 de septiembre de 2009]. Disponible en <http://www.llya-emilia-kabakov.com/>.

«Dissegno [italien]» [en línea]. París, Dictionnaires Le Robert, 2003, (c) Le Seuil / Dictionnaires le Robert, 2003 [citado el 22 de junio de 2009]. Disponible en <http://robert.bvdep.com/public/ vep/Pages_HTML/DISEGNO.HTM>.

«Mimêsis [grec]» [en línea]. París, Dictionnaires Le Robert, 2003, (c) Le Seuil / Dictionnaires le Robert, 2003 [citado el 22 de junio de 2009]. Disponible en <http://robert.bvdep.com/public/ vep/Pages_HTML/MIMESIS.HTM>.

«Dissegno [italien]» [en línea]. París, Dictionnaires Le Robert, 2003, (C) Le Seuil / Dictionnaires le Robert, 2003 [citado el 22 de junio de 2009]. Disponible en <http://robert.bvdep.com/public/ vep/Pages_HTML/DISEGNO.HTM>.

Página web y texto: “L’ANIMA E LE COSE. La natura morta nell’Italia pontificia nel XVII e XVIII secolo": http://www.provincia.ps.it/cultura/mostre/anima_cose/bibliografia.htm En sitio web: Provincia di Pesaro e Urbino y de Eventi Cultura", Titulada

Sitio web: Michael Shamansky, Bookseller Inc. Importer of European Publications in the Fine Arts: http://www.artbooks.com/

Página web de resultado de búsqueda: http://www.artbooks.com/wc.dll?ab $\sim$ gsearch $\sim 0 \sim$ re gions $\sim$ Lazio

John Constable, (1776-1837) [en línea]. s.l., s.f. [citado el 25 de junio de 2009]. Subtítulo: Excerpts from C.R. Lewis' Memoirs of the life of John Constable. Disponible en: <http://website. lineone.net/ carpenter9/artist/turner-constable.htm>.

John Constable Further Documents and Correspondence. En Ancestry.com.uk Discover Your Family History [sitio web en línea]. Provo, Utah, MyFamily.com, Inc., 2003 [citado el 25 de junio de 2009]. Disponible en <http://www.ancestry.co.uk/search/db.aspx?dbid=7531>. 
John Constable, (1776-1837) [en línea]. s.l., s.f. [citado el 25 de junio de 2009]. Subtítulo: Excerpts from C.R. Lewis' Memoirs of the life of John Constable. Disponible en: <http://website. lineone.net/ carpenter9/artist/turner-constable.htm>

O Connor, J. J. y Robertson, E. F. «Andrey Nikolaevich Kolmogorov». En MacTutor History of Mathematics [en línea] St. Andrews, Escocia, School of Mathematics and Statics, St. Andrews University, enero de 1999, JOC/EFR (C) January 1999 [citado el 26 de junio de 2009]. Biography Index; Kolmogorov, Andrey (2076*). Disponible en <http://www-history.mcs.st-andrews.ac.uk/ Mathematicians/Kolmogorov.html>. También disponible en <http://www-groups.dcs.st-and. ac.uk/ history/Mathematicians/Kolmogorov.html>.

Sánchez Fernández, Carlos y Valdés Castro, Concepción (Universidad de la Habana). «Andrei Nikolayevich Kolmogórov». En DivulgaMAT, Centro Virtual de Divulgación de las Matemáticas [sitio web en línea]. S.I. Comisión de Divulgación de la Real Sociedad Matemática Española (R.S.M.E.), s.f., (c) Comisión de Divulgación RSME.Lukas Multimedia (Mutriku.) [citado el 26 de junio de 2009]. Disponible en <http://www.divulgamat.net/weborriak/Historia/MateOspetsuak/ Kolmogorov.asp>.

Ficklin, Valerie. «Mannerist Staircases: A Twist in the Tale». En AllysPalladino-Craig (ed.), Athanor XIX, pp.27-32 [revista en línea]. Florida, F.S.U. Museum of Fine Arts Press y el Department of Art History de la Florida State University, primavera de 2001, num.19 [citado el 29 de junio de 2009]. pp.27-32. Disponible en formato pdf: <.http://www.fsu.edu/ arh/events/athanor/athxix/ AthanorXIX_ficklin.pdf $>$.

Analysis of Beauty. En Monamy [sitio web en línea]. s.I., 2004, (C) Charles Harrison Wallace 2004 [citado el 29 de junio de 2009]. Disponible en <http://www.cichw.net/pmanalysis.html>.

The Metropolitan Museum of Art [sitio web en línea]. Nueva York, The Metropolitan Museum of Art, 2000, (c) 2000-2005 The Metropolitan Museum of Art [citado el 28 de junio de 2009]. Lomazzo, Giovanni Paolo - Trattato dell' arte della pittura, scultura et architetettura. Works of Art; Permanent Collection; The Libraries; Collection Highlights. Disponible en <http://www.metmuseum.org/Works_of_Art/viewOne.asp?dep=16\&viewmode=0\&item=109A\%20L83>.

Página web: Recent Acquisitions 2002: http://www.library.yale.edu/beinecke/brblinfo/ brblguide_2002.html

En sitio wēb: Yale University. Beinecke Rare Book \& Manuscript Library: http://www.library.yale. edu/beinecke

Página web: Giovanni Paolo Lomazzo: http://wwar.com/masters///lomazzo-giovanni_paolo. html

En sitio web: World Wide Art Resources. absoluteart.com: http://wwar.com

Valéry, Paul. «Art and Progress» [en línea]. s.l., s.f. [citado el 24 de junio de 2009]. pp.45-50. Publicación original en The Yale Review, 1930. Disponible en formato pdf en <http://www.blackwellpublishing.com/content/BPL_Images/Journal_Samples/YREV0044-0124 89 4 544/544.pdf >.

Valéry, Paul. «Discurso de la Historia». Istor: Amnesia y amnistía [revista en línea]. D.F., México, CIDE: División de Historia del Centro de Investigación y Docencia Económicas, Año II, num.5, verano de 2001, [citado el 24 de junio de 2009]. Sección Textos recobrados, pp.101-110. Tr. del francés por Mario A. Zamudio Vega y Adolfo Castañón. Discurso pronunciado originalmente por Paul Valéry en el Liceo parisino Janson-de-Sailly, 13 de julio de 1932. Publicado en Presses Modernes, 1932. Reedición bajo el título de «El hecho histórico», Valéry Paul, Variété, Serie 
CEuvres, Tomo D, vol.I, 1934, pp.153-165. Disponible en formato pdf en <http://www.istor.cide. edu/archivos/num_5/textos\%20recobrados.pdf $>$.

Valéry Paul. «La conquête de l'ubiquité» [en línea]. Québec, Bibliothèque Paul-Émile-Boulet, Université du Québec à Chicoutimi, Colección "Les classiques des sciences sociales", 13 de enero de 2003 [citado el 24 de junio de 2009]. pp.5. Colección dirigida por Jean-Marie Tremblay. Edición original: Paul Valéry, "La conquête de l'ubiquité", 1928, en CEuvres, Tomo II, Pièces sur l'art, Gallimard, Bibl. de la Pléiade, 1960, p.1283-1287. disponible en formato pdf, en <http:// www.uqac.uquebec.ca/zone30/Classiques_des_sciences_sociales/classiques/Valery_paul/ conquete_ubiguite/valery_conquete_ubiquite.pdf $>$.

Valéry, Paul. «Miradas del mundo actual 1931». Istor: Kosovo [revista en línea]. D.F., México, CIDE: División de Historia del Centro de Investigación y Docencia Económicas, Año I, num.1, verano de 2000 [citado el 24 de junio de 2009]. Sección Textos recobrados, pp.98-113. Tr. del francés Lucía Segovia; con Presentación por Adolfo Castañón. Publicación traducida y presentada del texto publicado en Valéry, Paul, CEeuvres, París, Gallimard, Tomo II, 1960, p.913-928. Disponible en formato pdf, en <http://www.istor.cide.edu/archivos/num_1/Textos.pdf >.

Valéry, Paul. Crisis of the Mind. En Kreis, Steven. The History Guide [sitio web en línea]. s.l., revisado el 13 de mayo de 2004, (c) 2000 Steven Kreis [citado el 24 de junio de 2009]. Lectures on Twentieth Century Europe; Lecture 8 - The Age of Anxiety: Europe in the 1920s (1). $1^{\text {a }}$ publicación en inglés en The Athenaeum, Londres, 11 de abril y 2 de mayo de 1919. $1^{a}$ publicación en francés en La Nouvelle Revue Française, agosto de 1919. Disponible en <http://www.historyguide.org/europe/valery.html>.

Valéry Paul. «Réponse de M. Paul Valéry au discours de M. le maréchal Pétain». En Académie française [sitio web en línea]. París, Académie française, s.f. [citado el 24 de junio de 2009]. Les Immortels; Devenir immortel; Discours Académiques; Discours de réception. Discurso pronunciado en la Séance Publique, París, Palais de l'Institut, 31 de junio de 1931. Disponible en $<$ http://www.academie-francaise.fr/immortels/discours_reponses/valery.html>

Stimpson, Brian y Buch-Jepsen, Niels. Paul Valéry Studies - University of Newcastle upon Tyne [sitio web en línea]. Tyne, Reino Unido, School of Modern Languages, University of Newcastle, actualizado en junio de 2004 [citado el 23 de junio de 2009]. Disponible en $<$ http://www.paulvalery.org/>. También disponible en <http://www.ncl.ac.uk/paulvalery/valery-main.htm>

Stimpson, Brian y Buch-Jepsen, Niels. Paul Valéry Studies - University of Newcastle upon Tyne [sitio web en línea]. Tyne, Reino Unido, School of Modern Languages, University of Newcastle, actualizado en junio de 2003 [citado el 23 de junio de 2009]. Bibliographie / Bibliography. También disponible en: <http://www.ncl.ac.uk/paulvalery/valery-biblio.htm>.

Murzi, Mauro. «Jules Henri Poincaré (1854-1912)». En Fieser, James (ed.) y Dowden, Bradley (ed.), The Internet Encyclopedia of Phylosophy [en línea] (c) 2005 [citado el 26 de junio de 2009]. Disponible en <http://www.utm.edu/research/iep/p/poincare.htm>.

O`Connor, J. J. y Robertson E. F. «Jules Henri Poincaré». En MacTutor History of Mathematics [en línea] St. Andrews, Escocia, School of Mathematics and Statics, St. Andrews University, octubre de 2003, JOC/EFR (C) October 2003 [citado el 26 de junio de 2009]. Biography Index, Poincaré, J. Henri (3201*). Disponible en <http://www-history.mcs.st-andrews.ac.uk/Mathematicians/Poincare.html>. También disponible en <http://www-groups.dcs.st-and.ac.uk/ history/ Mathematicians/Poincare.html>. 
O`Connor, J. J. y Robertson E. F. «Chronology for 1890 to 1900». En MacTutor History of Mathematics [en línea] St. Andrews, Escocia, School of Mathematics and Statics, de la St. Andrews University, agosto de 2001, JOC/EFR August 2001 [citado el 26 de junio de 2009]. Chronology, 1890 to 1900. Disponible en <http://www-history.mcs.st-andrews.ac.uk/history/Chronology/1890_1900.html>. También disponible en <http://www-groups.dcs.st-and. ac.uk/ history/Chronōlogy/1890_1900.html\#1892>.

O`Connor, J. J. y Robertson E. F. «Chronology for 1900 to 1910». En MacTutor History of Mathematics [en línea] St. Andrews, Escocia, School of Mathematics and Statics, de la St. Andrews University, agosto de 2001, JOC/EFR August 2001 [citado el 26 de junio de 2009]. Chronology, 1900 to 1910. Disponible en <http://www-history.mcs.st-andrews.ac.uk/history/Chronology/1900_1910.html>. También disponible en <http://www-groups.dcs.st-and. ac.uk/ history/Chronology/1900_1910.html\#1904>.

Prigogine, Ilya. «Autobiography». En The Nobel Foundation. Nobe/prize.org [sitio web en línea]. Estocolmo, The Nobel Foundation, s.f., revisado el 14 de abril de 2005, (c) 2005 The Nobel Foundation [citado el 26 de junio de 2009]. Publicado originalmente en Frängsmyr, Tore (ed.) y Forsen, Sture (ed.), Nobel Lectures, Chemistry 1971-1980, Singapur, World Scientific Publishing Co., 1993. Disponible en <http://nobelprize.org/chemistry/laureates/1977/prigogineautobio.html>.

«Curriculum Vitae: Ilya Prigogine». En C.I.S.S.T., Centro Internazionale di Storia della Nozione e della Misura dello Spazio e del Tempo [sitio web en línea]. Brugine, Centro Internazionale di Storia della Nozione e della Misura dello Spazio e del Tempo, s.f. [citado el 26 de junio de 2009]. Disponible en <http://www.crs4.it/CISST/Curriculum-Prigogine.html>.

«llya Prigogine. 1917-2003». En Blanco Arturo (dir.). Antroposmoderno [sitio web en línea]. s.l., Antroposmoderno, s.f. [citado el 26 de junio de 2009]. Disponible en <http://www.antroposmoderno.com/antro-articulo.php?id_articulo $=456>$.

Prof. Ilya Prigogine. En The Center for Complex Quantum Systems [sitio web en línea]. Austin, Texas, The Center for Complex Quantum Systems, del Department of Physics, The University of Texas at Austin, actualizado el 4 de febrero de 2004, (C) 1995-1999 llya Prigogine Center for Studies in Statistical Mechanics and Complex Systems [citado el 26 de junio de 2009]. Disponible en: <http://order.ph.utexas.edu/people/Prigogine.htm>.

The European Graduate School [sitio web en línea]. Nueva York, The European Graduate School, 2005, (C) 1997-2005, European Graduate School EGS [citado el 13 de julio de 2009]. Faculty; Slavoj Žižek; Bibliography. Disponible en <http://www.egs.edu/faculty/slavojzizek. html>

«Slavoj Žižek». En Wikipedia, The Free Encyclopedia [sitio web en línea]. Versión en inglés, s.l., Wikipedia, The Free Encyclopedia, 2001 [citado el 13 de julio de 2009]. Disponible en <http:// en.wikipedia.org/wiki/Zizek>.

Gunther von Hagens' Body Worlds: The Anatomical Exhibition of Real Human Bodies [sitio web en línea]. Heidelberg, Alemania, Institut fuer Plastination, s.f., actualizado en abril de 2004, (c) Copyright 2001-2005, Institute for Plastination, 69126 Heidelberg/Germany [citado el 22 de agosto de 2008]. Disponible en <http://www.bodyworlds.com/>. Versión en inglés del sitio web disponible en <http://www.bodyworlds.com/en/pages/home.asp>. 
«Dr. Gunther von Hagens: A Life in Science». En Gunther von Hagens' Body Worlds: The Anatomical Exhibition of Real Human Bodies [sitio web en línea]. Heidelberg, Alemania, Institut fuer Plastination, s.f., actualizado en abril de 2004, (C) Copyright 2001-2005, Institute for Plastination, 69126 Heidelberg/Germany [citado el 22 de agosto de 2008]. Disponible en <http://www.bodyworlds.com/en/pages/gunther_von_hagens.asp>.

«Plastination Technique». En Gunther von Hagens' Body Worlds: The Anatomical Exhibition of Real Human Bodies [sitio web en línea]. Heidelberg, Alemania, Institut fuer Plastination, s.f., actualizado en abril de 2004, (c) Copyright 2001-2005, Institute for Plastination, 69126 Heidelberg/ Germany [citado el 22 de agosto de 2008]. Disponible en <http://www.bodyworlds.com/en/ pages/plastination.asp $>$. 
